\title{
REFERENCES
}

\begin{tabular}{|c|c|}
\hline AW70 & G Agarwal and E Wolf, Phys Rev D2 (1970) 2161; ibid 2187, ibid 2206 \\
\hline APW02 & $\begin{array}{l}\text { M Alonso, G Pogosyan, and K-B Wolf, J Math Phys } 43 \text { (2002) } 5857 \text { [quant- } \\
\text { ph/0205041] }\end{array}$ \\
\hline AW00 & J-P Amiet and S Weigert, Phys Rev A63 (2000) 012102 \\
\hline Ant01 & $\begin{array}{l}\text { J-P Antoine, J-P Gazeau, P Monceau, J Klauder, and K Penson, J Math Phys } 42 \\
\text { (2001) } 2349 \text { [math-ph/0012044] }\end{array}$ \\
\hline An97 & F Antonsen, [gr-qc/9710021] \\
\hline Ar83 & W Arveson, Comm Math Phys 89 (1983) 77-102 \\
\hline ACW98 & N Atakishiyev, S Chumakov, and K B Wolf, J Math Phys 39 (1998) 6247-6261 \\
\hline Bak58 & G Baker, Phys Rev 109 (1958) 2198-2206 \\
\hline Bak60 & G Baker, I McCarthy and C Porter, Phys Rev 120 (1960) 254-264 \\
\hline BJ84 & N Balasz and B Jennings, Phys Repts 104 (1984) 347 \\
\hline Bal63 & $\begin{array}{l}\text { R Balescu, Equilibrium and Nonequilibrium Statistical Mechanics (Wiley-Interscience, } \\
\text { New York, 1963) }\end{array}$ \\
\hline BRWK99 & $\begin{array}{l}\text { K Banaszek, C Radzewicz, K Wódkiewicz, and J Krasinski, Phys Rev A60 (1999) } \\
674-677\end{array}$ \\
\hline BBL80 & H Bartelt, K Brenner, and A Lohmann, Opt Commun 32 (1980) 32-38 \\
\hline $\operatorname{Bar} 45$ & M Bartlett, Proc Camb Phil Soc 41 (1945) 71-73 \\
\hline BM49 & M Bartlett and J Moyal, Proc Camb Phil Soc 45 (1949) 545-553 \\
\hline BKM03 & I Bars, I Kishimoto, and Y Matsuo, Phys Rev D67 (2003) 126007 \\
\hline BGL01 & $\begin{array}{l}\text { I Batalin, M Grigoriev, and S Lyakhovich, Theor Math Phys } 128 \text { (2001) 1109-1139 } \\
\text { [hep-th/0101089] }\end{array}$ \\
\hline BFF78 & $\begin{array}{l}\text { F Bayen, M Flato, C Fronsdal, A Lichnerowicz, and D Sternheimer, Ann Phys (NY) } \\
111 \text { (1978) 61-110; ibid 111-151; Lett Math Phys } 1 \text { (1977) 521-530 }\end{array}$ \\
\hline BF81 & F Bayen and C Fronsdal, $J$ Math Phys 22 (1981) 1345-1349 \\
\hline Ba79 & $\begin{array}{l}\text { F Bayen, in Group Theoretical Methods in Physics, W Beiglböck et al, eds, Lecture } \\
\text { Notes in Physics } 94 \text { (Springer-Verlag, Heidelberg, 1979) pp 260-271 }\end{array}$ \\
\hline BJY04 & A Belitsky, X Ji, and F Yuan, Phys Rev D69 (2004) 074014 \\
\hline $\mathrm{BC} 99$ & M Benedict and A Czirják, Phys Rev A60 (1999) 4034 \\
\hline Ber80 & F Berezin, Sov Phys Usp 23 (1980) 763-787 \\
\hline Ber75 & F Berezin, Comm Math Phys 40 (1975) 153--174 \\
\hline Ber77 & M Berry, Philos Trans R Soc London A287 (1977) 237-271 \\
\hline BCG97 & M Bertelson, M Cahen, and S Gutt, Class Quant Grav 14 (1997) A93-A107 \\
\hline Ber02 & P Bertet et al, Phys Rev Lett 89 (2002) 200402 \\
\hline BP96 & B Biegel and J Plummer, Phys Rev B54 (1996) 8070-8082 \\
\hline BHS02 & M Bienert, F Haug, W Schleich, and M Raizen, Phys Rev Lett 89 (2002) 050403 \\
\hline BHP02 & P Bianucci et al, Phys Lett A297 (2002) 353-358 \\
\hline BV94 & R Bishop and A Vourdas, Phys Rev A50 (1994) 4488-4501 \\
\hline Bon84 & J Gracia-Bondía, Phys Rev A30 (1984) 691-697 \\
\hline ВCT82 & E Braaten, T Curtright, and C Thorn, Phys Lett B118 (1982) 115 \\
\hline BM94 & A Bracken and G Melloy, J Phys A27 (1994) 2197-2211 \\
\hline BDW99 & $\begin{array}{l}\text { A Bracken, H Doebner, and J Wood, Phys Rev Lett } 83 \text { (1999) 3758-3761; } \\
\text { J Wood and A Bracken, J Math Phys } 46 \text { (2005) } 042103\end{array}$ \\
\hline
\end{tabular}


BCW02 A Bracken, G Cassinelli, and J Wood, J Phys A36 (2003) 1033-1057 [math$\mathrm{ph} / 0211001]$

$\mathrm{Bra02}$

BR93

Bra94

A Bracken, J Phys A36 (2003) L329-L335 [quant-ph/0210164]

BD98

G Braunss and D Rompf, J Phys A26 (1993) 4107-4116

BAD96

$\mathrm{CC03}$

CZ83

Car76

Cas91

Cas00

$\mathrm{CH} 87$

$\mathrm{CH} 86$

CV98

CL03

Coh95

G Braunss, J Math Phys 35 (1994) 2045-2056

Coh66

D Brown and P Danielewicz, Phys Rev D58 (1998) 094003

Coh76

CS75

V Bužek, G Adam, and G Drobný, Ann Phys (NY) 245 (1996) 37-97

A Cafarella, C Corianò, and M Guzzi, JHEP 11 (2003) 059

P Carruthers and F Zachariasen, Rev Mod Phys 55 (1983) 245-285

N Cartwright, Physica 83A (1976) 210-213

M Casas, H Krivine, and J Martorell, Eur J Phys (1991) 105-111

L Castellani, Class Quant Grav 17 (2000) 3377-3402 [hep-th/0005210]

L Chetouani and T Hammann, J Math Phys 28 (1987) 598-604

L Chetouani and T Hammann, Nuov Cim B92 (1986) 106-120

S Chountasis and A Vourdas, Phys Rev A58 (1998) 1794-1798

Y-J Chun and H-W Lee, Ann Phys (NY) 307 (2003) 438-451

L Cohen, Time-Frequency Analysis (Prentice-Hall PTR, Englewood Cliffs, 1995)

L Cohen, J Math Phys 7 (1966) 781

L Cohen, J Math Phys 17 (1976) 1863

F Cooper and D Sharp, Phys Rev D12 (1975) 1123-1131;

R Hakim and J Heyvaerts, Phys Rev A18 (1978) 1250-1260

CPP01

H García-Compeán, J Plebanski, M Przanowski, and F Turrubiates, Int J Mod Phys A16 (2001) 2533-2558

CPP02

H García-Compeán, J Plebanski, M Przanowski, and F Turrubiates, J Phys A35 (2002) 4301-4320

CGB91 G Cristóbal, C Gonzalo, and J Bescós, Advances in Electronics and Electron Physics 80 (1991) 309-397

CG92

T Curtright and G Ghandour, in Quantum Field Theory, Statistical Mechanics, Quantum Groups and Topology, Coral Gables 1991 Proceedings, T Curtright et al, eds (World Scientific, 1992) pp 333-344 [hep-th/9503080]

CUZ01 T Curtright, T Uematsu, and C Zachos, J Math Phys 42 (2001) 2396-2415 [hepth/0011137]

CZ99 T Curtright and C Zachos, J Phys A32 (1999) 771-779

CFZ98 T Curtright, D Fairlie, and C Zachos, Phys Rev D58 (1998) 025002

CFZm98 T Curtright, D Fairlie, and C Zachos, "Matrix Membranes and Integrability," in Supersymmetry and Integrable Models, Lecture Notes in Physics v 502, H Aratyn et al (eds), (Springer-Verlag, Heidelberg, 1998) pp 183-196 [hep-th/9709042]

$\mathrm{CZ01}$ T Curtright and C Zachos, Mod Phys Lett A16 (2001) 2381-2385

$\mathrm{CZ02}$ T Curtright and C Zachos, New J Phys 4 (2002) 1.1-1.16 [hep-th/0205063].

DS82 J Dahl and M Springborg, Mol Phys 47 (1982) 1001; Phys Rev A36 (1988) 1050-1062; Phys Rev A59 (1999) 4099-4100

Dah01 J P Dahl, Adv Quantum Chem 39 (2001) 1-18

DS02

Dah83

J P Dahl and W Schleich, Phys Rev A65 (2002) 022109

J Dahl, in Energy Storage and Redistribution, J Hinze, ed (Plenum Press, New York, 1983) pp 557-571 
DG80 I Daubechies and A Grossmann, J Math Phys 21 (1980) 2080-2090; I Daubechies, A Grossmann, and J Reignier J Math Phys 24 (1983) 239-254

DK85

I Daubechies and J Klauder, J Math Phys 26 (1985) 2239-2256

DG02

E Davis and G Ghandour, $J$ Phys 35 (2002) 5875-5891 [quant-ph/9905002]

deA98

A M Ozorio de Almeida, Phys Rep 295 (1998) 265-342

DeG74

$\mathrm{S}$ De Groot, La Transformation de Weyl et la fonction de Wigner (Presses de l'Université de Montreal, 1974)

DBB02 L Demeio, L Barletti, A Bertoni, P Bordone, and C Jacoboni, Physica B314 (2002) 104-107

DV97

deW83

T Dereli and A Vercin, J Math Phys 38 (1997) 5515-5530 [quant-ph/9707040]

DP01

M de Wilde and P Lecomte, Lett Math Phys 7 (1983) 487

Dir30

Dir33

Dir45

DKM88

Dit90

DM86

DN01

N Dias and J Prata, J Math Phys 42 (2001) 5565-5579

P Dirac, Proc Camb Phil Soc 26 (1930) 376-385

P Dirac, Phys $Z$ Sowjetunion 3 (1933) 64-72

P A M Dirac, Rev Mod Phys 17 (1945) 195-199

R Dirl, P Kasperkovitz and M Moshinsky, J Phys A21 (1988) 1835-1846

J Dito, Lett Math Phys 20 (1990) 125-134; J Math Phys 33 (1992) 791-801

V Dodonov and V Man'ko, Physica 137A (1986) 306-316

M Douglas and N Nekrasov, Rev Mod Phys 73 (2001) 977-1029;

R Szabo, Phys Rept 378 (2003) 207-299

DHSO0

D Dubin, M Hennings, and T Smith, Mathematical Aspects of Weyl Quantization and Phase (World Scientific, Singapore, 2000)

Dun95

Dun88

EGV89

Fai64

FFZ89

T Dunne et al, Phys Rev Lett 74 (1995) 884-887

G Dunne, J Phys A21 (1988) 2321-2335

R Estrada, J Gracia-Bondia and J Várilly, J Math Phys 30 (1989) 2789-2796

D Fairlie, Proc Camb Phil Soc 60 (1964) 581-586

D Fairlie and C Zachos, Phys Lett B224 (1989) 101-107;

D Fairlie, P Fletcher, and C Zachos, J Math Phys 31 (1990) 1088-1094

FM91

Fan03

Fan57

FBA96

FZ01

D Fairlie and C Manogue, $J$ Phys A24 (1991) 3807-3815

A Fannjiang, Comm Math Phys 254 (2005) 289-322 [math-ph/0304024]

U Fano, Rev Mod Phys 29 (1957) 74-93

A Farini, S Boccaletti, and F Arecchi, Phys Rev E53 (1996) 4447-4450

A Fedorova and M Zeitlin, in PAC2001 Proceedings, P Lucas and S Webber, eds (IEEE, Piscataway, NJ, 2001) pp 1814-1816 [physics/0106005]; A Fedorova and M Zeitlin, 18th Advanced ICFA Beam Dynamics Workshop on Quantum Aspects of Beam Physics: Capri, 2000, P Chen, ed (World Scientific, River Edge, NJ, 2002) pp 539-550 [physics/0101006]

Fed94 B Fedosov, J Diff Geom 40 (1994) 213-238

Fey87 R Feynman, "Negative Probability," in Essays in Honor of David Bohm, B Hiley and F Peat, eds (Routledge and Kegan Paul, London, 1987) pp 235-248

FM03 S Filippas and G Makrakis, Multiscale Mod Simul 1 (2003) 674-710

FLS76 M Flato, A Lichnerowicz, and D Sternheimer, J Math Phys 17 (1976) 1754

Fle90 P Fletcher, Phys Lett B248 (1990) 323-328

Fol89 G Folland Harmonic Analysis in Phase Space (Princeton University Press, Princeton, 1989)

Fra00 A Frank, A Rivera, and K Wolf, Phys Rev A61 (2000) 054102 
Fre87

FMS00

Gad95

GM80

GF91

GH93

Got99

GR94

Gro01

Gro46

Gro76

Hak99

HKN88

Han84

Har01

HS02

HSD95

Hie 82

Hie 84

HOS84

$\mathrm{HH} 02$

Hor 79

HL99

Hud74

HMS98

Hus40

Imr67

JBM03

JS02

JVS87

JN90

JY98

JD99

KO00

KZZ02

KJ99

KL99

KL01
W Frensley, Phys Rev B36 (1987) 1570-1578

O Friesch, I Marzoli, and W Schleich, New J Phys 2 (2000) 4.1-4.11

M Gadella, Fortschr Phys 43 (1995) 3, 229-264

G García-Calderón and M Moshinsky, J Phys A13 (1980) L185

I Gelfand and D Fairlie, Comm Math Phys 136 (1991) 487-500

M Gell-Mann and Hartle, Phys Rev D47 (1993) 3345-3382

M Gotay, J Math Phys 40 (1999) 2107-2116

E Gozzi and M Reuter, Int J Mod Phys A9 (1994) 5801-5820

K Gröchenig, Foundations of Time-Frequency Analysis (Birkhäuser, Boston, 2001)

H Groenewold, Physica 12 (1946) 405-460

A Grossmann, Comm Math Phys 48 (1976) 191-194

T Hakioglu, J Phys A32 (1999) 4111-4130; [quant-ph/0011076]; T Hakioglu and A Dragt, J Phys A34 (2002) 6603-6615.

D Han, Y Kim, and M Noz, Phys Rev A37 (1988) 807-814; Y Kim and E Wigner, ibid A38 (1988) 1159-1167; ibid A36 (1987) 1293-1297

F Hansen, Rep Math Phys 19 (1984) 361-381

J Harvey, "Komaba Lectures on Noncommutative Solitons and D-branes" [hepth/0102076]

A Hatzinikitas and A Smyrnakis, J Math Phys A43 (2002) 113-125

M Hennings, T Smith, and D Dubin, J Phys A28 (1995) 6779-6807; ibid 6809-6856

J Hietarinta, Phys Rev D25 (1982) 2103-2117

J Hietarinta, J Math Phys 25 (1984) 1833-1840.

M Hillery, R O'Connell, M Scully, and E Wigner, Phys Repts 106 (1984) 121-167

A Hirschfeld and P Henselder, Am J Phys 70 (2002) 537-547

L Hörmander, Comm Pure Appl Math 32 (1979) 359-443

X-G Hu and Q-S Li, J Phys A32 (1999) 139-146

R Hudson, Rep Math Phys 6 (1974) 249-252

M Hug, C Menke, and W Schleich, Phys Rev A57 (1998) 3188-3205; ibid 3206-3224

K Husimi, Proc Phys Math Soc Jpn 22 (1940) 264

K Imre et al, J Math Phys 8 (1967) 1097

C Jacoboni, R Brunetti, and S Monastra, Phys Rev B68 (2003) 125205

Y Japha and B Segev, Phys Rev A65 (2002) 063411

J Javanainen, S Varró, and O Serimaa, Phys Rev A35 (1987) 2791-2805; ibid A33 (1986) 2913-2927

J Jensen and Q Niu, Phys Rev A42 (1990) 2513-2519

A Jevicki and T Yoneya, Nucl Phys B535 (1998) 335

A Joshi and H-T Dung, Mod Phys Lett B13 (1999) 143-152

M Karasev and T Osborn, J Math Phys 43 (2002) 756-788 [quant-ph/0002041];

$J$ Phys A37 (2004) 2345-2363 [quant-ph/0311053]

Z Karkuszewski, J Zakrzewski, and W Zurek, Phys Rev A65 (2002) 042113; Z Karkuszewski, C Jarzynski, and W Zurek, Phys Rev Lett 89 (2002) 170405

C Kiefer and E Joos, in Quantum Future, P Blanchard and A Jadczyk, eds (SpringerVerlag, Berlin, 1999) pp 105-128 [quant-ph/9803052]; Li Diósi and C Kiefer, J Phys A35 (2002) 2675-2683

J-H Kim and H-W Lee, Can J Phys 77 (1999) 411-425

K-Y Kim and B Lee, Phys Rev B64 (2001) 115304 
KN91 Y Kim and M Noz, Phase Space Picture of Quantum Mechanics, Lecture Notes in Physics v 40 (World Scientific, Singapore, 1991)

KW90 Y Kim and E Wigner, Am $J$ Phys 58 (1990) 439 448

KW87 Y Kim and E Wigner, Phys Rev A36 (1987) 1293; ibid A38 (1988) 1159

Kis01 I Kishimoto, JHEP 0103 (2001) 025

KKFR89 N Kluksdahl, A Kriman, D Ferry, and C Ringhofer, Phys Rev B39 (1989) 7720-7735

Kol96

$\mathrm{KS} 02$

A Kolovsky, Phys Rev Lett 76 (1996) 340-343

KL94

Kon97

A Konechny and A Schwarz, Phys Repts 360 (2002) 353-465

H Konno and P Lomdahl, J Phys Soc Jp 63 (1994) 3967-3973

M Kontsevich, Lett Math Phys 66 (2003) [q-alg/9709040]; ibid 48 (1999) 35-72 [math.QA/9904055]

Kub64

R Kubo, J Phys Soc Jp 19 (1964) 2127-2139

Kun67

W Kundt, Z Nat Forsch a22 (1967) 1333-1336

KPM97

C Kurtsiefer, T Pfau, and J Mlynek, Nature 386 (1997) 150

Les 84

Lea68

Lee95

B Lesche, Phys Rev D29 (1984) 2270-2274

B Leaf, J Math Phys 9 (1968) 65-72; ibid 9 (1968) 769-781

H-W Lee, Phys Repts 259 (1995) 147-211

Lei96

LPM98

D Leibfried et al, Phys Rev Lett 77 (1996) 4281

Leo97

D Leibfried, T Pfau, and C Monroe, Physics Today 51 (April 1998) 22-28

U Leonhardt, Measuring the Quantum State of Light (Cambridge University Press, Cambridge, 1997)

LF01

LF94

M Levanda and V Fleurov, Ann Phys (NY) 292 (2001) 199-231

M Levanda and V Fleurov, J Phys: Cond Matt 6 (1994) 7889-7908

LSU02

B Lev, A Semenov, and C Usenko, J Russ Laser Res 23 (2002) 347-368 [quant$\mathrm{ph} / 0112146]$

Lie90

E Lieb, J Math Phys 31 (1990) 594-599

Lit86

Lou96

R Littlejohn, Phys Rep 138 (1986) 193

P Loughlin, ed, Special Issue on Time Frequency Analysis: Proceedings of the IEEE 84 (2001) No 9

Lvo01

A Lvovsky et al, Phys Rev Lett 87 (2001) 050402

MS95

MM84

MMT96

M Mallalieu and C Stroud, Phys Rev A51 (1995) 1827-1835

$J$ Martorell and E Moya, Ann Phys (NY) 158 1-30

MMM01

S Mancini, V Man'ko, and P Tombesi, Phys Lett A213 (1996) 1-6

O Man'ko, V Man'ko, and G Marmo, in Quantum Theory and Symmetries: Krakow 2001 Proceedings, E Kapuscik and A Horzela, eds (World Scientific, 2002) (quant$\mathrm{ph} / 0112112]$

MS96

M Marinov and B Segev, Phys Rev A54 (1996) 4752-4762

MMP94

P Markowich, N Mauser, and F Poupaud, J Math Phys 35 (1995) 1066-1094

$\mathrm{McD} 88$

S McDonald, Phys Rep 158 (1988) 337-416

$\mathrm{McC} 32$

N McCoy, Proc Nat Acad Sci USA 19 (1932) 674

MOT98

B McQuarrie, T Osborn, and G Tabisz, Phys Rev A58 (1998) 2944-2960; T Osborn, M Kondrat'eva, G Tabisz, and B McQuarrie, J Phys A32 (1999) 4149-4169

MH97 W Mecklenbräuker and F Hlawatsch, eds, The Wigner Distribution (Elsevier, Amsterdam, 1997)

Moy49 J Moyal, Proc Camb Phil Soc 45 (1949) 99-124

MM94

S Mrówczyński and B Müller, Phys Rev D50 (1994) 7542-7552 
Mue99

$\mathrm{Na} 97$

NO86

Neu31

OW81

$\mathrm{OC} 03$

OR57

OM95

Pei33

PT99

QC96

Raj83

Raj02

Ran66

RT00

Rie89

RA99

RO92

Roy 77

RG00

Sam00

$\mathrm{Sch} 02$

Sch69

SW99

SST00

SS02

Sha79

She59

SP81

SM00

Smi93

Sny 80

Ste80

Str57

Syl82

Tak54

Tak89

Tat83

Tay01

M Müller, J Phys A32 (1999) 1035-1052

H Nachbagauer, [hep-th/9703105]

F Narcowich and R O'Connell, Phys Rev A34 (1986) 1-6

J v Neumann, Math Ann 104 (1931) 570-578

R O'Connell and E Wigner, Phys Lett 85A (1981) 121-126

R O'Connell, J Opt B5 (2003) S349-S359

I Oppenheim and J Ross, Phys Rev 107 (1957) 28-32

T Osborn and F Molzahn, Ann Phys (NY) 241 (1995) 79-127.

R Peierls, Z Phys 80 (1933) 763

M Przanowski and J Tosiek Act Phys Pol B30 (1999) 179-201

S Qian and D Chen, Joint Time-Frequency Analysis (Prentice-Hall PTR, Upper Saddle River, NJ, 1996)

A Rajagopal, Phys Rev A27 (1983) 558-561

SG Rajeev, in Proceedings of the 7oth Meeting of Mathematicians and Physicists (Strassbourg, June 2002), V Turaev and T Wurzbacher, eds [hep-th/0210179]

B Rankin, Phys Rev 141 (1966) 1223-1230

N Reshetikhin and L Takhtajan, Amer Math Soc Transl 201 (2000) 257-276 [math.QA/9907171]

M Rieffel, Comm Math Phys 123 (1989) 531-562

A Rivas and A O de Almeida, Ann Phys (NY) 276 (1999) 223-256

C Roger and V Ovsienko, Russ Math Surv 47 (1992) 135-191

A Royer, Phys Rev A15 (1977) 449-450

M Ruzzi and D Galetti, J Phys A33 (2000) 1065-1082; D Galetti and A de Toledo Piza, Physica 149A (1988) 267-282

J Samson, J Phys A33 (2000) 5219-5229 [quant-ph/0006021]

W Schleich, Quantum Optics in Phase Space (Wiley-VCH, 2002)

J Schipper, Phys Rev 184 (1969) 1283-1302

N Seiberg and E Witten, JHEP 9909 (1999) 032

N Seiberg, L Susskind, and N Toumbas, JHEP 0006 (2000) 044 [hep-th/0005015]

A Sergeev and B Segev, J Phys A35 (2002) 1769-1789; B Segev, J Opt B5 (2003) S381-S387

P Sharan, Phys Rev D20 (1979) 414-418

J Shewell, Am J Phys 27 (1959) 16-21

S Shlomo and M Prakash, Nucl Phys A357 (1981) 157

R Simon and N Mukunda, J Opt Soc Am a17 (2000) 2440-2463

D Smithey et al, Phys Rev Lett 70 (1993) 1244-1247

J Snygg, Am J Phys 48 (1980) 964-970

S Stenholm, Eur J Phys 1 (1980) 244-248

R Stratonovich, Sov Phys JETP 4 (1957) 891-898

J Sylvester, Johns Hopkins University Circulars I (1882) 241-242; ibid II (1883) 46; ibid III (1884) 7-9. Summarized in The Collected Mathematics Papers of James Joseph Sylvester (Cambridge University Press, 1909) v III

T Takabayasi, Prog Theor Phys 11 (1954) 341-373

K Takahashi, Prog Theor Phys Suppl 98 (1989) 109-156

V Tatarskii, Sov Phys Usp 26 (1983) 311

W Taylor, Rev Mod Phys 73 (2001) 419 [hep-th/0101126]. 
TZM96 Go Torres-Vega, A Zúñiga-Segundo, and J Morales-Guzmán, Phys Rev A53 (1996) 3792-3797

TA99 F Toscano and A O de Almeida, J Phys A32 (1999) 6321-6346

TD97 C Tzanakis and A Dimakis, $J$ Phys A30 (1997) 4857-4866

VG89

Vo89

J Várilly and J Gracia-Bondía, Ann Phys (NY) 190 (1989) 107-148

Vo78

A Voros, Phys Rev A40 (1989) 6814-6825

A Voros, J Funct Analysis 29 (1978) 104-132; B Grammaticos and A Voros, Ann Phys (NY) 123 (1979) 359-380

Vey75 J Vey, Comment Math Helv 50 (1975) 421-454

vH51

L van Hove, Proc R Acad Sci Belgium 26 (1951) 1-102

WO87

L Wang and R O'Connell, Physica 144A (1987) 201-210

WO88

L Wang and R O'Connell, Found Phys 18 (1988) 1023-1033

Wey27

Wig32

H Weyl, Z Phys 46 (1927) 1-33; H Weyl, The Theory of Groups and Quantum Mechanics (Dover, New York, 1931)

Wis 97

E Wigner, Phys Rev 40 (1932) 749-759

Wok97

H Wiseman et al, Phys Rev A56 (1997) 55-75

Wo98

W Wokurek, in Proc ICASSP ' 97 (Munich, 1997) pp 1435-1438

Wo82

M-W Wong, Weyl Transforms (Springer-Verlag, Berlin, 1998)

$\mathrm{Wo} 02$

Woo87

C-Y Wong, Phys Rev C25 (1982) 1450-1475

C-Y Wong, J Opt B5 (2003) S420-S428 [quant-ph/0210112]

W Wootters, Ann Phys (NY) 176 (1987) 1-21

Yo89

T Yoneya, Mod Phys Lett A4 (1989) 1587

Zac00

C Zachos, J Math Phys 41 (2000) 5129-5134 [hep-th/9912238];

C Zachos, "A Survey of Star Product Geometry," in Integrable Hierarchies and Modern Physical Theories, H Aratyn and A Sorin, eds, NATO Science Series II 18 (Kluwer AP, Dordrecht, 2001) pp 423-435 [hep-th/0008010]

ZC99

C Zachos and T Curtright, Prog Theor Phys Suppl 135 (1999) 244-258 [hepth/9903254]

Zal03 K Zalewski Act Phys Pol B34 (2003) 3379-3388

ZP94

W Zurek and J Paz, Phys Rev Lett 72 (1994) 2508; S Habib, K Shizume, and W Zurek, Phys Rev Lett 80 (1998) 4361-4365; W Zurek, Rev Mod Phys 75 (2003) 715-775

Zu91 W Zurek, Physics Today 44 (Oct 1991) 36 
This page intentionally left blank 


\section{SELECTED PAPERS}

\section{H Weyl}

Z Phys 46 (1927) 1-46

Quantenmechanik und Gruppentheorie

\section{J v Neumann}

Math Ann 104 (1931) 570-578

Die Eindeutigkeit der Schrödingerschen Operatoren

\section{$3 \quad$ E Wigner}

Phys Rev 40 (1932) 749-759

On the Quantum Correction for Thermodynamic Equilibrium

\section{H Groenewold}

Physica 12 (1946) 405-460

On the Principles of Elementary Quantum Mechanics

\section{J Moyal}

Proc Camb Phil Soc 45 (1949) 99-124

Quantum Mechanics as a Statistical Theory

\section{M Bartlett and J Moyal}

Proc Camb Phil Soc 45 (1949) 545-553

The Exact Transition Probabilities of Quantum-Mechanical Oscillators Calculated by the Phase-Space Method

\section{$7 \quad$ T Takabayasi}

Prog Theor Phys 11 (1954) 341-373

The Formulation of Quantum Mechanics in Terms of Ensemble in Phase Space 


\section{G Baker}

Phys Rev 109 (1958) 2198-2206

Formulation of Quantum Mechanics Based on the Quasi-Probability Distribution Induced on Phase Space

\section{$9 \quad$ D Fairlie}

Proc Camb Phil Soc 60 (1964) 581-586

The Formulation of Quantum Mechanics in Terms of Phase Space Functions

\section{N Cartwright}

Physica 83A (1976) 210-212

A Non-Negative Wigner-Type Distribution

\section{A Royer}

Phys Rev A15 (1977) 449-450

Wigner Function as the Expectation Value of a Parity Operator

\section{F Bayen, M Flato, C Fronsdal, A Lichnerowicz, and D Sternheimer}

Ann Phys 111 (1978) 61-110; ibid 111-151

Deformation Theory and Quantization: I. Deformations of Symplectic Structures; II. Physical Applications

\section{G García-Calderón and M Moshinsky}

\section{J Phys A13 (1980) L185-L188}

Wigner Distribution Functions and the Representation of Canonical Transformations in Quantum Mechanics

\section{$14 \quad J$ Dahl and M Springborg}

Mol Phys 47 (1982) 1001-1019

Wigner's Phase Space Function and Atomic Structure. I. The Hydrogen Atom Ground State 
15 M Hillery, R O'Connell, M Scully, and E Wigner

Phys Rep 106 (1984) 121-167

Distribution Functions in Physics: Fundamentals

\section{$16 \quad \mathrm{Y}$ Kim and E Wigner}

Am J Phys 58 (1990) 439-448

Canonical Transformation in Quantum Mechanics

\section{$17 \quad$ R Feynman}

in Essays in Honor of David Bohm, B Hiley and F Peat, eds (Routledge and Kegan Paul, London, 1987) pp 235-248

Negative Probability

\section{$18 \quad M$ De Wilde and $P$ Lecomte}

Lett Math Phys 7 (1983) 487-496

Existence of Star-Products and of Formal Deformations of the Poisson Lie Algebra of Arbitrary Symplectic Manifolds

\section{B Fedosov}

J Diff Geom 40 (1994) 213-238

A Simple Geometrical Construction of Deformation Quantization

20 T Curtright, D Fairlie, and C Zachos

Phys Rev D58 (1998) 025002 1-14

Features of Time-Independent Wigner Functions

\section{T Curtright and C Zachos}

Mod Phys Lett A16 (2001) 2381-2385

Negative Probability and Uncertainty Relations 


\section{T Curtright, T Uematsu, and C Zachos}

$J$ Math Phys 42 (2001) 2396-2415

Generating All Wigner Functions

\section{M Hug, C Menke, and W Schleich}

Phys Rev A57 (1998) 3188-3205; ibid 3206-3224

Modified Spectral Method in Phase Space: Calculation of the Wigner Function: I. Fundamentals; II. Generalizations 


\section{INDEX}

Chebyshev polynomial, 13

Bohr ground-state orbit, 5

Born-Jordan prescription, 24

classical limit, 3, 8, 11, 24, 25

classical mechanics in Hilbert space, 24

classical trajectories, 14

Cohen classification, 24

coherent states, $13,15,16$

Darboux transformations, 13

deformation, 6, 24, 26, 29

diffusion in phase space, 10

distribution function, 4

dressings, 25,26

Ehrenfest's theorem, 10

entropy, 3

field theory, 2

Gaussian, 3, 11, 12, 14, 25

Glauber-Sudarshan prescription, 24

harmonic oscillator, 11

Husimi prescription, 24, 25

isospectral pairs, 13

Kirkwood-Rihaczek prescription, 24

Laguerre, 11, 16
Liouville potentials, 13

Liouville's theorem, 10

marginal probability, $3,15,25$

Morse potentials, 13

Moyal bracket, 6, 24, 26

Moyal's equation, 5,10

music score, 2

negative probability, 3

noncommutative geometry, 2

Pöschl--Teller potential, 13

path integral, 21

perturbation, 17

positivity, 9

projective orthogonality, 7

spreading wavepacket, 15

*-product, $1,2,6,10,12,19,25,26$

$\star$-genvalue, 7,30

time-frequency analysis, 2

tomographic representation, 25

transition amplitude, 9,16

turntable, 16

uncertainty, 2, 9, 15

Weyl correspondence, 1, 5, 21, 24

Wigner function, 1

Witten superpotentials, 13 
This page intentionally left blank 


\title{
Quantenmechanik und Gruppentheorie.
}

\author{
Von H. Weyl in Zürich.
}

Mit 1 Abbildung. (Eingegangen am 13. Oktober 1927.)

\begin{abstract}
Einleitung und Zusammenfassung. - I. Teil. Bedeutung der Repräsentation von physikalischen Grölen durch Hermitesche Formen. §1. Mathematische Grandbegriffe, die Hermiteschen Formen betreffend. §2. Der physikalische Begriff des reinen Falles. \& 3 . Die physikalische Bedeutung der repräsentierenden Hermiteschen Form. \$4. Statistik der Gemenge. - II. Teil. Kinematik als Gruppe. \$5. Über Gruppen und ihre unitären Darstellungen. \$6. Übertragung auf kontinuierliche Gruppen. \$7. Ersatz der kanonischen Variablen durch die Gruppe. Das Elektron. §8. Übergang zu Schrödingers Wellentheorie. III. Teil. Das dynamische Problem. §9. Das Gesetz der zeitlichen Veränderung. Die Zeitgesamtheit. \$10. Kinetische Energie und Coulombsche Kraft in der relativistischen Quantenmechanik. - Mathematischer Anhang.
\end{abstract}

\section{Einleitung und Zusammenfassung.}

In der Quantenmechanik kann man zwei Fragen deutlich voneinander trennen: 1. Wie komme ich zu der Matrix, der Hermiteschen Form, welche eine gegebene Größe in einem seiner Konstitution nach bekannten physikalischen System repräsentiert? 2. Wenn einmal die Hermitesche Form gewonnen ist, was ist ihre physikalische Bedeutung, was für physikalische Aussagen kann ich ihr entnehmen? Auf die zweite Frage hat v. Neumann in einer kürzlich erschienenen Arbeit* eine klare und weitreichende Antwort gegeben. Aber sie spricht noch nicht alles aus, was sich darüber sagen läßt, umfaßt auch nicht alle Ansätze, die bereits in der physikalischen Literatur mit Erfolg geltend gemacht worden sind. Ich glaube, daß ich in dieser Hinsicht zu einem gewissen Abschluß gelangt bin durch die Aufstellung des Begriffs des reinen Falles**. Ein reiner Fall von Atomen z. B. liegt dann vor, wenn der betrachtete Atomschwarm den höchsten Grad von Homogenität besitzt, der sich realisieren läßt. Der monochromatische polarisierte Lichtstrahl ist ein Beispiel aus anderem Gebiet. Der reine Fall wird repräsentiert durch die Variablen der Hermiteschen Form; die Form selber gibt AufschluB darüber, welcher Werte die durch sie repräsentierte Größe fähig ist, und mit welcher Wahrscheinlichkeit oder Häufigkeit diese Werte in irgend

* Mathematische Begründung der Quantenmechanik, Nachr. Gesellsch. d. Wissensch. Göttingen 1927, S. 1.

** Wie mir Herr v. Neumann mitteilt, ist auch er inzwischen zur Aufstellung dieses Begriffs gelangt [Zusatz bei der Korrektur].

Zeitschrift für Physilk. Bd. 46. 
einem vorliegenden reinen Fall angenommen werden. Auf diese Theorie des reinen Falles gründet sich erst die Statistik der Gemenge; v. Neumanns Ansatz bezog sich lediglich auf eine bestimmte Frage in diesen Gebiet.

Der II. Teil handelt von der tiefer greifenden Frage 1. Sie hängt aufs engste zusammen mit der Frage nach dem Wesen und der richtigen Definition der kanonischen Variablen. Ein Versuch in dieser Richtung, der das Problem erst in seiner wahren Allgemeinheit hervortreten ließ, ist von Herrn Jordan unternommen worden*. Doch enthalten seine Entwicklungen eine ernstliche Lücke - indem aus seinen Definitionen und Axiomen nicht hervorgeht, daß einer Funktion $f(q)$ der Lagekoordinaten $q$ diejenige Matrix $f(Q)$ zugeordnet ist, die nach dem gleichen Funktionsgesetz aus den $q$ repräsentierenden Matrizen $Q$ gebildet ist; geschweige denn, daß etwas Derartiges für Funktionen der Lage- und Impulskoordinaten geleistet würde. Ohne einen solchen Zusatz ist aber sein Schema inhaltsleer. Außerdem ist seine Fassung des Begriffs der kanonischen Variablen mathematisch unbefriedigend und physikalisch nicht haltbar. Hier glaube ich mit Hilfe der Gruppentheorie zu einer tieferen Einsicht in den wahren Sachverhalt gelangt zu sein **. Der innere prinzipielle Grund für die kanonische Paarung tritt dadurch deutlich hervor, die sich einstellt, wenn die zugrunde liegende Gruppe eine kontinuierliche ist; aber der Ansatz umspannt zugleich die diskreten Fälle wie das magnetische Elektron (Vierergruppe), wo von einer kanonischen Paarung vernünftigerweise nicht mehr die Rede sein kann. Im kontinuierlichen Gebiet mache ich gegenüber dem differentiellen den integralen Standpunkt geltend, indem ich überall die infinitesimale Gruppe, an welche die Formulierung bisher sich klammerte, durch die volle kontinuierliche Gruppe ersetze. Der Übergang zu Schrödingers Wellengleichungen läßt sich dann in aller Strenge vollziehen. Als weiteren Erfolg meines Ansatzes möchte ich anführen, daß er gestattet, den Funktionalausdruck einer Größe wie etwa der Energie durch die

* Uber eine neue Begründung der Quantenmechanik, ZS. f. Phys. 40, 809, 1927; 44, 1, 1927. Vgl. ferner P. A. M. Dirac, Proc. Royal Soc. (A) 113, 621, 1927, und D. Hilbert, J. จ. Neumann, L. Nordheim, Über die Grundlagen der Quantenmechanik, Math. Ann. 98, 1, 1927.

** Diese Verknüpfung mit der Gruppentheorie liegt in ganz anderer Richtung als die Ontersuchungen von Herrn Wigner, die erkennen lassen, daß die Struktur der Spektren nach ihrer qualitativen Seite hin durch die bestehende Symmetriegruppe bestimmt ist (mehrere Arbeiten in der ZS. f. Phys. 40, 492 und 883; 43, $624,1926 / 1927)$. 
kanonischen Variablen nach einer eindeutigen Vorschrift auf die Matrizen zu übertragen, um was für Funktionen es sich auch handeln mag; während die bisherige Fassung sich ernstlich nur auf Polynome bezog und auch dann noch dahingestellt bleiben mußte, ob man ein Monom wie $p^{2} q$ im Matrizenkalkül als $p^{2} q$ oder $q p^{2}$ oder $p q p$ oder als eine Kombination von dem allen $z u$ interpretieren hatte.

Die Durchführung konkreter Fälle verlangt die Lösung des dynamischen Problems. Das ist wohl im Grunde die Aufgabe, unter den Größen des Gruppengebiets diejenigen zu ermitteln, welche den gemessenen Ort und die gemessene Zeit bedeuten. Hier liegt ein Schema bisher nur für den Fall vor, daß die Zeit als einzige unabhängige Veränderliche auftritt (Ausschluß der Feldtheorie) und daß die Zeit auch nur als unabhängige Variable, nicht als reale Zustandsgröße vorkommt (Ausschluß der eigentlichen Relativitätsmechanik). Dennoch läßt sich wenigstens der relativistische Ansatz der kinetischen Energie ohne weiteres in die Quantenmechanik übertragen. Ich behandle diese Dinge im letzten Kapitel mehr zur Lllustration der allgemeinen Theorie. Die Analoga der Schrödingerschen Schwingnngsgleichungen sind dabei keine eigentlichen Differentialgleichungen, sondern an Stelle der gewöhnlichen Differentiation treten differentiationsartige Prozesse.

Über die benötigten mathematischen Begriffe und Tatsachen habe ich in eingeschobenen Absätzen kurz referiert. In einem Anhang sind die wichtigsten mathematischen Fundamente der Theorie durch Beweise gestützt worden. Dem physikalischen Leser hoffe ich damit mehr zu dienen als mit Hinweisen auf die mathematische Literatur, die ihm das hier Erforderliche meist nur in Verschlingung mit anderen, ihn nicht interessierenden Dingen bietet.

I. Teil. Bedeutung der Repräsentation von physikalischen Größen durch Hermitesche Formen.

§ 1. Mathematische Grundbegriffe, die Hermiteschen Formen betreffend. Die in der Überschrift angekündigten Grundbegriffe und -tatsachen stelle ich bier in der Nomenklatur der mehrdimensionalen analytischen Geometrie kurz zusammen. Das Abweichende von der gewöhnlichen $n$-dimensionalen Geometrie liegt darin, daß die Komponenten der Vektoren

$$
\mathfrak{x}=\left(x_{1}, x_{2}, \ldots, x_{n}\right)
$$


nicht nur reelle, sondern beliebige komplexe Zahlen sein können, und dab als Quadrat des Betrages eines Vektors dementsprechend die ${ }_{n}$ Hermitesche Einheitsform"

$$
|\mathfrak{z}|^{2}=x_{1} \bar{x}_{1}+x_{2} \bar{x}_{2}+\cdots+x_{n} \bar{x}_{n}
$$

der Metrik zugrunde liegt (der Querstrich bedeutet den Übergang zur konjugiert komplexen Zahl). Vektoren (1) werden in der üblichen Weise mit Zahlen multipliziert und addiert. Sie bilden eine $n$-dimensionale lineare Mannigfaltigkeit, den Vektorraum oder Vektorkörper $\mathfrak{\Re}_{n}$; d. h. es lassen sich auf mancherlei Art $n$ Vektoren $e_{1}^{*}, e_{2}^{*}, \ldots, e_{n}^{*}$ so auswählen, $\mathrm{da} \cap$ jeder Vektor $\mathfrak{x}$ auf eine und nur eine Weise in der Form

$$
\mathfrak{x}=x_{1}^{*} \mathrm{e}_{1}^{*}+x_{2}^{*} \mathrm{e}_{2}^{*}+\cdots+x_{n}^{*} \mathrm{e}_{n}^{*}
$$

sich darstellen läßt. Wird z. B. $e_{i}^{*}$ als der Vektor $\mathfrak{e}_{i}=(0,0, \ldots, 1,0, \ldots, 0)$ gewählt ( 1 steht an $i$-ter Stelle), so fallen die "Komponenten $x_{i}^{*}$ von $x$ in bezug auf das Koordinatensystem $\left(\mathfrak{e}_{1}^{*}, \mathfrak{e}_{2}^{*}, \ldots, \mathfrak{e}_{n}^{*}\right)^{\text {" mit den }}$ "absoluten Komponenten " $x_{i}$ zusammen. Ein Koordinatensystem, in welchem das Quadrat des Betrages von $\mathfrak{x}$ sich durch die Komponenten $x_{i}$ des willkürlichen Vektors x mittels der Formel (2) ausdrückt, heiße normal. Alle normalen Koordinatensysteme sollen als gleichberechtigt gelten, das durch unseren arithmetischen Ausgangspunkt bedingte spezielle Koordinatensystem $\left(e_{i}\right)$ soll unter ihnen seine ausgezeichnete Stellung verlieren. In Zukunft bedeutet daher auch $e_{i}$ ein beliebiges normales $\mathrm{K}_{0}$ ordinatensystem, $x_{i}$ die darauf bezüglichen Komponenten des Vektors $x_{.}$ Die Formeln für den Übergang vom Koordinatensystem $e_{i}$ zu einem anderen $e_{i}^{\prime}$ lauten allgemein:

$$
\mathrm{e}_{i}^{\prime}=\sum_{k} e_{i k} \mathrm{e}_{k}, \quad x_{k}=\sum_{i} e_{i k} x_{i}^{\prime} .
$$

Die Bedingungen, welche die Koeffizienten $e_{i k}$ erfüllen müssen, damit eine "unitäre Transformation" vorliegt, welche zwischen zwei normalen Koordinatensystemen vermittelt, sind leicht aus der Definition zu ermitteln und entsprechen genau den aus der elementaren analytischen Geometrie geläufigen. Wenn wir mit $E$ die Matrix $\left\|e_{i k}\right\|$ bezeichnen und der * das Transponieren einer Matrix, die Vertauschung von Zeilen und Spalten bedeutet, 1 aber die die Identität darstellende Einheitsmatrix, so lauten sie:

$$
E \bar{E}^{*}=\bar{E}^{*} E=\mathbf{1}
$$

Die Formeln (3) oder, wie ich jetzt lieber schreiben will:

$$
x_{k}^{\prime}=\sum_{i} e_{i k} x_{i}
$$


haben bekanntlich noch eine zweite Bedeutung; sie stellen, unter Zagrundelegung des festen normalen Koordinatensystems der $\mathfrak{e}_{\boldsymbol{i}}$, eine unitäre Abbildung des Vektorraumes auf sich selber dar, vermöge deren dem Vektor $\mathfrak{x}=\sum x_{i} \mathrm{e}_{i}$ der Vektor $\mathfrak{x}^{\prime}=\sum x_{i}^{\prime} \mathrm{e}_{i}$ zugeordnet wird. Ich bezeichne diese Abbildung kurz mit $\mathfrak{k}^{\prime}=\mathfrak{x}$. Dann drückt sich die Zusammensetzung zweier Abbildungen

$$
\mathfrak{x}^{\prime}=\mathfrak{x} E, \quad \mathfrak{x}^{\prime \prime}=\mathfrak{x}^{\prime} E^{\prime}
$$

naturgemäß durch $\mathfrak{x}^{\prime \prime}=\mathfrak{x}\left(E E^{\prime}\right)$ aus $-E, E^{\prime}$ folgen sich von links nach rechts, wie wir zu lesen gewohnt sind -, und man befindet sich in Einklang mit der üblichen Festsetzung des Matrizenkalküls, nach welcher aus

$$
E=\left\|e_{i k}\right\|, \quad E^{\prime}=\left\|e_{i k}^{\prime}\right\|
$$

durch Komposition die Matrix $E E^{\prime}$ mit den Koeffizienten

$$
\sum_{r} e_{i r} e_{r k}^{\prime}
$$

entsteht. Der geometrische Standpunkt kommt darauf hinaus, daß wir im Vektorraum nur solche Verhältnisse studieren, welche invariant sind gegenüber beliebigen unitären Abbildungen. Es ist noch bequem, neben (2) das skalare Produkt (xy) zweier Vektoren $\mathfrak{x}$ und $\mathfrak{y}$ durch

$$
\left(x^{\natural}\right)=x_{1} \bar{y}_{1}+x_{2} \bar{y}_{2}+\cdots+x_{n} \bar{y}_{n}
$$

einzuführen. (yx) ist das Konjugierte zu $(\mathfrak{y} y)$. Man wird zwei Vektoren senkrecht aufeinander nennen, wenn ihr skalares Produkt verschwindet.

Zwei von 0 verschiedene Vektoren gehören demselben Strahl an, wenn der eine aus dem anderen durch Multiplikation mit einer (komplexen, von 0 verschiedenen) Zahl hervorgeht. Ein Strahl kann eindeutig bezeichnet werden durch einen ihm angehörenden Vektor x vom Betrage 1 (Einheitsvektor). Aber dieser ist seinerseits durch den Strahl nicht eindeutig bestimmt, sondern an Stelle von $\mathfrak{x}$ kann mit gleichem Recht jeder Vektor $\varepsilon$ treten, der aus ihm durch Multiplikation mit einer beliebigen Zahl $\varepsilon$ vom absoluten Betrage 1 hervorgeht. Das ist wesentlich anders als im gewöhnlichen Raum, wo nur die Doppeldeutigkeit eines Vorzeichens \pm 1 übrigbleibt. Fasse ich eine unitäre Abbildung (4) auf nicht als Abbildung des Vektor-, sondern des Strahlenkörpers (homogener Standpunkt), so soll sie kurz eine Drehung heißen. $E$ und $E^{\prime}$ stellen dieselbe Drehung dar: $E \simeq E^{\prime}$, wenn $E^{\prime}=\varepsilon E$ ist; $\varepsilon$ bedeutet dabei, wie im folgenden stets, einen Zahlfaktor vom Betrage 1 . 
Eine Hermitesche Form ist eine Funktion des willkürlichen Vektors $\mathfrak{x}=\left(x_{i}\right)$ von der Gestalt*

$$
A(\mathfrak{l})=\sum_{i, k=1}^{n} a_{i k} x_{i} \bar{x}_{k},
$$

deren Koeffizienten $a_{i k}$ die Symmetriebedingung

$$
a_{k i}=\bar{a}_{i k} \quad \text { oder } \quad \overrightarrow{A^{*}}=A
$$

erfüllen. Mit $A$ bezeichne ich zugleich die Koeffizientenmatrix $\left\|a_{i k}\right\|$ in dem gerade benutzten Koordinatensystem. Wieder ist es zweckmäßig, damit die zugehörige bilineare Bildung zu verknüpfen:

$$
A(\mathfrak{x}, \mathfrak{y})=\sum_{i, k} a_{i k} x_{i} \bar{y}_{k} \text {. }
$$

Es ist zufolge der Symmetriebedingung

$$
A(\mathfrak{y}, \mathfrak{z})=\overline{A(\mathfrak{x}, \mathfrak{y}),}
$$

und das ist ihre von der Wahl des Koordinatensystems unabhängige Schreibweise. Insbesondere gilt $\overline{A\left(\mathfrak{l}^{*}\right)}=A\left(\mathrm{x}^{*}\right)$, d. h. die Werte der Hermiteschen Form sind reell; ihr Wert ändert sich nicht, wenn der Argumentvektor $\mathfrak{x}$ ersetzt wird durch $\varepsilon x$. Mit jeder Hermiteschen Form $A$ ist in unitär-invarianter Weise die Abbildung $\mathfrak{x}^{\prime}=\mathfrak{x} A$ verknüpft, welche dieselbe Koeffizientenmatrix besitzt. Die invariante Natur der Verknüpfung geht daraus hervor, dal die Abbildung einem Vektor $\mathfrak{x}$ denjenigen $\mathfrak{x}^{\prime}$ zuordnet, der identisch in $\mathfrak{y}$ die Gleichung erfüllt:

$$
\left(\mathfrak{x}^{\prime} \mathfrak{y}\right)=A(\mathfrak{x} \mathfrak{y}) \text {. }
$$

Die Grundtatsache für Hermitesche Formen ist der Satz von der Hauptachsentransformation: Fin normales Koordinatensystem $e_{i}$ kann zu $A$ so gewählt werden, dab in ihm

$$
A\left(l^{\prime}\right)=a_{1} x_{1} \bar{x}_{1}+a_{2} x_{2} \bar{x}_{2}+\cdots+a_{n} x_{n} \bar{x}_{n}
$$

wird. Die Eigenwerte $a_{1}, a_{2}, \ldots, a_{n}$ sind eindeutig durch die Hermitesche Form bestimmt (natürlich nur bis auf die Reihenfolge). Was die zugehörigen Hauptachsen oder Eigenvektoren $e_{i}$ betrifft, so steht es mit ihnen in Hinsicht der eindeutigen Bestimmtheit folgendermaßen. Seien etwa die Eigenwerte $a_{1}, a_{2}, a_{3}$ einander gleich, $=a$, und von den übrigen verschieden. Dann gehört zum Eigenwert $a$ der von den Grund vektoren $e_{1}, e_{2}, e_{3}$ aufgespannte dreidimensionale Eigenraum $\mathfrak{\Re}(a)$, der aus allen Vektoren ż von der Gestalt $x_{1} \mathfrak{e}_{1}+x_{2} \mathfrak{e}_{2}+x_{3} \mathfrak{e}_{3}$ besteht; in ihm ist $\left(e_{1}, e_{2}, e_{3}\right)$ ein normales Koordinatensystem. Die $z u$ den

* Formen und Matrizen werden stets mit großen lateinischen Buchstaben bezeichnet. 
numerisch verschiedenen Eigenwerten $a^{\prime}, a^{\prime \prime}, \ldots$ gehörigen Teilräume $\mathfrak{\Re}\left(a^{\prime}\right), \mathfrak{\Re}\left(a^{\prime \prime}\right), \ldots$, die gegenseitig aufeinander senkrecht stehen, sind durch $A$ eindeutig determiniert; in jedem von ihnen kann aber das normale Koordinatensystem willkürlich gewählt werden. Das letzte bedeutet in dem angenommenen Beispiel, daß $x_{1}, x_{2}, x_{3}$ untereinander noch einer beliebigen unitären Transformation unterworfen werden können, ohne daß die Normalform (7) zerstört wird.

Zwei Hermitesche Formen $A, B$ lassen sich dann und nur dann simultan auf Hauptachsen transformieren, wenn die Koeffizientenmatrizes vertauschbar sind: $A B=B A$. Ein entsprechender Satz gilt für mehr als zwei Hermitesche Formen, ja für irgend eine endliche oder unendliche Gesamtheit solcher Formen.

§2. Der physikalische Begriff des reinen Falles. Ich exemplifiziere am Beispiel des magnetischen Elektrons, weil hier sehr einfache, aber vom klassischen Standpunkt paradoxe Verhältnisse vorliegen. Nach der Annahme von Goudsmit und Uhlenbeck, die sich seither bestens bewährt hat, muB man dem Elektron ein eigenes Impulsmoment zuschreiben, dessen Komponente $\sigma_{x}$ in einer beliebigen Richtung, etwa der $x$-Richtung, nur der beiden Werte +1 und -1 fäbig ist, wenn $h / 4 \pi$ als Einheit zugrunde gelegt wird. Man kann sich vorstellen, daß aus einem gegebenen Elektronenstrom, durch ein Verfahren analog dem bekannten Stern-Gerlachschen Experiment zum Nachweis der Richtungsquantelung bei Atomen, der Schwarm derjenigen Elektronen ausgesondert wird, für welche $\sigma_{x}$ den Wert +1 hat. Die Elektronen dieses Schwarms $\mathfrak{S}_{x}$ mögen keine Störung erfahren, so daß für sie alle dauernd mit Sicherheit $\sigma_{x}$ den Wert +1 besitzt. In einem solchen Elektronenschwarm haben wir (wenn wir noch von Ort und Geschwindigkeit der Elektronen abstrahieren) einen "reinen Fall" vor uns: er ist von einer inneren Homogenität, die prinzipiell nicht mehr gesteigert werden kann. Denn alle physikalischen Fragen, welche sich sinnvoll mit Bezug auf ihn stellen lassen, finden eine von vornherein angebbare numerisch bestimmte Antwort. Solche Fragen sind allein die folgenden: Ist $r$ irgend eine Richtung, mit welcher Wahrscheinlichkeit hat für ein Elektron des $\mathfrak{S}_{x}$-Schwarms die Größe $\sigma_{r}$ den Wert +1 oder -1 ? Die numerisch bestimmte Antwort lautet: Wenn $\vartheta$ der Winkel ist, den die $r$ - mit der $x$-Richtung bildet, so sind die beiden Wahrscheinlichkeiten bzw.

$$
=\cos ^{2} \frac{\vartheta}{2} \text { und }=\sin ^{2} \frac{\vartheta}{2} \text {. }
$$


Die Wahrscheinlichkeit ist als Häufigkeit im Elektronenschwarm zu verstehen; sie würde sich, wenn mit dem Schwarm das Aussonderungsexperiment in der $r$-Richtung vorgenommen würde, in dem Stärkeverbältnis der beiden Teilstrahlen bekunden*. Hätten wir am Anfang statt der $x$ - eine andere, die $x^{\prime}$-Richtung zugrunde gelegt, so hätten wir einen anderen reinen Fall, den Elektronenschwarm $\mathfrak{S}_{x^{\prime}}$ bekommen. In ihm hat $\sigma_{r}$ mit der Wahrscheinlichkeit $\cos ^{2} \frac{\vartheta^{\prime}}{2}$ den Wert +1 , mit der Wahrscheinlichkeit $\sin ^{2} \frac{\vartheta^{\prime}}{2}$ den Wert -1 , wenn $\vartheta^{\prime}=\not\left(r, x^{\prime}\right)$ ist; insbesondere hat $\sigma_{x^{\prime}}$ mit Sicherheit den Wert +1 . Dieser reine Fall ist von dem ersten verschieden, weil die gleichen physikalischen Fragen hier andere numerische Antworten finden. Es gibt so viele verschiedene reine Fälle, wie es verschiedene Richtungen $x$ gibt. Wir können aus solchen reinen Strömen $\mathfrak{S}_{x}, \mathfrak{S}_{x^{\prime}}, \ldots$ Mischungen in irgend einem Verhältnis herstellen. Die Häufigkeit, mit welcher in einem solchen Mischstrom ein $\sigma_{r}=+1$ oder -1 ist, hängt von dem Mischungsverhältnis ab. Wir sind hier umgekehrt darauf angewiesen, aus den experimentell beobachteten Häufigkeiten Schlüsse auf die Konstitution des Mischstromes zu ziehen. Der Unterschied zwischen reinem Fall und Mischung, den ich hier aufstelle, ist analog zu den biologischen Begriffen der "reinen Linie" (innerhalb der reinen Linie gelten die Mendelschen Vererbungsgesetze) und der "Population" (auf welche sich die Gesetze von Galton bezogen). Hier wie dort ist es eine wichtige Aufgabe der Experimentierkunst, reine Linien zn isolieren. Die Unterscheidung: Theorie der reinen Fälle einerseits, Statistik der Gemenge andererseits, scheint mir fundamental für die richtige Erfassung des Sinnes der Quantenmechanik.

An dem 'Tatbestand, die Elektronenschwärme betreffend, wie er bisher beschrieben wurde, ist nichts Paradoxes. Statt vom Schwarm spreche ich in Zukunft vom einzelnen Elektron und demgemäb von Wahrscheinlichkeit statt von Häufigkeit. Etwas Paradoxes liegt erst in der Aussage, daß $\sigma_{x}$ die Komponente eines gewissen Vektors, des Impulsmomentes, in bezug auf die $x$-Richtung ist. Denn dies involviert doch, wenn wir ein rechtwinkliges Koordinatensystem $x y z$ im Raume ein-

* Obwohl also $\Xi_{x}$ noch wieder zerlegt werden kann, sind doch die so entstehenden Teilstrahlen nicht homogener als $\mathfrak{S}_{x}$ selbst. Das ist genau wie bei einem Lichtstrahl, der durch zwei gegeneinander verdrehte Nicols hindurchgegangen ist: er ist von derselben Beschaffenheit wie Licht, das nur durch den zweiten Nicol hindarchging. 
führen und die willkürliche Richtung $r$ die Richtungskosinus $a, b, c$ hat, die Gleichung

$$
\sigma_{r}=a \sigma_{x}+b \sigma_{y}+c \sigma_{z} \text {. }
$$

Wie verträgt sich das mit dem Umstand, daß $\sigma_{r}$ so gut wie $\sigma_{x}, \sigma_{y}, \sigma_{z}$ nur der Werte \pm 1 fähig ist? Aber in einem vorliegenden reinen Fall haben die hier auftretenden Größen überhaupt keine mit Sicherheit angebbaren Werte, so dal zunächst der Sinn der Gleichung (8), wenn er in der üblichen Weise auf die Werte der physikalischen Größen bezogen werden soll, ganz im Leeren hängt. Sie wird einen Inhalt erst gewinnen, wenn wir die physikalischen Größen durch solche mathematische Entitäten darstellen, welche Multiplikation mit reellen Zablen und Addition untereinander zulassen. - Und was soll es zweitens heißen, daß dieser Velktor mit den Komponenten $\sigma_{x}, \sigma_{y}, \sigma_{z}{ }_{n}$ Impulsmoment" ist? Damit wird offenbar ein bestimmtes Verhalten dieser Größen gegenüber einem das Elektron einbettenden Magnetfeld $\left(H_{x}, H_{y}, H_{z}\right)$ ausgesagt. Wenn wir uns das Elektron ganz naiv als ein rotierendes Kügelchen vorstellen, in welchem das Verhältnis von Ladungs- und Massendichte überall konstant ist, so ergibt sich in der Hamiltonschen Energiefunktion die Hälfte des Terms

$$
\mu\left(H_{x} \sigma_{x}+H_{y} \sigma_{y}+H_{z} \sigma_{z}\right)
$$

dessen Faktor $\mu=\frac{e h}{4 \pi m c}$ das Bohrsche Magneton ist (e Ladung $m$ Masse des Elektrons, $c$ Lichtgeschwindigkeit). Der spektroskopische Erfolg der Annahme von Goudsmit und Uhlenbeck beruht bekanntlich darauf, dal für das Elektron der Ausdruck (9) ohne den Faktor $1 / 2$ als gültig betrachtet wird. Wieder ist es nötig, den Sinn eines Rechenausdrucks wie (9) zu verstehen, der die Addierbarkeit der Größen $\sigma$ voraussetzt; darüber hinaus muß aber erkannt werden, in welcher Weise die Hamiltonsche Energiefunktion das dynamische Geschehen bestimmt.

§3. Die physikalische Bedeutung der repräsentierenden Hermiteschen Form. Der Kalkül der Hermiteschen Formen entspricht in rechnerischer Hinsicht allen Anforderungen, welche sich aus dem eben entwickelten Programm ergeben. Jede physikalische Größe wird repräsentiert durch eine Hermitesche Form, alle physikalischen Größen an demselben System durch Hermitesche Formen der gleichen Variablen $x_{i}$. Es ist der schwierigere Teil der Physik, die Regeln ausfindig zu machen, nach denen man zu einer physikalischen Größe die repräsentierende Form und ihre Matrix findet. Hier soll zunächst nur davon die Rede sein, was diese Matrix physikalisch 
bedeutet. Ich nehme dabei die Dimensionszahl $n$ des Vektorraums, die Zahl der Variablen $x_{i}$ endlich, obschon sie in den meisten Fällen unendlich groß ist. Alles Gesagte läßt sich aber analogisch auf den unendlich dimensionalen Vektorraum übertragen. Im oben besprochenen Beispiel des Elektrons ist, wie sich zeigen wird, $n=2$.

Der einzelne reine Fall wird durch einen Vektor $x$ vom Betrage 1 in unserem $n$-dimensionalen Vektorraum gegeben, die einzelne physikalische Größe $\alpha$ wird repräsentiert durch eine Hermitesche Form $A$ in diesem Raume. Mittels Einführung eines geeigneten normalen Koordinatensystems $\mathfrak{e}_{1}, \mathfrak{e}_{2}, \ldots, \mathfrak{e}_{n}$ bringe man $A(\mathfrak{k})$ auf Hauptachsen:

$$
\begin{aligned}
A(\mathfrak{x})=a_{1} x_{1} \bar{x}_{1}+a_{2} x_{2} \bar{x}_{2}+\cdots+a_{n} x_{n} \bar{x}_{n} \\
\left(x=x_{1} \mathrm{e}_{1}+x_{2} \mathrm{e}_{2}+\cdots+x_{n} \mathrm{e}_{n}\right) .
\end{aligned}
$$

Die Eigenwerte $a_{1}, a_{9}, \ldots, a_{n}$ bedeuten die Werte, deren die physikalische Größe $\alpha$ überhaupt fähig ist; die Zahlen $\left|x_{1}\right|^{2}$, $\left|x_{2}\right|^{2}, \ldots,\left|x_{n}\right|^{2}$ bedeuten die Wahrscheinlichkeiten $W(\mathrm{x})$, mit denen in dem reinen Fall $x$ diese Werte angenommen werden. Ihre Summe ist $=1$, weil $x$ ein Vektor vom Betrage 1 ist. Der zweite Teil der Aussage erfordert noch eine gewisse Präzisierung für den Fall, da $B$ mehrere Eigenwerte gleich sind. Sei etwa wieder $a_{1}=a_{2}=a_{3}=a$ von den übrigen Eigenwerten verschieden; dann gehört zu dem Eigenwert $a$ der dreidimensionale Eigenraum $\mathfrak{R}(a)$, der durch die Vektoren $e_{1}$, $e_{2}, e_{3}$ aufgespannt wird. Die Wahrscheinlichkeit, mit welcher die pbysikalische Größe $\alpha$ in dem reinen Fall $x$ den Wert $a$ annimmt, ist dann $=\left|x_{1}\right|^{2}+\left|x_{2}\right|^{2}+\left|x_{3}\right|^{2}$, d. i. gleich dem Quadrat des Betrages der senkrechten Projektion des Vektors $x$ auf den Eigenraum $\mathfrak{\Re ( a )}$. Es ist wesentlich zu bemerken, da $\boldsymbol{B}$ mit den Eigenräumen auch die in ihnen liegenden Projektionen des gegebenen Vektors $x$ durch die Form $A$ eindeutig bestimmt sind. Gemäß den Wahrscheinlichkeiten, mit denen die Werte $a_{i}$ angenommen werden, ist der Wert $A(x)$ der Hermiteschen Form selber der Mittelwert der Größe $\alpha$ im reinen Fall $x$.

Da alle Aussagen über den reinen Fall æุ numerisch ungeändert bleiben, wenn $\mathfrak{x}$ durch $\varepsilon \mathfrak{x}$ ersetzt wird, darf zwischen ihnen nicht unterschieden werden. Dem reinen Fall entspricht also nicht eigentlich der Vektor, sondern der Strahl; wir haben nicht im Vektor-, sondern im Strahlkörper zu operjeren. Dieser Umstand wird erst im zweiten Teil seine fundamentale Bedeutung enthüllen. 
Es ist klar, daß man Hermitesche Formen addieren und daß man sie mit reellen Zahlen multiplizieren kann, ohne dadurch aus ihrem Bereich herauszutreten. Die kalkulatorischen Anforderungen, die wir am Schluß von $\& 2$ erhoben, sind erfïllt.

Wenn die Werte, deren die physikalische Größe $\alpha$ fähig ist, sehr dicht liegen oder gar eine kontinuierliche Skale bilden, wird man nicht fragen nach der Wahrscheinlichkeit, mit welcher sie einen bestimmten Wert annimmt, sondern mit der sie in ein bestimmtes Wertintervall $a \leqq \alpha \leqq a^{\prime}$ hineinfällt. Nach unserer Anweisung haben wir dann im Hauptachsensystem diejenigen Eigenvektoren $e_{i}$ aufzusuchen, deren zugehörige Eigenwerte $a_{i}$ in jenes Intervall hineinfallen; sie spannen den Teilraum $\mathfrak{R}_{a}^{a^{\prime}}$ auf. Die gesuchte Wahrscheinlichkeit ist die auf diesen Teil der Indizes $i$ sich erstreckende Summe

$$
\sum_{i} x_{i} \bar{x}_{i} \quad\left(a \leqq a_{i} \leqq a^{\prime}\right)
$$

der quadrierte Betrag der senkrechten Projektion des den reinen Fall darstellenden Vektors $x$ auf den Teilraum $\mathfrak{R}_{a}^{a^{\prime}}$. Die Formen (11) sind es, welche v. Neumann a. a. O. als "Einzelformen " $E_{a}^{a^{\prime}}$ einführte.

Liegen mehrere Größen $\alpha, \beta, \ldots$ vor, deren zugehörige Hermitesche Formen vertauschbare Foeffizientenmatrizes besitzen, so lassen sie sich alle simultan durch Einführung eines geeigneten normalen Koordinatensystems $\mathfrak{e}_{i}$ auf Hauptachsen transformieren. Die korrespondierenden Eigenwerte zu $\mathrm{e}_{i}$ mögen $a_{i}, b_{i}, \ldots$ heißen. $\mathfrak{x}=\mathrm{e}_{i}$ stellt einen reinen Fall vor, in welchem jede der betrachteten Größen mit Sicherheit einen bestimmten Wert hat, nämlich $\alpha$ den Wert $a_{i}, \beta$ den Wert $b_{i}$ usw. Die klassische Physik nimmt an, daß es sich für alle Größen so verhält, und sie läßt nur die reinen Fälle $e_{1}, e_{2}, \ldots, e_{n}$, die besonders ausgezeichnet sind und in denen alle Größen einen bestimmten Wert haben, als reine Fälle zu und faßt die anderen bereits als Gemenge von ihnen auf. Sobald aber zwei physikalische Gröben auftreten, deren Matrizes nicht vertauschbar sind, entfällt diese Möglichkeit: In einem reinen Falle, in welchem die erste Größe einen mit Sicherheit angebbaren Wert hat, bestehen für die Werte der zweiten Größe nur Wahrscheinlichkeiten. Das ist in Einklang mit Heisenbergs Anschauungen, wie er sie kürzlich in dieser Zeitschrift $(43,172,1927)$ entwickelte.

Im Beispiel des Elektrons ist $n=2$, weil jede Größe nur zweier Werte fähig ist. Unter. Verwendung eines bestimmten normalen 
Hં. Weyl,

Koordinatensystems $\mathrm{e}_{1}, \mathrm{e}_{2}$ lauten die den Größen $\sigma_{x}, \sigma_{y}, \sigma_{z}$ entsprechenden Matrizen *

$$
S_{x}=\left\|\begin{array}{rr}
1 & 0 \\
0 & -1
\end{array}\right\|, \quad S_{y}=\left\|\begin{array}{ll}
0 & 1 \\
1 & 0
\end{array}\right\|, \quad S_{z}=\left\|\begin{array}{ll}
0 & i \\
-i & 0
\end{array}\right\|,
$$

oder als Hermitesche Formen geschrieben:

$$
x_{1} \bar{x}_{1}-x_{2} \bar{x}_{2}, \quad x_{1} \bar{x}_{2}+x_{2} \bar{x}_{1}, \quad i\left(x_{1} \bar{x}_{2}-x_{2} \bar{x}_{1}\right) \text {. }
$$

Jede von ihnen, ja auch das zu einer beliebigen anderen Richtung $r$ mit den Richtungskosinus $a, b, c\left(a^{2}+b^{2}+c^{2}=1\right)$ gehörige

$$
S_{r}=a S_{x}+b S_{y}+c S_{z}=\left\|\begin{array}{lr}
a, & b+i c \\
b-i c, & -a
\end{array}\right\|
$$

hat die Eigenwerte \pm 1 . Der reine Fall, bei welchem $\sigma_{x}$ mit Sicherheit den Wert +1 hat, ist durch den Vektor $e_{1}$ gegeben. Im reinen Fall $\mathfrak{x}=\left(x_{1}, x_{2}\right)$ sind die Wahrscheinlichkeiten für $\sigma_{2}= \pm 1$ bzw. gleich $\left|x_{1}\right|^{2},\left|x_{2}\right|^{2}$. Wir suchen eine Richtung $r$ auf, deren zugehöriges $\sigma_{r}$ in diesem Falle mit Sicherheit den Wert +1 hat, d. h. für welche der Vektor $\left(x_{1}, x_{2}\right)$ in die zum Eigenwert +1 gehörige Hauptachse von $S_{r}$ fällt:

Daraus ergibt sich

$$
\begin{aligned}
& a x_{1}+(b+i c) x_{2}=x_{1} \\
& (b-i c) x_{1}-a x_{2}=x_{2} .
\end{aligned}
$$

$$
x_{1}: x_{2}=b+i c: 1-a=1+a: b-i c .
$$

$a$ ist der Kosinus des Winkels $\vartheta$ zwischen der $r$ - und der $x$-Richtung. Wir finden

$$
\begin{aligned}
\left|x_{1}\right|^{2}:\left|x_{2}\right|^{2} & =b^{2}+c^{2}:(1-a)^{2}=1-a^{2}:(1-a)^{2} \\
& =1+a: 1-a=\cos ^{2} \frac{\vartheta}{2}: \sin ^{2} \frac{\vartheta}{2}
\end{aligned}
$$

\$ 4. Statistik der Gemenge. Liegt ein Gemenge vor, in welchem der reine Fall $\mathfrak{x}$ mit der relativen Stärke $v_{\mathfrak{z}}$ vertreten ist, $\sum v_{\mathfrak{z}}=1$, so ermitteln sich die in ihm stattfindenden Wahrscheinlichkeiten $W$ offenbar durch Summation über die den einzelnen reinen Fällen $\mathfrak{x}$ zugehörigen Wahrscheinlichkeiten $W(\mathfrak{l})$ in der Form

$$
W=\sum_{\Sigma} v_{\varepsilon} W(\mathfrak{x})
$$

Darin liegt keinerlei neuer Ansatz. Wenn das Gemenge ein ganzes Kontinuum reiner Fälle enthält, verwandeln sich die Summen in Integrale.

* W. Pauli jr., Zur Quantenmechanjk des magnetischen Elektrons, ZS. f. Phys. 43, 601, 1927; P. Jordan, ebenda 44, $21 \mathrm{ff}$., 1927. 
Wenn wir nur wissen, welche reinen Fälle æi in einem Gemenge vertreten sind - sie werden ein gewisses Gebiet \& des Strahlenkörpers ausfüllen —, werden wir der Statistik die Annahme zugrunde legen, daß innerhalb \&s alle xi gleichberechtigt sind. Diese Annahme ist möglich und hat einen klaren Sinn, weil der $x$-Raum als metrischer Raum ein natürliches Volumenmaß trägt. Solche Gemenge entstehen namentlich durch Störungen, z. B. durch die Wärmebewegung und die Zusammenstöße der Partikeln, auf welche sich die Wahrscheinlichkeitsfeststellungen beziehen. Zunächst ist bei Mittelung über den ganzen Strahlenkörper

$$
\left\langle x_{i} \bar{x}_{i}\right\rangle=\frac{1}{n}, \quad\left\langle x_{i} \bar{x}_{k}\right\rangle=0 \quad(i \neq k) .
$$

Die Klammer 〈〉 bezeichnet den Mittelwert. Danach ist der Mittelwert der durch die Form (5) dargestellten Größe $\alpha$, wenn über die auftretenden reinen Fälle gar nichts bekannt ist,

$$
=\frac{1}{n}\left(a_{12}+a_{22}+\cdots+a_{n n}\right) \text {. }
$$

Die Summe der Glieder in der Hauptdiagonale, die Spur der Hermiteschen Form, stellt sich übrigens dadurch als eine Invariante gegenüber unitären Transformationen heraus.

Ein weiteres Problem dieser Art ist das folgende: $\alpha$ und $\beta$ seien zwei bzw. durch $A$ und $B$ repräsentierte Grọ̈en. Ich führe die beiden aus den Eigenvektoren $\mathfrak{e}_{i}$ und $\mathrm{e}_{i}^{*}$ von $A$ bzw. $B$ bestehenden normalen Koordinatensysteme ein:

$$
A(\mathfrak{x})=\sum_{i} a_{i} x_{i} \bar{x}_{i}, \quad B(\mathfrak{x})=\sum_{i} b_{i} x_{i}^{*} \bar{x}_{i}^{*} \quad\left(\mathfrak{x}=\sum x_{i} \mathrm{e}_{i}=\sum x_{i}^{*} \mathrm{e}_{i}^{*}\right),
$$

und die unitäre Transformation, welche zwischen ihnen vermittelt:

$$
x_{k}^{*}=\sum_{i} t_{i k} x_{i} \text {. }
$$

Es sei bekannt, daß die Größe $\alpha$ sicher in den Grenzen $a \leqq \alpha \leqq a^{\prime}$ liegt; gefragt ist nach der Wahrscheinlichkeit $W$, mit welcher die Größe $\beta$ in den Grenzen $b \leqq \beta \leqq b^{\prime}$ liegt. Von den Eigenwerten der Form $A$ mögen etwa $a_{1}, a_{2}, \ldots, a_{e}$ dem Intervall $a, a^{\prime}$ angehören, während $b_{1}, b_{2}, \ldots, b_{\sigma}$ die Eigenwerte der Form $B$ sind, welche sich zwischen $b$ und $b^{\prime}$ finden. Dadurch, da $\beta$ wir wissen, $\alpha$ liegt mit Sicherheit zwischen $a$ und $a^{\prime}$, ist es ausgeschlossen, daß $\alpha$ einen von $a_{1}, a_{2}, \ldots, a_{\varrho}$ verschiedenen Eigenwert annimmt; die damit verträglichen reinen Fälle sind diejenigen, für welche $x_{Q+1}=\cdots=x_{n}=0$ ist, sie gehören 
dem von $e_{1}, e_{2}, \ldots, e_{Q}$ aufgespannten Teilraum $\mathfrak{R}_{a}^{a^{\prime}}$ an. Der ins Quadrat erhobene Betrag der senkrechten Projektion eines beliebigen Vektors a auf diesen Teilraum ist gegeben durch die Einzelform

$$
E_{a}^{a^{\prime}}=\sum_{i=1}^{\varrho} x_{i} \bar{x}_{i}=\sum_{i, k=1}^{n} e_{i k} x_{i} \bar{x}_{k}
$$

Die Wahrscheinlichkeit, mit der in einem reinen Fall $\mathfrak{x}$ die Größe $\beta$ einen der Werte $b_{1}, b_{2}, \ldots, b_{\sigma}$ annimmt, ist andererseits gegeben durch die Einzelform

$$
F_{b}^{b^{\prime}}=\sum_{i=1}^{\sigma} x_{i}^{*} \bar{x}_{i}^{*}=\sum_{i, k=1}^{n} f_{i k} x_{i} \bar{x}_{k} ; \quad f_{i k}=\sum_{s=1}^{\sigma} t_{i s} \bar{t}_{k s} .
$$

Nach unserer Anweisung hat man in $F_{b}^{b^{\prime}}$ alle Variablen $x_{i}$ außer den ersten $\varrho$ gleich Null zu setzen und dann über den Teilraum $\mathfrak{R}_{a}^{a^{\prime}}$ zu mitteln. Dabei ist

oder

$$
\left\langle x_{i} \bar{x}_{k}\right\rangle=\left\{\begin{array}{l}
1 / \varrho(\text { für } i=k \leqq \varrho) \\
0 \text { (für alle anderen Paare } i, k)
\end{array}\right.
$$

$$
\left\langle x_{i} \bar{x}_{k}\right\rangle=\frac{1}{\varrho} e_{k i} \quad(i, k=1,2, \ldots, n) .
$$

So kommt

$$
W=\frac{1}{\varrho} \sum_{r=1}^{\rho} f_{r r}=\frac{1}{\varrho} \sum_{i, k=1}^{n} f_{i k} e_{k i}=\frac{1}{\varrho} \sum_{r=1}^{\rho} \sum_{s=1}^{\sigma}\left|t_{r s}\right|^{2} .
$$

Hält man das Intervall $a a^{\prime}$ fest und will nur die relativen Wahrscheinlichkeiten miteinander vergleichen, die verschiedenen Intervallen $b b^{\prime}$ entsprechen, so kann man den konstanten Faktor $\frac{1}{\varrho}$ weglassen. Die Summe rechts ist die Spur von $E_{a}^{a^{\prime}} F_{b}^{b^{\prime}}$. Weil einer Hermiteschen Form die Abbildung mit derselben Koeffizientenmatrix unitär-invariant assoziiert ist, hat neben der Spurbildung auch die Zusammensetzung der Matrizen von Hermiteschen Formen einen invarianten Sinn. Infolgedessen genügt es, die Einzelformen $E_{a}^{a^{\prime}}, F_{b}^{b^{\prime}}$ in irgend einem normalen Koordinatensystem zu kennen, um daraus die gesuchten relativen Wahrscheinlichkeiten vermittelst der Formel

$$
W=\operatorname{Spur}\left(E_{a}^{a^{\prime}} \cdot F_{b}^{b^{\prime}}\right)
$$

zu finden. Diese Art von Fragen über Gemenge zieht v. Neumann a. a. O. allein in Betracht. Sein Schlußresultat ist mit unserem natürlich inhaltlich identisch, aber seine Formel ist komplizierter. In der ganzen 
Betrachtung kann $\propto$ durch mehrere Größen ersetzt werden, die simultan beobachtbar sind, deren Hermitesche Formen sich also simultan auf Hauptachsen bringen lassen, desgleichen $\beta$.

Erst bei solchen Fragen über Gemenge spielt die Statistik eine Rolle, welche "relativ ist auf unsere Kenntnis und Unkenntnis", wie Laplace sagt, oder auf Störungen, die man nicht im einzelnen verfolgen will, obwohl sie sich, wenigstens prinzipiell, verfolgen ließen. Die Wahrscheinlichkeit, von der in den reinen Fällen die Rede ist, hat hingegen eine völlig objektive Bedeutung, die nichts mit Störungen zu tun hat, und wird durch strenge Naturgesetze regiert.

\section{Teil. Kinematik als Gruppe.}

\$ 5. Über Gruppen und ihre unitären Darstellungen. Für die unitären Abbildungen gilt ein analoges Theorem, wie das von der Hauptachsentransformation der Hermiteschen Formen: Za einer gegebenen unitären Abbildung läßt sich ein solches normales Koordinatensystem $e_{i}$ finden, in welchem die Abbildung durch die Gleichungen

$$
x_{k}^{\prime}=e_{k} x_{k}
$$

wiedergegeben wird. Die Eigenwerte $e_{k}$ sind Zahlen vom absoluten

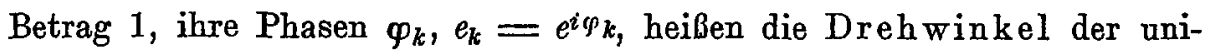
tären Abbildung. Analoge Bemerkungen, wie für die Hauptachsentransformation der Hermiteschen Formen, greifen Platz betreffs der Eindeutigkeit, mit welcher Eigenwerte und Eigenvektoren bestimmt sind, sowie betreffs der simultanen Überführung mehrerer wnitärer Abbildungen in die Normalform (15).

Aus einer Gruppe unitärer Abbildungen abstrahiert man das Gruppenschema, indem man die Abbildungen zu Elementen gleichgültiger Beschaffenheit degradiert und nur auf die Art ihrer Zusammensetzung achtet. Die abstrakte Gruppe ist also ein System von Elementen, innerhalb dessen durch "Komposition" aus zwei Elementen $a, b$ in bestimmter Reihenfolge ein Element $a b$ des Systems entspringt; in solcher Weise, dab

1. das assoziative Gesetz gilt: $(a b) c=a(b c)$;

2. ein "Einheitselement" 1 existiert, das die Gleichung $1 s=s 1$ $=s$ für jedes Element $s$ der Gruppe erfüllt; und daß

3. zu jedem Element $a$ ein inverses $a^{-1}$ vorhanden ist mit der Eigenschaft $a a^{-1}=a^{-1} a=1$. 
Die Gruppe der unitären Abbildungen erscheint dann als eine Verwirklichung oder Darstellung der abstrakten Gruppe, welche dadurch zustande kommt, daß jedem Gruppenelement $s$ eine unitäre Abbildung $U(s)$ in solcher Weise zugeordnet ist, daB allgemein

$$
U(s) U(t)=U(s t)
$$

gilt [es folgt daraus sofort $U(1)=\mathbf{1}$. Da das Gruppenschema aus der Darstellung abstrahiert wurde, ist die Darstellung getreu, d.h. verschiedenen Elementen entsprechen verschiedene Abbildungen $U$, oder, was dasselbe besagt, $U(s)$ ist $=1$ nur für $s=1$. Die Gruppe der unitären Abbildungen ist reduzibel, wenn in dem Vektorraum $\mathfrak{R}_{n}$, in welchem sich die unitären Abbildungen abspielen, ein linearer Unterraum $\mathfrak{\Re}_{m}$ existiert mit einer Dimensionszahl $m>0$, aber $<n$, der gegenüber allen $U(s)$ invariant ist. Die Vektoren, welche $z u$ allen in $\mathfrak{R}_{m}$ gelegenen senkrecht sind, bilden einen linearen Unterraum $\mathfrak{R}_{n-m}$; und es ist $\mathfrak{\Re}_{n}=\mathfrak{\Re}_{m}+\mathfrak{\Re}_{n-m}$ in dem Sinne, daß sich jeder Vektor auf eine und nur eine Weise in zwei Komponenten spalten läßt, von denen die erste $\mathfrak{\Re}_{m}$, die zweite $\Re_{n-m}$ angehört. Weil die $U(s)$ unitäre. Transformationen sind, lassen sie außer $\mathfrak{\Re}_{m}$ auch $\mathfrak{R}_{n-m}$ invariant: Die Darstellung zerfällt in eine $m$-dimensionale und eine $(n-m)$-dimensionale. Wählt man das normale Koordinatensystem $e_{i}$ so, daß die ersten $m$ Grundvektoren den Raum $\mathfrak{R}_{m}$ aufspannen, die letzten $n-m$ aber den Raum $\mathfrak{R}_{n-m}$, so kommt dieser Zerfall an den Koeffizientenmatrizen $U(s)$ unmittelbar zum Ausdruck. Man kann sich danach auf die Aúfsuchung der irreduziblen Darstellungen beschränken. Für irreduzible Darstellungen gilt der wichtige Satz: Ist die unitäre Matrix $A$ mit allen $U(s)$ vertauschbar: $A U(s)=U(s) A$, so ist $A=\varepsilon 1$ Multiplum der Einheitsmatrix 1. [Es ist dabei sogar unwesentlich, daß die $U(s)$ eine Gruppe bilden.]

Wir denken in erster Linie an endliche Gruppen. Zu jeder Gruppe gehört eine bestimmte "Größenalgebra“. Eine Größe im Gruppengebiet wird dadurch gegeben, daß jedem Gruppenelement $s$ eine Zahl $\xi(s)$ zugeordnet wird. Die Größen haben demnach so viele Zahlkomponenten, wie es Gruppenelemente gibt, sie sind sozusagen die Vektoren im Gruppenraum, in dem jedes Element eine Dimension, einen Grundvektor bedeutet*. Die Größe $\xi$ mit den Komponenten $\xi(s)$, die danach symbolisch mit $\sum \xi(s) . s$ bezeichnet werden mag, erscheint in

* Den in der mathematischen Literatur gebräuchlichen Namen Gruppenzahl vermeide ich, weil ich das Wort "Zahl" für die gewöhnlichen Zahlen reservieren möchte. 
der Verwirklichung der Elemente $s$ durch die unitären Abbjldungen $U(s)$ als die Matrix

$$
X=\sum_{s} \xi(s) U(s)
$$

Bildet man das Produkt zweier solcher Matrizen $X, Y$, welche zu den Größen $\xi$ und $\eta$ gehören, so entsteht wiederum eine Matrix $Z$, die zu einer bestimmten, durch $\xi$ und $\eta$ determinierten Größe $\xi$ gehört. Denn es ist

$$
\begin{aligned}
Z=X Y & =\sum_{t, t^{\prime}} U(t) U\left(t^{\prime}\right) \xi(t) \eta\left(t^{\prime}\right)=\sum_{t, t^{\prime}} U\left(t t^{\prime}\right) \xi(t) \eta\left(t^{\prime}\right) \\
& =\sum_{s} U(s) \xi(s), \quad \xi(s)=\sum_{t t^{\prime}=s} \xi(t) \eta\left(t^{\prime}\right) .
\end{aligned}
$$

Die Summe in (18) erstreckt sich über alle Paare von Elementen $t, t^{\prime}$, deren Kompositum $t t^{\prime}=s$ ist. Man kann sie als einfache Summe über alle Gruppenelemente $t$, aber weniger symmetrisch auch so schreiben:

$$
\xi(s)=\sum_{i} \xi\left(s t^{-1}\right) \eta(t)=\sum_{t} \xi(t) \eta\left(t^{-1} s\right) .
$$

(18) ist also das Multiplikationsgesetz der Größen im Gruppengebiet. Die Größen können danach, in genauer Anschmiegung an die zugehörigen Matrizen, addiert werden, mit Zahlen multipliziert und untereinander multipliziert werden; in solcher Weise, daß die wichtigsten algebraischen Axiome erfüllt bleiben. (Nur das kommutative Gesetz der Multiplikation und das Axiom, welches Nullteiler ausschließt, gelten nicht.)

Die Größe $\xi$ heilit reell, wenn ihre Komponenten der Gleichung

$$
\xi\left(s^{-1}\right)=\bar{\xi}(s)
$$

genügen. Die zugehörige Matrix $X$ ist dann Hermitesch. Denn aus $U(s) U\left(s^{-1}\right)=1 \quad$ zusammen mit $\quad \bar{U}^{*}(s) U(s)=1$

folgt $\widehat{U}^{*}(s)=U\left(s^{-1}\right)$. Darum gilt, unter der Voraussetzung (19),

$$
\bar{X}^{*}=\sum_{s} \bar{\xi}(s) \bar{U}^{*}(s)=\sum_{s} \xi\left(s^{-1}\right) U\left(s^{-1}\right)=\sum_{s} \xi(s) U(s)=X .
$$

Den Bereich der reellen Größen verläßt man nicht durch Addition, Multiplikation der Größen untereinander und durch ihre Multiplikation mit reellen Zablen*.

Für uns kommen vorzugsweise die Abelschen Gruppen in Betracht, bei welchen die Komposition der Elemente kommutativ ist:

* Von der natürlichen und wichtigen Rolle, welche diese Begriffe in der Darstellungstheorie spielen, die sich nachher auch als die grundlegenden in der Quantenmechanik herausstellen werden, kann man nur einen Eindruck gewinnen durch das Stadium dieser Theorie. Es sei insbesondere verwiesen auf: F. Peter und H. Weyl, Math. Ann. 97, 737, 1927. 
$s t=t s . \quad$ Eine endliche A belsche Gruppe besitzt eine Basis $a_{1}, a_{2}, \ldots, a_{f}$. Das sind $f$ Elemente der Gruppe mit folgenden Eigenschaften: Bedeuten $h_{1}, h_{2}, \ldots, h_{f}$ ihre Ordnungen, so erhält man alle Gruppenelemente in der Form

$$
s=a_{1}^{z_{1}} a_{2}^{z_{2}} \ldots a_{f}^{z_{f}},
$$

wenn $z_{i}$ ein volles Restsystem mod. $h_{i}$, z. B. die Zablen $1,2, \ldots, h_{i}$ durchläuft. (Ordnung $h$ eines Elementes $a$ ist der niederste Exponent, für welchen $a^{h}$ gleich dem Einheitselement 1 ist.) Die Auswahl der Basiselemente kann so normiert werden, daß $h_{2}$ ein Teiler von $h_{1}, h_{3}$ ein Teiler von $h_{2}, \ldots, h_{f}$ ein Teiler von $h_{f-1}$ ist. Unter diesen Umständen ist die Zahl der Basiselemente und die Teilerreihe $\left(h_{1}, h_{2}, \ldots, h_{f}\right)$ ihrer Ordnungen eindeutig durch die Gruppe bestimmt. Jene Teilerreihe charakterisiert umgekehrt vollständig die Struktur der Gruppe.

Die Aufsuchung der irreduziblen Darstellungen einer Abelschen Gruppe ist sehr einfach. Da nämlich die unitären Matrizen $U(s)$ in diesem Falle vertauschbar sind, kann man sie nach einem oben erwähnten Satz alle gleichzeitig "auf Hauptachsen bringen"; die Darstellung zerfällt also in lauter eindimensionale, es gibt nur eindimensionale irreduzible Darstellingen:

$$
x^{\prime}=\varepsilon(s) \cdot x \text {. }
$$

Dabei ist die Abhängigkeit der Zahl $\varepsilon(s)$ vom Gruppenelement $s$ so zu beschreiben: Dem Basiselement $a_{i}$ korrespondiert eine $h_{i}$-te Einheitswurzel $\varepsilon_{i}$, und es ist für (20):

$$
\varepsilon(s)=\varepsilon_{1}^{z_{1}} \varepsilon_{2}^{z_{2}} \ldots \varepsilon_{f}^{z_{f}}
$$

(Charaktere einer Abelschen Gruppe).

Aber das Darstellungsproblem stellt sich für uns in etwas anderer Gestalt, als es bislang besprochen wurde. Denn in der Quantenmechanik haben uicht die Vektoren eine Bedeutung, sondern lediglich die Strahlen; sie kennzeichnen die verschiedenen reinen Fälle. Wir gehen also zu dem homogenen Standpunkt über, für welchen die unitäre Matrix $U$ nicht eine Abbildung des Vektor-, sondern des Strahlenkörpers bedeutet und demgemäß mit der Abbildung $\varepsilon U$ zusammenfällt. So soll das Wort Darstellung in Zukunft verstanden werden: als getreue Darstellung durch Drehungen des Strahlenkörpers*. Die charakteristische Forderung lautet nunmehr:

$$
U(s) U(t) \simeq U(s t) .
$$

* Tiefgehende Untersuchungen über das Darstellungsproblem in diesem Sinne hat I. Schur angestellt: Crelles Journ. 127, 20, 1904 und 132, 85, 1907. 
Wir können den willkürlichen Faktor $\varepsilon$ in jedem $U(s)$ nach Gutdünken fixieren ("Eichung"). Als Gleichung wird dann (21) so zu lesen sein:

$$
U(s) U(t)=\delta(s, t) U(s t),
$$

wo $\delta$ eine von $s$ und $t$ abhängige $Z a h l$ vom absoluten Betrag 1 ist. Die Angabe einer Gröbe $\xi$ im Gruppengebiet ist relativ auf die benutzte Eichung; wird die Eichung gemäß der Formel $U(s) \rightarrow \varepsilon(s) U(s)$ verändert, so müssen die Komponenten $\xi(s)$ jeder Größe $\xi$ ersetzt werden durch $\varepsilon^{-1}(s) \xi(s)$. Das Multiplikationsgesetz lautet

$$
\xi(s)=\sum_{t t^{\prime}=8} \delta\left(t, t^{\prime}\right) \xi(t) \eta\left(t^{\prime}\right)
$$

Die Beschreibung (19) der reellen Größen $\xi$ ist nur dann zutreffend, wenn die Eichung so eingerichtet wurde, daß $U\left(s^{-1}\right)=U^{-1}(s)$ ist. Für eine irreduzible Darstellung gilt nach wie vor der Satz: Ist die feste Drehung $A$ mit allen $U(s)$ vertauschbar, $A^{-1} U(s) A=U(s)$, so ist $A \simeq \mathbf{1}$.

Die eindimensionalen Darstellungen verlieren jetzt jedes Interesse; denn die einzige eindimensionale Drehung ist die Identität. Aber im gegenwärtigen Sinne gibt es auch für Abelsche Gruppen mehrdimensionale irreduzible Darstellungen. Nicht freilich, wenn die Abelsche Gruppe zyklisch ist, aus den Wiederholungen eines einzigen Elementes $a$ besteht:

$$
1, a, a^{2}, \ldots, a^{h-1} \quad\left(a^{h}=1\right) .
$$

Denn ist $A$ die $a$ korrespondierende Matrix in der Darstellung, so ist $A^{h}=\varepsilon 1$. Indem man $A$ durch den Zahlfaktor $\sqrt[h]{\varepsilon}$ dividiert, erreicht man eine solche Eichung des $A$, daß $A^{h}=1$ wird. . Dann bilden aber die Potenzen von $A$ eine Darstellung der zyklischen Gruppe im alten inhomogenen Sinne. Wir illustrieren daher das Gesagte durch die einfachste nicht-zyklische Abelsche Gruppe. Das ist die Vierergruppe. Sie besteht aus vier Elementen 1, $a, b, c$, und ist beschrieben durch die Kompositionsregel

$$
\begin{gathered}
a^{2}=b^{2}=c^{2}=1, \\
b c=c b=a, \quad c a=a c=b, \quad a b=b a=c .
\end{gathered}
$$

Eine irreduzible mit ihr isomorphe Drehungsgruppe ist die folgende $\mathfrak{B}$ :

$$
\begin{gathered}
U(1)=\left\|\begin{array}{ll}
1 & 0 \\
0 & 1
\end{array}\right\|, \quad U(a)=\left\|\begin{array}{rr}
1 & 0 \\
0 & -1
\end{array}\right\|, \quad U(b)=\left\|\begin{array}{ll}
0 & 1 \\
1 & 0
\end{array}\right\|, \\
U(c)=\left\|\begin{array}{rr}
0 & i \\
-i & 0
\end{array}\right\| .
\end{gathered}
$$


Die Eichung ist so gewählt, daß $U^{2}(a)$ oder $U(a) U\left(a^{-1}\right)=1$ ist und Entsprechendes für die übrigen Elemente gilt. Die „reellen Größen“

$$
\varrho 1+\xi a+\eta b+\xi c
$$

sind also jene, deren Komponenten $\varrho, \xi, \eta, \xi$ reelle Zahlen sind. Thre Algebra ist die einfachste nicht-kommutative, welche existiert: die der Quaternionen (genauer derjenigen Quaternionen, von denen die skalare Komponente reell ist, die drei vektoriellen rein imaginär). In der Darstellung $\mathfrak{B}$ erscheint die Größe (23) als die Matrix

$$
X=\left\|\begin{array}{ll}
\varrho+\xi, & \eta+i \xi \\
\eta-i \xi, & \varrho-\xi
\end{array}\right\|
$$

Die Irreduzibilität geht ohne weiteres daraus hervor, daß zwischen den vier Koeffizienten dieser Matrix, wenn $\varrho, \xi, \eta, \xi$ als Variable betrachtet werden, keine homogene lineare Relation mit konstanten Zahlkoeffizienten besteht. Wir kennen dieses Beispiel schon vom magnetischen Elektron her. Allgemein werden wir erkennen, daß eine irreduzible $A$ belsche Drehungsgruppe im Strahlenkörper der reinen Fälle der Kinematik eines physikalischen Systems zugrunde liegt; die reellen Größen in diesem Gruppengebiet sind die physikalischen Größen des Systems.

Innerhalb einer A belschen Drehungsgruppe gilt für die (irgendwie geeichten) Matrizen zweier Drehungen $A$ und $B$ eine Gleichung

$$
A B=\varepsilon B A \text {. }
$$

Wir haben uns zu überlegen, in welcher Weise sie erfüllt sein kann. Bildet man auf beiden Seiten die Determinante, so ergibt sich $\varepsilon^{n}=1$, $\varepsilon$ ist also eine $n$-te Einheitswurzel. Ferner erhält man durch Induktion für $k=1,2,3, \ldots$ :

ebenso

$$
\left.\begin{array}{l}
A^{k} B=\varepsilon^{k} B A^{k} \\
A B^{l}=\varepsilon^{l} B^{l} A
\end{array}\right\}
$$

Kombiniert man beide Gleichungen, indem man die zweite auf $A^{k}$ und $B$ statt auf $A$ und $B$ anwendet, so erhält man die allgemeinere Regel

$$
A^{k} B^{l}=\varepsilon^{k l} B^{l} A^{k} \text {. }
$$

Weiter notieren wir die Gleichung

$$
(A B)^{k}=\varepsilon^{\frac{k(k+1)}{2}} \cdot B^{k} A^{k}
$$

Sie folgt sogleich durch Schluß von $k$ auf $k+1$, indem man die erste Formel (25) heranzieht. Setzen wir in (25) insbesondere $k=n$, so kommt $A^{n} B=B A^{n}$. Wenn die A belsche Drehungsgruppe irreduzibel ist, erschließt man aus dieser Vertauschbarkeit von $A^{n}$ mit allen Gruppenelementen $B: A^{n} \simeq 1$. Die 0rdnungen aller Elemente einer irre- 
duziblen Abelschen Drehungsgruppe in $n$ Dimensionen sind demnach Teiler von $n$.

Liegt eine endliche Abelsche Gruppe in abstracto vor, (20), so wird man zur Aufsuchung ihrer getreuen irreduziblen $n$-dimensionalen Darstellungen folgendermaßen verfahren. Für jedes Basiselement, z. B. $a_{1}=a$ von der Ordnung $h_{1}=h$, eicht man $U(a)=A$ in solcher Weise, daß $A^{h}=1$ ist. Nachdem dies geschehen, eiche man $U(s)$ für das Element (20) durch die Festsetzung

$$
U(s)=A_{1}^{z_{1}} A_{2}^{z_{2}} \ldots A_{f}^{z}
$$

Es kommt nun wesentlich auf die Bestimmung der Kommutatorzahlen $\varepsilon_{i k}$ in den Gleichungen

$$
A_{i} A_{k}=\varepsilon_{i k} A_{k} A_{i} \quad(i>k ; \quad i, k=1,2, \ldots, f)
$$

an. Da aus (28)

das ist

$$
A_{i}^{h_{i}} A_{k}=\varepsilon_{i k}^{h_{i}} A_{k} A_{i}^{h_{i}}
$$

$$
A_{k}=\varepsilon_{i k}^{h_{i}} A_{k}
$$

folgt, muß $\varepsilon_{i k}$ eine $h_{i}$-te Einheitswurzel sein.

§.6. Übertragung auf kontinuierliche Gruppen. Eine infinitesimale unitäre $\mathrm{Abbildung}$ ist eine solche, welcbe unendlich wenig von der Identität abweicht, durch die also alle Vektoren $\mathfrak{x}=\left(x_{i}\right)$ nur unendlich kleine Änderungen $d \mathfrak{x}=\left(d x_{i}\right)$ erfahren. Der analoge Begriff für reelle orthogonale Abbildungen des dreidimensionalen Raumes ist aus der Kinematik des starren Körpers geläufig: bei der kontinuierlichen Drehung eines Kreisels wird von Schritt zu Schritt eine infinitesimale Drehung vollzogen. Ein anderes einfaches Beispiel ist der Prozeß der kontinuierlichen Verzinsung zu festem Zinssatz, der eine Größe $x$ in jedem Zeitelement $d t$ mit dem Faktor $1+c d t$ multipliziert, ihr also den Zuwachs $d x=c x d t$ erteilt. Der Erfolg wird sein, daß sie im Zeitraum $t$ von $x$ auf $e^{c t} \cdot x$ angewachsen ist. $\quad \mathrm{m}$ die unendlich kleinen Größen zu vermeiden, ist es auch hier zweckmäßig, eine (rein fiktive) Zeit $\tau$ einzuführen und daher die infinitesimale unitäre Abbildung in der Form zu schreiben

$$
\frac{d \grave{i}}{d \tau}=\mathfrak{l} C, \quad \frac{d x_{k}}{d \tau}=\sum_{i} c_{i k} x_{i} .
$$

Die Forderung, daß $\sum x_{i} \bar{x}_{i}$ invariant bleiben soll, drückt sich in der Gleichung aus

$$
\sum_{k}\left(x_{k} \frac{d \bar{x}_{k}}{d \tau}+\bar{x}_{k} \frac{d x_{k}}{d \tau}\right)=0 \quad \text { oder } \sum_{i, k}\left(c_{i k}+\bar{c}_{k i}\right) x_{i} \bar{x}_{k}=0 .
$$


H. Weyl,

Die Hermitesche Form auf der linken Seite kann aber nur dann identisch in den $x_{i}$ verschwinden, wenn alle ihre Koeffizienten Null sind. So ergeben sich die Bedingungen der schiefen Symmetrie

$$
\bar{c}_{k i}=-c_{i k}, \quad \bar{C}^{*}=-C .
$$

Setzt man $C=i A$, so ist $A$ eine Hermitesche Matrix. Resultat: Mit jeder Hermiteschen Form $A$ ist in unitär-invarianter Weise (vgl. §1) die infinitesimale unitäre Abbildung

$$
\frac{d \underset{x}{q}}{d \tau}=i \mathfrak{x} A
$$

verbunden. Der Satz von der Hauptachsentransformation der Hermiteschen Formen stellt sich dadurch als der infinitesimale Grenzfall des entsprechenden Theorems für unitäre Abbildungen heraus. Diejenigen infinitesimalen Abbildungen. welche alle Strahlen ungeändert lassen, haben die Form

$$
\frac{d \mathfrak{x}}{d \tau}=i c \mathfrak{x}
$$

mit einem reellen Zahlfaktor $c$. Der homogene Standpunkt verlangt also hier, dal $A$ nicht von $A+c 1$ unterschieden wird.

Indem man in jedem Zeitelement $d \tau$ die gleiche infinitesimale unitäre Abbildung (29) wiederholt, erhält man durch Integration von (29)

$$
\mathfrak{x}(\tau)=\mathfrak{q} U(\tau) \text {. }
$$

$U(\tau)$ ist die endliche Drehung, welche im Zeitraum $\tau$ vor sich geht. Es ist natürlich

$$
U\left(\tau+\tau^{\prime}\right)=U(\tau) U\left(\tau^{\prime}\right)
$$

Die $U(\tau)$ bilden also eine einparametrige kontinuierliche Gruppe; gegenüber der Zusammensetzung verbält sich der Zeitparameter $\tau$ additiv, Vgl. den oben geschilderten Prozeß der kontinuierlichen Verzinsung! Die Integration von (29) kann in der gleichen Weise vorgenommen werden wie in diesem einfachsten Fall. Unter Benutzung einer gegen $\infty$ strebenden ganzen Zahl $m$ zerlegt man die Zeit $\tau$ in Flemente $\frac{\tau}{m}$. In jedem der $m$ Zeitelemente erfährt $\mathfrak{x}$ die Transformation $1+\frac{\tau}{m} C ;$ daher ist

$$
U(\tau)=\lim _{m=\infty}\left(\mathbf{1}+\frac{\tau C}{m}\right)^{m}=e^{\tau C} .
$$

Die Konvergenz kann ebenso leicht bewiesen werden wie im eindimensionalen Fall, wenn $C$ eine Zahl ist. Auch ergibt sich die Potenzreihe

$$
U(\tau)=1+\frac{\tau}{1 !} C+\frac{\tau^{2}}{2 !} C^{2}+\cdots
$$


Eine andere Methode ist die sukzessive Approximation; sie setzt nicht voraus, daß $C$ von $\tau$ unabhängig ist. Als nullte Approximation wird das für $\tau=0$ vorgegebene ’ genommen, allgemein wird die $l$-te aus der $(l-1)$-ten Annäherung mittels der Gleichung

$$
\frac{d \mathfrak{x}_{l}}{d \tau}=\mathfrak{x}_{l-1} C \quad \mathrm{zu} \quad \mathfrak{x}_{l}(\tau)=\mathfrak{x}+\int_{0}^{\tau} \mathfrak{x}_{l-1}(\tau) C d \tau
$$

bestimmt. Die Annäherungen $\mathfrak{x}_{l}(\tau)$ konvergieren mit $l \rightarrow \infty$ gegen die gesuchte Grenze $\mathfrak{x}(\tau)$. Es ergibt sich für $\mathfrak{x}(\tau)$ eine unendliche Reihe:

$$
\sum_{l=0}^{\infty} \int_{\left(0 \leqq \tau_{1} \leqq \tau_{2} \leqq \cdots \leqq \tau_{l} \leqq \tau\right)} C\left(\tau_{1}\right) C\left(\tau_{2}\right) \ldots C\left(\tau_{l}\right) d \tau_{1} d \tau_{2} \ldots d \tau_{l} .
$$

Bei zeitunabhängigem $C$ kommt wieder die Gleichung (30) heraus.

Eine Zwischenbemerkung: Es wurde erwähnt, daß in der Physik meist Formen mit unendlich vielen Variablen eine Rolle spielen. Die Theorie der Hermiteschen Formen von unendlich vielen Veränderlichen unter dem Einfluß unitärer Transformationen wurde von Hilbert und Hellinger entwickelt, unter der Voraussetzung, daß die Form beschränkt ist, d. h. daß eine Konstante $M$ existiert, unter der die Werte der Form ihrem absoluten Betrage nach für alle Vektoren vom Betrage 1 bleiben*. Die in der Physik vorkommenden Formen genügen dieser Bedingung nicht. Eine Erweiterung der Theorie, welche den physikalischen Anforderungen genügt, hat v. Neumann a. a. 0 . in Aussicht gestellt. Es ergibt sich hier die Aufgabe, das Analoge für die unitären Abbildungen zu leisten. Für sie wird die Theorie wesentlich befriedigender ausfallen, weil keinerlei spezielle, die Konvergenz garantierende Voraussetzungen zu machen sind, wie es die Hilbertsche Annahme der Beschränktheit war. Denn der Begriff der unitären Abbildung bringt es mit sich, daß in der Matrix die Quadratsumme der absoluten Beträge jeder Zeile und jeder Spalte konvergiert, nämlich $=1$ ist. (Die mathematische Durchführung soll an anderer Stelle gegeben werden.) Der integrale Standpunkt ist in begrifflicher Hinsicht dem infinitesimalen immer überlegen, er läbt zugleich die natürlichen Grenzen der differentiellen Begriffsbildungen erkennen. In diesem Sinne ist es zweckmäßig, da mit einer Größe $\alpha$ ja immer auch ihre reellen konstanten Multipla $k \alpha$ als physikalische Größen auftreten, diese zu ersetzen durch $e^{i k \alpha}$, die Hermiteschen Matrizen $k A$

* D. Hilbert, Grundzüge einer allgemeinen Theorie der Integralgleichungen, Leipzig 1912, insbesondere IV. Abschnitt. E. Hellinger, Crelles Journal 136, $1,1910$. 
durch die unitären $e^{i k A}$. Mit $A$ erscheinen sie zugleich auf Hauptachsen transformiert, wobei an Stelle der $a_{\mu}$ die Zahlen $e^{i k a_{\mu}}$ als Eigenwerte sich ergeben.

Doch nun zu den unendlichen Gruppen! Eine unendliche Gruppe kann diskontinuierlichen Charakter haben, wie die in der Lehre von der Kristallstraktur auftretende Gruppe der Gittertranslationen des Raumes, deren Komponenten in bezug auf die drei Achsen $x, y, z$ ganze Zahlen sind. Es können auch gemischte kontinuierlich-diskrete Gruppen vorkommen, wie die Gruppe aller Raumtranslationen, deren $x$-Komponente ganzzahlig ist. Doch haben wir jetzt insbesondere die kontinuierlichen Gruppen im Auge. Eine solche denkt man sich nach S. Lie erzeugt durch ihre infinitesimalen Elemente. Ist die Gruppe eine f-parametrige kontinuierliche Mannigfaltigkeit $\$$, so sind die infinitesimalen Elemente die Stellen auf der Gruppenmannigfaltigkeit, welche der Einheitsstelle 1 unendlich benachbart sind, oder die von 1 ausgehenden Linienelemente. Sie bilden also eine $f$-dimensionale lineare Mannigfaltigkeit. Halten wir uns sogleich an die Darstellung, an die konlkreten unitären Abbildungen statt an die abstrakten Elemente, so haben wir mithin eine $f$-dimensionale lineare Schar schiefer Matrizen vor uns:

$$
\mathrm{g}: \quad C_{1} d \sigma_{1}+C_{2} d \sigma_{2}+\cdots+C_{f} d \sigma_{f},
$$

innerhalb deren $C_{1}, C_{2}, \ldots, C_{f}$ eine willkürlich gewählte Basis ist und die Zahlparameter $d \sigma_{1}, d \sigma_{2}, \ldots, d \sigma_{f}$ aller reellen Werte fäbig sind. Setzt man in (32) $d \sigma_{i}=\alpha_{i} d t$ und iteriert diese infinitesimale $A b-$ bildung, die man sich im Zeitelement $d \tau$ vollzogen denkt, so gelangt man nach Ablauf der Zeit $\tau$, wenn an Stelle von $\alpha_{i} \tau$ jetzt wieder $\sigma_{i}$ geschrieben wird, zu

$$
U\left(\sigma_{1}, \sigma_{2}, \ldots, \sigma_{f}\right)=e^{\sigma_{1} C_{1}+\sigma_{2} C_{2}+\cdots+\sigma_{f} C_{f} .}
$$

Innerhalb der infinitesimalen Gruppe $\mathfrak{g}$ gibt sich die Komposition an den Parametern $d \sigma$ als Addition kund. Es könnte darum so scheinen, daß jede lineare Schar (32) eine f-parametrige kontinuierliche Gruppe nach der Formel (33) erzeugt. Das ist aber nicht der Fall, wie die folgende Betrachtung lehrt, die nach dem Muster bekannter Integrabilitätsüberlegungen verläuft. Sie nutzt für die infinitesimalen Elemente die Tatsache aus, daß mit zwei Abbildungen $V, \nabla$ auch der Kommutator $U V U^{-1} V^{-1}$ in der Gruppe enthalten sein muB. Sind also $C, C^{\prime}$ zwei in der Schar $g$ vorkommende Matrizen, so gehören die infinitesimalen Abbildungen

$$
d \mathfrak{x}=\mathfrak{x} C d \tau \quad \text { und } \quad d^{\prime} \mathfrak{x}=\mathfrak{C ^ { \prime }} d \tau^{\prime}
$$


zur Gruppe. Führt man sie beide hintereinander aus, das eine Mal in der Reihenfolge $d, d^{\prime}$, das andere Mal in der Reihenfolge $d^{\prime}, d$, so ist die Differenz der dadurch aus $\mathfrak{x}$ entstehenden Vektoren

$$
\Delta \mathfrak{x}=d d^{\prime} \mathfrak{x}-d^{\prime} d \mathfrak{x}=\mathfrak{x}\left(C C^{\prime}-C^{\prime} C\right) d \tau d \tau^{\prime} \text {. }
$$

Diese infinitesimale Abbildung ist der gesuchte Kommutator. Infolgedessen muß mit $C$ und $C^{\prime}$ auch immer $C C^{\prime}-C^{\prime} C$ der Schar $\mathfrak{g}$ angehören. An der Basis formuliert, heißt das, daß die Matrizen $C_{i} C_{k}-C_{k} C_{i}$ sich linear mittels reeller Zahlkoeffizienten aus $C_{1}, C_{2}, \ldots, C_{f}$ kombinieren müssen. Diese von Lie aufgestellte Bedingung, deren Herleitung leicht streng zu machen ist, ist nicht nur notwendig, sondern auch hinreichend*.

Dic Gruppe ist Abelsch, wenn der Kommutator irgend zweier Elemente gleich 1 ist. In diesem Falle müssen die Matrizen $C_{i}$ den Gleichungen

$$
C_{i} C_{k}-C_{k} C_{i}=0
$$

genügen, d. h. sie müssen vertauschbar sein. Für zwei vertauschbare Matrizen $A$ und $B$ gilt

$$
e^{A+B}=e^{A} \cdot e^{B}
$$

das ergibt sich genau wie für Zahlen. Die Gleichung (34), d. i. die Vertauschbarkeit der infinitesimalen Elemente, genügt also, wie das eigentlich selbstverständlich ist, um den A belschen Charakter der ganzen Gruppe sicherzustellen, es gilt auf Grund von (34)

$$
U\left(\sigma_{1}, \sigma_{2}, \ldots, \sigma_{f}\right) U\left(\tau_{1}, \tau_{2}, \ldots, \tau_{f}\right)=U\left(\sigma_{1}+\tau_{1}, \sigma_{2}+\tau_{2}, \ldots, \sigma_{f}+\tau_{f}\right) .
$$

Jede $f$-parametrige A belsche Gruppe ist danach isomorph mit der Gruppe der Translationen in einem $f$-dimensionalen Raume. Die $C_{i}$ spielen eine analoge Rolle wie die Basis bei den endlichen Abelschen Gruppen.

Wir werden es zwar mit einer Abelschen Gruppe zu tun haben, aber die Abbildungen sind als solche des Strahlenkörpers zu verstehen. Überall ist das Zeichen $=$ zwischen unitären Abbildungen durch $\simeq$ zu ersetzen. An Stelle der Bedingungen (34) treten danach solche von der Form

$$
C_{\mu} C_{v}-C_{v} C_{\mu}=i c_{\mu \nu} \mathbf{1}
$$

$c_{\mu \nu}$ ist ein schiefsymmetrisches System reeller Zahlen. Der Kommutator der infinitesimalen Abbildungen mit den Matrizen ist

$$
A=\sigma_{1} C_{1}+\cdots+\sigma_{f} C_{f} \text { und } B=\tau_{1} C_{1}+\cdots+\tau_{f} C_{f}
$$

$$
A B-B A=i \sum_{\mu, v} c_{\mu \nu} \sigma_{\mu} \tau_{\nu} .1 .
$$

* Genaueres ist etwa nachzulesen bei: H. Weyl, Mathematische Analyse des Raumproblems, Berlin 1923, S.33-36, und die dazu gehörigen Anhänge. 
Die schiefsymmetrische Form

$$
\sum_{\mu, v} c_{\mu \nu} \sigma_{u} \tau_{v}=h(\sigma, \tau)
$$

welche eine von der Basis unabhängige Bedeutung hat, nenne ich die Kommutatorform. Wendet man (26) an für eine gegen $\infty$ konvergierende Zahl $k=l=m$ und $1+\frac{A}{m}, 1+\frac{B}{m}$ an Stelle von $A$ und $B$, so erhält man im Limes als den Kommutator irgend zweier Elemente der Gruppe $U\left(\sigma_{1}, \sigma_{2}, \ldots, \sigma_{f}\right)=U(\sigma)$ und $U(\tau)$ :

$$
U(\sigma) U(\tau) U^{-1}(\sigma) U^{-1}(\tau)=e(h(\sigma, \tau)) .1 .
$$

[Um der Leserlichkeit willen schreibe ich oft $e(x)$ statt $e^{i x}$.] Dieselbe Einsetzung in (27) mit nachfolgendem Grenzübergang liefert noch

$$
U(\boldsymbol{\sigma}+\tau)=e\left(\frac{1}{2} h(\boldsymbol{\sigma}, \tau)\right) U(\tau) U(\boldsymbol{\sigma})=e\left(-\frac{1}{2} h(\boldsymbol{\sigma}, \tau)\right) U(\boldsymbol{\sigma}) U(\tau) .
$$

Wenn die Drehungsgruppe irreduzibel ist, kann ein festes $U(\sigma)$ nur dann mit allen $U(\tau)$ vertauschbar sein, wenn es $\simeq 1$ ist, d. h. wenn die Parameter $\sigma_{i}$ verschwinden. Das besagt, daß die Kommutatorform nicht-ausgeartet ist, nämlich für ein festes Wertsystem $\sigma_{i}$ nicht identisch in $\tau_{i}$ verschwinden kann, ohne daß alle $\sigma_{i}=0$ sind. (Es kommt das daranf hinaus, daß die Determinante $\left|c_{i k}\right| \neq 0$ ist.) Eine solche Form existiert nur, wenn die Variablenzahl $f$ gerade ist, und ihr kann durch geeignete Wabl der Basis (dadurch, daß die Variablen $\sigma_{i}$ und $\tau_{i}$ kogredient einer geeigneten linearen Transformation unterworfen werden) eine numerisch eindeutig bestimmte Gestalt verliehen werden : Die Koeffizientenmatrix $\left\|c_{i k}\right\|$ zerfällt in lauter zweireihige Quadrate $\left\|\begin{array}{rr}0 & 1 \\ -1 & 0\end{array}\right\|$, die sich längs der Hauptdiagonale aneinanderreihen. Es ist dann zweckmäßiger, if an Stelle von $f$ zu schreiben, die so eingeführte "kanonische Basis" mit

$$
i P_{v}, i Q_{v} \quad(v=1,2, \ldots, f)
$$

zu bezeichnen und die zugehörigen kanonisch gepaarten Parameter mit $\sigma_{v}, \tau_{v}$. Der Faktor $i$ ist beigefügt, um auf Hermitesche Formen $P_{v}, Q_{v}$ zu kommen. Es gelten die Vertauschungsrelationen und

$$
\left.\begin{array}{rl}
i\left(P_{\nu} Q_{\nu}-Q_{\nu} P_{\nu}\right) & =1, \quad i\left(P_{u} Q_{\nu}-Q_{\nu} P_{\mu}\right)=0 \text { für } \mu \neq \nu, \\
P_{\mu} P_{\nu}-P_{\nu} P_{\mu}=0, \quad Q_{\mu} Q_{\nu}-Q_{\nu} Q_{\mu}=0 \text { für alle } \mu, \nu .
\end{array}\right\}
$$

Die

$$
U(\sigma)=e\left(\sigma_{1} P_{1}+\sigma_{2} P_{2}+\cdots+\sigma_{f} P_{f}\right)
$$


bilden für sich eine $f$-parametrige Abelsche Gruppe unitärer (Vektor-) Abbildungen, ebenso die

$$
V(\tau)=e\left(\tau_{1} Q_{1}+\tau_{2} Q_{2}+\cdots+\tau_{f} Q_{f}\right)
$$

Hingegen ist

und

$$
U(\sigma) \nabla(\tau) U^{-1}(\sigma) \nabla^{-1}(\tau)=e\left(\sigma_{1} \tau_{1}+\cdots+\sigma_{f} \tau_{f}\right) \cdot 1
$$

$$
\begin{gathered}
e\left(\sigma_{1} P_{1}+\cdots+\sigma_{f} P_{f}+\tau_{1} Q_{1}+\cdots+\tau_{f} Q_{f}\right) \\
=e\left(\frac{1}{2} \sum_{i=1}^{f} \sigma_{i} \tau_{i}\right) V(\tau) U(\sigma)=e\left(-\frac{1}{2} \sum_{i=1}^{f} \sigma_{i} \tau_{i}\right) U(\sigma) V(\tau) .
\end{gathered}
$$

§ 7. Ersatz der kanonischen Variablen durch die Gruppe. Das Elektron. Unsere Entwicklungen sind bis zu dem Punkte gediehen, wo die Verbindung mit der Quantenmechanik in die Augen springt. Liegt ein mechanisches System von $f$ Freiheitsgraden vor, so genügen ja die Hermiteschen Matrizen, welche die kanonischen Variablen repräsentieren, gerade den Relationen (36), bis auf den Faktor $h / 2 \pi$, von dem noch die Rede sein wird und den wir einstweilen in die Maßeinheiten hineinstecken. Nehmen wir die Zahl der Freiheitsgrade $f$ zunächst $=1$ und bezeichnen in der üblichen Weise die kanonischen Variablen mit $p, q$, ihre repräsentierenden Formen mit $P, Q$, so sagt die Relation

$$
i(P Q-Q P)=\mathbf{1}
$$

aus, daß die beiden durch die Matrizen $i P, i Q$ gekennzeichneten infinitesimalen Drehungen dès Strahlenkörpers vertauschbar sind. Die durch sie erzeugte Abelsche Drehungsgruppe besteht aus den Drehungen

$$
U(\sigma, \tau)=e(P \sigma+Q \tau)
$$

( $\sigma, \tau$ reelle Parameter, die sich bei Zusammensetzung additiv verhalten). Die reelle Größe im Gruppengebiet, deren Komponenten $\xi(\sigma, \tau)$ der Gleichung (19) oder

$$
\bar{\xi}(\boldsymbol{\sigma}, \tau)=\xi(-\sigma,-\tau)
$$

genïgen, erscheint als die Hermitesche Form

$$
F=\int_{-\infty}^{+\infty} \int_{\infty}^{\infty} e(P \sigma+Q \tau) \xi(\sigma, \tau) d \sigma d \tau
$$

Eine physikalische Größe ist durch ihren Funktionsausdruck $f(p, q)$ in den kanonischen Variablen $p, q$ mathematisch definiert. Es blieb ein Problem, wie ein derartiger Ausdruck auf die Matrizen zu übertragen war. Ohne weiteres klar war das nur für die Potenzen $p^{k}, q^{l}$ und damit für Polynome. Freilich trat schon hier die Schwierigkeit auf, daß man nicht wubte, ob man einen Term wie $p^{2} q$ als $P^{2} Q$ oder $Q P^{2}$ oder $P Q P$ usw. 
zu interpretieren hatte. Der Ansatz ist offenbar viel zu formal. Unsere gruppentheoretische Auffassung zeigt sogleich den rechten Weg: die Hermitesche Form (41) repräsentiert die Größe

$$
f(p, q)=\int_{-\infty}^{+\infty} \int_{\infty}^{\infty} e(p \sigma+q \tau) \xi(\sigma, \tau) d \sigma d \tau .
$$

Nach dem Fourierschen Integraltheorem läßt sich ja jede Funktion $f(p, q)$ in dieser Form eindeutig entwickeln, und wenn $f$ eine reellwertige Funktion der reellen Veränderlichen $p, q$ ist, genügt $\xi(\sigma, \tau)$ gerade der Bedingung (40). Die Integralentwicklung (42) ist nicht immer ganz wörtlich zu verstehen; das wesentliche ist nur, dab rechts eine lineare Kombination der $e(p \sigma+q \tau)$ steht, in denen $\sigma$ und $\tau$ beliebige reelle Werte annehmen können. Wenn z. B. $q$ eine zyklische Koordinate ist, die nur mod. $2 \pi$ zu verstehen ist, so daB alle in Betracht kommenden Funktionen periodisch in $q$ mit der Periode $2 \pi$ sind, wird die Integration nach $\tau$ ersetzt werden müssen durch eine Summation über alle ganzen Zahlen $\tau$; wir haben dann den Fall einer gemischten kontinuierlichdiskreten Gruppe. Die Einschränkungen, denen $f(p, q)$ unterworfen sein muß, damit sie eine Entwicklung des Typus (42) gestattet, könnten noch Bedenken erregen. Nun wissen wir aber, dab es eigentlich gilt, $e(k f(p, q))$ so $z u$ entwickeln (lo irgend eine reelle Konstante), und in dieser Fassung läbt sich die Aufgabe nach neueren Untersuchungen von $\mathrm{N}$. Wiener, Bochner und $\mathrm{Hardy}$ in zwingender Weise eindeutig erledigen*.

Die Übertragung anf $f$ Freiheitsgrade liegt auf der Hand. Insbesondere sahen wir, wie aus der Forderung der Irreduzibilität im Falle der kontinuierlichen Gruppen die charakteristische kanonische Paarung entspringt. Für endliche Gruppen freilich existiert nicht ein so einheitliches Schema. Das ist im Einklang mit den physikalischen Tatsachen. Denn aus den Entwicklungen von P. Jordan $* *$ ging bereits hervor, daß beim magnetischen Elektron $\sigma_{y}$ so gut wie $\sigma_{z}$ als

* N. Wiener, On representations of functions by trigonometrical integrals, Math. ZS. 24, 575, 1926; S. Bochner und G.H.Hardy, Note on two theorems of N. Wiener, Journ. Lond. Math. Soc. 1, 240, 1926; S. Bocbner, Darstellung. reell variabler and analytischer Funktionen durch verallgemeinerte Fourier- und Laplaceintegrale, Math. Ann. 97, 635, 1927; vgl. dazu ferner die von H. Bohr stammende Theorie der fastperiodischen Funktionen; am einfachsten bei H. Weyl, Math. Ann. 07, 338, 1926.

** ZS. f. Phys. 44, 21-25, 1927. Nach P. Jordan, Über die Polarisation der Lichtquanten, ebenda, S. 292, ist die Kinematik der Lichtquanten die gleiche. 
die "kanonische Kunjugierte" von $\sigma_{x}$ angesehen werden kann. Höchstens von einem Tripel, nicht von einem Paar kanonisch konjugierter Größen könnte hier vernünftigerweise die Rede sein. Bestätigen wir, daß gerade auch in diesem diskreten, dem Kontinuierlichen am meisten entgegengesetzten Falle unsere Formulierung genau das Richtige trifft! Sie lautet, um das noch einmal zusammenzufassen, so: Der kinematische Charakter eines physikalischen Systems findet seinen Ausdruck in einer irreduziblen Abelschen Drehungsgrappe, deren Substrat der Strahlenkörper der "reinen Fälle" ist. Die reellen Größen dieses Gruppengebietes sind die physikalischen Größen; die Hermiteschen Matrizen, als welche sie vermöge der Darstellung dex abstrakten Gruppe durch Drehungen erscheinen, sind die Repräsentanten der physikalischen Größen, deren Bedeutung im I. Teil auseinandergesetzt wurde.

Nun: die früher beschriebene zweidimensionale Drehungsgruppe $\mathfrak{B}$, welche der Vierergruppe isomorph ist, kennzeichnet, wie der Vergleich mit $\S 2,(12)$ lehrt, die Kinematik des magnetischen Elektrons. Da $n=2$ ist, sind alle Größen nur zweier Werte fähig. Die einzigen physikalischen Größen, welche existieren, sind die mit Hilfe reeller Zahlkoeffizienten gebildeten linearen Kombinationen von $1, \sigma_{x}, \sigma_{y}, \sigma_{z}$. Aber das magnetische Elektron ergibt sich nicht nur als Sonderfall der Theorie, sondern die ihm eigentümliche Kinematik ist überhaupt die einzig mögliche, wenn alle Größen nur zweier Werte fähig sein sollen, wenn $n=2$ ist. Beweis: Wir wissen schon, daß unter dieser Voraussetzung jedes Gruppenelement $a$ außer dem Einheitselement von der Ordnung 2 ist. Die beiden Eigenwerte der korrespondierenden wweidimensionalen Matrix $A$ sind daher entgegengesetzt gleich. Wählen wir ein bestimmtes $a \neq 1$, so können wir das zugehörige $A$ samt einem normalen Koordinatensystem so festlegen, da $B$

$$
A=\left\|\begin{array}{rr}
1 & 0 \\
0 & -1
\end{array}\right\|
$$

wird. Die mit $A$ vertauschbaren Matrizen $U$ unserer Gruppe haben notwendig die Gestalt $\left\|\begin{array}{ll}c & 0 \\ 0 & c^{\prime}\end{array}\right\|$; wenn sie nicht $\simeq 1$ sind, ist $c^{\prime}=-c$, $U$ also $\simeq A$. Es gibt Gruppenelemente, deren Matrix $B$ nicht mit $A$ vertauschbar ist. Wir wissen, $\mathrm{da} ß$ in der Gleichung

$$
A B=\varepsilon B A
$$


$\varepsilon$ eine zweite Einheitswurzel, darum $\varepsilon=-1$ sein mub. Daraus folgt, da $B$ die Gestalt

$$
B=\left\|\begin{array}{cc}
0 & b \\
b^{\prime} & 0
\end{array}\right\|
$$

hat. Die Zahlen $b, b^{\prime}$ sind vom absoluten Betrag 1 . Wir wählen ein bestimmtes solches $B$, das gemäb $B^{2}=1$ geeicht sei: $b b^{\prime}=1$. Außerdem kann man $b$ zu 1 machen, indem man das bisherige normale Koordinatensystem $e_{1}, e_{2}$ durch $e_{1}, b e_{2}$ ersetzt; (43) wird dadurch nicht angegriffen:

$$
B=\left\|\begin{array}{ll}
0 & 1 \\
1 & 0
\end{array}\right\|
$$

Jede Matrix $U$ unserer Gruppe, welche mit $A$ vertauschbar ist, ist $\simeq 1$ oder $\simeq A$. Wenn sie nicht mit $A$ vertauschbar ist, hat sie die Form (44), und demnach ist ihre Zusammensetzung $U B$ mit dem durch (45) gegebenen bestimmten $B$ eine Diagonalmatrix. Als solche ist sie mit $A$ vertauschbar, also $\simeq 1$ oder $\simeq A$. Das Resultat ist, daß jedes $U \simeq$ einer von den vier Matrizen 1, $A, B, A B$ ist. Es liegt in der Tat die Vierergruppe vor und die Darstellung $\mathfrak{B}$ derselben.

§ 8. Übergang zu Schrödingers Wellentheorie. In ähnlicher Weise, wie soeben der Fall $n=2$ behandelt wurde, wollen wir jetzt zeigen, daß die zweiparametrigen kontinuierlichen Gruppen nur eine $\mathrm{c}$ irreduziblen Darstellung in unserem Sinne (außer der identischen) fähig sind. Wir erhalten jene Gruppen durch Grenzübergang aus den zweibasigen endlichen. Die irreduzible Abelsche Drehungsgruppe mit der Basis $A, B$ habe die Dimensionszahl $n$. In der Kommutatorgleichung

$$
A B=\varepsilon B A
$$

ist $\varepsilon$ eine $n$-te Einheitswurzel. Diese Gleichung gilt es jetzt näher zu untersuchen. Die Kommutatorzahl $\varepsilon$ sei eine primitive $m$-te Einheitswurzel, d. h. $\varepsilon^{m}$ sei die niederste Potenz, welche $=1$ ist; $m$ ist Teiler von $n$. Die Drehungen $A, B$ sind von einer in $n$ aufgehenden Ordnung: $A^{n} \simeq 1, B^{n} \simeq 1$, und die Matrizen können daher so geeicht werden, daß $A^{n}=B^{n}=1$ ist. Durch geeignete Wahl des normalen Koordinatensystems sei $B$ auf Hauptachsen gebracht; die Glieder in der Hauptdiagonale, $b_{i}$, sind lauter $n$-te Einheitswurzeln. Die Gleichung (46) liefert für die Koeffizienten von $A=\left\|a_{i k}\right\|$ :

$$
\frac{b_{k}}{b_{i}} a_{i k}=\varepsilon a_{i k} \text {. }
$$


Man teile die Indizes $i$ und zugehörigen Variablen $x_{i}$ in Klassen nach dem Prinzip, daß $i$ und $k$ in dieselbe Klasse fallen, wenn der Quotient $b_{i} / b_{k}$ eine $m$-te Einheitswurzel, eine Potenz von $\varepsilon$ ist. Dies ist wirklich eine Klasseneinteilung; da mit $b_{i} / b_{k}$ und $b_{k} / b_{l}$ auch $b_{i} / b_{l}$ Potenz von $\varepsilon$ ist. GemäB der Gleichung (47) ist $a_{i k}=0$, wenn $i$ und $k \mathrm{zu}$ verschiedenen Klassen gehören; die Matrix $A$ zerfällt demnach in der gleichen Weise, wie die Indizes in Klassen zerfallen. Wegen der vorausgesetzten Irreduzibilität ist also nur eine Klasse vorhanden.

Nachdem dies erkannt ist, gehen wir zu einer feineren Klasseneinteilung über: jetzt sollen $i$ und $k$ nur dann zur selben Klasse gehören, wenn $b_{i}=b_{k}$ ist. Wir wählen willkürlich eine dieser Klassen, für welche $b_{i}=b$ ist, als die erste, lassen dann als zweite diejenige folgen, für die $b_{i}=\varepsilon b$ ist, darauf die dritte mit $b_{i}=\varepsilon^{2} b, \ldots$, die $m$-te mit $b_{i}=\varepsilon^{m-1} b ;$ die $(m+1)$-te Klasse: $b_{i}=\varepsilon^{m} b$, ist wieder die erste. In dieser Reihenfolge denken wie auch die Variablen angeschrieben und numeriert. Nach der Gleichung (47) sind in der Matrix $A$ alle Felder $(i, k)$ leer, $a_{i k}=0$, deren Zeilen- und Spaltenindex $i$ und $k$ nicht zu zwei aufeinanderfolgenden Klassen gehören.

Die Matrix $A$ hat daher das angedeutete Schema (Fig. 1), in welchem die nicht schraffierten Gebiete leer stehen und übrigens $m=4$ angenommen wurde. In den schraffierten Gebieten stehen die "Teilmatrizen" $A^{(1)}, A^{(2)}, \ldots, A^{(m)}$. Da $A$ unitär ist, summieren sich die absoluten Quadrate der Glieder in jeder Zeile und in jeder Spalte zu 1. Infalgedessen gilt das gleiche für die Zeilen

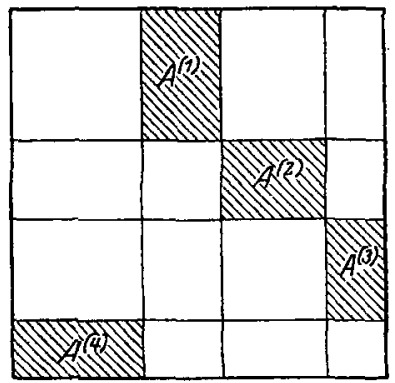

Fig. 1. und Spalten der eiuzelnen Teilmatrix. Die Summe der absoluten Quadrate aller in $A^{(1)}$ stehenden Glieder ist darum einerseits gleich ihrer Zeilen-, andererseits gleich ihrer Spaltenzahl. Das Rechteck $A^{(1)}$ ist in Wahrheit ein Quadrat, die zweite Klasse besteht aus ebenso vielen Individuen $d$ wie die erste. Alle Klassen sind gleich stark, $n=m d$. Danach ist die Figur zu korrigieren. Genauer ist jede der schraffierten Teilmatrizen für sich unitär. Indem wir auf die erste Klasse von Variablen die unitäre Transformation mit der Matrix $A^{(1)}$ ausïben, bewirken wir, daß sich $A^{(1)}$ in die $d$-dimensionale Einheitsmatrix verwandelt. Diese Normalform wird nicht zerstört, wenn man nachträglich die Variablen der ersten Klasse und ebenso die Variablen der zweiten Klasse, jede für sìch, der gleichen beliebigen unitären Transformation unterwirft. Dies 
können wir dazu benutzen, um auch die zweite Teilmatrix in die Einheitsmatrix umzuwandeln; und so fort bis zur $(m-1)$-ten. Die damit erzielte Normalform wird nicht zerstört, wenn die Variablen jeder Klasse untereinander der gleichen unitären Transformation unterliegen. Diese Transformation kann man schließlich, wie man weiß, noch so bestimmen, daß die letzte Teilmatrix $A^{(m)}$ eine Diagonalmatrix wird. Nunmehr nehmen wir eine Umnumerierung vor, indem wir zunächst aus jeder Klasse das erste Glied auslesen, darauf aus jeder Klasse das zweite usf. Dann zerfällt $A$ in $d$ Teilmatrizen, die sich längs der Hauptdiagonale aneinanderreihen. Wegen der vorausgesetzten Irreduzibilität ist nur eine davon vorhanden: $d=1, n=m$. Wir haben die Normalform (die nicht ausgefüllten Felder "stehen leer"):

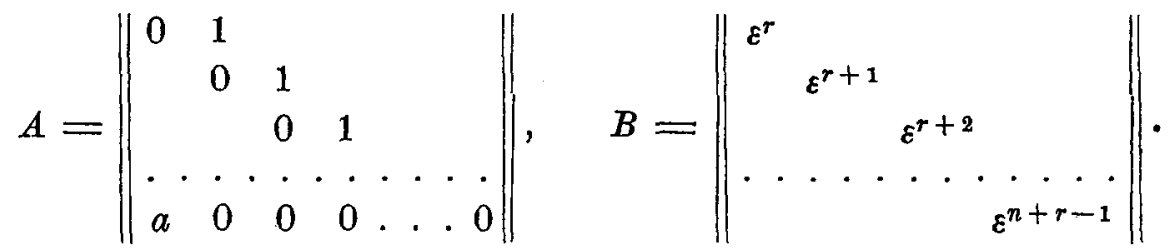

Die Exponenten in $B$ sind $n$ aufeinanderfolgende ganze Zahlen, $\varepsilon$ ist eine primitive $n$-te Einheitswurzel. Die Gleichung $A^{n}=1$ liefert endlich noch $a=1$. Lassen wir die Variablennummern von $r$ ab laufen und verstehen alle Indizes mod. $n$, so lauten die beiden Abbildungen:

$$
A: \quad x_{k}^{\prime}=x_{k-1}, \quad B: \quad x_{k}^{\prime}=\varepsilon^{k} x_{k} \text {. }
$$

Daraus sofort die Wiederholungen:

$$
A^{s}: \quad x_{k}^{\prime}=x_{k-8}, \quad B^{t}: \quad x_{k}^{\prime}=\varepsilon^{k t} x_{k} \text {. }
$$

Jetzt läßt sich in aller Strenge der Grenzübergang zu kontinuierlichen Gruppen vollziehen. Es sei (39) die kontinuierliche zweiparametrige irreduzible Abelsche Drehungsgruppe. Die Basis $i P, i Q$ sei nach (38) normiert. Wir identifizieren in unserer Betrachtung $A$ mit dem infinitesimalen $e(\xi P), B$ unit $e(\eta Q), \xi$ und $\eta$ reelle infinitesimale Konstanten. Es ist $e(\sigma P)=A^{s}, e(\tau Q)=B^{t}$, wenn im Limes $s \xi=\sigma$, $t \eta=\tau$ wird. $\quad \varepsilon$ fällt mit $e(\xi \eta)$ zusammen, $\varepsilon^{k t}$ ist $=e(\xi k \tau) . \quad e(\tau Q)$ ist die Repräsentation der physikalischen Größe $e^{i \tau q}$; diese ist also (bei beliebigem reellen $\tau$ ) der Werte fähig $e^{i \tau \xi k}$, wo $k$ die ganzen Zahlen durchläuft. Mit anderen Worten: die Größe $q$ ist der Werte $k \xi$ fähig, ihr Wertbereich das zusammenhängende Kontinum der reellen Zahlen von $-\infty$ bis $+\infty$. (Dabei ist $k$ freilich mod. $n, k \xi \bmod . n \xi$ zu verstehen; aber $n \xi$ ist ein Multiplum von $2 \pi / \eta$, folglich im Limes unendlich groß.) Darum schreiben wir jetzt $q$ an Stelle von $k \xi$, unter 
$q$ zugleich eine Variable verstehend, welche den Wertbereich der physikalischen Größe $q$ durchläuft, und $\sqrt{\xi} \cdot \psi(q)$ an Stelle von $x_{k} \cdot \psi(q)$ ist eine willkürliche komplexwertige Funktion, welche der Normierungsgleichung

$$
\int|\psi(q)|^{2} d q=1
$$

unterworfen ist. Ihre Werte sind aufzufassen als die den verschiedenen Werten von $q$ entsprechenden Komponenten eines "reinen Falles" in demjenigen normalen Koordinatensystem, das aus den Eigenvektoren der Größe $q$ besteht. - An Stelle der zweiten Gleichung (48) erhalten wir im Limes

$$
\psi^{\prime}=\psi \nabla_{\tau}: \quad \psi^{\prime}(q)=e^{i \tau q} \cdot \psi(q)
$$

das ist die unitäre Abbildung $V_{\tau}$, welche die Größe $e^{i \tau q}$ darstellt. Der gleiche Grenzübergang an der ersten Gleichung liefert die unitäre Abbildung

$$
\psi^{\prime}=\psi U_{\sigma}: \quad \psi^{\prime}(q)=\psi(q-\sigma),
$$

welche $e^{i \sigma p}$ repräsentiert. Beide Abbildungen sind in der Tat unitär, weil sie die Gleichung (49) invariant lassen; sie bilden, den verschiedenen Werten von $\sigma \mathrm{bzw} . \tau$ entsprechend, zwei einparametrige A b elsche Gruppen linearer Funktionaltransformationen :

$$
U_{\sigma+\sigma^{\prime}}=U_{\sigma} U_{\sigma^{\prime}}, \quad V_{\tau+\tau^{\prime}}=V_{\tau} V_{\tau^{\prime}}
$$

$\psi U_{\sigma} V_{\tau}$ ist die Funktion $e^{i \tau q} \cdot \psi(q-\sigma), \psi \nabla_{\tau} U_{\sigma}$ aber $=e^{i \tau(q-\sigma)} \cdot \psi(q-\sigma)$, so daß, wie es sein muß, die Kommutatorgleichung gilt:

$$
\psi U_{\sigma} \nabla_{\tau}=e^{i \sigma \tau} \cdot \psi \nabla_{\tau} U_{\sigma} .
$$

Der Größe $e(\sigma p+\tau q)$ entspricht nach (37) die Abbildung

$$
\psi(q) \rightarrow \psi^{\prime}(q)=e^{-1 / 2 i \sigma \tau} \cdot e^{i \tau q} \psi(q-\sigma)
$$

Geht man endlich auf die infinitesimalen Operationen zurück — was freilich im allgemeinen nicht zweckmäßig ist - so bekommt man als Repräsentation von

$$
p: \quad \delta \psi=i \frac{d \psi(q)}{d q}, \text { von } q: \delta \psi=q \cdot \psi(q)
$$

Damit sind wir bei der Schrödingerschen Fassung angelangt. Die Eigenfunktionen $\psi_{n}(q)$ seiner Wellengleichung baben danach die Bedeutung, daß sie die unitäre Transformation angeben, welche zwischen den beiden Hauptachsensystemen der Größe $q$ und der Energie $E$ vermittelt. Im Hinblick auf den ersten Teil ergeben sich daraus die bekannten Paulischen Ansätze für ihre Wabrscheinlichkeitsbedeutung.

Die Übertragung auf mehrere Freiheitsgrade ist mühelos durchführbar. Die Kinematik eines Systems, die durch eine konti- 
nuierliche Gruppe ausgedrückt wird, ist darum durch die Zahl der Freiheitsgrade $f$ eindeutig determiniert. Unsere Behandlung ist gültig auch für den Fall, daß die Größe $q$ eine zyklische Koordinate ist, die nur mod. $2 \pi$ in Betracht kommt. Dann durchläuft $\tau$ nur die ganzen Zahlen, die Gruppe ist halb diskontinuierlich. Die Repräsentationen (50) und (51) von $e^{i \tau q}$ und $e^{i \sigma p}$ bleiben bestehen; aber da $\tau$ nur ganzzahlige Werte annimmt, hat es keinen Sinn mehr, den Grenzübergang $\tau \rightarrow 0$ zu vollziehen. Eine "physikalische Größe $q^{4}$, welche durch eine Hermitesche Form zu repräsentieren wäre, gibt es überhaupt gar nicht, wohl aber z. B. $\cos q$.

Oft ist es zweckmäßig, Koordinaten und Impulse zu vertauschen, an Stelle der Komponenten $\psi(q)$ der Vektoren die Komponenten $\varphi(p)$ im System der Eigenvektoren von $p$ zu verwenden. Ihr Zusammenhang ist der durch die "Fouriersche Transformation"

$$
\psi(q)=\int_{-\infty}^{+\infty} e^{i q p} \varphi(p) d p
$$

gegebene*. Denn die Abbildung $V_{\tau}$ verwandelt $\psi(q)$ in

$U_{\sigma}$ aber in

$$
\int_{-\infty}^{+\infty} e^{i q(p+\tau)} \varphi(p) d p=\int_{-\infty}^{+\infty} e^{i q p} \varphi(p-\tau) d p
$$

Es ist also

$$
\int_{-\infty}^{+\infty} e^{i q p} \cdot e^{-i \sigma p} \varphi(p) d p
$$

$\varphi(p) \nabla_{\tau}=\varphi(p-\tau), \quad \varphi(p) U_{\sigma}=e^{-i \omega p} \varphi(p)$

III. Teil. Das dynamische Problem.

§ 9. Das Gesetz der zeitlichen Veränderung. Die Zeitgesamtheit. Die bisherigen Ansätze beanspruchen allgemeine Geltung. Nicht so günstig steht es mit dem dynamischen Problem, das eng mit der Frage nach der Rolle zusammenhängt, welche Raum und Zeit in der Quantenphysik spielen. In der Feldtheorie werden Zustandsgrößen behandelt, die in Raum und Zeit ausgebreitet sind, die Mechanik im engeren Sinne hat es nur mit der Zeit als der einzigen unabhängigen Veränderlichen zu tun. Die unabhängigen Veränderlichen sind keine

* Nach einem wichtigen Satz von Plancherel (Rend. Circ. Mat. Palermo 30, 330, 1910) und Titchmarsh [Lond. Matb. Soc. Proc. (2) 23, 279, 1924] hat diese Transformation für alle absolut quadratisch integrierbaren Funktionen einen klaren Sinn und erhält (bis auf den Faktor $2 \pi$ ) das Quadratintegral. 
gemessenen Größen, sie sind ein willkürlich in die Welt hineingetragenes gedachtes Koordinatenspinngewebe. Die Abhängigkeit einer physikalischen Größe von diesen Variablen ist also auch nicht etwas durch Messung zu Kontrollierendes; erst wenn mehrere physikalische Größen vorliegen, kommt man durch Elimination der unabhängigen Veränderlichen zu Beziehungen zwischen beobachtbaren Größen. Es mag sein, daß unter diesen Zustandsgrößen die Raumkoordinaten eines Elektrons auftreten; gemessener, real markierter Ort und natiürlich auch real markierte Zeit sind Zustandsgrößen und werden also durch Hermiteschen Formen zu repräsentieren sein. Diesem Sachverhalt gegenüber ist die nicht-relativistische Mechanik in der glücklichen Lage, die Zeit als Zustandsgröße ignorieren zu können, während die Relativitätsmechanik parallel mit den meßbaren Raumkoordinaten auch die meßbaren Zeitkoordinaten der Teilchen benötigt. Eine vollständige Durchführung der Quantentheorie liegt bisher nur in dem Umfang vor, in welchem die Zeit als einzige unabhängige Variable und die Zeit nur als unabhängige Variable auftritt.

Da die Hermitesche Form, welche zu einer physikalischen Größe gehört, nichts zu tun hat mit besonderen Werten, welche die Größe unter Umständen, insbesondere im Laufe der Zeit annimmt, bleibt sie von der Zeit unberührt. Was sich im Laufe der Zeit $t$ ändert, ist allein der reine Fall $\mathfrak{x}(t)$. Das dynamische Gesetz gibt die infinitesimale Verschiebung av, die xُ $(t)$ während des Zeitelements $d t$ erfährt:

$$
\frac{d \underline{x}}{d t}=\frac{2 \pi i}{h} \cdot \underset{x}{ } E .
$$

Hier ist $i E$ die infinitesimale unitäre Abbildung, welche mit der die Energie repräsentierenden Hermiteschen Form $E$ gekoppelt ist, $h$ das Wirkungsquantum. Die mit dem Vorrücken der Zeit um $d t$ verbundene Änderung $A(\mathfrak{q}+d \mathfrak{x})-A(\mathfrak{q})$ irgend einer Hermiteschen Form $A(\mathfrak{l})$ ist, wie man leicht ausrechnet,

$$
d A=\frac{2 \pi i d t}{h}(E A-A E)
$$

$d E$ ist $=0$. Bringt man die Hermitesche Form $E$ der Energie auf Hauptachsen:

$$
E\left(\lambda^{i}\right)=E_{1} x_{1} \bar{x}_{1}+E_{2} x_{2} \bar{x}_{2}+\cdots+E_{n} x_{n} \bar{x}_{n},
$$

so bezeichnen die Nummern 1 bis $n$ die möglichen Quantenzustände, $E_{i}$ die zugehörigen Energiestufen, und in den Gleichungen (54) separieren sich die Variablen:

$$
\frac{d x_{v}}{d t}=\frac{2 \pi i E_{\nu}}{h} x_{\nu} .
$$


Die Integration läßt sich sofort ausführen:

Die Hermitesche Form

$$
x_{v}(t)=x_{\nu} \cdot e\left(\frac{2 \pi t E_{v}}{h}\right) .
$$

$$
A(x)=\sum a_{\mu \nu} x_{\mu} \bar{x}_{\nu}
$$

ist nach Ablauf der Zeit $t$ übergegangen in

mit

$$
\sum a_{\mu v} x_{\mu}(t) \bar{x}_{\nu}(t)=\sum a_{\mu v}(t) x_{\mu} \bar{x}_{\nu}
$$

$$
a_{\mu v}(t)=a_{\mu v} \cdot e\left(\frac{2 \pi t\left(E_{\mu}-E_{v}\right)}{h}\right) .
$$

Die Komponenten $a_{\mu \nu}$ im Hauptachsensystem der Energie führen also einfache Schwingungen aus mit den Bohrschen Frequenzen. Nach(56) bleiben nicht nur die Energiestufen $E_{v}$ während der Bewegung erhalten sondern auch die Häufigkeiten $\left|x_{v}(t)\right|^{2}=\left|x_{v}\right|^{2}$, mit denen sie vertreten sind.

Das bisher Gesagte gilt für ein abgeschlossenes System. Wenn man innerhalb eines abgeschlossenen Systems ein Teilsystem ins Auge faßt, das unter dem Einfluß des Restes steht, dessen Rückwirkung auf den Rest aber vernachlässigt wird, so hat man den Fall der von außen eingeprägten Kräfte: die Hamiltonsche Funktion hängt explizite von der Zeit ab. Die Hermiteschen Formen, welche die Energie und andere Größèn $\alpha$ am System darstellen, sind Funktionen der Zeit: $A=A(t ; \mathfrak{x})$. Das Gesetz der zeitlichen Verschiebung des reinen Falles ${ }^{\prime}(t)$ bleibt das gleiche. Die Formel (31) in $\S 6$ gestattet die integrale Aneinanderreihung der von Schritt zu Schritt in der Zeit sich vollziehenden infinitesimalen Drehungen (54). So berechne man die Drehung $U\left(t_{1}, t_{2}\right)$, welche von $\mathfrak{x}\left(t_{1}\right)$ zu $\mathfrak{x}\left(t_{\mathbf{g}}\right)$ führt. Findet die Einwirkung von außen nur in dem Zeitr intervall $t_{1} t_{2}$ statt, während vor $t_{1}$ und nach $t_{2}$ das System abgeschlossen ist, so entnimmt man der Matrix $U\left(t_{1}, t_{2}\right)$ insbesondere, wie sich die Wahrscheinlichkeiten für die verschiedenen Energiestufen $E_{\mu}$ durch die Einwirkung verschoben haben. Darauf bezieht sich die Ontersuchung von M. Born über das Adiabatenprinzip in der Quantenmechanik*.

Wenn die Zeit nicht meßbare Größe, sondern nur unabhängige Variable ist, haben nur solche Beziehungen konkrete Bedeutung, aus denel die Zeit eliminiert ist. Tatbestände von diesem Charakter sind in der Quantenmechanik eines abgeschlossenen Systems: der Wertevorrat welchen eine gegebene Größe durchlaufen kann, und die zeitlichen Mittelwerte der Wahrscheinlichkeiten $W(\mathfrak{x})$, mit denen eine gegebene

* ZS. f. Phys. 40, 167, 1927. 
Größe Werte in gegebenen Grenzen annimmt. Handelt es sich um den reinen Fall

$$
\text { ․: } \quad x_{\nu}=c_{\nu} e\left(\gamma_{\nu}\right) \quad\left(c_{\nu} \geqq 0, \gamma_{\nu} \text { reell }\right),
$$

so durchläuft $\mathfrak{x}(t)$ nach $(56)$, wenn die Energiestufen nicht speziellen linearen Rationalitätsbeziehungen genügen, gleichmäßig dicht das ganze durch

$$
\left|x_{1}\right|=c_{1}, \quad\left|x_{2}\right|=c_{2}, \quad \ldots, \quad\left|x_{n}\right|=c_{n}
$$

definierte Gebilde $\mathfrak{S}$ von $n$ reellen Dimensionen. In den Ausnahmefällen reduziert sich die Dimensionszahl*. Zur Berechnung der zeitlichen Mittelwerte ist über dieses gleichmäßig dicht von der Zeitkurve erfüllte Gebiet $\mathfrak{D}$, die "Zeitgesamtheit", zu integrieren.

Ich erinnere noch kurz an die Beziehung der Energie und der Hamiltonschen Gleichungen zu den kanonischen Variablen. Hat das mechanische System einen Freiheitsgrad und ist eine Funktion (42) der kanonischen Variablen $p, q$ repräsentiert durch die Matrix (41), so sind gemäß unserer Festsetzung die beiden Ableitungen $\frac{\partial f}{\partial p}=f_{p}, \frac{\partial f}{\partial q}=f_{q}$ repräsentiert durch

$$
\begin{aligned}
& F_{p}=i \int_{-\infty}^{+\infty} e(\sigma P+\tau Q) \cdot \sigma \xi(\sigma, \tau) d \sigma d \tau, \\
& F_{q}=i \int_{-\infty}^{+\infty} e(\sigma P+\tau Q) \cdot \tau \xi(\sigma, \tau) d \sigma d \tau,
\end{aligned}
$$

da entsprechende Fourierentwicklungen für $f_{p}$ und $f_{q}$ gelten. Wegen (38) ergibt die Kommutatorregel (35), wenn man $U(\tau)$ wieder infinitesimal werden läßt, die beiden Gleichungen

also

$$
\begin{aligned}
& P . e(\sigma P+\tau Q)-e(\sigma P+\tau Q) \cdot P=\tau \cdot e(\sigma P+\tau Q), \\
& Q . e(\sigma P+\tau Q)-e(\sigma P+\tau Q) \cdot Q=-\sigma . e(\sigma P+\tau Q),
\end{aligned}
$$

$$
-F_{p}=i(Q F-F Q), \quad F_{q}=i(P F-F P) \text {. }
$$

Das dynamische Gesetz (54) läßt sich daher, wenn $f(p, q)$ die Energiefunktion ist, nach (55) so fassen:

$$
\frac{d P}{d t}=-\frac{2 \pi}{h} \cdot F_{q}, \quad \frac{d Q}{d t}=\frac{2 \pi}{h} \cdot F_{p}
$$

Daraus sieht man: wenn $a$ und $b$ zwei reelle Zahlen vom Produkt $h / 2 \pi$ sind, repräseníieren $a P$ und $t Q Q$ Größen, welche kanonisch sind in

* Vgl. H. Weyl, Über die Gleichverteilung von Zahlen mod. Eins, Math. Ann. 77, 313, 1916. 
dem Sinne, daß für sie die klassischen Bewegungsgleichungen gelten. Auf diese Weise wird in konkreten Beispielen die Bestimmung der Energie als Größe im Gruppengebiet durchgeführt. Bei solcher Beschreibung kommt das Wirkungsquantum nur einmal vor: in dem dynamischen Gesetz und nicht in den Vertauschungsrelationen. Sie basiert auf der Überzeugung, da $B$ die formalen Beziehungen der klassischen Physik als solche zwischen den repräsentierenden Matrizen, nicht zwischen den angenommenen Werten, bestehen bleiben.

Will man den gerügten Mangel des Zeitbegriffs der alten vorrelativistischen Mechanik aufheben, so werden die meßbaren Größen: Zeit $t$ und Energie $E$, als ein weiteres kanonisch konjugiertes Paar auftreten, wie ja bereits das Wirkungsprinzip der analytischen Mechanik erkennen läßt; das dynamische Gesetz kommt ganz in Fortfall. Die Behandlung eines Elektrons im elektromagnetischen Felde nach der Relativitätstheorie durch Schrödinger u. a. entspricht bereits diesem Standpunkt*. Eine allgemeine Formulierung liegt noch nicht vor.

$\$ 10$. Kinetische Energie und Coulombsche Kraft in der relativistischen Quantenmechanik. Innerhalb des Schemas, das die Zeit nur als unabhängige Variable kennt, ist wenigstens eine halbrelativistische Mechanik möglich, welche den richtigen Ausdruck für die kinetische Energie verwendet, aber die potentielle Energie nach wie vor als eine Funktion der Lagekoordinaten, und das heißt doch genauer: ihrer simultan en Werte, annimmt. Zur Illustration der Theorie behandle ich den Fall eines oder mehrerer Teilchen, deren Lage durch ihre rechtwinkligen Koordinaten $x, y, z$ gekennzeichnet wird. Der Ausdruck der kinetischen Energie in den zugehörigen Impulsen $u, v, w$ lautet, wenn $m$ die Masse des Teilchens bedeutet und $c$ die Lichtgeschwindigkeit:

$$
c \sqrt{m^{2} c^{2}+u^{2}+v^{2}+w^{2}}
$$

Für die Durchrechnung ist es zweckmäßig, die Koordinaten und Impulse des Teilchens auf die Maßeinheiten $\frac{h}{2 \pi m c}$ bzw. mc zu beziehen; dann sind sie dimensionslose Größen und zugleich mit der von uns befürworteten Normierung der kanonischen Koordinaten in Einklang. Es handelt sich darum, die Abbildung oder Hermitesche Form zu konstruieren, welche dieser Größe entspricht im Raume der Funktionen $\psi(x, y, z)$. Als Musterbeispiel diene der eindimensionale Fall. Es ist

* Siehe etwa E. Schrödinger, Abhandlungen zur Wellenmechanik, Leipzig 1927, S. 163, = Ann. d. Phys. (4) 81, 133, 1926. 
die Fourierzerlegung von $\sqrt{1+u^{2}}$ vorzunehmen. Im Sinne früherer Bemerkungen hat man diese Funktion zunächst etwa durch

$$
e^{-\alpha|u|} \sqrt{1+u^{2}}
$$

$z u$ ersetzen mit einem kleinen positiven $\alpha$ und dann $\alpha$ gegen 0 konvergieren zu lassen. Setzen wir

$$
\frac{1}{\pi} \Re \int_{0}^{\infty} e^{-\alpha u} \sqrt{1+u^{2}} e^{-i \sigma u} d u=G_{a}(\sigma)
$$

so ist die der Größe (57) korrespondierende Abbildung

$$
\psi(x) \rightarrow \psi_{\alpha}^{\prime}(x)=\int_{-\infty}^{+\infty} \psi(x-\sigma) G_{\alpha}(\sigma) d \sigma=\int_{-\infty}^{+\infty} G_{\alpha}(x-\xi) \psi(\xi) d \xi
$$

die Hermitesche Form der willkürlichen Funktion $\psi(x)$ lautet:

$$
\int_{-\infty}^{+\infty} G_{\alpha}(x-\xi) \psi(x) \bar{\psi}(\xi) d x d \xi
$$

Um an der geraden Funktion $G_{\alpha}(\sigma)$ für $\sigma>0$ den Grenzübergang zu $\alpha=0 \mathrm{zu}$ vollziehen, schlagen wir in dem Integral, von dem $\pi G_{\alpha}(\sigma)$ nach (58) der Realteil ist, den Integrationsweg in die negative imaginäre Halbachse hinüber: $u=-i t$, indem wir die Singularität $u=-i$ nach rechts hin umgehen:

$$
-i \int_{0}^{1} e^{-(\sigma-i \alpha) t} \sqrt{1-t^{2}} d t-\int_{1}^{\infty} e^{-(\sigma-i \alpha) t} \sqrt{t^{2}-1} d t .
$$

Im Limes für $\alpha=0$ ist der Realteil also

$$
G(\sigma)=-\frac{1}{\pi} \int_{1}^{\infty} e^{-\sigma t} \sqrt{t^{2}-1} d t \quad(\sigma>0) .
$$

Daraus liest man sofort $a b, d a ß$

$$
-G(\sigma)=\frac{1}{\pi \sigma^{2}}-\Gamma(\sigma)
$$

ist, wo $\Gamma$ für $\sigma=0$ nur noch logarithmisch unendlich wird. In (59) macht der Grenzübergang zu $\alpha=0$ an dem $\Gamma$-Teil keine Schwierigkeit. In (60) ist der erste Summand bei $\alpha+i \sigma=0$ regulär, der zweite hängt eng mit derjenigen Hankelschen Zylinderfunktion erster Ordnung $H$ zusammen, die mit positiv wachsendem б exponentiell zu 0 geht; er ist 
nämlich $=\frac{H(\alpha+i \sigma)}{\alpha+i \sigma}$. Darum ist bis auf einen additiv hinzutretenden Teil, der an der kritischen Stelle $\alpha+i \sigma=0$ nur logarithmisch unendlich wird,

$$
G_{a}(\sigma) \sim-\frac{1}{\pi} \Re \frac{1}{(\sigma-i \alpha)^{2}} .
$$

So kommt als Repräsentation der kinetischen Energie die Operation

$$
\begin{aligned}
\psi(x) \rightarrow \psi^{\prime}(x) & =\psi^{*}(x)+\int_{-\infty}^{+\infty} \Gamma(x-\xi) \psi(\xi) d \xi \\
-\psi^{*}(x) & =\lim _{z \rightarrow x} \Re \frac{1}{\pi} \int_{-\infty}^{+\infty} \frac{\psi(\xi) d \xi}{(z-\xi)^{2}}
\end{aligned}
$$

(der Einfachheit halber ist $\psi$ reell angenommen). Der Grenzübergang ist so $z \mathfrak{u}$ verstehen, $\mathrm{da} \beta z$ komplex $=x+i y$ ist mit positivem Imaginärteil $y$ und $y$ zu 0 strebt. Das in der letzten Gleichung hinter dem Zeichen $\Re$ stehende Integral ist das $i$-fache der Ableitung derjenigen analytischen Funktion in der oberen Halbebend $y>0$, deren Realteil $\psi$ auf der reellen Achse mit unserem $\psi(x)$ zusammenfällt. $-\psi^{*}(x)$ ist demnach die nach der inneren Normale $n$ genommene Ableitung $\frac{d \psi}{d n}$ dieser Potentialfunktion am Rande. Da das über den Rand erstreckte Integral von $-\psi \frac{d \psi}{d n}$ nichts anderes ist als das Dirichletsche Integral $D(\psi)$ über die obere Halbebene, haben wir schließlich als die der Größe $\sqrt{1+u^{2}}$ zugehörige Hermitesche Form:

$$
D(\psi)+\int_{-\infty}^{+\infty} \Gamma(x-\xi) \psi(x) \psi(\xi) d x d \xi
$$

Wenn es sich um ein einzelnes Teilchen handelt und eine (in der Einheit $m c^{2}$ gemessene) potentielle Energie $V(x)$ da ist, besteht das Eigenwertproblem darin,

$$
D(\psi)+\int_{-\infty}^{+\infty} \Gamma(x-\xi) \psi(x) \psi(\xi) d x d \xi+\int_{-\infty}^{+\infty} V(x) \psi^{2}(x) d x
$$

zum Extremum zu machen unter der Nebenbedingung $\int_{-\infty}^{+\infty} \psi^{2} d x=1$. Die Extremalwerte $\lambda$ sind die Energiestufen. 
Es ist klar, daß die Operation (61), wenn sie zweimal ausgeführt wird, zu derjenigen führen muß, die $1+u^{2}$ korrespondiert, d. i. zu $\psi(x)+\frac{d^{2} \psi}{d x^{2}}$. Deshalb kann die Schwingungsgleichung für das einzelne Teilchen auch in der Form einer gewöhnlichen Differentialgleichung angeschrieben werden:

$$
\frac{d^{2} \psi}{d x^{2}}+\psi(x)=(\lambda-V(x))^{2} \psi(x)
$$

Aber hier tritt der Eigenwertparameter $\lambda$ nicht mehr in linearer Weise auf, und die Hälfte der Eigenwerte sind falsche. Auf solchem Wege gelang es Schrödinger und P. Epstein, die Energiestufen und Eigenfunktionen des Wasserstoffatoms relativistisch zu berechnen*. Wenn aber mehrere Teilchen im Spiel sind, ist es unmöglich, durch Iteration zu Differentialgleichungen zu gelangen.

Wenn die wirkenden Kräfte Coulombsche Kräfte sind, die von einem festen Kern ausgehen, ist es zweckmäßig, die Komponenten $\varphi$ der reinen Fälle im Hauptachsensystem der Impulskomponenten zu benutzen. Die kinetische Energie ist dann einfach repräsentiert durch die Multiplikation

$$
\begin{gathered}
\varphi \rightarrow \varphi^{\prime}: \varphi^{\prime}(u, v, w)=\sqrt{1+s^{2}} \cdot \varphi(u, v, w) \\
\left(s^{2}=u^{2}+v^{2}+w^{2}\right) .
\end{gathered}
$$

Es gilt, die repräsentierende Fermitesche Form für das Potential $1 / r$ $\left(r^{2}=x^{2}+y^{2}+z^{2}\right)$ zu finden. Aus Konvergenzgründen werde $1 / r$ zunächst ersetzt durch $\frac{e^{-l r}}{r}$, wo $l$ eine kleine positive Konstante ist. Für das Integral in der Fourierzerlegung dieser Funktion

$$
\frac{1}{(2 \pi)^{3}} \int_{-\infty}^{+\infty} \int_{-\infty}^{\infty} \frac{e^{-l r}}{r} e^{-\imath(\alpha x+\beta y+\gamma z)} d x d y d z
$$

findet man leicht durch Einführung von Polarkoordinaten

$$
\frac{4 \pi}{l^{2}+\sigma^{2}} \quad\left(\sigma^{2}=\alpha^{2}+\beta^{2}+\gamma^{2}\right) .
$$

* E. Schrödinger, Abhandlungen zur Wellenmechanik, 1927, S. 164, = Ann. d. Phys. (4) 81, 134, 1926. P. S. Epstein, Two Remarks on Schrödinger's Quantum Theory, Proc. Amer. Nat. Acad. 13, 94, 1927. 
H. Weyl,

Die gesuchte Abbildung ist also diejénige, welche $\varphi(u, v, w)$ verwandelt in

$$
\begin{aligned}
P_{\varphi(u, v, w)} & =\frac{1}{2 \pi^{2}} \iint_{-\infty}^{+\infty} \int_{-\infty} \varphi(u+\alpha, v+\beta, w+\gamma) \frac{d \alpha d \beta d \gamma}{\sigma^{2}} \\
& =\frac{1}{2 \pi^{2}} \iint_{-\infty}^{+\infty} \frac{\varphi(\alpha, \beta, \gamma) d \alpha d \beta d \gamma}{(u-\alpha)^{2}+(v-\beta)^{2}+(w-\gamma)^{2}} \\
& =\frac{2}{\pi} \int_{0}^{\infty} M_{\sigma}(\varphi) d \sigma .
\end{aligned}
$$

In der letzten Gestalt bedeutet $M_{\sigma}(\varphi)$ den Mittelwert der Funktion $\varphi$ auf der Kugel vom Radius $\sigma$ um den Punkt $(u, v, w)$ im Impulsraum. Behält man $l$ zunächst noch bei, so tritt im Ausdruck (62) der Summand $7^{2}$ im Nenner hinzu. Die Funktion, die sich so ergibt, ist im vierdimensionalen Raum mit den Roordinaten $u, v, w, l$ diejenige Potentialfunktion $F$, welche aus der Massenbelegung der "Ebene" $l=0$ mit der Dichte $\varphi$ entsteht. $P_{\varphi}$ sind ihre Werte auf der belegten Ebene. Da offenbar

$$
\int_{-\infty}^{+\infty} \int_{-\infty}^{d \alpha d \beta d \gamma} \frac{\text { const }}{r_{10}^{y} r_{20}^{2}}
$$

ist, wo 1, 2, $0=(\alpha \beta \gamma)$ drei Purkte im Impulsraum bedeuten und $r_{10}$, $r_{20}, r_{12}$ ihre gegenseitigen Abstände, liefert die Wiederholung $P^{2}$ von $P$ den ProzeB, der im dreidimensionalen Impulsraum $\varphi$ überführt in die durch die Raumbelegung $\varphi$ erzeugte Potentialfunktion $\Phi$. Es gilt bekanntlich

$$
\frac{\partial^{2} \Phi}{\partial u^{2}}+\frac{\partial^{2} \Phi}{\partial v^{2}}+\frac{\partial^{2} \Phi}{\partial w^{2}}=\varphi
$$

Man wird nuch Kugelfunktionen zerspalten. Benutzt man die oben erwähnte vierdimensionale harmonische Funktion $F$ und macht den Ansatz

$$
F=Y_{n} \cdot F(s, l)
$$

in welchem $Y_{n}$ eine nur von der Richtung $u: v: w$ abhängige Kugelfunktion $n$-ter Ordnung sein soll, so genügt im oberen Halbraum $l>0$ der nur von $s$ und $l$ abhängige Faktor $F$ der Gleichung

$$
\frac{\partial}{\partial s}\left(s^{2} \frac{\partial F}{\partial s}\right)+s^{2} \frac{\partial^{2} F}{\partial l^{2}}=n(n+1) F^{\prime}
$$

und die Operation $P$ bedeutet den Übergang von den Randwerten ihrer normalen Ableitung zu ihren eigenen Randwerten. Vielleicht ist es 
bequemer, statt $F(s, l)$ die Funktion $s F(s, l)=F^{*}(s, l)$ zu behutzen. Für sie lautet die Differentialgleichung

$$
\frac{\partial^{2} F^{*}}{\partial s^{2}}+\frac{\partial^{2} F^{*}}{\partial l^{2}}=\frac{n(n+1)}{s^{2}} F^{*}
$$

$F^{*}$ ist eine Funktion in der oberen Hälfte $l>0$ einer $(s, l)$-Ebene, welche bei Spregelung an der l-Achse angerade ist. - Indem man in (62) den Faktor $1 / R^{2}$,

$$
R^{2}=(u-\alpha)^{2}+(v-\beta)^{2}+(w-\gamma)^{2}=s^{2}+\sigma^{2}-2 s \sigma \cos \theta,
$$

nach Kugelfunktionen $P_{n}(\cos \vartheta)$ entwickelt:

$$
\frac{1}{R^{2}}=\frac{1}{4 s \sigma} \sum_{n=0}^{\infty}(2 n+1) L_{n} \cdot P_{n}(\cos \vartheta)
$$

erhält man, wenn analog

$$
\varphi=Y_{n} \cdot s \varphi^{*}(s)
$$

angesetzt wird, als Ausdruck der Operation $P$ an solchen Funktionen die Formel

$$
\begin{gathered}
\varphi^{*}(s) \rightarrow \frac{1}{2 \pi} \int_{0}^{\infty} L_{n}\left(\frac{s^{2}+\sigma^{2}}{2 s \sigma}\right) \cdot \varphi^{*}(\sigma) d \sigma \\
L_{n}(t)=\int_{-1}^{+1} \frac{P_{n}(x) d x}{t-x} .
\end{gathered}
$$

Wenn das Einkörperproblem vorliegt, wird man, auf die Gefahr hin, eine Serie falscher Eigenwerte einzuschmuggeln, $\boldsymbol{P}$ iterieren und dadurch zu einer reinen Differentialgleichung kommen. Für das nichtrelativistische Wasserstoffatom sind die Eigenfunktionen $\varphi_{n}(u, v, w)$, die durch die Fouriersche Transformation aus den Schrödingerschen Eigenfunktionen $\psi_{n}(x, y, z)$, den Laguerreschen Polynomen, hervorgehen, in meiner Dissertation angegeben*. Sie können auch sehr schön direkt auf dem hier skizzierten Wege gewonnen werden. Im Mehrkörperproblem versagt die Iterationsmethode.

Coulombsche Kräfte $z$ wischen mehreren beweglichen Teilchen. Dem reziproken Abstand $1 / r_{12}$ zweier Teilchen 1 und 2 entspricht im Gebiet der Impulsfunktionen $\varphi\left(u_{1}, v_{1}, w_{1} ; u_{2}, v_{2}, w_{2}\right)$, wie man auf die gleiche Weise erkennt, die Abbildung

$$
\begin{aligned}
\varphi \rightarrow \varphi^{\prime}=\frac{1}{2 \pi^{2}} \int_{-\infty}^{+\infty} \int_{-\infty}^{\infty} \varphi\left(u_{1}+\alpha, v_{1}+\beta, w_{1}+\gamma ;\right. \\
\left.u_{2}+\alpha, v_{2}+\beta, w_{2}+\gamma\right) \frac{d \alpha d \beta d \gamma}{\alpha^{2}+\beta^{2}+\gamma^{2}} .
\end{aligned}
$$

* Math. Ann. 66, 307-309, 317-324, 1908. 
Die Bezeichnung soll natürlich nicht ausschließen, daß $\varphi$ auch von den Impulsen der übrigen Teilchen abhängt, diese werden aber von der Transformation nicht mit betroffen.

\section{Mathematischer Anhang.}

Beweis des Satzes von der.Hauptachsentransformation einer unitären Abbildung. Ist die unitäre Abbildung $A=\left\|a_{i k}\right\|$ gegeben, so bestimmen wir einen Vektor $\mathfrak{x} \neq 0$, der $\operatorname{durch} A$ in ein Multiplum von sich selber übergeht:

$$
\mathfrak{x} A=\varepsilon \mathfrak{x} \quad \text { oder } \sum_{i=1}^{n} a_{i k} x_{i}=\varepsilon x_{k} \text {. }
$$

Wählen wir $\varepsilon$ als eine Wurzel der Säkulargleichung

$$
\operatorname{det}(\varepsilon \mathbf{1}-A)=0 \text {, }
$$

so existiert tatsächlich ein derartiger Vektor $\mathfrak{x}=\mathrm{e}_{1}$. Indem wir seinen Betrag zu 1 normieren, ergänzen wir ihn durch weitere $n-1$ Vektoren $\mathrm{e}_{2}, \ldots, \mathrm{e}_{n}$ zu einem normalen Koordinatensystem. $\mathrm{Da}$ in $\mathrm{ihm}$ die Gleichungen (63) für $\mathfrak{e}_{1}$, d. i. für $x_{1}=1, x_{2}=0, \ldots, x_{n}=0$ erfüllt sind, ist jetzt

$$
a_{11}=\varepsilon, a_{12}=\cdots=a_{1 n}=0 .
$$

Die Quadratsumme der absoluten Beträge der ersten Koeffizientenzeile in $A \mathrm{muB} 1$ sein, darum ist $|\varepsilon|=1$. Aber auch die absolute Quadratsumme der Glieder, welche in der ersten Spalte stehen, ist $=1$, und das liefert

$$
1+\left|a_{21}\right|^{2}+\cdots+\left|a_{n 1}\right|^{2}=1, \quad a_{21}=\cdots=a_{n 1}=0 .
$$

Das ist der entscheidende Schluß. Die Matrix $A$ zerfällt nunmehr in der aus dem Schema ersichtlichen Weise:

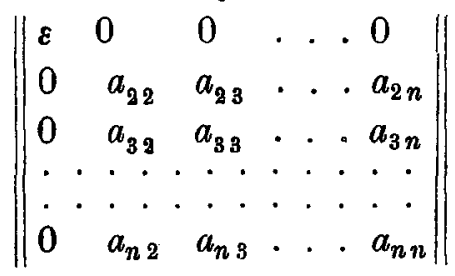

Durch Induktion in bezug auf die Dimensionszahl $n$ ist damit der Beweis vollendet.

Liegt die unitäre Abbildung $A$ in der Normalform vor, mit den Termen $a_{i}$ in der Hauptdiagonale, so genügen der Gleichung (63) offenbar alle und nur diejenigen Vektoren, welche sich aus Grundvektoren $e_{i}$ zusammensetzen, für die $a_{i}=\varepsilon$ ist. Daraus geht hervor, daß die verschiedenen Eigenwerte $a^{\prime}, a^{\prime \prime}, \ldots$ mit ihrer Vielfachheit und die zu- 
gehörigen Teilräume $\Re\left(a^{\prime}\right), \mathfrak{\Re}\left(a^{\prime \prime}\right), \ldots$, von denen in $\$ 1$ die Rede war, eindeutig durch $A$ bestimmt sind.

Wenn $A=\left\|a_{i k}\right\|, B=\left\|b_{i k}\right\|$ vertauschbare unitäre Matrizen sind, lassen sie sich simultan auf Hauptachsen transformieren. Beweis: $A$ kann sogleich in der Normalform angenommen werden, in welcher nur Glieder $a_{i}$ in der Hauptdiagonale auftreten. Die Vertauschbarkeitsforderung besagt

$$
\left(a_{i}-a_{k}\right) b_{i k}=0 \text {. }
$$

Wir teilen die Indizes in Klassen, indem $i$ und $k$ in dieselbe Klasse kommen, wenn $a_{i}=a_{k}$ ist. Die Gleichung (64) zeigt, daß $b_{i k}=0$ ist, wenn die Indizes $i$ und $k$ verschiedenen Klassen angehören; d. h. $B$ zerfällt in der gleichen Weise in Teilmatrizen: $B^{\prime}, B^{\prime \prime}, \ldots$, die sich längs der Hauptdiagonale aneinanderreiben, wie sich die $a_{i}$ in Klassen untereinander gleicher aufteilen: $a^{\prime}, a^{\prime \prime}, \ldots$ Die Abbildung $B$ läßt die zu den Eigenwerten $a^{\prime}, a^{\prime \prime}, \ldots$ gehörigen Teilräume $\Re\left(a^{\prime}\right), \mathfrak{\Re}\left(a^{\prime \prime}\right), \ldots$ einzeln invariant. Die Normalform von $A$ wird nicht zerstört, wenn die Variablen, welche der gleichen Klasse angehören, untereinander unitär transformiert werden, Durch geeignete Wahl dieser einzelnen unitären Transforma-

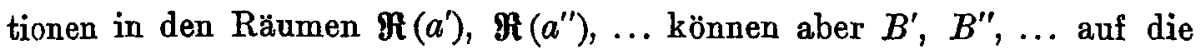
Normalform gebracht werden. - Das Verfahren ist ohne weiteres auf irgend eine kommutative Gesamtheit von unitären Matrizen zu übertragen.

Der Satz von der Hauptachsentransformation der Hermiteschen Formen ist ein Grenzfall des soeben bewiesenen, kann aber auch nach der gleichen Methode direkt abgeleitet werden. Der Schluß von

$$
a_{12}=\cdots=a_{1 n}=0 \text { auf } a_{21}=\cdots=a_{n 1}=0
$$

geschieht hier vermöge der Symmetriebedingung $a_{k i}=\bar{a}_{i k}$.

Beweis des Satzes, daß eine unitäre Abbildung $\boldsymbol{A}$ notwendig $=\varepsilon 1$ ist, wenn sie mit allen unitären Abbildungen eines gegebenen irreduziblen Systems $\mathfrak{U}$ vertauschbar ist. Man führe dasjenige normale Koordinatensystem ein, in welchem $A$ mit den Eigenwerten $a_{i}$ zur Diagonalmatrix wird. Sind nicht alle $a$ einander gleich, so zerfallen die sämtlichen Matrizen $U$ der vorgegebenen Gesamtheit in der gleichen Weise, wie die $a_{i}$ in Klassen untereinander gleicher zerfallen; $A$ bewirkt dann einen simultanen Zerfall aller Matrizen des Systems 11. 
Den Satz über die lineare Transformation einer nichtausgearteten schiefsymmetrischen reellen Bilinearform

$$
\sum_{i, k=1}^{f} c_{i k} x_{i} y_{k} \quad\left(c_{k i}=-c_{i k}\right)
$$

beweist man so. Man fasse das einzelne Zahlsystem $\left(x_{1}, x_{2}, \ldots, x_{f}\right)$ als einen Vektor $x$ auf und bezeichne (65) als das schiefe Produkt [ $[\mathfrak{y}]$ der beiden Vektoren $\mathfrak{x}$ und $\mathfrak{y}=\left(y_{i}\right)$. Man wähle einen Vektor $\mathfrak{e}_{1} \neq 0$. Nach Voraussetzung ist $\left[e_{1} \mathfrak{x}\right]$ nicht identisch in $\mathfrak{x}$ gleich 0 ; ich kann also einen $z$ weiten Vektor $e_{2}$ so finden, dab $\left[e_{1} e_{2}\right]=1$ ist. Die simultan zu erfüllenden Gleichungen

$$
\left[e_{1} x^{x}\right]=0, \quad\left[e_{2} x\right]=0
$$

haben mindestens $f-2$ linear unabhängige Lösungen $e_{3}, \ldots, e_{f}$. Auch $z$ wischen ihnen und $e_{1}, e_{2}$ findet keine lineare Relation statt. Denn ist

$$
\mathfrak{z}=\xi_{1} \mathrm{e}_{1}+\xi_{2} \mathrm{e}_{2}+\xi_{3} \mathrm{e}_{3}+\cdots+\xi_{f} \mathrm{e}_{f}=0,
$$

so folgt durch Bildung der beiden schiefen Produkte $\left[e_{1} x\right]=\xi_{2}$, $\left.e_{2} x^{*}\right]=-\xi_{1}$ daß $\xi_{1}=\xi_{2}=0$ wird. Man kann also $e_{1}, e_{2}, \ldots, e_{f}$ als Koordinatensystem, als Vektorenbasis verwenden. In den darauf bezüglichen Komponenten $\xi_{i}, \eta_{i}$ der beiden Vektoren $\mathfrak{x}$ und $\mathfrak{y}$ laute das schiefe Produkt

$$
[\mathfrak{x} y]=\sum_{i, k=1}^{f} \gamma_{i k} \xi_{i} \eta_{k} \text {. }
$$

Gemäß der Bestimmung der Grundvektoren gilt für die Koeffizienten $\gamma_{i k}=\left[\mathrm{e}_{i} \mathrm{e}_{k}\right]$ :

$$
\begin{aligned}
& \gamma_{11}=0, \quad \gamma_{12}=1 ; \gamma_{13}=0, \ldots, \gamma_{1 f}=0 \\
& \gamma_{21}=-1, \gamma_{22}=0 ; \gamma_{23}=0, \ldots, \gamma_{2 f}=0 .
\end{aligned}
$$

Wegen der schiefen Symmetrie sind infolgedessen auch alle $\gamma_{i 1}, \gamma_{i 2}$ mit $i=3, \ldots, f$ gleich 0 ; und die Matrix der $\gamma_{i k}$ zerfällt in das zweireihige Quadrat $\left\|\begin{array}{rr}0 & 1 \\ -1 & 0\end{array}\right\|$ und eine $(f-2)$-dimensionale schiefsymmetrische Matrix. Durch Induktion in bezug auf die Dimensionszahl $t$ ergibt sich der behauptete Satz. 


\section{Die Eindeutigkeit der Schrödingerschen Operatoren.}

Von

J. v. Neumann in Berlin.

1. Die sogenannte Vertauschungsrelation

$$
P Q-Q P=\frac{\hbar}{2 \pi i} 1
$$

ist in der neuen Quantentheorie von fundamentaler Bedeutung, sie ist es, die den "Koordinaten-Operator" $R$ und den "Impuls-Operator" $P$ im wesentlichen definiert ${ }^{1}$ ). Mathematisch gesprochen, liegt darin die folgende Annahme: Seien $P, Q$ zwei Hermitesche Funktionaloperatoren des Hilbertschen Raumes, dann werden sie durch die Vertauschungsrelation bis auf eine Drehung des Hilbertschen Raumes, d. i. eine unitäre Transformation $U$, eindeutig festgelegt ${ }^{2}$ ). Es liegt im Wesen der Sache, daß noch der Zusatz gemacht werden muß: vorausgesetzt, da $B, Q$ ein irreduzibles System bilden (vgl. weiter unten Anm. $\left.{ }^{\circ}\right)$ ). Wird num, wie es sich durch die Schrödingersche Fassung der Quantentheorie als besonders günstig erwies, der Hilbertsche Raum als Funktionenraum interpretiert - der Einfachheit halber etwa als Raum aller komplexen Funktionen $f(q)(-\infty<q<+\infty)$ mit endlichern $\int_{-\infty}^{+\infty}|f(q)|^{2} d q$-, so gibt es nach Schrödinger ein besonders einfaches Lösungssystem der Vertauschungsrelation

$$
\left.Q: \quad f(q) \rightarrow q f(q), \quad P: \quad f(q) \rightarrow \frac{h}{2 \pi i} \frac{d}{d q} f(q)^{3}\right)
$$

1) Vgl. Born-Heisenberg-Jordan, Zeitschr. f. Phys. 34 (1925), S. 858-888, ferner Dirac, Proc. Roy. Soc. 109 (1925) u. f. Besonders in der letztgenannten Darstellung ist die Rolle dieser Relation fundamental. Finen interessanten Versuch zur Begründung des im folgenden zu diskutierenden Eindeutigkeitssatzes machte Jordan, Zeitsohr. f. Phys. 37 (1926), S. 383-386. Indessen beruht dieser auf Konvergenzannahmen über Potenzreihen unbeschränkter Operatoren, deren Gültigkeitsbereich fraglioh ist.

5) Dieselbe bewirkt ein Ersetzen von $P, Q$ durch $U P U^{-1}, U Q U^{-1}$, wodurch weder der Hermitesche Charakter noch das Bestehen der Vertausohungsrelation berührt wird.

3) Vgl. Schrödinger, Annalen d. Phys. 79 (1926), S. 734-756. 
Sind nun dies die im wesentlichen einzigen (irreduziblen) Lösungen der Vertauschungsrelation?

Indessen ist die Aufgabe in dieser Form nicht genügend präzis formuliert. Denn als $P, Q$ sind, wie es die Schrödingerschen Lösungen zeigen, auch unbeschränkte, nicht überall definierte Operatoren ins Auge zu fassen, und für diese wird der Operator $P Q-Q P$ nicht überall definiert sein, während es der (auf der anderen Seite der Vertauschungsrelation stehende) Operator $\frac{h_{b}}{2 \pi i} 1$ ist. Die beiden Seiten können also nur gleichgesetzt werden, wenn ihre Definitionsbereiche (d. h. der der linken Seite) näher umschrieben werden. Dieser Schwierigkeit kann man folgendermaßen aus dem Wege gehen:

Durch formale Operatorenrechnung folgt aus der Vertauschungsrelation $\left(F(x)\right.$ analytisch, $F^{\prime}(x)$ seine Ableitung, vgl. Anm. $\left.{ }^{1}\right)$ )

$$
P F(Q)-F(Q) P=\frac{\hbar}{2 \pi i} F^{\prime}(Q),
$$

und hieraus für $F(x)=e^{\frac{2 \pi i}{h} \beta x}$

$$
e^{-\frac{2 \pi i}{h} \beta Q} P e^{\frac{2 \pi i}{h} \beta Q}=P+\beta 1 .
$$

Hieraus folgt wieder formal

$$
e^{-\frac{2 \pi i}{h} \beta Q} F(P) e^{\frac{y \pi i}{h} \beta Q}=F(P+\beta 1)
$$

und somit für $F(x)=e^{\frac{9 \pi i}{h} \alpha x}$

$$
e^{\frac{2 \pi i}{h} \alpha P} e^{\frac{9 \pi \pi}{h} \beta Q}=e^{\frac{2 \pi i}{h} \alpha \beta} \cdot e^{\frac{2 \pi i}{h} \beta Q} e^{\frac{2 \pi i}{h} \alpha P} .
$$

Diese Gleichung ist von Weyl aufgestellt und als Ersatz der Vertauschungsrelation vorgeschlagen worden $\left.{ }^{4}\right)$. Ihr großer Vorzug besteht in folgendem: Es ist unter Umständen möglich, mit Hilfe der Operatoren $P, Q$ einparametrige Scharen $U(\alpha)=e^{\frac{2 \pi i}{h} \alpha P}, V(\beta)=e^{\frac{8 \pi i}{h} \beta Q}$ zu definieren, die unitär sind, und dem Multiplilkationsgesetz

$$
U(\alpha) U(\beta)=U(\alpha+\beta), \quad V(\alpha) V(\beta)=V(\alpha+\beta)
$$

genügen $\left.{ }^{\beta}\right)$. Dann stehen auf beiden Seiten der Weylschen Gleichung

$$
U(\alpha) V(\beta)=e^{\frac{2 \pi i}{h} \alpha \beta} \cdot V(\beta) U(\alpha)
$$

4) Vgl. Weyl, Zeitschr. f. Phys. 46 (1928), Seite 1-46.

5) Vgl. Weyl, Anm. 4), ferner Stone, Proc. of Nat. Academy 1930. Im Schrödingerschen Falle wird, wie man leicht erkennt:

$$
U(\alpha): \quad f(q) \rightarrow f(q+\alpha), \quad V(\beta): f(q) \rightarrow e^{\frac{2 \pi i}{h} \beta q} f(q) .
$$


unitäre, also beschränkte und überall definierte Operatoren, so daß ihr Sinn ein völlig klarer ist.

Es bliebe daher zu zeigen, daß die einzigen irreduziblen Lösungen ${ }^{8}$ ) der Weylschen Gleichungen die Schrödingerschen (d. h. die aus Anm. ${ }^{5}$ )) sind. Beweisansätze hierfür gab Stone (vgl. Anm. ")) an, jedoch ist bisher ein Beweis auf dieser Grundlage, wie mir Herr Stone freundlichst mitteilte, nicht erbracht worden.

Im folgenden soll der genannte Eindeutigkeitssatz bewiesen werden. Wir werden sogar alle (auch die reduziblen) Lösungen angeben können.

2. Sei $\mathfrak{S}$ der Hilbertsche Raum (etwa durch alle Folgen komplexer Zahlen $\left\{x_{1}, x_{2}, \ldots\right\}$ mit endlichem $\sum_{n=1}^{\infty}\left|x_{n}\right|^{2}$ realisiert; oder auch durch alle komplexen Funktionen $f(q),-\infty<q<+\infty$, mit endlichem $\left.\int_{-\infty}^{+\infty}|f(q)|^{2} d q\right)$. Wir benützen die geometrische Terminologie in $\mathfrak{S}$, indem wir das „innere Produkt" $(f, g)$ (gleich $\sum_{n=1}^{\infty} x_{n} \bar{y}_{n}$ bzw. $\left.\int_{-\infty}^{+\infty} f(q) \overline{g(q)} d q\right)$ und den "absoluten Betrag" $|f|=\sqrt{(f, f)}\left(\right.$ gleich $\sqrt{\sum_{n=1}^{\infty}\left|x_{n}\right|^{2}}$ bzw. $\left.\sqrt{\int_{-\infty}^{+\infty}|f(q)|^{2} d q}\right)$ einführen $\left.{ }^{7}\right)$. Wir werden ausschließlich beschränkt-lineare (iiberall definierte) Operatoren in $S_{2}$ betrachten, den transponiert-konjugierten Operator des Operators $A$ nennen wir $A^{*}$ (er ist durch $(A f, g)=\left(f, A^{*} g\right),(f, A g)=\left(A^{*} f, g\right)$ definiert). Wir erwähnen noch eins: Wenn der Operator $A(\alpha)$ vom Parameter $\alpha$ abhängt, so nennen wir diese Abhängigkeit meßbar, wenn alle Funktionen $(A(\alpha) f, g)$ (dies sind komplexe Zablenfunktionen der. reellen Zahlenvariablen $\alpha$, dagegen betrachten wir $f, g$ als Parameter) im Lebesgueschen Sinne in $\alpha$ meBbar sind $\left.{ }^{8}\right)$. Daß mit $A(\alpha)$ auch $a A(\alpha), A(\alpha)^{*}$ und mit $A(\alpha), B(\alpha)$ auch $A(\alpha)+B(\alpha)$ meßbar ist, ist klar, aber auch $A(\alpha) B(\alpha)$ ist es. Dies folgt aus den bekannten Regeln der Matrizenmultiplikation, oder auch direkt, $\varphi_{1}, \varphi_{3}, \ldots$ sei ein vollständiges, normiertes

9) Ein System von Operatoren $A, B, \ldots$ (im vorliegenden Falle besteht es aus allen $U(\alpha)$ und $V(\beta))$ heißt irreduzibel, wenn es außer $O$ und dem vollen Hilbertsohen Raume keine abgeschlossene Linearmannigfaltigkeit (d. h. Hyperebene) $\mathfrak{M}$ mit der folgenden Eigensohaft gibt: mit $f$ gehören auoh $A f, B f, \ldots$ zu $\mathfrak{M}$. Vgl. auoh die Ausführungen im Buch von Born und Jordan, Elementere Quantenmechanik. Berlin 1930.

2) Vgl. E. Schmidt, Rend. Circ. Mat. Palermo 25 (1908), S. 57-73, ferner die Arbeit des Verf, Math. Annalen 102 (1930), S. 49-131, an die die Bezeichnungsweise anlehnt.

8) Sej $\varphi_{1}, \varphi_{2}, \ldots$ ein vollatändiges, normiextes Orthogonalsystem in $\mathscr{G}$. Dann ist $f=\sum_{n=1}^{\infty} x_{n} \varphi_{n}, g=\sum_{n=1}^{\infty} y_{n} \varphi_{n}$, also $(A(\alpha) f, g)=\operatorname{limes}_{M, N \rightarrow \infty} \sum_{m=1}^{M} \sum_{n=1}^{N} x_{m} \bar{x}_{n}\left(A(\alpha) \varphi_{m}, \varphi_{n}\right)$. Somit genügt die Meßbarkeit der $\left(A(\alpha) \varphi_{m}, \varphi_{n}\right)$, d. h. der Matrizenelemente von $A(\alpha)$ im Koordinatensystein $\operatorname{der} \varphi_{1}, \varphi_{2}, \ldots$ 
Orthogonalsystem:

$$
\begin{aligned}
(A(\alpha) B(\alpha) f, g)=\left(B(\alpha) f, A(\alpha)^{*} g\right) & =\sum_{n=1}^{\infty}\left(B(\alpha) f, \varphi_{n}\right)\left(\varphi_{n}, A^{*}(\alpha) g\right) \\
& =\sum_{n=1}^{\infty} \overline{\left(A(\alpha) g, \varphi_{n}\right)}\left(B(\alpha) f, \varphi_{n}\right) .
\end{aligned}
$$

Dasselbe gilt, wenn an der Stelle von $\alpha$ mehrere Variable $\alpha, \beta, \ldots$ stehen. Wir kehren nun zu unserem Problem zurïck, ersetzen aber in $\nabla(\beta)$ $\beta$ durch $\frac{h}{2 \pi} \beta$. Dann lautet es so:

Alle $U(\alpha), V(\beta)$ seien unitäre Operatoren, die meßbar von $\alpha, \beta$ abhängen. Es gelten die Relationen

$$
\begin{gathered}
U(\alpha) U(\beta)=U(\alpha+\beta), \quad V(\alpha) V(\beta)=V(\alpha+\beta), \\
U(\alpha) V(\beta)=e^{i \alpha \beta} V(\beta) U(\alpha) .
\end{gathered}
$$

Alle derartigen Systeme sind zu bestimmen.

Wenn wir die (von $\alpha, \beta$ meBbar abhängende, unitäre) Operatorenschar

$$
S(\alpha, \beta)=e^{-\frac{1}{2} i \alpha \beta} U(\alpha) V(\beta)=e^{\frac{1}{2} i \alpha \beta} V(\beta) U(\alpha)
$$

einführen, so können wir die obigen Relationen zu

$$
S(\alpha, \beta) S(\gamma, \delta)=e^{\frac{1}{2} i(\alpha \delta-\beta \gamma)} S(\alpha+\gamma, \beta+\delta)
$$

zusammenfassen. Infolgedessen ist $\mathcal{S}(0,0)$ die Einheit, und daher $S(-\alpha,-\beta)$ zu $S(\alpha, \beta)$ reziprok, also $S(\alpha, \beta)^{*}=S(-\alpha,-\beta)$. Es sollen nun Linearaggregate der $S(\alpha, \beta)$ betrachtet werden, diese werden folgendermaßen definiert: Sei $\alpha(\alpha, \beta)$ eine über die ganze $\alpha, \beta$-Ebene absolut integrierbare Funktion, dann ist wegen der Schwarzschen Ungleichheit

$$
|(S(\alpha, \beta) f, g)| \leqq|S(\alpha, \beta) f| \cdot|g|=|f| \cdot|g|,
$$

d. h. beschränkt, also auch das Integral

$$
\iint a(\alpha, \beta)(S(\alpha, \beta) f, g) d \alpha d \beta
$$

absolut konvergent. Und zwar ist es, wenn wir $c=\iint|a(\alpha, \beta)| d \alpha d \beta$ setzen, absolut $\leqq c \cdot|f||g|$. Dabei ist es in $f$ linear und in $g$ lonjugiertlinear. Daher ist ein Satz von F. Rieß anwendbar ${ }^{9}$ ), wonach bei festem $f$ ein $f^{*}$ existiert, so daß dieser Ausdruck für jedes $g=\left(f^{*}, g\right)$ ist, und zwar ist $\left|f^{*}\right| \leqq c \cdot|f| \cdot f^{*}$ ist durch $f$ bestimmt, und zwar ist die Abhängigkeit linear, wir können also einen linearen Operator $A$ durch $A f=f^{*}$ definieren, nach der obigen Formel ist $A$ auch beschränkt. Wir schreiben symbolisch

$$
A=\iint \boldsymbol{a}(\alpha, \beta) S(\alpha, \beta) d \alpha d \beta
$$

obwohl die Definition eigentlich

$$
(A f, g)=\iint a(\alpha, \beta)(S(\alpha, \beta) f, g) d \alpha d \beta
$$

lautet. $\boldsymbol{a}(\alpha, \beta)$ heiße der Kern von $A$.

9) $\nabla$ gl. auch a. a. O. Anm. 7), Math. Annalen 102 (1930), S. 94, Anm. ${ }^{53}$ ). 
Wir beweisen einige Rechenregeln für diese Operatoren. Da $a A$ den Kern $a \boldsymbol{a}(\alpha, \beta)$ hat, ist klar, $A^{*}$ hat wegen $S(\alpha, \beta)^{*}=S(-\alpha,-\beta)$ den Kern $\overline{a(-\alpha,-\beta)}, A S(u, v)$ und $S(u, v) A$ wegen der Multiplikationsregel der $S(\alpha, \beta)$ den Kern

$$
e^{\frac{1}{2} i(\alpha v-\beta u)} a(\alpha-u, \beta-v) \text { bzw. } e^{-\frac{1}{2} i(\alpha v-\beta u)} a(\alpha-u, \beta-v) .
$$

Haben $A, B$ die bzw. Kerne $\boldsymbol{a}(\alpha, \beta), \boldsymbol{b}(\alpha, \beta)$, so hat $A+B$ offenbar $\boldsymbol{a}(\alpha, \beta)+\boldsymbol{b}(\alpha, \beta)$, bei $A B$ dagegen ist eine kleine Rechnung notwendig:

$$
\begin{aligned}
& (A B f, g)=\left(B f, A^{*} g\right)=\iint \boldsymbol{b}(\alpha, \beta)\left(S(\alpha, \beta) f, A^{*} g\right) d \alpha d \beta \\
= & \iint \boldsymbol{b}(\alpha, \beta)(A S(\alpha, \beta) f, g) d \alpha d \beta \\
= & \iiint \int \boldsymbol{b}(\alpha, \beta) e^{\frac{1}{2} i\langle\gamma \beta-\delta \alpha\rangle} \boldsymbol{a}(\gamma-\alpha, \delta-\beta)(S(\gamma, \delta) f, g) d \alpha d \beta d \gamma d \delta \\
= & \iint\left[\iint e^{\frac{1}{2} i(\gamma \beta-\delta \alpha)} a(\gamma-\alpha, \delta-\beta) b(\alpha, \beta) d \alpha d \beta\right](S(\gamma, \delta) f, g) d \gamma d \delta .
\end{aligned}
$$

Der Kern von $A B$ ist also (statt $\gamma, \delta$ schreiben wir wieder $\alpha, \beta$, statt $\alpha, \beta \quad \xi, \eta) \iint e^{\frac{1}{2} i(\alpha, \eta-\beta \xi)} \boldsymbol{a}(\alpha-\xi, \beta-\eta) \boldsymbol{b}(\xi, \eta) d \xi d \eta$. (Die absolute Integrierbarkeit folgt aus der Dedultion.)

Schließlich zeigen wir: wenn $A$ verschwindet, so ist auch sein Kern (bis auf eine Lebesguesche Nullmenge) gleich 0 . Aus $A=0$ folgt nämlich $S(-u,-v) A S(u, v)=0$, also, da dieses den Kern $e^{i(\alpha v-\beta u)} a(\alpha, \beta)$ hat,

$$
\iint e^{i(\alpha v-\beta r)} a(\alpha, \beta)(S(\alpha, \beta) f, g) d \alpha d \beta=0 .
$$

Somit ist jedenfalls

$$
\iint P(\alpha, \beta) a(\alpha, \beta)(S(\alpha, \beta) f, g) d \alpha d \beta=0,
$$

wenn $P(\alpha, \beta)$ ein Linearaggregat von endlich vielen $e^{i(k \alpha+i \beta)}$ ist, also für jedes trigonometrische Polynom mit einer Periode $p>0$ in $\alpha, \beta$. Da der zweite Faktor absolut integrierbar ist, und der dritte beschränkt, können wir mit dem ersten $(P(\alpha, \beta))$ Grenzübergänge ausführen, falls dieser dabei gleichmäßig beschränkt bleibt. So können wir die Klasse der $P(\alpha, \beta)$ sukzessiv erweitern: 1 . zu allen stetigen Funktionen mit einer Periode $p>0$ in $\alpha, \beta, 2 . z u$ allen beschränkten stetigen Funktionen, 3. zu allen beschränkten Funktionen der ersten Baireschen Klasse. Wenn also $\Re$ ein beliebiges (endliches) Rechteck in der $\alpha, \beta$-Ebene ist, so können wir $P(\alpha, \beta)$ in $\Re$ gleich 1 und außerhalb $=0$ setzen, es wird:

$$
\iint_{\mathfrak{R}} \boldsymbol{\alpha}(\alpha, \beta)(S(\alpha, \beta) f, g) d \alpha d \beta=0
$$

für alle diese $\Re$. Daher ist (mit Ausnahme einer $\alpha, \beta$-Nullmenge) $\boldsymbol{a}(\alpha, \beta)(S(\alpha, \beta) f, g)=0$. Dies gilt bei festem $f, g$, ist aber nur $f$ fest, während $g$ ein vollständiges normiertes Orthogonalsystem durchläuft, so gilt es für dieses $f$ und alle genannten $g$ auch noch mit Ausnahme einer 
$\alpha, \beta$-Nullmenge. In diesem Falle ist aber $a(\alpha, \beta) S(\alpha, \beta) f=0$. Da nun für $f \neq 0|S(\alpha, \beta) f|=|f|>0$ ist, muß dann $a(\alpha, \beta)=0$ sein - womit alles bewiesen ist.

3. Die Lösung des Eindeutigkeits-Problems wird durch Betrachten des Operators

$$
A=\iint e^{-\frac{1}{4} \alpha^{2}-\frac{1}{2} \beta^{2}} S(\alpha, \beta) d \alpha d \beta
$$

gewonnen. Dieser Operator ist nach unseren bisherigen Resultaten hermitesch (d. h. $A=A^{*}$ ) und $\neq 0$, und hat außerdem die bemerkenswerte Eigenschaft, dab sich $A S(u, v) A$ nur um einen Zahlenfalktor von $A$ unterscheidet. In der Tat hat $A$ den Kern $e^{-\frac{1}{4} \alpha^{2}-\frac{1}{2} \beta^{2}}$, also $S(u, v) A$ den Kern $e^{-\frac{1}{2} i(\alpha v-\beta u)} e^{-\frac{1}{\left(2(\alpha-u)^{2}-\frac{1}{2}(\beta-v)^{2}\right.}} ;$ also $A S(u, v) A$

$$
\begin{aligned}
& \iint e^{\frac{1}{2} i(\alpha \eta-\beta \xi)} e^{-\frac{1}{\left(2(\alpha-\xi)^{2}-\frac{1}{4}(\beta-\eta)^{2}\right.}} e^{-\frac{1}{2} i(\xi v-\eta u)} e^{-\frac{1}{2}(\xi-u)^{2}-\frac{1}{2}(\eta-v)^{2}} d \xi d \eta \\
& =\iint e^{-\frac{1}{2} \xi^{2}-\frac{1}{2} \eta^{2}+\left(\frac{1}{2} \alpha+\frac{1}{2} u-\frac{1}{2} i \beta-\frac{1}{2} i v\right) \xi+\left(\frac{1}{2} \beta+\frac{1}{2} v+\frac{1}{2} i \alpha+\frac{1}{2} i u\right) \eta-\frac{1}{2} \alpha^{2}-\frac{1}{4} \beta^{2}-\frac{1}{4} u^{2}-\frac{1}{2} v^{2}} d \xi d \eta \\
& =e^{-\frac{1}{5} u^{2}-\frac{1}{1} v^{2}} e^{-\frac{1}{2} \alpha^{2}-\frac{1}{\alpha} \beta^{2}} \iint e^{-\frac{1}{2} \xi^{2}+\frac{1}{2}(\alpha+u-i \beta-i v)-\frac{1}{2} \eta^{2}+\frac{1}{2} i(\alpha+u-i \beta-i v) \eta} d \xi d \eta \\
& =e^{-\frac{1}{2} u^{2}-\frac{1}{2} v^{2}} e^{-\frac{1}{2} \alpha^{2}-\frac{1}{4} \beta^{2}} \iint e^{-\frac{1}{2}\left(\xi-\frac{1}{2}(\alpha+u-i \beta-i v)\right)^{2}-\frac{1}{2}\left(\eta-\frac{1}{2} i(\alpha+u-i \beta-i v)\right)^{2}} d \xi d \eta \\
& =e^{-\frac{1}{2} u^{2}-\frac{1}{4} v^{2}} e^{-\frac{1}{4} \alpha^{2}-\frac{1}{4} \beta^{2}} \iint e^{-\frac{1}{2} x^{2}-\frac{1}{2} y^{2}} d x d y \\
& =2 \pi \cdot e^{-\frac{1}{4} u^{2}-\frac{1}{2} t^{2}} \cdot e^{-\frac{1}{4} \alpha^{2}-\frac{1}{4} \beta^{2}} \text {. }
\end{aligned}
$$

Hierin ist der erste Falktor konstant und der zweite der Kern von $A$, also gilt

$$
A S(u, v) A=2 \pi e^{-\frac{1}{4} u^{2}-\frac{1}{2} v^{2}} \cdot A
$$

Wir betrachten nun die Lösungen der Gleichung $A f=2 \pi f$, da $A$ linear-beschränkt ist, bilden sie eine abgeschlossene Linearmannigfaltigkeit im Hilbertschen Raume, $\mathfrak{M}$. Jede von ihnen hat die Form $A g$ (mit $g=\frac{1}{2 \pi} f$ ), und umgekehrt gehört jedes $A g$ zu ihnen, da $A^{2}=2 \pi \cdot A$ ist (man setze in der obigen Gleichung $u=v=0$ ). Die zu $\mathfrak{M}$ orthogonale abgeschlossene Linearmannigfaltigkeit sei $\mathfrak{R}$, die Elemente $f$ von $\mathfrak{R}$ sind durch Orthogonalität zu allen Elementen von $\mathfrak{M}$ gekennzeichnet, d. h. zu allen $A g$. D. h.: immer $(f, A g)=0$, oder: $\operatorname{immer}(A f, g)=0$, oder: $A f=0$.

Wenn $f, g$ zu $\mathfrak{M}$ gehören, so ist

$$
\begin{aligned}
& (S(\alpha, \beta) f, S(\gamma, \delta) g)=\frac{1}{4 \pi^{2}}(S(\alpha, \beta) A f, S(\gamma, \delta) A g) \\
& =\frac{1}{4 \pi^{3}}(A S(-\gamma,-\delta) S(\alpha, \beta) A f, g)=\frac{1}{4 \pi^{2}} e^{\frac{1}{2} i(\alpha \delta-\beta \gamma)}(A S(\alpha-\gamma, \beta-\delta) A f, g) \\
& =\frac{1}{2 \pi} e^{-\frac{1}{1}(\alpha-\gamma)^{2}-\frac{1}{2}(\beta-\delta)^{2}+\frac{1}{2} i(\alpha \delta-\beta \gamma)}(A f, g)=e^{-\frac{1}{4}(\alpha-\gamma)^{2}-\frac{1}{4}(\beta-\delta)^{2}+\frac{1}{2} i(\alpha \delta-\beta \gamma)}(f, g) \text {. }
\end{aligned}
$$


Sei nun $\varphi_{1}, \varphi_{2}, \ldots$ ein normiertes Orthogonalsystem, welches in $\mathfrak{M}$ vollständig ist (d.h. $\mathfrak{M}$ aufgespannt, die Zahl seiner Elemente ist endlich oder abzählbar unendlich). Aus $\left(\varphi_{m}, \varphi_{n}\right)=\delta_{m n}$ (d.i. 1 für $m=n, 0$ sonst) folgt

$$
\left(S(\alpha, \beta) \varphi_{m}, S(\gamma, \delta) \varphi_{n}\right)=e^{-\frac{1}{\left(1(\alpha-\gamma)^{2}-\frac{1}{2}(\beta-\delta)^{2}+\frac{1}{2} i(\alpha \delta-\beta \gamma)\right.} \delta_{m n 2}}
$$

Die durch alle $S(\alpha, \beta) \varphi_{n}$ ( $n$ fest, $\alpha, \beta$ variieren) aufgespannte abgeschlossene Linearmannigfaltigkeit heiße $\mathfrak{B}_{n}$, nach der obigen Formel sind für $m \neq n$ $\mathfrak{P}_{m}, \mathfrak{P}_{n}$ zueinander orthogonal. Die $\mathfrak{F}_{1}, \mathfrak{F}_{2}, \ldots$ mögen zusammen die abgeschlossene Linearmannigfaltigkeit $\mathfrak{S}$ aufspannen, die zu $\mathfrak{S}$ komplementäre abgeschlossene Linearmannigfaltigkeit sei $\mathfrak{T}$.

Da jedes $S(\gamma, \delta)$ die $S(\alpha, \beta) \varphi_{n}$ (bis auf Zahlenfaktoren) in ebensolche transformiert, bildet es $\mathfrak{F}_{n}$ auf ein Teil von sich $a b$; da dasselbe für. $S(\gamma, \delta)^{-1}=S(-\gamma,-\delta)$ gilt, ist $\mathfrak{F}_{n}$ genau invariant. Also ist auch $\mathfrak{S}$ und $\mathfrak{T}$ invariant. $\mathfrak{S}$ umfaßt alle $\mathfrak{F}_{n}$, also alle $p_{n}$, also $\mathfrak{M}$, daher liegt $\mathfrak{T}$ in $\mathfrak{R}$. Somit gilt in $\mathfrak{T}$ stets $A f=0$. Nun gelten alle unsere über $A$ anngestellten Betrachtungen schon in $\mathfrak{T}$, denn die $S(\alpha, \beta)$ können als Operatoren in $\mathfrak{T}$ angesehen werden, da dieses ihnen gegenüber invariant ist. Da nun in $\mathfrak{I} A \equiv 0$ ist, kann nach unserem Beweise in $\mathfrak{I}$ niemals $f \neq 0$ sein. Also enthält $\mathfrak{I}$ nur die 0 , $\subseteq$ ist der Hilbertsche Raum, d. h.: $\mathfrak{F}_{1}, \mathfrak{q}_{3}, \ldots$ spannen den vollen Hilbertschen Raum auf.

Der Hilbertsche Raum erscheint somit als in eine endliche oder abzählbar unendliche Zahl von (paarweise orthogonalen) Unterräumen $\mathfrak{F}_{1}, \mathfrak{F}_{y}, \ldots$ zerlegt; jeder derselben ist gegenüber allen $S(\alpha, \beta)$ invariant, es genügt also das Verhalten $\operatorname{der} S(\alpha, \beta)$ (d. i. $\operatorname{der} U(\alpha), \nabla(\beta)$ ) in einem jeden derselben gesondert zu ermitteln, um über sie restlos informiert zu sein. (Im Falle der Trreduzibilität darf es natürlich nur ein $\Re_{n}$ geben, und dieses ist dann der volle Hilbertsche Raum.) In $\Re_{n}$ wissen wir nun über die $S(\alpha, \beta)$ die folgenden Tatsachen:

Wir nennen $\mathfrak{P}_{n} \quad \mathfrak{F}, S(\alpha, \beta) \varphi_{n} \quad f_{\alpha, \beta}$. Dann gilt:

$$
\begin{aligned}
S(\gamma, \delta) f_{\alpha, \beta} & =e^{\frac{1}{2} i(f \gamma-\alpha \delta)} f_{\alpha+\gamma, \beta+\delta}, \\
\left(f_{\alpha, \beta}, f_{\gamma, \delta}\right) & =e^{-\frac{1}{4}(\alpha-\gamma)^{2}-\frac{1}{4}(\beta-\delta)^{2}+\frac{1}{2} i(\alpha \delta-\beta \gamma)},
\end{aligned}
$$

und die Linearaggregate endlich vieler $f_{\alpha, \beta}$ (die beliebig wählbar sind!) liegen in $\$$ überall dicht.

Wenn wir nun zeigen können, daß irgend zwei solche $\$$, in deren jedem eine Schar von unitären Operatoren $S(\alpha, \beta)$ und Punkten $f_{\alpha, \beta}$ mit den obigen Eigenschaften gegeben ist, isomorph sind, so sind wir am Ziele. Isomorphie bedeutet: Existenz einer ein-eindeutigen, linearen und längentreuen Abbildung der beiden $\mathfrak{F}$ aufeinander, die die $f_{\alpha, \beta}$ und $S(\alpha, \beta)$ des einen $\mathfrak{P}$ in dieselben des anderen überführt. 
Unsere Formel für $\left(f_{\alpha \beta}, f_{\gamma \delta}\right)$ erlaubt für jedes Linearaggregat endlich vieler $f_{\alpha \beta}$ den Absolutwert zu berechnen, wenn wir also die gleichlautenden $f_{\alpha \beta}$-Linearaggregate beider $\mathfrak{F}$ einander zuordnen, so haben wir eine eineindeutige, lineare und längentreue Abbildung dieser Mengen aufeinander. Da sie in den bzw. $\mathfrak{P}$ überall dicht sind, sind sie stetig auf die ganzen $\mathfrak{F}$ ausdehnbar. Dabei bleiben Linearität und Längentreue, also auch Eineindeutigkeit, erhalten. Die bzw. $f_{a, \beta}$ entsprechen einander. Wegen der $S(\gamma, \delta) f_{\alpha, \beta}$-Formeln gehen auch die $S(\gamma, \delta)$ in ihre entsprechenden über: wenigstens für die $f_{\alpha, \beta}$, aber dann auch für deren Linearaggregate und Häufungspunkte - also in ganz $\mathfrak{S}$. Damit ist, wenn wir wieder zu den $U(\alpha), \nabla(\beta)$ zurückkehren, folgendes bewiesen:

Ein System unitärer Operatoren $U(\alpha), \nabla(\beta)$ nebst einem System von Punkten $f_{\alpha, \beta}$, die zusammen den ganzen Hilbertschen Raum aufspannen, ist durch die Eigenschaften

$$
\begin{aligned}
V(\gamma) f_{\alpha, \beta} & =e^{\frac{1}{2} i \beta \gamma} f_{\alpha+\gamma, \beta}, V(\delta) f_{\alpha, \beta}=e^{-\frac{1}{2} i \alpha \delta} f_{\alpha \beta+\delta} \\
\left(f_{\alpha, \beta}, f_{\gamma, \delta}\right) & =e^{-\frac{1}{4}(\alpha-\gamma)^{2}-\frac{1}{\alpha}(\beta-\delta)^{2}+\frac{1}{2} i(\alpha \delta-\beta \gamma)}
\end{aligned}
$$

bis auf eine unitäre Transformation $\left.{ }^{10}\right)$ eindeutig festgelegt.

Ein System unitärer Operatoren $U(\alpha), V(\beta)$ mit den Weylschen Multiplikations-Relationen (vgl. 1.) ist entweder eines der soeben genannten Systeme, oder es entsteht dadurch, daß der Hilbertsche Raum in endlich oder abzählbar unendlich viele (paarweise orthogonale, Hilbertsche) Unterräume zerfällt, und in jedem derselben ein solches System angenommen wird. D. h. es entsteht durch das Zusammenfügen derselben.

Die irreduziblen Lösungen sind offenbar die ersteren (die Zahl der linear unabhängigen Lösungen von $A f=2 \pi \cdot f$ nimmt für sie ihren Minimalwert 1 an).

4. Zum Schluß noch einige Zusatzbemerkungen.

Im Falle der Schrödingerschen Operatoren haben wir $U(\alpha), V(\beta)$ in Anm. $\left.{ }^{s}\right)$ angegeben: $f(q) \rightarrow f(q+\alpha), f(q) \rightarrow e^{i \beta q} f(q)\left(\frac{h}{2 \pi} \beta\right.$ statt $\left.\beta !\right)$, daher ist $S(\alpha, \beta): f(q) \rightarrow e^{i \beta\left(q+\frac{\alpha}{2}\right)} f(q+\alpha)$, und, wie man leicht berechnet, $A$ : $f(q) \rightarrow \sqrt{4 \pi} \int_{-\infty}^{+\infty} e^{-\frac{1}{2} q^{2}-\frac{1}{2} q^{\prime \prime}} f\left(q^{\prime}\right) d \dot{q}^{\prime}$. Die einzigen Lösungen von $A f=2 \pi \cdot f$ sind also die $e \cdot e^{-\frac{1}{2} q^{2}}$, somit ist $\varphi_{1}=p_{1}(q) \equiv \pi^{-\frac{1}{2}} e^{-\frac{1}{2} q^{2}}$, und

$$
f_{\alpha, \beta}=f_{\alpha, \beta}(q) \equiv \pi^{-\frac{1}{\alpha}} e^{-\frac{1}{2}(q+\alpha)^{2}+i \beta\left(q+\frac{\alpha}{2}\right)} \equiv \pi^{-\frac{1}{4}} e^{-\frac{1}{2} q^{2}+(-\alpha+i \beta) q+\left(-\frac{\alpha^{2}}{2}+\frac{i \alpha \beta}{2}\right)} .
$$

Man verifiziert dann leicht unsere diesbezüglichen Formeln. -

${ }^{10)}$ Sie beiße $U$, dann bewirkt sie (vgl. Anm. $\left.{ }^{2}\right)$ )

$$
U(\alpha) \rightarrow U U(\alpha) U^{-1}, \quad V(\beta) \rightarrow U V(\beta) U^{-1}, \quad f_{\alpha, \beta} \rightarrow U f_{\alpha, \beta} .
$$


578 J. v. Neumann. Eindeutigkeit der Schrödingerschen Operatoren.

Bei quantenmechanischen Problemen mit $k(=1,2, \ldots)$ Freiheitsgraden tritt das allgemeine Vertauschungsrelationen-System

$$
\left.\begin{array}{c}
P_{m} P_{n}=P_{n} P_{m}, \quad Q_{m} Q_{n}=Q_{n} Q_{m}, \\
P_{m} Q_{n}-Q_{n} P_{m}=\frac{\hbar}{2 \pi i} \delta_{m n} \cdot 1
\end{array}\right\} \quad(m, n=1, \ldots, k)
$$

auf. Durch Einführen von

$$
U_{n}(\alpha)=e^{\frac{2 \pi i}{h} \alpha P_{n}}, \quad V_{n}(\beta)=e^{i \beta Q_{n}} \quad(n=1, \ldots, k)
$$

entstehen hieraus die Weylschen Relationen

$$
\begin{aligned}
& U_{n}(\alpha) U_{n}(\beta)=U_{n}(\alpha+\beta), \quad V_{m}(\alpha) V_{n}(\beta)=V_{n}(\alpha+\beta), \\
& U_{n}(\alpha) U_{m}(\beta)=U_{n 3}(\beta) U_{n}(\alpha), \quad V_{m}(\alpha) V_{n}(\beta)=V_{n}(\beta) V_{m}(\alpha), \\
& U_{m}(\alpha) V_{n}(\beta)=e^{i \delta_{m n} \cdot \alpha \beta} \cdot V_{n}(\beta) U_{m}(\alpha) .
\end{aligned}
$$

Auch hier ist der Eindeutigkeitsbeweis mit unseren Methoden aus 2. bis 3. durchführbar. Wir setzen

$$
\begin{aligned}
S\left(\alpha_{1}, \ldots, \alpha_{k}, \beta_{1}, \ldots, \beta_{k}\right) & =e^{-\frac{1}{2} i\left(\alpha_{1} \beta_{1}+\ldots+\alpha_{k} \beta_{k l}\right)} U\left(\alpha_{1}\right) \ldots U\left(\alpha_{7 k}\right) V\left(\beta_{1}\right) \ldots V\left(\beta_{k k}\right) \\
& =e^{\frac{1}{2} i\left(\alpha_{1} \beta_{1}+\ldots+\alpha_{k} \beta_{k}\right)} V\left(\beta_{1}\right) \ldots V\left(\beta_{l_{k}}\right) U\left(\alpha_{1}\right) \ldots U\left(\alpha_{k}\right)
\end{aligned}
$$

und

$$
A=\iint \ldots \iint e^{-\frac{1}{4} \alpha_{1}^{3}-\ldots-\frac{1}{4} \alpha_{k}^{2}-\frac{1}{4} \beta_{1}^{2}-\ldots-\frac{1}{2} \beta_{k}^{2}} S\left(\alpha_{1}, \ldots, \alpha_{k}, \beta_{1}, \ldots, \beta_{k}\right) d \alpha_{1} \ldots d \alpha_{k} d \beta_{1} \ldots d \beta_{k} .
$$

Dann können wir, genau wie in 3.,

$$
A S\left(u_{1}, \ldots, u_{k}, v_{1}, \ldots, v_{k}\right) A=(2 \pi)^{k} e^{-\frac{1}{4} u_{1}^{2}-\ldots-\frac{1}{4} u_{k}^{2}-\frac{1}{4} v_{1}^{2}-\cdots-\frac{1}{4} v_{k}^{2}} A
$$

beweisen, und (durch Untersuchen der Lösungen von $A f=(2 \pi)^{k} \cdot f$ ) genau wie dort ans Ziel kommen. -

Vom allgemeinen darstellungstheoretischen Gesichtspunkte aus betrachtet, ist unsere Betrachtungsweise mit der Frobeniusschen Behandlung endlicher Gruppen mittels ihrer "charakteristischen Einheiten" verwandt bzw. mit der Weylschen Untersuchung abgeschlossener kontinuierlioher Gruppen mit Hilfe ibrer Gruppenzahlen $\left.{ }^{21}\right)$. Die Operatoren $A=\iint a(\alpha, \beta) S(\alpha, \beta) d \alpha d \beta$ sind nämlich als "Gruppenzahlen" $\operatorname{der} S(\alpha, \beta)$-Gruppe deutbar, und $A S(u, v) A=c_{u, v} A\left(c_{u, v}\right.$ eine Zahl!) ist der definierenden Eigenschaft der "primitiven" charakteristischen Einheiten gleichwertig.

11) Vgl. Frobenius, Berl. Ber. 1896 u. f., Peter und Weyl, Math. Annalen 96 (1926), S. $737-755$.

(Eingegangen am 31. 8. 1930.) 


\title{
On the Quantum Correction For Thermodynamic Equilibrium
}

\author{
By E. WIGNER \\ Department of Physics, Princeton University
}

(Received March 14, 1932)

The probability of a configuration is given in classical theory by the Boltzmann formula exp $[-V / h T]$ where $V$ is the potential energy of this configuration. For high temperatures this of course also holds in quantum theory. For lower temperatures, however, a correction term has to be introduced, which can be developed into a power series of $h$. The formula is developed for this correction by means of a probability function and the result discussed.

1

$\mathbf{I}^{\mathrm{N}}$ classical statistical mechanics the relative probability for the range $p_{1}$ to $p_{1}+d p_{1} ; p_{2}$ to $p_{2}+d p_{2} ; \cdots ; p_{n}$ to $p_{n}+d p_{n}$ for the momenta and $x_{1}$ to $x_{1}+d x_{1} ; x_{2}$ to $x_{2}+d x_{2} ; \cdots ; x_{n}$ to $x_{n}+d x_{n}$ for the coordinates is given for statistical equilibrium by the Gibbs-Boltzmann formula

$P\left(x_{1}, \cdots, x_{n} ; p_{1}, \cdots, p_{n}\right) d x_{1} \cdots d x_{n} d p_{1} \cdots d p_{n}=e^{-\beta \epsilon} d x_{1} \cdots d x_{n} d p_{1} \cdots d p_{n}(1)$

where $\epsilon$ is the sum of the kinetic and potential energy $V$

$$
\epsilon=\frac{p_{1}^{2}}{2 m_{1}}+\frac{p_{2}^{2}}{2 m_{2}}+\cdots+\frac{p_{n}^{2}}{2 m_{n}}+V\left(x_{1} \cdots x_{n}\right)
$$

and $\beta$ is the reciprocal temperature $T$ divided by the Boltzmann constant

$$
\beta=1 / k T \text {. }
$$

In quantum theory there does not exist any similar simple expression for the probability, because one cannot ask for the simultaneous probability for the coordinates and momenta. Moreover, it is not possible to derive a simple expression even for the relative probabilities of the coordinates alone-as is given in classical theory by $e^{-\beta V\left(x_{1} \cdots x_{n}\right)}$. One sees this by considering that this expression would give at once the square of the wave function of the lowest state $\left|\psi_{0}\left(x_{1} \cdots x_{n}\right)\right|^{2}$ when $\beta=\infty$ is inserted and on the other hand we know that it is not possible, in general, to derive a closed formula for the latter.

The thermodynamics of quantum mechanical systems is in principle, however, given by a formula of Neumann, ${ }^{1}$ who has shown that the mean value of any physical quantity is, (apart from a normalizing constant depending only on temperature), the sum of the diagonal elements of the matrix

$$
Q e^{-\beta H}
$$

where $Q$ is the matrix (operator) of the quantity under consideration and $H$ is the Hamiltonian of the system. As the diagonal sum is an invariant under

${ }^{1}$ J. von Neumann, Gött. Nachr. p. 273, 1927. 
transformations, one can choose any matrix or operator-representation for the $Q$ and $H$. In building the exponential of $H$ one must, of course, take into account the non-commutability of the different parts of $H$.

It does not seem to be easy to make explicit calculations with the form (4) of the mean value. One may resort therefore to the following method.

If a wave function $\psi\left(x_{1} \cdots x_{n}\right)$ is given one may build the following expression $^{2}$

$$
\begin{aligned}
& P\left(x_{1}, \cdots, x_{n} ; p_{1}, \cdots, p_{n}\right) \\
& =\left(\frac{1}{h_{\pi}}\right)^{n} \int_{-\infty}^{\infty} \cdots \int d y_{1} \cdots d y_{n} \psi\left(x_{1}+y_{1} \cdots x_{n}+y_{n}\right)^{*} \\
& \psi\left(x_{1}-y_{1} \cdots x_{n}-y_{n}\right) e^{2 i\left(p_{1} y_{1}+\cdots+p_{n} y_{n}\right) / h}
\end{aligned}
$$

and call it the probability-function of the simultaneous values of $x_{1} \cdots x_{n}$ for the coordinates and $p_{1} \cdots p_{n}$ for the momenta. In (5), as throughout this paper, $h$ is the Planck constant divided by $2 \pi$ and the integration with respect to the $y$ has to be carried out from $-\infty$ to $\infty$. Expression (5) is real, but not everywhere positive. It has the property, that it gives, when integrated with respect to the $p$, the correct probabilities $\left|\psi\left(x_{1} \cdots x_{n}\right)\right|^{2}$ for the different values of the coordinates and also it gives, when integrated with respect to the $x$, the correct quantum mechanical probabilities

$$
\left|\int_{-\infty}^{\infty} \cdots \int \psi\left(x_{1} \cdots x_{n}\right) e^{-i\left(p_{1} x_{1}+\cdots+p_{n} x_{n}\right) / h} d x_{1} \cdots d x_{n}\right|^{2}
$$

for the momenta $p_{1}, \cdots, p_{n}$. The first fact follows simply from the theorem about the Fourier integral and one gets the second by introducing $x_{k}+y_{k}$ $=u_{k} ; x_{k}-y_{k}=v_{k}$ into (5).

Hence it follows, furthermore, that one may get the correct expectation values of any function of the coordinates or the momenta for the state $\psi$ by the normal probability calculation with (5). As expectation values are additive this even holds for a sum of a function of the coordinates and a function of the momenta as, e.g., the energy $H$. In formulas, it is

$$
\begin{aligned}
\int_{-\infty}^{\infty} \cdots & \iint_{-\infty}^{\infty} \cdots \int d x_{1} \cdots d x_{n} d p_{1} \cdots d p_{n}\left[f\left(p_{1} \cdots p_{n}\right)+g\left(x_{1} \cdots x_{n}\right)\right] \\
& P\left(x_{1} \cdots x_{n} ; p_{1} \cdots p_{n}\right) \\
= & \int_{-\infty}^{\infty} \cdots \int \psi\left(x_{1} \cdots x_{n}\right)^{*}\left[f\left(\frac{h}{i} \frac{\partial}{\partial x_{1}}, \cdots, \frac{h}{i} \frac{\partial}{\partial x_{n}}\right)\right. \\
& \left.+g\left(x_{1} \cdots x_{n}\right)\right] \psi\left(x_{1} \cdots x_{n}\right) d x_{1} \cdots d x_{n}
\end{aligned}
$$

for any $\psi, f, g$, if $P$ is given by (5).

${ }^{2}$ This expression was found by L. Szilard and the present author some years ago for another purpose. 
Of course $P\left(x_{1}, \cdots, x_{n} ; p_{1}, \cdots, p_{n}\right)$ cannot be really interpreted as the simultaneous probability for coordinates and momenta, as is clear from the fact, that it may take negative values. But of course this must not hinder the use of it in calculations as an auxiliary function which obeys many relations we would expect from such a probability. It should be noted, furthermore, that (5) is not the only bilinear expression in $\psi$, which satisfies (6). There must be a great freedom in the expression (5), as it makes from a function $\psi$ of $n$ variables one with $2 n$ variables. It may be shown, however, that there does not exist any expression $P\left(x_{1} \cdots x_{n} ; p_{1} \cdots p_{n}\right)$ which is bilinear in $\psi$, satisfies (6) and is everywhere (for all values of $x_{1}, \cdots, x_{n}, p_{1}, \cdots, p_{n}$ ) positive, so (5) was chosen from all possible expressions, because it seems to be the simplest.

If $\psi\left(x_{1}, \cdots, x_{n}\right)$ changes according to the second Schrödinger equation

$$
i h \frac{\partial \psi}{\partial t}=-\sum_{k=1}^{n} \frac{h^{2}}{2 m_{k}} \frac{\partial^{2} \psi}{\partial x_{k}^{2}}+V\left(x_{2}, \cdots, x_{n}\right) \psi
$$

the change of $P\left(x_{1}, \cdots, x_{n} ; p_{1}, \cdots, p_{n}\right)$ is given by

$\frac{\partial P}{\partial t}=-\sum_{k=1}^{n} \frac{p_{k}}{m_{k}} \frac{\partial P}{\partial x_{k}}+\sum \frac{\partial^{\lambda_{1}+\cdots+\lambda_{n} V}}{\partial x_{1}^{\lambda_{1}} \cdots \partial x_{n}^{\lambda_{n}}} \frac{(h / 2 i)^{\lambda_{1}+\cdots+\lambda_{n}-1}}{\lambda_{1} ! \cdots \lambda_{n} !} \frac{\partial^{\lambda_{1}+\cdots+\lambda_{n}} P}{\partial p_{1}^{\lambda_{1}} \cdots \partial p_{n}^{\lambda_{n}}}(8)$

where the last summation has to be extended over all positive integer values of $\lambda_{1}, \cdots, \lambda_{n}$ for which the sum $\lambda_{1}+\lambda_{2}+\cdots+\lambda_{n}$ is odd. In fact we get for $\partial P / \partial t$ by $(5)$ and $(7)$

$$
\begin{aligned}
& \frac{\partial P}{\partial t}=\frac{1}{(h \pi)^{n}} \int \cdots \int d y_{1} \cdots d y_{n} e^{2 i\left(p_{1} y_{1}+\cdots+p_{n} y_{n}\right) / h} \\
& \quad \cdot\left\{\sum _ { k } \frac { i h } { 2 m _ { k } } \left[-\frac{\partial^{2} \psi\left(x_{1}+y_{1}, \cdots, x_{n}+y_{n}\right)^{*}}{\partial x_{k}^{2}} \psi\left(x_{1}-y_{1}, \cdots, x_{n}-y_{n}\right)\right.\right. \\
& +\psi\left(x_{1}+y_{1}, \cdots, x_{n}+y_{n}\right)^{*} \frac{\partial^{2} \psi\left(x_{1}-y_{1}, \cdots, x_{n}-y_{n}\right)}{\partial x_{k}^{2}} \\
& +\frac{i}{h}\left[V\left(x_{1}+y_{1}, \cdots, x_{n}+y_{n}\right)\right. \\
& \left.\left.-V\left(x_{1}-y_{1}, \cdots, x_{n}-y_{n}\right)\right] \psi\left(x_{1}+y_{1}, \cdots, x_{n}+y_{n}\right)^{*} \psi\left(x_{1}-y_{1}, \cdots x_{n}-y_{n}\right)\right\}
\end{aligned}
$$

Here one can replace the differentiations with respect to $x_{k}$ by differentiations with respect to $y_{k}$ and perform in the first two terms one partial integration with respect to $y_{k}$. In the last term we can develop $V\left(x_{1}+y_{1}, \cdots, x_{n}+y_{n}\right)$ and $V\left(x_{1}-y_{1}, \cdots, x_{n}-y_{n}\right)$ in a Taylor series with respect to the $y$ and get

$$
\begin{aligned}
& \frac{\partial P}{\partial t}=\frac{1}{(\pi h)^{n}} \int \cdots \int d y_{1} \cdots d y_{n} e^{2 i\left(p_{1} y_{1}+\cdots+p_{n} y_{n}\right) / h} \\
& \quad \cdot\left\{\sum _ { k } \frac { p _ { k } } { m _ { k } } \left[-\frac{\partial \psi\left(x_{1}+y_{1}, \cdots, x_{n}+y_{n}\right)^{*}}{\partial y_{k}} \psi\left(x_{1}-y_{1}, \cdots, x_{n}-y_{n}\right)\right.\right.
\end{aligned}
$$




$$
\begin{aligned}
& \left.+\psi\left(x_{1}+y_{1}, \cdots, x_{n}+y_{n}\right) * \frac{\partial \psi\left(x_{1}-y_{1}, \cdots, x_{n}-y_{n}\right)}{\partial y_{k}}\right] \\
& +\frac{i}{h} \sum_{\lambda} \frac{\partial^{\lambda_{1}}+\cdots+\lambda_{n} V}{\partial x_{1}{ }^{\lambda_{1}} \cdots \partial x_{n}{ }^{\lambda_{n}}} \frac{y_{1}^{\lambda_{1}} \cdots y_{n}^{\lambda_{n}}}{\lambda_{1} ! \cdots \lambda_{n} !} \psi\left(x_{1}+y_{1}, \cdots, x_{n}+y_{n}\right)^{*} \\
& \left.\quad \cdot \psi\left(x_{1}-y_{1}, \cdots, x_{n}-y_{n}\right)\right\},
\end{aligned}
$$

which is identical with (8) if one replaces now the differentiations with respect to $y_{k}$ by differentiations with respect to $x_{k}$. Of course, (8) is legitimate only if it is possible to develop the potential energy $V$ in a Taylor series.

Eq. (8) shows the close analogy between the probability function of the classical mechanics and our $P$ : indeed the equation of continuity

$$
\frac{\partial P}{\partial t}=-\sum_{k} \frac{p_{k}}{m_{k}} \frac{\partial P}{\partial x_{k}}+\sum_{k} \frac{\partial V}{\partial x_{k}} \frac{\partial P}{\partial p_{k}}
$$

differs from (8) only in terms of at least the second power of $h$ and at least the third derivative of $V$. Expression (8) is even identical with the classical when $V$ has no third and higher derivatives as, e.g., in a system of oscillators.

There is an alternative form for $\partial P / \partial t$, which however will not be used later on. It is

$$
\begin{aligned}
& \frac{\partial}{\partial t} P\left(x_{1}, \cdots, x_{n} ; p_{1}, \cdots, p_{n}\right)=-\sum_{k} \frac{p_{k}}{m_{k}} \frac{\partial}{\partial x_{k}} P\left(x_{1}, \cdots, x_{n} ; p_{1}, \cdots, p_{n}\right) \\
& +\int_{-\infty}^{\infty} \cdots \int d j_{1} \cdots d j_{n} P\left(x_{1}, \cdots, x_{n} ; P_{1}+j_{1}, \cdots, P_{n}+j_{n}\right) J\left(x_{1}, \cdots, x_{n} ;\right. \\
& \left.j_{1}, \cdots, j_{n}\right)
\end{aligned}
$$

where $J\left(x_{1}, \cdots, x_{n} ; j_{1}, \cdots, j_{n}\right)$ can be interpreted as the probability of a jump in the momenta with the amounts $j_{1}, \cdots, j_{n}$ for the configuration $x_{1}, \cdots, x_{n}$. The probability of this jump is given by

$$
\begin{aligned}
& J\left(x_{1}, \cdots, x_{n} ; j_{1}, \cdots, j_{n}\right) \\
& =\frac{i}{\pi^{n} h^{n+1}} \int_{-\infty}^{\infty} \cdots \int d y_{1} \cdots d y_{n}\left[V\left(x_{1}+y_{1}, \cdots, x_{n}+y_{n}\right)\right. \\
& \left.\quad-V\left(x_{1}-y_{1}, \cdots, x_{n}-y_{n}\right)\right] e^{-(2 i / h)\left(y_{1} j_{1}+\cdots+y_{n} j_{n}\right)}
\end{aligned}
$$

that is, by the Fourier expansion coefficients of the potential $V\left(x_{1}, \cdots, x_{n}\right)$. This form clearly shows the quantum mechanical nature of our $P$ : the momenta change discontinuously by amounts which would be half the momenta of light quanta if the potential were composed of light. ${ }^{2 a}$ To derive (11) one can insert both for $P$ and $J$ their respective values (5) and (11a) on the rig'at hand side of (11). In the first term one can replace $p_{k} e^{2 i\left(p_{1} y_{1}+\cdots+p_{n} y_{n}\right) / h}$ by

${ }^{2 a}$ Cf. F. Bloch, Zeits. f. Physik 52, 555 (1929). 
$(h / 2 i)\left(\partial / \partial y_{k}\right) e^{2 i\left(p_{1} y_{1}+\cdots+p_{n} y_{n}\right) / h}$ and then perform a partial integration with respect to $y_{k}$. Then one can replace the differentiation with respect to $y$ by differentiation with respect to $x$, upon which some terms cancel and the rest goes over to

$$
\begin{aligned}
& \sum_{k} \frac{h}{2 i m} \int \cdots \int d y_{1} \cdots d y_{n}\left[\frac{\partial^{2} \psi\left(x_{1}+y_{1}, \cdots, x_{n}+y_{n}\right)^{*}}{\partial x_{k}^{2}} \psi\left(x_{1}-y_{1}, \cdots, x_{n}-y_{n}\right)\right. \\
& \left.-\psi\left(x_{1}+y_{1}, \cdots, x_{n}+y_{n}\right) \frac{\partial^{2} \psi\left(x_{1}-y_{1}, \cdots, x_{n}-y_{n}\right)}{\partial x_{k}^{2}}\right] e^{2 i\left(p_{1} y_{1}+\cdots+p_{n} y_{n}\right) / h}
\end{aligned}
$$

which is just what we need for the left side of (11). By integrating the second term on the right side of (11)

$$
\begin{aligned}
& \int \cdots \int d y_{1} \cdots d y_{n} \psi\left(x_{1}+y_{1} \cdots x_{n}+y_{n}\right)^{*} \psi\left(x_{1}-y_{1} \cdots x_{n}-y_{n}\right) \\
& \cdot \int \cdots \int d j_{1} \cdots d j_{n} e^{(2 i / h)\left[\left(p_{1}+j_{1}\right) y_{1}+\cdots+\left(p_{n}+j_{n}\right) y_{n}\right]} \\
& \frac{i}{\pi^{n} h^{n+1}} \int \cdots \int d z_{1} \cdots d z_{n}\left[V\left(x_{1}+z_{1} \cdots x_{n}+z_{n}\right)\right. \\
& \left.-V\left(x_{1}-z_{1} \cdots x_{n}-z_{n}\right)\right] e^{-2 i\left(z_{1} j_{1}+\cdots+z_{n} j_{n}\right) / h}
\end{aligned}
$$

with respect to $z$ and $j$ one gets because of the Fourier theorem ${ }^{3}$

$$
\begin{aligned}
(i / h) & \int \cdots \int_{p_{n}} d y_{1} \cdots d y_{n} \psi\left(x_{1}+y_{1} \cdots x_{n}+y_{n}\right)^{*} \psi\left(x_{1}-y_{1} \cdots x_{n}-y_{n}\right) \\
& e^{2 i\left(p_{1} y_{1}+\cdots+p_{n}\right) / h} \cdot\left[V\left(x_{1}+y_{1} \cdots x_{n}+y_{n}\right)-V\left(x_{1}-y_{1} \cdots x_{n}-y_{n}\right)\right]
\end{aligned}
$$

and this gives the second part of the left side of (11).

\section{3}

So far we have defined only a probability function for pure states, which gives us the correct expectation values for quantities $f\left(p_{1} \cdots p_{n}\right)+$ $g\left(x_{1} \cdots x_{n}\right)$. If, however, we have a mixture, ${ }^{4}$ e.g., the pure states $\psi_{1}, \psi_{2}$, $\psi_{3}, \ldots$ with the respective probabilities $w_{1}, w_{2}, w_{3}, \cdots$ (with $w_{1}+w_{2}+w_{3}+$ $\cdots=1$ ) the normal probability calculation suggests a probability function

$$
P\left(x_{1}, \cdots, x_{n}, p_{1}, \cdots, p_{n}\right)=\sum_{\lambda} w_{\lambda} P_{\lambda}\left(x_{1}, \cdots, x_{n}, \cdots, p_{n}\right)
$$

where $P_{\lambda}$ is the probability function for $\psi_{\lambda}$. This probability function gives obviously the correct expectation values for all quantities, for which (5) gives correct expectation values and therefore will be adopted.

For a system in statistical equilibrium at the temperature $T=1 / k \beta$ the relative probability of a stationary state $\psi_{\lambda}$ is $e^{-\beta E_{\lambda}}$ where $E_{\lambda}$ is the energy of $\psi_{\lambda}$. Therefore the probability function is a part from a constant

${ }^{3}$ Cf. e. g., R. Courant und D. Hilbert, Methoden der mathematischen Physik I. Berlin 1924. p. 62, Eq. (29).

4 J. v. Neumann, Gött Nachr. 245, 1927. L. Landau, Zeits. f. Physik 45, 430 (1927). 


$$
\begin{aligned}
& P\left(x_{1} \cdots x_{n} ; p_{1} \cdots p_{n}\right) \\
& \quad=\sum_{\lambda} \int \cdots \int d y_{1} \cdots d y_{n} \psi_{\lambda}\left(x_{1}+y_{1} \cdots x_{n}+y_{n}\right)^{*} \\
& \quad e^{-\beta E_{\lambda} \psi\left(x_{1}-y_{1} \cdots x_{n}-y_{n}\right) e^{2 i\left(p_{1} y_{1}+\cdots+p_{n} y_{n}\right) / h} .}
\end{aligned}
$$

Now

$$
\sum_{\lambda} \psi_{\lambda}\left(u_{1} \cdots u_{n}\right)^{*} f\left(E_{\lambda}\right) \psi_{\lambda}\left(v_{1} \cdots v_{n}\right)
$$

is that matrix element of the operator $f(H)$, ( $H$ is the energy operator) which is in the $u_{1} \cdots u_{n}$ row and $v_{1} \cdots v_{n}$ column. Therefore (14) may be written as

$$
\begin{aligned}
& P\left(x_{1} \cdots x_{n} ; p_{1} \cdots p_{n}\right) \\
& =\int_{-\infty}^{\infty} \cdots \int d y_{1} \cdots d y_{n} e^{i\left[\left(x_{1}+y_{1}\right) p_{1}+\cdots+\left(x_{n}+y_{n}\right) p_{n}\right] / h}\left[e^{-\beta H}\right]_{x_{1}+y_{1} \cdots x_{n}+y_{n} i x_{1}-y_{1} \cdots x_{n}-y_{n}} \\
& \cdot e^{-i\left[\left(x_{1}-y_{1}\right) p_{1}+\cdots+\left(x_{n}-y_{n}\right) p_{n}\right] / h} \cdot
\end{aligned}
$$

so that we have under the integral sign the $x_{1}+y_{1} \cdots x_{n}+y_{n} ; x_{1}-y_{1} \cdots$ $x_{n}-y_{n}$ element of the matrix $e^{-8 \beta H}$ transformed by the diagonal matrix $e^{i\left(p_{1} x_{1}+\cdots+p_{n} x_{n}\right) / h}$. Instead of transforming $e^{-\beta H}$ we can transform $H$ first and then take the exponential with the transformed expression. By transforming $H$ we get the operator (the $p$ are numbers, not operators!)

$$
H=e^{i\left(x_{1} p_{1}+\cdots+x_{n} p_{n}\right) / h}\left(-\sum_{k} \frac{h^{2}}{2 m_{k}} \frac{\partial^{2}}{\partial x_{k}^{2}}+V\left(x_{1} \cdots x_{n}\right)\right) e^{-i\left(x_{1} p_{1}+\cdots+x_{n} p_{n}\right) / h}
$$

which is equal to

$$
\tilde{H}=\epsilon+\sum_{k=1}^{n}\left(\frac{i h p_{k}}{m_{k}} \frac{\partial}{\partial x_{k}}-\frac{h^{2}}{2 m_{k}} \frac{\partial^{2}}{\partial x_{k}^{2}}\right)
$$

where

$$
\epsilon=\sum_{k=1}^{n} \frac{p_{k}^{2}}{2 m_{k}}+V\left(x_{1}, \cdots, x_{n}\right)
$$

So we get for (15)

$$
\begin{aligned}
P\left(x_{1}, \cdots, x_{n} ; p_{1}, \cdots, p_{n}\right) & \\
& =\int \cdots \int d y_{1} \cdots d y_{n}\left[e^{-\beta \widetilde{H}}\right]_{x_{1}+y_{1} \cdots x_{n}+y_{n} ;} x_{1}-y_{1} \cdots x_{n}-y_{n}
\end{aligned}
$$

By calculating the mean value of a quantity $Q=f\left(p_{1}, \cdots, p_{n}\right)+g\left(x_{1}, \cdots, x_{n}\right)$ by (18) one has to obtain the same result as by using the original expression (4) of Neumann.

If we are dealing with a system, the behavior of which in statistical equilibrium is nearly correctly given by the classical theory, we can expand (18) into a power of $h$ and keep the first few terms only. The term with the zero power of $h$ is $\sum_{r}(-\beta)^{r} \epsilon^{r} / r$ ! Now $\epsilon^{r}$ is the operator of multiplication with the $r$ 
power of (17). Its $x_{1}+y_{1}, \cdots, x_{n}+y_{n} ; x_{1}-y_{1}, \cdots, x_{n}-y_{n}$ element is consequently

$$
\epsilon\left(x_{1}+y_{1}, \cdots, x_{n}+y_{n}\right)^{r} \delta\left(x_{1}+y_{1}, x_{1}-y_{1}\right) \cdots \delta\left(x_{n}+y_{n}, x_{n}-y_{n}\right) .
$$

As $\delta$ (also $\delta^{\prime}, \delta^{\prime \prime}, \ldots$ ) only depends on the difference of its two arguments, one can write $\delta\left(-2 y_{1}\right) \cdots \delta\left(-2 y_{n}\right)$ for the last factors and perform the integration by introducing $-2 y_{1}, \cdots,-2 y_{n}$ as new variables. The terms with the zero power of $h$, arising from the first part of (16) only, give thus

$$
\left(1 / 2^{n}\right) \sum_{r}(-\beta)^{r} \epsilon\left(x_{1}, \cdots, x_{n}\right) r / r !=e^{-\beta \epsilon} / 2^{n}
$$

which is just the classical expression.

The higher approximations of the probability function can be calculated in a very similar way. The terms of $e^{-\beta \tilde{H}}$, involving the first power of the second part of $\tilde{H}$ only, are

$$
\sum_{r=0}^{\infty} \frac{(-\beta)^{r}}{r !} \sum_{\rho=1}^{r} \epsilon^{\rho-1} \sum_{k}\left(\frac{i h p_{k}}{m_{k}} \frac{\partial}{\partial x_{k}}-\frac{h^{2}}{2 m_{k}} \frac{\partial^{2}}{\partial x_{k}^{2}}\right) \epsilon^{r-\rho}
$$

By replacing all operators by symbolic integral-kernels one gets for the $x_{1}+y_{1}, \cdots, x_{n}+y_{n} ; x_{1}-y_{1}, \cdots, x_{n}-y_{n}$ element of the operator (20)

$$
\begin{aligned}
& \sum_{r} \frac{(-\beta)^{r}}{r !} \sum_{\rho=1}^{r} \epsilon\left(x_{1}+y_{1}, \cdots, x_{n}+y_{n}\right)^{\rho-1} \\
& \cdot \sum_{k}\left[\frac{i h p_{k}}{m_{k}} \delta\left(-2 y_{1}\right) \cdots \delta^{\prime}\left(-2 y_{k}\right) \cdots \delta\left(-2 y_{n}\right)\right. \\
& \left.-\frac{h^{2}}{2 m_{k}} \delta\left(-2 y_{1}\right) \cdots \delta^{\prime \prime}\left(-2 y_{k}\right) \cdots \delta\left(-2 y_{n}\right)\right] \epsilon\left(x_{1}-y_{1}, \cdots, x_{n}-y_{n}\right)^{r-p} .
\end{aligned}
$$

Now

$$
\sum_{\rho=1}^{r} \epsilon_{+}^{\rho-1} \epsilon_{-}^{r-\rho}=\sum_{\rho=1}^{+} \epsilon_{-}^{r-1}\left(\frac{\epsilon_{+}}{\epsilon_{-}}\right)^{\rho-1}=\frac{\epsilon_{+}^{r}-\epsilon_{-}^{r}}{\epsilon_{+}-\epsilon_{-}}
$$

so that the summation over $\rho$ and $r$ can be performed in (21). By introducing again new variables $w_{1}, \cdots, w_{n}$ for $-2 y_{1}, \cdots,-2 y_{n}$ and performing the integration one has

$$
\begin{aligned}
\frac{1}{2^{n}} \sum_{k}\left[\frac{i h p_{k}}{m_{k}} \frac{\partial}{\partial w_{k}}-\frac{h^{2}}{2 m_{k}} \frac{\partial^{2}}{\partial w_{k}^{2}}\right] & \frac{e^{-\beta \epsilon\left(x_{1}, \cdots, x_{k}-w_{k} / 2, \cdots, x_{n}\right)}-e^{-\beta \epsilon\left(x_{k}, \cdots, x_{k}+w_{k} / 2, \cdots, x_{n}\right)}}{\epsilon\left(x_{1}, \cdots, x_{k}-\frac{1}{2} w_{k}, \cdots, x_{n}\right)-\epsilon\left(x_{1}, \cdots, x_{k}+\frac{1}{2} w_{k}, \cdots, x_{n}\right)}
\end{aligned}
$$

where $w_{k}=0$ must be inserted after differentiation. The first differential quotient vanishes at $w_{k}=0$, as the expression to be differentiated is an even function of $w_{k}$. The second part gives 


$$
\frac{e^{-\beta \epsilon}}{2^{n}} \sum_{k} \frac{h^{2}}{m_{k}}\left(-\frac{\beta^{2}}{8} \frac{\partial^{2} \epsilon}{\partial x_{k}{ }^{2}}+\frac{\beta^{3}}{24}\left(\frac{\partial \epsilon}{\partial x_{k}}\right)^{2}\right) .
$$

In principle it is possible to calculate in the same way the terms involving the higher powers of the second part of $\tilde{H}$ also, the summation over $r$ and the quantities corresponding to our $\rho$ can always be performed in a very similar way. In practice, however, the computation becomes too laborious. Still it is clear, that if we develop our probability function for thermal equilibrium in a power series of $h$

$$
P\left(x_{1}, \cdots, x_{n} ; p_{1}, \cdots, p_{n}\right)=e^{-\beta_{\mathbf{t}}}+h f_{1}+h^{2} f_{2}+\cdots
$$

(we can omit the factor $1 / 2^{n}$ before $e^{-\beta \epsilon}$, as we are dealing with relative probabilities anyway) all terms will be quite definite functions of the $p, V$ and the different partial derivatives of the latter. Furthermore it is easy to see, that $f_{k}$ will not involve higher derivatives of $V$ than the $k$-th nor higher powers of $p$ than the $k$-th. These facts enable us to calculate the higher terms of (22) in a somewhat simpler way, than the direct expansion of (18) would be.

The state (22) is certainly stationary, so that it would give identically $\partial P / \partial t=0$ when inserted into (8). By equating the coefficients of the different powers of $h$ in $\partial P / \partial t$ to zero one gets the following equations:

$$
\begin{aligned}
& \sum_{k}-\frac{p_{k}}{m_{k}} \frac{\partial e^{-\beta \epsilon}}{\partial x_{k}}+\sum_{k} \frac{\partial V}{\partial x_{k}} \frac{\partial e^{-\beta \epsilon}}{\partial p_{k}}=0 \\
& \sum_{k}-\frac{p_{k}}{m_{k}} \frac{\partial f_{1}}{\partial x_{k}}+\sum_{k} \frac{\partial V}{\partial x_{k}} \frac{\partial f_{1}}{\partial p_{k}}=0 \\
& \sum_{k}-\frac{p_{k}}{m_{k}} \frac{\partial f_{2}}{\partial x_{k}}+\sum_{k} \frac{\partial V}{\partial x_{k}} \frac{\partial f_{2}}{\partial p_{k}}-\sum_{k} \frac{\partial^{3} V}{\partial x_{k}^{3}} \frac{h^{2}}{24} \frac{\partial^{3} e^{-\beta \epsilon}}{\partial p_{k}^{3}} \\
& \quad-\sum_{k \neq l} \frac{\partial^{3} v}{\partial x_{k}^{2} \partial x_{l}} \frac{h^{2}}{8} \frac{\partial^{3} e^{-\beta \epsilon}}{\partial p_{k}^{2} \partial p_{l}}=0
\end{aligned}
$$

and so on. The first of these equations is an identity because of (17), as it must be; $(23, a),(23,2), \cdots$ will determine $f_{1}, f_{2}, \cdots$ respectively. All Eqs. $(23$, a) are linear inhomogeneous partial differential equations for the unknown $f$. From one solution $f_{a}$ of $(23$, a) one obtains the general solution by adding to it the general solution $F$ of the homogeneous part of $(23$, a), which is always

$$
\sum_{k}-\frac{p_{k}}{m_{k}} \frac{\partial F}{\partial x_{k}}+\sum_{k} \frac{\partial V}{\partial x_{k}} \frac{\partial F}{\partial p_{k}}=0 .
$$

This equation in turn is the classical equation for the stationary character of the probability distribution $F\left(x_{1}, \cdots, x_{n} ; p_{1}, \cdots, p_{n}\right)$. It has in general only one solution which contains only a finite number of derivatives of $V$, namely

$$
F\left(x_{1}, \cdots, x_{n} ; p_{1}, \cdots, p_{n}\right)=F\left(\sum_{k} \frac{p_{k}^{2}}{2 m_{k}}+v\left(x_{1} \cdots x_{n}\right)\right)=F(\epsilon) .
$$

In fact, if it had other integrals, like 


$$
F\left(p_{1}, \cdots, p_{n} ; V, \partial V / \partial x_{1}, \partial V / \partial x_{2}, \cdots\right)
$$

then all mechanical problems would have in addition to the energy-integral further integrals of the form (24) which, of course, is not true.

One solution of $(23,1)$ is $f_{1}=0$ and the most general we have to consider is therefore $f_{1}=F(\epsilon)$. We have to take however $F(\epsilon)=0$ as $f_{1}$ has to vanish for a constant $V$. So we get $f_{1}=0$, as we know it already from the direct expansion of (18). The same holds consequently for $f_{3}, f_{5}, \cdots$, as the inhomogeneous part of the equation for $f_{3}$ only contains $f_{1}$, the inhomogeneous part of the equation for $f_{\mathfrak{b}}$ only $f_{1}$ and $f_{3}$, and so on.

For $f_{2}$ one easily gets

$$
f_{2}=e^{-\beta_{e}}\left[\sum_{k}\left(-\frac{\beta^{2}}{8 m_{k}} \frac{\partial^{2} V}{\partial x_{k}^{2}}+\frac{\beta^{3}}{24 m_{k}}\left(\frac{\partial V}{\partial x_{k}}\right)^{2}\right)+\sum_{k, l} \frac{\beta^{3} p_{k} p_{l}}{24 m_{k} m_{l}} \frac{\partial^{2} V}{\partial x_{k} \partial x_{l}}\right]
$$

as a solution of $(23,2)$ and it is also clear, that this is the solution we need. The first two terms of $f_{2}$ we have already directly computed (21), the third arises from terms with the second power of the second part of $\tilde{H}$. Similarly $f_{4}$ is for one degree of freedom $(n=1)$

$$
\begin{aligned}
& 64 m^{2} \beta^{-2} e^{\beta \epsilon} f_{4}=H_{4}(q)\left[\beta^{2} V^{\prime \prime 2} / 72-\beta V^{\prime \prime \prime \prime} / 120\right] \\
&+H_{2}(q)\left[\beta^{3} V^{\prime 2} V^{\prime \prime} / 18-2 \beta^{2} V^{\prime \prime 2} / 15-\beta^{2} V^{\prime} V^{\prime \prime \prime} / 15+\beta V^{\prime \prime \prime \prime} / 15\right] \\
&+H_{0}(q)\left[\beta^{4} V^{\prime 4} / 18-22 \beta^{3} V^{\prime 2} V^{\prime \prime} / 45+2 \beta^{2} V^{\prime \prime 2} / 5+8 \beta^{2} V^{\prime} V^{\prime \prime \prime} / 15\right. \\
&\left.-4 \beta V^{\prime \prime \prime \prime} / 15\right]
\end{aligned}
$$

where $H_{r}$ is the $r$-th Hermitean polynomial and $q=\beta^{1 / 2} p /(2 m)^{1 / 2}$.

It does not seem to be easy to get a simple closed expression for $f_{k}$, but it is quite possible to calculate all of them successively. A discussion of Eqs. (23) shows, that the $g$ in

$$
P\left(x_{1}, \cdots, x_{n} ; p_{1}, \cdots, p_{n}\right)=e^{-\beta \epsilon}\left(1+h^{2} g_{2}+h^{4} g_{4}+\cdots\right)
$$

are rational expressions in the derivatives of $V$ only (do not contain $V$ itself) and all terms of $g_{k}$ contain $k$ differentiations and as functions of the $p$ are polynomials of not higher than the $k$-th degree. The first term in (27) with the zero power of $h$ is the only one, which occurs in classical theory. There is no term with the first power, so that if one can develop a property in a power series with respect to $h$, the deviation from the classical theory goes at least with the second power of $h$ in thermal equilibrium. One familiar example for this is the inner energy of the oscillator, where the term with the first power of $h$ vanishes just in consequence of the zero point energy. The second term can be interpreted as meaning that a quick variation of the probability function with the coordinates is unlikely, as it would mean a quick variation, a short wave-length, in the wave functions. This however would have the consequence of a high kinetic energy. The quantum mechanical probability is therefore something like the integral of the classical expression $e^{-\beta \epsilon}$ over a finite range of coordinates of the magnitude $\sim h / \bar{p}$ where $\bar{p}$ is the mean momentum $\sim(k T m)^{1 / 2}$. The correction terms of (27) have, among other effects, 
the consequence that the probability for a particle being in a narrow hole is smaller than would be in classical statistics. From now on we will keep only the first two terms of (27).

4

From (25) one easily calculates the relative probabilities of the different configurations by in tegration with respect to the $p$ :

$$
\begin{aligned}
\int \cdots \int d p_{1} \cdots & d p_{n} p\left(x_{1} \cdots x_{n} ; p_{1} \cdots p_{n}\right) \\
& =e^{-\beta V}\left[1-\frac{h^{2} \beta^{2}}{12} \sum_{k} \frac{1}{m_{k}} \frac{\partial^{2} V}{\partial x_{k}^{2}}+\frac{h^{2} \beta^{3}}{24} \sum_{k} \frac{1}{m_{k}}\left(\frac{\partial V}{\partial x_{k}}\right)^{2}\right] .
\end{aligned}
$$

Hence the mean potential energy is

$$
\begin{gathered}
\bar{V}=\frac{\int V e^{-\beta V} d x}{\int e^{-\beta V} d x}+\frac{h^{2} \beta^{2}}{24} \frac{\int \sum_{k} \frac{1}{m_{k}} \frac{\partial^{2} V}{\partial x_{k}^{2}} e^{-\beta V} d x \int V e^{-\beta V} d x}{\left(\int e^{-\beta V} d x\right)^{2}} \\
+\frac{h^{2} \beta}{24} \frac{\int \sum_{k} \frac{1}{m_{k}} \frac{\partial^{2} V}{\partial x_{k}^{2}}(1-\beta V) e^{-\beta V} d x}{\int e^{-\beta V} d x}
\end{gathered}
$$

where $d x$ is written for $d x_{1} \cdots d x_{n}$ and the higher power terms of $h$ are omitted. Similarly the mean value of the kinetic energy is

$$
\sum_{k} \frac{\overline{p_{k}{ }^{2}}}{2 m_{k}}=\frac{n}{2 \beta}+\frac{h^{2} \beta}{24} \frac{\int \sum_{k} \frac{1}{m_{k}} \frac{\partial^{2} V}{\partial x_{k}^{2}} e^{-\beta V} d x}{\int e^{-\beta V} d x}
$$

This formula also is correct only within the second power of $h$; in order to derive it one has to perform again some partial integrations with respect to the $x$. Eqs. (28), (29), (30) have a strict quantum mechanical meaning and it should be possible to derive them also from (4). One sees that the kinetic energy is in all cases larger than the classical expression $\frac{1}{2} n k T$.

5

One fact still needs to be mentioned. We assumed that the probability of a state with the energy $E$ is given by $e^{-\beta E}$. This is not true in general, since the Pauli principle forbids some states al together. The corrections thus introduced by the Bose or Fermi statistics even give terms with the first power of $h$, so that it seems, that as long as one cannot take the Bose of Fermi statistics into account, Eq. (25) cannot be applied to an assembly of identical par- 
ticles, as, e.g., a gas. There is reason to believe however, that because of the large radii of the atoms this is not true and the corrections due to Fermi and Bose statistics may be neglected for moderately low temperatures.

The second virial coefficient was first calculated in quantum mechanics by $\mathrm{F}$. London on the basis of his theory of inneratomic forces. ${ }^{5} \mathrm{He}$ also pointed out that quantum effects should be taken into account at lower temperatures. Slater and Kirkwood ${ }^{6}$ gave a more exact expression for the inneratomic potential of He and Kirkwood and Keyes ${ }^{7}$ calculated on this basis the classical part of the second virial coefficient of He. H. Margenau ${ }^{8}$ and Kirkwood ${ }^{9}$ performed the calculations for the quantum-correction. The present author also tried to calculate it by the method just outlined. He got results, which differ from those of Margenau and Kirkwood in some cases by more than 100 percent. ${ }^{10}$ It does not seem however to be easy to compare these results with experiment, as the classical part of the second virial coefficient is at low temperatures so sensitive to small variations of the parameters occurring in the expression of the interatomic potential, that it changes by more than 20 percent if the parameter in the exponential (2.43) is changed by $\frac{1}{2}$ percent and it does not seem to be possible to determine the latter within this accuracy.

${ }^{5}$ F. London, Zeits. f. Physik 63, 245 (1930).

6 J. C. Slater and J. G. Kirkwood, Phys. Rev. 37, 682 (1931).

7 J. G. Kirkwood and F. G. Keyes, Phys. Rev. 38, 516 (1931).

${ }^{8}$ H. Margenau, Proc. Nat. Acad. 18, 56, 230 (1932). Cf, also J. C. Slater, Phys. Rev, 38, 237 (1931).

J. G. Kirkwood, Phys. Zeits. 33, 39 (1932).

${ }^{10} \mathrm{I}$ am very much indebted to $\mathrm{V}$. Rojansky for his kind assistance with these calculations. The reason for the disagreement between our results and those of Margenau and Kirkwood may be the fact that they did not apply any corrections for the continuous part of the spectrum.

In a paper which appeared recently in the Zeits. f. Physik (74, 295 (1932)) F. Bloch gets results which are somewhat similar to those of the present paper. (Note added at proof.) 
Physica XII, no 7

October 1946

\section{ON THE PRINCIPLES \\ OF ELEMENTARY QUANTUM MECHANICS}

by H. J. GROENEWOLD

Natuurkundig Laboratorium der Rijks-Universiteit te Groningen

\section{Summary}

Our problems are about

$\alpha$ the correspondence $a \longleftrightarrow$ a between physical quantities $a$ and quantum operators a (quantization) and

$\beta$ the possibility of understanding the statistical character of quantum mechanics by averaging over uniquely determined processes as in classical statistical mechanics (interpretation).

$\alpha$ and $\beta$ are closely connected. Their meaning depends on the notion.of observability.

We have tried to put these problems in a form which is fit for discussion. We could not bring them to an issue. (We are inclined to restrict the meaning of $\alpha$ to the trivial correspondence $\mathbf{a} \rightarrow a$ (for $\lim \hbar \rightarrow 0$ ) ant to deny the possibility suggested in $\beta$ ).

Meanwhile special attention has been paid to the measuring process (coupling, entanglement; ignoration, infringement; selection, measurement).

For the sake of simplicity the discussion has been confined to elementary non-relativistic quantum mechanics of scalar (spinless) systems with one linear degree of freedom without exchange. Exact mathematical rigour has not been aimed at.

\section{Statistics and correspondence.}

1.01 Meaning. When poring over

a the correspondence $a \longleftrightarrow$ a between observables $a$ and the operators $\mathbf{a}$, by which they are represented in elementary quantum mechanics,

$\beta$ the statistical character of elementary quantum mechanics

(we need $\alpha$ for $\beta$ ), we run a continuous risk of lapsing into meaningiess problems. One should keep in mind the meaning of the conceptions and statements used. We only consider 
$M_{0}$ : observational meaning, determined by the relation with what is (in a certain connection) understood as observation,

$M_{f}$ : formal meaning, determined with respect to the mathematical formalism without regard to observation.

Only $M_{\mathrm{o}}$ is of physical interest, $M_{f}$ is only of academic interest. Dealing with $M_{f}$ may sometimes suggest ideas, fruitful in the sense of $M_{0}$, but may often lead one astray.

1.02 Quantization. Very simple systems suffice for demonstrating the essential features of $\alpha$ and $\beta$. In elementary classical point mechanics a system is described by the coordinates $q$ of the particles and the conjugate momenta $p$. We only write down a single set $p, q$, corresponding to one degree of freedom. Any other measurable quantity (observable) $a$ of the system is a function $a(p, q)$ of $p$ and $q$ (and possibly of the time $t$ ). The equations of motion can be expressed in terms of Pois son brackets

$$
(a, b)=\frac{\partial a}{\partial p} \frac{\partial b}{\partial q}-\frac{\partial a}{\partial q} \frac{\partial b}{\partial p} .
$$

When the same system is treated in elementary quantum mechanics, the (real) quantities $a$ are replaced by ( $\mathrm{H} \mathrm{e} \mathrm{r} \mathrm{m} \mathrm{it} \mathrm{i} \mathrm{a} \mathrm{n)}$ operators $\mathbf{a}$, which now represent the observables. In the equations of motion the Poisson brackets (1.01) are replaced by the operator brackets

$[\mathbf{a}, \mathbf{b}]=\frac{i}{\hbar}(\mathbf{a b}-\mathbf{b a})\left(\hbar=\frac{h}{2 \pi}, h \mathrm{Pl}\right.$ a n c k's constant of action). (1.02)

Problem $\alpha_{1}$ is to find the correspondence $a \rightarrow$ a (other problems $\alpha$ are stated further on).

1.03 Statistical character. The statements of quantum mechanics on observations are in general of statistical character. Problem $\beta$ is whether the statistical quantum processes could be described by a statistical average over uniquely determined processes (statistical description of the 1st kind, type $S^{1}$ ) or not (statistical description of the 2 nd kind, type $S^{2}$ ). The observability of the uniquely determined processes may be required (proper statistical description, type $S_{0}$ ) or not (formal statistical description, type $S_{f}$ ). (Classical statistical mechanics, e.g. are properly of the 1st kind, type $S_{o}^{1}$ ).

1.04 Transition operator. Before going on we have to deal for a moment with the operators and the wave functions. 
The $\mathrm{H}$ e $\mathrm{rm}$ it $\mathrm{i}$ a $\mathrm{n}$ operators a form a non-commutative ring. The normalized elements (wave functions) of (generalized) $\mathrm{Hilbert}$ space on which they act from the left are denoted by $\varphi_{\mu}$, the adjoint elements on which they act from the right are denoted by $\varphi_{\mu}^{\dagger}$. Unless otherwise stated the inner product of $\varphi_{\mu}^{\dagger}$ and $\varphi_{\nu}$ is simply written $\varphi_{\mu}^{\dagger} \varphi_{\nu}$. The outer product of $\varphi_{\mu}^{\dagger}$ and $\varphi_{\nu}$ defines the transition operator

$$
\mathbf{k}_{\nu \mu}=\varphi_{\nu} \varphi_{\mu}^{\dagger}, \quad \mathbf{k}_{\nu \mu}^{\dagger}=\mathbf{k}_{\mu \nu} \text {. }
$$

Take a complete system of orthonormal wave functions $\varphi_{\nu}$. The orthonormality is expressed by

the completeness by

$$
\begin{gathered}
\varphi_{\mu}^{\dagger} \varphi_{\nu}=\delta_{\mu \nu}, \\
\sum_{\mu} \varphi_{\mu} \varphi_{\mu}^{\dagger}=1
\end{gathered}
$$

In continuous regions of the parameter $\mu$ the Weierstrasz $\delta$-symbol must be replaced by the $\mathrm{D}$ ir a $\mathrm{c} \delta$-function and the sum by an integral. (1.04) and (1.05) show that every (normalizable) function $\varphi$ can be expanded into

$$
\varphi=\sum_{\mu} f_{\mu} \varphi_{\mu} \text { with } f_{\mu}=\varphi_{\mu}^{\dagger} \varphi \text {. }
$$

$\mathbf{k}_{\nu \mu}$ and $\mathbf{k}_{\nu \mu}^{\dagger}$ transform $\varphi_{\mu^{\prime}}$ and $\varphi_{\mu^{\prime}}^{\dagger}$ according to

$$
\mathbf{k}_{\nu \mu} \varphi_{\mu^{\prime}}=\varphi_{\nu} \delta_{\mu \mu^{\prime}} \text { and } \varphi_{\mu^{\prime}}^{\dagger} \mathbf{k}_{\nu \mu}^{\dagger}=\delta_{\mu^{\prime} \mu} \varphi_{\nu}^{\dagger}
$$

(that is why they are called transition operators). (1.04) gives

$$
\mathbf{k}_{\mu \nu} \mathbf{k}_{\nu^{\prime} \mu^{\prime}}=\mathbf{k}_{\mu \mu} \cdot \delta_{\nu \nu^{\prime}} .
$$

In particular $\mathbf{k}_{\mu \mu}$ and $\mathbf{k}_{\nu v}$ are for $\mu \neq \nu$ orthogonal projection operators (belonging to $\varphi_{\mu}$ and $\varphi_{\nu}$ respectively).

The trace of an operator a (resulting when a acts towards the right upon itself from the left, or opposite; when it bites its tail) is (according to (1.05)) defined by

$$
\operatorname{Tr} \mathbf{a}=\sum_{\mu} \varphi_{\mu}^{\dagger} \mathbf{a} \varphi_{\mu} .
$$

(Because the right hand member is invariant under unitary transformations of the $\varphi_{\mu}$, this definition is independent of the special choice of the complete orthonormal system of $\varphi_{\mu}$ ). This gives

$$
\operatorname{Tr}\left(\mathbf{k}_{\nu \mu} \mathbf{a}\right)=\varphi_{\mu}^{\dagger} \mathbf{a} \varphi_{\nu} .
$$

(1.04) and (1.05) can be written

$$
\begin{gathered}
T r \mathbf{k}_{v \mu}=\delta_{\nu \mu}, \\
\sum_{\mu} \mathbf{k}_{\mu \mu}=\mathbf{1}
\end{gathered}
$$


and further imply

$$
\begin{gathered}
\operatorname{Tr}\left(\mathbf{k}_{\mu \nu} \mathbf{k}_{\nu^{\prime} \mu^{\prime}}\right)=\delta_{\mu^{\prime} \mu} \delta_{\nu \nu^{\prime}}, \\
\sum_{\mu, \nu} \mathbf{k}_{\nu \mu} \operatorname{Tr}\left(\mathbf{k}_{\mu \nu} \mathbf{a}\right)=\mathbf{a}(\text { for every } \mathbf{a}) .
\end{gathered}
$$

(1.13) and (1.14) show that every operator a (with adjoint $\mathbf{a}^{\dagger}$ ) can be expanded into

$$
\mathbf{a}=\sum_{\mu, \nu} \alpha_{\nu \mu} \mathbf{k}_{\mu \nu} \text { with } \alpha_{\nu \mu}=\operatorname{Tr}\left(\mathbf{k}_{\nu \mu} \mathbf{a}\right)
$$

$\alpha_{\nu \mu}$ is the matrix element (1.10) of a with respect to $\varphi_{\nu}$ and $\varphi_{\mu}$. It follows further that if $\operatorname{Tr}(\mathbf{a c})=0$ for every $\mathbf{a}$, then $\mathbf{c}=0$ and therefore (1.14) is equivalent to

Further

$$
\left.\sum_{\mu, \nu} \operatorname{Tr}\left(\mathbf{k}_{\nu \mu} \mathbf{b}\right) \operatorname{Tr}\left(\mathbf{k}_{\mu \nu} \mathbf{a}\right)=\operatorname{Tr}(\mathbf{a b}) \text { (for every } \mathbf{a} \text { and } \mathbf{b}\right) .
$$

$$
\operatorname{Tr}(\mathbf{a b})=\operatorname{Tr}(\mathbf{b a}) .
$$

When $\mathbf{a}$ is a Hermitian operator

$$
\mathbf{a}^{\dagger}=\mathbf{a}, \quad \alpha_{\nu \mu}^{*}=\alpha_{\mu \nu}
$$

(the asterik denotes the complex conjugate), the system of eigenfunctions $\varphi_{\mu}$ with eigenvalues $a_{\mu}$

$$
\mathbf{a} \varphi_{\mu}=a_{\mu} \varphi_{\mu}
$$

can serve as reference system. In this representation (1.15) takes the diagonal form

$$
\mathbf{a}=\sum_{\mu} a_{\mu} \mathbf{k}_{\mu \mu}
$$

1.05 Statistical operator $\left.{ }^{1}\right)$. The quantum state of a system is said to be pure, if it is represented by a wave function $\varphi_{\mu}$. The statistical operator of the state is defined by the projection operator $\mathbf{k}_{\mu \mu}$ of $\varphi_{\mu}$. We will see that the part of the statistical operator is much similar to that of a statistical distribution function. The most general quantum state of the system is a statistical mixture of (not necessarily orthogonal) pure states with projection operators $\mathbf{k}_{\mu \mu}$ and nonnegative weights $k_{\mu}$, which are normalized by

$$
\sum_{\mu} k_{\mu}=1 \text {. }
$$

(In some cases the sum diverges and the right member actually should symbollically be written as a $\delta$-function). The statistical operator of the mixture is (in the same way as it would be done for 
a distribution function) defined by

$$
\mathbf{k}=\sum_{\mu} k_{\mu} \mathbf{k}_{\mu \mu}
$$

and because of (1.21) normalized by

$$
\operatorname{Tr} \mathbf{k}=1 \text {. }
$$

(we will always write 1 for the right member, though in some cases it actually should be written as a $\delta$-function). For brevity we often speak of the state (or mixture) $\mathbf{k}$.

An arbitrary non-negative definite normalized $\mathrm{H}$ e $\mathrm{r} \mathrm{m}$ it i a $\mathrm{n}$ operator $\mathbf{k}(\operatorname{Tr} \mathbf{k}=1)$ has non-negative eigenvalues $k_{\mu}$, for which $\sum_{\mu} k_{\mu}=1$ and corresponding eigenstates with projection operators $\mathbf{k}_{\mu \mu}$. Therefore $\mathrm{k}$ can according to (1.20) be expanded in the form (1.22) and represents a mixture of its (orthogonal) eigenstates with weights given by the eigenvalues.

The statistical operator $\mathbf{k}_{\mu \mu}$ of a pure state is from the nature of the case idempotent $\left(\mathbf{k}_{\mu \mu}^{2}=\mathbf{k}_{\mu \mu}\right)$. If on the other hand an idempotent normalized $\mathrm{Her}$ i i $\mathrm{i}$ a $\mathrm{n}$ operator $\mathbf{k}$ is expanded with respect to its eigenstates $\mathbf{k}_{\mu \mu}$ with eigenvalues $k_{\mu}$, we get

$$
\mathbf{k}^{2}=\mathbf{k}, k_{\mu}^{2}=k_{\mu} ; \operatorname{Tr} \mathbf{k}=1, \quad \sum_{\mu} k_{\mu}=1,
$$

so that one eigenvalue $k_{v}$ is 1 , all other are 0 . Then $\mathbf{k}$ is the projection operator of the pure state $p_{\nu}$

$$
\mathbf{k}=\mathbf{k}_{\nu v} .
$$

Therefore pure states and only these have idempotent statistical operators.

Suppose the normalized statistical operator $\mathbf{k}$ of an arbitrary quantum state is expanded in some way into other normalized (but not necessarily orthogonal) statistical operators $\mathbf{k}_{r}$ with non-negative weights $k_{r}$

This gives

$$
\mathbf{k}=\sum_{r} k_{r} \mathbf{k}_{r} ; \quad k_{r} \geqslant 0 .
$$

$$
\mathbf{k}-\mathbf{k}^{2}=\sum_{r} k_{r}\left(\mathbf{k}_{r}-\mathbf{k}_{r}^{2}\right)+\frac{1}{2} \sum_{r, s} k_{r} k_{s}\left(\mathbf{k}_{r}-\mathbf{k}_{s}\right)^{2} .
$$

If we expand with respect to pure states $\mathbf{k}_{r}\left(\mathbf{k}_{r}^{2}=\mathbf{k}_{r}\right),(1.27)$ becomes

$$
\mathbf{k}-\mathbf{k}^{2}=\frac{1}{2} \sum_{r, s} k_{r} k_{s}\left(\mathbf{k}_{r}-\mathbf{k}_{s}\right)^{2} .
$$


This shows that $\mathbf{k}-\mathbf{k}^{2}$ is a non-negative definite operator. If the given state is pure $\left(\mathbf{k}^{\mathbf{2}}=\mathbf{k}\right)$ all terms at the right hand side of (1.27) (which are non-negative definite) must vanish separately. For the terms of the first sum this means that all states $\mathbf{k}$ with non-vanishing weight $\left(k_{r}>0\right)$ must be pure, for the terms of the second sum it means further that all these states must be identical with each other and therefore also with the given state $\left(\mathbf{k}_{\boldsymbol{r}}=\mathbf{k}\right)$. The given state is then said to be indivisible. If the given state is a mixture, $\mathbf{k}-\mathbf{k}^{2}$ must be positive definite. Then at least one term at the right hand side of (1.28) must be different from zero. This means that at least two different states $\mathbf{k}_{\boldsymbol{r}}$ and $\mathbf{k}_{\boldsymbol{s}}\left(\mathbf{k}_{\boldsymbol{r}} \neq \mathbf{k}_{s}\right)$ must have non-vanishing weight $\left(k_{r}>0, k_{s}>0\right)$. The given state is then said to be divisible. Thus pure states and only these are indivisible. This has been proved in a more exact way by $\mathrm{v}$ o $\mathrm{n} \mathrm{N}$ e u $\mathrm{m}$ a n $\mathrm{n}^{\mathbf{1}}$ ).

1.06 Observation. In order to establish the observational meaning $M_{0}$, one must accept a definite notion of observation. We deal with 3 different notions:

$O_{c}:$ the classical notion: all observables $a(p, q)$ can be measured without fundamental restrictions and without disturbing the system,

$O_{q}$ : the quantum notion (elucidated in 2): measurement of an observable, which is represented by an operator a, gives as the value of the observable one of the eigenvalues $a_{\mu}$ of $\mathbf{a}$ and leaves the system in the corresponding eigenstate $\mathbf{k}_{\mu \mu}$ (cf. (1.20)); if beforehand the system was in a state $\mathbf{k}$, the probability of this particular measuring result is $\operatorname{Tr}\left(\mathbf{k k}_{\mu \mu}\right)$.

Suppose for a moment that the statistical description of quantum mechanics had been proven to be formally of the 1st kind $S_{f}^{1}$, but with respect to $O_{q}$ properly of the 2 nd kind $S_{o q}^{2}$. Then (if any) the only notion, which could give a proper sense to the formal description, would be

$O_{u}$ : the utopian notion: the uniquely determined processes are observable by methods, hitherto unknown, consistent with and complementary to the methods of $O_{q}$.

With respect to quantum theory classical theory is incorrect, though for many purposes it is quite a suitable approximation (for $\lim \hbar \rightarrow 0$ ). With regard to the utopian conception quantum theory would be correct, but incomplete. In this a description is called correct if none of its statements is in contradiction with observational data. It is called complete if another correct description, 
which leads to observable statements not contained in the given description, is impossible. This need not imply that all possible observational statements can be derived from a complete theory.

1.07 The fundamental controversy. Problem $\beta$ intends to state certain aspects of the well known controversy about the statistical character of quantum mechanics in a form fit for a reasonable discussion. Such a discussion is only possible as long as the theory is accepted as essentially correct (or rejected and replaced by a more correct theory). The completeness of the theory may be questioned.

The physical reasonings of $\mathrm{Boh} \mathrm{r}$ a.o. and the mathematical

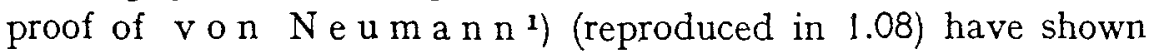
that (with respect to $O_{q}$ ) the statistical description of quantum mechanics is properly of the 2nd kind $S_{o q}^{2}$ (problem $\beta_{1}$ ). Yet many of the opponents did not throw up the sponge, some because they did not grasp the point, others because they perceived a gap in the reasoning. It seems that a great many of the escapes (as far as they consider quantum mechanics as essentially correct) debouch (if anywhere) into an expectation, which either is already contented with a fopmal statistical description of the 1ste kind $S_{f}^{1}$, or moreover hopes to give such a description a proper sense of type $S_{o u}^{1}$ by proclaiming the utopian notion of observation $O_{w}$. The examination of this conception is problem $\beta_{2}$.

Even if one did (we could not satisfactorily) succeed in proving the formal impossibility of type $S_{f}^{1}$ (and consequently of type $S_{o u}^{1}$ ), many of the opponents would not yet strike the flag. We have already gone to meet them in trying to formulize some of their most important objections in a form fit for fruitful discussion. It would be like flogging a dead horse in trying to do so with all vague objections they might possibly raise. Actually that is their own task. If they succeed in doing so, we try to prove the impossibility, they try to find the realization of their (formal or proper) expectations. Formal expectations can be realized by a formal construction, proper ones also require the realization of the type of observations from which they draw their observational meaning. As soon as the opponents succeed in finding a realization, we will (formally or properly) be converted (but not a minute before). As often as we succeed in proving the impossibility, some of the opponents may formulize (if anything) new objections for ever. At best they might be compelled to retreat step by step, they could never be finally vanquished. It 
may also happen that nobody succeeds in going further. Thus because of running on an infinite track or into a dead one, the controversy may be left undecided. Meanwhile we expect that in an infinite regression the opponents objections will lose more and more interest after every retreat.

1.08 von Neumann's proof. The only states with a meaning $M_{o q}$ with respect to quantum observations $O_{q}$ are quantum states (pure states or mixtures). Therefore in a statistical description of the Ist kind $S_{o q}^{1}$ a quantum state should be described as a statistical ensemble of quantum states. This is impossible for a pure state, because such a state is indivisible (cf. 1.05). Then the statistical description of quantum mechanics must (with respect to quantum observations) be of the 2nd kind $S_{o q}^{2}$. This is in our present mode of expression the point of $\mathrm{v}$ on $\mathrm{N}$ e u m a n n's proof ${ }^{1}$ ). It should be noted that in 1.05 the admission of non-negative probabilities only (non-negative weights and non-negative definite statistical operators) is an essential (and natural) feature of the proof.

Now before going into the details of problem $\beta_{2}$, we first turn to p,roblem $\alpha$ (we need $\alpha_{5}$ for $\beta_{2}$ ).

1.09 Correspondence $a(p, q) \longleftrightarrow \mathbf{a}$. In passing from classical to quantum mechanics, the coordinate and momentum $q$ and $p$, for which

$$
(p, q)=1 \text {, }
$$

are replaced by coordinate and momentum operators $\mathbf{q}$ and $\mathbf{p}$, for which

$$
[\mathbf{p}, \mathbf{q}]=1 \quad\left(\text { i.e. } \mathbf{p q}-\mathbf{q} \mathbf{p}=\frac{\hbar}{i}\right) .
$$

$p$ and $q$ are the generating elements of the commutative ring of classical quantities $a(q, p), \mathbf{p}$ and $\mathbf{q}$ the generating elements of the non-commutative ring of quantum operators $\mathbf{a}$. The non-commutability (1.30) of $\mathbf{p}$ and $\mathbf{q}$ entails that the quantities $a(p, q)$ cannot unambiguously be replaced by $a(\mathbf{p}, \mathbf{q})$. The ambiguity is of the order of $\hbar$. The classical quantities $a(p, q)$ can be regarded as approximations to the quantum operators a for $\lim \hbar \rightarrow 0$. The former can serve as guides to get on the track of the latter. Problem $\alpha_{1}$ asks for a rule of correspondence $a(p, q) \rightarrow \mathbf{a}$, by which the quantum operators a can be uniquely determined from the classical quantities $a(p, q)$.

In practical problems no fundamental difficulties seem to occur 
in finding the appropriate form of the required operators a. This suggests the problem (not further discussed here) whether all or only a certain simple class of operators a occur in quantum mechanics.

Suppose for a moment that all relevant quantum operators a had been fixed in one or other way. Then one might ask for a rule $\mathrm{a} \rightarrow a(p, q)$, by which the corresponding classical quantities $a(p, q)$ are uniquely determined (problem $\alpha_{2}$ ). Problem $\alpha_{2}$ would be easily solved in zero order of $\hbar$, ambiguities might arise in higher order. Now (with respect to $O_{q}$ ) the classical quantities have only a meaning as approximations to the quantum operators for $\lim \hbar \rightarrow 0$. Therefore, whereas in zero order of $\hbar$ it is hardly a problem, in higher order problem $\alpha_{2}$ has no observational meaning $M_{o q}$ (with respect to $O_{q}$ ).

Problems $\alpha_{1}$ and $\alpha_{2}$ could be combined into problem $\alpha_{3}$, asking for a rule of one-to-one correspondence $a(p, q) \longleftrightarrow$ a between the classical quantities $a(p, q)$ and the quantum operators a. Beyond the trivial zero order stage in $\hbar$, problem $\alpha_{3}$ can (with respect to $O_{q}$ ) only have an observational meaning $M_{o q}$ as a guiding principle for detecting the appropriate form of the quantum operators (i.e. as problem $\alpha_{1}$ ). A formal solution of problem $\alpha_{3}$ has been proposed by We y $1^{2}$ ) (cf. 4.03). We incidentally come back to problem $\alpha_{3}$ in 1.18 .

1.10 Quantum observables. In this section $a$ will not denote a classical quantity $a(p, q)$, but it will stand as a symbol for the observable, which (with regard to $O_{q}$ ) is represented by the quantum operator $\mathbf{a}$. According to $O_{q}$ two or more observables $a, b, \ldots$ can be simultaneously measured or not, according as the corresponding operators $\mathbf{a}, \mathbf{b}, \ldots$ respectively do or do not commute i.e. as they have all eigenstates in common or not. Problem $\alpha_{4}$ deals with the (one-to-one) correspondence $a \longleftrightarrow$ a between the symbols $a$ and the operators $\mathbf{a}$. Problem $\alpha_{4}$ has no sense as long as the symbols $a$ are undefined. They may, however, be implicitely defined just by putting a rule of correspondence. (When the symbols $a$ are identified with the classical quantities $a(p, q)$, problem $\alpha_{4}$ becomes identical with problem $\alpha_{3}$ ). $\mathrm{V}$ on $\mathrm{N}$ e u $\mathrm{m}$ a $\mathrm{n}^{1}{ }^{1}$ ) has proposed the rules

$$
\begin{aligned}
& \qquad \begin{array}{l}
\text { if } a \longleftrightarrow \mathbf{a} \text {, then } f(a) \longleftrightarrow f(\mathbf{a}), \\
\text { if } a \longleftrightarrow \mathbf{a} \text { and } b \longleftrightarrow \mathbf{b} \text {, then } a+b \longleftrightarrow \mathbf{a}+\mathbf{b} \text {. II }
\end{array} \\
& f(\mathbf{a}) \text { is defined as the operator, which has the same eigenstates as a } \\
& \text { with eigenvalues } f\left(a_{\mu}\right) \text {, where } a_{\mu} \text { are those of a. Then I seems to be } \\
& \text { obvious. The observable } f(a) \text { can be measured simultaneously with }
\end{aligned}
$$


$a$, its value is $f\left(a_{\mu}\right)$, where $a_{\mu}$ is that of $a$. When $\mathbf{a}$ and $\mathbf{b}$ commute, $\mathbf{a}+\mathbf{b}$ has the same eigenstates as $\mathbf{a}$ and $\mathbf{b}$ with eigenvalues $a_{\mu}+b_{\mu}$, where $a_{\mu}$ and $b_{\mu}$ are those of $\mathbf{a}$ and $\mathbf{b}$. Then II seems also to be obvious. $a+b$ can be measured simultaneously with $a$ and $b$, its value is $a_{\mu}+b_{\mu}$, where $a_{\mu}$ and $b_{\mu}$ are the values of $a$ and $b$. When $\mathbf{a}$ and $\mathbf{b}$ do not commute, II is proposed with some hesitation. Because according to $O_{q}$ the probability of finding a value $a_{\mu}$ for $a$ in a state $\mathbf{k}$ is $\operatorname{Tr}\left(\mathbf{k k}_{\mu \mu}\right.$ ) (and because of 1.20$)$ ), the expectation value (average value) of $a$ in this state is

$$
E x(a)=\sum_{\mu} \operatorname{Tr}\left(\mathbf{k k}_{\mu \mu}\right) a_{\mu}=\operatorname{Tr}(\mathbf{k} \mathbf{a})
$$

and similar for $b$. If one requires that for a certain pair of observables $a$ and $b$ always

$$
E x(a+b)=E x(a)+E x(b),
$$

one must, because of

have that

$$
\operatorname{Tr}(\mathbf{k}(\mathbf{a}+\mathbf{b}))=\operatorname{Tr}(\mathbf{k} \mathbf{a})+\operatorname{Tr}(\mathbf{k} \mathbf{b}),
$$

$$
E x(a+b)=\operatorname{Tr}(\mathbf{k}(\mathbf{a}+\mathbf{b})) \text {. }
$$

Because this has to hold for all states $\mathbf{k}, a$ and $b$ have to satisfy rule II. When II is given up for certain pairs $a, b$, the additivity of the expectation values of these pairs has also to be given up.

In 4.01 it will be shown that, if I and II shall be generally valid, the symbols $a$ have to be isomorphic with the operators $a$. But then there is no reason to introduce the former, their task (if any) can be left to the latter. Accordingly for the sake of brevity we shall henceforth speak of the (quantum) observable $\mathbf{a}$.

When on the other hand, the symbols $a$ are intended as real commuting quantities, the general validity of I and II cannot be maintained. As long as the symbols $a$ are not further defined, problem $\alpha_{4}$ comes to searching for a one-to-one correspondence $a \longleftrightarrow$ a between the commutative ring of real symbols $a$ and the non-commutative ring of $\mathrm{Her} \mathrm{mit}$ i a $\mathrm{n}$ operators $\mathrm{a}$. There may be no, one or more solutions. After the pleas for I and for II, one might be inclined to maintain 1 and to restrict II. In 1.13 we meet with a particular case (problem $\alpha_{5}$ ) for which II has to be maintained and therefore I has to be restricted. Because we are further exclusively interested in problem $\alpha_{5}$, we will not examine the possibility of solutions for which Il is restricted. 
1.11 Hidden parameters. We try to trace the conditions for the assumption that the statistical description of quantum mechanics is (at least formally) of the 1st kind $S^{1}$ (problem $\beta$ ). A statistical description $S^{1}$ must be obtained by statistical averaging over uniquely determined processes. The averaging must be described by integration or summation over a statistical distribution with respect to certain parameters. Unless they are further specified, we denote all parameters by a single symbol $\xi$ and integration (including a possible density function) and summation over continuous and discrete parameters by $\int d \xi$. Parameters, which are in no way observable with respect to $O_{q}$, are called hidden parameters. (We exclude their occurence in 1.15). As a pure superstate we define a state for which all parameters (inclusive the hidden ones) have a definite value.

1.12 Distributions. A quantum state must be described as an ensemble of pure superstates. The statistical operator $\mathbf{k}$ of the quantum state must correspond to at least one (non-negative definite) distribution function $k(\xi)$ for the superstates. For each definite value of $\xi$ all $k(\xi)$ must have definite values and therefore must commute. $k(\xi)$ must be normalized by $\int d \xi k(\xi)=1$, so that with (1.23)

$$
\operatorname{Tr} \mathbf{k}=\int d \xi k(\xi) \text {. }
$$

Further the correspondence must be linear

if $\mathbf{k}_{1} \longleftrightarrow k_{1}(\xi)$ and $\mathbf{k}_{2} \longleftrightarrow k_{2}(\xi)$, then $\mathbf{k}_{1}+\mathbf{k}_{2} \longleftrightarrow k_{1}(\xi)+k_{2}(\xi)$. (1.36)

The observable (with respect to $O_{q}$ ) represented by the statistical operator $\mathbf{k}_{\mu \mu}$ of a pure quantum state has the eigenvalue 1 in this quantum state and 0 in all orthogonal states. The probability of measuring in a system, which is originally in a quantum state $\mathrm{k}$, the value 1 (and leaving the system in the pure quantum state $\mathbf{k}_{\mu \mu}$ ) is $\operatorname{Tr}\left(\mathbf{k k}_{\mu \mu}\right)$. In a description of type $S^{1}$ this probability must be interpreted as the probability that any superstate belonging to the ensemble with distribution function $k(\xi)$ corresponding to $\mathbf{k}$ also belongs to the ensemble with distribution function $k_{\mu \mu}(\xi)$ corresponding to $\mathbf{k}_{\mu \mu}$. The latter probability is $\int d \xi k(\xi) k_{\mu \mu}(\xi)$. Therefore the correspondence $\mathbf{k} \longleftrightarrow k(\xi)$ must be so that always

$$
\operatorname{Tr}\left(\mathbf{k}_{1} \mathbf{k}_{2}\right)=\int d \xi k_{1}(\xi) k_{2}(\xi) .
$$

For two orthogonal states $k_{1}$ and $k_{2}$ this expression is zero, which guarantees that the distribution functions $k_{1}(\xi)$ and $k_{2}(\xi)$ do not overlap, provided they are non-negative definite. 
1.13 Superquantities. The expectation value of the observable a in the quantum state $\mathbf{k}$ is because of (1.31) and (1.37)

$$
\sum_{\mu} \operatorname{Tr}\left(\mathbf{k k}_{\mu \mu}\right) a_{\mu}=\sum_{\mu} \int d \xi k(\xi) k_{\mu \mu}(\xi) a_{\mu} .
$$

The right hand member of (1.38) can be interpreted as the average value of a quantity $a(\xi)=\sum_{\mu} a_{\mu} k_{\mu \mu}(\xi)$ (defined as the superquantity corresponding to the observable a) in the ensemble of superstates with distribution function $k(\xi)$. This is exactly the way in which the expectation value should appear in a description of type $S^{1}$. Thus with the correspondence $a \longleftrightarrow a(\xi)$ (which is a linear generalization of $\mathbf{k} \longleftrightarrow k(\xi))$ the expectation value of $\mathbf{a}$ in the state $\mathbf{k}$ can be written

$$
\operatorname{Tr}(\mathbf{k a})=\int d \xi k(\xi) a(\xi) .
$$

Comparison with (1.35) shows that the unit operator 1 has to correspond to the unit quantity 1

$$
1 \leftarrow \rightarrow 1 .
$$

III

By a further linear generalization of (1.39) we see that the correspondence $\mathbf{a} \longleftrightarrow a(\xi)$ must obey the rule

if $\mathbf{a} \longleftrightarrow a(\xi)$ and $\mathbf{b} \longleftrightarrow b(\xi)$, then $\operatorname{Tr}(\mathbf{a b})=\int d \xi a(\xi) b(\xi)$. IV

Rule II is a consequence of rule IV (the necessity of II is evident from the beginning, because average of sum = sum of averages). Therefore rule I cannot be satisfied without restrictions.

Problem $\alpha_{5}$ is how to establish the correspondence $\mathbf{a} \leftrightarrow a(\xi)$. $\alpha_{5}$ is, like $\alpha_{3}$, a special case of $\alpha_{4}$.

1.14 Equations of motion. The equations of motion for the quantum states must be obtained from the equations of motion for the superstates. The former are determined by the $\mathrm{Hamilt}$ on ian operator $\mathbf{H}$ (which may depend on time $t$ ) of the system according to the equation of motion of the statistical operator $\mathbf{k}$

$$
\frac{d \mathbf{k}}{d t}=-[\mathbf{H}, \mathbf{k}]
$$

(which is equivalent to the $\mathrm{Schr}$ od ing er equation

$$
-\frac{\hbar}{i} \frac{\partial \varphi}{\partial t}=\mathbf{H} \varphi
$$


for pure quantum states). Because the correspondence $\mathbf{k} \longleftrightarrow k(\xi)$ is linear, we have

$$
\frac{d \mathbf{k}}{d t} \leftarrow \frac{d k(\xi)}{d t}
$$

(1.40) can be integrated into

$$
\mathbf{k}(t)=e^{-\frac{i}{i} \int_{t_{0}}^{t} d t^{\prime} \mathbf{H}\left(t^{\prime}\right)} \mathbf{k}\left(t_{0}\right) e^{\frac{i}{i} \int_{t_{0}}^{t} d t^{\prime} \mathbf{H}\left(t^{\prime}\right)}
$$

(which is equivalent to $\varphi(t)=e^{-\frac{i}{h} \int_{t_{0}}^{t} d t^{\prime} \mathbf{H}\left(d t^{\prime}\right)} \varphi\left(t_{0}\right)$ for pure quantum states). If the superquantity corresponding to the bracket expression $[\mathbf{a}, \mathbf{b}]$ is written $((a(\xi), b(\xi)))$ (the former and consequently also the latter bracket expression is antisymmetrical), the equation of motion of the distribution function $k(\xi)$ reads

$$
\frac{d k(\xi)}{d t}=-((H(\xi), k(\xi))) \text {. }
$$

Because

$$
\frac{d}{d t} \operatorname{Tr}(\mathbf{k a})=\operatorname{Tr}\left(-[\mathbf{H}, \mathbf{k}] \mathbf{a}+\mathbf{k} \frac{\partial \mathbf{a}}{d t}\right)=\operatorname{Tr}\left(\mathbf{k}\left([\mathbf{H}, \mathbf{a}]+\frac{\partial \mathbf{a}}{d t}\right)\right)
$$

and correspondingly

$$
\begin{aligned}
\frac{d}{d t} \int d \xi k(\xi) a(\xi) & =\int d \xi\left(-((H(\xi), k(\xi))) a(\xi)+k(\xi) \frac{\partial a(\xi)}{\partial t}\right) \\
& =\int d \xi k(\xi)\left(((H(\xi), a(\xi)))+\frac{\partial a(\xi)}{\partial t}\right),
\end{aligned}
$$

the dynamical time dependence can be shifted from the wave functions $\varphi$ and the statistical operators $\mathbf{k}$ ( $\mathrm{S} \mathrm{chr}$ ö ding e r representation) and the distribution functions $k(\xi)$ to the operators a (H e i s e $\mathrm{n} \mathrm{b}$ e $\mathrm{r}$ g representation) and the superquantities $a(\xi)$.

Instead of (1.40), (1.43) we then get

$$
\begin{gathered}
\frac{d \mathbf{a}}{d t}=\frac{\partial \mathbf{a}}{\partial t}+[\mathbf{H}, \mathbf{a}], \\
\frac{d a(\xi)}{d t}=\frac{\partial a(\xi)}{\partial t}+((H(\xi), a(\xi))) .
\end{gathered}
$$

For those parameters $\xi$, which correspond to observable quantities (with respect to $O_{q}$ ) (1.47) must be valid and reads

$$
\frac{d \xi}{d t}=\frac{\partial \xi}{\partial t}+((H(\xi), \xi)) \text {. }
$$

Physica XII 
The equations of motion for the hidden parameters may be of a different form. When all parameters (inclusive the hidden ones) are continuous, their equations of motion have to satisfy the condition that when inserted in

$$
\frac{d a(\xi)}{d t}=\frac{\partial a(\xi)}{\partial t}+\frac{\partial a(\xi)}{\partial \xi} \frac{d \xi}{d t}
$$

(where the last term stands symbolically for a sum over all separate parameters $\xi$ ), they must give (1.47).

We may summarize that, in order to give a statistical description of the 1st kind, one would have to determine (only formally for type $S_{f}^{1}$, also experimentally for type $S_{o}^{1}$ ) the parameters $\xi$ (inclusive the hidden ones) and the density function, the (one-to-one or one-tomany) correspondence $\mathbf{a} \longleftrightarrow a(\xi)$ (problem $\alpha_{5}$ ) and the equations of motion for the hidden parameters (if there are any such), all with regard to the imposed conditions.

1.15 Correspondence $\mathrm{a} \longleftrightarrow a(\xi)$. Because a non-H ermitian operator $\mathbf{a}$ (with adjoint $\mathbf{a}^{\dagger}$ ) can be written as a complex linear combination of $\mathrm{Hermitian}$ operators

$$
\mathbf{a}=\frac{1}{2}\left(\mathbf{a}+\mathbf{a}^{\dagger}\right)+\frac{1}{2 i}\left(i \mathbf{a}-i \mathbf{a}^{\dagger}\right)
$$

the generalization of the correspondence $\mathbf{a} \longleftrightarrow a(\xi)$ to non-H. er$\mathrm{mit}$ i a $\mathrm{n}$ operators is uniquely determined. Now take the non-H e rmiti a n transition operators $\mathbf{k}_{\mu \nu}$, which according to (1.13), (1.14) form a complete orthonormal system in the ring of operators a. For the corresponding functions $k_{\mu \nu}(\xi)$ we get corresponding to (1.11), (1.12); (1.13), (1.14) and (1.15) (and using III, IV and (1.03)) the relations

$$
\begin{gathered}
\int d \xi k_{\mu \nu}(\xi)=\delta_{\mu \nu}, \\
\sum_{\mu} k_{\mu \mu}(\xi)=1 \\
\int d \xi k_{\mu \nu}^{*}(\xi) k_{\mu^{\prime} \nu^{\prime}}(\xi)=\delta_{\mu \mu^{\prime}} \delta_{\nu \nu^{\prime}} \\
\sum_{\mu, \nu} k_{\mu \nu}(\xi) k_{\mu \nu}^{*}\left(\xi^{\prime}\right)=\delta\left(\xi-\xi^{\prime}\right)
\end{gathered}
$$

$\left(\delta\left(\xi-\xi^{\prime}\right)\right.$ stands for a product of $\delta$-symbols for all parameters $\xi$ and the inverse of the density function) and

$$
a(\xi)=\sum_{\mu, \nu} \alpha_{\nu \mu} k_{\mu \nu}(\xi) \text { with } \alpha_{\nu \mu}=\int d \xi k_{\mu \nu}^{*}(\xi) a(\xi) .
$$


(the $\alpha_{\nu \mu}$ are the same as in (1.15)). These relations show, that the functions $a(\xi)$ can be regarded as elements of a (generalized) $\mathrm{H}$ il bert space, in which the $k_{\mu \nu}(\xi)$ form a complete orthonormal system; (1.52) expresses the orthonormality, (1.53) the completeness.

We now show that the correspondence $\mathbf{a} \longleftrightarrow a(\xi)$ has to be a one-to-one correspondence. Suppose for a moment there are operators $\mathbf{k}_{\mu \nu}$ to which there correspond more than one functions $k_{\mu \nu}(\xi)$, which we distinguish by an index $\rho, \mathbf{k}_{\mu \nu} \longleftrightarrow k_{\mu \nu ; \rho}(\xi)$. Then the expression

$$
\sum_{\mu^{\prime}, \nu^{\prime}} \int d \xi k_{\mu \nu ; \rho}(\xi) k_{\mu^{\prime} \nu^{\prime} ; \rho^{\prime}}^{*}(\xi) k_{\mu^{\prime} \nu^{\prime} ; \rho^{\prime \prime}}\left(\xi^{\prime}\right)
$$

evaluated with (1.52) gives $k_{\mu \nu ;} \rho^{\prime \prime}\left(\xi^{\prime}\right)$, evaluated with (1.53) it gives $k_{\mu \nu ; \rho}\left(\xi^{\prime}\right)$. Therefore $k_{\mu \nu ; \rho^{\prime \prime}}\left(\xi^{\prime}\right)$ and $k_{\mu \nu ; \rho}\left(\xi^{\prime}\right)$ have to be identical. To each operator a and only to this one there has to correspond one and only one superquantity $a(\xi)$. As a consequence the superquantities $a(\xi)$ must depend on the same number of parameters (at least if they are not too bizarre) as the operators a, i.e. on twice as many as the wave functions $\varphi$.

Thus to each (normalizable) real function $a(\xi)$ and only to this one there corresponds one and only one $\mathrm{H}$ e $\mathrm{r} \mathrm{m}$ it i a $\mathrm{n}$ operator a, which represents an observable quantity (with respect to $O_{q}$ ). In other words every real function $a(\xi)$ is a superquantity. Because this also holds for the (real and imaginary parts of the) parameters $\xi$ themselves, none of them can be hidden in the sense defined above. (An observable quantity may occasionally be inobservable in a measuring device adepted to an incommensurable quantity; in this sense a parameter may occasionally be hidden). In particular all parameters must obey (1.48).

Comparing (1.15) and (1.54) we see that the correspondence $\mathrm{a} \longleftrightarrow a(\xi)$ can be expressed by

with

$$
a(\xi)=\operatorname{Tr}(\mathbf{m}(\xi) \mathbf{a}), \mathbf{a}=\int d \xi \mathbf{m}(\xi) a(\xi),
$$

$$
\mathbf{m}(\xi)=\sum_{\mu, \nu} \mathbf{k}_{\mu \nu} k_{\mu \nu}^{*}(\xi) ; \quad \mathbf{m}^{\dagger}(\xi)=\mathbf{m}(\xi) \text {. }
$$

The Hermitian transformation nucleus $m(\xi)$ satisfies the relations

$$
\begin{gathered}
\operatorname{Tr} \mathbf{m}(\xi)=1, \\
\int d \xi \mathbf{m}(\xi)=\mathbf{1} \\
\operatorname{Tr}\left(\mathbf{m}(\xi) \mathbf{m}\left(\xi^{\prime}\right)\right)=\delta\left(\xi-\xi^{\prime}\right), \\
\int d \xi \operatorname{Tr}(\mathbf{m}(\xi) \mathbf{a}) \operatorname{Tr}(\mathbf{m}(\xi) \mathbf{b})=\operatorname{Tr}(\mathbf{a b})(\text { for every } \mathbf{a} \text { and } \mathbf{b})
\end{gathered}
$$


$(1.60)$ is equivalent to

$$
\int d \xi \mathbf{m}(\xi) \operatorname{Tr}(\mathbf{m}(\xi) \mathbf{a})=\mathbf{a}(\text { for every } \mathbf{a}) .
$$

(1.59) expresses that $\mathbf{m}(\xi)$ is orthonormal with respect to the ring of operators a, complete with respect to the ring of superquantities $a(\xi) ;(1.60)$ expresses the crossed properties.

If, on the other hand, a $\mathrm{Hermitian}$ transformation nucleus $\mathbf{m}(\xi)$ satisfies the conditions (1.57), (1.58); (1.59), (1.60), the correspondence (1.55) satisfies III and IV. We may either choose a complete orthonormal system of $\mathbf{k}_{\mu \nu}$, satisfying (1.11), (1.12); (1.13), (1.14) and determine the corresponding system of $k_{\mu v}(\xi)$, which then satisfy (1.50), (1.51); (1.52), (1.53), or we choose the latter system and determine the former one. In both cases $\mathbf{m}(\xi)$ can be expanded according to (1.56).

1.16 Uniqueness. Now let us see whether the correspondence $a \longleftrightarrow a(\xi)$ is uniquely determined by the conditions III and IV. Suppose we have two different nuclei $\mathbf{m}^{\prime}(\xi)$ and $\mathbf{m}^{\prime \prime}(\xi)$, depending on the same parameter $\xi$ and both satisfying (1.57), (1.58); (1.59), (1.60). When we choose for both the same complete orthonormal system of $k_{\mu \nu}(\xi)$ satisfying (1.50), (1.51); (1.52), (1.53), we find two corresponding systems of $\mathbf{k}_{\mu \nu}^{\prime}$ and $\mathbf{k}_{\mu \nu}^{\prime \prime}$, which each satisfy (1.11), $(1.12) ;(1.13),(1.14)$. Therefore the latter systems can be connected by a unitary transformation

$$
\mathbf{k}_{\mu \nu}^{\prime}=\mathbf{u k}_{\mu \nu}^{\prime \prime} \mathbf{u}^{\dagger}, \quad \mathbf{u u}^{\dagger}=1 ; \mathbf{k}_{\mu \nu}^{\prime \prime}=\mathbf{u}^{\dagger} \mathbf{k}_{\mu \nu}^{\prime} \mathbf{u}
$$

(expressed analoguous to (1.03) $\mathbf{u}$ can be written as $\left.\sum_{\mu} \varphi_{\mu}^{\prime} \varphi_{\mu}^{\prime \prime \dagger}\right)$. The same unitary transformation connects the nuclei $\mathbf{m}^{\prime}(\xi)$ and $\mathbf{m}^{\prime \prime}(\xi)$ and also the statistical operators $\mathbf{k}^{\prime}$ and $\mathbf{k}^{\prime \prime}$ corresponding to the same distribution function $k(\xi)$ and the operators $\mathbf{a}^{\prime}$ and $\mathbf{a}^{\prime \prime}$ corresponding to the same superquantity $a(\xi)$. Then the single and double dashed representations are isomorphous and in quantum mechanics regarded as equivalent. Therefore, when the parameters $\xi$ have been chosen, the correspondence $\mathbf{a} \longleftrightarrow a(\xi)$ (if there is any correspondence) can be considered as unique.

When we choose one set of parameters $\xi$ and another set of parameters $\eta$, the nuclei $\mathbf{m}(\xi)$ and $\mathbf{m}(\boldsymbol{\eta})$ (if there are any nuclei) can be considered as uniquely determined. When we take a complete orthonormal system of $\mathbf{k}_{\mu \nu}$ satisfying (1.11), (1.12); (1.13), (1.14), we find two corresponding systems of $k_{\mu \nu}^{\prime}(\xi)$ and $k_{\mu \nu}^{\prime \prime}(\eta)$, which each satisfy 
(1.50), (1.51); (1.52), (1.53). Then it follows that the superquantities $a^{\prime}(\xi)$ and $a^{\prime \prime}(\eta)$, corresponding to the same operator a are connected by

$$
a^{\prime}(\xi)=\int d \eta v(\xi ; \eta) a^{\prime \prime}(\eta) ; \quad a^{\prime \prime}(\eta)=\int d \xi v(\xi ; \eta) a^{\prime}(\xi),
$$

where the transformation nucleus

satisfies

$$
v(\xi ; \eta)=\sum_{\mu, \nu} k_{\mu \nu}(\xi) k_{\mu \nu}^{\prime \prime *}(\eta) ; v(\xi ; \eta)=v^{*}(\xi ; \eta)
$$

$$
\int d \xi v(\xi ; \eta)=\int d \eta v(\xi ; \eta)=1 ;
$$

$\int d \eta v(\xi ; \eta) v\left(\xi^{\prime} ; \eta\right)=\delta\left(\xi-\xi^{\prime}\right), \int d \xi v(\xi ; \eta) v\left(\xi ; \eta^{\prime}\right)=\delta\left(\eta-\eta^{\prime}\right)$.

The rings of $a^{\prime}(\xi)$ and of $a^{\prime \prime}(\eta)$ are not necessarily isomorphous. When they are, we must have

$\iint d \eta^{\prime} d \eta^{\prime \prime} v\left(\xi ; \eta^{\prime}\right) v\left(\xi ; \eta^{\prime \prime}\right) a^{\prime \prime}\left(\eta^{\prime}\right) b^{\prime \prime}\left(\eta^{\prime \prime}\right)=\int d \eta v(\xi ; \eta) a^{\prime \prime}(\eta) b^{\prime \prime}(\eta)$

for every $a^{\prime \prime}(\eta)$ and $b^{\prime \prime}(\eta)$, which requires

and similarly

$$
v\left(\xi ; \eta^{\prime}\right) v\left(\xi ; \eta^{\prime \prime}\right)=v\left(\xi ; \eta^{\prime}\right) \delta\left(\eta^{\prime}-\eta^{\prime \prime}\right)
$$

$$
v\left(\xi^{\prime} ; \eta\right) v\left(\xi^{\prime \prime} ; \eta\right)=v\left(\xi^{\prime} ; \eta\right) \delta\left(\xi^{\prime}-\xi^{\prime \prime}\right)
$$

The solutions of (1.67) and (1.68) have the form

and

$$
v\left(\xi ; \eta^{\prime}\right)=\delta\left(\eta(\xi)-\eta^{\prime}\right)
$$

$$
v\left(\xi^{\prime} ; \eta\right)=\delta\left(\xi^{\prime}-\xi(\eta)\right),
$$

where $\eta(\xi)$ and $\xi(\eta)$ are single valued functions. Because $(1.69)$ and (1.70) have to be identical, $\eta(\xi)$ and $\xi(\eta)$ have to be inverse to each other with unit functional determinant

$$
\left|\frac{\partial(\eta)}{\partial(\xi)}\right|=\left|\frac{\partial(\xi)}{\partial(\eta)}\right|=1
$$

(it should be remembered that we symbolically write $\xi$ or $\eta$ for what might be a whole set of parameters $\xi$ or $\eta$ ). With (1.69), (1.70) we get for (1.62)

$$
a^{\prime}(\xi)=a^{\prime \prime}(\eta(\xi)) ; \quad a^{\prime \prime}(\eta)=a^{\prime}(\eta(\xi)) .
$$

This shows that the transformation between two isomorphous representations $a^{\prime}(\xi)$ and $a^{\prime \prime}(\eta)$ can be regarded as merely a transformation of the parameters. It further follows that, if the dynamical conditions for (1.49) are fulfilled by one of these representations, they are also fulfilled by the other one. Therefore isomorphous representations can be regarded as equivalent. 
When the solution $v(\xi ; \eta)$ of $(1.64),(1.65)$ is not of the form (1.69), (1.70), the representations $a^{\prime}(\xi)$ and $a^{\prime \prime}(\eta)$ are non-isomorphous.

1.17 Parameters. In 4.03 we derive a correspondence, satisfying III and IV, in which the two independent parameters (denoted by $p$ and $q$ ), which run continuously between $-\infty$ and $+\infty$, correspond to the operators $\mathbf{p}$ and $\mathbf{q}$. This choice of parameters might seem the most satisfactory one, as it is adapted to the fundamental part played by the momentum and the coordinate. (By the way, because momentum and coordinate cannot simultaneously be measured, $p$ may be regarded as occasionally hidden in a coordinate measurement, $q$ similarly in a momentum measurement — or in a somewhat different conception $p$ may be regarded as occasionally hidden in $q$-representation, $q$ in $p$-representation; both $p$ and $q$ may be regarded as occasionally partially hidden in other measurements or representations).

In 1.16 we have seen that for each choice of a complete orthonormal system of $k_{\mu \nu}(p, q)$, satisfying (1.50), (1.51); (1.52), (1.53), there must for every other representation with parameters $\xi$ be a similar system of $k_{\mu \nu}(\xi)$ with the same set of indices $\mu, v$. That makes us expect that when $\xi$ stands for a set of not too bizarre continuous parameters, the latter can like $p$ and $q$ be represented by two independent real parameters $r$ and $s$. We do not examine the validity of this expectation (which would be very difficult).

1.18 Bracket expressions. When these parameters $r$ and $s$ are also independent of time, the consistency relation for $(1.47),(1.48)$ and (1.49) reads

$$
((H(r, s), a(r, s)))=\frac{\partial a(r, s)}{\partial r}((H(r, s), r))+\frac{\partial a(r, s)}{\partial s}((H(r, s), s))(1
$$

(for every $a(r, s)$ ).

When the superquantities $H(r, s)$ corresponding to the $\mathrm{H}$ a milt.onian operators $\mathbf{H}$ are not restricted to functions of a too special type, (1.73) requires (using the antisymmetry properties

$$
\begin{gathered}
((r, s))=-((s, r)) ;((r, r))=((s, s))=0) \\
\langle(a(r, s), b(r, s)))=((r, s))(a(r, s), b(r, s))(\text { for every } a(r, s) \text { and } b(r, s)),
\end{gathered}
$$

with the Poisson brackets (similar to (1.01))

$$
(a(r, s), b(r, s))=\frac{\partial a(r, s)}{\partial r} \frac{\partial b(r, s)}{\partial s}-\frac{\partial a(r, s)}{\partial s} \frac{\partial b(r, s)}{\partial r} .
$$


For the superquantities $p(r, s)$ and $q(r, s)$ corresponding to $\mathbf{p}$ and $\mathbf{q}$ we get because of $(1.30)$

$$
((p(r, s), q(r, s)))=((r, s))(p(r, s), q(r, s))=1 .
$$

Therefore (1.74) can also be written

$$
((a(r, s), b(r, s)))=\frac{(a(r, s), b(r, s))}{(p(r, s), q(r, s))} .
$$

This means that the correspondence $\mathbf{a} \longleftrightarrow a(r, s)$ has to satisfy the rule

if $\mathbf{a} \longleftrightarrow a(r, s), \mathbf{b} \longleftrightarrow b(r, s)$ and $\mathbf{p} \longleftrightarrow p(r, s), \mathbf{q} \longleftrightarrow q(r, s)$,

$$
\text { then } \quad[\mathbf{a}, \mathbf{b}] \leftrightarrow \frac{(a(r, s), b(r, s))}{(p(r, s), q(r, s))} .
$$

The analoguous derivation for the parameters $p$ and $q$ gives (independent of our unproved expectation about the parameters $r$ and $s)$ the condition

if $\mathbf{a} \longleftrightarrow a(p, q)$ and $\mathbf{b} \longleftrightarrow b(p, q)$, then $[\mathbf{a}, \mathbf{b}] \longleftrightarrow(a(p, q), b(p, q))$. V

For this choice of parameters problem $\alpha_{5}$ of the correspondence between the superquantities $a(p, q)$ and the quantum operators a seems very similar to problem $\alpha_{3}$ of the correspondence between the classical quantities $a(p, q)$ and the quantum operators a, by which they are replaced in the procedure of quantization. The fact that in this procedure the $\mathrm{P}$ o is s o $\mathrm{n}$ brackets in the equations of motion are replaced by operator brackets might suggest rule $V^{\prime}$ in problem $\alpha_{3}$. If a solution of $\alpha_{3}$ satisfying rules III, IV and $V^{\prime}$ could be found, the classical description could be regarded as the description of the uniquely determined processes in a statistical description of the 1st kind $S^{1}$. The utopian notion $O_{w}$, intended to proclaim these processes as observable, would coincide with the classical notion $O_{c}$. This would not (as it might seem) exactly mean a return towards the old classical theory, which was regarded as incorrect (with respect to $O_{q}$ and therefore also with respect to $O_{u}$, which regards $O_{q}$ as correct, though incomplete), because one would have to deal with peculiar distributions of classical systems. These distributions would have to be responsible for quantization.

But such a solution cannot be found. In 4.02 we show that $V^{\prime}$ is self contradictory (except for $\lim \hbar \rightarrow 0$ ). Because $V^{\prime}$ already fails 
for operators of occuring types, a restriction of the admitted operators could not help. Therefore a solution of problem $\alpha_{5}$ with $p$ and $q$ as parameters, which satisfies the dynamical conditions, is impossible, just as a solution of $\alpha_{3}$, which describes the quantization of the classical equations of motion by the same rule as the quantization of the classical observables.

This is in point of fact all we have been able to prove. Though $p$ and $q$ may seem the most satisfactory choice of parameters in a description of type $S^{1}$, the formal disproof of just this description does not involve the impossibility of any description of type $S_{f}^{l}$. A complete proof of the impossibility of a description of type $S_{f}^{1}$ does not seem simple and neither does the construction of such a description.

For a pair of continuous time independent parameters $r$ and $s$ condition $\mathrm{V}$ would have to be satisfied. When the commutator of $r$ and $s$ commutes with $r$ and $s, \mathrm{~V}$ is self contradictory just like $\mathrm{V}^{\prime}$. It is doubtful whether $\mathrm{V}$ can be consistent in other cases. A pair of continuous time dependent parameters $r(t)$ and $s(t)$ must at every time $t$ be unique single-valued functions of the initial values $r\left(t_{0}\right)$ and $s\left(t_{0}\right)$ at an arbitrary time $t_{0}$. Then instead of the time dependent $r(t)$ and $s(t)$ the time independent $r\left(t_{0}\right)$ and $s\left(t_{0}\right)$ can serve as parameters. Therefore, if our expectation about continuous parameters is justified, the difficulty for such parameters lies mainly in the consistency of V. It is difficult to see how parameters with entirely or partially discrete values or of too bizarre continuous type could give a satisfactory description of type $S^{1}$.

There are still more difficulties for a description $S^{1}$ as we will see in a moment.

1.19 Quasi-statistical description. Whereas it is doubtful whether the dynamical condition V can be fulfilled, conditions III and IV can be satisfied without much difficulties. With a solution of the latter conditions only, one can construct a quasi-statistical description of the 1 st kind $Q^{1}$, which looks very similar to a formal statistical description of the lst kind $S_{f}^{1}$, but in general does not satisfy the dynamical (and, as we will see in a moment, other necessary) conditions. A solution of III and IV gives according to (1.39) the correct average values. But the real distribution function $k(\xi)$ corresponding to a $\mathrm{H}$ e r m it i a n non-negative definite statistical operator $\mathbf{k}$ of a quantum state (pure state or mixture) is in general not non-negative definite. 
The difficulty of interpreting negative probabilities might perhaps be surmountable, at least in formal sense $M_{f}$. Meanwhile, according to the remark following (1.37), it is no longer guaranteed, that the distribution functions $k_{1}(\xi)$ and $k_{2}(\xi)$ corresponding to orthogonal quantum states $\mathbf{k}_{1}$ and $\mathbf{k}_{2}$ do not overlap. And overlapping of such distribution functions it not allowed by the notion of quantum observability $O_{q}$. We see this in the following way. Suppose we subject the system repeatedly to a measurement, which distinguishes between the states $k_{1}$ and $k_{2}$ (and other orthogonal states). When after one measurement the system is left in the state $k_{1}$, the probability of finding it after a repeated measurement in the state $k_{2}$ is 0 because of (1.37). In the quantum mechanical interpretation this means absolute certainty of not finding the state $k_{2}$. In the quasistatistical interpretation the zero value for the right hand member of (1.37) results from integration of positive and negative probabilities over the region of overlapping. Integration over a statistical distribution refers to a great number of measurements. In a proper statistical description of the 1st kind $S^{1}$ the absolute certainty of not finding the state $k_{2}$, even in a single measurement, can only be established if no superstate occurring in the ensemble $k_{1}(\xi)$ can also occur in the ensemble $k_{2}(\xi)$, i.e. if $k_{1}(\xi)$ and $k_{2}(\xi)$ do not overlap.

Therefore in order to find a statistical description of type $S_{f}^{1}$, one would have to satisfy not only conditions II, IV and $V$ (or another dynamical condition), but also the condition that the distribution functions of quantum states are non-negative definite, or at least that the distribution functions of orthogonal states do not overlap. This task does not look very promizing.

We incidentally remark that in any representation of type $Q^{1}$ either of the two parameters can be treated as occasionally hidden. Already after integration over this one parameter we get the quantum mechanical formalism in the representation of the other parameter. In particular no negative probabilities are left.

In 4.03 we derive a particular solution (W e y l's correspondence) of III and IV with parameters $p$ and $q$ and in $\mathbf{5}$ we discuss the quasistatistical description $Q^{1}$ to which it leads. We do so not only for the sake of curiosity, but also because it is very instructive to those opponents in the fundamental controversy, who have a description of type $S^{1}$ (similar to that of classical statistical mechanics) vaguely in mind. A description of type $Q^{1}$ might be the utmost (though 
rather poor) realization of such foggy ideas. (The mysterious hidden parameters then turn out as ordinary, occasionally inobservableobservables). Such a description clearly shows the obstacles (equa, tions of motion; non-negative probabilities or non-overlapping distributions) at which all such conceptions may be expected to break down.

So far the general line of reasoning. Before dealing further with correspondence in 4, for which we need the operator relations of 3 , we review in 2 the measuring process in terms of the operator representation.

\section{The measuring process.}

2.01 Deviation. Quite apart from the interpretation of 1.10 , the expectation value of a quantum observable $\mathbf{a}$ in a quantum state $\mathbf{k}$ is given by (1.31) or

$$
E x(\mathbf{k} ; \mathbf{a})=\operatorname{Tr}(\mathbf{k a}) .
$$

Further the deviation of this observable in this state is defined by

$$
\begin{aligned}
\operatorname{Dev}(\mathbf{k} ; \mathbf{a})=E x\left(\mathbf{k} ;(\mathbf{a}-\mathbf{1} E x(\mathbf{k} ; \mathbf{a}))^{2}\right) & =\operatorname{Tr}\left(\mathbf{k}(\mathbf{a}-\mathbf{1} \operatorname{Tr}(\mathbf{k} \mathbf{a}))^{2}\right)= \\
& =\operatorname{Tr}\left(\mathbf{k} \mathbf{a}^{2}\right)-(\operatorname{Tr}(\mathbf{k} \mathbf{a}))^{2} .
\end{aligned}
$$

First we review some consequences of this definition, detached of any interpretation.

It can be seen from the inner members of (2.02) that the deviation is non-negative. We form the transition operators $\mathbf{k}_{\nu \mu}$ (1.03) of the complete system of eigenfunctions $\varphi_{\mu}$ of a with eigenvalues $a_{\mu}$ and expand $\mathbf{k}$ according to (1.15) as

$$
\mathbf{k}=\sum_{\mu, \nu} x_{\nu \mu} \mathbf{k}_{\mu \nu} \text { with } x_{\nu \mu}=\operatorname{Tr}\left(\mathbf{k}_{\nu \mu} \mathbf{k}\right) \text {. }
$$

The normalization of $\mathbf{k}(T \mathbf{k}=1)$ gives with (1.11)

Then (2.02) gives

$$
\sum_{\mu} x_{\mu \mu}=1 \text {. }
$$

$$
\operatorname{Dev}(\mathbf{k} ; \mathbf{a})=\sum_{\mu} \chi_{\mu \mu} a_{\mu}^{2}-\left(\sum_{\mu} \chi_{\mu \mu} a_{\mu}\right)^{2}=\frac{1}{2} \sum_{\mu, \nu} \chi_{\mu \mu} \gamma_{\nu \nu}\left(a_{\mu}-a_{\nu}\right)^{2} .
$$

If $\mathbf{k}$ is a pure state with wave function $\varphi$, we have

$$
x_{\mu \mu}=\operatorname{Tr}\left(\mathbf{k}_{\mu \mu} \mathbf{k}\right)=\left|\varphi_{\mu}^{\dagger} \varphi\right|^{2} .
$$

$\chi_{\mu \mu}$ is then non-negative and (2.05) can only be zero, if $\varphi$ is a linear combination of eigenfunctions $\varphi_{\mu}$ all with the same eigenvalue $a_{\mu}$. 
If the normalized quantum state $\mathbf{k}$ (pure state or mixture) can be written as a mixture of other normalized states $\mathbf{k}_{\boldsymbol{r}}$ with weights $k$,

(2.02) gives

$$
\mathbf{k}=\underset{r}{\Sigma} k_{r} \mathbf{k}_{r} ; k_{r} \geqslant 0, \sum_{r} k_{r}=1,
$$

$$
\begin{gathered}
\operatorname{Dev}(\mathbf{k} ; \mathbf{a})=\sum_{r} k_{r} \operatorname{Tr}\left(\mathbf{k}_{r} \mathbf{a}^{2}\right)-\left(\sum_{r} k_{r} \operatorname{Tr}\left(\mathbf{k}_{r} \mathbf{a}\right)\right)^{2} \\
=\sum_{r} k_{r} \operatorname{Dev}\left(\mathbf{k}_{r} ; \mathbf{a}\right)+\frac{1}{2} \sum_{r, s} k_{r} k_{s}\left(E x\left(\mathbf{k}_{r} ; \mathbf{a}\right)-E x\left(\mathbf{k}_{s} ; \mathbf{a}\right)\right)^{2} .
\end{gathered}
$$

The deviation of $\mathbf{a}$ in the state $\mathbf{k}$ is therefore only zero, if all occuring states $k_{r}\left(k_{r}>0\right)$ in the mixture give zero deviation and the same expectation value for a. Taking for the $\mathbf{k}$, pure states (the eigenstates of $\mathbf{k}$ ), we see that $\mathbf{a}$ is only deviationless in the state $\mathbf{k}$, if the latter is a pure linear combination or a mixture of linear combinations of eigenstates of a all with the same eigenvalue.

Because one can easily find two non-degenerate quantum operators (i.e. quantum operators with no more than one eigenstate for each eigenvalue), which have no eigenstates in common (e.g. $\mathbf{p}$ and q), there can be no quantum states in which all observables have zero deviation (deviationless states) ${ }^{1}$ ). Here might seem to lie the reason why the observational statements of quantum mechanics are in general of statistical character. No doubt there is some connection, but this rapid conclusion should not be taken too rashly, because it implies an interpretation of the deviation, which is not entirely justified. Let us turn to this interpretation.

In a statistical description of the 1 st kind $S^{1}$ the deviation of a quantity $a$ is defined by

$$
\operatorname{Dev}(a)=E x\left((a-E x(a))^{2}\right)=E x\left(a^{2}\right)-(E x(a))^{2} .
$$

In an ensemble, in which this deviation is zero, $a$ must have the same value in all samples. Then it follows that for every function $f(a)$

$$
E x(f(a))=f(E x(a)) \text {. }
$$

Whereas in general $a$ has a proper value only in a sample and in an ensemble only an average value (expectation value), one can speak of the proper value of $a$ in an ensemble if the deviation is zero.

In quantum mechanics it is not entirely clear what is meant by the square or another function of an observable. In order to discuss things, let us have recourse for a moment to the notion of 1.10 and let $a$ stand for the observable represented by a $(a \longleftrightarrow \mathbf{a}$; problem $\left.\alpha_{4}\right)$. Then (2.09) is only identical with $(2.02)$ for all states $\mathbf{k}$ if 
$a^{2} \longleftrightarrow \mathbf{a}^{2}$. Further we have seen that a state $\mathbf{k}$, in which (2.02) is zero, must be a (mixture of) linear combination(s) of eigenstates of a all with the same eigenvalue $a_{\mu}$. In these states the eigenvalue of $f(\mathbf{a})$ is $f\left(a_{\mu}\right)$ and $\operatorname{Dev}(\mathbf{k} ; f(\mathbf{a}))=0$. We write the operator, which represents $f(a)$ as $\mathbf{f}(a)$. If $(2.10)$ shall be valid in a state $\mathbf{k}$, in which $(2.02)$ is zero, we must have

$\operatorname{Tr}(\mathbf{k f}(a))=f(\operatorname{Tr}(\mathbf{k a}))=f\left(a_{\mu}\right)=\operatorname{Tr}(\mathbf{k} f(\mathbf{a})) ; \operatorname{Dev}(\mathbf{k} ; \mathbf{f}(a))=0 .(2.11)$

The second part is a special case of the first. The first part requires that the matrix elements of $\mathbf{f}(a)$ with respect to the eigenstates of $\mathbf{a}$ with the same eigenvalue $a_{\mu}$ have to be the same as those of $f(\mathbf{a})$ (i.e. equal to $f\left(a_{\mu}\right)$ ), the second part that the matrix elements of $f(a)$ with respect to the eigenstates of a with different eigenvalues $a_{\mu}$ are zero like those of $f(\mathbf{a})$. This means $\mathbf{f}(a)=f(\mathbf{a})$ so that $I$ has to be satisfied. For every $a$, for which $I$ is accepted, (2.10) always holds in states in which $a$ has zero deviation. For those $a$, for which $I$ is rejected, (2.10) breaks down even in such states. In the latter case it should be kept in mind that if we speak about $a_{\mu}$ as the proper value of the observable $\mathbf{a}$ in such a state, this is actually more or less misleading.

Thus we could give a meaning to the deviation, as soon as we could give a meaning to problem $\alpha_{4}$ (or the special case $\alpha_{5}$ ). This meaning would only agree with the one which is usually prematurely accepted, as long as rule I would hold. From the quantummechanical point of view $O_{q}$ there is no need for such a meaning. Meanwhile from the formal point of view the definiteness of the expression (2.02) remains of interest.

2.02 The measuring device ${ }^{1}$ ). The aim of an (ideal) measuring process is to infer (the most complete) data of the object system from the data of the observational perception. Object system and observer interact by intervention of a chain of systems, which form the measuring instrument. This chain can be cut into two parts. The first part (which may be empty) can be added to the object system, the last part to the observer. Extended object system and extended observer interact directly. The (extended) object system is regarded as a physical system. It is described by a physical treatment. The (extended) observer is unsusceptible of a physical treatment. Its part consists in an act, which must be stated without further analysis. The result of the measuring process should be in- 
dependent of the place of the cut in the measuring system, provided the first part is entirely accessible to a physical treatment.

We make a simplified model of the extended object system in which all partaking systems have one degree of freedom. The original object system is denoted by 1 , the successive systems of the measuring instrument before the cut by $2,3, \ldots \ldots n$. Every pair of adjacent systems $l-1$ and $l(l=2,3, \ldots n)$ is coupled during a time interval $\left(t_{2 l-4}, t_{2 l-3}\right)$. The time intervals must be ordered so, that

$$
t_{2 k+1} \geqslant t_{2 k-1} \text {. }
$$

For the sake of simplicity we impose the condition that different time intervals do not overlap

$$
t_{k}>t_{k-1} \text {. }
$$

Then the couplings between the various pairs of adjacent systems can successively be treated separately.

In 1 we choose a complete system of orthonormal wave functions $\varphi_{1 \mu}^{\prime}(t)$. The time dependence can be described with the help of a Hermitian operator $\mathbf{H}_{1}^{\circ}(t)$ according to

$$
-\frac{\hbar}{i} \frac{\partial}{\partial t} \varphi_{1 \mu}^{\prime}(t)=\mathbf{H}_{1}^{0}(t) \varphi_{1 \mu}^{\prime}(t)
$$

1 is coupled with 2 during the time interval $\left(t_{0}, t_{1}\right)$. This means that during this time interval the $\mathrm{Hamilt}$ on ia $\mathbf{H}_{12}(t)$ of the combined systems 1 and 2 cannot be split up into the sum of two $\mathrm{Hamilt}$ onians $\mathbf{H}_{1}(t)$ and $\mathbf{H}_{2}(t)$ of the separate systems. The system 2 is supposed to be initially in the pure quantum state $\varphi_{20}\left(t_{0}\right)$.

We impose two conditions on $\mathbf{H}_{12}(t)$ and $\varphi_{20}\left(t_{0}\right)$. The first condition is that $\mathbf{H}_{12}(t)-\mathbf{H}_{1}^{0}(t)$ must be diagonal with respect to the system of $\varphi_{1 \mu}^{\prime}(t)$

$$
\left(\mathbf{H}_{12}(t)-\mathbf{H}_{1}^{0}(t)\right) \varphi_{1 \mu}^{\prime}(t)=\varphi_{1 \mu}^{\prime}(t) \mathbf{G}_{\mu 2}(t) .
$$

$\mathrm{G}_{\mu 2}$ is an operator with respect to the variables of 2 ( $q$-number), but an ordinary number with respect to the variables of 1 ( $c$-number).

When 1 is initially in the pure quantum state $\varphi_{1 \mu}^{\prime}\left(t_{0}\right)$, the final state of 1 and 2 together is because of the wave equation

given by

$$
\frac{\hbar}{i} \frac{\partial}{\partial t} \varphi_{12}(t)=-\mathbf{H}_{12}(t) \varphi_{12}(t)
$$

$$
e^{-\frac{i}{\hbar} \int_{t_{0}}^{t_{1}} d t \mathbf{H}_{12}(t)} \varphi_{1 \mu}^{\prime}\left(t_{0}\right) \varphi_{20}\left(t_{0}\right)=\varphi_{1 \mu}^{\prime}\left(t_{1}\right) e^{-\frac{i}{\hbar} \int_{t_{0}}^{t_{1}} d \mathbf{G} \mathbf{C}_{\mu 2(t)}} \varphi_{20}\left(t_{0}\right) .
$$


With arbitrary chosen functions $g_{\mu}(t)$ and

$$
\begin{aligned}
& \varphi_{1 \mu}(t)=\varphi_{1 \mu}^{\prime}(t) e^{-\frac{i}{\pi} \int_{t_{0}}^{t} d t^{\prime} g_{\mu}\left(t^{\prime}\right)} ; \\
& \varphi_{2 \mu}(t)=e^{-\frac{i}{\hbar} \int_{t_{0}}^{t} d t^{\prime}\left(-\beta_{\mu}\left(t^{\prime}\right)+\mathbf{G}_{\mu 2}(t)\right)} \varphi_{20}\left(t_{0}\right)\left(t_{0}<t<t\right),
\end{aligned}
$$

(2.17) becomes

$$
\varphi_{1 \mu}\left(t_{1}\right) \varphi_{2 \mu}\left(t_{1}\right) .
$$

The second condition, which we impose on $\mathbf{H}_{12}(t)$ and $\varphi_{20}(t)$ is that the (already normalized) $\varphi_{2 \mu}\left(t_{1}\right)$ must be orthogonal

$$
\begin{gathered}
\varphi_{2 \mu}^{\dagger}\left(t_{1}\right) \varphi_{2 \nu}\left(t_{1}\right)=\varphi_{20}^{\dagger}\left(t_{0}\right) e^{\frac{i}{\hbar} \int_{t_{0}}^{t_{2}} d t\left(-g_{\mu}(t)+\mathbf{G}_{\mu 2}(t)\right)} . \\
. e^{-\frac{i}{n} \int_{t_{0}}^{t_{1}} d t\left(-g_{\nu}(t)+\mathbf{G}_{\nu 2}(t)\right)} \varphi_{20}\left(t_{0}\right)=\delta_{\mu \nu} .
\end{gathered}
$$

The system of $\varphi_{2 \mu}\left(t_{1}\right)$ need not be complete.

For $t>t_{1}$, after the coupling has been dissolved, 1 and 2 have separate $\mathbf{H}$ amiltonian operators $\mathbf{H}_{1}(t)$ and $\mathbf{H}_{2}(t)$. The orthonormal functions $\varphi_{1 \mu}\left(t_{1}\right)$ and $\varphi_{2 \mu}\left(t_{2}\right)$ then transform into the orthonormal functions

$$
\text { and } \begin{aligned}
\varphi_{1 \mu}(t) & =e^{-\frac{i}{\hbar} \int_{i_{1}}^{t} d t^{\prime} \mathbf{H}_{1}\left(t^{\prime}\right)} \varphi_{1 \mu}\left(t_{1}\right) \\
\varphi_{2 \mu}(t) & =e^{-\frac{i}{\pi} \int_{t_{1}}^{t} d t^{\prime} \mathbf{H}_{2}\left(t^{\prime}\right)} \varphi_{2 \mu}\left(t_{1}\right) .
\end{aligned}
$$

The complete wave function (2.19) transforms into

$$
\varphi_{1 \mu}(t) \varphi_{2 \mu}(t) \quad\left(t \geqslant t_{1}\right)
$$

The succeeding pairs of adjacent systems are coupled analogously. The complete wave function of the first $m$ systems after the last coupling becomes, in the same way as (2.22),

$$
\varphi_{1 \mu}(t) \varphi_{2 \mu}(t) \ldots \varphi_{m \mu}(t) \quad\left(t_{2 m-3} \leqslant t \leqslant t_{2 m-2}\right) .
$$

More general 1 can, instead of being in a pure state $\varphi_{1 \mu}\left(t_{0}\right)$, be initially in a state with statistical operator $\mathbf{k}_{1}\left(t_{0}\right)$, which then can be expanded according to

$$
\mathbf{k}_{1}\left(t_{0}\right)=\sum_{\mu, \nu} \chi_{1 \nu \mu}\left(t_{0}\right) \mathbf{k}_{1 \mu \nu}\left(t_{0}\right) \text { with } \varkappa_{1 \nu \mu}\left(t_{0}\right)=\operatorname{Tr}\left(\mathbf{k}_{1 \nu \mu}\left(t_{0}\right) \mathbf{k}_{1}\left(t_{0}\right)\right)
$$


The statistical operator of the first $m$ systems after the last interaction then becomes with (2.23)

$$
\mathbf{k}_{12 \ldots m}(t)=\sum_{\mu, \nu} \chi_{1 \nu \mu}\left(t_{0}\right) \mathbf{k}_{1 \mu \nu}(t) \mathbf{k}_{2 \mu \nu}(t) \ldots \mathbf{k}_{m \mu \nu}(t)\left(t_{2 m-3} \leqslant t \leqslant t_{2 m-2}\right) \text {. }
$$

The interactions have affected the states of the partaking systems and established a correlation between them (entanglement).

2.03 Infringed states. When after the interaction the correlation between the state of an arbitrary system $l(1 \leqslant l \leqslant m)$ and the state of the other $m-1$ of the first $m$ systems is ignored, the latter state can irrespective of the former state according to (2.25) and (1.11) be described by the statistical operator

$$
\begin{gathered}
\mathbf{k}_{12 \ldots(l-1)(l+1) \ldots m}(t)=T r_{l} \mathbf{k}_{12 \ldots m}(t) \\
=\sum_{\mu} x_{1 \mu \mu}\left(t_{0}\right) \mathbf{k}_{1 \mu \mu}(t) \ldots \mathbf{k}_{(l-1) \mu \mu}(t) \mathbf{k}_{(l+1) \mu \mu}(t) \ldots \mathbf{k}_{m \mu \mu}(t)
\end{gathered}
$$

$\left(T r_{l}\right.$ denotes the trace with respect to the variables of $\left.l\right)$. More general the state of a selected series $l_{1}, l_{2}, \ldots l_{k}\left(1 \leqslant l_{1}<l_{2}<\ldots l_{k} \leqslant m\right)$ out of the chain of the first $m$ systems irrespective of the state of the other systems is described by the statistical operator

$$
\mathbf{k}_{h_{1} l_{2} \ldots l_{k}}(t)=\sum_{\mu} \varkappa_{1 \mu \mu}\left(t_{0}\right) \mathbf{k}_{h_{\mu \mu}}(t) \mathbf{k}_{l_{2 \mu \mu} \mu}(t) \ldots \mathbf{k}_{l_{k \mu \mu}}(t)\left(t \geqslant t_{2 l_{k}, 3}\right) \text {. }
$$

(2.27) is the statistical operator of a mixture of pure quantum states $\varphi_{h_{1} \mu}(t) \varphi_{l_{2} \mu}(t) \ldots \varphi_{l_{k} \mu}(t)$ with weights $x_{1 \mu \mu}\left(t_{0}\right)$. The ignorance of the correlation with other systems has also partially destroyed the correlation between the selected systems themselves. According to the remaining correlation only individual pure quantum states $\varphi_{t_{\mu}}(t)$ of the systems $l_{1}, l_{2}, \ldots l_{k}$ with the same Greek index occur together. We denote a state of a group of systems, which has come about by interaction with other, afterwards ignored, systems as an infringed state. $((2.25)$ is the entangled state (2.27) the infringed state).

We consider two particular cases of infringed states. First we put $m=n$ and let the selected series consist of the systems 1 and $n$ only. (2.27) then becomes

$$
\mathbf{k}_{1 n}(t)=\sum_{\mu} x_{1 \mu \mu}\left(t_{0}\right) \mathbf{k}_{1 \mu \mu}(t) \mathbf{k}_{n \mu \mu}(t)\left(t \geqslant t_{2 n-3}\right) .
$$

The correlation between 1 and $n$, which is left in this infringed state, justifies the inference that when for $n$ the pure quantum state $\varphi_{n \mu}(t)$ is realized, the corresponding pure quantum state $\varphi_{1 \mu}(t)$ (with 
the same $\mu$ ) is realized for 1 . With this inference the correlation is completely exhausted.

In the second place we put $m=n+1$ (supposing that the interaction between $n$ and $n+1$, which crosses the cut, is still accessible to a physical treatment) and select the systems $1,2, \ldots . n$. Then $(2.27)$ gives

$$
\mathbf{k}_{12 \ldots n}(t)=\sum_{\mu} \chi_{1 \mu \mu}\left(t_{0}\right) \mathbf{k}_{1 \mu \mu}(t) \mathbf{k}_{2 \mu \mu}(t) \ldots \mathbf{k}_{n \mu \mu}(t) \quad\left(t \geqslant t_{2 n-1}\right) .
$$

(2.29) determines the infringed state in which the extended object system is left after the interaction with the observer; if the state of the observer is afterwards ignored.

If in (2.29) we put $n=1$, we get

$$
\mathbf{k}_{1}(t)=\sum_{\mu} x_{1 \mu \mu}\left(t_{0}\right) \mathbf{k}_{1 \mu \mu}(t) \quad\left(t \geqslant t_{1}\right)
$$

which determines the infringed state of the original object system after the interaction with the measuring instrument, irrespective of the final state of the latter (and of the observer).

2.04 The measurement conclusion. When the original object system and observer are connected by a measuring instrument, which consists of an unramified chain of one or more interacting systems, it follows from (2.28) that the conclusion about the original object system, which the observer can infer from his final perception, certainly cannot go further than to indicate which of the pure quantum states $\varphi_{1 \mu}(t)$ is realized. According to the quantum notion of observation $O_{q}$ the observer can in principle actually infer that conclusion under ideal conditions and he cannot infer more under any condition. This rule establishes the connection between the mathematical formalism and the observers perceptions. The rule does not follow from the formalism. The formalism is in harmony with the rule. The rule justifies the representation of the formalism in terms of pure quantum states.

The conclusion derived from the measurement thus consists in indicating which pure quantum state of the mixture (2.29) or (2.30) of the extended or original object system is realized after this measurement. It could indicate equally well the realized pure quantum state of an arbitrary system or group of systems of the measuring instrument. For a great number of measurements on identical object systems with identical initial operators the statistical probability of realization of a pure quantum state with index $\mu$ is 
according to the statistical interpretation of $(2.29)$ or $(2.30) x_{1 \mu \mu}\left(t_{0}\right)$ (cf. $O_{q}$ ). The measuring result is independent of the place of the cut in the measuring instrument $\mathbf{1}$ ).

Formally we can distinguish the following stages in the measuring act. First the object system is coupled with the measuring instrument, which gives the entangled state, then the systems of the measuring chain are ignored, which gives the infringed mixture, from which finally the realized state is selected. They are represented by the scheme:

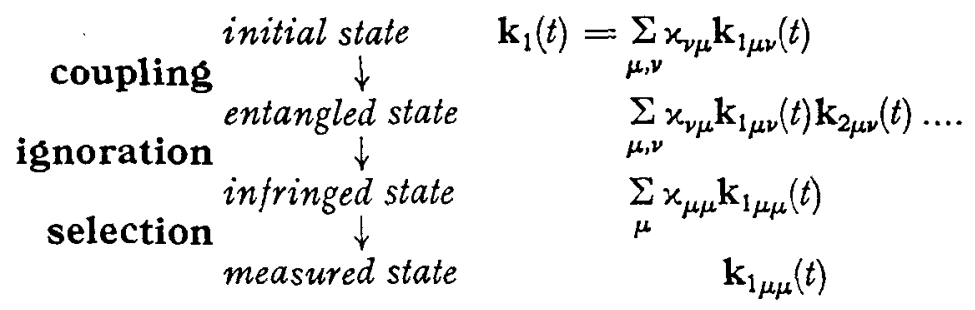

2.05 The measuring of observables. For every system $l$ we can define a $\mathrm{Hermitia}$ operator $\mathrm{a}_{l}(t)$ for which the functions $\varphi_{l_{\mu}}(t)$ form a system of orthonormal eigenfunctions with arbitrary prescribed eigenvalues $a_{l \mu}(t)$. $\mathbf{a}_{l}(t)$ commutes with $\mathbf{H}_{l}^{0}(t)$

$$
\left[\mathbf{H}_{l}^{0}(t), \mathbf{a}_{l}(t)\right]=0 \text {. }
$$

The condition (2.15) is then equivalent to the condition that $\mathbf{H}_{12}(\dot{\xi})$ must commute with $\mathbf{a}_{1}(t)$, or in general

$$
\left[\mathbf{H}_{l(l+1)}(t), \mathbf{a}_{l}(t)\right]=0
$$

In the pure quantum state $\varphi_{l \mu}(t)$ the observable $a_{l}(t)$ has the value $a_{l \mu}(t)$. A measurement, which decides which of the states $\varphi_{l \mu}(t)$ of $l$ is realized, also determines the value of $\mathbf{a}_{l}(t)$. It can be regarded as a measurement of the observable $\mathbf{a}_{l}(t)$. This establishes the experimental meaning of the value of an observable. Meanwhile, remembering 2.01, one should be careful in regarding $a_{t \mu}(t)$ as the proper value of $\mathbf{a}_{l}(t)$.

If all eigenvalues of $\mathbf{a}_{\iota}(t)$ are different

$$
a_{l \mu}(t) \neq a_{l v}(t) \text { for } \mu \neq \nu,
$$

the value of $\mathbf{a}_{l}(t)$ on the other hand uniquely determines the pure quantum state of the system $l$. Therefore, instead of indicating which state $\varphi_{l \mu}(t)$ of $l$ is realized, the observer can in the ideal case (2.33) equally well (and otherwise less well) record the value of 
$\mathbf{a}_{l}(t)$. Usually the measuring results are thus stated in terms of values of observables and not in terms of states. For this purpose it is immaterial whether these values (defined as eigenvalues) have a proper meaning in the sense of 2.01 or not.

2.06 Correlated observables. Similarly a correlation between the states of various systems can also be expressed as a correlation between the values of observables of these systems. As a particular case we consider the effect of ignoring the correlation with some systems (infringement) on the correlation between the remaining systems. This effect has in 2.03 been found to consist in the disappearance of the non-diagonal statistical operators $\mathbf{k}_{l \nu \mu}(t)(\mu \neq \nu)$ of the latter systems. This has no influence upon the expectation values of those observables, for which the operators are diagonal with respect to the functions $\varphi_{i_{\mu}}(t)$. That means that the correlation between such observables, for which the operators commute with the $\mathbf{a}_{l}(t)$, remains unaffected. For other observables the non-diagonal elements are dropped and the correlation is more or less destroyed. For observables, for which the operator has no non-zero diagonal elements with respect to the $\varphi_{i \mu}(t)$, no elements remain and the correlation is entirely destroyed.

2.07 The pointer reading. When for some system in the chain, say $l$, the functions $\varphi_{l \mu}(t)$ read in $q$-representation

$$
\varphi_{l \mu}(t)=\delta\left(q_{l}-q_{l \mu}\right)
$$

so that they are eigenfunctions of $\mathbf{q}_{l}$

$$
q_{l} \varphi_{l \mu}=q_{l \mu} \varphi_{l \mu},
$$

we denote the measurement as a (pointer) reading. $l$ is called the scale system. The measuring result of a reading can be expressed by the value of the coordinate of the scale system.

A simplified model, which gives such a coupling between the systems $(l-1)$ and $l$, that the values of the observables $\mathbf{a}_{(l-1)}(t)$ are measured by the values of the coordinate $\mathrm{q}_{l}$, is obtained ${ }^{1}$ ) with a $\mathrm{Hamilt}$ anian operator of the type

$$
\mathbf{H}_{(l-1) l}(t)=h\left(\mathbf{a}_{(l-1)}(t)\right)+f\left(\mathbf{a}_{(l-1)}(t)\right) \mathbf{p}_{l} .
$$

The condition (2.32) is satisfied. With the choice

$$
g_{\mu}(t)=h\left(a_{(l-1) \mu}(t)\right)
$$


(2.18) gives

$$
\varphi_{l \mu}(t)=e^{-\frac{i}{h} \int_{l_{0}}^{t_{1}} d t /\left(a_{(l-1) \mu}(t)\right) p_{l}} \varphi_{l o}\left(t_{0}\right) .
$$

We suppose that the wave function of the initial state of $l$ reads in $q_{l}$-representation

$$
\varphi_{10}\left(q_{l} ; t_{0}\right)=\delta\left(q_{l}-q_{20}\right)
$$

so that $\mathbf{q}_{l}$ has the initial value $q_{l 0}$

(2.38) then gives

$$
\mathbf{q}_{l} \varphi_{l 0}\left(t_{0}\right)=q_{l 0} \varphi_{l 0}\left(t_{0}\right)
$$

$$
\Phi_{l \mu}\left(t_{1}\right)=\delta\left(q_{l}-q_{l 0}-F\left(a_{(l-1) \mu}\right)\right) ; F\left(a_{(l-1) \mu}\right)=\int_{t_{0}}^{t_{1}} d t f\left(a_{(l-1) \mu}(t)\right) \text {. }
$$

If we put

(2.41) becomes

$$
q_{l \mu}=q_{l}-F\left(a_{(l-1) \mu}\right)
$$

$$
\varphi_{l \mu}\left(t_{1}\right)=\delta\left(q_{l}-q_{l \mu}\right)
$$

These wave functions are eigenfunctions of $\mathbf{q}_{l}$ with eigenvalues $q_{i \mu}$

$$
\mathbf{q}_{l} \varphi_{i_{\mu}}\left(t_{1}\right)=q_{l_{\mu}} \varphi_{l_{\mu}}\left(t_{1}\right) \text {. }
$$

The orthogonality condition (2.20) requires

$$
q_{l \mu} \neq q_{l v} \text { for } \mu \neq \nu,
$$

which is at the same time equivalent to the condition (2.33). (2.45) is satisfied if

$$
F\left(a_{(l-1) \mu}\right) \neq F\left(a_{(l-1) v}\right) \text { for } \mu \neq v .
$$

The spectrum of the values $q_{i \mu}$ (2.42) need not necessarily cover the whole domain of values of $\mathbf{q}_{b}$ from $-\infty$ until $+\infty$.

The momentum operator $\mathbf{p}_{l}$ reads in $q_{l}$-representation

$$
\mathbf{p}_{l}=\frac{\hbar}{i} \frac{\partial}{\partial q_{l}}
$$

The matrix elements with respect to the functions (2.43) are

$$
\operatorname{Tr}\left(\mathbf{p}_{l} \mathbf{k}_{l \nu \mu}\right)=\frac{\hbar}{i} \frac{\partial}{\partial q_{l \nu}} \delta\left(q_{l \nu}-q_{t_{\mu}}\right) .
$$

The diagonal elements $(\mu=v)$ are zero. Therefore the correlation of the momentum $\mathbf{p}_{l}$ of the scale system with observables of other systems is entirely destroyed by the measurement of the canonical conjugate coordinate $\mathbf{q}_{l}$. 
2.08 Observational connections. For a relation between observational data we need at least two measurements. We consider two succeeding measurements during the time intervals $\left(t_{0}, t_{1}\right)$ and $\left(t_{0}^{\prime}, t_{1}^{\prime}\right)$ with

$$
t_{0}^{\prime}>t_{1}
$$

performed on the same system 1 . The first measurement measures the states $\varphi_{1 \mu}(t)$ or a corresponding observable $a_{1}(t)$, the second one measures the states $\varphi_{1 \mu}^{\prime}(t)$ or a corresponding observable $\mathbf{a}_{1}^{\prime}(t)$.

If the first measuring result indicates the final pure quantum state $\varphi_{1 \mu}(t)\left(t_{1} \leqslant t \leqslant t_{0}^{\prime}\right)$, the statistical operator at the beginning $t_{0}^{\prime}$ of the second measurement is $\mathbf{k}_{\mathbf{1 \mu \mu}}\left(t_{0}^{\prime}\right)$, which is expanded according to

with

$$
\mathbf{k}_{1 \mu \mu}\left(t_{0}^{\prime}\right)=\sum_{\mu^{\prime}, \nu^{\prime}} x_{1 \mu \mu, \nu^{\prime} \mu^{\prime}}^{\prime}\left(t_{0}^{\prime}\right) \mathbf{k}_{1 \mu^{\prime} \nu^{\prime}}^{\prime}\left(t_{0}^{\prime}\right)
$$

$$
x_{1 \mu \mu, \nu^{\prime} \mu^{\prime}}^{\prime}\left(t_{0}^{\prime}\right)=\operatorname{Tr}\left(\mathbf{k}_{1 v^{\prime} \mu^{\prime}}^{\prime}\left(t_{0}^{\prime}\right) \mathbf{k}_{1 \mu \mu}\left(t_{0}^{\prime}\right)\right. \text {. }
$$

The statistical probability, that, after the first measuring result has indicated the pure quantum state $\varphi_{1 \mu}(t)\left(t_{1} \leqslant t \leqslant t_{0}^{\prime}\right)$, the second measuring result will indicate the pure quantum state $\varphi_{1 \nu^{\prime}}^{\prime}(t)\left(t \geqslant t_{1}^{\prime}\right)$ is

$$
x_{1 \mu \mu, \nu^{\prime} \nu^{\prime}}^{\prime}\left(t_{0}^{\prime}\right)=\operatorname{Tr}\left(\mathbf{k}_{1 v^{\prime} \nu^{\prime}}^{\prime}\left(t_{0}^{\prime}\right) \mathbf{k}_{1 \mu \mu}\left(t_{0}^{\prime}\right)\right)=\left|\varphi_{1 \nu^{\prime}}^{\prime \dagger}\left(t_{0}^{\prime}\right) \varphi_{1 \mu}\left(t_{0}^{\prime}\right)\right|^{2} .
$$

This conditional probability is actually the most elementary expression contained in the formalism, which denotes an observable connection and which has a directly observable statistical meaning.

When the functions $\varphi_{1 \mu}^{\prime}(t)$ coincide with the $\varphi\left(t_{1 \mu}\right)$, i.e. when $\mathbf{a}_{1}^{\prime}(t)$ and $\mathbf{a}_{1}(t)$ commute, (2.51) becomes

$$
x_{1 \mu \mu, \nu^{\prime} \nu}^{\prime}\left(t_{0}^{\prime}\right)=\delta_{v^{\prime} \mu}
$$

and the second measuring result can be predicted with certainty from the first. In this case we have essentially the repetition of a measurement. (2.52) expresses the reproducibility of the measuring result.

2.09 Intermingled states. The entangled state of two object systems 1 and 2 after a coupling of the type described above is of the kind

$$
\mathbf{k}_{12}=\sum_{\mu, \nu} \chi_{\nu \mu} \mathbf{k}_{1 \mu \nu} \mathrm{k}_{2 \mu \nu} .
$$

The probability of finding system 1 in a state $\mathbf{k}_{1}$ and 2 in a state $\mathbf{k}_{2}$ is

$$
\operatorname{Tr}\left(\mathbf{k}_{12} \mathbf{k}_{1} \mathbf{k}_{2}\right)=\sum_{\mu, \nu} \varkappa_{\nu \mu} \operatorname{Tr}\left(\mathbf{k}_{1 \mu \nu} \mathbf{k}_{1}\right) \operatorname{Tr}\left(\mathbf{k}_{2 \mu \nu} \mathbf{k}_{2}\right)
$$

When $\mathbf{k}_{1}$ and $\mathbf{k}_{2}$ coincide with the projection operators $\mathbf{k}_{1 \mu \mu}$ and $\mathbf{k}_{2 v \boldsymbol{v}}$, 
(2.54) becomes equal to $x_{\mu \mu} \delta_{\mu v}$ This might (wrongly) suggest that (after the coupling and before the measurement) the state of 1 and 2 is the mixture

$$
\mathbf{k}_{12}^{\prime}=\sum_{\mu} x_{\mu \mu} \mathbf{k}_{1 \mu \mu} \mathbf{k}_{2 \mu \mu}
$$

instead of the state (2.53). In this way the correlation between 1 and 2 would be partially destroyed by the omission of the non-diagonal terms. In the mixture (2.55) the expectation value of the states $\mathbf{k}_{1}$ and $\mathbf{k}_{2}$ would be

$$
\operatorname{Tr}\left(\mathbf{k}_{12}^{\prime} \mathbf{k}_{1} \mathbf{k}_{2}\right)=\sum_{\mu} \chi_{\mu \mu} \operatorname{Tr}\left(\mathbf{k}_{\mathbf{1}_{\mu \mu}} \mathbf{k}_{1}\right) \operatorname{Tr}\left(\mathbf{k}_{2 \mu \mu} \mathbf{k}_{2}\right)
$$

instead of (2.54). It has been emphasized by $\mathrm{F} \mathrm{u} \mathrm{r} \mathrm{r} \mathrm{y}{ }^{3}$ ) (in a somewhat different form and particularly against our common opponents, cf. 2.11) that only if neither $\mathbf{k}_{1}$ nor $\mathbf{k}_{2}$ coincides with any of the $\mathbf{k}_{1 \mu \mu}$ or $\mathbf{k}_{2 v v}$ respectively, (2.56) can be different from (2.54). Because the latter case hardly occurs in the relevant applications, one is apt to make the mistake of replacing (2.53) by (2.55) (and to draw unjustified conclusions whenever this case does occur).

If 1 and 2 had been coupled with one or more further systems $3, \ldots$ according to

$$
\mathbf{k}_{123 \ldots .}=\sum_{\mu, \nu} x_{\nu \mu} \mathbf{k}_{\mathfrak{I} \mu \nu} \mathbf{k}_{2 \mu \nu} \mathbf{k}_{3 \mu \nu} \ldots
$$

and these further systems had been ignored afterwards, the infringed state of 1 and 2 would correctly be given by (2.55) indeed. This infringed state is quite distinct from the entangled state (2.53).

2.10 Multilateral correlation. In (2.53) the transition operators $\mathbf{k}_{1 \mu \nu}$ and $\mathbf{k}_{2 \mu \nu}$ belong to two systems of orthonormal wave functions $\varphi_{1 \mu}$ and $\varphi_{2 \mu}$, which span the (generalized) Hilbert subspaces $R_{1}$ and $R_{2}$. An interesting case ) is that for which $\mathbf{k}_{12}$ can similar to (2.53) also be expanded with respect to the transition operators $\mathbf{1}_{1 \rho \sigma}$ and $\mathbf{l}_{2 \rho \sigma}$ belonging to any two systems of wave functions $\psi_{1 \rho}$ and $\psi_{2 \rho}$ in $R_{1}$ and $R_{2}$, when one system is chosen arbitrarily variable but orthonormal and complete, the other system suitably to the first

$$
\sum_{\mu, \nu} x_{\nu \mu} \mathbf{k}_{1 \mu \nu} \mathbf{k}_{2 \mu \nu}=\sum_{\rho, \sigma} \lambda_{c \rho} 1_{1 \rho \sigma} 1_{2 \rho \sigma} .
$$

A necessary and sufficient condition 4 ) for the occurrence of this case is that the $x_{\nu \mu}$ are of the form

$$
x_{\nu \mu}=x_{\nu}^{*} x_{\mu} ;\left|x_{\mu}\right|=x .
$$


The factorization of $x_{\nu \mu}$ means that $\mathbf{k}_{12}$ is a pure quantum state of the combined systems 1 and 2 with wave function

$$
\varphi_{12}=\sum_{\mu} x_{\mu} \varphi_{1 \mu} \varphi_{2 \mu} \text {. }
$$

The unimodular coefficients $x_{\mu} / x$ could even be included in $\varphi_{1 \mu}$ or $\varphi_{2 \mu}$.

The special case under discussion can easily be generalized to the following case. The functions $\varphi_{1 \mu}$ and $\varphi_{2 \mu}$ are taken together in groups $\varphi_{1 \mu_{1}}, \varphi_{1 \mu_{2}}, \ldots$ and $\varphi_{2 \mu_{1}}, \varphi_{2 \mu_{2}}, \ldots$, which span the (generalized) $\mathrm{H}$ il b e r t subspaces $R_{11}, R_{12}, \ldots$ and $R_{21}, R_{22}, \ldots$ respectively $\left(R_{1}=R_{11}+R_{12}+\ldots\right.$ and $\left.R_{2}=R_{21}+R_{22}+\ldots\right)$. In these subspaces we take any two sets of systems $\psi_{1 \rho_{1}}, \psi_{1 \rho_{1}}, \ldots$ and $\psi_{2 \rho_{1}}, \psi_{2 \rho_{2}}, \ldots$, of which one set is chosen arbitrarily variable but orthonormal and complete, the other suitably to the first. It is easily seen that the last part of condition (2.59) then has to be replaced by $\left|x_{\mu_{p}}\right|=x_{p}$. In 1 -dimensional subspaces $R_{1 p}$ and $R_{2 p}$ all 1-representations are essentially the same.

An equivalent formulation of the generalized case is obtained by taking instead of any two systems of wave functions $\psi_{1 \rho}$ and $\psi_{2 \rho}$, as in the special case, two definite systems of which one is chosen arbitrarily fixed but orthonormal and complete, the other suitably to the first. $R_{11}, R_{12}, \ldots$ or $R_{21}, R_{22}, \ldots$ are then determined by the sharpest division of $R_{1}$ or $R_{2}$ into subspaces, which span linearly independent groups of $\varphi_{1 \mu}$ and $\psi_{1 \rho}$ or $\varphi_{2 \mu}$ and $\psi_{2 \rho}$ at the same time.

We restrict ourselves to the special case. First we show the necessity of (2.59). With (1.13) it follows from (2.58) that

$$
\begin{aligned}
& x_{\nu \mu} \operatorname{Tr}_{1}\left(\mathbf{k}_{1 \mu \nu} \mathbf{1}_{1 \sigma \rho}\right)=\lambda_{\sigma \rho} T r_{2}\left(\mathbf{k}_{2 \nu \mu} \mathbf{1}_{2 \rho \sigma}\right), \\
& x_{\nu \mu} \operatorname{Tr}_{2}\left(\mathbf{k}_{2 \mu \nu} \mathbf{1}_{2 \rho \sigma}\right)=\lambda_{\sigma \rho} \operatorname{Tr}_{1}\left(\mathbf{k}_{1 \nu \mu} \mathbf{1}_{1 \rho \sigma}\right) .
\end{aligned}
$$

It follows directly that

$$
\varkappa_{\mu \nu} \varkappa_{\nu \mu} T r_{l}\left(\mathbf{k}_{l \mu \nu} \mathbf{1}_{l \sigma \rho}\right)=\lambda_{\sigma \rho} \lambda_{\rho \sigma} T r_{l}\left(\mathbf{k}_{l \mu \nu} \mathbf{1}_{l \sigma \rho}\right)(l=1,2),
$$

so that (with $x_{\mu \nu}=x_{\nu \mu}^{*}, \lambda_{\rho \sigma}=\lambda_{\sigma \rho}^{*}$ )

$$
\left|x_{\mu \nu}\right|^{2}=\left|\lambda_{\rho \sigma}\right|^{2} \text { or } \operatorname{Tr}_{l}\left(\mathbf{k}_{l \mu \nu} \mathbf{1}_{l \sigma \rho}\right)=0(l=1 \text { and } 2) \text {. }
$$

Because one of the systems $\mathbf{1}_{1 \rho \sigma}$ or $\mathbf{1}_{2 \rho \sigma}$ is arbitrarily variable and complete in $R_{1}$ or $R_{2}$ the latter alternative is excluded and we must have

$$
\left|x_{\mu \nu}\right|=\left|\lambda_{\rho \sigma}\right|=x^{2}=\lambda^{2}(x=\lambda>0) .
$$


With (1.13) it further follows from (2.58) that

$$
\begin{aligned}
& \sum_{\mu, \nu} x_{\nu \mu} T r_{1}\left(\mathbf{k}_{1 \mu \nu} \mathbf{1}_{1 \sigma \rho}\right) \mathbf{k}_{2 \mu \nu}=\lambda_{\sigma \rho} \mathbf{l}_{2 \rho \sigma}, \\
& \sum_{\mu, \nu} x_{\nu \mu} T r_{2}\left(\mathbf{k}_{2 \mu \nu} 1_{2 \sigma \rho}\right) \mathbf{k}_{1 \mu \nu}=\lambda_{\sigma \rho} 1_{1 \rho \sigma} .
\end{aligned}
$$

These relations connect the arbitrarily and the suitably chosen systems and establish the orthonormality and completeness of the latter. With (1.08) we derive from (2.65)

$\mathbf{1}_{2 \rho \sigma} \mathbf{l}_{2 \sigma^{\prime} \rho^{\prime}}=\frac{1}{\lambda_{\sigma \rho} \lambda_{\rho^{\prime} \sigma^{\prime}}} \sum_{\mu, \nu, \mu^{\prime}} x_{\nu \mu} x_{\mu^{\prime} v} \operatorname{Tr}_{1}\left(\mathbf{k}_{1 \mu \nu} \mathbf{1}_{1 \sigma \rho}\right) \operatorname{Tr}\left(\mathbf{k}_{1 \nu \mu^{\prime}} \mathbf{1}_{1 \rho^{\prime} \sigma^{\prime}}\right) \mathbf{k}_{2 \mu \mu^{\prime}}$

and

$$
\mathbf{l}_{2 \rho \rho^{\prime}} \delta_{\sigma \sigma^{\prime}}=\frac{1}{\lambda_{\rho \rho^{\prime}}} \sum_{\mu, \nu, \mu^{\prime}} x_{\mu^{\prime} \mu} \operatorname{Tr}_{1}\left(\mathbf{k}_{1 \mu \nu} \mathbf{l}_{1 \sigma \rho}\right) \operatorname{Tr}_{1}\left(\mathbf{k}_{1 \nu \mu^{\prime}} \mathbf{l}_{1 \rho^{\prime} \sigma^{\prime}}\right) \mathbf{k}_{2 \mu \mu^{\prime}}
$$

and similarly for interchanged indices 1 and 2. (2.66) and (2.67) must be identical according to (1.08). Because one of the systems $1_{1 \rho \sigma}$ or $1_{2 \rho \sigma}$ is arbitrarily variable and complete in $R_{1}$ or $R_{2}$, we must have (remembering (2.64))

$$
x_{\mu^{\prime} \nu} x_{\nu \mu}=x^{2} x_{\mu^{\prime} \mu} ; \lambda_{\rho^{\prime} \sigma} \lambda_{\sigma \rho}=\lambda^{2} \lambda_{\rho^{\prime} \rho}(x=\lambda>0) .
$$

Then $x_{\nu \mu}$ and $\lambda_{\rho \sigma}$ must have the form

$$
x_{\nu \mu}=x_{\nu}^{*} x_{\mu},\left|x_{\mu}\right|=x ; \lambda_{\sigma \rho}=\lambda_{\sigma}^{*} \lambda_{\rho},\left|\lambda_{\rho}\right|=\lambda
$$

This shows the necessity of (2.59).

The sufficiency can be shown in the following way. Choose, say in $R_{1}$, a complete system of orthonormal wave functions $\psi_{1 \rho}$ and choose for each $\rho$ a constant $\lambda_{\rho}$ with $\left|\lambda_{\rho}\right|=\lambda=x$. Then take the functions

$$
\psi_{2 \rho}=\frac{1}{\lambda_{\rho}} \Sigma_{\mu} x_{\mu}\left(\psi_{1 \rho}^{\dagger} \varphi_{1 \mu}\right) \varphi_{2 \mu}
$$

which are orthonormal and complete in $R_{2}$. From (2.70) it follows that

$$
\psi_{1 \rho}=\lambda_{\rho} \sum_{\mu} \frac{1}{x_{\mu}}\left(\psi_{2 \rho}^{\dagger} \varphi_{2 \mu}\right) \varphi_{1 \mu} .
$$

The indices 1 and 2 could equally well have been interchanged. For the transition operators we get

$$
\begin{aligned}
& \mathbf{l}_{2 \rho \sigma}=\frac{1}{\lambda_{\sigma \rho}} \sum_{\mu, \nu} \varkappa_{\nu \mu} \operatorname{Tr}_{1}\left(k_{1 \mu \nu} \mathrm{I}_{1 \sigma \rho}\right) \mathbf{k}_{2 \mu \nu}, \\
& \mathbf{l}_{\mathrm{l} \rho \sigma}=\lambda_{\sigma \rho} \sum_{\mu, \nu} \frac{1}{x_{\nu \mu}} \operatorname{Tr}_{2}\left(\mathbf{k}_{2 \mu \nu} \mathbf{l}_{2 \sigma \rho}\right) k_{1 \mu \nu}
\end{aligned}
$$


and

Therefore

$$
x_{\nu \mu} T r_{1}\left(\mathbf{k}_{1 \mu \nu} \mathbf{1}_{1 \sigma \rho}\right)=\lambda_{\sigma \rho} T r_{2}\left(\mathbf{k}_{2 \nu \mu} \mathbf{l}_{2 \rho \sigma}\right)
$$

$$
\begin{aligned}
& \sum_{\mu, \nu} \chi_{\nu \mu} \mathbf{k}_{1 \mu \nu} \mathbf{k}_{2 \mu \nu}=\underset{\mu, \nu ; \rho, \sigma}{\sum} x_{\nu \mu} T r_{1}\left(\mathbf{k}_{1 \mu \nu} \mathbf{l}_{1 \sigma \rho}\right) \mathbf{l}_{1 \rho \sigma} \mathbf{k}_{2 \mu \nu} \\
& =\underset{\mu, \nu ; \rho, \sigma}{=} \lambda_{\sigma \rho} \operatorname{Tr}_{2}\left(\mathbf{k}_{2 \nu \mu} \mathbf{l}_{2 \sigma \rho}\right) \mathbf{l}_{1 \rho \sigma} \mathbf{k}_{2 \mu \nu}=\sum_{\rho, \sigma} \lambda_{\sigma \rho} \mathbf{l}_{1 \rho \sigma} \mathbf{l}_{2 \rho \sigma} .
\end{aligned}
$$

This shows the sufficiency of (2.59).

It is of importance for the discussion of the measuring process, that (contrary to the expectation of $\mathrm{R} \mathrm{u} \mathrm{a} \mathrm{rk}^{5}$ )) multilateral correlation between more than two systems is impossible. We first show this impossibility for the case of 3 systems.

Suppose we would have the expansions

$$
\mathbf{k}_{123}=\sum_{\mu, \nu} x_{\nu \mu} \mathbf{k}_{1 \mu \nu} \mathbf{k}_{2 \mu \nu} \mathbf{k}_{3 \mu \nu}=\sum_{\rho, \sigma} \lambda_{\sigma \rho} \mathbf{1}_{1 \rho \sigma} \mathbf{l}_{2 \rho \sigma} \mathbf{l}_{3 \rho \sigma} .
$$

With (1.13) it follows from (2.75) that

$$
\begin{aligned}
& x_{\nu \mu} T r_{1}\left(\mathbf{k}_{1 \mu \nu} \mathbf{l}_{1 \sigma \rho}\right) T r_{2}\left(\mathbf{k}_{2 \mu \nu} \mathbf{l}_{2 \sigma \rho}\right)=\lambda_{\sigma \rho} T r_{3}\left(\mathbf{k}_{3 \nu \mu} \mathbf{l}_{3 \rho \sigma}\right)(c y c l .), \\
& x_{\nu \mu} T r_{3}\left(\mathbf{k}_{3 \mu \nu} \mathbf{l}_{3 \sigma \rho}\right)=\lambda_{\sigma \rho} T r_{1}\left(\mathbf{k}_{1 \nu \mu} \mathbf{l}_{1 \rho \sigma}\right) T r_{2}\left(\mathbf{k}_{2 \nu \mu} \mathbf{l}_{2 \rho \sigma}\right)(c y c l .) .
\end{aligned}
$$

In the same way as before it follows that

$$
\left|x_{\mu \nu}\right|^{2}=\left|\lambda_{\rho \sigma}\right|^{2} \text { or } \operatorname{Tr}_{l}\left(\mathbf{k}_{l \mu \nu} \mathbf{1}_{l \sigma \rho}\right)=0 \quad(l=1,2 \text { and } 3) .
$$

Because one of the systems $\boldsymbol{l}_{l p \sigma}$ must be arbitrarily variable and complete in $R_{l}$, we must have

$$
\left|x_{\mu \nu}\right|=\left|\lambda_{\rho \sigma}\right|=x^{2}=\lambda^{2} \quad(x=\lambda>0) \text {. }
$$

It further follows from (2.76) that

$$
\begin{gathered}
\operatorname{Tr}_{3}\left(\mathbf{k}_{3 \mu \nu} \mathbf{l}_{3 \sigma \rho}\right) \operatorname{Tr}_{3}\left(\mathbf{k}_{3 \nu \mu} \mathbf{l}_{3 \rho \sigma}\right)=1 \\
\operatorname{Tr}_{1}\left(\mathbf{k}_{1 \mu \nu} \mathbf{l}_{\text {lop }}\right) \operatorname{Tr}_{2}\left(\mathbf{k}_{2 \nu \mu} \mathbf{l}_{2 \rho \sigma}\right)=0(c y c l .) .
\end{gathered}
$$

Then we must have

$$
T r_{1}\left(\mathbf{k}_{1 \mu \nu} \mathbf{1}_{1 \sigma \rho}\right)=T r_{2}\left(\mathbf{k}_{2 \mu \nu} \mathbf{l}_{2 \sigma \rho}\right)=T r_{3}\left(\mathbf{k}_{3 \mu \nu} \mathbf{1}_{3 \sigma \rho}\right)=1 \text { or } 0 .
$$

This would mean that the systems of $1_{1 \rho \sigma}, 1_{2 \rho \sigma}$ and $1_{3 \rho \sigma}$ should (but for a simultaneous change of enumeration of the Greek indices of the three corresponding operators and but for unimodular constants) be identical with those of $\mathbf{k}_{1 \mu \nu}, \mathbf{k}_{2 \mu \nu}$ and $\mathbf{k}_{3 \mu \nu}$. This is against the assumption. Multilateral correlation between the states of 1,2 and 3 is therefore impossible. 
For more systems $1,2,3, \ldots$ the impossibility of multilateral correlation can easier be shown in the following way. Suppose we would have the expansions

$$
\mathbf{k}_{123 \ldots .}=\sum_{\mu, \nu} x_{\nu \mu} \mathbf{k}_{1 \mu \nu} \mathbf{k}_{2 \mu \nu} \mathbf{k}_{3 \mu \nu} \ldots=\sum_{\rho, \sigma} \lambda_{\sigma \rho} \mathbf{l}_{i \rho \sigma} \mathbf{l}_{2 \rho \sigma} \mathbf{l}_{3 \rho \sigma} \ldots \ldots
$$

Then

$$
\operatorname{Tr}_{34 \ldots .} \mathbf{k}_{123 \ldots .}=\sum_{\mu} \chi_{\mu \mu} \mathbf{k}_{1 \mu \mu} \mathbf{k}_{2 \mu \mu}=\sum_{\rho} \lambda_{\rho \rho} \mathbf{1}_{1 \rho \rho} \mathbf{l}_{2 \rho \rho} .
$$

Similar to (2.61) and (2.62) we get

and

$$
\begin{aligned}
& x_{\mu \mu} \operatorname{Tr}\left(\mathbf{k}_{1 \mu \mu} \mathbf{1}_{1 \rho \rho}\right)=\lambda_{\rho \rho} T r_{2}\left(\mathbf{k}_{2 \mu \mu} \mathbf{l}_{2 \rho \rho}\right), \\
& x_{\mu \mu} \operatorname{Tr}_{2}\left(\mathbf{k}_{2 \mu \mu} \mathbf{1}_{2 \rho \rho}\right)=\lambda_{\rho \rho} T r_{1}\left(\mathbf{k}_{1 \mu \mu} \mathbf{1}_{1 \rho \rho}\right)
\end{aligned}
$$

so that

$$
\chi_{\mu \mu}^{2} T r_{l}\left(\mathbf{k}_{l \mu \mu} \mathbf{1}_{l \rho \rho}\right)=\lambda_{\rho \rho}^{2} T r_{l}\left(\mathbf{k}_{l \mu \mu} \mathbf{1}_{l \rho \rho}\right)(l=1,2) \text {, }
$$

$$
x_{\mu \mu}= \pm \lambda_{\rho \rho} \text { or } \operatorname{Tr}_{l}\left(\mathbf{k}_{l \mu \mu} \mathbf{l}_{l \rho \rho}\right)=0(l=1 \text { and } 2) .
$$

Because one of the systems $l_{l \rho \rho}$ is arbitrarily variable the latter alternative is excluded and because the traces in (2.83) are non-negative we must have

$$
x_{\mu \mu}=\lambda_{\rho \rho}
$$

Further we have similar to $(2.65)$

$$
\begin{aligned}
& \sum_{\mu} \operatorname{Tr}_{1}\left(\mathbf{k}_{1 \mu \mu} \mathbf{l}_{1 \rho \rho}\right) \mathbf{k}_{2 \mu \mu}=\mathbf{1}_{2 \rho \rho}, \\
& \sum_{\mu} \operatorname{Tr}{ }_{2}\left(\mathbf{k}_{2 \mu \mu} \mathbf{l}_{2 \rho \rho}\right) \mathbf{k}_{1 \mu \mu}=\mathbf{l}_{1 \rho \rho},
\end{aligned}
$$

from which we derive

and

$$
\mathbf{1}_{\mathrm{i} \rho \rho} \mathbf{1}_{1 \sigma \sigma}=\sum_{\mu} T r_{1}\left(\mathbf{k}_{1 \mu \mu} \mathbf{1}_{\mathrm{l}_{\rho \rho}}\right) \operatorname{Tr} \mathbf{r}_{1}\left(\mathbf{k}_{1 \mu \mu} \mathbf{l}_{1 \sigma \sigma}\right) \mathbf{k}_{2 \mu \mu}
$$

$$
\mathbf{l}_{1 \rho \rho} \delta_{\rho \sigma}=\sum_{\mu} T r_{1}\left(\mathbf{k}_{1 \mu \mu} \mathbf{l}_{1 \rho \rho}\right) \delta_{\rho \sigma} \mathbf{k}_{2 \mu \mu}
$$

and similarly for interchanged indices 1 and 2. Because (2.88) and (2.89) have to be identical according to (1.08) we must have

$$
T r_{1}\left(\mathbf{k}_{1 \mu \mu} \mathbf{l}_{1 \rho \rho}\right) T r_{1}\left(\mathbf{k}_{1 \mu \mu} \mathbf{1}_{1 \sigma \sigma}\right)=T r_{1}\left(\mathbf{k}_{1 \mu \mu} \mathbf{1}_{1 \rho \rho}\right) \delta_{\rho \sigma} .
$$

This would require

$$
T r_{1}\left(\mathbf{k}_{1 \mu \mu} \mathbf{l}_{1 \rho \rho}\right)=\delta_{\rho \sigma}
$$

for every $\mu, \rho$ and $\sigma$, which is impossible. Multilateral correlation cannot extend over more than two systems. 
The proofs given for the special case of multilaterial correlation in the entire spaces $R_{1}, R_{2}, \ldots$ can easily be generalized to the general case of multilateral correlation in the subspaces $R_{11}, R_{21}, \ldots$; $R_{12}, R_{22}, \ldots, \ldots$ only.

Now we see that also in the measuring process multilateral correlation (in the special or in the generalized sense) cannot be transmitted through the chain of systems of the measuring instrument. The correlation $(2.28)$ is uniquely determined. This excludes the possibility of surpassing in the measurement conclusion the maximum inference discussed in 2.04 by the application of multilateral correlation.

2.11 Einstein's paradox. We return to the two object systems 1 and 2 in the multilateral correlated state (2.58).

If the state of one of the systems, say 2 , is entirely ignored, the infringed state of 1 becomes

$$
\varkappa^{2} \sum_{\mu} \mathbf{k}_{1 \mu \mu}=\lambda^{2} \sum_{\rho} \mathbf{l}_{\mathrm{l} \rho \rho} .
$$

The sums (which are identical) denote the projection operator of the (generalized) $\mathrm{Hi}$ ib e r t subspace $R_{1}$. In the mixture (2.92) all states in $R_{1}$ have the same probability $x^{2}=\lambda^{2}$. If $R_{1}$ coincides with the entire (generalized) $\mathrm{Hil}$ b e r t space of wave functions of 1 , the infringed state (2.92) becomes entirely undetermined.

If in dealing with the entangled state $(2.58)$ one would make the mistake pointed out by Fur r y (cf. 2.09), one would get

$$
\chi^{2} \sum_{\mu} \mathbf{k}_{1 \mu \mu} k_{2 \mu \mu}=\lambda^{2} \sum_{\rho} 1_{i_{\rho \rho}} 1_{2 \rho \rho} \text {. }
$$

In dealing with (2.82) we have seen that (2.93) cannot hold. (2.85) does not express a correlation between pure quantum states of 1 and pure quantum states of 2 (in the way a member of (2.93) would do).

If, however, (after the interaction between 1 and 2, which establishes the state (2.58)) one of the systems, say 2 , interacts with a measuring instrument, which measures the states $1_{2 \rho \rho}$, the infringed state of 1 and 2 together after the latter interaction is

$$
\lambda_{.}^{2} \sum_{\rho} 1_{1 \rho \rho} 1_{2 \rho \rho}
$$

This mixture is different for different types of measurements, i.e. for different systems $1_{2 \rho \rho}$. (2.94) does express a correlation between peur states of 1 and pure states of 2 . This correlation is of unilateral 
type. When the measuring result selects for 2 the state $1_{2 \rho p}$, the state of 1 is $1_{1 \rho \rho}$.

After the interaction between 1 and 2 has taken place, an observable $\mathbf{b}_{1}$ of 1 with eigenstates $1_{1 \rho \rho}$ can be measured in two different ways: either by a direct measurement on 1 , or by measuring an observable $b_{2}$ of 2 with eigenstates $1_{2 \rho \rho}$ (corresponding to $1_{1 \rho \rho}$ ) by a direct measurement on 2 (then 2 can be conceived as a part of the measuring chain). At a first glance it might seem surprising and perhaps even paradoxical that it is still possible to decide which observable of 1 will be measured by a measurement on 2 after all interaction with 1 has been abolished ${ }^{6}$ ) and that it is possible to measure independently two incommensurable observables $a_{1}$ and $\mathbf{b}_{1}\left(\left[\mathbf{a}_{1}, \mathbf{b}_{1}\right] \neq 0\right)$ by applying the two measuring methods side by side $\left.{ }^{7}\right)^{4}$ ). (Of course one should care for not making the mistake of (2.93), which would naturally lead to paradoxical results).

When the eigenstates of $\mathbf{a}_{1}$ are $\mathbf{k}_{1 \mu \mu}$ and those of $\mathbf{b}_{1}$ are $\mathbf{l}_{1 \rho \rho}$, a measurement of $\mathbf{a}_{1}$ selects a state out of the left member, a measurement of $\mathbf{b}_{1}$ selects a state out of the right member of the expression (2.92) for the infringed state of 1 . The probability that one measurement selects the state $\mathbf{k}_{1 \mu \mu}$, if the other selects the state $\mathbf{1}_{1 \rho \rho}$ (or opposite) is according to (2.51)

$$
\operatorname{Tr}\left(\mathbf{k}_{1 \mu \mu} \mathbf{l}_{1 \rho \rho}\right),
$$

no matter whether $\mathbf{a}_{1}$ and $\mathbf{b}_{1}$ are both (successively) measured directly on 1 or (no matter whether successively or simultaneously) one of them on 1 and the other one on 2 . When both are directly measured on 1 , the state in which 1 is left after the succeeding measurements is $\mathbf{k}_{1 \mu \mu}$ if the final measurement was that of $\mathbf{a}_{1}$, it is $\mathbf{1}_{1 \rho \rho}$ if the final measurement was that of $\mathbf{b}_{1}$. A paradoxical situation seems to arise if one asks in which state 1 is left after $\mathbf{a}_{1}^{j}$ has been measured on 1 and $\mathbf{b}_{1}$ on 2 (or opposite). We have to remember (cf. 2.08) that all observational statements bear on connections between measurements. The state in which 1 is left has only an observational meaning with regard to a succeeding measurement of an observable of 1 , say $c_{1}$ with eigenstates $\mathbf{m}_{1 \pi r}$. When the measurement of $\mathbf{a}_{1}$ has selected the state $\mathbf{k}_{\mathbf{1} \mu \mu}$, the probability that the measurement of $\mathbf{c}_{1}$ will select the state $\mathbf{m}_{1 \tau \tau}$ is

$$
\operatorname{Tr}\left(\mathbf{k}_{1 \mu \mu} \mathbf{m}_{1 \tau \tau}\right) .
$$


When the measurement of $b_{1}$ has selected the state $\mathbf{l}_{\mathfrak{l} \rho \rho}$, the probability that the measurement of $\mathbf{c}_{1}$ will select the state $\mathbf{m}_{1 \tau \tau}$ is

$$
\operatorname{Tr}\left(\mathbf{1}_{1 \rho \rho} \mathbf{m}_{1 \tau \tau}\right) \text {. }
$$

Thus we get two different probabilities for the same event. This is not unfamiliar in statistics, because the probabilities are (always) conditional. They have only a meaning for a great number of combined measurements of $\mathbf{a}_{1}, \mathbf{b}_{1}$ and $\mathbf{c}_{1}$. The probability of finding a state $\mathbf{k}_{1 \mu \mu}$ is $x^{2}$, the probability of finding a state $\mathbf{1}_{1 \rho \rho}$ is $\lambda^{2}$, the probability of finding a state $\mathbf{m}_{1 \tau \tau}$ is then according to $(2.95 b)$ or $(2.95 c)$

$$
\chi^{2} \sum_{\mu} \operatorname{Tr}\left(\mathbf{k}_{1 \mu \mu} \mathbf{m}_{1 \tau \tau}\right) \text { or } \lambda^{2} \sum_{\rho} \operatorname{Tr}\left(\mathbf{1}_{1_{\rho \rho}} \mathbf{m}_{1 \tau \tau}\right) .
$$

Only these sums have to be identical and they are so according to (2.92). The correlations between the measuring results for $\mathbf{a}_{1}, \mathbf{b}_{1}$ and $c_{1}$ are described by (2.95).

Let us consider once more the measurement of $\mathbf{a}_{1}$ and of $\mathbf{b}_{1}$, one of them directly on 1 and the other directly on 2 . The latter measurement can also be conceived as a direct measurement on 1 (the system 2 is then regarded as a part of the measuring chain), which preceedes the first mentioned measurement. The only pecularity of the present case is that after the coupling between the object system 1 and the first system 2 of the measuring chain of the earliest measurement has been abolished (and even after the succeeding measurement has been performed) one can thanks to the multilateral correlation between 1 and 2 still decide which observable will be measured by this earliest measurement. But when we pay due regard to the correlations between the various measuring results, this leads to no paradox.

An illustrative example, which has been discussed by $E$ inst e in a.o. $\left.{ }^{7}\right)^{4}$ ) and by $\mathrm{B}$ oh $\mathrm{r}$ a.o. $\left.\left.{ }^{8}\right)^{3}\right)^{5}$ ), is that of two particles (each with one linear degree of freedom) in an entangled state for which the wave function reads in $q$-representation

$$
\varphi_{12}=\frac{1}{\sqrt{ } h} \delta\left(q_{1}-q_{2}+Q\right) e^{\frac{i}{h} \frac{q_{1}+q_{2}}{2} p} .
$$

This state can be realized by two particles 1 and 2 directly after passing through two parallel slits at a distance $Q$ in a diaphragm. (2.97) describes the motion in the direction perpendicular to the slits, parallel to the diaphragm. The total momentum $P$ can be determined from the total momentum directly before the passage 
through the diaphragm and the change of momentum of the diaphragm. The slits can be taken so far apart, that exchange effects can be neglected.

(2.97) is of the form (2.60) with (2.59), as can be seen by expanding (2.97) with respect to e.g. coordinate or momentum eigenfunctions of 1 and 2

$$
\begin{aligned}
\varphi_{12} & =\frac{1}{\sqrt{h}} \int d \xi e^{\frac{i}{h} \xi P} \delta\left(q_{1}-\xi+\frac{Q}{2}\right) \delta\left(q_{2}-\xi-\frac{Q}{2}\right) \\
& =\frac{1}{h \sqrt{ } h} \int d \eta e^{\frac{i}{h} \eta Q} e^{\frac{i}{h} q_{1}\left(\eta+\frac{P}{2}\right)} e^{\left.\frac{i}{h} q_{1}-\eta+\frac{P}{2}\right)} .
\end{aligned}
$$

$R_{\mathrm{j}}$ coincides with the entire (generalized) $\mathrm{Hil}$ b e $\mathrm{rt}$ space of wave functions of 1 . The infringed state of 1 is entirely undertermined. After a measuring result $q_{2}=q_{2 \mu}$ or $p_{2}=p_{2 \rho} 1$ is "left" in the state

$$
\delta\left(q_{1}-q_{2 \mu}+Q\right) \text { or } \frac{1}{\sqrt{h}} e^{\frac{i}{\hbar} q_{1}\left(P-p_{2} \rho\right)}
$$

and $q_{1}=q_{2 \mu}-Q$ or $p_{1}=p-p_{2 \rho}$ respectively. In this way the coordinate or momentum of 1 is measured by the coordinate or momentum of 2 after the interaction between 1 and 2 . We come back to this example in 5.06 .

\section{Operator relations.}

3.01 Exponentials. In the ring of operators a generated by two non-commuting. Hermitian basic operators $\mathbf{p}$ and $\mathbf{q}$, for which

$$
[\mathbf{p}, \mathbf{q}]=1 \text {, i.e. } \mathbf{p q}-\mathbf{q} \mathbf{p}=\frac{\hbar}{i}(\hbar>0),
$$

we are going to derive a Fourie $\mathrm{r}$ expansion similar to that in a commutative ring of functions $a(p, q)$ of two real basic variables $p$ and $q$. For this purpose we need some exponential relations. It should be remembered that we still have a rather specialized case, because the commutator (3.01) of $\mathbf{p}$ and $\mathbf{q}$ commutes with $\mathbf{p}$ and $\mathbf{q}$.

With (3.01) one has ${ }^{2}$ )

$$
\begin{aligned}
e^{\bar{\hbar}^{(\mathbf{p}+\mathbf{q})}}=\lim _{n \rightarrow \infty}\left(1+\frac{1}{n} \frac{i}{\hbar}(\mathbf{p}+\mathbf{q})\right)^{n}=\lim _{n \rightarrow \infty}\left(\left(1+\frac{1}{n} \frac{i}{\hbar} \mathbf{p}\right)\left(1+\frac{1}{n} \frac{i}{\hbar} \mathbf{q}\right)\right)^{n} \\
=\lim _{n \rightarrow \infty}\left(1+\frac{1}{n} \frac{i}{\hbar} \mathbf{p}\right)^{n}\left(1+\frac{1}{n} \frac{i}{\hbar} \mathbf{q}\right)^{n}\left(1-\frac{1}{n^{2}} \frac{i}{\hbar}\right)^{\frac{(n-1) n}{2}}= \\
=e^{\frac{i}{\hbar} \mathbf{p}} e^{\frac{i}{\hbar} \mathbf{q}} e^{-\frac{i}{2 \hbar}} . \quad(3.02)
\end{aligned}
$$


With $(x \mathbf{p}+y \mathbf{q})$ and $\left(x^{\prime} \mathbf{p}+y^{\prime} \mathbf{q}\right)$ instead of $\mathbf{p}$ and $\mathbf{q}$ we get for (3.01) and for (3.02)

$$
\left[(x \mathbf{p}+y \mathbf{q}),\left(x^{\prime} \mathbf{p}+y^{\prime} \mathbf{q}\right)\right]=x y^{\prime}-y x^{\prime}
$$

$$
e^{\frac{i}{\hbar}\left(\left(x+x^{\prime}\right) \mathbf{p}+\left(y+y^{\prime}\right) \mathbf{q}\right)}=e^{\frac{i}{\hbar}(x \mathbf{p}+y \mathbf{q})} e^{\frac{i}{\hbar}\left(x^{\prime} \mathbf{p}+y^{\prime} \mathbf{q}\right)} e^{-\frac{i}{2 \hbar}\left(x y^{\prime}-y x^{\prime}\right)} .
$$

(Important special cases are $y=x^{\prime}=0$ or $x=y^{\prime}=0$ ). Further

$$
e^{-\frac{i}{h}(\xi \mathbf{p}+\eta \mathbf{q})} e^{\frac{i}{h}(x \mathbf{p}+y \mathbf{q})} e^{\frac{i}{h}(\xi \mathbf{p}+\eta \mathbf{q})}=e^{\frac{i}{h}(x \mathbf{p}+y \mathbf{q})} e^{\frac{i}{h}(x \eta-y \xi)} .
$$

Analogous to the (symbolical) relation

$$
\frac{1}{h^{2}} \iint d q d q e^{\frac{i}{h}(x p+y q)}=\delta(x) \delta(y)
$$

(3.05) gives the operator relation

$$
\frac{1}{h^{2}} \iint d \xi d \eta e^{-\frac{i}{h}(\xi \mathbf{p}+\eta \mathbf{q})} e^{\frac{i}{\hbar}(\mathbf{x p}+y \mathbf{q})} e^{\frac{i}{h}(\xi \mathbf{p}+\eta \mathbf{q})}=\delta(x) \delta(y) .
$$

Further analogous to

$$
\frac{1}{h^{2}} \iiint \int d x d y d p^{\prime} d q^{\prime} a\left(p^{\prime}, q^{\prime}\right) e^{-\frac{i}{h}\left(x p^{\prime}+y q^{\prime}\right)} e^{\frac{i}{h}(x p+y q)}=a(p, q)
$$

we have

$$
\begin{gathered}
\frac{1}{h^{2}} \iiint \int d x d y d \xi d \eta e^{-\frac{i}{\hbar}(\xi \mathbf{p}+\eta \mathbf{q})} \mathbf{a} e^{-\frac{i}{\hbar}(x \mathbf{p}+y \mathbf{q})} e^{-(\xi \mathbf{p}+\eta \mathbf{q})} e^{\bar{h}(x \mathbf{p}+y \mathbf{q})} \\
=\frac{1}{h^{2}} \iiint \int d x d y d \xi d \eta e^{-\frac{i}{\hbar}(\xi \mathbf{p}+\eta \mathbf{q})} \mathbf{a} e^{\bar{\hbar}(\xi \mathbf{p}+\eta \mathbf{q})} e^{-\frac{(\xi y-\eta x)}{\hbar}} \\
=\iint d \xi d \eta e^{-\frac{i}{\hbar}(\xi \mathbf{p}+\eta \mathbf{q})} \mathbf{a} e^{\frac{i}{h}(\xi \mathbf{p}+\eta \mathbf{q})} \delta(\xi) \delta(\eta)=\mathbf{a} .
\end{gathered}
$$

In the same way as (3.08) and (3.06) show that every (normalizable) function $a(p, q)$ can be expanded into a Fourier integral

$$
a(p, q)=\iint d x d y \alpha(x, y) e^{\frac{i}{h}(x p+y q)}
$$

with

$$
\alpha(x, y)=\frac{1}{h^{2}} \iint d p d q a(p, q) e^{-\frac{i}{\hbar}(x p+y q)},
$$

(3.09) and (3.07) show that every operator a (with adjoint $\mathbf{a}^{\dagger}$ ) can be expanded into

$$
\mathbf{a}=\iint d x d y \alpha(x, y) e^{\bar{\pi}^{-(x \mathbf{p}+y \mathbf{q})}}
$$


with $\alpha(x, y)=\frac{1}{h^{2}} \iint d \xi d \eta e^{-\frac{i}{\lambda}(\xi \mathbf{p}+\eta \mathbf{q})} \mathbf{a} e^{-\frac{i}{\lambda}(\mathbf{x p}+y \mathbf{q})} e^{\frac{i}{\lambda}(\xi \mathbf{p}+\eta \mathbf{q})}$.

This is already the F o u ri e r expansion, but the coefficients $\alpha(x, y)$ can still be expressed in a more simple form.

3.02 The trace. When $\mathbf{U}$ is a unitary operator

$$
\mathbf{U}^{\dagger} \mathbf{U}=\mathbf{1}
$$

the unitary transformation

$$
\mathbf{a}^{\prime}=\mathbf{U}^{\dagger} \mathbf{a} \mathbf{U} ; \varphi^{\prime}=\mathbf{U} \varphi, \varphi^{\prime \dagger}=\varphi^{\dagger} \mathbf{U}^{\dagger}
$$

leaves all operator relations invariant. Therefore the latter can be derived in a suitably chosen representation.

The eigenvalues $q$ of $\mathbf{q}$ and $p$ of $\mathbf{p}$ are assumed to run continuously between $-\infty$ and $+\infty$. In $q$-representation the operators $\mathbf{q}$ and $\mathbf{p}$ can be taken in the form

$$
\mathbf{q}=\mathbf{q}^{\dagger}=q, \mathbf{p}=\mathbf{p}^{\dagger}=\frac{\hbar}{i} \frac{\partial}{\partial q} \text { or }-\frac{\hbar}{i} \frac{\delta}{\delta q}
$$

$(\delta / \delta q$ is meant to operate to the left). With (3.04) we can write

$$
e^{\frac{i}{h}(x \mathbf{p}+y \mathbf{q})}=e^{\frac{i}{2 \hbar} x \mathbf{p}} e^{\frac{i}{\hbar} y \mathbf{q}} e^{\frac{i}{2 \hbar} x \mathbf{p}}=e^{\frac{x}{2} \frac{\partial}{\partial q}} e^{\frac{i}{h} y q} e^{\frac{x}{2} \frac{\partial}{\partial q}} .
$$

Expressing occasionally the inner product explicitely by an integral, we get with (1.09), (3.15) and (1.05)

$$
\begin{aligned}
& \frac{1}{h} \operatorname{Tr} e^{\frac{i}{h}(\mathbf{x}+y \mathbf{q})}=\frac{1}{h} \sum_{\mu} \int d q \varphi_{\mu}^{\dagger}(q) e^{-\frac{x}{2} \frac{\delta}{\delta q}} e^{\frac{i}{h} y q} e^{\frac{x}{2} \frac{\partial}{\partial q}} \varphi_{\mu}(q) \\
& \quad=\frac{1}{h} \sum_{\mu} \int d q \varphi_{\mu}^{\dagger}\left(q-\frac{x}{2}\right) e^{\frac{i}{h} y q} \varphi_{\mu}\left(q+\frac{x}{2}\right)=\delta(x) \delta(y) .
\end{aligned}
$$

The result is independent of the chosen representation. Comparing (3.16) with (3.07) and remembering the linear expansion (3.11) of a, we see that Tra can invariantly be represented by the operator relation

$$
\frac{1}{h} \operatorname{Tr} \mathbf{a}=\frac{1}{h^{2}} \iint d \xi d \eta e^{-\frac{i}{h}(\xi \mathbf{p}+\eta \mathbf{q})} \mathbf{a} e^{\frac{i}{\hbar}(\xi \mathbf{p}+\eta \mathbf{q})} .
$$

3.03 Fourier expansion. Rewriting (3.07), (3.09) and (3.11) with the help of (3.17) we get

$$
\frac{1}{h} \operatorname{Tr} e^{\overline{\bar{h}}(\mathbf{x}+y \mathbf{q})}=\delta(x) \delta(y),
$$




$$
\frac{1}{h} \iint d x d y \operatorname{Tr}\left(\mathbf{a} e^{-\frac{i}{\lambda}(x \mathbf{p}+y \mathbf{q})}\right) e^{\frac{i}{h}(x \mathbf{p}+y \mathbf{q})}=\mathbf{a}
$$

and

$$
\mathbf{a}=\iint d x d y \alpha(x, y) e^{\frac{i}{\lambda}(x \mathbf{p}+y \mathbf{q})}
$$

with

$$
\alpha(x, y)=\frac{1}{h} \operatorname{Tr}\left(\mathbf{a} e^{-\frac{i}{h}(x \mathbf{p}+y \mathbf{q})}\right) .
$$

(3.18), (3.19) and (3.20) are entirely analogous to (1.13), (1.14) and (1.15) (3.18) and (3.19) respectively express the orthonormality and the completeness of the systems of operators

$$
\frac{1}{\sqrt{ } h} e^{\frac{i}{h}(x \mathbf{p}+y \mathbf{q})} \quad \text { (with variable } x \text { and } y \text { ). }
$$

(1.15) and (3.20) are the two ways we use for the expansions of operators.

\section{Correspondence.}

4.01 von Neumann's rules. We now examine the rules of correspondence I, II, III, IV and V'. First I and II.

We show that if between the elements $a$ of one ring and the elements $a$ of another ring there is a one-to-one correspondence $a \longleftrightarrow$ a, which satisfies von $\mathrm{Ne} \mathrm{umann's} \mathrm{rules} \mathrm{(cf.} \mathrm{1.10)}$ if $a \longleftrightarrow \mathbf{a}$, then $f(a) \longleftrightarrow f(\mathbf{a})$,

if $a \longleftrightarrow \mathbf{a}$ and $b \longleftrightarrow \mathbf{b}$, then $a+b \longleftrightarrow \mathbf{a}+\mathbf{b}$,

the two rings are isomorphous.

We get using I and II

$$
(a+b)^{2}-a^{2}-b^{2}=a b+b a \longleftrightarrow \mathbf{a b}+\mathbf{b a}
$$

and also using (4.01)

$$
a(a b+b a)+(a b+b a) a-a^{2} b-b a^{2}=2 a b a \longleftrightarrow 2 \mathbf{a b a}
$$

and further'using (4.02)

$$
\begin{aligned}
(a b+b a)^{2}-b(2 a b a)-(2 a b a) b= & \\
=-(a b-b a)^{2} & \longrightarrow-(\mathbf{a b}-\mathbf{b a})^{2} .
\end{aligned}
$$

Therefore we have

$$
a b-b a \longleftrightarrow \pm(\mathbf{a b}-\mathbf{b a})
$$


and with (4.01)

$a b \longleftrightarrow$ ab (for all $a$ and $b$ ) or $a b \longleftrightarrow$ ba (for all $a$ and $b$ ). (4.05)

This means that the rings are isomorphous.

It follows that, if one ring is commutative and the other not, I and II are inconsistent ${ }^{9}$ ). (When the commutators are of the order of $\hbar$, the discrepancy is according to (4.03) of the order of $\hbar^{2}$ ).

4.02 Bracket expressions. Then $V^{\prime}$. For the correspondence $a \longleftrightarrow$ a between the commutative ring with generating elements $p$ and $q$ and the non-commutative ring with generating elements $\mathbf{p}$ and $\mathbf{q}$ with commutator $(3.01)(p \longleftrightarrow$ p and $q \longleftrightarrow \mathbf{q})$ we show that the rule (cf. 1.18)

if $a(p, q) \longleftrightarrow \mathbf{a}$ and $b(p, q) \longleftrightarrow \mathbf{b}$, then $(a(p, q), b(p, q)) \longleftrightarrow[\mathbf{a}, \mathbf{b}] \quad V^{\prime}$ is self contradictory.

With

$$
p^{2} \longleftrightarrow \mathbf{x}_{1}, q^{2} \longleftrightarrow \mathbf{x}_{2} ; p^{3} \longleftrightarrow \mathbf{y}_{1}, q^{3} \longleftrightarrow \mathbf{y}_{2}
$$

we find from

$$
\begin{aligned}
& \frac{1}{2}\left(p^{2}, q\right)=p \longleftrightarrow \frac{1}{2}\left[\mathbf{x}_{1}, \mathbf{q}\right]=\mathbf{p}, \\
& \frac{1}{2}\left(p^{2}, p\right)=0 \longleftrightarrow \frac{1}{2}\left[\mathbf{x}_{1}, \mathbf{p}\right]=0
\end{aligned}
$$

(and similar relations for $q^{2}$ and $\mathbf{x}_{2}$ ) that

$$
p^{2} \leftrightarrow \mathbf{p}^{2}+c_{1}, q^{2} \leftrightarrow \mathbf{q}^{2}+c_{2}
$$

and from

$$
\begin{aligned}
& \frac{1}{3}\left(p^{3}, q\right)=p^{2} \leftrightarrow \frac{1}{3}\left[\mathbf{y}_{1}, \mathbf{q}\right]=\mathbf{p}^{2}+c_{1}, \\
& \frac{1}{3}\left(p^{3}, p\right)=0 \leftrightarrow \frac{1}{3}\left[\mathbf{y}_{1}, \mathbf{p}\right]=0
\end{aligned}
$$

(and similar relations for $q^{3}$ and $\mathbf{y}_{2}$ ) that

$$
p^{3} \longleftrightarrow \mathbf{p}^{3}+3 c_{1} \mathbf{p}+d_{1}, q^{3} \longleftrightarrow \mathbf{q}^{3}+3 c_{2} \mathbf{q}+d_{2}
$$

$\left(c_{1}, c_{2} ; d_{1}, d_{2}\right.$ are undetermined constants). Further we get

$$
\begin{aligned}
& \frac{1}{6}\left(p^{3}, q^{2}\right)=p^{2} q \leftrightarrow \frac{1}{6}\left[\left(\mathbf{p}^{3}+3 c_{1} \mathbf{p}+d_{1}\right),\left(\mathbf{q}^{2}+c_{2}\right)\right]=\frac{1}{2}\left(\mathbf{p}^{2} \mathbf{q}+\mathbf{q} \mathbf{p}^{2}\right)+c_{1} \mathbf{q}, \\
& p q^{2} \leftrightarrow
\end{aligned}
$$

and

$$
\begin{aligned}
\frac{1}{9}\left(p^{3}, q^{3}\right) & =p^{2} q^{2} \leftrightarrow \frac{1}{9}\left[\left(\mathbf{p}^{3}+3 c_{1} \mathbf{p}+d_{1}\right),\left(\mathbf{q}^{3}+3 c_{2} \mathbf{q}+d_{2}\right)\right] \\
& =\frac{1}{2}\left(\mathbf{p}^{2} \mathbf{q}^{2}+\mathbf{q}^{2} \mathbf{p}^{2}\right)+\frac{1}{3} h^{2}+c_{1} \mathbf{q}^{2}+c_{2} \mathbf{p}^{2}+c_{1} c_{2} .
\end{aligned}
$$


With (4.11) we get

$$
\begin{aligned}
\frac{1}{3}\left(p^{2} q, p q^{2}\right) & =p^{2} q^{2} \leftrightarrow \frac{1}{3}\left[\left(\frac{1}{2}\left(\mathbf{p}^{2} \mathbf{q}+\mathbf{q} \mathbf{p}^{2}\right)+c_{1} \mathbf{q}\right),\left(\frac{1}{2}\left(\mathbf{p} \mathbf{q}^{2}+\mathbf{q}^{2} \mathbf{p}\right)+c_{2} \mathbf{p}\right)\right] \\
& =\frac{1}{2}\left(\mathbf{p}^{2} \mathbf{q}^{2}+\mathbf{q}^{2} \mathbf{p}^{2}\right)+\frac{2}{3} \hbar^{2}-c_{1} \mathbf{q}^{2}-c_{2} \mathbf{p}^{2}-\frac{1}{3} c_{1} c_{2} .
\end{aligned}
$$

(4.12) and (4.13) can only be identical for $c_{1}=c_{2}=0$ and $\hbar=0$. Therefore $V^{\prime}$ is self inconsistent (the deficiency is of the order of $\hbar^{2}$ ). $4.03 \mathrm{~W}$ e yl's correspondence. And finally III and IV with parameters $p$ and $q$ (i.e. for the same rings as in 4.02). We denote the density function by $p(p, q)$. The rules (cf. 1.13)

$$
\begin{gathered}
1 \longleftrightarrow \mathbf{1}, \\
\text { if } a(p, q) \longleftrightarrow \mathbf{a} \text { and } b(p, q) \longleftrightarrow \mathbf{b}, \\
\text { then } \iint d p d q \rho(p, q) a(p, q) b(p, q)=\operatorname{Tr}(\mathbf{a b}) \text { IV }
\end{gathered}
$$

can be satisfied by (1.55)

$$
a(p, q)=\operatorname{Tr}(\mathbf{m}(p, q) \mathbf{a}), \mathbf{a}=\iint d p d q \rho(p, q) \mathbf{m}(p, q) a(p, q)
$$

with a transformation nucleus $\mathrm{m}(p, q)$, which satisfies (1.57), (1.58); (1.59), (1.60)

$$
\begin{gathered}
\operatorname{Tr} \mathbf{m}(p, q)=1 \\
\iint d p d q \rho(p, q) \mathbf{m}(p, q)=\mathbf{1} \\
\operatorname{Tr}\left(\mathbf{m}(p, q) \mathbf{m}\left(p^{\prime}, q^{\prime}\right)\right)=p^{-1}(p, q) \delta\left(p-p^{\prime}\right) \delta\left(q-q^{\prime}\right), \\
d p d q \rho(p, q) \operatorname{Tr}(\mathbf{m}(p, q) \mathbf{a}) \operatorname{Tr}(\mathbf{m}(p, q) \mathbf{b})= \\
=\operatorname{Tr}(\mathbf{a b})(\text { for every a and } \mathbf{b}),
\end{gathered}
$$$$
\iint d p d q \rho(p, q) \operatorname{Tr}(\mathbf{m}(p, q) \mathbf{a}) \operatorname{Tr}(\mathbf{m}(p, q) \mathbf{b})=
$$

When we replace in (1.56) the complete orthonormal systems $k_{\mu \nu}^{*}(p, q)$ of (1.54) and $\mathbf{k}_{\mu \nu}$ of (1.15) by the complete orthonormal systems

$$
\frac{1}{h} e^{-\frac{i}{h}(x p+y q)} \text { of }(3.10) \text { and } e^{\frac{i}{h}(x p+y q)} \text { of }(3.20) \text {, }
$$

we find a solution

$$
\mathbf{m}(p, q)=\frac{1}{h} \iint d x d y e^{\frac{i}{h}(x \mathbf{p}+y \mathbf{q})} e^{-\frac{i}{h}(x p+y q)}
$$

of $(4.15),(4.16) ;(4.17),(4.18)$ with the density function

Then we get for (4.14)

$$
p(p, q)=\frac{1}{h} \text {. }
$$

$$
\begin{gathered}
a(p, q)=\frac{1}{h} \iint d x d y e^{\frac{i}{h}(x p+y q)} \operatorname{Tr}\left(e^{-\frac{i}{h}(\mathbf{x p}+y \mathbf{q})} \mathbf{a}\right), \\
\mathbf{a}=\frac{1}{h} \iint d x d y e^{\frac{i}{h}(x \mathbf{p}+y \mathbf{q})} \frac{1}{h} \iint d p d q e^{-\frac{i}{h}(x p+y q)} a(p, q) .
\end{gathered}
$$


With the Fourier expansions (3.10) and (3.20) this correspondence reads

$$
\iint d x d y \alpha(x, y) e^{\frac{i}{h}(x p+y q)} \longleftrightarrow \iint d x d y \alpha(x, y) e^{\frac{i}{h}(x \mathbf{p}+y \mathbf{q})},
$$

which is W e y l's correspondence ${ }^{2}$ ).

II is a consequence of IV and is therefore satisfied by the correspondence (4.21). We will see what is left of I and $V^{\prime}$. If $a \longleftrightarrow \mathbf{a}$ and $b \longleftrightarrow \mathrm{b}$ according to (4.21) we find with (3.04)

$$
\begin{aligned}
& \mathbf{a b}=\frac{1}{h^{4}} \iint \ldots \iint d x d y d x^{\prime} d y^{\prime} d p d q d p^{\prime} d q^{\prime} . \\
& . e^{\frac{i}{h}\left(\left(x+x^{\prime}\right) \mathbf{p}+\left(y+y^{\prime}\right) \mathbf{q}\right)} e^{\frac{i}{2 \hbar}\left(x y^{\prime}-y x^{\prime}\right)} e^{-\frac{i}{\hbar}\left(x p+y q+x^{\prime} p^{\prime}+y^{\prime} q^{\prime}\right)} a(p, q) b(p, q) .
\end{aligned}
$$

With the variables

$$
\begin{aligned}
\xi=x+x^{\prime}, \quad \eta=y+y^{\prime}, \quad \sigma=\frac{p+p^{\prime}}{2}, \quad \tau=\frac{q+q^{\prime}}{2}, \\
\xi^{\prime}=\frac{x-x^{\prime}}{2}, \quad \eta^{\prime}=\frac{y-y^{\prime}}{2}, \quad \sigma^{\prime}=p-p^{\prime}, \quad \tau^{\prime}=q-q^{\prime},
\end{aligned}
$$

this becomes

$$
\begin{aligned}
\mathbf{a b}= & \frac{1}{h^{4}} \iint \ldots \iint d \xi d \eta d \xi^{\prime} d \eta^{\prime} d \sigma d \tau d \sigma^{\prime} d \tau^{\prime} e^{\frac{i}{\hbar}(\xi \mathbf{p}+\eta \mathbf{q})} e^{\frac{i}{2 \hbar}\left(-\xi \eta^{\prime}+\eta \xi^{\prime}\right)} \\
& e^{-\frac{i}{\hbar}\left(\xi \sigma+\eta \tau+\xi^{\prime} \sigma^{\prime}+\eta^{\prime} \tau^{\prime}\right)} a\left(\sigma+\frac{1}{2} \sigma^{\prime}, \tau-\frac{1}{2} \tau^{\prime}\right) b\left(\sigma-\frac{1}{2} \sigma^{\prime}, \tau+\frac{1}{2} \tau^{\prime}\right. \\
= & \frac{1}{h^{2}} \iiint \int d \xi d \eta d \sigma d \tau e^{\frac{i}{\hbar}(\xi \mathbf{p}+\eta \mathbf{q})} e^{-\frac{i}{\hbar}(\xi \sigma+\eta \tau)} \\
& a\left(\sigma+\frac{1}{4} \eta, \tau-\frac{1}{4} \xi\right) b\left(\sigma-\frac{1}{4} \eta, \tau+\frac{1}{4} \xi\right) \\
= & \frac{1}{h^{2}} \iiint \int d \xi d \eta d \sigma d \tau e^{\frac{i}{\hbar}(\xi \mathbf{p}+\eta \mathbf{q})} e^{-\frac{i}{\hbar}(\xi \sigma+\eta \tau)} \\
& \left(e^{\frac{1}{4}\left(\eta \frac{\partial}{\partial \sigma}-\xi \frac{\partial}{\partial \tau}\right)} a(\sigma, \tau)\right)\left(e^{-\frac{1}{4}\left(\eta \frac{\partial}{\partial \sigma}-\xi \frac{\partial}{\partial \tau}\right)} b(\sigma, \tau)\right) .
\end{aligned}
$$

The expressions in brackets at the end are a symbolical representation of $\mathrm{T}$ a $\mathrm{y} l$ or expansion. With the substitution

$$
\xi \rightarrow x, r_{1} \rightarrow y, \sigma \rightarrow p, \tau \rightarrow q
$$

we get by partial integration

$$
\begin{aligned}
\mathbf{a b}=\frac{1}{h} \iint d x d y e^{\frac{i}{h}(x \mathbf{p}+y \mathbf{q})} \frac{1}{h} \iint d p d q . \\
\cdot e^{-\frac{i}{\hbar}(x p+y q)}\left(a(p, q) e^{\frac{\hbar}{2 i}\left(\frac{\delta}{\delta p} \frac{\partial}{\partial q}-\frac{\delta}{\delta q} \frac{\partial}{\partial p}\right)} b(p, q)\right) .
\end{aligned}
$$


This gives for the Hermitian operators $\frac{1}{2}(\mathbf{a b}+\mathbf{b a})$ and $\frac{i}{2}$.

. (ab - ba) the correspondence

$$
\begin{aligned}
& a(p, q) \cos \frac{\hbar}{2}\left(\frac{\delta}{\delta p} \frac{\partial}{\partial q}-\frac{\delta}{\delta q} \frac{\partial}{\partial p}\right) b(p, q) \longleftrightarrow \frac{1}{2}(\mathbf{a b}+\mathbf{b a}), \\
& a(p, q) \sin \frac{\hbar}{2}\left(\frac{\delta}{\delta p} \frac{\partial}{\partial q}-\frac{\delta}{\delta q} \frac{\partial}{\partial p}\right) b(p, q) \longleftrightarrow \frac{i}{2}(\mathbf{a b}-\mathbf{b a}) .
\end{aligned}
$$

To the neglect of terms of order of $\hbar^{2}$ and higher (4.28) and (4.29) would read

$$
\begin{gathered}
a(p, q) b(p, q) \longleftrightarrow \frac{1}{2}(\mathbf{a b}+\mathbf{b a}), \\
a(p, q) \frac{\hbar}{2}\left(\frac{\delta}{\delta p} \frac{\partial}{\partial q}-\frac{\delta}{\partial q} \frac{\partial}{\partial p}\right) b(p, q) \longleftrightarrow \frac{i}{2}(\mathbf{a b}-\mathbf{b a}) .
\end{gathered}
$$

(4.30) would lead to $I,(4.31)$ is equivalent to $\mathrm{V}^{\prime}$.

We examine which functions $f(a)$ satisfy I. From (4.28) we see that the correspondence

$$
\text { if } a \longleftrightarrow \mathbf{a} \text {, then } a^{n} \longleftrightarrow \mathbf{a}^{n} \text { (for every integer } n \text { ) }
$$

only holds if

$a^{k} \cos \frac{\hbar}{2}\left(\frac{\delta}{\partial p} \frac{\partial}{\partial q}-\frac{\delta}{\delta q} \frac{\partial}{\partial p}\right) a^{l}=a^{k+l}$ (for all integers $k$ and $l$ ).

First take for $a$ a homogeneous polynomial in $p$ and $q$ of degree $n$. An elementary calculation shows that the condition

or

$$
a \cos \frac{\hbar}{2}\left(\frac{\delta}{\delta p} \frac{\partial}{\partial q}-\frac{\delta}{\delta q} \frac{\partial}{\partial p}\right) a=a^{2}
$$

$$
\left.a\left(\frac{\delta}{\delta p} \frac{\partial}{\partial q}-\frac{\delta}{\delta q} \frac{\partial}{\partial p}\right)^{2 k} a=a^{2} \text { (for } 0<2 k \leqslant n\right)
$$

is only satisfied if $a$ is of the form $(x p+y q)^{n}$. Then it follows that any polynomial in $p$ and $q$ can only satisfy (4.33) if it is a polynomial in $x p+y q$. This finally means that I can only be satisfied if $a$ is a function of a certain linear combination $x p+y q$ of $p$ and $q$. With the help of the Fourie r expansion (4.22) it is easily seen that every (normalizable) function of $x p+y q$ does satisfy I. Therefore the least restricted form of.I, which is consistent with the correspondence $(4.21)$ is

$$
f(x p+y q) \leftarrow f(x \mathbf{p}+y \mathbf{q}) .
$$


As to $\mathrm{V}^{\prime}$, we see from (4.31) that for the correspondence (4.21) the bracket expression $((a(p, q), b(p, q)))$ (cf. 1.14) defined by if $a(p, q) \leftrightarrow \mathbf{a}$ and $b(p, q) \longleftrightarrow \mathbf{b}$, then $((a(p, q), b(p, q))) \longleftrightarrow[\mathbf{a}, \mathbf{b}](4.37)$ is given by

$$
((a(p, q), b(p, q)))=a(p, q) \frac{2}{\hbar} \sin \left(\frac{\hbar}{2} \frac{\delta}{\delta p} \frac{\partial}{\partial q}-\frac{\delta}{\delta q} \frac{\partial}{\partial p}\right) b(p, q) .
$$

If $a(p, q)$ or $b(p, q)$ is a polynomial in $p$ and $q$ of at most 2 nd degree, we have a special case for which the bracket expressions $((a, b))$ and $(a, b)$ coincide.

The correspondence (4.21) is a solution of III and IV. We have not investigated the possibility of other solutions with the same parameters $p$ and $q$.

\section{Quasi-distributions.}

5.01 Proper and improper representations. With We y l's correspondence (4.22) as a special solution of

$$
1 \longleftrightarrow 1
$$

if $\mathbf{k} \longleftrightarrow k(p, q)$ and $\mathbf{a} \longleftrightarrow a(p, q)$,

$$
\text { then } \operatorname{Tr}(\mathbf{k a})=\frac{1}{h} \iint d p d q k(p, q) a(p, q)
$$

(with parameters $p$ and $q$ and density function $p(p, q)=1 / h$ ), we obtain a special case of a transformation between a representation in terms of operators $\mathbf{k}$ and $\mathbf{a}$ and a representation in terms of functions $k(p, q)$ and $a(p, q)$. Quantum statistics are usually represented in terms of operators, classical statistics in terms of functions. We assert that the usual description is also the proper one. The statistical operator $\mathbf{k}$ of the quantum representation and the statistical distribution function $k(p, q)$ of the classical representation are non-negative definite, but in general the quantum $k(p, q)$ and the classical $\mathbf{k}$ are not. This makes that for orthogonal states, for which

$$
\operatorname{Tr}\left(\mathbf{k}_{1} \mathbf{k}_{2}\right)=\frac{1}{h} \iint d p d q k_{1}(p, q) k_{2}(p, q)=0,
$$

the product $\mathbf{k}_{1} \mathrm{k}_{2}$ or $k_{1}(p, q) k_{2}(p, q)$ vanishes in the proper representation, but in the improper representation it need not. The equations 
of motion of the quantum $\mathbf{k}$ are described by infinitesimal unitary transformations, those of the classical $k(p, q)$ by infinitesimal canonical transformations (contact transformations), but the equations of motion of the classical $\mathbf{k}$ and the quantum $k(p, q)$ are in general not of these types. Because the improper representation is formally equivalent to the proper one, it is (provided it is not misinterpreted) a correct description, though it is in general a rather impracticable one.

In spite of its deficiences, or rather because of them, we discuss some aspects of the improper representation of quantum mechanics in terms of $k(p, q)$ and $a(p, q)$, i.e. the quasi-statistical description of the 1st kind $Q^{1}$ (cf. 1.19). It more or less illustrates the ways along which some opponents might hope to escape Boh r's reasonings and von Neumann's proof and the places where they are dangerously near breaking their necks.

5.02 Transition functions. For the transition functions $k_{\mu \nu}(p, q)$ corresponding to the transition operators (1.03) according to (4.21) we find with the help of the $q$-representation (occasionally expressing the inner product explicitely by an integral) similar to (3.16)

$$
\begin{aligned}
& k_{\mu \nu}(p, q)=\frac{1}{h} \iint d x d y e^{\frac{i}{h}(x p+y q)} \int d q^{\prime} \varphi_{\mu}^{\dagger}\left(q^{\prime}\right) e^{\frac{x}{2} \frac{\delta}{\delta q^{\prime}}} e^{\frac{i}{h} y q} e^{-\frac{x}{2} \frac{\partial}{\partial q^{\prime}} \varphi_{\nu}\left(q^{\prime}\right)} \\
& =\int d x \varphi_{\mu}^{\dagger}(q) e^{\frac{x}{2} \frac{\delta}{\delta q}} e^{\frac{i}{h} x \phi} e^{-\frac{x}{2} \frac{\partial}{\partial q}} \varphi_{\nu}(q) \\
& =\int d x \varphi_{\mu}^{\dagger}\left(q+\frac{x}{2}\right) e^{\frac{i}{\hbar} x p} \varphi_{\nu}\left(q-\frac{x}{2}\right) .
\end{aligned}
$$

Because the wave functions $\varphi_{\mu}$ are only determined but for a factor $e^{i / \hbar} \gamma_{\mu}(\gamma$ real $)$, the $k_{\mu \nu}(p, q)$ are only determined but for a factor $e^{i / \hbar}\left(\gamma_{\mu}-\gamma_{\nu}\right)$. The distribution functions, which are thus obtained with W e y l's correspondence ${ }^{2}$ ) become identical to those given by Wig n e r ${ }^{10}$ ).

5.03 Proper value. In a distribution $\mathbf{k}$ or $k(p, q)$ a quantity a or $a(p, q)$ can be regarded to have a proper value if the condition $(2.10)$

or

$$
\operatorname{Tr}(\mathbf{k f}(a))=f(\operatorname{Tr}(\mathbf{k a}))
$$

$$
\frac{1}{h} \iint d p d q k(p, q) f(a(p, q))=f\left(\frac{1}{h} \iint d p d q k(p, q) a(p, q)\right)
$$


is satisfied for every $f$. Whereas the validity of (5.04) is for a proper (non-negative definite) $k(p, q)$ already guaranteed by the validity of the special case $f(a)=a^{2}$, it is not for a proper $\mathbf{k}$ or an improper $k(p, q)$. For a proper $\mathbf{k}$ the validity of (5.03) or (2.11) requires that $\mathbf{a}$ is of the form

$$
a(x \mathbf{p}+y \mathbf{q})
$$

and $\mathbf{k}$ an eigenstate of $\mathbf{a}$. For any $k(p, q)$ the validity of (5.04) requires that $k(p, q)$ is of the form

$$
\delta\left(a(p, q)-a_{\mu}\right)
$$

which is a proper (i.e. non-negative definite) one. Because (5.03) and (5.04) are identical, the conditions (5.05) and (5.06) are equivalent. This means that the eigenstates of the operators $a(x \mathbf{p}+y \mathbf{q})$ and of no other operators correspond with proper (and orthonormal and therefore non-overlapping) distributions of the form (5.06), in which $a_{\mu}$ is the corresponding eigenvalue. This case would be rather encouraging for a statistical description of the Ist kind $S^{1}$, if it were not just an exceptional case.

The eigenfunctions of $a(x \mathbf{p}+y \mathbf{q})$ are in $q$-representation

$$
\begin{array}{ll}
\varphi_{\rho}(q)=\frac{1}{\sqrt{x h}} e^{\frac{i}{h}\left(-\frac{1}{2 x y}(y q-\rho)^{3}+\gamma(\rho)\right)} & \text { for } x \neq 0, \\
\varphi_{\rho}(q)=\sqrt{ } y \delta(y q-\rho) e^{\frac{i}{h} \gamma(\rho)} & \text { for } x=0 .
\end{array}
$$

$(\gamma(\rho)$ real arbitrary). The corresponding eigenvalues are $a(\rho)$

$$
a(x \mathbf{p}+y \mathbf{q}) \varphi_{\rho}=a\left(\rho_{\rho}\right) \varphi_{\rho} .
$$

$\rho$, which is the eigenvalue of $x \mathbf{p}+y \mathbf{q}$ (for arbitrary fixed $x$ and $y$ ), runs between $-\infty$ and $+\infty$. The domain of eigenvalues of $a(x \mathbf{p}+y \mathbf{q})$ is therefore the same as that of the functions $a(z)$ $(-\infty \leqslant z \leqslant \infty)$. This means that the domain of the proper values of observables, which have such, are unrestricted by quantum conditions.

Inserting the eigenfunctions (5.07) in (5.02) we get

$$
k_{\mu \nu}(p, q)=\delta\left(x p+y q-\frac{\rho_{\mu}+\rho_{\nu}}{2}\right) e^{-\frac{i}{\hbar}\left(\left(\frac{p}{y}-\frac{q}{x} ; \frac{\rho_{\mu}-\rho_{\nu}}{2}+\gamma^{\prime}\left(\rho_{\mu}\right)-\gamma^{\prime}\left(\rho_{\nu}\right)\right)\right.} .
$$

(The expression in brackets in the exponent in (5.09) is a canonical 
conjugate of $x p+y q)$. The $k_{\mu \mu}(p, q)$ are actually of the form (5.06).

5.04 The harmonic oscillator. After we have treated in 5.03 a special case for which the $k(p, q)$ are of proper type themselves, we now deal with a case for which their equations of motion are of proper type. According to (1.43) and condition $V^{\prime}$ they are if $((H(p, q), k(p, q)))$ coincides with $(H(p, q), k(p, q))$ and according to (4.38) this is the case for every $k(p, q)$ if $H(p, q)$ is a polynomial in $p$ and $q$ of at most 2 nd degree. This condition is satisfied for the harmonic oscillator, for which $H(p, q)$ coincides with the classical Hamiltonian

$H(p, q)=\frac{p^{2}}{2 m}+\frac{m \omega^{2}}{2} q^{2}=\frac{\omega}{2}\left(p^{\prime 2}+q^{2}\right) ; p^{\prime}=\frac{p}{\sqrt{m \omega}}, q^{\prime}=q \sqrt{m \omega}$

$m$ is the mass, $\omega$ the classical circular frequency of the binding. We consider $p^{\prime}$ and $q^{\prime}$ as new canonical coordinates and omit the dash.

In $q$-representation the normalized stationary solutions of the wave equation

$$
-\frac{\hbar}{i} \frac{\partial}{\partial t} \varphi_{n}(q)=\frac{\omega}{2}\left(-\hbar^{2} \frac{\partial^{2}}{\partial q^{2}}+q^{2}\right) \varphi_{n}(q)
$$

are

$$
\vartheta_{n}(q)=\frac{1}{\sqrt{2^{n} n ! \sqrt{\pi \hbar}}} e^{-\frac{1}{2 \hbar} q^{2}} H_{n}\left(\frac{q}{\sqrt{\hbar}}\right) e^{-i n \omega} \quad(n=0,1,2, \ldots) .
$$

The Hermitian polynomials $H_{n}\left(\frac{q}{\sqrt{ } \hbar}\right)$ have the generating function

$$
e^{\frac{-\xi^{2}+2 \xi \underline{\eta}}{\hbar}}=\sum_{n=0}^{\infty} \frac{1}{n !}\left(\frac{\xi}{\sqrt{ } \hbar}\right)^{n} H_{n}\left(\frac{q}{\sqrt{ } \hbar}\right)
$$

(5.02) becomes with (5.12)

$$
\begin{array}{r}
k_{m n}(p, q)=\frac{1}{\sqrt{2^{m+\hbar} n ! m ! \pi \hbar}} \int d x e^{-\frac{1}{2 \hbar}\left(q+\frac{x}{2}\right)^{2}} H_{m}\left(\frac{q+\frac{x}{2}}{\sqrt{\hbar}}\right) . \\
\cdot e^{\frac{i}{\hbar} x p} e^{\frac{1}{2 \hbar}\left(q-\frac{x}{2}\right)^{2}} H_{n}\left(\frac{q-\frac{x}{2}}{\sqrt{\hbar}}\right) e^{-i(m-n) \omega t} .
\end{array}
$$


With (5.13) we get

$$
\begin{gathered}
\sum_{m, n} \sqrt{\frac{2^{m+n}}{m ! n !}}\left(\frac{\xi}{\sqrt{\hbar}}\right)^{m}\left(\frac{\eta}{\sqrt{\hbar}}\right)^{n} k_{m n}(p, q) e^{i(m-n) \omega t} \\
=\frac{1}{\sqrt{\pi \hbar}} \int d x e^{\frac{1}{2 \hbar}\left(q+\frac{x}{2}\right)^{2}-\frac{1}{\hbar}\left(\xi-q-\frac{x}{2}\right)^{2}} e^{\frac{i}{\hbar} x p} e^{\frac{1}{2 \hbar}\left(q-\frac{x}{2}\right)^{2}-\frac{1}{\hbar}\left(\eta-q+\frac{x}{2}\right)^{2}} \\
=2 e^{-\frac{1}{\hbar}[(q+i p)(q-i p)-2 \xi(q+i p)-2 \eta(q-i p)+2 \xi \eta]} \\
=2 e^{-\frac{1}{\hbar}\left(q^{2}+p^{z}\right)} \sum_{\mu, \nu, \kappa=0}^{\infty} \frac{1}{\mu ! \nu ! x !}\left[\frac{2}{\hbar} \xi(q+i p)\right]^{\mu}\left[\frac{2}{\hbar} \eta(q-i p)\right]^{\nu}\left[-\frac{2}{\hbar} \xi \eta_{i}\right]^{\kappa} \cdot
\end{gathered}
$$

This gives

$$
\begin{gathered}
k_{m n}(p, q)=2 \sqrt{m ! n !} e^{-\frac{1}{\hbar}\left(p^{2}+q^{2}\right)} \sum_{\kappa=0}^{m i n(m, n)} \frac{(-1)^{\kappa}}{(m--x) !(n-x) ! x !}(q+i p)^{m-\kappa} . \\
\cdot(q-i p)^{n-\kappa}\left(\frac{2}{\hbar}\right)^{\frac{m+n}{2}-\kappa} e^{-i(m-n) \omega t} \\
=2 \sqrt{m ! n !} e^{-\frac{1}{\hbar}\left(p^{2}+q^{2}\right)} \sqrt{\frac{2}{\hbar}\left(p^{2}+q^{2}\right)} \sum_{\kappa=0}^{\mid m-n ! \min (m, n)} \frac{(-1)^{\kappa}}{(m-x) !(n-x) ! x !} . \\
\cdot\left[\frac{2}{\hbar}\left(p^{2}+q^{2}\right)\right]^{m i n(m, n)-\kappa} e^{i(m-n) \arctan \frac{p}{q}} e^{-i(m-n) \omega t} \\
=2(-1)^{\max (m, n)} \frac{\sqrt{m ! n !}}{m a x(m, n) !^{2}} e^{-\frac{1}{2}\left[\frac{2}{\hbar}\left(p^{2}+q^{2}\right)\right]} \sqrt{\frac{2}{\hbar}\left(p^{2}+q^{2}\right)} \\
L_{\max (m, n)}^{(\operatorname{lm} m)}\left(\frac{2}{\hbar}\left(p^{2}+q^{2}\right)\right) e^{i(m-n)\left(\arctan \frac{p}{q}-\omega t\right)}
\end{gathered}
$$

The $L_{\lambda}^{(\mu)}$ are associated Legendre polynomials. $k_{m n}(p, q)$ is separated into a product of functions of the canonical conjugates $\frac{1}{2}\left(p^{2}+q^{2}\right\rangle$ and arc $\tan \langle p \mid q\rangle$. The $k_{m n}(p, q)$ actually form a complete orthonormal system. For the distribution function $k_{m n}(p, q)$ of the $m^{\text {th }}$ eigenstate of $\frac{1}{2}\left(\mathbf{p}^{2}+\mathbf{q}^{2}\right)$, the average value of $\frac{1}{2}\left(p^{2}+q^{2}\right)$ is $\left(m+\frac{1}{2}\right) \hbar$, but it is not a proper value.

With (5.10) the transformation (1.47) gives the contact transformation determined by

$$
\frac{d p}{d t}=-\omega q, \frac{d q}{d t}=\omega p
$$

with solutions

$$
p=a \cos (\omega t-\chi), q=a \sin (\omega t-\chi) .
$$


The representative point in the phase space of a superstate rotates uniformly about the origin with constant radius $\sqrt{p^{2}+q^{2}}$ and circular frequency $\omega$. The rotation of the entire distribution $k_{m n}(p, q)$ with this circular frequency $\omega$ produces according to the last factor of (5.16) a periodicity with circular frequency $(m-n) \omega$ (like a rotating wheel with $|m-n|$ spokes). Also this would have a hopeful aspect for a description of type $S^{1}$, if it were not one out of a few exceptional cases.

5.05 The scale system. We shortly return to the measuring process. We start with the most favourable case for a description of the 1st kind $S^{1}$ and consider a system $l$ in the measuring chain, for which the distributions $k_{l \mu \mu}\left(p_{l}, q_{l}\right)$ do not overlap. The corresponding $\mathbf{k}_{l \mu \mu}$ are then eigenstates of an operator of the form $x \mathbf{p}_{l}+y \mathbf{q}_{l}$ (cf. 5.03). The scale system is a special case $(x=0)$, which shows all essential features. According to (5.09) we have

$$
k_{l \mu \nu}\left(p_{l}, q_{l}\right)=\delta\left(q_{l}-\frac{q_{l \mu}+q_{l \nu}}{2}\right) e^{\frac{i}{h}\left(q_{l \mu}-q_{l \nu}\right) p_{l} .}
$$

By ignoration of one or more systems of the measuring chain the non-diagonal functions $(\mu \neq \nu)$ are dropped and only the diagonal functions remain. Instead of (5.19) we get

$$
k_{l \mu \nu}\left(p_{l}, q_{l}\right)=\delta\left(q_{l}-q_{l \mu}\right) \delta\left(q_{l \mu}-q_{l \nu}\right) .
$$

(The latter $\delta$-function is actually a remainder of the ignored distribution functions). The effect on (5.19) of ignoration of other systems is formally the same as that of integration over $p$ with density function $1 / h$. This illustrates even more plainly than before (cf. 2.07) how the correlation between $p_{l}$ and other observables is completely destroyed by the reading of $q_{l}$. So far there is no difficulty with an interpretation of the 1 st kind. We are only concerned with the value of $q_{l}$, which is a proper value and uniquely determines the distribution (5.20). The value of $p_{l}$ is indifferent. As soon as inference is made about other systems in the chain with overlapping $k_{\mu \mu}(p, q)$, correct results are only obtained after the integration over $p_{l}$ (with density function $1 / h$ ) has been performed (cf. 1.19). In a description of the 1st kind this integration could only be interpreted as an averaging over a great number of measurements. But the integration has already to be performed in a single reading and therefore an interpretation of the 1 st kind is excluded. 
5.06 Einstein's paradox. The multilateral correlated state (2.97) has according to (5.02) the distribution

$$
k_{12 P Q P Q}\left(p_{1}, q_{1} ; p_{2}, q_{2}\right)=\delta\left(q_{1}-q_{2}+Q\right) \delta\left(p_{1}+p_{2}-P_{1} .\right.
$$

This shows clearly the correlation between $q_{1}$ and $q_{2}$ and between $p_{1}$ and $p_{2}$. The similarity to a genuine distribution of the 1 st kind is very tempting.

Because (5.21) is highly singular we also consider the distribution

$$
\begin{array}{r}
k_{12 P^{\prime} Q^{\prime} P^{\prime \prime} Q^{\prime \prime}}\left(p_{1}, q_{1} ; p_{2}, q_{2}\right)=\delta\left(q_{1}-q_{2}+\frac{Q^{\prime}+Q^{\prime \prime}}{2}\right) \delta\left(p_{1}+p_{2}-\frac{P^{\prime}+P^{\prime \prime}}{2} .\right. \\
\cdot e^{-\frac{i}{\hbar}\left(q_{1}+q_{2}\right) \frac{P^{\prime}-P^{\prime \prime}}{2}} e^{\frac{i}{\hbar}\left(p_{1}-p_{2}\right) \frac{Q^{\prime}-Q^{\prime \prime}}{2}}(5.22)
\end{array}
$$

(properly instead of (5.21) we should use eigendifferentials). The infringed distribution after a measurement of $q_{2}$ or $p_{2}$ can be found from (5.22) by integration over $p_{2}$ or $q_{2}$ respectively with density function $1 / h$. This gives

$$
\frac{1}{h} \delta\left(q_{1}-q_{2}+\frac{Q^{\prime}+Q^{\prime \prime}}{2}\right) e^{-\frac{i}{\hbar}\left(q_{1}+q_{2}\right) \frac{P^{\prime}+P^{\prime \prime}}{2}} e^{\frac{i}{h}\left(p_{1}-\frac{P^{\prime}+P^{\prime \prime}}{2}\right)\left(Q^{\prime}-Q^{\prime \prime}\right)}
$$

or

$$
\frac{1}{h} \delta\left(p_{1}+p_{2}-\frac{P^{\prime}+P^{\prime \prime}}{2}\right) e^{\frac{i}{h}\left(p_{1}-p_{2}\right) \frac{Q^{\prime}-Q^{\prime \prime}}{2}} e^{-\frac{i}{h}\left(q_{1}+\frac{Q^{\prime}+Q^{\prime \prime}}{2}\right)\left(P^{\prime}-P^{\prime \prime}\right)}
$$

respectively. For the distribution (5.21) this becomes

$$
\frac{1}{h} \delta\left(q_{1}-q_{2}+Q\right) \text { or } \frac{1}{h} \delta\left(p_{1}+p_{2}-P\right) .
$$

The correlation between $p_{1}$ and $p_{2}$ or $q_{1}$ and $q_{2}$ respectively has entirely disappeared.

If the state of 2 is entirely ignored, the distribution of the infringed state of 1 can be found from (5.22) by integration over $p_{2}$ and $q_{2}$ with density function $1 / h$. This gives

$$
\frac{1}{h} e^{-\frac{i}{\hbar} q_{1}\left(P^{\prime}-P^{\prime \prime}\right)} e^{\frac{i}{\hbar} p_{1}\left(Q^{\prime}-Q^{\prime \prime}\right)} e^{-\frac{i}{\hbar} \frac{P^{\prime} Q^{\prime}-P^{\prime \prime} Q^{\prime \prime}}{2}} .
$$

For the distribution (5.21) the result is $1 / h$, the infringed state is entirely undetermined (the normalization can be understood from (5.26)). A measuring result $q_{2}=q_{2 \mu}$ or $p_{2}=p_{2 \rho}$ selects from (5.23). 
or $(5.24)$ for 1 the distribution

$$
\frac{1}{h} \delta\left(q_{1}-q_{2 \mu}+\frac{Q^{\prime}+Q^{\prime \prime}}{2}\right) e^{-\frac{i}{\hbar}\left(q_{1}+q_{2 \mu}\right) \frac{P^{\prime}-P^{\prime \prime}}{2}} e^{\frac{i}{\hbar}\left(p_{1}-\frac{P^{\prime}+P^{\prime \prime}}{2}\right)\left(Q^{\prime}-Q^{\prime \prime}\right)}
$$

or

$$
\frac{1}{h} \delta\left(p_{1}+p_{2 \rho}-\frac{P^{\prime}+P^{\prime \prime}}{2} e^{\frac{i}{h}\left(p_{1}-p_{2 \rho}\right) \frac{Q^{\prime}-Q^{\prime \prime}}{2}} e^{-\frac{i}{h}\left(q_{1}+\frac{Q^{\prime}+Q^{\prime \prime}}{2}\right)\left(P^{\prime}-P^{\prime \prime}\right)} .\right.
$$

For (5.25) this gives

$$
\frac{1}{h} \delta\left(q_{1}-q_{2 \mu}+Q\right) \text { or } \frac{1}{h} \delta\left(p_{1}+p_{2 \rho}-P\right) .
$$

Also in this example, in which all distribution functions derived from (5.21) are non-negative definite, it is already the particular part of the immediate integration over half of the parameters even in a single measurement, which does not fit into an interpretation of the lst kind.

These few attempts and failures to carry through a genuine statistical description of the 1st kind $S^{1}$ may suffice to illustrate the intention and troubles of such a conception.

\section{REFERENCES}

1) J. v. N e u m a n n, Mathematische Grundlagen der Quantenmechanik, Berlin 1932; New York 1943.

2) H. W e y 1, Z.Phys. 46, 1, 1927; Gruppentheorie und Quantenmechanik, Leipzig 1928.

3) W. H. Furry, Phys. Rev. (2) 19, 393, 476, 1936.

4) E. Schrö ding er, Proc. Camb. Phil. Soc. 31, 555, 1935; 32, 446, 1936; Naturw. 23, 807, 823, 844, 1935.

5) A. E. R u a r k, Phys. Rev. (2) 48, 446, 1935.

6) L. F. v. Weizs äcker, Z. Phys. 70, 114, 1931.

7) A. Einstein, B. Podolsky and N. Rosen, Phys. Rev. (2) 47, 777, 1935.

8) N. B o hr, Phys. Rev. (2) 48, 466, 1935.

9) G. Temple, Nature 135, 957, 1935; H. Fröhlich and E. Guth, G. Te m ple, Nature 136, 179, 1935; R. P e i e $1 \mathrm{~s}$, Nature 136, 395, 1935.

10) E. Wigner, Phys. Rev. (2) 10, 749, 1932. 


\title{
[ 99 ]
}

\section{QUANTUM MECHANICS AS A STATISTICAL THEORY}

\author{
Bx J. E. MOYAL \\ Communicated by M. S. BARTLETT \\ Received 12 November 1947

\section{INTRODUCTION}

Statistical concepts play an ambiguous role in quantum theory. The critique of acts of observation, leading to Heisenberg's 'principle of uncertainty' and to the necessity for considering dynamical parameters as statistical variates, not only for large aggregates, as in classical kinetic theory, but also for isolated atomic systems, is quite fundamental in justifying the basic principles of quantum theory; yet paradoxically, the expression of the latter in terms of operations in an abstract space of 'state' vectors is essentially independent of any statistical ideas. These are only introduced as a post hoc interpretation, the accepted one being that the probability of a state is equal to the square of the modulus of the vector representing it; other and less satisfactory statistical interpretations have also been suggested (of. Dirac(1)).

One is led to wonder whether this formalism does not disguise what is an essentially statistical theory, and whether a reformulation of the principles of quantum mechanics in purely statistical terms would not be worth while in affording us a deeper insight into the meaning of the theory. From this point of view, the fundamental entities would be the statistical variates representing the dynamical parameters of each system; the operators, matrices and wave functions of quantum theory would no longer be considered as having an intrinsic meaning, but would appear rather as aids to the calculation of statistical averages and distributions. Yet there are serious difficulties in effecting such a reformulation. Classical statistical mechanics is a 'crypto-deterministic' theory, where each element of the probability distribution of the dynamical variables specifying a given system evolves with time according to deterministic laws of motion; the whole uncertainty is contained in the form of the initial distribu. tions. A theory based on such concepts could not give a satisfactory account of such non-deterministic effects as radioactive decay or spontaneous emission (cf. Whittaker (2)). Classical statistical mechanics is, however, only a special case in the general theory of dynamical statistical (stochastic) processes. In the general case, there is the possibility of 'diffusion' of the probability 'fluid', so that the transformation with time of the probability distribution need not be deterministic in the classical sense. In this paper, we shall attempt to interpret quantum mechanics as a form of such a general statistical dynamics.

\section{QUANTUM KINEMATICS}

2. THE EXISTENCE OF PHASE-SPAOE DISTRIBUTIONS IN QUANTUM THEORY In the accepted statistical interpretation of quantum theory, the possible values of a dynamical variable $s$ are the eigenvalues $s_{i}$ of the corresponding operator (observable) 
$s$ in the Hilbert space of the state vectors. The probability of finding $s_{i}$ in a state $\psi$ is then equal to the square of the modulus $\left|a_{i}\right|^{2}$ of the projection $a_{i}$ of $\psi$ on the corresponding eigenvector $\psi_{i}$. A complete or irreducible representation for a given mechanical system is given by a set of commuting observables $s$ such that their eigenvectors $\psi_{i}$ span the whole space, i.e. such that any $\psi=\sum_{i} a_{i} \psi_{i}$. Hence we obtain directly from $\psi$ the joint distribution of the variables $s$. It is known, however, that these s are not sufficient in themselves to specify the system completely; we need, in addition, another complementary set, say $\mathbf{r}$, which does not in general commute with $\mathbf{s}$; for example, a complete representation is given by either the Cartesian coordinates q or their conjugate momenta $\mathbf{p}$, but the complete dynamical specification of the system requires both q's and p's. Hence, the phase-space distributions of complete sets of dynamical variables, which are required for a statistical theory, are not given directly by $\psi$.

It has been argued (3) that such distributions do not exist, because of the impossibility of measuring non-commuting observables simultaneously. This argument is not conclusive for two reasons; one is that the impossibility of physical measurements does not preclude us from considering the proposition that there exists a well-defined probability for the two variables to take specified values or sets of values; in fact, the theory of probability is introduced to deal with such situations where exact measurement is impossible (see Jeffreys (4)). The other reason is that it is possible in principle to form operators $G$ corresponding to functions $G(r, s)$ of non-commuting observables; the expectation value of $\mathrm{G}$ in a state $\psi$ is then given by the scalar product $(\psi, \mathrm{G} \psi)$. But the joint distribution of $r$ and $s$ can be reconstructed from a set of such expectation ralues, $e . g$. the values of all the joint moments $\overline{r k} s^{n}$. The formalism of quantum theory allows us therefore to derive the phase-space distributions indirectly if a theory of functions of non-commuting observables is specified and conversely.

There are serious difficulties to be met, however, in defining these distributions unambiguously. This may be seen, for example, in the case of the harmonic oscillator. The energy eigenvalues form a discrete set $E_{n}=\left(n+\frac{1}{2}\right) h \nu$. The corresponding eigenfunctions $u_{n}(q), v_{n}(p)$ are sets of Hermite functions, continuous in $p$ and $q$. Hence any joint distribution for $p$ and $q$ in a state consistent with the individual distributions

$$
\psi(q) \psi^{*}(q)=\sum_{i, k} a_{i}^{*} a_{k} u_{i}^{*}(q) u_{k}(q) \quad \text { and } \quad \phi(p) \phi^{*}(p)=\sum_{i, k} a_{i}^{*} a_{k} v_{i}^{*}(p) v_{k}(p)
$$

must extend continuously over the whole $(p, q)$ plane, while any joint distribution for the energy $H=\frac{1}{2}\left(p^{2} / m+2 \pi m \nu q^{2}\right)$ and the phase angle $\theta=\tan ^{-1} p / q$ consistent with probabilities $a_{n} a_{n}^{*}$ for $w_{n}$, will be concentrated on a set of ellipses

$$
\frac{1}{2}\left(p^{2} / m+2 \pi m \nu q^{2}\right)=\left(n+\frac{1}{2}\right) h \nu \text {. }
$$

We are thus forced to the conclusion that phase-space distributions are not unique for a given state, but depend on the variables one is going to measure. In Heisenberg's words (5), 'the statistical predictions of quantum theory are thus significant only when combined with experiments which are actually capable of observing the phenomena treated by the statistics'. Since the introduction of statistical concepts in atomic theory is justified by an analysis of the interaction between observed system and observer, it is perhaps not surprising that different distributions should arise according to the 
experimental set-up. For example, measurement of the spectra of an atom corresponds to a distribution with discrete values for the energy and angular momenta. Direct transformation of this distribution to $(p, q)$ space, corresponding to a distribution concentrated on discrete orbits, would not be appropriate for the treatment of collisions of the same atom with a beam of electrons; the appropriate distribution in the latter case arises from wave functions filling the whole space continuously, and is incompatible with discrete orbits.

The statistical interpretation of quantum kinematios will thus have to give methods for setting up the appropriate phase-space distributions of each basic system of dynamical variables in terms of the wave vectors, and for transforming such distribution into one another.

\section{Phase-Spade distributions in terms of Wave Viectors}

We denote by $\mathbf{r}$ a set of commuting observables or operators giving a complete representation, $\mathbf{s}$ the complementary set, such that $\mathbf{s}$ do not commute with $\mathbf{r}$ and that $\mathbf{r}$ and $\mathbf{s}$ together form a basic set of dynamical variables, characterizing a given system; $r$ and $s$ are their possible values or eigenvalues (these are, of course, ordinary commuting variables). The most natural way of obtaining the phase-space distribution $F(r, s)$ is to look for its Fourier inverse, i, $\theta$. the mean of $\exp \{i(\tau r+\theta s)\}$ (known in statistical terminology as the characteristic function). On forming the corresponding operator

$$
\mathbf{M}(\tau, \theta)=\exp \{i(\tau \mathbf{r}+\theta \mathbf{s})\}=\sum_{n} \frac{i^{n}}{n !}(\tau \mathbf{r}+\theta \mathbf{s})^{n}
$$

the characteristio function in a state $\psi$ is given by the scalar product

$$
M(\tau, \theta)=\left(\psi, e^{i(\tau r+\theta s)} \psi \gamma\right) .
$$

From well-known formulae for Fourier inversion, the phase-space distribution function is then

$$
F(r, s)=\frac{1}{4 \pi^{2}} \iint\left(\psi, e^{i(\tau r+\theta s)} \psi\right) e^{-i(\tau r+\theta s)} d \tau d \theta
$$

for continuous eigenvaluest, and

$$
F^{\prime}\left(r_{i}, s_{k}\right)=\lim _{T \rightarrow \infty} \frac{1}{4 T^{2}} \int_{-T}^{T} \int_{-T}^{T}\left(\psi, e^{i(\tau r+08)} \psi\right) e^{-i\left(r_{i}+\theta_{s}\right)} d \tau d \theta
$$

for discrete eigenvalues $r_{i}, s_{k}$ (Cramér (6))

The operator $(3 \cdot 1)$ takes a specially simple form for canonically conjugate coordinates and momenta $\mathbf{q}, \mathbf{p}(\mathbf{p q}-\mathbf{q p}=\hbar / i)$,

$$
\mathbf{M}(\tau, \theta)=e^{\sharp i \hbar \tau \theta} e^{i \theta \mathfrak{q}} e^{i \tau \mathfrak{p}}=e^{-i i \tau \rrbracket} e^{i \theta \mathfrak{q}} e^{i i \tau \mathfrak{p}}
$$

(cf. Kermack and McCrea (7)). From the second expression for $\mathbf{M}$, we find

$$
M(\tau, \theta)=\int \psi^{*}\left(q-\frac{1}{2} \hbar \tau\right) e^{i \theta q} \psi\left(q+\frac{1}{2} \hbar \tau\right) d q,
$$

$\dagger$ When no limits are specified, all integrals are to be taken as from $-\infty$ to $+\infty$.

\$ The term distribution function is used in this paper to denote the probability density of continuous eigenvalues, and the finite probability of discrete eigenvalues. 
102

J. E. MOYAL

and hence by Fourier inversion

$$
F(p, q)=\frac{1}{2 \pi} \int \psi^{*}\left(q-\frac{1}{2} \hbar \tau\right) e^{-i \tau p} \psi\left(q+\frac{1}{2} \hbar \tau\right) d \tau,
$$

an expression first given by Wigner (8). From the first operator form of $\mathbf{M}$ in (3.5), and by expressing $\psi(q)$ in terms of the momentum wave function $\phi(p)$

$$
\psi(q)=h^{-1} \int \phi(p) e^{i p q \mid \pi} d p
$$

we find, by a series of partial integrations,

$$
\begin{aligned}
& M(r, \theta)=h^{-t} \iint\left[\psi^{*}(q) \phi(p) e^{i p q / n}\right] e^{-i i \hbar \tau \theta} e^{i(\tau p+\theta q)} d p d q
\end{aligned}
$$

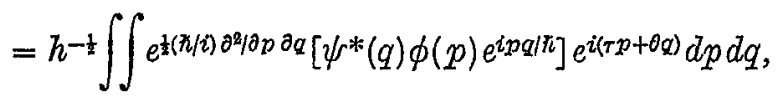

and hence the alternative expression for the phase-space distribution

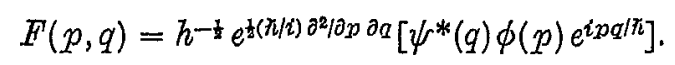

It is shown in Appendix 1 that the Heisen berg inequality $\Delta p \Delta q \geqslant \frac{1}{2} \hbar$ follows directly from the expression for $F(p, q)$ given above. In this sense, the expression of the phasespace distributions in terms of the wave vectors may be considered as a more complete formulation of the uncertainty principle than that given by the inequalities, since it should contain all possible restrictions on the probabilities and expectation values of non-commuting observables.

This choice of expression for the phase-space distributions constitutes a new hypothesis, not already included in the basio postulates of quantum theory as they are usually formulated. The discussion of certain difficulties associated with this choice, in particular the appearance of 'negative probabilities' for certain states, is made clearer by further developments of the theory, and will therefore be deferred to $\S 15$. Other possible ohoices and the possibilities of experimental verification are discussed briefly in $\S 17$.

\section{Phast-SPaCe EIGennunotions}

If we insert the expansion of the wave vector $\psi$ in terms of an orthonormal set of eigenvectors

$$
\psi=\sum_{l} a_{l} \psi_{l}
$$

in the expression $(3 \cdot 3)$ for $F(r, s)$, we find for the latter the expansion

$$
F(r, s)=\sum_{l, l_{k}} a_{l}^{*} a_{k k} f_{l k}(r, s),
$$

where the functions $f_{l k}(r, s)$ are the Fourier inverses of the matrices

$$
m_{l k}(\tau, \theta)=\left(\psi_{l}, e^{i(\tau+\theta)} \psi_{k}\right)=m_{k l}^{*}(-\tau,-\theta)
$$

of the operator (3.1) in the representation of the $\psi_{l}$. Explicitly, we have

$$
\begin{gathered}
f_{l k}(r, s)=\frac{1}{4 \pi^{2}} \iint\left(\psi_{l,} e^{i\left(\tau \boldsymbol{r}+\theta_{\mathrm{B}}\right)} \psi_{k}\right) e^{-i(\tau r+\theta s)} d \tau d \theta, \\
f_{l k}\left(r_{\alpha}, s_{\beta}\right)=\lim _{T \rightarrow \infty} \frac{1}{4 T^{2}} \int_{-T}^{T} \int_{-T}^{T}\left(\psi_{l}, e^{i(\tau r+\theta 8)} \psi_{k}\right) e^{-i\left(r_{\alpha}+\theta_{\beta}\right)} d \tau d \theta
\end{gathered}
$$




\section{Quantum mechanics as a statistical theory}

where $(4 \cdot 4)$ refers to the case of continuous eigenvalues $r, s$ and $(4 \cdot 5)$ to that of discrete eigenvalues $r_{\alpha}, s_{\beta}$. The functions $f_{l k}(r, s)$ form a complete orthogonal set in the Hilbert space of the phase-space functions $F(r, s)$, satisfying the relations $\dagger$

$$
\begin{gathered}
\iint f_{l l c}(r, s) f_{l^{\prime} k^{\prime}}^{*}(r, s) d r d s=h^{-1} \delta_{l l^{\prime}} \delta_{k k^{\prime}}, \\
\sum_{l, k_{k}} f_{l l_{k}}(r, s) f_{l k}^{*}\left(r^{\prime}, s^{\prime}\right)=h^{-1} \delta\left(r-r^{\prime}\right) \delta\left(s-s^{\prime}\right),
\end{gathered}
$$

and also the 'self-orthogonality' relations

$$
\begin{gathered}
\iint f_{l k}(r, s) d r d s=\delta_{l k}, \\
\sum_{l} f_{l l}(r, s)=h^{-1} .
\end{gathered}
$$

In the general case, this follows from the fact that $(4 \cdot 3)$ and $(4 \cdot 4)$ or $(4 \cdot 5)$ form a unitary transformation from a vector, sary $\psi_{l k}$, of components $\psi_{l}{ }^{*}, \psi_{k}$ in the product space of the vectors $\psi^{*}$ with the vectors $\psi$, to $f_{l k}$. The vectors $\psi_{l k}$ form a complete orthogonal (and self-orthogonal) set, and these properties are invariant under a unitary transformation. Furthermore, it is easily seen from their definition that the $f_{l l}$ form a Hermitian matrix with respect to their subscripts $l, k$

$$
f_{l k}(r, s)=f_{i l l}^{*}(r, s) \text {. }
$$

We shall see later ( $\$ 7$ and 8 ) that the $f_{l l c}$ can be interpreted as the eigenfunctions of characteristic equations for the phase-space distribution functions, corresponding to the eigenvalue equations of the $\psi$ 's; we therefore call them phase-space eigenfunctions.

In the case of the canonical coordinates and momenta $q$ and $p$, relations $(4 \cdot 6)-(4 \cdot 9)$ can be proved by elementary methods (cf. Appendix 2), and the $f_{l l}(p, q)$ have the explicit expressions, corresponding to $(3 \cdot 7)$ and $(3 \cdot 8)$,

$$
\begin{aligned}
& f_{l l}(p, q)=\frac{1}{2 \pi} \int \psi_{l}^{*}\left(q-\frac{1}{2} \hbar \tau\right) e^{-i \tau p} \psi_{l l}\left(q+\frac{1}{2} \hbar \tau\right) d \tau, \\
& f_{l l}(p, q)=h^{-\frac{1}{2}} e^{z(\pi / i) \partial^{2} / \partial p \partial q}\left[\psi_{l}^{*}(q) \phi_{l l}(p) e^{i p q / \hbar}\right] .
\end{aligned}
$$

Substituting the eigenfunctions $\psi_{p^{\prime}}(q)=h^{-\frac{1}{2}} e^{i p^{\prime} \alpha / \hbar}$ in a $p$-representation, we find

$$
f_{p^{\prime} p^{\prime}}(p, q)=h^{-1} \delta\left(p-\frac{p^{\prime}+p^{\prime \prime}}{2}\right) e^{i q\left(p^{*}-p^{\prime}\right) / \hbar}
$$

The expansion of $F(p, q)$ in terms of $f_{p^{\prime} p^{\prime \prime}}$

$$
\begin{aligned}
F(p, q) & =h^{-1} \iint \phi^{*}\left(p^{\prime}\right) \phi\left(p^{\prime \prime}\right) \delta\left(p-\frac{p^{\prime}+p^{\prime \prime}}{2}\right) e^{i q\left(p^{\prime \prime}-p^{\prime}\right) \mid \hbar} d p^{\prime \prime} d p^{\prime} \\
& =\frac{1}{2 \pi} \int \phi^{*}\left(p+\frac{1}{2} \hbar \theta\right) e^{-i \theta q} \phi\left(p-\frac{1}{2} \hbar \theta\right) d \theta
\end{aligned}
$$

is the equivalent of (3.7) in terms of the momentum wave functions $\phi(p)$.

$\dagger$ Integration must be replaced by summation in what follows when the eigenvalues of $\mathbf{r}, \mathbf{s}$ are discrete. 


\section{Mtan valumis, operators and Matriotes of functions OF THE DYNAMTOAL VARTABLEES}

The mean value of an ordinary function $Q(r, s)$ taken with respect to the phase-space distribution $F(r, s)$ is

$$
\begin{aligned}
\bar{Q} & =\iint G(r, s) F(r, s) d r d s \\
& =\iiint \int G(r, s)\left(\psi, e^{i(7 r+\theta \theta)} \psi\right) e^{-i(\tau r+\theta \theta)} d r d s d \tau d \theta \\
& =\left(\psi,\left\{\iint \gamma(\tau, \theta) e^{i(7 \mathbf{r}+\theta s)} d r d \theta\right) \psi\right),
\end{aligned}
$$

where $\gamma(\tau, \theta)$ is the ordinary Fourier inverse of $G(r, s)$

$$
\gamma(\tau, \theta)=\iint G(r, s) e^{-i(r r+0 s)} d r d s
$$

$\bar{G}$ is thus the mean of the operator

$$
\mathbf{G}=\iint \gamma(\tau, \theta) e^{i(\tau r+\theta s)} d \tau d \theta,
$$

which is thus the operator corresponding to the ordinary function $G(r, s)$ in our theory.

It now follows that the matrix $G_{l l s}$ of $G$ in any representation of eigenvectors $\psi_{l}$ can be obtained by integration of the ordinary function $G(r, s)$ with respect to the corresponding phase-space eigenfunction $f_{l l k}(r, s)$

$$
\begin{aligned}
G_{l k} & =\iint G(r, s) f_{l k}(r, s) d r d s=\iiint \int G(r, s)\left(\psi_{l}, e^{i(r r+\theta s)} \psi_{l k}\right) d r d s d \tau d \theta \\
& =\left(\psi_{l}, \mathbf{G} \psi_{k}\right) .
\end{aligned}
$$

Since $f_{l k}$ is a Hermitian matrix with respect to $l$ and $k$, we see at once from (5.4) that $G_{l k}$ will be Hermitian if $Q(r, s)$ is real.

The operators and matrices corresponding to any function of the basic variables $r, s$ are thus uniquely defined by the phase-space distributions. In other words, our theory of phase-space distributions is equivalent to a theory of functions of noncommuting operators. Inversely, this theory of functions defines the phase-space distributions uniquely.

In the special case of functions $G(p, q)$ of canonically conjugate coordinates and momenta, (5.3) coincides with an expression derived by Weyl (9) on group-theoretical considerations. An alternative expression corresponding to $(3 \cdot 10)$ for $F(p, q)$ is

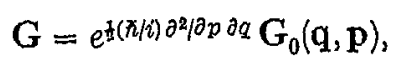

where $\mathbf{G}_{0}(\mathbf{q}, \mathbf{p})$ is obtained directly from the ordinary function $G(p, q)$ by writing all the operators $\mathbf{p}$ to the right (e.g. $\mathbf{q}^{n} \mathbf{p}^{m}$ ), and this order is maintained when applying the

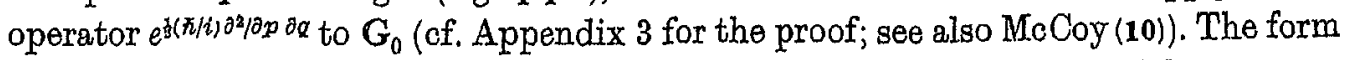
of the usual operators of quantum theory: energy, angular momenta, radial momenta, etc., are not changed when they are derived by this method from the corresponding classical functions of $p$ and $q$. 


\section{QUANTUM DYNAMICS}

\section{Thm LaWs of MOTION OF GHNERAL DYNamidat STOOHASTIC PROOHSSTS}

We now come to the statistical interpretation of quantum dynamics. What we have to do for this purpose is to find the temporal transformation laws of the phase-space distributions of quantum theory corresponding to the quantum equations of motion. As mentioned in $\$ 1$, this cannot be done within the framework of classical statistical mechanics, which is a 'crypto-deterministic' theory, but appears rather as a special case in the general theory of dynamical stochastic processes. We start therefore with a brief survey of the integral and differential relations through which laws of motion can be expressed for such processes. The theory will be developed for Cartesian coordinates and momenta only.

The fundamental integral relation connecting the probability distributions $F(p, q ; t)$ and $T_{0}\left(p_{0}, q_{0} ; t_{0}\right)$ at times $t$ and $t_{0}$ for a given mechanical system is

$$
F(p, q ; t)=\iint K\left(p, q \mid p_{0}, q_{0} ; t-t_{0}\right) F_{0}\left(p_{0}, q_{0} ; t_{0}\right) d p_{0} d q_{0}
$$

where $K$ is the distribution of $p, q$ at $t$ conditional in $p_{0}, q_{0}$ at $t_{0} . K$ is therefore the temporal transformation function, and must express the laws of motion of the system. While $F_{0}$ and $F$ depend on the initial and final states of the system, $K$ must be independent of these states, and depend on the inherent dynamical properties of the system. Hence the assumption that $K$ is homogeneous, i.e. invariant for a translation of the origin in $t$, and dependent only on the interval $t-t_{0}$ (as long as there are no external time-dependent forces acting on the system).

$K$ gives the transformation for finite intervals. We now derive the corresponding infinitesimal transformation. The characteristic function $\Lambda$ for the differences $q-\xi$, $p-\eta$ conditional in $\xi, \eta$ is

$$
\left.\Lambda\langle\tau, \theta| \eta, \xi ; t-t_{0}\right)=\iint e^{i[0(q-\theta)+\tau(p-\eta)]} K\left(p, q \mid \eta, \xi ; t-t_{0}\right) d p d q .
$$

We make the second assumption that in the stochastic processes of physics, the probability of a transition from $\xi, \eta$ to $q \neq \xi, p \neq \eta$ in a small interval $t-t_{0}$ is of the order of $t-t_{0}$. For $t=t_{0}$, obviously $K=\delta(p-\eta) \delta(q-\xi)$ and $\Lambda=1$. Hence $(\Lambda-1) /\left(t-t_{0}\right)$ tends to a finite limit $L$ when $t \rightarrow t_{0}$

$$
\lim _{t \rightarrow t_{0}} \frac{\Lambda-1}{t-t_{0}}=L(\tau, \theta \mid \eta, \xi) \text {. }
$$

We shall call $L$ the derivate characteristic function. If $M\left(\tau, \theta ; t_{0}\right)$ is the characteristic function at $t_{0}$

$$
M\left(\tau, \theta ; t_{0}\right)=\iint e^{i(\tau \eta+O \xi)} F_{0}\left(\eta, \xi ; t_{0}\right) d \eta d \xi
$$

then the characteristic function at $t$ is

$$
M(\tau, \theta ; t)=\iint e^{i(\tau \eta+\theta \xi)} \Lambda\left(\tau, \theta \mid \eta, \xi ; t-t_{0}\right) F_{0}\left(\eta, \xi ; t_{0}\right) d \eta d \xi
$$


Hence

$$
\begin{aligned}
\frac{\partial M}{\partial t} & =\lim _{t_{0} \rightarrow t} \iint \frac{\Lambda-1}{t-t_{0}} e^{i(\tau \eta+\theta \xi)} F_{0}\left(\eta, \xi ; t_{0}\right) d \eta d \xi \\
& =\iint L(\tau, \theta \mid \eta, \xi) e^{i(\tau \eta+\theta \xi)} F(\eta, \xi ; t) d \eta d \xi .
\end{aligned}
$$

This can be expressed in the operational form

$$
\frac{\partial M}{\partial t}=L\left(\tau, \theta \mid \frac{1}{i} \frac{\partial}{\partial \tau}, \frac{1}{i} \frac{\partial}{\partial \theta}\right) M(\tau, \theta ; t)
$$

(first suggested to the author by Prof. M. S. Bartlett). (6.5) and (6.6) express the infinitesimal transformation corresponding to (6.1) in terms of characteristic functions; they can be inverted to express this transformation directly in terms of distribution functions. This may be achieved in two ways; if $L$ admits a Fourier inverse

$$
S(p, q \mid \eta, \xi)=\iint L(\tau, \theta \mid \eta, \xi) e^{i[\tau(\eta-p)+\theta(\xi-q)]} d \tau d \theta,
$$

we obtain for $F$ the integro-differential equation

$$
\frac{\partial}{\partial t} F(p, q ; t)=\iint S(p, q \mid \eta, \xi) F(\eta, \xi ; t) d \eta d \xi .
$$

If, on the other hand, it is possible to expand $L$ in the form

$$
\begin{aligned}
L(\tau, \theta \mid \eta, \xi) & =\lim _{t \rightarrow t_{0}} \iint_{\sum_{n=0}}^{\infty} \sum_{r=0}^{n} \frac{(i \tau)^{n-r}(i \theta)^{r}}{(n-r) ! r !} \frac{(p-\eta)^{n-r}(q-\xi)^{r}}{t-t_{0}} K\left(p, q \mid \eta, \xi ; t-t_{0}\right) d p d q \\
& =\sum_{n=0}^{\infty} \sum_{r=0}^{n} \frac{(i \tau)^{n-r}(i \theta)^{r}}{(n-r) ! r !} \alpha_{n r}(\eta, \xi)
\end{aligned}
$$

(where the $\alpha_{n r}(\eta, \xi)$ are called the derivate moments of the system), then $F$ satisfies the differential equation of infinite order

$$
\frac{\partial}{\partial t} F(p, q ; t)=\sum_{n=0}^{\infty} \sum_{r=0}^{n} \frac{(-1)^{n}}{(n-r) ! r !}\left(\frac{\partial}{\partial p}\right)^{n-r}\left(\frac{\partial}{\partial q}\right)^{r}\left[\alpha_{n r}(p, q) F(p, q ; t)\right] .
$$

This reduces to an equation of finite order if the expansion (6.9) for $L$ terminates, i.e. if the derivate moments vanish above given powers of $p$ and $q$.

\section{EqdatTons OF THE MOTION FOR THE PHASM-SPAOT DISTRIBUTIONS OT QUANTUM THMORY}

In order to derive the equations of motion for the quantum phase-space distributions, we look for the time derivatives of their characteristic functions. We find from the Poisson-bracket form of the quantum equations of motion

$$
\frac{\partial M}{\partial t}=\int \psi^{*}(q)[\mathbf{M}, \mathbf{H}] \psi(q) d q=\frac{i}{\hbar} \int \psi^{*}(q)[\mathbf{M H}-\mathbf{H M}] \psi(q) d q,
$$

where $\mathbf{M}(\tau, \theta)$ is the characteristic function operator (3.5), and $\mathbf{H}$ the Hamiltonian operator, expressed from $(5 \cdot 3)$ by

$$
\mathbf{H}=\iint W(\sigma, \mu) e^{\ell(\sigma \mathrm{g}+\mu q)} d \sigma d \mu
$$


Quantum mechanics as a statistical theory

$W(\sigma, \mu)$ being the Fourier inverse of the corresponding classical Hamiltonian $H(p, q)$. Hence, using expression $(3 \cdot 5)$, we obtain

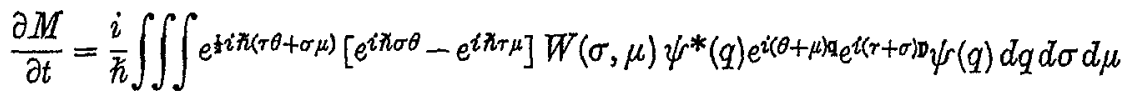

$$
\begin{aligned}
& =\frac{2}{\hbar} \iiint \int \sin \frac{1}{2} \pi(\tau \mu-\sigma \theta) e^{\tau[(\tau+\sigma) p+(\theta+\mu) \Omega]} W(\sigma, \mu)
\end{aligned}
$$

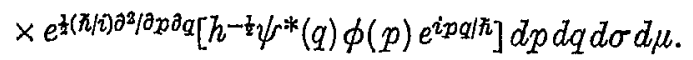

Using expression (3.10) for $F(p, q ; t)$, we obtain the two equivalent expressions

$$
\begin{gathered}
\frac{\partial M}{\partial t}=\frac{i}{\hbar} \iint\left[H\left(p+\frac{1}{2} \pi \theta, q-\frac{1}{2} \hbar \tau\right)-H\left(p-\frac{1}{2} \hbar \theta, q+\frac{1}{2} \hbar \tau\right)\right] F(p, q ; t) e^{i(\tau p+\theta q)} d p d q, \\
\frac{\partial M}{\partial t}=\iint e^{i l(\tau p+\theta)}\left\{\frac{2}{\hbar} \sin \frac{\hbar}{2}\left[\frac{\partial}{\partial p_{F}} \frac{\partial}{\partial q_{H F}}-\frac{\partial}{\partial p_{H}} \frac{\partial}{\partial q_{F}}\right] H(p, q) F^{\prime}(p, q ; t)\right\} d p d q,
\end{gathered}
$$

where $\partial / \partial p_{H}, \partial / \partial q_{H}$ in the right hand of $(7 \cdot 4)$ operate only on $H$ and $\partial / \partial p_{F}, \partial / \partial q_{F}$ only on $F$. The comparison of $(7 \cdot 3)$ with $(6 \cdot 5)$ gives the derivate characteristic function

$$
L(\tau, \theta \mid p, q)=\frac{i}{\hbar}\left[H\left(p+\frac{1}{2} \hbar \theta, q-\frac{1}{2} \hbar \tau\right)-H\left(p-\frac{1}{2} \hbar \theta, q+\frac{1}{2} \hbar \tau\right)\right] .
$$

If $L$ possesses a Fourier transform

$S(p, q \mid \eta, \xi)=\frac{i}{\hbar} \iint\left[H\left(\eta+\frac{1}{2} \hbar \theta, \xi-\frac{1}{2} \hbar \tau\right)-H\left(\eta-\frac{1}{2} \hbar \theta, \xi+\frac{1}{2} \hbar \tau\right)\right] e^{i[\tau(\eta(\eta-p)+\theta(\xi-q)]} d \tau d \theta$,

then $F^{\prime}(p, q ; t)$ satisfies an integro-differential equation of form (6.8)

$$
\frac{\partial}{\partial t} \mathbb{F}(p, q ; t)=\iint S(p, q \mid \eta, \xi) \mathbb{F}^{\prime}(\eta, \xi ; t) d \eta d \xi
$$

with the kernel $S$ given by (7.6). Similarly, we find from (7.4)

$$
\frac{\partial}{\partial t} F(p, q ; t)=\frac{2}{\hbar} \sin \frac{\pi}{2}\left[\frac{\partial}{\partial p_{F}} \frac{\partial}{\partial q_{H}}-\frac{\partial}{\partial p_{H}} \frac{\partial}{\partial q_{F}}\right] H(p, q) F(p, q ; t),
$$

which is easily shown equivalent to $(6 \cdot 10)$ with derivate moments

$$
\alpha_{2 n+1, r}(p, q)=(-1)^{n+r}\left(\frac{1}{2} h\right)^{2 n}\left(\frac{\partial}{\partial p}\right)^{r}\left(\frac{\partial}{\partial q}\right)^{2 n+1-r} H(p, q), \quad \alpha_{2 n, r}(p, q) \equiv 0 .
$$

Inversely, the quantum equations of motion, and in particular the Schrödinger equation, may be derived from the equations above for $F(p, q ; t)$ (cf. Appendix 4). There is thus complete equivalence between the two.

Finally, we may notice the analogy between the right-hand side of $(7 \cdot 8)$ and the classical Poisson braclzet. This may be generalized in the following way. It may be shown by a method similar to that leading to (7.8), that the commutator $i \hbar[R G-G R]$ of two operators $\mathbf{R}, \mathbf{G}$ obtained (e.g. by (5.3) or $(5 \cdot 5)$ ) from the ordinary functions $R(p, q), G(p, q)$ is identical with the operator corresponding (by the same rules) to

$$
\frac{2}{\hbar} \sin \frac{\hbar}{2}\left[\frac{\partial}{\partial p_{G}} \frac{\partial}{\partial q_{R}}-\frac{\partial}{\partial p_{R}} \frac{\partial}{\partial q_{G}}\right] R(p, q) G(p, q) .
$$

In other words, $(7 \cdot 10)$ is the analogue of the classical Poisson bracket when the laws of quantum mechanics are expressed in phase-space, and the commutator is the 
108

J. E. Moyax

corresponding operator in a $q$ - or $p$-representation. It is also seen from this that operators whose classical analogue is 0 may correspond to non-vanishing phase-space functions in the present theory†.

\section{THE OHARACTERTSTIO TQUATIONS OF PHASE-SPACE HIGENFUNOTIONS}

The expansion of the distributions $F^{\prime}(p, q$; $t$ ) of a conservative system in terms of its energy phase-space eigenfunctions $f_{i k}(p, q)$ is, from (4.2),

$$
F(p, q ; t)=\sum_{i, k} a_{i}^{*} a_{k e} f_{i k}(p, q) e^{i\left(E_{i}-Z_{i}\right) t / \hbar} .
$$

Substituting in (7.7) and identifying term-by-term, we see that the $f_{i l t}$ are the eigenfunctions of the homogeneous integral equation

$$
f_{i k}(p, q)=\frac{i \hbar}{E_{k c}-E_{i}} \iint S(p, q \mid \eta, \xi) f_{i k}(\eta, \xi) d \eta d \xi .
$$

The kernel 8 can therefore be expanded in terms of the $f_{i t}$

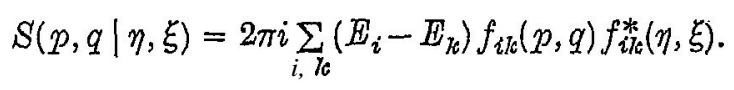

Similar characteristic equations can be found for the eigenfunctions $g_{i k}(p, q)$ of any operator $\mathrm{G}$ corresponding to the classical function $G(p, q)$. Let $\gamma_{i}$ be the eigenvalues of $\mathrm{G}$

$$
\mathrm{G} u_{i}(q)=\gamma_{i} u_{i}(q) \text {. }
$$

Calculating the mean of the commutator $[\mathrm{G}, \mathrm{M}]$ from the two sides of $(8 \cdot 4)$

$$
\begin{aligned}
& \int u_{i}^{*}(q) {[\mathrm{GM}-\mathrm{MG}] u_{k}(q) d q=\left(\gamma_{i}^{*}-\gamma_{k}\right) \iint e^{i(\tau p+\theta q)} g_{i l l}(p, q) d p d q } \\
& \quad=\iint\left[G\left(p+\frac{1}{2} \hbar \theta, q-\frac{1}{2} \hbar \tau\right)-G\left(p-\frac{1}{2} \hbar \theta, q+\frac{1}{2} \hbar \tau\right)\right] g_{i l l}(p, q) e^{i(\tau p+\theta q)} d p d q \\
& \quad=\frac{2}{i} \iint e^{i(\tau p+\theta q)} \sin \frac{\hbar}{2}\left[\frac{\partial}{\partial p_{g}} \frac{\partial}{\partial q_{G}}-\frac{\partial}{\partial p_{G}} \frac{\partial}{\partial q_{g}}\right] G(p, q) g_{i l k}(p, q) d p d q,
\end{aligned}
$$

$w e$ find the characteristic equations for $g_{\imath k}$

where the kernel

$$
\begin{aligned}
g_{i k}(p, q) & -\frac{\dot{*} \cdot}{\gamma_{k}-\gamma_{i}^{*} J J} \operatorname{rr} S_{G}(p, q \mid \eta, \xi) g_{i k}(\eta, \xi) d \eta d \xi \\
& =\frac{2 i}{\gamma_{k}-\gamma_{i}^{*}} \sin \frac{\hbar}{2}\left[\frac{\partial}{\partial p_{g}} \frac{\partial}{\partial q_{G}}-\frac{\partial}{\partial p_{G}} \frac{\partial}{\partial q_{\theta}}\right] G(p, q) g_{i k}(p, q),
\end{aligned}
$$

$$
\begin{aligned}
S_{Q}(p, q \mid \eta, \xi) & =\frac{i}{\hbar} \iint\left[G\left(p+\frac{1}{2} \hbar \theta, q-\frac{1}{2} \hbar \tau\right)-G\left(p-\frac{1}{2} \hbar \theta, q+\frac{1}{2} \hbar \tau\right)\right] e^{i[\tau(\eta-p)+\theta(\xi-q)]} d \tau d \theta \\
& =2 \pi i \sum_{i, k}\left(\gamma_{i}^{*}-1^{*}\right) g_{i k}(p, q) g_{i k}^{*}(\eta, \xi) .
\end{aligned}
$$

$\dagger$ This question was raised by the referee. 


\section{TransformatToN BQUATIONS FOR FINITR INTERVALS}

Having derived the infinitesimal transformations in phase-space, we now return to the transformation equations for a finite interval (cf. §6)

$$
\left.\begin{array}{rl}
F(p, q ; t) & =\iint K_{10}\left(p, q \mid p_{0}, q_{0} ; t-t_{0}\right) F_{0}\left(p_{0}, q_{0} ; t_{0}\right) d p_{0} d q_{0} \\
P_{0}\left(p_{0}, q_{0} ; t_{0}\right) & =\iint K_{01}\left(p_{0}, q_{0} \mid p, q ; t_{0}-t\right) F(p, q ; t) d p d q .
\end{array}\right\}
$$

We introduce the operator solutions of the Schrödinger equation

$$
\mu_{k}\left(q ; t-t_{0}\right)=e^{-\imath\left(t-t_{0}\right) \mathbf{H} / \pi} u_{k}(q)
$$

for an arbitrary orthonormal set of functions $u_{k}(q)$. The corresponding phase-space functions are

$$
\begin{gathered}
g_{i k}\left(p_{0}, q_{0}\right)=\frac{1}{2 \pi} \int u_{i}^{*}\left(q_{0}-\frac{1}{2} \hbar \tau\right) e^{-i \tau p_{0}} u_{k}\left(q_{0}+\frac{1}{2} \hbar \tau\right) d \tau, \\
\gamma_{i k}\left(p, q ; t-t_{0}\right)=\frac{1}{2 \pi} \int \mu_{i}^{*}\left(q-\frac{1}{2} \hbar \tau ; t-t_{0}\right) e^{-i \tau p} \mu_{k}\left(q+\frac{1}{2} \hbar \tau ; t-t_{0}\right) d \tau \\
=\sum_{i, m} U_{i l}\left(t_{0}-t\right) g_{l m}(p, q) U_{m k}\left(t-t_{0}\right), \\
U_{i k}\left(t-t_{0}\right)=\int u_{i}^{*}(q) e^{-i\left(t-t_{0}\right) \mathbf{B} / \hbar} u_{k}(q) d q .
\end{gathered}
$$

where

On substituting in $(9 \cdot 1)$ the expansions of $F(p, q ; t)$ and $F_{0}\left(p_{0}, q_{0} ; t_{0}\right)$ in terms of the $g_{i k}$ and $\gamma_{i k}$, a term-by-term identification shows that

$$
\begin{aligned}
\gamma_{i k}\left(p, q ; t-t_{0}\right) & =\iint K_{10}\left(p, q \mid p_{0}, q_{0} ; t-t_{0}\right) g_{i k}\left(p_{0}, q_{0}\right) d p_{0} d q_{0}, \\
g_{i l_{b}}\left(p_{0}, q_{0}\right) & =\iint K_{01}\left(p_{0}, q_{0} \mid p, q ; t-t_{0}\right) \gamma_{i k}\left(p, q ; t-t_{0}\right) d p d q .
\end{aligned}
$$

The expansion of $K_{10}$ in terms of the $g_{i k}: K_{10}=\Sigma \lambda_{i k} g_{i k}$ has coefficients

$$
\lambda_{i k}=\hbar \iint K_{10}\left(p, q \mid p_{0}, q_{0} ; t-t_{0}\right) g_{i l k}^{*}\left(p_{0}, q_{0}\right) d p_{0} d q_{0}=h \gamma_{i l i}^{*}\left(p, q ; t-t_{0}\right)
$$

and similarly for $K_{01}$, so that the two are identical,

$$
K_{01}=K_{10}=K\left(p, q \mid p_{0}, q_{0} ; t-t_{0}\right)=h \sum_{i, k} g_{i k}\left(p_{0}, q_{0}\right) \gamma_{i k}^{*}\left(p, q ; t-t_{0}\right)
$$

We have thus found an expression for the transformation function $K$ in terms of the $g_{i k}$ and $\gamma_{i k}$; from it we see that $K$ satisfies the iteration relation

$K\left(p_{2}, q_{2} \mid p_{0}, q_{0} ; t-t_{0}\right)=\iint K\left(p_{2}, q_{2} \mid p_{1}, q_{1} ; t_{2}-t_{1}\right) K\left(p_{1}, q_{1} \mid p_{0}, q_{0} ; t_{1}-t_{0}\right) d p_{1} d q_{1}$

The transformation (9.1) form therefore a continuous unitary group. Stochastic processes s\&tisfying the iteration relations $(9 \cdot 8)$ are known as Markoff processes (cf. Hostinsky (11); see also Jeffreys (12)).

The energy eigenfunctions $f_{i k}(p, q)$ of a conservative system are easily seen from $(9 \cdot 4)$ and $(9 \cdot 6)$ to satisfy the homogeneous integral equation

$$
f_{i k}(p, q)=e^{-i\left(E_{i}-E_{k}\right)\left(t-t_{0}\right) / \hbar} \iint K\left(p, q \mid p_{0}, q_{0} ; t-t_{0}\right) f_{i k}\left(p_{0}, q_{0}\right) d p_{0} d q_{0}
$$


The transformation function of a conservative system therefore forms a kernel symmetrical in $p, q$, antisymmetrical in $t$

$$
\begin{aligned}
K\left(p, q \mid p_{0}, q_{0} ; t-t_{0}\right) & =\hbar \sum_{i, k} f_{i k}(p, q) f_{i k}^{*}\left(p_{0}, q_{0}\right) e^{i\left(E_{i}-\mathbb{H}_{k}\right)\left(\left(-t_{0}\right) / \hbar\right.} \\
& =K\left(p_{0}, q_{0} \mid p, q ; t_{0}-t\right) .
\end{aligned}
$$

An alternative expression for $K$ can be given in terms of the transformation wave function

$$
\psi\left(q \mid q_{0} ; t-t_{0}\right)=\sum_{n} u_{n}^{*}(q) u_{n}\left(q_{0}\right) e^{i \Psi_{n}\left(l-t_{0}\right) / \hbar} .
$$

Substituting expression (4.11) for $f_{i l}$ in $(9 \cdot 10)$, we find

$$
K\left(p, q \mid p_{0}, q_{0} ; t-t_{0}\right)=\frac{\hbar}{2 \pi} \iint e^{-i\left(\tau, p-\tau_{0} p_{0}\right)} \psi^{*}\left(q-\frac{1}{2} \hbar \tau \mid q_{0}-\frac{1}{2} \hbar \tau_{0}\right) \psi\left(q+\frac{1}{2} \hbar \tau \mid q_{0}+\frac{1}{2} \hbar \tau_{0}\right) d \tau d \tau_{0} .
$$

10. The RgLATION BETWEEN INHTNTTESTMAT AND FINITE TRANSFORMatToNs: APPLICATION TO WAVR PACKET AND COLLISION PROBLEMS AND TO THI OALOULATION OF TRANSITION PROBABLITIES

It is seen from the expansions (8.3) and (9.10) of $S$ and $K$ in terms of the energy eigenfunctions that

$$
S\left(p, q \mid p_{0}, q_{0}\right)=\lim _{t_{0} \rightarrow t} \frac{\partial}{\partial\left(t-t_{0}\right)} K\left(p, q \mid p_{0}, q_{0} ; t-t_{0}\right) .
$$

Inversely, $K$ can be expanded in terms of $S$

$$
\begin{array}{r}
K\left(p, q \mid p_{0}, q_{0} ; t-t_{0}\right) \\
=\delta\left(p-p_{0}\right) \delta\left(q-q_{0}\right)+\sum_{n=0}^{\infty} \frac{\left(t-t_{0}\right)^{n+1}}{(n+1) !} \int_{(n)} \int S\left(p, q \mid \eta_{1}, \xi_{1}\right) S\left(\eta_{1}, \xi_{1}\left|\eta_{2}\right| \xi_{2}\right) \\
\ldots S\left(\eta_{n}, \xi_{n} \mid p_{0}, q_{0}\right) d \eta_{1} d \xi_{1} \ldots d \eta_{10} d \xi_{n} .
\end{array}
$$

This is easily verified by substituting from (8.3) for $S$ and comparing with $(9 \cdot 10)$ for $K$.

Since $S$ has a simple expression, obtained directly from the Hamiltonian, (10.2) supplies also a convenient method of approximation for $K$ when the energy eigenfunctions are not known exactly. We have thus a new method of solving problems in quantum mechanics, without having to solve the Schrödinger equation.

The distribution $P(p, q ; t)$ of a wave packet at any time $t$ is obtained by the transformation $(9 \cdot 1)$ from the initial distribution $F_{0}\left(p_{0}, q_{0} ; t_{0}\right)$ at $t_{0}$. We can apply this to the solution of collision problems by introducing a suitable initial distribution $F_{0}$ describing the motion of the two particles before the collision, and calculating the transformation function $K$ by $(10 \cdot 2)$ and $(7 \cdot 6)$ from the Hamiltonian for the colliding particles.

These methods can also be applied to the calculation of transition probabilities. Let $f_{i k}(p, q)$ be the energy eigenfunctions corresponding to the unperturbed Hamiltonian $H_{0}$. We can approximate for $K$ from (10.2), using the kernel $S$ corresponding to the complete Hamiltonian $H=H_{0}+H_{1}$ (where $H_{1}$ is the perturbing term). Taking a single diagonal eigenfunction $f_{k e l}\left(p_{0}, q_{0}\right)$ as the initial distribution at $t=0$, the expansion of the transformed distribution $F_{k}(p, q ; t)$ at time $t$ in terms of the $f_{i k}$ is

$$
F_{l k}(p, q ; t)=\sum_{n, m} \alpha_{k n}^{*} \alpha_{k m} f_{n m}(p, q)
$$


The transition probabilities $c_{k n}(t)$ from state $k$ to state $n$ are the diagonal coefficients $c_{k n}=\alpha_{k n}^{*} \alpha_{k n}$ whose expression in terms of $K$ will clearly be

$$
c_{k n}=\alpha_{k n n}^{*} \alpha_{k n}=\iiint \int K\left(p, q \mid p_{0}, q_{0} ; t\right) f_{k k k}\left(p_{0}, q_{0}\right) f_{n n}(p, q) d p_{0} d q_{0} d p d q .
$$

\section{ThE PROBLEM OF DETRRMLNISM IN QUANTUM MEOHANIOS}

The present theory should help to elucidate the question whether quantum mechanics is deterministic in the classical kinetic theory senset, since it permits a direct comparison between the two. The infinitesimal time transformation of quantum phasespace distributions $(7 \cdot 8)$ may be written in the form

$$
\frac{\partial F}{\partial t}+\frac{2}{\hbar} \sin \frac{\hbar}{2}\left\{\frac{\partial}{\partial p}, \frac{\partial}{\partial q}\right\} H(p, q) F(p, q ; t)=0,
$$

where $\{\partial / \partial p, \partial / \partial q\}$ is the phase-space differential operator giving the classical Poisson bracket. The corresponding transformation of classical kinetic theory is given by Liouville's theorem

$$
\frac{\partial F}{\partial t}+\left\{\frac{\partial}{\partial p}, \frac{\partial}{\partial q}\right\} H(p, q) F(p, q ; t)=0 .
$$

Its deterministio character may be seen from the fact that the characteristics of this first order partial differential equation are simply the classical paths in phase-space. Alternatively, we may say that $F$ is an integral invariant of the transformation. generated by the operator $\{\partial / \partial p, \partial / \partial q\}$; an element $S_{0}$ of phase-space will transform to $S_{l}$ in the interval $t$, and

$$
\int_{S_{0}} F\left(p_{0}, q_{0}\right) d p_{0} d q_{0}=\int_{S_{t}} F(p, q ; t) d p d q
$$

This no longer holds in the case of quantum theory; the transformation generated by the operator $(2 / \hbar) \sin \frac{1}{2} \hbar\{\partial / \partial p, \partial / \partial q\}$ is equivalent to $\{\partial / \partial p, \partial / \partial q\}$ when applied to $H p, H q$, but not in general when applied to $H F$, so that while $S_{0}$ will transform into $S$, exactly as for the corresponding classical system, yot generally

$$
\int_{S_{0}} F\left(p_{0}, q_{0}\right) d p_{0} d q_{0} \neq \int_{S_{t}} F(p, q ; t) d p d q
$$

Hence the present theory leads to the conclusion that quantum theory is not generally deterministic in the classical sense.

In the correspondence principle limit, when $h \rightarrow 0$, the quantum equation $(11 \cdot 1)$ is seen to reduce to the classical equation (11.2); this will equally well be the case if the Hamiltonian $H(p, q)$ is a second degree polynomial in $q$ and $p$, leading to the surprising conclusion that systems such as a free or uniformly accelerated particle, or a harmonic oscillator, are deterministic in quantum theory: this should not be taken too seriously, since even small perturbations or non-linear terms would, according to $(11 \cdot 1)$, destroy this deterministic character.

The phase-space transformations with time of quantum theory form a continuous unitary group, which reduces therefore to the group of contact transformation of

$\dagger \mathrm{Cf}$. in this connexion Whittaker(2), Jeffreys(12) and also Reichenbach(25). 
classical mechanios in the correspondence principle limit and for the 'deterministic' quantum systems whose Hamiltonian is a second degree polynomial; the transformation function $K$ of $\S 9$, which is the probability distribution of $p$ and $q$ at time $t$ conditional in $p_{0}, q_{0}$, at time $t_{0}$, degenerates in the classical limit to a singular distribution, with complete concentration of the probability 'mass' on the classical path in phase-space issuing from $p_{0}, q_{0} ; K$ may then be expressed as a product of delta functions

$$
K=\delta\left[p-p\left(p_{0}, q_{0}, t-t_{0}\right)\right] \delta\left[q-q\left(p_{0}, q_{0}, t-t_{0}\right)\right],
$$

where $p$ and $q$ are the classical solutions as functions of the initial values $p_{0}, q_{0}$ and the interval $t-t_{0}$. The phase-space distributions $F$ at $t$, will be obtained from $F_{0}$ at $t_{0}$ by substituting the classical solutions for $p$ and $q$. This has been shown directly by Prof. M. S. Bartlett and the author in the 'deterministic' cases of the free and uniformly accelerated particle and the harmonic oscillator.

Owing to the fact that the transformation is unitary, the eigenvalues of the integral equations $(9 \cdot 8),(9 \cdot 9)$ are all of modulus 1 ; in fact, of the form

$$
\lambda_{i k}=e^{i\left(E_{i}-E_{u}\right)\left(t-t_{0}\right) / \hbar} .
$$

In the theory of discrete Markoff processes (where the random variables have only a discrete and finite set of possible values) characteristic roots of modulus I for the transformation matrix correspond to deterministic processes (non-degenerate processes involving roots of the form $\left.\left|e^{-\mu\left(t-t_{0}\right)}\right|<1\right)$. Yet we saw above that the quantum mechanical process is not deterministic in the classical sense. The explanation of this discrepancy must await the further study of unitary-Markoff processes of this type.

\section{QUANTUM STATISTICS}

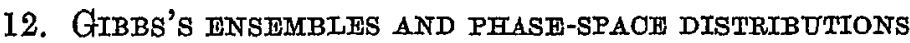

A possible field of application for the statistical approach to quantum mechanics lies in the kinetic theories of matter, where the joint distributions of coordinates, and momenta are required. As a first step in this direction, we shall study the equilibrium distributions in large assemblies of similar systems.

The notion of Gibbs's ensemble is translated into the quantum theory of statistical assemblies by introduoing 'mixed' states, where the assembly has a probability $P_{n}$ to be in a state $\psi_{n}$ and the average of any dynamical variable $G$ is given by the diagonal sum

$$
\vec{G}=\sum_{n}\left(\psi_{n}, \mathrm{G} \psi_{n}\right) P_{n}
$$

(Dirac (13)); the introduction of Gibbs's ensembles in quantum theory is due to von Neumann. The phase-spane distribution corresponding to a Gibbs's ensemble may be found in accordance with the method of $\$ 3$, by calculating the mean of $e^{i \Sigma_{\sigma}\left(\tau_{\sigma} \tau_{\sigma}+\theta_{\sigma} \delta_{\sigma}\right)}$ from (12.1) $\left(r_{\sigma}, s_{\sigma}\right.$ being the dynamical variables charaoterizing the assembly), and taking its Fourier inverse. For the Cartesian coordinates and momenta of an assembly of $N$ degrees of freedom

$$
M\left(\tau_{\sigma}, \theta_{\sigma}\right)=\sum_{n} P_{n} \int_{(N)} \int_{n} \psi_{n}^{*}\left(q_{\sigma}\right) e^{i \Sigma_{\sigma}\left(\tau_{\sigma}{\nabla_{\sigma}}_{\sigma}+\theta_{\sigma} q_{\sigma}\right)} \psi_{n}\left(q_{\sigma}\right) d q_{1} \ldots d q_{N}
$$


and the phase-space distribution $\rho$ is a sum of diagonal eigenfunctions $\rho_{n}$ (see $\$ 3$ and 4 )

$$
\begin{aligned}
& \rho\left(p_{\sigma}, q_{\sigma}\right)=\sum_{n} \rho_{n}\left(p_{\sigma}, q_{\sigma}\right) P_{n} \\
& \rho_{n}\left(p_{\sigma}, q_{\sigma}\right)=(2 \pi)^{-N} \int_{(N)} \int \psi_{n}^{*}\left(q_{\sigma}-\frac{1}{2} \hbar \tau_{\sigma}\right) e^{-i \Sigma_{\sigma} \tau_{\sigma} p_{\sigma}} \psi_{n}\left(q_{\sigma}+\frac{1}{2} \hbar \tau_{\sigma}\right) d \tau_{1} \ldots d \tau_{N} \\
& =h^{-i N} e^{i(\hbar / i) \Sigma_{\sigma} \partial^{2} / \partial p_{\sigma} \partial \alpha_{\sigma}}\left[\psi_{n}^{*}\left(q_{\sigma}\right) \phi_{n}\left(p_{\sigma}\right) e^{i \Sigma_{\sigma} p_{\sigma} q_{\sigma} / \hbar}\right],
\end{aligned}
$$

where $\psi_{n}\left(q_{\sigma}\right), \phi_{n}\left(p_{\sigma}\right)$ are the eigenfunotions in $q_{\sigma}, p_{\sigma}$ representations respectively.

Since each term $\rho_{n}$ in the right-hand side of $(12 \cdot 3)$ is a solution of the phase-space equation of the motion (7.8), the transformation with time of $\rho$ will be governed by the same equation, which now appears as a generalization of Liouville's theorem for the probability densities in phase-space of statistical assemblies. Introducing the phasespace differential operator of a Poisson bracket

we have symbolically $\frac{\partial \rho}{\partial t}+\frac{2}{\hbar} \sin \frac{\hbar}{2}\left\{\frac{\partial}{\partial p_{\sigma}}, \frac{\partial}{\partial q_{\sigma}}\right\} H \rho=0$.

It has been held that the existence of Gibbs's ensembles 'is rather surprising in view of the fact that phase-space has no meaning in quantum mechanics' (Dirac(13)). This apparent paradox is removed by the statistical approach to quantum theory, which leads, as seen above, to an interpretation of ensembles closely analogous to that of classical statistical mechanics.

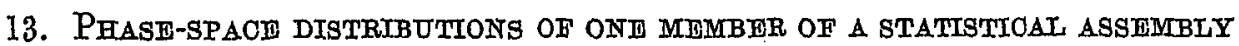

We consider now an assembly of similar particles in weak interaction. For a given energy $E_{n}$ of the whole assembly, we find complexions $\alpha_{n}$ with $a_{1}$ particles of energy $\epsilon_{1}, a_{2}$ of energy $\epsilon_{2}, \ldots, a_{k}$ of energy $\epsilon_{l \epsilon}, N=\sum_{1}^{k} a_{i}$, and $E_{n}=\sum_{1}^{l} a_{i} \epsilon_{i}$. Assume at first that the energy eigenstates of individual particles are non-degenerate. The eigenfunctions corresponding to $\alpha_{n}$ are

$$
\left.\begin{array}{ll}
\text { M.B. case: } & \psi_{\alpha_{n}}=u_{1}\left(q_{1}\right) u_{1}\left(q_{2}\right) \ldots u_{1}\left(q_{a_{1}}\right) u_{2}\left(q_{a_{1}+1}\right) \ldots u_{k}\left(q_{N}\right), \\
\text { B.E. case: } & \psi_{a_{n}}=(N !)^{-\frac{1}{-}} \sum_{P} P\left[u_{1}\left(q_{1}\right) u_{1}\left(q_{2}\right) \ldots u_{k}\left(q_{N}\right)\right], \\
\text { F.D. case: } & \psi_{a_{n}}=(N !)^{-\ddagger} \sum_{p} \pm P\left[u_{1}\left(q_{1}\right) u_{1}\left(q_{2}\right) \ldots u_{k}\left(q_{N}\right)\right],
\end{array}\right\}
$$

where M.B. refers to a Maxwell-Boltzmann, B.E. to a Bose-Einstein (symmetrical), and F.D. to a Fermi-Dirac (antisymmetrical), assembly, $P$ denotes all the permutations of the $q_{\sigma}$, and the + or - signs in the F.D. case refer to even or odd permutations. The numbers of distinct wave functions for each energy $E_{n}$ are

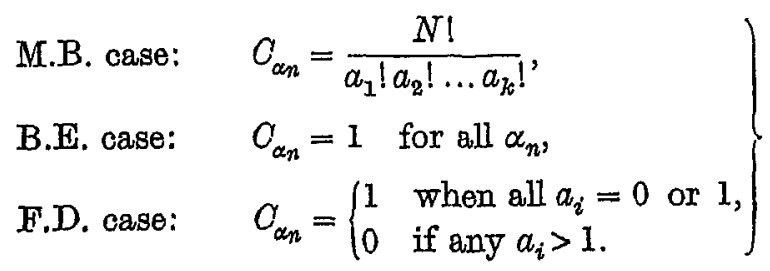


The phase-space distribution $\rho\left(p_{\sigma}, q_{\sigma}\right)$ and eigenfunctions $\rho_{\alpha_{n}}\left(p_{\sigma}, q_{\sigma}\right)$ for the assembly are obtained by substituting from $(13 \cdot 1)$ in $(12 \cdot 3),(12 \cdot 4)$. It is easily seen that in the M.B. case $\rho_{\alpha_{n}}$ is a product of diagonal eigenfunotions $f_{i i}(p, q)$ of the individual particles only, while in the B.E. and F.D. cases, non-diagonal eigenfunctions occur too.

The phase-space distribution for one particle is obtained by integrating over the coordinates and momenta of the remaining particles

$$
f\left(p_{1}, q_{1}\right)=\int_{2\left(N_{-1}\right)} \int \rho\left(p_{\sigma}, q_{\sigma}\right) d p_{2} d q_{2} d p_{3} d q_{3} \ldots d p_{N} d q_{N} .
$$

Owing to this integration, all terms in $\rho_{\alpha_{n}}$ involving non-diagonal eigenfunction cancel, because $\iint f_{i k} d p d q=\delta_{i l}$. Hence in all three cases $f\left(p_{1}, q_{1}\right)$ appears as a sum of diagonal eigenfunctions

$$
f\left(p_{1}, q_{1}\right)=\sum_{i} n_{i} f_{i i}\left(p_{1}, q_{1}\right) .
$$

It is easily shown that the $n_{i}$ are simply the average frequencies of the occupation numbers $a_{i}$ of $(13 \cdot 1)$. Introducing a canonical ensemble, where the $P_{n}$ of $(12 \cdot 3)$ are proportional to $e^{-E_{n} / / k T}$, we obtain

$$
n_{i}=\sum_{n, \alpha_{n}} \frac{a_{i}}{N} C_{\alpha_{n}} e^{-E_{n} / l k T} / \sum_{n, \alpha_{n}} C_{a_{n}} e^{-E_{n} l / k T}
$$

By substituting from (13.2) for the $O_{\alpha_{n}}$, the $n_{i}$ can be calculated by the method of 'sums-over-states' (Schrödinger (14)), leading to the well-known expressions

$$
n_{i}=\frac{1}{(1 / \xi) e^{\varepsilon_{i} / k T}-\gamma}
$$

$$
\text { M.B. case: } \gamma=0 \text {; B.E. case: } \gamma=1 \text {; F.D. case: } \gamma=-1 \text {, }
$$

which can be substituted in (13.4) to give an explicit expression for the phase-space distribution of one member of an assembly. As usual in equilibrium theory, all results are independent of the type of ensemble provided that the dispersion of the total energy is sufficiently small.

The effect of degeneracy of the individual energy eigenstates is to introduce nondiagonal terms in (13.4). As a result, the $n_{i}$ must be multiplied by the corresponding order of degeneracy $w_{i}$, while the $f_{i i}$ must each be replaced by

$$
\overline{f_{i i}}\left(p_{1}, q_{1}\right)=\frac{1}{w_{i}} \sum_{k, l} f_{i i, k l}\left(p_{1}, q_{1}\right)
$$

where the indices $k, l$ refer to the degenerate phase-space eigenfunctions at the $i$ th level, supposed orthogonal.

The foregoing may be used to justify the introduction of ensembles in quantum theory. If we think of an ensemble as an assembly of similar assemblies, then the distribution of one assembly will have the diagonal expansion (12.3) for the same reason that the distribution of one particle in an assembly has the diagonal expansion (13.4), even if the ensemble is in a pure state. If the ensemble consists of an infinite number of distinguishable assemblies, then the coefficients $P_{n}$ of the expansion must be M.B. factors $e^{-E_{n} / k T}$ ( $E_{n}$ being now the energy of one whole assembly) and we thus have a canonical ensemble. 


\section{Quantum mechanics as a statistical theory}

We may compare averaging over an ensemble to averaging over time. If an assembly is in a pure state, non-diagonal terms in the expansion of its distribution function

$$
\rho\left(p_{\sigma}, q_{\sigma} ; t\right)=\sum_{i, k} a_{i}^{*} a_{k t} \rho_{i k}\left(p_{\sigma}, q_{\sigma}\right) e^{i\left(E_{i}-E_{k}\right) t / \hbar}
$$

cancel in a time average, leaving a diagonal expansion similar to (12-3). This is analogous to the ergodic principle of classical theory.

\section{JOINT PHASH-SPACE DISTRIBUTION FOR TWO MEMLBERS OF AN ASSEMREIX} The distribution function for two particles is obtained by integrating $\rho$ over the coordinates and momenta of the remaining particles.

$$
f\left(p_{1}, q_{1}, p_{2}, q_{2}\right)=\int_{2(N-2)} \int \rho\left(p_{\sigma}, q_{\sigma}\right) d p_{3} d q_{3} \ldots d p_{N} d q_{N}
$$

In the M.B. case, the integration of each eigenfunction $\rho_{\alpha_{n}}$ yields only products of diagonal eigenfunctions of the form $f_{i i}\left(p_{1}, q_{1}\right) f_{k k k}\left(p_{2}, q_{2}\right)$. In the other two cases, it is seen that if $i \neq k$, there will be in addition non-diagonal terms (obtained by permuting the two particles) $f_{i k}\left(p_{1}, q_{1}\right) f_{k i}\left(p_{2}, q_{2}\right)$, preceded by a + sign in the B.E. case, a - sign in the F.D. case. Other non-diagonal terms in $\rho_{\alpha_{n}}$ cancel by integration as in the case of a single particle. Hence we can write for all three cases

$$
f\left(p_{1}, q_{1}, p_{2}, q_{2}\right)=\sum_{i, k} n_{i l} f_{i i}\left(p_{1}, q_{1}\right) f_{k k l}\left(p_{2}, q_{2}\right)+\gamma \sum_{i \neq k} n_{i k c} f_{i k}\left(p_{1}, q_{1}\right) f_{k i}\left(p_{2}, q_{2}\right),
$$

where $\gamma$ has the same meaning as in (13.7). The coefficients of this expansion are easily found to be for a canonical ensemble

$$
\left.\begin{array}{l}
n_{i l}=\sum_{n, \alpha_{n}} \frac{a_{i} a_{k}}{N(N-1)} C_{\alpha_{n}} e^{-E_{n} k T} / \sum_{n, \alpha_{n}} C_{\alpha_{n}} e^{-E_{n} / k T} \quad(i \neq k) \\
n_{i i}=\sum_{n, \alpha_{n}} \frac{a_{i}\left(a_{i}-1\right)}{N(N-1)} C_{\alpha_{n}} e^{-E_{n} / k T} / \sum_{n, \alpha_{n}} C_{\alpha_{n}} e^{-E_{n} l k T}
\end{array}\right\} .
$$

Carrying out the summations in (14.3) by the 'sum-over-states' method, we find that the non-diagonal coefficients $(i \neq k)$ are

$$
n_{i k}=n_{i} n_{i k}
$$

where the $n_{i}$ are the average frequencies of the $a_{i}$, as given in (13.6), while the diagonal coefficients are

$$
\text { M.B. case: } n_{i i}=n_{i}^{2} \text {, B.E. case: } n_{i i}=2 n_{i}^{2} \text {, F.D. case: } n_{i i}=0 . \dagger
$$

The last (F.D. case) is of course a result of the exclusion principle. Substituting in (14.2) we have

$$
f\left(p_{1}, q_{1}, p_{2}, q_{2}\right)=\sum_{i, k} n_{i} n_{k_{k}} f_{i i}\left(p_{1}, q_{1}\right) f_{k l k}\left(p_{2}, q_{2}\right)+\gamma \sum_{i, k} n_{i} n_{k_{k}} f_{i k}\left(p_{1}, q_{1}\right) f_{k k}\left(p_{2}, q_{\mathrm{a}}\right)
$$

whioh may be written, after comparison with $(13 \cdot 4)$,

$$
f\left(p_{1}, q_{1}, p_{2}, q_{2}\right)=f\left(p_{1}, q_{1}\right) f\left(p_{2}, q_{2}\right)+\frac{1}{2} \gamma \sum_{i, k}\left[f_{i k}\left(p_{1}, q_{1}\right) f_{k i}\left(p_{2}, q_{2}\right)+f_{k i}\left(p_{1}, q_{1}\right) f_{i k}\left(p_{2}, q_{2}\right)\right]
$$

$\dagger$ Strictly spealking, the right-hand sides of $(14 \cdot 4)$ and $(14 \cdot 5)$ should be multiplied by a normalizing factor $\left(1+\gamma \sum_{i} n_{i}^{2}\right)$. 
We see thus that symmetry (or antisymmetry) conditions introduce a probability dependence between any two particles in B.E. (or F.D.) assemblies even in the absence of any energy interaction. For example the coordinates and momenta of the two particles will be correlated, with covariance

$$
\left.\begin{array}{l}
\mu\left(q_{1} q_{2}\right)=\overline{q_{1} q_{2}}-\overline{q_{1}} \overline{q_{2}}=\gamma \sum_{i, k} n_{i} n_{k}\left|Q_{n k}\right|^{2}, \\
\mu\left(p_{1} p_{2}\right)=\overline{p_{1} p_{2}}-\overline{p_{1}} \overline{p_{2}}=\gamma \sum_{i, k} n_{i} n_{k}\left|P_{n k}\right|^{2},
\end{array}\right\}
$$

where $Q_{n k}, P_{n k}$ are the matrices of the individual q's and p's,

$$
Q_{n k}=\iint q f_{n k}(p, q) d p d q, \quad P_{n k}=\iint p f_{n l c}(p, q) d p d q .
$$

It is this dependence which gives rise to the 'exchange energy' between the particles when they interact.

\section{LIMITATIONS OF THE STATISTICAL APPROACH TO QUANTUM THIMORY}

The results obtained so far seem to offer a fairly complete scheme for treating quantum mechanics as a form of statistical dynamics. It is important now to return to the difficulties mentioned at the beginning of this paper, and discuss the limitations of this approach.

First, we notice that phase-space eigenfunctions must generally take negative as well as positive values, since they are orthogonal. Only one eigenfunction (generally the ground state one) may possibly be non-negative for all values of the dynamical variables, except for singular eigenfunctions involving delta functions, such as the momenta eigenfunctions (4.13). Hence, on taking for example Cartesian coordinates and momenta $p, q$ as the basic system, the phase-space distribution in the $n$th energy eigenstate formed according to the method of $\S 3$ would be the diagonal eigenfunction, $f_{n n}(p, q)$, which can be negative, and is therefore not a true probability. This is not really surprising, because we have seen in $\S \theta$ that the dynamical equations are those of a Markoff process. The existence of eigenfunction solutions for the fundamental equations (9.8), (9.9) of Markoff processes is well known (see Hostinsky (11)), and it is also known, that these eigenfunctions are not generally probabilities by themselves. Probability distributions are expressed as non-negative linear combinations of these eigenfunctions.

In the language of quantum theory, we may say that true probability distributions of any given set of non-commuting variables do not exist for every state; the physical interpretation would be that where the distribution, as calculated by the method of $\S 3$, can take negative values, it is not an observable quantity. This is a restatement of the necessity, already discussed in $\S 2$, for postulating the existence of different phase-space distributions according to the basic set of dynamical variables. Take, for example, a system composed of one proton and one electron. The distribution $F^{\prime}(p, q)$ corresponding to the $\psi(q)$ of a Gaussian wave-packet is positive for all $p$ and $q$, and is hence an observable quantity. On the other hand, there would be no observable $(p, q)$ 
distributions for the energy eigenstates of a hydrogen atom, though an observable distribution may exist for some other set of variables.

It is usually accepted that a dynamical variable $\mathrm{G}$ is exactly equal to its eigenvalue $g_{n}$ when the system is in the corresponding eigenstate. This means that the operator $W$ corresponding to the function $W(G)$ should be equal to the function $W$ of the operator $\mathbf{G}, \mathbf{W}=W(\mathbf{G})$, since if $G$ is exactly equal to $g_{n}$ the mean of $W$ is $\bar{W}=W\left(g_{n}\right)$, and hence $\bar{W}=\left(\psi_{n}, W \psi_{n}\right)=\left(\psi_{n}, W(\mathbf{G}) \psi_{n}\right)=\left(\psi_{n}, W\left(g_{n}\right) \psi_{n}\right)=W\left(g_{n}\right)$.

Now it is easily seen (Appendix 5) that according to the theory of functions of $\S 5$ this condition is fulfilled only when $G$ is a function of some linear combination of the brsic variables $r, s: G(a r+b s)$. This again is connected with the necessity for phase-space distributions adapted to the experimental situation; if the latter involves observation of $G$, then the distributions must be set up for some set of variables $r, s$ such that $G=G(a r+b s)$.

In order for the scheme to be consistent, it should be possible to prove that if a state $\psi$ admits a non-negative phase-space distribution $F$ at the time $t=0$, then $F$ will be non-negative at any time $t$. This is easily seen for isolated systems possessing at least one cyclic coordinate $\theta$. Suppose that $\theta$ and its conjugate $g$ are obtained by a canonical transformation from the original system $q_{i}, p_{i}$, and let $Q_{i}, P_{i}$ be the other (transformed) coordinates and momenta, $H\left(g, \theta, P_{i}, Q_{i}\right)$ the transformed Hamiltonian. Then

$$
\frac{\partial H}{\partial \theta}=0, \quad \frac{\partial H}{\partial g}=\text { constant }=\omega .
$$

The transformed equation of the motion $(7 \cdot 8)$ can be written

$$
\frac{\partial F}{\partial t}+\omega \frac{\partial F}{\partial \theta}+\frac{2}{\hbar} \sin \frac{\pi}{2}\left\{\frac{\partial}{\partial P_{i}}, \frac{\partial}{\partial Q_{i}}\right\} H F=0 .
$$

Separating the variables, we have

$$
\left.\begin{array}{rl}
F\left(g, \theta, P_{i}, Q_{i} ; t\right) & =F_{1}(\theta, t) F_{r}\left(g, P_{i}, Q_{i}\right), \\
\frac{1}{F_{1}}\left(\frac{\partial F_{1}}{\partial t}+\omega \frac{\partial F_{1}}{\partial \theta}\right) & =2 i \mu \quad(\mu \text { constant }), \\
F_{1} & =e^{i \mu(t+\theta \mid \omega) .}
\end{array}\right\}
$$

Comparing with the expansion of $F$ in energy eigenfunctions, we see that it must be of the form

$$
F\left(g, \theta, P_{i}, Q_{i} ; t\right)=\sum_{i, k} a_{i}^{*} a_{l l} Q_{i k}\left(g, P_{i}, Q_{i}\right) e^{i\left(\left(E_{i}-E_{k}\right)(l+\theta)(\omega)\right\} t \pi} .
$$

Hence, if $F \geqslant 0$ for all $\theta$ at $t=0$, it must be non-negative for all $t$. This proof was suggested to the author by Prof. M. S. Bartlett.

Finally, we may discuss the meaning in the present theory of observables having no classical analogue. $\$$ 2-5 on quantum kinematios are framed so as to apply to such observables as well as to those having a classical analogue. The phase-space distributions represent for both types the joint distributions of eigenvalues for non-commuting sets, and are subject to the same restrictions. The quantum equations of motion in phase-space, on the other hand, were expressed only for Cartesian coordinates and momenta, so as to bring out the relationship with the theory of general stochastio 
processes. It is clear, however, that they can be extended to general quantum observables, say $\mathbf{r}$ and $\mathbf{s}$. If $F(r, s, t)$ is their joint distribution, then as in $\S 7, \partial F / \partial t$ is obtained by Fourier inversion of

where $\mathbf{M}=e^{i(x+0 s)}$

$$
\frac{\partial M}{\partial t}=\left(\psi^{*}, \frac{i}{\hbar}[\mathbf{M}, \mathbf{H}] \psi\right)
$$

\section{Pradtrdat appLIOATIONS OF THE THEORY}

The foregoing restrictions are necessary as long as we require probabilities in phasespace. They may be relaxed in practical applications of the theory, where we introduce phase-space distributions as aids to calculation, and where the observable quantities we wish to calculate are necessarily non-negative, independently of whether the phasespace distribution takes negative values or not. It is not difficult to see that the phasespace distributions and eigenfunctions obtained by the rules of $\S \S 3$ and 4, though not necessarily non-negative, obey the other fundamental rules of probability theory, i.e. the addition and multiplication laws. Bartlett (15) has discussed the introduction of such 'negative probabilities' as aids to calculation, and has shown that they can be manipulated according to the rules of the calculus of probabilities (with suitable precautions) provided we combine them in the end to give true (non-negative) probabilities. He remarks that ' where negative probabilities have appeared spontaneously in quantum theory, it is due to the mathematical segregation of systems or states which physically only exist in combination'.

Now this relaxation will be possible in practical applications, because the phasespace distributions oontain more information than is generally required for comparison with observations. For example, if we wish to calculate the way the distribution in space $\rho(q ; t)$ of a wave-packet varies with time, we may use the method of $\S 10$, because $\rho(q ; t)=\int F(p, q ; t) d p=\psi(q ; t) \psi^{*}(q ; t)$ will never be negative, even if $F(p, q ; t)$ can be negative. Similarly, transition probabilities calculated by the method outlined in the same paragraph will always be non-negative, whether $F$ takes negative values or not. Finally, we may use the methods of $\$$ 12-14 to calculate the phase-space distributions of members of an assembly even if the phase-space distribution for the whole assembly can be negative.

We conclude that in applications of the theory, we need not be concemed whether the phase-space distributions are true probabilities, provided that the final results, expressed either as linear combinations of these distributions or as integrals over part of their range, are necessarily true, non-negative probabilities.

\section{UNIQUXNESS OF THE THEORY AND POSSIBTLITIES OF EXPERTMENTAI VERIFICATTON}

The statistical approach to quantum theory involves the introduction of an additional postulate on the form of the phase-space distribution, which is equivalent to a theory of functions of non-commuting observables. The choice of this postulate is not unique. Dirac (16) has given a theory of functions of non-commuting observables which differs from the one obtained in $\S 5$ of this paper; it has the advantage of being 


\section{Quantum mechanics as a statistical theory}

independent of the basic set of variables, but, as might be expected from the foregoing disoussion, it leads to complex quantities for the phase-space distributions which can never be interpreted as probabilities. $\dagger$

It is natural to ask therefore whether any experimental evidence is obtainable on this subject. In so far as observable results calculated by such theories are equivalent to those obtained by orthodox methods, e.g. transition probabilities, or distributions of coordinates only, this is obviously impossible. However, though the simultaneous measurement of coordinates and momenta is not possible for single particles, there is some hope that experiments on large number of particles might be devised to verify the phase-space distributions predicted by the theory. Altermatively, one might hope to verify the corresponding theory of functions of non-commuting observables if experimental evidence became available on some Hamiltonian involving products of $q$ and $p$.

\section{APPENDICES}

Appendix 1. Space-conditional averages of the momenta and the uncertainty relations The space-conditional moments $\overline{\overline{p^{n}}} \ddagger$ are the means of $p^{n}$ when $q$ is given. They may be obtained either from expression (4.14) for $F(p, q)$

$$
\begin{aligned}
\rho(q) \overline{\overline{p^{n}}} & =\int p^{n} F(p, q) d p \\
& =\iiint p^{n} \phi^{*}\left(p^{\prime}\right) \phi\left(p^{\prime \prime}\right) \delta\left(p-\frac{p^{\prime}+p^{\prime \prime}}{2}\right) e^{i q\left(p^{\prime \prime}-p^{\prime}\right) / \pi} d p d p^{\prime} d p^{\prime \prime} \\
& =\iint \phi^{*}\left(p^{\prime}\right) \phi\left(p^{\prime \prime}\right)\left(\frac{p^{\prime}+p^{\prime \prime}}{2}\right)^{n} e^{i g\left(p^{\prime \prime}-p^{\prime}\right) / \pi} d p^{\prime} d p^{\prime \prime} \\
& =\left(\frac{\hbar}{2 i}\right)^{n}\left\{\left(\frac{\partial}{\partial q_{1}}-\frac{\partial}{\partial q_{2}}\right)^{(n)} \psi\left(q_{1}\right) \psi^{*}\left(q_{2}\right)\right\}_{q_{1}=\alpha_{2}=q},
\end{aligned}
$$

where $\rho(q)=\int F(p, q) d p=\psi(q) \psi^{*}(q)$, or from the characteristic function $M(\tau \mid q)$ of $p$ conditional in $q$ (see Bartlett (17)) which is seen, from (3.7), to be

$$
M(\tau \mid q)=\frac{1}{\rho} \int F(p, q) e^{i \tau p} d p=\psi^{*}\left(q-\frac{1}{2} \hbar \tau\right) \psi\left(q+\frac{1}{2} \hbar \tau\right) / \psi^{*}(q) \psi(q)
$$

On writing

$$
\psi(q)=\rho^{\mathbf{t}}(q) e^{i \mathrm{~S}(Q) / \pi}
$$

the logarithm of $M(\tau \mid q)$ or 'cumulant' function (Kendall (18))

$K(\tau \mid q)=\log M(\tau \mid q)=\frac{1}{2} \log \rho\left(q+\frac{1}{2} \hbar \tau\right) \rho\left(q-\frac{1}{2} \hbar \tau\right)-\log \rho(q)+\frac{i}{\hbar}\left[S\left(q+\frac{1}{2} \hbar \tau\right)-S\left(q-\frac{1}{2} \hbar \tau\right)\right]$

leads to a simple expression for the 'oumulants' $\bar{\kappa}_{n}(q)$ (coefficients of $(i \tau)^{n} / n !$ in the Taylor expansion of $K$ )

$$
\bar{\kappa}_{2 n+1}(q)=\left(\frac{\hbar}{2 i}\right)^{2 n}\left(\frac{\partial}{\partial q}\right)^{2 n+1} S(q), \quad \bar{\kappa}_{n}(q)=\left(\frac{\hbar}{2 i}\right)^{2 n}\left(\frac{\partial}{\partial q}\right)^{2 n} \log \rho(q) .
$$

$\dagger$ Note added in proof. Reference should also be made to a recent paper by Feymman (26) giving an alternative approach.

$\ddagger$ The double bar - denotes a conditional moment, while a single bar - denotes a mean over the distribution of both $p$ and $q$. 
The $\bar{\kappa}_{n}$ bear simple relations to the moments $\overline{\overline{p^{n}}}$ (Kendall (18)). In particular, the first moment by both methods is

$$
\bar{\kappa}_{1}(q)=\overline{\bar{p}}(q)=\frac{\partial S}{\partial q},
$$

leading to the interpretation of the argument of the wave-function $\psi(q)$ as the potential $S(q)$ of the space-conditional mean $\overline{\bar{p}}(q)$. The conditional mean-square deviation is $\dagger$

$$
\bar{\kappa}_{2}(q)=\sigma_{p \mid q}^{2}=\overline{\overline{p^{2}}}-(\overline{\bar{p}})^{2}=-\frac{\hbar^{2}}{4} \frac{\partial^{2} \log \rho}{\partial q^{2}} .
$$

We note also that the asymmetry of a distribution depends only on its odd cumulants; hence the asymmetry of the conditional distribution of $p$ depends entirely on $S(q)$.

Formulae (A 1.6) and (A 1.7) lead directly to Heisenberg's inequality for the meansquare deviations of $p$ and $q$. Let $\alpha, \beta$ be any two random variables with zero means. We have the well-known Schwarz inequality

$$
\left|\left(\overline{\alpha^{2}} \overline{\beta^{2}}\right)\right|=\sigma_{\alpha} \sigma_{\beta} \geqslant|\overline{\alpha \beta}| \text {. }
$$

Now take $\alpha=\overline{\bar{p}}(q)$, where we suppose $\overline{\bar{p}}$ to become random when we allow $q$ to vary; take also $\beta=q$. Then from (A 1.8) above, and assuming (as can be done without loss of generality) that $\bar{p}=\bar{q}=0$, we obtain

$$
\sigma_{u} \sigma(\overline{\bar{p}}) \geqslant\left|\int q \overline{\bar{p}} \rho(q) d q\right|=\mid \bar{q} \bar{p} .
$$

Take now

$$
\begin{aligned}
\alpha & =\partial \log \rho / \partial q, \quad \bar{\alpha}=\int \frac{\partial \log \rho}{\partial q} \rho d q=0, \\
\overline{\alpha^{2}} & =\int\left(\frac{\partial \log \rho}{\partial q}\right)^{2} \rho d q=-\int \frac{\partial^{2} \log \rho}{\partial q^{2}} \rho d q=\frac{4}{\bar{\hbar}^{2}} \int \sigma_{p \mid q}^{2} \rho d q, \\
\overline{\alpha q} & =\int q \frac{\partial \log \rho}{\partial q} \rho d q=-1 .
\end{aligned}
$$

Hence, from (A 1.8),

$$
\sigma_{q}^{2} \int \sigma_{p / Q}^{2} \rho d q \geqslant \frac{1}{4} \hbar^{2}
$$

Since

$$
\sigma_{p}^{2}=\int\left[\sigma_{p \mid q}^{2}+(\overline{\bar{p}})^{2}\right] \rho d q
$$

the sum of the two inequalities (A 1.9) and (A 1.10) gives Heisenberg's inequality

$$
\sigma_{p}^{2} \sigma_{q}^{2} \geqslant(\overline{p q})^{2}+\frac{1}{4} \hbar^{2}
$$

This derivation of Heisenberg's inequality was pointed out to the author by Prof. M. S. Bartlett.

† The fact that $\sigma_{p \mid q}^{s}$ can be negative according to (A 1-7) results from the possibility of the formal expression for $F(p, q)$ being negative in certain states. The restrictions thus imposed on the interpretation of $F(p, q)$ as a probability are discussed in $\S 15$. 
Appendix 2. Orthogonality and completeness of the phase-space eigenfunctions for canonically conjugate variables

The orthogonality relations of the phase-space eigenfunctions for canonically conjugate variables can be seen quite simply. We have, from (4.11),

$\iint f_{l k}(p, q) f_{l^{\prime} k^{\prime}}(p, q) d p d q$

$$
\begin{aligned}
& =(2 \pi)^{-2} \iiint \int u_{l}^{*}\left(q-\frac{1}{2} \hbar \tau\right) u_{k}\left(q+\frac{1}{2} \hbar \tau\right) u_{\gamma^{\prime}}\left(q-\frac{1}{2} \hbar \tau^{\prime}\right) u_{k^{\prime}}^{*}\left(q+\frac{1}{2} \hbar \tau^{\prime}\right) e^{-i\left(\tau-\tau^{\prime}\right) p} d \tau d \tau^{\prime} d p d q \\
& =h^{-1} \iint u_{l}^{*}(x) u_{\eta^{\prime}}(x) u_{k}(y) u_{k^{\prime}}^{*}(y) d x d y=h^{-1} \delta_{l l^{\prime}} \delta_{k k^{\prime}}
\end{aligned}
$$

(the second line following from the change of variables $x=q-\frac{1}{2} \hbar \tau, y=q+\frac{1}{2} \hbar \tau$ ), and

$$
\begin{aligned}
\iint f_{l k}(p, q) d p d q & =(2 \pi)^{-1} \iiint u_{l}^{*}\left(q-\frac{1}{2} \hbar \tau\right) u_{k}\left(q+\frac{1}{2} \hbar \tau\right) e^{-i \tau p} d \tau d p d q \\
& =\int u_{l}^{*}(q) u_{l c}(q) d q=\delta_{l l k} .
\end{aligned}
$$

The completeness relations follow from the corresponding relation for the $u_{\imath}(q)$

$$
\begin{gathered}
\sum_{l, k} f_{l k}^{*}(p, q) f_{l k}^{*}\left(p^{\prime}, q^{\prime}\right) \\
=(2 \pi)^{-2} \iint \sum_{l, k} u_{l}^{*}\left(q-\frac{1}{2} \hbar \tau\right) u_{l}\left(q^{\prime}-\frac{1}{2} \hbar \tau^{\prime}\right) u_{k}\left(q+\frac{1}{2} \hbar \tau\right) u_{k^{\prime}}^{*}\left(q^{\prime}+\frac{1}{2} \hbar \tau^{\prime}\right) e^{i\left(\tau^{\prime} p^{\prime}-\tau p\right)} d \tau d \tau^{\prime} \\
=(2 \pi)^{-2} \iint \delta\left[(q-q)^{\prime}+\frac{1}{2} \hbar\left(\tau-\tau^{\prime}\right)\right] \delta\left[\left(q-q^{\prime}\right)-\frac{1}{2} \hbar\left(\tau-\tau^{\prime}\right)\right] e^{i\left(\tau^{\prime} p^{\prime}-\tau p\right)} d \tau d \tau^{\prime} \\
=h^{-1} \delta\left(q-q^{\prime}\right) \delta\left(p-p^{\prime}\right), \\
\sum_{l} f_{l l}(p, q)=(2 \pi)^{-1} \int \sum_{l} u_{l}^{*}\left(q-\frac{1}{2} \hbar \tau\right) u_{l}\left(q+\frac{1}{2} \hbar \tau\right) e^{-i \tau p} d \tau \\
=(2 \pi)^{-1} \int \delta(\hbar \tau) e^{-i \tau p} d \tau=h^{-1}
\end{gathered}
$$

Appendix 3. Operators corresponding to functions of canonically conjugate variables

The proof of $(5 \cdot 5)$ follows from expression $(3 \cdot 10)$ for the phase-space distribution $F(p, q)$.

$$
\begin{aligned}
& \overline{G(p, q)}=\iint G(p, q) F(p, q) d p d q
\end{aligned}
$$

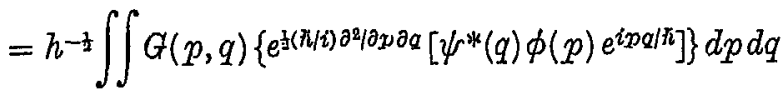

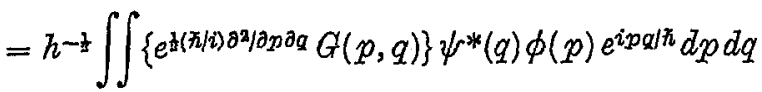

$$
\begin{aligned}
& =\int \psi^{*}(q)\left\{e^{\frac{z}{(\pi / 2) \partial^{2} / \partial p \partial q}} \mathbf{G}_{0}(\mathbf{q}, \mathbf{p})\right\} \psi(q) d q \\
& =\int \psi^{*}(q) \mathbf{G} \psi(q) d q
\end{aligned}
$$

and hence

$$
\mathbf{G}=e^{\underline{z}(\boldsymbol{z} / i) \partial^{2} / \partial p \partial q} \mathbf{G}_{0}(\mathbf{q}, \mathbf{p})
$$


The operator corresponding to a function

$$
G(p, q)=\sum_{n} \mu_{n}(q) p^{n}
$$

is obtained very simply from $(A 1 \cdot 1)$. We have

and hence

$$
\begin{aligned}
\overline{\mu_{n}(q) p^{n}} & =\int \mu_{n}(q) \overline{p^{n}} \rho(q) d q \\
& =\left(\frac{\hbar}{2 i}\right)^{n} \int \mu_{n}(q)\left\{\left(\frac{\partial}{\partial q_{1}}-\frac{\partial}{\partial q_{2}}\right)^{(n)} \psi\left(q_{1}\right) \psi^{*}\left(q_{2}\right)\right\}_{q_{1}=q_{2}=q} d q \\
& =\int \psi^{*}(q)\left\{\sum_{k=0}^{n}\left(\begin{array}{l}
n \\
c
\end{array}\right) \mathbf{p}^{p^{k}} \mu_{n}(\mathbf{q}) \mathbf{p}^{n-k}\right\} \psi(q) d q
\end{aligned}
$$

This could also be derived from (A 3.2) (cf. MoCoy (10)).

\section{Appendix 4. Transport equations and the Schrödinger equation}

The 'transport' equation of any quantity $g(p, q, t)$ is defined as the equation governing the time variation of the mean $\overline{\bar{g}}(q, t)$ at every point $q$ (space-conditional mean). It is obtained from (7.7) or (7.8) by integrating over the momenta $p$ and making use of the expressions in Appendix 1 for the conditional moments of $p$. In the case of a particle of mass $m$, charge $e$ in an electromagnetic field, whose classical Hamiltonian is

$$
H\left(p_{i}, q_{i}\right)=\frac{1}{2 m} \sum_{i}\left(p_{i}-\frac{e}{c} A_{i}\right)^{2}+V\left(q_{i}, t\right) \quad(i=1,2,3)
$$

$\left(A_{i}\left(q_{l_{k}}, t\right)\right.$ being the vector, $V\left(q_{l_{e}}, t\right)$ the scalar, potentials) integration of $(7 \cdot 8)$ and substitution of $\overline{\overline{p_{i}}}=\partial S / \partial q_{i}$ from $(A 1 \cdot 6)$ lead to the continuity equation

$$
\frac{\partial \rho}{\partial t}+\sum_{i} \frac{\partial}{\partial q_{i}}\left(\rho \frac{\partial S}{\partial q_{i}}\right)=0
$$

where $\rho\left(q_{i}\right)$ is the distribution function of the coordinates. Multiplying $(7 \cdot 8)$ by $p_{k}$ and integrating gives the transport equation for $\overline{\overline{p_{k}}}$

$$
\frac{\partial}{\partial t}\left(\rho \overline{\overline{p_{k}}}\right)+\sum_{i} \frac{\partial}{\partial q_{i}}\left(\rho \overline{\overline{\partial p_{k}}} \overline{\frac{\partial \vec{H}}{\partial q_{i}}}\right)+\rho \frac{\overline{\overline{\partial H}}}{\partial q_{k}}=0 .
$$

Substituting in the above from (A I.6) and (A 1.7), and combining with (A 4.2), we find

$$
\frac{\partial}{\partial q_{k}}\left\{\frac{\partial S}{\partial t}+\overline{\bar{H}}-\frac{\hbar^{2}}{8 m \rho} \sum_{i} \frac{\partial^{2} \rho}{\partial q_{i}^{2}}\right\}=0 \quad(k=1,2,3) .
$$

Hence the quantum-mechanical equivalent of the classical Hamilton-Jacobi equation

$$
\frac{\partial S}{\partial t}+\overline{\bar{H}}=\frac{\hbar^{2}}{8 m \rho} \nabla^{2} \rho
$$

Substituting $\rho=\psi \psi^{* *}$ and $S=\pi / 2 i \log \left(\psi / \psi^{*}\right)$ and adding and subtracting (A 4.2) and (A 4.5) we find the Schrödinger equation of a charged particle in the field

$$
\frac{1}{2 m} \sum_{i}\left(\frac{\hbar}{i} \frac{\partial}{\partial q_{i}}-\frac{e}{c} A_{i}\right)^{2} \psi+\nabla \psi=i \hbar \frac{\partial \psi}{\partial t} \text {. }
$$


Appendix 5. Operators corresponding to functions of linear combinations of the basic variables

According to $(5 \cdot 2)$ and $(5 \cdot 3)$, the operator corresponding to $G(a r+b s)$, where $a$ and $b$ are constants, is

$$
\mathbf{G}=\iint e^{i(\tau \boldsymbol{x}+\theta \boldsymbol{\theta})} d \tau d \theta \iint G(a r+b s) e^{-i(\tau r+\theta s)} d r d s .
$$

Changing to the variables

$$
\xi=a r+b s, \quad \eta=a r-b s, \quad \lambda=\frac{\tau}{2 a}+\frac{\theta}{2 b}, \quad \mu=\frac{\tau}{2 a}-\frac{\theta}{2 b},
$$

we find

$$
\begin{aligned}
\mathbf{G} & =\iint e^{i[(\lambda+\mu) a \mathbf{r}+(\lambda-\mu) b \boldsymbol{s}]} d \lambda d \mu \iint G(\xi) e^{-i[\lambda \xi+\mu \eta]} d \xi d \eta \\
& =\int e^{i \lambda(a \mathbf{s}+b \mathbf{s})} d \lambda \int G(\xi) e^{-i \lambda \xi} d \xi=G(a \mathbf{r}+b \mathbf{s})
\end{aligned}
$$

I should like to acknowledge my indebtedness to Profs. P. A. M. Dirac, H. Jeffreys and the late R. H. Fowler for their criticisms, suggestions and encouragement in carrying out this work, and my gratitude to Prof. M. S. Bartlett for many invaluable discussions and the communication of his various results referred to in the text. M. J. Bass and Dr H. J. Groenewold have studied the same subject independently (cf. Bass (19) (20), Groenewold(21)), and I have benefited from discussions and correspondence with them. The papers of Powell (22), Stueckelberg (23). Dedebant (24) and Reichenbach's book(25) also have a bearing on the questions discussed in the present paper (I am indebted to Prof. Bartlett for these last references).

\section{SUMMARY}

An attempt is made to interpret quantum mechanics as a statistical theory, or more exactly as a form of non-deterministic statistical dynamics. The paper falls into three parts. In the first, the distribution functions of the complete set of dynamical variables specifying a mechanical system (phase-space distributions), which are fundamental in any form of statistical dynamics, are expressed in terms of the wave vectors of quantum theory. This is shown to be equivalent to specifying a theory of functions of non-commuting operators, and may hence be considered as an interpretation of quantum kinematics. In the second part, the laws governing the transformation with time of these phase-space distributions are derived from the equations of motion of quantum dynamics and found to be of the required form for a dynamical stochastic process. It is shown that these phase-space transformation equations can be used as an alternative to the Schrödinger equation in the solution of quantum mechanical problems, such as the evolution with time of wave packets, collision problems and the calculation of transition probabilities in perturbed systems; an approximation method is derived for this purpose. The third part, quantum statistics, deals with the phase-space distribution of members of large assemblies, with a view to applications of quantum mechanics to kinetic theories of matter. Finally, the limitations of the theory, its uniqueness and the possibilities of experimental verification are discussed. 
J. E. MoyaI

\section{REFERENCES}

(1) Dirao, P. A. M. Commun. Dublin Inst. Adv. Stud. A, I (1943), 11.

(2) WhitTakgr, ti. T. Proc. Phys. Soc., London, 55 (1943), 459-70.

(3) DIRAC, P. A. M. The principles of quantum mechanics (2nd ed., Cambridge, 1935), p. 48.

(4) JETHRAYs, H. Phil. Mag. 32 (1941), 195.

(5) Hrisensera, W. The physical principles of the quantum theory (Cambridge, 1930), p. 34.

(6) Crambr, H. Random variables and probability distributions (Cambridge, 1937), p. 24.

(7) Kremaok, W. O. and MoCrea, W. H. Proc. Edinburgh Math. Soc. 2, series 2 (1931), 224.

(8) WIGNerR, E. Phys. Rev, 40 (1832), 749.

(9) WEYL, H. The theory of groups and quantum mechanics (London, 1931), p. 274.

(10) McCox, N. H. Proc. Nat. Acad. Sci., Wash., 18 (1932), 674.

(11) Hostinsky, M. B. Méthodes générales du calcul des probabilités (Paris, 1931), p. 47.

(12) Jermptrys, H. Phil. Mag. 33 (1942), 815.

(13) Dirad, P. A. M. The principles of quantum mechanics (2nd ed., Cambridge, 1935), pp. 140-2.

(14) SolezöDnvamR, E. Statistical thermodynamics (Cambridge, 1946), p. 43.

(15) Barmetett, M. S. Proc. Cambridge Phil. Soc. 41 (1944), 71.

(16) Drrao, P. A. M. Rev. Mod. Phys. 17 (1945), 195-9.

(17) BARTiETT, M. S. J. London Math. Soc. 13 (1938), 62-7.

(18) KENDATL, M. G. The advanced theory of statistics, 1 (London, 1943), 60, 90.

(19) BAss, J. Oomptes Rendus, 221 (1945), 46-9.

(20) BAss, J. Rev. Scient. 3240 (1945), 11-18.

(21) GROENawold, H. J. Physica, 12 (1946), 405-60.

(22) Powert, F. C. Proc. Cambridge Phil. Soc. 41 (1945), 57.

(23) Sturokeuberg, E. O. G. Helv. Phys. Acta, 18 (1945), 195.

(24) DmDerbant, G. Portugaliae Physica, 2 (1946), 149.

(25) ReronendaOE, H. Philosophic foundations of quantum mechanics (Berkeley and Los Angeles, 1946).

(26) Feymman, R. P. Rev. Mod. Phys. 20 (1948), 367-87.

\section{Department ofr Mathematical Phystos \\ THE QUEHA's UNIVERSITY, BHLFAST}




\title{
$[545]$
}

\section{THE EXACT TRANSTTION PROBABILITIES OF QUANTUM- MECHANICAL OSCILLATORS CALCULATED BY THE PHASE-SPACE METHOD}

\author{
BY M. S. BARTLETT AND J. E. MOYAL
}

Received 14 September 1948

\section{INTRODUCTION}

The calculation by the usual perturbation methods of transition probabilities between the unperturbed states of a quantum-mechanical system yields approximate results, valid only for small perturbations. The object of this paper is to calculate the exact transition probabilities between the unperturbed states of quantum oscillators, valid for large as well as small perturbations, by using the 'phase-space' method developed by one of the authors (Moyal (1), referred to henceforth as (I)).

We give first the main results of $(I)$ required in this paper. The probability distribution in phase-space of a system in a state described by the wave-function $\psi(q)$ in $q$-space is $†$

$$
F(p, q)=\frac{1}{2 \pi} \int \psi^{*}\left(q-\frac{1}{2} \hbar \tau\right) e^{-i \tau p} \psi\left(q+\frac{1}{2} \hbar \tau\right) d \tau
$$

Corresponding to the expansion of $\psi(q ; t)$ in terms of energy eigenfunctions $u_{n}(q)$

$$
\psi(q ; t)=\sum_{n} a_{n} u_{n}(q) e^{-i E n d / \pi}
$$

we have an expansion for $F(p, q ; t)$

$$
I F(p, q ; t)=\sum_{k, n} a_{i c}^{*} a_{n} f_{k n}(p, q) e^{\left.i\left(E_{k}\right)-E_{n}\right) t / \hbar}
$$

in terms of the energy phase-space eigenfunctions

$$
f_{l i n}(p, q)=\frac{1}{2 \pi} \int u_{k}^{*}\left(q-\frac{1}{2} 7 i \tau\right) e^{-i \tau)} u_{n}\left(q+\frac{1}{2} \hbar i \tau\right) d \tau .
$$

These functions form a complete orthogonal system in phase-space which is also 'selforthogonal' and hermitian with respect to the indices $k, n$, i.e.

$$
\iint f_{k n} f_{k^{\prime} n^{\prime}}^{*} d p d q=h^{-1} \delta_{k k^{\prime}} \delta_{n n^{\prime}}, \quad \iint f_{k n} d p d q=\delta_{k n}, \quad f_{l k n}=f_{n k k^{\prime}}^{*}
$$

Furthermore, the matrix $G_{l e n}$ corresponding to an ordinary function $G(p, q)$ is given by

$$
G_{k n}=\iint G(p, q) f_{k n}(p, q) d p d q \text {. }
$$

The transformation with time of $F(p, q ; t)$ corresponding to the quantum equations of the motion is given symbolically by

$$
\frac{\partial}{\partial t} F(p, q ; t)=\frac{2}{\hbar} \sin \left\{\frac{\hbar}{2}\left(\frac{\partial}{\partial p_{F}} \frac{\partial}{\partial q_{H}}-\frac{\partial}{\partial p_{H}} \frac{\partial}{\partial q_{T}}\right)\right\} H(p, q) F(p, q ; t)
$$

† When no limits are specified, all integrals are to be taken as from $-\infty$ to $+\infty$. 
546

M. S. BartuetT and J. E. Moyad

where $\partial / \partial p_{H}, \partial / \partial q_{H}$ operate only on the classical Hamiltonian $H(p, q)$ of the system; $\partial / \partial p_{F}, \partial / \partial q_{F}$ on $F(p, q, t)$. This is seen to be an extension of Liouville's theorem

$$
\frac{\partial F}{\partial t}=\frac{\partial H}{\partial q} \frac{\partial F}{\partial p}-\frac{\partial H}{\partial p} \frac{\partial F}{\partial q}
$$

and reduces to the latter in the correspondence principle limit $(h \rightarrow 0)$ and for systems whose Hamiltonian is a polynomial of the 2 nd degree or less in $p$ and $q$. For such systems (and they include the free and the uniformly accelerated particle, and the oscillator) the transformation with time of $F(p, q ; t)$ is of the 'deterministic' type of classical kinetic theory, each element of the distribution transforming in phase-space according to the laws of classical mechanics. A direct verification of the deterministic character of these systems in given in Appendix 1 and in $\$ 2 . \dagger$

Equation (1.7) specifies the infinitesimal transformation with time of $F(p, q ; t)$. The transformation over a finite interval $t-t_{0}$ can be given in terms of a 'transformation function' $K\left(p, q \mid p_{0}, q_{0} ; t-t_{0}\right)$;

$$
F(p, q ; t)=\iint K\left(p, q \mid p_{0}, q_{0} ; t-t_{0}\right) F\left(p_{0}, q_{0} ; t-t_{0}\right) d p_{0} d q_{0} .
$$

$K$ is interpreted as the probability of $p, q$ at $t$ conditional in $p_{0}, q_{0}$ at $t_{0}$, and may bo expressed either in terms of the phase-space eigenfunctions by an expansion similar to $(1 \cdot 3)$

$$
K\left(p, q \mid p_{0}, q_{0} ; t-t_{0}\right)=h \sum_{k, n} f_{k n z}\left(p_{0}, q_{0}\right) f_{k n n}^{*}(p, q) e^{i\left(\left[E_{l i k}-E_{n}\right)\left(t-t_{0}\right) / \pi\right.},
$$

or in terms of the wave transformation-function

by an integral similar to $(1 \cdot 1)$

$$
\psi\left(q \mid q_{0} ; t-t_{0}\right)=\sum_{n} u_{n}\left(q_{0}\right) u_{n}^{*}(q) e^{-i E_{n}\left(b-t_{0}\right) / t i},
$$

$K\left(p, q \mid p_{0}, q_{0} ; t-t_{0}\right)=\frac{\hbar}{2 \pi} \iint \psi^{*}\left(q-\frac{1}{2} h \tau \mid q_{0}-\frac{1}{2} h \tau_{0}\right) e^{i\left(\tau_{0} p_{0}-\tau p\right)} \psi\left(q+\frac{1}{2} l i \tau \mid q_{0}+\frac{1}{2} h \tau_{0}\right) d \tau d \tau_{0}$.

The phase-space theory of quantum mechanics may be applied to calculate the transition probabilities of a perturbed system. If $K$ is known for the perturbed Hamiltonian $H$, and we wish to calculate the transition probabilities from the leth unperturbed state in an interval $t$, we take as initial distribution the $l_{t h}$ diagonal phase-space eigenfunction corresponding to the unperturbed Hamiltonian $H^{(0)}: F_{0}\left(p_{0}, q_{0}\right)=f_{k k}^{(0)}\left(p_{0}, q_{0}\right)$. The transformed distribution after an interval $t$ is then from (1.9) and (1.3)

$$
\left.F_{(j)}(p, q ; t)=\iint K\langle p, q| p_{0}, q_{0} ; t\right) f_{k k}^{*(0)}\left(p_{0}, q_{0}\right) d p_{0} d q_{0}=\sum_{l, n} a_{l}^{*} a_{n} f_{i n}^{(0)}(p, q\rangle
$$

The transition probability from state $l o$ to state $n$ is then given exactly by $\ddagger$

$$
p_{k n}(t)=a_{n}^{*}(t) a_{n}(t)=\hbar \iint F_{(k)}(p, q ; t) f_{n \pi}^{(0)}(p, q) d p d q .
$$

$\dagger$ Cf., in this connexion, Coulson and Rushbrooke(7).

It may be shown that the transition probabilities obtained in this way are in fact identical with those of ordinary quantum theory; the proof of this statement is given in Appendix 2. 


\section{Transition probabilities of quantum-mechanical oscillators}

In the particular case of deterministic systems the transformation function $K$ must reduce to a product of delta-functions expressing the contact transformation of classical mechanics (this is verified in $\S 2$ for the harmonio oscillator). The distribution at $t$ follows simply by substituting the classical solutions in the initial distribution: $F_{(k)}(p, q ; t)=f_{k k}^{(0)}\left[p_{0}(p, q, t), q_{0}(p, q, t)\right]$.

\section{PhaSe-SPACE THEORY OP THE HARMONIO OSOILLATOR}

We now develop the phase-space theory of the one-dimensional oscillator of mass $m$, angular frequency $\omega$, coordinate $Q$ and momentum $P$. In terms of the reduced variables $q=(m \omega / \hbar)^{\frac{1}{2}} Q, p=(m \omega \hbar)^{-\frac{1}{2}} P$, its Hamiltonian is

$$
H=\frac{1}{2}\left(P^{2} / m+m \omega^{2} Q^{2}\right)=\frac{1}{2}\left(p^{2}+q^{2}\right) \hbar \omega .
$$

The energy eigenfunctions in $p$ - and $q$-space are $u_{n}(q), u_{n}(p)$, where

$$
\begin{aligned}
& u_{n}(q)=(-1)^{n}\left(2^{n} \pi^{\frac{1}{2}} n !\right)^{-\frac{1}{2}} e^{\frac{1}{1} q^{2}}\left(\frac{\partial}{\partial q}\right)^{n}\left(e^{-q^{2}}\right)=\left(2^{n} \pi^{\frac{1}{2}} n !\right)^{-\frac{1}{2}} e^{-\frac{1}{-1} q^{2}} H_{n}(q), \\
& u_{n}(p)=\frac{1}{\sqrt{(2 \pi)}} \int u_{n}(q) e^{-i p q} d q .
\end{aligned}
$$

The phase-space energy eigenfunctions are then, from $(1 \cdot 4), \uparrow$

$$
\begin{aligned}
& f_{k n}(p, q)=\frac{1}{2 \pi} \int u_{n}^{*}\left(q-\frac{1}{2} \tau\right) e^{-i \tau p} u_{n}\left(q+\frac{1}{2} \tau\right) d \tau \\
& \left.=(-1)^{n+k}(2 \pi)^{-1}\left(2^{n+k} \pi n !\right) !\right)^{-\frac{1}{2}} \int e^{-i \tau p+\frac{1}{2}(q-\mathrm{d} \tau)^{2}+\mathrm{d}\left(\alpha+\frac{1}{3}\right)^{2}}\left(\frac{\partial}{\partial q_{1}}\right)^{k}\left(e^{-\left(q_{1}-\mathrm{t} \tau\right)^{2}}\right)\left(\frac{\partial}{\partial q_{2}}\right)^{n}\left(e^{-\left(q_{2}+\frac{1}{t} \tau\right)^{2}}\right) d \tau \\
& =(-1)^{n+k}(2 \pi)^{-1}\left(2^{n+k} \pi n ! k !\right)^{-\frac{1}{2}}\left(\frac{\partial}{\partial q_{1}}\right)^{k}\left(\frac{\partial}{\partial q_{2}}\right)^{n} e^{a^{2}-q_{1}^{3}-q_{2}^{2}} \int e^{-i \tau \gamma^{2}-\frac{k}{2} \tau^{2}+\tau\left(q_{1}-q_{2}\right)} d \tau \\
& =(-1)^{n+l c}\left(2^{n+k} \pi^{2} n ! k !\right)^{-k} e^{p^{2}+q^{2}}\left(\frac{\partial}{\partial q_{1}}\right)^{k}\left(\frac{\partial}{\partial q_{2}}\right)^{n}\left(e^{-2\left(q_{1}-i p\right)\left(\alpha_{3}+i p\right)}\right), \quad\left(q_{1}=q_{2}=q\right),
\end{aligned}
$$

or, on introducing the variables $z=q+i p, z^{*}=q-i p$

$$
f_{7 c n}\left(z, z^{* *}\right)=\left(-\sqrt{\frac{1}{2}}\right)^{n+/ k}\left(\pi^{2} n ! k !\right)^{-\frac{1}{2}} e^{z \approx *}\left(\frac{\partial}{\partial z^{* k}}\right)^{k}\left(\frac{\partial}{\partial z}\right)^{n}\left(e^{-2 z z * * k}\right) .
$$

A more convenient expression is obtained by substituting the variables

$$
w=2 z z^{*}=2\left(p^{2}+q^{2}\right)=4 H / F i \omega, \quad \theta=\tan ^{-1}(p / q) .
$$

The phase-space eigenfunctions then break up into the products of an associated Laguerre function of $w$ and a trigonometric function of $\theta$

$$
\begin{aligned}
f_{k u}(w, \theta) d w d \theta & =\frac{1}{2}(-1)^{k}(k ! n !)^{-\frac{1}{2}} w^{d(k-n)} e^{j w}\left(\frac{\partial}{\partial w}\right)^{k}\left(w^{n} e^{-w}\right) d w(2 \pi)^{-1} e^{i(k-n) \theta} d \theta \\
& =\frac{1}{2}(-1)^{k}(k ! / n !)^{\frac{1}{ \pm}} w^{-\frac{1}{(}(k-n)} e^{-\frac{1}{d} w} L_{l c}^{n-k}(w) d w(2 \pi)^{-1} e^{i(k-n) \theta} d \theta
\end{aligned}
$$

The diagonal eigenfunctions are simple Laguerre functions

$$
\begin{aligned}
f_{n n}(w, \theta) d w d \theta & =\frac{1}{2}(-1)^{n}(n !)^{-1} e^{\frac{3}{3} w}\left(\frac{\partial}{\partial w}\right)^{n}\left(w^{n} e^{-w}\right) d w d \theta / 2 \pi \\
& =\frac{1}{2}(-1)^{n} e^{-\frac{1}{1} w} L_{n}(w) d w d \theta / 2 \pi .
\end{aligned}
$$

$\dagger$ An expression for these eigenfunctions has been found independently by Dr H. I. Groenewold (2). 
The determinism of the oscillator may be verified by calculating the phase-space transformation function over a finite interval of time $t$, on using equation (1-12). The wave transformation function over this interval is given by the well-known Mehler expansion for Hermite polynomials (3)

$$
\begin{aligned}
\psi\left(q \mid q_{0} ; t\right) & =\sum_{n} u_{n}\left(q_{0}\right) u_{n}^{*}(q) e^{-i(n+j) \omega t} \\
& =(2 \pi i \sin \omega t)^{-1} \exp \left\{i(2 \sin \omega t)^{-1}\left[\left(q^{2}+q_{0}^{2}\right) \cos \omega t-2 q q_{0}\right]\right\} .
\end{aligned}
$$

The phase-space transformation function is then

$$
\begin{aligned}
& K\left(p, q \mid p_{0}, q_{0} ; t\right) \\
& =\left(4 \pi^{2} \sin \omega t\right)^{-1} \iint \exp \left[i\left\{\tau_{0} p_{0}-\tau p+(\sin \omega t)^{-1}\left[\left(\tau q+\tau_{0} q_{0}\right) \cos \omega t-\tau q_{0}-\tau_{0} q\right]\right\}\right] d \tau d \tau_{0} \\
& =\left(4 \pi^{2} \sin \omega t\right)^{-1} \iint \exp \left\{i ( \operatorname { s i n } \omega t ) ^ { - 1 } \left[\tau\left(q \cos \omega t-p \sin \omega t-q_{0}\right)\right.\right. \\
& \left.\left.\quad+\tau_{0}\left(q_{0} \cos \omega t+p_{0} \sin \omega t-q\right)\right]\right\} d \tau d \tau_{0} \\
& =\sin \omega t \delta\left(q \cos \omega t-p \sin \omega t-q_{0}\right) \delta\left(q_{0} \cos \left(\omega t+p_{0} \sin \omega t-q\right),\right.
\end{aligned}
$$

a product of delta functions expressing the contact transformation of classical mechanics for the oscillator. The expansion ( $1 \cdot 10)$ of $K$ in terms of the phase-spaoe eigenfunctions gives the following interesting formula for the associated Laguerre functions

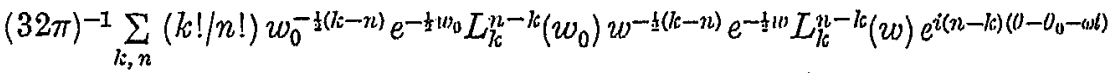

$$
\begin{aligned}
& =\delta\left(w-w_{0}\right) \delta\left(0-0_{0}-\omega t+2 r \pi\right),
\end{aligned}
$$

where the $\delta$-functions are normalized over the ranges of $w$ and $\theta, r$ being an integer such that $0 \leqslant \theta_{0}+\omega t-2 r \pi \leqslant 2 \pi$.

In Appendix 3, the above results are applied to derive the equilibrium phase-space distribution of members of a statistical assembly of oscillators.

\section{TRANSITION PROBABILITIES OF A PERTURBLD OSCILLATOR}

We shall now apply the method outlined in $\S 1$ to calculate the exact transition probabilities of a perturbed oscillator for a perturbing potential of the form $V=q \mathscr{E}(t)$, where $\mathscr{E}(t)$ is an arbitrary function of the time. On using equation (1.14), the transition probability from state $k$ to state $n$ is given in terms of the variables $w=2\left(p^{2}+q^{2}\right)$ and $\theta=\tan ^{-1}(p / q)$ used in $\S 2$ by

$$
p_{l e n}(t)=8 \pi \int_{0}^{\infty} \int_{0}^{2 \pi} f_{k l s}\left(w_{0}, \theta_{0}\right) f_{n n}^{*}(w, \theta) d w_{0} d \theta_{0}
$$

where $w_{0}, \theta_{0}$ are the initial values at $t=0, w$ and $\theta$ those at time $t$ obtained from the classical solution for the perturbed oscillator

$$
\begin{aligned}
& q=q_{0} \cos \omega t+p_{0} \sin \omega t-\omega \int_{0}^{t} \mathscr{E}(\tau) \sin \omega(t-\tau) d \tau \\
& p=p_{0} \cos \omega t-q_{0} \cos \omega t-\omega \int_{0}^{t} \mathscr{E}(\tau) \cos \omega(t-\tau) d \tau .
\end{aligned}
$$

Hence

$$
w=w_{0}+2\left(w_{0} \alpha\right)^{\sharp} \cos \left(\theta_{0}-\phi\right)+\alpha
$$

where

$$
\left(\frac{1}{2} \alpha\right)^{t} e^{i \phi}=i \omega \int_{0}^{t} \mathscr{E}(\tau) e^{i \omega \tau} d \tau
$$




\section{Transition probabilities of quantum-mechanical oscillators}

It is easily seen that $\epsilon=\frac{1}{4} \hbar \omega \alpha$ is the non-fluotuating part of the work done by the perturbing force, while $\phi$ is the phase change of the oscillator. We now substitute these solutions in (3.1) and also introduce two auxiliary variables $\gamma, \xi$ which we shall equate to I after all the indicated integrations and differentiations have been carried out. This yields a closed expression for the transition probability

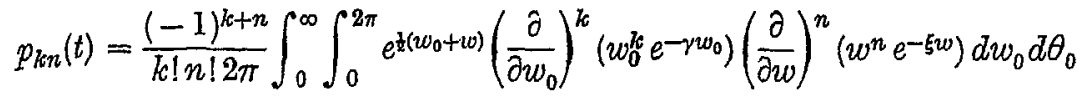

$$
\begin{aligned}
& =\frac{(-1)^{k+n}}{k ! n ! 2 \pi}\left(\frac{\partial}{\partial \gamma}\right)^{k}\left(\frac{\partial}{\partial \xi}\right)^{n} \gamma^{k} \xi^{n} \int_{0}^{\infty} \int_{0}^{2 \pi} \exp \left\{w_{0}(1-\gamma-\xi)\right. \\
& =\frac{(-1)^{k+n}}{k ! n !}\left(\frac{\partial}{\partial \gamma}\right)^{k}\left(\frac{\partial}{\partial \xi}\right)^{n} \gamma^{i k} \xi^{n} e^{\left(\frac{1}{1}-\xi\right) \alpha} \int_{0}^{\infty} e^{-w_{0}(\gamma+\xi-1)} I_{0}\left[2\left(w_{0} \alpha\right)^{\left.\frac{1}{2}\left(\frac{1}{2}-\xi\right)\right] d w_{0}} \quad(\gamma=\xi=1),\right.
\end{aligned}
$$

where $I_{0}(x)$ is the modified zero-order Bessel function of the first lind $\left(I_{0}(x)=J_{0}(i x)\right)$. The integration is easily carried out, for example, by substituting for $I_{0}(x)$ its Taylor expansion and integrating term by term, whence

$$
p_{k n}(t)=\frac{(-1)^{k+n}}{k ! n !}\left(\frac{\partial}{\partial \gamma}\right)^{k}\left(\frac{\partial}{\partial \xi}\right)^{n}\left(\frac{\gamma^{k} \xi^{n}}{\gamma+\xi-1} \exp \left[-\alpha \frac{\left(\gamma-\frac{1}{2}\right)\left(\xi-\frac{1}{2}\right)}{\gamma+\xi-1}\right]\right) \quad(\gamma=\xi=1) .
$$

Carrying out the indicated differentiation on $\gamma^{k}, \xi^{n}$, one finds that

$$
p_{l n}(t)=(-1)^{k+n} \sum_{\nu=0}^{k}\left(\begin{array}{l}
k \\
\nu
\end{array}\right) \frac{1}{\nu !}\left(\frac{\partial}{\partial \gamma}\right)^{\nu} \cdot \sum_{\mu=0}^{n}\left(\begin{array}{l}
n \\
\mu
\end{array}\right) \frac{1}{\mu !}\left(\frac{\partial}{\partial \xi}\right)^{\mu}\left(\frac{1}{\gamma+\xi-1} \exp \left[-\alpha \frac{\left(\gamma-\frac{1}{2}\right)\left(\xi-\frac{1}{2}\right)}{\gamma+\xi-1}\right]\right)
$$

or symbolically

$$
p_{k n}(t)=(-1)^{k+n} L_{k}\left(-\frac{\partial}{\partial \gamma}\right) L_{n}\left(-\frac{\partial}{\partial \xi}\right)\left(\frac{1}{\gamma+\xi-1} \exp \left[-\alpha \frac{\left(\gamma-\frac{1}{2}\right)\left(\xi-\frac{1}{2}\right)}{\gamma+\xi-1}\right]\right) \quad(\gamma=\xi=1) \text {. }
$$

With the use of the expression for the Laguerre polynomials generating function (3)

$$
\frac{1}{1-\tau} \exp \left[-\frac{\tau x}{1-\tau}\right]=\sum_{n=0}^{\infty} L_{n}(x) \tau^{n}
$$

a 'probability generating function' (p.g.f.) may be calculated for the $p$

$$
\begin{aligned}
G(\tau, \theta) & =\sum_{l i, n} p_{l c n} \theta^{l} \tau^{n} \\
& =\frac{1}{(1+\tau)(I+\theta)} \exp \left(-\frac{\theta}{1+\theta} \frac{\partial}{\partial \gamma}\right) \exp \left(-\frac{\tau}{1+\tau} \frac{\partial}{\partial \xi}\right) \\
& =\frac{1}{1-\tau \theta} \exp \left\{-\frac{\epsilon}{\hbar \omega} \frac{(I-\tau)(1-\theta)}{1-\tau \theta}\right\} .
\end{aligned}
$$

The coofficient of $\theta^{\text {ra }}$ in the Taylor expansion of $G(\tau, \theta)$ in powers of $\theta$ only, will be the p.g.f. $G_{l c}(\tau)$ for transitions from the $7 c t h$ state; that of $\theta^{l c} \tau^{n}$ in the expansion in powers of both $\theta$ and $\tau$ will be $p_{k n}(t)$. For $n \geqslant k$

$$
\begin{aligned}
p_{k n}(t)=\frac{1}{(n-k) !}\left(\frac{\epsilon}{\hbar \omega}\right)^{n-i \epsilon} e^{-\epsilon / \hbar \omega} & \sum_{\mu=0}^{k} \sum_{\nu=0}^{k-\mu}\left(\frac{\epsilon}{\hbar \omega}\right)^{\mu+2 \nu} \\
& \times\left(\frac{(n-k) !(n+\nu) !(-2)^{\mu}}{\mu ! \nu !(n-k+\nu) !(k-\mu-\nu) !(n-k+\mu+2 \nu) !}\right) .
\end{aligned}
$$


Since, as is obvious from (3.3) or (3.4), the $p_{k n}$ satisfy the principle of detailed balance, i.e. $p_{k n}=p_{n k}$, the probability of transitions to states $n<k$ is simply obtained by interchanging the indices $n$ and $k$ in the right-hand side of (3.7).

The p.g.f. $G_{0}(\tau)$ and the probabilities $p_{0 n}(t)$ for transitions from the ground state are simply those of a Poisson distribution

$$
G_{0}(\tau)=e^{(\varepsilon / \hbar \omega)\}(\tau-1)}, \quad p_{0 n}(t)=\frac{1}{n !}\left(\frac{\epsilon}{\hbar \omega}\right)^{n} e^{-\epsilon / \hbar \omega} .
$$

These exact results may now be compared with the approximate ones obtained by the standard perturbation method. The Taylor expansion of the approximate expression for the p.g.f.

$$
G(\tau, \theta) \sim \frac{1}{1-\tau \theta}\left[1-\frac{\epsilon}{\hbar \omega} \frac{(1-\tau)(1-\theta)}{1-\tau \theta}\right]
$$

gives approximate values for the

$$
p_{l n n}(t)=\delta_{l c, n}+\frac{\epsilon}{l i \omega}\left[(k+1) \delta_{l e+1, n}+k \delta_{l c-1, n}-(2 l i+1) \delta_{l, n}\right]
$$

correct to the first power in $\epsilon$, whose expression is identical with the first approximation of the perturbation method. Expression (3.7) shows that in general the probability of a $2 n$ th-pole transition for small $\epsilon$ is of the order of $(\epsilon / \hbar \omega)^{n}$, i.e. only dipole transitions have an appreciable probability. The perturbation method equates to 1 the exponential factor $\exp \{-\epsilon \mid \pi i \omega\}$ in the exact expression (3.7). This procedure is justified only for small $\epsilon$; as the perturbation energy increases, however, multipole transitions become progressively more probable. In order to find the most probable ones from the ground state, let us substitute the continuous variable $x$ for $n$ in $(3 \cdot 8)$

$$
\begin{aligned}
p_{0 x} & =\frac{1}{x !}\left(\frac{\epsilon}{\hbar \omega}\right)^{x} e^{-\epsilon / \hbar \omega}, \\
\frac{d p_{0 x}}{d x} & =\frac{1}{x !}\left(\frac{\epsilon}{\hbar \omega}\right)^{x} e^{-\epsilon / h \omega}\left[\log \left(\frac{\epsilon}{\hbar \omega}\right)-\frac{d}{d x}(\log x !)\right] .
\end{aligned}
$$

The most probable transition is therefore to the state $n$ given by

$$
\frac{d}{d x}(\log x !)_{(x-m)}=\psi(n) \sim \log (\epsilon / \hbar \omega)
$$

where the logarithmic clerivative $\psi(x)$ of the factorial function $x$ ! is an increasing function of $x$ (Jahnke-Emde (4)). For large $x, \psi(x) \sim \log x$, and hence $n \pi \omega=\mathbb{E}_{n}-\mathbb{E}_{0} \sim \varepsilon$. Similar considerations apply to the general case: it will be seen from $(3 \cdot 7)$ that the most probable transitions are those from states $k$ to states $n$ such that $(n-k) \hbar \omega=E_{n}-E_{k} \sim \varepsilon$. Hence the physically plausible result that for large perturbations the most probable transitions will be those for which the change in energy is approximately equal to the work done by the perturbing forces.

\section{APPENDIX}

\section{(1) Free particle and particle under constant force}

The way in which the phase-space method may be used to solve wave-packet problems is easily exemplified in the deterministic cases of the free particle and the particle under 
Transition probabilities of quantum-mechanical oscillators

constant force. In both these cases, the Schrödinger equation is most easily solved in momentum space. We describe the particle at $t=0$ by a Gaussian wave-packet

$$
\phi_{0}\left(p_{0}\right)=\left(2 \pi s_{0}^{2}\right)^{-1} \exp \left[-p_{0}^{2} / 4 s_{0}^{2}\right]
$$

corresponding to the minimum uncertainty $\sigma_{0} s_{0}=\frac{1}{2} \hbar$ on its position and momentum (cf. Kennard (5)), $s_{0}$ and $\sigma_{0}$ being respectively the mean square deviations of $p_{0}$ and $q_{0}$ and talking the origin at the mean of $p_{0}$ and $q_{0}$. The corresponding phase-space distribution is by $(1 \cdot 1)$

$$
\begin{aligned}
F_{0}\left(p_{0}, q_{0}\right) & =\frac{1}{2 \pi} \int \phi_{0}^{*}\left(p_{0}-\frac{1}{2} \hbar \tau\right) e^{i \tau q} \phi_{0}\left(p_{0}+\frac{1}{2} \hbar \tau\right) d \tau \\
& =(\pi \hbar)^{-1} \exp \left[-\frac{1}{2}\left(p_{0}^{2} / s_{0}^{2}+q_{0}^{2} / \sigma_{0}^{2}\right)\right] .
\end{aligned}
$$

The solution is then obtained simply by substituting in (A. 1.2) the classical solutions for $p$ and $q$ in terms of $p_{0}, q_{0}, t$. In the case of the free particle, this gives for the distribution at $t$

$$
F(p, q ; t)=(\pi \hbar)^{-1} \exp \left[-\frac{1}{2}\left(p / s_{0}\right)^{2}-\frac{1}{2}\left(q / \sigma_{0}-p t / m \sigma_{0}\right)^{2}\right] .
$$

It is easily shown that this corresponds by $(1 \cdot 1)$ to the wave-function

$$
\phi(p ; t)=\left(2 \pi s_{0}^{2}\right)^{-\frac{t}{t}} \exp \left[-\left(p / 2 s_{0}\right)^{2}+i p^{2} t / 2 m i n\right],
$$

which is the solution of the Schrödinger equation

$$
\frac{p^{2}}{2 m} \phi=-\frac{\hbar}{i} \frac{\partial \phi}{\partial t}
$$

with $\phi_{0}\left(p_{0}\right)$ as initial wave-function at $t=0$ (cf. Darwin (6)).

Similarly, for the particle under constant force $m g$ we find for the same initial distribution $I_{0}\left(p_{0}, q_{0}\right)$

$$
F(p, q ; t)=\frac{1}{\pi \hbar} \exp \left[-\frac{1}{2}\left(\left(\frac{p-m g t}{s_{0}}\right)^{2}+\left(\frac{q-p t / m-\frac{1}{2} g t^{2}}{\sigma_{0}}\right)^{2}\right\}\right]
$$

which again corresponds to the solution

$$
\phi(p ; t)=\left(2 \pi s_{0}^{2}\right)^{-t} \exp \left[-\left\{\left(\frac{p-m g t}{2 s_{0}}\right)^{2}+\frac{i}{\bar{h}}\left(\frac{p^{2} t}{2 m}-\frac{g p t^{2}}{2}+\frac{m g^{2} t^{3}}{6}\right)\right\}\right]
$$

of the Schrödinger equation $\frac{p^{2}}{2 m} \phi+\frac{m g h i}{i} \frac{\partial \phi}{\partial p}=-\frac{\hbar}{i} \frac{\partial \phi}{\partial t}$.

\section{(2) Equivalence between the transition probabilities calculated by the phase-space method and those of standard quantum theory}

It is convenient in the calculations that follow to introduce Dirac's notation: $\left\langle s_{1} \mid q_{1}\right\rangle$ for the coorclinate eigenfunction corresponding to state $s_{1}$, at time $t_{1},\left\langle s_{2} \mid q_{2}\right\rangle$ for state $s_{2}$ at $t_{2},\left\langle q_{1} \mid q_{2}\right\rangle$ for the wave transition function from $q_{1}$ at $t_{1}$ to $q_{2}$ at $t_{2},\left\langle s_{1} \mid s_{2}\right\rangle$ for the transition matrix from $s_{1}$ at $t_{1}$ to $s_{2}$ at $t_{2}$; the corresponding transition probability in the standard theory is then $\left|\left\langle s_{1} \mid s_{2}\right\rangle\right|^{2}$. The transition probability $p_{s_{1} s_{2}}$, calculated by the phase-space method, is from (1.13) and (1.14)

$$
p_{s_{1} s_{2}}=\int \ldots \int f_{s_{1} \beta_{2}}^{*}\left(p_{2}, q_{2}\right) K\left(p_{2}, q_{2} \mid p_{1}, q_{1}\right) f_{s_{1} s_{2}}\left(p_{1}, q_{1}\right) d p_{2} d q_{2} d p_{1} d q_{1} .
$$


552

M. S. BaRTletTt and J. E. Moyad

Substituting from expressions (1.4) for $f_{s s}(p, q)$ in terms of $\langle s \mid q\rangle$ and $(1 \cdot 12)$ for $K$ in terms of $\left\langle q_{1} \mid q_{2}\right\rangle$, we have

$$
\begin{aligned}
& p_{s_{1} s_{2}}=\frac{\hbar^{2}}{4 \pi^{2}} \int \ldots \int \iint\left\langle s_{1} \mid q_{1}+\frac{1}{2} \hbar \tau_{1}\right\rangle e^{-i \tau_{1} p_{1}}\left\langle q_{1}-\frac{1}{2} \hbar \tau_{1} \mid s_{1}\right\rangle d \tau_{1} \\
& \times \iint\left\langle q_{1}+\frac{1}{2} \hbar \theta_{1} \mid q_{2}+\frac{1}{2} \hbar \theta_{2}\right\rangle e^{i\left(\theta_{1} p_{1}-\theta_{2} p_{2}\right)}\left\langle q_{2}-\frac{1}{2} \hbar \theta_{2} \mid q_{1}-\frac{1}{2} \hbar \theta_{1}\right\rangle d \theta_{1} d \theta_{2} \\
&\left.\times \int\left\langle s_{2} \mid q_{2}-\frac{1}{2} \hbar \tau_{2}\right\rangle e^{i \tau_{2} p_{2}}\left\langle q_{2}+\frac{1}{2} \hbar \tau_{2} \mid s_{2}\right\rangle d \tau_{2}\right\} d p_{1} d q_{1} d p_{2} d q_{2} \\
&=\iint\left\langle s_{1} \mid x_{1}\right\rangle\left\langle x_{1} \mid x_{2}\right\rangle\left\langle x_{2} \mid s_{2}\right\rangle d x_{1} d x_{2} \times \iint\left\langle s_{2} \mid x_{2}^{\prime}\right\rangle\left\langle x_{2}^{\prime} \mid x_{1}^{\prime}\right\rangle\left\langle x_{1}^{\prime} \mid s_{1}\right\rangle d x_{1}^{\prime} d x_{2}^{\prime},
\end{aligned}
$$

where the change of variables $x_{1}=q_{1}+\frac{1}{2} 7 i \tau_{1}, x_{1}^{\prime}=q_{1}-\frac{1}{2} \hbar \tau_{1}$, etc., has been made. Hence

$$
p_{s_{1} s_{2}}=\left|\left\langle s_{1} \mid s_{2}\right\rangle\right|^{2} \text {, }
$$

i.e. the two expressions for the transition probabilities are formally equivalent.

(3) Phase-space distribution of a member of a statistical assembly of oscillator's

The equilibrium distribution of the coordinates and momenta of one member of a statistical assembly of similar particles is expressed in I, p. 114, as a sum of diagonal phase-space energy eigenfunctions relative to the individual particles

$$
f(p, q)=C \sum_{k i} n_{l i} f_{l k i}(p, q),
$$

where $C$ is a normalizing constant and the $\imath_{n}=e^{-\mathcal{C}_{n} l / l^{\prime} !}$ in the case of a Maxwell-Boltzmann assembly. On substituting from $(2 \cdot 6)$ for an assembly of oscillators, this becomes

$$
\begin{aligned}
& f(w, \theta)=(4 \pi)^{-1}\left(1-e^{-\hbar \omega / c c^{\prime}}\right) \sum_{n}(-1)^{n} e^{-i t r-n \hbar \omega / k T} L_{n}(w) \\
& =(4 \pi)^{-1} \tanh (\pi \omega / 2 \pi T) \exp \left\{-\frac{1}{2}[w \tanh (7 i \omega / 2 \pi T)]\right\},
\end{aligned}
$$

where the last line follows from (3.5). Transforming back from $w$ and $\theta$ to $p$ and $q$, we finally find a Gaussian distribution for the coordinates and momenta of a member of an assembly of oscillators

$$
f(p, q)=(2 \pi)^{-1}(\hbar \omega / E) \exp \left\{-\frac{1}{2}\left[\left(p^{2}+q^{2}\right)(\hbar \omega / E)\right]\right\},
$$

where $E$ is the mean energy

$$
E=\frac{1}{2} \hbar \omega \operatorname{coth}(\hbar \omega / 2 k T)=\hbar \omega\left(e^{i \omega / k T}-1\right)^{-1}+\frac{1}{2} \hbar \omega .
$$

We may note that the mean-square deviation of the energy calculated from the above distribution is $\sigma_{E}^{2}=E^{2}$ instead of the usual expression $\sigma_{E}^{2}=E^{2}-\left(\frac{1}{2} \hbar \omega\right)^{2}$. This follows from the fact that the phase-space theory of quantum mechanics yields different distributions according to the basic system of variables chosen (see I, p. 100 for a fuller discussion). If the energy is one of these variables, then it is quantized, with possible values $\epsilon_{k}=\left(k+\frac{1}{2}\right) \hbar \omega$, and its distribution is simply

$$
\rho\left(\epsilon_{k}\right)=2 \sinh (\hbar \omega / 2 \pi T) e^{-\varepsilon_{k l} / l c t},
$$

yielding the second value $\sigma_{E}^{2}=E^{2}-\left(\frac{1}{2} \hbar \omega\right)^{2}$ for the m.s. deviation of the energy. If $p$ and $q$ are chosen as the basic system, then the energy distribution becomes continuous, with a $\mathrm{m}$.s. deviation of $\left(\frac{1}{2} \hbar \omega\right)^{2}$ for each of the energy eigenfunctions, leading thus to the first value $\sigma_{E}^{2}=E^{2}$. 


\section{SUMMARY}

The 'phase-space' method in quantum theory is used to derive exact expressions for the transition probabilities of a perturbed oscillator. Comparison with the approximate results obtained by perturbation methods shows that the latter must be multiplied by an exponential factor $\exp (-\epsilon / \hbar \omega)$, where $\epsilon$ is the non-fluctuating part of the work done by the perturbing forces; as long as $\epsilon$ is small, $\exp (-\epsilon / \hbar \omega) \sim 1$ and only dipole transitions have an appreciable probability. As the perturbation energy increases, however, this is no longer true, and multipole transitions become progressively more probable, the most probable ones being those for which the change in energy is approximately equal to the work done by the perturbing forces.

\section{REFERENCES}

(1) Moyat, J. E. Proc. Cambridge Phil. Soc. 45 (1949), 99-124.

(2) GROENIWOLd, H. J. Physica, 12 (1946), 405-60.

(3) SzEGö, G. Orthogonal polynomials (New York, 1939), pp. 97, 102.

(4) J AFMKR, E. and EMDE, F. Tables of functions (3rd ed.) (Leipzig, 1938), p. 19.

(5) Konnard, E. H. Z. Phys. 44 (1927), 326.

(6) Darwin, S. G. Proc. Roy. Soc. A, 117 (1928), 258-93.

(7) Coulson, C. A. and Rushbiroomw, G. S. Proc. Cambridge Phil. Soc. 42 (1946), 286-91.

Department of Mathomatras

UNIVERSITy OF MaNOIFESTER 
Progress of Theoretical Physics, Vol. 11, Nos. 4-5, April $\sim$ May 1954

\title{
The Formulation of Quantum Mechanics in terms of Ensemble in Phase Space ${ }^{1)}$
}

\author{
Takehiko TAKABAYASI \\ Plyysical Institute, Nagoya University
}

(Received November 16, 1953)

\begin{abstract}
The formulation of non-relativistic quantum mechanics in terms of ensemble in phase space is established by clarifying the subsidiary conditions for the phase space ensemble to represent a pure state, and thereby the equivalent correspondence between this formulation and the alternative formulation in terms of quantum potential previously developed is exhibited.
\end{abstract}

\section{Introduction and summary}

The ordinary formulation of quantum mechanics, as established by the fusion of Heisenberg's matrix mechanics and Schrödinger's wave mechanics, is certainly the most fundamental and powerful one, having its own 'picture' in a broad sense* essentially nonclassical. Nevertheless we may consider another consistent formulation of quantum mechanics with its associated picture, for instance, path integral formulation by Feynman ${ }^{3)}$. Generally such a new formulation and picture would reveal new aspects of physical and mathematical construction of quantum mechanics, and might serve to suggest new clues to future progress of quantum theory itself**, apart from its usefulness for practical applications to specified class of problems.

From such viewpoint we have examined in detail a certain formulation of quantum mechanics in previous papers)5) (see $\$ 5$ (a)): The method is based on the transformation of customary Schrödinger equation into simultaneous equations for the phase and amplitude of the wave function, which are found to be of the form of Hamilton-Jacobi-like equation or Euler's equation of motion for velocity potential, and the equation of continuity. According to this expression we have the representation of quantum mechanical motion in terms of an ensemble of trajectories in configuration space subject to some additional force (so-called 'quantum force'), or equivalently in terms of an irrotational flow of perfect fluid with peculiar internal stress ('quantum stress'). We shall call this method the method of the configuration space cnsemble (abbreviated as cs. en.).

Now the Schrödinger equation can be transformed into a form describable in classical

*) Extending "the meaning of the word 'picture' to include any way of looking at the fundamental laws which makes their self-consistency obvious", according to Dirac").

**) In this paper, however, we shall not try any such suggestion, confined merely in the reformulation of the present quantum theory. 
languages in still another way: That is, we can transform the Schrödinger equation into Liouville-like equation for a distribution function in phase space which is produced as a certain fouriet transform of a bilinear form of the wave function, leading to the picture of certain Markoff-like process of an ensemble in phase space for quantum-mechanical motion. This method, which we will refer to as the method of the phasc space cuscmble (abbreviated as ps. en.), was initiated by Wigner ${ }^{6)}$ and later by Moyal'). The purpose of the present paper is to develop this method into a consistent formulation of quantum mechanics by establishing the subsidiary conditions for a ps. en. to represent a purc state, and also to prove thereby the equivalence of this formulation with the cs. en. formulation formerly mentioned.

In the phase space formulation the knowledge involved in the phase of the original wave function is reflected upon the momentum distribution in such a manner that the phase space distribution function (abbreviated as ps. df.) implies the representation of a state symmetrical in coordinates and momenta. But the manifold of the ps. df. covets wider possibilities than that of the original wave functions. Now, according to our preseription, a mixing of states corresponds to a supurposition with positive coefficients of relevant distribution functions which as well satisfies the same Liouville-like equation, because the latter is linear in the df. Accordingly a ps. df. in general would be the representative of a mixed state, in so far as it satisfies certain 'positivity condition'. Thus in this formulation of quantum mechanics it is an essential problem to obtain the subsidiary conditions*) that a ps. df. should particularly correspond to a pure state. We explicitly obtain these conditions, which must be of some non-linear relations ( $\$ 4)$. This is made tractable by first replacing the usual pure state condition for the density matrix (4.2) by local relations (4.4). Transforming the latter we acquire the pure state conditions on the ps. df., which consist of the condition of irrotationality of mean momentum field, (4.19), and the condition (4.6) which we call the 'quantum condition'. The latter will further be transformed into a series of relations between distribution moments in respect to momentum components of successively higher orders.

Now, in virtue of these pure state conditions, we can prove the equivalence and correspondence between the cs. en. formulation and the ps. en. formulation $(\$ 5)$. For instance, the quantum potential in the former may be looked upon as an apparent force appearing as a result of 'projecting' the ps. en. onto the configuration space.

The cs. en. formulation and ps. en. formulation, though they are equivalent and transmutable to each other, are of very different characters. The effect of quantum fluctuations is represented with fluctuations of continuous trajectories ${ }^{5)}$ due to quantum potential in the former, while in the latter with Markoff-like transitions, the properties of which we shall examine in detail $(\S 3)$. The ps. en. seems to be one step superior to the cs. en. in that it correctly yields quantum-mechanical expectation values as the mean values over the ensemble for wider class of dynamical quantities, yet it must be emphasized that

*) Moyal7) unnoticed the presence of these conditions, while other authors have been unable to obtain their expression. 
The Formulation of Quantum Mechanics in terms of Ensemble in Phase Space 3.4

it cannot do so for all hermitian quantities and that we must in return allow of negative probabilities (\$2).

The ps. en. formulation is formally consistent within its limited range of applicability and accompanied with the picture working along classical lines, but we cannot take the picture too realistically, just as in the case of the cs. en. formulation ${ }^{4)}$. Instead, these formulations provide concrete analyses as to the degrec in which the statistical properties of quantum mechanics can be understood along any statistical scheme bascd on some lidden variables.

The ps. df. is a rial quantity produced as a bilincar form of the wave function, as is needed for the representation in terms of it to have classical pictures, but that would just mean greater complications in mathematical treatments usually. It is well known that the method of ps. df. is useful for the treatment of quantum statistical mechanics ${ }^{\mathrm{m} / \mathrm{s})}$. We shall, however, show how this method of ps. en. can effectively be applied to pure state problems for a few elementary examples $(\$ 6)$.

In the last section we consider the positivity condition and also express the pure state condition in an alternative form.

\section{$\S$ 2. Phase space distributions and mean values}

For simplicity, we shall confine ourselves to the simplest case of a single non-relativistic particle without spin throughout*. A quantum-mechanical mixed state can be specified by a density matrix ${ }^{s a)} \rho$, or $\left\langle\boldsymbol{x}|\rho| \boldsymbol{x}^{\prime}\right\rangle \equiv \rho\left(\boldsymbol{x}, \boldsymbol{x}^{\prime}\right)$ in coordinate representation, which must satisfy the conditions to be

$$
\begin{array}{ll}
\text { hermitian : } & \rho\left(\boldsymbol{x}, \boldsymbol{x}^{\prime}\right)=\rho^{*}\left(\boldsymbol{x}^{\prime}, \boldsymbol{x}\right), \\
\text { normalizable : } & \mathrm{Sp} \rho=\int_{-\infty}^{\infty} \rho(\boldsymbol{x}, \boldsymbol{x}) d \boldsymbol{x}=\mathbf{1}, \\
\text { and positive definite : } & \mathrm{Sp}\left(\rho A^{2}\right) \geq 0,
\end{array}
$$

for any hermitian operator $A$.

Conversely, any function $\rho\left(x, x^{\prime}\right)$ satisfying these conditions can be expanded in a form

with

$$
\left.\begin{array}{l}
\rho\left(\boldsymbol{x}, \boldsymbol{x}^{\prime}\right)=\sum_{n} w_{n} \phi_{n}(\boldsymbol{x}) \phi_{n}^{*}\left(\boldsymbol{x}^{\prime}\right), \\
z u_{n} \geqq 0, \quad \sum_{n}^{\prime} z u_{n}^{\prime}=1,
\end{array}\right\}
$$

where $\psi_{n}(x)$ and $w_{n}$ mean eigen-functions and eigen-values of $\rho$ respectively, which fact indicates that the $\rho\left(\boldsymbol{x}, \boldsymbol{x}^{\prime}\right)$ corresponds to a mixture of pure states of wave functions $\psi_{n}(\boldsymbol{x})$ with respective weights $\mathfrak{v}_{n}$.

The density matrix $\rho$ gives the quantum-mechanical expectation value of any quantity

*) The region of applicability of our formulation is rather limited. When a vector potential is acting, the Markoff-like picture to be stated in $\$ 3$ requires certain extension.

**) In this paper we indicate an abstract operator by attaching an underline. 
$A$ by

$$
\langle\underline{A}\rangle_{\mathrm{gu}}=\mathrm{Sp}(\underline{\rho} \underline{A}) \text {. }
$$

Now, from $\rho$ we define, according to Wigner ${ }^{(i)}$, a function $f(\boldsymbol{x}, \boldsymbol{p})$ by the transformation,

$$
\begin{aligned}
f(\boldsymbol{x}, \boldsymbol{p}) & =\frac{1}{(2 \pi \hbar)^{3}} \int \rho\left(x-\frac{\boldsymbol{y}}{2}, x+\frac{\boldsymbol{y}}{2}\right) c^{i \boldsymbol{p} y / \hbar} d \boldsymbol{y} \\
& =\frac{1}{(2 \pi \hbar)^{3}} \rho\left(\boldsymbol{x}-\frac{\hbar}{2 i} \nabla_{p}, \quad \boldsymbol{x}+\frac{\hbar}{2 i} \nabla_{p}\right) \delta(\boldsymbol{p}) \\
& =(\pi \hbar)^{-3} \int\left\langle\boldsymbol{p} \mid \boldsymbol{x}^{\prime}\right\rangle\left\langle\boldsymbol{x}^{\prime}\left|p^{\prime}\right| \boldsymbol{x}^{\prime \prime}\right\rangle\left\langle\boldsymbol{x}^{\prime \prime} \mid \boldsymbol{p}\right\rangle \delta\left(\boldsymbol{x}^{\prime}+\boldsymbol{x}^{\prime \prime}-2 \boldsymbol{x}\right) d \boldsymbol{x}^{\prime} d \boldsymbol{x}^{\prime \prime}
\end{aligned}
$$

and will use the latter for the specification of the mixed state. The function can also be written in the riciprocal form:

$$
f(\boldsymbol{x}, \boldsymbol{p})=\frac{1}{(2 \pi \hbar)^{3}} \int \rho\left(\boldsymbol{p}-\frac{\boldsymbol{q}}{2}, \boldsymbol{p}+\frac{\boldsymbol{q}}{2}\right) \mathcal{c}^{-i \boldsymbol{\gamma} x / \hbar} d \boldsymbol{q}
$$

where $\rho\left(\boldsymbol{p}, \boldsymbol{p}^{\prime}\right)$ is the momentum representation of the density matrix. Eqs. $(2 \cdot 6)$ and (2.7) show that the function $f(\boldsymbol{x}, \boldsymbol{p})$ is the fourier transform of $\rho\left(\boldsymbol{x}, \boldsymbol{x}^{\prime}\right)$ or $\rho\left(\boldsymbol{p}, \boldsymbol{p}^{\prime}\right)$ along its antidiagonal; in other words, if we consider the density matrix to be a function of 'mean coordinate' and 'relative coordinate', as

$$
\bar{\rho}(\boldsymbol{x}, \boldsymbol{y})=\rho(\boldsymbol{x}-\boldsymbol{y} / 2, \boldsymbol{x}+\boldsymbol{y} / 2),
$$

$f$ is the fourier transform of $\bar{\rho}$ in respect to the relative coordinate.

The function $f(x, p)$ should be, corresponding to $(2 \cdot 1)$,

$$
f(\boldsymbol{x}, \boldsymbol{p})=\text { real, (though not necessarily positive), }
$$

and satisfy, corresponding to $(2 \cdot 2)$,

$$
\int f(\boldsymbol{c}, \boldsymbol{p}) d \boldsymbol{x} d \boldsymbol{p}=1
$$

We may thus imagine, corresponding to a mixed state, an 'ensemble' with the 'probability distribution' in pluasc space, $f(\boldsymbol{x}, \boldsymbol{p})$, though we must then allow of negative probabilities. The function $f(\boldsymbol{x}, \boldsymbol{p})$, which we call the phase space distribution function (ps. df.), can be regarded as the representative of state symmetrical in coordinate' and momentum.

From $(2 \cdot 6)$ or $(2 \cdot 7)$ we get

$$
\left\{\begin{array}{l}
P(\boldsymbol{x})=\int f(\boldsymbol{x}, \boldsymbol{p}) d \boldsymbol{p}=\langle\boldsymbol{x}|\vartheta| \boldsymbol{x}\rangle, \\
Q(\boldsymbol{p})=\int f(\boldsymbol{x}, \boldsymbol{p}) d \boldsymbol{x}=\langle\boldsymbol{p}|\vartheta| \boldsymbol{p}\rangle ;
\end{array}\right.
$$

that is, our ps. df. $f(\boldsymbol{x}, \boldsymbol{p})$ leads to the positional distribution and momentum distribu-

*) In this paper integral usually means a definite integral over whole coordinate space or whole momentum space. In such case we shall hereafter omit to note the boundaries $\pm \infty$. 
tion of quantum-mechanical particle correctly. Accordingly, we have further

$$
\langle A\rangle_{\text {ru }}=\mathrm{Sp}(\rho, A(\boldsymbol{x}, \boldsymbol{p}))=\int A(\boldsymbol{x}, \boldsymbol{p}) f(\boldsymbol{x}, \boldsymbol{p}) d \boldsymbol{x} d \boldsymbol{p}
$$

provided $\underline{A}(\underline{\boldsymbol{x}}, \underline{\boldsymbol{p}})$ belongs to the quantities that sepatate as

$$
\underline{A}(\underline{\boldsymbol{x}}, \underline{\boldsymbol{p}})=\underline{A_{1}}(\underline{\boldsymbol{x}})+\underline{A}_{2}(\underline{\boldsymbol{p}}) .
$$

This means that our phase space ensemble (ps. en.) correctly gives the quantum-mechanical expectation values as the average values over the ensemble for any quantity of type $(2 \cdot 12 \mathrm{~b})^{6}$.

However, for a more general function $A(\boldsymbol{x}, \boldsymbol{p})$ involving cross terms of $\boldsymbol{x}$ and $\boldsymbol{p}$ there exist ambiguities in the definition of the corresponding quantum-mechanical function $\underline{A}(\underline{x}, \underline{p})$ of non-commutable operators $x$ and $\underline{p}$, so that in such a case our ps. df. may give the mean value correctly only for a special quantity $A^{(w)}(x, \underline{p})$ among the quantities $\underline{A}(\underline{\boldsymbol{x}}, \underline{\boldsymbol{p}})$ corresponding to the same c-number function $A(\boldsymbol{x}, \boldsymbol{p})$. Such $A^{(W)}(\underline{\boldsymbol{x}}, \underline{\boldsymbol{p}})$ is the same with that defined by Weyl's's procedure, i.e.,

$$
\underline{A}^{(J V)}(\underline{\boldsymbol{x}}, \underline{\boldsymbol{p}})=\int a(\sigma, \tau) e^{i(\sigma \underline{x}+\tau \underline{w})} d \sigma d \tau,
$$

where $a(\sigma, \tau)$ is the classical fourier coefficient of $A(\boldsymbol{x}, \boldsymbol{p})$ :

$$
A(\boldsymbol{x}, \boldsymbol{p})=\int \alpha(\boldsymbol{\sigma}, \tau) e^{i(\boldsymbol{\sigma} x+\tau)} d \boldsymbol{\alpha} d \tau \text {. }
$$

The above mentioned validity of the relation,

$$
\left\langle\underline{A}^{(w)}(\underline{\boldsymbol{x}}, \underline{\boldsymbol{p}})\right\rangle_{\mathrm{qu}}=\int A(\boldsymbol{x}, \boldsymbol{p}) f(\boldsymbol{x}, \boldsymbol{p}) d \boldsymbol{x} d \boldsymbol{p},
$$

is clear from another expression of the ps. df.:

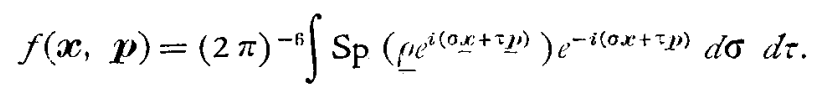

Thus it may readily be found that the ps. df. does not give mean values correctly for quantities such as, e.g., the commutator $\left[\underline{p}_{i}, \underline{x}_{i}\right]$, the square of the energy $H^{2}$ (except for the case of free particle), or the magnitude* of angular momentum $l^{2}$. In other words our ps. df. does not reflect quantum-mechanical probability distributions correctly for quantities such as $\underline{H}$ or $l_{i}$ (a component of angular momentum), in contrast to the case of $A_{1}(\underline{\boldsymbol{c}})$ or $\underline{A_{2}}(\underline{\boldsymbol{p}})$.

By the way, our ps. df. can also be written as

$$
f(x, \boldsymbol{p})=\exp \left(\hbar / 2 i \cdot \Gamma_{p} \Gamma_{x}\right) g(x, \boldsymbol{p}),
$$

in terms of

$$
g(\boldsymbol{x}, \boldsymbol{p})=\left\langle\left.\boldsymbol{p}\right|_{1} \mid \boldsymbol{x}\right\rangle\langle\boldsymbol{x} \mid \boldsymbol{p}\rangle
$$

Here the latter distribution function $g(\boldsymbol{x}, \boldsymbol{p})$, though not real, gives the mean values correctly for the 'well-ordered' functions ${ }^{10)}$ of the form, $\underline{A}(\underline{x}, \underline{p})=\sum_{n, m} a_{n m} x^{n} \underline{p}^{n}$.

*) For the components of angular momentum, the ps. df. yields expectation values correctly. 
Now we must consider the condition $(2 \cdot 3)$. Taking a function of $\underline{x}$ alone, or of $\underline{p}$ alone, $(2 \cdot 3)$ requires

$$
\left\{\begin{array}{l}
\operatorname{Sp}\left(\rho A_{1}(\boldsymbol{x})^{2}\right)=\int A_{1}(\boldsymbol{x})^{2} P(\boldsymbol{x}) d \boldsymbol{x} \geqq 0 \\
\mathrm{Sp}\left(\rho \underline{A}_{2}(\underline{\boldsymbol{p}})^{2}\right)=\int A_{2}(\boldsymbol{p})^{2} Q(\boldsymbol{p}) d \boldsymbol{p} \geqq 0
\end{array}\right.
$$

These relations hold for any real function $A_{1}(\boldsymbol{x})$ or $A_{2}(\boldsymbol{p})$, so that we must have

$$
P(\boldsymbol{x}) \geqq 0 \text { and } Q(\boldsymbol{p}) \geqq 0
$$

This is a necessary condition but not sufficient for $(2 \cdot 3)$ (see $\$ 7$ ).

We could represent a general quantum-mechanical mixed state with a phase space ensemble, whose distribution function $f(\boldsymbol{x}, \boldsymbol{p})$ is not itself necessarily positive everywhere, though required to produce a positive configuration-space df. $P(x)$ and positive momentumspace df. $Q(\boldsymbol{p})$. Conversely, any ps. df. $f(\boldsymbol{x}, \boldsymbol{p})$ satisfying $(2 \cdot 8),(2 \cdot 9)$, and certain 'positivity condition' including $(2 \cdot 19)$, is a permissible one corresponding to a mixed state. The non-positive-definiteness of our general ps. df., which stems from the same property of the ps. df. for pure states, discloses the physically unreal nature of our ps. en. It is a general characteristic of quantum-mechanical probability distributions for non-commuting quantities that they cannot be derived from a single statistical ensemble based on hidden variables, at least without admitting of negative probabilities.

When we are given the configuration and momentum distribution functions $P(\boldsymbol{x})$ and $Q(\boldsymbol{p})$ independently, except for the normalization condition,

$$
\int P(\boldsymbol{x}) d \boldsymbol{x}=\int Q(\boldsymbol{p}) d \boldsymbol{p}=1,
$$

we can construct many ps. dfs. which are compatible with those given $P(\boldsymbol{x})$ and $Q(\boldsymbol{p})$. Indeed the ps. df.

$$
f_{0}(\boldsymbol{x}, \boldsymbol{p})=P(\boldsymbol{x}) Q(\boldsymbol{p})
$$

is clearly such one, and moreover any ps. df.

$$
f(\boldsymbol{x}, \boldsymbol{p})=P(\boldsymbol{x}) Q(\boldsymbol{p})+f_{1}(\boldsymbol{x}, \boldsymbol{p})
$$

in which $f_{1}$ is an arbitrary function staisfying

$$
\int f_{1}(\boldsymbol{x}, \boldsymbol{p}) d \boldsymbol{p}=\int f_{1}(\boldsymbol{x}, \boldsymbol{p}) d \boldsymbol{x}=0,
$$

also leads to the given $P(x)$ and $Q(\boldsymbol{p})$. Such ps. df., $(2 \cdot 21)$ or $(2 \cdot 22)$, is a permissible one, corresponding generally to a mixed state, provided it satisfies the positivity condition. The ps. df. that factorizes as $(2 \cdot 21)$ is a particular one having no correlation at all between particle position and momentum*). In this connection, it is further to be

*) Such propetty cannot generally be conserved with the passage of time in classical as well as in quantum ps. en. In the former, however, this property persists in the special case of stationary canonical ensemble, while in the latter it is not so. This is due to the difference of the 'Liouville' equations for ps. $\mathrm{d}$ s. in both cases (see $\$ 3$ ). 
The Formulation of Quantum Mechanics in terms of Ensemble in Phase Space 347

remarked that there can exist many distribution functions in phase space other than $f(x, \boldsymbol{p})$, which satisfy $(2 \cdot 8)$ and $(2.9)$ and give expectation values correctly for any quantity of type $(2 \cdot 12 b)$. Examples are

and

$$
f_{\mathfrak{a}}(\boldsymbol{x}, \boldsymbol{p})=\cos \left(\hbar / 2 \cdot \nabla_{\boldsymbol{p}} \nabla_{\ell}\right) f(\boldsymbol{x}, \boldsymbol{p}),
$$

$$
f_{\mathrm{b}}(\boldsymbol{x}, \boldsymbol{p})=\operatorname{Re}[g(\boldsymbol{x}, \boldsymbol{p})] \text {. }
$$

We have considered the df. defined in $\boldsymbol{x}-\boldsymbol{p}$ space, but it may also be possible to introduce a distribution as a function of another variables $\xi$ and $\eta$, where $\underline{\xi}$ or $\eta$ represents each a complete set of commuting observables, in such a way that it correctly gives the quantum-mechanical probability distributions for quantities of type $A_{1}(\xi)$ and $A_{2}(\underline{\eta})$; this distribution*, however, differs from the original one, $f(\boldsymbol{x}, \boldsymbol{p})$. In this sense the ps. en. has not the meaning invariant to such pairs of unitary transformations ${ }^{11)}(x, p \rightarrow \xi, \underline{\eta})$,

\section{$\S 3$. Time development of the distribution}

\section{(a) Equation of motion and the transition in momentum}

We shall now represent the temporal change of state in terms of ps. en. The equation of motion for $\rho$,

$$
i \hbar d o / d t=\underline{H} \underline{-}-\underline{\rho} H
$$

is written, in $x$-representation, as

$$
\text { iћ } \partial_{i} \rho / \partial t=-\hbar^{2} / 2 m \cdot\left(\Delta_{x}-\Delta_{x^{\prime}}\right) \rho+\left(V(\boldsymbol{x})-V\left(\boldsymbol{x}^{\prime}\right)\right) \rho,
$$

since we take hamiltonian, $H=\boldsymbol{p}^{2} / 2 m+V(\boldsymbol{x})$, corresponding to a particle in a scalar potential $V(\boldsymbol{x})$. For the intermediary function

$$
\bar{\rho}(\boldsymbol{x}, \boldsymbol{y})=\rho(\boldsymbol{x}-\boldsymbol{y} / 2, \boldsymbol{x}+\boldsymbol{y} / 2)=\int f(\boldsymbol{x}, \boldsymbol{p}) c^{-i \boldsymbol{p} y / \hbar} d \boldsymbol{p},
$$

$(3 \cdot 2)$ is written as

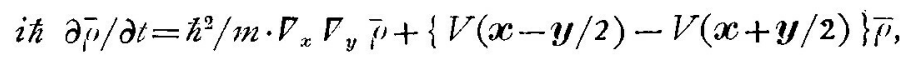

which, by fourier transformation, leads to the equation of motion for our df.:

with

$$
\partial f / \partial t+\boldsymbol{p} / m \cdot \nabla f=A[f],
$$

$$
\begin{aligned}
& A[f]=\int J\left(x, \boldsymbol{p}-\boldsymbol{p}^{\prime}\right) f\left(\boldsymbol{x}, \boldsymbol{p}^{\prime}\right) d \boldsymbol{p}^{\prime}, \\
& J(\boldsymbol{x}, \boldsymbol{p})=-\frac{2}{\hbar} \frac{1}{(2 \pi \hbar)^{3}} \int V\left(\boldsymbol{x}+\frac{\boldsymbol{y}}{2}\right) \sin \frac{\boldsymbol{p} \boldsymbol{y}}{\hbar} d \boldsymbol{y}
\end{aligned}
$$

*) It is given by

$f(\xi, \eta)=(\pi \hbar)^{-1} \int\left\langle\eta \mid \xi^{\prime}\right\rangle\left\langle\xi^{\prime}|\dot{\rho}| \xi^{\prime \prime}\right\rangle\left\langle\xi^{\prime \prime} \mid \eta\right\rangle \delta\left(\xi^{\prime}+\xi^{\prime \prime}-2 \xi\right) d \xi^{\prime} d \xi^{\prime \prime}$. 


$$
=-\frac{2^{4}}{\hbar} \operatorname{Im}\left[V(2 \boldsymbol{p}) \ell^{-2 i p x / \hbar}\right]
$$

where

$$
V(\boldsymbol{p})=\frac{1}{(2 \pi \hbar)^{3}} \int V(\boldsymbol{x}) e^{i p^{x} / \hbar} d \boldsymbol{x}
$$

The appearance of the fourier component, $V(2 \boldsymbol{p})$, may more easily be understood by starting from the momentum representation of $(3 \cdot 1)$,

$$
\begin{aligned}
& i \hbar \frac{\partial f^{\prime}\left(\boldsymbol{p}, \boldsymbol{p}^{\prime}\right)}{\partial t}=\frac{1}{2 m}\left(\boldsymbol{p}^{2}-\boldsymbol{p}^{\prime \prime}\right) \rho^{\prime}\left(\boldsymbol{p}, \boldsymbol{p}^{\prime}\right) \\
& \quad+\int\left(V\left(\boldsymbol{p}-\boldsymbol{p}^{\prime \prime}\right) \rho^{\prime}\left(\boldsymbol{p}^{\prime \prime}, \boldsymbol{p}^{\prime}\right)-\rho\left(\boldsymbol{p}, \boldsymbol{p}^{\prime \prime}\right) \nu^{\prime}\left(\boldsymbol{p}^{\prime \prime}-\boldsymbol{p}^{\prime}\right)\right) d \boldsymbol{p}^{\prime \prime},
\end{aligned}
$$

and transforming it by use of $(2 \cdot 7)$.

By expansion $\int$ may also be written as

$$
J(\boldsymbol{x}, \boldsymbol{p})=\sum_{n}^{\prime} \sum_{n_{1}+n_{2}+n_{3}=n} \frac{(-\varepsilon)^{(n-1) / 2}}{n_{1} ! n_{2} ! n_{3} !} \frac{\partial^{n} V}{\partial x_{1}^{n_{1}} \partial x_{2}^{n_{2}} \partial{x_{3}{ }^{n_{3}}}_{n_{3}}} \frac{\partial^{n} \delta(\boldsymbol{p})}{\partial p_{1}^{n_{1}} \partial p_{2}^{n_{2}} \partial p_{:}^{n_{3}}},
$$

where $\varepsilon \equiv \hbar^{2} / 4$, and $\sum_{n}{ }^{\prime}$ means the summation over positive odd integers. Using this form, the integral operator $A$ is expressed as an infinite series of differential operators ${ }^{\left({ }^{())}\right)}$:

$$
\begin{aligned}
A[f] & =\sum_{n}^{\prime} \sum_{n_{1}+n_{2}+n_{3}=n} \frac{(-\varepsilon)^{(\boldsymbol{n}-1) / 2}}{n_{1} ! n_{2} ! n_{3} !} \frac{\partial^{n} V}{\partial x_{1}^{n_{2}}} \frac{V}{\partial x_{:}^{n_{2}} \partial x_{3}^{n_{3}}} \frac{\partial^{n^{\prime}} f}{\partial p_{1}^{n_{2}} \partial p_{2}^{n_{2}} \partial p_{3}^{n_{\mathrm{a}}}}, \\
& =2 / \hbar \cdot \sin \left(\frac{\hbar}{2} \nabla_{: x} \nabla_{p}\right) V(\boldsymbol{x}) f(\boldsymbol{x}, \boldsymbol{p}),
\end{aligned}
$$

with the understanding that $\nabla_{: x}$ in $(3 \cdot 12)$ operates on $V(x)$ alone. Expressions $(3 \cdot 10)$ and $(3 \cdot 11)$ may be regarded as expansions in ascending powers of $\varepsilon$, of which first terms are

$$
J^{(0)}(\boldsymbol{x}, \boldsymbol{p})=\boldsymbol{\nabla} V \cdot \boldsymbol{V}_{p} \partial(\boldsymbol{p}), \quad A^{(\boldsymbol{N})}[f]=\boldsymbol{\nabla} V^{\top} \cdot \Gamma_{p} f
$$

If $V(x)$ is a polynomial in or below second power, only the first terms $(3.13)$ in the

*) To next page: The circumstance that in case of potential quadratic (including below quadtatic) in $x$, the ps. en. moves purely classically is closely connected with the fact that in this case, speaking with the language of matrix mechanics, the Hamilton's or Newton's eqnation of motion for $q$-number coordinates is $\left(i n e^{2}\left(\eta^{x^{2}}\right)\right.$. Generally in quantum mechanics formally the same equation of motion as in classical theory holds for q-number quantities, but, if this equation of motion be linear, there does not appear any froduct of ij-mumbirs, the rule on which specifies the essential diference of quantum mechanics from classical theory, and thet efore each matrix element changes like classical quantity. In this case the difference of quantum mechanics from classical theory can only present itself in the definition of the initial condicions which is represented by the commutation relation in matrix mechanics, and by the subsidiaty conditions for pure state (to be stated in $\S 4$ ) in our formulation. It is to be noted that the above case includes a generaized forced 'oscillator' with the hamiltonian, $I I=a(t) p^{\prime}+$ $\beta(t) \underline{x}+r(t) \underline{x}$. 
The Formulation of Quantum Mechanics in torms of Enscmbli in Pluas Spaci 3.49

series survive, and then $(3.5)$ reduces to the form identical with the Liouville equation for the classical $\mathrm{df}$. Therefore in such a case the time development of our ps. en. can be regarded as is produced by the process that each point of the ensemble moves along its purely classical continuous trajectory, in precisely the same manner as in the classicalstatistical ensemble.*

Such a picture, however, fails in general cases, where $A[f]$ is an integral operator in momentum space. Yet, looking upon the second and higher order terms in the expansion (3.11) as quantum-mechanical corrections, we call (3.5) 'quantum-mechanical Liouville equation'. The formal interpretation of this equation leads to the following stochastic picture for the time development of the ensemble: The coordinate $x$ of each particle of the ensemble changes continuously with the velocity $\boldsymbol{p} / m$, while the value of its momentum jumps with a 'transition probability' $J(J(\boldsymbol{c}, \boldsymbol{p}) d \boldsymbol{p}$ meaning the probability with which the momentum jumps in unit time by an amount $\boldsymbol{p} \sim \boldsymbol{p}+d \boldsymbol{p}$ at point $\boldsymbol{x}$ ).

Now this stochastic picture has further following features: (i) $J$ is an odd function of $\boldsymbol{p}$; therefore it takes negative as well as positive values, and also

$$
\iint\left(\boldsymbol{x}, \boldsymbol{p}^{\prime}\right) d \boldsymbol{p}^{\prime}=0
$$

that is, this transition probability is not normalizable, though $(3 \cdot 14)$ serves to ensure the distribution probability:

$$
\frac{d}{d t} \int f d x d p=0
$$

(ii) The transition probability depends upon the amount of jump alone, irrespective of the value of momentum before or after the jump. (iii) The external field $V(x)$ acts so as to induce indeterministic transitions in particle momentum, but the transition probability $J$ itself is perfectly determined by this potential. (iv) As is seen in $(3.8) J(x$, $\boldsymbol{p}$ ) is of a form of a perfect sinusoidal wave in $x$-space with no damping in far away irrespective of the form of $V(\boldsymbol{x})$. The amplitude of this wave is the fourier component** $V(2 \boldsymbol{p})$; while its wave-length is $\hbar / 2 p$, so that for larger jumps of momentum the $\boldsymbol{x}$ space oscillation of $J$ is more rapid, having therefore less effects when we consider the space average over the ensemble. (v) Since

$$
\int \boldsymbol{p} J(x, \boldsymbol{p}) d \boldsymbol{p}=-\nabla V
$$

the rate of average change of momentum agrees with the classical value. In each individual case, however, particle fuctuates, performing jumps in momentum, which may well be far greater than the mean value, and may thus, for instance, penetrate a potential barrier.

(vi) The various 'transition moments' of momentum components are found to be

**) The circumstance that the probablity of momentum transition from $\boldsymbol{p}_{0}$ to $\boldsymbol{p}$ is determined by $V^{r}\left(2\left(\boldsymbol{p}-\boldsymbol{p}_{0}\right)\right)$ in our stochastic picture is somewhat similar to the usual perturbation-theotetical result of quantum mechanics, where the probability of transition from the state of momentum $\boldsymbol{p}_{0}$ to that of $\boldsymbol{p}$ is proportional to $\left|\boldsymbol{r}\left(\boldsymbol{p}-\boldsymbol{p}_{0}\right)\right|^{2}$. 


$$
\begin{aligned}
m_{n_{1} n_{2} n_{3}} & =\int p_{1}^{n_{1}} p_{2}^{n_{2}} p_{3}^{n_{3}} J(\boldsymbol{x}, \boldsymbol{p}) d \boldsymbol{p} \\
& =\left\{\begin{array}{cl}
-(-\varepsilon)^{(n-1) / 2} \frac{\partial^{n} V}{\partial x_{1}^{n_{1}} \partial x_{2}^{n_{2}} \partial x_{3}^{n_{3}}}, & \text { if } n=\sum_{i} n_{i}=\text { odd }, \\
0, & \text { if } n=\text { even, }
\end{array}\right.
\end{aligned}
$$

including (3.14) and $(3.16)$ as special cases. On account of the odd character of $J$, transition moments of even orders vanish while those of odd orders survive, in contrast to the usual Brownian processes. In the latter, the transition moments in and above third orders are assumed to vanish, resulting in the differential equation of Fokker-Planck-Kramers ${ }^{13)}$ type for the df.; the diffusion takes place in a manner essentially determined by the second order moment, the distribution always diffusing monotonously and irreversibly. On the other hand in our case the moments of third and higher odd orders give rise to a quite different type of 'diffusion' '*)**)***). The non-vanishing of third or higher order moments means that in our process the probability that the value of momentum changes by a finite amount in a small time interval cannot be regarded as small.

We have thus obtained a stochastic picture of distinctive features for a quantummechanical change of state. Though this picture cannot be taken as a real one, for instance, on account of (i), it may be said to represent quantum fluctuations in a picturesque manner.

\section{(b) Transition probability for a finite time interval}

Our df. develops with time according to the linear integro-differential equation $(3 \cdot 5)$ which is of the first degree in $t$, and therefore, given the initial distribution $f\left(\boldsymbol{x}_{0}, \boldsymbol{p}_{0}, t_{0}\right)$, later distributions will be uniquely determined. The time development of $f$ may thus be written in an integral form,

$$
f(\boldsymbol{x}, \boldsymbol{p}, t)=\int T\left(\boldsymbol{x p} t \mid \boldsymbol{x}_{0} \boldsymbol{p}_{0} t_{0}\right) f\left(\boldsymbol{x}_{0}, \boldsymbol{p}_{0}, t_{0}\right) d \boldsymbol{x}_{0} d \boldsymbol{p}_{0},
$$

where the kernel $T\left(\boldsymbol{x} \boldsymbol{p} t \mid \boldsymbol{x}_{0} \boldsymbol{p}_{0} t_{0}\right)$ embodies the temporal development law of the distribution independently of the initial condition, and implies the transition probability in phasespace for finite time interval, i.e., the distribution at $t$ conditional in $x_{0}, p_{0}$ at $t_{0}$.

Naturally this function is closely connected with the kernel (propagation function) for the time development of the wave function $\psi(x, t)$, which is written as

$$
\phi(x, t)=\int K\left(x t \mid x_{0} t_{0}\right) \phi\left(x_{0} t_{0}\right) d x_{0} \text {. }
$$

*) Cf. $\$ 6$ (a) and appendix A.

**) Such a result corresponds to the circumstance that the wave function (the probability amplitude) satisfies a diffusion-type differential equation with imaginary time coefficient, and therefore, when we transform this equation to that for a real quantity interpretable as a probability distribusion by an iteration procedure, the latter equation can no longer be of a diffusion type.

***) In conventional Brownian processes, furthermore, there acts a frictional force which is proportional to particle velocity and makes it tend to the equilibrium distribution. In our process, however, such effects do not occur and it is impossible that any distribution should converge with the passage of time to some equilibrium distribution that would correspond to a stationary state [see $\S 6$ (b) iii)]. 
The Formulation of Quantum Mechanics in terms of Enscmble in Phase Space 351

This kernel $K\left(\boldsymbol{x} t \mid \boldsymbol{x}_{0} t_{0}\right)$ is nothing but the transformation function which transforms the representation making $\underline{x}_{t_{0}}$ (particle position at $t_{0}$ ) diagonal to the one making $\underline{x}_{t}$ (position at $t$ ) diagonal, i.e.,

$$
K\left(x t \mid x_{0} t_{0}\right)=\left\langle x_{\imath}^{\prime} \mid x_{t_{0}}{ }^{\prime}\right\rangle, \quad \begin{aligned}
& \text { with } x=x_{t}^{\prime}, x_{0}=x_{t_{0}}^{\prime}, \\
& \text { numerically. }
\end{aligned}
$$

Hence it satisfies, as is well known, the iteration law :

$$
K\left(\boldsymbol{x} t \mid \boldsymbol{x}_{0} t_{0}\right)=\int K\left(\boldsymbol{x} t \mid \boldsymbol{x}_{1} t_{1}\right) K\left(\boldsymbol{x}_{1} t_{1} \mid \boldsymbol{x}_{0} t_{0}\right) d \boldsymbol{x}_{1},
$$

and the unitarity condition:

$$
\int K\left(\boldsymbol{x} t \mid \boldsymbol{x}_{0} t_{0}\right) K\left(\boldsymbol{x}_{0} t_{0} \mid \boldsymbol{x}^{\prime} t\right) d \boldsymbol{x}_{0}=\hat{\delta}\left(\boldsymbol{x}-\boldsymbol{x}^{\prime}\right),
$$

and so

$$
K\left(\boldsymbol{x} t_{0} \mid \boldsymbol{x}_{0} t_{0}\right)=\delta\left(\boldsymbol{x}-\boldsymbol{x}_{0}\right) .
$$

As $K\left(\boldsymbol{x} t \mid \boldsymbol{x}_{0} t_{0}\right)$ also satisfies the Schrödinger equation, it can be determined by solving that equation under the initial condition $(3 \cdot 23)$. For a conservative system $K$ may be written as

$$
K\left(\boldsymbol{x} t \mid \boldsymbol{x}_{0} t_{0}\right)=\left\langle\boldsymbol{x}\left|e^{-i H\left(t-t_{0}\right) / \hbar}\right| \boldsymbol{x}_{0}\right\rangle,
$$

which is a function of $t-t_{0}$ alone in respect to the time, and satisfies

$$
K\left(\boldsymbol{x} t \mid \boldsymbol{x}_{0_{0}}\right)=K^{*}\left(\boldsymbol{x}_{0} t_{0} \mid \boldsymbol{x} t\right) .
$$

Now, corresponding to $(3 \cdot 19)$, the kernel for the time development of the density matrix $\rho\left(\boldsymbol{x}, \boldsymbol{x}^{\prime}, t\right)$ is given by

$$
\int K\left(\boldsymbol{x} t \mid \boldsymbol{x}_{0} t_{0}\right) K^{*}\left(\boldsymbol{x}^{\prime} t \mid \boldsymbol{x}_{0}^{\prime} t_{0}\right) d \boldsymbol{x}_{0} d \boldsymbol{x}_{0}^{\prime},
$$

and accordingly the relation of our transformation function $T$ with $K$ is found to be

$$
\begin{aligned}
T\left(\boldsymbol{x p} t \mid \boldsymbol{x}_{0} \boldsymbol{p}_{0} t_{0}\right) & =\frac{1}{(2 \pi \hbar)^{3}} \int K\left(\boldsymbol{x}-\frac{\boldsymbol{y}}{2}, t \mid \boldsymbol{x}_{0}-\frac{\boldsymbol{y}_{0}}{2}, t_{0}\right) \times \\
& \times K^{*}\left(\boldsymbol{x}+\frac{\boldsymbol{y}}{2}, t \mid \boldsymbol{x}_{0}+\frac{\boldsymbol{y}_{0}}{2}, t_{0}\right) c^{(i / \hbar)\left(\boldsymbol{m} y-p^{\prime} 0 y_{0}\right)} d \boldsymbol{y} d \boldsymbol{y}_{0}
\end{aligned}
$$

From the properties of $K,(3.21)-(3.25)$, we can find the corresponding properties of T. First, $T$ is real, satisfies the iteration law :

$$
T\left(\boldsymbol{x} \boldsymbol{p} t \mid \boldsymbol{x}_{0} \boldsymbol{p}_{0} t_{0}\right)=\int T\left(\boldsymbol{x} \boldsymbol{p} t \mid \boldsymbol{x}_{1} \boldsymbol{p}_{1} t_{1}\right) T\left(\boldsymbol{x}_{1} \boldsymbol{p}_{1} t_{1} \mid \boldsymbol{x}_{0} \boldsymbol{p}_{0} t_{0}\right) d \boldsymbol{x}_{1} d \boldsymbol{p}_{1},
$$

and the unitarity:

$$
\int T\left(\boldsymbol{x} \boldsymbol{p} t \mid \boldsymbol{x}_{\mathbf{0}} \boldsymbol{p}_{0} t_{0}\right) T\left(\boldsymbol{x}_{0} \boldsymbol{p}_{0} t_{0} \mid \boldsymbol{x}^{\prime} \boldsymbol{p}^{\prime} t\right) d \boldsymbol{x}_{0} d \boldsymbol{p}_{0}=\delta\left(\boldsymbol{x}-\boldsymbol{x}^{\prime}\right) \delta\left(\boldsymbol{p}-\boldsymbol{p}^{\prime}\right),
$$

and so we also have

$$
T\left(\boldsymbol{x p} t_{0} \mid \boldsymbol{x}_{0} \boldsymbol{p}_{0} t_{0}\right)=\delta\left(\boldsymbol{c}-\boldsymbol{x}_{0}\right) \delta\left(\boldsymbol{p}-\boldsymbol{p}_{0}\right) .
$$

The $T$-function itself satisfies the quantum Liouville equation:

$$
\frac{\partial T\left(\boldsymbol{x} \boldsymbol{p} t \mid \boldsymbol{x}_{\mathbf{0}} \boldsymbol{p}_{0} t_{0}\right)}{\partial t}+\frac{\boldsymbol{p}}{m} \nabla T=\int J\left(\boldsymbol{x}, \boldsymbol{p}-\boldsymbol{p}^{\prime}\right) T\left(\boldsymbol{x} \boldsymbol{p}^{\prime} t \mid \boldsymbol{x}_{0} \boldsymbol{p}_{0} t_{0}\right) d \boldsymbol{p}^{\prime}
$$


and we may determine $T$ by solving (3.31) under the initial condition (3.30). For a conservative system, $T\left(x \boldsymbol{p} t \mid x_{0} \boldsymbol{p}_{0} t_{0}\right)$ depends on $t-t_{0}$ alone in respect to the time, and is symmetric:

$$
T\left(\boldsymbol{x} \boldsymbol{p} t \mid \boldsymbol{x}_{0} \boldsymbol{p}_{0} t_{0}\right) \doteq T\left(\boldsymbol{x}_{0} \boldsymbol{p}_{0} t_{0} \mid \boldsymbol{x} \boldsymbol{p} t\right),
$$

and normalized :

$$
\int T\left(\boldsymbol{x} \boldsymbol{p} t \mid \boldsymbol{x}_{0} \boldsymbol{p}_{0} t_{0}\right) d \boldsymbol{x} d \boldsymbol{p}=1 .
$$

Eq. (3.28) with $(3 \cdot 30)$ and $(3.33)$ shows that our stochastic process is a sort of Markoff process in phase-space with the transition probability $T$, though we must allow of negative probabilities, since $T$ as well as $f$ is not necessarily positive. The law of composition (3.28) may be regarded as the integral equation ("Smoluchowski equation") for the transition probability function $T$, which may be reduced to the 'differential form' (3.31) with (3.10). The latter equation, however, is of a type quite different from the Fokker-Kramers-Kolmogoroff equation for usual Brownian processes, since, in our process, the differential coefficients of $V$ in and above third degree, in so far as they do not vanish, play the roles of higher transition moments for momentum components.

Eq. (3.31) with (3.30) is written as

$$
\begin{aligned}
&\left.T(\boldsymbol{x p} t\} \boldsymbol{x}_{0} \boldsymbol{p}_{0} t_{0}\right)=\delta\left(\boldsymbol{x}-\boldsymbol{x}_{0}\right) \delta\left(\boldsymbol{p}-\boldsymbol{p}_{0}\right)-\int_{t_{0}}^{t} \boldsymbol{p} / m \cdot \boldsymbol{\nabla} T \\
&+\int_{t_{0}}^{t} d t \int J\left(\boldsymbol{x}, \boldsymbol{p}-\boldsymbol{p}^{\prime}\right) T^{\prime}\left(\boldsymbol{x} \boldsymbol{p}^{\prime} t \mid \boldsymbol{x}_{0} \boldsymbol{p}_{0} t_{0}\right) d \boldsymbol{p}^{\prime},
\end{aligned}
$$

which may be solved by iteration as a power series in $t-t_{0}$ :

$$
T\left(x \boldsymbol{p} t \mid \boldsymbol{x}_{0} \boldsymbol{p}_{0} t_{0}\right)=\delta\left(\boldsymbol{x}-\boldsymbol{x}_{0}\right) \delta\left(\boldsymbol{p}-\boldsymbol{p}_{0}\right)+\left(t-t_{0}\right) T_{1}^{+}+\frac{\left(t-\cdots t_{0}\right)^{2}}{2} T_{2}^{*}+\cdots
$$

with

$$
\begin{aligned}
& T_{1}\left(\boldsymbol{x p} \mid \boldsymbol{x}_{0} \boldsymbol{p}_{0}\right)=-\frac{\boldsymbol{p}}{m} \delta\left(\boldsymbol{p}-\boldsymbol{p}_{0}\right) \nabla_{x} \delta\left(\boldsymbol{x}-\boldsymbol{x}_{0}\right)+\delta\left(\boldsymbol{x}-\boldsymbol{x}_{0}\right) J\left(\boldsymbol{x}, \boldsymbol{p}-\boldsymbol{p}_{0}\right), \\
& T_{2}\left(\boldsymbol{c} \boldsymbol{p} \mid \boldsymbol{x}_{0} \boldsymbol{p}_{0}\right)=-{ }_{m^{2}}^{1} \delta\left(\boldsymbol{p}-\boldsymbol{p}_{0}\right)(\boldsymbol{p} \boldsymbol{F})\left(\boldsymbol{p}_{0} \nabla_{0}\right) \delta\left(\boldsymbol{x}-\boldsymbol{x}_{0}\right) \\
& \quad \frac{\boldsymbol{p}+\boldsymbol{p}_{0}}{m} \Gamma_{x} \delta\left(\boldsymbol{x}-\boldsymbol{x}_{0}\right) J\left(\boldsymbol{x}, \boldsymbol{p}-\boldsymbol{p}_{0}\right)+\delta\left(\boldsymbol{x}-\boldsymbol{x}_{0}\right) \int J\left(\boldsymbol{x}, \boldsymbol{p}-\boldsymbol{p}^{\prime}\right) J\left(\boldsymbol{x}, \boldsymbol{p}^{\prime}-\boldsymbol{p}_{0}\right)(\boldsymbol{t})^{\prime} .
\end{aligned}
$$

When the potential $V^{r}(x)$ is, in particular, a polynomial in or below second power, $T$ is the solution of the classical Liouville equation with the initial condition (3.30), and hence is given by

$$
T\left(\boldsymbol{x} \boldsymbol{p} t \mid \boldsymbol{x}_{0} \boldsymbol{p}_{0} t_{0}\right)=\delta\left(\boldsymbol{x}-\boldsymbol{x}_{\ell}\left(\boldsymbol{x}_{0} \boldsymbol{p}_{0} t_{0}\right)\right) \delta\left(\boldsymbol{p}-\boldsymbol{p}_{t}\left(\boldsymbol{x}_{0} \boldsymbol{p}_{0} t_{0}\right)\right),
$$

where $\left(\boldsymbol{x}_{l}, \boldsymbol{p}_{l}\right)$ is the solution of the classical Newtonian equation of motion. For example, for a free patticle we have

$$
T\left(x p t \mid x_{0} p_{0} t_{0}\right)=\delta\left(p-p_{0}\right) \delta\left(x-x_{0}-p_{0} / m \cdot\left(t \cdots t_{0}\right)\right),
$$

which is quite different from the kemel for the usual diffusion, while the kernel for probability ampiitude is, as is well known, of diffusion type with imaginary time coefficient:

$$
K^{\top}\left(\boldsymbol{x}<\mid \boldsymbol{x}_{0} \tau_{0}\right)=\left(\frac{m}{2 \pi / i\left(t-t_{0}\right)}\right)^{m / 2} \exp \left(\frac{i m \frac{\left(\boldsymbol{x}-\boldsymbol{x}_{0}\right)^{2}}{2 \pi}}{t-t_{0}}\right)
$$

But the fourier transformation of (3.36), taking account of the relation (3.27), gives 


$$
\begin{array}{r}
K\left(\boldsymbol{x}-\frac{\boldsymbol{y}}{2}, t \mid \boldsymbol{x}_{0}-\frac{\boldsymbol{y}_{0}}{2}, t_{0}\right) K^{*}\left(\boldsymbol{x}+\frac{\boldsymbol{y}}{2}, t \mid \boldsymbol{x}_{0}+\frac{\boldsymbol{y}_{0}}{2}, t_{0}\right) \\
=-\left(\frac{m}{2 \pi t\left(t-t_{0}\right)}\right)^{3} \exp \left(-\frac{i m b}{t} \frac{\left(\boldsymbol{x}-\boldsymbol{x}_{0}\right)\left(\boldsymbol{y}-\boldsymbol{y}_{0}\right)}{t-t_{0}}\right),
\end{array}
$$

from which we can derive (3.37).

\section{\$4. Subsidiary conditions for pure state}

(a) As was stated in $\$ 2$, generally a ps. df. $f(\boldsymbol{x}, \boldsymbol{p})$, in so far as it satisfies the positivity condition, corresponds to a mixed state, and the procedure of mixing of states corresponds to a superposition (with positive coefficients) of relevant distribution functions. Therefore, various relations thus far stated which are valid for any mixed states (including pure states as their special cases) must be linear ones (except for the positivity condition). In fact; the expression of mean values (2.12), and the time development equation (3.5) or (3.18) are all linear in $f$. Therefore the subsidiary condition that must be imposed upon a df. in order that the df. should in particular correspond to a pure state, must be some non-linear relation. It must be further of such character as to restrict the functional space of the df. which is one real function of six independent variables to that of two real functions of three independent variables, as a pure state corresponds to a complex function $\phi(\boldsymbol{x})$ or $\phi(\boldsymbol{p})$.

Since our df. $f$ correctly gives expectation values of dynamical quantities at least of type $(2.12 b)$ as the mean values over $f$, the df. for pure state must satisfy the 'uncertainty relation' as the relation between the mean deviations of $x$ and $\boldsymbol{p}$ :

$$
\left\{\left\langle x_{i}{ }^{2}\right\rangle_{f}-\left(\left\langle x_{i}\right\rangle_{f}\right)^{2}\right\}\left\{\left\langle p_{i}{ }^{2}\right\rangle_{f}-\left(\left\langle p_{i}\right\rangle_{j}\right)^{2}\right\} \geqq \varepsilon \equiv \hbar^{2} / 4 \text {. }
$$

This relation, being non-linear in $f$, is a necessary condition for the correspondence of $f$ to a pure state, but not a sufficient one.

The condition that a mixed state should in particular fall into a pure state can be expressed, in terms of the density matrix, as $\rho^{2}==\rho$, i.e.,

$$
\int \rho\left(\boldsymbol{x}, \boldsymbol{x}^{\prime \prime}\right) \rho\left(\boldsymbol{x}^{\prime \prime}, \boldsymbol{x}^{\prime}\right) d \boldsymbol{x}^{\prime \prime}=\rho\left(\boldsymbol{x}, \boldsymbol{x}^{\prime}\right) .
$$

Transforming this relation according to $(2 \cdot 6)$ we may immediately obtain the pure state condition for $f$, but then the result is not of a convenient form (see $\S 7$ )*; so we will prefer another way.

Now, if $(4 \cdot 2)$ is satisfied, there exists a suitable complex function $\phi(x)$ that makes $\rho\left(x, x^{\prime}\right)$ written as

$$
\left(x, x^{\prime}\right)=\phi(x) \phi^{*}\left(x^{\prime}\right)
$$

on account of $(2 \cdot 1),(2 \cdot 2)$, and $(2 \cdot 3)$. It is because $(4 \cdot 2)$ with $(2 \cdot 3)$ requires $w v_{n}=\delta_{n n_{0}}$ (with certain fixed $\left.n_{0}\right)$, when $\rho\left(\boldsymbol{x}, \boldsymbol{x}^{\prime}\right)$ is put in the form $(2 \cdot 4)$. But if $(4 \cdot 3)$ be satisfied, we have clearly

*) But there the condition is expressed in a form symmetrical in $x$ and $p$. 


$$
\begin{array}{r}
\frac{\partial_{\rho} \rho}{\partial x_{i}} \frac{\partial^{\prime \prime}}{\partial x_{k}^{\prime}}-\frac{\partial^{2} \rho}{\partial x_{i} \partial x_{k}^{\prime}}=-\rho \frac{\partial^{\prime}}{\partial x_{k}^{\prime}} \frac{\partial}{\partial x_{i}} \log \left(\frac{\partial}{\partial x_{k}^{\prime}} \log \rho\right)=0 ; \\
(i, k=1,2,3)
\end{array}
$$

and conversely, if $(4 \cdot 4)$ be satisfied for every $i$ and $k$, we get $(4 \cdot 3)$ by integrating $(4 \cdot 4)$ and by use of $(2 \cdot 1),(2 \cdot 2)$. We can therefore adopt the local relation (4.4), in place of the intcgral relation $(4 \cdot 2)$, as the pure state condition, under the premises $(2 \cdot 1),(2 \cdot 2)$, and $(2 \cdot 3)$.

Eq. $(4.4)$ is of course compatible* with the equation of motion for $\rho$, which determines $\rho\left(\boldsymbol{x}, \boldsymbol{x}^{\prime}, t\right)$ from its initial value $\rho\left(\boldsymbol{x}, \boldsymbol{x}^{\prime}, t_{0}\right)$ uniquely, so it is sufficient to impose the pure state condition at a certain instant.

Now we can get the pure state condition for the ps. df. $f(\boldsymbol{x}, \boldsymbol{p})$ satisfying the general conditions $(2 \cdot 8),(2 \cdot 9)$ by transforming $(4 \cdot 4)$ into the relation as to $f$ through $(2 \cdot 6)$. For the intermediary function $\bar{p}(\boldsymbol{x}, \boldsymbol{y})$ of $(3 \cdot 3),(4 \cdot 4)$ is written as

$$
\begin{aligned}
\left(\frac{1}{2} \frac{\partial}{\partial x_{i}}\right. & \left.-\frac{\partial}{\partial y_{i}}\right) \bar{\rho} \cdot\left(\frac{1}{2} \frac{\partial}{\partial x_{k}}+\frac{\partial}{\partial y_{k}}\right) \bar{\rho} \\
& =\bar{l} \cdot\left(\frac{1}{2} \frac{\partial}{\partial x_{i}}-\frac{\partial}{\partial y_{i}}\right)\left(\frac{1}{2} \frac{\partial}{\partial x_{k}}+\frac{\partial}{\partial y_{k}}\right) \bar{\rho},
\end{aligned}
$$

which, by the fourier transformation, separates into the following real and imaginary part equations :

$$
\left\{\begin{array}{l}
\left(p_{i} f\right) *\left(p_{k} f\right)-f_{*}\left(p_{i} p_{k} f\right)=-\varepsilon\left(\frac{\partial f}{\partial x_{i}} * \frac{\partial f}{\partial x_{k}}-f * \frac{\partial^{2} f}{\partial x_{i} \partial x_{k}}\right), \\
\frac{\partial f}{\partial x_{i}} *\left(p_{k} f\right)-\frac{\partial f}{\partial x_{k}} *\left(p_{i} f\right)=f *\left(p_{k} \frac{\partial f}{\partial x_{i}}-p_{i} \frac{\partial f}{\partial x_{k}}\right),
\end{array}\right.
$$

where the notation such as $f_{1} * f_{2}$ means the convolution with respect to $\boldsymbol{p}$, i.e.,

$$
\begin{aligned}
f_{1}(\boldsymbol{x}, \boldsymbol{p}) * f_{2}(\boldsymbol{x}, \boldsymbol{p}) & \equiv \int f_{1}\left(\boldsymbol{x}, \boldsymbol{p}^{\prime}\right) f_{2}\left(\boldsymbol{x}, \boldsymbol{p}-\boldsymbol{p}^{\prime}\right) d \boldsymbol{p}^{\prime} \\
& =\int f_{1}\left(\boldsymbol{x}, \boldsymbol{p}^{\prime}\right) f_{2}\left(\boldsymbol{x}, \boldsymbol{p}^{\prime \prime}\right) \delta\left(\boldsymbol{p}-\boldsymbol{p}^{\prime}-\boldsymbol{p}^{\prime \prime}\right) d \boldsymbol{p}^{\prime} d \boldsymbol{p}^{\prime \prime}
\end{aligned}
$$

We have thus obtained the subsidiary conditions for the correspondence to a pure state, which have following properties:

(i) The condition consists of six relations (4.6) symmetrical in $i$ and $k$ and three real anti-symmetrical ones (4.7). Since $f$ is a scalar, $(4 \cdot 6)$ is a tensor equation and $(4 \cdot 7)$ a vector equation, both covariant to coordinate transformations.

(ii) They are 'kinematical' relations independent of the dynamical characteristics of the system. Planck's constant which appeared in the time development equation (3.5) with $(3 \cdot 11)$ also enters the first condition $(4 \cdot 6)$, both in the form $\varepsilon \equiv \hbar^{2} / 4$. Thus in our

*) See the foot-note of appendix B. 
The Formulation of Quantum Mechunics in terms of Enscmble in Pharse Space 355

formulation of quantum mechanics Planck's constant has to play such tresofold roles. We may call $(4 \cdot 6)$ the 'quantum condition'** for the ps. en. formulation, and $(4 \cdot 7)$ the 'irrotationality condition' (see below).

(iii) The conditions are surely not linear in $f$, but are again integral equations quadratic in $f$. If we have two distributions $f_{1}$ and $f_{2}$ satisfying both $(4 \cdot 6)$ and $(4 \cdot 7)$, the distribution obtained by their superposition, (which corresponds to mixing of states), no longer satisfies these conditions, as it should not.

We could adopt, in place of $(4 \cdot 4)$, the similar relation for $\rho\left(\boldsymbol{p}, \boldsymbol{p}^{\prime}\right)$ :

$$
\frac{\partial^{\prime}}{\partial p_{i}} \frac{\partial \rho}{\partial p_{k}^{\prime}}-\rho \frac{\partial^{2} \rho}{\partial p_{i}} \partial p_{k}^{\prime}=0
$$

which, by fourier transformation using $(2 \cdot 7)$, leads to relations :

$$
\left\{\begin{array}{l}
\left(x_{i} f\right) *\left(x_{k} f\right)-f *\left(x_{i} x_{k} f\right)=-\varepsilon\left(\frac{\partial f}{\partial p_{i}} * \frac{\partial f}{\partial p_{k}}-f * \frac{\partial^{2} f}{\partial p_{i} \partial p_{k}}\right) \\
\frac{\partial f}{\partial p_{i}} *\left(x_{k} f\right)-\frac{\partial f}{\partial p_{k}} *\left(x_{i} f\right)=f *\left(x_{k} \frac{\partial f}{\partial p_{i}}-x_{i} \frac{\partial f}{\partial p_{k}}\right)
\end{array}\right.
$$

where the convolution is to be taken in respect to $\boldsymbol{x}$ in place of $\boldsymbol{p}$. This set of relations is an alternative form of the pure state condition, being equivalent to the set $(4 \cdot 6)$ and $(4 \cdot 7)$.

(b) Our next task is to re-express the conditions $(4 \cdot 6)$ and $(4 \cdot 7)$ in another forms. For that purpose, first, we integrate $(4 \cdot 6)$ and $(4 \cdot 7)$ throughout over the $\boldsymbol{p}$-space, which procedure we shall call the 'projcction of the relations onto the coordinate space', and employ the factorization formula for the convolution :

$$
\int\left(f_{1} * f_{2}\right) d \boldsymbol{p}=\int f_{1} d \boldsymbol{p} \int f_{2} d \boldsymbol{p} .
$$

Then we get from $(4 \cdot 6)$

$$
P_{i} P_{k}-P \cdot P_{i k}=\varepsilon\left(P \partial_{i} \partial_{k} P-\partial_{i} P \cdot \partial_{k} P\right), \quad\left(\partial_{i} \equiv \partial / \partial x_{i}\right)
$$

and from $(4 \cdot 7)$

$$
\partial_{i} P \cdot P_{k}-\partial_{k} P \cdot P_{i}=P\left(\partial_{i} P_{k}-\partial_{k} P_{i}\right)
$$

where $P$ is what was given by $(2 \cdot 10)$, and

$$
\left\{\begin{array}{l}
P_{i}(\boldsymbol{x})=\int p_{i} f(\boldsymbol{x}, \boldsymbol{p}) d \boldsymbol{p}, \\
P_{i k}(\boldsymbol{x})=\int p_{i} p_{k} f(\boldsymbol{x}, \boldsymbol{p}) d \boldsymbol{p}
\end{array}\right.
$$

ate distribution moments with respect to momentum components of first and second orders,

**) It is to be noted that the "quantum condition" in the old quantum theory determines stationary (pure) states, while our 'quantum condition' selects pure states out of mixtures. 
respectively. Further, by introducing the mean values of $p_{i}$ and $p_{i} p_{k}$ at each space point,

$$
\bar{p}_{i}(x)=P_{i} / P, \quad \bar{p}_{i} p_{k}(x)=P_{i k} / P,
$$

$(4 \cdot 13)$ and $(4 \cdot 14)$ are simplified into

$$
\left\{\begin{array}{l}
\bar{p}_{i} p_{k}-\bar{p}_{i} \cdot \bar{p}_{k}=-\varepsilon \partial^{2} \mathfrak{P} / \partial x_{i} \partial x_{k}, \quad(\mathfrak{P}=\log P) \\
\text { curl } \bar{p}=0 .
\end{array}\right.
$$

Eq. $(4 \cdot 18)$ means the relation that the dispersion tensor of momentum, $\overline{p_{i} p_{k}}-\bar{p}_{i} \cdot \bar{p}_{k}$, at a point $\boldsymbol{x}$ should be connected with the space derivative of the space density at the point*, while (4.19) implies the irrotationality of the mean momentum field $\bar{p}(\boldsymbol{x})$.

Next, we multiply $(4 \cdot 6)$ by $p_{j}$ and then again project the result onto the coordinate space to obtain

$$
\begin{aligned}
P_{i j} P_{k}+P_{i} & P_{j k}-P_{j} P_{i k}-P \cdot P_{i j k} \\
& =\varepsilon\left\{\left(P_{j} \partial_{i} \partial_{k} P+P \partial_{i} \partial_{k} P_{j}\right)-\left(\partial_{i} P_{j} \partial_{k} P+\partial_{k} P_{j} \cdot \partial_{i} P\right)\right\} .
\end{aligned}
$$

By use of $(4 \cdot 18)$ and $(4 \cdot 19)$, this can be transformed into relations symmetrical ${ }^{* *}$ in $i, j$, and $k$ :

$$
{\overline{p_{i} p_{j} p_{k}}}_{k}-\bar{p}_{i} \cdot \bar{p}_{j} \cdot \bar{p}_{k}=-\varepsilon\left\{\left(\sum_{\mathrm{cyc}} \bar{p}_{i} \partial_{j} \partial_{k}\right) \mathfrak{P}+\partial_{i} \partial_{j} \bar{p}_{k}\right\}
$$

which are ten relations for the (symmetrical) moment tensor of the third order:

$$
P_{i j k}(x)=P \cdot \ddot{p_{i} p_{j} p_{k}}=\int p_{i} p_{j} p_{k} f(\boldsymbol{x}, \boldsymbol{p}) d \boldsymbol{p} .
$$

Continuing similar procedures on $(4 \cdot 18)$, we get in succession relations for successively higher moments. For instance, for the forth order moments we get 18 symmetrical relations :

$$
\begin{aligned}
\overline{p_{i} \bar{p}_{j} p_{k} p_{l}}-\bar{p}_{i} \bar{p}_{j} \bar{p}_{k} \bar{p}_{l}=-\varepsilon\left(\sum p_{i} \partial_{j} \partial_{k} p_{l}+\sum p_{i} p_{j} \partial_{k} \partial_{l} \mathfrak{P}\right) \\
+\varepsilon^{2}\left(\sum_{c y c} \partial_{i} \partial_{j} \mathfrak{P} \cdot \partial_{k} \partial_{l} \mathfrak{B}+\partial_{i} \partial_{j} \partial_{k} \partial_{l} \mathfrak{P}\right)
\end{aligned}
$$

On the other hand similar operations on $(4 \cdot 7)$ lead to no new relations. We can now take, as the pure state condition, $(4 \cdot 6)$ and $(4 \cdot 19)$ in place of $(4 \cdot 6)$ and $(4 \cdot 7)$, or take $(4 \cdot 19)$ and all of the relations for successively higher moments : $(4 \cdot 18),(4 \cdot 21)$ $(4 \cdot 23), \cdots$, which reduce every moment in and above second order to even order

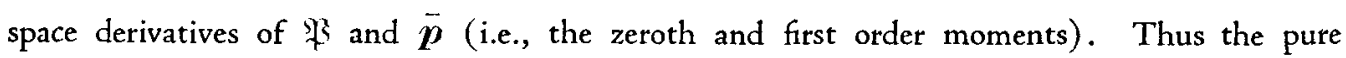
state conditions imply such restrictions to the df. that leave the zeroth moment free, restrict the first moments to being irrotational, and then uniquely determine the higher moments in terms of the zeroth and first moments. Thus we find that the functional

*) It is to be noted that the mean deviation of momentum components $\bar{f}_{i}{ }^{2}-\left(\bar{f}_{i}\right)^{2}$ at a space point is not necessarily positive for our ensemble whose df. $f(\boldsymbol{x}, \boldsymbol{p})$ is not necessarily positive, and is equal to $-\epsilon \hat{\partial}^{2} \mathfrak{\beta} / \partial x_{i}{ }^{2}$ for pure states.

**) $\partial_{i} \partial_{j} \vec{f}_{k}$ is symmetric by virtue of (4.19).

***) In the right side of (4.23) the first summation contains 4 terms, the second summation 6 terms, and the third summation 3 terms. 
space of the df. $f(\boldsymbol{x}, \boldsymbol{p})$ is indeed just limited to that of two real functions of $\boldsymbol{x}$ by means of our pure state conditions.

In a similar fashion we may also transform the conditions (4.10) and (4.11), by use of the projection onto the momentum space. We then obtain the relations in which the roles of $x$ and $\boldsymbol{p}$ in $(4 \cdot 18),(4 \cdot 19),(4 \cdot 21), \cdots$ are just exchanged. For instance, in place of $(4 \cdot 18)$ and $(4 \cdot 19)$, we get

$$
\left\{\begin{array}{l}
\overline{x_{i} x_{k}}-\bar{x}_{i} \cdot \bar{x}_{k}=-\varepsilon \partial^{2} \Omega / \partial p_{i} \partial p_{k}, \quad(\Omega \equiv \log Q) \\
\operatorname{curl}_{p} \bar{x}=0,
\end{array}\right.
$$

where

$$
\begin{cases}\bar{x}_{i}(\boldsymbol{p})=Q_{i} / Q, & Q_{i}(\boldsymbol{p})=\int x_{i} f d \boldsymbol{x}, \\ \overline{x_{i} x_{k}}(\boldsymbol{p})=Q_{i k} / Q, & Q_{i k}(\boldsymbol{p})=\int x_{i} x_{k} f d \boldsymbol{c} .\end{cases}
$$

Finally there is a problem more general than that of the pure state condition, i.e., to give a measure to 'the degree of mixture' for an arbitrary distribution $f(\boldsymbol{x}, \boldsymbol{p})$. It may be achieved by the introduction of entropy $\Sigma$ defined by

$$
\Sigma=\operatorname{Sp}(\rho \log \rho)=\sum_{n=1}^{\infty}(-1)^{n} / n \cdot \operatorname{Sp}\left\{\left(\theta^{2}-\rho\right)(\rho-1)^{n-1}\right\}
$$

In terms of $f$, however, $\sum$ should take a too complicated form.

(c) In our formulation quantum-mechanical change of pure state is described by the quantum Liouville equation (3.5) for the df. $f(x, p, t)$ and the subsidiary conditions $(4 \cdot 6)$ and $(4 \cdot 19)$ which is compatible with (3.5). Naturally this description is equivalent to the usual one in terms of the wave function $\phi(x, t)$ that obeys the Schrödinger equation: First, if the latter is given, we construct the df. $f(x, p t)$ by use of $\rho\left(x, x^{\prime}\right.$, $t)=\psi(x, t) \psi\left(x^{\prime}, t\right) *$ and (2.6), then this df. clearly satisfies the quantum Liouville equation and the pure state conditions. Conversely, if a df. $f(\boldsymbol{x}, \boldsymbol{p}, t)$ satisfying the quantum Liouville equation and the pure state condition is first given, we produce the corresponding $\rho\left(\boldsymbol{x}, \boldsymbol{x}^{\prime}, t\right)$ by use of (3.3). Then this $\%$ must be hermitian and satisfy (4.4), and hence factorize as (4.3) i.e.,

$$
\rho\left(\boldsymbol{x}, \boldsymbol{x}^{\prime}, t\right)=\phi(\boldsymbol{x}, t) \phi^{\prime *}\left(\boldsymbol{x}^{\prime}, t\right) .
$$

This determines the wave function $\phi$ up to an arbitrary phase depending upon time only; that is $\psi(x, t)$ can be written as

$$
\phi(x, t)=\psi_{0}(x, t) c^{i \Lambda(t)}
$$

where $A(t)$ is an arbitrary function. Furthermore, $\phi_{0}^{\prime}(\boldsymbol{x}, t)$ here can be taken to be the Schrödinger equation :

$$
K[\phi] \equiv\left(\hbar / i \cdot \partial / \partial t-\hbar^{2} / 2 m \cdot \Delta+V(x)\right) \psi=0,
$$

because the above $\rho$ must satisfy its equation of motion (3.2) and so $\phi(x, t)$ in (4.27) satisfies 


$$
K[\phi(\boldsymbol{x})] \psi^{*}\left(\boldsymbol{x}^{\prime}\right)-K^{*}\left[\phi^{*}\left(\boldsymbol{x}^{\prime}\right)\right] \psi(\boldsymbol{x})=0 .
$$

Consequently we can uniquely determine the wave function $\phi(x, t)$ that corresponds to the given df. from (4.27) and the 'supplimintary' condition' (4.29).

\section{§. Equivalence between the formulation in terms of phase-space ensemble and that in terms of configuration space ensemble}

(a) We have established that a quantum-mechanical change of pure state is described by the ps. df. obeying quantum Liouville equation and certain subsidiary conditions, as well as by the wave function obeying the Schrödinger equation. On the other hand quantum-mechanical motion can also be represented by certain trajectory ensemble in configuration space (cs. en.), as was analysed in our previous papers ${ }^{4)}$. Therefore, the representation of quantum-mechanical motion for the case of pure state in terms of ps. en. must be equivalent to that in terms of the cs. en. We shall now examine this point in a direct manner, taking out the correspondence between both formulations.

First we briefly recapitulate the method of the cs. en. for the case of a single particle under consideration. This method represents a quantum-mechanical state of wave function

$$
\phi=R e^{i S / \hbar} \quad(R, S: \text { real })
$$

with an ensemble which consists of a probability distribution of a particle in the density

$$
P(\boldsymbol{x})=R(\boldsymbol{x})^{2},
$$

the particle momentum $\boldsymbol{p}$ being uniquely correlated with its position $\boldsymbol{x}$ by

$$
\boldsymbol{p}(\boldsymbol{x})=\boldsymbol{F} S(\boldsymbol{x}) \text {. }
$$

Thus the momentum field satisfies

$$
\text { curl } \boldsymbol{p}=0
$$

and the ensemble has a particular plarse-space distribution:

$$
f_{c}(\boldsymbol{x}, \boldsymbol{p})=R(\boldsymbol{x})^{2} \cdot \boldsymbol{\delta}(\boldsymbol{p}-\nabla S(\boldsymbol{x})) .
$$

The Schrödinger equation is written, in terms of $R$ and $S$, as

$$
\left\{\begin{array}{l}
\partial S / \partial t+1 / 2 m \cdot(\nabla S)^{2}+V-\left(\hbar^{2} / 2 m\right) \Delta R / R=0 \\
\partial\left(R^{2}\right) / \partial t+\operatorname{div}\left(R^{2} \nabla S / m\right)=0
\end{array}\right.
$$

of which the latter gives the equation of continuity for the cs. en. :

$$
\partial P / \partial t+\operatorname{div}(P \boldsymbol{v})=0, \quad(\boldsymbol{v}=\boldsymbol{p} / m)
$$

while the former leads to the equation of motion for a particle of the ensemble :

with

$$
m d \boldsymbol{v} / d t=-\nabla\left(V+V^{\prime}\right)
$$

$$
V^{\prime \prime}=-\hbar^{2} / 2 m \cdot \Delta R / R
$$


Thus the temporal development of the ensemble can be regarded as is built up through the process in which each point of the ensemble moves along a continuous path with the momentum $(5 \cdot 3)$ at each instant, accelerated not only by the external potential $V$ but also by the additional 'quantum potential' $(5 \cdot 10)$. In place of (5.9) we may also adopt the relation of momentum conservation :

$$
\frac{\partial\left(P p_{i}\right)}{\partial t}+\frac{1}{m} \sum_{k} \frac{\partial\left(P p_{i} p_{k}\right)}{\partial x_{k}}=-P \frac{\partial V}{\partial x_{i}}+\sum_{k}-\frac{\partial \sigma_{i k}}{\partial x_{k}}
$$

where $\sigma_{i k}$ means the 'quantum stress',

$$
\sigma_{i k}=\hbar^{2} / 4 m \cdot P \partial^{2}(\log P) / \partial x_{i} \partial x_{k} \text {. }
$$

We could thus associate an ensemble of trajectories satisfying

$$
\left.\begin{array}{l}
\text { equation of motion }(5.9) \text {, (or }(5.11)) \text {, } \\
\text { equation of continuity }(5.8), \\
\text { subsidiary condition }(5.4),
\end{array}\right\}
$$

with a wave function $\phi(x, t)$ satisfying the Schrödinger equation, by means of (5.2) and (5.3). Conversely, any ensemble of trajectories that satisfies (A) corresponds to a quantum-mechanical change of state as follows: Given a solution of $(\mathrm{A}), P(x, t)$ and $\boldsymbol{p}(\boldsymbol{x}, t)$, we can determine $R$ and $\nabla S$ by (5.2) and (5.3), and so $S(\boldsymbol{x}, t)$ itself can also be determined up to an arbitrary function of time, $A(t)$. But this arbitrariness is excluded by imposing on $S$ the 'supplementary condition' that $S$ should satisfy (5.6), which condition is clearly compatible with the equation of motion (5.9). Thus we uniquely get the wave function $\phi=R c^{i S / \hbar}$ satisfying the Schrödinger equation*.

(b) We shall now explicitly show the correspondence between our ps. en. representation and the cs. en. representation outlined just now in two steps.

i) In the first place, given a phase space distribution $f(\boldsymbol{x}, \boldsymbol{p}, t)$ corresponding to a change of pure state, the corresponding cs. en. can be produced by 'projecting' the ps. en. onto the coordinate space. This means that we introduce the cs. en. which consists of the density and momentum fields, $P(\boldsymbol{x}, t)$ and $\overline{\boldsymbol{p}}(\boldsymbol{x}, t)$, derived from the ps. df. $f(\boldsymbol{x}, \boldsymbol{p}, t)$, by (2.10) and (4.17) with (4.15); in other words we eliminate the momentum dispersion at each space point $x$ in the ps. en., adopting the average momentum and the total density at each point $x$. We can then show that the cs. en. obtained satisfies the condition (A) and represents the same quantum-mechanical change of state.

To show this, first we project the quantum Liouville equation (3.5) for $f$ onto the coordinate space to obtain

$$
\partial P / \partial t+\operatorname{div}(P \bar{p} / m)=0
$$

*) Apart from a physically meaningless arbitrary additive constant in the phase.

**) The stochastic transitions in momentum have no effect on the time change of the total space density, since they occur with positive as well as negative probabilities for various jumps and cancell out in the sum. 
which expresses the continuity equation $(5.8)$ for the cs. en. $(P, \overline{\boldsymbol{p}})$ derived by projection.

Next we project the momentum conservation relation for the ps. en.,

$$
\frac{\partial\left(p_{i} f\right)}{\partial t}+\frac{1}{m} \sum_{k} p_{i} p_{k} \frac{\partial f}{\partial x_{k}}=\int p_{i} J\left(\boldsymbol{x}, \boldsymbol{p}-\boldsymbol{p}^{\prime}\right) f\left(\boldsymbol{x}, \boldsymbol{p}^{\prime}\right) d \boldsymbol{p}^{\prime},
$$

obtainable from (3.5), and get

$$
\frac{\partial\left(P \vec{p}_{i}\right)}{\partial t}+\frac{1}{m} \sum_{k} \frac{\partial}{\partial x_{k}}\left(P \overline{\left.p_{i} p_{k}\right)}=-P \frac{\partial V}{\partial x_{i}} .\right.
$$

Here we take into account one of the pure state conditions (4.18) for the original phase space distribution, then the second term in $(5 \cdot 15)$ may be rewritten as

$$
\frac{1}{m} \sum_{k} \frac{\partial}{\partial x_{k}}\left(P \overline{\left.p_{i} p_{k}\right)}=\frac{1}{m} \sum_{k} \frac{\partial}{\partial x_{k}}\left(P \bar{p}_{i} \cdot \bar{p}_{k}\right)-\frac{\hbar^{2}}{4 m} \sum_{k} \frac{\partial}{\partial x_{k}}-\left(P \frac{\partial^{2} \log P}{\partial x_{i} \partial x_{k}}\right) .\right.
$$

This means that the contribution from the convection term in the ps. en. picture transforms to the convection term in the derived cs. en. picture plus the extra momentum flow such as is ascribable to the occurrence of the 'quantum stress' $(5 \cdot 12)$. Now (5.15) with $(5 \cdot 16)$ is exactly the momentum conservation $(5 \cdot 11)$ for the derived cs. en. $(P, \bar{p})$, and so we can also obtain the equation of motion (5.9).

Furthermore another one of pure state conditions, $(4 \cdot 19)$, for the ps. en. immediately warrants the subsidiary condition $(5 \cdot 4)$ for the derived cs. en. $(P, \bar{p})$. Thus we can conclude that the cs. en. produced from the original ps. en. by projection is in fact a possible one satisfying $(\mathrm{A})$.

ii) Conversely, if we are given a cs. en. specified with $P(x)$ and $\bar{p}(\boldsymbol{x})$, satisfying (A), we can consider many a phase space distribution $f(\boldsymbol{x}, \boldsymbol{p})$ which can yield that cs. en. $(P, \overline{\boldsymbol{p}})$ by projection. However, from $P$ and $\overline{\boldsymbol{p}}$ we determine successively quantities, $\bar{p}_{i} p_{k}, \bar{p}_{i} p_{j} p_{k}, \cdots$, according to $(4 \cdot 18),(4 \cdot 21), \cdots$, and then we can determine a ps. df. $f(\boldsymbol{x}, \boldsymbol{p})$ ziniquely, such that it takes those values, $\boldsymbol{P}, \bar{p}_{i},{\overline{p_{i}}}_{p_{k}}, \bar{p}_{i} p_{j} p_{k}, \cdots$, as its successively higher moments, since now every order moment is specified for the df. This ps. df.** is the only one that yields $(P, \bar{p})$ by projection and satisfies at the same time the pure state conditions. We can further show that this ps. df. fulfills the quantum Liouville equation.

*) In this equation for the time change of mean momentum, the effects of the stochastic transitions in momentum induced by the external potential $V$ are reduced to the classical value $-P \partial V / \partial x_{i}$.

**) The explicit form of this df. can be written down as

$$
f(\boldsymbol{x}, \boldsymbol{p}, t)=\frac{1}{(2 \pi \hbar)^{3}} \int\left[P\left(\boldsymbol{x}-\frac{\boldsymbol{y}}{2}, t\right) P\left(\boldsymbol{x}+\frac{\boldsymbol{y}}{2}, t\right)\right]^{\mathrm{J} / 2} \exp \frac{i}{\hbar}\left[S\left(\boldsymbol{x}-\frac{\boldsymbol{y}}{2}, t\right)-S\left(\boldsymbol{x}+\frac{\boldsymbol{y}}{2}, t\right)+\boldsymbol{p} \boldsymbol{y}\right] d \boldsymbol{y},
$$

where $S$ is a potential function for $\bar{p}$, i.e., $\nabla S=\bar{p}$. 
The Formulation of Quantum Mechanics in terms of Ensemble in Phase Space 361

In all above the equivalent correspondence between ps. en. and cs. en. has perfectly been verified.

(c) In a previous paper ${ }^{5)}$, we inquired whether the quantum potential (5.10) in the cs. en. formulation could be analysed into a mechanism like any Markoff process underlying. The problem is now explained more clearly: From the viewpoint of the ps. en. formulation, the quantum potential can be regarded as an apparent force appearing as the result of projecting on to the coordinate space the ps. en. that satisfies the pure state condition and changes according to a sort of Markoff process. We cannot, however, regard the latter picture as a literally real one any more than the picture of trajectory ensemble under quantum potential, on account of the inevitable appearance of negative probabilities. Furthermore it is also to be noted that the ps. en. could not yield mean values correctly for certain quantities, and that the pure state condition was in a sense ad hoc.

Notwithstanding, our formulation of quantum mechanics in terms of Markoff-like picture might further tempt the idea of some hidden mechanism of irregular external disturbances which vanish in the average yet make the particle momentum fluctuate, acting on particle irrespective of its momentum [see (ii) of $\S 3(\mathrm{a})]$. But the features of stochastic transitions stated in $\S 3$ (a) do not allow to construct any such model rialistically.

Recently Weizel ${ }^{14)}$ attempted to derive the quantum potential from certain stochastic process based on some model. He proceeded in a considerably different fashion, but the nature of his method may also be illuminated from our viewpoint which may be more far-reaching than his method, standing upon the systematic formulation of quantum mechanics in terms of the ps. en.

By the way, the mean kinetic energy of particle for the observer moving with the mean velocity in the ps. en. is $E_{1}=1 / 2 m \cdot\left\{\overline{\boldsymbol{p}}^{2}-(\overline{\boldsymbol{p}})^{2}\right\}$, which is not necessarily positive, and becomes $E_{1}=-\varepsilon / 2 m \cdot \Delta \mathfrak{H}$ for a pure state due to $(4 \cdot 18)$. On the other hand the mean pressure $p_{r}$ in the corresponding cs. en. is ${ }^{4)} p_{r}=-\frac{1}{3} \sum_{i} \sigma_{i i}=-\frac{1}{3} \frac{\varepsilon}{m} P \Delta \Re$, and so we have the relation $p_{r}=2 / 3 \cdot P E_{1}$.

This shows that the pressure in the cs. en. results from the momentum dispersion of the underlying ps. en. just in the same manner as the pressure of ideal gas results from the thermal motion of molecules.

(d) We have explained that a cs. en. can be looked upon as the projection of a ps. en. for pure state. It is to be remarked that as a result of such contraction the cs. en. gets free from an unrealistic property of the ps. en., i.e., negative probabilities, but at the same time it partly loses the property of the ps. en. to give correctly the quantum-mechanical expectation values as the ensemble averages for most of usual quantities: The cs. en. defined with density and momentum fields, $P(x)$ and $\nabla S(x)$, yields the mean values for a quantity $\underline{A}(\underline{\boldsymbol{x}}, \underline{\boldsymbol{p}})$ as

$$
\langle A\rangle_{c}=\int A(\boldsymbol{x}, \nabla S) P(\boldsymbol{x}) d \boldsymbol{x},
$$


which agrees with $(2 \cdot 12 a)$ for quantities of zeroth or first order in $\boldsymbol{p}$ but not for those of second or higher orders ${ }^{4)}$.

As for the ps. en., relations known to hold between quantum mechanical expectation values of some physical quantities usually hold also with the understanding that the average over the ps. en. is to be taken, since it yields the expectation values correctly as the ensemble averages for most of usual physical quantities. An example is the 'uncertainty relation' stated in $\$ 4(a)$; another one is the 'Ehrenfest's theorem ': Integrating $(5 \cdot 15)$ throughout over the $x$-space we get

$$
a^{2}\left\langle x_{i}\right\rangle_{f} / d t^{2}=d\left\langle p_{i}\right\rangle_{J} / d t=-\left\langle\partial V / \partial x_{i}\right\rangle_{f}
$$

which is valid for general mixed states. In the particular case of pure states, this relation may also be written, in terms of the quantities in the cs. en., as

$$
m \frac{d^{2}}{d t^{2}} \int \boldsymbol{x} P d \boldsymbol{x}=\frac{d}{d t} \int P \overline{\boldsymbol{p}} d \boldsymbol{x}=-\int P \nabla V d \boldsymbol{x}
$$

Still another example is the 'virial theorem',

$$
d\langle\boldsymbol{x p}\rangle_{f} / d t=1 / m \cdot\left\langle\boldsymbol{p}^{2}\right\rangle_{f}+\langle\boldsymbol{x} V V\rangle_{f},
$$

and also the variational theorem, into which we do not enter here.

\section{§. Applications of the ps. en. formulation to some elementary examples of pure state cases}

\section{(a) Distributions without correlation and the diff usion of wave packets}

i) We shall ask whether there can exist any pure state distributions having no correlation at all between particle position and momentum. Such distribution must factorize as

$$
f(\boldsymbol{x}, \boldsymbol{p})=P(\boldsymbol{x}) Q(\boldsymbol{p}),
$$

and therefore satisfies one of the pure state conditions $(4 \cdot 19)$ from the outset. Since it must further satisfy $(4 \cdot 6)$, we obtain

$$
\left\{\begin{array}{l}
\frac{\partial^{2} \log P}{\partial x_{i} \partial x_{k}}=-\frac{1}{2} \alpha_{i k}, \quad\left(\alpha_{i k}=\alpha_{k i}=\text { real const. }\right) \\
\left(p_{i} Q\right) *\left(p_{k} Q\right)-Q *\left(p_{i} p_{k} Q\right)=-(1 / 2) \varepsilon \alpha_{i k} Q * Q .
\end{array}\right.
$$

Eq. $(6 \cdot 2)$ yields

$$
P=\text { const. } \exp \left[-\sum_{i, k} \alpha_{i k} x_{i} x_{k}+\sum_{i} \gamma_{i} x_{i}\right]
$$

which can be led, by a suitable orthogonal coordinate transformation, 
The Formulation of Quantum Mechanics in terms of Ensemble in Phase Space 363

$$
x_{i}^{\prime}=\sum_{i} c_{i k} x_{k}
$$

to the form

$$
P(x)=\text { const. } \exp \left[-\sum_{i} \alpha_{i}\left(x_{i}^{\prime}-a_{i}^{\prime}\right)^{2}\right],
$$

where each $\alpha_{i}$ should be positive so that $P$ should be normalizable.

Next*, re-expressing $(6 \cdot 3)$ in terms of the fourier transform for $Q(\boldsymbol{p})$,

$$
\chi(n)=\int Q(\boldsymbol{p}) e^{i_{\boldsymbol{p}} \eta} d \boldsymbol{p},
$$

we get

$$
-\frac{\partial \chi}{\partial \eta_{i}} \frac{\partial \chi}{\partial \eta_{k}}+\chi \frac{\partial^{2} \chi}{\partial \eta_{i} \partial \eta_{k}}=-\frac{\varepsilon}{2} \alpha_{i k} \chi^{2}
$$

This is a equation similar to $(6.2)$, and can be integrated into

$$
\log \chi=-\varepsilon \sum_{i} \alpha_{i}\left(\eta_{i}^{\prime}-\delta_{i}^{\dagger}\right)^{2}+\text { const., }
$$

where $\eta_{i}^{\prime}$ 's are the new components produced by the coordinate transformation (6.5) applied to $\eta_{i}$ 's. We have now

$$
Q(\boldsymbol{p})=\text { const. } \exp \left[-\sum_{i}\left(1 / 4 \varepsilon \boldsymbol{\alpha}_{i}\right)\left(p_{i}^{\prime}-b_{i}^{\prime}\right)^{2}\right],
$$

where $p_{i}^{\prime}=\sum_{k} c_{i k} p_{k}$. Altogether, our distribution must be of the form

$$
\left\{\begin{array}{c}
f(\boldsymbol{x}, \boldsymbol{p})=\text { const. } \exp \left[-\sum_{i}\left\{\alpha_{i}\left(x_{i}^{\prime}-a_{i}^{\prime}\right)^{2}+\beta_{i}\left(p_{i}^{\prime}-b_{i}^{\prime}\right)^{2}\right\}\right], \\
\alpha_{i} \beta_{i}=1 / \hbar^{2},
\end{array}\right.
$$

namely it is Gaussian for each freedom of position and momentum components in a suitable coordinate system, with the relation $(6.10 \mathrm{~b})$. It has the minimum 'uncertainty product':

$$
\left\langle\left(x_{i}-\left\langle x_{i}\right\rangle_{f}\right)^{2}\right\rangle_{f} \cdot\left\langle\left(p_{i}-\left\langle p_{i}\right\rangle_{f}\right)^{2}\right\rangle_{f}=\varepsilon
$$

The wave function corresponding to (6.10) can be obtained according to the procedure of $\S 4$ (c): First we derive

$$
\begin{aligned}
& \bar{p}(\boldsymbol{x}, \boldsymbol{y})=\int f(\boldsymbol{x}, \boldsymbol{p}) e^{-i p y / \hbar} d \boldsymbol{p}=P(\boldsymbol{x}) \cdot \chi(-\boldsymbol{y} / \hbar) \\
& =\text { const. } \exp \left[-\sum_{i}\left\{\alpha_{i}\left(x_{i}^{\prime}-a_{i}^{\prime}\right)^{2}+(1 / 4) \alpha_{i} y_{i}^{\prime 2}+(i / \hbar) b_{i}^{\prime} y_{i}^{\prime}\right\}\right] \text {, }
\end{aligned}
$$

from which the density matrix is obtained as

$$
\rho\left(\boldsymbol{x}, \boldsymbol{x}_{1}\right)=\text { const. } \exp \sum_{i}\left[-\alpha_{i} / 2 \cdot\left\{\left(x_{i}^{\prime}-a_{i}^{\prime}\right)^{2}+\left(x_{1 i}^{\prime}-a^{\prime}\right)^{2}\right\}+(i / \hbar)\left(b_{i}^{\prime}\left(x_{i}^{\prime}-x_{12}{ }^{\prime}\right)\right],\right.
$$

so the wave function takes the form

$$
\psi(x)=\text { const. } \exp \left[-\sum_{i} \frac{\alpha_{i}}{2}\left(x_{i}^{\prime}-a_{i}^{\prime}\right)^{2}+i\left(\sum_{i} b_{i}^{\prime} x_{i}^{\prime} / \hbar+A(t)\right)\right],
$$

*) From hete on it would be simpler to proceed as follows: The other form of the pure state condition, (4.10), yields $\partial^{2} \log Q / \partial p_{i} \partial p_{k}=-\beta_{i k} / 2$ which is similar to (6.2), and the condition (4.18) further requires $(6.10 \mathrm{~b})$. 
which is nothing but the general form of the 'minimum wave packet'.

ii) Next we shall ask whether or not the form of the distribution (6.10) (i.e., the property of having no correlation) be conserved during the course of time. First, taking up the case of free particle*, we suppose that a distribution of type (6.10),

$$
f_{0}(x, p)=\frac{1}{\pi \hbar} \exp \left[-\alpha(x-a)^{2}-\frac{1}{\alpha \hbar^{2}}(p-b)^{2}\right]
$$

(here considering one-dimensional case for simplicity) occurs at a time $t=t_{0}$. In this case, as was stated in $\S 3$ (a), each point in the ps. en. moves classically with its respective constant velocity, and the distribution at time $t$ is given by

$$
\begin{aligned}
f(x, p, t)=f_{0} & \left(x-p / m \cdot\left(t-t_{0}\right), p\right) \\
= & \frac{1}{\pi \hbar} \exp \left[-\alpha\left(x-a-\frac{p}{m}\left(t-t_{0}\right)\right)^{2}-\frac{1}{\alpha \hbar^{2}}(p-b)^{2}\right] .
\end{aligned}
$$

But this is no longer of type (6.10), and indicates that the correlation grows with time. The phase space distribution (6.13) gives at once the space density in the well-known form

$$
P(x)=\int f d p=\text { const }\left[\frac{\alpha}{1+\left\{(\alpha \hbar / m) \cdot\left(t-t_{0}\right)\right\}^{2}}\right]^{1 / 2} \exp \left[-\frac{\alpha(x-\alpha)^{2}}{\left\{1+(\alpha \hbar / m) \cdot\left(t-t_{0}\right)\right\}^{2}}\right],
$$

showing that the distribution in coordinate space diffuses with the passage of time. Thus the so-called "diffusion of wave-packet" in this case is, from our viewpoint, simply a result of the fact that each point of the ps. en. performs the purely classical motion with its respective momentum ${ }^{15}$. In other words the simple circumstance that the particles which move faster cover the greater distances brings about the spreading of the packet and at the same time introduces correlation.

\section{(b) Linear oscillator}

i) The hamiltonian is

$$
H(x, p)=1 / 2 \cdot\left(p^{2} / m+m \omega^{2} x^{2}\right),
$$

and the quantum Liouville equation is identical with the classical one:

$$
\partial f / \partial t+p / m \cdot \partial f / \partial x-m\left(\omega^{2} x \partial f / \partial p=0,\right.
$$

of which the general solution is

$$
f=F\left(p^{2}+(m \omega x)^{2},-p \sin \omega t+m \omega x \cos \omega t\right) .
$$

Now in case of oscillator; if there can exist a pure-state distribution having no correlation during the course of titre, such distribution must be of the form (6.12) and at the same time consistent with the form (6.15). This determines the parameters in (6.12) such that

*) For the case of oscillator, see (b) i). 
The Formulation of Quantum Mechanics in terms of Enscmble in Phase Space 365

$$
\alpha=m \omega / \hbar, \quad a=a_{0} \cos \omega t, \quad b=-m \omega a_{0} \sin \omega t, \quad\left(a_{0}: \quad \text { const. }\right)
$$

and so we must have the df. of the form,

$$
f(x, p, t)=\frac{1}{\pi \hbar} \exp \left[-\frac{m \omega}{\hbar}\left(x-a_{0} \cos \omega t\right)^{2}-\frac{1}{m \omega \hbar}\left(p+\alpha_{0} m \omega \sin \omega t\right)^{2}\right] .
$$

This distribution takes its maximum value at the point $\left(x=a_{0} \cos \omega t, p=-a_{0} m \omega \sin \omega t\right)$ in phase space, decreasing around it in Gaussian manner. With the passage of time the distribution rotates, kccping its form rigidly, along an ellipse around the origin of phase space with the angular frequency $\omega$.

The corresponding wave function ${ }^{16)}$ is obtained by inserting $(6 \cdot 16)$ into $(6 \cdot 11)$ as

$$
\psi(x, t)=\exp \left[-\frac{m \omega}{2 \hbar}\left(x-a_{0} \cos \omega t\right)^{2}-\frac{i}{\hbar} m \omega x \alpha_{0} \sin \omega t+i A(t)\right] .
$$

Its phase, $S=-m \omega / \hbar \cdot x c_{0} \sin \omega t+A(t)$, involves a yet undetermined part $A(t)$, which is determined, by the 'supplementary condition' (5.6) for $S$, as

$$
A(t)=\frac{1}{4} \frac{m \omega}{\hbar} a_{0}^{\circ} \sin 2 \omega t-\frac{1}{2} \omega t .
$$

ii) As previously stated, for quadratic potential such as in case of oscillator, the ps. en. develops classically. On the other hand, in such potential, also in the cs. en. formulation, we have particular solutions ${ }^{4)}$ which consist of purely classical trajectories, with quantum potential vanishing, and are determined by the following equations :

$$
\left\{\begin{array}{l}
\dot{S}+1 / 2 m \cdot(\nabla S)^{2}+V=0, \\
\nabla(\Delta S)=0, \\
P(t)=\text { const } \cdot \exp \left[-(1 / m) \int^{t} \Delta S d t\right] .
\end{array}\right.
$$

Now, such a cs. en. corresponds to a ps. en. with the df.

$$
f(\boldsymbol{x}, \boldsymbol{p}, t)=\frac{1}{(2 \pi \hbar)^{3}} P(t) \int \exp \frac{i}{\hbar}\left[S\left(\boldsymbol{x}-\frac{\boldsymbol{y}}{2}, t\right)-S\left(\boldsymbol{x}+\frac{\boldsymbol{y}}{2}, t\right)+\boldsymbol{p y}\right] d \boldsymbol{y},
$$

which can be simplified in one-dimensional case as

$$
f(x, p, t)=P(t) \cdot \delta(p-\partial S / \partial x)
$$

because from $(6.21)$ we have $S(x-y / 2)-S(x+y / 2)=-y \partial S / \partial x$. The expression $(6 \cdot 24)$ (together with $(5 \cdot 5)$ ) shows that for such particular quantum-mechanical motion the ps. en. and the cs. en. become identical with each other.

In the case of oscillator, a solution satisfying $(6.20),(6.21)$, and $(6.22)$ is given by ${ }^{4)}$

$$
\left\{\begin{array}{l}
P=\text { const } / \sin \omega \tau, \\
S=(m \omega / 2 \sin \omega \tau)\left\{\left(x^{2}+x_{0}{ }^{2}\right) \cos \omega \tau-2 x x_{0}\right\},
\end{array}\right.
$$


and so by $(6.24)$ the corresponding df. becomes

$$
f(x, p)=f_{c}(x, p)=\text { const. } \partial\left(p \sin \omega \tau-m \omega\left(x \cos \omega \tau-x_{0}\right)\right) . \quad(6 \cdot 26) *
$$

This expresses an ensemble of trajectories flowing out $x_{0}$ at $t_{0}$ with any velocity. The corresponding wave function $P^{1 / 2} e^{i S / \hbar}$ is nothing but the propagation kernel $K\left(x t \mid x_{0} t_{0}\right)$. It is to be noted that the 'transition probability' of $\S 3$ (b) is a different thing from the above df., and is given by (3.35) in this case, implying the distribution at $t$ when a particle starts from $x_{0}$ at $t_{0}$ with a definite momentum $p_{0}$.

iii) We call a time-independent solution of (3.5) a stationary distribution, where the deviation of the distribution to be caused by the momentum transition with the transition probability $J\left(\boldsymbol{x}, \boldsymbol{p}^{\prime}-\boldsymbol{p}\right)$ is exactly compensated with the effect of the translation of particles.

A quantum-mechanical energy eigen-state corresponds to a stationary distribution such as satisfies the pure state conditions in our phase space formulation. It is, however, to be remarked that such distribution is not suited to be called "energy eigenstate" in our picture. Generally quantum-mechanical eigenstates for $\underline{H}$ or $\underline{l_{i}}$ cannot be specified as the ps. ensembles satisfying pure state conditions and having no dispersion in respect to respective quantities (cf. $\S 2$ ). We shall next see this point for the case of oscillator.

As is well-known the stationary state wave functions for the oscillator are

$$
\phi_{n}(x, t)=\left(\frac{\kappa}{2^{n} \pi^{1 / 2} n !}\right)^{1 / 2} e^{-x^{2} x^{2} / 2} H_{n}(\kappa x) e^{-i(n+1 / 2) \omega t}, \quad \kappa=(m \omega / \hbar)^{1 / 2}
$$

from which we can obtain the corresponding ps. dfs. as

$$
f_{n}(x, p, t)=\frac{(-1)^{n}}{\pi \hbar} \mathcal{C}^{-2 H(x, p) / \hbar \omega} L_{n}(4 H(x, p) / \hbar(v) .
$$

Each of these distributions has a constant density on an energy surface, as it should for a stationary distribution in case of any quadratic potential, and takes negative as well as positive values, giving the quantum-mechanical expectation value of energy correctly as

$$
\langle H\rangle f_{n}=\int H(x, p) f_{n}(x, p) d x d p=(n+1 / 2) \hbar\left(u=E_{n}=\langle\underline{H}\rangle_{n}\right.
$$

However, it cannot give the expectation value correctly for any power of energy, $H^{2}(\nu \geqq 2)$, because $f_{n}$ distributes over an arca in phase space.

The ps. distribution that yields the probability distribution correctly for $\underline{H}$ is clearly the

*) In this case the wave function and therefore the ps. df. are not normalizable; the const. in (6.22) and $(6.26)$ are in reality infinitesimal.

$\left.{ }^{* *}\right) \quad L_{n 2}(\zeta)$ is a Laguerre polynomial defined by $L_{n k}(\zeta)=\sum_{k=0}^{n} \frac{(-1)^{n}}{k !}\left(\begin{array}{c}n \\ k\end{array}\right) \zeta^{k}$. These distribution functions $(-1)^{n} \pi f_{n}(x, p)(n=0,1,2 \cdots)$ constitute a complete orthonormal set as functions of $(4 / \hbar \omega) I I(x, \lambda)$ in the domain $(0, \infty)$. 
The Formulation of Quantnm Mechanics in terms of Ensimble in Phasi' Space 367

one which concentrates on the ellipse, $H(x, p)=(n+1 / 2) \hbar(\omega$, in phase space, i.e.,

$$
f_{n}^{\prime}(x, p) \propto \delta(H(x, p)-(n+1 / 2) \hbar(\omega) \text {. }
$$

Such distribution cannot, however, correspond to any state, as is understood, from the fact that it does not satisfy the Wigner's condition $(7 \cdot 1)$.

\section{$\S 7$. Remarks on the Wigner's condition and alternative forms of the pure state condition}

(a) E.P. Wigner pointed out* that following two important conditions are further necessary, besides the conditions (2.9) and $(2.19)$, for a ps. df. $f(\boldsymbol{x}, \boldsymbol{p})$ to be a permissible one corresponding generally to a mixed state. They are

$$
\begin{aligned}
& |f(\boldsymbol{x}, \boldsymbol{p})| \leqq(2 / h)^{3}, \\
& h^{3} \int f(\boldsymbol{x}, \boldsymbol{p})^{2} d \boldsymbol{x} d \boldsymbol{p} \leqq 1 .
\end{aligned}
$$

The condition (7.1) which is derivable by applying Schwarz inequality to (2.6) with (2.4) indicates that a possible df. should extend at least over a phase volume $(/ / 2)^{3}$, expressing in a certain degree the uncertainty principle for the general case of a mixed state. The left side of $(7 \cdot 2)$, being

$$
l^{3} \int f(\boldsymbol{x}, \boldsymbol{p})^{2} d \boldsymbol{x} d \boldsymbol{p}=\mathrm{Sp}{\underline{t^{2}}}^{2}=\sum_{n} x_{n}^{\prime}{ }^{2}
$$

(where $i e_{n}^{\prime}$ is the quantity defined by (2.4)), becomes unity for a pure state and is smaller for a general mixed state. This quantity may be taken as giving a measure to the degree of mixing, though it is different from entropy defined in $\$ 4$ (b).

The Wigner's conditions (7.1) and (7.2) must be regarded, together with (2.19) as a part of the 'positivity condition' stated in $\S 2$, which means the condition to be imposed upon any possible ps. df. corresponding to (2.3). These conditions (2.19), (7.1), and (7.2) may not yet constitute the sufficient one, since the positivity condition means that every $z w_{n}$ be non-negative and so it would require infinitely many inequalities of a type such as (7.2). Indeed, the condition (7.2), which is expressible in terms of density matrix as

$$
\int \rho\left(\boldsymbol{x} x^{\prime}\right) \rho\left(\boldsymbol{x}^{\prime} \boldsymbol{x}\right) d \boldsymbol{x} d \boldsymbol{x}^{\prime} \leqq 1,
$$

is merely a part of the condition

$$
\int \rho\left(\boldsymbol{x} \boldsymbol{x}^{\prime}\right) \rho\left(\boldsymbol{x}^{\prime} \boldsymbol{x}\right) d \boldsymbol{x}^{\prime} \leqq \rho(\boldsymbol{x} \boldsymbol{x})=P(\boldsymbol{x}) .
$$

The latter condition $(7.4)$ is also a necessary one, and is expressed in the language of the ps. df. as

$$
{ }^{3} \int f\left(\boldsymbol{x}^{\prime} \boldsymbol{p}\right) f\left(\boldsymbol{x}^{\prime} \boldsymbol{p}^{\prime}\right) \cos \left[2 / \hbar \cdot\left(\boldsymbol{p}^{\prime}-\boldsymbol{p}\right)\left(\boldsymbol{x}^{\prime}-\boldsymbol{x}\right)\right] d \boldsymbol{p} d \boldsymbol{p}^{\prime} d \boldsymbol{x}^{\prime}
$$

*) Comment on the author's work at Nagoya (Sep. 1953). 


$$
\leqq \int f(\boldsymbol{x p}) d \boldsymbol{p}=P(\boldsymbol{x})
$$

The left side of $(7.5)$ is non-negative, and therefore (7.5) means a severer condition than the first relation of (2.19), and at the same time involves $(7 \cdot 2)$. Similarly the second relation of (2.19) can better be replaced by

$$
2^{3} \int f\left(\boldsymbol{x} \boldsymbol{p}^{\prime}\right) f\left(\boldsymbol{x}^{\prime} \boldsymbol{p}^{\prime}\right) \cos \left[2 / \hbar \cdot\left(\boldsymbol{p}^{\prime}-\boldsymbol{p}\right)\left(\boldsymbol{x}^{\prime}-\boldsymbol{x}\right)\right] d \boldsymbol{x} d \boldsymbol{c}^{\prime} d \boldsymbol{p}^{\prime} \leqq Q(\boldsymbol{p})
$$

(b) Next we shall reconsider the pure state condition. Taking the equality sign in $(7 \cdot 2)$ we obtain

$$
l^{3} \int f(\boldsymbol{x}, \boldsymbol{p})^{2} d \boldsymbol{x} d \boldsymbol{p}=1
$$

as a necessary condition for a ps. df. to correspond to a pure state. This condition has a different form from those obtained in $\S 4$. Now we can show that the pure state condition can also be expressed as a series of infinitely many relations each of which is of a type similar to $\left(7 \cdot 2^{\circ}\right)$, the series including $\left(7.2^{\circ}\right)$ itself as its first relation. For that purpose we start from the original form of the pure state condition for density matrix, $(4 \cdot 2)$, in place of (4.4). Re-expressing (4.2) in terms of ps. df., we obtain

$$
\begin{aligned}
2^{3} \int f\left(\boldsymbol{x}^{\prime}-\frac{\boldsymbol{y}}{2}, \boldsymbol{p}\right) f\left(\boldsymbol{x}^{\prime}+\frac{\boldsymbol{y}}{2}, \boldsymbol{p}^{\prime}\right) \exp \frac{i}{\hbar}\left[2\left(\boldsymbol{p}^{\prime}-\boldsymbol{p}\right)\left(\boldsymbol{c}^{\prime}-\boldsymbol{x}\right)-\left(\boldsymbol{p}+\boldsymbol{p}^{\prime}\right) \boldsymbol{y}\right] d \boldsymbol{x}^{\prime} d \boldsymbol{p} d \boldsymbol{p}^{\prime} \\
=\int f(\boldsymbol{x}, \boldsymbol{p}) \exp (-2 i / \hbar \cdot \boldsymbol{p} \boldsymbol{y}) d \boldsymbol{p}
\end{aligned}
$$

This complicated relation involving two continuous parameters $\boldsymbol{x}$ and $\boldsymbol{y}$ can be split into a series of infinitely many simpler relations by the following two-step procedure. First, integrating (7.7) over the whole $x$-space, we obtain

$$
\begin{aligned}
l^{3} \int f\left(x-\frac{y}{2}, \boldsymbol{p}\right) f(\boldsymbol{x} & \left.+\frac{\boldsymbol{y}}{2}, \boldsymbol{p}\right) \exp \left(-2 \frac{i}{\hbar} \boldsymbol{p y}\right) d \boldsymbol{x} d \boldsymbol{p} \\
& =\int f(\boldsymbol{x}, \boldsymbol{p}) \exp \left(-2 \frac{i}{\hbar} \boldsymbol{p y}\right) d \boldsymbol{x} d \boldsymbol{p} .
\end{aligned}
$$

Next we integrate $(7 \cdot 7)$ after multiplying $x_{i}$ on both sides to obtain

$$
\begin{array}{r}
h^{3} \int f\left(\boldsymbol{x}-\frac{\boldsymbol{y}}{2}, \boldsymbol{p}\right)\left\{\frac{\hbar}{2 i} \frac{\partial}{\partial p_{\boldsymbol{i}}} f\left(\boldsymbol{x}+\frac{\boldsymbol{y}}{2}, \boldsymbol{p}\right)+\left(x_{\boldsymbol{i}}-\frac{y_{i}}{2}\right) f\left(\boldsymbol{x}+\frac{\boldsymbol{y}}{2}, \boldsymbol{p}\right)\right\} \times \\
\times \exp \left(-2 \frac{i}{\hbar} \boldsymbol{p y}\right) d \boldsymbol{x} d \boldsymbol{p} \\
=\int x_{i} f(\boldsymbol{x}, \boldsymbol{p}) \exp \left(-2 \frac{i}{\hbar} \boldsymbol{p y}\right) d \boldsymbol{x} d \boldsymbol{p} .
\end{array}
$$

In similar fashion, we multiply (7.7) successively with $x_{i} x_{j}, x_{i} x_{j} x_{k}, \cdots$, and then integrate the results over the whole $x$-space to get a series of relations involving $p$-differentiation of successively higher orders. This series of relations, (7.8), (7.9), ,.., may be regarded as equivalent with the original (7.7). 
The Formulation of Quantum Mechanics in terms of Enscmble' in Phase Spaci 369

The second step is the Taylor expansions of $(7.8),(7.9), \cdots$ with respect to $y$. Then we get from (7.8) the relations:

$$
\begin{aligned}
& \left(7.2^{\circ}\right), \\
& h^{3} \int p_{i} f^{2} d x d \boldsymbol{x}=\int p_{i} f d \boldsymbol{x} d \boldsymbol{p}, \\
& h^{3} \int\left(\frac{\partial f}{\partial x_{i}}-\frac{\partial f}{\partial x_{k}}+\frac{4}{\hbar^{2}} p_{i} p_{k} f^{2}\right) d \boldsymbol{x} d \boldsymbol{p}=\frac{4}{\hbar^{2}} \int p_{i} p_{k} f d \boldsymbol{x} d \boldsymbol{p},
\end{aligned}
$$

Similarly (7.9) yields

$$
\left\{\begin{array}{l}
l^{3} \int x_{i} f^{2} d \boldsymbol{x} d \boldsymbol{p}=\int x_{i} f d \boldsymbol{x} d \boldsymbol{p}, \\
l^{3} \int\left(-\frac{\partial f}{\partial x_{k}} \frac{\partial f}{\partial p_{i}}+\frac{4}{\hbar^{2}} x_{i} p_{k} f^{2}\right) d \boldsymbol{x} d \boldsymbol{p}=\frac{4}{\hbar^{2}} \int x_{i} p_{k} f d x d \boldsymbol{p}, \\
\ldots \ldots \ldots \ldots \ldots \ldots \ldots \ldots \ldots \ldots \ldots \ldots \ldots \ldots \ldots \ldots \ldots
\end{array}\right.
$$

We have thus found that the pure state condition can also be expressed with a set of infinitely many relations,

$$
\left(7.2^{\circ}\right), \quad(7.10), \quad(7.11), \cdots ; \quad(7.12), \quad(7.13), \cdots ; \cdots,
$$

which are symmetrical in $\boldsymbol{x}$ and $\boldsymbol{p}$ and of different expressions from the previously obtained ones,

$$
(4.6), \quad(4.19) ; \text { or }(4.19), \quad(4.18), \quad(4.21), \cdots \text {. }
$$

But both forms should be equivalent with each other, which fact may be understood if we return to the expressions in $\rho$, though it may be difficult to show it directly.*

(c) We could take either (4.2) or (4.4) as the pure state condition in terms of density matrix. We have, however, still another relation valid for a pure state,

$$
\rho(\boldsymbol{x} \boldsymbol{x}) \rho\left(\boldsymbol{x}^{\prime} \boldsymbol{x}^{\prime}\right)=\rho\left(\boldsymbol{x} \boldsymbol{x}^{\prime}\right) \rho\left(\boldsymbol{x}^{\prime} \boldsymbol{x}\right)=\left|\rho\left(\boldsymbol{x} \boldsymbol{x}^{\prime}\right)\right|^{2},
$$

though it is a necessary but not sufficient relation for the pure state condition. It can be shown that the relation (7.14) is derivable from (4.4) by the Taylor expansion of the former. It is also to be noted that the integration of $(7 \cdot 14)$ throughout over the whole $\boldsymbol{x}^{\prime}$-space yields

$$
\rho(\boldsymbol{x} \boldsymbol{x})=\int \rho\left(\boldsymbol{x} \boldsymbol{x}^{\prime}\right) \rho\left(\boldsymbol{x}^{\prime} \boldsymbol{x}\right) d \boldsymbol{x}
$$

which is also a special case of (4.2).

Now we shall translate the relation (7.14) into the language of the ps. df. to obtain

$$
P(\boldsymbol{x}-\boldsymbol{y} / 2) \quad P(\boldsymbol{x}+\boldsymbol{y} / 2)=\left|\int f(\boldsymbol{x}, \boldsymbol{p}) e^{-i \boldsymbol{p} \boldsymbol{y} / \boldsymbol{t}} d \boldsymbol{p}\right|^{2} .
$$

*) For this point, see also (c). 
If we next expand (7.16) into the power series of $y,(7.16)$ turns into a set of relations,

$$
\begin{aligned}
& \sum_{r_{1} r_{2} r_{3}} \sum_{s_{1} s_{2} s_{3}} \frac{(-1)_{i}^{\sum} r_{i}}{r_{1} ! r_{2} ! r_{3} ! s_{1} ! s_{2} ! s_{3} !}\left[P_{r_{1} r_{2+3}}(x) P_{s_{1} s_{253}}(x)\right. \\
& \left(r_{i}+s_{i}=n_{i}\right) \\
& \begin{array}{c}
\left.-(-\varepsilon)^{n / 2} \partial_{1}{ }_{1} \partial_{2}{ }_{2} \partial_{3}{ }_{3} P(\boldsymbol{x}) \cdot \partial_{1} s_{1} \partial_{2} s_{3} \partial_{3} s_{3} P(\boldsymbol{x})\right]=0, \\
\left(n \equiv \sum_{i} n_{i}=2,4, \cdots \cdots\right),
\end{array}
\end{aligned}
$$

with

$$
P_{r_{1} r_{2} r_{3}}=\int p_{1}^{r_{1}} p_{2}{ }^{r_{2}} p_{3}^{r_{3}} f(\boldsymbol{x}, \boldsymbol{p}) d \boldsymbol{p},
$$

where the summation is to be taken for zero or integer values of each $r_{i}, s_{i}$, with $r_{i}+s_{i}$ $=n_{i}$ fixed. The lowest relation $(n=2)$ of $(7.17)$ is nothing but (4.13) (i.e., (4.18)), and the next one involves the fourth order moment.* Thus we see that the relation (7.17) or (7.16) consists of just a half of the former relations (4.19), (4.18), (4.21), .. of the pure state condition corresponding to (4.4).

The relation (7.15) is expressed in terms of $f$ as (7.5) with equality sign, which can be split into a series of relations, $\left(7.2^{\circ}\right),(7.12), \cdots$ by the procedure of taking moments with respect to $x$. These relations, on one hand, naturally coincide with a part of relations obtained in ( $\mathbf{b})$, and, on the other, must be derivable from (7.17), since (7.15) was a result of (7.14).

Our method is essentially the transcription of von Neumann's density matrix method ${ }^{\text {sa) }}$ through a particular fourier transformation of a specified representation of the latter which formulates quantum mechanics generally for mixture and characterizes a pure state by a subsidiary condition, thus leading to formulating quantum mechanics in a closed form in such a way that it is associated with the phase-space ensemble picture.

Really the method was described for the case of single non-relativistic particle, but it would also be interesting to apply this method to the case of a many particle system.

In conclusion the author would like to express his sincere thanks to Professor $S$. Sakata, Professor K. Husimi and Dr. S. Nakajima, and also to Professor E. P. Wigner, for kind interests and valuable discussions on this work.

*) For one-dimensional case it is

$$
P P_{4}^{3}-4 P_{1} P_{3}+3 P_{1}^{2}=(\hbar / 4)^{4}\left\{P \partial^{4} P-4 \partial P \cdot \partial^{3} P+3\left(\partial^{3} P\right)^{2}\right\},
$$

with

$$
P_{r}=\int p r f(x p) d t .
$$


The Formulation of Quantum Michunics in toms of Ensimble in Pluase Space 371

\section{Appendix}

A. Examples of the momentum transition probability $\widetilde{J}(\boldsymbol{x}, \boldsymbol{p})$, simple but not reducible to $\nabla \boldsymbol{V} \nabla_{p} \delta(\boldsymbol{p})$

i) For a linear rectangular potential bartier: $V(x)=V_{0}$ for $|x| \leqq \alpha / 2$, and 0 for $|x| \geqq a / 2$; we have $V^{\top}(p)=1 / \pi \cdot V_{0}$ sin $(p a / 2 \hbar) / p$, and so

$$
J(x, p)=-2 V_{0} / \pi \hbar p \cdot \sin (p a / \hbar) \sin (2 p x / \hbar) .
$$

ii) For a periodic potential, $V(\boldsymbol{x})=\sum_{n} V_{n} c^{i k_{n} \boldsymbol{x}}$, we have $V(\boldsymbol{p})=\sum_{n} V_{n} \delta\left(\boldsymbol{p}+\hbar \boldsymbol{k}_{n}\right)$, and so

$$
J(\boldsymbol{x}, \boldsymbol{p})=-\frac{2}{\hbar} \operatorname{Im}\left[\sum_{n} V_{n} \varepsilon^{2 i j x / \hbar}\right] \cdot \delta\left(\boldsymbol{p}+\frac{1}{2} \hbar \boldsymbol{k}_{n}\right) .
$$

Therefore particle momentum can jump only by an amount of some ' resonance value' $\hbar \boldsymbol{k}_{n} / 2$. iii) For Coulomb potential $V=-e^{2} / r$, we have $V(\boldsymbol{p})=-\left(\epsilon^{2} / 2 \pi^{2} \hbar\right) 1 / \nu^{2}$, so we obtain

$$
J(\boldsymbol{x}, \boldsymbol{p})=\frac{2 c^{2}}{\pi^{2} \hbar^{2}} \frac{\sin (2 p x / \hbar)}{p^{2}}
$$

In this case momentum cannot jump in the direction perpendicular to the force.

\section{B. Alternative procedure for obtaining the pure state conditions in the form of $\$ 4(b)$}

When our pure state condition for the density matrix, (4.4), is satisfied, we can derive from it the relations,

$$
D\left(n_{1} n_{2} n_{3}\right) \rho \cdot \partial_{k}^{\prime} \rho-\rho \cdot D\left(n_{1} n_{2} n_{3}\right) \partial_{k}^{\prime} \rho=0
$$

by differentiation, or further, even more general form

$$
D\left(n_{1} n_{2} n_{3}\right) \rho \cdot D^{\prime}\left(n_{1}^{\prime} n_{2}^{\prime} n_{3}^{\prime}\right) \rho-\rho \cdot D\left(n_{1} n_{2} n_{3}\right) D^{\prime}\left(n_{1}^{\prime} n_{2}^{\prime} n_{3}^{\prime}\right) \rho=0,
$$

where $D\left(n_{1} n_{2} n_{3}\right) \equiv \partial_{1}^{n_{1}} \partial_{2}^{n_{2}} \partial_{3}^{n_{3}}, D^{\prime}\left(n_{1}^{\prime} n_{2}{ }^{\prime} n_{3}{ }^{\prime}\right) \equiv \partial_{1}{ }^{\prime n_{1}} \partial_{2}{ }^{\prime n_{2}} \partial_{3}{ }^{n^{\prime} \mathrm{s}}$ with $\partial_{i}=\partial / \partial x_{i}, \quad \partial_{k}{ }^{\prime}=$ $\partial / \partial x_{k}{ }^{\prime}, n_{l}$ and $n_{l}^{\prime}$ being non-negative integers*).

Now, if (4.4) holds for any values of $\boldsymbol{x}$ and $\boldsymbol{x}^{\prime}$, we must have

$$
\begin{gathered}
{\left[D\left(n_{1} n_{2} n_{3}\right)\left(\partial_{i} \rho \partial_{k}^{\prime} \rho-\rho \partial_{i} \partial_{k}^{\prime} \rho\right)\right]_{x=x^{\prime}}=0,} \\
\text { for } \sum_{l} n_{l}=0,1,2, \cdots \infty,
\end{gathered}
$$

by the Taylor expansion of (4.4) on the diagonal. (B.3) can further by replaced by

$$
\begin{gathered}
{\left[D\left(n_{1} n_{2} n_{3}\right) \rho \cdot \partial_{k}{ }^{\prime} \rho-\rho \cdot D\left(n_{1} n_{2} n_{3}\right) \partial^{\prime}{ }_{k} \rho\right]_{x=x^{\prime}}=0,} \\
\text { for } \sum_{l} n_{l}=1,2,3, \cdots \infty .
\end{gathered}
$$

*) It is to be noted that the compatibility of the pure state condition (4.4) with the equation of motion (3.2) for $\rho$ can here be shown explicitly, as we can derive

$$
\partial / \partial t\left(\partial_{i} \rho \partial_{k}^{\prime} \rho-\partial_{i} \partial_{k}{ }^{\prime} \rho\right)=0
$$

from (3.2) and (B.2). 
We can thus replace the pure state condition (4.4) by a siric's of relations on the diagonal, (B.4). The lowest relation of (B.4) is

$$
\left[\partial_{i} \rho \partial_{k}^{\prime} \rho-\rho \partial_{i} \partial_{k}^{\prime} \rho\right]_{x=x_{i}^{\prime}}=0
$$

and its complex conjugate is

$$
\left[\partial_{k} \rho^{\prime} \partial_{i}^{\prime} \rho-\rho \partial_{k} \partial_{i}^{\prime} \rho\right]_{x=x^{\prime}}=0,
$$

which is, however, identical with the relation (B.5) with $i$ and $k$ inter ihanged. Therefore the nine complix relations, (B.5), are not independent of each other but consist of six symmetrized real equations,

$$
\left[\left(\partial_{i} \rho \partial_{k}^{\prime} \rho+\partial_{k} \rho \partial_{i}^{\prime} \rho\right)-\rho\left(\partial_{i} \partial_{k}^{\prime} \rho+\partial_{k} \partial_{i}^{\prime} \rho\right)\right]_{x=x x^{\prime}}=0,
$$

and three anti-symmetrized redl ones,

$$
i\left[\left(\partial_{i} \rho \partial_{k}^{\prime} \rho-\partial_{k} \rho \partial_{i}{ }^{\prime} \rho\right)-\rho\left(\partial_{i} \partial_{k}^{\prime} \rho-\partial_{k} \partial_{i}^{\prime} \rho\right)\right]_{x=x^{\prime}}=0 .
$$

The next relations of (B.4),

$$
\left[\partial_{i} \partial_{j} \rho \partial_{k}^{\prime} \rho-\rho \partial_{i} \partial_{j} \partial_{k}^{\prime} \rho\right]_{x=x^{\prime}}=0
$$

are not independent among themselves, too, on account of (B.5).

Now our next task is to represent the conditions (B.4) in terms of the distribution function. First we re-express (B.4) in terms of $\bar{\rho}(\boldsymbol{x}, \boldsymbol{y})$ to obtain

$$
\begin{gathered}
{\left[\left\{\prod_{l=1,2,3}\left(\frac{1}{2} \frac{\partial}{\partial x_{l}}-\frac{\partial}{\partial y_{l}}\right)^{n}\right\} \bar{l} \cdot\left(\frac{1}{2} \frac{\partial}{\partial x_{k}}+\frac{\partial}{\partial y_{k}}\right) \bar{l}\right]_{y=0}} \\
=\left[\bar{l} \cdot\left\{I_{l=1,2,3}\left(\frac{1}{2} \frac{\partial}{\partial x_{l}}-\frac{\partial}{\partial y_{l}}\right)^{n}\right\}\left(\frac{1}{2} \frac{\partial}{\partial x_{k}}+\frac{\partial}{\partial y_{k}}\right) \bar{l}\right]_{y=0} .
\end{gathered}
$$

Here, using the relation

$$
\left.\left[\left\{l_{l}\left(\frac{\partial}{\partial y_{l}}\right)^{r}\right\}^{l}\right]^{\prime}\right]_{y=0}=\left(-\frac{i}{\hbar}\right)^{r_{1}+r_{2}+r_{3}} P_{r_{1} r_{2} r_{3}}(x),
$$

with

$$
p_{r_{1} r_{2} r_{3}} \equiv \int p_{1}^{r_{1}} p_{2}^{r_{2}} p_{3}^{r_{3}} f(\boldsymbol{x}, \boldsymbol{p}) d \boldsymbol{p},
$$

(B.10) is transformed into the relation:

$$
\begin{aligned}
& \sum_{r_{1}, r_{2}, r_{3}=0}^{n_{3}, r_{2}, n_{3}}\left(\frac{2 i}{\hbar}\right)^{r_{1}+r_{2}+r_{3}}\left(\begin{array}{l}
n_{1} \\
r_{1}
\end{array}\right)\left(\begin{array}{l}
n_{2} \\
r_{2}
\end{array}\right)\left(\begin{array}{l}
n_{3} \\
r_{3}
\end{array}\right)\left[\left(I I \partial_{l}{ }^{n}{ }^{-} r_{2}\right) P_{r_{1} r_{2} r_{3}}\left(\frac{1}{2} \partial_{k} P-\frac{i}{\hbar} P_{k}\right)\right. \\
& \left.-P\left(\prod_{l} \partial_{l}{ }^{n}{ }^{-r_{l}}\right)\left(\frac{1}{2} \partial_{k} P_{r_{1} r_{2} r_{3}}-\frac{i}{\hbar} P\left(r_{1} r_{2} r_{3}\right)+1_{k}\right)\right]=0,
\end{aligned}
$$

which may further be separated into real and imaginary part equations. Thus we have obtained the pure state conditions in the form of relations between distribution moments

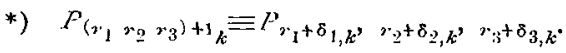


of successively higher orders in respect to $\boldsymbol{p}$. Especially we find that the lowest relations (B. 7) and (B. 8) transform, according to these procedures, just into (4.18) and (4.19), respectively, while the transforms of the next relation (B.9) become (4.21).

\section{References}

1) The content of this article was reported in Prog. Theor, Phys. 10 (1953), 119, 121, 122, in its essentials, and also in Busseiron-Kenkyu No. 66 (Sept. 1953), p. 48, in Japanese nearly in full .

2) P. A. M. Dirac, The Principles of Quantum Mechanics, third ed. p. 10.

3) R. P. Feynman, Rev. Mod. Phys. 20 (1948), 367.

4) T. Takabayasi, Prog. Theor. Phys. 8(1952), 143; also see D. Bohm, Phys. Rev. 84 (1952), 166, 180; L. de Broglie, La Physique Quantique Restra-t-elle Indétcrministe? (Gauthier-Villars, Paris, 1953).

5) T. Takabayasi, Prog. Theor. Phys. 9 (1953), 187.

6) E. P. Wigner, Phys. Rev. 40 (1932), 749.

7) J. E. Moyal, Proc. Cambridge Phil. Soc. 45 (1949), 99.

8) H. S. Green, J. Chem. Phys. 19 (1951), 955; J. H. Irving and R. W. Zwanzig, J. Chem. Phys. 19 (1951), 1173; H. Mori and S. Ono, Prog. Theor. Phys. 8 (1952), 327; H. Moti, ibid. 9(1953), 473.

8a) J. v. Neumann, Mathematische Grundlagen de' Qurntenmechanik (1932).

9) H. Weyl, Gruppentheorie und Quantennechanik (1931), p. 244.

10) Cf. P.A. M. Dirac, Rev. Mod. Phys. 17 (1945), 195.

11) Cf. F. Bopp, ZS. f. Naturforsch. 2a (1947), 202; also cf. reference 4) $\S 1$.

12) See T. Takabayasi, J. of History of Science, Japan, No. 19 (1951). It would be interesting to compare our viewpoint with that of K. Husimi, Prog. Theor. Phys. 9(1953), 381.

13) H. A. Kramers, Physica 7(1940), 284.

14) W. Weizel, ZS. f. Phys. 134 (1953), 264.

15) Compare with D. Bohm, Quantum T'heory' (Prentice-Hall, New York, 1951) p. 240.

16) Cf. E. Schrödinger, Naturwiss. 14 (1926), 664; L. Schiff, Quantum Mechanirs, p. 67.

\section{Note added in proof}

1) To page 345: For instance, the $q$-no. function due to Weyl's procedure corresponding to a $c$-no. function $A(x, p)=x_{i} p_{i}$ is found to be $\left(x_{i} p_{i}+\underline{p}_{i} \underline{x}_{i}\right) / 2$, so

$$
\left\langle\left(\underline{x}_{i} \underline{p}_{i}+\underline{p}_{i} \underline{x}_{i}\right) / 2\right\rangle_{\mathrm{qu}}=\int x_{i} p_{i} f(\boldsymbol{x}, \boldsymbol{p}) d \boldsymbol{x} d \boldsymbol{p} .
$$

Further, if we take this hermitian quantity not belonging to $(2.12 \mathrm{~b})$ for the $A$ in (2.3), we obtain another one of positivity conditions,

$$
\int x_{i}^{2} p_{i}^{2} f(x, p) d x d p \geqq-z^{2} / 4
$$

2) To page 346: A quantum-mechanical state compatible with given $P(x)$ and $Q(\boldsymbol{p})$ cannot be determined uniquely even when the state is restricted within pure cases (see K. Husimi, Kagaku 5 (1935), 370).

3) To page 352: The transformation function $T$ for the case of forced oscillator was given by $T$. Nishiyama, Prog. Theor. Phys. 8 (1952), 655. 582).

4) To $\$ 5$ (c): Recently Weizel applied his method to many particle system (ZS. f. Phys. 136 (1954),

5) To $\$ 7$ (a): The positivity condition is to be regarded as involving the uncertainty for the case of mixture, since it means that a permissible ps. df. $f(\boldsymbol{x}, \boldsymbol{p})$ should be expanded as the superposition with positive coefficients of mutually orthogonal ps. dfs. $f_{n z}$ satisfying pure state conditions, as

$$
f(\boldsymbol{x}, \boldsymbol{p})=\sum_{n} w_{n} f_{n}(\boldsymbol{x}, \boldsymbol{p})
$$

with $2 w_{n} \geqq 0, \int f_{n 2}(\boldsymbol{x}, \boldsymbol{p}) f_{m}(\boldsymbol{x}, \boldsymbol{p}) d \boldsymbol{x} d \boldsymbol{p}=\delta_{n m} / h^{3}$. It was, however, not easy to express the sufficient positivity condition in a more convenient form. 


\title{
Formulation of Quantum Mechanics Based on the Quasi-Probability Distribution Induced on Phase Space*
}

\author{
GEORGE A. BAKer, JR. \\ University of California, Berkeley, California \\ (Received March 25, 1957)
}

\begin{abstract}
We postulate a formulation of quantum mechanics which is based solely on a quasi-probability function on the classical phase space. We then show that this formulation is equivalent to the standard formulation, and that the quasi-probability function is exactly analogous to the density matrix of Dirac and von Neumann. We investigate the theory of measurement in this formulation and derive the following remarkable results. As is well known, the correspondence between classical functions of both the position and conjugate momentum and quantum mechanical operators is ambiguous because of noncommutativity. We show that the solution of this correspondence problem is completely equivalent to the solution of the eigenvalue problem. This result enables us to give a constructive method to compute eigenvalues and eigenfunctions.
\end{abstract}

\section{INTRODUCTION AND SUMMARY}

$T$ is well known that, as a general rule, for macroscopic phenomena, classical mechanics furnishes quite a good description of nature. If we have a mechanical system, it is described classically by a Hamiltonian function $H\left(q_{k}, p_{k}, t\right)$. Classical mechanics asserts that if we measure the system, we will find it with unit probability at a point, $\left(q_{k}(t), p_{k}(t)\right)$, in phase space which moves in accordance with Hamilton's canonical equations,

$$
\dot{q}_{k}=\left\{q_{k}, H\right\}, \quad \dot{p}_{k}=\left\{p_{k}, H\right\},
$$

where $\{A, B\}$ is the classical Poisson bracket. ${ }^{1}$

We find experimentally, however, that it is not possible to make the measurements necessary to establish the classical trajectory. The fundamental limitation is expressed by Heisenberg's uncertainty principle which states that it is impossible to ascertain the position of a system in phase space more accurately than to say that it is in a volume of the order of $h^{n}$, where $n$ is the number of degrees of freedom and $h$ is Planck's constant. The uncertainty principle shows us

* Submitted in partial fulfillment of the requirement for the Ph.D. degree, University of California, Berkeley, California. $\dagger$ Now at Los Alamos Scientific Laboratory, Los Alamos, New Mexico.

${ }_{1}$ H. Goldstein, Classical Mechanics (Addison-Wesley Publishing Company, Inc., Cambridge, 1953). the need for a different representation than the classical, moving phase-point.

For the case of quantum-mechanical systems in which all observables may be expressed as functions of the coordinates and their canonical momenta $\left(q_{k}, p_{k}\right)$, we may represent the system by a quasi-probability (not everywhere necessarily non-negative) distribution in phase space, instead of the more usual Heisenberg or Schrödinger representations. We shall see that the impossibility of simultaneously measuring complementary quantities (such as $q$ and $p$ ) will be closely related to the occurrence of "negative probability." We show that the quasi-probability distributional representation is equivalent to the standard formulation. In our formulation, we replace the classical condition of a point representation with a corresponding quantum condition, and with the aid of the correspondence principle, are able to derive the dynamical law.

By introducing the appropriate orthonormal set, we are able to show that the quasi-probability function which we use is isomorphic to the statistical operator of von Neumann. ${ }^{2}$

2 J. von Neumann, Mathematical Foundalions of Quantum Mechanics, translated by $\mathrm{R}$. T. Beyer (Princeton University Press, Princeton, 1955). 
As a result of our study of the quantum theory of measurement, we are able to develop a method for constructing the solution to any quantum mechanical eigenfunction problem. The problem of the correspondence between phase space functions and the powers of a given physical quantity is shown to be equivalent to the solution of the eigenfunction problem, and we give an explicit rule to determine this correspondence.

\section{QUASI-PROBABILITY DISTRIBUTIONAL FORMULA- TION OF QUANTUM MECHANICS}

This formulation of quantum mechanics is based on the following postulate:

Postulate Q.-There exists a quasi-probability distribution function $f\left(q_{k}, p_{k}, t\right)$ of the conjugate coordinates $\left(q_{k}, p_{k}\right)$ and the time, $l$, satisfying the conditions

$$
\begin{gathered}
\int_{-\infty}^{+\infty} \cdots \int_{-\infty}^{+\infty} f d q_{1} \cdots d q_{n} d p_{1} \cdots d p_{n}=1, \\
\text { (normalization) } \\
\int_{-\infty}^{+\infty} \cdots \int_{-\infty}^{+\infty}|f|^{2} d q_{1} \cdots d q_{n} d p_{1} \cdots d p_{n} \text { exists, } \\
\text { (boundedness) } \\
f=h^{n}(f, f), \quad \text { (quantum), } \\
\frac{\partial f}{\partial \ell}=\frac{-1}{\hbar}[f, H], \quad \text { (dynamical), }
\end{gathered}
$$

where $H\left(q_{k}, p_{k}, l\right)$ is the classical Hamiltonian function, which completely defines the quantum mechanical state of the system.

We have used the definitions

$$
\begin{aligned}
(A, B)=\left(\frac{2}{h}\right)^{2 n} \int_{-\infty}^{+\infty} \cdots \int_{-\infty}^{+\infty} \cos \left\{\frac{2}{\hbar} \sum_{j=1}^{n} \operatorname{det}\left[\begin{array}{ccc}
1 & q_{j} & p_{j} \\
1 & \tau_{j} & \sigma_{j} \\
1 & \xi_{j} & \eta_{j}
\end{array}\right]\right\} \\
\quad \times A\left(\tau_{k}, \sigma_{k}\right) B\left(\xi_{k}, \eta_{k}\right) d \xi_{1} \cdots d \xi_{n} d \eta_{1} \cdots \\
\times d \eta_{n} d \tau_{1} \cdots d \tau_{n} d \sigma_{1} \cdots d \sigma_{n},
\end{aligned}
$$

and

$$
\begin{aligned}
{[A, B]=2 } & \left(\frac{2}{h}\right)^{2 n} \int_{-\infty}^{+\infty} \cdots \int_{-\infty}^{+\infty} \sin \left\{\frac{2}{\hbar} \sum_{j=1}^{n} \operatorname{det}\left|\begin{array}{ccc}
1 & q_{j} & p_{j} \\
1 & \tau_{j} & \sigma_{j} \\
1 & \xi_{j} & \eta_{j}
\end{array}\right|\right\} \\
& \times A\left(\tau_{k}, \sigma_{k}\right) B\left(\xi_{k}, \eta_{k}\right) d \xi_{1} \cdots d \xi_{n} d \eta_{1} \cdots \\
& \times d \eta_{n} d \tau_{1} \cdots d \tau_{n} d \sigma_{1} \cdots d \sigma_{n} .
\end{aligned}
$$

We remark that one can show for properly restricted $A$ and $B$, by applying a suitable form of Riemann's theorem on trigonometric integrals, and an integration by parts in the second case, that, in the limit as $h$ goes to zero,

$$
\begin{aligned}
(A, B) & \rightarrow A\left(q_{k}, p_{k}\right) B\left(q_{k}, p_{k}\right), \\
\frac{1}{\hbar^{2}}[A, B] & \rightarrow\{A, B\}=\sum_{j=1}^{n}\left(\frac{\partial A}{\partial q_{j}} \frac{\partial B}{\partial p_{j}}-\frac{\partial A}{\partial p_{j}} \frac{\partial B}{\partial q_{j}}\right) .
\end{aligned}
$$

The relation for the sine bracket converts condition (4) into Liouville's theorem and hence in the classical limit $f$ changes in time like a classical statistical mechanical distribution would. The relation for the cosine bracket, together with condition (3), implies that $f$ tends to a distribution on a set of measure zero in the classical limit. Thus, in the classical limit, this formulation reduces to a phase point executing a classical trajectory.

It is now our purpose to show how the quasi-probability distributional formulation is related to the density matrix formulation of von Neumann and Dirac. To do so, we first show that the distribution function may be written in the form given by Wigner. ${ }^{3}$ We then show, by introducing an appropriate orthonormal set, the one-to-one correspondence between the quasi-probability distributional formulation and the density matrix formulation.

It may be useful in following the derivations given herein to think of the quasi-probability distribution function as a particular representation of the more familiar density matrix, and the sine and cosine brackets as the commutator and one-half the anticommutator brackets, respectively. We show that there is an isomorphism between the density matrix formulation and the quasi-probability distributional formulation.

We now show that we may write

$$
\begin{array}{r}
\int_{-\infty}^{+\infty} \cdots \int_{-\infty}^{+\infty} \exp \left\{-\frac{2 i}{\hbar \sum_{k=1}^{n}} s_{k} p_{k}\right\} f\left(q_{k}, p_{k}\right) d p_{1} \cdots d p_{n} \\
=g^{*}\left(q_{k}+s_{k}\right) g\left(q_{k}-s_{k}\right)
\end{array}
$$

where $g$ depends on the state of the system. It follows from the definition that $[A, B]=-[B, A]$. Therefore, $[f, f]=0$. So, by condition (3) of postulate $Q$,

$$
f=h^{n}\left((f, f)+\frac{i}{2}[f, f]\right)
$$

or

$$
\begin{aligned}
& f=\frac{2^{2 n}}{h^{n}} \int_{-\infty}^{+\infty} \cdots \int_{-\infty}^{+\infty} \exp \left\{\frac { 2 i } { \hbar } \sum _ { j = 1 } ^ { n } \left[p_{j}\left(\tau_{j}-\xi_{j}\right)-\sigma_{j}\left(q_{j}-\xi_{j}\right)\right.\right. \\
&\left.\left.-\eta_{j}\left(\tau_{j}-q_{j}\right)\right]\right\} f\left(\tau_{k_{1}} \sigma_{k}\right) f\left(\xi_{k}, \eta_{k}\right) d \xi_{1} \cdots \\
& \quad \times d \xi_{n} d \eta_{1} \cdots d \eta_{n} d \tau_{1} \cdots d \tau_{n} d \sigma_{1} \cdots d \sigma_{n} .
\end{aligned}
$$

'E. Wigner, Phys. Rev. 40, 749 (1932). 
Let us make a change of variables of integration:

$$
\tau_{j}-\xi_{j}=y_{j}, \quad \tau_{j}+\xi_{j}=w_{j}+q_{j}, \quad \text { Jacobian }=\left(\frac{1}{2}\right)^{n} .
$$

Then

$$
\begin{aligned}
f= & \left(\frac{2}{n}\right)^{n} \int_{-\infty}^{+\infty} \cdots \int_{-\infty}^{+\infty} \exp \left\{\frac { 2 i } { \hbar } \sum _ { j = 1 } ^ { n } \left[p_{j} y_{j}-\frac{1}{2} \sigma_{j}\left(q_{j}+y_{j}\right.\right.\right. \\
\left.\left.\left.-w_{j}\right)+\frac{1}{2} \eta_{j}\left(q_{j}-y_{j}-w_{j}\right)\right]\right\} & f\left(\left(w_{k}+y_{k}+q_{k}\right) / 2, \sigma_{k}\right) \\
& \times f\left(\left(w_{k}+q_{k}-y_{k}\right) / 2, \eta_{k}\right) d w_{1} \cdots d w_{n} d y_{1} \cdots \\
& \times d y_{n} d \eta_{1} \cdots d \eta_{n} d \sigma_{1} \cdots d \sigma_{n} .
\end{aligned}
$$

If we take the Fourier transform of the above relation with respect to $\left(p_{k}\right)$,then, defining the auxiliary function

$$
\begin{aligned}
G\left(q_{k}+s_{k}, q_{k}-s_{k}\right)=\int_{-\infty}^{+\infty} \cdots \int_{-\infty}^{+\infty} & \exp \left\{-\frac{2 i}{\hbar} \sum_{j=1}^{n} p_{j} s_{j}\right\} \\
& \times f\left(q_{k}, p_{k}\right) d p_{1} \cdots d p_{n},
\end{aligned}
$$

we obtain, by Fourier's integral theorem, ${ }^{4}$

$$
\begin{aligned}
& G\left(q_{k}+s_{k}, q_{k}-s_{k}\right) \\
& \quad=\int_{-\infty}^{+\infty} \cdots \int_{-\infty}^{+\infty} G\left(q_{k}+s_{k}, w_{k}\right) G\left(w_{k}, q_{k}-s_{k}\right) d w_{1} \cdots d w_{n} .
\end{aligned}
$$

If we think of $G\left(q_{k}+s_{k}, w_{k}\right)$ as the kernel of a homogeneous, linear integral equation, we see that it has at least one solution, i.e., $G\left(w_{k}, q_{k}-s_{k}\right)$ and its eigenvalue is unity. By a slight modification of the arguments of Courant and Hilbert, ${ }^{5}$ we know

$$
\int_{-\infty}^{+\infty} \cdots \int_{-\infty}^{+\infty}\left|G\left(q_{k}, w_{k}\right)\right|^{2} d q_{1} \cdots d q_{n} d w_{1} \cdots d w_{n} \geq \sum_{i=1}^{\infty} \frac{1}{\left|\lambda_{i}\right|^{2}}
$$

where the $\lambda_{i}$ are the eigenvalues. But, by the relation we derived above, the integral becomes

$$
\int_{-\infty}^{+\infty} \cdots \int_{-\infty}^{+\infty} G\left(q_{k}, q_{k}\right) d q_{1} \cdots d q_{n}
$$

as $G(x, y)=G^{*}(y, x)$, which is, by definition, equal to

$$
\int_{-\infty}^{+\infty} \cdots \int_{-\infty}^{+\infty} f\left(q_{k}, p_{k}\right) d q_{1} \cdots d q_{n} d p_{1} \cdots d p_{n}=1,
$$

by the normalization of $f$. Hence

$$
1 \geq 1+\sum_{i=2}^{\infty} \frac{1}{\left|\lambda_{i}\right|^{2}}
$$

IE. C. Titchmarch, Introduction to the Theory of Fourier Iniegrals (Clarendon Press, Oxford, 1937), Chap. III.

${ }_{6} \mathbf{R}$. Courant and D. Hilbert, Methods of Mathematical Physics (Interscience Publishers, Inc., New York, 1953), Chap. III, Sec. 4.
Therefore, there is only one eigenvalue, 1 , and by the above-mentioned arguments of Courant and Hilbert, we see that $G(x, y)$ is a degenerate kernel, and so must be of the form

which is $\left(3^{\prime}\right)$.

$$
G(x, y)=g^{*}(x) g(y),
$$

If we take the inverse Fourier transform of $\left(3^{\prime}\right)$ on $\left(s_{w}\right)$ and identify $g$ with the wave function, $\psi$, we obtain the Wigner form for $f$. Hence

$$
\begin{aligned}
f\left(q_{k}, p_{k}\right)=\left(\frac{2}{h}\right)^{n} & \int_{-\infty}^{+\infty} \cdots \int_{-\infty}^{+\infty} \exp \left\{\frac{2 i}{\hbar} \sum_{k=1}^{n} p_{k} y_{k}\right\} \\
& \times \psi^{*}\left(q_{k}+y_{k}\right) \psi\left(q_{k}-y_{k}\right) d y_{1} \cdots d y_{n}
\end{aligned}
$$

It is this form which Wigner" chose "from all possible expressions, because it seems to be the simplest," although he knew only that it gave the correct marginal distributions. Moyal ${ }^{6}$ has shown that it also gives the correct joint distribution if we make the "Weyl correspondence"7 (see also, Sec. III below) between operators and phase-space functions. Moyal investigates the quasi-probability distribution function from the point of view of modern statistical theory and the theory of general stochastic processes. Groenwold ${ }^{8}$ and Takabayasi $^{9}$ have also investigated this form and some equivalent forms of the quasi-probability distribution function.

We remark that, if we integrate first on $p$ and then on $q$ that the normalization of $f$ insures that $\psi$ must be square-integrable, and hence belong to a Hilbert space.

\section{RELATION BETWEEN THE QUASI-PROBABILITY DISTRIBUTION AND THE STATISTICAL OPERATOR OF VON NEUMANN ${ }^{2}$}

Following von Neumann, we introduce an ensemble of systems each of which is in a "pure state," and each state has a certain frequency of occurrence in the ensemble. The quasi-probability distribution function for the ensemble need not satisfy condition (3) of postulate $Q$, but rather it is a sum of functions which do. Hence $f$ for the ensemble will be

$$
f=\sum_{\rho} w_{\rho} f_{p}\left(q_{k}, p_{k}\right) \text {. }
$$

Let us introduce a complete orthonormal set of wave functions $\left\{\psi_{j}\left(q_{k}\right)\right\}$. From the form $\left(3^{\prime}\right)$ of $f$, we know that to each $f_{p}$, there corresponds a $\psi_{p}$ which we may expand as

$$
\psi_{p}=\sum_{j} a_{p j} \psi_{j}
$$

It then follows at once that

$$
f=\sum_{\rho, i, j} w_{p} a_{\rho i}{ }^{*} a_{\rho j} f_{i j}
$$

J. E. Moyal, Proc. Cambridge Phil. Soc, 45, 99 (1949).

'H. Weyl, The Theory of Groups and Quantum Mechanics, translated from the German by H. P. Robertson (Dover Publications, New York, 1931), p. 274.

H. J. Groenwold, Physica 12, 405 (1946).

- T. Takabayasi, Progr. Theoret. Phys. Japan 11, 341 (1954). 
where we define

$$
\begin{aligned}
f_{i j}\left(q_{k}, p_{k}\right)=\left(\frac{2}{h}\right)^{n} \int_{-\infty}^{+\infty} & \cdots \int_{-\infty}^{+\infty} \exp \left\{\frac{2 i}{\hbar} \sum_{k=1}^{n} y_{k} p_{k}\right\} \\
& \times \psi_{i}^{*}\left(q_{k}+y_{k}\right) \psi_{j}\left(q_{k}-y_{k}\right) d y_{1} \cdots d y_{n} .
\end{aligned}
$$

The $f_{i j}$ have certain orthogonality properties which we shall now note. These properties have been, in essence, derived by $\mathrm{Moyal}^{6}$ for one degree of freedom, but their proof for $n$ degrees is the same. They are as follows (variables of integration suppressed):

(i) $\int f_{i j}^{*} f_{k m}=0$ if and only if

$$
\int \psi_{i}^{*} \psi_{k}=0, \text { or } \int \psi_{j}^{*} \psi_{m}=0
$$

(ii) $\int\left|f_{i j}\right|^{2}=h^{-n}$.

(iii) The $\psi_{i}$ are an orthonormal set if and only if the $h^{n / 2} f_{i i}$ are

(iv) $\int f_{i j}=\delta_{i j}$, if the set $\left\{\psi_{i}\right\}$ is orthonormal.

(v) If and only if the set $\left\{\psi_{i}\right\}$ is a complete orthonormal set,

$$
\begin{aligned}
\sum_{i, j} f_{i j}\left(q_{k}, p_{k}\right) f_{i j}{ }^{*}\left(q_{k}{ }^{\prime}, p_{k}{ }^{\prime}\right) & \\
= & h^{-n} \prod_{k=1}^{n} \delta\left(q_{k}-q_{k}{ }^{\prime}\right) \delta\left(p_{k}-p_{k}{ }^{\prime}\right) .
\end{aligned}
$$

(vi) If $\left\{\psi_{i}\right\}$ is a complete orthonormal sec, then $h^{n / 2} f_{i j}$ is a complete orthonormal set in the Hilbert space of phase-space functions. This is to say that, not only do the $f_{i j}$ form a basis for the quasi-probability distribution functions, but they also span the entire Hilbert space $\left(L_{2}\right)$ of functions on phase space.

If we now compute the matrix

$$
\left[h^{n} \int_{-\infty}^{+\infty} \cdots \int_{-\infty}^{+\infty} f_{i j}^{*} f d q_{1} \cdots d q_{n} d q_{1} \cdots d p_{n}\right]
$$

we obtain

$$
\left[\sum_{\rho} w_{\rho} a_{\rho i}{ }^{*}, a_{\rho j}\right] \text {, }
$$

which is just the matrix for von Neumann's statistical operator $\left[U_{i j}\right]$. The matrix corresponding to a quantity $R\left(q_{k}, p_{k}\right)$ is seen to be

$$
\begin{aligned}
{\left[R_{j m}\right]=\int_{-\infty}^{+\infty} \cdots \int_{-\infty}^{+\infty} } & R\left(q_{k}, p_{k}\right) \\
& \times f_{j_{1} m}{ }^{*}\left(q_{k}, p_{k}\right) d q_{1} \cdots d q_{n} d p_{1} \cdots d p_{n},
\end{aligned}
$$

as the expected value of $R\left(q_{k}, p_{k}\right)$ is given correctly by von Neumann's rule:

$$
\langle R\rangle=\operatorname{Trace}(R U)
$$

for all $U$. For

$$
\begin{aligned}
\operatorname{Tr}(R U)= & \sum_{i, m} R_{j m} U_{m j} \\
= & \sum_{i, m} \int_{-\infty}^{+\infty} \cdots \int_{-\infty}^{+\infty} R\left(q_{k}, p_{k}\right) f_{j, m}^{*}\left(q_{k}, p_{k}\right) \\
& \times\left[\sum_{p} w_{p} a_{p m}{ }^{*} a_{p j}\right] d q_{1} \cdots d q_{n} d p_{1} \cdots d p_{n},
\end{aligned}
$$

and as $f_{j m}^{*}=f_{m j}$, this becomes

$$
\begin{aligned}
\operatorname{Tr}(R U)= & \int_{-\infty}^{+\infty} \cdots \int_{-\infty}^{+\infty} R\left(q_{k}, p_{k}\right) \\
& \times\left[\sum_{p, j, m} w_{p} a_{p m}{ }^{*} a_{p j} f_{m j}\left(q_{k}, p_{k}\right)\right] \\
& \times d q_{1} \cdots d q_{n} d p_{1} \cdots d p_{n} \\
= & \int_{-\infty}^{+\infty} \cdots \int_{-\infty}^{+\infty} R\left(q_{k}, p_{k}\right) f\left(q_{k}, p_{k}\right) d q_{1} \cdots \\
& \times d q_{n} d p_{1} \cdots d p_{n}=\left\langle R\left(q_{k}, p_{k}\right)\right\rangle .
\end{aligned}
$$

These results indicate that the quasi-probability distribution is directly analogous to von Neumann's statistical operator. Where he uses infinite matrices as the basis of his theory, we use functions of the real variables $\left(q_{k}, p_{k}\right)$. It is worth noting that, using the above method to define a matrix for a function, the matrix for the cosine bracket, $(A, B)$, is one-half the anti-commutator of the matrix for $A$ and the matrix for $B$. Also the matrix for the sine bracket, $[A, B]$, is simply the commutator divided by $i$ of the matrix for $A$ and the matrix for $B$. These results serve to establish an isomorphism between the space of functions of real variables and the space of infinite matrices. They may be verified by a straightforward formal calculation, which starts from the following rule for the result of $R\left(q_{k}, p_{k}\right)$ acting on $\psi$. This rule follows at once from our definition of the matrix elements $R_{j m}$. It is

$$
\begin{aligned}
\mathcal{Q} \psi\left(q_{1}, \cdots q_{n}\right) & =h^{-n} \int_{-\infty}^{+\infty} \cdots \int_{-\infty}^{+\infty} \exp \left\{\frac{i}{\hbar} \sum_{k=1}^{n} \eta_{k}\left(q_{k}-\xi_{k}\right)\right\} \\
\times & R\left(\left(q_{k}+\xi_{k}\right) / 2, \eta_{k}\right) \psi\left(\xi_{k}\right) d \xi_{1} \cdots d \xi_{n} d \eta_{1} \cdots d \eta_{n} .
\end{aligned}
$$

We note that this rule may also be derived from the correspondence suggested by Wey ${ }^{7}$ by some fairly straightforward manipulations involving the use of Fourier's integral theorem. Let $\sigma$ be the operator corresponding to $p$ and 2 be the operator corresponding to $q$. Let them satisfy the commutation relation

$$
\mathcal{P}-2 \mathcal{Q}=(h / i) \mathcal{E}
$$


where $\mathcal{E}$ is the identity operator. If

$$
R(\xi, p)=\frac{1}{h} \int_{-\infty}^{+\infty} \int_{-\infty}^{+\infty} \exp \left\{\frac{i}{h}(\sigma \xi+\tau p)\right\} \zeta(\sigma, \tau) d \sigma d \tau
$$

then, according to Weyl, the correct operator is obtained by replacing $\xi$ by 2 and $p$ by $P$. In this derivation, use is made of an identity of Kermack and $\mathrm{McCrea}^{10}$ :

$$
\exp \left\{\frac{i}{\hbar}(\sigma \mathcal{\rho}+\tau \mathcal{2})\right\}=\exp \left(\frac{i \sigma \tau}{2 \hbar}\right) \exp \left(\frac{i \tau \mathcal{2}}{\hbar}\right) \exp \left(\frac{i \sigma \mathcal{\rho}}{\hbar}\right) .
$$

Our quantum condition, $(f, f)=h^{n} f$, becomes then, in matrix language,

$$
U U=U,
$$

which is just von Neumann's characterization of a "pure state." The physical interpretation in the two cases is similar. In matrix language, it characterizes a projection operator onto some state, while our condition may be thought of as characterizing sort of a smearedout projection operator for a region of phase space. It represents a modification of the classical delta function which projects onto a phase-point.

\section{QUANTUM DYNAMICS AND THE CORRESPONDENCE PRINCIPLE}

We show in this section that the dynamical equation of quantum mechanics can be derived from the quantum condition, with the aid of the Bohr correspondence principle. For this demonstration, it is convenient to define a dot product as

$$
\begin{aligned}
& A \cdot B=\int_{-\infty}^{+\infty} \cdots \int_{-\infty}^{+\infty} A\left(q_{k}, p_{k}\right) B\left(q_{k}, p_{k}\right) \\
& \times d q_{1} \cdots d q_{n} d p_{1} \cdots d p_{n} .
\end{aligned}
$$

It is easy to verify from the definitions that

$$
[A, B] \cdot C=A \cdot[B, C] \text {, }
$$

and to verify, by formal integration by parts and Fourier's integral theorem, that

$$
[A, B]=h\{A, B\} \text {, }
$$

if $A$ is a polynomial, at most quadratic, where $\{A, B\}$ is the classical Poisson bracket.

The large-scale experimental validity of classical mechanics tells us that quantum theory must, in some sense, correspond closely to classical mechanics. We have altered the classical concept of a moving point in phase space to that of a quasi-probability distribution which changes in time. This distribution (see Sec. II) is imagined to be concentrated about the classical point, so that a crude measurement will be unable to differentiate between the two theories. To insure this

${ }^{10}$ W. O. Kermack and W. H. McCrea, Proc. Edinburg Math. Soc. 2, 224 (1931). correspondence, we shall use the statement which actually seems to be given by experiments on the average, Hamilton's canonical equations hold. It can be shown, say by using the Wigner form $\left(3^{\prime \prime}\right)$ of $f$ and some of the properties given in the next section, and making an infinitesmal change $\psi$, that the most general infinitesmal change $\delta f$ which preserves the normalization and quantum conditions is given by

$$
\delta f=[f, \delta g],
$$

where $\delta g$ is arbitrary. Since by "the average of $\dot{q}_{k}$ " we mean the time rate of change of the expected value of $q_{k}$, we have

$$
\text { Average }\left(\dot{q}_{k}\right)=\frac{d}{d l}\left(q_{k} \cdot f\right)=q_{k} \cdot \frac{\partial f}{\partial l}
$$

Also

$$
\delta f \equiv \delta l(\partial f / \partial l)
$$

We must have, by the correspondence principle,

$$
\begin{aligned}
\delta l\left(q_{k} \cdot \frac{\partial f}{\partial l}\right) & =q_{k} \cdot[f, \delta g] \\
& \equiv-\left[q_{k}, \delta g\right] \cdot f \\
& \equiv-\hbar\left\{q_{k}, \delta g\right\} \cdot f \\
& =\delta l\left\{q_{k}, H\right\} \cdot f .
\end{aligned}
$$

Thus we see, as the above equation must hold for all $q_{k}$ and $p_{k}$, and for any possible $f$, we must (outside an arbitrary, additive constant, $V_{0}$ ) choose for $\delta g$

$$
\delta g=-H \delta t / \hbar \text {. }
$$

Thus we obtain the dynamical equation

$$
\frac{\partial f}{\partial l}=-\frac{1}{\hbar}[f, H]
$$

which is given by condition (4) of postulate $Q$. It should be noted that this equation is the direct analog of Liouville's theorem of classical statistical mechanics. ${ }^{1}$

We see, therefore, that in this formulation, the change in the formal structure from classical to quantum mechanics consists in replacing the equation $f=\left(0^{+}\right) f^{2}$ by $f=h^{n}(f, f)$. (See Sec. II for limiting behavior of the cosine bracket as $h \rightarrow 0$.) The quasi-probability distributional formulation has the advantage that it does not depend on the two superfluous constants, the arbitrary phase factor and the additive constant in the classical potential energy which appears in the standard Schrödinger formulation. This lack of dependence on arbitrary, unobservable constants is not only an advantage, per se, but should be a grea $i$ convenience in the treatment of the asymptotic behavior in scattering problems. Furthermore, our formulation provides a sort of intuitive picture of what the system is doing in phase space. 


\section{FORMAL PROPERTIES}

(I) One property of the quasi-probability distribution which is easy to demonstrate is that it is uniformly bounded (see also, Takabayasi ${ }^{9}$ ). In terms of the wave function $\psi\left(q_{k}\right)$, we have

$$
\begin{aligned}
f\left(q_{k}, p_{k}\right)=(2 / h)^{*} \int_{-\infty}^{+\infty} & \cdots \int_{-\infty}^{+\infty} \exp \left[\frac{2 i}{\hbar} \sum_{k=1}^{n} y_{k} p_{k}\right] \\
& \times \psi^{*}\left(q_{k}+y_{k}\right) \psi\left(q_{k}-y_{k}\right) d y_{1} \cdots d y_{n} .
\end{aligned}
$$

By the Schwartz inequality, ${ }^{4}$ we have

$$
\begin{aligned}
\left|f\left(q_{k}, p_{k}\right)\right|^{2} \leq & (2 / h)^{2 n}\left|\int_{-\infty}^{+\infty} \cdots \int_{-\infty}^{+\infty}\right| \exp \left[\frac{2 i}{k} \sum_{k=1}^{n} y_{k} p_{k}\right] \\
& \left.\times \psi^{*}\left(q_{k}+y_{k}\right) \mid{ }^{2} d y_{1} \cdots d y_{n}\right\} \\
& \times\left\{\int_{-\infty}^{+\infty} \cdots \int_{-\infty}^{+\infty}\left|\psi\left(q_{k}-y_{k}\right)\right|^{2} d y_{1} \cdots d y_{n}\right\},
\end{aligned}
$$

which. as $\int \psi \psi^{*}=1$, implies

$$
\left|f\left(q_{k}, p_{k}\right)\right| \leq(2 / h)^{n} \text {. }
$$

(II) A second property is the following one. Let us define

$$
\begin{aligned}
f_{\mathrm{I}}=\frac{1}{N} \sum_{k=1}^{N} \int_{-\infty}^{+\infty} \int_{-\infty}^{+\infty} & \exp \left[\frac{2 i}{\hbar} \sum_{j=1}^{n} p_{j} y_{j}\right] \\
& \times \phi_{k}^{*}\left(q_{j}+y_{j}\right) \phi_{k}\left(q_{j}-y_{j}\right) d y_{1} \cdots d y_{n},
\end{aligned}
$$

where the $\phi_{k}$ 's are orthonormal.

Let $\left[a_{i k}\right]$ be a unitary transformation and let us also define

$$
\chi_{i}\left(q_{j}\right)=\sum_{k=1}^{n} a_{i k} \phi_{k}\left(q_{j}\right)
$$

and

$$
\begin{aligned}
f_{\mathrm{II}}=\frac{1}{N} \sum_{i=1}^{n} \int_{-\infty}^{+\infty} \cdots \int_{-\infty}^{+\infty} \exp \left[\frac{2 i}{\hbar} \sum_{j=1}^{n} p_{j} y_{j}\right] \\
\quad \quad \quad \chi_{i}^{*}\left(q_{j}+y_{j}\right) \chi_{i}\left(q_{j}-y_{j}\right) d y_{1} \cdots d y_{n},
\end{aligned}
$$

then $f_{\mathbf{I}}=f_{\mathrm{II}}$. This means that if $f$ represents an ensemble composed of equal numbers of systems in $N$ orthogonal states, then we get the same $f$ no matter in which way we make up the orthogonal states. To see this, we expand $f_{I I}$ as

$$
\begin{aligned}
f_{\mathrm{II}}= & \frac{1}{N} \int_{-\infty}^{+\infty} \cdots \int_{-\infty}^{+\infty} \exp \left[\frac{2 i}{\hbar} \sum_{j=1}^{n} p_{j} y_{j}\right] \\
& \quad \times \sum_{k, m}^{N} \sum_{i=1}^{N} a_{i k}{ }^{*} \phi_{k}^{*}\left(q_{j}+y_{j}\right) a_{i m} \phi_{m}\left(q_{j}-y_{j}\right) d y_{1} \cdots d y_{n} .
\end{aligned}
$$

Now, as $\left[a_{i k}\right]$ is unitary,

$$
\sum_{i=1}^{N} a_{i k}{ }^{*} a_{i m}=\delta_{k m} .
$$

Thus, by summing over $m$, it reduces to the definition of $f_{\mathrm{I}}$.

(III) The third group of properties listed below follow by straightforward, but somewhat tedious, formal calculation directly from the definitions. They are, however, obvious from the analogy to the density matrix formulation with the dot product playing the role of the trace.

$$
\begin{gathered}
{[A, B] \cdot f=[f, A] \cdot B=[B, f] \cdot A=A \cdot[B, f],} \\
{[A, B]=-[B, A],} \\
(A, B)=(B, A), \\
(A, B) \cdot f=(f, A) \cdot B, \text { etc., } \\
{[A,[B, C]]+[C,[A, B]]+[B,[C, A]]=0,} \\
{[A,(B, C)]=([A, B], C)+([A, C], B) .}
\end{gathered}
$$

If $f_{i i}$ and $f_{j j}$ are orthogonal to each other, then $\left(f_{i i}, f_{j j}\right)=0,\left[f_{i i}, f_{j j}\right]=0$, and, of course, $\left[f_{i i}, f_{i i}\right]=0$.

\section{MEASUREMENT}

We are now in a position to discuss the effect of measurement on a quantum-mechanical system. In the standard Schrödinger representation, the measurement of a quantity, $R\left(q_{k}, p_{k}\right)$, leaves the system in a state described by a $\psi$ which satisfies the eigenvalue equation,

$$
\Re \psi=\lambda \psi,
$$

where $R$ is the operator corresponding to $R\left(q_{k}, p_{k}\right)$. We know that this equation is equivalent ${ }^{11}$ to the extremal condition

or

$$
\delta(\langle R\rangle)=0,
$$

$$
\delta(R \cdot f)=R \cdot \delta f=R \cdot[f, \delta g]=[R, f] \cdot \delta g=0,
$$

where $\delta g$ is an arbitrary variation. Because $\delta g$ is arbitrary, we must have

$$
[R, f]=0 .
$$

This condition generates a sequence of quasi-probability distribution functions, $f_{\lambda \lambda}$, indexed by $\lambda$, where it is understood that several distinct $f_{\lambda \lambda}$ may be given the same name by this naming process, and

$$
\lambda=R \cdot f_{\lambda \lambda} \text {. }
$$

We shall say that the $\left\{f_{\lambda \lambda}\right\}$ form a "complete" set if

$$
1=h^{n} \sum_{\lambda} f_{\lambda \lambda} \cdot f
$$

(conservation of probability) for all quasi-probability distribution functions $f$.

11 H. Jeffreys and B. S. Jeffreys, Methods of Mathematical Physics (Cambridge University Press, New York, 1950), Sec. 10.14. 
The case of the degenerate $f_{\lambda \lambda}$ (more than one $f$ with the same value of $\lambda$ ) can be clarified as follows. We know from the standard quantum theory that the $\psi_{\lambda}$ corresponding to different $\lambda$ are orthogonal and hence (Sec. III) the $f_{\lambda \lambda}$ are. Further the $\psi_{\lambda}$ corresponding to the same $\lambda$ can be made orthogonal by the Schmidt process. By property II of Sec. V, it does not matter in which way it is done, since $\sum_{\lambda} f_{\lambda \lambda}$ involves equal weights to each $f_{\lambda \lambda}$. Thus we must understand by the above "completeness" condition that all the $f_{\lambda \lambda}$ are to be orthogonal to each other, pairwise. We may now formulate the following measurement postulate.

Posiulate M.--If we have an ensemble represented by a normalized, weighted sum $\mathcal{F}$ of quasi-probability distribution functions, then the measurement of a dynamical quantity, $R\left(q_{k}, p_{k}\right)$, decomposes the ensemble into a set of subensembles indexed by the measured value of $R\left(q_{k}, p_{k}\right)$. Each subensemble is represented by a quasi-probability distribution function $f_{\lambda \lambda}$, which satisfies the condition $\left[R, f_{\lambda \lambda}\right]=0$, and in each subensemble $R\left(q_{k}, p_{k}\right)$ takes on precisely its measured value, $\lambda$. In order for a measurement to be possible, all the conditions of this postulate must be enforceable for all possible F.

Now by the results of Sec. III, we know that we can expand any quasi-probability distribution function, and hence any weighted, normalized sum of them in terms of a complete orthonormal set $\left(h^{n / 2} f_{i j}\right)$. Now if we assume $R\left(q_{k}, p_{k}\right)$ measurable, the condition $\left[R, f_{\lambda \lambda}\right]$ $=0$ must form a "complete" set, or we would not be able to decompose the whole ensemble. Each $f_{\lambda \lambda}$ implies a corresponding $\psi_{\lambda}$, and hence we can construct a complete orthonormal system, $\left(h^{n / 2} f_{\lambda_{\nu}}\right)$, by the method of Sec. III. We note that this orthonormal system has the property that the $f_{\lambda \lambda}$ are quasi-probability distribution functions, while the $f_{\lambda v}, \lambda \neq \nu$ are not. Let us expand $\mathcal{F}$ in terms of it. By Sec. III, it becomes

$$
\mathcal{F}=\sum_{\rho, \lambda, \nu} w_{p} a_{\rho \lambda}{ }^{*} a_{\rho \nu} f_{\lambda \nu}\left(q_{k}, p_{k}\right) .
$$

If we make a measurement, by postulate $M$, the $f_{\lambda \text {, }}$, $\lambda \neq \nu$, are destroyed. (This results in no loss of normalization as $\int f_{\lambda \nu}=\delta_{\lambda}$, by Sec. III, iv.) Hence a measurement of $R\left(q_{k}, p_{k}\right)$ transforms $\mathcal{F}$ into

$$
\mathfrak{F}^{\prime}=\sum_{\rho, \lambda} w_{\rho} a_{p \lambda}{ }^{*} a_{\rho \lambda} f_{\lambda \lambda}\left(q_{k}, p_{k}\right) .
$$

We may now compute the distribution of measured values of $R\left(q_{k}, p_{k}\right)$ by means of the orthogonality relations as

$$
F(R)-F(0)=\sum_{0 \leq \lambda \leq R}^{\prime} f_{\lambda \lambda} \cdot F
$$

where $F(R)$ is the cumulative distribution of $R$. By $\Sigma^{\prime}$, we mean that if there is a contribution at either end point, we take only half of it. This is done to adapt the function $F$ to Fourier analysis.
However, we can proceed otherwise to obtain the cumulative distribution (and it is a true cumulative distribution for $\sum w_{\rho}\left|a_{\rho \lambda}\right|^{2} \geq 0$ ) and obtain an important result thereby. We first obtain the standard statistical characteristic function

$$
C(S)=\sum_{\nu \rightarrow 0}^{\infty}(-i S / \hbar)^{\nu}\left(\frac{\mu_{\nu}(\xi)}{\nu !}\right)
$$

where $\mu_{\nu}$ is the $\nu$ th moment of $R$, given $F$, computed from the above cumulative distribution. It can be shown that there exist functions $R^{(\nu)}\left(q_{k}, p_{k}\right)$ (if $\left.\left|\mu_{\nu}\right|<\infty\right)$ such that

$$
\mu_{\nu}(\mathfrak{F})=R^{(v)} \cdot \mathfrak{F}
$$

for all $\mathcal{F}$. According to Kendall, ${ }^{12}$ the cumulative distribution is then

$$
F(R)-F(0)=\frac{1}{2 \pi} \int_{-\infty}^{+\infty} \frac{[1-\exp (i R S / \hbar)]}{i S} C(S) d S .
$$

Substituting for $C(S)$ and equating these two expressions, we see, when the appropriate interchange of limit processes is permissible, that we must have, as $T$ is arbitrary by the relations of Sec. III (vi),

$$
\begin{aligned}
\sum_{0 \leq \lambda \leq R}^{\prime} f_{\lambda \lambda}\left(q_{k}, p_{k}\right)=\frac{1}{2 \pi k^{n}} \int_{-\infty}^{+\infty} & \frac{[1-\exp (i R S / \hbar)]}{i S} \\
& \times\left(\sum_{\nu=0}^{\infty} \frac{(-i S)^{\nu}}{\hbar} \frac{R^{(\nu)}\left(q_{k}, p_{k}\right)}{\nu !}\right) d S .
\end{aligned}
$$

Thus we see that the $f_{\lambda \lambda}$ must be constructed from the $R^{(\nu)}\left(q_{k}, p_{k}\right)$. Conversely, we must have

$$
\begin{aligned}
R^{(\nu)}\left(q_{k}, p_{k}\right) & =h^{n} \sum_{\text {all } \lambda} \lambda^{v} f_{\lambda \lambda}\left(q_{k}, p_{k}\right) \\
& =\int_{\lambda=-\infty}^{+\infty} \lambda^{v} d F_{\lambda}\left(q_{k}, p_{k}\right), \quad \text { (Stieltjes integral), }
\end{aligned}
$$

where we define

$$
F_{\lambda}\left(q_{k}, p_{k}\right)=h^{n} \sum_{0 \leq \mu \leq \lambda}^{\prime} f_{\mu \mu}\left(q_{k}, p_{k}\right)
$$

It can be shown by use of the relations of Sec. V, property III, that the $R^{(v)}\left(q_{k}, p_{k}\right)$ satisfy the equation

$$
R^{(p)} \cdot \mathfrak{F}=\left(R, R^{(r-1)}\right) \cdot \mathfrak{F}
$$

for all $\mathcal{F}$, as we would expect from the analog pointed out in Sec. III. As Moyal ${ }^{8}$ has shown, $R^{(0)}=1$, so that we may use the above relation to construct successively the $R^{(v)}$.

This result gives an explicit method of solving the eigenfunction problem for the measurement of $R$. We use the above equation to compute the $R^{(\nu)}$ and then

${ }^{12}$ M. G. Kendall, The Advanced Theory of Statistics (Charles Griffen and Company, Ltd., London, 1947), Chap. 4. 
use them to compute the $f_{\lambda \lambda}$. We see that the problem of which quantity corresponds to the $\nu$ th power of an observed quantity is equivalent to the eigenfunction problem.

\section{SIMULTANEOUS MEASUREMENT}

Two quantities $R$ and $S$ are clearly simultaneously measurable if and only if postulate $M$ can be imposed for both at once. This means that $\mathcal{F}$ must be decomposable into a set of subensembles represented by quasi-probability distribution functions $f_{\rho \rho, \sigma \sigma}$ indexed by

$$
\rho=R \cdot f_{\rho \rho_{,} \sigma \sigma}, \quad \sigma=S \cdot f_{\rho \rho_{,} \sigma \sigma}
$$

where $\left[R, f_{\rho \rho, \sigma \sigma}\right]=\left[S, f_{\rho \rho, \sigma \sigma}\right]=0$, and $R$ and $S$ take on the precise values $\rho$ and $\sigma$, respectively. We must also have

$$
1=h^{n} \sum_{\rho, \sigma} f_{\rho \rho . \sigma \sigma} \cdot \mathcal{F}
$$

for all $\mathcal{F}$. We now have, as before, for the cumulative joint distribution

$$
F(R, S)-F(0,0)=h^{n} \sum_{\substack{\rho, \sigma \\ 0 \leq \rho \leq R \\ 0 \leq \sigma \leq S}} f_{\rho \rho, \sigma \sigma} \cdot \mathcal{F} .
$$

An argument analogous to that given above (Sec. VI) shows the quantity $\left(R^{(v)} S^{(\mu)}\right)$ corresponding to the $(\nu, \mu)$ th moment of the above distribution is

$$
\left(R^{(\nu)} S^{(\mu)}\right)=h^{n} \sum_{\text {all }(\rho, \sigma)} \rho^{y} \sigma^{\mu} f_{\rho \rho, \sigma \sigma}\left(q_{k}, p_{k}\right)
$$

We compute symbolically the cosine bracket

$$
\begin{aligned}
\left(R^{(\nu)}, S^{(\mu)}\right) & =h^{2 n}\left(\sum_{\text {all }(\rho, \sigma)} \rho^{\nu} f_{\rho \rho, \sigma \sigma}, \sum_{\text {all }(\rho, \sigma)} \sigma^{\mu} f_{\rho \rho_{1} \sigma \sigma}\right) \\
& =\left(R^{(\nu)} S^{(\mu)}\right),
\end{aligned}
$$

where use has been made of the relations of Sec. V. By virtue of their nature as weighted sums of the same quasi-probability distribution functions, we see that

$$
[R, S] \cdot \mathcal{F}=0
$$

for all $F$. That is to say, if two quantities are simultaneously measurable, their operators commute, a well-known result of the standard formulations.

Let us define an $N$ th order cosine bracket as

$$
\left(T_{1}, T_{2}, \cdots, T_{N}\right)=\frac{1}{N ! \text { all permutations }}
$$

$$
\times\left\{T_{1},\left[T_{2},\left(\cdots, T_{N}\right) \cdots\right]\right\}
$$

This is totally symmetric in the $T_{k}$. We see at once, from the work of this and the previous section, that the joint distribution of $N$ simultaneously measurable quantities $T_{1}, \cdots, T_{N}$ must be

$$
\begin{aligned}
F\left(T_{1}, \cdots, T_{N}\right)-F(0, \cdots, 0) & \\
& =\left[F_{T_{1}}\left(q_{k}, p_{k}\right), \cdots, F_{r_{N}}\left(q_{k}, p_{k}\right)\right] \cdot \Im,
\end{aligned}
$$

where

with

$$
F_{T_{j}}\left(q_{k}, p_{k}\right)=\sum_{0 \leq \tau_{j} \leq T_{i}}^{\prime} f_{r_{j}}\left(q_{k}, p_{k}\right)
$$

$$
\left[T_{j}, f_{\tau_{j}}\right]=0, \quad \tau_{j}=T_{j} \cdot f_{\tau_{j}},
$$

and the condition $\left[T_{j}, T_{k}\right] \cdot \mathcal{F}=0$ must hold for all $j, k$, and $\mathcal{F}$. Then the expected value of any function

$$
G\left(T_{1}, \cdots, T_{N}\right)
$$

is given by

$$
\langle G\rangle=\int_{\substack{\text { entire range } \\ \text { of the } T_{k}}} \cdots\left(T_{1} \cdots, T_{N}\right) d F\left(T_{1}, \cdots, T_{N}\right) .
$$

As we can form $F\left(T_{1}, \cdots, T_{N}\right)-F(0, \cdots, 0)$ in an unambiguous manner according to our above definition for any $\left(T_{k}\right)$, whether they are simultaneously measurable or not, we might wonder what its significance is, if any, for nonsimultaneously measurable quantities. Now for this case, von Neumann ${ }^{3}$ (Chap. IV, Sec. 2) has shown that $F$ cannot be a true cumulative distribution function for all possible states of the system as this would lead to dispersion-free ensembles, which are impossible. We have exhibited an $F$ which is a true distribution, if the $\left(T_{k}\right)$ are simultaneously measurable. We see that the only way it can satisfy von Neumann's theorem in the case of nonsimultaneously measurable variables is that it must imply "negative probabilities." Thus we arrive at the important physically meaningful conclusion that the $F$ defined above is a true distribution function if and only if the $\left(T_{k}\right)$ are simultaneously measurable. This is to say, when quantum mechanics predicts an impossible result like a "negative probability," then the interpretation is that there is no physically realizable experiment to measure the joint distribution. It is worth noting that in the case $T_{1}=q$ and $T_{2}=p$, that

$$
\frac{d^{2}[F(q, p)]}{d q d p}=\frac{1}{h^{n / 2}} \operatorname{Re}\left\{\psi(q) \phi^{*}(p) \exp (-i p q / \hbar)\right\}
$$

which is not the quasi-probability distribution function. Nor could it be expected to be, because of the basic impossibility of establishing an isomorphism between a commutative and a noncommutative linear algebra. As we have seen, it is necessary, to satisfy the measurement postulate, to have the operator of the "square" of a quantity be the square of the operator; thus, if the operators do not commute, we are forced into trying to establish the above-mentioned impossible correspondence, in order to try to make a definition which correctly gives the distribution for the simultaneously measurable variables also give the quasi-probability distribution for the conjugate variables $p$ and $q$.

We emphasize that these results are in accord with the fact that a dynamical quantity $R\left(q_{k}, p_{k}\right)$ which is a 
function of noncommuting variables is a separate and distinct entity which should be denoted by a separate symbol, $\mathbf{R} . R\left(q_{k}, p_{k}\right)$ has the property that $\langle\mathbf{R}\rangle$ $=\left\langle R\left(q_{k}, p_{k}\right)\right\rangle$ for any distribution; however, we do not expect

but instead

$$
\left\langle\mathbf{R}^{2}\right\rangle=\left\langle R^{2}\left(q_{k}, p_{k}\right)\right\rangle,
$$

$$
\left\langle\mathbf{R}^{2}\right\rangle=\left\langle R^{(2)}\left(q_{k}, p_{k}\right)\right\rangle \text {. }
$$

In this formulation, we can correctly find the expected value of $\mathbf{R}$ by using $R\left(q_{k}, p_{k}\right)$, but it is not possible, in general, to study a function $G(R)$ in terms of $G\left[R\left(q_{k}, p_{k}\right)\right]$. As we have seen above, the solution of this correspondence problem in general is equivalent to the solution of the corresponding eigenvalue problem.

\section{APPENDIX. EXAMPLE OF THE QUASI-PROBABILITY DISTRIBUTION : THE HARMONIC OSCILLATOR}

It is a matter of straightforward calculation ${ }^{8,9}$ to show that for the one-dimensional harmonic oscillator, the energy eigen-quasi-probability-distribution-functions are:

$$
\begin{aligned}
& f_{n}(H, \theta) d H d \theta=\left[(-1)^{n} /(2 \pi n !)\right] L_{n}(4 H / h \nu) \\
& \times \exp (-2 H / h \nu) d(2 H / h \nu) d \theta,
\end{aligned}
$$

where $L_{n}(x)$ are the Laguerre polynomials, ${ }^{13}$ and we have made the algebraic change to the variables

$$
\theta=\tan ^{-1}[p /(2 \pi m \nu q)], \quad H=\left(p^{2} / 2 m\right)+2 \pi^{2} m \nu^{2} q^{2} .
$$

The dynamical equation satisfied by $f$, in this example, is the same as the classical equation. It is

$$
\frac{\partial f}{\partial t}=-(p / m) \frac{\partial f}{\partial q}+4 \pi^{2} m \nu^{2} q \frac{\partial f}{\partial p} .
$$

${ }^{13}$ See, for example, P. M. Morse and H. Feshbach, Methods of Theoretical Physics (McGraw-Hill Book Company, Inc., New York, 1953), p. 784.
It is also of interest to compute the generating function,

$$
G(s)=\sum_{\nu=0}^{\infty}(-i s / h)^{\nu} H^{(\nu)}(q, p) /(\nu !) .
$$

By the relations we have obtained, this is also equal to

$$
G(s)=h \sum_{\text {all } \lambda} \exp (-i s \lambda / \hbar) f_{\lambda \lambda}(q, p),
$$

which we may compute by means of the formula for the generating function for the Laguerre polynomials. ${ }^{13}$ Thus

$$
\begin{aligned}
G(s)= & h \sum_{n=0}^{\infty} \exp \left[-\frac{1}{2} i s(2 n+1) h \nu / \hbar\right](2 / h \nu) \\
& \times(-1)^{n}(n !)^{-1} L_{n}(4 H / h \nu) \exp (-2 H / h \nu) \\
= & \exp \left[-(i / \hbar)(2 H / \omega) \tan \left(\frac{1}{2} s \omega\right)\right] / \cos \left(\frac{1}{2} s \omega\right),
\end{aligned}
$$

where $\omega=2 \pi \nu$.

We now obtain the various $H^{(w)}$ from $G(s)$ by the relation

$$
H^{(v)}=\left.\left(-\frac{\hbar}{i} \frac{\partial}{\partial s}\right)^{\prime} G(s)\right|_{s=0},
$$

and the eigenfunctions by the relation

$$
f_{n}=(2 \pi h)^{-1} \int_{-\infty}^{+\infty} \exp (i \omega s n)[1-\exp (i \omega s)](i s)^{-1} G(s) d s .
$$

We obtain by differentiation

$$
\begin{gathered}
H^{(0)}=1, \quad H^{(1)}=H, \quad H^{(2)}=H^{2}-\left(\frac{1}{2} h \nu\right)^{2}, \\
H^{(3)}=H^{3}-5\left(\frac{1}{2} h \nu\right)^{2} H, \quad \text { etc. }
\end{gathered}
$$

which agree with what we obtain by the direct application of the recursion relation. 
Proc. Camb. Phil. Soc. (1964), 60, 581

Printed in Great Britain

581

\title{
The formulation of quantum mechanics in terms of phase space functions
}

\author{
By D. B. FAIRLIE \\ St Salvator's College, St Andrews
}

(Received 9 November 1963)

Abstract. A relationship between the Hamiltonian of a system and its distribution function in phase space is sought which will guarantee that the average energy is the weighted mean of the Hamiltonian over phase space. This relationship is shown to imply the existence of a wave function satisfying the Schrödinger equation, and dictates the possible forms of time-dependence of the distribution function.

The re-formulation of established theory in terms of new principles and alternative hypotheses sometimes facilitates the solution of specific problems, but chiefly illuminates the structure of the theory. Such is the case with the development of quantum mechanics in terms of the distribution function in phase space. We shall develop an eigenvalue equation for the distribution function, which may be solved for the case of a particle in a harmonic ocillator potential, and which has the same solution as that given by previous authors on the basis of Wigner's original introduction of the phase space function in terms of wave functions (7).

Baker (1) has shown that this wave-function expression may be deduced from certain results for the phase space function obtained by Moyal (5) and Takabayasi (6). However, his postulated condition for a stationary (time-independent) distribution function is by no means intuitively obvious. We shall deduce his results and the time-dependence of the distribution function from the hypothesis that this function is determined by the Hamiltonian so that the average energy is automatically constant. For reasons of notational simplicity the discussion will be confined to a two-dimensional phase space.

We postulate the existence of a bounded (i.e. square integrable) time-dependent distribution function $f(x, p, t)$ such that

$$
\int_{-\infty}^{\infty} \int_{-\infty}^{\infty} H(x, p) f(x, p, t) d x d p=E \int_{-\infty}^{\infty} \int_{-\infty}^{\infty} f(x, p, t) d x d p,
$$

where $E$, the energy of the system, is time-independent provided $H(x, p)$, the Hamiltonian, is. We seek an integral equation for $f$ such that (1) will be automatically true.

Consider

$$
\begin{aligned}
I(x, p, t)=\frac{4}{h^{2}} \int_{-\infty}^{\infty} \ldots \int_{-\infty}^{\infty} \exp \frac{2 i}{h}[p(\tau-\sigma) & +x(\mu-\lambda)+\alpha(\sigma \lambda-\tau \mu)] \\
& \times \phi(\alpha) H(\tau, \lambda) f(\sigma, \mu, t) d \tau d \lambda d \sigma d \mu d \alpha
\end{aligned}
$$

where $\int_{-\infty}^{\infty} \phi(\alpha) d \alpha=1$ and $h$ is a constant, to be identified later with Planck's constant. 
582

D. B. FATRLIE

Then

$$
\begin{aligned}
\int_{-\infty}^{\infty} \int_{-\infty}^{\infty} I(x, p, t) d x d p & =\int_{-\infty}^{\infty} \int_{-\infty}^{\infty} H\left(x^{\prime}, p^{\prime}\right) f\left(x^{\prime}, p^{\prime}, t\right) d x^{\prime} d p^{\prime} \\
& =E \int_{-\infty}^{\infty} \int_{-\infty}^{\infty} f\left(x^{\prime}, p^{\prime}, t\right) d x^{\prime} d p^{\prime}
\end{aligned}
$$

We postulate that there are no intrinsically distinguished points in phase space; i.e. any local continuous mapping of $x, p$ to $x^{\prime}, p^{\prime}$ should leave either all points or none fixed. These mappings are restricted to be pure translations by Brouwer's Translation Theorem (3). (I am indebted to Dr P.H.H. Fantham for this reference.) Thus we may have

or more generally

$$
I(x, p, t)=E f(x, p, t)
$$

$$
I(x, p, t)=E f(x+a, p+b, t)
$$

as possible local relations between $I$ and $f$. In other words the relationship is chosen to be translation invariant. We further require that if $H=$ constant there is no restriction on $f$. This will be so if $\phi(\alpha)=\delta(\alpha-1)$, and the more general form of identification $(4 a)$ is rejected.

We shall now introduce the sine and cosine bracket notation of Baker and write

$$
\begin{gathered}
{[f(x, p), g(x, p)]=\frac{4}{h^{2}} \int_{-\infty}^{\infty} \ldots \int_{-\infty}^{\infty} \sin \frac{2}{h}(p(\tau-\sigma)+x(\mu-\lambda)+\lambda \sigma-\tau \mu)} \\
\quad \times f(\tau, \lambda) g(\mu, \sigma) d \tau d \lambda d \mu d \sigma \\
(f(x, p), g(x, p))=\frac{4}{h^{2}} \int_{-\infty}^{\infty} \ldots \int_{-\infty}^{\infty} \cos \frac{2}{h}(p(\tau-\sigma)+x(\mu-\lambda)+\lambda \sigma-\tau \mu) \\
\quad \times f(\tau, \lambda) g(\mu, \sigma) d \tau d \lambda d \mu d \sigma
\end{gathered}
$$

and employ the abbreviation

$$
f \cdot g=\int_{-\infty}^{\infty} \int_{-\infty}^{\infty} f(x, p) g(x, p) d x d p
$$

The undernoted identities, which follow by formal calculation from the above definitions (1), are quoted for convenience.

$$
\left.\begin{array}{l}
{[A, B] \cdot C=[C, A] \cdot B=[B, C] \cdot A,} \\
{[A, B]=-[B, A],} \\
(A, B)=(B, A), \\
(A, B) \cdot C=(C, A) \cdot B, \text { etc., } \\
{[A,[B, C]]+[C,[A, B]]+[B,[C, A]]=0,} \\
{[A,(B, C)]=([A, B], C)+([A, C], B) .}
\end{array}\right\}
$$

We may then write the condition (4) as

$$
(H, f)+i[H, f]=2 E f \text {. }
$$

Consider two eigenfunctions $f_{i}$ and $f_{j}$ with real eigenvalues $E_{i}$ and $E_{j}$, respectively, which satisfy (6). (The eigenvalues must be real since they represent the possible 
The formulation of quantum mechanics

energy values of the system.) Then with the aid of (5) we may deduce the following equations

$$
\begin{gathered}
H .\left\{\left(f_{i} f_{j}^{*}\right)+i\left[f_{i} f_{j}^{*}\right]\right\}=2 E_{i} f_{i} \cdot f_{j}^{*}, \\
H .\left\{\left(f_{i}^{*} f_{j}\right)-i\left[f_{i}^{*} f_{j}\right]\right\}=2 E_{j} f_{i}^{*} \cdot f_{j} .
\end{gathered}
$$

Let us examine how far (7) and (8) are consistent with the assumption that equations of type (6) hold for both $\left(f_{i} f_{j}^{*}\right)+i\left[f_{i} f_{j}^{*}\right]$ and its complex conjugate, i.e.

$$
\begin{aligned}
\left(H\left\{\left(f_{i} f_{j}^{*}\right)+i\left[f_{i} f_{j}^{*}\right]\right\}\right)+i\left[H\left\{\left(f_{i} f_{j}^{*}\right)+i\left[f_{i} f_{j}^{*}\right]\right\}\right] & =2 E_{i}\left\{\left(f_{i} f_{j}^{*}\right)+i\left[f_{i} f_{j}^{*}\right]\right\}, \\
\left(H\left\{\left(f_{i}^{*} f_{j}\right)-i\left[f_{i}^{*} f_{j}\right]\right\}\right)+i\left[H\left\{\left(f_{i}^{*} f_{j}\right)-i\left[f_{i}^{*} f_{j}\right]\right\}\right] & =2 E_{j}\left\{\left(f_{i}^{*} f_{j}\right)-i\left[f_{i}^{*} f_{j}\right]\right\} .
\end{aligned}
$$

Equations (9) and (10) are consistent with (7) and (8) upon integration.

We may then label the eigenfunctions of (6) according to their eigenvalues and those of their complex conjugates as

$$
\left(f_{i} f_{j}^{*}\right)+i\left[f_{i} f_{j}^{*}\right]=k f_{i j}
$$

where $k$ is a normalization constant.

By definition

$$
f_{i j}^{*}=f_{j i} .
$$

Rearrangement of (9) and (10) with their complex conjugate equations yields

$$
\begin{aligned}
\left(H, f_{i j}\right) & =\left(E_{i}+E_{j}\right) f_{i j}, \\
{\left[H, f_{i j}\right] } & =-i\left(E_{i}-E_{j}\right) f_{i j} .
\end{aligned}
$$

Equation (14) has been given by Moyal (5) and is already implicit in previous work (7): equation (13) does not appear to have been stated before.

Comparison of (7) with the complex conjugate of (8) provides the further consistency requirement

$$
f_{i} \cdot f_{j}^{*}=0 \text { unless } E_{i}=E_{j} \text {. }
$$

Similarly, $f_{i} . f_{j}^{*}=0$ unless $f_{i}^{*}$ and $f_{j}^{*}$ also have equal eigenvalues. In terms of the notation introduced above

$$
f_{i l} \cdot f_{m j}=0 \text { unless } i=j \text { and } l=m .
$$

This is the orthogonality condition for the eigenvalues of (6). (11) may be rewritten as

Then by (16)

$$
\left(f_{i l}, f_{m j}\right)+i\left[f_{i l}, f_{m j}\right]=K f_{i j} \text {. }
$$

or

$$
\begin{gathered}
f_{j i} \cdot\left(f_{i l}, f_{m j}\right)+f_{j i} \cdot\left[f_{l}, f_{m j}\right] \neq 0, \\
\left\{\left(f_{j i}, f_{i l}\right)+i\left[f_{j i}, f_{i]}\right]\right\} \cdot f_{m j} \neq 0
\end{gathered}
$$

by (5). Applying (16) again, we require

$$
\left(f_{j i}, f_{i l}\right)+i\left[f_{j i}, f_{i l}\right]=f_{j m} \text {. }
$$

This is possible only if $m=l$. Thus we see that for consistency, (17) must be modified to read

$$
\left(f_{i l}, f_{m j}\right)+i\left[f_{i l}, f_{m j}\right]=K \delta_{l m} f_{i j} \text {. }
$$


584

D. B. FAIRLIE

This is the relationship which is adopted by Baker (1) as an initial postulate, in the case where $i=j=l=m$. He shows that this law implies that $f_{n}(x, p)$ may be written as

$$
f_{l}=2 K \int_{-\infty}^{\infty} \psi_{l}^{*}(x+y) \psi_{l}(x-y) \exp \frac{2 i}{\hbar} p y d y,
$$

i.e. in the form of Wigner's distribution function (7). The generalization to 'off diagonal' functions is obvious and yields

$$
f_{i j}(x, p)=2 K \int_{-\infty}^{\infty} \psi_{i}^{*}(x+y) \psi_{j}(x-y) \exp \frac{2 i}{\hbar} p y d y .
$$

The orthogonality condition (16), when applied to (20) gives the usual orthogonality requirements for the functions $\psi_{i}$, namely

$$
\int_{-\infty}^{\infty} \psi_{i}^{*}(x, t) \psi_{j}(x, t) d x=\delta_{i j} .
$$

The normalization of the functions $\psi_{i}$ in (20) has been chosen so that

This implies

$$
\begin{gathered}
\int_{-\infty}^{\infty}\left|\psi_{i}\right|^{2} d x=1 . \\
\int_{-\infty}^{\infty} \int_{-\infty}^{\infty} f_{i j}(x, p) d x d p=\frac{K}{h} .
\end{gathered}
$$

Distribution functions are conventionally normalized to have unit integral so that they may be interpreted as probability densities: the choice $K=h$ leads to no loss of generality of the theory and permits the observance of this convention. These last relations may be used to deduce the following equation for $\psi$ :

$$
\frac{1}{h} \int_{-\infty}^{\infty} \int_{-\infty}^{\infty} H\left(\frac{x+y}{2}, \sigma\right) \psi(y) \exp i \frac{\sigma(x-y)}{\hbar} d \sigma d y=E \psi(x),
$$

or

$$
H\left(x,-\frac{\hbar}{i} \frac{\partial}{\partial x}\right) \psi(x)=E \psi
$$

This is the time-independent Schrödinger equation, if $h$ is identified with Planck's constant. It may be obtained from (22) by expanding $H\left\{\frac{1}{2}(x+y), \sigma\right\}$ in a power series in $\sigma$, integrating, and summing formally.

To complete our investigation of this formulation of quantum mechanics we shall deduce the admissible form of time dependence for $f_{i j}$ from (6). Differentiating we have

$$
\left(H, \frac{\partial f_{i j}}{\partial t}\right)+i\left[H, \frac{\partial f_{i j}}{\partial t}\right]=E_{i} \frac{\partial f_{i j}}{\partial t} .
$$

Thus $\partial f_{i j} / \partial t$ may be expanded in terms of the eigenfunctions of (6) with eigenvalue $E_{i}$. Suppose

Since

$$
\frac{\partial f_{i j}}{\partial t}=\sum_{l} c_{i j l} f_{i l} .
$$

$$
\begin{gathered}
\frac{\partial}{\partial t} f_{i j}=\frac{\partial}{\partial t} f_{j i}^{*}, \\
\sum_{l} c_{i l l} f_{i l}=\sum_{m} c_{j i m}^{*} f_{m j} .
\end{gathered}
$$


In consequence of the orthogonality condition (16) $c_{i j l}=0$ unless $l=j$. We may drop the third suffix and write the consequence of choosing $l=j$ as

$$
c_{i j}=c_{j i}^{*}
$$

and the expansion of $\partial f_{i j} / \partial t$ as $\quad \frac{\partial f_{i j}}{\partial t}=c_{i j} f_{i j}$.

The result of differentiating (18) and substituting (28) gives a further condition on $c_{i j}$, i.e.

$$
c_{k l}+c_{l j}=c_{k j} \quad(\text { all } k, l \text { and } j) .
$$

Put $k=l$ in the above relationship: then $c_{k k}=0$, or $(\partial / \partial t) f_{k k}=0$, i.e. the real eigenfunctions $f_{i i}$ are stationary. This permits the expansion of $H$ in terms of the $f_{i i}$ as

$$
H=\Sigma E_{i} f_{i i}
$$

since $H$ is time-independent and real, and this resolution of $H$ guarantees the consistency of (18). Put $k=j$ in (29); then

$$
\begin{aligned}
& c_{k l}+c_{l k}=0, \\
& c_{k l}+c_{k l}^{*}=0 .
\end{aligned}
$$

Thus $c_{k l}$ is pure imaginary, and must be written in the form

$$
c_{k l}= \pm i(F(k)-F(l))
$$

in order to satisfy (29). This is as far as we can go in the determination of $c_{k l}$ without involving some dynamical principle; we have not used the fact that $t$ is a time variable except in supposing the independence of $E$ and $H$ of it. We appeal to the correspondence principle to verify that the simplest non-trivial choice of arbitrary function in (33), namely

$$
c_{k l}=\frac{i}{\hbar}\left(E_{k}-E_{l}\right)
$$

will do. The factor $1 / \hbar$ is necessary to give $c_{k l}$ the dimension of an inverse time.

Then equations (13) and (14) take the form

$$
\begin{gathered}
\left(H, f_{i j}\right)=\left(E_{i}+E_{j}\right) f_{i j}, \\
{\left[H, f_{i j}\right]=\hbar \frac{\partial f_{i j}}{\partial t}}
\end{gathered}
$$

and the second equation in the limit $h \rightarrow 0$ is just the classical Liouville equation, thus verifying (34).

Finally, as an example of the simultaneous solution of the above system we consider the harmonic oscillator Hamiltonian

$$
H=\frac{1}{2}\left(p^{2}+x^{2}\right) \hbar w .
$$

If we write

$$
f_{k l}(x, p, t)=u_{k l}(x, p) \exp i(k-l) w t
$$

both (35) and (36) may be written as differential equations of finite order

$$
\begin{gathered}
\left(\frac{\partial^{2}}{\partial x^{2}}+\frac{\partial^{2}}{\partial p^{2}}\right) u_{k l}-4\left(x^{2}+p^{2}\right) u_{k l}+2(k+l-1) u_{k i}=0 \\
-p \frac{\partial u_{k l}}{\partial x}+x \frac{\partial u_{k l}}{\partial p}-(k-l) u_{k l}=0
\end{gathered}
$$


586

D. B. FAIRIIE

where $E_{k}$ has been set equal to $\left(k+\frac{1}{2}\right) \hbar w$. These equations have the solution

$$
u_{k l}=\frac{1}{4 \pi}(-1)^{k}(l ! k !) v^{\frac{t}{2}(k-\eta)} e^{-\frac{1}{2} v} L_{k}^{l-k}(v) e^{i(k-\eta) \theta},
$$

where $L_{k}^{l-k}(v)$ is the associated Laguerre function, $v=2\left(p^{2}+x^{2}\right)$ and $\tan \theta=p / x$. This solution has been obtained before, $(2,4)$ by calculation of $(20)$, using the known harmonic oscillator wave functions.

\section{REFERENCES}

(1) Baxma, G. A. Phys. Rev. 109 (1958), 2198-2206.

(2) Barmanit, M. S. and Moyal, J. E. Proc. Cambridge Philos. Soc. 45 (1949), 545-553.

(3) Brouwer, L. E. J. Math. Ann. 72 (1912), 34-57.

(4) GromatwoId, H. J. Physica, 12 (1946), 405-460.

(5) Moyal, J. E. Proc. Cambridge Phitos. Soc. 45 (1949), 99-124.

(6) Takabayasi, T. Progr. Theoret. Phys. 11 (1954), 341-373.

(7) WIGNke, E. P. Phy8. Rev. 40 (1932), 749-759. 
Physica 83A (1976) 210-212 (C) North-Holland Publishing Co.

\title{
A NON-NEGATIVE WIGNER-TYPE DISTRIBUTION ${ }^{*}$
}

\author{
N.D. CARTWRTGHT \\ Department of Philosophy, Stanford University, \\ Stanford, California 94305, USA
}

Received 19 September 1975

The Wigner function, which is commonly used as a joint distribution for non-conmuting observables, is shown to be non-negative in all quantum states when smoothed with a gaussian whose variances are greater than or equal to those of the minimum uncertainty wave packet.

The Wigner function, introduced by Eugene Wigner in $1932^{1}$ ) to study problems of statistical equilibrium, has long been used in quantum thermodynamics'). More recently, it has been introduced in quantum optics to study coherence properties of $\operatorname{light}^{3}$ ), and it is currently applied in the study of plasmas ${ }^{4}$ ) as well. The function serves as a joint probability density for non-commuting observables despite the fact that it is known to take negative values in many states. Its use as a probability is frequently defended by the assumption that the function will be non-negative when employed in a way that does not violate the uncertainty principle. Mori, Oppenheim, and Ross, for example, conjecture that the Wigner function is everywhere non-negative when integrated over regions of phase space of the order of $\hbar^{3 N 5}$ ). Thus (restricting attention to one dimension for simplicity) it is frequently supposed that

$$
W_{\uparrow}\left(p^{\prime}, q^{\prime}\right)=\int_{p^{\prime}}^{p^{\prime}+\hbar / 2} \int_{q^{\prime}-\hbar / 2}^{q^{\prime}+\hbar / 2} W(p, q) \mathrm{d} p \mathrm{~d} q \geq 0,
$$

for all quantum states, $\psi(q)$, and for all points $p^{\prime}, q^{\prime}$, where $W(p, q)$ is the Wigner function:

$$
W(p, q)=(1 / 2 \pi) \int \mathrm{e}^{-1 \tau p} \psi^{*}\left(q-\frac{1}{2} \tau \hbar\right) \psi\left(q+\frac{1}{2} \tau \hbar\right) \mathrm{d} \tau
$$

A result weaker than eq. (1), but of the same import will be proven here.

₹ Research supported by NSF grant GS-42681. 
Integrating $W(p, q)$ in the manner of eq. (1) is equivalent to smoothing $W(p, q)$ around each point, $\left(p^{\prime}, q^{\prime}\right)$, by convoluting it with a density $D(p, q)$ which is uniform in an interval of size $\hbar$ around $p^{\prime}$ and around $q^{\prime}$, and zero outside:

$$
\begin{aligned}
D(p, q) & =1 / \hbar^{2}, \quad p^{\prime}-\hbar / 2 \leq p \leq p^{\prime}+\hbar / 2 ; q^{\prime}-\hbar / 2 \leq q \leq q^{\prime}+\hbar / 2 \\
& =0, \quad \text { otherwise. }
\end{aligned}
$$

If instead we smooth the Wigner function with a gaussian distribution

$$
G(p, q)=\left(2 \pi \sigma_{p} \sigma_{q}\right)^{-1} \exp \left(-p^{2} / 2 \sigma_{p}^{2}-q^{2} / 2 \sigma_{q}^{2}\right),
$$

the convoluted Wigner function, $W_{\mathrm{C}}\left(p^{\prime}, q^{\prime}\right)$, will be non-negative so long as the gaussian is as wide or wider than the minimum uncertainty wave packet. Thus by introducing fluctuations of the order of the uncertainty principle we can guarantee a proper distribution. So we wish to prove

$$
\begin{aligned}
W_{\mathrm{C}}\left(p^{\prime}, q^{\prime}\right)= & \frac{(\beta \alpha)^{\frac{1}{2}}}{2 \pi^{2} \hbar} \iiint \psi^{*}\left(q-\frac{1}{2} \tau \hbar\right) \psi\left(q+\frac{1}{2} \tau \hbar\right) \\
& \times \exp \left(-\mathrm{i} \tau p-\beta\left(p-p^{\prime}\right)^{2} / \hbar-\alpha\left(q-q^{\prime}\right)^{2} / \hbar\right) \mathrm{d} \tau \mathrm{d} q \mathrm{~d} p \geq 0,
\end{aligned}
$$

for $\alpha, \beta>0$ and $\alpha \beta \leq 1$, where $\alpha \beta=(\hbar / 2)\left(\sigma_{p} \sigma_{q}\right)^{-1}$.

Integrating by $\mathrm{d} p$ and changing variables so that $x=q-\frac{1}{2} \tau \hbar, y=q+\frac{1}{2} \tau \hbar$, we obtain

Letting

$$
\begin{aligned}
W_{\mathrm{C}}\left(p^{\prime}, q^{\prime}\right)= & \frac{(\pi \alpha \hbar)^{\frac{1}{2}}}{2 \pi^{2} \hbar^{2}} \iint \psi^{*}(x) \psi(y) \\
& \times \exp \left[(-\alpha / \hbar)\left(\frac{1}{2}(x+y)-q^{\prime}\right)^{2}\right. \\
& \left.-\left(\mathrm{i} p^{\prime} / \hbar\right)(y-x)-(y-x)^{2} / 4 \beta \hbar\right] \mathrm{d} x \mathrm{~d} y .
\end{aligned}
$$

$$
f(u)=\psi^{*}(u) \exp \left[u^{2}(-\alpha / 4 \hbar-1 / 4 \beta \hbar)+u\left(\alpha q^{\prime} / \hbar+\mathrm{i} p^{\prime} / \hbar\right)\right]
$$

and $\gamma=(1 / 2 \hbar)(1 / \beta-\alpha)$, we can write [for well behaved $f(u)]$

$$
\begin{aligned}
W_{\mathrm{C}}\left(p^{\prime}, q^{\prime}\right) & \left.=\frac{(\pi \hbar \alpha)^{\frac{1}{2}}}{2 \pi^{2} \hbar^{2}} \exp \left[-\alpha q^{\prime 2} / \hbar\right)\right] \iint f(x) f^{*}(y) \mathrm{e}^{\gamma x y} \mathrm{~d} x \mathrm{~d} y \\
& =\frac{(\pi \hbar \alpha)^{\frac{1}{2}}}{2 \pi^{2} \hbar^{2}} \exp \left[-\alpha q^{\prime 2} / \hbar\right] \sum_{n=0}^{\infty} \gamma^{n} / n ! \int f(x) x^{n} \mathrm{~d} x \int f^{\prime *}(y) y^{n} \mathrm{~d} y .
\end{aligned}
$$

When $\alpha, \beta>0$ and $\alpha \beta \leq 1$, we have $\gamma \geq 0$. Thus $W_{\mathrm{C}}\left(p^{\prime}, q^{\prime}\right) \geq 0$, since each term in the sum is of the form $\gamma^{n} / n ! c_{n}^{*} c_{n}$, and is hence non-negative. 


\section{References}

1) E.P. Wigner, Phys. Rev. 40 (1932) 749.

2) J. Vlieger, P. Mazur and S.R. de Groot, Physica 27 (1961) 353, 957 and 974.

H. Mori, I. Oppenheim and J. Ross, in Studies in Statistical Mechanics, Vol. I, J. de Boer and G. E. Uhlenbeck, eds. (North-Holland, Amsterdam, 1962).

3) I.Bialynicki-Birula and Z. Bialynicki-Birula, Phys. Rev. A8 (1973) 3146.

R.J.Glauber, Phys. Rev. 130 (1963) 2529.

C.L.Mehta and E.Wolf, Phys. Rev. 134 (1964) A1149. M.Lax and W.H.Louisell, I.E.E.E. J. of Q. Electronics QE-3 (1967) 47.

4) J. P. Hansen, Phys. Rev. A8 (1973) 3096.

E.L. Pollack and J.P.Hansen, Phys. Rev. A8 (1973) 3110.

L. J. Roszman and C.F. Hooper, Phys. Rev. A7 (1973) 2121.

5) H.Mori, I.Oppenheim and J. Ross, loc. cit. n2. 


\title{
Wigner function as the expectation value of a parity operator
}

\author{
Antoine Royer \\ Centre de Recherches Mathématiques, Université de Montréal, Montréal H3C 3J7, Canada \\ (Received 30 August 1976)
}

\begin{abstract}
It is pointed out that the Wigner function $f(r, p)$ is $2 / h$ times the expectation value of the parity operator that performs reflections about the phase-space point $r, p$. Thus $f(r, p)$ is proportional to the overlap of the wave function $\psi$ with its mirror image about $r, p$; this is clearly a measure of how much $\psi$ is centered about $r, p$, and the Wigner distribution function now appears physically more meaningful and natural than it did previously.
\end{abstract}

In 1932, Wigner ${ }^{1}$ associated with the quantum wave function $\psi(r)$ a phase-space quasiprobability distribution function

$$
f(r, p)=\frac{2}{h} \int d s e^{-2 i p s / \hbar} \psi(r-s)^{*} \psi(r+s),
$$

or, in terms of the momentum representative $\widetilde{\psi}(p)=h^{-1 / 2} \int d r e^{-i p r / h} \psi(\gamma)$,

$$
f(r, p)=\frac{2}{h} \int d k e^{-21 k_{r} / h} \bar{\psi}(p+k) * \bar{\psi}(p-k) .
$$

This Wigner "representation" has proved useful for studying the passage from quantum to classical mechanics and establishing quantum corrections to classical results, and generally it enhances understanding by favoring the use of classical intuition in quantum problems. ${ }^{2}$

At first sight the constructions (1) and (2) seem rather ad hoc and devoid of any deep physical or mathematical significance. A somewhat more meaningful expression for $f(r, p)$ was provided by Moyal, ${ }^{3}$ namely

$$
f(r, p)=h^{-2} \int d k \int d s e^{-i(k r+s p) / n}\left\langle\psi\left|e^{i(k \hat{R}+s \hat{P}) / n}\right| \psi\right\rangle,
$$

where $\hat{R}$ and $\hat{P}$ are the position and momentum operators, respectively, satisfying $[\hat{R}, \hat{P}]=i \hbar$. The form ( 3$)$ is conspicuous to statisticians: $\left\langle\psi\left|e^{i(k \hat{R}+s \hat{P})}\right| \psi\right\rangle$ appears as a "characteristic function," being the expectation of the operator that corresponds to the function $e^{i(k r+s p)}$ in Weyl's rule of association. ${ }^{4}$

Here we wish to point out that $f(r, p)$ has a much more direct physical meaning, in that it is the expectation value of the parity operator about the phase-space point $r, p$.

To show this, let us first rewrite

$$
f(r, p)=(2 / h)\left\langle\psi\left|\Pi_{r p}\right| \psi\right\rangle,
$$

where the operator $\Pi_{r p}$ has the following three equivalent expressions in view of (1) $-(3)$ :

$$
\begin{aligned}
\Pi_{r p} & =\int d s e^{-2 i p s / n}|r-s\rangle\langle r+s|, \\
& =\int d k e^{-21 k r / s}|p+k\rangle\langle p-k|, \\
& =\frac{1}{2 h} \int d k \int d s \exp \{(i / \hbar)[k(\hat{R}-r)+s(\hat{P}-p)]\},
\end{aligned}
$$

where $|r\rangle$ and $|p\rangle$ are eigenstates of $\hat{R}$ and $\hat{P}$, respectively. Let us now consider the special case $r=0, p=0$, and denote $\Pi_{r=0, p=0} \equiv \Pi$; we have

$$
\begin{aligned}
\Pi & =\int d r|-r\rangle\langle r|, \\
& =\int d p|p\rangle\langle-p|, \\
& =\frac{1}{2 h} \int d k \int d s e^{i(k \hat{R}+s \hat{P}) / n} .
\end{aligned}
$$

From (6) or $\left(6^{\prime}\right)$ it is immediately apparent that II is the parity operator (about the origin): it changes $\psi(r)$ into $\psi(-r)$ and $\psi(p)$ into $\psi(-p)$, or equivalently (note that $\Pi^{-1}=I$ ),

$$
\Pi \hat{R} \Pi=-\hat{R}, \quad \Pi \hat{P} \Pi=-\hat{P} .
$$

We now observe that $\Pi_{r p}$ may be obtained from $\Pi$ by a unitary transformation

$$
\Pi_{r p}=D(r, p) \Pi D(r, p)^{-1}
$$

here

$$
D(r, p) \equiv e^{i(p \hat{R}-r \hat{P}) / \hbar}
$$

is a phase-space displacement operator, introduced by Glauber ${ }^{5}$ in connection with a different, though related, type of phase-space representation of quantum mechanics, the coherent-state representation. We have the actions

$$
\begin{aligned}
& D(r, p)^{-1} \hat{R} D(r, p)=\hat{R}+r, \\
& D(r, p)^{-1} \hat{P} D(r, p)=\hat{P}+p,
\end{aligned}
$$

and more generally 


$$
D(r, p)^{-1} F(\hat{R}, \hat{P}) D(r, p)=F(\hat{R}+r, \hat{P}+p)
$$

$[F(\hat{R}, \hat{P})$ being a power series in $\hat{R}$ and $\hat{P}]$, whence Eq. (8), in view of (5") and $\left(6^{\prime \prime}\right)$ [and noting that $\left.D(r, p)^{-1}=D(-r,-p)\right]$.

Using (7), (8), and (10), we readily verify that

$$
\begin{aligned}
& \Pi_{r p}(\hat{R}-r) \Pi_{r \phi}=-(\hat{R}-r), \\
& \Pi_{r p}(\hat{P}-p) \Pi_{r \phi}=-(\hat{P}-p) ;
\end{aligned}
$$

that is, $\Pi_{r p}$ reflects about the phase-space point $r, p$ and is thus the parity operator about that point. Note that

$$
\left(\Pi_{r \rho}\right)^{2}=1 \text {. }
$$

The Wigner function, Eq. (4), is thus $2 / h$ times the expectation value of the parity operator about $r, p$. Alternatively, $f(r, p)$ is proportional to the overlap of $\psi$ with its mirror image about $r, p$, which is clearly a measure of how much $\psi$ is "centered" about $r, p$.

Let us now discuss some simple implications of the preceding considerations.

We first observe that $\Pi_{r p}$ has eigenvalues \pm 1 [in view of (12)], and its eigenfunctions $\phi_{r \beta}^{ \pm}$, satisfying

$$
\Pi_{r p}\left|\phi_{r p}^{ \pm}\right\rangle= \pm\left|\phi_{r p}^{ \pm}\right\rangle,
$$

are functions that are either symmetric or antisymmetric about $r, p$. They may be obtained by displacing in phase-space functions of the same symmetry about the origin, i.e.,

$$
\left|\phi_{r p}^{ \pm}\right\rangle=D(r, p)\left|\phi^{ \pm}\right\rangle \text {, }
$$

where $\phi^{*}$ and $\phi^{-}$satisfy $\Pi\left|\phi^{ \pm}\right\rangle= \pm\left|\phi^{ \pm}\right\rangle$, or equivalently $\phi^{ \pm}(-r)= \pm \phi^{ \pm}(r), \tilde{\phi}^{ \pm}(-p)= \pm \tilde{\phi}^{ \pm}(p)$.

Let us define projectors $P_{r p}^{+}$and $P_{r p}^{-}$on the spaces of functions symmetric and functions antisymmetric about $r, p$, respectively:

$$
\begin{aligned}
P_{r p}^{ \pm} & \equiv \frac{1}{2}\left(1 \pm \Pi_{r p}\right) \\
& =D(r, p) P^{ \pm} D(r, p)^{-1},
\end{aligned}
$$

where $P^{ \pm}=\frac{1}{2}(1 \pm \Pi)$ projects on the space of functions symmetric (antisymmetric) about the origin. We have

$$
\begin{aligned}
& \left(P_{r p}^{ \pm}\right)^{2}=P_{r p}^{*}, \\
& P_{r p}^{+}+P_{r p}^{-}=1, \\
& P_{r p}^{+}-P_{r p}^{-}=\Pi_{r p} .
\end{aligned}
$$

Let us now separate $\psi$ into components symmetric and antisymmetric about $r, p$ :

$$
\psi=\psi_{r p}^{+}+\psi_{r p}^{-},
$$

where

$$
\left|\psi_{r p}^{ \pm}\right\rangle \equiv P_{r p}^{ \pm}|\psi\rangle \text {. }
$$

By (16) we have

$$
\left\langle\psi\left|P_{r p}^{ \pm}\right| \psi\right\rangle=\left\langle\psi_{r p}^{ \pm} \mid \psi_{r p}^{ \pm}\right\rangle \equiv\left\|\psi_{r p}^{ \pm}\right\|^{2} .
$$

Then by (4), (18), and (21),

$$
f(r, p)=(2 / h)\left(\left\|\psi_{r p}^{*}\right\|^{2}-\left\|\psi_{r p}^{-}\right\|^{2}\right) .
$$

That is, the Wigner function equals $2 / h$ times the difference of the squared norms of the symmetric and antisymmetric (about $r, p$ ) parts of $\psi$. By (17) and (21) we further have

$$
\langle\psi \mid \psi\rangle=1=\left\|\psi_{r p}^{+}\right\|^{2}+\left\|\psi_{r p}^{-}\right\|^{2} .
$$

This implies $\left\|\psi_{r p}^{ \pm}\right\| \leqslant 1$, implying in turn, in view of $(22)$, that $f(r, p)$ is bounded by the values $-2 / h$ and $2 / h$ :

$$
-2 / h \leqslant f(r, p) \leqslant 2 / h .
$$

This result was previously obtained by means of Schwarz's inequality. ${ }^{B}$ We can now be much more specific: the lower equality in (24) is realized if and only if $\psi$ is antisymmetric about $r, p$, i.e., of the form (14) (-sign), and the upper equality if and only if $\psi$ is antisymmetric about $r, p$. One may, in fact, construct $\psi$ such that the corresponding $f(r, p)$ equal any preassigned value $f$ inside the interval $[-2 / h, 2 / h]$. Indeed, given any two normalized functions $\phi^{+}$and $\phi^{-}$, respectively symmetric and antisymmetric about the origin, set

$$
|\psi\rangle=D(r, p)\left(c_{+}\left|\phi^{+}\right\rangle+c_{-}\left|\phi^{-}\right\rangle\right) \text {. }
$$

We then have $\left\langle\psi\left|\Pi_{r p}\right| \psi\right\rangle=c_{+}^{2}-c_{-}^{2}$ and $\langle\psi \mid \psi\rangle=c_{+}^{2}+c_{-}^{2}$. We thus simply require that $c_{+}$and $c_{-}$satisfy $(2 / h)\left(c_{+}^{2}-c_{-}^{2}\right)=f$ and $c_{+}^{2}+c_{-}^{2}=1$.

\footnotetext{
${ }^{1}$ E. P. Wigner, Phys. Rev. 40, 749 (1932).

${ }^{2}$ See, for instance, R. Balescu, Equilibrium and NonEquilibrium Statistical Mechanics (Wiley, New York, 1975); S. R. de Groot and L. G. Suttorp, Foundations of Electrodynamics (North-Holland, Amsterdam, 1972); E. A. Remler, Ann. Phys. (N.Y.) 95, 455 (1975); B. Leaf, J. Math. Phys. 9 , 65, 769 (1968).

${ }^{3}$ J. E. Moyal, Proc. Cambr. Phil. Soc. 45, 99 (1949).
}

${ }^{4}$ See, e.g., L. Cohen, in Contemporary Research in the Foundations and Philosophy of Quantum Mechanics, edited by C. A. Hooker (Reldel, New York, 1973). ${ }^{5}$ R. J. Glauber, Phys. Rev. 131, 2766 (1963), Eqs. (3.10) and (3.11).

${ }^{6}$ See, e.g., S. R. de Groot and L. G. Suttorp, Foundations of Electrodynamics (North-Holland, Amsterdam, 1972). 
INNALS OR PEYSICS 111, 61-110 (1978)

\title{
Deformation Theory and Quantization.* \\ I. Deformations of Symplectic Structures
}

\author{
F. BAYEN \\ Département de Mathématiques, Université de Paris 6, 75230 Paris Cedex 05, France \\ M. Flato ${ }^{\dagger}$ and C. Fronsdal \\ University of California, Los Angeles, California 90024 \\ AND \\ A. LiChNerowicz AND D. STERNheImer \\ Physique Mathématique, College de France, 75231 Paris Cedex 05, France \\ Received May 19, 1977
}

\begin{abstract}
We present a mathematical study of the differentiable deformations of the algebras associated with phase space. Deformations of the Lie algebra of $C^{\infty}$ functions, defined by the Poisson bracket, generalize the well-known Moyal bracket. Deformations of the algebra of $C^{\infty}$ functions, defined by ordinary multiplication, give rise to noncommutative, associative algebras, isomorphic to the operator algebras of quantum theory. In particular, we study deformations invariant under any Lie algebra of "distinguished observables," thus generalizing the usual quantization scheme based on the Heisenberg algebra.
\end{abstract}

\section{INTRODUCTION}

The usual probabilistic interpretation of quantum mechanics contrasts with the deterministic character of classical mechanics. The axiomatic settings of the two types of mechanics are relatively disjoint; consequently the paradigm of quantization-and to some extent also the reverse process of passage to the classical limit-does not seem natural.

This situation has encouraged attempts to interpret quantum mechanics as a statistical theory over phase space. Already in 1932. Wigner [1] introduced a phase space distribution function, related to Weyl's quantization procedure [2-4]. A most interesting development is due to Moyal [5], who introduced the "sine-Poisson" bracket, now called Moyal bracket, for functions on phase space. It is this bracket,

* This work was supported in part by the National Science Foundation.

† Permanent address: Physique Mathématique; Collège de France, 75231 Paris Cedex 05 and Université de Dijon, 21000 Dijon, France. 
and not the Poisson bracket, that corresponds to the commutator bracket of quantum mechanics. Essential aspects of quantum mechanics can be given a classical formulation in terms of the Moyal bracket and the question thus arises whether this structure has a natural place in classical mechanics.

Recently some of us [6] studied deformations (in the sense of Gerstenhaber [7]) of the Lie algebra $N$ of differentiable functions on a symplectic manifold with the Poisson bracket, in terms of 1-differentiable cochains (bidifferential operators of order $\leqslant 1$ in each argument). Such deformations are trivial in the flat case (manifold $\mathbb{R}^{2 l}$ with the ordinary symplectic structure) but are interesting in other cases, as was illustrated by some physical applications [6c]. Vey [8] studied deformations of the algebra of polynomials (with the ordinary product) and derived, in the flat case, a nontrivial deformation of the Poisson Lie algebra in terms of differentiable cochains of increasing order. The Vey bracket turned out to be identical with the Moyal bracket. Vey also demonstrated the existence of such deformations of the Poisson bracket on general symplectic manifolds with vanishing (de Rham) 3-cohomology. Other mathematical properties and physical applications were sketched by some of us [9].

These developments encourage attempts to view quantum mechanics as a theory of functions or distributions on phase space, with deformed products and brackets. We suggest that quantization be understood as a deformation of the structure of the algebra of classical observables, rather than as a radical change in the nature of the observables. Incidentally, the nontriviality of the deformations throws some light on the nontrivial nature of the correspondence principle. As will be shown in the companion paper [10], our treatment of deformations of classical mechanics is a viable alternative to conventional quantum mechanics. This suggests the possibility of developing new methods for quantum theories, especially quantum field theories.

This article will emphasize mathematical aspects of deformations; physical applications are presented in the companion paper. In the first two sections we introduce the notion of Poisson manifold (a collection of symplectic leaves), on which a Poisson bracket is defined by a (possibly degenerate) 2-tensor $\Lambda$, and examine an important example (the coadjoint representation of a Lie algebra). In Section 3 we treat the case of flat Poisson manifolds (which have connections $\Gamma$ without torsion and curvature such that the covariant derivative of $\Lambda$ vanishes) and show the unicity of Moyaltype deformations that are formal functions of the Poisson bracket. We next deal with infinitesimal deformations of the Poisson bracket on general symplectic manifolds, giving a simple proof of the nontriviality and making more precise the relation to symplectic connections. In Sections 5 and 6 we determine all derivations (infinitesimal automorphisms) of the deformed structures, both those that do, and those that do not, depend on the deformation parameter $\hbar$. In the second case the result is a finitedimensional Lie algebra, a fact that is key to the selection of the proper quantization procedure for a physical system. Section 7 is concerned with the unicity of the lie algebra deformations. It is shown that, in the flat case, there is only one nontrivial choice to make at each order of $\hbar^{2}$. In Section 8, we present a fairly general procedure for constructing deformations in the case of nonfiat symplectic manifolds. 
From Section 9 onward, the emphasis is on invariance of the deformed products (which we call *-products). We believe that the classical observables (functions on phase space independent of $\hbar$ ) that generate symplectic transformations under which the deformations are invariant are of special physical significance. It is therefore natural to attempt to determine all *-products that are invariant under a finitedimensional Lie algebra given a priori. This problem is formulated precisely in Section 9. In Section 10 we give some particular examples. Section 11 gives general results concerning the construction of invariant *-products on $a d^{*} \mathscr{A}$ invariant submanifolds of the dual $\mathscr{A}^{*}$ of any Lie algebra $\mathscr{A}$, including explicit calculations for some simple cases. In the last section we introduce an important tool, the *-exponential function Exp, an application from $\mathscr{A}$ to the formal power series on $\mathscr{A}^{*}$. This function provides an alternative method for constructing deformations and is of direct interest to the physical applications. We end with several suggestions for further applications to the theory of representations and generalized Fourier transforms.

\section{Notion of Poisson Manifold}

(a) Let $W$ be a differentiable, connected, paracompact manifold of dimension $m$ and class $C^{\infty}$. We denote by $\left\{x^{i}\right\}(i, j=1, \ldots, m)$ a local chart of $W$ of domain $U$ and we set $N=C^{\infty}(W, \mathbb{R})$. A p-tensor is, by definition, a skew-symmetric contravariant tensor of order $p$.

For such tensors, Schouten and Nijenhuis [11] have introduced a useful tool, the Schouten bracket; if $A$ (resp. $B$ ) is a $p$-tensor (resp. $q$-tensor), $[A, B]$ is a $(p+q-1)$-tensor defined in the following way: for every closed $(p+q-1)$-form $\beta$ we have

$$
i([A, B]) \beta=(-1)^{p_{q+\alpha}} i(A) d i(B) \beta+(-1)^{p} i(B) d i(A) \beta
$$

where $i()$ is the interior product. For $p=1,[A, B]=\mathscr{L}(A) B$, where $\mathscr{L}$ is the Lie derivative operator. We have

$$
[A, B]=(-1)^{p q}[B, A] .
$$

Moreover, if $C$ is an $r$-tensor, we have the pseudo "Jacobi identity"

$$
S(-1)^{p q}[[B, C], A]=0
$$

where $S$ is the summation over cyclic permutations. An elementary calculation gives for the components of $[A, B]$, on the domain of an arbitrary local chart

$$
\begin{aligned}
{[A, B]^{k_{2} \cdots k_{p+q}}=} & \frac{1}{(p-1) ! q !} \epsilon_{i_{2} \cdots i_{p} j_{1} \cdots j_{q}}^{k_{2} \cdots k_{p}} A^{i i_{2} \cdots i_{p}} \partial_{t} B^{j_{1} \cdots j_{q}} \\
& +\frac{(-1)^{p}}{p !(q-1) !} \epsilon_{i_{1} \cdots i_{p} j_{2} \cdots j_{q}}^{k_{2} \cdots k_{p+q}} B^{t j_{2} \cdots j_{q}} \partial_{t} A^{i_{1} \cdots i_{p}}
\end{aligned}
$$

where $\partial_{t}=\partial / \partial x^{t}$ and where $\epsilon$ is the skew-symmetric Kronecker indicator.

$595 / \mathrm{x} \times \mathrm{X} / \mathrm{x}-5$ 
(b) Introduce on $W$ a 2-tensor $\Lambda$ and, on the space $N=C^{\circ}(W, \mathbb{R})$, the bracket $\{$,$\} (generalized Poisson bracket) defined by:$

$$
\{u, v\} \equiv i(\Lambda)(d u \wedge d v)=\Lambda(d u, d v), \quad u, v \in N .
$$

If $u, v, w \in N$ we have

$$
S\{\{u, v\}, w\}=\frac{1}{2} i([\Lambda, \Lambda])(d u \wedge d v \wedge d w)=\frac{1}{2}[\Lambda, \Lambda](d u, d v, d w)
$$

Definition 1. A structure of Poisson manifold is defined on a manifold $W$ of dimension $m$ by a 2-tensor $\Lambda$ such that $[\Lambda, \Lambda]=0$. The Poisson structure is called regular if $\Lambda$ has constant rank $2 n\left(\Lambda^{n} \neq 0, \Lambda^{n+1}=0\right.$, everywhere $)$; in this case $h=m-2 n$ is called the codimension of the manifold.

For a Poisson manifold $(W, \Lambda),(1-5)$ defines on $N$ a Lie algebra structure, the socalled Poisson Lie algebra.

(c) A symplectic structure is defined generally on a manifold $W$ of dimension $2 n$ by a closed 2 -form $F$ of rank $2 n$. We denote by $\mu: T W \rightarrow T^{*} W$ the isomorphism of vector bundles defined by $\mu(X)=-i(X) F$; this isomorphism is extended to the tensor bundles in a natural way. Let $\Lambda$ be the 2-tensor $\mu^{-1}(F)$ of $\operatorname{rank} 2 n$; the Poisson bracket of $(W, F)$ is defined by $(1-5)$ and we have $[\Lambda, \Lambda]=0$. A symplectic structure is nothing other than a regular Poisson structure $(W, \Lambda)$ of codimension 0 . Moreover, if $A$ is a $p$-tensor, we have

$$
\mu([\Lambda, A])=d \mu(A)
$$

It is well known that there are, on a symplectic manifold $(W, \Lambda)$, atlases of canonical charts $\left\{x^{i}\right\}=\left\{x^{\alpha}, x^{\vec{\alpha}}\right\}(\alpha=1, \ldots, n ; \vec{\alpha}=\alpha+n)$; for such a chart, the only nonvanishing components of $\Lambda$ are

$$
\Lambda^{\alpha, \bar{\alpha}}=-\Lambda^{\bar{\alpha}, \alpha}=1 .
$$

(d) Let $(W, \Lambda)$ be a regular Poisson manifold of codimension $h \neq 0 ; \Lambda$ defines on $W$ by $\Lambda^{i j} \omega_{j}=0$ a Pfaffian system which is integrable and so a foliation of $W$ of codimension $h$. The restriction of $A$ to each connected component of a leaf determines on this manifold a structure of symplectic manifold. Thus we have the following [12]

Proposmon 2. A regular Poisson manifold admits a foliation of codimension $h$ by symplectic manifolds. There exist on $(W, \Lambda)$ atlases of canonical charts $\left\{x^{\lambda}, x^{a}\right\}=$ $\left\{x^{\lambda}, x^{\alpha}, x^{\bar{\alpha}}\right\}(\lambda=1, \ldots, h ; \alpha=h+1, \ldots, h+n ; \bar{\alpha}=\alpha+n)$ such that the only nonvanishing components of $\Lambda$ are

$$
\Lambda^{\alpha, \bar{\alpha}}=-\Lambda^{\tilde{\alpha}, \alpha}=1 .
$$

In particular, $\Lambda^{i \lambda}=0$ and $x^{\lambda}=$ const along a leaf. 
More generally, there are on the Poisson manifold $(W, \Lambda)$ atlases of charts $\left\{x^{i}\right\}$ such that the components of $\Lambda$ in the charts are constant. Such a chart is called a natural chart for the manifold.

(e) A Poisson connection (resp. symplectic connection) $\Gamma$ on the Poisson (resp. symplectic) manifold $(W, \Lambda)$ is a linear connection without torsion such that $\nabla \Lambda=0$, where $\nabla$ is the operator of covariant differentiation defined by $\Gamma$. If $\Gamma_{j k}^{t}$ are the usual coefficients of a connection $\Gamma$ in a natural chart $\left\{x^{i}\right\}$, introduce the quantities $\Gamma^{d j k}=$ $\Lambda^{i l} \Lambda^{k m} \Gamma_{l m}^{i} ; \Gamma$ is a Poisson connection if and only if the $\Gamma^{i j k}$ 's are completely symmetric for each natural chart. It is easy to see that a regular Poisson manifold admits an infinity of Poisson connections; for a symplectic manifold the difference between two symplectic connections is deduced from a completely symmetric contravariant tensor of rank 3.

\section{Example of Poisson Manifold: Coadjoint Representation of a Lie Algebra}

(a) Let $\mathscr{A}$ be a Lie algebra of dimension $m$ over $\mathbb{R}, \mathscr{A}^{*}$ the dual vector space of $\mathscr{A},\langle$,$\rangle the bilinear duality form. Denote by \left\{L^{A}\right\}(A=1, \ldots, m)$ a basis for $\mathscr{A}$ and by $\left\{\lambda_{A}\right\}$ the dual basis for $\mathscr{A}^{*}$; then

$$
\left[L^{A}, L^{B}\right]=C_{C}^{A B} L^{C}
$$

where $\left\{C_{C}^{A B}\right\}$ is the structure tensor of the Lie algebra $\mathscr{A}$. The Jacobi identity can be expressed by

$$
S C_{D}^{A B} C_{E}^{C D}=0
$$

where $S$ is the summation over cyclic permutations of $(A, B, C)$. Denote by $\xi^{A}$ the components of $\xi \in \mathscr{A}^{*}$ and introduce on $\mathscr{A}^{*}$ the 2-tensor $A$ defined by

We have

$$
A(a, b)=\langle\xi,[a, b]\rangle \therefore \Lambda^{A B}=C_{c}^{A B} \xi^{C} \text {. }
$$

$$
\frac{1}{2}[\Lambda, \Lambda]^{A B C}=S \Lambda^{D A} \partial_{D} \Lambda^{B C}=\left(S C_{E}^{D A} C_{D}^{B C}\right) \xi^{E} .
$$

It thus follows from (2.1) that $\Lambda$ satisfies

$$
[\Lambda, \Lambda]=0
$$

and defines on $\mathscr{A}^{*}$ a Poisson structure.

Conversely, let $V$ be a vector space of dimension $m$ and suppose that we have on $V$ a 2-tensor $\Lambda$ satisfying (2-3) and depending linearly on the vectors $\xi \in V$. We deduce from $A$ a tensor $C$ which can be considered as the structure tensor of a Lie algebra defined on the dual space $V^{*}$ of $V$.

For $\left(\mathscr{A}^{*}, \Lambda\right)$ we denote by $2 r(\xi)$ the rank of $\Lambda$ at $\xi \in \mathscr{A}^{*}$, and set $r=\operatorname{Max} r(\xi)$, 
$\xi \in \mathscr{A}^{*}$. The set of points $\xi$ such that $r(\xi)=r$ is an open submanifold $W$ of $\mathscr{A}^{*}$, the complementary set of which in $\mathscr{A}^{*}$ is a cone; the restriction of $\Lambda$ to $W$ defines on $W$ a structure of regular Poisson manifold.

(b) Let $G$ be a connected Lie group having $\mathscr{A}$ as Lie algebra; $G$ acts naturally on $\mathscr{A}^{*}$ by its coadjoint representation $\mathrm{Ad}^{*}{ }_{G}$. We recall some well-known facts concerning the Lie algebra ad* $\mathscr{A}$ of the group $\mathrm{Ad}^{*} G$. Let $a \in \mathscr{A}$ and $\exp (t a)$ the one parameter subgroup of $G$ defined by $a$. The action of this group on $\xi \in \mathscr{A}^{*}$ gives $\xi(t)=\left(\mathrm{Ad}^{*} \exp (t a)\right) \xi$. It follows from the definition of the coadjoint representation that, for each $b \in \mathscr{A}$,

$$
\langle\xi(t), b\rangle=\langle\xi, \operatorname{Ad} \exp (-t a) b\rangle
$$

Differentiating with respect to $t$, we obtain at $t=0$ :

$$
\langle d \xi(t) / d t, b\rangle_{t=0}=\langle\xi,[a, b]\rangle .
$$

We deduce from (2-4) the map $a \in \mathscr{A} \mapsto \mapsto^{*} a \in \mathrm{ad}^{*} \mathscr{A}$, where ${ }^{*} a$ is the linear vector field on $\mathscr{A}^{*}$ given by

$$
{ }^{*} a^{A}=C_{C}^{B A} \xi^{C} a_{B}=\Lambda^{B A} a_{B} .
$$

This map is a homomorphism of Lie algebras admitting as kernel the center of $\mathscr{A}$. The tensor field $\Lambda$ on $\mathscr{A}^{*}$ is invariant under the Lie algebra ad* $\mathscr{A}$; this is a direct consequence of the Jacobi identity.

(c) Choose a point $\xi$ of $\mathscr{A}^{*}$ and consider the linear map $v_{\xi}: a \in \mathscr{A} \mapsto$ $* a(\xi) \in T_{\xi} \mathscr{A} *$. We have

$$
\left(\nu_{\xi}(a)\right)^{A}=\Lambda^{B A}(\xi) a_{B} .
$$

We obtain a field of vector spaces $H_{\xi}=\nu_{\xi}(\mathscr{A})$ defined by the values at $\xi$ of the elements $* a \in T_{\xi} \mathscr{A} *$. We have

$$
\begin{gathered}
\operatorname{dim} H_{\xi}=\operatorname{rank} \text { of } \Lambda(\xi)=2 r(\xi), \\
\operatorname{dim} \operatorname{Ker} \nu_{\xi}=m-2 r(\xi) .
\end{gathered}
$$

An element $b \in \mathscr{A}$ is in $\operatorname{Ker} \nu_{\xi}$ if and only if $\Lambda^{A B}(\xi) b_{A}=0$. An element $\zeta$ of $H_{\xi}$ satisfies, for each $b \in \operatorname{Ker} \nu_{\xi},\langle\zeta, b\rangle=0$ and conversely. We see that $A(\xi)$ can be interpreted as a 2-tensor on $H_{\xi}$ of $\operatorname{rank} 2 r(\xi)$.

(d) Let $M\left(\xi_{0}\right)$ be the orbit through $\xi_{0} \in \mathscr{A}^{*}$ of the coadjoint action of the group $G ; M\left(\xi_{0}\right)$ is a connected manifold imbedded in $\mathscr{A}^{*}$. The rank of $\Lambda$ is constant along $M\left(\xi_{0}\right)$ and the tangent space $T_{\xi} M\left(\xi_{0}\right)$ at each point $\xi \in M\left(\xi_{0}\right)$ is nothing other than 
$H_{\xi}$. Therefore $M\left(\xi_{0}\right)$ has even dimension $2 r\left(\xi_{0}\right)$ and the orbits depend only on the Lie algebra $\mathscr{A}$ and are independent of the choice of the group $G$.

Let $U$ be a domain of $\mathscr{A}^{*}$ such that $M\left(\xi_{0}\right) \cap U \neq \varnothing$. Introduce a local chart $\left\{\xi^{\lambda}, \xi^{\alpha}\right\}\left(a=1, \ldots, 2 r\left(\xi_{0}\right)\right)$ of $\mathscr{A}^{*}$ with domain $U$ such that $M\left(\xi_{0}\right)$ is locally defined by $\xi^{\lambda}=0$. For $\xi \in M\left(\xi_{0}\right) \cap U$, we have in this chart $\Lambda^{A \lambda}(\xi)=0$ and the restriction of $\Lambda$ to $M\left(\xi_{0}\right)$ defines a 2-tensor $\Lambda_{M\left(\xi_{0}\right)}$ of rank $2 r\left(\xi_{0}\right)$ on $M\left(\xi_{0}\right)$ with components $\left\{\Lambda^{a b}\right\}$. We deduce from (2-3):

$$
\left[\Lambda_{M\left(\varepsilon_{0}\right)}, \Lambda_{M\left(\varepsilon_{0}\right)}\right]=0
$$

and the 2-tensor $\Lambda_{M\left(\xi_{0}\right)}$ defines on $M\left(\xi_{0}\right)$ a symplectic structure.

\section{Composition law $* \lambda$ and Bracket $P_{\nu}$ for a Flat Poisson Manifold}

(a) A flat Poisson manifold is a regular Poisson manifold that admits a Poisson connection without curvature. Let $(W, \Lambda)$ be such a manifold and define the covariant derivative $\nabla$ in terms of a Poisson connection without curvature; we introduce the bidifferential operator $P^{r}$, of order $r$ in each argument, defined by the following expression on the domain $U$ of a chart $\left\{x^{i}\right\}$ :

$$
\left.P^{r}(u, v)\right|_{U}=\Lambda^{i_{1} j_{1}} \cdots \Lambda^{i_{r} j_{r}} \nabla_{i_{1} \cdots i_{r}} u \nabla_{j_{1} \cdots j_{r}} l .
$$

We set $P^{0}(u, v)=u v$. For $r=1$, we obtain the Poisson bracket $P$, with $P^{1}(u, v)=$ $\left\{u, v_{\}} ; P^{r}(u, v)\right.$ is symmetric if $r$ is even, skew symmetric if $r$ is odd.

Let $E(N ; \lambda)$ be the space of the formal series in $\lambda \in \mathbb{C}$, with coefficients in $N$. Given a formal series $f(z)$ with constant coefficients, such that $f(0)=1$, we substitute $P^{r}$ for $z^{r}$ in the development of $f(\lambda z)$; we obtain a bilinear map $(u, v) \in N \times N \rightarrow$ $u *_{\lambda} v \in E(N ; \lambda)$. This map can be extended in a natural way to $E(N ; \lambda)$. If

we have

$$
f(z)=\sum_{r=0}^{\infty} a_{r}\left(z^{r} / r !\right), \quad a_{0}=1
$$

$$
u \alpha_{\lambda} v=\sum_{r=0}^{\infty} \lambda^{r}\left(a_{r} / r !\right) \operatorname{Pr}^{r}(u, v) \quad(u, v \in N) .
$$

This defines a formal associative deformation of the usual associative algebra defined on $N$ by $u, v \mapsto u v$ if we have formally:

$$
\left(u *_{\lambda} v\right) *_{\lambda} w=u *_{\lambda}\left(v *_{\lambda} w\right) \quad(u, v, w \in N)
$$

We obtain immediately:

$$
\left(u *_{\lambda} v\right) *_{\lambda} w=\sum_{t=0}^{\infty} \lambda^{t} \sum_{\substack{r+s=t \\ r, s>0}}\left(a_{s} a_{s} / r ! s !\right) P^{r}\left(P^{s}(u, v), u\right)
$$


and

$$
u *_{\lambda}\left(v *_{\lambda} w\right)=\sum_{t=0}^{\infty} \lambda^{t} \sum_{r+g=t}\left(a_{r} a_{s} / r ! s !\right) P^{r}\left(u, P^{s}(v, w)\right) .
$$

We search for functions $f$ such that (3-3) is satisfied formally, that is

$$
T_{t}(u, v, w)=U_{t}(u, v, w) \quad(t=0,1, \ldots)
$$

where we have defined:

$$
\begin{aligned}
& T_{t}(u, v, w) \equiv \sum_{r+s=t}\left(a_{r} a_{s} / r ! s !\right) P^{r}\left(P^{s}(u, v), w\right), \\
& U_{t}(u, v, w)=\sum_{r+s=t}\left(a_{r} a_{s} / r ! s !\right) P^{r}\left(u, P^{s}(v, w)\right) .
\end{aligned}
$$

We obtain, taking into account the properties of the connection:

$$
\begin{aligned}
P^{\gamma}\left(u, P^{s}(v, w)\right)= & \Lambda^{i_{1} i_{1}} \cdots \Lambda^{i_{r} i_{r}} \Lambda^{k_{1} l_{1}} \cdots \Lambda^{k, l_{2},} \nabla_{i_{1} \cdots i_{r}} u \\
& \times \sum_{r^{\prime}=0}^{r}\left(\begin{array}{l}
r^{\prime} \\
r
\end{array}\right) \nabla_{j_{1} \cdots j_{r} \cdot k_{1} \cdots i_{s} v} v \nabla_{j_{r^{\prime}+1} \cdots j_{r} l_{1} \cdots l_{s}} k^{\prime} .
\end{aligned}
$$

It follows that

$$
\begin{aligned}
U_{t}(u, v, w)= & \sum_{r^{\prime}+s<t}\left(a_{t-s} a_{s} / r^{\prime} ! s !\left(t-r^{\prime}-s\right) !\right) \Lambda^{i_{2} j_{1}} \cdots \Lambda^{i_{t-s} j_{t-s}} \Lambda^{k_{1} l_{1}} \cdots \Lambda^{k_{s} l_{s}} \\
& \times \nabla_{i_{1} \cdots i_{t-s^{\prime}}} u \nabla_{j_{1} \cdots j_{r} \cdot k_{1} \cdots k_{s}} v \nabla_{j_{r^{\prime}+1} \cdots j_{t-s} l_{1} \cdots l_{s}} \mathrm{~W}^{\prime} .
\end{aligned}
$$

We obtain similarly:

$$
\begin{aligned}
& T_{t}(u, v, w)=\sum_{r^{\prime}+s<t}\left(a_{t-8} a_{s} / r^{\prime} ! s !\left(t-r^{\prime}-s\right) !\right) \Lambda^{i_{1} j_{1}} \cdots \Lambda^{i_{t-s} j_{t-s}} \Lambda^{k_{1} l_{1}} \cdots \Lambda^{k_{s} l_{v}}
\end{aligned}
$$

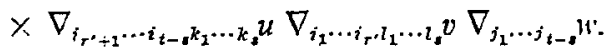

It follows by exchange between $r^{\prime}$ and $s$ :

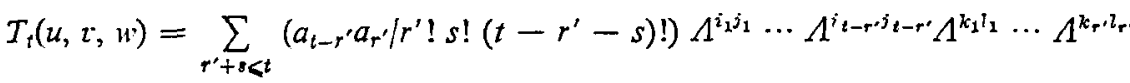

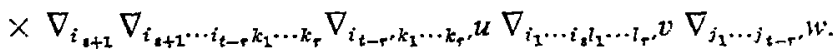

It follows from (3-5) and (3-6) that (3-4) is satisfied if and only if

$$
a_{t-s} a_{s}=a_{t-r^{\prime}} a_{r^{\prime}} \quad\left(r^{\prime}+s \leqslant t ; t=0,1,2, \ldots\right) .
$$

For $t=0,1$, we obtain only identities; the coefficient $a_{1}$ is arbitrary and we can take $a_{1}=1$ by a linear change of the variable $\lambda$. For $t=2$, (3-7) gives $a_{2}=1$. We deduce 
from (3-7) by induction that necessarily $a_{t}=1$ for each $t$. Conversely, if such is the case, (3-3) is satisfied. We have thus obtained:

THEOREM 3. If $(W, \Lambda)$ is a flat Poisson manifold, there is only one formal function of the Poisson bracket (up to a constant factor and a linear change of variable) that generates a formal deformation of the associative algebra defined on $N$ by the usual product: it is the exponential function.

Symbolically, we can write this deformation, for instance,

$$
u *_{\lambda} v=\exp (\lambda P)(u, v)
$$

Since the composition law (3-8) is associative, the bracket defined by $\left(u *_{\lambda} v-v *_{\lambda} u\right)$ satisfies the Jacobi identity. We are led to consider the bracket:

$$
(2 \lambda)^{-1}\{\exp (\lambda P)-\exp (-\lambda P)\}(u, v),
$$

that is:

$$
\lambda^{-1} \sinh (\lambda P)(u, v)
$$

which can be written:

$$
[u, v]_{\nu}=\sum_{\tau+0}^{\infty}\left(\nu^{r} /(2 r+1) !\right) P^{2 r+1}(u, v)
$$

where we have set $\nu=\lambda^{2}$. The first term of (3-10) is $P(u, v)$. We see that (3-9) or (3-10) defines a formal deformation of the Poisson Lie algebra $N$.

(b) Let $(W, \Lambda)$ be any regular Poisson manifold. Consider the Chevalley cohomology of the corresponding Poisson Lie algebra $N$; it is the cohomology, with values in $N$ itself, defined by the adjoint representation: a $p$-cochain is an alternate $p$-linear map of $N^{P}$ in $N$, the 0 -cochains being identified with the elements of $N$. The coboundary of the $p$-cochain $C$ is the $(p+1)$-cochain $2 C$ given by

$$
\begin{aligned}
\partial C\left(u_{0}, \ldots, u_{p}\right)= & (1 / p !) \epsilon_{0 \ldots p}^{\lambda_{0} \ldots \lambda_{p}}\left\{u_{\lambda_{0}}, C\left(u_{\lambda_{1}}, \ldots, u_{\lambda_{p}}\right)\right\} \\
& -(1 / 2(p-1) !) \epsilon_{0 \ldots p}^{\lambda_{0} \cdots \lambda_{p}} C\left(\left\{u_{\lambda_{0}}, u_{\lambda_{1}}\right\}, u_{\lambda_{2}}, \ldots, u_{\lambda_{p}}\right)
\end{aligned}
$$

where $u_{\lambda_{f}} \in N$. We note that the space of the 1-cocycles of $N$ is the space of the derivations of $N$; the space of the exact 1-cocycles is the space of the inner derivations.

A $p$-cochain $C$ is called local (support preserving) if, for each $u_{1} \in N$, such that $u_{1}, U=0$ on a domain $U$, we have $\left.C\left(u_{1}, \ldots, u_{D}\right)\right|_{U}=0$. If $C$ is local, $\partial C$ is local. We obtain thus the so-called "diagonal complex" in the terminology of GelfandFuks. A p-cochain $C$ is called $d$-differentiable $(d \geqslant 1)$ if the cochain is local and if its restriction to each domain $U$ of $W$ is a $d$-differentiable $p$-cochain of $N(U)=C^{\star}(U ; \mathbf{R})$ in a clear sense. Such a cochain is defined by a multidifferential operator of maximum 
order $d$. If $C$ is $d$-differentiable, $\partial C$ is also $d$-differentiable. We have proved [12] the following proposition (see Section $6 \mathrm{~b}$ for the symplectic case):

Proposition 4. Let $(W, \Lambda)$ be a regular Poisson manifold. If $C$ is a local 1-cochain of $N$ such that $\partial C$ is a d-differentiable 2-cochain, then $C$ is itself d-differentiable.

We note that if $(W, \Lambda)$ is symplectic and if $\partial C$ is null on the constants, we have $C(1)=$ constant.

(c) We come back to a flat Poisson manifold $(W ; \Lambda)$. Given a formal series $f(z)$ with constant coefficients, without constant term, we substitute $P^{r}$ for $z^{r}$ in the development of $\lambda^{-1} f(\lambda z)$, where $P^{r}$ is defined by (3-1). We obtain a bilinear map $N \times N \rightarrow E(N ; \lambda)$ which is skew symmetrical only if $f$ is odd. If

$$
f(z)=\sum_{r=0}^{\infty}\left(a_{r} /(2 r+1) !\right) z^{2 r+1} \quad\left(a_{0}=1\right)
$$

we have:

$$
P_{\nu}(u, v)=P(u, v ; \nu)=\sum_{r=0}^{\infty} \nu^{r}\left(a_{r} /(2 r+1) !\right) P^{2 r+1}(u, v) \quad\left(\nu=\lambda^{2}\right) .
$$

We search for functions $f$ such that (3-12) determines a formal deformation of the Lie algebra $N$; (3-12) satisfies formally the Jacobi identity if and only if, for $t=1,2, \ldots$ :

$$
D_{t} \equiv \sum_{r+s=t ; r, s>0} a_{r} a_{s} E_{r, s}=0
$$

where, for $u, v, w \in N$,

$$
E_{r, 8}(u, v, w) \equiv S(1 /(2 r+1) !(2 s+1) !) P^{2 r+1}\left(P^{2 s+1}(u, v), w\right) .
$$

Introduce the local Chevalley cohomology of $N$. For $t=1, D_{1}=0$ expresses only that $P^{3}$ is a 2-cocycle for this cohomology and the coefficient $a_{1}$ is arbitrary. We can take $a_{1}=1$ by a linear change of the variable $\nu$. We obtain by an argument similar to the argument of Section 3a that $D_{t}=0$ if and only if $a_{t}=1$ for each $t$. We have thus determined the required formal deformations of the Poisson Lie algebra $N$.

Consider the 2-cocycle $P^{3}$ which corresponds to the term linear in $v$. If this cocycle were exact, it would be the coboundary of a local 1-cochain which would be necessarily 3-differentiable, according to Proposition 4. But it is easy to see that such a coboundary has no term of bidifferential type $(3,3)$. More generally, it is possible to prove in the same way that for a flat Poisson manifold, the second space of local cohomology of $N$ has the dimension $1 ; P^{3}$ defines a cohomology 2-class $\beta$ which is a generator for this space. We have proved:

THEOREM 5. If $(W, \Lambda)$ is a flat Poisson manifold, there is only one formal function of the Poisson bracket (up to a constant factor and a linear change of variable) that 
generates a formal deformation of the Poisson Lie algebra $N$ of the manifold: it is the sinh function. The corresponding deformation is nontrivial even for the order 1 .

Thus we obtain only the deformation $M\left(u, v ; v=\lambda^{2}\right)$ given by (3-9), which is therefore nontrivial. It is remarkable that for $\lambda=i \hbar / 2$, we obtain a bracket given many years ago by Moyal [5]. We often suppress the mention of the variable $\nu$ and call $M(u, v)$ the Moyal-Vey bracket of the flat Poisson manifold $(W, \Lambda, \Gamma)$; this bracket depends on the choice of the flat connection $\Gamma$. (For $W=\mathbb{R}^{2}$ and $\Gamma=0$, the unicity of the sine-bracket as a function of $P$ has been noticed in 1964 by C. L. Mehta).

(d) Consider a general symplectic manifold $(W, \Lambda)$ and a linear connection such that $\nabla \Lambda=0$. We introduce the bidifferential operators $P^{r}$ defined by:

$$
\left.P^{r}(u, v)\right|_{U}=\Lambda^{i_{1} j_{l}} \cdots \Lambda^{i_{r} j_{r}} \nabla_{i_{1} \cdots i_{r}} u \nabla_{j_{1} \cdots j_{r}} v \quad(u, v \in N)
$$

and set

$$
u *_{\lambda} v=\sum_{r=0}^{\infty}\left(\lambda^{r} / r !\right) P^{r}(u, v)
$$

If (3-14) is limited to the order 2, we see that the associative property (3-3) is satisfied up to the order 3 if and only if $\nabla_{i_{1} i_{2}} u$ is always symmetric, that is if $\Gamma$ is without torsion. If (3-14) is limited to the order 3 , then (3-3) is satisfied up to the order 4 if and only

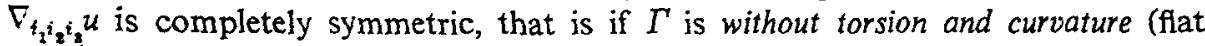
symplectic connection). In this case (3-14) satisfies (3-3) to all orders.

\section{Deformations of the Poisson Lie Algebra of a Symplectic Manifold}

(a) Consider a symplectic manifold $(W, \Lambda)$ with an arbitrary symplectic connection $\Gamma$ (without torsion, but with curvature). We denote by $F$ the closed 2-form of the manifold. If $\left\{\Gamma_{j k}^{i}\right\}$ are the usual coefficients of the connection $\Gamma$ in a natural chart $\left\{x^{i}\right\}$, we introduce the quantities $\Gamma_{i j k}=F_{i l} \Gamma_{j k}^{l}$ which are completely symmetric. If $u \in N$, we denote by $X_{u}$, for simplicity, the corresponding Hamiltonian vector field $\left(X_{u}=\mu^{-1}(d u)\right) ; \mathscr{L}\left(X_{u}\right) \Gamma$ is the completely symmetric covariant 3 -tensor defined by means of the Lie derivative of the connection $\Gamma$ by the vector field $X_{u}$. We have locally for a natural chart:

$$
\left(\mathscr{L}\left(X_{u}\right) \Gamma\right)_{i_{1} i_{2} i_{3}}=\partial_{i_{1} i_{2} i_{2}} u-S \Lambda^{k l} \Gamma_{k i_{1} i_{2}} \hat{c}_{l i_{3}} u-\Lambda^{k l} \partial_{k} \Gamma_{i_{1} i_{2} i_{3}} \partial_{l} u
$$

If $T$ is a completely symmetric covariant 3-tensor, we have:

$$
\left(\mathscr{L}\left(X_{u}\right) T_{i_{1} i_{2} i_{3}}=-S \Lambda^{k i} T_{k i_{1} i_{2}} \partial_{l i_{3}} u-\Lambda^{k l} \hat{\partial}_{k} T_{i_{1} i_{2} i_{3}} \partial_{l} u .\right.
$$

Consider the 2-cochains $S_{\Gamma}{ }^{3}$ defined by:

$$
S_{\Gamma}^{2}(u, v)_{U}=\Lambda^{i_{1} j_{1}} \Lambda^{i_{2} j_{2}} \Lambda^{i_{3} j_{3}}\left(\mathscr{L}\left(X_{u}\right) \Gamma\right)_{i_{1} i_{2} i_{3}}\left(\mathscr{L}\left(X_{\tau}\right) \Gamma\right)_{j_{1} j_{2} j_{3}} .
$$


In the special case when $\Gamma$ is flat, $S_{\Gamma}{ }^{3}$ coincides with $P^{3}$. In the general case, we deduce from $X_{\{u, v\}}=\left[X_{u}, X_{v}\right]$ :

$$
S S_{\Gamma}^{3}(P(u, v), w)=S \Lambda^{i_{1} j_{1}} \Lambda^{i_{2} j_{2}} \Lambda^{i_{3} j_{3}}\left(\mathscr{L}\left(\left[X_{u}, X_{v}\right]\right) \Gamma\right)_{i_{1} t_{2} i_{3}}\left(\mathscr{L}\left(X_{w}\right) \Gamma\right)_{i_{1} j_{2} j_{3}} .
$$

On the other hand, we deduce from the properties of the Lie derivative by $X_{w}$ :

$$
\begin{aligned}
S P\left(S_{\Gamma}{ }^{3}(u, v), w\right)= & -S \Lambda^{i_{1} j_{1}} \Lambda^{i_{2} j_{2}} \Lambda^{i_{3} j_{2}}\left(\mathscr{L} X_{w} \mathscr{L}\left(X_{u}\right) \Gamma\right)_{i_{1} i_{2} i_{3}}\left(\mathscr{L}\left(X_{v}\right) \Gamma\right)_{j_{1} j_{2} j_{3}} \\
& -S \Lambda^{i_{1} j_{1}} \Lambda^{i_{2} j_{2}} \Lambda^{i_{3} j_{3}}\left(\mathscr{L}\left(X_{u}\right) \Gamma\right)_{i_{1} i_{2} i_{3}}\left(\mathscr{L}\left(X_{w}\right) \mathscr{L}\left(X_{v}\right) \Gamma\right)_{j_{1} j_{2} j_{3}} .
\end{aligned}
$$

It follows that:

$$
S P\left(S_{\Gamma}{ }^{3}(u, v), w\right)=-S \Lambda^{i_{1} j_{1}} \Lambda^{i_{2} j_{2}} \Lambda^{i_{3} j_{3}}\left(\mathscr{L}\left(\left[X_{u}, X_{v}\right]\right) \Gamma\right)_{i_{1} i_{2} i_{3}}\left(\mathscr{L}\left(X_{w}\right) \Gamma\right)_{j_{1} j_{2} j_{3}}
$$

and thus

$$
S S_{\Gamma}^{3}(P(u, v), w)+S P\left(S_{\Gamma}^{3}(u, v), w\right)=0 .
$$

According to (3-11), this means that

$$
\partial S_{\Gamma}^{3}=0
$$

and $S_{\Gamma}{ }^{3}$ is a 2-cocycle for the considered cohomology of $N$. The same argument as for the flat case shows that the 2-cocycle $S_{\Gamma}{ }^{3}$ is nonexact.

(b) Let $T$ be a completely symmetric covariant 3-tensor. We can associate to the 3-tensor $T$ and to the symplectic connection $\Gamma$ the second-order differential operator $A_{T}$ given by:

$$
A_{T}(v)=\Lambda^{i_{1} j_{1}} \Lambda^{i_{2} j_{2}} \Lambda^{i_{3} j_{3}} T_{i_{1} i_{2} i_{3}}\left(\mathscr{L}\left(X_{v}\right) T\right)_{j_{1} j_{2} j_{3}} \quad(v \in N)
$$

and the third-order differential operator $B_{T}$ given by:

$$
B_{T}(v)=\Lambda^{i_{1} j_{1}} \Lambda^{i_{2} j_{2}} \Lambda^{i_{2} j_{3}} T_{i_{1} i_{2} i_{3}}\left(\mathscr{L}\left(X_{v}\right) \Gamma\right)_{j_{1} j_{2} i_{8}} \quad(v \in N) .
$$

The coboundary $\partial C$ of a 1 -cochain $C$ is given by:

$$
\partial C(u, v)=\mathscr{L}\left(X_{u}\right) C(v)-\mathscr{L}\left(X_{v}\right) C(u)-C(\{u, v\}) \quad(u, v \in N) .
$$

We deduce from (4-5):

$$
\partial A_{T}(u, v)=2 \Lambda^{i_{1} j_{1}} \Lambda^{i_{2} j_{2}} \Lambda^{i_{3} i_{3}}\left(\mathscr{L}\left(X_{u}\right) T\right)_{i_{1} i_{2} i_{3}}\left(\mathscr{L}\left(X_{v}\right) T\right)_{j_{1} j_{2} j_{3}}
$$

and:

$$
\begin{aligned}
\partial B_{T}(u, v)= & \Lambda^{i_{1} i_{1}} \Lambda^{i_{2} i_{2}} \Lambda^{i_{3} i_{3}}\left[\left(\mathscr{L}\left(X_{u}\right) T\right)_{i_{1} i_{2} i_{3}}\left(\mathscr{L}\left(X_{v}\right) \Gamma\right)_{j_{1} y_{2} j_{2}}\right. \\
& \left.-\left(\mathscr{L}\left(X_{v}\right) T\right)_{i_{1} i_{2} i_{3}}\left(\mathscr{L}\left(X_{u}\right) \Gamma\right)_{j_{1} j_{2} j_{z}}\right] .
\end{aligned}
$$


Proposition 6. The cohomology 2-class $\beta$ defined by the 2-cocycle $S_{\Gamma}{ }^{3}$ does not depend on the choice of the symplectic connection $\Gamma$.

Proof. Consider two symplectic connections $\Gamma$ and $\Gamma^{\prime}$ and take for $T$ the 3-tensor defined by the difference between the two connections. We obtain:

$$
\begin{aligned}
\left(S_{\Gamma^{\prime}}^{a}-S_{\Gamma}^{3}\right)(u, v)= & \Lambda^{i_{1} j_{1}} \Lambda^{i_{2} j_{2}} \Lambda^{i_{3} j_{3}}\left\{\left(\mathscr{L}\left(X_{u}\right) T\right)_{i_{1} i_{2} i_{3}}\left(\mathscr{L}\left(X_{v}\right) T\right)_{j_{2} j_{2} j_{3}}\right. \\
& \left.+\left(\mathscr{L}\left(X_{u}\right) T\right)_{i_{1} i_{2} i_{2}}\left(\mathscr{L}\left(X_{v}\right) T\right)_{j_{3} j_{2} j_{3}}\right\} \\
& +\Lambda^{i_{1} j_{1}} \Lambda^{i_{2} j_{3}} \Lambda^{i_{3} j_{3}}\left(\mathscr{L}\left(X_{u}\right) T\right)_{i_{1} i_{2} i_{3}}\left(\mathscr{L}\left(X_{v}\right) T\right)_{j_{1} j_{2} j_{2}} .
\end{aligned}
$$

Therefore we have:

$$
S_{\Gamma^{\prime}}^{3}-S_{\Gamma}^{3}=\partial\left(B_{T}+\frac{1}{2} A_{T}\right)
$$

and the cohomology class of $S_{\Gamma}{ }^{3}$ is independent of the choice of $\Gamma$.

(c) Proposition 7. Let $Q^{3}$ be a 2-cocycle belonging to $\beta$, defined by a bidifferential operator of maximum order 3 on each argument, null on the constants. There exists a unique symplectic connection $\Gamma$ such that

$$
Q^{3}=S_{\Gamma}^{3}+\partial K
$$

where $K$ is a differential operator of order $\leqslant 2$.

Proof. Let $\Gamma^{\prime}$ be an arbitrary symplectic connection; $Q^{3}-S_{\Gamma^{\circ}}^{3}$ is exact and, according to Proposition 4 of Section $3 \mathrm{~b}$ there is a differential operator $C$ of order $\leqslant 3$ such that:

$$
Q^{3}-S_{\Gamma^{\prime}}^{3}=\hat{\alpha} C \text {. }
$$

Consider the part of order 3 of $C$; this part is defined by a completely symmetric contravariant 3-tensor $T$, such that, in a natural chart $\left\{x^{i}\right\}$ :

$$
C(u)=T^{i_{1} i_{2} i_{3}} \partial_{i_{1} i_{2} i_{2}} u+\cdots
$$

This tensor defines, by means of $\mu$, a symmetric covariant 3-tensor still denoted by $T$. The terms of order 3 in $\partial C$ can be written:

$$
\begin{aligned}
& \partial C(u, v)=-3 \Lambda^{k l} T^{i_{1} i_{2} i_{2}}\left(\hat{\epsilon}_{i_{1} i_{2} k} u \partial_{i_{2} l} u-\hat{\partial}_{i_{1} i_{2} k} v \partial_{i_{2} z} u\right) \\
& \div \Lambda^{k t} \partial_{k} T^{i_{1} i_{s} i_{3}}\left(\partial_{i_{1} i_{3} i_{2}} u \partial_{l} z-\partial_{i_{1} i_{2} i_{3}} v \partial_{l} u\right)+\cdots \text {. }
\end{aligned}
$$

Let $B_{T}(v)$ be defined locally by:

$$
B_{T}(v)_{U}^{\prime}=T^{j_{1} j_{2} j_{2}}\left(\mathscr{L}\left(X_{t}\right) \Gamma^{\prime}\right)_{j_{1} y_{2} j_{3}}
$$


and consider the terms of order 3 in $\partial B_{T}(u, v)$. It follows from (4-1), (4-2), and (4-6) that we obtain the two first terms on the right-hand side of (4-9). We see that $Q^{3}-S_{\Gamma^{\prime}}^{3}-\partial B_{T}$ is an exact 2-cocycle defined by a bidifferential operator of maximum order 2 . We are led to introduce the symplectic connection $\Gamma$ such that the difference $\Gamma-\Gamma^{\prime}$ is defined by the 3-tensor $T$. It follows from (4-7) that $S_{\Gamma^{\prime}}^{3}-S_{\Gamma}{ }^{3}+\partial B_{T}$ is an exact 2-cocycle defined also by a bidifferential operator of maximum order 2. The same is true for $Q^{3}-S_{r}{ }^{3}$, and the connection $\Gamma$ is a solution to our problem. Conversely we will see in Section 5 that $\partial B_{T}$ is a bidifferential operator of maximum order 2 if and only if $T=0$. It follows that the symplectic connection satisfying (4-8) is unique.

(d) Consider a symplectic manifold $(W, \Lambda)$ such that the third de Rham cohomology space $H^{3}(W ; \mathbb{R})$ of the manifold is null; this cohomology corresponds to the homology with compact supports. Vey [8] has recently proved, by a long and fine study using Gelfand-Fuks results, the following

THEOREM 8 (Vey). Let $(W, \Lambda)$ be a symplectic manifold such that $H^{3}(W ; \mathbb{R})=\{0\}$. There exists a formal deformation of the Poisson Lie algebra $N$ :

$$
Q(u, v ; \nu)=\sum_{r=0}^{\infty} \nu^{r} \frac{1}{(2 r+1) !} Q^{2 r+1}(u, v) \quad(u, v \in N)
$$

where the 2-cochain $Q^{2 r-1}$ is defined by a bidifferential operator of order $(2 r+1)$ on each argument, null on the constants and for which the principal symbol coincides with the principal symbol of $P^{2 r+1}$.

In particular, $Q^{1}=P$ and $Q^{3}$ belongs to the class $\beta$ defined in Proposition 6. We say that such a deformation is a Vey deformation of the Poisson Lie algebra or that it is a formal Vey Lie algebra. It is not known if the condition $H^{3}(W ; \mathbb{R})=\{0\}$ is necessary. General explicit forms for $Q^{2 r+1}(r>1)$ are not known.

\section{Derivations Independent of $\nu$ of a Vey Lie Algebra}

The Lie algebra of the infinitesimal automorphisms of an arbitrary Lie algebra is given by the Lie algebra of the derivations.

(a) Concerning the Poisson Lie algebra $N$, we recall that a derivation $D$ is an endomorphism $D: N \rightarrow N$ such that, for any $u, v \in N$, we have:

$$
\{D u, v\}+\{u, D v\}-D\{u, v\}=0
$$

that is, $\partial D=0$. We note that we have for $D$ no locality, continuity, or differentiability assumption.

A vector $Z$ defines a symplectic infinitesimal transformation (i.t.) of $(W, F)$ if $\mathscr{L}(Z) F=0$; we denote by $L$ the Lie algebra of the symplectic i.t.; $Z$ defines a con- 
formal symplectic i.t. if $\mathscr{L}(Z) F=a F$, where $a$ is a scalar; if $\operatorname{dim} W>2, a$ is necessarily a constant. In all cases, we denote by $L^{c}$ the Lie algebra of vector fields $Z$ such that there exists a constant $k(Z)$ for which:

$$
\mathscr{L}(Z) F+k(Z) F=0
$$

or

$$
\mathscr{L}(Z) \Lambda=k(Z) \Lambda
$$

If $F$ is nonexact (in particular if $W$ is compact), $L^{c}$ coincides with $L$. If $F$ is exact, $L$ is, the commutator ideal of $L^{c}$ and $\operatorname{dim} L^{c} / L=1$. Avez and Lichnerowicz [13] have proved the following:

Theorem 9. Let $(W, F)$ be a symplectic manifold and $N$ its Poisson Lie algebra. If $W$ is noncompact, each derivation $D$ of $N$ is given by $\mathscr{L}(Z)+k(Z)$, where $Z \in L^{c}$. If $W$ is compact, each derivation $D$ of $N$ is given by:

$$
D u=\mathscr{L}(Z) u+c \int_{W} u \eta
$$

where $Z \in L, c \in \mathbb{R}$, and $\eta$ is the symplectic volume element; these are nonlocal derivations (for $c \neq 0$ ).

We suppose now that $W$ is noncompact. The results concerning the compact case are similar, since it is possible to prove that the nonlocal derivations do not appear in the following study.

(b) Consider an infinitesimal Vey deformation of the Poisson Lie algebra of the symplectic manifold $(W, \Lambda)$

$$
Q_{1}(u, v ; v)=P(u, v)+(\nu / 3 !) Q^{3}(u, v)
$$

where $Q^{3}$ is a 2 -cocycle satisfying Proposition 7 ; we have

$$
Q^{3}=S_{\Gamma}^{3}+\partial K
$$

where $T$ is a symplectic connection and where $K$ is a differential operator of order $\leqslant 2$.

An infinitesimal automorphism $D$-independent of $\nu$ - of the bracket (5-4) is defined by an endomorphism $D: N \rightarrow N$ such that, for every $u, v \in N$ and $\nu \in \mathbb{C}$, we have:

$$
Q_{1}(D u, v)+Q_{1}(u, D v)-D Q_{1}(u, v)=0
$$

The space of these infinitesimal automorphisms admits, for the natural bracket of the endomorphisms, a structure of Lie algebra. For $\nu=0$, we obtain $\partial D=0$; 
that is, $D$ is a derivation of the Poisson Lie algebra. It follows from the above theorem that necessarily

$$
D=\mathscr{L}(Z)+k(Z) \quad\left(Z \in L^{c}\right)
$$

and $(5-6)$ is then reduced to

$$
\partial_{8} D(u, v) \equiv Q^{3}(D u, v)+Q^{3}(u, D v)-D Q^{3}(u, v)=0 .
$$

(c) Consider the differential operator $K$ of order 2 introduced in (5-5). This operator is defined in terms of the connection $\Gamma$ by a symmetric contravariant 2-tensor $H$, a vector $J$, and a constant $c$ so that, on the domain $U$ of a chart, we have:

$$
\left.K(u)\right|_{U}=H^{k l} \nabla_{k l} u+J^{k} \nabla_{k} u+c u .
$$

Here $c$ is a constant since $\partial K$ is null on the constants (as noticed at the end of Section 3b).

We obtain easily according to the Ricci identity

$$
\begin{aligned}
\left.\partial K(u, v)\right|_{v}= & \Lambda^{i j} \nabla_{i} H^{k l}\left(\nabla_{k i} u \nabla_{\jmath} v-\nabla_{k \imath} v \nabla_{\jmath} u\right)-\Lambda^{i j} H^{k l}\left(\nabla_{k i} u \nabla_{l j} v-\nabla_{k i} v \nabla_{l j} u\right) \\
& -\Lambda^{i j} H^{k l} R_{l, i k}^{r}\left(\nabla_{\tau} u \nabla_{\jmath} v-\nabla_{\tau} v \nabla_{\jmath} u\right) \\
& +\left(\Lambda^{i j} \nabla_{i} J^{k}-\Lambda^{i k} \nabla_{\jmath} J^{j}\right) \nabla_{k k} u \nabla_{\jmath} v+c \Lambda^{i j} \nabla_{i} u \nabla_{\jmath} v
\end{aligned}
$$

where we have introduced the curvature tensor of $\Gamma$.

We are led to evaluate, for $D=\mathscr{L}(Z)+k(Z)$ (with $Z \in L^{c}$ ):

$$
E_{Z}(u, v) \equiv \partial K(D u, v)+\partial K(u, D v)-D \partial K(u, v)
$$

that is:

$E_{Z}(u, v)=\partial K(\mathscr{L}(Z) u, v)+\partial K(u, \mathscr{L}(Z) v)-\mathscr{L}(Z) \partial K(u, v)+k(Z) \partial K(u, v) .(5-11)$

We have the following lemma:

LEMMA 10. The bidifferential operator $E_{Z}$ defined by (5-11), where $Z \in L^{c}$, is of maximum order 2 on each argument.

Proof. Computing (5-11) with the help of (5-10) and the identity

$$
\left(\mathscr{L}(Z) \nabla_{k} \nabla_{l}-\nabla_{k} \nabla_{l} \mathscr{L}(Z)\right) u=\left(\mathscr{L}(\mathcal{Z}) \Gamma^{r}\right)_{k l}^{i} \nabla_{i} u
$$

we see immediately that all terms in $E_{z}$ of order $>2$ in each argument cancel out, and the lemma is proved. 
(d) We have

$$
\begin{aligned}
\partial_{3} D(u, v)= & S_{\Gamma}^{3}(\mathscr{L}(Z) u, v)+S_{\Gamma}^{3}(u, \mathscr{L}(Z) v)-\mathscr{L}(Z) S^{3} \Gamma(u, v) \\
& +k(Z) S_{\Gamma}^{3}(u, v)+E_{Z}(u, v)
\end{aligned}
$$

Introduce the symmetric covariant 3-tensor $T=\mathscr{L}(Z) \Gamma$ and the differential operator $B_{T}$ corresponding to $T$ and $T$ defined in (4-4). It follows from (5-12) that:

$$
\hat{\partial}_{3} D=-\hat{c} B_{T}-4 k(Z) S_{\Gamma}^{3}+E_{Z}
$$

and (5-8) can be written, on the domain $U$ of a natural chart:

$$
\begin{aligned}
& \Lambda^{i_{1} j_{1}} \Lambda^{i_{2} j_{2}} \Lambda^{i_{2} y_{2}}\left\{\left(\mathscr{L}\left(X_{u}\right) T\right)_{i_{1} i_{2} i_{3}}\left(\mathscr{L}\left(X_{v}\right) \Gamma\right)_{j_{1} j_{2} j_{3}}-\left(\mathscr{L}\left(X_{u}\right) \Gamma\right)_{j_{1} j_{2} j_{3}}\left(\mathscr{L}\left(X_{v}\right) T\right)_{i_{1} i_{2} i_{z}}\right. \\
& \left.\quad+4 k(Z)\left(\mathscr{L}\left(X_{u}\right) \Gamma\right)_{i_{1} i_{2} i_{3}}\left(\mathscr{L}\left(X_{v}\right) \Gamma\right)_{j_{1} j_{2} j_{3}}\right\}-E_{Z}(u, v)=0 .
\end{aligned}
$$

Let $x$ be a point of $U$ and introduce an element $u$ of $N$ admitting a null 2-jet at $x$. We have at this point:

$$
\left(\mathscr{L}\left(X_{u}\right) T\right)(x)=0, \quad\left(\mathscr{L}\left(X_{u}\right) \Gamma \Gamma(x)=\tau\right.
$$

where we can choose arbitrarily the symmetric 3-tensor $\tau$ related, according to (4-1), to the third derivatives of $u$ at $x$. Lemma 10 gives $E_{z}(u, v)(x)=0$ and we deduce from (5-14):

$$
\tau^{i_{1} i_{2} i_{3}}\left[\left(\mathscr{L}\left(X_{v}\right) T\right)_{i_{1} i_{2} i_{3}}+2 k(Z)\left(\mathscr{L}\left(X_{v}\right) \Gamma\right)_{i_{1} i_{2} i_{z}}\right](x)=0 .
$$

It follows that necessarily, for every $v \in N$

$$
\mathscr{L}\left(X_{v}\right) T+4 k(\mathcal{Z}) \mathscr{L}\left(X_{v}\right) \Gamma=0 .
$$

If we take for $v$ an element of $N$ admitting a null 2-jet at $x$, we obtain $k(Z)=0$. Therefore $Z$ belongs necessarily to the Lie algebra $L ;(5-15)$ gives the result

$$
\mathscr{L}\left(X_{v}\right) T=0
$$

for every $v \in N$.

Consider an element $v \in N$ such that $\left(\partial_{k l} v\right)(x)=0,\left(\partial_{z} v\right)(x)$ being arbitrary. According to (4-2), we have at $x$ :

$$
\left(\partial_{k} T_{i_{1} i_{2} i_{2}}\right)(x)=0
$$

and the components $T_{i_{1} z_{2} t_{3}}$ of $T$ are constant on $U$. We shall raise indices in $T$ with the help of $\Lambda$.

If $v$ is now a function such that at $x$ :

$$
\left(\partial_{k l} v\right)(x)=\tau_{k l}
$$


where $\tau$ is an arbitrary symmetric 2-tensor, $(5-16)$ gives at $x$ :

$$
\tau_{k i_{1}} T_{i_{2} i_{3}}^{k}+\tau_{k i_{2}} T_{i_{3} i_{1}}^{k}+\tau_{k i_{3}} T_{i_{1} i_{2}}^{k}=0
$$

Choose for $\tau$ a tensor which has as only nonvanishing component $\tau_{11}=1$; take $i_{1}=1$ and successively $i_{2}=i_{3}=1 ; i_{2}=1, i_{3} \neq 1 ; i_{2} \neq 1, i_{3} \neq 1$. We obtain $T_{i_{2} i_{3}}^{1}=0$ for arbitrary indices $i_{2}, i_{3} ; 1$ being an arbitrary index, it follows $T=0$; that is,

$$
\mathscr{L}(\mathcal{Z}) \Gamma=0
$$

$Z$ preserves the connection $\Gamma$. In particular $Z$ preserves separately $S_{\Gamma}{ }^{3}$ and $\partial K$. A similar argument shows that if $Z$ preserves $\Lambda, \Gamma$, and also $\partial K$, we have with the representation (5-9)

$$
\mathscr{L}(Z) H=0
$$

and

$$
[\mathscr{L}(Z) J, \Lambda]=0 .
$$

The vector field $\mathscr{L}(Z) J$ defines a symplectic i.t.

We note that the same argument proves also the uniqueness of the connection defined by Proposition 7 .

We denote by $L_{S A}$ the symplectic subalgebra of the Lie algebra of the affine infinitesimal transformations corresponding to the connection $\Gamma$. Let $L\left(Q_{1}\right)$ be the Lie algebra of infinitesimal automorphisms (independent of $\nu$ ) of the bracket (5-4) (Vey infinitesimal deformation). We have proved:

THEOREM 11. The Lie algebra $L\left(Q_{1}\right)$ of infinitesimal automorphisms of the bracket $Q_{1}$ which do not depend on $\nu$ is a subalgebra of the algebra $L_{S A}$ of the symplectic affine infinitesimal transformations of the symplectic connection $\Gamma$ associated with the 2-cocycle $Q^{3}$. Therefore $L\left(Q_{1}\right)$ is finite dimensional.

We note that if $Q^{3}=S_{\Gamma}^{3}$, we have $L\left(Q_{1}\right)=L_{S A}$.

For a Vey Lie algebra, with the bracket $Q$ given by (4-10), it follows from Theorem 11 that:

COROLlaRY 12. The Lie algebra $L(Q)$ of the derivations independent of $v$ of a formal Vey Lie algebra is finite dimensional. If $(W, \Lambda, \Gamma)$ is a flat symplectic manifold and $M$ the natural Moyal-Vey bracket given by the sine function, we have $L(M)=L_{S A}$.

(e) Remarks. Invariance of a Vey deformation.

(i) The Lie algebra of vector fields $Z$ (infinitesimal geometric transformations of the manifold $W$ ) which do not depend on $\nu$ and preserve the bracket $Q_{1}$ is also $L\left(Q_{1}\right)$ [9]. (We note that in this case necessarily $Z \in L$.)

(ii) If we now look for vector fields $Z_{v}=Z_{0}+\nu Z_{1}$, where $Z_{0}$ and $Z_{1}$ are 
vector fields independent of $\nu$, which preserve an infinitesimal Vey deformation $Q_{1}$ given by (5-4), we see immediately that $Z_{0} \in L\left(Q_{1}\right)$ and the invariance of $Q_{1}$ (in our notations) reduces to:

$$
i\left(\left[\Lambda,\left[Z_{0}, J\right]+Z_{1}\right]\right)(d u \wedge d v)=0
$$

Proposition 13. A vector field $Z_{0}+\nu Z_{1}$ preserves an infinitesimal Vey deformation $Q_{1}$ if and only if $Z_{0} \in L\left(Q_{1}\right)$ and $\left[Z_{0}, J\right]+Z_{1} \in L$.

(iii) More generally. if we look for a formal series

$$
Z_{v}=\sum_{r=0}^{\infty} \nu^{r} Z_{r}
$$

preserving formally a Vey deformation $Q$ given by (4-10), we need more information on the 2-cochains $Q^{2 r+1}$. In the case of a flat symplectic manifold, (5-21) will preserve formally the natural Moyal-Vey bracket given by (3-10) if and only if, for every $r$, $\mathscr{L}\left(Z_{r}\right) A=0=\mathscr{L}\left(Z_{r}\right) \Gamma$, that is $Z_{r} \in L_{S A}$. For instance, in the case $W=\mathbb{R}^{2 n}$ with the usual connection and the usual Moyal bracket, $Z_{j}$ belongs to the algebra of affine symplectic transformations with coefficients in the field of formal series in $\nu$.

(iv) Still more generally for a flat Poisson manifold $W$, if $u_{\lambda} \in N$ has an inverse $\left(u_{\lambda} *\right)^{-1}$ with respect to the $*_{\lambda}$ product (3-8), $v \rightarrow u_{\lambda} *_{\lambda} v *_{\lambda}\left(u_{\lambda} *\right)^{-1}$ is an automorphism of $N(W)$ depending on $\lambda$. This leads us to the next section.

\section{Derivations Depending on $y$ of a Vey Lie Algebra}

Consider linear maps $D_{v}: N \rightarrow E(N ; \nu)$ defined by means of the formal series:

$$
D_{\nu}=\sum_{s=0}^{\infty} \nu^{s} D_{s}
$$

where $D_{s}$ is an endomorphism of $N$ independent of $\nu$.

Let us look for derivations $D_{\nu}$ of a formal Vey Lie algebra corresponding to a bracket defined by (4-10); we will have formally, for every $u, v \in N$ :

$$
Q\left(D_{\nu} u, v ; \nu\right)+Q\left(u, D_{\nu} v ; \nu\right)-D_{\nu} Q(u, v ; \nu)=0 .
$$

(a) Taking the term of (6-2) independent of $\nu$, we see first that $D_{0}$ is a derivation of the Poisson Lie algebra. There is a $Z_{0}=Z \in L^{c}$ such that

$$
D_{0}=\mathscr{L}(Z)+k(Z) \text {. }
$$

For the term linear in $\nu$, we obtain with the above notations:

$$
\partial D_{1}+(1 / 3 !) \hat{c}_{3} D_{0}=0 .
$$

$595 / \operatorname{III} / \mathrm{x}-6$ 
If we set $T=\mathscr{L}(Z) \Gamma$, we deduce from (5-13) that (6-3) can be written:

$$
\partial D_{1}-(1 / 3 !)\left(\partial B_{T}+4 k(Z) S_{\Gamma}^{3}-E_{Z}\right)=0,
$$

where $E_{z}$ is a bidifferential operator of maximum order 2. It follows from (6-4) that $\partial D_{1}$ is a bidifferential operator of maximum order 3 . Therefore $D_{1}$ is necessarily a differential operator of maximum order 3 and $\partial D_{1}$ has no terms of bidifferential type $(3,3)$. This fact implies $k(Z)=0$. We obtain

LEMMA 14. We have necessarily $D_{0}=\mathscr{L}\left(Z_{0}\right)$, where $Z_{0} \in L$.

(b) If $D$ is an endomorphism of $N$, we set:

$$
\left(\partial_{2 \tau+1} D\right)(u, v) \equiv Q^{2 r+1}(D u, v)+Q^{2 r+1}(u, D v)-D Q^{2 r+1}(u, v) .
$$

Let $Z$ be an element of $L$. If $U$ is a contractible domain of $W$, there is a function $w_{U} \in N(U)$, defined up to an additive constant, such that:

$$
\left.Z\right|_{U}=\mu^{-1}\left(d w_{U}\right)
$$

Since $Q^{2 r+1}$ is null on the constants, we can define a differential operator $Q_{z}^{2 r+1}$ of order $(2 r+1)$ by

$$
\left.Q_{Z}^{2 r+1}(u)\right|_{U}=Q^{2 r+1}\left(w_{U},\left.u\right|_{v}\right) \quad(u \in N) .
$$

It is easy to verify that, if $Z \in L$ satisfies (6-6) on $U$, we have:

$$
\left.\left(\partial_{2 r+1} \mathscr{L}(Z)+\partial Q_{Z}^{2 r+1}\right)(u, v)\right|_{v}=-\partial Q^{2 r+1}\left(\left.u\right|_{v},\left.v\right|_{v}, w_{v}\right) .
$$

For $r=1, \partial Q^{2}=0$ and (6-3) can be written with the above notations:

$$
\partial\left(D_{1}-(1 / 3 !) Q_{z_{0}}^{3}\right)=0 .
$$

We thus obtain:

Proposition 15. The derivations $D_{v}=D_{0}+\nu D_{1}$ of $Q$ up to the order 2 are given by:

$$
D_{0}=\mathscr{L}\left(Z_{0}\right), \quad D_{1}=(1 / 3 !) Q_{Z_{0}}^{3}+\mathscr{L}\left(Z_{1}\right)+k\left(Z_{1}\right)
$$

where $Z_{0} \in L$ and $Z_{1} \in L^{c}$.

(c) $Q$ being a deformation of the Poisson Lie algebra, we have:

$$
\frac{1}{(2 t+1) !} \partial Q^{2 t+1}(u, v, w)=\sum_{\substack{r+s-t \\ r, s>1}} S \frac{1}{(2 r+1) !(2 s+1) !} Q^{2 r+1}\left(Q^{2 s+1}(u, v), w\right)
$$


where $S$ is the summation after cyclic permutation on $u, v, w$. According to the defination of $Q_{Z}^{2 r+1}$, we have on the domain $U$, for $Z \in L$ satisfying (6-6):

$$
\mathscr{S} S Q^{2 r+1}\left(Q^{2 s+1}\left(\left.u\right|_{v},\left.v\right|_{U}\right), w_{U}\right)=\mathscr{S}\left(\partial_{2 r+1} Q_{Z}^{2 \xi+1}\right)(u, v)_{U} \quad(u, v \in N),
$$

where $\mathscr{S}$ is the symmetrizer in $(r, s)$. It follows from $(6-8),(6-9),(6-10)$ that for $Z \in L$ :

$$
\frac{1}{(2 t+1) !}\left(\partial_{2 t+1} \mathscr{L}(Z)+\partial Q_{Z}^{2 t+1}\right)=-\sum_{\substack{r+s=i \\ r, 8>1}} \frac{1}{(2 r+1) !(2 s+1) !} \partial_{2 r+1} Q_{Z}^{2 s+1} .
$$

We deduce from (6-11) that $D_{\nu}$ defined by (6-1) satisfies formally (6-2) if and only if for each $t=1,2, \ldots$ :

$$
\partial D_{t}-\frac{1}{(2 t+1) !} \partial Q_{z_{0}}^{2 t+1}+\sum_{\substack{r+s=t \\ t, s>1}} \frac{1}{(2 r+1) !} \partial_{2 r+1}\left(D_{s}-\frac{1}{(2 s+1) !} Q_{z_{0}}^{2 s+1}\right)=0
$$

(d) Consider a derivation of $Q$ :

$$
D_{v}=\sum_{s=0}^{t-1} \nu^{s} D_{s}
$$

up to the order $t$. We shall prove by induction that we have for $s \leqslant t-2$

$$
D_{s}=\sum_{\substack{r+s^{\prime}=8 \\ r^{\prime}, s^{\prime}>0}} \frac{1}{\left(2 r^{\prime}+1\right) !} Q_{z_{z^{\prime}}+1}^{2 r^{\prime}+1}
$$

that is:

$$
D_{s}=\frac{1}{(2 s+1) !} Q_{Z_{a}}^{2 s+1}+\sum_{\substack{r^{\prime}+s^{\prime}=s \\ r^{\prime}, z^{\prime}>1}} \frac{1}{\left(2 r^{\prime}+1\right) !} Q_{Z_{s^{\prime}}}^{2 r^{\prime}+1}+\mathscr{L}\left(Z_{s}\right)
$$

where $Z_{s} \in L$ for $s=0,1, \ldots,(t-2)$ and for $s=t-1$ :

$$
D_{t-1}=\frac{1}{(2 t-1) !} Q_{Z_{0}}^{2 t-1}+\sum_{r^{\prime}+s^{\prime}=t-1} \frac{1}{\left(2 r^{\prime}+1\right) !} Q_{Z_{z^{\prime}}}^{2 r^{\prime}+1}+\mathscr{L}\left(Z_{t-1}\right)+k\left(Z_{t-1}\right)
$$

where $Z_{t-1} \in L^{c}$.

If we introduce (6-13), (6-14) in (6-12), we obtain:

$$
\begin{aligned}
\partial D_{t} & -\frac{1}{(2 t+1) !} \partial Q_{Z_{0}}^{2 t+1}+\sum_{\substack{r+r^{\prime}+s=t \\
r, r^{\prime}, s>1}} \frac{1}{(2 r+1) !\left(2 r^{\prime}+1\right) !} \partial_{2 r+1} Q_{z_{d}}^{2 r^{\prime}+1} \\
& +\sum_{\substack{r+s=t \\
r>2, i>1}} \frac{1}{(2 r+1) !} \partial_{2 r+1} \mathscr{L}\left(Z_{s}\right)+\frac{1}{3 !} \partial_{3}\left(\mathscr{L}\left(Z_{t-1}\right)+k\left(Z_{t-1}\right)\right)=0 .
\end{aligned}
$$


But, according to (6-11), we have for $s \leqslant t-2$ :

$\frac{1}{(2 r+1) !}\left(\partial_{2 r+1} \mathscr{L}\left(Z_{s}\right)+\partial Q_{Z_{\star}}^{2 r+1}\right)=-\sum_{\substack{r^{\prime}+R^{\prime}-r \\ r^{\prime}, a^{\prime} \geq 2}} \frac{1}{\left(2 r^{\prime}+1\right) !\left(2 s^{\prime}+1\right) !} \partial_{2 r^{\prime}+1} Q_{z_{s}}^{2 s^{\prime}+1}$.

Changing the notations, we obtain:

$$
\begin{aligned}
& \sum_{\substack{r+8=t \\
r>2, s>1}} \frac{1}{(2 r+1) !} \hat{\sigma}_{2 r+1} \mathscr{L}\left(Z_{s}\right)+\sum_{\substack{r+r^{\prime}+s=t \\
r, r^{\prime}, 8>1}} \frac{1}{(2 r+1) !\left(2 r^{\prime}+1\right) !} \partial_{2 r+1} Q_{Z_{s}}^{2 r^{\prime}+1} \\
& =-\sum_{\substack{r+s=t \\
r \geqslant 2,8 \geqslant 1}} \frac{1}{(2 r+1) !} \partial Q_{Z_{z}}^{2 r+1}
\end{aligned}
$$

and (6.15) can be written

$$
\begin{aligned}
\partial D_{t} & -\frac{1}{(2 t+1) !} \partial Q_{Z_{0}}^{2 t+1} \\
& -\sum_{\substack{r+8-t \\
r \geq 2,8>1}} \frac{1}{(2 r+1) !} \partial Q_{Z_{t}}^{2 r+1}+\frac{1}{3 !} \partial_{3}\left(\mathscr{L}\left(Z_{t-1}\right)+k\left(Z_{t-1}\right)\right)=0 .
\end{aligned}
$$

We see that $\partial_{3}\left(\mathscr{L}\left(Z_{t-1}\right)+k\left(Z_{t-1}\right)\right)$ is an exact 2-cocycle. The argument of Section 6 a gives $k\left(Z_{t-1}\right)=0$ and $Z_{t-1}$ belongs necessarily to $L$. We obtain:

$$
\partial\left(D_{t}-\frac{1}{(2 t+1) !} Q_{Z_{0}}^{2 t+1}-\sum_{\substack{r+s=t \\ r, s \geq 1}} \frac{1}{(2 r+1) !} Q_{z_{s}}^{2 r+1}\right)=0 .
$$

Therefore:

$$
D_{t}=\frac{1}{(2 t+1) !} Q_{Z_{0}}^{2 t+1}+\sum_{\substack{r+s-t \\ r, s \geqslant 1}} \frac{1}{(2 r+1) !} Q_{Z_{t}}^{2 r+1}+\mathscr{L}\left(Z_{t}\right)+k\left(Z_{t}\right)
$$

where $Z_{t} \in L^{c}$. We have proved:

Proposition 16. The derivations $D_{\nu}$ of $Q$ up to the order $t$ are given by (6-13) and (6-14).

(e) We denote by $L^{*}$ the Lie algebra of the globally Hamiltonian vector fields. It is known that $[L, L]=L^{*}$ and $\operatorname{dim} L / L^{*}=b_{1}(W)$, where $b_{1}(W)$ is the first Betti number of $W$. Let $E(L ; \nu)$ (resp. $E\left(L^{*} ; \nu\right)$ ) be the space of the formal series in $\nu$ with coefficients in the Lie algebra $L$ (resp. $L^{*}$ ). An element $Z_{\nu}$ of $E(L ; \nu)$ is given by:

$$
Z_{\nu}=\sum_{s=0}^{\infty} \nu^{s} Z_{s} \quad\left(Z_{s} \in L\right)
$$

$E(L ; \nu)$ admits a natural structure of Lie algebra given by the bracket of the vector fields and $[E(L ; \nu), E(L ; \nu)]=E\left(L^{*} ; \nu\right)$. 
It follows from the above proposition that there is an isomorphism from the space $E(L ; \nu)$ onto the space of the derivations

$$
D_{\nu}=\sum_{t=0}^{x} \nu^{t} D_{t}
$$

defined by $\rho: Z_{\nu} \rightarrow D_{\nu}$, with:

$$
D_{t}=\sum_{\substack{r \rightarrow R=t \\ r, a \geq 0}} \frac{i}{(2 r+1) !} Q_{Z_{x}}^{2 r+1}
$$

If $Z$ belongs to $L$, we obtain

$$
\rho(Z)=\sum_{t=0}^{x} \frac{v^{t}}{(2 t+1) !} Q_{Z}^{2 t+1}
$$

and we have:

$$
\rho\left(Z_{v}\right)=\sum_{r, s=0}^{\infty} \frac{\nu^{r+s}}{(2 r+1) !} Q_{Z_{s}}^{2 r-1}=\sum_{s=0}^{x} \nu^{s} \rho\left(Z_{s}\right)
$$

If $Z_{\nu} \in E\left(L^{*} ; \nu\right)$ we obtain an inner derivation of the Vey Lie algebra and if $Z_{;}^{\prime} \in E\left(L^{*} ; \nu\right)$ we have in the sense of the endomorphisms of $E(N ; \nu)$ :

$$
\rho\left(\left[Z_{\nu}, Z_{\nu}^{\prime}\right]\right)=\rho\left(Z_{\nu}\right) \rho\left(Z_{\nu}^{\prime}\right)-\rho\left(Z_{\nu}^{\prime}\right) \rho\left(Z_{\nu}\right)
$$

If we consider a contractible domain of $W$, the formula (6-21) can be extended to arbitrary $Z_{\nu}, Z_{\nu}{ }^{\prime} \in E(L ; \nu)$. Therefore $\rho$ is an isomorphism of the Lie algebra $E(L ; \lambda)$ onto the Lie algebra of the derivations. We have proved:

THEOREM 17. The Lie algebra of the derivations of a Vey Lie algebra defined by $Q$ is isomorphic with the Lie algebra $E(L ; \nu)$ by the following isomorphism $\rho: Z_{y} \in E(L ; v) \mapsto D_{v}$, where

$$
D_{\nu}=\sum_{r, s} \frac{\nu^{r+s}}{(2 r+1) !} Q_{Z_{s}}^{2 r-1} \quad(r, s \geqslant 0)
$$

The Lie algebra of the inner derivations is isomorphic to the Lie algebra $E\left(L^{*} ; \nu\right)$ and the first cohomology space $H^{1}(Q)$ of the Vey Lie algebra for the Chevalley cohomology is isomorphic to $E(L ; \nu) / E\left(L^{*} ; \nu\right)$. If $b_{1}(W)=0$, all the derivations of a Vey Lie algebra are inner derivations.

The derivations of associative algebra deformations giving rise to a Vey Lie algebra coincide with the (local) derivations of that Lie algebra. 


\section{C-Equivalence of Deformations of $N$}

(a) Let $[u, v]_{v}^{(0)}$ be a formal deformation of $N$

$$
[u, v]_{v}^{(0)}=\sum_{r=0}^{\infty} \nu^{\tau} C_{r}^{(0)}(u, v)=\{u, v\}+\sum_{r=1}^{\infty} \nu^{r} C_{r}^{(0)}(u, v)
$$

where the $C_{r}^{(0)}(r \geqslant 1)$ are differentiable 2-cochains on $N$.

Consider an alternate bilinear map $N \times N \rightarrow E(N ; \nu)$ which gives a formal series in $\nu$ :

$$
[u, v]_{v}^{(1)}=\sum_{r=0}^{\infty} v^{r} C_{r}^{(1)}(u, v)=\{u, v\}+\sum_{r=1}^{\infty} \nu^{r} C_{r}^{(1)}(u, v)
$$

where the $C_{r}^{(1)}(r \geqslant 1)$ are also differentiable 2-cochains on $N$. All these cochains can be extended naturally to $E(N ; \nu)$. We set:

$$
D_{r}^{(1)}(u, v, w)=\sum_{\substack{r+g=t \\ r, s>0}} S C_{r}^{(1)}\left(C_{8}^{(1)}(u, v), w\right) .
$$

We have $D_{0}^{(1)}=0 ;(7-2)$ is a deformation if and only if $D_{t}^{(1)}=0$ for $t=1,2, \ldots$ Consider next a formal series in $\nu$ :

$$
T_{\nu}=\sum_{s=0}^{\infty} \nu^{8} T_{s}=I d+\sum_{s=1}^{\infty} \nu^{8} T_{s}
$$

where the $T_{s}$ are differential operators on $N ; T_{v}$ acts naturally on $E(N ; \nu)$. We have also a natural definition of a product $T_{\nu} \cdot T_{v}{ }^{\prime}$ and of the inverse $T_{\nu}^{-1}$ of $T_{\nu}$. Consider:

$$
T_{\nu}[u, v]_{\nu}^{(1)}-\left[T_{\nu} u, T_{\nu} v\right]_{\nu}^{(0)}=\sum_{t=0}^{\infty} \nu^{t} F_{t}(u, v)
$$

where we have introduced the 2-cochains:

$$
F_{t}(u, v) \equiv \sum_{r+s=t} T_{s} C_{r}^{(1)}(u, v)-\sum_{r+s+s^{\prime}=t} C_{\tau}^{(0)}\left(T_{s} u, T_{s^{\prime}} v\right) \quad\left(r, s, s^{\prime} \geqslant 0\right)
$$

We have $F_{0}=0$. We set:

$$
\begin{aligned}
G_{t}(u, v) \equiv & \sum_{r+s=t} T_{s} C_{\tau}^{(1)}(u, v)-\sum_{r+s+s^{\prime}=t} C_{\tau}^{(0)}\left(T_{s} u, T_{s^{\prime}} v\right)-\sum_{s+s^{\prime}=t}\left\{T_{s} u, T_{s} v\right\} \\
& -\sum_{\tau+s=t}\left(C_{\tau}^{(0)}\left(T_{s} u, v\right)+C_{r}^{(0)}\left(u, T_{s} v\right)\right) \quad\left(r, s, s^{\prime} \geqslant 1\right)
\end{aligned}
$$


and we obtain:

$$
F_{t}=C_{t}^{(1)}-C_{t}^{(0)}-\partial T_{t}+G_{t}
$$

If we evaluate $S T_{v}\left[[u, v]_{v}^{(1)}, w\right]_{v}^{(1)}$ in two different ways, we obtain:

LEMMA 18. The formal deformation (7-1) being given, for each bilinear map (7-2) and for each formal series (7-3), we have the identities for $t=1,2, \ldots$ :

$$
\begin{aligned}
D_{t}^{(1)}(u, v, w) & +\sum_{r+s=t} T_{s} D_{r}^{(1)}(u, v, w) \\
= & -\partial F_{t}(u, v, w)+S \sum_{r+s=t} F_{r}\left(C_{s}^{(1)}(u, v), w\right)+S \sum_{r+s=t}\left\{F_{r}(u, v), T_{s} u^{\prime}\right\} \\
& +S \sum_{r+s=t} C_{r}^{(0)}\left(F_{s}(u, v), w\right)+S \sum_{r+s+s^{\prime}=t} C_{r}^{(0)}\left(F_{s}(u, v), T_{s}^{\prime} w\right) \quad\left(r, s, s^{\prime} \geqslant 1\right) .
\end{aligned}
$$

Suppose (7-2), (7-3) such that we have formally the identity:

$$
T_{\nu}[u, v]_{\nu}^{(1)}-\left[T_{\nu} u, T_{\nu} v\right]_{\nu}^{(0)}=0
$$

that is $F_{t}=0(t=1,2, \ldots)$. We have $C_{t}^{(1)}=C_{t}^{(0)}+\partial T_{t}-G_{t}$. It follows that (7-3) determines (7-2) satisfying (7-6) in a unique way. For this map (7-2), we deduce from (7-5):

$$
D_{t}^{(1)}(u, v, w)+\sum_{r+s=t} T_{s} D_{r}^{(1)}\left(u, v, w^{\prime}\right)=0 \quad(r, s \geqslant 1 ; t=1,2, \ldots)
$$

and so, by induction, $D_{t}^{(1)}=0$ for each $t$. Therefore (7-2) satisfies formally the Jacobi identity.

Proposition 19. The formal deformation (7-1) being given, each formal series (7-3) generates a unique bilinear map (7-2) satisfying (7-6). This map is a new formal deformation of the Lie algebra $N$.

(b) We are led to the following definition.

DEFINIIION 20. Two formal deformations of $N$ are called cohomologically equivalent (c-equivalent) if there is a formal series (7-3) such that the identity (7-6) is formally satisfied.

It is easy to verify that we have defined thus effectively an equivalence relation.

Consider a formal deformation $[u, v]_{v}^{(1)}$ of $N\left(D_{t}^{(1)}=0\right.$ for $\left.t=1,2, \ldots\right)$ and suppose this deformation $c$-equivalent to the deformation $[u, v]_{v}^{(0)}$, up to the order $q$ : We have by assumption $F_{t}=0$ for $t=1,2, \ldots,(q-1)$ for some $T_{t}$ 's, that is $C_{t}^{(1)}-C_{t}^{(0)}+$ $G_{t}=\partial T_{t}(t=1, \ldots,(q-1))$. For $t=q,(7-5)$ gives only

$$
\partial\left(C_{q}^{(1)}-C_{a}^{(0)}+G_{q}\right)=0 .
$$


The deformation $[u, v]_{v}^{(1)}$ is c-equivalent to the deformation $[u, v]_{v}^{(0)}$ up to the order $(q+1)$ if the 2-cocycle $\left(C_{q}^{(1)}-C_{q}^{(0)}+G_{q}\right)$ is exact. The cohomology class defined by this 2-cocycle is the obstruction to the c-equivalence at the order $q$.

We have $G_{1}=0$. An infinitesimal deformation defined by the 2 -cocycle $C_{1}^{(1)}$ is $c$-equivalent to the infinitesimal deformation defined by the 2-cocycle $C_{1}^{(0)}$ if the 2-cocycle $\left(C_{1}^{(\mathbf{1})}-C_{\mathbf{1}}^{(\mathbf{0})}\right)$ is exact.

We recall that, for the flat case, we have for the local Chevalley cohomology:

$$
\operatorname{dim} H^{2}(N)=1
$$

Therefore, at each order $q$, we have in the flat case only two choices of cochains $C_{q}$, up to $c$-equivalence of formal deformations (the trivial, and the one given by the cohomology class $\beta$ ): altogether, we have at most $2^{q}$ deformations (up to $c$-equivalence) at order $q$, and $2^{\aleph_{0}}=\aleph_{1}$ classes of formal deformations. However, at each level there is only one nontrivial choice to make in this case.

\section{General Deformations of the Associative Algebra $N$ (A STAR-PRODUCT IS BORN)}

We saw that (3-14) defines a deformation of the associative algebra $N$ of $C^{\infty}$ functions over a symplectic manifold $W$ if $\Gamma$ is without torsion and curvature. It is natural to ask whether a formula analogous to (4-10) can be obtained for the associative algebra when such connections do not exist. Vey proved the existence of a Lie algebra deformation (4-10) -without giving explicit formulas for $Q^{2 r+1}$ when $r>1$-under the technical assumption $H^{3}(W ; \mathbb{R})=0$ by tracing at each step the possible obstructions to the continuation of the truncated deformation in the (finite-dimensional) third differentiable cohomology space. However, in the associative case the obstructions space is isomorphic to the huge functional space of the global sections over $W$ of the fiber bundle $A^{3} T W$ (skew-symmetric 3-tensor fields): the same method is therefore impractical, except of course when $\operatorname{dim} W=2$, in which case the obstructions disappear. As a matter of fact, Vey was able to find cochains $Q^{r}$ satisfying the associative property modulo terms of higher order in $\lambda$ only up to the order $r=5$.

We shall present a procedure for obtaining an associative deformation which we may write symbolically as $\exp (\lambda Q)(u, v)$ :

$$
u *_{\lambda} v=u v+\sum_{r=1}^{\infty} \frac{\lambda^{r}}{r !} Q^{r}(u, v), \quad u, v \in N
$$

where $Q^{1}=P$ and the cochains $Q^{r}$ are explicitly determined, when the manifold $W$ can be imbedded in some $\mathbb{R}^{2 k}$ in a suitable way. We shall illustrate the procedure by an example [14] that will be needed later for the hydrogen atom problem. 
Let the sphere $S^{l}$ be imbedded in $\mathbb{R}^{l+1}$ with radius 1 , and consider the symplectic manifold $W=T^{*} S^{l}$ in $\hat{W}=\mathbb{R}^{2 l+2}=T^{*} \mathbb{R}^{l+1}$ defined by the two constraints [15]:

$$
|\pi|^{2}=\sum_{\alpha=1}^{l+1}\left(\pi^{\alpha}\right)^{2}=1, \quad \pi \cdot \xi \equiv \sum_{\alpha=1}^{l+1} \pi^{\alpha} \xi_{\alpha}=0 .
$$

Here $\left(\pi^{\alpha}, \xi_{\alpha}\right)$ are canonical coordinates of $T^{*} \mathbb{R}^{l+1}$ and this space is endowed with the usual symplectic structure $\hat{F}=\sum_{\alpha=1}^{l+1} d \pi^{\alpha} \wedge d \xi_{\alpha}$. We shall denote by $\hat{\Gamma}$ the canonical flat symplectic connection of $\hat{W}$, so that in the coordinates $\left(\pi^{2}, \xi_{\alpha}\right)$ the covariant derivative is nothing but the usual partial derivative, and by $\hat{P r}$ the bidifferential operator defined by (3-1)-the $r$ th power of the Poisson bracket $\hat{P}$ of $\hat{W}$ in the canonical coordinates.

Notice that $\hat{P}\left(\frac{1}{2}|\pi|^{2}, \pi \cdot \xi /|\pi|^{2}\right)=1$; that is, $W$ is defined by a pair of canonically conjugate constraints. In accordance with the general theory of second-class submanifolds $[6 c, 16 a]$ the canonical symplectic form $F$ of $W$, induced by $\hat{F}$, defines the Poisson bracket $P$ of $W$.

We shall now define a "thickening" of $W$ to an open subset of $W$ by a group $G$ of symplectic transformations, so that on $G$-invariant functions $P$ will coincide with $P$. Moreover $G$ will be chosen as a subgroup of $S p(2 l+2, \mathbb{R})$, hence will be affine symplectic for $\hat{P}$, so that the restriction of $\hat{P}^{r}$ to $G$-invariant functions will still be a $G$-invariant function and thus define a cochain $Q^{r}$ on $N(W)$. More precisely, let $G$ be the following representation of the two-dimensional (non-Abelian) solvable group in $\mathbb{R}^{2 l+2}$ :

$$
\left(\pi^{\alpha}, \xi_{\alpha}\right) \mapsto\left(\rho \pi^{\alpha}, \rho^{-1} \xi_{\alpha}+\sigma \pi^{\alpha}\right), \quad \rho>0, \sigma \in \mathbb{R} .
$$

The space of the orbits of $G$ in $\hat{W}_{0}=\left(\mathbb{R}^{l+1}-\{0\}\right) \times \mathbb{R}^{l+1}$ is diffeomorphic to $W=T^{*} S^{l}$, the projection of $\hat{W}_{0}$ onto $W$ being given by

$$
\phi:\left(\pi^{\alpha}, \xi_{\alpha}\right) \mapsto\left(\pi^{\alpha} /|\pi|,|\pi| \xi_{\alpha}-(\pi \cdot \xi /|\pi|) \pi^{\alpha}\right) .
$$

Note that it is the representation of $W$ as a suitable quotient that matters, the imbedding being used for commodity only. Now $\phi$ defines an isomorphism $\bar{\phi}$ between the space $\hat{N}_{G}$ of differentiable $G$-invariant functions on $\hat{W}_{0}$ and $N=N(W)$ by

$$
\tilde{\phi}:\left.\hat{N}_{G} \ni \hat{u} \mapsto \hat{u}\right|_{W}=u \in N, \quad \oint^{-1}: u \mapsto \hat{u}=u \circ \phi .
$$

From what has been said before, we take $\phi(\hat{P}(\hat{u}, \hat{v}))=P(u, v)$. The group $G$ is generated in $\hat{W}$ by the vector fields

$$
Z=\pi^{\alpha}\left(\partial / \partial \pi^{\alpha}\right)-\xi_{\alpha}\left(\delta / \partial \xi_{\alpha}\right), \quad T=\pi^{\alpha}\left(\partial / \hat{\epsilon} \xi_{\alpha}\right) .
$$

We have

$$
\mathscr{L}(Z) \Lambda=0=\mathscr{L}(T) \Lambda, \quad \mathscr{L}(Z) \hat{\Gamma}=0=\mathscr{L}(T) F
$$


therefore, with $\nabla$ defined in $\hat{W}$ by $\hat{\Gamma}$, for every $\hat{u}, \hat{z} \in \hat{N}_{G}$ :

$$
\hat{P}^{r}(\hat{u}, \hat{v})=\hat{\Lambda}^{A_{1} B_{1}} \cdots \hat{\Lambda}^{A_{r} B_{\tau}} \nabla_{A_{1} \cdots A_{r}} \hat{u} \nabla_{B_{1} \cdots B_{r}} \hat{v} \in \hat{N}_{G}
$$

(summation $A, B=1, \ldots, 2 l+2$ ) so that we can define, for $u, v \in N$ :

$$
Q^{r}(u, v)=\tilde{\phi} \hat{P}^{r}\left(\tilde{\phi}^{-1} u, \tilde{\phi}^{-1} v\right)=\left.\hat{P}^{r}(\hat{u}, \hat{v})\right|_{W}
$$

and (8-1) defines in a natural and global way an associative $*_{\lambda}$-product on $N(W)$, with a corresponding Vey deformation

$$
Q_{v}(u, v)=\sum_{r=0}^{\infty}\left(\nu^{r} /(2 r+1) !\right) Q^{2 r+1}(u, v)
$$

This procedure can obviously be generalized to other symplectic manifolds that can be realized as quotients of an open set in some $\mathbb{R}^{2 k}$, foliated by the orbits of an affine symplectic subgroup. For example, one could take a hyperboloid instead of a sphere by replacing in (8-2) the Euclidean summation by a pseudo-Euclidean one. (It is important to take $|\pi|^{2} \neq 0$ because the cone is $G$-invariant. When $|\pi|^{2}=0$ one does not have a pair of conjugate constraints and the representation of $W$ as a quotient fails.) Using procedures of this kind [16b], twisted products for cotangent bundles of most classical groups and Stiefel manifolds have been obtained.

\section{INVARIANT *-PRODUCTS}

(a) Let $(W, A)$ be a Poisson manifold and $N=C^{\infty}(W, \mathbb{C})$. For $f, g \in N$, $\{f, g\}=\Lambda(d f, d g)$. Every $a \in N$ defines an infinitesimal canonical transformation given by $X_{a} f=\{a, f\}$ that preserves the Poisson bracket (Jacobi identity):

$$
X_{a}\{f, g\}=\left\{X_{a} f, g\right\}+\left\{f, X_{a} g\right\}, \quad \forall f, g \in N .
$$

This is an inner derivation of the Poisson Lie algebra $N$.

Let a *-product on $W$ (a bilinear, associative, internal composition law on $N$ ) be given and let $a \in N$. We say that the *-product is $a$-invariant if $X_{a}$ preserves the *-product:

$$
X_{a}(f * g)=\left(X_{a} f\right) * g+f *\left(X_{a} g\right)
$$

In other words

$$
\{a, f * g\}=\{a, f\} * g+f *\{a, g\}, \quad \forall f, g \in N .
$$

If the *-product is $a$-invariant and $b$-invariant then it is $\{a, b\}$-invariant. The set of all $a \in N$ for which the *-product is $a$-invariant is thus a Poisson Lie algebra of derivations of $N$ (with the *-product structure). 
(b) Conversely, let $\mathscr{A}$ be any finite-dimensional subalgebra of the Poisson Lie algebra $N$. We pose the problem of constructing a $*$-product on $W$ that is $\mathscr{A}$-invariant; that is, $a$-invariant for every $a \in \mathscr{A}$. This, in our view, is a central problem of quantization, a problem that is discussed at length in the companion article [10]. Recall that the Moyal *-product is invariant under the group of affine symplectic transformations, and that conventional quantization realizes this group as a group of unitary operators. In general, the $C^{x}$ functions on $W$ that belong to $\mathscr{A} C N$ will be taken to have significance as a preferred set of physical observables; hence we require that the Lie algebra $\mathscr{A}$ be preserved by the deformation; precisely (henceforth we write $*$ for $*_{\lambda}$ )

$$
a * b-b * a=i \hbar\{a, b\}, \quad \forall a, b \in \mathscr{A}
$$

where $i \hbar / 2=\lambda$ is the deformation parameter. In addition, it will be supposed that the set of observables belonging to $\mathscr{A}$ is "sufficiently large." Let $\left\{L^{A}\right\}(A=1, \ldots, m)$ be a basis for $\mathscr{A}$ and let $J$ be the map of $W$ into $\mathscr{A}^{*}$ given by $x \mapsto \xi(x)$ where $\xi^{\wedge}(x)=$ $L^{A}(x)$ [17]. The action of the vector field $X_{a}$ in $W$ is now transferred to the image of $J$ by $d J$ and this is just the coadjoint action ad* of $\mathscr{I}$ in $\mathscr{I}^{*}$. The image $M$ of $W$ by the map $J$ is therefore an $a^{*} \mathscr{A}^{*}$-invariant submanifold of $\mathscr{A}^{*}$. The algebra $\mathscr{A}$ is "sufficiently large" if this manifold is diffeomorphic to the manifold of actual interest; this happens if $J: W \rightarrow M$ is locally bijective (if $W$ is the manifold of interest) or more generally if we are interested in constraint manifolds with constraints in Ker $J$. In any case we now direct the attention to $M \subset \mathscr{A}^{*}$ and formulate a precise mathematical problem.

(c) Let $\mathscr{A}$ be a Lie algebra of dimension $m$ over $R$ and $\mathscr{A}^{*}$ its real dual. We identify $\mathscr{A}$ with the space $\mathscr{A}^{* *}$ of linear functionals over $\mathscr{A}^{*}$; in particular this means that a basis $\left\{L^{A}\right\}(A=1, \ldots, m)$ for $\mathscr{A}$ is also a set of coordinates for $\mathscr{A}^{*}$. A polynomial over $\mathscr{A}^{*}$ is a polynomial in $L^{1}, \ldots, L^{\mathrm{m}}$ with coefficients in $\mathbb{C}$. We denote by $U(\mathscr{A})$ the enveloping algebra and by $S(\mathscr{A})$ the symmetric algebra of the complex extension of $\mathscr{A}$, and by $\mathscr{P}$ the algebra of polynomials over $\mathscr{A}^{*}$, naturally isomorphic to $S(\mathscr{A})$ [18]. The natural Poisson structure on $\mathscr{A}^{*}$ was described in Section 2.

Let $M$ be an algebraic submanifold of $\mathscr{A}^{*}$, invariant under ad* ${ }^{*}$, and let $\Pi$ denote the projection of $\mathscr{P}, \mathscr{P} \rightarrow \mathscr{P} / \mathscr{I}$ where $\mathscr{I}$ is the ideal of polynomials in $\mathscr{P}$ vanishing on $M$. Thus $\operatorname{Ker} \Pi=\mathscr{I}=\{f \in \mathscr{P} ; f \mid M=0\}$ and $\Pi(\mathscr{P})=\mathscr{P} / \operatorname{Ker} \Pi$. Commutativity of the diagram

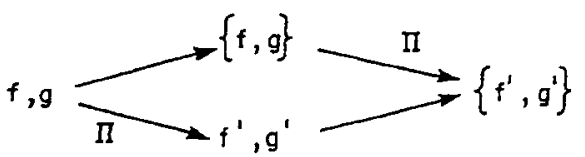

defines the Poisson bracket $\left\{f^{\prime}, g^{\prime}\right\}$ on $\Pi(\mathscr{P})$ and induces on $M$ the structure of a Poisson manifold. This is well defined because $\operatorname{Ker} \Pi$ is ad $\mathscr{A}$-invariant: $f \in \operatorname{Ker} \Pi \Rightarrow$ $\{a, f\} \in \operatorname{Ker} \Pi, \forall a \in \mathscr{A}$. 
DEFINITION 21. An invariant *-product on $M$ is an internal composition law on $\Pi(\mathscr{P})$, written $f, g \mapsto f^{*} g$, associative and distributive over $\mathbb{C}$, such that

$$
\left.\begin{array}{l}
k * f=f * k=k f, \\
a * b-b * a=i \hbar\{a, b\}, \\
\{a, f * g\}=\{a, f\} * g+f *\{a, g\},
\end{array}\right\} \forall f, g \in \Pi(\mathscr{P}) .
$$

Here and below we still denote by $a, b$ the restrictions to $M$ of $a, b \in \mathscr{A}$, considered as linear functions on $A^{*}$. The problem that we are interested in is the construction of all invariant ${ }^{*}$-products on $M$. Concerning the motivation, we may add that the restriction of $\mathscr{A}^{*}$ to $M$ sometimes has a direct physical interpretation. In fact, any element $q$ in the center of the Lie algebra $\mathscr{P}$ (with Poisson bracket) is a canonical invariant and is expected to remain so after quantization. Fixing $q$ in $\mathbb{R}$ defines an invariant submanifold $M$ of $\mathscr{A}^{*}$; see also Section $11 \mathrm{~b}$.

\section{EXAmples of INVARIANT *-Products}

We shall make use of the formula (3-8) to obtain some examples of invariant *-products.

(a) Let $(W, F, \Gamma)$ be a connected, paracompact, symplectic $C^{\infty}$ manifold of dimension $2 n$, fundamental 2-form $F$, and connection $\Gamma$. It will be assumed throughout that the covariant derivative $\nabla$ of $F$ vanishes. Let $\left\{x^{i}\right\}(i, j=1, \ldots, 2 n)$ be a local chart with domain $U$. For $u, v \in C^{x}(W, \mathbb{C})$ define

$$
u * v=\sum_{k=0}^{\infty} \frac{\lambda^{k}}{k !} u^{i_{1} \cdots i_{k}} v_{i_{1} \cdots i_{k}}
$$

with $\lambda=i \hbar / 2$ and

$$
v_{i_{1} \cdots i_{k}}=\nabla_{i_{1} \cdots i_{k}} v=F_{i_{1} s_{1}} \cdots F_{i_{k} j_{k}} v^{j_{1} \cdots j_{k}}
$$

Recall from Section 3d that this product is associative if and only if the torsion and the curvature of $\Gamma$ vanish and suppose that this is the case. Denote by $\operatorname{Inv}(F, \Gamma)$ the subalgebra of the Poisson Lie algebra $N=C^{\infty}(W, \mathbb{C})$ that consists of all $a \in N$, independent of $\lambda$, such that $(10-1)$ is $a$-invariant (Section 9a). This algebra is isomorphic to-and, if $T=0$, equal to-the semidirect product of $\operatorname{Sp}(2 n, \mathbb{R})$ and the Heisenberg Lie algebra $H_{n}$. Of course, its representation by vector fields (considered in Section 5) is the semidirect product of $\operatorname{Sp}(2 n, \mathbb{R})$ and the Abelian algebra $\mathbb{R}^{2 n}$.

(b) Let $\mathscr{A}$ be any subalgebra of $\operatorname{Inv}(F, \Gamma)$ and $J$ the map of $W$ into $\mathscr{A}^{*}$ defined in Section 9c. Let $M=\operatorname{Im}(J) \subset \mathscr{A}^{*}$ and denote by $J^{*}$ the map of $C^{\infty}(M, \mathbb{C})$ into $N$ defined by

$$
J^{*}: f \mapsto f \circ J
$$


Finally, let $N_{0}=\operatorname{Im}\left(J^{*}\right) \subset N$ and assume that $N_{0}$ is a *-subalgebra of $N$. In that case a *-product on $M$ is defined by

$$
(f * g)=J=(f \circ J) *(g \circ J) .
$$

We give some examples, taking $(W, F, \Gamma)$ to be $\mathbb{R}^{n} \times \mathbb{R}^{n}$ with the ordinary symplectic structure.

EXAMPLE 22. Let $\mathscr{A}=H_{n}$ with basis $x^{2}, \ldots, x^{2 n}, x^{2 n+1}=e ; M=\operatorname{Im}(J)$ is determined by $e=1$ and is a single $2 n$-dimensional orbit of ad* $\mathscr{A d}^{*}$ in $\mathscr{A}^{*}$. Moreover, ad ${ }^{*}$ can be identified with $W, J$ is the identity map, and $N_{0}=N$.

EXAMPLE 23. Let $\mathscr{A}=\operatorname{Sp}(2 n, \mathbb{R})$ with basis $\left\{x^{i} x^{j}\right\}(i, j=1, \ldots, 2 n) ; M$ is a single, $2 n$-dimensional orbit; $N_{0}$ consists of all even functions of $x^{1}, \ldots, x^{2 n}$ and is a ${ }^{*}$-subalgebra of $N$.

EXAMPLE 24. Let $x^{1}, \ldots, x^{2 n}=q^{1}, \ldots, q^{n} ; p^{1}, \ldots t p^{n}$, and $\mathscr{A}=S O(n)$ with basis $L^{i j}=q^{i} p^{j}-q^{j} p^{i}(i, j=1, \ldots, n)$. The commutant $\mathscr{B}$ of $\mathscr{A}$ in $\operatorname{Inv}(F, \Gamma)$ has the basis $\sum q^{i} q^{i}, \sum q^{i} p^{i}, \sum p^{i} p^{i}$. The commutant $N_{\mathscr{B}}$ of $\mathscr{B}$ in $N$ consists of functions of $L^{i j}$ and therefore it coincides with $N_{0}$. It follows (see the Lemma below) that $N_{0}$ is a *-subalgebra of $N$. In this case $M$ contains many orbits.

This last example has a number of easy generalizations; thus one may introduce a symmetric, nondegenerate form $g$ on $\mathbb{R}^{n}$ and take for $\mathscr{B}$ the span of $g(q, q), g(q, p)$, $g(p, p)$, obtaining an invariant ${ }^{*}$-product on $M \in \mathscr{A}^{*}$, where $\mathscr{A}$ is the pseudoorthogonal algebra defined by $g$. The success of these constructions depends on

LEMMA 25. Let $\mathscr{B}$ be any subalgebra of $\operatorname{Inv}(F, \Gamma)$ and $N_{\mathscr{B}}$ the commutant of $\mathscr{B}$ in $N$; then $N_{\rightarrow}$ is a ${ }^{*}$-subalgebra of $N$.

Proof. If $u, v \in N_{\mathscr{B}}$ and $b \in \mathscr{B} \subset \operatorname{Inv}(F, \Gamma)$, then $\{b, u * v\}=\{b, u\} * v+u *\{b, v\}=0$ so that $u * v \in N_{\text {a }}$.

These ideas have interesting applications to systems with constraints, especially in connection with the problem of quantization. Such applications, where one takes for $\mathscr{B}$ the algebra of first and second class constraints, are discussed in Section 8 and in Part II [10].

(c) We return to a flat symplectic $(W, F, \Gamma)$ with structure tensor $\Lambda=\mu^{-1}(F)$. For $x \in U$, let

$$
L_{i}{ }^{A}(x)=\dot{c} L^{A}(x) / \partial x^{1}
$$

be the components of $\left.d J\right|_{x}$. Any contravariant tensor $S(x)$ with components $S^{i_{1} \cdots t_{j}}(x)$ at $x$ determines a contravariant tensor $S(\xi)=\left.d J\right|_{x} S(x)$ at $\xi=J(x)$, with components

$$
S^{A_{1} \cdots A_{k}}(\xi)=L_{i_{1}}^{A_{1}}(x) \cdots L_{i_{k}}^{A_{k}}(x) S^{i_{1} \cdots i_{k}}(x),
$$


and a tensor field $S$ on $W$, projectable by $J$, determines a tensor field on $M=\operatorname{Im}(J)$. In particular,

$$
\hat{\Lambda}^{A B}=L_{i}{ }^{A} L_{j}^{B} \Lambda^{i j}
$$

and $\hat{\Lambda}$ describes the restriction $\Lambda_{M}$ to $M$ of the structure 2-tensor of $\mathscr{A}^{*}$ introduced in Section $2 a$. A tensor defined by (10-6) vanishes if any argument is in $\operatorname{Ker}\left(\left.d J\right|_{x}\right)$; therefore by restriction to $T_{\xi} M$ a $J$-projectable tensor field $S$ on $W$ defines by (10-6) a tensor field $S_{M}$ on $M$. Note that any tensor field $S_{M}$ on $M$ can be defined by components with respect to a basis in $\mathscr{A}^{*}$.

From now on it will be supposed that the map $J: W \rightarrow M$ is locally bijective. [If $J$ is locally bijective except on a subset of lower dimension one removes this subset from $W$.$] In this case M$ is an orbit of ad* ${ }^{*}$ in $\mathscr{A}^{*}$ and $\Lambda_{M}$ determines a symplectic structure on $M$; also $\operatorname{Ker}(d J)=\operatorname{Ker} \hat{\Lambda}$. We stress that this limitation is a matter of convenience, since a $*$-product is induced on $M$ under the weaker condition that $N_{0}$ be a *-subalgebra of $N$.

The image $f=d J(T)$ is a "pseudoconnection" and its components can be defined by

$$
F^{A B . C}=L_{i}{ }^{A} L_{j}{ }^{B}\left(\Lambda^{i k} \Lambda^{j l} L_{k l}^{C}-\Gamma^{i j k} L_{k}{ }^{C}\right)
$$

where $L_{k l}^{C}=\partial^{2} L^{C} / \partial x^{k} \partial x^{l}$. We can set $\hat{\Lambda}^{A D} f_{D}^{B C}=f_{A B . C}$, so that the components $F_{C}^{A B}$ of the "pseudoconnection" are determined (and need to be determined) only to the extent that they are defined by this identity.

The "contravariant derivative" of the field (10-6) is the image by $d J$ of the contravariant derivative of $S$. Since $S$ vanishes on $\operatorname{Ker} \Lambda$, its components are well defined by

$$
\left\{L^{B} ; S^{A_{1} \cdots A_{k}}\right\} \equiv\left\{L^{B}, S^{A_{1} \cdots A_{k}}\right\}-\sum_{i=1}^{k} \Gamma^{B A_{i}} S^{A_{1} \cdots C \cdots A_{k}}
$$

The *-product $f * g$ for $f, g \in C^{\infty}(M, \mathbb{C})$ was defined by (10-4); direct calculation gives

$$
f * g=\sum_{k=0}^{\infty}\left(\lambda^{k} / k !\right) f^{A_{1} \cdots A_{k}} g_{A_{1} \cdots A_{k}}
$$

where

$$
f^{A_{1} \cdots A_{k}} \equiv\left\{L^{A_{k}} ;\left\{\cdots ;\left\{L^{A_{1}}, f\right\} \cdots\right\}\right.
$$

and where the "covariant components" $g_{A_{1} \cdots A_{k}}$ are defined (and need to be defined) only to the extent that they are determined by the equation $g^{B_{1} \cdots B_{k}}=\bar{A}^{B_{1} A_{1}} \cdots$ $\Lambda^{B_{k} A_{k}} g_{A_{1} \cdots A_{k}}$.

(d) Conversely, we may pose the question of finding necessary and sufficient conditions on $\hat{\Gamma}$ in order that (10-10), (10-11) define an associative, invariant 
*-product. Since the covariant derivative of $\Lambda$ vanishes, $\Gamma^{i j k}$ is completely symmetric and an elementary calculation gives

$$
\begin{aligned}
& \Gamma^{A B, C}-\Gamma^{B A, C}=0, \\
& \Gamma^{A B, C}-\Gamma^{B C, A}=A^{B D} C_{D}^{A C} .
\end{aligned}
$$

The last equation is the condition for $\left\{L^{A} ; \hat{A}^{B C}\right\}$ to vanish; hence $(M, \hat{A}, \hat{H})$ is a symplectic manifold with fundamental 2-tensor $\Lambda_{M}$ and "pseudoconnection" $\digamma$ such that the contravariant derivative of $\bar{\Lambda}$ vanishes. Moreover, $\Gamma$ is $\mathscr{A}$-invariant by hypothesis and therefore $\hat{\Gamma}$ is also $\mathscr{A}$-invariant, which is expressed by

$$
\left\{L^{A}, \hat{\Gamma}^{B C, D}\right\}-C_{E}^{A B} \hat{\Gamma}^{E C, D}-C_{E}^{A C} \Gamma^{B E, D}-C_{E}^{A D} \hat{\Gamma}^{B C, E}=0 .
$$

Finally, we express the fact that $R(T)$ vanishes. Let $X$ be a vector field on $\mathscr{A}^{*} \mid M$ that vanishes on $\operatorname{Ker} \hat{\Lambda}$ and whose components can therefore be expressed as as $X^{B}=\bar{\Lambda}^{A B} \beta_{B}$. Then one finds

$$
\left\{L^{A} ;\left\{L^{B} ; X^{C}\right\}\right\}-\left\{L^{B} ;\left\{L^{A} ; X^{C}\right\}\right\}=R^{A B C D} \beta_{D}
$$

where the contravariant "curvature tensor"

$$
R^{A B C D}=\left\{L^{B}, f^{D A, C}\right\}-\left\{L^{A}, \Gamma^{D B, C}\right\}+\Gamma_{E}^{A C} \Gamma^{B E, D}-f_{E}^{B C} \Gamma^{A E, D}+C_{E}^{A B} \Gamma^{D E, C}
$$

is the image by $d J$ of $R(T)$. Hence $R(I)=0$ implies that

$$
\hat{R} A B C D=0 .
$$

Proposition 26. The *-product defined by (10-10), (10-11) is $\mathscr{A}$-invariant and associative if and only if the "pseudo connection" $f$ satisfies (10-12)-(10-15).

(e) Equations (10-12)-(10-15) imply that

$$
f^{A B C} \equiv\left\{L^{C} ;\left\{L^{B} ;\left\{L^{A}, f\right\}\right\}\right\}=0 \quad \text { if } f \text { is linear, }
$$

which means that the series that defines $L^{A} * g$ ends with the third term. If $g$ is a polynomial in $L^{1}, \ldots, L^{m}$ (more precisely, $g \in \Pi(\mathscr{P})$, in the terminology of Section 9 ),

$$
L^{A} * g=L^{A} g+\lambda\left\{L^{A}, g\right\}+\frac{1}{2} \lambda^{2}\left(\hat{\Gamma}^{B C \cdot A} \partial_{B} \partial_{C}+K^{A D} \partial_{D}\right) g
$$

where

In particular,

$$
K^{A B} \equiv-L_{C}^{D A} L_{D}^{C B}
$$

$$
L^{A} * L^{B}=L^{A} L^{B}+\lambda \Lambda^{A B}+\frac{1}{2} \lambda^{2} K^{A B} .
$$

Concerning (10-18) we find by direct calculation: 
PROPOSITION 27. (1) $K^{A B}$ is constant on each orbit; that is, $\left\{L^{A}, K^{B C}\right\}=0$. (2) The 3-tensor $K^{A D} C_{D}^{B C}$ is completely skew symmetric [19].

The *-product on $M$ is determined by (10-17); precisely:

Proposition 28. If $\hat{\Gamma}$ satisfies (10-12)-(10-15), then (10-17) is compatible with a unique invariant *-product on $M$, namely, that given by (10-10), (10-11).

EXAMPLe 29. Let $W=\mathbb{R}^{2 n}, \Gamma=0$, and $\mathscr{A}=\mathrm{Sp}(2 n, \mathbb{R})$. The components of $F$ and of $\Lambda=\mu^{-1}(F)$ are related by

$$
\Lambda^{i j} F_{k j}=\delta_{k}^{i} .
$$

Lower case Latin indices are raised and lowered as follows

$$
X^{i}=\Lambda^{i j} X_{j} ; \quad X_{i}=X^{j} F_{3 i} .
$$

A basis for $\mathscr{A}$ is given by real, second-order polynomials

$$
L^{A}=\frac{1}{2} \sum_{i j}^{A} x^{i} x^{j}, \quad A=1, \ldots, m=n(2 n+1)
$$

where $\Sigma_{i j}^{A}=\Sigma_{j i}^{A}$. Define $g^{A B}$ by

$$
\Sigma_{i}^{A j}=-\sum_{B=1}^{m} g^{A B} \Sigma_{j}^{B i}
$$

and normalize so that

$$
\begin{aligned}
\sum_{i j}^{A} \Sigma^{B k l} g_{A B} & =\delta_{i}{ }^{k} \delta_{j}{ }^{2}+\delta_{i}{ }^{l} \delta_{j}^{k}, \\
\sum_{i j}^{A} \Sigma^{B i j} & =2 g^{A B} .
\end{aligned}
$$

Here $\left(g_{A B}\right)$ is the inverse matrix of $\left(g^{A B}\right)$. The $\Sigma^{A}$ s may be chosen so that

$$
\left(g^{A B}\right)=\left(g_{A B}\right)=\left(\begin{array}{llllll}
1 & & & & & \\
\ddots & & & & & \\
& & & & & \\
& & -1 & & \\
& & & \ddots & & \\
& & & & & \\
& & & & & -1
\end{array}\right]
$$

with $n^{2}$ entries equal to +1 ; in that case $L^{1}, \ldots, L^{n}$ span the compact subalgebra. We find

$$
\begin{gathered}
\hat{A}^{A B}=\left\{L^{A}, L^{B}\right\}=-\operatorname{tr}\left(\Sigma^{A} \Sigma^{B} \Sigma^{C}\right) L^{D} g_{C D} \\
\hat{\Gamma}^{A B, C}=L_{i}^{A} L_{j}^{B} \Sigma^{C i j}=\operatorname{tr}\left(\Sigma^{B} \Sigma^{C} \Sigma^{A} \Sigma^{D}\right) L^{E} g_{D E} \\
K^{A B}=2 g^{A B}
\end{gathered}
$$


The case $n=1: \operatorname{Sp}(2, \mathbb{R})$ is locally isomorphic to $S O(2,1)$ and is of interest in connection with quantization of the harmonic oscillator. In this case we take

$$
\begin{gathered}
L^{1}=\frac{1}{2}\left(x^{1} x^{1}+x^{2} x^{2}\right), \quad L^{2}=x^{1} x^{2}, \quad L^{3}=\frac{1}{2}\left(x^{1} x^{1}-x^{2} x^{2}\right), \\
\left(g^{A B}\right)=\left(\begin{array}{cc}
1 & \\
-1 & \\
-1
\end{array}\right) \\
\hat{\Gamma} A B, C=2\left(g^{A C} L^{B}+g^{B C} L^{A}-g^{A B} L^{C}\right) .
\end{gathered}
$$

The centers of $\mathscr{P}$ and of the *-algebra are generated by

$$
\begin{aligned}
& Q=L^{A} L^{B} g_{A B}=0 \\
& Q=L^{A} * L^{B} g_{A B}=\left(\lambda^{2} / 2\right) K^{A B} g_{A B}=\frac{3}{4}(i \hbar)^{2}
\end{aligned}
$$

For future reference we list the lowest order symmetrized *-monomials:

$$
\begin{aligned}
(1 / 2 !) & \sum_{\text {Perm }} L^{A} * L^{B}=L^{A} L^{B}+\lambda^{2} g^{A B}, \\
(1 / 3 !) & \sum_{\text {Perm }} L^{A} * L^{B} * L^{C}=L^{A} L^{B} L^{C}+\frac{5}{2} \lambda^{2}\left(g^{A B} L^{C}+g^{A C} L^{B}+g^{B C} L^{A}\right) .
\end{aligned}
$$

\section{Construction of InVARIANT *-Products}

(a) We begin by studying invariant *-products on $\mathscr{A} *$. Let us call *-polynomial an expression involving elements of $\mathbb{C}$ and of $\mathscr{A} \subset \mathscr{P}$ and the operations of addition and *-multiplication, and formal *-product algebra (*-algebra for brevity) the algebra of *-polynomials with the identifications (9-2). This algebra is obviously isomorphic (by rescaling in $\mathscr{A}$ ) to $U(\mathscr{A})$. A ${ }^{*}$-product on $\mathscr{A}^{*}$ maps the $*$-polynomials into $\mathscr{P}$; precisely:

Proposition 30. An invariant *-product on $\mathscr{A}^{*}$ defines a $\mathbb{C}$-linear map $\Phi: U(\mathscr{A}) \rightarrow \mathscr{P}$ such that, $\forall a \in \mathscr{A}:$

$$
\begin{gathered}
\Phi(1)=1, \quad \Phi(a)=a / i \hbar, \\
\Phi \circ \operatorname{ad}_{\mathscr{A}}(a)=\operatorname{ad}_{\mathscr{A}}(a) \circ \Phi, \\
\operatorname{Ker} \Phi=\text { bilateral ideal of } U(\mathscr{A}) .
\end{gathered}
$$

Conversely, any C-linear map $\Phi$ of $U(\mathscr{A})$ onto $\mathscr{P}$ that satisfies (11-1) defines a $*$-product on $\mathscr{A}^{*}$ given by

$$
f * g=\Phi_{0}\left(\Phi_{0}^{-1}(f) \Phi_{0}^{-1}(g)\right), \quad \forall f, g \in \mathscr{P}
$$

where $\Phi_{0}$ is the bijection $U(\mathscr{A}) / \operatorname{Ker} \Phi \rightarrow \mathscr{P}$ induced by $\Phi$.

$595 / \mathrm{I} \times 1 / \mathrm{I}-7$ 
EXAMPLE 31. The canonical bijection between $\mathscr{P}$ and $U(\mathscr{A})$, together with a change of scale, gives a linear map defined by $\Phi\left(a^{n}\right)=(a / i \hbar)^{n}$, or $a * \cdots * a=a^{n}, \forall a \in \mathscr{A}$. This is the quantization rule proposed by Abellanas and Martinez-Alonso [20].

EXAmple 32. More generally, for $k=2,3, \ldots$, let

$$
(1 / k !) \sum_{\text {Perm }} L^{A_{1}} * \cdots * L^{A_{k}}=c_{k} L^{A_{1}} \cdots L^{A_{k}}+T^{A_{1} \cdots A_{k}}
$$

where $c_{k} \in \mathbb{C}$ and $T$ is a tensor of rank $k$ whose components are polynomials of order less than $k$. This defines a bijection if $c_{k} \neq 0, k=2,3, \ldots$. Example 31 is recovered by taking $c_{k}=1$ and $T=0$.

A *-product on $\mathscr{A}^{*}$ will be called regular if $\Phi$ is onto. More generally, let $M$ be any algebraic ad* $\mathscr{A}^{*}$-invariant submanifold of $\mathscr{A}^{*}$, and $\Pi(\mathscr{P})$ the associated projection of $\mathscr{P}$. To any invariant ${ }^{*}$-product on $M$ we associate a map $\Psi$ (with properties analogous to (11-1)).

Definition 33. An invariant *-product on $M$ is called regular if the map $\Psi: U(\mathscr{A}) \rightarrow \Pi(\mathscr{P})$ associated with it is onto [21].

The ${ }^{*}$-product (11-3) is regular if $c_{k} \neq 0, k=2,3, \ldots$.

(b) Next, consider the possibility of inducing an invariant*-product on $M$ by restriction from $\mathscr{A}^{*}$. More generally, let $M \subset M^{\prime} \in \mathscr{A}^{*}$, where $M$ and $M^{\prime}$ are

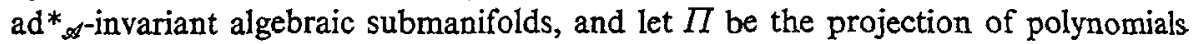
induced by the restriction of $M^{\prime}$ to $M$.

Definmon 34. An invariant *-product on $M^{\prime}$ is said to be compatible with $\Pi$ if $\operatorname{Ker} \Pi$ is *-invariant; that is, if $f \in \operatorname{Ker} \Pi$ implies that $a * f \in \operatorname{Ker} \Pi, \forall a \in \mathscr{A}$.

If an invariant *-product on $M^{\prime}$ is compatible with $\Pi$, then commutativity of the

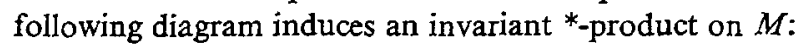

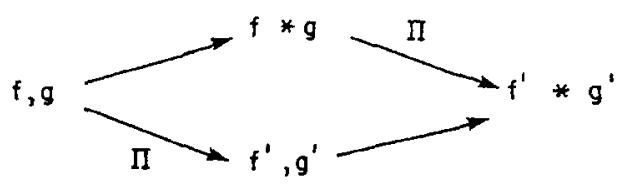

Let $Z(\mathscr{P})$ denote the center of the Poisson Lie algebra $\mathscr{P}$ and let $\mathscr{C}$ denote the set of homomorphisms from $Z(\mathscr{P})$ to $\mathbb{C}$ that reduce to the identity on the scalars. For any $\pi \in \mathscr{C}$, the family of equations $q-\pi(q)=0, \forall q \in Z(\mathscr{P})$, defines an ad $\pi^{*}$ invariant submanifold $M_{\pi}$. If $\Pi_{\pi}$ is the projection of $\mathscr{P}$ defined by $M_{\pi}$ we have $\Pi_{\pi} \mid Z(\mathscr{P})=\pi$. We now restrict ourselves to projections of this type.

Definition 35. Let $R$ and $R^{\prime}$ be commutative rings and $\psi: R \rightarrow R^{\prime}$ a ring homomorphism. Let $A$ be an $R$-module, $A^{\prime}$ an $R^{\prime}$ module and $\psi: A \rightarrow A^{\prime}$ any map that 
preserves addition: $\Psi\left(a_{1}+a_{2}\right)=\Psi\left(a_{1}\right)+\Psi\left(a_{2}\right)$. Then $\Psi$ is called [22] semilinear (relatively to $\psi$ ), in short $\psi$-linear, if $\Psi(r a)=\psi(r) \Psi(a)$, for all $r \in R$ and $a \in A$.

Let $Z(\mathscr{A})$ be the center of $U(\mathscr{A})$ and consider $U(\mathscr{A})$ as a $Z(\mathscr{A})$-module and $\Pi_{\pi}(\mathscr{P})$ as a $C$-module.

Proposinion 36. Let $\Phi: U(\mathscr{A}) \rightarrow \mathscr{P}$ be the map associated with any *-product on $\mathscr{P}$, compatible with $\Pi_{n}$, and $\phi$ the restriction of $\Phi$ to $Z(\mathscr{A})$. Then $\psi=\pi \circ \phi$ is an algebra homomorphism and $\Psi=\Pi \circ \Phi$ is $\psi$-linear.

Proof. Let $q \in Z(\mathscr{P})$ and $f \in \mathscr{P} ; q-\pi(q) \in \operatorname{Ker} \Pi_{\pi}$. Since the *-product is compatible with $\Pi_{\pi}$ we have $(q-\pi(q)) * f \in \operatorname{Ker} \Pi_{\pi}$ and thus $\Pi_{\pi}(q * f)=\pi(q) \Pi_{\pi}(f)$. Thus for any $\hat{q} \in Z(\mathscr{A})$ and $\hat{f} \in U(\mathscr{A}), \Psi\left(\hat{q} f^{\prime}\right)=\Pi_{\pi} \circ(\hat{q} f)=\Pi_{\pi}(\phi(\hat{q}) * \Phi(\hat{f}))=$ $\psi(\hat{q}) \Psi(f)$.

A converse is also true; it will be formulated below. Since, for every $q \in Z(\mathscr{P})$ there is some $\pi \in \mathscr{C}$ such that $\pi(q) \neq 0$, we have

COROLlARY 37. Let a regular *-product on $\mathscr{A}^{*}$ be given, and let $\Phi$ be the associated map of $U(\mathscr{A})$ onto $\mathscr{P}$. Then each of the following statements implies the other two:

(i) The *-product is compatible with $\Pi_{\pi}, \forall \pi \in \mathscr{C}$;

(ii) $\Phi$ is $\phi$-linear $[\phi \equiv \Phi \mid Z(\mathscr{A})]$;

(iii) $q * f=q f, \quad \forall q \in Z(\mathscr{P}), \quad \forall f \in \mathscr{P}$.

Definition 38. A regular, invariant $*$-product on $\mathscr{A}^{*}$ that satisfies any one (and therefore all) of the conditions (11-5) is called normal. The associated map $\Phi$ will also be called normal in this case; hence any map $\Phi: U(\mathscr{A}) \rightarrow \mathscr{P}$ is normal if it is onto, $\phi$-linear, and satisfies (11-1).

(c) Let an invariant *-product on $M_{\pi}$ be given and consider the question of its "lifting" to $\mathscr{I}^{*}$; the following gives a partial answer that covers the most interesting cases:

THEOREM 39. Let an invariant, regular *-product on $M_{\pi}$ be given, with the associated map $\Psi: U(\mathscr{A}) \rightarrow \Pi_{x}(\mathscr{P})$ supposed $\psi$-linear from the $Z(\mathscr{A})$-module $U(\mathscr{A})$ to the $\mathbb{C}$-module $\Pi_{\pi}(\mathscr{P})(\psi \equiv \Psi \mid Z(\mathscr{A}))$. Suppose that either $\mathscr{A}=H_{n}$, the Heisenberg algebra, or that $\mathscr{A}$ is semisimple and that the ideal $\operatorname{Ker} \Psi$ is generated by $\operatorname{Ker} \psi$. Then there exists a normal *-product on $\mathscr{A} *$ with associated map $\Phi: U(\mathscr{A}) \rightarrow \mathscr{P}$ (bijective in the semisimple case) such that $\Pi_{x} \circ \Phi=\Psi$.

Proof. In both cases $U(\mathscr{A})$ and $\mathscr{P}$ are free modules over $Z(\mathscr{A})$ and $Z(\mathscr{P})$ (respectively); $Z(\mathscr{A})$ is a polynomial algebra in a finite number of "Casimir" elements $\hat{q}_{\alpha} \in Z(\mathscr{A})$ [18]. We denote by $\Phi_{0}$ the "canonical" bijection $U(\mathscr{A}) \rightarrow \not B$ obtained from the canonical bijection $U(\mathscr{A}) \rightarrow S(\mathscr{A})$ by rescaling, and by $\phi_{0}$ its restriction to $Z(\mathscr{A})$. We give a proof for the semisimple case. 
(i) Construction of $\phi=\Phi \mid \mathcal{Z}(\mathscr{A})$. We need an algebra isomorphism $\phi: Z(\mathscr{A}) \rightarrow Z(\mathscr{P})$ such that $\pi \circ \phi=\psi$. To show that one exists let $\phi_{0}\left(\hat{q}_{\alpha}\right) \equiv q_{\alpha}$ and $\phi\left(\hat{q}_{\alpha}\right)=q_{\alpha}-\pi\left(q_{\alpha}\right)+\psi\left(\hat{q}_{\alpha}\right)=q_{\alpha}+\lambda_{\alpha}=q_{\alpha}{ }^{\prime}$ with $\lambda_{\alpha}$ in $\mathbb{C}$. We extend $\phi$ as a (polynomial) ring isomorphism $Z(\mathscr{A})=\mathbb{C}\left[\hat{q}_{\alpha}\right] \rightarrow Z(\mathscr{P})=\mathbb{C}\left[q_{\alpha}^{\prime}\right]$.

(ii) Construction of bases. We can write $\mathscr{P}=\bigoplus_{n=0}^{\infty} \mathscr{P}{ }^{n}$ as a graded algebra and $\mathscr{P}=\bigcup_{n=0}^{\infty} \mathscr{P}_{n}$ as a filtered algebra. The adjoint action of $\mathscr{A}$ in $\mathscr{P}$ preserves the grading and filtration and is fully reducible in each component (since $\mathscr{A}$ is semisimple). The ideal $\mathscr{I}=\operatorname{Ker} \Pi_{\pi}$ is ad $\mathscr{d}_{\mathscr{A}}$ invariant and filtered into $\mathscr{I}=\cup \mathscr{I}_{n}, \mathscr{I}_{n}=\mathscr{I} \cap \mathscr{P}_{n}$. This allows us to construct by induction a (graded) supplementary subspace $\mathscr{P}$ to $\mathscr{F}$ in $\mathscr{P}$, invariant under $\operatorname{ad}_{\mathscr{A}}$, and therefore a basis $\left\{x^{i}\right\}(i=1,2, \ldots)$ of $\mathscr{P}$ as a $Z(\mathscr{P})$ module with each $x^{i}$ in $\mathscr{P}$. (These constructions are similar to those of [18, Sect. 8.2].) Let $\left\{x_{i}\right\}(i=1,2, \ldots)$ be a basis for $\mathscr{P}$ as a $Z(\mathscr{P})$ module obtained in this way, and let $\hat{x}_{i}=\Phi_{0}^{-1}\left(x_{i}\right)$; then $\left\{\hat{x}_{i}\right\}$ is a basis for $U(\mathscr{A})$ as a $Z(\mathscr{A})$ module and the $\Pi_{n}\left(x_{i}\right)$ form a basis for $\Pi_{n}(\mathscr{P})$ (as a $C$-module). We have $\Psi\left(\hat{x}_{i}\right)=\sum_{j} C_{i j} \Pi_{n}\left(x_{j}\right)$ (finite sum), with $C_{i j}$ in $\mathrm{C}$.

(iii) Construction of $\Phi$. We take $\Phi\left(\hat{x}_{i}\right)=\sum_{j} C_{i j} x_{j}$ and extend by $\phi$-linearity: any $\hat{x}$ in $U(\mathscr{A})$ can be written in a unique way as $\hat{x}=\sum_{i} Q_{i} \hat{x}_{i}$, with $Q_{i} \in Z(\mathscr{A})$; we define $\Phi(\hat{x})=\sum_{i} \phi\left(Q_{i}\right) \Phi\left(\hat{x}_{i}\right)=\sum_{i, j} \phi\left(Q_{i}\right) C_{i j} x_{j}$. Then $\Phi$ is $\phi$-linear (by construction) and commutes with $\operatorname{ad}_{\mathscr{A}}$ (because $\Psi$ does). Furthermore, $\Phi(1)=1$ and $\Phi(a)=a / i \hbar$ for $a$ in $\mathscr{A}$. Finally, the $\Phi$ that is constructed in this way is bijective (because $\operatorname{Ker} \Psi$ is generated by $\operatorname{Ker} \psi$ and $\operatorname{Ker} \phi=\{0\}$ ).

The Heisenberg case is straightforward. The fact that $\operatorname{Ker} \Phi$ is a bilateral ideal can be seen using the unique decomposition of any $X$ in $U(\mathscr{A})$ into $X=$ $\sum_{k \rightarrow 1}^{k}\left(e^{k}-\psi\left(e^{k}\right)\right) Y_{k}+Y_{0}$ with $Y_{j}$ in $\Phi_{0}^{-1}(\tilde{\mathscr{P}})(j=0,1, \ldots, K)$.

EXAMPLE 40 . Let $\mathscr{A}=H_{1}$, with basis $p, q, e$ and structure

$$
[q, p]=e, \quad[q, e]=[p, e]=0 .
$$

Let $S$ mean symmetrization with respect to the order of factors and take, for $k, l, m=0,1,2, \ldots$ :

$$
\Phi\left(S p^{k} q^{l} e^{m}\right) \equiv(1 / i \hbar)^{k+l+m} S\left(p^{*}\right)^{k}\left(q^{*}\right)^{l}\left(e^{*}\right)^{m}=C^{k l m}
$$

where $\left\{C^{k l m} ;\right.$ are polynomials in $p, q, e$, with $C^{000}=1, C^{100}=p / i \hbar, C^{010}=q / i \hbar$, $C^{001}=e / i \hbar$. This $*$-product is $\mathscr{A}$-invariant if and only if the following recursion relations hold:

$$
\begin{aligned}
& i \hbar e(c / c q) C^{k l m}=l C^{k, l-1, m+1}, \\
& i \hbar h(c / \partial p) C^{k l m}=k C^{k-1,1, m+1} .
\end{aligned}
$$

The center of $U(\mathscr{A})$ is generated by $e$; hence (11-7) is $\phi$-linear if and only if $e * f=e f$, $\forall f \in \not{Z} ;$; that is, $C^{k l m}=(e / i \hbar)^{m} C^{k l}$ where $C^{k l}$ is a polynomial in $p, q$. The necessary 


\section{DEFORMATION THEORY AND QUANTIZATION, I}

and sufficient conditions for (11-7) to be both invariant and $\phi$-linear can be expressed by [23]

$$
\sum_{n=0}^{\infty} \frac{(i \hbar)^{-n}}{n !}[(\alpha p+\beta q+\gamma e) *]^{n}=C(\alpha, \beta) e^{(\alpha \nu+\beta q+\gamma e) / i \hbar}
$$

where $C(\alpha, \beta)$ is a formal power series in $\alpha, \beta$ and the equality is to be interpreted in the sense of equality of formal power series in $\alpha, \beta$. Comparing the constant and linear terms in (11-9) one sees that $C(\alpha, \beta)$ must have constant term $=1$ and no linear terms, so that

$$
S(p *)^{k}(q *)^{l}(e *)^{m}=\left(p^{k} q^{l}+\cdots\right) e^{m}
$$

where the unwritten terms are monomials in $p, q$ of order $\leqslant k$ in $p, \leqslant l$ in $q$, and $<k+l$ in $p, q$. Therefore (11-9) is regular and thus normal. Thus one finds, in the case $\mathscr{A}=H_{1}$, that invariance and $\phi$-linearity imply regularity. In the case $C(\alpha, \beta)=1$ we recover the ordinary Moyal product; that special case is characterized by the natural invariance under the semidirect $\operatorname{sum} \operatorname{Sp}(2, \mathbb{R}) \cdot H_{1}$.

EXAMPLe 41. Let $\mathscr{A}=S O(2,1)$ with basis $\{L A\}(A, B=1,2,3)$ and structure

$$
\left[L^{A}, L^{B}\right]=\Lambda^{A B}=\epsilon^{A B C} L^{D} g_{C D}
$$

with $\left(g_{A B}\right)=\left(g^{A B}\right)$ given by $(10-26)$. The center of $\mathscr{P}$ is generated by

$$
Q \equiv L^{A} L^{B} g_{A B}
$$

The center of the *-algebra is generated by

$$
Q=L^{A} * L^{B} g_{A B}
$$

On any $M_{\pi}, Q$ becomes fixed in $\mathbb{C}$ by the projection $\pi$ and $Q$ becomes fixed in $\mathbb{C}$ by the map $\phi$. A basis for $\mathscr{P}$-as a $Z(\mathscr{P})$ module-is given by $\left\{T_{(\alpha)}\right\}(\alpha=1,2, \ldots)$, where

$$
\begin{aligned}
T_{(\alpha)}^{A_{1} \cdots A_{\alpha}}= & \sum_{k=\alpha, \alpha-2, \cdots}(-)^{(\alpha-k) / 2} \frac{(k+\alpha-1) ! !}{k !(\alpha-k) ! !} S g^{A_{1} A_{2}} \cdots g^{A_{\alpha-k-1} A_{\alpha-k}} \\
& \times g_{B_{1} B_{2}} \cdots g_{B_{\alpha-k-1} B_{\alpha-k}} L^{B_{1}} \cdots L^{B_{\alpha-k}} L^{A_{\alpha-k+1}} \cdots L^{A_{\alpha}} .
\end{aligned}
$$

Here $S$ means symmetrization with respect to permutation of the indices. Let $\left\{P_{\alpha}(a)\right\}$ be the "solid spherical polynomials" defined by

$$
P_{\alpha}(a)=T_{(\alpha)}(a, \ldots, a)
$$


and let $P_{\alpha}(a)$ be the *-polynomial obtained from $P_{\alpha}(a)$ by the substitutions $L^{A_{1}} \cdots L^{A_{k}} \rightarrow L^{A_{1}} * \cdots * L^{A_{k}}$. The map $\Phi$ must take the form

$$
P_{\alpha}(a)=c_{\alpha} P_{\alpha}(a), \quad \forall a \in \mathscr{A},
$$

with $c_{\alpha} \in \mathbb{C}-\{0\}, \alpha=1,2, \ldots, c_{1}=1$. Taking $\alpha=2,3$ we find in particular:

$$
\begin{gathered}
S L^{A} * L^{B}=c_{2} L^{A} L^{B}+\frac{1}{3}\left(Q-c_{2} Q\right) g^{A B}, \\
S L^{A} * L^{B} * L^{C}=c_{3} L^{A} L^{B} L^{C}+\frac{1}{5}\left(Q-c_{3} Q+\frac{4}{3}(i \hbar)^{2}\right)\left(L^{A} g^{B C}+L^{B} g^{C A}+L^{C} g^{A B}\right) .
\end{gathered}
$$

These results reduce to (10-30), (10-31), when $c_{2}=c_{3}=1$ and $Q, Q$ take the values (10-28), (10-29). If, for the same values of $Q, Q$, one takes $c_{\alpha}=1, \alpha=1,2, \ldots$, then the *-product given by (11-15) reduces to that calculated in Section 10: Eqs. (10-10), $(10-11)$ with (10-8), (10-9), and (10-27).

(d) The results obtained here may be summarized as follows. The definition (11-3), with $c_{k}=1$ and $T=0$, defines an invariant $*$-product on $\mathscr{A}^{*}$ in the simplest possible way. However, this $*$-product is not compatible with the projection to an invariant submanifold of $\mathscr{A}^{*}$, and it becomes interesting to calculate the required modifications; that is, to find $c_{k}$ and $T$ such that the *-product becomes compatible with the projection. Corollary 37 solves this problem in the case of invariant submanifolds $M_{\pi}$ defined by fixing $Z(\mathscr{P})$. Equation (11-15) gives the general form of the solution for the case $\mathscr{A}=S O(2,1)$. Unfortunately, these results are incomplete, since the set $\left\{M_{\pi}\right\}(\pi \in \mathscr{C})$ does not include all the orbits of ad* in $\mathscr{A}^{*}$.

Definition 42. An orbit $M$ of ad* $\mathscr{A}$ in $\mathscr{A}$ is called regular if there is a $\pi \in \mathscr{C}$ such that $M$ is open in $M_{\pi}$, otherwise exceptional.

The term exceptional is justified by the following fact. Let $\xi \in \mathscr{A}^{*}$ and $M(\xi)$ be the orbit of ad* through $\xi$. Then the set of all $\xi \in \mathscr{A}^{*}$ such that $M(\xi)$ is regular is open in $\mathscr{A}^{*}$ and its complement is a cone. This is not to say that exceptional orbits are uninteresting; on the contrary, the construction of invariant *-products on exceptional orbits presents a challenging and physically interesting problem.

\section{2. *-EXPONENTIALS}

Here we attempt to generalize, to any Lie algebra, the ideas that underlie the Weyl correspondence [2], a tool that played an important role in the discovery of the Moyal bracket. We begin with a brief review of the simplest case (a restatement of the usual Weyl correspondence). 
(a) Let $\mathscr{A}$ be the Heisenberg algebra $H_{1}$, with basis $q, p$, $e$ and commutation relations (11-6). Let $\alpha, \beta, \gamma$ be a set of coordinates for $\mathbb{R}^{3}$ and consider the formula:

$$
f(p, q, e)=\int e^{(\alpha q+\beta p+\gamma e) / i \hbar} F(\alpha, \beta, \gamma) d \alpha d \beta d \gamma
$$

Under suitable restrictions on the class $\{f\}$ of functions and the class $\{F\}$ of distributions, this is a bijection.'

On the other hand, let $q^{\prime}, p^{\prime}, e^{\prime}$, be operators in $L^{2}(-\infty,+\infty)$ defined by

$$
q^{\prime} \psi(x)=x \psi(x), \quad p^{\prime} \psi(x)=-i \hbar \frac{\partial}{\partial x} \psi(x), \quad e^{\prime} \psi(x)=\psi(x)
$$

There is a common domain of analytic vectors on which $q^{\prime}, p^{\prime}, e^{\prime}$ are essentially selfadjoint, allowing us to define a group of unitary operators

$$
U(\alpha, \beta, \gamma)=e^{\left(\alpha q^{\prime}+\beta p^{\prime}+\gamma \epsilon^{\prime}\right) / \hbar \hbar}, \quad(\alpha, \beta, \gamma) \in \mathbb{R}^{3}
$$

with the multiplication law

$$
U(\alpha, \beta, \gamma) U\left(\alpha^{\prime}, \beta^{\prime}, \gamma^{\prime}\right)=U\left(\alpha+\alpha^{\prime}, \beta+\beta^{\prime}, \gamma+\gamma^{\prime}+\frac{1}{2}\left(\alpha \beta^{\prime}-\alpha^{\prime} \beta\right)\right)
$$

Now consider the formula

$$
A=\int e^{\left(\alpha q^{\prime}+\beta p^{\prime}+\gamma \theta^{\prime}\right) / i \hbar} F(\alpha, \beta, \gamma) d \alpha d \beta d \gamma
$$

(the last integral being an operator integral with the strong topology). Under suitable restrictions, (12-1) and (12-4) establish a bijection $A \mapsto f$ between a class $\{A\}$ of operators in $L^{2}$ and a class $\{f\}$ of functions on $\mathscr{A}^{*}$; this is the Weyl correspondence.

Now let $A, B, \ldots$, be operators in $L^{2}$ and $A_{W}, B_{W}, \ldots$, their images under the Weyl correspondence. The Moyal *-product is then defined by

$$
A_{W} * B_{W}=(A B)_{W}
$$

In particular, let

$$
\begin{array}{cl}
A=U(\alpha, \beta, \gamma), & B=U\left(\alpha^{\prime}, \beta^{\prime}, \gamma^{\prime}\right), \\
A_{W}=e^{(\alpha \alpha+\beta p+\gamma e) / i \hbar}, & B_{W}=e^{\left(\alpha^{\prime} \varsigma+\beta^{\prime} p+\gamma^{\prime} \theta\right) / i \hbar} .
\end{array}
$$

Then (12-3) gives

$$
A_{W} * B_{W}=A_{W} e^{(i \hbar / 2) \Delta} B_{W}
$$


where $\Delta$ is the operator

$$
f \Delta g=\{f, g\}
$$

The result (12-6) is easily generalized to a large class of functions, including all polynomials on $\mathscr{A}^{*}$.

The essential point here is that the functions $(U(\alpha, \beta, \gamma))_{W}$ form a group under *-multiplication that is isomorphic to the operator group (12-3). We now investigate invariant *-products on any Lie algebra from this point of view.

(b) Consider the formal group [24] with Lie algebra $\mathscr{A}$. For $a \in \mathscr{A}$, let $\{\exp (t a)\}$ $(t \in \mathbb{R})$ be the one-parameter formal group $\exp (t a) \cdot \exp \left(t^{\prime} a\right)=\exp \left(\left(t+t^{\prime}\right) a\right)$. For $a, b \in \mathscr{A}$ let $c=c(a, b)$ be defined by the Campbell-Hausdorff formula:

$$
\exp (a) \cdot \exp (b)=\exp (c)
$$

Let $\mathscr{P}^{\prime}$ be the extension of $\mathscr{P}$ to the algebra of formal power series over $\mathscr{A}^{*}$.

Defrntion 43. We call $*$-exponential the function $\operatorname{Exp}: \mathscr{A} \rightarrow \mathscr{P}^{\prime}, a \mapsto \operatorname{Exp}(a)$, defined by

$$
\begin{gathered}
\operatorname{Exp}(a)=\sum_{n=0}^{\infty} \frac{1}{n !}(i \hbar)^{-n}(a *)^{n}, \\
(a *)^{n} \equiv a * \cdots * a \quad \text { (n factors). }
\end{gathered}
$$

Proposition 44. The fumction Exp enjoys the following properties:

$$
\text { (i) } \operatorname{Exp}(a) * \operatorname{Exp}(b)=\operatorname{Exp}(c)
$$

where $c=c(a, b)$ is defined by (12-7).

$$
\text { (ii) }\left(\operatorname{ad}_{\mathscr{A}}(a) \operatorname{Exp}\right)(b)=\{a, \operatorname{Exp}(b)\} \equiv \operatorname{ad}_{\mathscr{A}}^{*}(a) \operatorname{Exp}(b)
$$

where $\operatorname{ad}_{\mathscr{A}}$ is the extension of the adjoint action of $\mathscr{A}$ in $\mathscr{A}$ to formal power series over $\mathscr{A}$.

$$
\text { (iii) } \begin{aligned}
\operatorname{Exp}(a) & =1+a / i \hbar+\cdots \\
& =\sum_{n=0}^{\infty} \frac{1}{n !}(i \hbar)^{-n} T_{(n)}(a, \ldots, a),
\end{aligned}
$$

where $T_{(n)}$ is an $n$-linear map of $\mathscr{A}$ into $\mathscr{P}$.

Proof. (i) This follows from (12-7) and Eq. (9-2):

$$
(a * b-b * a) / i \hbar=\{a, b\}, \quad \forall a, b \in \mathscr{A} .
$$


(ii) From (12-10) we extract the terms linear in $a$ and obtain

$$
(1 / i \hbar)(a * \operatorname{Exp}(b)-\operatorname{Exp}(b) * a)=\{a, \operatorname{Exp}(b)\}
$$

the left-hand side is $\left(\operatorname{ad}_{\mathscr{A}}(a) \operatorname{Exp}\right)(b)$.

(iii) This follows immediately from (12-8).

Conversely, we have

Proposition 45. Let $f: \mathscr{A} \rightarrow \mathscr{P}^{\prime}$ be any function such that

$$
\text { (i) } \begin{aligned}
\operatorname{ad}_{\mathscr{A}}(a) & f(b)=\{a, f(b)\}, \\
\text { (ii) } f(a) & =1+a / i \hbar+\cdots \\
& =\sum_{n=0}^{\infty} \frac{1}{n !}(i \hbar)^{-n} T_{(n)}(a, \ldots, a)
\end{aligned}
$$

where $T_{(n)}$ is an $n$-linear map of $\mathscr{A}$ into $\mathscr{P}$. Then there is a unique $\mathbb{C}$-linear map $\Phi: U(\mathscr{A}) \rightarrow \mathscr{P}$, given by

$$
(a *)^{n}=T_{(n)}(a, \ldots, a) .
$$

If $\operatorname{Ker} \Phi$ is a bilateral ideal of $U(\mathscr{A})$, then $\Phi$ defines a unique invariant *-product on $\mathscr{A}^{*}$ and $f$ is the function $\operatorname{Exp}$ for this *-product.

Proof. From (12-15) and (12-16) we conclude that $\Phi$ commutes with ad $\mathscr{A}$ and that $\Phi(1)=1, \Phi(a)=a / i \hbar$; therefore, if $\operatorname{Ker} \Phi$ is a bilateral ideal of $U(\mathscr{A})$, we have an invariant *-product by Proposition 30. Substituting (12-17) into (12-16), we see that $f$ coincides with the function Exp defined by (12-8).

Remarks. (1) The condition that $\operatorname{Ker} \Phi$ is a bilateral ideal of $U(\mathscr{A})$ is necessary as well as sufficient. (2) Any function $f: \mathscr{A} \rightarrow \mathscr{P}^{\prime}$ that satisfies the conditions of Proposition 45, with the exception of (12-15), defines an associative *-product on $\mathscr{P}$.

EXAMPLE 46. Let $\mathscr{A}$ be the Heisenberg algebra with basis $x^{1}, \ldots, x^{2 n+1}=q^{1}, \ldots, q^{n}$; $p^{1}, \ldots, p^{n} ; e$ with $\left[q^{i}, p^{j}\right]=\delta^{i j} e$, and the other commutators equal to zero. Let $q^{1}, \ldots, p^{n} \rightarrow Q^{1}, \ldots, P^{n}=y^{1}, \ldots, y^{2 n}$ be a canonical transformation and define

$$
\operatorname{Exp}\left(\alpha_{i} q^{i}+\beta_{i} p^{i}+\gamma e\right)=e^{\left(\alpha_{i} \emptyset^{i}+\beta_{i} p^{i}+\gamma e\right) / i \pi} .
$$

Then the associated *-product is given by $(10-1)$ and $(10-2)$, with $\lambda=i \hbar / 2$ and

$$
\Gamma_{i j}^{k}=\frac{\partial y^{l}}{\partial x^{i}} \frac{\partial y^{m}}{\partial x^{j}} \frac{\partial^{2} x^{k}}{\partial y^{l} \partial y^{m}} \quad(i, j, \ldots=1, \ldots, 2 n) ;
$$

it is $\mathscr{A}$-invariant if and only if $y_{i}-x_{i}$ are constants and then it is an invariant $*$-product on $\mathscr{A}^{*}$. 
(c) Next, consider *-products on an invariant submanifold $M$ of $\mathscr{A}^{*}$ and the restrictions on Exp implied by compatibility of the *-product with the associated projection $I I$. Recall from Section 11c, Theorem 39, and Corollary 37, that many regular, invariant $*$-products on $M_{\pi}, \pi \in \mathscr{C}$, can be obtained by projection from a regular, invariant *-product on $\mathscr{A}^{*}$ with the property

$$
q * f=q f, \quad \forall q \in Z(\mathscr{P}), \quad \forall f \in \mathscr{P} .
$$

Of course, (12-18) remains valid for $f \in \mathscr{P}^{\prime}$. In particular,

$$
q * \operatorname{Exp}(b)=q \operatorname{Exp}(b), \quad \forall q \in Z(\mathscr{P}), \quad \forall b \in \mathscr{A} .
$$

We shall show that the structure equations (12-10) allow us to reduce these equations to partial differential equations for Exp. First, an example.

EXAMPLE 47. Suppose that $\mathscr{A}$ has a nontrivial center $\mathscr{A}_{0} ;$ then any $\pi \in \mathscr{C}$ defines, by restriction, a linear map $\sigma: \mathscr{A}_{0} \rightarrow \mathbb{C}$. [This map defines a submanifold $M_{\sigma}$ of $\mathscr{A}^{*}$; the following applies to the problem of construction of a *-product on either $M_{\text {r }}$ or $M_{0}$.] Let a normal *-product on $\mathscr{A}^{*}$ be given, and let Exp be the associated *-exponential. Then (12-18) holds and implies that

$$
a_{0} * \operatorname{Exp}(b)=a_{0} \operatorname{Exp}(b), \quad \forall a_{0} \in \mathscr{A}_{0}, \quad \forall b \in \mathscr{A} .
$$

Using (12-8) and (12-10) it is now easy to see that

$$
\operatorname{Exp}\left(b+a_{0}\right)=\operatorname{Exp}(b) e^{a_{0} / t \hbar}, \quad \forall a_{0} \in \mathscr{A}_{0}, \quad \forall b \in \mathscr{A} .
$$

In particular, Exp reduces to an ordinary exponential if $\mathscr{A}$ is Abelian. The calculations that follow will give analogous results for the general case.

Let $t \in \mathbb{R}$ and $c_{t}=c(t a, b)$, where $c(a, b)$ is defined as in (12-7). From $\operatorname{Exp}(t a) * \operatorname{Exp}(b)=\operatorname{Exp}\left(c_{t}\right)$ we get by formal differentiation of formal power series with respect to $t$ at $t=0$ :

$$
a * \operatorname{Exp}(b)=\left.i \hbar \partial_{t} \operatorname{Exp}\left(c_{t}\right)\right|_{t \rightarrow 0}=i \hbar \eta^{a} \operatorname{Exp}(b)
$$

where $\eta^{a}$ denotes the vector field on $\mathscr{A}$ defined by

$$
\left.\eta^{a}\right|_{b}=\left.\partial_{t} c_{t}\right|_{t=0}
$$

[The tangent space at any point $b \in \mathscr{A}$ is canonically identified with $\mathscr{A}$.] We have

$$
\begin{aligned}
\left.\eta^{a}\right|_{b} & =a+\frac{1}{2}[a, b]+\frac{1}{12}[[a, b], b]+\cdots \\
& =\sum_{n=0}^{\infty} B_{n} x^{n} a
\end{aligned}
$$


where $x$ is the linear operator $x a=-\operatorname{ad}_{\mathscr{A}}(b) a$ and the coefficients $B_{n}$ are the Bernoulli numbers. The identity $\sum_{n=0}^{\infty} B_{n} x^{n}=x /\left(1-e^{-x}\right)$ between formal power series can be used to evaluate $\eta^{a}$. For example, if $\operatorname{ad}_{\mathscr{A}}(b)$ is diagonable and $\mathscr{A}=\oplus_{\lambda} E_{\lambda}$ is the eigenspace decomposition and $\left\{P_{\lambda}\right\}$ the associated projection operators, then we have $x=-\sum \lambda P_{\lambda}$ and

$$
\left.\eta^{a}\right|_{b}=\left(P_{0}+\sum_{\lambda \neq 0} \frac{\lambda / 2}{\tanh \lambda / 2} P_{\lambda}\right) a+\frac{1}{2}[a, b]
$$

Let $\left\{L^{A}\right\}(A, B=1, \ldots, m)$ be a basis for $\mathscr{A}$, and $a=a_{A} L^{A}, \eta^{a}=a_{A} \eta^{A}$; then $\left\{\eta^{A}\right\}$ is a family of vector fields over $\mathscr{A}$ and we have

$$
L^{A} * \operatorname{Exp}=i \hbar \eta^{\wedge} \operatorname{Exp}
$$

Let $Q$ be any element of the center of the formal *-product algebra of the form

$$
Q=Q_{A_{1} \cdots A_{n}} L^{A_{1}} * \cdots * L^{A_{n}}
$$

where the coefficient tensor is completely symmetric. The value of $Q$ in $Z(\mathscr{P})$ is also denoted $Q$. Then

$$
Q * \operatorname{Exp}=(i \hbar)^{n} Q_{A_{1} \cdots A_{n}} \eta^{\Lambda_{1}} \cdots \eta^{\Lambda_{n}} \text { Exp. }
$$

Proposition 48. Let a normal *-product on $\mathscr{A}^{*}$ be given, and let Exp be the associated *-exponential. Let $Q$ be any element of the center of the formal *-product algebra of the form (12-24). Then Exp satisfies the following partial differential equation:

$$
(i \hbar)^{n} Q_{A_{1} \cdots A_{n}} \eta^{A_{1}} \cdots \eta^{A_{n}} \operatorname{Exp}=Q \operatorname{Exp}
$$

Proof. Replace $q \rightarrow Q$ in (12-19) and compare with (12-25). Combining this with Proposition 45 one has

THEOREM 49. Let $f: \mathscr{A} \rightarrow \mathscr{P}^{\prime}$ be any function such that:

(i) $\operatorname{ad}_{\mathscr{A}}(a) f(b)=\{a, f(b)\}$.

(ii) $f(a)=1+a / i \hbar+\cdots=\sum_{n=0}^{\infty}(1 / n !)(i \hbar)^{-n} T_{(n)}(a, \ldots, a)$.

(iii) The C-linear map $\Phi: U(\mathscr{A}) \rightarrow \mathscr{P}$ defined by $(a *)^{n}=T_{(n)}(a, \ldots, a)$ is bijective.

(iv) For every element $Q$ of the center of the formal *-product algebra of the form $Q=Q_{A_{1} \cdots A_{x}} L^{A_{1}} * \cdots * L^{A_{n}}$,

$$
(i \hbar)^{n} Q_{A_{1} \cdots A_{n}} \eta^{A_{1}} \cdots \eta^{A_{n} f}=Q f .
$$

Then $\Phi$ is normal and defines a unique invariant *-product on $\mathscr{A}^{*}$, compatible with $\Pi_{\pi}$ for every $\pi \in \mathscr{C}$, and $f$ is the associated function Exp. 
EXAMPLE 50. Let $\mathscr{A}=S O(2,1)$ and adopt the notations of Example 41. Let $b=b_{A} L^{A} \in \mathscr{A}$ and let $\tilde{b}$ denote the matrix of $-\operatorname{ad}_{\mathscr{A}}(b)$. We have

$$
\begin{gathered}
\tilde{b}_{A}^{B}=C_{A}^{B C_{b}}, \quad \tilde{b}_{A}{ }^{B}=4\left(b_{A} b^{B}-t^{2} \delta_{A}^{B}\right), \\
t^{2} \equiv g(b, b)=b_{0}{ }^{2}-b_{1}{ }^{2}-b_{2}{ }^{2} .
\end{gathered}
$$

If $t^{2} \neq 0$, then $b$ is diagonable, with projectors satisfying

$$
P_{2 i}+P_{-2 i}=-\tilde{b}^{2} / 4 t=1-P_{0} .
$$

Thus we get from (12-22) (and the definition $\eta^{\alpha}=a_{A} \eta^{A}$ ):

$$
\begin{gathered}
\eta^{A}=\left(1+\frac{1}{2} \tilde{b}+\frac{1}{4} \tilde{b}^{2} \sigma(t)\right)_{B}{ }^{A} \partial^{B}, \\
\sigma(t) \equiv\left(1 / t^{2}\right)(1-t / \tan t)
\end{gathered}
$$

where $\partial^{B}$ denotes differentiation with respect to $b_{B}$. The center of $U(\mathscr{A})$ is generated by the second-order Casimir operator and the set (10-26) of differential equations reduces to

$$
(i \hbar)^{2} g_{A B} \eta^{A} \eta^{B} \operatorname{Exp}=Q \operatorname{Exp}
$$

or

$$
\begin{aligned}
& {\left[2\left(\sigma-t^{2} \sigma^{2}-1\right) b_{A} \partial^{A}+g_{A B} \partial A \partial^{B}+\left(2 \sigma-t^{2} \sigma^{2}-1\right)\left(b_{A} b_{B}-t^{2} g_{A B}\right) \partial^{A} \partial^{B}\right.} \\
& \left.\quad-(i \hbar)^{-2} Q\right] \operatorname{Exp}=0 .
\end{aligned}
$$

This equation is of course ad $d_{\mathscr{A}}$ invariant and can be separated by introducing pseudospherical coordinates: $t, z=\cosh \theta=b\left(t^{2} Q\right)^{-1 / 2}$ and a polar angle. The invariance property of Exp, namely, Eq. (12-11), means that Exp does not depend on the polar angle and can be expanded in terms of Legendre functions; formally $\operatorname{Exp}(b)=$ $\sum_{\alpha} C_{\alpha}^{\prime}(t) P_{\alpha}(z)$. Now $\operatorname{Exp}(b)$ must be interpreted as a formal power series in $\left\{b_{A}\right\}$ as well as in $\left\{L^{A}\right\}$; we therefore restrict the summation to values of $\alpha \in \mathbb{C}$ such that each term is a formal power series; that is

$$
\operatorname{Exp}(b)=\sum_{\alpha=0}^{\infty} C_{\alpha}(t) P_{\alpha}(b)
$$

Here $P_{\alpha}(b)$ is the "solid spherical polynomial" defined by (11-13) and (11-14); it differs from the usual Legendre functions by a factor $t^{\alpha} Q^{\alpha / 2}$ and is a polynomial in both $\left\{b_{A}\right\}$ and $\left\{L^{A}\right\}$. Of course, (12-28) must be interpreted as an equality of formal power series. For $C_{\alpha}(t)$ we find

$$
\left[\partial_{t}^{2}+\frac{2}{\tan t} \partial_{t}-\frac{\alpha(\alpha+1)}{\sin ^{2} t}-(i \hbar)^{-2} Q\right] t^{\alpha} C_{\alpha}(t)=0
$$


Consider the limit $t^{2} \rightarrow 0$ with $b \neq 0$, then

$$
P_{\alpha}(b) \rightarrow \frac{(2 \alpha-1) ! !}{\alpha !} b^{\alpha}
$$

Therefore, the only acceptable solution of $(12-29)$ is the one that is regular at $t=0$ :

$$
C_{\alpha}(t)=\frac{c_{\alpha}}{(2 \alpha-1) ! !}\left(\frac{\sin t}{i \hbar t}\right)_{2}^{\alpha} F_{1}\left(\frac{\alpha}{2}+l+1, \frac{\alpha}{2}-l ; \alpha+\frac{3}{2} ; \sin ^{2} t\right)
$$

where $c_{\alpha}$ is a constant and the parameter $l$ is defined by

$$
Q=(2 \hbar)^{2} l(l+1)
$$

Equating equal powers of $\left\{b_{A}\right\}$ in (12-28) we get $(b *)^{n}=c_{\alpha} b^{n}+a$ polynomial of order $n$ in $\left\{L^{A}\right\}$ that vanishes when either $Q$ or $t^{2}$ vanishes. The constants $c_{\alpha}$ in (12-31) can therefore be identified with the constants $c_{\alpha}$ in (11-15); that is, Eqs. (12-28) and (12.31) give the function Exp for the *-product defined by Eq. (11-15). Note that $c_{0}$ and $c_{1}$ must both be equal to 1 .

In particular, if we specialize once again to the interesting special case $Q=0$, $Q=\frac{3}{4}(i \hbar)^{2}$ (i.e., $l=-\frac{3}{4}$ ) and $c_{\alpha}=1$, then

$$
\operatorname{Exp}(b)=\left(\cos \frac{t}{2}\right)^{-1} e^{((2 / t) \tan (t / 2)) b / t \pi}
$$

In Part II [10] we shall rediscover this formula and obtain from it the spectrum of the harmonic oscillator.

In order to show the connection between $(12-28)$ and $(11-15)$ in more detail we give explicitly all terms up to the third order in $\left\{b_{A}\right\}$ in Eq. $(12-28)$ :

$$
\begin{aligned}
1+b / i \hbar & +(b *)^{2} / 2(i \hbar)^{2}+(b *)^{3} / 6(i \hbar)^{3}+\cdots \\
= & 1+b / i \hbar+\left[c_{2} b^{2}+\frac{1}{3}\left(Q-c_{2} Q\right) t^{2}\right] / 2(i \hbar)^{2} \\
& +\left[c_{3} b^{3}+\frac{3}{5}\left(Q-c_{3} Q+\frac{4}{3}(i \hbar)^{2} t^{2} b\right] / 6(i \hbar)^{3}+\cdots,\right.
\end{aligned}
$$

from which one recovers Eq. (11-16).

(d) We believe that the function Exp can be a useful tool for representation theory. Consider the formula

$$
f(\xi)=\int \tilde{f}(a) \operatorname{Exp}_{\xi}(a) d \tilde{\mu}(a)
$$

where $\tilde{f}$ is some function on $\mathscr{A}, d \tilde{\mu}$ is the Lebesgue measure on $\mathscr{A}$, and $\operatorname{Exp}_{\xi}(a)$ is 
the value of $\operatorname{Exp}(a)$ at $\xi \in \mathscr{A}^{*}$. When $\mathscr{A}$ is Abelian and the *-product is normal, then this reduces to the definition of the ordinary Fourier transform. In general, one has a novel and possibly interesting notion of Fourier transform that relates $\tilde{f}$ on $\mathscr{A}$ to $f$ on $\mathscr{A}^{*}$. We shall not approach the problem of determining the precise conditions under which (12-34) makes sense, but limit ourselves to some formal observations.

One has

$$
f * g=\int \tilde{f}(a) \tilde{g}(b) \operatorname{Exp}_{\xi}(c) d \tilde{\mu}(a) d \tilde{\mu}(b)
$$

Here and below $c$ stands for the Campbell-Hausdorff function $c(a, b)$. If the *-product is normal we can restrict $f$ and $g$ to $M_{\pi}$ and integrate to obtain a type of Plancherel formula:

$$
\int_{M_{\pi}} f * g d \mu(\xi)=\int \tilde{f}(a) \tilde{g}(b) K(a, b) d \tilde{\mu}(a) d \tilde{\mu}(b)
$$

where $d \mu$ is the Liouville measure on $M_{\pi}$ and

$$
K(a, b)=\int \operatorname{Exp}_{\xi}(c) d \mu(\xi) \equiv \chi(c)
$$

In the case of the Heisenberg algebra, the support of $K$ reduces to $\{c=0\}$ and $\int f * g d \mu(\xi) \sim \int \tilde{g} \tilde{g} d \tilde{\mu}(a)$; this shows that $\int f * g d \mu(\xi)=\int f g d \mu(\xi)$ in this case.

Another interesting possibility (verified in some cases) is that $\operatorname{Exp}(t a)$, for $t \in \mathbb{R}$ and $a \in \mathscr{A}$, have a Fourier-Dirichlet expansion:

$$
\operatorname{Exp}(t a)=\int \pi_{\lambda} e^{t \lambda / \hbar \hbar} d \lambda
$$

One can define the "spectrum" $\Sigma$ of $a$ to be the support of $\pi_{\lambda}$ and the "multiplicity" of a discrete point $\lambda \in \Sigma$ by the integral of $\pi_{\lambda}$ over phase space. This idea finds support in several particular instances that are investigated in Part II [10].

Let a faithful, unitary representation of the group $S O(2,1)$ be given, together with a map of the type of the Weyl correspondence, that maps operators to $\mathscr{P}^{\prime}: A \mapsto A_{W}$. A *-product is defined on $\mathscr{P}^{\prime}$ by $A_{W} * B_{W}=(A B)_{W}$. Let $H$ be the operator that represents the generator $L^{1}$ of the compact subgroup of $S O(2,1)$, so that $H_{W}=L^{1}$ and $\left(e^{t \boldsymbol{t} / i^{i}}\right)_{W}=\operatorname{Exp}\left(t L^{1}\right)$. Now, since the spectrum of $H / 2 \hbar$ consists of integers, we must have $\operatorname{Exp}\left(\pi L^{1}\right)=1$ for this *-product. Examination of (12-31) reveals that the period of each term in (12-28) is $2 \pi n$, where $n$ is the smallest integer such that $2 n l$ is integer. This indicates that the *-products that were found for $S O(2,1)$ are related to faithful representations of $S O(2,1)$ or to coverings of $S O(2,1)$. In particular, it is known that $(12-33)$ is related to a representation of the fourfold (metaplectic) covering of $S O(2,1)$; that is, the twofold covering of $S L(2, \mathbb{R})$. 


\section{ACKNOWLEDGMENTS}

We thank Professor J. Schwinger for helpful advice and Dr. D. Arnal and Professor R. Račka for interesting discussions. One of the authors (M.F.) thanks the Physics Department, UCLA, for hospitality. Another author (C.F.) thanks l'Université de Dijon for hospitality received during the early part of this collaboration.

\section{REFERENCES}

1. E. P. Wrgner, Phys. Rev. 40 (1932), 749.

2. H. WEYL, "Gruppentheorie und Quantenmechanik," Hirzel-Verlag, Leipzig, 1928; Z. Phys. 46 (1927), 1.

3. G. S. AGarwal and E. Wolf, Phys. Rev. D $2(1970), 2161$.

4. K. CHI Liv, J. Math. Phys. 17 (1976), 859.

5. J. E. Moyal, Proc. Cambridge Phil. Soc. 45 (1949), 99. See also E. A. Remler, Ann. Phys. (N.Y.) 95 (1975), 455.

6. M. Flato, A. Lichnerowicz, and D. Sternheimer, (a) C. R. Acad. Sci. Paris Ser. A 279 (1974), 877; (b) Compositio Math. 31 (1975), 47; (c) J. Math. Phys. 17 (1976), 1754.

7. M. Gerstenhaber, Ann. Math. 79 (1964), 59.

8. J. VEY, Comment. Math. Helvet. 50 (1975), 421.

9. M. Flato, A. Lichnerowicz, And D. Sternheimer, C. R. Acad. Sci. Paris Ser. A 283 (1976), 19.

10. F. Bayen, M. Flato, C. Fronsdal, A. Lichnerowicz, and D. Sternheimer, Deformation theory and quantization. II. Physical applications, Ann. Phys. (N.Y.) 111 (1978), 111.

11. A. Nuenhuis, Indag. Math. 17 (1955), 390.

12. A. Lichnerowicz, Les Variétés de Poisson et leurs Algèbres de Lie associées, J. Differential Geometry, to appear.

13. A. Ayez and A. Lichnerowicz, C. R. Acad. Sci. Paris Ser. A 275 (1972), 113; A. Avez, A. Lichnerowicz, and A. Diaz-Miranda, J. Differential Geometry 9 (1974), 1.

14. F. Bayen, M. Flato, C. Fronsdal, A. Lichnerowicz, and D. Sternheimer, Lett. Math. Phys. 1, 521 (1977).

15. P. A. M. Dirac, "Lectures on Quantum Mechanics," Belfer Graduate School of Sciences Monograph Series No. 2, Yeshiva Univ., New York, 1964.

16. A. Lichnerowicz, (a) C. R. Acad. Sci. Paris Ser. A 280 (1976), 523. (b) Lett. Math. Phys. 2(2) (1977).

17. This map was introduced by J. M. Souriau, "Structures des Systèmes Dynamiques," Dunod, Paris, 1970.

18. For information about enveloping algebras, see J. Dixmier, "Algèbres Enveloppantes," GauthierVillars, Paris, 1974.

19. In the examples of *-products for semisimple algebras that have been calculated so far, $K$ turned out to be a multiple of the Killing form.

20. L. Abellanas and L. Martinez-Alonso, J. Math. Phys. 17 (1976), 1363. See also M. Vergne, Bull. Soc. Math. France 100 (1972), 301. When $\mathscr{A}=H_{n}$ (with basis $q_{1} \cdots p_{n}, e$ ), the "canonical" bijection between $\mathscr{P}$ and $U(\mathscr{A})$ defines a bijection $\Psi_{0}$ between the quotient of $U(\mathscr{A})$ by the ideal generated by $(e-1)-\mathrm{a}$ Weyl algebra [18]-and the quotient of $\mathscr{P}$ by the corresponding ideal; in the Heisenberg representation of $\mathscr{A}, \Psi_{0}^{-1}$ gives the Weyl quantization rule. Other bijections, defined with different vector space bases of $U(\mathscr{A})$, correspond to different orderings [3] (standard, normal, etc.). This is one of the motivations for the restriction made from the next subsection onward to projections defined by characters of the center of the Poisson Lie algebra 9 .

21. We have found some invariant *-products that are not regular; they are related to finite-dimensional representations of the algebra and are of interest on compact symplectic manifolds.

22. N. BourbakI, "Algèbre," Chap. II, Sect. 1, No. 13, 3rd ed., 1962 or new edition, 1970, Hermann, Paris. 
23. The general form (11-9) for the Exp of an $H_{1}$-invariant, normal *-product corresponds exactly to the general " $\Omega$-association law"considered by Agarwal and Wolf [3]. The result is easily extended to $H_{n}$.

24. E. B. DynkIN, Amer. Math. Soc. Transl. 97 (1953). [Uspehi Mat. Nauk (N.S.) 5, No. 1 (35) (1950), 135]. See also N. Jacobson, "Lie Algebras," Interscience, New York, 1962; G. Hochschild, "The Structure of Lie Groups," Holden-Day, San Francisco, 1966. 


\title{
Deformation Theory and Quantization.* II. Physical Applications
}

\author{
F. BAYEN \\ Département de Mathématiques, Université de Paris 6, 75230 Paris Cedex 05, France \\ M. Flato ${ }^{+}$and C. Fronsdal \\ University of California, Los Angeles, California 90024
}

AND

A. Lichnerowicz AND D. STERNHEIMER

Physique Mathématique, College de France, 75231 Paris Cedex 05, France

Received May 19, 1977

\begin{abstract}
In the preceding paper general deformations of the structures based on the classical symplectic manifolds were examined. Quantization can be understood as a deformation of the algebra of observables without any need for introducing a Hilbert space. By a slight but crucial restatement of the usual interpretation of classical mechanics we find a framework for the description of both classical and quantum mechanics, within which the continuity of the quantization process is brought out. The spectra of some important physical observables are determined by direct phase space methods; this helps support the belief that a complete and autonomous theory, equivalent to ordinary quantum mechanics in special cases, but capable of wide generalization, can be constructed.
\end{abstract}

\section{A. General Physical Considerations}

\section{Contractions and Deformations in Physics}

(a) Nonrelativistic physics (more precisely: Galilei-relativistic physics) can be viewed as a "contraction" of relativity theory (Lorentz- or Poincaré-relativistic theory). The word contraction is used here in the sense of Segal-Wigner-Inönü contraction of groups [1]; the Poincaré group contracts to the Galilei group in the limit $c \rightarrow \infty$ (contraction parameter $c=$ velocity of light). A deformation [2] is a sort of inverse

* This work was supported in part by the National Science Foundation.

† Permanent address: Physique Mathérnatique; Collège de France, 75231 Paris Cedex 05 and Université de Dijon, 21000 Dijon, France. 
to contraction: one determines, in a precise mathematical sense, all groups that are "close" to the Galilei group and finds the Poincaré group (among a small number of possibilities). In this sense, relativity theory is a deformation of nonrelativistic physics.

Another instance of contraction is the passage from quantum theory to the classical limit $\hbar \rightarrow 0$ (contraction parameter $\hbar=$ Planck's constant). Here the inverse process of deformation is nothing but the general problem of quantization. The radical change in interpretation that accompanies the passage to quantum theory might discourage attempts to apply the concepts and techniques of deformation theory; nevertheless it is our aim to show that it can be done.

(b) The basic mathematical structures of classical mechanics are the symplectic structures attached to phase space: the algebra $(N)$ of $C^{\infty}$ functions on phase space $(W)$ under ordinary multiplication of functions, and the Lie algebra structure induced on $N$ by the Poisson bracket that is defined by the symplectic form $(F)$ on $W$. In the preceding paper [3] we have examined the formal differentiable deformations of these algebras; in particular, we have introduced an associative algebra $\left({ }^{*}\right.$-product algebra or *-algebra for brevity) that is a deformation of the algebra $N$ of functions with ordinary multiplication. For $f, g \in N=C^{\circ}(W, \mathbb{C})$ we write the new (deformed) composition law on $N$ as $(f, g) \mapsto f * g$. The corresponding Lie algebra defined by $(f, g) \mapsto[f * g] \equiv(f * g-g * f) / i \hbar$ is a deformation of the Poisson Lie algebra. A particular instance of this type of deformation of classical mechanics is familiar and is known as the Moyal product and associated Moyal bracket.

It is our intention to demonstrate that quantum mechanics can be replaced by $a$ deformation of classical mechanics: a description of quantum phenomena in terms of ordinary functions on phase space, including a complete and autonomous physical interpretation. Naturally, this alternative formulation of quantum theory will include some features that are not usually associated with phase space. In order to know what to expect it is worth while to recall the elements of the theory of Weyl [4], Wigner [5], and Moyal [6]. See also the preceding paper [3]. (I, Section 12a).

\section{The Weyl-Wigner-Moyal Formalism}

(a) Consider the Schrödinger quantum mechanical description of a particle interacting with a potential. Let $A$ be a linear operator in Hilbert space; the following can be made rigorous provided $A$ belongs to a large class of operators including those that are Hilbert-Schmidt. A unique function on phase space (here $W=\mathbb{R}^{3} \times \mathbb{R}^{3}$ ) is defined in terms of the configuration space matrix elements of $A$ (integral kernel associated with $A$ ) by the formula [5]

$$
A_{W}(\vec{p}, \vec{q})=\int\langle\vec{x}|A| \vec{y}\rangle e^{\vec{p} \cdot(\vec{x}-\vec{y}) / i \hbar} \delta^{3}\left(\vec{q}-\frac{\vec{x}+\vec{y}}{2}\right) d^{3} x d^{3} y .
$$

This defines a one-one correspondence-the Weyl correspondence-between a large class of operators in Hilbert space and a large family $\mathscr{N}$ of functions or distri- 
butions on phase space [7]. The map that sends $A_{W}$ to $A$ is called the Weyl application and denoted $\Omega$; one has

$$
\Omega: f \rightarrow \hat{f}=\int \hat{f}(\vec{\xi}, \vec{\eta}) e^{(\vec{\xi} \cdot \vec{p}+\vec{n} \cdot \vec{o}) / i \hbar} d^{3} \xi d^{3} \eta
$$

where $\tilde{f}$ is the inverse Fourier transform of the function or distribution $f$, and $\vec{P}, \vec{Q}$ are the Schrödinger operators that correspond to $\vec{p}, \vec{q}$.

An associative ${ }^{*}$-product (Moyal *-product) is induced in $\mathscr{N}$ in a natural manner. Let $f, g \in \mathscr{N}$ and $f, \hat{g}$ the corresponding operators, so that $f=\hat{f}_{W}, \hat{f}=\Omega(f)$, etc.; then

$$
f * g=(\hat{f} \hat{g})_{W} \in \mathscr{N} .
$$

That is, the composition law $(f, g) \mapsto f * g$ is defined by the commutativity of the diagram

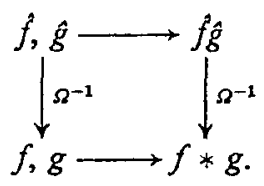

Direct calculation gives

$$
f * g=\sum_{n=0}^{\infty} \frac{\lambda^{n}}{n !} P^{n}(f, g)=f e^{\lambda} \vec{P}_{g} \quad(\lambda=i \hbar / 2)
$$

where $P^{n}$ is the $n$th power of the Poisson bracket (interpreted as a bidifferential operator acting on the couple $(f, g)$ and $\overleftrightarrow{P}$ is defined by (throughout part $\mathrm{A}$ of this paper, we take for $P$ what is denoted by $-P$ in part $B$ and in the preceding paper):

$$
\{f, g\} \equiv f \stackrel{\leftrightarrow}{P} g=\frac{\partial f}{\partial q^{i}} \frac{\partial g}{\partial p_{i}}-\frac{\partial f}{\partial p_{i}} \frac{\partial g}{\partial q^{i}}=P(f, g) .
$$

The Moyal bracket [6] is

$$
\{f, g\}_{M} \equiv[f * g] \equiv(f * g-g * f) / i \hbar .
$$

It is this bracket, and not the Poisson bracket, that corresponds to the quantum commutator: $\{f, g\}_{M}=(1 / i \hbar)[\hat{f}, \hat{g}]_{W}$.

The fact that one has to do with a formal deformation of classical mechanics, with Planck's constant $\hbar$ playing the role of deformation parameter, is brought out by Eq. $(2-4)$.

Other rules of association (other orderings) between functions and operators have been considered in the literature (see e.g., Agarwal and Wolf, Ref. 7). They are of the type (2.2), with the difference that the measure $d \xi d \eta$ is multiplied by a weight function

$$
\Omega_{1}=1+\sum_{r=1}^{\infty} \hbar^{r} T_{r} \omega_{2 r}
$$


where $\omega_{2 r}$ is a homogeneous polynomial; we shall call them $\Omega_{1}$-laws. In the orderings usually considered (standard, normal, etc.) $\Omega_{1}=\exp \left(\hbar \omega_{2}\right)$, with $\omega_{2}$ a homogeneous quadratic polynomial. Its Fourier transform will thus be a formal series

$$
T_{\hbar}=I+\sum_{r=1}^{\infty} \hbar^{r} T_{r},
$$

where the $T_{r}$ are differential operators. If the functions $f$ and $g$ give the operators $f$ and $\hat{g}$ under the $\Omega_{1}$-law, we shall denote by $f *^{\prime} g$ the inverse $\Omega_{1}$-image of $\hat{f} \hat{g}$. Then we have $T_{n} f=f_{W}$ and therefore $T_{n}\left(f *^{\prime} g\right)=T_{n} f * T_{n} g$. Thus $T_{n}$ realizes the $c$ equivalence (in the sense of Definition 20 of I) between the Moyal bracket and the $\Omega_{\mathrm{x}}$-bracket $\left[f *^{\prime} g\right]$, and similarly between the two associative algebra deformations.

All orderings correspond therefore to cohomologically equivalent deformations, and any treatment done in one ordering can be translated into another ordering via this equivalence. In this sense the two formalisms are equivalent, though the same classical function will in general correspond to operators of different form in the different orderings.

(b) Many problems of quantum physics have already been translated into the Moyal idiom [8]. Our point of view is different: we want to make the "classical" formulation autonomous in order to open up a vast field of generalizations with all kinds of interesting applications (see Section 5). For this reason it is necessary to deal with some problems of interpretation. We begin with an examination of the Moyal equations of motion.

Let $f$ be any operator without explicit time dependence, $\hat{H}$ the Hamiltonian operator, and $f, H$ the corresponding functions on phase space. The Schrödinger equation of motion for $f$ is translated by the Weyl correspondence into the Moyal equations of motion for $f$, namely,

$$
(d / d t) f=[f * H]=(f * H-H * f) / i \hbar .
$$

The Moyal bracket defines a derivation of the *-product algebra; that is,

$$
[f *(g * h)]=[f * g] * h+g *[f * h]
$$

whence

$$
\frac{d}{d t}(f * g)=\left(\frac{d}{d t} f\right) * g+f *\left(\frac{d}{d t} g\right) .
$$

However, unless $f$ is a polynomial of order $\leqslant 2$, we have for almost all $g, h$ :

$$
[f *(g h)] \neq[f * g] h+g[f * h] .
$$

[The significance of the exception made for polynomials of order $\leqslant 2$ is discussed 
in Section 3b.] In order words, one solves the Moyal equations of motion (2-7) for $f, g$, and $f g$ and discovers that, in general,

$$
(f g)(t) \neq f(t) g(t)
$$

The impression that this result is paradoxical must be dispelled by a proper interpretation.

Every student of the Hamiltonian formulation of classical mechanics has to overcome the difficulty that is posed by the dual interpretation of the $p$ 's and the $q$ 's. On the one hand, these quantities are elements of the Poisson Lie algebra of functions on phase space; this gives a meaning to the Poisson brackets $\left\{q^{i}, p_{j}\right\}=\delta_{j}{ }^{i}$, etc. On the other hand, the solutions of the equations of motion are trajectories in phase space, described by an application $t \in \mathbb{R} \mapsto\left(q^{i}(t), p_{i}(t)\right) \in \mathbb{R}^{6}$, and no sense can be attached to the bracket $\left\{q^{i}(t), p_{j}(t)\right\}$. The error is more serious than just the usual failure to distinguish between function and value, for there is here an unfortunate confusion between observable and state. We shall sketch a formulation of classical mechanics that makes a fundamental distinction between the $p$ 's and the $q$ 's as observables (elements of $N$ ) and the coordinates of points on a trajectory in phase space. It will be seen that this in effect prepares the way: the shock of a complete reinterpretation of the process of measurement that usually attends quantization is softened and the continuous passage that is implied by the use of deformation theory is brought out. The idea is to isolate the two principal elements of the theory, equations of motion and initial conditions, from each other and to associate the former with observables and the latter with states.

The Hamiltonian equation of motion for an observable $f$,

$$
(d / d t) f=-\{H, f\}, \quad f \in N,
$$

will be interpreted as defining a derivation of the algebra $N$ of $C^{*}$ functions on $W$. The solution

$$
f(t)=e^{-t(H \cdot \cdot f f}
$$

defines a map of $\mathbb{R} \times N$ into $N,(t, f) \rightarrow f(t)$. Thus we are permitted to write

$$
(d / d t) f(t)=-\{H, f(t)\}
$$

since $f(t)$ is a function on $W$. The image of the map $(t, f) \rightarrow f(t)$ is a trajectory in $N$ through $f$. In particular, $q^{i}(t)$ and $p_{i}(t)$ are functions on $W$ and there is not yet any reference to trajectories in $W$. The entire discussion is in terms of functions on phase space and is not directly concerned with values $f(t)\left(p^{\prime}, q^{\prime}\right)$ of $f(t)$ at any point $p^{\prime}, q^{\prime}$ in $W$.

To any set of initial conditions one can associate a real (pseudoprobability) distribution $\rho$ on phase space, normalized so that

$$
\int \rho d^{3} p d^{3} q=1 .
$$


We refer to such a distribution as a state. In most problems of classical physics it is enough to consider "distributions" of the form $\rho=\delta^{3}\left(\vec{p}-\vec{p}^{\prime}\right) \delta^{3}\left(\vec{q}-\vec{q}^{\prime}\right)$ where $\left(\vec{p}^{\prime}, \vec{q}^{\prime}\right) \in \mathbb{R}^{6}$. The result of a measurement of the observable $f$ at the time $t$ on the state $\rho$ is

$$
\langle f\rangle_{t}=\int f(t) \rho d^{3} p d^{3} q
$$

EXAMPLE 1. Take $H=p^{2} / 2 m, f=q^{2}$; Eq. (2-12) gives the trajectory in $N$ given by $f(t)=(\vec{q}+t \vec{p} / m)^{2}$. With $\rho=\delta^{3}\left(\vec{p}-\vec{p}^{\prime}\right) \delta^{3}\left(\vec{q}-\vec{q}^{\prime}\right)$ one gets $\langle f\rangle_{t}=\left(\vec{q}^{\prime}+t \vec{p}^{\prime} / m\right)^{2}$.

This interpretation lends itself to statistical generalizations though it remains completely deterministic as long as the first-order equation of motion (2-12) is retained. Determinism, in the usual narrow sense, is lost when (2-12) is replaced by the nonlocal equation of motion (2-7). It is then that phenomena such as "spreading of the wave packet" appear [9].

We return now to the discussion of (2-10). In classical mechanics we are dealing with the algebra $N$ of functions on phase space with ordinary multiplication of functions. The Poisson bracket $\{H, f\}$ defines a derivation of this algebra and therefore so does the time development determined by the equations of motion. In addition, it is clear that $(f g)(t)$ must perforce be equal to $f(t) g(t)$ as long as one is dealing with a single trajectory in phase space and $f(t), g(t),(f g)(t)$ are identified with their numerical values at the point on the trajectory labeled by $t$. In Moyal dynamics, on the other hand, the relevant structure on $N$ is the *-product; the equation of motion shows that $d / d t$ is a derivation of this new structure and $f(t) * g(t)=(f * g)(t)$. The "paradox" of (2-11) means that trajectories in phase space have no invariant meaning: if $\vec{p}, \vec{q} \rightarrow \vec{P}, \vec{Q}$ is a canonical transformation, then the trajectory $\vec{p}(t), \vec{q}(t)$ does not necessarily coincide with the trajectory $\vec{P}(t), \vec{Q}(t)$. Of course, this is directly related to the fact that the system

$$
\left(\vec{p}-\vec{p}^{\prime}\right) * \rho=0=\left(\vec{q}-\vec{q}^{\prime}\right) * \rho, \quad\left(\vec{p}^{\prime}, \vec{q}^{\prime}\right) \in \mathbb{R}^{8}
$$

does not possess solutions when $\hbar \neq 0$.

(c) The analog of the formula (2-15) for the measured value $\langle f\rangle_{t}$ of the observable $f \in \mathscr{N}$ at time $t$ for the state $\rho \in \mathscr{N}$, in Moyal dynamics, is

$$
\langle f\rangle_{t}=\int f(t) * \rho d^{3} \vec{p} d^{3} \vec{q}
$$

This can be derived from quentum mechanics by means of the Weyl correspondence (2-1) with the following interpretations: $\hat{\rho}=\Omega(\rho)$ is a density matrix, $\hat{f}(t)=\Omega(f(t))$, $\langle f\rangle_{t}=\operatorname{tr}(f \hat{\rho})$. If $\hat{\rho}$ is pure, $\hat{\rho}=|\psi\rangle\langle\psi|$, then $\rho=(|\psi\rangle\langle\psi|)_{W}$ is called the Wigner function for the state $|\psi\rangle$.

Remark. Equation (2-17) appears in the literature in the equivalent form (2-15). The equality $\int f * g d^{3} p d^{3} q=\int f g d^{3} p d^{3} q$ was discussed in [3] (I, Sect. 12d); it is 
valid for the Moyal *-product (and equivalent orderings related to the Heisenberg algebras $H_{n}$ ), but not for ${ }^{*}$-products in general. We shall adopt (2-17) in the general case.

\section{General *-Products and the Notion of Preferred Coordinates}

(a) The general notion of deformation of symplectic structures studied in the preceding paper provides the means for a wide generalization of the conventional process of quantization. Given any classical mechanical system, is it possible to identify a more or less unique *-product and thus the "correct" quantization scheme? The question is not well posed, since the answer must depend on the extent to which the classical system is well defined and endowed with a complete physical interpretation. We shall suggest a partial answer based on the idea of the existence of a set of "distinguished observables" or "preferred coordinates."

(b) It is curious to notice that the concept of "observable" seems to be more fully developed in quantum theory than in classical mechanics. Indeed, a fairly accurate definition in quantum theories without superselection rules is to call observable every self-adjoint operator. In classical mechanics there has been a tendency to call observable every function on phase space. To avoid semantic difficulties we shall call "good observables" functions of a more restricted class.

If $f$ is a self-adjoint operator in Hilbert space, then one has a 1-parameter group $G$ of unitary operators $\left\{e^{i t}\right\}(t \in \mathbb{R})$. Let $f$ be the function on phase space related to $f$ by the Weyl correspondence; then $f$ is real and defines an infinitesimal canonical transformation; that is, a derivation $g \mapsto\{f, g\}$ of $N$, and a globally Hamiltonian vector field on phase space. By the usual exponentiation of vector fields one obtains an action of $G$ in $W$. This motivates the following

Definition 2. A function $F \in N$ is a good observable if it generates, by the Poisson bracket, a group of symplectic diffeomorphisms of $W$.

For $a \in N$ we have (I, Sect. 9) called $a$-invariant any *-product such that

$$
\{a, f * g\}=\{a, f\} * g+f *\{a, g\}, \quad \forall f, g \in N .
$$

Let $\mathscr{A}$ be the Lie algebra of all $a \in N$ such that the ${ }^{*}$-product is $\mathscr{A}$-invariant. In the case of a Vey deformation (defined by the differentiable cochains of increasing order), we have seen that $\mathscr{A}$ is always finite dimensional. [It is likely, though not proved, that $\mathscr{A}$ is finite dimensional for more general deformations as well.] Therefore, every Vey quantization scheme (one formalizable as a Vey deformation) distinguishes a finite subalgebra of $N$. This algebra is a subalgebra of the algebra $\operatorname{Inv}(F, \Gamma)$ that generates the infinitesimal symplectic transformations, affine for a connection $\Gamma$ on $W$.

The Moyal *-product is invariant under $\operatorname{Inv}(F, \Gamma)$, where $\Gamma$ is the usual flat connection on $\mathbf{R}^{2 l}$. If we take the natural coordinates on $\mathbb{R}^{2 l}$ such that the components 
$\Gamma_{j k}^{i}$ of $\Gamma$ vanish, then the elements of $\operatorname{Inv}(F, \Gamma)$ are the polynomials of order $\leqslant 2$. We note that these are all good observables. Furthermore, there are enough of them to "coordinatize" $W$; more precisely, $\operatorname{Inv}(F, T)$ is "sufficiently large" in the sense of

Definition 3. A finite subalgebra $\mathscr{A}$ of $N$ is called sufficiently large if the map $J: W \rightarrow \mathscr{A}^{*}$ given by $x \mapsto \lambda_{A} L^{A}(x)$ is injective. Here $\left\{L^{A}\right\}(A=1, \ldots, m)$ is a basis for $\mathscr{A}$ and $\left\{\lambda_{A}\right\}$ is the dual basis for $\mathscr{A}^{*}$.

If $\mathscr{A}$ is sufficiently large we can use the $L^{A}$ 's as a set of (supernumerary) coordinates for $W$.

We believe that the identification of good observables must play an important role in the physical interpretation of any system. We shall therefore limit ourselves to *-products that are invariant under a sufficiently large algebra of good observables. Furthermore, we assume that these good observables remain good after quantization; that is, we assume that the infinitesimal automorphisms of the *algebra defined by $f \mapsto[a * f], a \in \mathscr{A}, f \in N$, generate a group of automorphisms. The simplest way to guarantee this is to suppose that $[a * f]=\{a, f\}$ for $a \in \mathscr{A}, \forall f \in N$. [Note that this is implied by the apparently weaker assumption that $\mathscr{A}$ be preserved by quantization: $[a * b]=\{a, b\}$ for $a, b \in \mathscr{A}$, provided any $f \in N$ can be expressed as a limit of a sequence of $*$-polynomials in $L^{1}, \ldots, L^{n}$.]

Thus we feel justified in making the following

Definimion 4. A quantization on a symplectic space $(W, F)$ is a $*$-product defined on $N=C^{\infty}(W, \mathbb{C})$, invariant under a sufficiently large finite subalgebra $\mathscr{A} \subset N$ of good observables, such that $[a * f]=\{a, f\}$ for $\forall a \in \mathscr{A}, \forall f \in N$, where ih is the deformation parameter. The elements of $\mathscr{A}$ will be called the distinguished observables or the preferred coordinates for the quantization.

[By associating quantum observables with self-adjoint operators we have deliberately, for simplicity, restricted ourselves to the narrow framework of conventional wisdom. As we know by certain examples in quantum mechanics, and also from studying the question of integrability of finite-dimensional Lie algebras to Lie groups (both in geometry and in analysis), it may very well be so that special circumstances require a more liberal definition of observables. Consequently, it may sometimes be necessary to extend our definition of good observables to include certain types of derivations that do not exponentiate to Lie groups of symplectomorphisms.]

According to Definition 4, the problem of quantization of any physical system may be approached as follows: (i) identify a finite algebra of distinguished observables; (ii) replace $W$ by the image $M$ of the map $J: W \rightarrow \mathscr{A}^{*}$; (iii) select an invariant *-product on $M$. This last problem was solved, in principle, under fairly general conditions, in the preceding paper. We are led to the crux of the problem of quantization: To quantize a physical system, one must identify a finite algebra $\mathscr{A}$ of distinguished observables.

That the algebra $A$ of distinguished observables plays a very special role in the 
deformed (quantized) theory is evident. Let $a \in \mathscr{A}$ and consider the differential equation $(d / d t) f=[a * f]$. This coincides with $(d / d t) f=\{a, f\}$. For the Poisson bracket we have the ordinary derivation rule; therefore this differential equation defines a group of geometric transformations of phase space. In particular, if the Hamiltonian $H$ belongs to 21 , then the time development of the system can be associated with a classical trajectory through phase space. The harmonic oscillator is a wellknown example.

(c) The specification of the distinguished observables for a classical physical system is an important part of the interpretation of it. Since it is impossible to treat this problem in general we shall discuss only one particular case.

The classical Kepler problem is characterized by the following Hamiltonian function:

$$
H=\frac{1}{2} p^{2}-(1 / r)
$$

[Units have been chosen so that both physical parameters of the problem are equal to unity.] Here

$$
p^{2}=\vec{p} \cdot \vec{p}, \quad r=(\vec{q} \cdot \vec{q})^{1 / 2}>0,
$$

and $(\vec{q}, \vec{p}) \in\left(\mathbb{R}^{3}-\{0\}\right) \times \mathbb{R}^{3}$. The singularity of (3-2) at the origin must be removed; this will be done by a method that goes back to Poincaré and even to Kepler himself.

The equation of motion for $f \in C^{\infty}\left(\mathbb{R}^{6}, \mathbb{C}\right)$, namely,

$$
(d / d t) f=-\{H, f\}
$$

together with the subsequent restriction to an energy surface:

$$
H-E \approx 0, \quad E \in \mathbb{R}
$$

( $H-E$ vanishes weakly in Dirac's sense [11]) can be replaced by

$$
(d / d s) f=\{r(E-H), f\} \quad \text { and } \quad r(E-H) \approx 0 .
$$

Here $s$ is the mean anomaly introduced by Kepler; comparison of (3-4) and (3-5) shows that $d s / d t=1 / r$. In this way the singular Hamiltonian (3-2) is replaced by the smooth function

$$
r(E-H)=E r-\frac{1}{2} r p^{2}-1 \text {. }
$$

However, singularities are introduced if one evaluates

$$
(d / d s) \vec{p}=\left\{r(E-H, \vec{p}\}=\left(E-\frac{1}{2} p^{2}\right) \vec{q} / r\right.
$$

therefore the choice of the $p_{i}$ as preferred coordinates leaves something to be desired. No singularities appear in

$$
(d / d s) \vec{q}=\{r(E-H), \vec{q}\}=r \vec{p}
$$


or in higher derivatives such as

$$
\left(d^{2} / d s^{2}\right) \vec{q}=\{r(E-H), r \vec{p}\}=E \vec{q}+(q \cdot p) \vec{p}-\frac{1}{2} p^{2} \vec{q}
$$

This strongly suggests that $\vec{q}$ and $r \vec{p}$ be taken as distinguished coordinates. These six functions generate, by the Poisson bracket, a 10-dimensional algebra isomorphic to the Poincare algebra, with the basis

$$
\left\{L^{A}\right\}=\left\{q^{i}, r ; q^{i} p_{j}-q^{j} p_{i}, r p_{i}\right\} \quad(A=1, \ldots, 10) .
$$

This algebra would be a reasonable choice of distinguished observables for many systems with a $1 / r$ potential. The special case of the Kepler problem, however, is characterized by a special symmetry - the $S O(4)$ symmetry associated with the RungeLenz constants of the motion [12]. The generators of $S O(4)$ are not included in the Poincaré algebra spanned by (3-8) and this suggests that the set of distinguished observables be enlarged. That this can be done is well known; the easiest construction is found by asking whether the function (3-6) can be included. One finds a 15-dimensional algebra isomorphic to so $(4,2)$, with the basis (3-8) and

$$
\left\{L^{A}\right\}=\left\{r p^{2}, p \cdot q,(q \cdot p) \vec{p}-\frac{1}{2} p^{2} \vec{q}\right\} \quad(A=11, \ldots, 15) .
$$

The larger algebra includes the so(4) symmetry algebra of the Hamiltonian.

Although the Poincaré algebra spanned by (3-8) is sufficiently large, there are advantages to including (3-9) and taking so(4,2) as the algebra of distinguished observables. Because the function $r(E-H)$ is an element of $s o(4,2)$ (for $E$ fixed in $R$ ), one finds that every element of $s o(4,2)$ has simple harmonic $s$-dependence, which trivializes the solution of the equations of motion [13]. In addition, the arbitrariness in the choice of $*$-product is always reduced when the algebra of invariance is enlarged.

The map $J$ defined by $(q, p) \mapsto \lambda_{A} L^{A}(\vec{p}, \vec{q})(A=1, \ldots, 15)$ sends $W$ onto a sixdimensional submanifold of the dual $\mathscr{A}^{*}$ of $\mathscr{A}=s o(4,2)$. This is an exceptional orbit of the coadjoint action ad* $\mathscr{A}$ of $\mathscr{A}$ in $\mathscr{A}^{*}$ (most orbits are 12-dimensional; see I, Sect. 11d). The construction of invariant *-products on such orbits is a very interesting problem.

\section{Spectral Theory, a Beginning}

(a) For $f \in N$ and $t \in \mathbb{R}$ consider the formal series (see I, Sect. 12)

$$
\operatorname{Exp}(f t)=\sum_{n=0}^{\infty} \frac{1}{n !}(t / i \hbar)^{n}(f *)^{n}
$$

Assume that there exists a $\rho>0$ such that for $|t|<\rho$ the power series in $t$ converges to a distribution on $W$. Suppose also that, for $t$ fixed in some complex neighborhood 
of the origin, $\operatorname{Exp}(f t)$ considered as a distribution on $W$ has a Fourier-Dirichlet expansion

$$
\operatorname{Exp}(f t)=\sum_{\lambda \in I} \pi_{\lambda} e^{\lambda t / i \hbar}
$$

where $I$ is a sequence in $\mathbb{C}$ and $\pi_{\lambda} \in N$ for $\lambda \in I$. In the special case of the Moyal *-product, if $\Omega(f)$ is a normal operator in Hilbert space, then $I$ is the spectrum of this operator and the $\Omega\left(\pi_{\lambda}\right)$ are the projectors for the spectral decomposition. This motivates the following definition (we return to the general case):

DefinITION 5. If $f \in N$ satisfies (4-2) we call $I$ the spectrum of $f$, any $\lambda \in I$ an eigenvalue of $f$, and $\pi_{\lambda}$ the projector associated with $\lambda$.

From (4-1) one obtains

$$
f * \operatorname{Exp}(f t)=i \hbar(d / d t) \operatorname{Exp}(f t)
$$

and from this it follows easily that

$$
\begin{aligned}
f * \pi_{\lambda} & =\lambda \pi_{\lambda}, \\
f & =\sum_{\lambda \in I} \lambda \pi_{\lambda}, \\
\pi_{\lambda} * \pi_{\lambda^{\prime}} & =\delta_{\lambda \lambda^{\prime}} \pi_{\lambda} .
\end{aligned}
$$

More generally, we may consider the Fourier transform (in a generalized-function sense); formally

$$
\operatorname{Exp}(f t)=\int e^{\lambda t / i \hbar} d \mu(\lambda)
$$

In general, the support of $d \mu(\lambda)$ will be referred to as the spectrum of $f$. It is the (Fourier) spectrum of $\operatorname{Exp}(f t)$ as a distribution in $t$, in the sense of L. Schwartz.

(b) Let a *-product $(f, g) \mapsto f * g$ on $N=C^{\infty}(W, \mathbb{C})$ be given; then the composition law

$$
(f, g) \mapsto f \bar{*} g \equiv \overline{\bar{g} * \bar{f}}
$$

( $f=$ complex conjugate of $f$ ) defines another *-product on $N$. In particular, let $\mathscr{A}$ be a real Lie algebra, $\mathscr{A}^{*}$ its real dual, and $f * g$ an invariant $*$-product on some ad* $\mathscr{A}^{*}$-invariant submanifold $M$ of $\mathscr{A}^{*}$ (see I, Sects. 9-11); then $f \bar{*} g$ is another invariant *-product on $M$.

Definirion 6. A *-product is called symmetric if, for $f, g \in N$, we have $f * g=f \bar{*} g$, that is, if $\overline{f * g}=\bar{g} * \bar{f}$.

From now on, we limit ourselves to symmetric *-products (the Moyal *-product is symmetric).

(c) If $f$ in (4-2) is real, then $I$ is symmetric (that is, $\lambda \in I \Rightarrow \lambda \in I$ ) and $\bar{\pi}_{\lambda}=\pi_{\lambda}$. 
Moreover, if $g * g \geqslant 0$ for any real $g \in N$ (the expansion (42) being supposed unique), then $I$ and $\pi_{\lambda}$ are real. We suppose now that this is the case, and define $N_{\lambda}$ by $\left(N_{\lambda} \in \mathbb{R}\right.$ if the integral converges, otherwise we shall say that $N_{\lambda}$ is infinite):

$$
N_{\lambda} \equiv \int_{W} \pi_{\lambda} d \mu(x)
$$

where $d \mu(x)$ is the Liouville measure on $W$ (with some normalization to be chosen later). Assuming $N_{\lambda}$ is finite we have a normalized state $\rho_{\lambda}=\pi_{\lambda} / N_{\lambda}$. Now let $g$ be another function with an expansion of the type (4-2), with real spectrum $I^{\prime}$ and projectors $\pi_{\kappa}{ }^{\prime}$, and define $N_{\kappa}{ }^{\prime} \equiv \int_{W} \pi_{\kappa}{ }^{\prime} d \mu(x), \rho_{\kappa}{ }^{\prime}=\pi_{\kappa}{ }^{\prime} / N_{\kappa}{ }^{\prime}$. Measuring the observable $\pi_{\lambda}$ in the state $\rho_{\kappa}{ }^{\prime}$ and the observable $\pi_{\kappa}{ }^{\prime}$ in the state $\rho_{\lambda}$ one obtains

$$
N_{\kappa}{ }^{\prime}\left\langle\pi_{\lambda}\right\rangle=\int \pi_{\lambda} * \pi_{\kappa}{ }^{\prime} d \mu(x)=\int \pi_{\kappa}{ }^{\prime} * \pi_{\lambda} d \mu(x)=N_{\lambda}\left\langle\pi_{\kappa}{ }^{\prime}\right\rangle
$$

The principle of detailed balance thus tells us that $N_{\lambda}$ and $N_{\kappa}^{\prime}$ are (up to a common factor) the multiplicities of the states $\rho_{\lambda}$ and $\rho_{\kappa}{ }^{\prime}$; that is, the multiplicities of the eigenvalues $\lambda$ of $f$ and $\kappa$ of $g$.

Henceforth, we shall take the Liouville measure $d \mu(x)$ on $W$ to be so normalized that (4-6) gives precisely the multiplicity of the eigenvalue $\lambda$ of $f$. In the case of the Moyal *-product on $\mathbb{R}^{2 n}$ one verifies easily that $N_{\lambda}=\operatorname{tr} \Omega\left(\pi_{\lambda}\right)$ if one takes

$$
d \mu(x)=d^{n} p d^{n} q /(2 \pi \hbar)^{n}
$$

\section{Suggestions}

(a) It is apparent that we have tried to avoid dealing with distributions (generalized functions) on phase space beyond those that can be defined in some sense by formal power series. Attempts to generalize lead to interesting questions; for example, we need to know under what conditions associativity is retained. Our "classical" spectral theory is very far from being developed; one may ask, for example, under what conditions a distribution $f$ has a real spectrum for a given quantization.

Equations (4-2) and (4-5) pose a problem that seems to have received scant notice up to now: given a distribution, find the support of its Fourier-Dirichlet series (or Fourier transform). This question replaces the much more familiar but hardly easier problem of the determination of spectra of operators. In fact, it seems that all aspects of operator theory now find analogs in classical analysis.

(b) A promising aspect of the approach to quantization by means of deformation theory is its generality. Symplectic manifolds with nontrivial homology groups are of interest-sometimes for obvious reasons and sometimes as a result of the globalization of phase space that is realized by the choice of distinguished observables. The states are not necessarily one-valued on phase space and this gives rise to cohomologically nontrivial factors and projective representations of groups of 
invariance. The Bohm-Aharonov effect should provide a very interesting example [14].

Applications to open systems are also possible. One-differentiable rigorous deformations of the Poisson Lie algebra have been shown to apply to classical systems with friction or viscosity [15]. [The losses occur as a consequence of giving up the derivation rule.] Perhaps this type of deformation could be combined with the quantization to create a coherent description of decaying systems.

(c) In classical field theory one has a Poisson bracket (in terms of functional derivatives) [16]. Formally it is straightforward to write a corresponding Moyal bracket [17]. It would be worthwhile to develop techniques (on infinite-dimensional symplectic manifolds) for giving a rigorous meaning to deformations of the Poisson bracket of classical field theory. An analog of the *-product for infinite-dimensional symplectic manifolds would also be of interest. It would be natural to begin with an investigation of semiclassical approximations, including WKB and tree approximations, in field theories subject to strictly canonical quantization. For want of a rigorous treatment one could study quantizations at some order of $h$.

Even more exciting is the possibility of discovering new quantization schemes for field theories, such as quantum electrodynamics, Yang-Mills theories with or without a Higgs-Kibble mechanism, theories with soliton or monopole solutions, for which the conventional canonical quantization is clearly inappropriate. Also, "quarks" may be "confined" because quark fields are quantized so as never to create any free particle states in the first place [18].

(d) Anti-Poisson brackets on Grassmann algebras have been studied recently [19], after the invention of supersymmetry in dual models [20] and in quantum field theory [21]. Let $N$ be the Grassmann algebra generated by $\left\{\theta^{a}\right\}(a, b=1, \ldots, n)$ and $\Lambda$ a real, constant symmetric 2-tensor; that is a $\Lambda=\left\{\Lambda^{a b}\right\}$ with $\Lambda^{a b}=\Lambda^{b a} \in \mathbb{R}$. Define the anti-Poisson bracket for $f, g \in N$ by

$$
\{f, g\}=f \stackrel{\leftrightarrow}{P} g=f \vec{c}_{a} \Lambda^{a b} \vec{\partial}_{b} g
$$

The simplest deformation of $N$ is given by the anti-Moyal *-product defined for $f, g \in N$ by

$$
f * g=f e^{\lambda \vec{p}} g \quad(\lambda=i \hbar / 2) .
$$

With this product $N$ is a Clifford algebra. The corresponding deformation of the anti-Poisson algebra is given by

$$
[f * g] / i \hbar=(2 / \hbar) f \sin ((\hbar / 2) \overleftrightarrow{P}) g
$$

This bracket has the correct symmetry properties and satisfies the (generalized) Jacobi identity. 
Generalizations are immediate. In the first place, $\Lambda$ need not be constant. The antiPoisson bracket (5-1) satisfies the Jacobi identity if and only if the (generalized) Schouten bracket $[\Lambda, \Lambda]$ vanishes. The powers of $\overleftrightarrow{P}$ that appear in (5-2) must be understood in terms of covariant derivatives and conditions are imposed on the connection by associativity. Applications include quantization of classical (Grassmann algebra valued) Fermi fields.

(e) From the general considerations and the particular examples of invariant *-products developed in $I$, from the remarks made about our "classical" spectral theory in this paper, and from the partial success of the Kostant-Souriau geometrical approach to group representations, it seems more than evident that *-products have a promising future in representation theory.

(f) One of the most important theorems of classical mechanics-it can be taken as the starting point for a formulation of statistical mechanics-is the Liouville theorem. One form of this theorem states that the generalized velocity vector in phase space is divergenceless. In ordinary classical mechanics (phase space $W=\mathbb{R}^{2 n}$ with $\left\{x^{i}\right\}=\left\{q^{1} \cdots p^{n}\right\}$ ) this reads

$$
-\operatorname{div} \dot{x}=\left(\partial / \partial x^{i}\right)\left\{H, x^{i}\right\}=0 .
$$

The validity of this formula follows easily from the equations of motion. In Moyal mechanics the Liouville theorem continues to hold. The reason for this is that $[H * a] / i \hbar=\{H, a\}$ for every first-order polynomial $a=a_{i} x^{i}$ in $x^{1}, \ldots, x^{2 n}$. [This statement remains valid for all the generalizations of the Weyl correspondence considered in the literature.] It is interesting to study the validity of the Liouville theorem for general deformations and invariant *-products.

(g) The Weyl application establishes a correspondence between functions on phase space and linear operators in Hilbert space. To the product of operators corresponds the *-product of functions and to the commutator of operators corresponds the *-commutator of functions (Moyal bracket). One may ask: What is the image of the Poisson bracket of functions in the ring of operators? That is, what is the contraction limit $\hbar \rightarrow 0$ of the ring of operators of quantum mechanics? In other words, we are interested in the empty box in Fig. 1 . The application indicated by a dashed line is defined by commutativity of the diagram. The physics described by the mathematical structure in the empty box applies to certain situations in quantum optics in the coherent states formalism.

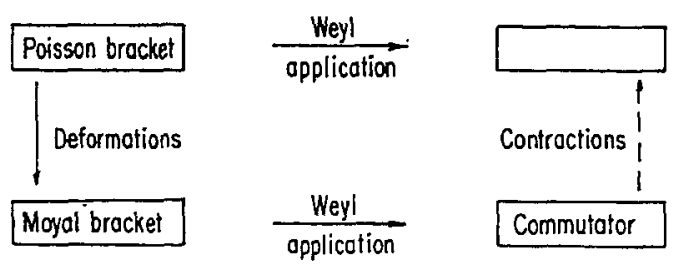

Figure 1 
(h) Finally, it should be noted that our suggestion to regard Moyal mechanics and its generalizations as autonomous physical theories raises the question of whether or not all such theories can be cast in a form that fits the general axiomatic formulation of quantum mechanics.

\section{B. Calculation of Spectra}

\section{Harmonic Oscillator}

In this section the energy levels of an l-dimensional harmonic oscillator will be computed with the help of the Moyal product. This will be achieved by considering the function $\operatorname{Exp}(H t)$ and its Fourier decomposition as explained in the previous section. Though some of the calculations that will appear may be more or less well known, it does not seem that such a "classical" treatment exists in the literature. Here by "classical" we mean that we deal only with functions defined in phase space and that no operator of the quantum mechanical Hilbert space corresponding to the problem appears.

(a) One-dimensional case. We denote the Hamiltonian function by $H$; for the harmonic oscillator

$$
H(p, q)=\frac{1}{2}\left(p^{2}+q^{2}\right) .
$$

Suppose $f: \mathbb{R} \rightarrow \mathbb{C}$ is a $C^{\infty}$ function. Then $f(H)$ is a $C^{\infty}$ function defined in phase space and a straightforward computation gives:

$$
H * f(H)=H f(H)-\left(\hbar^{2} / 4\right) f^{\prime}(H)-\left(\hbar^{2} / 4\right) H f^{\prime \prime}(H) .
$$

Equation (6-1) proves that in this case $(H *)^{n}$ is a function of $H$ only. We can therefore write $(H *)^{n}=K_{n}(H)(n=0,1, \ldots)$ where $K_{n}$ is a function of one variable. According to (6-1) we have:

$$
K_{n+1}(H)=H K_{n}(H)-\left(\hbar^{2} / 4\right) K_{n}^{\prime}(H)-\left(\hbar^{2} / 4\right) H K_{n}^{\prime \prime}(H) ;
$$

$K_{n}$ is therefore a polynomial of degree $n$ and the same parity as $n$. We are now in position to formulate:

Proposition 1. For any fixed $(p, q) \in \mathbb{R}^{2}$, the power series in $t$ :

$$
\sum_{n=0}^{\infty} \frac{1}{n !}\left(\frac{t}{i \hbar}\right)^{n} K_{n}(H(p, q))=\left.\sum_{n=0}^{\infty} \frac{1}{n !}\left(\frac{H t}{i \hbar} *\right)^{n}\right|_{p, a}
$$

has a radius of convergence equal to $\pi$. For $|t|<\pi$ one has

$$
\sum_{n=0}^{\infty} \frac{1}{n !}\left(\frac{t}{i \hbar}\right)^{n} K_{n}(H)=\left(\cos \frac{t}{2}\right)^{-1} \exp \left(\frac{2 H}{i \hbar} \tan \frac{t}{2}\right) .
$$


Proof. Consider the function

$$
(t, H) \mapsto \phi(t, H)=\left(\cos \frac{t}{2}\right)^{-1} \exp \left(\frac{2 H}{i \hbar} \tan \frac{t}{2}\right)
$$

which is analytic in the following open set $U$ of $\mathbb{C}^{2}$ :

$$
U=\left\{(t, H) \in \mathbb{C}^{2} \mid t \neq(2 k+1) \pi, k \in \mathbb{Z}\right\}
$$

Write the Taylor expansion of $\phi$ with respect to $t$ around the origin:

$$
\phi(t, H)=\sum_{n=0}^{\infty} \frac{1}{n !}\left(\frac{1}{i \hbar}\right)^{n} C_{n}(H) t^{n}, \quad|t|<\pi
$$

and remark that $\phi$ satisfies the following partial differential equation in $U$ :

$$
i \hbar \frac{\partial \phi}{\partial t}=H \phi-\frac{\hbar^{2}}{4} \frac{\partial \phi}{\partial H}-\frac{\hbar^{2}}{4} H \frac{\partial^{2} \phi}{\partial H^{2}} .
$$

It is obvious that the coefficients $C_{n}$ satisfy the recursion relation (6-2) with $C_{0}=1$. It follows that for any $n, C_{n}=K_{n}$. Compare $I$, Eq. (12-33).

This pointwise convergence property of the series $\sum_{n=0}^{\infty}(1 / n !)\left((H t / i \hbar)^{*}\right)^{n}$ allows us to prove the convergence of $(6-3)$ in the usual $\mathscr{D}^{\prime}\left(\mathbb{R}^{2}\right)$ space of distributions in the variables $p$ and $q$.

Proposition 2. For fixed $t \in]-\pi, \pi[$ (or $|t|<\pi$ and $t \in \mathbb{C})$ the series (6-3) converges in $\mathscr{D}^{\prime}\left(\mathbb{R}^{2}\right)$ for the weak topology to

$$
\left(\cos \frac{t}{2}\right)^{-1} \exp \left[\frac{1}{i \hbar}\left(p^{2}+q^{2}\right) \tan \frac{t}{2}\right] .
$$

Proof. In fact with respect to the variable $H \in \mathbb{C}$ the series converges uniformly on compact sets in the complex plane. It follows that when $H$ is replaced by $\frac{1}{2}\left(p^{2}+q^{2}\right)$ the series converges uniformly on compact sets in the $(p, q)$ plane.

Now the map

$$
t \mapsto\left(\cos \frac{t}{2}\right)^{-1} \exp \left[\frac{1}{i \hbar}\left(p^{2}+q^{2}\right) \tan \frac{t}{2}\right]
$$

from the disk $|t|<\pi$ into $\mathscr{D}^{\prime}\left(\mathbb{R}^{2}\right)$ is weakly analytic and has a (weak) analytic continuation in the open set $U^{\prime}=\mathbb{C}-\{(2 k+1) \pi \mid k \in \mathbb{Z}\}$. We therefore define $\operatorname{Exp}(H t)$ as the distribution (6-5) in the variables $(p, q)$ for fixed $t \in U^{\prime}$. One easily checks that if $t \in U^{\prime}, \operatorname{Im} t \leqslant 0$, the distribution $\operatorname{Exp}(H t) \in \mathscr{S}^{\prime}\left(\mathbb{R}^{2}\right)$, i.e., is tempered.

In order to define the Fourier expansion of $\operatorname{Exp}(H t)$ we remark that for fixed $(p, q) \in \mathbb{R}^{2}$ the function $(6-5)$ is periodic in $t$ with period $4 \pi$. However, this function does not belong to $L^{1}(0,4 \pi)$. We therefore consider (6-5) as a distribution in the variable $t \in \mathbb{R}$. In fact we have: 
Proposition 3. For fixed $(p, q) \in \mathbb{R}^{2}-\{0\}$ the function

$$
\left(\cos \frac{t}{2}\right)^{-1} \exp \left[\frac{1}{i \hbar}\left(p^{2}+q^{2}\right) \tan \frac{t}{2}\right]
$$

defines a periodic distribution $S$ in $\mathscr{D}^{\prime}(\mathbb{R})$. Its Fourier expansion is:

$$
S=\sum_{n=0}^{\infty} \pi_{n}(p, q) e^{-i(n+1 / 2) t}
$$

with

$$
\pi_{n}(p, q)=2 \exp \left(-\frac{2}{\hbar} H(p, q)\right)(-1)^{n} L_{n}\left(\frac{4}{\hbar} H(p, q)\right)
$$

Here $L_{n}=L_{n}{ }^{0}$ denotes the usual Laguerre polynomial of degree $n$.

Proof. By a rescaling of the time $t$ we can consider $f(\tau)=(\cos \tau)^{-1} e^{i R t g \tau}$ with $R=\hbar^{-1}\left(p^{2}+q^{2}\right)>0$ and prove the proposition for $f$. One first shows that $f$ defines a periodic distribution $S$, for example, by the formula:

$$
\langle S, \phi\rangle=\sum_{k=-\infty}^{+\infty}\left(\lim _{\varepsilon \rightarrow+0} \int_{-\pi / 2+k n+\epsilon}^{\pi / 2+k \pi-\epsilon} f(\tau) \phi(\tau) d \tau\right)
$$

where the test function $\phi \in \mathscr{D}(\mathbb{R})$. This allows us to compute the Fourier coefficients $a_{n}$ of $S$ and to write $S=\sum_{n=0}^{\infty} a_{n} e^{i n \tau}$. If we denote by $S$ the distribution defined on the one-dimensional torus associated with $S$, one has $a_{n}=\left\langle\tilde{S}, e^{-i n \tau}\right\rangle$. The coefficients $a_{n}$ are then computed with the help of the function

$$
\exp \left(R \frac{Z^{2}-1}{Z^{2}+1}\right)\left(Z^{2}+1\right)^{-1} Z^{-n}
$$

and a suitable contour integration in the complex plane. One finds that $a_{2 n+1}=$ $2(-1)^{n} e^{-R} L_{n}(2 R)$ for $n \geqslant 0$ and that all other coefficients vanish.

The Fourier expansion of $\operatorname{Exp}(H t)$ being defined, we can now examine the convergence (in the distribution sense, in the variables $p$ and $q$ ) for fixed $t$ of the series (6-6). This leads us to our main proposition:

Proposition 4. For fixed $t \in \mathbb{C}$ with $\operatorname{Im} t \leqslant 0$ and $t \neq(2 k+1) \pi(k \in \mathbb{Z})$

$$
\operatorname{Exp}(H t) \equiv\left(\cos \frac{t}{2}\right)^{-1} \exp \left(\frac{2 H}{i \hbar} \tan \frac{t}{2}\right)=\sum_{n=0}^{\infty} \pi_{n} e^{-i(n+1 / 2) t}
$$

the series converging in $\mathscr{S}^{\prime}\left(\mathbb{R}^{2}\right)$ for the weak topology. Moreover, if $t= \pm \pi$ the series converges (in $\mathscr{S}^{\prime}\left(\mathbb{R}^{2}\right)$ ) to $\mp i \pi \hbar \delta$. 
Proof. We denote by $H_{n}$ the Hermite polynomials of degree $n$ and by $\phi_{n}$ the corresponding orthonormalized function in $L^{2}(\mathbb{R}): \phi_{n}(x)=\pi^{-1 / 4}\left(n ! 2^{n}\right)^{-1 / 2} H_{n}(x) e^{-x^{2} / 2}$. If $T \in \mathscr{S}^{\prime}\left(\mathbb{R}^{2}\right)$ one knows that

$$
T=\sum_{n_{1} \cdot n_{2} \in \mathbb{N}}\left\langle T, \phi_{n_{1}} \otimes \phi_{n_{2}}\right\rangle \phi_{n_{1}} \otimes \phi_{n_{2}}
$$

where the series in the right-hand side is weakly summable. Between Laguerre and Hermite polynomials the following well-known formula holds:

$$
L_{n}\left(x^{2}+y^{2}\right)=(-1)^{n} 2^{-2 n} \sum_{m=0}^{n} \frac{1}{m !(n-m) !} H_{2 m}(x) H_{2 n-2 m}(y) .
$$

Thus in (6-8) one can express $\pi_{n}$ with the help of this formula. One then checks that, up to an obvious (constant) rescaling of the variables $p$ and $q$, the result is identical to the expansion of the left-hand side of (6-8) in tensor products $\phi_{n_{1}} \otimes \phi_{n_{2}}$ of Hermite functions. The case $t= \pm \pi$ is an easy exercise left to the reader.

The last point of Proposition 4 is by no means surprising since $\lim _{t \rightarrow \pm n, \operatorname{Im} t<0}$ $\operatorname{Exp}(H t)=\mp i \pi \hbar \delta$ holds in $\mathscr{S}^{\prime}\left(\mathbb{R}^{2}\right)$ for the weak topology.

We may now summarize the content of the preceding considerations in the following way. The distribution $\operatorname{Exp}(H t)$ has been constructed with the help of a power series expansion around the origin. The application $t \mapsto \operatorname{Exp}(H t)$ may be considered as a periodic (with period $4 \pi$ ) distribution-valued function defined in $\mathbb{R}$. It has a Fourier expansion in $\mathscr{S}^{\prime}\left(\mathbb{R}^{2}\right)$ and the only harmonics which occur in this expansion are $e^{-i(n+1 / 2) t}$. The coefficients $\pi_{n} \in \mathscr{S}^{\prime}\left(\mathbb{R}^{2}\right)$ which appear in the Fourier series satisfy (as is easily checked) $\int_{\mathbf{R}^{2}} \pi_{n} d p d q=2 \pi \hbar$. We thus recover the standard result of quantum mechanics: $E_{n}=\left(n+\frac{1}{2}\right) \hbar$, the multiplicity of the corresponding state being equal to one. Furthermore, it is clear that, via the Weyl correspondence $\Omega$, (6-8) becomes the spectral decomposition of the unitary operator $\operatorname{Exp}\left(\hat{H} t / i^{\prime}\right)$ where $\hat{H}=\Omega(H)$, the functions $\pi_{n}$ becoming projectors.

Remarks. (1) Obviously if $\hbar \rightarrow 0, \operatorname{Exp}(\hbar H t) \rightarrow \exp (-i H t)$ and the discrete

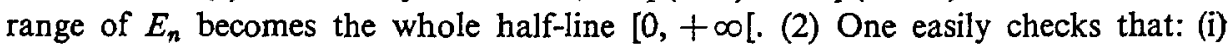
$\pi_{n}=\left(\hbar^{-n} / n !\right)\left(\bar{a}^{n}\right) * \pi_{0} *\left(a^{n}\right)$ where $a=2^{-1 / 2}(q+i p)$ and the bar denotes complex conjugation $\left((a *)^{n}=a^{n}\right)$.

$$
\begin{gathered}
H * \pi_{n}=\pi_{n} * H=\left(n+\frac{1}{2}\right) \hbar \pi_{n}, \\
\pi_{n}=\bar{\pi}_{n}, \\
\pi_{n} * \pi_{m}=\delta_{n m} \pi_{n} .
\end{gathered}
$$

Conversely one may verify that solutions of the system

$$
\begin{gathered}
H * \psi=\psi * H=E \psi, \\
\psi=\psi \\
\psi * \psi=\psi
\end{gathered}
$$


analytic near 0 (with respect to $p$ and $q$ ) and belonging to $\mathscr{S}^{\prime}\left(\mathbb{R}^{2}\right)$ exist if and only if $E=\left(n+\frac{1}{2}\right) \hbar(n=0,1, \ldots)$. Furthermore, in that case $\psi=\pi_{n}$. (3) The spectral decomposition (6-8) allows us to compute in principle any *-function of $H$, such as the resolvent $\left((H-\lambda)^{*}\right)^{-1}$. One may check that for any $\lambda \in \mathbb{C}-(\hbar(\mathbb{N}+1 / 2))$ the series

$$
\sum_{n=0}^{\infty}((n+1 / 2) \hbar-\lambda)^{-1} \pi_{n}=((H-\lambda) *)^{-1}
$$

converges in $\mathscr{S}^{\prime}\left(\mathbb{R}^{2}\right)$ and that if $\operatorname{Re} \lambda<\hbar / 2$ one has

$$
((H-\lambda) *)^{-1}=2 \hbar^{-1} \int_{0}^{\pi / 2} \exp \left(-\frac{2 H}{\hbar} \cos \theta\right)\left(\tan \frac{\theta}{2}\right)^{-2 \lambda / \hbar} d \theta
$$

(b) l-dimensional case. In this case $H=\frac{1}{2}\left(p^{2}+q^{2}\right)$ with $p^{2}=\sum_{j=1}^{l} p_{j}^{2}$, $q^{2}=\sum_{j=1}^{l} q_{j}^{2}$. We also write $p \cdot q=\sum_{j=1}^{l} p_{j} q_{j}$. For convenience and in connection with Sections 9-12 of $\mathrm{I}$, we introduce a dynamical Lie algebra: $\left\{X=\alpha p^{2}+2 \beta p \cdot q+\right.$ $\left.\gamma q^{2} \mid \alpha, \beta, \gamma \in \mathbb{R}\right\}$ is an $s o(2,1)$ Lie algebra with respect to Moyal (and Poisson) bracket. Suppose that $f: \mathbb{R} \rightarrow \mathbb{C}$ is a $C^{\infty}$ function; then as in Section $6 a$ we have $\left(d \equiv \alpha \gamma-\beta^{2}\right)$ :

$$
X * f(X)=X f(X)-l d \hbar^{2} f^{\prime}(X)-d \hbar^{2} X f^{\prime \prime}(X) .
$$

This proves that for any $n=0,1,2, \ldots,\left(X^{*}\right)^{n}$ may be expressed as a function of $X$ only. Propositions 1 and 2 may be generalized as follows:

Proposition 5. For any $(p, q) \in \mathbb{R}^{2 l}$, the power series in $t$

$$
\sum_{n=0}^{\infty} \frac{1}{n !}\left(\frac{X t}{i \hbar} *\right)^{n}
$$

has a radius of convergence $\rho=\pi /\left(2|d|^{1 / 2}\right)(\infty$ if $d=0)$. If $|t|<\rho$ one has:

$$
\begin{aligned}
\sum_{n=0}^{x} \frac{1}{n !}\left(\frac{X t}{i \hbar} *\right)^{n} & =\left[\cos \left(|d|^{1 / 2} t\right)\right]^{-l} \exp \left[\frac{X}{i \hbar|d|^{1 / 2}} \tan \left(|d|^{1 / 2} t\right)\right] & & \text { if } d>0, \\
& =\exp (X t / i \hbar) & & \text { if } d=0, \\
& =\left[\cosh \left(|d|^{1 / 2} t\right)\right]^{-l} \exp \left[\frac{X}{i \hbar|d|^{1 / 2}} \tanh \left(|d|^{1 / 2} t\right)\right] & & \text { if } d<0 .
\end{aligned}
$$

Proposmon 6. For fixed $t \in]-\rho, \rho[$ (or $|t|<\rho$ and $t \in \mathbb{C}$ ) the series (6-10) converges in $\mathscr{D}^{\prime}\left(\mathbb{R}^{2}\right)$ for the weak topology to one of the expressions (6-11) according to the sign of $d$.

Proofs are analogous to those of Propositions 1 and 2. This allows us to define $\operatorname{Exp}(X t)$ for fixed $t \in \mathbb{C}$ outside the singularities of the functions (6-11) as in Section 6a. 
Thus $\operatorname{Exp}(X t)$ can be viewed as an element of $\mathscr{D}^{\prime}\left(\mathbb{R}^{2 l}\right)$ and, if $X \geqslant 0, \operatorname{Im} t \leqslant 0$, $\operatorname{Exp}(X t) \in \mathscr{S}^{\prime}\left(\mathbb{R}^{2 l}\right)$.

In case $d>0$, Fourier analysis may be worked out with the same results as previously. We consider the case $X=H$. Obviously

$$
\begin{aligned}
\operatorname{Exp}(H t) & =\operatorname{Exp}\left(H_{1} t\right) * \cdots * \operatorname{Exp}\left(H_{l} t\right) \\
& =\operatorname{Exp}\left(H_{1} t\right) \otimes \operatorname{Exp}\left(H_{2} t\right) \cdots \otimes \operatorname{Exp}\left(H_{1} t\right)
\end{aligned}
$$

where $H_{j}=\frac{1}{2}\left(p_{j}{ }^{2}+q_{j}{ }^{2}\right)(1 \leqslant j \leqslant l)$. Hence one gets formally:

$$
\operatorname{Exp}(H t)=\sum_{n=0}^{\infty}\left(\sum_{n_{1}+\cdots+n_{l}=n} \pi_{n_{1}} \otimes \pi_{n_{2}} \otimes \cdots \otimes \pi_{n_{l}}\right) e^{-i(n+l / 2) t} .
$$

Let $L_{n}^{(\alpha)}$ denote the generalized Laguerre polynomial of degree $n$. The known formula:

$$
\sum_{m=0}^{n} L_{m}^{(\alpha)}(x) L_{n-m}^{(\beta)}(y)=L_{n}^{(\alpha+\beta+1)}(x+y)
$$

implies that

$$
\pi_{n}^{(l)} \equiv \sum_{n_{1}+\cdots+n_{l}=n} \pi_{n_{1}} \otimes \pi_{n_{2}} \otimes \cdots \otimes \pi_{n_{2}}=2^{l} \exp \left(-\frac{2 H}{\hbar}\right)(-1)^{n} L_{n}^{l-1}\left(\frac{4 H}{\hbar}\right) .
$$

We thus finally obtain:

Proposition 7. For fixed $t \in \mathbb{C}$ with $\operatorname{Im} t \leqslant 0$ and $t \neq(2 k+1) \pi(k \in \mathbb{Z})$

$$
\operatorname{Exp}(H t) \equiv\left(\cos \frac{t}{2}\right)^{-l} \exp \left(\frac{2 H}{i \hbar} \tan \frac{t}{2}\right)=\sum_{n=0}^{\infty} \pi_{n}^{(l)} e^{-i(n+l / 2) t}
$$

the series (6-12) converging in $\mathscr{S}^{\prime}\left(\mathbb{R}^{2 l}\right)$ for the weak topology. Moreover, if $t= \pm \pi$ the series (6-12) converges $\left(\right.$ in $\left.\mathscr{S}^{\prime}\left(\mathbb{R}^{2 l}\right)\right)$ to $(\mp i \pi h)^{l} \delta$.

The proof is analogous to that of Proposition 4.

We have thus obtained the energy levels $E_{n}=(n+l / 2) \hbar$ of an $l$-dimensional (isotropic) harmonic oscillator. The multiplicities of the levels are also the right ones. For example, if $l=3$ one gets $\int_{\mathbb{R}^{8}} \pi_{n}^{(3)}(p, q) d p d q=(2 \pi h)^{3} \frac{1}{2}(n+1)(n+2)$.

In the case $d<0$, Fourier analysis may be worked out directly. To simplify we take $d=-\frac{1}{4}$. A straightforward computation yields

$$
\operatorname{Exp}(X t)=\left(\cosh \frac{t}{2}\right)^{-i} \exp \left(\frac{2 X}{i \hbar} \tanh \frac{t}{2}\right)=\int_{-x}^{\infty} e^{\lambda t / i \hbar} \pi(\lambda, X) d \lambda
$$

where the (real) generalized projectors $\pi(\lambda, X)$ are given by

$$
\pi(\lambda, X)=(\pi \hbar)^{-1} 2^{l-1} \frac{\Gamma(l / 2-i \lambda / \hbar) \Gamma(l / 2+i \lambda / \hbar)}{\Gamma(l)} e^{-2 i X / \hbar} F_{1}\left(\frac{l}{2}-\frac{i \lambda}{\hbar} ; l ; \frac{4 i X}{\hbar}\right) .
$$


Here ${ }_{1} F_{1}$ denotes the confluent hypergeometric function. For any $\lambda \in \mathbb{R}, \pi(\lambda, X(p, q)) \in$ $\mathscr{S}^{\prime}\left(\mathbb{R}^{2 l}\right)$ and one has $X * \pi(\lambda, X)=\pi(\lambda, X) * X=\lambda \pi(\lambda, X)$. Furthermore, if we define $E(\lambda)=\int_{-\infty}^{\lambda} \pi(\mu, X) d \mu$, the map $\lambda \mapsto E(\lambda)$ is a continuous map from $\mathbb{R}$ into $\mathscr{S}^{\prime}\left(\mathbb{R}^{2 l}\right)$ endowed with the weak topology, such that $\lim _{\lambda \rightarrow-\infty} E(\lambda)=0$ and $\lim _{\lambda \rightarrow \infty} E(\lambda)=1$ hold in this topology. In this case also, *-functions or distributions may be computed. For example, if $T \in \mathscr{S}^{\prime}(\mathbb{R}), T(X *)$ is defined by the formula (where $\tilde{T}$ is the Fourier transform of $T$ )

$$
T(X *) \equiv\langle T, \pi(\lambda, X)\rangle=(2 \pi)^{-1 / 2}\langle\tilde{T}, \operatorname{Exp}(-s \hbar X)\rangle
$$

and the function $X \mapsto T(X *)$ is a $C^{\circ}$ function of polynomial growth. For example, we have

$$
(X *)^{n}=\int_{-\infty}^{+\infty} \lambda^{n} \pi(\lambda, X) d \lambda
$$

Remarks. (1) In the previous analysis we have observed that the function $\operatorname{Exp}(H t)$ had singularities in $t$. This fact is not surprising. Assume for simplicity that of $\hbar=1$ and $l=1$. In the Hilbert space $L^{2}(\mathbb{R})$ one can show that for $0<|t|<\pi(t \in \mathbb{R})$ and $f \in L^{2}(\mathbb{R})$ one has:

$$
\begin{aligned}
& (\exp (-i \hat{H} t) f)(x)=\exp \left[-i(\operatorname{sgn} t) \frac{\pi}{4}\right](2 \pi|\sin t|)^{-1 / 2} \\
& \quad \times \operatorname{li.m} \operatorname{mis}_{R \rightarrow \infty}^{+R} \exp \left[\frac{i}{4}\left(\frac{1}{\tan t / 2}(x-y)^{2}-(\tan t / 2)(x+y)^{2}\right)\right] f(y) d y .
\end{aligned}
$$

Thus if $t \rightarrow \pi$ this expression for $\exp (-i \hat{H} t)$ becomes singular, though the oneparameter group $t \mapsto \exp (-i \hat{H} t)$ of unitary operators is continuous and $\exp (-i \hat{H} \pi)=$ $-i^{2}=\Omega(-i \pi \delta)$. (F्F denotes the Fourier transformation.) (2) In order to get $\operatorname{Exp}(X t)$ we utilized a power series. Another definition of the exponential function, namely, $e^{x}=\lim _{n \rightarrow \infty}(1+x / n)^{n}$, is also available. In fact it is easy to prove that

$$
\lim _{n \rightarrow \infty}\left(\left(1+\frac{t X}{n i \hbar}\right) *\right)^{n}=\operatorname{Exp}(X t)
$$

holds for $t \in \mathbb{C}$ and $|t|<\pi$ for pointwise convergence and weak convergence in $\mathscr{V}^{\prime}\left(\mathbb{R}^{2 l}\right)$. (3) The computation of the continuous spectrum (case $d<0$ ) is not only completely autonomous in our formalism, but also much easier than the corresponding operatorial treatment. (4) The function $\frac{1}{2} H=\frac{1}{4}\left(p^{2}+q^{2}\right)$ "represents" the usual compact (elliptic) generator of $s o(2,1)$, i.e., the generator with period $2 \pi$ when exponentiated in the structure to the group $S O(2,1)$ (and period $4 \pi$ in $S L(2, \mathbb{R})$ ). The other two usual (hyperbolic) generators are represented by $\frac{1}{2} p q$ and $\frac{1}{4}\left(p^{2}-q^{2}\right)$, and the lowering and raising generators by $(p \pm i q)^{2}$. For $l=1$, from Remark 2 in Section $6 \mathrm{a}$, one sees that $(p-i q)^{2} * \pi_{n} *(p+i q)^{2}$ is proportional to $\pi_{n+2}$. The multiplicity being 1 in that case, the *-exponentials of the generators of $\operatorname{so}(2,1)$ close to the direct sum of two irreducible *-representations of the metaplectic group, the twofold covering of $\operatorname{Sp}(2, \mathbb{R})=S L(2, \mathbb{R})$. The group appears thus naturally 
in our *-formalism (without any tricks). The spectrum $\{n+l / 2\}$ of $H$ splits into $\{2 m+l / 2\} \cup\{2 m+3 l / 2\}$, with $m=[n / 2]$.

\section{Angular Momentum}

In this section we determine the spectrum of the angular momentum $\vec{L}^{2}$ and more generally of the first Casimir element of $s o(l)(l>2)$ in the specific representation of this Lie algebra for which the canonical representatives $M_{j k}$ of $s o(l)$ are $M_{j k}=q_{j} p_{k}-q_{k} p_{j}(1 \leqslant j<k \leqslant l)$. The reason for this generalization (which as will be seen is straightforward) is twofold: (a) The spectral problem of the Hamiltonian of the hydrogen atom will be shown to be closely linked to that of this first Casimir in the case $l=4$. (b) In this specific representation of $s o(l)$, the Moyal *-product defined on the $p$ 's and $q$ 's induces an invariant *-product on the Lie algebra $s o(l)$ in the sense of Section 9 of I. In fact it is easily shown that the *-product $M_{i_{1} k_{1}} * \cdots * M_{j_{n} k_{n}}$ is equal to a polynomial in the elements $M_{j k}$. It is thus interesting to get in this instance the spectrum of an element of the enveloping algebra.

It is obvious that the functions $M_{j k}$ satisfy (for Moyal and Poisson brackets) the commutation relations of the Lie algebra $s o(l)$. The spectrum of $M_{12}=L_{3}$ may be found in Appendix A-1. Here we shall compute the spectrum of the first Casimir

$$
C=\sum_{1<j<k<l}\left(M_{j k} *\right)^{2}=g^{2}-l(l-1) \frac{\hbar^{2}}{4}
$$

where $g^{2}(p, q)=p^{2} q^{2}-(p \cdot q)^{2}$ and $g \geqslant 0$. In the particular case $l=3$, we denote by $\vec{L}=\left(L_{j}\right)(1 \leqslant j \leqslant 3)$ the three functions $M_{j k}$ and we have

$$
C=(\vec{L} *)^{2}=\sum_{1}^{3}\left(L_{j} *\right)^{2}=\vec{L}^{2}-\frac{3}{2} \hbar^{2},
$$

i.e., up to a constant the square of classical angular momentum.

The following considerations will show that the spectrum of $C$ may be deduced from the results of Section 6. Let $f: \mathbb{R}_{+} \rightarrow \mathbb{C}$ be a $C^{\infty}$ function. To begin with we compute $\left(g^{2}\right) * f\left(g^{2}\right)$. One first calculates

$$
M_{j k} * f\left(g^{2}\right)=M_{j k}\left(f\left(g^{2}\right)-\frac{3 \hbar^{2}}{2} f^{\prime}\left(g^{2}\right)-\hbar^{2} g^{2} f^{\prime \prime}\left(g^{2}\right)\right)
$$

and then one gets the cumbersome formula:

$$
\begin{aligned}
\left(g^{2}\right) * f\left(g^{2}\right)= & g^{2} f\left(g^{2}\right)+\hbar^{2}\left[3 l(l-1) \frac{\hbar^{2}}{8}-(l+2) g^{2}\right] f^{\prime}\left(g^{2}\right) \\
& +\hbar^{2} g^{2}\left[\left(l^{2}+9 l+5\right) \frac{\hbar^{2}}{4}-2 g^{2}\right] f^{\prime \prime}\left(g^{2}\right) \\
& +(l+4) \hbar^{4} g^{4} f^{\prime \prime \prime}\left(g^{2}\right)+\hbar^{4} g^{6} f^{(4)}\left(g^{2}\right)
\end{aligned}
$$

where $f^{\prime}, \ldots, f^{(4)}$ are the derivatives of $f$. 
Let $t, x \in \mathbb{R}$ and consider the function

$$
\psi(t, x)=\left(\cos \frac{t}{2}\right)^{2-\imath} \exp \left[\frac{2 x}{i \hbar} \tan \frac{t}{2}\right]
$$

which has been encountered in Section 6 in connection with the $l$-2-dimensional harmonic oscillator. One has

$$
\psi(t, x)=\sum_{n=0}^{\infty} \frac{1}{n !}\left(\frac{t}{i \hbar}\right)^{n} G_{n}(x)
$$

$|t|<\pi$, where $G_{n}$ is a polynomial of degree $n$ and the same parity as $n\left(G_{n}=K_{n}\right.$ when $l=3$ ).

LEMMA 1. For any integer $n \geqslant 0$ the following equality holds

$$
\left(\left[g^{2}-(3 l-4) \hbar^{2} / 4\right] *\right)^{n}=g^{-1} G_{2 n+1}(g) .
$$

The proofs of this lemma and of those that follow are given in Appendix A-2.

We thus prove that, up to a constant, the Moyal powers of the Casimir $C$ are the odd Moyal powers of the Hamiltonian $H$ of the $l$ - 2-dimensional harmonic oscillator divided by $g$ (after replacing $H$ by $g$ ).

The idea is now to find a ${ }^{*}$-square root $y$ of $g^{2}-(3 l-4)\left(\hbar^{2} / 4\right)=C+(l-2)^{2}\left(\hbar^{2} / 4\right)$ in order to compute $\operatorname{Exp}(\gamma s)$. We consider the function $\gamma=g-(l-2) \hbar^{2} / 4 g$ defined in the open set $U=\left\{(p, q) \in \mathbb{R}^{2 l} \mid g(p, q) \neq 0\right\}$; we shall prove that $(\gamma *)^{2}=$ $g^{2}-(3 l-4) \hbar^{2} / 4$ holds in $U$. It is legitimate to restrict ourselves to this open set of $\mathbb{R}^{2 l}$ since it is an open symplectic submanifold of $\mathbb{R}^{2 l}$ with induced symplectic structure.

LEMMA 2. Let $Q(y)$ be any polynomial; denote by $\mathscr{R}$ the function $\mathscr{R}(p, q)=$ $Q\left(g^{2}(p, q)\right)$ and by $R$ the polynomial $R(x)=Q\left(x^{2}\right)$. Then in $U$ we have

$$
(\gamma * \mathscr{R})(p, q)=(\mathscr{R} * \gamma)(p, q)=(A R)(g(p, q))
$$

where $A$ is the differential operator

$$
A=-\frac{\hbar^{2}}{4}\left(x \frac{d^{2}}{d x^{2}}+l \frac{d}{d x}\right)+x-\frac{(l-2) \hbar^{2}}{4 x} .
$$

The next step will be to show that (7-4) holds for more general functions of $g^{2}$. $\mathbf{U}_{\mathrm{p}}$ to now we have not used the fact that $\gamma$ depends on $\hbar$. As a matter of fact, as we mentioned before, the *-product can be naturally extended from the differentiable functions $N$ to the formal series $E(N, \hbar)$ in the parameter $\hbar$ of the deformation with coefficients in $N$. Let $\phi \in C^{\infty}(U)$ and suppose first that $\phi$ does not depend on $\hbar$; 
$\gamma * \phi$ will be the power series in $\hbar$ which is obtained after a reordering of the powers of $\hbar$ in the series $\sum_{0}^{\infty}(1 / n !)(i \hbar / 2)^{n} P^{n}(\gamma, \phi)$, i.e.,

$$
\begin{aligned}
\gamma * \phi= & g \phi+\frac{i \hbar}{2} P(g, \phi)-\frac{\hbar^{2}}{4}\left(\frac{l-2}{g} \phi+\frac{1}{2} P^{2}(g, \phi)\right) \\
& +\sum_{n=3}^{\infty} \frac{1}{n !}\left(\frac{i \hbar}{2}\right)^{n}\left[P^{n}(g, \phi)+(l-2) n(n-1) P^{n-2}\left(\frac{1}{g}, \phi\right)\right] .
\end{aligned}
$$

We have:

LEMMA 3. Let $\gamma=g-[(l-2) / 4 g] \hbar^{2}$ be defined as before and suppose that $\equiv C^{\infty}\left(\mathbb{R}_{+}-\{0\}\right)$ does not depend on $\hbar$. Denote by $\phi$ the function $\phi(p, q)=F(g(p, q))$. ien in $U$ we have

$$
(\gamma * \phi)(p, q)=(\phi * \gamma)(p, q)=(A F)(g(p, q))
$$

Here $A$ is the differential operator defined in Lemma 2.

We finally consider the case when $F=\sum_{k=0}^{p} \hbar^{k} F_{k}$ is a polynomial in $\hbar$ with coefficients $F_{k} \in C^{\infty}\left(\mathbb{R}_{+}^{*}\right)$ and show that (7-6) holds also in this case. In the expansion of the star product $\gamma * F(g)$ the coefficient of $\hbar^{n}$ will be after reordering:

$$
\begin{aligned}
& \left(\frac{i}{2}\right)^{n} \frac{1}{n !} \sum_{k}\left(\frac{2}{i}\right)^{k} n(n-1) \cdots(n-k+1) \\
& \quad \times\left[P^{n-k}\left(g, F_{k}(g)\right)+(l-2)(n-k)(n-k-1) P^{n-k-2}\left(g^{-1}, F_{k}(g)\right)\right] .
\end{aligned}
$$

According to Eq. (A-3) of Appendix A-2 all terms such that $n-k>2$ will cancel. Hence we get for such an $F$ :

$$
\gamma * F(g)=\gamma F(g)-\left(\hbar^{2} / 8\right) P^{2}(g, F(g))=(A F)(g)
$$

We are now in position to prove:

LEMMA 4. In the open set $U$ we have $(\gamma *)^{2}=g^{2}-[(3 l-4) / 4] \hbar^{2}$ and more generally

$$
(\gamma *)^{n}=g^{-1} G_{n+1}(g) \quad \text { if } n \geqslant 1 \text {. }
$$

One has thus shown that the nth Moyal powers of the function $\gamma(p, q)=g(p, q)-$ $[(l-2) / 4] \hbar^{2} g(p, q)^{-1}$ are identical to the $(n+1)$ th Moyal powers of the Hamiltonian $H$ of the $l-2$-dimensional harmonic oscillator divided by $g$ (after replacing $H$ by $g$ ) and that $(\gamma *)^{2}=C+\left[(l-2)^{2} / 4\right] \hbar^{2}$.

It is easy to check that the function $g^{-1} \in L_{\text {loc }}^{1}\left(\mathbb{R}^{2 l}\right)$. Thus for any integer $n>0$, $(\gamma *)^{n} \in \mathscr{D}^{\prime}\left(\mathbb{R}^{2 l}\right)$ and these distributions are tempered. It is now trivial to prove: 
Proposition 1. For any $(p, q) \in U$, the power series in $s$

$$
\left.\sum_{n=0}^{\infty} \frac{1}{n !}\left(\frac{\gamma s}{i \hbar} *\right)^{n}\right|_{b, q}
$$

has a radius of convergence equal to $\pi$. If $|s|<\pi$ one has

$$
\sum_{n=0}^{\infty} \frac{1}{n !}\left(\frac{\gamma s}{i \hbar} *\right)^{n}=\frac{\partial}{\partial s}\left[\frac{i \hbar}{g}\left(\cos \frac{s}{2}\right)^{2-l} \exp \left(\frac{2 g}{i \hbar} \tan \frac{s}{2}\right)\right]
$$

Moreover the series (7-8) converges in $\mathscr{D}^{\prime}\left(\mathbb{R}^{2 l}\right)$ for the weak topology to the right-hand side of (7-9) if $|s|<\pi$ and $s$ is fixed.

Proof. Equations (7-2) and (7-7) imply that in $U$ :

$$
\begin{aligned}
\sum_{n=0}^{\infty} \frac{1}{n !}\left(\frac{\gamma s}{i \hbar} *\right)^{n} & =\sum_{n=0}^{\infty} \frac{1}{n !}\left(\frac{s}{i \hbar}\right)^{n} g^{-1} G_{n+1}(g) \\
& =\frac{\partial}{\partial s}\left[\frac{i \hbar}{g} \sum_{n=0}^{\infty} \frac{1}{n !}\left(\frac{s}{i \hbar}\right)^{n} G_{n}(g)\right] \\
& =\frac{\partial}{\partial s}\left[\frac{i \hbar}{g} \psi(s, g)\right]
\end{aligned}
$$

if $|s|<\pi$. Suppose now that $s$ is fixed and $|s|<\pi$. It is clear that with respect to $x$ the series $\sum(1 / n !)(s / i \hbar)^{n} G_{n+1}(x)$ converges uniformly on compact sets in $\mathbb{R}$. Thus for any $b>0$ and any $\epsilon>0$ there exists $N_{0}=N_{0}(\epsilon, b)$ such that for any $n \geqslant N_{0}$ and any $x \in[-b, b], \quad\left|\sum_{m>n}(1 / m !)(s / i \hbar)^{m} G_{m+1}(x)\right| \equiv\left|R_{n}(x)\right|<\epsilon$. Let $\phi \in \mathscr{Z}\left(\mathbb{R}^{2 l}\right), K=\operatorname{Supp} \phi, b=\sup _{(p, q) \in K} g(p, q)$, and $M=\int_{K} g(p, q)^{-1} d p d q$. For any $n \geqslant N_{0}\left(\epsilon M^{-1}\|\phi\|_{\infty}^{-1}, b\right)$ we have

$$
\left|\left\langle g^{-1} \sum_{m>n} \frac{1}{m !}\left(\frac{s}{i \hbar}\right)^{m} G_{m+1}(g), \phi\right\rangle\right| \leqslant \int_{K}\left|R_{n}(x)\right| g^{-1}\|\phi\|_{\infty} d p d q \leqslant \epsilon .
$$

If $|s|<\pi$ and $s$ is fixed we can now define

$$
\begin{aligned}
\operatorname{Exp}(\gamma s)= & \partial / \partial s\left(i \hbar g^{-1} \psi(s, g)\right) \\
= & i \hbar(2 g)^{-1}(\cos s / 2)^{-l}\left[(l-2) \sin (s / 2) \cos (s / 2)+2 g(i \hbar)^{-1}\right] \\
& \times \exp ((2 g / i \hbar) \tan s / 2)
\end{aligned}
$$

This is an element of $\mathscr{E}^{\prime}\left(\mathbb{R}^{2 l}\right)$ and the process of weak analytic continuation allows, as in Section 6, to define $\operatorname{Exp}(\gamma s)$ by the same formula if $s \in U^{\prime}=\mathbb{C}-\{(2 k+1) \pi \mid k \in \mathbb{Z}\}$. It is obvious that if $s \in U^{\prime}, \operatorname{Im} s \leqslant 0$, the distribution $\operatorname{Exp}(\gamma s)$ is tempered.

Expansion (6-12) may now be used to expand $\operatorname{Exp}(\gamma s)$ in a Fourier-Dirichlet series. 
Proposition 2. For fixed $s \in \mathbb{C}$ with $\operatorname{Im} s<0$, one has

$$
\operatorname{Exp}(\gamma s)=\sum_{n=0}^{\infty} \Pi_{n} e^{-t\left(n+\frac{l-2}{2}\right) s}
$$

where

$$
\Pi_{n}=2^{l-2} h g^{-1} e^{-2 g / \hbar}(-1)^{n}\left(n+\frac{l-2}{2}\right) L_{n}^{l-3}\left(\frac{4 g}{\hbar}\right)
$$

the series converging in $\mathscr{S}^{\prime}\left(\mathbb{R}^{2 l}\right)$ for the weak topology.

Proof. To simplify the proof we replace $g / \hbar$ by $g$ and write $e^{-t s}=\tau, \Pi_{n}=g^{-1} a_{n}(g)$. With the help of the generating function of the generalized Laguerre polynomials it is straightforward to prove that for any $s \in \mathbb{C}$ with $\operatorname{Im} s<0$ one has

$$
\operatorname{Exp}(\gamma s)=g^{-1} e^{-i(l-2) s / 2} \sum_{n>0} a_{n}(g) \tau^{n}
$$

Moreover, Eq. (7-10) allows one to make an estimate of the remainder of the previous series: for any $\tau \in \mathbb{C}$ such that $|\tau| \leqslant r<\rho<1$ where $r$ and $\rho$ are arbitrary, any $g \geqslant 0$ and any $n \geqslant 0$, the following inequality holds:

$$
\left|\sum_{k>n} a_{k}(g) \tau^{k}\right| \leqslant 2^{l}(\rho-r)^{-1}(1-\rho)^{-l}\left(\frac{l-2}{4}+g\right) \exp \left(-2 g \frac{1-\rho}{1+\rho}\right)\left(\frac{r}{\rho}\right)^{n+1} .
$$

From this inequality it follows immediately that for any $\phi \in \mathscr{S}\left(\mathbb{R}^{2 l}\right)$

$$
\lim _{n \rightarrow \infty}\left\langle\operatorname{Exp}(\gamma s)-\sum_{k \leqslant n} \Pi_{k} e^{-i\left(k+\frac{l-2}{2}\right) s}, \phi\right\rangle=0
$$

Remark. When $s \rightarrow s_{0} \in U^{\prime} \cap \mathbb{R}$ (with Im $s<0$ ) one can show that in $\mathscr{S}^{\prime}\left(\mathbb{R}^{2 l}\right.$ ) one has $\operatorname{Exp}(\gamma s) \rightarrow \operatorname{Exp}\left(\gamma s_{0}\right)$, and obviously

$$
\sum_{n=0}^{N} \Pi_{n} e^{-i\left(n+\frac{l-2}{2}\right) s} \rightarrow \sum_{n=0}^{N} \Pi_{n} e^{-l\left(n+\frac{l-2}{2}\right) s} .
$$

This gives a meaning to the representation (7-11) of $\operatorname{Exp}\left(\gamma s_{0}\right)$ by the infinite series when $s=s_{0}$ and defines a topology for which the series converges.

We have thus obtained the spectrum of $\gamma$ :

$$
\operatorname{Sp} \gamma=\left\{\hbar\left(n+\frac{l-2}{2}\right) \mid n=0,1, \ldots\right\}
$$

and hence the spectrum of $C: \operatorname{Sp} C=\operatorname{Sp}(\gamma *)^{2}-(l-2) \hbar^{2} / 4=\left\{n(n+l-2) \hbar^{2} \mid\right.$ $n=0,1, \ldots\}$. In particular if $l=3$ we get $n(n+1) \hbar^{2}$. Finally one checks that $C * \Pi_{n}=\Pi_{n} * C=n(n+l-2) \hbar^{2} \Pi_{n}$. 
Further formulas concerning functions of $C$ or of $\gamma$ may be obtained with the help of the $\Pi_{n}$ given by (7-12). In particular

$$
\begin{aligned}
& (\gamma *)^{-1}=g^{-1} \\
& (\gamma *)^{-2}=2 \hbar^{-1} g^{-1} \int_{0}^{\pi / 2}(\sin t)^{l-3} e^{-(2 g / \hbar) \cos t} d t .
\end{aligned}
$$

Formula (7-13) will be used in the treatment of the Kepler problem.

\section{Hydrogen Atom}

(a) In this section we determine the spectrum of the Hamiltonian $H$ of the hydrogen atom (H.A.). This will be accomplished with *-product techniques analogous to those of Sections 6 and 7 but slightly more involved. In fact, the difficulties that we shall meet with the Moyal *-product will compell us to change the *-product; namely, to introduce a *-product already described in Sections 8 and 10 of $I$ and associated with the geometry of the Kepler problem. We start with the well-known classical so(4) symmetry of the Kepler problem. We reparameterize by stereographic projection from the cotangent bundle $T^{*}\left(S^{3}\right) \subset \mathbb{R}^{8}$ over the three-dimensional sphere. The "good" star product, denoted by $*$, will then be deduced from the Moyal *-product in the embedding space $\mathbb{R}^{8}$ by suitable restrictions.

It appears that for any $l \geqslant 2$, the Kepler problem in $l$-dimensional configuration space may be worked out in the same manner as in the case $l=3$. The reparameterization will be done in that case with the cotangent bundle $T^{*}\left(S^{l}\right) \subset \mathbb{R}^{2 l+2}$ over the l-dimensional sphere.

(b) Difficulties with the Moyal *-product and some notations. Let $(p, q) \in \mathbb{R}^{2 l}$ $(l \geqslant 2)$ and let $r=\left(q_{1}^{2}+\cdots+q_{l}^{2}\right)^{1 / 2}=|q|$. We consider the following Hamiltonian

$$
H(p, q)=p^{2} / 2-r^{-1}
$$

and attempt to get its spectrum by *-product algorithms. One may at first think of (at least) three approaches, all of which meet with difficulties if we keep the usual Moyal product in $\mathbb{R}^{2 l}$.

(i) Direct exponentiation of $H$ as in Sections 6 and 7. This seems for the moment hopeless: successive ${ }^{*}$-powers $(H *)^{n}$ of $H$ are not in general functions of $H$ only; these powers become more and more singular as $n$ increases and no simple recursion formula seems to hold among them. For example, when $l=3$ one finds that

$$
\begin{aligned}
& (H *)^{3}=H^{3}-\hbar^{2}\left(\frac{1}{4 r^{4}}+\frac{p^{2}}{4 r^{3}}-\frac{3(p \cdot q)^{2}}{4 r^{5}}\right), \\
& (H *)^{4}=H^{4}+\hbar^{2}\left(-\frac{3(p \cdot q)^{2}}{r^{6}}+\frac{3(p \cdot q)^{2} p^{2}}{2 r^{5}}+\frac{1}{r^{5}}+\frac{p^{2}}{2 r^{4}}-\frac{\left(p^{2}\right)^{2}}{2 r^{3}}\right)+\frac{3 \hbar^{4}}{4 r^{6}} .
\end{aligned}
$$

Besides, $H * \phi$ has in general an infinite number of terms and a direct resolution of the equations $H * \phi=\phi * H=\lambda \phi$ seems difficult. 
(ii) Direct transcription of the well-known $\operatorname{so}(2,1) \subset \operatorname{so}(l+1,2)$ dynamical method. In our case this amounts to linearizing, with the help of the generators of an $s o(2,1)$ Lie algebra, the function $U \equiv r *(H-E)$ or, if one wants to deal with real functions, $V \equiv r^{1 / 2} *(H-E) * r^{1 / 2}$. In the first case, the functions that generate a representation of the Lie algebra so $(2,1)$ with the Moyal bracket are

$$
\begin{gathered}
\Gamma_{0}=\frac{1}{2} r *\left(p^{2}+1\right)=\frac{1}{2} r\left(p^{2}+1\right)-\frac{i \hbar}{2} \frac{p \cdot q}{r}-\frac{(l-1) \hbar^{2}}{8 r}, \\
\Gamma_{4}=\frac{1}{2} r *\left(p^{2}-1\right)=\frac{1}{2} r\left(p^{2}-1\right)-\frac{i \hbar}{2} \frac{p \cdot q}{r}-\frac{(l-1) \hbar^{2}}{8 r}, \\
S=p \cdot q-i \hbar / 2 \equiv T-i \hbar / 2 .
\end{gathered}
$$

The Casimir is

$$
C=\left(\Gamma_{0} *\right)^{2}-\left(\Gamma_{4} *\right)^{2}-(S *)^{2}=g^{2}-\frac{3}{4}(l-1) \hbar^{2}
$$

and one has

$$
U=\frac{1}{2}\left(\Gamma_{0}+\Gamma_{4}\right)-E\left(\Gamma_{0}-\Gamma_{4}\right)-1
$$

as expected. Let $E<0$ and write $e^{8}=(-2 E)^{1 / 2}$. The function $\operatorname{Exp}(T s)$ may be easily computed with the help of the results of Section 6. One verifies that, if $f$ is a polynomial in the variables $p$ and $q$,

$$
\operatorname{Exp}(-T s) * f(p, q)=f\left(e^{8} p, e^{-8} q\right) * \operatorname{Exp}(-T s) .
$$

Thus this equation will hold on formal series and hence on all (generalized) functions for which the above *-products are convergent. This allows us to write

$$
\operatorname{Exp}(-T s) * f(p, q) * \operatorname{Exp}(T s)=f\left(e^{8} p, e^{-8} q\right) .
$$

In the case of $U$ one gets

$$
\begin{aligned}
\operatorname{Exp}(-T s) * U * \operatorname{Exp}(T s) & =\frac{1}{2} e^{8}\left(\Gamma_{0}+\Gamma_{4}\right)-E e^{-s}\left(\Gamma_{0}-\Gamma_{4}\right)-1 \\
& =(-2 E)^{1 / 2} \Gamma_{0}-1 .
\end{aligned}
$$

An analogous manipulation is possible in the case $E>0\left(\Gamma_{4}\right.$ replacing $\left.\Gamma_{0}\right)$. However, though the spectrum of the Casimir is known (Section 7), this is not the case for $\Gamma_{0}$. Here also a direct exponentiation of $\Gamma_{0}$ seems difficult: the ${ }^{*}$-powers of $\Gamma_{0}$ are not functions of $\Gamma_{0}$ only, and no simple recursion formula seems to hold among them. However, here the even ${ }^{*}$-powers of $\Gamma_{0}$ are polynomials in $p, q$ and thus regular.

In the case where one considers $V$, the generators of the Lie algebra $s o(2,1)$ are $r^{-1 / 2} * \Gamma_{0} * r^{1 / 2} \equiv \gamma_{0}^{\prime}, \quad r^{-1 / 2} * \Gamma_{4} * r^{1 / 2} \equiv \gamma_{4}^{\prime}, \quad T=r^{-1 / 2} * S * r^{1 / 2}=p q$ and an identical treatment is a priori possible. Though here the generators are real valued, the diffculties are the same and furthermore all *-powers of the compact generator are singular. 
In this approach expressions for the generators $\left(\hat{M}_{\alpha \beta}\right)(0 \leqslant \alpha<\beta \leqslant l+2)$ of the Lie algebra $s o(l+1,2)$ of the problem are easy to find: $\hat{M}_{0 j}=r * p_{j}, \bar{M}_{0, l+1}=\Gamma_{4}$, $\hat{M}_{0, l+2}=\Gamma_{0}, \quad \hat{M}_{j k}=q_{j} p_{k}-q_{k} p_{j}, \quad \hat{M}_{j, l+1}=\frac{1}{2} q_{j} *\left(p^{2}\right)-p_{j} *\left(\sum q_{k} * p_{k}\right)-\frac{1}{2} q_{j}$, $\hat{M}_{j, l+2}=\hat{M}_{j, l+1}+q_{j}, \hat{M}_{l+1, l+2}=S(1 \leqslant j, k \leqslant l)$.

(iii) A third approach, based on the $S O(l+1)$ symmetry group of the problem, is the following. The functions $M_{j k}=q_{j} p k-q_{k} p_{j}$ and $M_{j, l+1}=A_{f}=$ $-\frac{1}{2}\left(p^{2}-1\right) q_{j}+(p \cdot q) p_{j}(j=1, \ldots, l)$ define with Moyal or Poisson brackets a representation of $s o(l+1)$, the first Casimir of which is

$$
\begin{aligned}
C_{1} & =\sum_{1<j<k \leqslant l}\left(M_{j k} *\right)^{2}+\sum_{j=1}^{l}\left(A_{j} *\right)^{2} \\
& =\frac{1}{4} q^{2}\left(p^{2}+1\right)^{2}-\left(\hbar^{2} / 4\right)(l-2) p^{2}-\left(\hbar^{2} / 4\right) l(l-1) .
\end{aligned}
$$

Consider the following function

$$
\gamma_{0}=\frac{1}{2}\left(p^{2}+1\right)^{1 / 2} * r *\left(p^{2}+1\right)^{1 / 2} .
$$

One easily checks that $\left(\gamma_{0} *\right)^{2}$ involves only a finite number of terms and one gets

$$
\left(\gamma_{0} *\right)^{2}=C_{1}+\left(h^{2} / 4\right)(l-1)^{2}
$$

Furthermore, if $E<0$ and $e^{s}=(-2 E)^{1 / 2}$ (as before) one has $\operatorname{Exp}(-T S) *(H-E) *$ $\operatorname{Exp}(T s)={ }_{2}^{1} e^{2 s}\left(p^{2}+1\right)^{1 / 2} *\left(1-e^{-8}\left(\gamma_{0} *\right)^{-1}\right) *\left(p^{2}+1\right)^{1 / 2}$ where $\left(\gamma_{0} *\right)^{-1}=$ $2\left(p^{2}+1\right)^{-1 / 2} * r^{-1} *\left(p^{2}+1\right)^{-1 / 2}$. Thus the knowledge of the spectrum of $\gamma_{0}$ would give the negative part of the spectrum of $H$. Although here the even powers of $\gamma_{0}$ are polynomials (in $p, q$ ), the situation is not better for computing $\operatorname{Exp}\left(\gamma_{0} s\right)$. No simple recursion formula appears for the power $\left(\gamma_{0} *\right)^{2 n}$.

In this approach the previous representation of $s o(l+1)$ may be enlarged to a representation of $s o(l+1,1)$. Let $M_{j, l+2}=\frac{1}{2}\left(p^{2}+1\right) q_{j}-(p \cdot q) p_{j}(j=1, \ldots, l)$, $M_{l+1, l+2}=T=p \cdot q$. Then $\left\{M_{\alpha \beta}\right\}(1 \leqslant \alpha<\beta \leqslant l+2)$ do form a representation of $s o(l+1,1)$ with respect to Moyal and Poisson brackets. However, this representation is not equivalent to that obtained with the generators $\left(\hat{M}_{\alpha \beta}\right)$ of (ii). In fact in this case one gets $\frac{1}{2} M_{\alpha \beta} * M^{\alpha \beta}=-\left(\hbar^{2} / 4\right) l^{2}$ whereas for the two representations of $s o(l+1,1)$ with "hatted" generators the value of the same Casimir is equal to $-\left(\hbar^{2} / 4\right)\left(l^{2}-1\right)$.

All this strongly suggests that there is something wrong with the *-product of $\mathbb{R}^{2 l}$ we used at first. Hence we shall try to choose a new *-product that is suggested by the geometry and the symmetry group of the problem: $S O(l+1)$. We are working in $2 l$-dimensional phase space. This leads to parameterizing the problem with a manifold on which $S O(l+1)$ acts naturally. In view of Section 8 of $\mathrm{I}$, the cotangent bundle $T^{*}\left(S^{l}\right)$ appears as a natural condidate.

(c) The new *-product. In Section 8 of I, we obtained the natural *-product for the manifold $W=T^{*}(S)$ embedded in $\mathbb{R}^{22+2}$. We utilize the same notations. Let $f, g \in N(W)$ and $\hat{f}, \hat{g}$ the corresponding elements of $\hat{N}_{G}$ (differentiable $G$-invariant 
functions on $\hat{W}_{0}=\left(\mathbb{R}^{i+1}-\{0\}\right) \times \mathbb{R}^{l+1}$. We denote by $*_{w}$ the new $*$-product on the manifold $W$ and $*_{0}$ the Moyal product on the open subset $W_{0}$ of $\mathbb{R}^{2 l+2}$. We thus get:

$$
f *_{w} g=\left(\hat{f} *_{0} \hat{g}\right) \mid W .
$$

If one chooses a chart on $W$ one will get a *-product in an open subset of $\mathbb{R}^{2 l}$. This *-product will depend on the choice of coordinates and will be different from the usual Moyal product in $\mathbb{R}^{2 l}$. However, it results from our study that $Q^{3}$ and $P^{3}$ (the third power of the Poisson bracket on $\mathbb{R}^{2 l}$ ), restricted to the considered open subset, will belong to the same (nontrivial) cohomology class, i.e., define equivalent infinitesimal deformations.

We now give an expression for the product $*_{w}$ in coordinates. We choose for $S^{t}$ the stereographic projection from the north pole:

$$
p^{j}=\left(1-\pi^{l+1}\right)^{-1} \pi^{j} \quad(1 \leqslant j \leqslant l)
$$

which is defined on $S^{\imath}-\{(0, \ldots, 0,1)\}$ and compute the corresponding cotangent coordinates. We have:

$$
d p^{j}=\left(1-\pi^{l+1}\right)^{-1} d \pi^{j}+\left(1-\pi^{l+1}\right)^{-2} \pi^{j} d \pi^{l+1} .
$$

On $S^{l}$ we shall take the usual line element given by

$$
d s^{2}=\left(1-\pi^{l+1}\right)^{2} \sum_{j=1}^{l}\left(d p^{j}\right)^{2}=\sum_{i, j} g_{i j} d p^{i} d p^{j},
$$

and this will define the duality between vectors and covectors. The expression of cotangent coordinates will thus be:

$$
q_{j}=\left(1-\pi^{l+1}\right) \xi_{j}+\pi^{j} \xi_{l+1} \quad(1 \leqslant j \leqslant l) .
$$

Formulas (8-3) and (8-4) define a chart for $W$ on the open subset $\Omega=W-$ $\left(B^{-1}(0, \ldots, 0,1)\right)$ where $B$ is the projection of the bundle $W$ on its base $S^{l}$. This chart will be denoted by $c=(\Omega, \psi)$ where $\psi$ is the map $(\pi, \xi) \mapsto(p, q)$ defined by (8-3) and (8-4).

The corresponding curvilinear coordinates on $W_{0}$ defined by the projection $\psi \circ \phi$ from $\hat{W}_{0}$ on $\mathbb{R}^{2 l}$ are:

$$
\begin{aligned}
& x^{j}=\left(|\pi|-\pi^{l+1}\right)^{-1} \pi_{j} \\
& y_{j}=|\pi| \xi_{j}-\frac{\pi \cdot \xi}{|\pi|} \pi_{j}-\xi_{j} \pi^{l+1}+\xi_{l+1} \pi^{j} \quad(1 \leqslant j \leqslant l) .
\end{aligned}
$$

These functions are defined on $\Omega=\mathscr{W}_{0}-\left(\left(\mathbb{R}_{+} * \cdot(0, \ldots, 0,1)\right) \times \mathbb{R}^{l+1}\right)$.

In the following, in order to simplify the writing, we shall no longer make a distinc- 
tion between upper and lower indices, since both $p$ 's and $q$ 's can be considered as coordinates on $W$. The inverse map $\psi^{-1}: \mathbb{R}^{2 l} \rightarrow \Omega$ may be written:

$$
\begin{array}{ll}
\pi_{j}=2\left(p^{2}+1\right)^{-1} p_{j}, & \pi_{l+1}=\left(p^{2}+1\right)^{-1}\left(p^{2}-1\right), \\
\xi_{j}=\frac{1}{2}\left(p^{2}+1\right) q_{j}-(p q) p_{j}, & \xi_{l+1}=p \cdot q .
\end{array}
$$

Let $f \in N(W)$; its expression with the help of the chart $c$ will be the function $F \in C^{\infty}\left(\mathbb{R}^{2 l}\right)$ which is defined by $F(p, q)=f(\pi, \xi)$. The corresponding function which is defined by $F(p, q)=f(\pi, \xi)$. The corresponding function $\hat{F}$ defined in $\Omega$ will be the function $\hat{F}(\pi, \xi)=F(x(\pi), y(\pi, \xi))=f\left(|\pi|^{-1} \pi,|\pi| \xi-|\pi|^{-1}(\pi \cdot \xi) \pi\right)$. In the specific chart $c$ we shall denote the twisted product $*_{w}$ by $*^{\prime}$. We thus finally get for two such functions $F, G \in C^{\propto}\left(\mathbb{R}^{2 t}\right)$

$$
F *^{\prime} G=\left(\left(\hat{F} *_{0}^{\prime} \hat{G}\right) \mid W\right) \circ \psi^{-1}
$$

where $*_{0}{ }^{\prime}$ is the usual Moyal product on the open subset $\Omega$. It is this product $*^{\prime}$ that we shall utilize in order to solve the Kepler problem.

Remark. The functions $x^{j}$ and $y_{j}$, together with the two functions $x^{l+1}(\pi)=$ $\log |\pi|$ and $y_{l+1}(\pi, \xi)=\pi \cdot \xi$, define a (Poisson) canonical diffeomorphism of $\Omega$ onto $\mathbb{R}^{2 l+2}$ :

$$
\sum_{\alpha=1}^{t+1} d x^{\alpha} \wedge d y_{\alpha}=\left.\sum_{\alpha=1}^{\imath+1} d \pi^{\alpha} \wedge d \xi_{\alpha}\right|_{\hat{\Omega}}
$$

and by restriction $\psi$ is a symplectic diffeomorphism from $\Omega$ onto $\mathbb{R}^{2 l}$.

We now study in detail the properties of the product $*^{\prime}$. Let $F, G \in C^{\infty}\left(\mathbb{R}^{2 l}\right)$; we define the bracket $M^{\prime}$ by

$$
M^{\prime}(F, G)=(i \hbar)^{-1}\left(F *^{\prime} G-G *^{\prime} F\right) .
$$

With respect to this bracket the Heisenberg commutation relations obviously hold:

$$
M^{\prime}\left(p_{j}, p_{k}\right)=M^{\prime}\left(q_{j}, q_{k}\right)=0, \quad M^{\prime}\left(p_{j}, q_{k}\right)=\delta_{j k} \quad(1 \leqslant j, k \leqslant l) .
$$

Let $m, n \in \mathbb{N}^{l}$ and $p^{m}=p_{1}^{m_{1}} \cdots \cdots \cdot p_{l}^{m_{l}}, q^{n}=q_{1}^{n_{1}} \cdots \cdots \cdot q_{l}^{n_{l}}$. Now define a linear map $\tau$ by

$$
\begin{aligned}
& \tau(1)=1, \\
& \tau\left(p_{j}\right)=p_{j}, \quad 1 \leqslant j \leqslant l, \\
& \tau\left(q_{j}\right)=q_{j}, \quad 1 \leqslant j \leqslant l, \\
& \tau\left(q^{n} * p^{m}\right)=\left(q_{1} *^{\prime}\right)^{n_{1}} *^{\prime} \cdots *^{\prime}\left(q_{l} *^{\prime}\right)^{n_{l}} *^{\prime}\left(p_{1} *^{\prime}\right)^{m_{1}} *^{\prime} \cdots *^{\prime}\left(p_{l} *^{\prime}\right)^{m_{l}} .
\end{aligned}
$$

It is obvious that $\tau\left(p^{m}\right)=p^{m}$ but in general $\tau\left(q^{n}\right) \neq q^{n}$. For example, we have

$$
q_{j} *^{\prime} q_{k}=q_{j} q_{k}+\left((l+2) \frac{p_{j} p_{k}}{\left(p^{2}+1\right)^{2}}-\frac{2}{p^{2}+1} \delta_{j k}\right) \hbar^{2}, \quad 1 \leqslant j, \quad k \leqslant l
$$


and

$$
\sum_{j=1}^{l}\left(q_{j} *^{\prime}\right)^{2}=r^{2}-\frac{2 l+(l-2) p^{2}}{\left(p^{2}+1\right)^{2}} \hbar^{2}
$$

One checks that $\tau$ maps polynomials in the variables $p, q$ into polynomials in $q$ 's with coefficients in the ring of rational fractions in $p$ 's whose denominators are powers of $p^{2}+1$. If $R$ and $S$ are polynomials we thus get

$$
\tau(R * S)=\tau(R) *^{\prime} \tau(S)
$$

and one can define easily an extension of this homomorphism to the ring of polynomials in $q$ 's whose coefficients are $C^{\infty}$ functions of $p$. Moreover, $\tau$ will map formal series in $p_{j}, q_{j}$ into formal series in the variables $p_{j}, q_{j}$, and $z \equiv\left(p^{2}+1\right)^{-1}$, and the ring of formal series in $q_{j}$ with coefficients that are $C^{\infty}$ functions of $p$, into itself, in such a way that (8-7) will hold. This relation (8-7) exhibits the "c-equivalence" (in the sense of I, Section 7 ) between the associative algebra deformations defined by the twisted products $*$ and $*^{\prime}$.

Remark. One should note that in relation (8-6) the *' product of two "position coordinates" is a function of linear momentum also. This feature is completely different from what one gets with the usual Moyal product, related by the usual Weyl correspondence to the operator product. The product $*^{\prime}$, which is a natural product for the preferred set of observables for the hydrogen atom problem, though being (as we shall see) equivalent spectrally to the product $*$, differs radically in its functional form from the latter. [It has the correct classical limit when $\hbar \rightarrow 0$.]

We now consider the product which is induced on $s o(l+1)$ by $*^{\prime}$. The generators are $M_{j k}=q_{j} p_{k}-q_{k} p_{j}, M_{j, l+1}=A_{j}=-\frac{1}{2}\left(p^{2}-1\right) q_{j}+(p \cdot q) p_{j}(1 \leqslant j, k \leqslant l)$. One checks that on the open set $\Omega$ one has $\left(M_{\alpha \beta} \circ \psi\right)(\pi, \xi)=\xi_{\alpha} \pi_{\beta}-\xi_{\beta} \pi_{\alpha}(1 \leqslant \alpha$, $\beta \leqslant l+1)$. We thus have on $s o(l+1)$ the $*$-product mentioned at the beginning of Section $7(l+1$ replacing $l)$. The product $*^{\prime}$ is $s o(l+1)$ invariant in the sense of Section 9 of I, i.e., we have for $F, G \in C^{\infty}\left(\mathbb{R}^{2 l}\right)$ and any $X=\sum_{\alpha<\beta} \lambda_{\alpha \beta} M_{\alpha \beta}$ where $\lambda_{\alpha, \beta} \in \mathbb{R}$

$$
\left\{F *^{\prime} G, X\right\}=F *^{\prime}\{G, X\}+\{F, X\} *^{\prime} G .
$$

The spectrum of the generator $M_{\alpha \beta}$ is known from Appendix A-1. In the particular case in which we are primarily interested $(l=3)$, the well-known decomposition $s o(4)=s o(3) \oplus s o(3)$ allows us to exponentiate easily all generators of either $s o(3)$ subalgebra. Let $X=\sum_{j=1}^{3}\left(\alpha_{j} / 2\right)\left(M_{k m} \pm M_{j 4}\right)$ where $(j k m)$ is an even permutation of (123) and $\sum_{j=1}^{3} \alpha_{j}^{2}=1$. Suppose $f \in C^{\infty}(\mathbb{R})$; then one gets as in Section 6

$$
\begin{aligned}
& X *^{\prime} f(X)=X f(X)-\frac{\hbar^{2}}{4}\left(f^{\prime}(X)+\frac{1}{4} X f^{\prime \prime}(X)\right) \\
& \operatorname{Exp}(X s)=\left(\cos \frac{s}{4}\right)^{-4} \exp \left[-\frac{4 i X}{\hbar} \tan \frac{s}{4}\right]
\end{aligned}
$$


The results of Section 7 allow us to compute the spectrum of Casimir

$$
C=\sum_{1<\alpha<\beta<l+1} M_{\alpha \beta} *^{\prime} M_{\alpha \beta}=\Gamma^{2}-l(l+1) \frac{\hbar^{2}}{4}
$$

where $\Gamma=\frac{1}{2} r\left(p^{2}+1\right)=|\xi|$ and where the corresponding ( $G$-invariant) function is $\Gamma(\pi, \xi)=\Gamma(x(\pi), y(\pi, \xi))=\left(\pi^{2} \xi^{2}-(\pi \cdot \xi)^{2}\right)^{1 / 2}$. One finds Sp $C=\left\{n(n+l-1) h^{2}\right.$ $n=0,1, \ldots\}$. The square root (for the product $*^{\prime}$ ) of $C+(l-1)^{2}\left(h^{2} / 4\right)$ is $\gamma=\Gamma-[(l-1) / 4 \Gamma] \hbar^{2}$. The Fourier-Dirichlet expansion of the $*^{\prime}$-exponential $\operatorname{Exp}(\gamma s)$ is obtained from formula $(7-11)$ :

$$
\operatorname{Exp}(\gamma s)=\sum_{n=0}^{\infty} \Pi_{n}^{\prime} e^{-i\left(n+\frac{l-1}{2}\right)^{2}}
$$

where

$$
\Pi_{n}^{\prime}=2^{l-1} \hbar \Gamma^{-1} e^{-2 \Gamma / \hbar}(-1)^{n}\left(n+\frac{l-1}{2}\right) L_{n}^{l-2}\left(\frac{4 \Gamma}{\hbar}\right)
$$

Moreover for any $s \in U^{\prime}$ with $\operatorname{Im} s \leqslant 0$ the distribution $\operatorname{Exp}(\gamma s)$ is tempered and Eq. (8-8) holds in $\mathscr{S}^{\prime}\left(\mathbb{R}^{2 l}\right)$ for the weak topology if $\operatorname{Im} s<0$.

One easily checks that

$$
\int_{\mathbf{R}^{2 l}} \Pi^{\prime}{ }_{n}(p \cdot q) d p d q=(2 \pi \hbar)^{l} N_{n, l}
$$

with

$$
N_{n, l}=(2 n+l-1) \frac{(n+l-2) !}{n !(l-1) !}
$$

This is [22] the number of spherical harmonics of degree $n$ on $S^{t}$. In particular if $l=3, N_{n, 3}=(n+1)^{2}$ and if $l=2, N_{n, 2}=2 n+1$.

Remarks. (1) Consider the subalgebra $s o(l) \subset s o(l+1)$ spanned by the generators $\left(M_{j k}\right), 1 \leqslant j<k \leqslant l$. It is obvious that on this subalgebra the product induced by $*^{\prime}$ is the same as the product induced by the ordinary Moyal product in $\mathbb{R}^{2 l}$ (the stereographic projection is the identity on a $S^{l-1}$, considered as embedded in $\mathbb{R}^{l+1}$ ). (2) Consider the Lie algebra $s o(l+1,1)$ introduced in Section $8 \mathrm{~b}$ with generators $\left(M_{\alpha \beta}\right)(1 \leqslant \alpha<\beta \leqslant l+2)$. One has $M_{\alpha, l+2} \circ \psi(\pi, \xi)=\xi_{\alpha}$ and

$$
\xi_{\alpha}=\mid \pi: \xi_{\alpha}-\frac{\pi \cdot \xi}{|\pi|} \pi_{\alpha} \quad(1 \leqslant \alpha \leqslant l+1) .
$$

However, here the product $*^{\prime}$ does not induce an invariant *-product (in the sense of Section 9 of $\mathrm{I}$ ) on the Lie algebra $s o(l+1,1)$. For example, one gets

$$
M_{j, l+2} *^{\prime} M_{j . l+2}=\left(M_{j, l+2}\right)^{2}+\left((l+2) \frac{p_{j}^{2}}{\left(p^{2}+1\right)^{2}}-\frac{1}{2}\right) \hbar^{2} .
$$


144

BAYEN ET AL.

(d) Discrete spectrum of $H$. We shall solve in this section the problem of the discrete spectrum of $H$, i.e., we suppose $E<0$. This will be done in a Schrödingerlike approach: We look for solutions of

$$
\begin{gathered}
(H-E) * \Phi=0, \\
\Phi=\Phi
\end{gathered}
$$

where the bar denotes complex conjugation. We utilize the notations introduced in Section 8b: $e^{s}=(-2 E)^{1 / 2}, \gamma_{0}=\frac{1}{2}\left(p^{2}+1\right)^{1 / 2} * r *\left(p^{2}+1\right)^{1 / 2}, T=p \cdot q$. We have

$$
\operatorname{Exp}(-T s) *(H-E) * \operatorname{Exp}(T s)=\frac{1}{2} e^{2 s}\left(p^{2}+1\right)^{1 / 2} *\left(1-e^{-s}\left(\gamma_{0} *\right)^{-1}\right) *\left(p^{2}+1\right)^{1 / 2}
$$

Thus if we set

$$
\tilde{\Phi}=\left(p^{2}+1\right)^{1 / 2} * \operatorname{Exp}(-T S) * \Phi * \operatorname{Exp}(T s) *\left(p^{2}+1\right)^{1 / 2}
$$

we obtain

$$
\begin{gathered}
\left(1-e^{-s}\left(\gamma_{0} *\right)^{-1}\right) * \tilde{\Phi}=0 \\
\tilde{\Phi}=\tilde{\Phi}
\end{gathered}
$$

If we introduce $\Psi=\left(\gamma_{0} *\right)^{-1} * \Phi *\left(\gamma_{0} *\right)^{-1}$ we finally get

$$
\begin{gathered}
\left(\gamma_{0}-e^{-8}\right) * \Psi=0 \\
\Psi=\Psi
\end{gathered}
$$

We now show that the spectrum of $\gamma_{0}$ for Moyal *-product is identical to the spectrum of $\gamma=\Gamma-[(l-1) / 4 \Gamma] \hbar^{2}$ for the $*^{\prime}$-product. To begin with we have $\tau\left(\gamma_{0} * \gamma_{0}\right)=$ $\gamma * \gamma$. In fact

$$
\begin{aligned}
\tau\left(\gamma_{0} * \gamma_{0}\right) & =\tau\left(\sum_{1<\alpha<\beta<l+1}\left(M_{\alpha \beta} *\right)^{2}+\frac{\hbar^{2}}{4}(l-1)^{2}\right) \\
& =\sum\left(\tau\left(M_{\alpha \beta}\right) *^{\prime}\right)^{2}+\frac{\hbar^{2}}{4}(l-1)^{2} \\
& =\sum_{1<\alpha<\beta<l+1}\left(M_{\alpha \beta} *^{\prime}\right)^{2}+\frac{\hbar^{2}}{4}(l-1)^{2}=\gamma *^{\prime} \gamma .
\end{aligned}
$$

We know that

$$
\gamma *^{\prime} \gamma=\sum_{n \geqslant 0}\left(n+\frac{l-1}{2}\right)^{2} \hbar^{2} \Pi_{n}^{\prime}
$$

where the $\Pi^{\prime}{ }_{n}$ are given by Eq. (8-9) and satisfy:

$$
\Pi_{n}^{\prime} * \Pi_{n}^{\prime}=\Pi_{n}^{\prime}=\Pi_{n}^{\prime}
$$


Let us consider the $G$-invariant function $\hat{\Pi}_{n}^{\prime}$ associated with $\Pi^{\prime}{ }_{n}$. We can develop $\hat{\Pi}^{\prime}{ }_{n}$ as a series in the variables $\pi, \xi$ with respect to the Moyal ${ }^{*}$-product in $\mathbb{R}^{2 l+2}$. From this follows a development of $\Pi^{\prime}{ }_{n}$ as a series in the variables $p, q$ with respect to the twisted product $*^{\prime}$. Now if we consider the same series in the variables $p$ and $q$ but with respect to Moyal *-product in $\mathbb{R}^{2 l}$ we obtain a function $\Pi_{n}$ such that

$$
\begin{gathered}
\tau\left(\Pi_{n}\right)=\Pi_{n}^{\prime}, \\
\Pi_{n} * \Pi_{n}=\Pi_{n}=\Pi_{n} .
\end{gathered}
$$

With the help of these functions we thus get

and finally

$$
\gamma_{0} * \gamma_{0}=\sum_{n \geqslant 0}\left(n+\frac{l-1}{2}\right)^{2} \hbar^{2} \Pi_{n}
$$

$$
\gamma_{0}=\sum_{n \geqslant 0} \pm\left(n+\frac{l-1}{2}\right) \hbar \Pi_{n} .
$$

We now prove that we have only plus signs:

$$
\gamma_{0}=\sum_{n \geqslant 0}\left(n+\frac{l-1}{2}\right) \hbar \Pi_{n} .
$$

Let $f=2^{-1 / 2}\left(p^{2}+1\right)^{1 / 2} * r^{1 / 2} ;$ we have $\gamma_{0}=f * f$ and

$$
\Pi_{n} * \gamma_{0} * \Pi_{n}=\left(\Pi_{n} * f\right) *\left(\overline{\Pi_{n} * f}\right)= \pm\left(n+\frac{l-1}{2}\right) \hbar \Pi_{n}
$$

As mentioned in Section $2 c$, if $f, g \in L^{2}\left(\mathbb{R}^{2 l}\right)$ we have:

$$
\int_{\mathbf{R}^{2 l}}(f * \bar{g})(p, q) d p d q=\int_{\mathbb{R}^{2 l}}(f \bar{g})(p, q) d p d q
$$

We thus obtain

$$
\begin{aligned}
\int_{\mathbf{R}^{2 l}}\left(\Pi_{n} * f\right) *\left(\overline{\Pi_{n} * f}\right) d p d q & =\int_{\mathbf{R}^{2 l}}\left|\Pi_{n} * f\right|^{2} d p d q \\
& = \pm\left(n+\frac{l-1}{2}\right) \hbar \int_{\mathbb{R}^{2 l}} \Pi_{n} d p d q \\
& = \pm\left(n+\frac{l-1}{2}\right) \hbar(2 \pi \hbar)^{l} N_{n, L}
\end{aligned}
$$

and hence only the plus sign is admissible since the left-hand side is positive.

Finally we get

$$
\frac{1}{(-2 E)^{1 / 2}}=e^{-s}=\left(n+\frac{l-1}{2}\right) \hbar \quad \text { for all } \quad n=0,1,2, \ldots
$$

and in the particular case $l=3, E=-1 / 2(n+1)^{2} \hbar^{2}$ with multiplicity $(n+1)^{2}$. 
(e) Continuous spectrum of $H$. We now consider the case $E>0$ and we write $(2 E)^{1 / 2}=e^{s}$. We have in this case:

$$
\begin{aligned}
\operatorname{Exp}(-T s) *(H-E) * \operatorname{Exp}(T s) & =\frac{1}{2} e^{28}\left(p^{2}-1\right)-e^{8} r^{-1} \\
& =e^{28} r^{-1 / 2} *\left(\gamma_{4}^{\prime}-e^{-8}\right) * r^{-1 / 2}
\end{aligned}
$$

where $\gamma_{4}^{\prime}=\frac{1}{2} r^{1 / 2} *\left(p^{2}-1\right) * r^{1 / 2}$. Thus the problem is now to "diagonalize" the function $\gamma_{4}^{\prime}$.

We show that the diagonalization of $\gamma_{4}^{\prime}$ is equivalent to the diagonalization of $T=p \cdot q$. Expansion (8-13) for $\gamma_{0}$ allows us to define the function $\left(\gamma_{0} *\right)^{-1 / 2}$ by

$$
\left(\gamma_{0} *\right)^{-1 / 2}=\sum_{n \geqslant 0}\left(\left(n+\frac{l-1}{2}\right) \hbar\right)^{-1 / 2} \Pi_{n} .
$$

Consider the function $u=2^{-1 / 2}\left(\gamma_{0} *\right)^{-1 / 2} *\left(p^{2}+1\right)^{1 / 2} * r^{1 / 2}$ whose $*$-inverse is the function $(u *)^{-1}=2^{1 / 2} r^{-1 / 2} *\left(p^{2}+1\right)^{-1 / 2} *\left(\gamma_{2} *\right)^{1 / 2}$ where $\left(\gamma_{0}^{*}\right)^{1 / 2}$ is defined by

$$
\left(\gamma_{0} *\right)^{1 / 2}=\sum_{n>0}\left(\left(n+\frac{l-1}{2}\right) \hbar\right)^{1 / 2} \Pi_{n} .
$$

It is trivial to check that one has $(u *)^{-1}=2^{-1 / 2} r^{1 / 2} *\left(p^{2}+1\right)^{1 / 2} *\left(\gamma_{0} *\right)^{-1 / 2}$ and that if $\gamma_{0}^{\prime}=\frac{1}{2} r^{1 / 2} *\left(p^{2}+1\right) * r^{1 / 2}$ one has $\gamma_{0}=u * \gamma_{0}^{\prime} *(u *)^{-1}$. The functions $\gamma_{0}^{\prime}$, $\gamma_{4}^{\prime}, T$ already mentioned in Section $8 \mathrm{~b}$ satisfy the commutation relations of $s o(2,1)$ for Moyal bracket. It follows that $\gamma=\tau\left(\gamma_{0}\right), \gamma_{4}=\tau\left(u * \gamma_{4}^{\prime} *(u *)^{-1}\right)$, and $\tau\left(u * T *\left(u^{*}\right)^{-1}\right)$ satisfy the commutation relations of $s o(2,1)$ for the bracket $M^{\prime}$. Consider the abstract Lie algebra so $(2,1)$ with the following commutation relations $\left[\Gamma_{0}^{\prime}, \Gamma_{4}^{\prime}\right]=i T^{\prime},\left[\Gamma_{4}^{\prime}, T^{\prime}\right]=-i \Gamma_{0}^{\prime},\left[T^{\prime}, \Gamma_{0}^{\prime}\right]=i \Gamma_{4}^{\prime}$. One has $\operatorname{Ad}\left(\exp \left(-i t \Gamma_{0}^{\prime}\right)\right)$. $\Gamma_{4}^{\prime}=(\cos t) \Gamma_{4}^{\prime}+(\sin t) T^{\prime}$. If $|s|<\pi$ the function $\operatorname{Exp}(\gamma s)$ is well defined by its power series expansion

$$
\operatorname{Exp}(\gamma s)=\sum_{n \geqslant 0} \frac{1}{n !}\left(\frac{\gamma s}{i \hbar} *^{\prime}\right)^{n}
$$

and it follows that:

$$
\operatorname{Exp}\left(\gamma \frac{\pi}{2}\right) *^{\prime} \gamma_{4} *^{\prime} \operatorname{Exp}\left(-\gamma \frac{\pi}{2}\right)=\tau\left(u * T *(u *)^{-1}\right)
$$

The function $\operatorname{Exp}(\gamma(\pi / 2))$ may be written with the help of Eq. (8-8):

$$
\begin{aligned}
\operatorname{Exp}\left(\gamma \frac{\pi}{2}\right) & =\sum_{n>0} \exp \left(-i\left(n+\frac{l-1}{2}\right) \frac{\pi}{2}\right) \Pi_{n}^{\prime} \\
& =\tau\left[\sum_{n>0} \exp \left(-i\left(n+\frac{l-1}{2}\right) \frac{\pi}{2}\right) \Pi_{n}\right]
\end{aligned}
$$


We thus finally get $T=v * \gamma_{4}^{\prime} *(v *)^{-1}$ where

$$
v=(u *)^{-1} *\left(\sum_{n \geqslant 0} \exp \left(-i\left(n+\frac{l-1}{2}\right) \frac{\pi}{2}\right) \Pi_{n}\right) * u .
$$

It follows that for the product $*^{\prime}$ the spectra of $\tau\left(\gamma_{4}^{\prime}\right)$ and $\tau(T)=T$ are identical. It is easy to show that this spectrum is the real line. One first proves that if $T *^{\prime} \phi_{\lambda}=$ $\phi_{\lambda} *^{\prime} T=\lambda \phi_{\lambda}(\lambda \in \mathbb{R})$ with $\phi_{\lambda}=\bar{\phi}_{\lambda}$, then for any $\alpha \in \mathbb{R}$ the function $\phi_{\lambda+\hbar \alpha}=$ $p !^{i \alpha} *^{\prime} \phi *^{\prime}|p|^{-i \alpha}$ satisfies the same equations with $\lambda+\hbar \alpha$ instead of $\lambda$. Thus one only needs to show that there exists a function $\phi_{0}$ such that $T *^{\prime} \phi_{0}=\phi_{0} *^{\prime} T=0$, $\phi_{0}=\bar{\phi}_{0}$. The function $\phi_{0}=\tau(\pi(0, T))$ where $\pi(0, T)$ is given by Eqs. $(6-13)$ satisfies these requirements, and moreover $\phi_{\lambda} *^{\prime} \phi_{\mu}=\delta(\lambda-\mu) \phi_{\mu}$. Note that the spectrum of $T=p \cdot q$ for the Moyal product has been obtained in Section $6 \mathrm{~b}$. It is of course the real line (which shows in this case also that $\tau$ is isospectral). If we denote the generalized eigenvalue by $\lambda \in \mathbb{R}$, we have $\lambda=e^{-s}$ and thus $E=1 / 2 \lambda^{2}>0$.

We have thus succeeded in getting the spectrum of the hydrogen atom Hamiltonian. In our approach the singular Coulomb potential $r^{-1}$ has been replaced by the (probably smooth) velocity-dependent potential

$$
\begin{aligned}
\tau\left(r^{-1}\right) & =\tau\left(\frac{1}{2}\left(p^{2}+1\right)^{1 / 2} *\left(\gamma_{0} *\right)^{-1} *\left(p^{2}+1\right)^{1 / 2}\right) \\
& =\left(p^{2}+1\right)^{1 / 2} *^{\prime} \frac{1}{r\left(p^{2}+1\right)} *^{\prime}\left(p^{2}+1\right)^{1 / 2} .
\end{aligned}
$$

\section{APPENDIX}

\section{(A-1) Two-Dimensional Isotropic Oscillator.}

In this appendix we consider a two-dimensional harmonic oscillator with Hamiltonian $H=\frac{1}{2}\left(p_{1}{ }^{2}+{p_{2}}^{2}+q_{1}^{2}+q_{2}^{2}\right)$. We also consider the angular momentum $L_{3}=q_{1} p_{2}-q_{2} p_{1}$ and will give a complete treatment of the twisted diagonalization problem with respect to the dynamical functions $H$ and $L_{3}$; i.e., we solve the eigenvalue problem:

$$
\begin{aligned}
H * \phi & =\phi * H=E \phi, \\
L_{3} * \phi & =\phi * L_{3}=M \phi, \\
\phi & =\bar{\phi} \\
\phi * \phi & =\phi .
\end{aligned}
$$

In order to do this we introduce the following linear canonical transformation:

$$
\begin{array}{ll}
q_{1}^{\prime}=2^{-1 / 2}\left(q_{1}+p_{2}\right), & p_{1}^{\prime}=-2^{-1 / 2}\left(q_{2}-p_{1}\right) \\
q_{2}^{\prime}=2^{-1 / 2}\left(q_{1}-p_{2}\right), & p_{2}^{\prime}=2^{-1 / 2}\left(q_{2}+p_{1}\right),
\end{array}
$$


together with the functions:

$$
\begin{array}{ll}
a_{r}=2^{-1 / 2}\left(q_{1}^{\prime}+i p_{1}^{\prime}\right), & N_{r}=\bar{a}_{r} * a_{r}, \\
a_{l}=2^{-1 / 2}\left(q_{2}^{\prime}+i p_{2}^{\prime}\right), & N_{l}=\bar{a}_{l} * a_{l} .
\end{array}
$$

The functions $a_{r}$ and $a_{l}$ are (respectively) "creation functions" of left and right quantas: $a_{r}=2^{-1 / 2}\left(a_{1}-i a_{2}\right), \quad a_{l}=2^{-1 / 2}\left(a_{1}+i a_{2}\right)$ where $a_{j}=2^{-1 / 2}\left(q_{j}+i p_{j}\right)$, $j=1,2$. The functions $N_{r}$ and $N_{l}$ commute (for $*$ ) and one has

$$
\begin{aligned}
& H=N_{\tau}+N_{l}+1, \\
& L_{3}=N_{\tau}-N_{l} .
\end{aligned}
$$

It follows from Section 6 that, for $s \in \mathbb{R}$ and $\alpha=r$ or $\alpha=l$ :

$$
\begin{aligned}
\operatorname{Exp}\left(\left(N_{\alpha}+\frac{1}{2}\right) s\right) & =\left(\cos \frac{s}{2}\right)^{-1} \exp \left(-i\left(2 N_{\alpha}+1\right) \tan \frac{s}{2}\right) \\
& =\sum_{k=0}^{\infty} 2(-1)^{k} e^{-\left(2 N_{\alpha}+1\right)} L_{k}\left(4 N_{\alpha}+2\right) e^{-i(k+(1 / 2)) s}
\end{aligned}
$$

the series converging in $\mathscr{S}^{\prime}\left(\mathbb{R}^{4}\right)$. Hence if $n \in \mathbb{N}, m=n, n-2, \ldots,-n$, and

$$
\phi=\pi_{n, m}=4(-1)^{n} e^{-2 H} L_{(1 / 2)(n+m)}\left(2\left(H+L_{3}\right)\right) L_{(1 / 2)(n-m)}\left(2\left(H-L_{3}\right)\right)
$$

the system (A-1) is satisfied with $E=n+1, M=m$.

Conversely the decomposition (A-2) allows one to show that solutions of the system (A-1), analytic in a neighborhood of 0 and belonging to $\mathscr{S}^{\prime}\left(\mathbb{R}^{4}\right)$, exist if and only if $E=n$ is a nonnegative integer, $M=m, m=n, n-2, \ldots,-n$. In such a case $\phi=\pi_{n, m}$.

\section{(A-2) Proofs of the Lemmas of Section 7}

LEMMA 1. Consider the function $\theta(x, t)=(\cos (a t))^{\alpha} \exp [i \mu x \tan (a t)]$ where $\alpha \in \mathbb{Z}$, $a>0$, and $\mu \in \mathbb{R}^{*}$. Let $|t|<\pi / 2 a$; then

$$
\theta(x, t)=\sum_{n=0}^{\infty} \frac{1}{n !}\left(\frac{t}{i \hbar}\right)^{n} \widetilde{G}_{n}(x) .
$$

$\theta$ satisfies the partial differential equation

$$
i \frac{\partial \theta}{\partial t}=a \mu^{-1} x \frac{\partial^{2} \theta}{\partial x^{2}}-\alpha a \mu^{-1} \frac{\partial \theta}{\partial x}-a \mu x \theta .
$$

Hence the following recursion relation holds for the polynomials $G_{n}$ :

$$
\begin{aligned}
\tilde{G}_{n+1}(x) & =\hbar a\left[\mu^{-1} x \widetilde{G}_{n}^{\prime \prime}-\alpha \mu^{-1} \widetilde{G}_{n}^{\prime}-\mu x \widetilde{G}_{n}\right], \\
G_{0}(x) & =1 .
\end{aligned}
$$


It is straightforward to check that the functions $S_{n}$ defined by

$$
S_{n}(y)=y^{-1 / 2}(-\hbar)^{-n-1} G_{n+1}\left(y^{1 / 2}\right), \quad n \geqslant 0 \quad(y>0)
$$

satisfy the relation:

$$
\begin{aligned}
S_{n+2}(y)= & a^{2}\left(\mu^{2} y+3 \alpha-2\right) S_{n}(y)+2 a^{2}\left[2(\alpha-4) y+3(\alpha-1)(\alpha-2) \mu^{-2}\right] S_{n}^{\prime}(y) \\
& +4 a^{2} y\left[\left(x^{2}-13 x+27\right) \mu^{2}-2 y\right] S_{n}^{\prime \prime}(y)-16 a^{2} \mu^{-2}(\alpha-6) y^{2} S_{n}^{\prime \prime}(y) \\
& +16 a^{2} \mu^{-2} y^{3} S_{n}^{(4)}(y)
\end{aligned}
$$

On the other hand let $\left(\left(g^{2}-(3 l-4)\left(\hbar^{2} / 4\right)\right)^{*}\right)^{n}=T_{n}\left(g^{2}\right)$; Eq. (7-1) implies an obvious relation for the polynomials $T_{n}$ :

$$
T_{n+1}\left(g^{2}\right)=\left(g^{2}-(3 l-4)\left(\hbar^{2} / 4\right)\right) T_{n}\left(g^{2}\right)+\cdots+\hbar^{4} g^{6} T_{n}^{(4)}\left(g^{2}\right) .
$$

If $a=\mu^{-1}=\hbar / 2$ and $\alpha=2-l$ the two previous recursion relations have the same coefficients:

$$
\begin{aligned}
g^{2}-(3 l-4) \hbar^{2} / 4 & =a^{2} \mu^{2} g^{2}+(3 \alpha-2) a^{2} \\
\hbar^{2}\left[3 l(l-1) \hbar^{2} / 8-(l+2) g^{2}\right] & =2 a^{2}\left[3(\alpha-1)(\alpha-2) \mu^{-2}+2(\alpha-4) g^{2}\right] \\
\hbar g^{2}\left[\left(l^{2}+9 l+5\right) \hbar^{2} / 4-2 g^{2}\right] & =4 a^{2} g^{2}\left[\left(\alpha^{2}-13 \alpha+27\right) \mu^{2}-2 g^{2}\right] \\
(l+4) \hbar^{2} g^{4} & =-16 a^{2} \mu^{-2}(\alpha-6) g^{4} \\
\hbar^{4} g^{6} & =16 a^{2} \mu^{-2} g^{6} .
\end{aligned}
$$

Furthermore $T_{1}\left(g^{2}\right)=S_{2}\left(g^{2}\right)$. Hence $T_{n}\left(g^{2}\right)=S_{2 n}\left(g^{2}\right)=g^{-1}(-\hbar)^{-2 n-1} G_{2 n+1}(g)=$ $g^{-1} G_{2 n+1}(g)$ for any $n>0$ and the proof is complete.

LEMMA 2. The commutativity of the product is clear. In fact for any function $f \in C^{x}\left(\mathbb{R}_{+}\right)$the Moyal bracket $M\left(M_{j k}, f\left(g^{2}\right)\right)=0(1 \leqslant j, k \leqslant l)$. Hence for any integer $n \geqslant 1$ one gets $M\left(\left(g^{2 *}\right)^{n}, f\left(g^{2}\right)\right)=0$ and the powers $\left(g^{2 *}\right)^{n}$ generate all polynomials in the variable $\mathrm{g}^{2}$.

Next define recursively the following functions $R_{0}(x)=1, R_{n}=A^{n} R_{0}(n>0)$. It is straightforward to check that for any $n \geqslant 0, R_{n}(x)=x^{-1} G_{n+1}(x)$ where $G_{n}$ is the polynomial which is defined in expansion (7-2). On the other hand let $F \in C^{\infty}\left(\mathbb{R}_{+}-\{0\}\right)$; then

$$
\left(A^{2} F\right)(g)=\left(g^{2}-(3 l-4)\left(\hbar^{2} / 4\right)\right) * F(g) .
$$

To see this one only needs to rewrite Eq. (7-1) with $f\left(g^{2}\right)=F(g)$. It follows from $R_{2 n+1}=A^{2 n} R_{1}=A R_{2 n}$ and $R_{1}(x)=x-\left[(l-2) \hbar^{2} / 4 x\right]$ that

$$
\left(\left(g^{2}-(3 l-4)\left(\hbar^{2} / 4\right)\right) *\right)^{n} * y !_{p, q}=\left(A R_{2 n}\right)(g(p, q)) .
$$


This proves relation (7-4) in the case $Q(y)=T_{n}(y)$ for $R_{2 n}(g)=g^{-1} G_{2 n+1}(g)=$ $T_{n}\left(g^{2}\right)$. The powers $\left(\left(g^{2}-[(3 l-4) / 4] \hbar^{2}\right) *\right)^{n}$ generate all polynomials in the variable $g^{2}$, whence the result.

Lemma 3. One first computes $P^{2}(g, F(g))$ and finds

$$
P^{2}(g, F(g))=2\left(g F^{\prime \prime}(g)+l F^{\prime}(g)\right) .
$$

It follows from Lemma 2 that in the case $\phi(p, q)=Q\left(g^{2}(p, q)\right)$, where $Q$ is a polynomial, we have:

$$
\gamma * \phi=\gamma \phi-\left(\hbar^{2} / 8\right) P^{2}(g, \phi) .
$$

On the other hand, for such a $\phi$, Eq. (7-5) holds (the series has only a finite number of nonvanishing terms) and $P(g, \phi)=0$. Hence for any $n>2$ we get

$$
P^{n}(g, \phi)+(l-2) n(n-1) P^{n-2}\left(g^{-1}, \phi\right)=0
$$

in the case $\phi=Q\left(g^{2}\right)$. We now show that the previous equality holds for any $\phi=F(g)$. Let $n>2$ be a fixed integer. It is easy to prove that there exists a sequence of polynomials $\left(P_{k}\right)_{k>1}$ such that the polynomials $R_{k}$ defined by $R_{k}(x)=P_{k}\left(x^{2}\right)$ have the following property: on any compact subset of $\mathbb{R}_{+}{ }^{*}$, the polynomials $R_{k}, R_{k}^{\prime}, \ldots, R_{k}^{(n)}$ converge uniformly (respectively) to $F, F^{\prime}, \ldots, F^{(n)}$ as $k \rightarrow \infty$. Let us write $R_{k}(g(p, q))=\phi_{k}(p, q)$. On any compact subset of $U$ the expression $P^{n}\left(g, \phi_{k}\right)+(l-2) n(n-1) P^{n-2}\left(g^{-1}, \phi_{k}\right)$, which is 0 , converges uniformly to $P^{n}(g, \phi)+(l-2) n(n-1) P^{n-2}\left(g^{-1}, \phi\right)$ as $k \rightarrow \infty$. Hence this last expression is identically 0 on $U$.

LEMMA 4. Let $g(x)=x-[(l-2) / 4 x] \hbar^{2}$. One immediately checks that $(A g)(x)=$ $x^{2}-[(3 l-4) / 4] \hbar^{2}$, which proves the lemma for $(\gamma *)^{2}$. We prove by induction the end of the lemma. One has $g(x)=x^{-1} G_{2}(x)$. Suppose that (7-7) holds for $n$ and that $x^{-1} G_{n+1}(x)=R_{n}(x)$ is a polynomial in $\hbar$. Lemma 3 implies:

$$
\left(\gamma^{*}\right)^{n+1}=\gamma *\left(\gamma^{*}\right)^{n}=\left(A R_{n}\right)(g)=R_{n+1}(g)=g^{-1} G_{n+2}(g)
$$

and obviously $g^{-1} G_{n+2}(g)$ is a polynomial in $\hbar$.

Remark. Even powers of $\gamma$ are polynomials in the variable $g^{2}$ and odd powers of $\gamma$ are quotients of polynomials in the variable $g^{2}$ by $g$.

\section{REFERENCES}

1. I. E. Segal, Duke Math. J. 18 (1951), 221; E. Inönu AND E. P. Wigner, Proc. Nat. Acad. Sci. U.S.A. 39 (1953), 510, and 40 (1954), 119.

2. M. Gerstenhaber, Ann. Math. 79 (1964), 59. 
3. F. Bayen, M. Flato, C. Fronsdal, A. Lichnerowicz, and D. Sternhelmer, Deformation theory and quantization. I. Deformations of symplectic structures, Ann. Phys. (N.Y.) 111 (1978), 61 ; henceforth referred to as I.

4. H. WEYL, "The Theory of Groups and Quantum Mechanics," Dover, New York, 1931.

5. E. P. Wigner, Phys. Rev. 40 (1932), 749.

6. J. E. Moyal, Proc. Cambridge Phil. Soc. 45 (1949), 99. See also H. J. Groenewold, Physica 12 (1946), 405.

7. The domain of the Weyl correspondence has been studied by many authors. In particular, it e.g., K. Chi LiU, J. Math. Phys. 17 (1976), 859 and references quoted there. See also G. S. Agarwal and E. Wolf, Phys. Rev. D 2(1970), 2161.

8. See, e.g., E. Remler, Ann. Phys. (N.Y.) 95 (1975), 455. See also S. R. De Groot and L. G. SutToRP. "Foundations of electrodynamics." North-Holland, Amsterdam, 1972; AND S. R. DE GROOT. "La transformation de Weyl et la fonction de Wigner: une forme alternative de la mécanique quantique." Presses Universitaires de Montréal, 1974.

9. The nonlocality of the equations of motion provides the basis for the introduction of fuzzy phase space, in the sense of E. Prugovečki, J. Math. Phys. 17 (1976), 517, 1673; S. T. Ali AND E. Prugovečki, J. Math. Phys. 18 (1977), 219.

:0. The map $J$ is Souriau's "moment"; J. M. Souriau, "Structure des Systèmes Dynamiques," p. 105, Dunod, Paris, 1970; See also C.-M. Marle, in "Differential Geometry and Relativity," volume dedicated to A. Lichnerowicz (M. Cahen and M. Flato, Eds.), Reidel, Dordrecht, 1977.

11. P. A. M. Dirac, "Lectures on Quantum Mechanics," Belfer Graduate School of Sciences Monograph Series No. 2, Yeshiva Univ., New York, 1964.

12. See, e.g., G. Györgyı, Nuovo Cimento A 53 (1968), 717.

13. See, e.g., C. Fronsdal and R. W. Huff, Phys. Rev. D 7 (1973), 3609.

14. See C. Martin, Lett. Math. Phys. 1 (1976), 155.

I5. M. Flato, A. Lichnerowicz, and D. Sternheimer, J. Math. Phys. 17 (1976), 1754.

16. I. E. Segal, "Symposia Math.," Vol. XIV, pp. 99-117, Academic Press, New York/London, 1974 , and earlier references quoted therein.

17. One simply substitutes in (2-4) formal powers of the field-theoretical Poisson bracket (using higher-order functional derivatives). This has of course to be justified. See also G. S. AGARWAL ANd E. Wolf, Phys. Rev. D 2 (1970), 2187, 2206; E. Remler, preprint, College of William and Mary, 1977.

18. M. Guenin, Phys. Lett., 62B (1976), 81 and Ref. 8. M. M. Flato and M. Guenin, Helv. Phys. Acta, 50 (1977), 117.

19. R. Casalbuoni, CERN preprint TH. 2139 (March 1976). K. DrüHL, Max-Planck-Institute preprint, Starnberg, December 1976. A. SuDBERY, Univ. of York preprint, October 1975.

20. J. L. Gervais and B. Sakita, Nucl. Phys. B 34 (1971).

21. J. Wess and B. Zumino, Nucl. Phys. B 70 (1974), 39. See also J. Schwinger, Phys. Rev. 92 (1953), 1283 and Proc. Nat. Acad. Sci. U.S.A. 48 (1962), 603; M. Flato and P. Hullion, Phys. Rev. D 1 (1970), 1667.

22. A. ERdéLYI (Ed.), "Higher Transcendental Functions," Vol. 2, McGraw-Hill, New York, 1953. 


\title{
LETTER TO THE EDITOR
}

\section{Wigner distribution functions and the representation of canonical transformations in quantum mechanics}

\author{
G García-Calderón and M Moshinsky ${ }^{\dagger}$ \\ Instituto de Física, UNAM, Apdo Postal 20-364, México 20, DF
}

Received 10 March 1980

\begin{abstract}
In this Letter we show how for classical canonical transformations we can pass, with the help of Wigner distribution functions, from their representation $U$ in the configurational Hilbert space to a kernel $K$ in phase space. The latter is a much more transparent way of looking at representations of canonical transformations, as the classical limit is reached when $\hbar \rightarrow 0$ and the successive quantum corrections are related with the power of $\hbar^{2 n}, n=1,2, \ldots$.
\end{abstract}

In recent publications one of the authors (MM) and his collaborators have discussed extensively the representation in quantum mechanics of non-linear and non-bijective canonical transformations (Mello and Moshinsky 1975, Kramer et al 1978, Moshinsky and Seligman 1978, 1979a, b). The representations, to be denoted by $U$, are given in definite Hilbert spaces like, for example, the one associated with coordinate $q$; thus the matrix elements $\left\langle q^{\prime}|U| q^{\prime \prime}\right\rangle$ related with specific canonical transformations were derived explicitly. It is not easy though to see from these matrix elements the quantum modifications to the canonical transformations, as the latter are formulated in phase space rather than in Hilbert space. Thus it is interesting to discuss the representation of canonical transformations in the phase space version of quantum mechanics that was developed originally by Wigner (1932), with the help of the distribution functions that now bear his name. We shall do this in the present Letter, illustrating the analysis with the representations of some simple examples of canonical transformations.

We begin by recalling the definition of Wigner's distribution function $f(q, p)$ for a given wavefunction $\psi(q)$, i.e.

$$
f(q, p)=(\pi \hbar)^{-1} \int_{-\infty}^{\infty}\langle\psi \mid q+y\rangle\langle q-y \mid \psi\rangle \exp \left(\frac{2 \mathrm{i} p y}{\hbar}\right) \mathrm{d} y
$$

where we use Dirac's notation $\langle q \mid \psi\rangle=\psi(q),\langle\psi \mid q\rangle=\psi^{*}(q)$, and restrict ourselves to a single degree of freedom. As is well known (Wigner 1932), the integration of $f(q, p)$ with respect to $p$ or $q$ gives the probability density for the state $|\psi\rangle$ in configuration or momentum space respectively.

We consider now a canonical transformation

$$
Q=Q(q, p), \quad P=P(q, p) ; \quad\{Q, P\} \equiv \frac{\partial Q}{\partial q} \frac{\partial P}{\partial p}-\frac{\partial Q}{\partial p} \frac{\partial P}{\partial q}=1
$$

$\uparrow$ Member of the Instituto Nacional de Investigaciones Nucleares and El Colegio Nacional.

$0305-4470 / 80 / 060185+04 \$ 01.50$ (C) 1980 The Institute of Physics 
under which a classical distribution function $f(q, p)$ would of course transform into $F(q, p)$ given by

$$
F(q, p)=f[Q(q, p), P(q, p)] .
$$

In quantum mechanics though, the state $|\psi\rangle$ transforms into (Mello and Moshinsky 1975, Kramer et al 1978, Moshinsky and Seligman 1978, 1979a, b)

$$
|\psi\rangle \rightarrow|\Psi\rangle=U|\psi\rangle
$$

and thus

$$
\begin{aligned}
F(q, p)=(\pi \hbar)^{-1} \int_{-\infty}^{\infty}\langle\Psi \mid q+y\rangle\langle q-y \mid \Psi\rangle \exp \left(\frac{2 \mathrm{i} p y}{\hbar}\right) \mathrm{d} y \\
=(\pi \hbar)^{-1} \iiint_{-\infty}^{\infty} \mathrm{d} z_{+} \mathrm{d} y \mathrm{~d} z_{-}\left\langle\psi \mid z_{+}\right\rangle\left\langle z_{+}\left|U^{\dagger}\right| q+y\right\rangle \\
\\
\times\left\langle q-y|U| z_{-}\right\rangle\left\langle z_{-} \mid \psi\right\rangle \exp \left(\frac{2 \mathrm{i} p y}{\hbar}\right) .
\end{aligned}
$$

Writing $z_{ \pm}=q^{\prime} \pm y^{\prime}$ when it is associated with $\psi$, and $z_{ \pm}=q^{\prime} \pm \bar{y}^{\prime}$ when it is associated with $U$, and integrating over $q^{\prime}, y^{\prime}, \bar{y}^{\prime}, y$, with the extra factor

$$
\delta\left(y^{\prime}-\bar{y}^{\prime}\right)=(\pi \hbar)^{-1} \int_{-\infty}^{\infty} \exp \left(\frac{2 \mathrm{i} p^{\prime}\left(y^{\prime}-\bar{y}^{\prime}\right)}{\hbar}\right) \mathrm{d} p^{\prime},
$$

we immediately arrive at the relation

$$
F(q, p)=\int_{-\infty}^{\infty} \int^{\infty} \mathrm{d} q^{\prime} \mathrm{d} p^{\prime} f\left(q^{\prime}, p^{\prime}\right)\left\langle q^{\prime} p^{\prime}|K| q p\right\rangle,
$$

in which the kernel $K$ is given by

$$
\begin{aligned}
\left\langle q^{\prime} p^{\prime}|K| q p\right\rangle= & 2(\pi \hbar)^{-1} \int_{-\infty}^{\infty} \int_{-\infty} \mathrm{d} y \mathrm{~d} y^{\prime}\left\langle q^{\prime}+y^{\prime}\left|U^{\dagger}\right| q+y\right\rangle \\
& \times\left\langle q-y|U| q^{\prime}-y^{\prime}\right\rangle \exp \left(\frac{\mathrm{i}\left(2 p y-2 p^{\prime} y^{\prime}\right)}{\hbar}\right),
\end{aligned}
$$

where from (3) we expect that

$$
\lim _{h \rightarrow 0}\left\langle q^{\prime} p^{\prime}|K| q p\right\rangle=\delta\left[q^{\prime}-Q(q, p)\right] \delta\left[p^{\prime}-P(q, p)\right] .
$$

To obtain $K$ we must known $U$ which, in principle (Dirac 1947), is determined by the equations (Mello and Moshinsky 1975, Kramer et al 1978, Moshinsky and Seligman 1978, 1979a, b)

$$
Q(q, p)=U q U^{\dagger}, \quad P(q, p)=U p U^{+},
$$

where $q, p$ are now quantum mechanical operators. As $U^{\dagger} U=I$, we can pass $U^{\dagger}$ to the left-hand side, and taking matrix elements between a bra $\left\langle q^{\prime}\right|$ and a ket $\left|q^{\prime \prime}\right\rangle$ obtain the 
equations (Mello and Moshinsky 1975, Kramer et al 1978, Moshinsky and Seligman $1978,1979 a, b)$

$$
\begin{aligned}
& Q\left(q^{\prime}, \frac{\hbar}{\mathrm{i}} \frac{\partial}{\partial q^{\prime}}\right)\left\langle q^{\prime}|U| q^{\prime \prime}\right\rangle=q^{\prime \prime}\left(q^{\prime}|U| q^{\prime \prime}\right\rangle, \\
& P\left(q^{\prime}, \frac{\hbar}{\mathrm{i}} \frac{\partial}{\partial q^{\prime}}\right)\left\langle q^{\prime}|U| q^{\prime \prime}\right\rangle=-\frac{\hbar}{\mathrm{i}} \frac{\partial}{\partial q^{\prime \prime}}\left\langle q^{\prime}|U| q^{\prime \prime}\right\rangle .
\end{aligned}
$$

Of course these equations only make sense when $Q, P$ are well defined operators; otherwise, more sophisticated procedures need to be used (Moshinsky and Seligman $1978,1979 a, b)$.

We shall now consider two simple examples of canonical transformations. The first will be the linear one

$$
Q=a q+b p, \quad P=c q+d p ; \quad a d-b c=1, \quad b>0,
$$

where the constants are all real. We have then (Moshinsky and Quesne 1971)

$$
\left\langle q^{\prime}|U| q^{\prime \prime}\right\rangle=(2 \pi b)^{-1 / 2} \exp \left[(-\mathrm{i} / 2 b)\left(a q^{\prime 2}-2 q^{\prime} q^{\prime \prime}+d q^{\prime \prime 2}\right)\right],
$$

which satisfies equations (10) if we note from (11) that $c=(a d-1) / b$. Introducing (12) in (7) and using the relation $\left\langle q^{\prime}\left|U^{\dagger}\right| q^{\prime \prime}\right\rangle=\left\langle q^{\prime \prime}|U| q^{\prime}\right\rangle^{*}$ we immediately obtain

$$
\left\langle q^{\prime} p^{\prime}|K| q p\right\rangle=\delta\left[q^{\prime}-(a q+b p)\right] \delta\left[p^{\prime}-(c q+d p)\right] .
$$

Thus for the linear canonical transformation the kernel coincides with its classical limit (8), in agreement with the fact that for this type of transformation Poisson and Moyal (1949) brackets coincide.

In the second example we take $Q$ as the Hamiltonian of a linear potential (Landau and Lifshitz 1958), and thus we have the canonical transformation

$$
Q=\left(p^{2} / 2 m\right)-F_{0} q, \quad P=-p / F_{0},
$$

where $m$ is the mass, $F_{0}$ a constant of the dimension of force, and $\{Q, P\}=1$. Equation (10a) leads then to an Airy function (Landau and Lifshitz 1958), and we also satisfy $(10 b)$ and get a normalised (Landau and Lifshitz 1958) unitary representation if we write

$$
\begin{aligned}
& \left\langle q^{\prime}|U| q^{\prime \prime}\right\rangle=A \Phi(-\xi), \\
& \xi=\left[q^{\prime}+\left(q^{\prime \prime} / F_{0}\right)\right]\left(2 m F_{0} / \hbar^{2}\right)^{1 / 3}, \\
& A=(2 m)^{1 / 3} \pi^{-1 / 2} F_{0}^{-1 / 6} \hbar^{-2 / 3}, \\
& \Phi(\xi)=(4 \pi)^{-1 / 2} \int_{-\infty}^{\infty} \exp \left\{\mathrm{i}\left[\left(u^{3} / 3\right)+u \xi\right]\right\} \mathrm{d} u .
\end{aligned}
$$

Substituting (15a) into (7) and making use of (15d) we can show straightforwardly that for the canonical transformation (14) the kernel $K$ becomes

$$
\left\langle q^{\prime} p^{\prime}|K| q p\right\rangle=\left\{2\left(\frac{m}{\hbar^{2} F_{0}^{2}}\right)^{1 / 3} \pi^{-1 / 2} \Phi\left[2\left(\frac{m}{\hbar^{2} F_{0}^{2}}\right)^{1 / 3}\left(\frac{p^{2}}{2 m}-F_{0} q-q^{\prime}\right)\right]\right\} \delta\left(p^{\prime}+\frac{p}{F_{0}}\right) .
$$

We note first that when $\hbar \rightarrow 0$ the function $\Phi$ becomes (Landau and Lifshitz 1958) either very small or very rapidly oscillating except when $q^{\prime} \simeq\left(p^{2} / 2 m\right)-F_{0} q$. Furthermore, with the help of $(15 d)$ we easily see that $\pi^{-1 / 2} \int_{-\infty}^{\infty} \Phi(x) \mathrm{d} x=1$. Thus the expression in 


\section{L188 Letter to the Editor}

\{\} in (16) tends to a $\delta$ function in the limit $\hbar \rightarrow 0$, so that the kernel $K$ goes into its classical limit (8), where $Q$ and $P$ are given by (14).

To see what the quantum corrections are, it is best to apply the $K$ of (16) to a smooth distribution function $f(q, p)$, rather than study it directly. We choose

$$
f(q, p)=(\pi a b)^{-1} \exp \left[-\left(q^{2} / a^{2}\right)-\left(p^{2} / b^{2}\right)\right],
$$

where from (1) we will have the relation $b=\hbar / a$ if $f$ is obtained from a Gaussian state in configuration space. Again using $(15 d)$ we obtain for the new distribution function $F(q, p)$ the expression

$$
F(q, p)=f(Q, P) \sum_{k=0}^{\infty} \frac{\hbar^{2 k} F_{0}^{2 k} m^{-k}}{(2 a)^{3 k}}\left(\sum_{\substack{i=0 \\ 3 k \rightarrow \text { even }}}^{3 k} \frac{(-1)^{(3 k-t) / 2}(2 Q)^{t}(3 k) !}{a^{t} t ![(3 k-t) / 2] ! k ! 3^{k}}\right),
$$

where $Q, P$ are given by (14). As indicated in (3), $f(Q, P)$ is the classical change in the distribution function due to the canonical transformation, and it will be the only one remaining in (18) if $\hbar \rightarrow 0$. Thus the terms associated with the higher powers of $\hbar^{2}$ indicate the successive quantum corrections to the distribution function when we perform the canonical transformation.

The examples discussed in this Letter are very specialised, but they clearly indicate the procedure to be followed in general. Among the more interesting cases where this formalism can be applied are those of non-bijective (Kramer et al 1978, Moshinsky and Seligman 1978, 1979a, b) canonical transformations. The concepts of ambiguity group and ambiguity spin used in the derivation of the representation $U$ can then give interesting insights into the structure of phase space as a carrier of canonical transformations, as will be discussed in future publications.

The authors are indebted to Professor E P Wigner for a stimulating presentation of his distribution function formalism and helpful discussions, during his recent stay in Mexico.

\section{References}

Dirac P A M 1947 The Principles of Quantum Mechanics (Oxford: UP) Kramer P, Moshinsky M and Seligman T H 1978 J. Math. Phys. 19683 Landau L D and Lifshitz E M 1958 Quantum Mechanics (London: Pergamon) pp 73-4 Mello P A and Moshinsky M 1975 J. Math. Phys. 162017 Moshinsky M and Quesne C 1971 J. Math. Phys. 121772 Moshinsky M and Seligman T H 1978 Ann. Phys., NY 114243

— 1979a Ann. Phys., NY 120402

- 1979b J. Phys. A: Math. Gen. 12 L135

Moyal J E 1949 Proc. Camb. Phil. Soc. 4599

Wigner E P 1932 Phys. Rev. 40749 
Molecular Physics, 1982, Vol. 47, No. 5, 1001-1019

\title{
Wigner's phase space function and atomic structure
}

\section{The hydrogen atom ground state}

\author{
by JENS PEDER DAHL and MICHAEL SPRINGBORG \\ Department of Chemical Physics, Technical University of Denmark, \\ DTH 301, DK-2800 Lyngby, Denmark
}

(Received 25 May 1982 ; accepted 29 fune 1982)

\begin{abstract}
We have constructed the Wigner function for the ground state of the hydrogen atom and analysed its variation over phase space. By means of the Weyl correspondence between operators and phase space functions we have then studied the description of angular momentum and resolved a dilemma in the comparison with early quantum mechanics. Finally we have discussed the introduction of local energy densities in coordinate space and demonstrated the validity of a local virial theorem.
\end{abstract}

\section{INTRODUCTION}

This is the first of a series of papers devoted to the phase space description of atomic and molecular systems. Phase space representations of quantum mechanics have been extensively discussed since the classical works by Weyl [1], Wigner [2], Groenewold [3] and Moyal [4]. They have been applied in quantum statistical studies of transport processes and radiation (see, for example, [5] and [6]), and in treatments of molecular and nuclear dynamics (for example, [7-10]). They have, however, not yet been used in such detailed theories as the theories of atomic and molecular electronic structure.

In this and forthcoming papers we shall investigate the possibility of extending the application of phase space representations to such theories as well. Very accurate wavefunctions are now available for all atoms and for a large class of molecules. These wavefunctions have always been generated in coordinate space, but there has been a considerable interest in their momentum space representatives as well. The use of phase space representations allows one to include the coordinate and momentum characteristics in a single picture, and hence it may serve to improve our understanding of the dynamical behaviour of electrons in atoms and molecules.

The phase space formulation of quantum mechanics treats states and transitions in an equivalent manner. Thus, there is a phase space function associated with every quantum state and with every quantum transition as well. This function is the Wigner function.

In the present paper we shall only consider Wigner functions associated with states. Operationally, such functions play the rôle of probability densities in phase space. The values of the functions are, however, not restricted to being positive or zero, although they are always real. Hence, one may not interpret the functions as probability densities. Such an interpretation would of course also be inconsistent with the uncertainty principle. 
If a Wigner function cannot be interpreted as a probability density, how may it then be interpreted? This question, which has attracted considerable attention, was discussed in a recent article by one of the authors [11]. The conclusion is that one must reoonsider the rôle played by a point in phase space. The significance of such a point is not, as in classical mechanics, that it defines a simultaneous position and momentum of a particle. It is instead that it defines an inversion operator, the so-called Wigner operator $[12,13]$.

The properties of the Wigner operator and the group theoretical basis it lends to the phase space representation of quantum mechanics has been thoroughly discussed by one of us [14], but since only one-dimensional motion was considered we shall here list a few of the relevant expressions for a particle in three dimensions.

The inversion operator defined by the phase space point $(\mathbf{r}, \mathbf{p})$ is

$$
\begin{aligned}
\hat{\Pi}(\mathbf{r}, \mathbf{p})=\left(\frac{1}{2 h}\right)^{3} \iint d \mathbf{u} d \mathbf{v} \exp \left[\frac{i}{\hbar}(\mathbf{r} \cdot \mathbf{u}+\mathbf{p} \cdot \mathbf{v})\right] \\
\times \exp \left[-\frac{i}{\hbar}(\mathbf{p} \cdot \mathbf{u}+\mathbf{p} \cdot \mathbf{v})\right]
\end{aligned}
$$

with the caret $(\wedge)$ denoting operators. The Wigner function associated with a normalized state vector $|\psi\rangle$ is

$$
f(\mathbf{r}, \mathbf{p})=\left(\frac{2}{h}\right)^{\mathbf{3}}\langle\psi|\Pi(\mathbf{r}, \mathbf{p})| \psi\rangle
$$

It is normalized such that

$$
\iint f(r, p) d r d p=1
$$

If $\psi(\mathbf{r})$ and $\phi(\mathbf{p})$ are the coordinate and momentum wavefunctions, respectively, that is

then we may also write

$$
\begin{aligned}
& \psi(\mathbf{r})=\langle\mathbf{r} \mid \psi\rangle, \\
& \phi(\mathbf{p})=\langle\mathbf{p} \mid \psi\rangle,
\end{aligned}
$$

and

$$
f(\mathbf{r}, \mathbf{p})=\left(\frac{2}{h}\right)^{3} \int d \mathbf{r}^{\prime} \psi\left(\mathbf{r}-\mathbf{r}^{\prime}\right)^{*} \psi\left(\mathbf{r}+\mathbf{r}^{\prime}\right) \exp \left(-\frac{2 i}{\hbar} \mathbf{p} \cdot \mathbf{r}^{\prime}\right)
$$

$$
f(\mathbf{r}, \mathbf{p})=\left(\frac{2}{h}\right)^{3} \int d \mathbf{p}^{\prime} \phi\left(\mathbf{p}-\mathbf{p}^{\prime}\right)^{*} \phi\left(\mathbf{p}+\mathbf{p}^{\prime}\right) \exp \left(\frac{2 i}{h} \mathbf{r} \cdot \mathbf{p}^{\prime}\right) \text {. }
$$

Further we have the relations

and

$$
\begin{aligned}
& \int d \mathbf{p} f(\mathbf{r}, \mathbf{p})=\psi(\mathbf{r})^{*} \psi(\mathbf{r}), \\
& \int d \mathbf{r} f(\mathbf{r}, \mathbf{p})=\phi(\mathbf{p})^{*} \phi(\mathbf{p}),
\end{aligned}
$$

$$
\langle\psi|\hat{a}| \psi\rangle=\iint d \mathbf{r} d \mathbf{p} f(\mathbf{r}, \mathbf{p}) a(\mathbf{r}, \mathbf{p}),
$$

where $a(\mathbf{r}, \mathbf{p})$ is the Weyl transform [1] of the operator $\hat{a}$, as discussed in the Appendix. 
It is the relations (3) and (8)-(10) that show how the Wigner function plays the rôle of a probability density in an operational sense. Let us also note that the eigenvalues of $\Pi(\mathbf{r}, \mathbf{p})$ must be \pm 1 , since it is an inversion operator. Hence [13] we get that

$$
|f(\mathbf{r}, \mathbf{p})| \leqslant\left(\frac{2}{h}\right)^{3}
$$

and consequently that $f(\mathbf{r}, \mathbf{p})$ must have support in a volume not smaller than $(h / 2)^{3}$.

With the value of $f$ at the point $(r, p)$ being equal to $2 / h$ times the overlap between $1 \psi\rangle$ and its mirror image with respect to $(\mathbf{r}, \mathbf{p})$, we may say that $f(\mathbf{r}, \mathbf{p})$ is a measure of the way the point $(\boldsymbol{r}, \boldsymbol{p})$ supports the given quantum state. Similarly, we may talk about the way a certain region or a certain trajectory in phase space supports a state. A proper use of this kind of language leads to an integrated description of the wave and particle characteristics of quantum states.

It is the purpose of the present paper to show how this kind of description works for the ground state of the hydrogen atom.

\section{THE WIGNER FUNCTION FOR $1 s$ ORBITALS}

In what follows we shall use atomic units, and hence put $m, e$ and $\hbar$ equal to one, $m$ being the electron's mass and $-e$ its charge. We shall consider nuclear masses as infinite and exclude spin and relativistic effects. The hamiltonian for a hydrogen-like atom with nuclear charge $Z$ is then

$$
H=\frac{\hat{p}^{2}}{2}-\frac{Z}{f}
$$

The coordinate wavefunction for the ground state has the well known form

$$
\psi_{18}(r)=\left(\frac{Z^{3}}{\pi}\right)^{1 / 2} \exp (-Z r)
$$

and the corresponding momentum wavefunction is [15]

$$
\phi_{1 s}(\mathbf{p})=\frac{2 \sqrt{ } 2}{\pi} Z^{\mathbf{s} / 2} \frac{1}{\left(p^{2}+Z^{2}\right)^{2}} .
$$

Thus we obtain the following equivalent expressions for the Wigner function by using equations (6) and (7)

$$
f_{1 s}(\mathbf{r}, \mathbf{p})=\frac{Z^{\mathrm{s}}}{\pi^{4}} \int d \mathbf{r}^{\prime} \exp \left(-Z\left|\mathbf{r}-\mathbf{r}^{\prime}\right|\right) \exp \left(-Z\left|\mathbf{r}+\mathbf{r}^{\prime}\right|\right) \exp \left(-2 i \mathbf{p} \cdot \mathbf{r}^{\prime}\right)
$$

and

$$
f_{1 s}(\mathbf{r}, \mathbf{p})=\frac{8 Z^{5}}{\pi^{5}} \int d \mathbf{p}^{\prime}\left[\left(\mathbf{p}-\mathbf{p}^{\prime}\right)^{2}+Z^{2}\right]^{-2}\left[\left(\mathbf{p}+\mathbf{p}^{\prime}\right)+Z^{2}\right]^{-2} \exp \left(2 i \mathbf{r} \cdot \mathbf{p}^{\prime}\right)
$$

Neither of the integrals involved can be evaluated in a closed analytical form and the Wigner function is consequently not expressible in terms of standard functions. This is in accordance with the fact that it satisfies a differential equation of infinitely high order [16], while the usual standard functions satisfy differential equations of the first or second order. 
The integrals (15) and (16) are, however, not newcomers in the theory of electronic structures. The integral (15) is, for a fixed value of $r$, the Fourier transform of the product of two $1 s$ orbitals centred around the points $-r$ and $r$ respectively. Thus it is recognized as a generalized scattering factor in the theory of X-ray diffraction of molecular crystals and as a standard integral in those band theories of solids that are based on Fourier transform methods. Several procedures have, accordingly, been devised for the evaluation of this integral by methods of approximation.

Thus, McWeeny [17] and Silverstone [18] have studied methods in which one orbital is expanded in an infinite series about the origin of the other. Such methods are only rapidly convergent for small values of $r$, and hence they are not applicable in the present context where all values of $r$ must be considered. Other methods implying the summation of an infinite series or the numerical evaluation of an integral have been suggested by several authors ([19-21] and references therein). Although very powerful for single values of $r$ where the accuracy can be readily assessed, these methods are again not easily applied when $\mathbf{r}$ is allowed to vary freely.

The natural procedure to follow in the present context is to approximate the function (13) by a finite series of gaussians and insert this series in (15). The resulting integrals can then be evaluated analytically. This method is capable of giving a good representation of the Wigner function for all values of $r$ and $p$, and it can easily be extended to other orbitals than the $1 s$ orbital. Generalized scattering factors have been calculated along these lines by McWeeny [22] and Stewart [23].

We write accordingly

$$
\psi_{1 s}^{(M)}(\mathbf{r})=\sum_{i=1}^{M} c_{i} \chi_{i}(\mathbf{r})
$$

with $\chi_{i}(r)$ being a normalized gaussian

This gives

$$
\chi_{i}(r)=\left(\frac{2 \alpha_{i}}{\pi}\right)^{3 / 4} \exp \left(-\alpha_{i} r^{2}\right)
$$

$$
f_{1 s}^{(M)}(\mathbf{r}, \mathbf{p})=\sum_{i=1}^{M} c_{i}^{2} P_{i i}(\mathbf{r}, \mathbf{p})+\sum_{i>j=1}^{M} c_{i} c_{j}\left\{P_{i j}(\mathbf{r}, \mathbf{p})+P_{j i}(\mathbf{r}, \mathbf{p})\right\}
$$

where we have used the definition

$$
P_{i j}(\mathbf{r}, \mathbf{p})=\frac{1}{\pi^{3}} \int d \mathbf{r}^{\prime} \chi_{i}\left(\mathbf{r}-\mathbf{r}^{\prime}\right) \chi_{j}\left(\mathbf{r}+\mathbf{r}^{\prime}\right) \exp \left(-2 i \mathbf{p} \cdot \mathbf{r}^{\prime}\right)
$$

A straightforward integration results in

$$
P_{i j}(\mathbf{r}, \mathbf{p})=\frac{1}{\pi^{3}}\left(\frac{\gamma_{i j}}{\alpha_{i}+\alpha_{j}}\right)^{3 / 4} \exp \left(-\gamma_{i \gamma^{2}} \boldsymbol{r}^{2}\right) \exp \left(-\frac{p^{2}}{\alpha_{i}+\alpha_{j}}\right) \exp \left(2 i \tau_{i j} \mathbf{p} \cdot \mathbf{r}\right)
$$

in which

and

$$
\gamma_{i j}=\frac{4 \alpha_{i} \alpha_{j}}{\alpha_{i}+\alpha_{j}}
$$

$$
\tau_{i j}=\frac{\alpha_{i}-\alpha_{j}}{\alpha_{i}+\alpha_{j}}
$$


Hence we get that

$$
\begin{aligned}
f_{1 s}{ }^{(M)}(\mathbf{r}, \mathbf{p})=\frac{1}{\pi^{3}} \sum_{i=1}^{M} c_{i}{ }^{2} \exp \left(-2 \alpha_{i} r^{2}\right) \exp \left(-\frac{p^{2}}{2 \alpha_{i}}\right)+\frac{2}{\pi^{3}} \sum_{i>j=1}^{M} c_{i} c_{j}\left(\frac{\gamma_{i j}}{\alpha_{i}+\alpha_{j}}\right)^{3 / 4} \\
\times \exp \left(-\gamma_{i j} r^{2}\right) \exp \left(-\frac{p^{2}}{\alpha_{i}+\alpha_{j}}\right) \cos \left(2 \tau_{i j} \mathbf{p} \cdot \mathbf{r}\right)
\end{aligned}
$$

In the following sections we shall study this expression for the hydrogen atom, using an $M=10$ representation of the $1 s$ orbital determined by Duijneveldt [24]. This is the extremely good approximation to the true 1 s orbital, leading for instance to an energy which only deviates 0.00015 per cent from the true value. The parameters defining the expansion are reproduced in table 1.

Table 1. Gaussian approximation to the 1s hydrogen orbital [24].

\begin{tabular}{rrr}
\hline$i$ & $\alpha_{i} / a_{0}^{-2}$ & \multicolumn{1}{c}{$c_{\mathfrak{t}}$} \\
\hline 1 & 0.062157 & 0.107330 \\
2 & 0.138046 & 0.339658 \\
3 & 0.304802 & 0.352349 \\
4 & 0.710716 & 0.213239 \\
5 & 1.794924 & 0.090342 \\
6 & 4.915078 & 0.030540 \\
7 & 15.018344 & 0.008863 \\
8 & 54.698039 & 0.002094 \\
9 & 254.017712 & 0.000372 \\
10 & 1776.775559 & 0.000044
\end{tabular}

We shall also make certain comparisons with the variationally determined $M=1$ representation of the hydrogen $1 s$ orbital. As is well known, this approximation is obtained for $\alpha=8 / 9 \pi=0.282942 a_{0}{ }^{-2}$.

\section{A CHANGE OF VARIABIES}

The Wigner function is a function in six-dimensional phase space. It is, however, obvious from (24) that $f_{1 s}(r, p)$ only depends upon the three quantities $r, p$ and $u$, with $u$ being the angle between the vectors $r$ and $\mathbf{p}$. Let us therefore define new phase space variables instead of

$$
r=\left(x_{1}, x_{2}, x_{3}\right)
$$

and

$$
\mathbf{p}=\left(p_{1}, p_{2}, p_{3}\right)
$$

by introducing three mutually orthogonal unit vectors [25]

$$
\left.\begin{array}{l}
\mathbf{e}_{1}=\frac{1}{2 \sin u / 2}\left(\frac{\mathbf{r}}{r}-\frac{\mathbf{p}}{p}\right), \\
\mathbf{e}_{2}=\frac{1}{2 \cos u / 2}\left(\frac{\mathbf{r}}{r}+\frac{\mathbf{p}}{p}\right), \\
\mathbf{e}_{3}=\frac{1}{r p \sin u} \mathbf{r} \times \mathbf{p}=\mathbf{e}_{1} \times \mathbf{e}_{2} .
\end{array}\right\}
$$


These vectors define a right handed coordinate system $S$ in ordinary threespace. The orientation of $S$ with respect to a laboratory system $S_{0}$ may be specified by three Euler angles $\alpha, \beta, \gamma$ such that $S$ is obtained from $S_{0}$ by

(1) a rotation about the third axis of $S_{0}$ through the angle $\alpha$,

(2) a rotation about the new second axis through the angle $\beta$,

(3) a rotation about the new third axis through the angle $\gamma$.

The following relations are then valid:

$$
\begin{aligned}
& x_{1}=-r\left[\cos \alpha \cos \beta \sin \left(\gamma-\frac{u}{2}\right)+\sin \alpha \cos \left(\gamma-\frac{u}{2}\right)\right] \\
& x_{2}=-r\left[\sin \alpha \cos \beta \sin \left(\gamma-\frac{u}{2}\right)-\cos \alpha \cos \left(\gamma-\frac{u}{2}\right)\right] \\
& x_{3}=r \sin \beta \sin \left(\gamma-\frac{u}{2}\right) \\
& p_{1}=-p\left[\cos \alpha \cos \beta \sin \left(\gamma+\frac{u}{2}\right)+\sin \alpha \cos \left(\gamma+\frac{u}{2}\right)\right] \\
& p_{2}=-p\left[\sin \alpha \cos \beta \sin \left(\gamma+\frac{u}{2}\right)-\cos \alpha \cos \left(\gamma+\frac{u}{2}\right)\right] \\
& p_{3}=p \sin \beta \sin \left(\gamma+\frac{u}{2}\right)
\end{aligned}
$$

and

$$
d r d p=r^{2} d r p^{2} d p \sin u d u \sin \beta d \beta d \alpha d \gamma .
$$

The quantities $r, p, u, \alpha, \beta, \gamma$ are our new phase space variables; $r$ and $p$ range from 0 to $\infty, u$ and $\beta$ from 0 to $\pi, \alpha$ and $\gamma$ from 0 to $2 \pi$.

We shall refer to the plane defined by $r$ and $p$ as the dynamical plane. Its normal, which is $e_{3}$, has the spherical polar coordinates $(\beta, \alpha)$. The angle $\gamma$ will be called the dynamical angle.

With these designations we may express the fact that $f_{1 s}$ is independent of $\alpha, \beta$ and $\gamma$ by saying, that all dynamical planes and all dynamical angles are equivalent. By displaying the dependence on $r, p$ and $u$ we obtain a complete picture of the $1 s$-state in the phase space representation. Let us first consider the picture obtained in the $M=1$ approximation.

\section{The single gaussian approximation to the 1 s state}

This simple approximation corresponds to a coordinate wavefunction of the form (18), that is

$$
\psi_{1 s}^{(1)}(\mathbf{r})=\left(\frac{2 \alpha}{\pi}\right)^{3 / 4} \exp \left(-\alpha r^{2}\right)
$$

with $\alpha=8 / 9 \pi=0.282942 a_{0}{ }^{-2}$. The corresponding momentum wavefunction is

$$
\phi_{1 s}^{(1)}(\mathbf{p})=\left(\frac{1 \cdot}{2 \pi \alpha}\right)^{3 / 4} \exp \left(-\frac{p^{2}}{4 \alpha}\right)
$$


and the Wigner function (24) becomes

$$
f_{1 s}^{(1)}(r, p)=\frac{1}{\pi^{8}} \exp \left(-2 \alpha r^{2}\right) \exp \left(-\frac{p^{2}}{2 \alpha}\right)
$$

This function is not only independent of $\alpha, \beta$ and $\gamma$. It is independent of $u$ as well. By integrating it over $\alpha, \beta, \gamma, u$ and multiplying it with $r^{2} p^{2}$ we obtain the function

$$
F_{1 s}^{(1)}(r, p)=\frac{16}{\pi} r^{2} p^{2} \exp \left(-2 \alpha r^{2}\right) \exp \left(-\frac{p^{2}}{2 \alpha}\right)
$$

which is normalized such that

$$
\int_{0}^{\infty} \int_{0}^{\infty} F_{1 s}^{(1)}(r, p) d r d p=1
$$

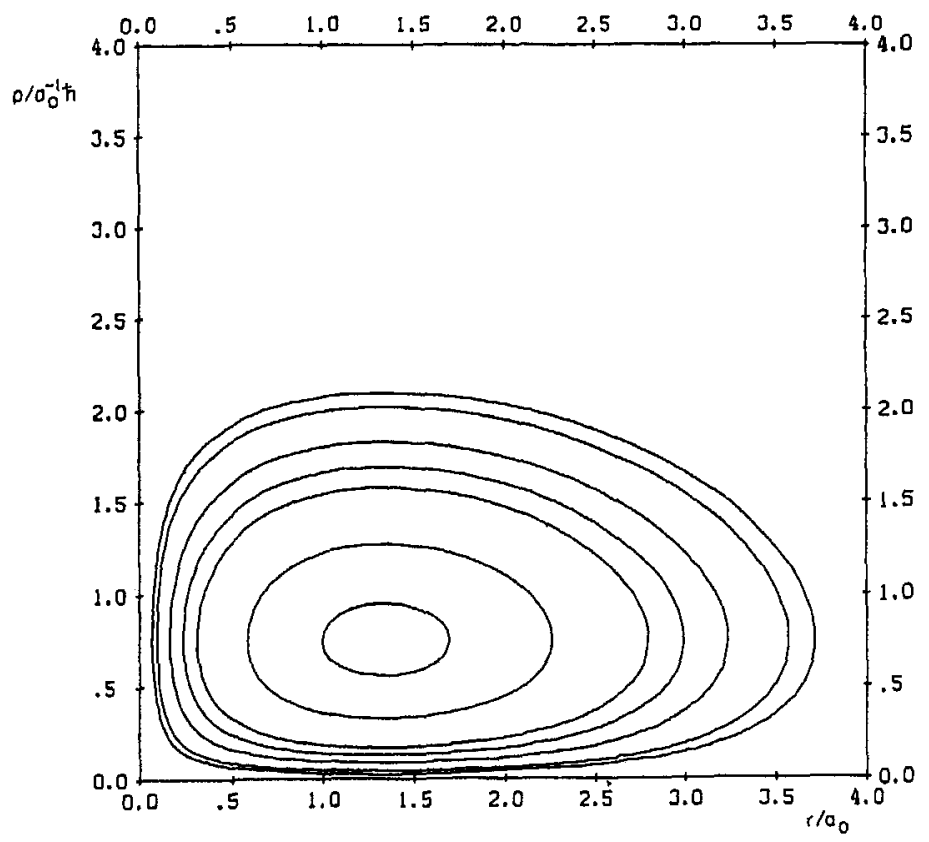

Figure 1. Contour map of the function $F_{18}{ }^{(1)}(r, p)$. The function attains its maximum value, $0.6893 h^{-1}$, at the point $\left(r_{0}, p_{0}\right)=\left(1.3293 a_{0}, 0.7523 a_{0}{ }^{-1} \hbar\right)$. Starting from the maximum, contours have been drawn at $0.6,0.3,0.1,0.06,0.03,0.01,0.006 \mathrm{k}^{-1}$.

The function $F_{18}{ }^{(1)}(r, p)$ is displayed in figure 1 through a contour map. As is evident from (34) it is everywhere non-negative. It has a maximum at the point

$$
\left(r_{0}, p_{0}\right)=\left(\frac{1}{\sqrt{ }(2 \alpha)}, \sqrt{ }(2 \alpha)\right)=\left(1.3293 a_{0}{ }^{1}, 0.7523 a_{0}{ }^{-1} \hbar\right)
$$

the maximum value being

$$
F_{18}^{(1)}\left(r_{0}, p_{0}\right)=\frac{16}{\pi e^{2}}=0.6893 \hbar^{-1}
$$


It is obvious that $F_{18}(\mathbf{l})(r, p)$ gives us complete information about the 1 s state in the single gaussian approximation. Thus, integration over $p$ gives the radial density in configuration space (with maximum at $r_{0}$ ) and integration over $r$ gives the radial density in momentum space (with maximum at $p_{0}$ ). Actually $F_{18}{ }^{(1)}$ is nothing but the product of these two radial densities.

As far as the function $f_{18}{ }^{(1)}(\mathbf{r}, \mathbf{p})$ itself is concerned, we note that it attains its maximum at the origin $(0,0)$. The $1 s$ state is symmetric with respect to inversion in this point, and the corresponding value of $f_{18}{ }^{(1)}$ is accordingly the largest possible one, which from the relation (11) is known to be $(2 / h)^{3}$, that is, $(1 / \pi)^{3} \hbar^{-3}$ in atomic units.

\section{The $M=10$ Description of the $1 s$ state}

This description, whose parameters are listed in table 1 , is as previously mentioned an exceedingly accurate one. The Wigner function, for which we have the expression (24), is no longer independent of $u$ and hence we cannot display all its features by means of a single contour map of the type shown in figure 1. A complete picture requires the drawing of a map for each value of $u$ in the interval $0 \leqslant u \leqslant \pi / 2$. As is obvious from the expression (24), we obtain the same maps for $u$ and $\pi-u$.

It is still expedient to integrate the expression (24) over $\alpha, \beta$ and $\gamma$ and to multiply with $r^{2} p^{2}$. Hence we obtain the function

$$
F_{1 s}(r, p, u)=8 \pi^{2} r^{2} p^{2} f_{1 s}{ }^{(10)}(r, p) \text {. }
$$

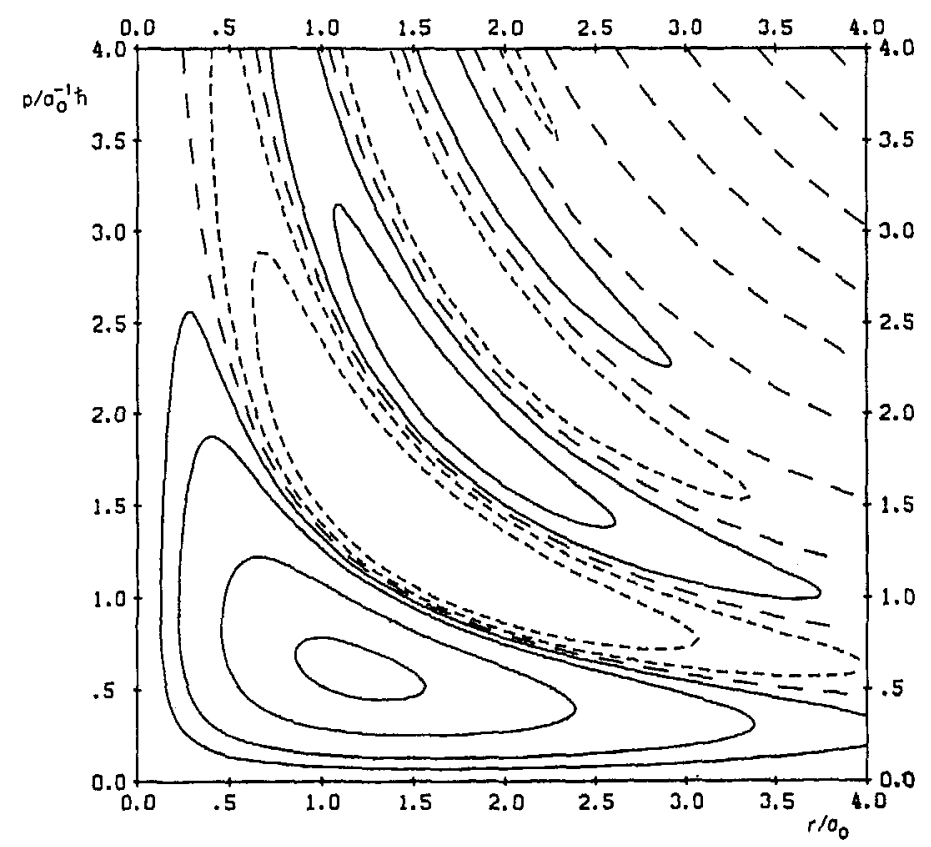

Figure 2. Contour map of the function $F_{1 s}(r, p, u)$ for $u=0$. Starting from the nodal curves (dashed lines, contour value $(0.0)$ ) contours have been drawn at $0.01,0.03$, $0.1,0.2 \hbar^{-1}$ (solid lines), $-0.01,-0.03 \hbar^{-1}$ (dotted lines). 


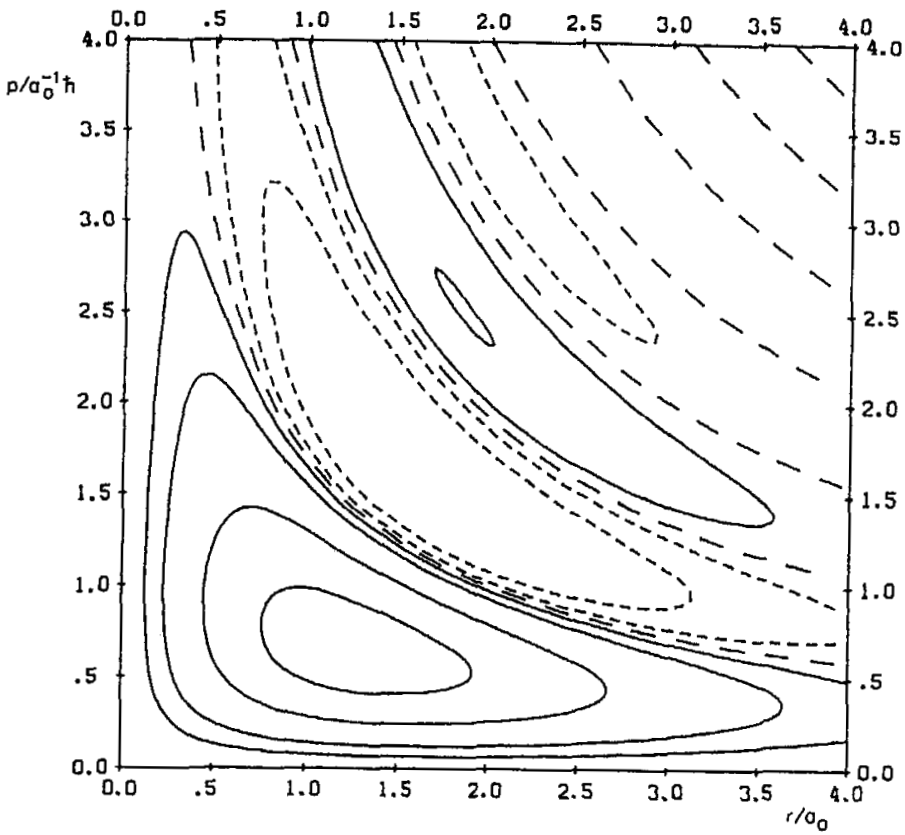

Figure 3. As figure 2 except $u=\pi / 4$.

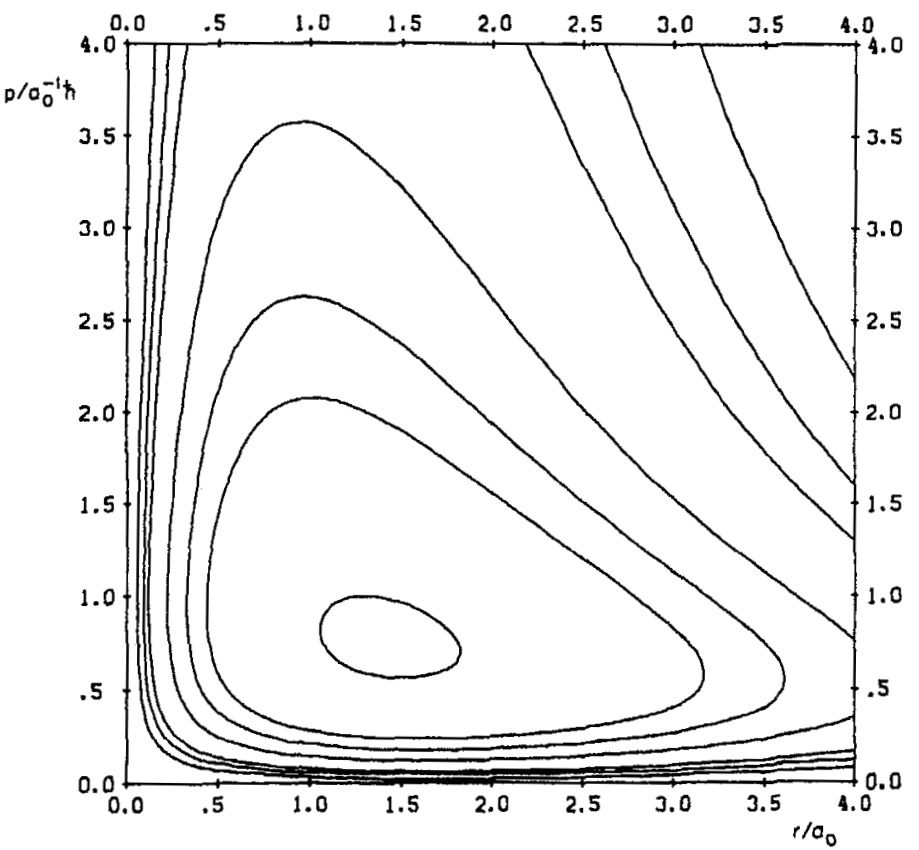

Figure 4. Contour map of the function $F_{1 s}(r, p, u)$ for $u=\pi / 2$. Starting from the maximum $\left(r_{0}, p_{0}\right)=\left(1.405 a_{0}, 0.759 a_{0}^{-1} \hbar\right)$, contours have been drawn at $0.3,0.1$, $0.06,0.03,0.01,0.006,0.003 \hbar^{-1}$. 
This function is displayed in figures 2,3 and 4 for $u$ equal to $0, \pi / 4$ and $\pi / 2$ respectively. For $u=\pi / 2$ it is non-negative everywhere, but for all other values of $u$ it has negative as well as positive regions.

For several purposes it is sufficient to know the function obtained from (38) by integrating over $u$. We shall call this function the radial phase space function and designate it $F_{18}(r, p)$. It satisfies the normalization condition (35). From (24) it is found to be

$$
\begin{aligned}
F_{18}(r, p)=\frac{16}{\pi} r^{2} p^{2} \sum_{i=1}^{M} c_{i}{ }^{2} \exp \left(-2 \alpha_{i} r^{2}\right) \exp \left(-\frac{p^{2}}{2 \alpha_{i}}\right) \\
+\frac{32}{\pi} r^{2} p^{2} \sum_{i>j=1}^{M} c_{i} c_{j}\left(\frac{\gamma_{i j}}{\alpha_{i}+\alpha_{j}}\right)^{3 / 4} \\
\quad \times \exp \left(-\gamma_{i j} r^{2}\right) \exp \left(-\frac{p^{2}}{\alpha_{i}+\alpha_{j}}\right) j_{0}\left(2 \tau_{i j} p r\right),
\end{aligned}
$$

where

$$
j_{0}(x)=\frac{\sin x}{x}
$$

is a spherical Bessel function.

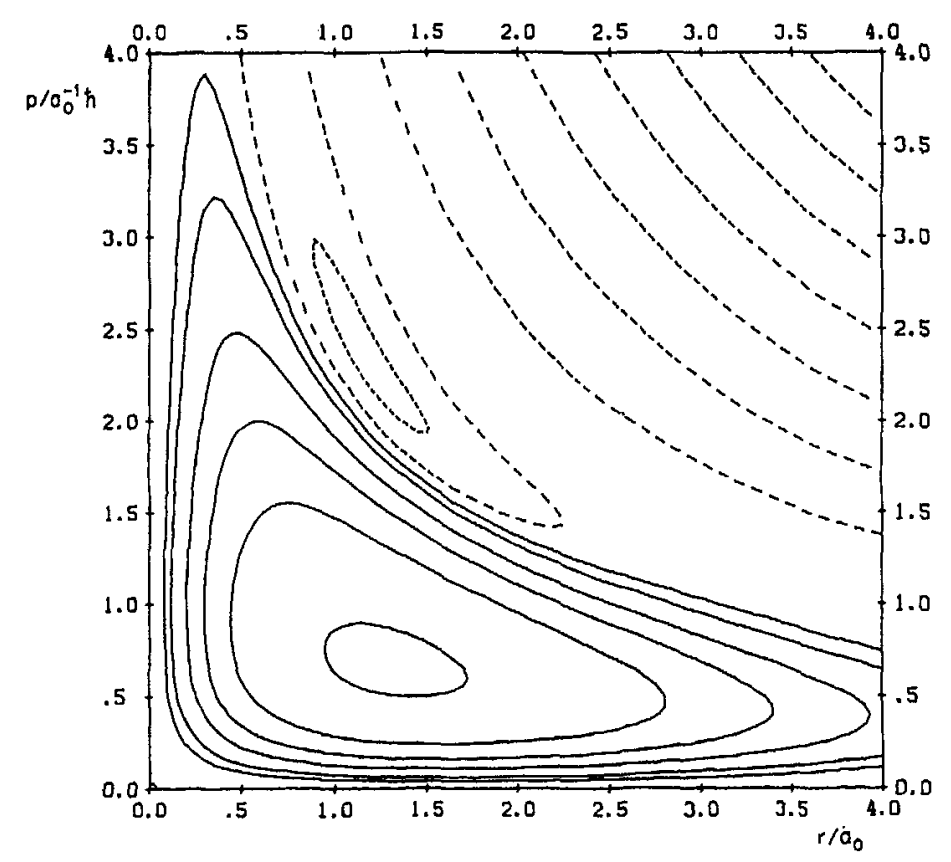

Figure 5. Contour map of the function $F_{18}(r, p)$. The function attains its maximum value, $0.5617 \hbar^{-1}$, at the point $\left(r_{0}, p_{0}\right)=\left(1.30 a_{0}, 0.68 a_{0}^{-1} \hbar\right)$. Starting from the nodal curves (dashed lines, contour value 0.0 ), contours have been drawn at 0.01 , $0.02,0.05,0.1,0.2,0.5 \hbar^{-1}$ (solid lines), $-0.01 \hbar^{-1}$ (dotted lines). 
The function $F_{18}(r, p)$ is displayed in figure 5 . It is characterized by a dominant region in which it is positive, and by an oscillatory behaviour outside this region. The amplitudes of the oscillations are, however, fairly small (see table 2), but they are definitely not due to lack of accuracy in the wavefunction used.

Table 2. Selected values of the function $F_{1 s}(r, p)$ for $r=p$.

\begin{tabular}{cc}
\hline$\left(r / a_{0}\right)=\left(p / a_{0}^{-1} \hbar\right)$ & $F_{1 d}(r, p) / \hbar^{-1}$ \\
\hline 0.0 & 0.0 \\
0.3 & 0.0326 \\
0.6 & 0.2676 \\
0.9 & 0.4648 \\
1.2 & 0.3015 \\
1.5 & 0.0473 \\
1.8 & -0.0047 \\
2.1 & 0.0081 \\
2.4 & -0.0031 \\
2.7 & 0.0014 \\
3.0 & -0.00063 \\
3.3 & 0.00021 \\
\hline
\end{tabular}

When the product of $p$ and $r$ is large, a regular albeit weak damped wave is disclosed by figure 5 . The presence of such a wave is readily understandable from the expression (39). When both $r$ and $p$ are large, the dominant terms in (39) will be cross terms for which one $\alpha$ is large and the other $\alpha$ is small, since it is only for such terms that both $\gamma_{i j}$ and $1 /\left(\alpha_{i}+\alpha_{j}\right)$ become small and hence lead to slowly decaying exponentials. Since (23) shows that $\left|\tau_{i j}\right| \approx 1$ when one $\alpha$ value is much larger than the other, we find that the relevant Bessel functions in (39) approach $j_{0}(p r)$, and this leads to a damped wave as observed.

Applying a similar argument to the expression (24) shows that the contour maps for the functions $F_{1 s}(r, p, u)$ must disclose damped oscillations in $\cos (2 \mathbf{p} \cdot \mathbf{r})$ when both $p$ and $r$ are large. That this is in fact the case is apparent from figures 2 and 3 . In figure $4, \cos (2 p, r)$ equals 1 for all $r$ and $p$ (the wavelength becomes infinite), and the phase space function is accordingly nonnegative everywhere.

The damped oscillations which we have discussed will, of course, have their counterparts in the theory of generalized scattering factors (cf. $\$ 2$ ). The appearance of the oscillations in that context has been noticed and discussed by Avery [26], on the basis of arguments quite different from ours.

In closing this section it is worthwhile drawing attention to the complexity of the exact phase space function, as compared to the simplicity of the approximate phase space function discussed in the previous section, and a natural question presents itself. What must a wavefunction look like in order that the associated Wigner function be non-negative everywhere? Hudson [27] has given a mathematical answer to this question for one-dimensional motion. His analysis showed that the wavefunction must have the form

$$
\psi(x)=\exp \left[-\frac{1}{2}\left(a x^{2}+2 b x+c\right)\right]
$$


where $a, b$ are arbitrary complex numbers with $\operatorname{Re} a>0$ and the complex number $c$ is chosen so as to ensure correct normalization. When $\operatorname{Im} a$ is zero, this wavefunction describes a minimum uncertainty state [28] in one dimension.

The conclusions of Hudson may probably be extended to three dimensions in a straightforward manner. That the wavefunction (31) describes a minimum uncertainty state in three dimensions is in accordance with this assumption.

\section{The DOMINANT SUBSPACE AND THE CLASSICAL SUBSPACE}

The function $F_{1 s}(r, p)$ of (39) and figure 5 was obtained from the function $F_{1 s}(r, p, u)$ of (38) by integrating over $u$. It is interesting to integrate over $r$ and $p$ instead to obtain a function $F_{18}(u)$, normalized such that

$$
\int_{0}^{\pi} F_{18}(u) \sin u d u=1
$$

The expression for this function is found to be

$$
F_{28}(u)=\frac{1}{2} \sum_{i=1}^{10} c_{i}{ }^{2}+\sum_{i>j=1}^{10} c_{i} c_{j} \sigma_{i j}{ }^{3 / 4}\left(\sigma_{i j}-2 \tau_{i j}{ }^{2} \cos ^{2} u\right) /\left(\sigma_{i j}+\tau_{i j}{ }^{2} \cos ^{2} u\right)^{5 / 2}
$$

with $\tau_{i j}$ as defined by (23) and

$$
\sigma_{i j}=\frac{4 \alpha_{i} \alpha_{j}}{\left(\alpha_{i}+\alpha_{j}\right)^{2}}
$$

Figure 6 shows the functions $F_{1 s}(u)$ and $F_{1 s}(u) \sin u$. Both functions have a sharp maximum at $u=\pi / 2$.

Thus, the condition $u=\pi / 2$ defines a dominant subspace in which the Wigner function finds it maximum support. As already seen (figure 4), the function is everywhere non-negative in this subspace.

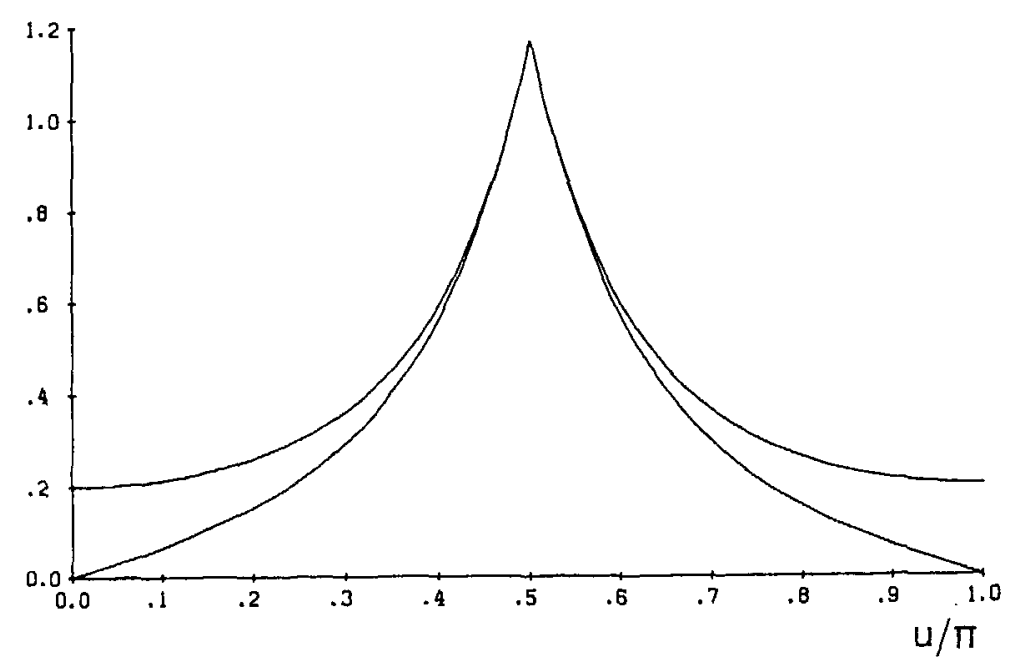

Figure 6. The functions $F_{18}(u)$ (upper curve) and $F_{18}(u) \sin u$ (lower curve) as a function of $u / \pi$. 
The dominant subspace is five-dimensional. It contains a three-dimensional subspace of particular interest, namely the subspace obtained by putting $r=1 a_{0}$ and $p=1 a_{0}{ }^{-1} \hbar$. It is represented by the point $(1,1)$ in figure 4 . This is the subspace to which the ground state motion was restricted in early quantum mechanics, since a Bohr orbit (in ordinary space) was just a circle with radius $r=1 a_{0}$, in which the electron was supposed to move with the constant momentum $p=1 \hbar a_{0}-1$. Hence we shall call the subspace in question the classical subspace.

The following important statement may now be made, on the basis of the present section and figures 2 and 3 . The Wigner function attains a large, positive and constant value in the classical subspace. It is also large and positive in a large region surrounding this subspace. In particular, it is everywhere non-negative in the dominant subspace. The regions in which the Wigner function becomes negative are well separated from the classical subspace.

\section{The angular Momentum Dilemma}

In this section we shall comment on the angular momentum of the $1 s$ state, as calculated by the expression on the right hand side of (10). $a(\mathbf{r}, \mathbf{p})$ is, as mentioned in $\$ 1$, the Weyl transform of the operator $\hat{a}$. The Weyl correspondence is discussed in the Appendix and there it is shown that if $\hat{a}$ is a component of the angular momentum vector operator, say

$$
l_{3}=\hat{x}_{1} \hat{p}_{2}-\hat{x}_{2} \hat{p}_{1}
$$

then $a(\mathbf{r}, \mathbf{p})$ is the same component of the classical angular momentum vector, that is,

$$
l_{3}=x_{1} p_{2}-x_{2} p_{1}
$$

As is well known, the left hand side of $(10)$ is zero when $|\psi\rangle$ is the 1 state and $\hat{a}$ is $l_{1}, l_{2}$ or $l_{3}$. Hence the right hand side must also be zero. That this is actually the case is easily seen by remembering that $f(\mathbf{r}, \mathbf{p})$ is independent of the Euler angles $\alpha, \beta$ and $\gamma$. This makes all directions of the vector $\mathbf{e}_{3}$ in (27) equivalent. But the direction of $e_{3}$ is also seen to be the direction of the angular momentum vector and thus each component of this vector does in fact have a zero mean value.

As regards the length of the angular momentum vector, it is shown in the Appendix that the classical function

$$
\lambda^{2}=l_{1}^{2}+l_{2}^{2}+l_{3}^{2}
$$

is the Weyl transform of the operator

$$
\lambda^{2}=l_{1}^{2}+l_{2}^{2}+l_{3}^{2}+\frac{3}{2} \hbar^{2} .
$$

Evaluating the right hand side of $(10)$ with $a(\mathbf{r}, \mathbf{p})=\lambda^{2}$ will accordingly produce the value $\frac{3}{2} \hbar^{2}$.

This interesting result allows us to resolve a pedagogical dilemma which has bothered writers of elementary textbooks [29]. How does one bring the fact that the angular momentum in a Bohr orbit is $\hbar$ into accordance with the fact that the angular momentum in the Schrödinger picture is zero ? 
The dilemma is obviously resolved by remarking that the operator that occurs in the Schrödinger picture, viz.

$$
l^{2}=l_{1}^{2}+l_{2}^{2}+l_{3}^{2}
$$

is different from the operator that corresponds to the classical function $\lambda^{2}$ of (47). Averaging $\lambda^{2}$ over the classical subspace described in the previous section does in fact give the value $\hbar^{2}$, as in the Bohr description.

\section{LOCAL DENSITIES}

An advantage of the phase space formulation of quantum mechanics is that it leads to a natural definition of a local density in coordinate space for a given operator and a given state. Thus (10) suggests that we consider the quantity

$$
\alpha(\mathbf{r})=\int d \mathbf{p} f(\mathbf{r}, \mathbf{p}) a(\mathbf{r}, \mathbf{p})
$$

as being the local density associated with the operator $\hat{a}$ and the state $|\psi\rangle$. Integration over the spatial coordinate gives the expectation value of $\hat{a}$

$$
\langle\psi|\hat{a}| \psi\rangle=\int d \mathbf{r} \alpha(\mathbf{r}) .
$$

When $a(\mathbf{r}, \mathbf{p})=a(\mathbf{r})$, a function of $\mathbf{r}$ alone, we may use (8) to get

$$
\alpha(\mathbf{r})=a(\mathbf{r}) \psi(\mathbf{r})^{*} \psi(\mathbf{r})
$$

As an example, the potential energy operator

$$
\hat{\nu}=-\frac{Z}{\hat{r}}
$$

defines the local potential energy density

$$
\epsilon_{\mathrm{P}}(\mathbf{r})=-\frac{Z}{r} \psi(\mathbf{r})^{*} \psi(\mathbf{r})
$$

For the ground state of the hydrogen atom this becomes, by observing (13),

$$
\epsilon_{\mathrm{P}}(\mathbf{r})=-\frac{1}{\pi} \frac{\exp (-2 r)}{r}
$$

As an important example of an operator that is not a function of $p$ we consider the kinetic energy operator

$$
\hat{T}=\frac{\hat{p}^{2}}{2}
$$

The local kinetic energy density becomes

$$
\epsilon_{\mathrm{K}}(\mathbf{r})=\int d \mathbf{p} f(\mathbf{r}, \mathbf{p}) \frac{p^{2}}{2}
$$

It may be evaluated when $f(\mathbf{r}, \mathbf{p})$ is known, but as shown by Ziff et al. [30] and by Cohen [31] it may also be evaluated directly from the coordinate wavefunction by using (6). The result is

$$
\epsilon_{\mathrm{K}}(r)=\frac{1}{2}\left(|\nabla \psi|^{2}-\frac{1}{4} \nabla^{2}|\psi|^{2}\right)
$$


or equivalently

It is seen that

$$
\epsilon_{\mathrm{K}}(\boldsymbol{r})=\frac{1}{2}\left(\frac{1}{2}|\nabla \psi|^{2}-\frac{1}{4} \psi^{*} \nabla^{2} \psi-\frac{1}{4} \psi \nabla^{2} \psi^{*}\right)
$$

where

$$
\epsilon_{\mathrm{K}}(\mathbf{r})=\frac{1}{2}\left(\epsilon_{\mathrm{KB}}(\mathbf{r})+\epsilon_{\mathrm{KC}}(\mathbf{r})\right)
$$

$$
\epsilon_{\mathrm{KB}}(\boldsymbol{r})=\frac{1}{2}|\nabla \psi|^{2}
$$

and

$$
\epsilon_{\mathrm{KC}}(\mathbf{r})=-\frac{1}{4}\left(\psi^{*} \nabla^{2} \psi+\psi \nabla^{2} \psi^{*}\right)
$$

When $\psi$ is real, $\epsilon_{\mathrm{KC}}(\boldsymbol{r})$ becomes equal to

$$
\epsilon_{\mathrm{KA}}(\mathbf{r})=-\frac{1}{2} \psi^{*} \nabla^{2} \psi
$$

The expressions $\epsilon_{\mathrm{KA}}, \epsilon_{\mathrm{KB}}, \epsilon_{\mathrm{KKC}}$ and $\epsilon_{\mathrm{K}}$ were all discussed by Cohen [31] (who used the designations $K_{A}, K_{B}, K_{C}$ and $K_{D}$, respectively). He showed that each expression could be derived from phase space descriptions discussed earlier by him [32].

For the ground state of the hydrogen atom we obtain the following explicit expressions

$$
\begin{aligned}
\epsilon_{\mathrm{KA}}(r) & =\epsilon_{\mathrm{KKO}}(\mathbf{r})=\frac{1}{\pi}\left(\frac{1}{r}-\frac{1}{2}\right) \exp (-2 r), \\
\epsilon_{\mathrm{KB}}(r) & =\frac{1}{2 \pi} \exp (-2 r), \\
\epsilon_{\mathrm{KK}}(r) & =\frac{1}{2 \pi r} \exp (-2 r) .
\end{aligned}
$$

These will be discussed further in the following section.

With reference to Cohen's work [31,32], we want to make the comment that, although a whole set of mathematically consistent phase space representations of quantum mechanics exists, there are compelling reasons why one should consider the Weyl-Wigner representation used in the present work as the canonical one. These reasons were discussed at length in a previous paper [11].

\section{A LOCAL VIRIAL THEOREM}

Let

$$
\begin{aligned}
E_{\mathrm{K}} & =\langle\psi|\hat{T}| \psi\rangle, \\
E_{\mathrm{P}} & =\langle\psi|\hat{V}| \psi\rangle, \\
E & =\langle\psi|\hat{T}+\hat{\nu}| \psi\rangle
\end{aligned}
$$

be the expectation values of the kinetic energy, the potential energy and the total energy, respectively, for a stationary state of the hydrogen atom. As for any Coulomb system we then have the well-known virial theorem

$$
E_{\mathrm{K}}=-\frac{1}{2} E_{\mathrm{P}}
$$

which expresses a global balance between the kinetic and potential energy. Due to the obvious relation

$$
E=E_{\mathrm{K}}+E_{\mathrm{P}}
$$


we may also write

$$
E_{\mathrm{K}}=-E \text {, }
$$

Bader and his co-workers have shown that for a molecular system it is possible to perform a spatial partitioning of the charge distribution in such a manner that the kinetic and potential energies of the resulting fragments obey the virial theorem (see [33]). For the ground state of the hydrogen atom they also noted [33] that

$$
\epsilon_{\mathrm{KB}}(\mathbf{r})=-E|\psi|^{2},
$$

which is a local virial theorem if the right hand side is identified as the local counterpart of the total energy.

Such an identification is, however, not quite satisfactory, since the natural definition of this local energy density would be

$$
\epsilon_{\mathrm{B}}(\mathbf{r})=\epsilon_{\mathrm{KB}}(\mathbf{r})+\epsilon_{\mathrm{P}}(\mathbf{r})
$$

in accordance with (71) and this quantity is different from the right hand side of (73). As a consequence $\epsilon_{\mathrm{KKB}}(\mathbf{r})$ and $\epsilon_{\mathrm{P}}(\mathbf{r})$ do not satisfy a local analogue of (70).

It is, on the other hand, easily seen that if we work with $\epsilon_{\mathbf{K}}(\mathbf{r})$, defined through the Weyl-Wigner correspondence, then we obtain a completely satisfactory local form of the virial theorem

$$
\begin{aligned}
\epsilon_{\mathrm{K}}(\mathbf{r}) & =-\frac{1}{2} \epsilon_{\mathrm{P}}(\mathbf{r}), \\
\epsilon_{\mathrm{K}}(\mathbf{r}) & =-\epsilon(\mathbf{r}), \\
\epsilon(\mathbf{r}) & =\epsilon_{\mathrm{KK}}(\mathbf{r})+\epsilon_{\mathrm{P}}(\mathbf{r}) .
\end{aligned}
$$

It must be stressed, however, that this remarkable result only holds for the ground state of a hydrogen-like atom.

In forthcoming publications we plan to study the local balance between the potential and kinetic energy for other atomic and molecular systems.

\section{Discussion and conclusions}

The phase space description of a quantum mechanical system is an alternative to the description based on wavefunctions. It is from several points of view a more complicated description. From other points of view it is a richer description.

The state of a system is described by a Wigner function. In the present paper we have constructed this function for the ground state of the hydrogen atom and analysed its properties. The analysis was facilitated by the introduction of concepts like the dynamical plane and the dynamical angle, the classical subspace and the dominant subspace. The orientation of the dynamical plane is closely related to the angular momentum vector ; the classical subspace is that part of phase space to which the ground state motion was confined in early quantum mechanics.

The Wigner function is found to be independent of the orientation of the dyanamical plane. It attains a large, positive and constant value in the classical subspace and it remains large and positive in an extended region containing that subspace. Outside this region the Wigner function shows a rich structure 
which includes oscillations of a de Broglie wave-like character for large values of $r$ and $p$. We have illustrated the general variation over phase space by means of a series of contour maps and a graph which shows that the Wigner function finds its maximum support in the subspace where $\mathbf{r} \cdot \mathbf{p}=0$, the so-called dominant subspace.

A dynamical variable is represented by an operator in a description based on wavefunctions. In the phase space description it is represented by an ordinary function of $\mathbf{r}$ and $\mathbf{p}$. The connection between the two representations is given by the so-called Weyl correspondence which we have described in the Appendix. In $\S 7$ we have discussed the Weyl transformation of the angular momentum and thus resolved a pedagogical dilemma which previously obscured the comparison between early quantum mechanics and the Schrödinger description.

In $\S \S 8$ and 9 we have shown how an integration over the momentum coordinates leads to a local configuration space description of all dynamical quantities. We have then studied the local kinetic and potential energies and shown that the virial theorem is locally satisfied for the ground state of the hydrogen atom.

In forthcoming papers we shall extend the present study by including excited states, and atoms and molecules with more than one electron.

We are very grateful to Dr. Sten Rettrup for his kind assistance at an early stage of this work. We also want to thank Dr. Helge Johansen for letting us use his density contour programs and Dr. Kurt Nielsen for interesting discussions.

\section{APPENDIX}

\section{The Weyl correspondence}

To every operator $\hat{a}$ in spin-free Hilbert space there corresponds a phase space function $a(\mathbf{r}, \mathbf{p})$, such that $(10)$ is valid. The relation between $\hat{a}$ and $a(r, p)$ is given by the so-called Weyl correspondence [1], which we prefer to write in the form [11]

$$
\hat{a}=\left(\frac{2}{h}\right)^{3} \iint d \mathbf{r} d \mathbf{p} a(\mathbf{r}, \mathbf{p}) \Pi(\mathbf{r}, \mathbf{p}),
$$

where $\Pi(\mathbf{r}, \mathbf{p})$ is the inversion operator (1). $\quad \hat{a}$ and $a(\mathbf{r}, \mathbf{p})$ are said to be mutual Weyl transforms.

Whenever $a(\mathbf{r}, \mathbf{p})$ is a function of $\mathbf{r}$ or $\mathbf{p}$ alone, then $\hat{a}$ is the same function of the vector operator $\hat{p}$ or $\hat{\mathbf{p}}$. In the general case one obtains the operator $\hat{a}$ from the function $a(\mathbf{r}, \mathbf{p})$ by the replacement of $\mathbf{r}$ with $\hat{p}$ and $\mathbf{p}$ with $\hat{\mathbf{p}}$, followed by a proper symmetrization of products of non-commuting operators. This symmetrization is such that, if $x_{i}$ and $p_{i}$ are corresponding components of $r$ and $p$, then the operator associated with the function $x_{i}{ }^{n} p_{i}{ }^{m}$ is

$$
\begin{aligned}
\hat{a} & =\frac{1}{2^{n}} \sum_{r=0}^{n}\left(\begin{array}{l}
n \\
r
\end{array}\right) \hat{x}_{i}^{r} \hat{p}_{i}^{m} \hat{x}_{i}^{n-r} \\
& =\frac{1}{2^{m}} \sum_{s=0}^{m}\left(\begin{array}{l}
m \\
s
\end{array}\right) \hat{p}_{i}^{s} \hat{x}_{i}^{n} \hat{p}_{i}^{m-s} .
\end{aligned}
$$

These expressions were first derived by McCoy [34]. 
As an important example let us consider the classical angular momentum vector

$$
1=\mathbf{r} \times \mathbf{p}=\left(x_{2} p_{3}-x_{3} p_{2}, x_{3} p_{1}-x_{1} p_{3}, x_{1} p_{2}-x_{2} p_{1}\right) .
$$

Direct substitution does not introduce products of non-commuting operators. The Weyl transform of $l$ is accordingly

$$
\hat{1}=\hat{p} \times \hat{p}=\left(\hat{x}_{2} \hat{p}_{3}-\hat{x}_{3} \hat{p}_{2}, \hat{x}_{3} \hat{p}_{1}-\hat{x}_{1} \hat{p}_{3}, \hat{x}_{1} \hat{p}_{2}-\hat{x}_{2} \hat{p}_{1}\right)
$$

which is just the ordinary quantum mechanical angular momentum vector.

For the square of an angular momentum component, $l_{3}$ say, we obtain

$$
l_{3}^{2}=x_{1}^{2} p_{2}^{2}+x_{2}^{2} p_{1}^{2}-2 x_{1} p_{1} x_{2} p_{2} .
$$

Symmetrization according to (A 2) gives the corresponding operator which we denote $\hat{\lambda}_{3}^{2}$

$$
\hat{\lambda}_{3}^{2}=\hat{x}_{1}^{2} \hat{p}_{2}^{2}+\hat{x}_{2}^{2} \hat{p}_{1}^{2}-\frac{1}{2}\left(\hat{x}_{1} \hat{p}_{1}+\hat{p}_{1} \hat{x}_{1}\right)\left(\hat{x}_{2} \hat{p}_{2}+\hat{p}_{2} \hat{x}_{2}\right) \text {. }
$$

Squaring the third component of $\hat{\mathbf{1}}$ gives, on the other hand, the operator

$$
l_{3}^{2}=\hat{x}_{1}^{2} \hat{p}_{2}^{2}+\hat{x}_{2}^{2} \hat{p}_{1}^{2}-\hat{x}_{1} \hat{p}_{1} \hat{p}_{2} \hat{x}_{2}-\hat{p}_{1} \hat{x}_{1} \hat{x}_{2} \hat{p}_{2} \text {. }
$$

Using the commutation relation

twice shows that

$$
\left[\hat{x}_{k}, \hat{p}_{k}\right]=i \hbar
$$

$$
\hat{\lambda}_{3}^{2}=l_{3}^{2}+\frac{1}{2} \hbar^{2}
$$

and hence that

$$
\lambda^{2}=l^{2}+\frac{3}{2} \hbar^{2},
$$

where

$$
\hat{\lambda}^{2}=\hat{\lambda}_{1}^{2}+\hat{\lambda}_{2}^{2}+\hat{\lambda}_{3}^{2}
$$

and

$$
l^{2}=l_{1}^{2}+l_{2}^{2}+l_{3}^{2} \text {. }
$$

Thus, there is a difference of $\frac{3}{2} \hbar^{2}$ between the Weyl transform of $l^{2}$ and the ordinary quantum mechanical operator $l^{2}$. This difference was apparently first noticed by Shewell [35] in connection with a general discussion of correspondence and symmetrization rules.

\section{REFERENCES}

[1] WEYL, H., 1931, The Theory of Groups and Quantum Mechanics (Dover).

[2] Wigner, E., 1932, Phys. Rev., 40, 749.

[3] Groenewold, H. J., 1946, Physica, 12, 405.

[4] Moyal, E. J., 1949, Proc. Camb. phil. Soc, math. phys, Sci., 45, 99.

[5] Balescu, R., 1975, Equilibrium and Nonequilibrium Statistical Mechanics (John Wiley \& Sons).

[6] LourselL, W. H., 1973, Quantum Statistical Properties of Radiation (John Wiley \& Sons).

[7] Brlling, G. D., 1978, Thesis, University of Copenhagen.

[8] Brown, R. C., and Heller, E. J., 1981, F. chem. Phys., 75, 186.

[9] Hutchinson, J. S., and Wyatt, R. E., 1981, Phys. Rev. A, 23, 1567.

[10] Esbensen, H., Winther, A., Broglia, R. A., and Dasso, C. H., 1978, Phys. Rev. Lett., 41, 296.

[11] Dakl, J. P., 1982, Physica A, 112, 439.

[12] Grossmann, A., 1976, Commun. Math. Phys., 48, 191. 
[13] Royer, A., 1977, Phys. Rev. A, 15, 449.

[14] Dahl, J. P., 1982, Physica scripta, 25, 499.

[15] Podolsky, B., and Pauling, L., 1929, Phys, Rev., 34, 109.

[16] DAHL, J. P., 1982, Molecular Structure and Energy Scrambling, edited by J. Hinze (Plenum).

[17] McWeENy, R., 1952, Acta crystallogr., 5, 463.

[18] Silverstone, H. J., 1968, $\mathfrak{F}$. chem. Phys., 48, 4098.

[19] Laurenzi, B. J., 1969, Int. F. quant. Chem., 3, 489.

[20] Monkhorst, H. J., and HARris, F. E., 1972, Int. $\%$ quant. Chem., 6, 601.

[21] Guidotti, C., Arrighini, G. P., and Marinelli, F., 1979, Theor. chim. Acta, 53, 165.

[22] MCWeENy, R., 1953, Acta crystallogr., 6, 631.

[23] Stewart, R. F., 1969, J. chem. Phys., 51, 4569.

[24] Van Duijnevelor, F. B., 1971, Gaussian Basis Sets for the Atoms $H$-Ne for Use in Molecular Calculations, IBM Technical Report RJ 945.

[25] Dahl, J. P., Mat. fys. Meddr., 39, No. 12.

[26] Avery, J., 1978, Acta crystallogr. A, 34, 582.

[27] Hudson, R. L., 1974, Rep. Math. Phys. (Poland), 6, 249.

[28] ScHIFF, L. I., 1955, Quantum Mechanics (McGraw-Hill).

[29] Pauling, L., 1970, General Chemistry, 3rd ed. (W. H. Freeman \& Co.), p. 125.

[30] ZifF, R. M., UhlenBeck, G. E., and KAC, M., 1977, Phys. Rep., C 32, 1970.

[31] Cohen, L., 1979, F. chem. Phys., 70, 788.

[32] Cohen, L., 1966, F. math. Phys., 7, 781.

[33] Bader, R. F. W., and Beddall, P. M., 1972, F. chem. Phys., 56, 3320.

[34] McCoy, N. H., 1932, Proc. natn. Acad. Sci. U.S.A., 18, 674.

[35] Shewell, J. R., 1959, Am. F. Phys., 27, 16. 


\title{
DISTRIBUTION FUNCTIONS IN PHYSICS: FUNDAMENTALS
}

\author{
M. HILLERY \\ Institute for Modern Optics, University of New Mexico, Albuquerque, NM 87131, \\ U.S.A. \\ and \\ Max-Planck Institut fur Quantenoptik, D-8046 Garching bei Munchen, \\ West Germany \\ R.F. O'CONNELL \\ Department of Physics and Astronomy, Louisiana State University, Baton Rouge, \\ LA 70803, U.S.A.

\section{M.O. SCULLY} \\ Max-Planck Institut fur Quantenoptik, D-8046 Garching bei Munchen, \\ West Germany \\ and \\ Institute for Modern Optics, University of New Mexico, Albuquerque, NM 87131, \\ U.S.A.

\section{E.P. WIGNER} \\ Department of Physics and Astronomy, Louisiana State University, Baton Rouge, \\ LA 70803, U.S.A.
}

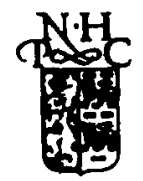

NORTH-HOLLAND PHYSICS PUBLISHING-AMSTERDAM 
PHYSICS REPORTS (Review Section of Physics Letters) 106, No. 3 (1984) 121-167. North-Holland, Amsterdam

\title{
DISTRIBUTION FUNCTIONS IN PHYSICS: FUNDAMENTALS
}

\author{
M. HILLERY \\ Institute for Modern Optics, University of New Mexico, Albuquerque, NM 87131, U.S.A. \\ and \\ Max-Planck Institus fur Quansenoptik, D-8046 Garching bei Munchen, West Germany \\ R.F. O'CONNELL \\ Department of Physics and Astronomy, Louisiana State University, Baton Rouge, LA 70803, U.S.A. \\ M.O. SCULLY \\ Max-Planck Institut fur Quantenoptik, D-8046 Garching bei Munchen, West Germany \\ and \\ Institute for Modern Optics, University of New Mexico, Albuquerque, NM 87131, U.S.A.

\section{E.P. WIGNER*} \\ Department of Physics and Astronomy, Louisiana State University, Baton Rouge, LA 70803, U.S.A. \\ Received December 1983
}

Contents:

1. Introduction 123

2. Wigner distribution $\quad 126$

2.1. Properties 126

2.2. Associated operator ordering 132

2.3. Dynamics 135

2.4. An example 142

2.5. Statistics and second-quantized notation 146

3. Other distribution functions 150)

4. Distribution functions in terms of creation and annibilation operators
4.1. Normal ordering 156

4.2. Symmetric ordering $\quad 158$

4.3. Anti-normal ordering 161

4.4. Examples 162

4.5. Distribution functions on four-dimensional phase space 163

5. Conclusion 166

References $\quad 166$

* Permanent address: Department of Physics, Joseph Henry Laboratory, Princeton University, Princeton, NJ 08540, U.S.A.

Single orders for this issue

PHYSICS REPORTS (Review Section of Physics Letters) 106, No. 3 (1984) 121-167.

Copies of this issue may be obtained at the price given below. All orders should be sent directly to the Publisher. Orders must be accompanied by check.

Single issue price Dfl. 29.00 , postage included.

0 370-1573/84/\$14.40 @ Elsevier Science Publishers B.V. (North-Holland Physics Publishing Division) 
Abstract:

This is the first part of what will be a two-part review of distribution functions in physics. Here we deal with fundamentals and the second part will deal with applications. We discuss in detail the properties of the distribution function defined earlier by one of us (EPW) and we derive some new results. Next, we treat various other distribution functions. Among the latter we emphasize the so-called $P$ distribution, as well as the generalized $\boldsymbol{P}$ distribution, because of their importance in quantum optics.

\section{Introduction}

It is well known that the uncertainty principle makes the concept of phase space in quantum mechanics problematic. Because a particle cannot simultaneously have a well defined position and momentum, one cannot define a probability that a particle has a position $q$ and a momentum $p$, i.e. one cannot define a true phase space probability distribution for a quantum mechanical particle. Nonetheless, functions which bear some resemblance to phase space distribution functions, "quasiprobability distribution functions", have proven to be of great use in the study of quantum mechanical systems. They are useful not only as calculational tools but can also provide insights into the connections between classical and quantum mechanics.

The reason for this latter point is that quasiprobability distributions allow one to express quantum mechanical averages in a form which is very similar to that for classical averages. As a specific example let us consider a particle in one dimension with its position denoted by $q$ and its momentum by $p$. Classically, the particle is described by a phase space distribution $P_{\mathrm{CI}}(q, p)$. The average of a function of the position and momentum $A(q, p)$ can then be expressed as

$$
\langle A\rangle_{\mathrm{Cl}}=\int \mathrm{d} q \int \mathrm{d} p A(q, p) P_{\mathrm{Cl}}(q, p)
$$

The integrations in this equation are from $-\infty$ to $+\infty$. This will be the case with all integrations in this paper unless otherwise indicated. A quantum mechanical particle is described by a density matrix $\hat{\rho}$ (we will designate all operators by $\mathrm{a}^{\wedge}$ ) and the average of a function of the position and momentum operators, $\hat{A}(\hat{q}, \hat{p})$ is

$$
\langle\hat{A}\rangle_{\text {quant }}=\operatorname{Tr}(\hat{A} \hat{\rho})
$$

(Tr $\hat{Q}$ means the trace of the operator $\hat{Q}$ ). It must be admitted that, given a classical expression $A(q, p)$, the corresponding self-adjoint operator $\hat{A}$ is not uniquely defined-and it is not quite clear what the purpose of such a definition is. The use of a quasiprobability distribution, $P_{\mathrm{O}}(q, p)$, however, does give such a definition by expressing the quantum mechanical average as

$$
\langle\hat{A}\rangle_{\text {quant }}=\int \mathrm{d} q \int \mathrm{d} p A(q, p) P_{\mathrm{O}}(q, p)
$$

where the function $A(q, p)$ can be derived from the operator $\hat{A}(\hat{q}, \hat{p})$ by a well defined correspondence rule. This allows one to cast quantum mechanical results into a form in which they resemble classical ones.

The first of these quasiprobability distributions was introduced by Wigner [1932a] to study quantum corrections to classical statistical mechanics. This particular distribution has come to be known as the 
Wigner distribution, $\dagger$ and we will designate it as $P_{w}$. This is, and was meant to be, a reformulation of Schrödinger's quantum mechanics which describes states by functions in configuration space. It is non-relativistic in nature because it is not invariant under the Lorentz group; also, configuration space quantum mechanics for more than one particle would be difficult to formulate relativistically. However, it has found many applications primarily in statistical mechanics but also in areas such as quantum chemistry and quantum optics. In the case where $P_{\mathrm{O}}$ in eq. (1.3) is chosen to be $P_{w}$, then the correspondence between $\hat{A}(q, p)$ and $\hat{A}$ is that proposed by Weyl [1927], as was first demonstrated by Moyal [1949]. Quantum optics has given rise to a number of quasiprobability distributions, the most well-known being the $P$ representation of Glauber [1963a] and Sudarshan [1963], which have also found extensive use. As far as the description of the electromagnetic field is concerned, these do exhibit (special) relativistic invariance. Other distribution functions have also been proposed (Husimi [1940]; Margenau and Hill [1961]; Cohen [1966]) but have found more limited use, although, more recently, extensive use has been made of the generalized $P$ representations by Drummond, Gardiner and Walls $[1980,1981]$. In this paper we will discuss the basic formalism of these quasiprobability distributions and illustrate them with a few simple examples. We will defer any detailed consideration of applications to a later paper.

We now proceed to the basic problem: how do we go about constructing a quantum mechanical analogue of a phase space density? Let us again consider, for simplicity, a one particle system in one dimension which is described by a density matrix $\hat{\rho}$. In this paper we will work, for simplicity, in one dimension; the generalization to higher dimensions will be given in a few cases but is in most circumstances obvious. It is possible to express the position and momentum distributions of the particle as

$$
\begin{aligned}
& P_{\text {pos }}(q)=\operatorname{Tr}(\hat{\rho} \delta(q-\hat{q})) \\
& P_{\text {mom }}(p)=\operatorname{Tr}(\hat{\rho} \delta(p-\hat{p}))
\end{aligned}
$$

where $\delta(q-\hat{q})$ is the operator which transforms $\left|q^{\prime}\right\rangle$ as follows:

$$
\delta(q-\hat{q})\left|q^{\prime}\right\rangle \equiv|q\rangle\left\langle q \mid q^{\prime}\right\rangle=\delta\left(q-q^{\prime}\right)\left|q^{\prime}\right\rangle
$$

and similarly for $\delta(p-\hat{p})$. We introduce the function $\rho\left(q^{\prime}, q^{\prime \prime}\right)$ defined by

$$
\rho\left(q^{\prime}, q^{\prime \prime}\right)=\left\langle q^{\prime}|\hat{\rho}| q^{\prime \prime}\right\rangle=\sum_{\lambda} w_{\lambda} \psi_{\lambda}\left(q^{\prime}\right) \psi_{\lambda}\left(q^{\prime \prime}\right)^{*}
$$

where $w_{\lambda}$ is the probability of the system being in the state $\psi_{\lambda}$, and the $\left\{\psi_{\lambda}\right\}$ form a complete set. Then

$$
P_{\mathrm{pos}}(q)=\rho(q, q)
$$

and

$$
P_{\text {mom }}(p)=(2 \pi \hbar)^{-1} \int \mathrm{d} x \int \mathrm{d} x^{\prime} \rho\left(x, x^{\prime}\right) \exp \left\{i p\left(x^{\prime}-x\right) / \hbar\right\} .
$$

\footnotetext{
† We use this designation here and throughout the paper despite the strenuous objections of one of us since the majority of us feel we should adhere to what is now common nomenclature.
} 
To show that this corresponds to the usual definition we will examine $P_{\text {pos }}(q)$. We have that, in the Dirac bracket notation,

$$
\begin{aligned}
P_{\text {pos }}(q) & =\operatorname{Tr}(\hat{\rho} \delta(q-\hat{q}))=\int \mathrm{d} q^{\prime}\left\langle q^{\prime}|\hat{\rho} \delta(q-\hat{q})| q^{\prime}\right\rangle \\
& =\int \mathrm{d} q^{\prime} \delta\left(q-q^{\prime}\right)\left\langle q^{\prime}|\hat{\rho}| q^{\prime}\right\rangle=\langle q|\hat{\rho}| q\rangle
\end{aligned}
$$

which is a more conventional expression for the position density. A first guess for some kind of a phase space density might then be

$$
P_{1}(q, p)=\operatorname{Tr}(\hat{\rho} \delta(q-\hat{q}) \delta(p-\hat{p}))
$$

On the other hand, we might choose instead

$$
P_{2}(q, p)=\operatorname{Tr}(\hat{\rho} \delta(p-\hat{p}) \delta(q-\hat{q}))
$$

But these expressions are not equal and although either of them, or a combination of both, could be used to evaluate expectation values of functions of $\hat{q}$ and $\hat{p}$ (provided the operators are ordered properly, the ordering for $P_{1}$ being different than that for $P_{2}$ ), they do not possess what we regard as desirable properties (see section 2). In fact, they are, in general, not real.

The association of distribution functions with operator ordering rules (or, equivalently, the association of operators with classical expressions) is one which will recur throughout this paper. Each of the distribution functions which we will discuss can be used to evaluate expectation values of products of operators ordered according to a certain rule. We will consider distribution functions which can be used to compute expectation values of products of the position and momentum operators $\hat{q}$ and $\hat{p}$, and also distribution functions which can be used to compute expectation values of products of the creation and annihilation operators, $\hat{a}^{+}$and $\hat{a}$. The latter are useful in problems involving electromagnetic fields. Because the creation and annihilation operators are simply related to $\hat{q}$ and $\hat{p}$ there is a relation between these two types of distribution functions. The Wigner distribution, for example, has proved useful in both the $\hat{a}, \hat{a}^{+}$and $\hat{p}, \hat{q}$ contexts. The basic criterion for the choice of a distribution function for a particular problem is convenience.

In the next two sections we will continue to examine distribution functions expressed in terms of both the position and momentum variables. The Wigner function, $P_{w}$, will be discussed first in section 2 for not only was it the first quantum mechanical phase space distribution to be considered, but also it satisfies a number of properties which make it quite useful in applications. First of all, we will discuss its properties and then show that Wigner's distribution function gives the same expectation value for every function of $p$ and $q$ as does the corresponding operator, as proposed by Weyl [1927], for the density matrix which describes the same state to which the distribution function corresponds. As was mentioned before, this was first observed by Moyal [1949]. Next we derive an equation, in many different forms, for the time dependence of $P_{\mathrm{w}}$. Finally, we apply the formalism we have developed to the calculation of $P_{w}$ for the eigenstates of the harmonic oscillator and also for the case of a canonical ensemble of harmonic oscillators at temperature $T$.

In section 3 we discuss distribution functions other than $P_{w}$ which correspond to operator ordering 
schemes different from that of Weyl-Wigner. Then in section 4 we treat distribution functions in terms of creation and annihilation operators, with emphasis on normal, symmetric and anti-normal ordering. In particular, we emphasize the normal ordering from which arises the well-known $P$ distribution of quantum optics. We also discuss the generalized $P$ representations. Finally, in section 5 we present our conclusions.

Applications will be treated in a future paper but we would be remiss not to mention the recent extensive review of quantum collision theory using phase space distributions (Carruthers and Zachariasan [1983]) and the work on relativistic kinetic theory - in addition to extensive discussions on the Wigner-Weyl correspondence - by the Amsterdam group (Suttorp and de Groot [1970]; Suttorp [1972]; de Groot [1974]; de Groot, van Leeuwen and van Weert [1980]). Also, a brief overview of some applications is presented in O'Connell [1983a,b].

\section{Wigner distribution}

\subsection{Properties}

In a 1932 paper (Wigner [1932a]) the distribution

$$
P_{w}(q, p)=\frac{1}{\pi \hbar} \int_{-\infty}^{\infty} \mathrm{d} y\langle q-y|\hat{\rho}| q+y\rangle \mathrm{e}^{2 i p y / \hbar}
$$

was proposed to represent a system in a mixed state represented by a density matrix $\hat{\rho}$. In the case of a pure state, $\psi$, it follows from eq. (1.6) that $\rho\left(q^{\prime}, q^{\prime \prime}\right)=\psi\left(q^{\prime}\right) \psi^{*}\left(q^{\prime \prime}\right)$ and hence

$$
P_{\mathrm{w}}(q, p)=\frac{1}{\pi \hbar} \int_{-\infty}^{\infty} \mathrm{d} y \psi^{*}(q+y) \psi(q-y) \mathrm{e}^{2 \mathrm{i} p y / \hbar}
$$

The latter result refers to one dimension. In the case of more than one dimension, the $\pi \hbar$ must be replaced by $(\pi \hbar)^{-n}$, where $n$ is the number of the variables of $\psi$ (or the number of variables of the rows or columns of $\hat{\rho}$ ) and $q, y$ and $p$ are $n$-dimensional vectors, with $p y$ the scalar product of the two. The integration is then over all components of $y$. Explicitly, eq. (2.2a) generalizes to

$$
\begin{aligned}
P_{\mathrm{w}}\left(q_{1}, \ldots q_{n} ; p_{1}, \ldots p_{n}\right)= & (\pi \hbar)^{-n} \int_{-\infty}^{\infty} \ldots \int_{-\infty}^{x} \mathrm{~d} y_{1} \cdots \mathrm{d} y_{n} \psi^{*}\left(q_{1}+y_{1}, \ldots q_{n}+y_{n}\right) \\
& \times \psi\left(q_{1}-y_{1} \ldots q_{n}-y_{n}\right) \exp \left[2 \mathrm{i}\left(p_{1} y_{1}+\cdots+p_{n} y_{n}\right) / \hbar\right]
\end{aligned}
$$

It was mentioned that this choice for a distribution function was by no means unique and that this particular choice was made because it seemed to be the simplest of those for which each Galilei transformation corresponds to the same Galilei transformation of the quantum mechanical wave functions. In later work Wigner [1979] returned to this issue by considering properties which one would want such a distribution to satisfy. He then showed that the distribution given by eq. (2.1) was the only 
one which satisfied these properties. A subsequent paper by O'Connell and Wigner [1981a] considered a somewhat different list of properties and showed that these, too, led to the expression in eq. (2.1).

The properties for a distribution function, $P(q, p)$, which were considered of special interest, for the case of a pure state (generalization to the case of a mixed state is straightforward), are as follows (O'Connell and Wigner [1981a]):

(i) $P(q, p)$ should be a Hermitean form of the state vector $\psi(q)$, i.e. $P$ is given by

$$
P(q, p)=\langle\psi|\hat{M}(q, p)| \psi\rangle
$$

where $\hat{M}(q, p)$ is a self-adjoint operator depending on $p$ and $q$. Therefore, $P(q, p)$ is real.

(ii)

$$
\begin{aligned}
& \int \mathrm{d} p P(q, p)=|\psi(q)|^{2}=\langle q|\hat{\rho}| q\rangle \\
& \int \mathrm{d} q P(q, p)=\langle p|\hat{\rho}| p\rangle \\
& \int \mathrm{d} q \int \mathrm{d} p P(q, p)=\operatorname{Tr}(\hat{\rho})=1
\end{aligned}
$$

(iii) $P(q, p)$ should be Galilei invariant, i.e. if $\psi(q) \rightarrow \psi(q+a)$ then $P(q, p) \rightarrow P(q+a, p)$ and if $\psi(q) \rightarrow \exp \left(i p^{\prime} q / \hbar\right) \psi(q)$ then $P(q, p) \rightarrow P\left(q, p-p^{\prime}\right)$.

(iv) $P(q, p)$ should be invariant with respect to space and time reflections, i.e. if $\psi(q) \rightarrow \psi(-q)$ then $P(q, p) \rightarrow P(-q,-p)$ and if $\psi(q) \rightarrow \psi^{*}(q)$ then $P(q, p) \rightarrow P(q,-p)$.

It should be admitted, however, that neither of these transformations is relativistic and also that they do not yet involve the spin variable.

(v) In the force-free case the equation of motion is the classical one

$$
\frac{\partial P}{\partial t}=-\frac{P}{m} \frac{\partial P}{\partial q}
$$

(vi) If $P_{\psi}(q, p)$ and $P_{\phi}(q, p)$ are the distributions corresponding to the states $\psi(q)$ and $\phi(q)$ respectively then

$$
\left|\int \mathrm{d} q \psi^{*}(q) \phi(q)\right|^{2}=(2 \pi \hbar) \int \mathrm{d} q \int \mathrm{d} p P_{\psi}(q, p) P_{\phi}(q, p) .
$$

Property (vi) has two interesting consequences. If we set $\phi(q)=\psi(q)$ we get

$$
\int \mathrm{d} q \int \mathrm{d} p\left[P_{\psi}(q, p)\right]^{2}=\frac{1}{2 \pi \hbar}
$$

and, in the case of a mixed state, the right-hand side of eq. (2.9) is multiplied by $\Sigma_{\beta} w_{k}^{2}$ where the $w_{k}$ are the probabilities for the different states (the characteristic values of $\hat{\rho})$. This implies that $P_{\psi}(q, p)$ is not too highly peaked and rules out such distributions as $P_{\psi}(q, p)=\delta(q-\hat{q}) \delta(p-\hat{p})$ which would be 
possible classically. We can also choose $\phi$ and $\psi$ so that they are orthogonal. We then have that

$$
\int \mathrm{d} q \int \mathrm{d} p P_{\psi}(q, p) P_{\phi}(q, p)=0
$$

which implies that $P(q, p)$ cannot be everywhere positive. This conclusion is actually rather general. Wigner [1979] has shown that any distribution function as long as it satisfies properties (i) and (ii) assumes also negative values for some $p$ and $q$.

(vii)

$$
\int \mathrm{d} q \int \mathrm{d} p A(q, p) B(q, p)=(2 \pi \hbar) \operatorname{Tr}(\hat{A} \hat{B})
$$

where $A(q, p)$ is the classical function corresponding to the quantum operator $\hat{A}$, and is given, according to Wigner's prescription, by

$$
A(q, p)=\int \mathrm{d} z \mathrm{e}^{\mathrm{i} p z / \hbar}\left\langle q-\frac{1}{2} z|\hat{A}| q+\frac{1}{2} z\right\rangle
$$

so that $\iint \mathrm{d} q \mathrm{~d} p A(q, p)=2 \pi \hbar \operatorname{Tr}(\hat{A})$. A similar relation exists between $B(q, p)$ and $\hat{B}$.

The proof of eq. (2.11) will be shown below to follow as a particular case of a more general relation (eq. (2.23)) for $F(q, p)$, in terms of $A(q, p)$ and $B(q, p)$, where $\hat{F}=\hat{A} \hat{B}$. From eq. (2.12), it is at once evident that the phase space description $A(q, p)$ of the operator $\hat{A}$ is real if $\hat{A}$ is self-adjoint (Hermitean) and is imaginary if $\hat{A}$ is skew Hermitean. Since in neither case does $A(q, p)$ vanish, it is evident that if it is real, its operator $\hat{A}$ is self-adjoint, if it is imaginary $\hat{A}$ is skew symmetric. It is also evident that the phase space description of the Hermitean adjoint $\hat{A}^{+}$of $\hat{A}$ is the complex conjugate of the similar description of $\hat{A}$. Similarly, if the phase space descriptions of two operators are complex conjugates of each other, then the operators are Hermitean adjoints of each other.

By comparison of eqs. (2.1) and (2.12), it is clear that $P(q, p)$, derived from the density matrix, is $(2 \pi \hbar)^{-1}$ times the phase space operator which corresponds to the same matrix. Also, for $\hat{A}=\hat{\rho}$ and $\hat{B}$ equal to the unit matrix, eq. (2.6) immediately follows from eq. (2.11). Furthermore, for $\hat{B}=\hat{\rho}$, eq. (2.11) reduces to

$$
\int \mathrm{d} q \int \mathrm{d} p A(q, p) P_{\mathrm{w}}(q, p)=\operatorname{Tr}(\hat{\rho} \hat{A}(\hat{q}, \hat{p})),
$$

which is equivalent to eqs. (1.2) and (1.3). This result was originally obtained (Wigner [1932]) for the special case of $\hat{A}$ being the sum of a function of $\hat{p}$ only and a function of $\hat{q}$ only but Moyal [1949] showed it was actually true in the case where $\hat{A}$ is any function of $\hat{q}$ and $\hat{p}$, if $\hat{A}(\hat{q}, \hat{p})$ is the Weyl operator (discussed below in section 2.2) for $A(q, p)$. In addition, if we take $\hat{A}=\hat{B}=\hat{\rho}$ in eq. (2.11) and use the fact that, if $\hat{\rho}$ represents a pure state, $\operatorname{Tr}(\hat{\rho})^{2}=\operatorname{Tr} \hat{\rho}=1$, we obtain eq. (2.9) again.

(viii) If we define the Fourier transform of the wave function

$$
\phi(p)=(2 \pi \hbar)^{-1} \int \mathrm{d} q \psi(q) \mathrm{e}^{-\mathrm{i} q p / \hbar},
$$


then eq. (2.2a) can be re-written in the form

$$
P(q, p)=(\pi \hbar)^{-1} \int \mathrm{d} p^{\prime} \phi^{*}\left(p+p^{\prime}\right) \phi\left(p-p^{\prime}\right) \mathrm{e}^{-2 i q p^{\prime} / \hbar},
$$

exhibiting the basic symmetry under the interchange $q \leftrightarrow p$.

It may be worth observing also that the contraction of the distribution function from $n$ to $n-1$ variables

$$
\begin{aligned}
\iint & P\left(q_{1}, \ldots q_{n-1}, q_{n} ; p_{1}, \ldots p_{n-1}, p_{n}\right) \mathrm{d} q_{n} \mathrm{~d} p_{n} \\
= & (\pi \hbar)^{n} \int \cdots \int \rho\left(q_{1}-y_{1}, \ldots q_{n-1}-y_{n-1}, q_{n}-y_{n} ; q_{1}+y_{1}, \ldots q_{n-1}+y_{n-1}, q_{n}+y_{n}\right) \\
& \times \exp \left[2 \mathrm{i}\left(p_{1} y_{1}+\cdots+p_{n-1} y_{n-1}+p_{n} y_{n}\right) / \hbar\right] \mathrm{d} y_{1} \cdots \mathrm{d} y_{n-1} \mathrm{~d} y_{n} \mathrm{~d} q_{n} \mathrm{~d} p_{n} \\
= & (\pi \hbar)^{n-1} \int \cdots \int \rho\left(q_{1}-y_{1}, \ldots q_{n-1}-y_{n-1}, q_{n}-y_{n} ; q_{1}+y_{1}, \ldots q_{n-1}+y_{n-1}, q_{n}+y_{n}\right) \\
& \times \exp \left[2 \mathrm{i}\left(p_{1} y_{1}+\cdots+p_{n-1} y_{n-1}\right) / \hbar\right] \delta\left(y_{n}\right) \mathrm{d} y_{1} \cdots \mathrm{d} y_{n-1} \mathrm{~d} y_{n} \mathrm{~d} q_{n} \\
= & (\pi \hbar)^{n-1} \int \cdots \int\left[\rho\left(q_{1}-y_{1}, \ldots q_{n-1}-y_{n-1}, q_{n} ; q_{1}+y_{1}, \ldots q_{n-1}+y_{n-1}, q_{n}\right) \mathrm{d} q_{n}\right] \\
& \times \exp \left[2 \mathrm{i}\left(p_{1} y_{1}+\cdots+p_{n-1} y_{n-1}\right) / \hbar\right] \mathrm{d} y_{1} \cdots \mathrm{d} y_{n-1}
\end{aligned}
$$

gives the distribution function which corresponds to the properly contracted $\rho$ (in square brackets). Actually, this is true also for the other distribution functions which will be considered in section 3 .

Wigner in his 1971 paper also showed that properties (i)-(v) determined the distribution function uniquely. O'Connell and Wigner [1981a] showed that properties (i)-(iv) and (vi) also accomplish this. In both cases the distribution function was that given by eq. (2.1).

Finally, we draw attention to two restrictions on the distribution function discussed above. First of all, as already mentioned, it is non-relativistic. Secondly, not all functions $P(q, p)$ are allowed, as we will now demonstrate by turning to the question of the admissability of $P$ and asking what condition is necessary so that $P$ implies the existence of the density function $\hat{\rho}$, the expectation values of which are, naturally, positive or zero. Our starting-point is eq. (2.2a) from which it follows that

$$
\int \mathrm{d} p \mathrm{e}^{-2 \mathrm{i} p y / \hbar} P(q, p)=\rho(q-y, q+y) .
$$

Hence, changing variables to $u=q+y$ and $v=q-y$, we obtain

$$
\rho(v, u)=\int \mathrm{d} p \mathrm{e}^{-\mathrm{i} p(u-v) / \hbar} P\left(\frac{1}{2}(u+v), p\right) .
$$

We remark that since $p$ on the right-side of eq. (2.18) is a dummy variable it is clear that it could be replaced by $q$.

Now the condition for $P(q, p)$ to be a permissible distribution function is that the corresponding 
density matrix be positive definite, i.e.

$$
\int \mathrm{d} x \int \mathrm{d} x^{\prime} \psi^{*}(x) \rho\left(x, x^{\prime}\right) \psi\left(x^{\prime}\right) \geq 0
$$

for all $\psi$. Using eq. (2.18) and eq. (2.19a), it follows that the condition that $P(q, p)$ be permissible is that

$$
\int \mathrm{d} q \int \mathrm{d} p P(q, p) P^{\prime}(q, p) \geq 0
$$

for any $P^{\prime}(q, p)$ which corresponds to a pure state. This is evident already from eq. (2.8). It also follows from eq. (2.11) and the fact that $\operatorname{Tr}\left(\hat{\rho} \hat{\rho}^{\prime}\right) \geq 0$. Eq. (2.19b) holds, of course, for any $P^{\prime}$ which is itself permissible but the permissibility of $P$ follows already if it is valid for all $P^{\prime}$ which correspond to a pure state.

Eight properties of the distribution function were discussed above, eqs. (2.3) to (2.16), with the emphasis on the use of this function to form another description of a quantum mechanical state, i.e. be a substitute for the density matrix. Just as eq. (2.1) permits one to give a phase space formulation to the density matrix $\hat{\rho}$, we emphasize that eq. (2.12) permits one also to give a phase space formulation to any matrix - or operator - and it may be useful to consider the properties of eq. (2.12).

In particular, we wish to derive an expression for the function $F(q, p)$ which corresponds to the product $\hat{F}=\hat{A} \hat{B}$ of two operators $\hat{A}$ and $\hat{B}$ to which the $q, p$ functions $A(q, p)$ and $B(q, p)$ correspond. We assume that the operators $\hat{A}$ and $\hat{B}$ are matrices, the rows and columns of which can be characterized by a single variable, but the generalization to a many-dimensional configuration space is obvious. We can write, therefore

$$
\hat{F}\left(x, x^{\prime \prime}\right)=\int \hat{A}\left(x, x^{\prime}\right) \hat{B}\left(x^{\prime}, x^{\prime \prime}\right) \mathrm{d} x^{\prime}
$$

Analogous to eqs. (2.17) and (2.18), eq. (2.20) can be written as (taking $\hbar=1$ for this derivation)

$$
\begin{aligned}
\int \mathrm{d} p_{1} F\left(\frac{1}{2}\left(x+x^{\prime \prime}\right), p_{1}\right) \mathrm{e}^{-\mathrm{i} p_{1}\left(x^{\prime \prime}-x\right)}= & (2 \pi)^{-1} \iiint \mathrm{d} x^{\prime} \mathrm{d} p^{\prime} \mathrm{d} p^{\prime \prime} A\left(\frac{1}{2}\left(x+x^{\prime}\right), p^{\prime}\right) \mathrm{e}^{-\mathrm{i} p^{\prime}\left(x^{\prime}-x\right)} \\
& \times B\left(\frac{1}{2}\left(x^{\prime}+x^{\prime \prime}\right), p^{\prime \prime}\right) \mathrm{e}^{-\mathrm{i} p^{\prime \prime}\left(x^{\prime \prime}-x^{\prime}\right)} .
\end{aligned}
$$

Substituting $x=q+q^{\prime}, x^{\prime \prime}=q-q^{\prime}$, multiplying with $\mathrm{e}^{-2 \mathrm{i} q^{\prime} p}$ and integrating over $q^{\prime}$ one obtains

$$
\begin{aligned}
F(q, p)= & 2(2 \pi)^{-2} \iiint \int \mathrm{d} q^{\prime} \mathrm{d} x^{\prime} \mathrm{d} p^{\prime} \mathrm{d} p^{\prime \prime} A\left(\frac{1}{2}\left(q+q^{\prime}+x^{\prime}\right), p^{\prime}\right) B\left(\frac{1}{2}\left(q-q^{\prime}+x^{\prime}\right), p^{\prime \prime}\right) \\
& \times \exp \left\{-\mathrm{i} q^{\prime}\left(2 p-p^{\prime}-p^{\prime \prime}\right)-\mathrm{i}\left(p^{\prime \prime}-p^{\prime}\right)\left(q-x^{\prime}\right)\right\} .
\end{aligned}
$$

Introducing finally new variables $y=\frac{1}{2}\left(q+x^{\prime}\right), y^{\prime}=\frac{1}{2} q^{\prime}, p^{\prime}=\rho-\rho^{\prime}, p^{\prime \prime}=\rho+\rho^{\prime}$, one obtains

$$
\begin{aligned}
& F(q, p)=16(2 \pi)^{-2} \iiint \int \mathrm{d} y \mathrm{~d} y^{\prime} \mathrm{d} \rho \mathrm{d} \rho^{\prime} A\left(y+y^{\prime}, \rho-\rho^{\prime}\right) B\left(y-y^{\prime}, \rho+\rho^{\prime}\right) \\
& \quad \times \exp \left\{-4 \mathrm{i} y^{\prime}(p-\rho)-4 \mathrm{i} \rho^{\prime}(q-y)\right\} \\
& =16(2 \pi)^{-2} \iiint \int \mathrm{d} y \mathrm{~d} y^{\prime} \mathrm{d} \rho \mathrm{d} \rho^{\prime} A\left(q+y+y^{\prime}, p+\rho-\rho^{\prime}\right) B\left(q+y-y^{\prime}, p+\rho+\rho^{\prime}\right) \mathrm{e}^{4 i\left(c y^{\prime}+y \rho^{\prime}\right)}
\end{aligned}
$$


This expression for $F(q, p)$, which is a new result, also shows the similarity of the roles of $p$ and $q$ in Hamiltonian mechanics. In the next subsection, another expression (eq. (2.59)) for $F(q, p)$ will be presented.

If we integrate $F(q, p)$ in eq. (2.23) over $q$ and $p$, we obtain

$$
\begin{gathered}
\iint F(q, p) \mathrm{d} q \mathrm{~d} p=16(2 \pi)^{-2} \iiint \int \mathrm{d} y \mathrm{~d} y^{\prime} \mathrm{d} \rho \mathrm{d} \rho^{\prime} A\left(y+y^{\prime}, \rho-\rho^{\prime}\right) B\left(y-y^{\prime}, \rho+\rho^{\prime}\right) \\
\times \exp \left\{4 i y^{\prime} \rho+4 i \rho^{\prime} y\right\}\left(4 \pi^{2} / 16\right) \delta\left(y^{\prime}\right) \delta\left(\rho^{\prime}\right) .
\end{gathered}
$$

Hence

$$
\iint F(q, p) \mathrm{d} q \mathrm{~d} p=\iint A(q, p) B(q, p) \mathrm{d} q \mathrm{~d} p
$$

Since the left-hand side of this equation is the same as $(2 \pi h) \operatorname{Tr}(\hat{F})$, it is clear that eq. $(2.25)$ is the same as eq. (2.11). In the case of $n$ dimensions, the $n$th power of $\left(4 / \pi^{2}\right)$ appears in the expression corresponding to eq. (2.23).

Eq. (2.23) provides also a means to ascertain, in terms of the phase space descriptions of $\hat{A}$ and $\hat{B}$, whether these two operators commute. Naturally, the condition for the commutative nature is

$$
\begin{aligned}
& \iiint \int \mathrm{d} y \mathrm{~d} y^{\prime} \mathrm{d} \rho \mathrm{d} \rho^{\prime} A\left(y+y^{\prime}, \rho-\rho^{\prime}\right) B\left(y-y^{\prime}, \rho+\rho^{\prime}\right) \exp \left\{-4 \mathrm{i} y^{\prime}(p-\rho)-4 \mathrm{i} \rho^{\prime}(q-y)\right\} \\
& \quad=\iiint \int \mathrm{d} y \mathrm{~d} y^{\prime} \mathrm{d} \rho \mathrm{d} \rho^{\prime} B\left(y+y^{\prime}, \rho-\rho^{\prime}\right) A\left(y-y^{\prime}, \rho+\rho^{\prime}\right) \exp \left\{-4 \mathrm{i} y^{\prime}(p-\rho)-4 \mathrm{i} \rho^{\prime}(q-y)\right\} .
\end{aligned}
$$

Since this is valid for all $p$ and $q$, the integration over the variables which are their factors in the exponent (i.e. $y^{\prime}$ and $\rho^{\prime}$ ) can be omitted. This gives as condition for the commutability of $\hat{A}$ and $\hat{B}$ (we replace $y, y^{\prime}$ by $q, q^{\prime}$ and $\rho, \rho^{\prime}$ by $\left.p, p^{\prime}\right)$ :

$$
\begin{aligned}
& \iint \mathrm{d} p \mathrm{~d} q\left[A\left(q+q^{\prime}, p-p^{\prime}\right) B\left(q-q^{\prime}, p+p^{\prime}\right)-A\left(q-q^{\prime}, p+p^{\prime}\right) B\left(q+q^{\prime}, p-p^{\prime}\right)\right] \\
& \quad \times \exp \left\{4 \mathrm{i}\left(q^{\prime} p+p^{\prime} q\right)\right\}=0
\end{aligned}
$$

a somewhat unexpected expression.

The last quantum mechanical relation that will be translated into phase space language is the equation $\hat{A} \hat{\rho}=\lambda \hat{\rho}$ specifying that the wave functions of which $\hat{\rho}$ consists are characteristic functions (eigenfunctions) of $\hat{A}$ with the characteristic value $\lambda$. Whether $\hat{\rho}$ contains only one or more such characteristic functions depends whether or not its phase space representation, $P_{w}$, satisfies eq. (2.9), i.e. whether its square integral is equal to or smaller than $(2 \pi \hbar)^{-1}$.

The $\hat{A} \hat{\rho}=\lambda \hat{\rho}$ relation, with $\hat{\rho}$ represented by $P_{w}$, reads, according to eq. (2.23), in phase space language: 
132

$$
\begin{aligned}
& \left(4 / \pi^{2}\right) \iiint \int \mathrm{d} y \mathrm{~d} y^{\prime} \mathrm{d} \rho \mathrm{d} \rho^{\prime} A\left(y+y^{\prime}, \rho-\rho^{\prime}\right) P_{\mathrm{w}}\left(y-y^{\prime}, \rho+\rho^{\prime}\right) \exp \left\{4 i y^{\prime}(\rho-p)+4 \mathrm{i} \rho^{\prime}(y-q)\right\} \\
& \quad=\lambda P_{\mathrm{w}}(q, p) .
\end{aligned}
$$

In order to simplify this, one can multiply with $\exp \left\{4 i\left(q^{\prime} p+p^{\prime} q\right)\right\}$ and integrate over $p$ and $q$ to obtain, substituting also $q$ and $p$ for the integration variables $y$ and $\rho$.

$$
\begin{aligned}
& \iint \mathrm{d} q \mathrm{~d} p A\left(q+q^{\prime}, p-p^{\prime}\right) P_{\mathrm{w}}\left(q-q^{\prime}, p+p^{\prime}\right) \exp \left\{4 \mathrm{i}\left(q^{\prime} p+p^{\prime} q\right)\right\} \\
& =\lambda \iint \mathrm{d} q \mathrm{~d} p P_{\mathrm{w}}(q, p) \exp \left\{4 \mathrm{i}\left(q^{\prime} p+p^{\prime} q\right)\right\}
\end{aligned}
$$

Both eqs. (2.27) and (2.29) are a good deal more complicated than the quantum mechanical equations for which they substitute. It is questionable whether they are really useful. We thought that they should be derived in spite of this because the final form is considerably simpler than the original one and because they clearly demonstrate the essential phase space equivalence of $q$ and $p$. It may be worth remarking finally that in the case of several dimensions all variables should be considered as vectors, and products like $q^{\prime} p$ or $p^{\prime} q$ should be replaced by scalar products of these vectors.

\subsection{Associated operator ordering}

We will now discuss the connection between a classical function of $q$ and $p$ and a quantum mechanical operator which is supposed to correspond to it. The result of the measurement of a quantum mechanical operator is well defined: it is supposed to transfer the state of the system on which the measurement is carried out into one of the characteristic vectors of the operator in question, and the probabilities with which the different characteristic vectors would result from the measurement are also well defined. They are the squares of the scalar products of the normalized initial state of the system on which the measurement is carried out and of the operator's normalized characteristic vector into which the state of the system is transformed. It must be admitted, even in this case, that, given an arbitrary operator, it is in many cases difficult, in others impossible, to construct an apparatus which can carry out the measurement, i.e. the desired change of the state of the system on which the measurement is to be carried out.

But as far as the measurement of a classical function of $p$ and $q$ is concerned, no similar postulate exists which can be formulated in classical terms. But Weyl did propose the association of a quantum mechanical operator to every function of $q$ and $p$ and defined the measurement of the classical quantity as being identical with the above described quantum mechanical measurement of the operator which he associated to the classical function of $q$ and $p$. This association will be described below. What is remarkable, however, and what has been first pointed out by Moyal [1949], is the close connection between Weyl's proposal and the distribution function as defined above. In particular, the expectation value of the result of the measurement of the operator $\hat{A}$, which Weyl associates with the classical function $A(q, p)$ if carried out on a system in the state $\psi$,

$$
\langle\psi|\hat{A}| \psi\rangle=\int \mathrm{d} q \int \mathrm{d} p P_{\mathrm{w}}(q, p) A(q, p)
$$


is equal to the expectation value of the classical function $A(q, p)$ to which $\hat{A}$ corresponds assuming that the system is described by the distribution function $P_{\mathrm{w}}(q, p)$ which corresponds to $\hat{\rho}$. This is the content of eq. (2.30) and it is valid, as will be demonstrated below, for every state vector $\psi$ and also for any density matrix $\hat{\rho}$

$$
\operatorname{Tr}(\hat{\rho} \hat{A})=\int \mathrm{d} q \int \mathrm{d} p P_{\mathrm{w}}(q, p) A(q, p)
$$

Actually eq. (2.31) is an easy consequence of eq. (2.30) and only the latter will be proved below.

In order to prove eq. (2.30), we start with Weyl's expansion of $A(q, p)$ into a Fourier integral (taking $\hbar=1$ for the purpose of this proof):

$$
A(q, p)=\int \mathrm{d} \sigma \int \mathrm{d} \tau \alpha(\sigma, \tau) \mathrm{e}^{\mathrm{i}(\sigma q+\tau p)}
$$

Weyl then defines the operator which corresponds to the exponential in the integrand on the right-hand side of eq. (2.32) as $\exp \{i(\sigma \hat{q}+\tau \hat{p})\}$. The operator which corresponds to $A(q, p)$ is then given by

$$
\hat{A}(\hat{q}, \hat{p})=\int \mathrm{d} \sigma \int \mathrm{d} \tau \alpha(\sigma, \tau) \exp \{\mathrm{i}(\sigma \hat{q}+\tau \hat{p})\}
$$

If we substitute this result for $\hat{A}$ into the left-hand side of eq. $(2.30)$ and replace $A(q, p)$ on the right-hand side by the right-hand side of eq. (2.32), it becomes evident that all we have to prove is that

$$
\begin{aligned}
\langle\psi|\exp \{\mathrm{i}(\sigma \hat{q}+\tau \hat{p})\}| \psi\rangle & =\int \mathrm{d} q \int \mathrm{d} p P_{\mathrm{w}}(q, p) \exp \{\mathrm{i}(\sigma q+\tau p)\} \\
& =\frac{1}{2 \pi} \int \mathrm{d} y \int \mathrm{d} q \int \mathrm{d} p \psi^{*}\left(q+\frac{1}{2} y\right) \psi\left(q-\frac{1}{2} y\right) \exp \{\mathrm{i} p y+\mathrm{i}(\sigma q+\tau p)\}
\end{aligned}
$$

The integration over $p$ gives $2 \pi \delta(y+\tau)$ and hence the right-hand side of eq. (2.34) becomes

$$
\int \mathrm{d} q \psi^{*}\left(q-\frac{1}{2} \tau\right) \psi\left(q+\frac{1}{2} \tau\right) \mathrm{e}^{\mathrm{i} \sigma q}
$$

In order to evaluate the left-hand side of (2.34) we note that according to the Baker-Hausdorff theorem (Messiah [1961]), if the commutator $\hat{D}=[\hat{A}, \hat{B}]$ commutes with $\hat{A}$ and $\hat{B}$ then

$$
\mathrm{e}^{\hat{A}+\hat{B}}=\mathrm{e}^{\hat{A}} \mathrm{e}^{\hat{B}} \mathrm{e}^{-\hat{D} / 2} \text {. }
$$

It then follows that

$$
\mathrm{e}^{\mathrm{i}(\sigma \phi+\tau)}=\mathrm{e}^{\mathrm{i} \sigma q} \mathrm{e}^{\mathrm{i} \tau p} \mathrm{e}^{\mathrm{i} \sigma \tau / 2}
$$

Hence, the left-hand side of eq. (2.34) becomes 


$$
\mathrm{e}^{\mathrm{i} \sigma / 2}\left\langle\psi\left|\mathrm{e}^{\mathrm{i} \sigma q} \mathrm{e}^{i \tau p}\right| \psi\right\rangle
$$

Next, using the fact that

$$
\mathrm{e}^{\mathrm{i} \gamma \hat{p}}|\psi(x)\rangle=|\psi(x+\tau)\rangle
$$

and transferring the $\mathrm{e}^{\mathrm{i} \hat{\mathrm{q}} \mathrm{t}}$ to the left-hand side, this becomes

$$
\mathrm{e}^{\mathrm{i} \sigma \tau / 2}\left\langle\mathrm{e}^{-\mathrm{i} \sigma x} \psi(x) \mid \psi(x+\tau)\right\rangle=\int \mathrm{d} x \mathrm{e}^{\mathrm{i}(\sigma x+\sigma \tau / 2)} \psi^{*}(x) \psi(x+\tau),
$$

which is equal to the expression obtained above for the right-hand side of eq. (2.34). Thus, we have proved eq. (2.34) and hence also eq. (2.30).

In summary, if a classical function

$$
A(q, p)=\int \mathrm{d} \sigma \int \mathrm{d} \tau \mathrm{e}^{(i / h)(\alpha q+p p)} \alpha(\sigma, \tau)
$$

goes over to the quantum operator

$$
\hat{A}(\hat{q}, \hat{p})=\int \mathrm{d} \sigma \int \mathrm{d} \tau \mathrm{e}^{(\mathrm{i} / h)(\sigma q+\tau \hat{p})} \alpha(\sigma, \tau)
$$

then the relation between $A(q, p)$ and $\hat{A}$ is that given by Wigner in eq. (2.12). Furthermore, it is clear that if, for all $A(p, q)$

$$
\int \mathrm{d} q \int \mathrm{d} p P(q, p) A(q, p)=\int \mathrm{d} q \int \mathrm{d} p P^{\prime}(q, p) A(q, p)
$$

then $P^{\prime}$ is identical with $P$.

In addition, we mention that under the Weyl correspondence the classical quantity $q^{n} p^{m}$ becomes

$$
q^{n} p^{m} \rightarrow \frac{1}{2^{n}} \sum_{r=0}^{n}\left(\begin{array}{l}
n \\
r
\end{array}\right) \hat{q}^{n-r} \hat{p}^{m} \hat{q}^{r}
$$

as can be seen by considering the $\sigma^{n} \tau^{m}$ coefficient in $(\sigma \hat{q}+\tau \hat{p})^{n+m}$.

Finally, we would like to mention the role played by the characteristic function. This is a description of the state $\hat{\rho}$ by means of a function of two new variables, $\sigma$ and $\tau$,

$$
C(\sigma, \tau)=\operatorname{Tr}(\hat{\rho} \hat{C}(\sigma, \tau)),
$$

where

$$
\hat{C}(\sigma, \tau)=\mathrm{e}^{(\mathrm{i} / \hbar)(\sigma q+\tau \beta)} .
$$


Here we are following the nomenclature of Moyal which has now become standard in describing this quantity as a "characteristic function". This description stems from statistical terminology, and, in particular, should not be confused with the sometime usage of "characteristic function" in quantum mechanics to denote an eigenfunction.

$C(\sigma, \tau)$ is just the Fourier transform of $P(q, p)$. To see this we note that the function corresponding to $\hat{C}(\sigma, \tau)$ is just $\exp \{(\mathrm{i} / \hbar)(\sigma q+\tau p)\}$. Making use of eq. (2.11) gives

$$
C(\sigma, \tau)=\operatorname{Tr}(\hat{\rho} \hat{C}(\sigma, \tau))=\int \mathrm{d} q \int \mathrm{d} p \mathrm{e}^{(\mathrm{i} / \hbar)(\sigma q+\tau)} P_{\mathrm{w}}(q, p)
$$

so that

$$
P_{\mathrm{w}}(q, p)=\left(\frac{1}{2 \pi \hbar}\right)^{2} \int \mathrm{d} \sigma \int \mathrm{d} \tau \mathrm{e}^{(-\mathrm{i} / h)(\sigma q+\tau p)} C(\sigma, \tau)
$$

We can use the characteristic function to compute expectation values of Weyl-ordered products of $p$ and $q$. We have that

$$
\left.\left(\frac{\hbar}{\mathrm{i}}\right)^{m+n} \frac{\partial^{m}}{\partial \sigma^{m}} \frac{\partial^{n}}{\partial \tau^{n}} C(\sigma, \tau)\right|_{\sigma=\tau=0}=\int \mathrm{d} q \int \mathrm{d} p q^{m} p^{n} P_{\mathrm{w}}(q, p),
$$

the right-hand side of which is just the average of the Weyl-ordered product $q^{m} p^{n}$.

\subsection{Dynamics}

We would now like to derive equations for the time-dependence of $P_{w}$. As before, our detailed considerations will be confined to one dimension but some results will also be quoted for the multi-dimensional case. The time-dependence of $P_{w}$ may be decomposed into two parts (Wigner [1932a])

$$
\frac{\partial P_{\mathrm{w}}}{\partial t}=\frac{\partial_{\mathrm{k}} P_{\mathrm{w}}}{\partial t}+\frac{\partial_{v} P_{\mathrm{w}}}{\partial t}
$$

the first part resulting from the $(i \hbar / 2 m) \partial^{2} / \partial q^{2}$ part, the second from the potential energy $V / i \hbar$ part of the expression for $\partial \psi / \partial t$.

From the definition of $P_{w}$, given by eq. (2.2a), it follows that

$$
\frac{\partial_{k} P_{\mathrm{w}}}{\partial t}=-\frac{\mathrm{i}}{2 \pi m} \int \mathrm{d} y\left[\frac{\partial^{2} \psi^{*}(q+y)}{\partial y^{2}} \psi(q-y)-\psi^{*}(q+y) \frac{\partial^{2} \psi(q-y)}{\partial y^{2}}\right] \mathrm{e}^{2 \mathrm{i} p y / \hbar},
$$

where we have taken advantage of the functional dependence of $\psi$ to replace $\partial^{2} / \partial q^{2}$ by $\partial^{2} / \partial y^{2}$. Next we perform one partial integration with respect to $y$ to obtain

$$
\frac{\partial_{k} P_{\mathrm{w}}}{\partial t}=-\frac{p}{\pi \hbar m} \int \mathrm{d} y\left[\frac{\partial \psi^{*}(q+y)}{\partial y} \psi(q-y)-\psi^{*}(q+y) \frac{\partial \psi(q-y)}{\partial y}\right] e^{2 \mathrm{i} p y / \hbar}
$$


since the boundary term does not contribute. Switching back from $\partial / \partial y$ to $\partial / \partial q$, we finally obtain

$$
\frac{\partial_{k} P_{\mathrm{w}}}{\partial t}=-\frac{p}{m} \frac{\partial P_{\mathrm{w}}(q, p)}{\partial q}
$$

This is identical with the classical (Liouville) equation for the corresponding part of $\partial P / \partial t$, as was mentioned at eq. (2.7). We next calculate

$$
\begin{aligned}
\frac{\partial_{v} P_{\mathrm{w}}}{\partial t} & =\frac{\mathrm{i}}{\pi \hbar^{2}} \int \mathrm{d} y\left\{\left[V \psi^{*}(q+y)\right] \psi(q-y)-\psi^{*}(q+y)[V \psi(q-y)]\right\} \mathrm{e}^{2 \mathrm{i} p y / \hbar} \\
& =\frac{\mathrm{i}}{\pi \hbar^{2}} \int \mathrm{d} y[V(q+y)-V(q-y)] \psi^{*}(q+y) \psi(q-y) \mathrm{e}^{2 \mathrm{i} p y / \hbar}
\end{aligned}
$$

Assuming that $V$ can be expanded in a Taylor series, we write

$$
V(q+y)=\sum_{\lambda=0}^{\infty} \frac{y^{\lambda}}{\lambda !} V^{(\lambda)}(q)
$$

where $V^{(\lambda)}(q)=\partial^{\lambda} V / \partial q^{\lambda}$. It follows that

$$
\frac{\partial_{v} P_{\mathrm{w}}}{\partial t}=\frac{2 \mathrm{i}}{\pi \hbar^{2}} \int \mathrm{d} y \sum_{\lambda} \frac{y^{\lambda}}{\lambda !} V^{(\lambda)}(q) \psi^{*}(q+y) \psi(q-y) \mathrm{e}^{2 \mathrm{i} p y / \hbar},
$$

where now the summation over $\lambda$ is restricted to all odd positive integers. It is clear that in the powers $y^{\lambda}$ in the integrand we can replace $y$ by $(\hbar / 2 i)(\partial / \partial p)$. It then follows that

$$
\frac{\partial_{v} P_{\mathrm{w}}}{\partial t}=\sum_{\lambda} \frac{1}{\lambda !}\left(\frac{\hbar}{2 \mathrm{i}}\right)^{\lambda-1} \frac{\partial^{\lambda} V(q)}{\partial q^{\lambda}} \frac{\partial^{\lambda} P_{\mathrm{w}}(q, p)}{\partial p^{\lambda}}
$$

$\lambda$ again being restricted to odd integers. An alternative form for $\partial_{v} P_{w} / \partial t$ is given by

$$
\frac{\partial_{v} P_{\mathrm{w}}}{\partial t}=\int \mathrm{d} j P_{\mathrm{w}}(q, p+j) J(q, j)
$$

where

$$
\begin{aligned}
J(q, j) & =\frac{\mathrm{i}}{\pi \hbar^{2}} \int \mathrm{d} y[V(q+y)-V(q-y)] \mathrm{e}^{-2 \mathrm{i} p y / \hbar} \\
& =\frac{\mathrm{i}}{\pi \hbar^{2}} \int \mathrm{d} y[V(q+y)-V(q-y)] \sin (2 j y / \hbar)
\end{aligned}
$$

is the probability of a jump in the momentum by an amount $j$ if the positional coordinate is $q$. The first part of eq. (2.55a) may be verified by inserting the Fourier expansion, with respect to $y$, of $V(q+y)$ - 
$V(q-y)$ into eq. (2.51). The second part is obtained by replacing the exponential by cos $+\mathrm{i}$ sin and noting that the expansion in the square bracket is odd so that the integral of the cos part vanishes.

In the multi-dimensional case where $P_{\mathrm{w}}=P_{\mathrm{w}}\left(q_{1}, \ldots q_{n} ; p_{1}, \ldots p_{n}\right)$, the corresponding results are

$$
\frac{\partial P_{w}}{\partial t}=-\sum_{k=1}^{n} \frac{p_{k}}{m_{k}} \frac{\partial P_{w}}{\partial q_{k}}+\sum \frac{\partial^{\lambda_{1}+\cdots+\lambda_{n}} V}{\partial \dot{q}_{1}^{\lambda_{1} \cdots} \cdot \partial \ddot{q}_{n}^{\lambda_{n}}} \frac{(\hbar / 2 i)^{\lambda_{1}+\cdots+\lambda_{n}-1}}{\lambda_{1} ! \cdots \lambda_{n} !} \frac{\partial^{\lambda_{1}+\cdots+\lambda_{n}} P_{\mathrm{w}}}{\partial \bar{p}_{1}^{\lambda_{1} \cdots} \cdot \partial \bar{p}_{n}^{\lambda_{n}}}
$$

where the last summation has to be extended over all positive integer values of $\lambda_{1}, \ldots \lambda_{n}$ for which the sum $\lambda_{1}+\lambda_{2}+\cdots+\lambda_{n}$ is odd.

The lowest term of eq. (2.56) in which only one $\lambda$ is 1 and the others vanish, and which has no $\hbar$ factors, is identical with the corresponding term of Liouville's equation. Hence eq. (2.56) reproduces the classical (but non-relativistic) equation if $\hbar$ is set equal to zero. The $\hbar^{2}$ terms give the quantum correction if this is very small. We will obtain a somewhat similar equation for the $1 / T$ dependence of the distribution function of the canonical ensemble, which also is useful if the temperature $T$ is not too low so that the quantum correction is small.

Eq. (2.56) is the generalization of eq. (2.50) and eq. (2.54) for an $n$-dimensional configuration space. The same generalization of eq. (2.50) with eq. (2.55) is

$$
\frac{\partial P_{\mathrm{w}}}{\partial t}=-\sum_{k} \frac{p_{k}}{m_{k}} \frac{\partial P_{\mathrm{w}}}{\partial q_{k}}+\int \mathrm{d} j_{1} \cdots \int \mathrm{d} j_{n} P_{\mathrm{w}}\left(q_{1}, \ldots q_{n} ; p_{1}+j_{1}, \ldots p_{n}+j_{n}\right) J\left(q_{1}, \ldots q_{n} ; p_{1}, \ldots p_{n}\right)
$$

where $J\left(q_{1}, \ldots q_{n} ; j_{1}, \ldots j_{n}\right)$ can be interpreted as the probability of a jump in the momenta with the amounts $j_{1}, \ldots j_{n}$ for the configuration $q_{1}, \ldots q_{n}$. The probability of this jump is given by

$$
\begin{aligned}
J\left(q_{1}, \ldots q_{n} ; j_{1}, \ldots j_{n}\right)= & \frac{\mathrm{i}}{\pi^{n} \hbar^{n+1}} \int \mathrm{d} y_{1} \cdots \int \mathrm{d} y_{n}\left[V\left(q_{1}+y_{1}, \ldots q_{n}+y_{n}\right)-V\left(q_{1}-y_{1}, \ldots q_{n}-y_{n}\right)\right] \\
& \times \exp \left\{-(2 \mathrm{i} / \hbar)\left(y_{1} j_{1}+\cdots+y_{n} j_{n}\right)\right\}
\end{aligned}
$$

that is, by the Fourier expansion coefficients of the potential $V\left(q_{1}, \ldots q_{n}\right)$.

From eq. (2.56) it is clear that the equation of motion is the same as the classical equation of motion when $V$ has no third and higher derivatives as, for example, in the case of a uniform electric field or for a system of oscillators. However, there is still a subtle difference in that the possible initial conditions are restricted. This comes about because not all $P(q, p)$ are permissible (see eq. $(2.19 b)$ ).

While we consider that the above form for the equations of motion (Wigner [1932]) are the simplest to use in practice, we will now discuss some other forms which occur frequently in the literature.

Before doing so it is useful to take note of another relation, in addition to that given by eq. (2.23), which expresses the Weyl function corresponding to an operator $\hat{F}=\hat{A} \hat{B}$ in terms of the Weyl functions corresponding to $\hat{A}$ and $\hat{B}$. This relation was first derived by Groenewold [1946] and was also discussed by Imre, Ozizmir, Rosenbaum and Zweifel [1967]. They find that the function corresponding to $\hat{F}$ is

$$
\begin{aligned}
\hat{A} \hat{B}=\hat{F} \rightarrow F(q, p) & =A(q, p) \mathrm{e}^{(\Lambda A / 2 \mathrm{i})} B(q, p) \\
& =B(q, p) \mathrm{e}^{-(A \alpha / 2 \mathrm{i})} A(q, p),
\end{aligned}
$$


where

$$
\Lambda=\frac{\grave{\partial}}{\partial p} \frac{\vec{\partial}}{\partial q}-\frac{\grave{\partial}}{\partial q} \frac{\vec{\partial}}{\partial p}
$$

and the arrows indicate in which direction the derivatives act. Also $(\partial / \partial p)(\partial / \partial q)$ is considered as the multi-dimensional scalar product of $\partial / \partial p$ and $\partial / \partial q$, or, in other words, it is equal to $\left(\partial / \partial p_{i}\right)\left(\partial / \partial q_{i}\right)$, where $i=(1, \ldots n)$ and $n$ denotes the number of dimensions and, as usual, repeated indices denotes summation.

To derive this result we first note that

$$
\left\langle q^{\prime \prime}|\hat{A}| q^{\prime}\right\rangle=\int \mathrm{d} \sigma \exp \left\{(\mathrm{i} / \hbar) \sigma\left(q^{\prime}+q^{\prime \prime}\right) / 2\right\} \alpha\left(\sigma, q^{\prime}-q^{\prime \prime}\right)
$$

where $\alpha$ is defined by eq. (2.32). This result follows from eq. (2.33) by taking the matrix element of both sides. A similar result follows for $\left\langle q^{\prime \prime}|\hat{B}| q^{\prime}\right\rangle$ except that $\alpha$ is replaced by $\beta$, the Fourier transform of $B(q, p)$ :

$$
\hat{B}(\hat{q}, \hat{p})=\int \mathrm{d} \sigma \int \mathrm{d} \tau \exp \{(\mathrm{i} / \hbar)(\sigma \hat{q}+\tau \hat{p})\} \beta(\sigma, \tau)
$$

We can now calculate $F(q, p)$. We have from eq. (2.12) that

$$
\begin{aligned}
F(q, p)= & \int \mathrm{d} z \mathrm{e}^{(\mathrm{i} / \hbar) p z}\left\langle q-\frac{z}{2}|\hat{A} \hat{B}| q+\frac{z}{2}\right\rangle \\
= & \int \mathrm{d} z \int \mathrm{d} q^{\prime} \mathrm{e}^{(\mathrm{i} / h) p z}\left\langle q-\frac{z}{2}|\hat{A}| q^{\prime}\right\rangle\left\langle q^{\prime}|\hat{B}| q+\frac{z}{2}\right\rangle \\
= & \int \mathrm{d} z \int \mathrm{d} q^{\prime} \int \mathrm{d} \sigma \int \mathrm{d} \sigma^{\prime} \mathrm{e}^{(i / h) \sigma\left(q^{\prime}+q-z / 2\right) / 2} \mathrm{e}^{(\mathrm{i} / \hbar) \sigma^{\prime}\left(q^{\prime}+q+z / 2\right) / 2} \\
& \times \alpha\left(\sigma, q^{\prime}-q+\frac{z}{2}\right) \beta\left(\sigma^{\prime}, q-q^{\prime}+\frac{z}{2}\right) \mathrm{e}^{(\mathrm{i} / \hbar) p z}
\end{aligned}
$$

We now define two new variables of integration $\tau=q^{\prime}-q+(z / 2)$ and $\tau^{\prime}=q-q^{\prime}+(z / 2)$ so that

$$
F(q, p)=\int \mathrm{d} \tau \int \mathrm{d} \tau^{\prime} \int \mathrm{d} \sigma \int \mathrm{d} \sigma^{\prime} \mathrm{e}^{(\mathrm{i} / \hbar)(\sigma q+\tau p)} \alpha(\sigma, \tau) \mathrm{e}^{(\mathrm{i} / h)\left(\sigma^{\prime} \tau-\sigma \tau^{\prime}\right) / 2} \mathrm{e}^{(\mathrm{i} / \hbar)\left(\sigma^{\prime} q+\tau^{\prime} p\right)} \beta\left(\sigma^{\prime}, \tau^{\prime}\right)
$$

It is possible to replace the exponential factor $\exp \left\{(\mathrm{i} / \hbar)\left(\sigma^{\prime} \tau-\sigma \tau^{\prime}\right) / 2\right\}$ by $\exp (\hbar \Lambda / 2 \mathrm{i})$ so that eq. (2.64) becomes

$$
F(q, p)=A(q, p) \mathrm{e}^{A \Lambda / 2 i} B(q, p)
$$

i.e. just the first expression appearing on the right-hand side of eq. (2.59). The second expression also follows readily from eq. (2.64). 
We can also make use of eq. (2.64) to find an alternative expression for $F(q, p)$ involving the Bopp operators (Bopp [1961] and Kubo [1964\})

$$
Q=q-\frac{\hbar}{2 \mathrm{i}} \frac{\partial}{\partial p}, \quad P=p+\frac{\hbar}{2 \mathrm{i}} \frac{\partial}{\partial q}
$$

We first note that

$$
\exp \left\{\frac{\mathrm{i}}{\hbar}\left[\sigma\left(q-\frac{\hbar}{2 \mathrm{i}} \frac{\partial}{\partial p}\right)+\tau\left(p+\frac{\hbar}{2 \mathrm{i}} \frac{\partial}{\partial q}\right)\right]\right\}=\exp \left\{\frac{\mathrm{i}}{\hbar}(\sigma q+\tau p)\right\} \exp \left\{\frac{1}{2}\left(\tau \frac{\partial}{\partial q}-\sigma \frac{\partial}{\partial p}\right)\right\}
$$

so that

$$
\exp \left\{\frac{\mathrm{i}}{\hbar}\left[\sigma\left(q-\frac{\hbar}{2 \mathrm{i}} \frac{\partial}{\partial p}\right)+\tau\left(p+\frac{\hbar}{2 \mathrm{i}} \frac{\partial}{\partial q}\right)\right]\right\} \mathrm{e}^{(\mathrm{i} / \hbar)\left(\sigma^{\prime} q+\tau^{\prime} p\right)}=\mathrm{e}^{(\mathrm{i} / \hbar)(\sigma q+\tau p)} \mathrm{e}^{(\mathrm{i} / \hbar)\left(\sigma^{\prime} \tau-\sigma \tau^{\prime}\right) / 2}
$$

Using this result in eq. (2.64) we then have that

$$
F(q, p)=\int \mathrm{d} \tau \int \mathrm{d} \tau^{\prime} \int \mathrm{d} \sigma \int \mathrm{d} \sigma^{\prime} \mathrm{e}^{(\mathrm{i} / \hbar)(\sigma Q+\tau P)} \alpha(\sigma, \tau) \mathrm{e}^{(\mathrm{i} / \hbar)\left(\sigma^{\prime} q+\tau^{\prime} p\right)} \beta\left(\sigma^{\prime}, \tau^{\prime}\right)
$$

From eq. (2.33) we see that the expression

$$
\tilde{A}(Q, P) \equiv \int \mathrm{d} \tau \int \mathrm{d} \sigma \mathrm{e}^{(\sigma / \hbar)(\sigma O+\tau P)} \alpha(\sigma, \tau)
$$

is just the Weyl-ordered operator $\hat{A}(\hat{q}, \hat{p})$ with $\hat{q} \rightarrow Q$ and $\hat{p} \rightarrow P . \tilde{A}(Q, P)$ is also an operator but not on the Hilbert space on which $\hat{A}(\hat{q}, \hat{p})$ is an operator; it operates on functions in phase space. We can, therefore, express $F(q, p)$ as

$$
F(q, p)=\tilde{A}(Q, P) B(q, p)
$$

In a similar manner one can show that

$$
F(q, p)=\tilde{B}\left(Q^{*}, P^{*}\right) A(q, p),
$$

where

$$
Q^{*}=q+\frac{\hbar}{2 \mathrm{i}} \frac{\partial}{\partial p}, \quad P^{*}=p-\frac{\hbar}{2 \mathrm{i}} \frac{\partial}{\partial q} .
$$

It is now possible to make use of the fact that the Wigner distribution is the function which is associated with $(1 / 2 \pi \hbar) \hat{\rho}$. The equation of motion for $\hat{\rho}$ is just

$$
\mathrm{i} \hbar \partial \hat{\rho} / \partial \tau=[\hat{H}, \hat{\rho}] \text {. }
$$


This implies that we have for the Wigner function

$$
\mathrm{i} \hbar \partial P_{\mathrm{w}} / \partial t=H(q, p) \mathrm{e}^{h / 1 / 2 \mathrm{i}} P_{\mathrm{w}}(q, p)-P_{\mathrm{w}}(q, p) \mathrm{e}^{\hbar \lambda / 2 \mathrm{i}} H(q, p)
$$

or

$$
\hbar \partial P_{\mathrm{w}} / \partial t=-2 H(q, p) \sin (\hbar \Lambda / 2) P_{\mathrm{w}}(q, p)
$$

where $H(q, p)$ is the function corresponding to the Hamiltonian operator for the system, $\hat{H}$. Actually, this is an abbreviated form of eq. (2.56) as can be verified by expanding the sin into a power series. Note that if we take the $\hbar \rightarrow()$ limit of this equation we obtain the classical Liouville equation

$$
\partial P_{\mathrm{w}}^{\mathrm{c}} / \partial t+\left\{P_{\mathrm{w}}^{\mathrm{c}}, H\right\}=0
$$

where \{\} denote Poisson brackets and the superscript $c$ on $P_{\mathrm{w}}$ indicates the classical limit. For an $H(q, p)$ which is at most quadratic in $q$ and $p$, e.g. a free particle or an harmonic oscillator, eqs. (2.75) and (2.76) coincide. In these systems, then, the difference between a classical and a quantum ensemble is the restriction on the initial conditions in the case of latter (cf. eq. (2.19)).

We also want to quote two alternate forms of eq. (2.75). The first follows immediately from our discussion of the Bopp operators. We have, using eqs. (2.65), (2.71), (2.72) and (2.75), that

$$
i \hbar \partial P_{\mathrm{w}} / \partial t=\left[\tilde{H}(Q, P)-\tilde{H}\left(Q^{*}, P^{*}\right)\right] P_{\mathrm{w}}(q, p),
$$

a result first obtained by Bopp [1961]. Analogous to the definition of $A(\tilde{Q}, P)$, given by eq. (2.70). $\tilde{H}(Q, P)$ is the Weyl-ordered operator with $\hat{q} \rightarrow Q$ and $\hat{p} \rightarrow P$, where $O$ and $P$ are defined in eq. (2.66). These equations do not exhaust the possible formulations of the dynamics of the Wigner function. One can also make use of propagation kernels. This approach is discussed by Moyal [1949] and Mori, Oppenheim and Ross [1962].

We turn now to a consideration of a canonical ensemble. If $\beta=1 / k T$ where $k$ is Boltzmann's constant and $T$ is the temperature, then the density matrix of the canonical ensemble is

$$
\hat{\rho}=\frac{1}{Z(\beta)} \mathrm{e}^{-\beta \dot{H}} \equiv \frac{1}{Z(\beta)} \hat{\Omega}
$$

and $Z(\beta)=\operatorname{Tr}\left(\mathrm{e}^{-\beta \hat{H}}\right)$. The unnormalized density matrix, $\hat{\Omega}$, then satisfies the equation

$$
\partial \hat{\Omega} / \partial \beta=-\hat{H} \hat{\Omega}=-\hat{\Omega} \hat{H},
$$

subject to the initial condition $\hat{\Omega}(\beta=0)=\hat{I}$ where $\hat{I}$ is the identity operator. Eq. (2.79) is referred to as the Bloch [1932] equation for the density matrix of a canonical ensemble. Using the product rule given by eq. (2.59) we have that

$$
\partial \Omega(q, p) / \partial \beta=-H(q, p) \mathrm{e}^{\hbar A / 2 \mathrm{i}} \Omega(q, p)=-H(q, p) \mathrm{e}^{-\hbar \Lambda / 2 \mathrm{i}} \Omega(q, p),
$$

$\Lambda$ being given by eq. (2.60) so that 


$$
\partial \Omega(q, p) / \partial \beta=-H(q, p) \cos (\hbar \Lambda / 2) \Omega(q, p)
$$

This is the Wigner translation of the Bloch equation, which was entensively studied by many authors and was first derived in this form by Oppenheim and Ross [1957]. It is useful in the calculation of quantum mechanical corrections to classical statistical mechanics. The initial condition for this equation is just the Wigner function corresponding to $\hat{\Omega}(\beta=0)=\hat{I}$. Inserting $I$ in eq. (2.12) we find that the initial condition is just $\left.\Omega(q, p)\right|_{\beta=0}=1$.

It is also worth noting that $P_{\mathrm{w}}(q, p)$ does not satisfy the Wigner translation of the Bloch equation simply because of the fact that it must be multiplied by the $\beta$-dependent factor $(2 \pi \hbar) Z(\beta)$ in order to obtain $\Omega(q, p)$.

Finally, we emphasize that all equations from eq. (2.59) onwards hold in the multi-dimensional case, where we simply interpret $(q, p)$ to be $\left(q_{1}, \ldots q_{n} ; p_{1}, \ldots p_{n}\right)$ and the simple products in the exponents as scalar products. The solution of eq. (2.81) in the multi-dimensional case, is to order $\hbar^{2}$ (Wigner [1932a]),

$$
\Omega_{\mathrm{w}}(q, p)=\mathrm{e}^{-\beta H\left(q_{.} p\right)}\left\{1+(2 \pi \hbar)^{2}\left[\sum_{k}\left(-\frac{\beta^{2}}{8 m_{k}} \frac{\partial^{2} V}{\partial q_{k}^{2}}+\frac{\beta^{3}}{24 m_{k}}\left(\frac{\partial V}{\partial q_{k}}\right)^{2}\right)+\sum_{k, l} \frac{\beta^{3} p_{k} p_{l}}{24 m_{k} m_{l}} \frac{\partial^{2} V}{\partial q_{k} \partial q_{l}}\right]\right\}
$$

Actually, the Wigner translation of the Bloch equation, eq. (2.18) above, can be simplified further into a form, analogous to that of eq. (2.56), which is more convenient for applications. This is achieved by writing the cos term as the real part of the operator

$$
\hat{0} \equiv \exp \left[\frac{\mathrm{i} \hbar}{2}\left(\frac{\grave{\partial}}{\partial p} \frac{\vec{\partial}}{\partial q}-\frac{\dot{\partial}}{\partial q} \frac{\vec{\partial}}{\partial p}\right)\right]
$$

where we have used the explicit form for $\Lambda$ given in eq. (2.60), again noting that the arrows indicate in which direction the derivatives act and that the gradient operators are $3 N$-dimensional. Next we decompose $\hat{0}$ by means of the Baker-Hausdorff theorem (eq. (2.35a)), and using the fact that

$$
\frac{\partial}{\partial p} \frac{\partial}{\partial q} H(q, p)=0
$$

it follows that we may write

$$
\hat{0}=\exp \left[\frac{i \hbar}{2} \frac{\grave{\partial}}{\partial p} \frac{\vec{\partial}}{\partial q}\right] \exp \left[-\frac{i \hbar}{2} \frac{\grave{\partial}}{\partial q} \frac{\vec{\partial}}{\partial p}\right]
$$

where we have neglected terms which do not contribute in the present context. Again because of eq. (2.84), and also using the fact that we are only interested in the real part, it follows that the only terms in $\hat{0}$ which contribute are

$$
\exp \left[-\frac{i \hbar}{2} \frac{\grave{\partial}}{\partial q} \frac{\vec{\partial}}{\partial p}\right]-\frac{\hbar^{2}}{8} \frac{\grave{\partial}}{\partial p_{i}} \frac{\check{\partial}}{\partial p_{j}} \frac{\vec{\partial}}{\partial q_{i}} \frac{\vec{\partial}}{\partial q_{j}}
$$

where $i, j=1, \ldots n$ (and as usual, it is understood that $(\partial / \partial q)(\partial / \partial p)$ stands for $\left(\partial / \partial q_{i}\right)\left(\partial / \partial p_{i}\right)$ ). From henceforth, we will assume that we are dealing with a system of $(n / 3)$ identical particles of mass $m$. 
Hence, since $H=\left(p^{2} / 2 m\right)+V$, it follows that

$$
H \hat{0} \Omega=\left\{\exp \left[-\frac{i \hbar}{2} \frac{\vec{\partial}}{\partial q} \frac{\vec{\partial}}{\partial p}\right] V-\frac{\hbar^{2}}{2 m} \frac{\vec{\partial}^{2}}{\partial q^{2}}+\frac{p^{2}}{2 m}\right\} \Omega
$$

where it is to be understood that the $(\vec{\partial} / \partial q)$ term in the exponential operates only on $V$ and not on $\Omega$ (whereas the $\vec{\partial}^{2} / \partial q^{2}$ term operates on $\Omega$ ). Also, the $\vec{\partial} / \partial p$ term has no effect on $V$ and thus operates only on $\Omega$. Since all arrows now operate to the right, they will be omitted from henceforth so that we finally obtain

$$
\begin{aligned}
\frac{\partial \Omega(q, p)}{\partial \beta} & =-\left\{\frac{p^{2}}{2 m}+\cos \left(\frac{\hbar}{2} \frac{\partial}{\partial q} \frac{\partial}{\partial p}\right) V-\frac{\hbar^{2}}{8 m} \frac{\partial^{2}}{\partial q^{2}}\right\} \Omega \\
& =\left\{-H+2 \sin ^{2}\left(\frac{\hbar}{4} \frac{\partial}{\partial q} \frac{\partial}{\partial p}\right) V+\frac{\hbar^{2}}{8 m} \frac{\partial^{2}}{\partial q^{2}}\right\} \Omega,
\end{aligned}
$$

where the $\partial / \partial q$ term in the cos and sin terms is to be understood as operating only on $V$. Such a form was given for the first time by Alastuey and Jancovici [1980] and, in fact, their result also takes account of the presence of a magnetic field. We recall that $(\partial / \partial p)(\partial / \partial q)$ is considered as the multi-dimensional scalar product of $\partial / \partial p$ and $\partial / \partial q$, or, in other words it is equal to $\left(\partial / \partial p_{i}\right)\left(\partial / \partial q_{i}\right)$ where $i$ goes from 1 to $n$ and $n$ denotes the number of dimensions. Hence, the explicit form of eq. (2.88a) is

$$
\frac{\partial \Omega(q, p)}{\partial \beta}=-\left\{\frac{p_{i} p_{i}}{2 m}-\frac{\hbar^{2}}{8 m} \frac{\partial^{2}}{\partial q_{i} \partial q_{i}}+\sum \frac{(\mathrm{i} \hbar / 2)^{\lambda_{1}+\lambda_{2}+\cdots+\lambda_{n}}}{\lambda_{1} ! \lambda_{2} ! \cdots \lambda_{n} !} \frac{\partial^{\lambda_{1}+\cdots+\lambda_{n}} V}{\partial q_{1}^{\lambda_{1}} \cdots \partial q_{n}^{\lambda_{n}}} \frac{\partial^{\lambda_{1}+\cdots+\lambda_{n}}}{\partial p_{1}^{\lambda_{1}} \cdots p_{n}^{\lambda_{n}}}\right\} \Omega
$$

where the last summation is to be extended over all positive integer values, as well as zero values, of $\lambda_{1}, \lambda_{2}, \ldots \lambda_{n}$, for which the sum $\lambda_{1}+\lambda_{2}+\cdots+\lambda_{n}$ is even. This form for the Wigner translation of the Bloch equation is the most convenient from the point of view of applications.

One of the earliest applications of these results was to the quantum corrections of the classical equations of state and to similar corrections to chemical reaction rates (Wigner [1932b, 1938]) and they have been extensively used in statistical mechanics (Oppenheim and Ross [1957]; Mori, Oppenheim and Ross [1962]; Nienhuis [1970], for example). However, we will defer a detailed discussion of applications to Part II of our review, to be published at a later date.

\subsection{An example}

We would now like to use some of the formalism which we have developed to actually calculate some distribution functions. The system which we will consider is the harmonic oscillator and we will consider both pure and mixed states. We will find the Wigner functions corresponding to the eigenstates of the harmonic oscillator and also the function corresponding to a canonical ensemble of harmonic oscillators at temperature $T$.

The eigenstates of the harmonic oscillator are (Landau and Lifshitz [1965])

$$
U_{n}(q)=\left(\frac{\alpha^{2}}{4}\right)^{1 / 4}\left(\frac{1}{2^{n} n !}\right)^{1 / 2} \mathrm{e}^{-\alpha^{2} q^{2} / 2} H_{n}(\alpha q)
$$


where $H_{n}$ is the $n$th Hermite polynomial and $\alpha=(m \omega / \hbar)^{1 / 2}$. Substituting this expression into the definition of the distribution function, eq. (2.2a), we find that

$$
U_{n}^{*}(q+y) U_{n}(q-y)=\left(\frac{\alpha^{2}}{\pi}\right)^{1 / 2} \frac{1}{2^{n} n !} \exp \left\{-a^{2}\left[(q+y)^{2}+(q-y)^{2}\right] / 2\right\} H_{n}(\alpha(q+y)) \cdot H_{n}(\alpha(q-y))
$$

so that

$$
P_{w}(q, p)=\frac{1}{\pi \hbar} \frac{\alpha}{\sqrt{\pi}} \frac{1}{2^{n} n !} \mathrm{e}^{-\alpha^{2} q^{2}} \int \mathrm{d} y \mathrm{e}^{2 \mathrm{i} p y / \hbar} \mathrm{e}^{-\alpha^{2} y^{2}} H_{n}(\alpha(q+y)) H_{n}(\alpha(q-y))
$$

We now note that

$$
\alpha^{2} y^{2}-2 i p y / \hbar=\alpha^{2}\left(y-i p / \alpha^{2} \hbar\right)^{2}+p^{2} / \alpha^{2} \hbar^{2}
$$

and define a new variable

$$
z=\alpha\left(y-\mathrm{i} p / \alpha^{2} \hbar\right)
$$

We then have that

$$
P_{\mathrm{w}}(q, p)=\frac{1}{\sqrt{\pi}} \frac{1}{\pi \hbar} \frac{1}{2^{n} n !} \mathrm{e}^{-\alpha q^{2}} \mathrm{e}^{\beta^{2}} \int \mathrm{d} z \mathrm{e}^{-z^{2}} H_{n}(\alpha q+z+\beta) H_{n}(\alpha q-z-\beta),
$$

where $\beta=\mathrm{i} / \alpha \hbar$. Noting the $H_{n}(-x)=(-1)^{n} H_{n}(x)$ we find

$$
P_{\mathrm{w}}(q, p)=\frac{1}{\sqrt{\pi}} \frac{1}{\pi \hbar} \frac{(-1)^{n}}{2^{n} n !} \mathrm{e}^{-\alpha q^{2}} \mathrm{e}^{\beta^{2}} \int \mathrm{d} z \mathrm{e}^{-z^{2}} H_{n}(\alpha q+z+\beta) H_{n}(z+\beta-\alpha q) .
$$

The above integral can be done (Gradshteyn and Ryzhik [1980]) and is

$$
\int \mathrm{d} z \mathrm{e}^{-z^{2}} H_{n}(z+\beta+\alpha q) H_{n}(z+\beta-\alpha q)=2^{n} \sqrt{\pi} n ! L_{n}\left(2\left(\alpha^{2} q^{2}-\beta^{2}\right)\right),
$$

where $L_{n}$ is the $n$th Laguerre polynomial. Re-expressing $\alpha$ and $\beta$ in terms of $q$ and $p$ we have

$$
\alpha^{2} q^{2}-\beta^{2}=\frac{2}{\hbar \omega}\left(\frac{p^{2}}{2 m}+\frac{1}{2} m \omega^{2} q^{2}\right)=\frac{2}{\hbar \omega} H(q, p)
$$

so that (Groenewold [1946]; Takabayaski [1954]; Dahl [1982])

$$
P_{\mathrm{w}}(q, p)=(1 / \pi \hbar)(-1)^{n} \mathrm{e}^{-2 H / \hbar \omega} L_{n}(4 H / \hbar \omega) .
$$

Before discussing this result we will first calculate the distribution for an ensemble of oscillators at temperature $T$ (Imre, Ozizmir, Rosenbaum and Zweifel [1967]). Here we proceed by way of the Wigner 
translation of the Bloch equation (eq. (2.88b)) which for this system results in

$$
\frac{\partial \Omega(q, p)}{\partial \beta}=\left\{-\left(\frac{p^{2}}{2 m}+\frac{1}{2} m \omega^{2} q^{2}\right)+2 \sin ^{2}\left(\frac{\hbar}{4} \frac{\partial}{\partial q} \frac{\partial}{\partial p}\right) V+\frac{\hbar^{2}}{8 m} \frac{\partial^{2}}{\partial q^{2}}\right\} \Omega
$$

Because $V$ is quadratic in $q^{2}$ it is clear that only the leading order term in the $\sin ^{2}$ expansion will contribute, and since $\partial^{2} V / \partial q^{2}=m \omega^{2}$, it follows that the Wigner translation of the Bloch equation for the oscillator reduces to

$$
\frac{\partial \Omega}{\partial \beta}=-\left(\frac{p^{2}}{2 m}+\frac{1}{2} m \omega^{2} q^{2}\right) \Omega+\frac{\hbar^{2}}{8}\left(\frac{1}{m} \frac{\partial^{2} \Omega}{\partial q^{2}}+m \omega^{2} \frac{\partial^{2} \Omega}{\partial p^{2}}\right)
$$

To solve this equation we make the Ansatz

$$
\Omega(q, p)=\exp \{-A(\beta) H+B(\beta)\}
$$

where $A(0)=B(0)=0$, and $H=\left(p^{2} / 2 m\right)+\frac{1}{2} m \omega^{2} q^{2}$. Substituting this into eq. (2.101) gives us

$$
\begin{aligned}
\left(-\frac{\mathrm{d} A}{\mathrm{~d} \beta} H+\frac{\mathrm{d} B}{\mathrm{~d} \beta}\right) \Omega & =-H \Omega+\frac{\hbar^{2}}{8}\left[\frac{1}{m} \omega^{2}\left(-m A+m \omega^{2} q^{2} A^{2}\right)+m \omega^{2}\left(-\frac{A}{m}+\frac{p^{2}}{m}\right) A^{2}\right] \Omega \\
& =-H \Omega+\frac{(\hbar \omega)^{2}}{4}\left(-A+H A^{2}\right) \Omega .
\end{aligned}
$$

This equation can be re-expressed in the form

$$
H(q, p)\left[-\frac{\mathrm{d} A}{\mathrm{~d} \beta}+1-\frac{(\hbar \omega)^{2}}{4} A^{2}\right]+\left[\frac{\mathrm{d} B}{\mathrm{~d} \beta}+\frac{(\hbar \omega)^{2}}{4} A\right]=0
$$

Because this equation must hold for all $q$ and $p$, and the terms in the brackets are independent of $q$ and $p$, they must vanish independently, i.e.

$$
\begin{aligned}
& \frac{\mathrm{d} A}{\mathrm{~d} \beta}+\frac{(\hbar \omega)^{2}}{4} A^{2}-1=0 \\
& \frac{\mathrm{d} B}{\mathrm{~d} \beta}+\frac{(\hbar \omega)^{2}}{4} A=0 .
\end{aligned}
$$

Eq. (2.105) can be integrated directly. One has that

$$
\int \frac{\mathrm{d} A}{1-(\hbar \omega / 2)^{2}} \bar{A}^{2}=\int \mathrm{d} \beta
$$

or

$$
\beta=\frac{1}{\hbar \omega} \ln \left[\left(1+\frac{\hbar \omega}{2} A\right) /\left(1-\frac{\hbar \omega}{2} A\right)\right]
$$


Inverting this equation gives us that

$$
A(\beta)=(2 / \hbar \omega) \tanh (\hbar \omega \beta / 2) \text {. }
$$

This can now be substituted into eq. (2.106) to give

$$
B(\beta)=-\frac{\hbar \omega}{2} \int_{0}^{\beta} \mathrm{d} \beta^{\prime} \tanh \left(\frac{\hbar \omega \beta^{\prime}}{2}\right)=-\ln \cosh \left(\frac{\hbar \omega \beta}{2}\right) .
$$

Therefore, we have

$$
\Omega(q, p)=\operatorname{sech}(\hbar \omega \beta / 2) \exp [-(2 / \hbar \omega) \tanh (\hbar \omega \beta / 2) H(q, p)]
$$

To complete our derivation we need to normalize the above expression. As was noted before the Wigner function is the function which corresponds to the operator $(\hat{\rho} / 2 \pi \hbar)$. From eq. $(2.78)$ we then have

$$
P_{\mathrm{w}}(q, p)=\frac{1}{2 \pi \hbar} \frac{1}{Z(\beta)} \Omega(q, p)
$$

as $\Omega(q, p)$ is just the function corresponding to $\mathrm{e}^{-\beta A}$. We also have from eq. (2.11) (setting $\hat{A}=\mathrm{e}^{-\beta A}$ and $\hat{B}=\hat{I}$ )

$$
Z(\beta)=\operatorname{Tr}\left(\mathrm{e}^{-\beta A}\right)=\frac{1}{2 \pi \hbar} \int \mathrm{d} q \int \mathrm{d} p \Omega(q, p)
$$

Substituting eq. (2.111) into eq. (2.113) we find

$$
Z(\beta)=\frac{1}{2}[\sinh (\hbar \omega \beta / 2)]^{-1}
$$

Finally we obtain for $P_{\mathrm{w}}(q, p)$, from eqs. (2.111), (2.112) and (2.114),

$$
P_{\mathrm{w}}(q, p)=(1 / \pi \hbar) \tanh (\hbar \omega \beta / 2) \exp [-(2 / \hbar \omega) \tanh (\hbar \omega \beta / 2) H(q, p)]
$$

We now want to compare the two expressions (eq. (2.99) and eq. (2.115)) for $P_{w}$ for the pure and mixed states, respectively. Examining the first few Laguerre polynomials

$$
\begin{aligned}
& L_{0}(x)=1 \\
& L_{1}(x)=1-x \\
& L_{2}(x)=1-2 x+x^{2}
\end{aligned}
$$

we see that for the ground state of the oscillator $P_{\mathrm{w}}(q, p)>0$ while for excited states $P_{\mathrm{w}}(q, p)$ can assume negative values. The result for the canonical ensemble, however, is always positive. It does not have the oscillatory structure which is present in the expressions given by eq. (2.99). The incoherence induced by a finite temperature leads to a much smoother distribution function. 
2.5. Statistics and second-quantized notation (Klimintovich [1958]; Brittin and Chappell [1962); Imre, Ozizmir, Rosenbaum and Zweifel [1967])

When one is dealing with more than one particle one has to include the effects of quantum statistics. To illustrate how these effects come in to the Wigner function we will first consider an example. We will then show how the Wigner function can be expressed in second-quantized notation. In this form it is easier to take the effects of statistics into account, but two of us have an article in preparation (O'Connell and Wigner [1983]) which not only will take the effect of statistics into account, but will also include spin effects.

Let us consider two identical particles in one dimension in a harmonic potential well. We will further assume that the particles are bosons. The Hamiltonian for the system is

$$
\hat{H}=\frac{1}{2 m}\left(\hat{p}_{1}^{2}+\hat{p}_{2}^{2}\right)+\frac{1}{2} m \omega^{2}\left(\hat{q}_{1}^{2}+\hat{q}_{2}^{2}\right) \text {. }
$$

Suppose that we want to find the Wigner distribution for a canonical ensemble of these systems at a temperature $T$. We would again like to use the Wigner translation of the Bloch equation but now we must be more careful; the initial condition is no longer so simple.

To see this we first find the density matrix for the system. The eigenstates of the Hamiltonian given by eq. (2.117) are

$$
\phi_{n 1 n_{2}}\left(q_{1}, q_{2}\right)= \begin{cases}\frac{1}{\sqrt{2}}\left(U_{n_{1}}\left(q_{1}\right) U_{m_{2}}\left(q_{2}\right)+U_{n_{2}}\left(q_{1}\right) U_{n_{1}}\left(q_{2}\right)\right) & \text { if } n_{1}>n_{2} \\ U_{n 1}\left(q_{1}\right) U_{n 1}\left(q_{2}\right) & \text { if } n_{1}=n_{2},\end{cases}
$$

where $U_{n}(q)$ is given by eq. (2.90). This state has an energy $E_{n 1 n_{2}}$ given by

$$
E_{n 1 n_{2}}=\hbar \omega\left(n_{1}+n_{2}+1\right) \text {. }
$$

The unnormalized density matrix for this system is just

$$
\hat{\Omega}=\sum_{n_{1} \geq n_{2}} \exp \left(-\beta E_{n_{1} n_{2}}\right)\left|\phi_{n_{1} n_{2}}\right\rangle\left\langle\phi_{n_{1} n_{2}}\right|
$$

In the $\beta \rightarrow 0$ limit this becomes

$$
\hat{\Omega}(\beta=0)=\sum_{n_{1} \geq n_{2}}\left|\phi_{n_{1} n_{2}}\right\rangle\left\langle\phi_{n_{1} n_{2}}\right| .
$$

Taking matrix elements we find

$$
\begin{aligned}
\left\langle q_{1}^{\prime}, q_{2}^{\prime}|\hat{\Omega}(\beta=0)| q_{1}, q_{2}\right\rangle= & \sum_{n_{1}>n_{2}} \frac{1}{2}\left(U_{n_{1}}\left(q_{1}^{\prime}\right) U_{n_{2}}\left(q_{2}^{\prime}\right)+U_{n_{2}}\left(q_{1}^{\prime}\right) U_{n_{1}}\left(q_{2}^{\prime}\right)\right) \\
& \times\left(U_{n_{1}}^{*}\left(q_{1}\right) U_{n_{2}}^{*}\left(q_{2}\right)+U_{n_{2}}^{*}\left(q_{1}\right) U_{n_{1}}^{*}\left(q_{2}\right)\right)+\sum_{n} U_{n}\left(q_{1}^{\prime}\right) U_{n}\left(q_{2}^{\prime}\right) U_{n}^{*}\left(q_{1}\right) U_{n}^{*}\left(q_{2}\right) \\
= & \frac{1}{2} \sum_{n_{1} n_{2}}\left(U_{n_{1}}\left(q_{1}^{\prime}\right) U_{n_{2}}\left(q_{2}^{\prime}\right) U_{n_{1}}^{*}\left(q_{1}\right) U_{n_{2}}^{*}\left(q_{2}\right)+U_{n_{1}}\left(q_{1}^{\prime}\right) U_{n_{2}}\left(q_{2}^{\prime}\right) U_{n_{1}}^{*}\left(q_{2}\right) U_{n_{2}}^{*}\left(q_{1}\right)\right) .
\end{aligned}
$$

We can now make use of the identity 


$$
\sum_{n} U_{n}\left(q_{1}^{\prime}\right) U_{n}^{*}\left(q_{1}\right)=\delta\left(q_{1}-q_{1}^{\prime}\right)
$$

to give

$$
\left\langle q_{1}^{\prime}, q_{2}^{\prime}|\hat{\Omega}(\beta=0)| q_{1}, q_{2}\right\rangle=\frac{1}{2}\left[\delta\left(q_{1}^{\prime}-q_{1}\right) \delta\left(q_{2}^{\prime}-q_{2}\right)+\delta\left(q_{1}^{\prime}-q_{2}\right) \delta\left(q_{2}^{\prime}-q_{1}\right)\right],
$$

as was to be expected. If we operate on an arbitrary two particle state, $|\psi\rangle$, with $\hat{\Omega}(\beta=0)$ we have that

$$
\begin{aligned}
\left\langle q_{1}^{\prime}, q_{2}^{\prime}|\hat{\Omega}(\beta=0)| \psi\right\rangle & =\int \mathrm{d} q_{1} \int \mathrm{d} q_{2}\left\langle q_{1}^{\prime}, q_{2}^{\prime}|\hat{\Omega}(\beta=0)| q_{1}, q_{2}\right\rangle\left\langle q_{1}, q_{2} \mid \psi\right\rangle \\
& =\frac{1}{2}\left[\psi\left(q_{1}^{\prime}, q_{2}^{\prime}\right)+\psi\left(q_{2}^{\prime}, q_{1}^{\prime}\right)\right] .
\end{aligned}
$$

If $\psi$ is symmetric the result on the right-hand side of eq. (2.125) is $\psi$, if $\psi$ is anti-symmetric the result is 0 .

Therefore, $\hat{\Omega}(\beta=0)$ is just the projection operator, $\hat{P}_{\mathrm{s}}$ say, onto the state of symmetric two-particle wave functions. This result is also true for an arbitrary number of particles, $N$. Our result that $\hat{\Omega}(\beta=0)$ is $\hat{P}_{\mathrm{S}}$ was derived for bosons. Similarly, if the particles are fermions $\hat{\Omega}(\beta=0)$ is $\hat{P}_{\mathrm{A}}$, the projection onto the space of anti-symmetric $N$-particle wave functions, but in this case, the spin variable should also be included.

Returning now to our example we want to find the initial condition for the Wigner translation of Bloch equation, i.e. we must find the function corresponding to $\hat{P}_{\mathrm{S}}$. Making use of the two-particle extension of eq. (2.12) we find

$$
\begin{aligned}
\Omega\left(q_{1}, q_{2}, p_{1}, p_{2}\right)= & \int \mathrm{d} y_{1} \int \mathrm{d} y_{2} \exp \left\{(\mathrm{i} / \hbar)\left(p_{1} y_{1}+p_{2} y_{2}\right)\right\}\left\langle q_{1}-\frac{1}{2} y_{1}, q_{2}-\frac{1}{2} y_{2}\left|\hat{P}_{\mathrm{s}}\right| q_{1}+\frac{1}{2} y_{1}, q_{2}+\frac{1}{2} y_{2}\right\rangle \\
= & \int \mathrm{d} y_{1} \int \mathrm{d} y_{2} \exp \left\{(\mathrm{i} / \hbar)\left(p_{1} y_{1}+p_{2} y_{2}\right)\right\} \frac{1}{2}\left[\delta\left(y_{1}\right) \delta\left(y_{2}\right)\right. \\
& \left.+\delta\left(q_{2}-q_{1}+\frac{1}{2}\left(y_{2}+y_{1}\right)\right) \delta\left(q_{1}-q_{2}+\frac{1}{2}\left(y_{1}+y_{2}\right)\right)\right] \\
= & \frac{1}{2}+\pi \hbar \delta\left(q_{1}-q_{2}\right) \delta\left(p_{1}-p_{2}\right) .
\end{aligned}
$$

The corresponding result for fermions has a minus sign in front of the second term. This initial condition is considerably more complicated than the initial condition, $\Omega(q, p)=1$, which was obtained in the one-dimensional case. The situation rapidly becomes worse with larger numbers of particles.

Second-quantized notation provides, in principle, a convenient way to deal with the problems imposed by quantum statistics. We will consider a Fock space and designate the vacuum state of this space by $|0\rangle$, and the quantized field operators at the point $r$ by $\hat{\psi}^{+}(r)$ and $\hat{\psi}(r)$. The interpretation of the field operators is that $\hat{\psi}^{+}(r)$ adds a particle at point $r$ to the system whereas $\hat{\psi}(r)$ removes a particle at point $r$. They are defined as

$$
\begin{aligned}
& \hat{\psi}(r)=\sum_{p} \frac{1}{\sqrt{V}} \mathrm{e}^{\mathrm{i} p \cdot r} \hat{a}_{p} \\
& \hat{\psi}^{+}(r)=\sum_{p} \frac{1}{\sqrt{V}} \mathrm{e}^{-\mathrm{i} p \cdot r} \hat{a}_{p}^{+}
\end{aligned}
$$


where the so-called annihilation and creation operators, $\hat{a}_{p}$ and $\hat{\boldsymbol{a}}_{p}^{+}$, respectively (discussed in detail in section 4), act to remove or create a particle of momentum $p$ in a box of volume $V$. For bosons these operators obey the commutation relation

$$
\begin{aligned}
& {\left[\hat{\psi}(r), \hat{\psi}^{\dagger}\left(r^{\prime}\right)\right]=\delta^{(3)}\left(r-r^{\prime}\right)} \\
& {\left[\hat{\psi}(r), \hat{\psi}\left(r^{\prime}\right)\right]=0}
\end{aligned}
$$

and for fermions the anti-commutation relation

$$
\begin{aligned}
& \left\{\hat{\psi}(\boldsymbol{r}), \hat{\psi}^{\dagger}\left(\boldsymbol{r}^{\prime}\right)\right\}=\delta^{(3)}\left(\boldsymbol{r}-\boldsymbol{r}^{\prime}\right) \\
& \left\{\hat{\psi}(\boldsymbol{r}), \hat{\psi}\left(\boldsymbol{r}^{\prime}\right)\right\}=0 .
\end{aligned}
$$

To every $N$-particle state $\left|\Psi_{N}\right\rangle$ in the Fock space corresponds an $N$-particle wave function given by (Schweber [1961])

$$
\Psi_{N}\left(r_{1}, \ldots, r_{N}\right)=\frac{1}{\sqrt{N} !}\left\langle 0\left|\hat{\psi}\left(r_{N}\right) \cdots \hat{\psi}\left(r_{1}\right)\right| \Psi_{N}\right\rangle
$$

The distribution function for the state $\left|\Psi_{N}\right\rangle$ then, is given by

$$
\begin{aligned}
& P\left(\boldsymbol{r}_{1}, \ldots, \boldsymbol{r}_{N} ; \boldsymbol{p}_{1}, \ldots \boldsymbol{p}_{N}\right)=\left(\frac{1}{2 \pi \hbar}\right)^{3 N} \int \mathrm{d}^{3} y_{1} \cdots \int \mathrm{d}^{3} y_{N} \exp \left\{(\mathrm{i} / \hbar)\left(p_{1} \cdot y_{1}+\cdots+\boldsymbol{p}_{N} \cdot y_{N}\right)\right\} \\
& \times \Psi_{N}^{*}\left(r_{1}+\frac{1}{2} y_{1}, \ldots r_{N}+\frac{1}{2} y_{N}\right) \Psi_{N}\left(r_{1}-\frac{1}{2} y_{1}, \ldots, r_{N}-\frac{1}{2} y_{N}\right) \\
& ==\left(\frac{1}{2 \pi \hbar}\right)^{3 N} \frac{1}{N !} \int \mathrm{d}^{3} y_{1} \cdots \int \mathrm{d}^{3} y_{N} \exp \left\{(\mathrm{i} / \hbar)\left(p_{1} \cdot y_{1}+\cdots+p_{N} \cdot y_{N}\right)\right\} \\
& \times\left\langle 0\left|\hat{\psi}\left(\boldsymbol{r}_{N}-\frac{1}{2} \boldsymbol{y}_{N}\right) \cdots \hat{\psi}\left(\boldsymbol{r}_{1}-\frac{1}{2} \boldsymbol{y}_{1}\right)\right| \Psi_{N}\right\rangle\left\langle\Psi_{N}\left|\hat{\psi}^{\dagger}\left(\boldsymbol{r}_{1}+\frac{1}{2} \boldsymbol{y}_{1}\right) \cdots \hat{\psi}^{\dagger}\left(\boldsymbol{r}_{N}+\frac{1}{2} \boldsymbol{y}_{N}\right)\right| 0\right\rangle .
\end{aligned}
$$

This expression readily extends to $N$-particle density matrixes, $\hat{\rho}_{N}$, so that

$$
\begin{aligned}
P\left(r_{1}, \ldots r_{N} ; p_{1}, \ldots p_{N}\right)= & \left(\frac{1}{2 \pi \hbar}\right)^{3 N} \frac{1}{N !} \int d^{3} y_{1} \cdots \int d^{3} y_{N} \exp \left\{(i / \hbar)\left(p_{1} \cdot y_{1}+\cdots+p_{N} \cdot y_{N}\right)\right\} \\
& \times\left\langle 0\left|\hat{\psi}\left(r_{N}-\frac{1}{2} y_{N}\right) \cdots \hat{\psi}\left(r_{1}-\frac{1}{2} y_{1}\right) \hat{\rho}_{N} \hat{\psi}^{\dagger}\left(r_{1}+\frac{1}{2} y_{1}\right) \cdots \hat{\psi}^{\dagger}\left(r_{N}+\frac{1}{2} y_{N}\right)\right| 0\right\rangle
\end{aligned}
$$

where, in the case of a pure state,

$$
\hat{\rho}_{N}=\left|\Phi_{N}\right\rangle\left\langle\Phi_{N}\right|
$$

with $\left|\Phi_{N}\right\rangle$ denoting the $N$-particle ket basis vector. An $N$-particle density matrix has the property that if $\Phi_{N^{\prime}}$ and $\Phi_{N^{*}}$ are $N^{\prime}$-particle and $N^{\prime \prime}$-particle states respectively, then $\left\langle\Phi_{N^{*}}\left|\hat{\rho}_{N}\right| \Phi_{N^{\prime}}\right\rangle=0$ unless $N^{\prime}=N^{\prime \prime}=$ $N$. Therefore, eq. (2.132) can be expressed as 


$$
\begin{aligned}
P\left(r_{1}, \ldots r_{N} ; p_{1}, \ldots p_{N}\right)= & \left(\frac{1}{2 \pi h}\right)^{3 N} \frac{1}{N !} \int d^{3} y_{1} \cdots \int d^{3} y_{N} \exp \left\{(i / \hbar)\left(p_{1} \cdot y_{1}+\cdots+p_{N} \cdot y_{N}\right)\right\} \\
& \times \operatorname{Tr}\left(\hat{\psi}\left(r_{N}-\frac{1}{2} y_{N}\right) \cdots \hat{\psi}\left(r_{1}-\frac{1}{2} y_{1}\right) \hat{\rho}_{N} \hat{\psi}^{\dagger}\left(r_{1}+\frac{1}{2} y_{1}\right) \cdots \hat{\psi}^{\dagger}\left(r_{N}+\frac{1}{2} y_{N}\right)\right) \\
= & \left(\frac{1}{2 \pi \hbar}\right)^{3 N} \frac{1}{N !} \int d^{3} y_{1} \cdots \int d^{3} y_{N} \exp \left\{(i / \hbar)\left(p_{1} \cdot y_{1}+\cdots+p_{N} \cdot y_{N}\right)\right\} \\
& \times \operatorname{Tr}\left(\hat{\rho}_{N} \hat{\psi}^{\dagger}\left(r_{1}+\frac{1}{2} y_{1}\right) \cdots \hat{\psi}^{\dagger}\left(r_{N}+\frac{1}{2} y_{N}\right) \hat{\psi}\left(r_{N}-\frac{1}{2} y_{N}\right) \cdots \hat{\psi}\left(r_{1}-\frac{1}{2} y_{1}\right)\right) .
\end{aligned}
$$

This is the desired expression for the Wigner function in second-quantized form (Brittin and Chappell [1962]; Imre, Ozizmir, Rosenbaum and Zweifel [1967]).

It is also possible to derive expressions for the reduced distribution functions in terms of the quantized field operators (Brittin and Chappell [1962]; Imre, Ozizmir, Rosenbaum and Zweifel [1967]). The distribution function of order $N$, reduced to the $j$ th order, is defined as

$$
P_{j}\left(r_{1}, \ldots r_{j} ; p_{1}, \ldots p_{j}\right)=\int d^{3} r_{j+1} \cdots \int d^{3} r_{N} \int d^{3} p_{j+1} \cdots \int d^{3} p_{N} P\left(r_{1}, \ldots r_{N} ; p_{1}, \ldots p_{N}\right)
$$

and this definition will be used for the rest of this section. This can also be expressed, by making use of eq. (2.134), as

$$
\begin{aligned}
& P_{j}\left(r_{1}, \ldots r_{i} ; p_{1}, \ldots p_{j}\right)=\left(\frac{1}{2 \pi \hbar}\right)^{3 N} \frac{1}{N !} \int \mathrm{d}^{3} r_{j+1} \cdots \int \mathrm{d}^{3} r_{N} \int \mathrm{d}^{3} p_{j+1} \cdots \int \mathrm{d}^{3} p_{N} \int \mathrm{d}^{3} y_{1} \cdots \int \mathrm{d}^{3} y_{N} \\
& \quad \times \exp \left\{i\left(p_{1} \cdot y_{1}+\cdots+p_{N} \cdot y_{N}\right) / \hbar\right\} \operatorname{Tr}\left(\hat{\rho}_{N} \hat{\psi}^{\dagger}\left(r_{1}+\frac{1}{2} y_{1}\right) \cdots \hat{\psi}^{\dagger}\left(r_{N}+\frac{1}{2} y_{N}\right) \hat{\psi}\left(r_{N}-\frac{1}{2} y_{N}\right) \cdots \hat{\psi}\left(r_{1}-\frac{1}{2} y_{1}\right)\right) \\
& =\left(\frac{1}{2 \pi \hbar}\right)^{3 j} \frac{1}{N !} \int \mathrm{d}^{3} r_{j+1} \cdots \int \mathrm{d}^{3} r_{N} \int \mathrm{d}^{3} y_{1} \cdots \int \mathrm{d}^{3} y_{j} \exp \left\{i\left(p_{1} \cdot y_{1}+\cdots+p_{j} \cdot y_{j}\right) / \hbar\right\} \operatorname{Tr}\left(\hat{\rho}_{N} \hat{\psi}^{\dagger}\left(r_{1}+\frac{1}{2} y_{1}\right)\right. \\
& \left.\quad \cdots \hat{\psi}^{\dagger}\left(r_{j}+\frac{1}{2} y_{j}\right) \hat{\psi}^{\dagger}\left(r_{j+1}\right) \cdots \hat{\psi}^{\dagger}\left(r_{N}\right) \hat{\psi}\left(r_{N}\right) \cdots \hat{\psi}\left(r_{j+1}\right) \hat{\psi}\left(r_{j}-\frac{1}{2} y_{j}\right) \cdots \hat{\psi}\left(r_{1}-\frac{1}{2} y_{1}\right)\right) .
\end{aligned}
$$

In order to analyze this expression further we first note that

$$
\int d^{3} r \hat{\psi}^{\dagger}(r) \hat{\psi}(r)=\hat{N}
$$

where $\hat{N}$ is just the number operator. We then have that, for both bosons and fermions

$$
[\hat{\psi}(r), \hat{N}]=\hat{\psi}(r)
$$

Therefore,

$$
\int \mathrm{d}^{3} \boldsymbol{r}_{N-1} \hat{\psi}^{\dagger}\left(\boldsymbol{r}_{N-1}\right) \hat{N} \hat{\psi}\left(\boldsymbol{r}_{N-1}\right)=\hat{N}(\hat{N}-1)
$$

and 
150

$$
\int \mathrm{d}^{3} r_{j+1} \cdots \int \mathrm{d}^{3} r_{N-1} \hat{\psi}^{\dagger}\left(r_{j+1}\right) \cdots \hat{\psi}^{\dagger}\left(r_{N-1}\right) \hat{N} \hat{\psi}\left(r_{N-1}\right) \cdots \hat{\psi}\left(r_{j+1}\right)=\hat{N}(\hat{N}-1) \cdots(\hat{N}-N+j+1)
$$

Eq. (2.136) becomes

$$
\begin{aligned}
& P_{i}\left(r_{1}, \ldots \boldsymbol{r}_{j} ; \boldsymbol{p}_{1}, \ldots \boldsymbol{p}_{j}\right)=\left(\frac{1}{2 \pi \hbar}\right)^{3 j} \frac{1}{N !} \int \mathrm{d}^{3} y_{1} \cdots \int \mathrm{d}^{3} y_{j} \exp \left\{i\left(p_{1} \cdot y_{1}+\cdots+p_{j} \cdot y_{j}\right) / \hbar\right\} \\
& \quad \times \operatorname{Tr}\left(\hat{\rho}_{N} \hat{\psi}^{\dagger}\left(\boldsymbol{r}_{1}+\frac{1}{2} \boldsymbol{y}_{1}\right) \cdots \hat{\psi}^{\dagger}\left(\boldsymbol{r}_{j}+\frac{1}{2} \boldsymbol{y}_{j}\right) \hat{N}(\hat{N}-1) \cdots(\hat{N}-N+j+1) \hat{\psi}\left(\boldsymbol{r}_{j}-\frac{1}{2} y_{j}\right) \cdots \hat{\psi}\left(\boldsymbol{r}_{1}-\frac{1}{2} \boldsymbol{y}_{1}\right)\right) .
\end{aligned}
$$

Because $\hat{\rho}_{N}$ is an $N$-particle density matrix we have that

$$
\hat{N}(\hat{N}-1) \cdots(\hat{N}-N+j+1) \hat{\psi}\left(\boldsymbol{r}_{j}-\frac{1}{2} \boldsymbol{y}_{j}\right) \cdots \hat{\psi}\left(\boldsymbol{r}_{1}-\frac{1}{2} \boldsymbol{y}_{1}\right) \hat{\rho}_{N}=(N-j) ! \hat{\psi}\left(\boldsymbol{r}_{j}-\frac{1}{2} \boldsymbol{y}_{j}\right) \cdots \hat{\psi}\left(\boldsymbol{r}_{1}-\frac{1}{2} \boldsymbol{y}_{1}\right) \hat{\rho}_{N},
$$

so that our final expression for the reduced Wigner function is

$$
\begin{aligned}
P_{j}\left(\boldsymbol{r}_{1}, \ldots \boldsymbol{r}_{j} ; \boldsymbol{p}_{1}, \ldots \boldsymbol{p}_{j}\right)= & \left(\frac{1}{2 \pi \hbar}\right)^{3 j} \frac{(N-j) !}{N !} \int \mathrm{d}^{3} \mathbf{y}_{1} \cdots \int \mathrm{d}^{3} y_{j} \exp \left\{\mathrm{i}\left(\boldsymbol{p}_{1} \cdot \boldsymbol{y}_{1}+\cdots+\boldsymbol{p}_{i} \cdot \boldsymbol{y}_{j}\right) / \hbar\right\} \\
& \times \operatorname{Tr}\left(\hat{\rho}_{N} \hat{\psi}^{\dagger}\left(\boldsymbol{r}_{1}+\frac{1}{2} \boldsymbol{y}_{1}\right) \cdots \hat{\psi}^{\dagger}\left(r_{j}+\frac{1}{2} \boldsymbol{y}_{j}\right) \hat{\psi}\left(\boldsymbol{r}_{j}-\frac{1}{2} \boldsymbol{y}_{j}\right) \cdots \hat{\psi}\left(\boldsymbol{r}_{1}-\frac{1}{2} \boldsymbol{y}_{\mathrm{t}}\right)\right)
\end{aligned}
$$

It is now possible to formulate the dynamics of this theory in a way which is independent of the number of particles. We first go to the Heisenberg picture in which the field operators become time dependent. We then consider the operators

$$
\begin{aligned}
& \hat{F}_{j}\left(\boldsymbol{r}_{1}, \ldots \boldsymbol{r}_{j} ; \boldsymbol{p}_{1}, \ldots \boldsymbol{p}_{i}\right)=\left(\frac{1}{2 \pi \hbar}\right)^{3 j} \int \mathrm{d}^{3} \boldsymbol{y}_{1} \cdots \int \mathrm{d}^{3} \boldsymbol{y}_{j} \exp \left\{\mathrm{i}\left(\boldsymbol{p}_{1} \cdot \boldsymbol{y}_{1}+\cdots+\boldsymbol{p}_{j} \cdot \boldsymbol{y}_{j}\right) / \hbar\right\} \\
& \quad \times \hat{\psi}^{\dagger}\left(\boldsymbol{r}_{1}+\frac{1}{2} \boldsymbol{y}_{1} ; t\right) \cdots \hat{\psi}^{\dagger}\left(\boldsymbol{r}_{j}+\frac{1}{2} \boldsymbol{y}_{j} ; t\right) \cdots \hat{\psi}\left(\boldsymbol{r}_{j}-\frac{1}{2} \boldsymbol{y}_{j} ; t\right) \cdots \hat{\psi}\left(\boldsymbol{r}_{1}-\frac{1}{2} \boldsymbol{y}_{i} ; t\right) .
\end{aligned}
$$

The distribution functions for an $N$-particle theory are then just

$$
\hat{P}_{j}\left(r_{1}, \ldots r_{j} ; p_{1}, \ldots p_{j}\right)=\frac{(N-j) !}{N !} \operatorname{Tr}\left(\hat{\rho}_{N} \hat{F}_{j}\left(r_{1}, \ldots r_{j} ; p_{1}, \ldots p_{j}\right)\right)
$$

We see that in this formulation all of the dynamical information is contained in the operators $\hat{F}_{j}$ which contain no reference to a specific particle number and also contain the information about the statistics of the particles. Thus, in principle, the second-quantized formalism should be a useful starting-point for the incorporation of statistics into problems involving a system of identical particles. However, it must be admitted that - to our knowledge - no application has been made along these lines.

\section{Other distribution functions}

We now want to examine certain other distributions besides the one considered so far. These may arise out of a desire to make use of an operator ordering scheme other than that proposed by Weyl or a desire to have a distribution function with certain properties. For example, we may want to make use of 
symmetric ordering

$$
q^{m} p^{n} \rightarrow \frac{1}{2}\left(\hat{q}^{m} \hat{p}^{n}+\hat{p}^{n} \hat{q}^{m}\right)
$$

in which case we would use the distribution function (Margenau and Hill [1961]; Mehta [1964])

$$
P_{s}(q, p)=\frac{1}{4 \pi \hbar} \operatorname{Re}\left\{\psi(q) \int_{\infty}^{\infty} \mathrm{d} y \mathrm{e}^{-(\mathrm{i} / \hbar) p y} \psi^{*}(q-y)\right\}
$$

On the other hand, we may want to consider a distribution which is always greater than or equal to zero. We will discuss a distribution which has this property shortly.

A scheme for generating distribution functions was proposed by Cohen [1966] and further examined by Summerfield and Zweifel [1969]. They give the rather general expression

$$
\begin{aligned}
P_{\mathrm{z}}(q, p) & =\left(\frac{1}{2 \pi \hbar}\right)^{2} \int \mathrm{d} \sigma \int \mathrm{d} \tau \int \mathrm{d} u \exp \{-(\mathrm{i} / h)[\sigma(q-u)+\tau p]\} g(\sigma, \tau) \psi^{*}\left(u-\frac{\tau}{2}\right) \psi\left(u+\frac{\tau}{2}\right) \\
& =\int \mathrm{d} q^{\prime} \int \mathrm{d} p^{\prime} \tilde{g}\left(q-q^{\prime}, p-p^{\prime}\right) P_{w}\left(q^{\prime}, p^{\prime}\right)
\end{aligned}
$$

for the distribution function of the pure state $\psi(q)$, where

$$
\tilde{g}(q, p)=\int \mathrm{d} \sigma \int \mathrm{d} \tau \exp \{-(\mathrm{i} / \hbar)(\sigma q+\tau p)\} g(\sigma, \tau)
$$

Thus the function $P$ is simply the original function $P_{w}$ smeared with another function $g$. The basic requirement which leads to eq. (3.3) is that $P$ transform correctly with respect to space displacement, $\psi(q) \rightarrow \psi(q-a)$, and transition to a uniformly moving coordinate system, $\psi(q) \rightarrow \exp (-\mathrm{i} m v q) \psi(q)$. These requirements were formulated in giving the form eq. (3.3a) to $P_{8}$-and the satisfaction of the requirements can easily be verified; eq. (3.3b) then follows.

Cohen also pointed out that it is possible to obtain distributions whose dependence upon the wave function of the system is other than bilinear simply by choosing $g(\sigma, \tau)$ to depend upon $\psi(q)$. For example, one can choose

$$
g(\sigma, \tau)=\int \mathrm{d} q \psi\left(q-q_{0} \frac{\sigma \tau}{\hbar}\right) \psi^{*}\left(q+q_{0} \frac{\sigma \tau}{\hbar}\right)
$$

where $q_{0}$ is an arbitrary value of $q$. This choice for $g(\sigma, \tau)$ satisfies $g(0, \tau)=g(\sigma, 0)=1$ so that the correct marginal distributions are obtained. On the other hand, we now have the rather awkward situation that the function-operator correspondence depends upon the wave function. An even simpler choice is, of course

$$
P_{\mathbf{g}}(q, p)=(\pi \hbar)^{-1}|\psi(q)|^{2}|\phi(p)|^{2},
$$

where $\phi(p)$, the Fourier transform of $\psi(q)$ is defined by eq. (2.14). The conditions on $\tilde{g}(q, p)$ which must be satisfied so that the correct marginal distributions are obtained are 


$$
\begin{aligned}
& \int \mathrm{d} q \tilde{g}(q, p)=(2 \pi \hbar)^{2} \delta(p) \\
& \int \mathrm{d} p \tilde{g}(q, p)=(2 \pi \hbar)^{2} \delta(q) .
\end{aligned}
$$

One choice of $\tilde{g}(q, p)$ which does not satisfy eqs. (3.7) but which is interesting nonetheless is given by

$$
\tilde{g}(q, p ; \alpha)=\left(\frac{1}{\pi h}\right) \mathrm{e}^{-q^{2} / \alpha} \mathrm{e}^{-\alpha p^{2} / \hbar^{2}} .
$$

The use of this smearing function was first proposed by Husimi [1940] and has been investigated by a number of authors since (Bopp [1956]; Kano [1965]; McKenna and Frisch [1966]; Cartwright [1976]; Prugovecki [1978]; O'Connell and Wigner [1981b]). It leads to a distribution function, $P_{\mathrm{H}}(q, p)$, where the subscript $\mathrm{H}$ denotes Husimi, which is non-negative for all $p$ and $q$. One can see this by noting that $\tilde{g}\left(q-q^{\prime}, p-p^{\prime} ; \alpha\right)$ is just the Wigner distribution function which one obtains from the displaced (in both position and momentum) harmonic oscillator ground state wave function

$$
\psi_{q, p}\left(q^{\prime} ; \alpha\right)=(\pi \alpha)^{-1 / 4} \mathrm{e}^{-\left(q^{\prime}-q\right)^{2} / 2 \alpha} \mathrm{e}^{\mathrm{i} q q^{\prime} / \hbar} .
$$

which we will call $P_{q, p}\left(O^{\prime}\right.$ Connell and Wigner [1981b]). If the Wigner distribution in question, $P_{\phi}$, corresponds to a wave function $\phi(q)$ we have

$$
P_{\mathrm{H}}(q, p)=\int \mathrm{d} q^{\prime} \int \mathrm{d} p^{\prime} P_{q, p}\left(q^{\prime}, p^{\prime}\right) P_{\phi}\left(q^{\prime}, p^{\prime}\right)=\left(\frac{1}{2 \pi \hbar}\right)\left|\int \mathrm{d} q^{\prime} \psi_{q, p}^{*}\left(q^{\prime}\right) \phi\left(q^{\prime}\right)\right|^{2} \geq 0,
$$

where we have used eq. (2.8). Note that in order to get a positive distribution function we had to violate condition (ii) on our list of properties of the Wigner function. Property (vi) is also violated as was shown by Prugovecki [1978] and by O'Connell and Wigner [1981a].

We will encounter $P_{\mathrm{H}}(q, p)$ again in the next section in a somewhat different form. It is the " $Q$ " or "anti-normally-ordered" distribution function of quantum optics. It is one of a number of distributions which are useful in the description of harmonic oscillators, and, hence, modes of the electromagnetic field. We now proceed to examine these distribution functions.

\section{Distribution functions in terms of creation and annihilation operators}

The harmonic oscillator is a system that is ubiquitous in physics, so that it is not surprising that quantum distribution functions have been developed which are tailored to its description. It is in the description of the modes of the electromagnetic field that these distribution functions have found their widest application.

It should be emphasized that many problems in quantum optics require a fully quantized treatment not only of the atoms but also of the field. For example, an analysis of experiments dealing with photon counting or a derivation of the fluctuations in intensity of a laser near threshold both require the quantum theory of radiation (Scully and Lamb [1967]; De Giorgio and Scully [1970]; Graham and Haken 
[1970]). The latter is developed within the framework of annihilation and creation operators for bosons (see below) but it is then possible to go to a description in terms of c-numbers (while fully retaining the quantum aspects of the situation) by means of distribution functions. In most cases, this greatly facilitates the calculation while, at the same time, it contributes to a better understanding of the connection between the quantum and classical descriptions of the electromagnetic field.

A number of studies of these distribution functions have been done (Mehta and Sudarshan [1965]; Lax and Louisell [1967]; Lax [1968]; Cahill and Glauber [1969]; Agarwal and Wolf [1970]; Louisell [1973]). We will rely most heavily upon the papers by Cahill and Glauber [1969] in our treatment. Their discussion considers a continuum of possible operator ordering schemes, and hence distributions (an even larger class is considered in Agarwal and Wolf [1970]) but we will consider only three of these. A final section will discuss distributions defined on a 4-dimensional, rather than a 2-dimensional, phase space.

We will describe the system in terms of its annihilation and creation operators

$$
\begin{aligned}
& \hat{a}=\left(\frac{1}{2 \hbar}\right)^{1 / 2}\left(\lambda \hat{q}+\frac{\mathrm{i}}{\lambda} \hat{p}\right) \\
& a^{+}=\left(\frac{1}{2 \hbar}\right)^{1 / 2}\left(\lambda \hat{q}-\frac{\mathrm{i}}{\lambda} \hat{p}\right),
\end{aligned}
$$

satisfying

$$
\left[\hat{a}, \hat{a}^{+}\right]=1 \text {. }
$$

As mentioned before, it is assumed that the field operators we consider obey Bose statistics. Each pair of $\hat{a}, \hat{a}^{+}$refers to a certain function of position. These functions form an orthonormal set which is countable if the basic domain is assumed to be finite, and continuous if infinite. We deal with a very large, but finite, system so that the system is only approximately relativistically invariant (exact invariance is achieved for an infinitely large system, but this would make the calculation in other ways difficult).

The various functions of $\hat{a}$ and $\hat{a}^{+}$are investigated individually because the corresponding $\hat{a}$ and $\hat{a}^{+}$ do not interact with the $\hat{a}$ and $\hat{a}^{+}$of another member of the set. They interact with the matter which is in the basic domain. Thus, for example, when we apply this formalism to the case of the electromagnetic field, we investigate each mode (corresponding to a definite momentum and definite direction of polarization) separately, and the operators associated with different modes commute (no interaction between modes). In addition, there will be a distribution function corresponding to each mode.

The $\hat{a}$ and $\hat{a}^{+}$operators act on the basis vectors $|n\rangle$, the so-called "particle number states", and have the properties:

$$
\begin{aligned}
& \hat{a}|n\rangle=\sqrt{n}|n-1\rangle \\
& \hat{a}^{+}|n\rangle=\sqrt{n+1}|n+1\rangle \\
& \hat{a}^{+} a|n\rangle=n|n\rangle \\
& \hat{a}|0\rangle=0 .
\end{aligned}
$$

In addition, one can prove that 


$$
\left[\hat{a},\left(\hat{a}^{+}\right)^{n}\right]=n\left(\hat{a}^{+}\right)^{n-1}
$$

If we are considering an oscillator of mass $m$ and angular frequency $\omega$ we take $\lambda=(m \omega)^{1 / 2}$ and if we are considering a mode of the electromagnetic field of angular frequency $\omega$ we set $\lambda=\left(\hbar^{1 / 2} \omega / c\right)$.

We also want to consider a special class of states known as coherent states (Schrödinger [1926]; Glauber [1963a]; Glauber [1963b]; Sudarshan [1963]; Glauber [1965]). To define these we first define for each complex number $\alpha$ the unitary displacement operator:

$$
\hat{D}(\alpha)=\mathrm{e}^{\left(\alpha \hat{a}^{*}-\alpha \cdot \hat{a}\right)}=\mathrm{e}^{-|\alpha|^{2} / 2} \mathrm{e}^{\alpha \hat{a}^{*}} \mathrm{e}^{-\alpha^{*} \hat{a}} .
$$

where the last expression is obtained by use of the Baker-Hausdorff theorem (eq. (2.35a)) and the commutation relation given by eq. (4.2). The operator $\hat{D}(\alpha)$ has the property that

$$
\begin{aligned}
& \hat{D}^{-1}(\alpha) \hat{a} \hat{D}(\alpha)=\hat{a}+\alpha \\
& \hat{D}^{-1}(\alpha) \hat{a}^{+} \hat{D}(\alpha)=\hat{a}^{+}+\alpha^{*}
\end{aligned}
$$

The proof of eq. (4.4) readily follows from eqs. (4.2e) and (4.3). We now define the coherent state (Glauber [1963a]; Glauber [1963b]; Sudarshan [1963]), which we denote by $|\alpha\rangle$, as

$$
|\alpha\rangle \equiv \hat{D}(\alpha)|0\rangle=\mathrm{e}^{-|\alpha|^{2 / 2}} \sum_{n=0}^{\infty} \frac{\alpha^{n}}{n !}\left(\hat{a}^{+}\right)^{n}|0\rangle=\mathrm{e}^{-|\alpha|^{2 / 2}} \sum_{n=0}^{\infty} \frac{\alpha^{n}}{(n !)^{1 / 2}}|n\rangle .
$$

where $|0\rangle$ is the ground state of the oscillator. This state has the property that it is an eigenstate of the annihilation operators with eigenvalue $\alpha$. Again, this can be verified by using eq. (4.2e). Perhaps it should be emphasized that the symbol $\alpha$ always refers to a complex eigenvalue whereas $|\alpha\rangle$ always denotes a state, just as $n$ denotes a real eigenvalue and $|n\rangle$ a state, the so-called "number state". Also, just as $|n\rangle$ refers to a definite state of excitation of a system of one mode, $|\alpha\rangle$ also refers to a state of one mode.

The $|\alpha\rangle$ states are not orthogonal but they are complete (in fact overcomplete). Explicitly,

$$
\langle\beta \mid \alpha\rangle=\exp \left[-\frac{1}{2}\left(|\alpha|^{2}+|\beta|^{2}\right)+\beta^{*} \alpha\right],
$$

which follows immediately from eq. (4.5) and the fact that the number states are orthonormal. Furthermore, it is possible to express the identity operator as

$$
I=\frac{1}{\pi} \int \mathrm{d}^{2} \alpha|\alpha\rangle\langle\alpha|
$$

where $d^{2} \alpha=d(\operatorname{Re} \alpha) d(\operatorname{Im} \alpha)=\frac{1}{2} d \alpha d \alpha^{*}$. The proof of eq. (4.7a) follows by setting $\alpha=r e^{i \theta}$, so that $\mathrm{d}^{2} \alpha=r \mathrm{~d} r \mathrm{~d} \theta$, and then using eq. (4.5) to get

$$
\frac{1}{\pi} \int \mathrm{d}^{2} \alpha|\alpha\rangle\langle\alpha|=\frac{1}{\pi} \sum_{m=0}^{\infty} \sum_{n=0} \frac{|m\rangle\langle n|}{(m !)^{1 / 2}(n !)^{1 / 2}} \int_{0}^{\infty} \mathrm{d} r \mathrm{e}^{-r^{2}} r^{m+n+1} \int_{0}^{2 \pi} \mathrm{e}^{\mathrm{i}(m-n) \theta} \mathrm{d} \theta=2 \sum_{n} \frac{|n\rangle\langle n|}{n !} \int_{0}^{\infty} \mathrm{d} r \mathrm{e}^{-r^{2}} r^{2 n+1}
$$


where we have used the fact that the angular integral simply equals $2 \pi \delta_{m n}$. The latter radial integral equals $n ! / 2$, so that using the fact that $\Sigma_{n}|n\rangle\langle n|=1$, eq. (4.7a) readily follows. A direct consequence of eq. $(4.7 \mathrm{a})$ is that the trace of any operator $\hat{A}$ is just

$$
\operatorname{Tr}(\hat{A})=\frac{1}{\pi} \int \mathrm{d}^{2} \alpha\langle\alpha|\hat{A}| \alpha\rangle
$$

It is also of use to compare the expression for the displacement operator $\hat{D}(\alpha)$ to our previous results and use this comparison to derive an expansion for a general operator $\hat{A}$ in terms of $\hat{D}^{-1}(\alpha)$. This will be of use later. First we note that if we set $\alpha=(2 \hbar)^{-1 / 2}\left(\lambda \tau+i \lambda^{-1} \sigma\right)$ then (see eq. (4.1))

$$
\hat{D}(\alpha)=\exp \{(\mathrm{i} / \hbar)(\sigma \hat{q}+\tau \hat{p})\}=\hat{C}(\sigma, \tau)
$$

where $\hat{C}$ was defined earlier by eq. (2.43). Thus from eqs. (2.42) and (4.9) it is clear that the characteristic function is the expectation value of the displacement operator. This in conjunction with eqs. (4.5), (4.6) and (4.8) gives

$$
\operatorname{Tr}\left(\hat{D}(\alpha) \hat{D}^{-1}(\beta)\right)=\pi \delta^{(2)}(\alpha-\beta)
$$

where the $\delta$ function here is $\delta^{2}(\xi)=\delta(\operatorname{Re} \xi) \delta(\operatorname{Im} \xi)$. Suppose that we can expand the operator $\hat{A}\left(\hat{a}, \hat{a}^{+}\right)$ as

$$
\hat{A}=\frac{1}{\pi} \int \mathrm{d}^{2} \xi g(\xi) \hat{D}^{-1}(\xi)
$$

Using eq. (4.10) we find that

$$
g(\xi)=\operatorname{Tr}(\hat{A} \hat{D}(\xi))
$$

It can be shown (Cahill and Glauber [1969]) that if $\hat{A}$ is Hilbert-Schmidt (i.e. $\operatorname{Tr}\left(\hat{A}^{+} \hat{A}\right)<\infty$ ) then the function $g(\xi)$ is square integrable.

The three types of ordering of the operators $\hat{a}$ and $\hat{a}^{+}$which we wish to consider are defined as follows:

(i) Normal ordering-A product of $m$ annihilation operators and $n$ creation operators is normally ordered if all of the annihilation operators are on the right, i.e. if it is in the form $\left(\hat{a}^{+}\right)^{n} \hat{a}^{m}$.

(ii) Symmetric ordering - A product of $m$ annihilation operators and $n$ creation operators can be ordered in $(n+m) ! / n ! m !$ ways. The symmetrically ordered product of these operators, denoted by $\left\{\left(\hat{a}^{+}\right)^{n} \hat{a}^{m}\right\}$, is just the average of all of these differently ordered products. For example

$$
\begin{aligned}
& \left\{\hat{a}^{+} \hat{a}\right\}=\frac{1}{2}\left(\hat{a}^{+} \hat{a}+\hat{a} \hat{a}^{+}\right) \\
& \left\{\hat{a}^{+} \hat{a}^{2}\right\}=\frac{1}{3}\left(\hat{a}^{+} \hat{a}^{2}+\hat{a} \hat{a}^{+} \hat{a}+\hat{a}^{2} \hat{a}^{+}\right) \\
& \left\{\hat{a}^{+2} \hat{a}^{2}\right\}=\frac{1}{6}\left(\hat{a}^{+2} \hat{a}^{2}+\hat{a}^{+} \hat{a} \hat{a}^{+} \hat{a}+\hat{a}^{+} \hat{a}^{2} \hat{a}^{+}+\hat{a} \hat{a}^{+2} \hat{a}+\hat{a} \hat{a}^{+} \hat{a} \hat{a}^{+}+\hat{a}^{2} \hat{a}^{+2}\right) .
\end{aligned}
$$

(iii) Anti-normal ordering-A product of $m$ annihilation operators and $n$ creation operators is 
anti-normally ordered if all of the annihilation operators are on the left, i.e. if it is of the form $\hat{a}^{m}\left(\hat{a}^{+}\right)^{n}$.

For each operator ordering we have a rule which associates a function of $\alpha$ and $\alpha^{*}$ with a given operator. The rule is as follows: for any operator ordering scheme the product of $m$ annihilation and $n$ creation operators, ordered according to that scheme, is associated with the function $\left(\alpha^{*}\right)^{n} \alpha^{m}$. For example, if we are considering normal ordering the product $\left(\hat{a}^{n}\right)^{n} \hat{a}^{m}$ is associated with $\left(\alpha^{*}\right)^{n} \alpha^{m}$; if anti-normal ordering is being considered then $\hat{a}^{m}\left(\hat{a}^{+}\right)^{n}$ is associated with $\alpha^{m}\left(\alpha^{*}\right)^{n}$. We will now make the meaning of our rule more explicit by considering each of these orderings and its associated distribution function.

\subsection{Normal ordering}

Let us suppose that we can expand a given operator $\hat{A}\left(\hat{a}, \hat{a}^{+}\right)$in a normally ordered power series

$$
\hat{A}=\sum_{n, m=0}^{\infty} c_{n m}\left(\hat{a}^{+}\right)^{n} \hat{a}^{m}
$$

Let us further suppose that we can express the density matrix as

$$
\hat{\rho}=\int d^{2} \alpha P(\alpha)|\alpha\rangle\langle\alpha|
$$

where $P(\alpha)$ is a c-number and the state $|\alpha\rangle$ is given by eq. (4.5). $P(\alpha)$ is called the $P$-representation of the density matrix (or the distribution function representing the density matrix) of the particular mode under study. It should be emphasized that both the real and imaginary parts of $\alpha$ are used as the variables of the distribution function. Also, it is probably worthwhile mentioning again that our discussion is restricted to a system of bosons and thus the distribution functions under study are not applicable to, for instance, a gas of neutrinos. Also, we are dealing with a very large but countable set since we assumed that the basic domain is finite.

From eqs. (4.10) and (4.7a) and because $\left\langle\alpha\left|\hat{a}^{+n} \hat{a}^{m}\right| \alpha\right\rangle=\alpha^{* n} \alpha^{m}$, it follows that

$$
\begin{aligned}
\operatorname{Tr}(\hat{A} \hat{\rho}) & =\frac{1}{\pi} \int \mathrm{d}^{2} \beta \int \mathrm{d}^{2} \alpha P(\alpha)\langle\beta|\hat{A}| \alpha\rangle\langle\alpha \mid \beta\rangle=\int \mathrm{d}^{2} \alpha P(\alpha)\langle\alpha|\hat{A}| \alpha\rangle \\
& =\int \mathrm{d}^{2} \alpha P(\alpha)\left[\sum_{n, m=0}^{\infty} c_{n m}\left(\alpha^{*}\right)^{n} \alpha^{m}\right] \equiv \int \mathrm{d}^{2} \alpha P(\alpha) A_{\mathrm{N}}\left(\alpha, \alpha^{*}\right),
\end{aligned}
$$

with

$$
A_{N}\left(\alpha, \alpha^{*}\right)=\langle\alpha|\hat{A}| \alpha\rangle=\sum_{n, m=0}^{\infty} c_{n m}\left(\alpha^{*}\right)^{n} \alpha^{m}
$$

Therefore, we associate the operator $\hat{A}\left(\hat{a}, \hat{a}^{+}\right)$with the function $A_{\mathrm{N}}\left(\alpha, \alpha^{*}\right)$ in the evaluation of expectation values with the $P$-representation.

We now want to derive two expressions for $P(\alpha)$ in terms of the density matrix. It is not always possible to find a useful representation of $\hat{\rho}$ of the form given by eq. (4.15). For some density matrices $P(\alpha)$ would have to be so singular that it would not even be a tempered distribution (Cahill [1965]; Klauder and Sudarshan [1968]). This difficulty will be apparent in our formal expression for $P(\alpha)$. 
Let us now choose for the operator $A$

$$
\hat{A}=\mathrm{e}^{\xi^{+}} \mathrm{e}^{-\xi^{*} a}
$$

The corresponding function is then $A_{\mathrm{N}}\left(\alpha, \alpha^{*}\right)=\exp \left(\xi \alpha^{*}-\xi^{*} \alpha\right)$. Inserting these expressions into eq. (4.16) we find that

$$
\chi_{N}(\xi) \equiv \operatorname{Tr}\left(\hat{\rho} \mathrm{e}^{\xi a^{+}} \mathrm{e}^{-\xi^{*} a}\right)=\int \mathrm{d}^{2} \alpha P(\alpha) \mathrm{e}^{\xi \alpha^{*}-\xi^{*} \alpha}
$$

The function $\chi_{\mathrm{N}}(\xi)$ is known as the normally ordered characteristic function. The right-hand side of eq. (4.19) is just a Fourier transform in a somewhat disguised form. In fact one has that if

$$
f(\alpha)=\frac{1}{\pi} \int \mathrm{d}^{2} \xi \mathrm{e}^{\alpha \xi^{*}-\alpha * \xi} \tilde{f}(\xi)
$$

then

$$
\tilde{f}(\xi)=\frac{1}{\pi} \int \mathrm{d}^{2} \alpha \mathrm{e}^{\xi \alpha^{*}-\xi^{*} \alpha} f(\alpha),
$$

and vice versa. Therefore, we have for $P(\alpha)$

$$
P(\alpha)=\frac{1}{\pi^{2}} \int \mathrm{d}^{2} \xi \mathrm{e}^{\alpha \xi^{*}-\alpha^{*} \xi} \chi_{\mathrm{N}}(\xi)
$$

The problem with this expression is that $\chi_{\mathrm{N}}(\xi)$ can grow rather rapidly. In fact we have that because $\exp \left(\xi \hat{a}^{+}-\xi^{*} \hat{a}\right)$ is unitary

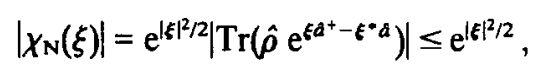

which suggests the type of behavior which is possible. For example, if $\hat{\rho}=|n\rangle\langle n|$, where $|n\rangle$ is the eigenstate of the number operator with eigenvalue $n$, then for large $|\xi|$ we have $\left|\chi_{N}(\xi)\right| \sim|\xi|^{2 n}$. This representation, then, is not appropriate for all density matrices, but, nonetheless, is useful in many of the cases of interest.

Finally, we will derive an expression for $P(\alpha)$ in terms of a series expansion for the density matrix. Let us suppose that we can express the density matrix as an anti-normally ordered series

$$
\hat{\rho}=\sum_{n, m=0}^{\infty} \rho_{n m} \hat{a}^{m}\left(\hat{a}^{+}\right)^{n}
$$

If we again consider the expression for $\hat{A}\left(\hat{a}, \hat{a}^{+}\right)$given by eq. (4.14) we find that

$$
\operatorname{Tr}(\hat{\rho} \hat{A})=\sum_{n, m=0}^{\infty} \sum_{r, s=0}^{\infty} \rho_{n m} c_{r s} \operatorname{Tr}\left(\hat{a}^{m}\left(\hat{a}^{+}\right)^{n}\left(\hat{a}^{+}\right)^{r} \hat{a}^{s}\right)
$$

The trace in eq. (4.24) can be expressed as 


$$
\operatorname{Tr}\left(\hat{a}^{m}\left(\hat{a}^{+}\right)^{n+r} \hat{a}^{s}\right)=\operatorname{Tr}\left(\left(\hat{a}^{+}\right)^{n+r} \hat{a}^{s+m}\right)
$$

so that

$$
\operatorname{Tr}(\hat{\rho} \hat{A})=\frac{1}{\pi} \int \mathrm{d}^{2} \alpha \sum_{n, m=0}^{\infty} \sum_{r, s=0}^{\infty} \rho_{n m} c_{r s} \alpha^{* n} \alpha^{m} \alpha^{* r} \alpha^{s} .
$$

Comparing this with eq. (4.16) we see that

$$
P(\alpha)=\frac{1}{\pi} \sum_{n, m=0}^{\infty} \rho_{n m} \alpha^{* n} \alpha^{m} .
$$

The difficulties which we had when considering eq. (4.21) suggest that we will have similar problems with eq. (4.26). In fact the problem goes back to eq. (4.23). The class of operators for which a meaningful anti-normally ordered expansion exists is highly restricted. One can see this by considering the representation for an operator given by eq. (4.11). Expand $\hat{D}^{-1}(\xi)=\exp \left(\xi^{*} \hat{a}\right) \exp \left(-\xi \hat{a}^{+}\right) \exp \left(\frac{1}{2}|\xi|^{2}\right)$ in an anti-normally ordered power series and insert it back into eq. (4.11). This gives us an anti-normally-ordered power series for $\hat{A}$ :

$$
\hat{A}=\sum_{n, m=0}^{\infty} d_{n m} \hat{a}^{m}\left(\hat{a}^{+}\right)^{n}
$$

with the coefficients given by

$$
d_{n m}=\frac{1}{n ! m !} \frac{1}{\pi} \int \mathrm{d}^{2} \xi \operatorname{Tr}(\hat{A} \hat{D}(\xi)) \mathrm{e}^{|\xi|^{2 / 2}}(-\xi)^{n}\left(\xi^{*}\right)^{m}
$$

For these coefficients to exist $\operatorname{Tr}(\hat{A} \hat{D}(\xi))$ must be a very rapidly decreasing function of $|\xi|$. Our previous remarks indicate that this will not be true in general for Hilbert-Schmidt operators and, in fact, will not be true in general for operators of trace class (operators, $\hat{A}$, for which $\left.\operatorname{Tr}\left(\left[\hat{A}^{+} \hat{A}\right]^{1 / 2}\right)<\infty\right)$ such as density matrices.

It should be mentioned that normally-ordered power series expansions are far better behaved. A derivation similar to the one above gives for the coefficients $c_{n m}$ in eq. (4.14)

$$
c_{n m}=\frac{1}{n ! m !} \frac{1}{\pi} \int \mathrm{d}^{2} \xi \operatorname{Tr}(\hat{A} \hat{D}(\xi)) \mathrm{e}^{-|\xi|^{2 / 2}}(-\xi)^{n}\left(\xi^{*}\right)^{m}
$$

This clearly exists for a much wider class of operators than does $d_{n m}$. The $c_{n m}$ 's exist, in fact, for all Hilbert-Schmidt operators and the series converges in the sense that if one takes its matrix element between two coherent states, $\langle\alpha|$ on the left and $|\beta\rangle$ on the right, the resulting series converges to $\langle\alpha|A| \beta\rangle$.

\subsection{Symmetric ordering}

Before proceeding with a discussion of the distribution function for this case we would like to consider a few properties of the ordering scheme itself. We first note that 


$$
\left(\xi_{1} \hat{a}^{+}+\xi_{2} \hat{a}\right)^{n}=\sum_{l=0}^{n} \xi_{1}^{(n-l)} \xi_{2}^{l}\left(\begin{array}{l}
n \\
l
\end{array}\right)\left\{\left(\hat{a}^{+}\right)^{n-1} \hat{a}^{l}\right\},
$$

which implies that

$$
\mathrm{e}^{\left(\xi_{1} a^{+}+\xi_{2} a\right)}=\sum_{l, m=0}^{\infty} \frac{1}{l ! m !} \xi_{1}^{m} \xi_{2}^{l}\left\{\left(\hat{a}^{+}\right)^{m} \hat{a}^{l}\right\} .
$$

Our operator-function correspondence is now done in a way analogous to that of the preceding section. Expand an operator $\hat{A}\left(\hat{a}, \hat{a}^{+}\right)$in a symmetrically ordered power series

$$
\hat{A}=\sum_{n, m=0}^{\infty} b_{n m}\left\{\left(\hat{a}^{+}\right)^{n} \hat{a}^{m}\right\}
$$

The function corresponding to the operator is then

$$
A_{\mathrm{s}}\left(\alpha, \alpha^{*}\right)=\sum_{n, m=0}^{\infty} b_{n m}\left(\alpha^{*}\right)^{n} \alpha^{m}
$$

Under this correspondence we see from eq. (4.30) that the function $\hat{D}(\xi)$ goes to

$$
\hat{D}(\xi)=\mathrm{e}^{\xi a^{+}-\xi^{*} a} \rightarrow \mathrm{e}^{\xi \alpha^{*}-\xi^{*} \alpha} .
$$

Comparison with eq. (4.9) shows us that this is nothing other than Weyl ordering expressed in a different form. The distribution function, therefore, should be the Wigner function. As before we define this as the Fourier transform of the characteristic function $\chi(\xi)$ (see eqs. (2.42)-(2.45)) and we use the real and imaginary parts of $\alpha=\alpha_{\mathrm{r}}+\mathrm{i} \alpha_{\mathrm{i}}$ as the variables of the distribution function, so that, analogous to eq. (4.1), $\alpha=(2 \hbar)^{-1 / 2}(\lambda q+(\mathrm{i} / \lambda) p)$, where $\lambda=(m \omega)^{1 / 2}$. Thus

$$
\begin{aligned}
W(\alpha) & =\frac{1}{\pi} \int \mathrm{d}^{2} \xi \mathrm{e}^{\left(\alpha \xi^{*}-\alpha^{*} \xi\right)} \chi(\xi)=\frac{1}{\pi} \iint \mathrm{d} \xi_{\mathrm{r}} \mathrm{d} \xi_{\mathrm{i}} \mathrm{e}^{2 \mathrm{i}\left(\alpha_{\mathrm{i}} \xi_{\mathrm{r}}-\alpha_{\mathrm{r}} \xi_{\mathrm{i}}\right)} \operatorname{Tr}\left[\hat{\rho} \mathrm{e}^{\xi \hat{a}^{+}-\xi^{*} \hat{a}}\right] \\
& =\frac{1}{\pi} \iint \mathrm{d} \xi_{\mathrm{r}} \mathrm{d} \xi_{\mathrm{i}} \operatorname{Tr}\left[\hat{\rho} \exp \left\{2 \mathrm{i} \xi_{\mathrm{r}}\left(\alpha_{\mathrm{i}}-\frac{\hat{p}}{(2 \hbar)^{1 / 2} \lambda}\right)-2 \mathrm{i} \xi_{\mathrm{i}}\left(\alpha_{\mathrm{r}}-\frac{\lambda \hat{q}}{(2 \hbar)^{1 / 2}}\right)\right\}\right],
\end{aligned}
$$

where

$$
\chi(\xi)=\operatorname{Tr}(\hat{\rho} \hat{D}(\xi))
$$

It may be verified, using eqs. (2.42), (2.45) and (4.35) that

$$
\begin{aligned}
W(\alpha) & =(2 \pi \hbar) P_{\mathrm{w}}(q, p)=2 \int_{-\infty}^{\infty} \mathrm{d} y \sum_{n} \sum_{m}\langle q-y \mid n\rangle\langle n|\hat{\rho}| m\rangle\langle m \mid q+y\rangle \mathrm{e}^{2 \mathrm{i} p y / n} \\
& =\beta \int_{-\infty}^{\infty} \mathrm{d} y \sum_{n} \sum_{m}\left(\frac{1}{2^{n} n !}\right)^{1 / 2}\left(\frac{1}{2^{m} m !}\right)^{1 / 2} \mathrm{e}^{-\beta^{2}\left(q^{2}+y^{2}\right)} \mathrm{e}^{2 \mathrm{i} p y / \hbar} H_{n}(\beta(q+y)) H_{m}(\beta(q-y)) \psi_{n}^{*} \psi_{m}
\end{aligned}
$$


where, in the derivation of the last line from the previous line, we have used eq. (2.90) and where $\beta=(m \omega / \hbar)^{1 / 2}$ and $\langle n|\hat{\rho}| m\rangle=\psi_{n}^{*} \psi_{n}$.

Examination of eqs. (4.11) and (4.34) shows us that the function $A_{s}$ which corresponds, by eqs. (4.32) and (4.33), to the operator $\hat{A}\left(\hat{a}, \hat{a}^{+}\right)$can also be represented as

$$
A_{\mathrm{s}}\left(\alpha, \alpha^{*}\right)=\frac{1}{\pi} \int \mathrm{d}^{2} \xi \operatorname{Tr}(\hat{A} \hat{D}(\xi)) \mathrm{e}^{\xi^{*} \alpha-\xi \alpha}
$$

We would now like to use this to show that

$$
\operatorname{Tr}(\hat{\rho} \hat{A})=\frac{1}{\pi} \int \mathrm{d}^{2} \alpha A_{\mathrm{s}}\left(\alpha, \alpha^{*}\right) W(\alpha) .
$$

Evaluating the right-hand side we see that

$$
\frac{1}{\pi} \int \mathrm{d}^{2} \alpha A_{\mathrm{s}}\left(\alpha, \alpha^{*}\right) W(\alpha)=\frac{1}{\pi^{2}} \int \mathrm{d}^{2} \alpha \int \mathrm{d}^{2} \xi \operatorname{Tr}(\hat{A} \hat{D}(\xi)) \mathrm{e}^{\xi^{*} \alpha-\xi \alpha^{*}} W(\alpha)
$$

Making use of the relation

$$
\delta^{(2)}(\alpha)=\frac{1}{\pi^{2}} \int \mathrm{d}^{2} \xi \mathrm{e}^{\alpha \xi^{*}-\alpha^{*} \xi},
$$

we find that

$$
\frac{1}{\pi} \int \mathrm{d}^{2} \alpha \mathrm{e}^{\xi^{*}-\xi^{*}} W(\alpha)=\chi(-\xi)
$$

We also have from eqs. (4.11) and (4.36)

$$
\frac{1}{\pi} \int \mathrm{d}^{2} \xi \chi(-\xi) \hat{D}(\xi)=\frac{1}{\pi} \int \mathrm{d}^{2} \xi \chi(\xi) \hat{D}^{-1}(\xi)=\hat{\rho}
$$

so that

$$
\frac{1}{\pi} \int \mathrm{d}^{2} \alpha A_{\mathrm{s}}\left(\alpha, \alpha^{*}\right) W(\alpha)=\frac{1}{\pi} \int \mathrm{d}^{2} \xi \operatorname{Tr}(\hat{A} \hat{D}(\xi)) \chi(-\xi)=\operatorname{Tr}(\hat{A} \hat{\rho})
$$

which proves eq. (4.39) and shows that $A_{s}\left(\alpha, \alpha^{*}\right)$ and $W(\alpha)$ can be used to calculate the expectation values of symmetrically ordered operators.

We would also like to say a word about symmetrically ordered power series. Comparison of eqs. (4.11) and (4.31) allows us to calculate the coefficients appearing in eq. (4.32)

$$
b_{n m}=\frac{1}{n ! m !} \frac{1}{\pi} \int \mathrm{d}^{2} \xi \operatorname{Tr}(\hat{A} \hat{D}(\xi))(-\xi)^{n}\left(\xi^{*}\right)^{m}
$$


These coefficients, then, will exist for all operators which have the property that all moments of $\operatorname{Tr}(\hat{A} \hat{D}(\xi))$ are finite. While this behavior is not as good as that for a normally ordered power series it is certainly better than that of anti-normally ordered series.

It is also of interest to examine the behavior of $W(\alpha)$. First we note that

$$
\frac{1}{\pi} \int \mathrm{d}^{2} \xi|\chi(\xi)|^{2}=\frac{1}{\pi} \int \mathrm{d}^{2} \xi \operatorname{Tr}\left[\operatorname{Tr}(\hat{\rho} \hat{D}(\xi)) \hat{D}^{-1}(\xi) \hat{\rho}\right]=\operatorname{Tr} \hat{\rho}^{2} \leq 1
$$

so that $\chi(\xi)$ is a square integrable function. As $W(\alpha)$ is just the Fourier transform of $\chi(\xi)$ it too is square integrable. Therefore, $W(\alpha)$ is far better behaved than $P(\alpha)$ and will exist for all density matrices.

It is also possible to express the Wigner distribution in terms of the $P$ representation. If we can represent the density matrix as in eq. (4.15) we then have that

$$
\chi(\xi)=\int \mathrm{d}^{2} \beta P(\beta)\left\langle\beta\left|\mathrm{e}^{\xi \hat{a}^{+}-\xi^{* a}}\right| \beta\right\rangle=\int \mathrm{d}^{2} \beta P(\beta) \mathrm{e}^{\xi \beta^{*}-\xi^{*} \beta-|\xi|^{2 / 2}}
$$

Taking the Fourier transform of $\chi(\xi)$ gives us, with the use of eqs. (4.35) and (4.37),

$$
\begin{aligned}
W(\alpha) & =\frac{1}{\pi} \int \mathrm{d}^{2} \xi \int \mathrm{d}^{2} \beta P(\beta) \mathrm{e}^{\alpha \xi^{*}-\alpha^{*} \xi} \mathrm{e}^{\xi \beta^{*}-\xi^{*} \beta} \mathrm{e}^{-|\xi|^{2 / 2}} \\
& =\frac{1}{\pi} \int \mathrm{d}^{2} \beta \int \mathrm{d}^{2} \xi P(\beta) \mathrm{e}^{(\alpha-\beta) \xi^{*}-\left(\alpha^{*}-\beta^{*} \xi \xi^{-|\xi|^{2} / 2}\right.} \\
& =2 \int \mathrm{d}^{2} \beta P(\beta) \mathrm{e}^{-2|\alpha-\beta|^{2}} .
\end{aligned}
$$

\subsection{Anti-normal ordering}

Let us suppose that we have an operator given by an anti-normally ordered power series as in eq. (4.27). The function corresponding to the $\hat{A}$ of eq. (4.27) is then

$$
A_{\mathrm{a}}\left(\alpha, \alpha^{*}\right)=\sum_{n, m=0} d_{n m} \alpha^{m}\left(\alpha^{*}\right)^{m}
$$

By analogy with our discussion of the $P$ representation (eq. (4.26)) we can then express $\hat{A}\left(\hat{a}, \hat{a}^{+}\right)$as

$$
\hat{A}\left(\hat{a}, \hat{a}^{+}\right)=\frac{1}{\pi} \int \mathrm{d}^{2} \alpha A_{\mathrm{a}}\left(\alpha, \alpha^{*}\right)|\alpha\rangle\langle\alpha|
$$

We then have that

$$
\operatorname{Tr}(\hat{\rho} \hat{A})=\frac{1}{\pi} \int \mathrm{d}^{2} \alpha A_{\mathrm{a}}\left(\alpha, \alpha^{*}\right) \operatorname{Tr}(\hat{\rho}|\alpha\rangle\langle\alpha|)=\int \mathrm{d}^{2} \alpha A_{\mathrm{a}}\left(\alpha, \alpha^{*}\right) Q(\alpha),
$$


where we have set (Kano [1965])

$$
Q(\alpha)=\frac{1}{\pi}\langle\alpha|\hat{\rho}| \alpha\rangle
$$

This distribution can also be expressed in terms of a characteristic function

$$
\chi_{\mathrm{A}}(\xi)=\operatorname{Tr}\left(\hat{\rho} \mathrm{e}^{-\xi^{*} a} \mathrm{e}^{\xi \hat{a}^{+}}\right)
$$

We have that

$$
\chi_{\mathrm{A}}(\xi)=\frac{1}{\pi} \int \mathrm{d}^{2} \alpha\left\langle\alpha\left|\mathrm{e}^{\xi_{\hat{a}}^{+}} \hat{\rho} \mathrm{e}^{-\xi^{*} \hat{a}}\right| \alpha\right\rangle=\frac{1}{\pi} \int \mathrm{d}^{2} \alpha \mathrm{e}^{\xi \alpha^{*}-\xi^{*} \alpha}\langle\alpha|\hat{\rho}| \alpha\rangle
$$

so that

$$
\begin{aligned}
Q(\alpha) & =\frac{1}{\pi^{2}} \int \mathrm{d}^{2} \xi \mathrm{e}^{\alpha \xi^{*}-\alpha^{*} \xi} \chi_{\mathrm{A}}(\xi) \\
& =\frac{1}{\pi^{3}} \iint \mathrm{d}^{2} \xi \mathrm{d}^{2} \beta \mathrm{e}^{\alpha \xi^{*}-\alpha^{*} \xi} \mathrm{e}^{\beta^{*} \xi-\beta \xi^{*}}\langle\beta|\hat{\rho}| \beta\rangle=\frac{1}{\pi}\langle\alpha|\hat{\rho}| \alpha\rangle .
\end{aligned}
$$

Again by considering our derivation of the $P$ representation we can derive an alternate expression for $A_{\mathrm{a}}\left(\alpha, \alpha^{*}\right)$. Examining eq. (4.21) we see that

$$
A_{\mathrm{a}}\left(\alpha, \alpha^{*}\right)=\frac{1}{\pi} \int \mathrm{d}^{2} \xi \mathrm{e}^{\alpha \xi^{*-\alpha} \alpha^{*}} \operatorname{Tr}\left(\hat{A} \mathrm{e}^{\xi \hat{a}^{+}} \mathrm{e}^{-\xi^{*} a}\right)
$$

The "function" $A_{\mathrm{a}}\left(\alpha, \alpha^{*}\right)$ has, of course, all of the singularity problems of the $P$ representation.

The distribution function, $Q(\alpha)$, has, on the other hand, no singularity problems at all. It exists for all density matrixes, is bounded, and is even greater than or equal to zero for all $\alpha$. The problems in this ordering scheme arise in the representation of the operators.

As a final remark, we note that all of the distribution functions can be written in terms of the Wigner distribution function (McKenna and Frisch [1966]; Agarwal and Wolf [1970]; Haken [1975]; O'Connell [1983b]), by use of integrals or derivatives.

\subsection{Examples}

We would now like to calculate $Q(\alpha)$ and $P(\alpha)$ for a single mode of the radiation field of angular frequency $\omega$. The system which we will consider will be a canonical ensemble at temperature $T \equiv(k \beta)^{-1}$. Our discussion will follow that given in Nussenzveig [1973].

We first consider the anti-normal distribution function $Q(\alpha)$. The density matrix for this system is

$$
\hat{\rho}=\left(1-\mathrm{e}^{-\beta \hbar \omega}\right) \sum_{n=0}^{\infty} \mathrm{e}^{-n \beta \hbar \omega}|n\rangle\langle n| .
$$


For $Q(\alpha)$ we than have from eq. (4.52)

$$
\begin{aligned}
Q(\alpha) & =\frac{1}{\pi}\left(1-\mathrm{e}^{-\beta \hbar \omega}\right) \sum_{n=0}^{\infty} \mathrm{e}^{-n \beta \hbar \omega}\langle\alpha \mid n\rangle\langle n \mid \alpha\rangle \\
& =\frac{1}{\pi}\left(1-\mathrm{e}^{-\beta \hbar \omega}\right) \sum_{n=0}^{\infty} \mathrm{e}^{-n \beta \hbar \omega} \mathrm{e}^{-|\alpha|^{2}} \frac{|\alpha|^{2 n}}{n !} \\
& =\frac{1}{\pi}\left(1-\mathrm{e}^{-\beta \hbar \omega}\right) \exp \left[-|\alpha|^{2}\left(1-\mathrm{e}^{-\beta \hbar \omega}\right)\right] .
\end{aligned}
$$

To obtain $P(\alpha)$ we make use of our result for $Q(\alpha)$. We first find $\chi_{\mathrm{A}}(\xi)$ from eq. (4.54). If we set

$$
s=\left(1-\mathrm{e}^{-\beta \hbar \omega}\right), \quad \xi=x+\mathrm{i} y, \quad \alpha=r+\mathrm{i} k
$$

then

$$
\begin{aligned}
X_{\mathrm{A}}(\xi) & =\frac{s}{\pi} \int \mathrm{d}^{2} \alpha \mathrm{e}^{\xi \alpha^{*}-\xi^{*} \alpha} \mathrm{e}^{-s|\alpha|^{2}}=\frac{s}{\pi} \int \mathrm{d} r \int \mathrm{d} k \exp \left\{-2 \mathrm{i}(k x-r y)-s\left(r^{2}+k^{2}\right)\right\} \\
& =\frac{s}{\pi} \int \mathrm{d} r \int \mathrm{d} k \exp \left\{-s(r-\mathrm{i} y / s)^{2}-s(k+\mathrm{i} x / s)^{2}\right\} \exp \left\{-\left(x^{2}+y^{2}\right) / s\right\}=\mathrm{e}^{-|\xi|^{2 / s}} .
\end{aligned}
$$

To calculate $\chi_{\mathrm{N}}(\xi)$, given by eq. (4.19), we now use the general relation

$$
\chi_{\mathrm{N}}(\xi)=\operatorname{Tr}\left(\hat{\rho} \mathrm{e}^{\xi a^{+}} \mathrm{e}^{-\xi^{*} a}\right)=\operatorname{Tr}\left(\hat{\rho} \mathrm{e}^{-\xi^{*} a} \mathrm{e}^{\xi a^{+}}\right) \mathrm{e}^{|\xi|^{2}}=\mathrm{e}^{|\xi|^{2}} \chi_{\mathrm{A}}(\xi)
$$

Therefore, we see that

$$
\chi_{N}(\xi)=\exp \left\{-|\xi|^{2}(1-s) / s\right\}
$$

If we set $\lambda=(1-s) / s=\left(\mathrm{e}^{\beta \hbar \omega}-1\right)^{-1}$ then from eq. (4.21) we have

$$
\begin{aligned}
P(\alpha) & =\frac{1}{\pi^{2}} \int \mathrm{d}^{2} \xi \mathrm{e}^{\alpha \xi^{*}-\alpha^{*} \xi} \mathrm{e}^{-\lambda|\xi|^{2}}=\frac{1}{\pi^{2}} \int \mathrm{d} x \int \mathrm{d} y \exp \left\{2 \mathrm{i}(k x-r y)-\lambda\left(x^{2}+y^{2}\right)\right\} \\
& =\frac{1}{\pi \lambda} \mathrm{e}^{-|\alpha|^{2} / \lambda}=\frac{1}{\pi}\left(\mathrm{e}^{\beta \hbar \omega}-1\right) \exp \left[-|\alpha|^{2}\left(\mathrm{e}^{\beta \hbar \omega}-1\right)\right] .
\end{aligned}
$$

For this system $P(\alpha)$ is a well-behaved function, a Gaussian in fact, and has no singularities. It is even positive definite. $Q(\alpha)$ is also well behaved, but this comes as no surprise. Our general discussion had ensured that this would be the case.

\subsection{Distribution functions on four-dimensional phase space}

We would now like to briefly discuss some distribution functions which are functions on a fourrather than a two-dimensional phase space. The first of these, the $R$ representation, was discussed by 
Glauber in his 1963 paper. It is very well behaved but has found little use in applications. More recently a new class of these distributions, the generalized $P$ representations, has been used to study the photon statistics of various non-linear optical devices [Walls, Drummond and McNeil [1981]; Drummond and Gardiner [1980]; Drummond, Gardiner and Walls [1981]).

The $R$ representation of the density matrix is obtained by using the coherent state resolution of the identity twice. One has

$$
\hat{\rho}=\frac{1}{\pi^{2}} \int \mathrm{d}^{2} \alpha \int \mathrm{d}^{2} \beta \exp \left\{-\frac{1}{2}\left(|\alpha|^{2}+|\beta|^{2}\right)\right\} R\left(\alpha^{*}, \beta\right)|\alpha\rangle\langle\beta|,
$$

where $|\alpha\rangle$ is defined in eq. (4.5) and $|\beta\rangle$ has the corresponding meaning, and

$$
R\left(\alpha^{*}, \beta\right)=\exp \left\{\frac{1}{2}\left(|\alpha|^{2}+|\beta|^{2}\right)\right\}\langle\alpha|\hat{\rho}| \beta\rangle \text {. }
$$

This representation has no singularity problems. Also it exists and is unique for all density matrices provided that $R\left(\alpha^{*}, \beta\right)$ is an analytic function of $\alpha^{*}$ and $\beta$ (Glauber [1963b]). It can be used to evaluate normally ordered products. One has

$$
\left\langle\left(\hat{a}^{+}\right)^{n} \hat{a}^{m}\right\rangle=\operatorname{Tr}\left[\hat{\rho}\left(\hat{a}^{+}\right)^{n} \hat{a}^{m}\right]=\frac{1}{\pi^{2}} \int \mathrm{d}^{2} \alpha \int \mathrm{d}^{2} \beta \exp \left\{-\left(|\alpha|^{2}+|\beta|^{2}\right)+\beta^{*} \alpha\right\} R\left(\alpha^{*}, \beta\right) \alpha^{m}\left(\beta^{*}\right)^{n} .
$$

The generalized $P$ representations (Drummond and Gardiner [1980]; Drummond, Gardiner and Walls [1981]) are again functions of two complex variables but are not necessarily defined for all values of these variables. To define these representations we define the operator

$$
\hat{\Lambda}(\alpha, \beta)=|\alpha\rangle\left\langle\beta^{*}\right| /\left\langle\beta^{*} \mid \alpha\right\rangle
$$

and an integration measure $\mathrm{d} \mu(\alpha, \beta)$. It is the choice of this measure which determines the distribution function. We will consider two different choices. The density matrix is then

$$
\hat{\rho}=\int_{\mathbf{D}} \mathrm{d} \mu(\alpha, \beta) P(\alpha, \beta) \hat{\Lambda}(\alpha, \beta),
$$

where $\mathrm{D}$ is the domain of integration. Normally ordered products are then given by

$$
\left\langle\left(\hat{a}^{+}\right)^{n}(\hat{a})^{m}\right\rangle=\int \mathrm{d} \mu(\alpha, \beta) P(\alpha, \beta) \beta^{n} \alpha^{m}
$$

Our first integration measure is $\mathrm{d} \mu(\alpha, \beta)=\mathrm{d} \alpha \mathrm{d} \beta$ where $\alpha$ and $\beta$ are to be integrated on some contours $C$ and $C^{\prime}$ respectively. This gives rise to what is called the complex $P$ representation. Let us consider the case in which $C$ and $C^{\prime}$ are contours which enclose the origin. One can then show (Drummond and Gardiner [1980]) that if the density matrix is of the form

$$
\hat{\rho}=\sum_{n} \sum_{m} c_{n m}|n\rangle\langle m|
$$


where both sums are finite then $P(\alpha, \beta)$ exists and is analytic when neither $\alpha$ nor $\beta$ is 0 . Whether $P(\alpha, \beta)$ exists for a general density matrix is not known. The complex $P$ representation is also not unique; if one complex $P$ representation exists for a given density matrix, then an infinite number of representation exist.

The second measure which we wish to consider is $\mathrm{d} \mu(\alpha, \beta)=\mathrm{d} \alpha^{2} \mathrm{~d} \beta^{2}$. Because the coherent states are linearly dependent such a representation is not unique. In fact we have encountered one representation of this type already, the $R$ representation. It is possible to choose $P(\alpha, \beta)$ so that it is real and non-negative (Drummond and Gardiner [1980]), i.e.

$$
P(\alpha, \beta)=\left(1 / 4 \pi^{2}\right) \exp \left\{-\frac{1}{4}\left|\alpha-\beta^{*}\right|^{2}\right\}\left\langle\frac{1}{2}\left(\alpha+\beta^{*}\right)|\hat{\rho}| \frac{1}{2}\left(\alpha+\beta^{*}\right)\right\rangle .
$$

This representation, the positive $P$ representation, is defined for all density matrices.

These two distributions have been used in problems in which non-classical photon states (states which are more like number states than coherent states) are produced. Under these conditions the above defined generalized $P$ representations are better behaved than the original $P$ representation. For example, the $P$ representation corresponding to a density matrix $\hat{\rho}=|n\rangle\langle n|$ contains derivatives of delta functions up to order $2 n$. On the other hand, the complex $P$ representation for this state (again defined on two contours $C$ and $C^{\prime}$ encircling the origin) is just (Drummond and Gardiner [1980])

$$
P(\alpha, \beta)=-\left(1 / 4 \pi^{2}\right) n ! \mathrm{e}^{\alpha \beta}(1 / \alpha \beta)^{n+1}
$$

while the positive $P$ representation is, from eq. (4.70)

$$
P(\alpha, \beta)=\left(1 / 4 \pi^{2}\right)(1 / n !) \exp \left\{-\frac{1}{4}\left|\alpha-\beta^{*}\right|^{2}\right\} \exp \left\{-\frac{1}{2}\left|\alpha+\beta^{*}\right|^{2}\right\}\left|\frac{1}{2}\left(\alpha+\beta^{*}\right)\right|^{2 n} .
$$

Both of these functions are far less singular than the original $P$ representation.

The original motivation for the introduction of these generalized $P$ distributions was connected with their practical applicability to the solution of quantum mechanical master equations (Drummond and Gardiner [1980]; Drummond, Gardiner and Walls [1981]). In general, using a coherent state basis, it is possible to develop phase-space Fokker-Planck equations that correspond to quantum master equations for the density operator (Haken [1970]; Louisell [1973]). From this equation observables are obtained in terms of moments of the $P$ function. However, for various problems, as for example the analysis of recent experiments on atomic fluorescence (Kimble, Dagenais and Mandel [1978]) where we are dealing with non-classical photon statistics (Carmichael and Walls [1976]), the Glauber-Sudarshan $P$ function is singular whereas the generalized $P$ function discussed above is not. Also, use of the latter leads to Fokker-Planck equations with positive semi-definite diffusion coefficients whereas the former gives rise to non-positive-definite diffusion coefficients. In particular, the generalized $P$ representations were applied successfully to non-linear problems in quantum optics (two-photon absorption; dispersive bistability; degenerate parametric amplifier) and chemical reaction theory (Drummond and Gardiner [1980]; Drummond, Gardiner and Walls [1981]; Walls and Milburn [1982]). On the other hand, the usefulness of the Wigner distribution in quantum optics has been demonstrated in a paper by Lugiato, Casagrande and Pizzuto [1982] who consider a system of $N$ two-level atoms interacting with a resonant mode radiation field and coupled to suitable reservoirs. The presence of an external CW coherent field injected into the cavity is also included, which allows for the possibility of treating optical bistability (which occurs when a non-linear optical medium, interacting with a coherent driving field, has more than one stable steady state) as well as a laser with injected signal. 


\section{Conclusion}

We have given what we hope is a useful summary of some of the formalism surrounding the use of quantum mechanical quasiprobability distribution functions. To be of use, however, the formalism should either provide insight or convenient methods of calculation. In our next paper dealing with applications we hope to show that this particular formalism does both in that it has proven to be a tool of great effectiveness in many areas of physics.

\section{Acknowledgments}

R.F.O'C. acknowledges support from the Dept. of Energy, Division of Material Sciences, under Contract No. DE-AS05-79ER10459. He would also like to thank the Max-Planck Institute for Quantum Optics for hospitality, during the summers of 1981 and 1982, at which time part of this work was carried out. M.O.S. acknowledges support from the Office of Scientific Research, under Contract No. AFOSR81-0128-A.

\section{References}

Agarwal, G.S. and E. Wolf, 1970, Phys. Rev. D10, 2161, 2187, 2206.

Alastuey, A. and B. Jancovici, 1980, Physica 102A, 327.

Bloch, F., 1932, Zeits. f. Physik 74, 295.

Bopp, F., 1956, Ann. Inst. H. Poincaré 15, 81.

Bopp. F., 1961, Werner Heisenberg und die Physik unserer Zeit (Vieweg, Braunschweig) p. 128.

Brittin, W.E. and W.R. Chappell, 1962, Rev. Mod. Phys. 34, 620.

Cahill, K.E., 1965, Phys. Rev. 138, B1566.

Cahill, K.E. and R.J. Glauber, 1969, Phys. Rev. 177, 1857, 1883.

Carmichael, H.J. and D.F. Walls, 1976, J. Phys. B9, 1199.

Carruthers, P. and F. Zachariasan, 1983, Rev. Mod. Phys. 55, 245.

Cartwright, N.D., 1976, Physica 83A, 210.

Cohen, L., 1966, J. Math. Phys. 7, 781.

Dahl, J.P., 1982, Physica Scripta 25, 499.

De Giorgio, V. and M.O. Scully, 1970, Phys. Rev. A2, 1170.

De Groot, S.R. and L.G. Suttorp, 1972, Foundations of Electrodynamics (North-Holland, Amsterdam).

De Groot, S.R., 1974, La transformation de Weyl et la fonction de Wigner: une forme alternative de la mécanique quantique (Les Presses

Universitaires de Montréal, Montréal).

De Groot, S.R., W.A. van Leeuwen and C.G. van Weert, 1980, Relativistic Kinetic Theory (North-Holland, Amsterdam).

Drummond, P.D. and C.W. Gardiner, 1980, J. Phys. A13, 2353.

Drummond, P.D., C.W. Gardiner and D.F. Walls, 1981, Phys. Rev. A24, 914.

Glauber, R.J., 1963a, Phys. Rev. Lett. 10, 84.

Glauber, R.J., 1963b, Phys. Rev. 131, 2766.

Glauber, R.J., 1965, in: Quantum Optics and Electronics, eds. C. DeWitt, A. Blandin and C. Cohen-Tannoudji (Gordon and Breach, New York).

Gradshteyn, I.S. and M. Ryzhik, 1980, Table of Integrals, Series and Products (Academic Press, New York) p. 838.

Graham, R. and H. Haken, 1970, Z. Physik 237, 31.

Groenewold, H.J., 1946, Physica 12, 405.

Haken, H., 1970, Handbuch der Physik, Vol. XXV/2c (Springer, Berlin).

Haken, H., 1975, Rey. Mod. Phys. 47, 67.

Husimi, K., 1940, Proc. Phys. Math. Soc. Japan 22, 264.

Imre, K., E. Ozizmir, M. Rosenbaum and P. Zweifel, 1967, J. Math. Phys. 8, 1097

Kano, Y., 1965, J. Math. Phys. 6, 1913.

Kimble, H.J., M. Dagenais and L. Mandel, 1978, Phys. Rev. A18, 201.

Klauder J.R. and E.C.G. Sudarshan, 1968, Quantum Optics (Benjamin, New York) p. 178.

Klimintovich, I.L., 1958, Sov. Phys. JETP 6, 753. 
Kubo, R., 1964, J. Phys. Soc. Japan 19, 2127.

Landau, L.D. and E.M. Lifshitz, 1965, Quantum Mechanics (Pergamon, Oxford).

Lax, M., 1968, Phys. Rev. 172, 350.

Lax, M. and W.H. Louisell, 1967, J. Quant. Electron. QE3, 47.

Louisell, W.H., 1973, Quantum Statistical Properties of Radiation (Wiley, New York).

Lugiato, L.A., F. Cassagrande and L. Pizzuto, 1982, Phys. Rev. A26, 3438.

Margenau, H. and R.N. Hill, 1961, Prog. Theoret. Phys. (Kyoto) 26, 722.

McKenna, J. and H.L. Frisch, 1966, Phys. Rev. 145, 93.

Mehta, C.L., 1964, J. Math. Phys. 5, 677.

Mehta, C.L. and E.C.G. Sudarshan, 1965, Phys. Rev. 138, B274.

Messiah, A., 1961, Quantum Mechanics (North-Holland, Amsterdam) Vol. 1, p. 442.

Mori, H., I. Oppenheim and J. Ross, 1965, in: Studies in Statistical Mechanics, eds. J. de Boer and G.E. Uhlenbeck (North-Họland, Amsterdam)

Vol. 1, p. 213.

Moyal, J.E., 1949, Proc. Cambridge Phil. Soc. 45, 99.

Nienhuis, G., 1970, J. Math. Phys. 11, 239.

Nussenzveig, H.M., 1973, Introduction to Quantum Optics (Gordon and Breach, New York) p. 71.

O'Connell, R.F., 1983a, Found. Phys. 13, 83.

O'Connell, R.F., 1983b, in: Proc. Third New Zealand Symp. on Laser Physics, eds. J.D. Harvey and D.F. Walls (Springer-Verlag, Berlin and New

York), Lecture Notes in Physics No. 182.

O'Connell, R.F. and E.P. Wigner, 1981a, Phys. Lett. 83A, 145.

O'Connell, R.F. and E.P. Wigner, 1981b, Phys. Lett. 85A, 121.

O'Connell, R.F. and E.P. Wigner, 1983, in preparation.

Oppenheim, I. and J. Ross, 1957, Phys. Rev. 107, 28.

Prugovecki, E., 1978, Ann. Phys. (NY) 110, 102.

Schrödinger, E., 1926, Naturwissenschaften 14, 664.

Schweber, S.S., 1961, An Introduction to Relatjvistic Quantum Fjeld Theory (Happer and Row, New York) pp. 133, 140.

Scully, M.O. and W.E. Lamb Jr., 1967, Phys. Rev. 159, 208.

Sudarshan, E.C.G., 1963, Phys. Rev. Lett. 10, 277.

Summerfield, G.C. and P.F, Zweifel, 1969, J, Math. Phys. 10, 233.

Suttorp, L.G. and S.R. de Groot, 1970, Nuovo Cimento 65A, 245.

Takabayashi, T., 1954, Prog. Theor. Phys. 11, 341.

Walls, D.F., P.D. Drummond and K.J. McNeil, 1981, in: Optical Bistability, eds. C.M. Bowden, M. Ciftan and H.R. Robl (Plenum, New York).

Walls, D.F. and G.J. Milburn, 1982, in: Proc. NATO ASl in Bad Windsheim, West Germany, ed. P. Meystre (Plenum, New York).

Weyl, H., 1927, Z. Phys. 46, 1.

Wigner, E., 1932a, Phys. Rev. 40, 749.

Wigner, E., 1932b, 2. Phys. Chem. B19, 203.

Wigner, E., 1938, Trans. Faraday Soc. 34, 29.

Wigner, E.P., 1979, in: Perspectives in Quantum Theory, eds. W. Yourgrau and A. van der Merwe (Dover, New York) p. 25. 


\section{Canonical transformation in quantum mechanics}

Y.S. Kim

Department of Physics and Astronomy, University of Maryland, College Park, Maryland 20742

E. P. Wigner

Joseph Henry Laboratories, Princeton University, Princeton, New Jersey 08544

(Received 23 November 1988; accepted for publication 22 June 1989)

The phase-space picture of quantum mechanics and some examples illustrating it are presented. Since the position and momentum are $c$ numbers in this picture, it is possible to introduce the concept of phase space in quantum mechanics. The uncertainty relation is stated in terms of an area element in phase space, whose minimum size is Planck's constant. Area-preserving canonical transformations in phase space are therefore uncertainty-preserving transformations. The wavepacket spread, coherent-state representation, and squeezed states of light are discussed as illustrative examples.

\section{INTRODUCTION}

The present organization of the first-year graduate course in quantum mechanics is largely based on the Schrödinger picture and its applications to atomic and nuclear physics. The first widely accepted textbook on this subject was Schiff's book entitled Quantum Mechanics, whose first edition was published in $1949 .{ }^{1}$ There are now many excellent textbooks, but their basic organization is not significantly different from that of Schiff's first edition. These days, due to many new physical applications, we are led to consider adding to the physics curriculum representations 
of quantum mechanics other than the Heisenberg or Schrödinger picture.

The phase-space picture of quantum mechanics is a case in point. ${ }^{2,3}$ Starting from the Shrödinger wavefunction, it is possible to construct a distribution function in phase space in terms of the $c$-number position and momentum variables. Using this distribution function, we can perform canonical transformations in quantum mechanics. The earliest application of the phase-space distribution function was made in quantum corrections to thermodynamics in $1932 .{ }^{4}$ Now, this phase-space approach is an important scientific language for many branches of physics, and there are a number of review articles. ${ }^{5-7}$

From the pedagogical point of view, the phase-space picture of quantum mechanics is a useful tool for demonstrating the transition from classical to quantum mechanics. In this picture, it is possible to perform canonical transformations, just as in classical mechanies. ${ }^{8,9}$ Canonical transformations in quantum mechanics lead to a more precise picture of the uncertainty relation, particularly for the spreading wave packet. ${ }^{10}$ It also allows us to define the uncertainty relation in a Lorentz-invariant manner. ${ }^{11}$

In addition, the phase-space picture of quantum mechanics is a practical research tool in modern optics. Coherent and squeezed states are of current interest, ${ }^{12-15}$ and they deserve to be included in the existing quantum mechanics curriculum in their own right. The phase-space picture of quantum mechanics is the simplest language for these states. ${ }^{16}$

The group theory of linear canonical transformations in phase space is a very important theoretical tool in many branches of physics. ${ }^{16-21}$ In particular, the group of homogeneous linear canonical transformations is locally isomorphic to the $(2+1)$-dimensional Lorentz group. ${ }^{19}$ This allows us to study Lorent $z$ transformations while performing canonical transformations in phase space that correspond to physical processes in optics laboratories. ${ }^{16}$

The purpose of this article is to present some of the features of the phase-space picture that can be easily accommodated in the existing quantum mechanics curriculum. In Sec. II, we introduce the phase-space distribution function and its general properties. In Secs. III and IV, we discuss linear canonical transformations in classical mechanics and in the phase-space picture of quantum mechanics. In Sec. V, the wave-packet spread is shown to be an example of canonical transformations in phase space. In Sec. VI, coherent and squeezed states of light are introduced as minimum-uncertainty states. In Secs. VII and VIII, the coherent and squeezed states are discussed in terms of canonical transformations. It is pointed out in Sec. IX that we can study the Lorentz kinematics of the Thomas precession in terms of canonical transformations of squeezed states.

\section{BASIC PROPERTIES OF THE PHASE-SPACE DISTRIBUTION FUNCTION}

If $\psi(x, t)$ is a solution of the Schrödinger equation

$$
i \frac{\partial}{\partial t} \psi(x, t)=-\frac{1}{2 m}\left(\frac{\partial}{\partial x}\right)^{2} \psi(x, t)+V(x) \psi(x),
$$

we can construct a function of $x, p$, and $t$ defined as ${ }^{4-6}$

$$
W(x, p, t)=\frac{1}{\pi} \int \psi^{*}(x+y, t) \psi(x-y, t) e^{2 i p y} d y .
$$

The parameters $x$ and $p$ are $c$ numbers. Therefore, this form is a distribution function defined over the two-dimensional phase space of $x$ and $p$. We shall call this function the phase-space distribution function or PSD function.

The PSD function is real, but not always positive. The PSD function is not a probability distribution function. Nevertheless, it is possible to derive from this function many useful relations in quantum mechanics. It is not unlike the case of the partition function in statistical mechanics. It is very difficult, if not impossible, to give a physical interpretation to the partition function, but it is possible to derive many useful physical quantities from it.

We can derive from the PSD function the positive probability distributions in the position and momentum coordinates $^{4-6,22}$ :

$$
\begin{aligned}
& \rho(x, t)=|\psi(x, t)|^{2}=\int W(x, p, t) d \rho, \\
& \sigma(p, t)=|\chi(p, t)|^{2}=\int W(x, p, t) d x,
\end{aligned}
$$

where $\chi(p)$ is the momentum wavefunction. It is also possible to compute the absolute square of the inner product of two wavefunctions. Let us next consider two wavefunctions $\psi(x, t)$ and $\phi(x, t)$. If $W_{\psi}(x, p, t)$ and $W_{\phi}(x, p, t)$ are the PSD functions for $\psi(x)$ and $\phi(x)$, respectively, then $^{4-6,23}$

$$
\begin{aligned}
& \int W_{\psi}(x, p, t) W_{\phi}(x, p, t) d x d p \\
& =(1 / 2 \pi)|(\phi(x, t), \psi(x, t))|^{2} .
\end{aligned}
$$

This expression is nonnegative, but can become zero if the two wavefunctions are orthogonal to each other, indicating that the PSD functions are not positive everywhere in phase space. For instance, the one-dimensional harmonic oscillator wavefunction takes the form

$$
\begin{aligned}
& \psi_{0}(x)=(1 / \pi)^{1 / 4} e^{-x^{2} / 2}, \\
& \psi_{1}(x)=(4 / \pi)^{1 / 4} e^{-x^{2} / 2},
\end{aligned}
$$

for the ground and first-excited states, respectively. Then, the corresponding PSD functions are

$$
\begin{aligned}
& W_{0}(x, p)=(1 / \pi) e^{-\left(x^{2}+p^{2}\right)}, \\
& W_{1}(x, p)=(2 / \pi)\left(x^{2}+p^{2}-\frac{1}{2}\right) e^{-\left(x^{2}+p^{2}\right)} .
\end{aligned}
$$

These examples confirm the properties of the PSD function given in Eqs. (3) and (4).

The time-dependent Schrödinger equation leads to the differential equation ${ }^{4-6}$

$$
\begin{aligned}
\frac{\partial}{\partial t} W(x, p, t) \\
=-\left(\frac{p}{m}\right) \frac{\partial}{\partial x} W(x, p, t) \\
\quad+\sum_{n=0}^{\infty}\left(\frac{1}{2}\right)^{2 n} \frac{1}{(2 n+1) !}\left[\left(\frac{\partial}{\partial x}\right)^{2 n+1} V(x)\right] \\
\quad \times\left(\frac{\partial}{\partial p}\right)^{2 n+1} W(x, p, t),
\end{aligned}
$$

where $m$ is the mass of the particle, and $V(x)$ is the potential. If the particle is free, the above differential equation becomes

$$
\frac{\partial}{\partial t} W(x, p, t)=-\left(\frac{p}{m}\right) \frac{\partial}{\partial x} W(x, p, t) .
$$


In the case of the harmonic oscillator with $V(x)=K x^{2} / 2$, the differential equation becomes

$$
\begin{aligned}
\frac{\partial}{\partial t} W(x, p, t)= & -\left(\frac{p}{m}\right) \frac{\partial}{\partial x} W(x, p, t) \\
& +K x \frac{\partial}{\partial p} W(x, p, t) .
\end{aligned}
$$

There are many other interesting properties of the PSD function, and they are extensively discussed in the literature. $^{4-11}$ In this article, we are interested only in the fact that canonical transformations are possible in quantum mechanics through the use of the PSD function.

The probability density functions in Eq. (3) clearly indicate that $x$ and $p$ are the position and momentum variables in quantum mechanics. On the other hand, they are $c$ numbers, allowing us to define a function over the phase space of $x$ and $p$. Does this mean that we can determine the $x$ and $p$ variables simultaneously? The answer to this question is no.

The uncertainty principle does not allow us to determine a point in phase space. However, it does not forbid the area element that satisfies $(\Delta x)(\Delta p) \geqslant 1$. Since canonical transformations are area-preserving transformations, they preserve the uncertainty relation. Indeed, we may achieve a deeper understanding of the uncertainty principle through canonical transformations in phase space, which are possible in the phase-space picture of quantum mechanics.

\section{LINEAR CANONICAL TRANSFORMATIONS IN CLASSICAL MECHANICS}

Classical mechanics can be formulated in terms of the position and momentum variables. If $U$ and $V$ are two functions of $x$ and $p$, then their Poisson bracket is defined as ${ }^{\gamma}$

$$
[U, V]_{x p}=\frac{\partial U}{\partial x} \frac{\partial V}{\partial p}-\frac{\partial U}{\partial p} \frac{\partial V}{\partial x} .
$$

Under the canonical transformation

$$
X=X(x, p), \quad P=P(x, p),
$$

the Poisson bracket remains invariant. For one pair of canonical variables, this leads to the condition that the Jacobian determinant be 1 :

$$
\left|\begin{array}{ll}
\frac{\partial X}{\partial x} & \frac{\partial P}{\partial x} \\
\frac{\partial X}{\partial p} & \frac{\partial P}{\partial p}
\end{array}\right|=1
$$

This means that the area element in phase space is preserved under canonical transformations.
We are interested in linear canonical transformations of the form

$$
\begin{aligned}
& X=a_{11} x+a_{12} p+b_{1}, \\
& P=a_{21} x+a_{22} p+b_{2} .
\end{aligned}
$$

The parameters $b_{1}$ and $b_{2}$ are for translations, which are area-preserving canonical transformations. If we do not consider this transformation by setting $b_{1}=b_{2}=0$, the above equations represent homogeneous linear transformations. The most familiar linear transformation is the rotation around the origin:

$$
\left(\begin{array}{l}
X \\
P
\end{array}\right)=\left(\begin{array}{ll}
\cos (\theta / 2) & -\sin (\theta / 2) \\
\sin (\theta / 2) & \cos (\theta / 2)
\end{array}\right)\left(\begin{array}{l}
x \\
p
\end{array}\right) .
$$

We use the angle $\theta / 2$ instead of $\theta$ for later convenience. Another area-preserving linear transformation is the squeeze along the $x$ axis:

$$
\left(\begin{array}{l}
X \\
P
\end{array}\right)=\left(\begin{array}{cc}
\exp (\eta / 2) & 0 \\
0 & \exp (-\eta / 2)
\end{array}\right)\left(\begin{array}{l}
x \\
p
\end{array}\right) .
$$

We are now ready to formulate the group linear canonical transformations in phase space. This group consists of translations, rotations, and squeezes in phase space. The coordinate transformation representing translations

$$
X=x+b_{1}, \quad P=p+b_{2},
$$

can be written as

$$
\left(\begin{array}{l}
X \\
P \\
1
\end{array}\right)=\left(\begin{array}{ccc}
1 & 0 & b_{1} \\
0 & 1 & b_{2} \\
0 & 0 & 1
\end{array}\right)\left(\begin{array}{l}
x \\
p \\
1
\end{array}\right)
$$

The matrix performing the rotation around the origin by $\theta / 2$ takes the form

$$
R(\theta)=\left(\begin{array}{ccc}
\cos (\theta / 2) & -\sin (\theta / 2) & 0 \\
\sin (\theta / 2) & \cos (\theta / 2) & 0 \\
0 & 0 & 1
\end{array}\right) .
$$

It is possible to define the polar variables $r$ and $\phi$ in phase space, with $r=\left(x^{2}+p^{2}\right)^{1 / 2}$ and $\phi=\tan ^{-1}(p / x)$. The $x$ direction in this case is the $\phi=0$ direction. We can thus write $S_{x}(\eta)=S(\phi=0, \eta)$. Then,

$$
S(0, \eta)=\left(\begin{array}{ccc}
e^{\eta / 2} & 0 & 0 \\
0 & e^{-\eta / 2} & 0 \\
0 & 0 & 1
\end{array}\right)
$$

The elongation along the $x$ axis is necessarily the contraction along the $p$ axis. The squeeze along the direction that makes an angle $\phi / 2$ with the $x$ axis is

$$
\begin{aligned}
S(\phi, \eta) & =R(\phi) S(\eta, 0) R(-\phi) \\
& =\left(\begin{array}{ccc}
\cosh (\eta / 2)+(\cos \phi) \sinh (\eta / 2) & (\sin \phi) \sinh (\eta / 2) & 0 \\
(\sin \phi) \sinh (\eta / 2) & \cosh (\eta / 2)-(\cos \phi) \sinh (\eta / 2) & 0 \\
0 & 0 & 1
\end{array}\right) .
\end{aligned}
$$

Since a canonical transformation followed by another one is a canonical transformation, the most general form of the transformation matrix is a product of the above three forms of matrices. We can simplify this mathematics by 
using the generators of the transformation matrices. If we use $T\left(b_{1}, b_{2}\right)$ for the translation matrix given in Eq. (17), it can be

$$
T(u, v)=e^{-i\left(b_{1} N_{1}+b_{2} N_{2}\right)},
$$

where

$$
N_{1}\left(\begin{array}{lll}
0 & 0 & i \\
0 & 0 & 0 \\
0 & 0 & 0
\end{array}\right), \quad N_{2}=\left(\begin{array}{lll}
0 & 0 & 0 \\
0 & 0 & i \\
0 & 0 & 0
\end{array}\right)
$$

These generators commute with each other:

$$
\left[N_{1}, N_{2}\right]=0 \text {. }
$$

The rotation matrix is generated by

$$
L=\left(\begin{array}{ccc}
0 & -i / 2 & 0 \\
i / 2 & 0 & 0 \\
0 & 0 & 0
\end{array}\right)
$$

and

$$
R(\theta)=e^{-i \theta L} \text {. }
$$

These generators satisfy the following commutation relations with $N_{1}$ and $N_{2}$ :

$$
\left[N_{1}, L\right]=(i / 2) N_{2}, \quad\left[N_{1}, L\right]=(-i / 2) N_{1} \text {. }
$$

Indeed, $L, N_{1}$, and $N_{2}$ satisfy the closed commutation relations. They generate the two-dimensional Euclidean group consisting of rotations and translations in two-dimensional space. $^{24,25}$

The squeeze matrix of Eq. (19) can be written as

$$
S(0, \eta)=e^{-i \eta K_{1}} \text {, }
$$

where

$$
K_{1}=\left(\begin{array}{ccc}
i / 2 & 0 & 0 \\
0 & -i / 2 & 0 \\
0 & 0 & 0
\end{array}\right)
$$

In addition, if we introduce the matrix $K_{2}$ defined as

$$
K_{2}=\left(\begin{array}{ccc}
0 & i / 2 & 0 \\
i / 2 & 0 & 0 \\
0 & 0 & 0
\end{array}\right)
$$

which generates the squeeze along the direction that makes a $45^{\circ}$ angle with the $x$ axis, then the matrices $L, K_{1}$, and $K_{2}$ satisfy the following commutation relations:

$$
\left[K_{1}, K_{2}\right]=-i L, \quad\left[K_{1}, L\right]=-i K_{2}, \quad\left[K_{2}, L\right]=i K_{1} .
$$

This set of commutation relations is identical to that for the generators of the $(2+1)$-dimensional Lorentz group. ${ }^{19,24,25}$ The group generated by the above three operators is known also as the symplectic group $S p(2),{ }^{16-21}$ and its connection with the Lorentz group has been extensively discussed in the literature.

If we take into account the translation operators, the commutation relations become

$$
\begin{array}{ll}
{\left[K_{1}, N_{1}\right]=(i / 2) N_{1},} & {\left[K_{1}, N_{2}\right]=(-i / 2) N_{2},} \\
{\left[K_{2}, N_{1}\right]=(i / 2) N_{2},} & {\left[K_{2}, N_{2}\right]=(i / 2) N_{1} .}
\end{array}
$$

These commutators together with those of Eq. (28) form the set of closed commutation relations (or Lie algebra) of the group of canonical transformations. This group is the inhomogeneous symplectic group in two-dimensional space which is often called $\operatorname{ISp}(2){ }^{16,20,21,26}$

\section{LINEAR CANONICAL TRANSFORMATIONS IN QUANTUM MECHANICS}

Since the PSD function is real and defined over the phase space of $x$ and $p$, we can perform area-preserving canonical transformations as in the case of classical mechanics. Let us consider first linear canonical transformations applicable to a function of $x$ and $p$. This is then a matter of converting the matrix generators given in Sec. III, into differential forms.

The generators of translations are

$$
N_{1}=-i \frac{\partial}{\partial x}, \quad N_{2}=-i \frac{\partial}{\partial p},
$$

while rotations around the origin are generated by

$$
L=\frac{i}{2}\left(p \frac{\partial}{\partial x}-x \frac{\partial}{\partial p}\right) .
$$

The squeezes along the $x$ axis and along the direction that makes an angle of $45^{\circ}$ are generated by

$$
K_{1}=\frac{i}{2}\left(x \frac{\partial}{\partial x}-p \frac{\partial}{\partial p}\right), \quad K_{2}=\frac{i}{2}\left(x \frac{\partial}{\partial p}+p \frac{\partial}{\partial x}\right),
$$

respectively. These operators satisfy the commutation relations for the generators of the group of linear canonical transformations given in Sec. III. Therefore, we can continue using the matrix formalism of classical mechanics in the phase-space picture of quantum mechanics.

Next, let us see why canonical transformations are not discussed in the Schrödinger picture of quantum mechanics. In the Schrödinger picture, the wavefunction is a function of $x$ or $p$, but not both. On the other hand, the transformations corresponding to those applicable to the PSD function are possible on the Schrödinger wavefunction. Indeed, the following transformations on $\psi(x, t)$, through the definition given in Eq. (2), lead to the transformations given in Eqs. $(30)-(32)^{16}$ :

$$
\begin{aligned}
& \hat{N}_{1}=-i \frac{\partial}{\partial x}, \hat{N}_{2}=x \\
& \hat{L}=\frac{1}{4}\left[x^{2}-\left(\frac{\partial}{\partial x}\right)^{2}\right] \\
& \hat{K}_{1}=-\frac{i}{4}\left(2 x \frac{\partial}{\partial x}+1\right), \quad \hat{K}_{2}=\frac{1}{4}\left[x^{2}+\left(\frac{\partial}{\partial x}\right)^{2}\right]
\end{aligned}
$$

These operators are all Hermitian in the Schrödinger picture. Therefore, linear canonical transformations in phase space correspond to unitary transformations in the Schrödinger picture of quantum mechanics.

The question then is whether these operators satisfy the commutation relations for the generators of the group of linear canonical transformations. The answer to this question is no, but almost yes. They satisfy all the commutation relations except one. The operators $\hat{N}_{1}$ and $\hat{N}_{2}$ do not commute with each other, while $N_{1}$ and $N_{2}$ do:

$$
\left[\widehat{N}_{1}, \hat{N}_{2}\right]=-i, \quad \text { while }\left[N_{1}, N_{2}\right]=0 \text {. }
$$

This causes a factor of modulus unity when the translation along $p$ is commuted with the translation along the $x$ direction, and the group of linear canonical transformations in the Schrödinger picture is not the same as that in classical mechanics.

Let us next look at the subgroups. The group generated 
by $N_{1}$ and $N_{2}$ is the translation subgroup of the group of linear canonical transformations in phase space. This is an Abelian group. On the other hand, the operators $\hat{N}_{1}$ and $\hat{N}_{2}$ do not form a closed Lie algebra. They have to be supplemented by an identity operator to form a group. This is known as the Heisenberg group. This means that the Heisenberg group is represented in phase space as the translation group. The operators $N_{1}, N_{2}$, and $L$ form the twodimensional Euclidean group. On the other hand, $\widehat{N}_{1}, \widehat{N}_{2}$, and $L$ need the identity operator to form a group.

The operators $K_{1}, K_{2}$, and $L$ generate the group of homogeneous linear transformations. The counterparts in the Schrödinger picture, unlike the case with $\widehat{N}_{1}$ and $\widehat{N}_{2}$, satisfy the same set of commutation relations given in Eq. (28). Furthermore, the Lie algebra of Eq. (28) is identical to that of the $(2+1)$-dimensional Lorentz group, where $K_{1}$ and $K_{2}$ are the generators of boosts along the $x$ and $y$ directions, respectively, while $L$ generates rotations around the $z$ axis. This correspondence allows us to study the group of Lorentz transformations using the phase-space picture of quantum mechanics.

\section{WAVE-PACKET SPREADS IN TERMS OF CANONICAL TRANSFORMATIONS}

Let us consider the wave-packet spread of a free particle with mass $m$. If the initial momentum distribution is of the form

$$
g(k)=(b / \pi)^{1 / 4} e^{-b k^{2 / 2}},
$$

at $t=0$, the time-dependent Schrödinger wavefunction becomes

$$
\begin{aligned}
\psi(x, t)= & (b / \pi)^{1 / 4}[1 /(b+i t / m)]^{1 / 2} \\
& \times e^{-x^{2} / 2(b+i t / m)} .
\end{aligned}
$$

In order to obtain the PSD function, we solve the differential equation for $W(x, p, t)$ given in Eq. (28) for the free particle. The solution is

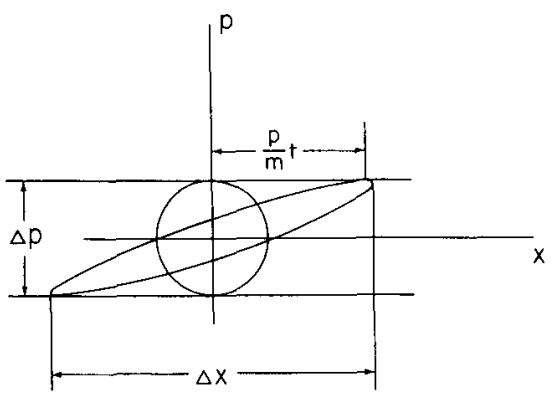

Fig. 1. Wave-packet spread in phase space. If the uncertainty is defined in terms of the volume of the error box, the spreading wave packet preserves the uncertainty. On the other hand, in the Schrödinger picture of quantum mechanics, $\Delta p$ remains constant, while $\Delta x$ increases as time progresses. This is commonly known as the wave-packet spread. The phasespace picture gives a more precise description of the uncertainty relation for spreading wave packets.

$$
W(x, p, t)=W(x-p t / m, p, 0) .
$$

If the initial momentum distribution is Gaussian as is given in Eq. (35),

$$
W(x, p, t)=(1 / \pi) \exp \left\{-\left[(x-p t / m)^{2} / b+b p^{2}\right]\right\} .
$$

This distribution is concentrated within the region where the exponent is less than 1 in magnitude. This is the region of uncertainty, which these days is called the error box. ${ }^{27}$ We can choose the coordinate system in which $b=1$. Then, the above PSD function is a circle at $t=0$. As time progresses, the circle becomes a tilted ellipse while preserving its area, ${ }^{10,11}$ as is described in Fig. 1.

In the Schrödinger picture of quantum mechanics, as time progresses, the momentum distribution $\sigma(p, t)$ remains unchanged, while the spatial distribution $\rho(x)$ becomes widespread. This is called the wave-packet spread. On the other hand, in the phase-space picture of quantum mechanics, the uncertainty is defined in terms of the error box. The volume of the error box, which measures the uncertainty, remains constant. Thus we achieve a deeper understanding of the wave-packet spread in the phase-space picture.

The above-mentioned elliptic deformation is a canonical transformation. Indeed, the transformation matrix is

$$
\left(\begin{array}{l}
x^{\prime} \\
p^{\prime}
\end{array}\right)=\left(\begin{array}{cc}
1 & t / m \\
0 & 1
\end{array}\right)\left(\begin{array}{l}
x \\
p
\end{array}\right) .
$$

This transformation is generated by

$$
G=\left(\begin{array}{ll}
0 & i \\
0 & 0
\end{array}\right),
$$

which leads to

$$
e^{-i(t / m) G}=\left(\begin{array}{cc}
1 & t / m \\
0 & 1
\end{array}\right)
$$

The transformation property in phase space of this shear is illustrated in Fig. 1.

The question then is whether the above transformation can be derived from the generators of linear canonical transformations given in Sec. III. The simplest answer to this question is to note that the generator $G$ can be written as $G=K_{2}-L$. It is also possible to prove this using explicit matrices. With $t / m=2[\sinh (\eta / 2)]$, the above matrix can be written as

$$
\begin{aligned}
\left(\begin{array}{cc}
1 & 2[\sinh (\eta / 2)] \\
0 & 1
\end{array}\right)= & \left(\begin{array}{ll}
\cos (\alpha / 2) & -\sin (\alpha / 2) \\
\sin (\alpha / 2) & \cos (\alpha / 2)
\end{array}\right) \\
& \times\left(\begin{array}{ll}
\cosh (\eta / 2) & \sinh (\eta / 2) \\
\sinh (\eta / 2) & \cosh (\eta / 2)
\end{array}\right) \\
& \times\left(\begin{array}{cc}
\cos (\alpha / 2) & -\sin (\alpha / 2) \\
\sin (\alpha / 2) & \cos (\alpha / 2)
\end{array}\right),
\end{aligned}
$$

where $\sin \alpha=\tanh (\eta / 2)$. On the right-hand side, each of the three matrices is a canonical transformation derivable from the generators given in Sec. III. Thus the left-hand side is a canonical transformation matrix.

\section{MINIMUM-UNCERTAINTY STATES}

Because the variables $x$ and $p$ are $c$ numbers, it is possible to perform even nonlinear canonical transformations in the phase-space picture of quantum mechanics. Let us consid- 
er the transformation from the Cartesian coordinate system of $q$ and $p$ into a polar coordinate system, as is indicated in Fig. 2, and the canonical transformation

$$
n=\frac{1}{2}\left(q^{2}+p^{2}-1\right), \quad \phi=\tan ^{-1}(p / q),
$$

with

$$
\left|\begin{array}{ll}
\frac{\partial n}{\partial q} & \frac{\partial \phi}{\partial q} \\
\frac{\partial n}{\partial p} & \frac{\partial \phi}{\partial p}
\end{array}\right|=1 .
$$

This means that the uncertainty $(\Delta n)(\Delta \phi)$ (Ref. 28) is equal to $(\Delta q)(\Delta p)$. Thus, in order to study the minimum uncertainty in $\phi$ and $n$, it is sufficient to study the uncertainty for the $q$ and $p$ variables.

In the real world, the relation $(\Delta n)(\Delta \phi)$ appears as the phase-intensity or phase-number uncertainty relation for nonlocalizable light waves. ${ }^{12}$ Let us consider the coherentstate representation. If $|n\rangle$ is the $n$-photon state, the coherent state is defined as ${ }^{12.13}$

$$
|\alpha\rangle=e^{-\alpha \alpha^{*} / 2} \sum_{n} \frac{\alpha^{n}}{\sqrt{n !}}|n\rangle .
$$

If $a$ and $a^{\dagger}$ are the annihilation and creation operators, respectively, with

$$
\left[a, a^{\dagger}\right]=1 \text {, }
$$

from this commutation relation, it is possible to define the number operator $N=a^{\dagger} a$, where

$$
N|n\rangle=n|n\rangle \text {. }
$$

The coherent state $|\alpha\rangle$ is not an eigensate of this number operator, but is an eigenstate of the annihilation operator, satisfying the eigenvalue equation

$$
a|\alpha\rangle=\alpha|\alpha\rangle \text {. }
$$

The probability of the coherent state $|\alpha\rangle$ being in the $n$ photon state is $\left(\alpha \alpha^{*}\right)^{n} /\left[n ! \exp \left(\alpha \alpha^{*}\right)\right]$, which means that the number of photons in the coherent state has a Poisson distribution. The expectation value of the number operator is

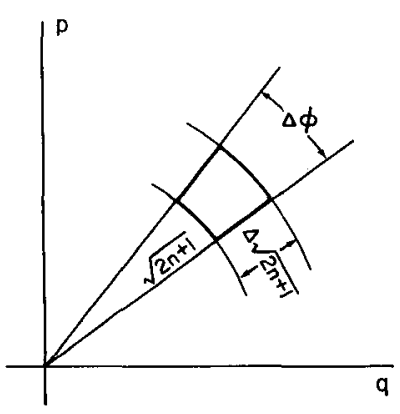

Fig. 2. Polar coordinate system in phase space. Since both $q$ and $p$ are $c$ numbers, it is possible to make the canonical transformation given in Eq(43). The minimum uncertainty in $n$ and $\phi$ means the same uncertainty in $q$ and $p$. The coherent or squeezed state is a minimum-uncertainty state.

$$
\langle\alpha|N| \alpha\rangle=\alpha \alpha^{*}
$$

In order to see the uncertainty relation associated with the photon number, we note that each number state can be represented by a harmonic oscillator wavefunction:

$$
\langle\alpha \mid n\rangle=\left[1 /\left(\sqrt{\pi} 2^{n} n !\right)\right]^{1 / 2} H_{n}(q) \exp \left(-q^{2} / 2\right),
$$

where the variable $q$ is not the $x$ variable for spatial displacement. This variable, together with its conjugate $p$, is related to the photon number $n$ through the canonical transformation of Eq. (43). If we write $a$ and $a^{\dagger}$ as

$$
a=\left(\frac{1}{\sqrt{2}}\right)\left(q+\frac{\partial}{\partial q}\right), \quad a^{\dagger}=\left(\frac{1}{\sqrt{2}}\right)\left(q-\frac{\partial}{\partial q}\right),
$$

then Eq. (48) is a first-order differential equation in $q$, and its normalized solution is ${ }^{12}$

$$
\langle q \mid \alpha\rangle=(1 / \pi)^{1 / 4} e^{-|\operatorname{Im}(\alpha)|^{2}} e^{-(q-\sqrt{2} \alpha)^{2} / 2} .
$$

The parameter $\alpha$ is a complex number that can be represented in the two-dimensional complex plane. This wavefunction of the Gaussian form gives the minimum-uncertainty product. ${ }^{1,12}$

It is possible to change the width of the above Gaussian form without changing the minimality in uncertainty. ${ }^{14,15}$ While it is posible to write the coherent-state representation of Eq. (45) as

$$
|\alpha\rangle=\exp \left(\alpha a^{\dagger}-\alpha^{*} a\right)|0\rangle,
$$

we can consider the state

$$
|\xi, \alpha\rangle=S(\zeta)|\alpha\rangle \text {, }
$$

with

$$
S(\xi)=\exp \left\{\frac{1}{4}\left[\xi\left(a^{\dagger} a^{\dagger}\right)-\xi^{*}(a a)\right]\right\} .
$$

If $\xi$ is a real number $\eta, S(\xi)$ can be written as

$$
S(\xi)=\exp \left[-\left(\frac{\eta}{2}\right)\left(\frac{1}{2}+q \frac{\partial}{\partial q}\right)\right] .
$$

The generator of the above form is $\hat{K}_{1}$ of Eq. (33) with $x$ replaced by $q$. This operator expands the width of the Gaussian wavefunction of Eq. (52) by $e^{\eta / 2}$. Consequently, the width of the momentum distribution is contracted by $e^{-\eta / 2}$. This is an operation of squeeze. What happens if $\xi$ becomes complex? This question can most conveniently be answered in the phase-space picture of quantum mechanics, as we shall see in the following sections.

\section{CANONICAL TRANSFORMATIONS OF COHERENT STATES}

It is straightforward to evaluate the PSD function for the coherent state given in Eq. (52). The result is ${ }^{5-7,11,12}$

$$
W(q, p)=(1 / \pi) \exp \left[-(q-a)^{2}-(p-b)^{2}\right],
$$

where $a=\sqrt{2} \operatorname{Re}(\alpha)$ and $b=\sqrt{2} \operatorname{Im}(\alpha)$. This function is concentrated within a circular region described by the equation

$$
(q-a)^{2}+(p-b)^{2}=1 .
$$

If $\alpha=0$, then both $a$ and $b$ vanish, and the above circle is centered around the origin:

$$
q^{2}+p^{2}=1
$$


This is the vacuum or zero-photon state. We can obtain the circle of Eq. (57) by translating the above circle to $(a, b)$. This translation is a canonical transformation.

If we multiply $\alpha$ by $e^{i \theta / 2}$, the circle of Eq. (57) becomes rotated around the origin, and the resulting equation is

$$
\left(q-a^{\prime}\right)^{2}+\left(p-b^{\prime}\right)^{2}=1,
$$

where

$$
\left(\begin{array}{l}
a^{\prime} \\
b^{\prime}
\end{array}\right)=\left(\begin{array}{cc}
\cos (\theta / 2) & -\sin (\theta / 2) \\
\sin (\theta / 2) & \cos (\theta / 2)
\end{array}\right)\left(\begin{array}{l}
a \\
b
\end{array}\right) .
$$

The group of transformations consisting of rotations and translations in the two-dimensional space is called the twodimensional Euclidean group. ${ }^{24,25}$ The above rotation preceded by the translation to $(a, b)$ from the origin is represented by

$$
\left(\begin{array}{ccc}
\cos (\theta / 2) & -\sin (\theta / 2) & 0 \\
\sin (\theta / 2) & \cos (\theta / 2) & 0 \\
0 & 0 & 1
\end{array}\right)\left(\begin{array}{lll}
1 & 0 & a \\
0 & 0 & b \\
0 & 0 & 1
\end{array}\right)
$$

applicable to the column vector $(x, p, 1)$, as was discussed in Sec. III. The above form can also be written as

$$
\left(\begin{array}{lll}
1 & 0 & a^{\prime} \\
0 & 1 & b^{\prime} \\
0 & 0 & 1
\end{array}\right)\left(\begin{array}{ccc}
\cos (\theta / 2) & -\sin (\theta / 2) & 0 \\
\sin (\theta / 2) & \cos (\theta / 2) & 0 \\
0 & 0 & 1
\end{array}\right)
$$

where $a^{\prime}$ and $b^{\prime}$ are given in Eq. (59). However, the circle centered at the origin is invariant under rotations. Therefore, the net effect is the translation

$$
\left(\begin{array}{llc}
1 & 0 & a^{\prime} \\
0 & 1 & b^{\prime} \\
0 & 0 & 1
\end{array}\right)
$$

Indeed, every coherent state is a translation of the vacuum state.

This two-dimensional Euclidean group is isomorphic to the internal space-time symmetry group of massless particles and has been discussed extensively in the literature. ${ }^{24,25,29}$ It is interesting to note that we can study this group in terms of canonical transformations of coherent states of light.

\section{SQUEEZED STATES}

Squeezed states of light are of current interest. ${ }^{14,15,30}$ They are often called generalized coherent states and are, like coherent states, represented by infinite series. ${ }^{26}$ On the other hand, as is seen in Sec. VII, the coherent state takes an unusually simple form in the phase-space picture of quantum mechanics. We shall therefore continue using this representation for squeezed states.

In Sec. VII, the coherent state has a Gaussian distribution in phase space that can be described by a circle. The squeezed state also has a Gaussian distribution in phase space. Unlike the case of coherent states, the distribution for a squeezed state is elliptic. The circle in phase space for the coherent state is linearly deformed in such a manner that the area is preserved.

The squeeze along the $q$ direction means that $q$ and $p$ are replaced by $\left(e^{-\eta / 2}\right) q$ and $\left(e^{\eta / 2}\right) p$, respectively, in the equation for a circle. The result is that the circle in Eq. (57) becomes an ellipse specified by

$$
e^{-\eta}\left(q-e^{\eta / 2} a\right)^{2}+e^{\eta}\left(p-e^{-\eta / 2} b\right)^{2}=1 .
$$

This is a canonical transformation. The squeeze can also be made along an arbitrary direction. The squeeze along the $\phi / 2$ direction is given in the matrix form in Eq. (20).

If we perform the rotation $R(\theta)$ on the circle of Eq. (58) centered around the origin, it remains invariant. If the same rotation is applied to the circle of Eq. (57), which is not centered around the origin, its effect is

$$
\left(q-a^{\prime}\right)^{2}+\left(p-b^{\prime}\right)^{2}=1,
$$

where

$$
\left(\begin{array}{l}
a^{\prime} \\
b^{\prime}
\end{array}\right)=\left(\begin{array}{cc}
\cos (\theta / 2) & -\sin (\theta / 2) \\
\sin (\theta / 2) & \cos (\theta / 2)
\end{array}\right)\left(\begin{array}{l}
a \\
b
\end{array}\right) .
$$

As was noted in Sec. III, if there are no translations, we can represent the transformations using $2 \times 2$ matrices.

Under the squeeze $S(\theta, \lambda)$, the circle of $\mathrm{Eq}$. (57) becomes a tilted ellipse ${ }^{16,31}$ :

$$
\begin{aligned}
& e^{-\lambda}\left[\left(q-a^{\prime \prime}\right) \cos (\theta / 2)+\left(p-b^{\prime \prime}\right) \sin (\theta / 2)\right]^{2} \\
& +e^{\lambda}\left[\left(q-a^{\prime \prime}\right) \sin (\theta / 2)-\left(p-b^{\prime \prime}\right) \cos (\theta / 2)\right]^{2}=1,
\end{aligned}
$$

with

$$
\left(\begin{array}{l}
a^{\prime \prime} \\
b^{\prime \prime}
\end{array}\right)=\left(\begin{array}{ll}
\cosh (\lambda / 2)+(\cos \theta) \sinh (\lambda / 2) & (\sin \theta) \sinh (\lambda / 2) \\
(\sin \theta) \sinh (\lambda / 2) & \cosh (\lambda / 2)-(\cos \theta) \sinh (\lambda / 2)
\end{array}\right)\left(\begin{array}{l}
a \\
b
\end{array}\right) .
$$

This is of course an area-preserving transformation.

Let us next consider repeated squeezes. If we apply $S(\theta, \lambda)$ after $S(0, \eta)$ on the circle centered around the origin with $a=b=0$, the net effect is another tilted ellipse which can be obtained from the operation of $S(\phi, \xi)$ on the circle, with

$\cosh \xi=(\cosh \eta) \cosh \lambda+(\sinh \eta)(\sinh \lambda) \cos \theta$

$\tan \phi=\frac{(\sin \theta)[\sinh \lambda+(\tanh \eta)(\cosh \lambda-1) \cos \theta]}{(\sinh \lambda) \cos \theta+(\tanh \eta)\left[1+(\cosh \lambda-1)(\cos \theta)^{2}\right]}$.

This means that the resulting ellipse is that of Eq. (65), where $\theta$ and $\lambda$ are replaced by $\phi$ and $\xi$, respectively, with $a^{\prime \prime}=b^{\prime \prime}=0$. Thus we are tempted to conclude that $S(\theta, \lambda) S(0, \eta)=S(\phi, \xi)$, which leads to $[S(\phi, \xi)]^{-1} S(\theta, \lambda) S(0, \eta)=2 \times 2$ identity matrix. This is not correct! The matrix multiplication of the left-hand side gives

$$
[S(\phi, \xi)]^{-1} S(\theta, \lambda) S(0, \eta)=R(\Omega),
$$

where 


$$
\tan \frac{\Omega}{2}=\frac{(\sin \theta)[\tanh (\lambda / 2)][\tanh (\eta / 2)]}{1+[\tanh (\lambda / 2)][\tanh (\eta / 2)](\cos \theta)} .
$$

Since the circle centered at the origin is invariant under rotations, the effect of $R(\Omega)$ is the same as the identity transformation.

Indeed, if we apply the above three successive squeezes on the circle of Eq. (57) not centered at the origin, the net effect is

$$
(q-f)^{2}+(p-g)^{2}=1
$$

where

$$
\left(\begin{array}{l}
f \\
g
\end{array}\right)=\left(\begin{array}{cc}
\cos (\Omega / 2) & -\sin (\Omega / 2) \\
\sin (\Omega / 2) & \cos (\Omega / 2)
\end{array}\right)\left(\begin{array}{l}
a \\
b
\end{array}\right) .
$$

This is clearly a rotation. ${ }^{32}$

Since the group of canonical transformation discussed in this section is locally isomorphic to the $(2+1)$-dimensional Lorentz group, it is possible to study rotations associated with successive Lorentz boosts, including the Thomas precession. ${ }^{31.33}$ We shall illustrate this in terms of a simple Lorentz kinematics in Sec. IX.

\section{KINEMATICS OF THE THOMAS PRECESSION}

As was noted in Secs. III and IV, the generators of homogeneous canonical transformations, which can be repre- sented by $2 \times 2$ matrices, satisfy the same set of commutation relations as that for the $(2+1)$-dimensional Lorentz group applicable to the space of $(x, y, t)$. Therefore, it is possible to carry out calculations of Lorentz transformations using the $2 \times 2$ matrix representation of $S p(2) .{ }^{19,34}$ In fact, a detailed calculation of the Thomas rotation angle has been carried out within the framework of this $2 \times 2$ representation. ${ }^{31}$ In this section, we shall discuss a simpler Lorentz kinematics that contains all the essential features of the Thomas precession. ${ }^{35}$

The $(2+1)$-dimensional Lorentz group consists of boosts along the $x$ and $y$ directions and rotations around the $z$ axis. Indeed, the $2 \times 2$ rotation matrix $R(\theta)$ of Eq. (14) corresponds to the rotation matrix applicable to $(x, y, t)$;

$$
R(\theta)=\left(\begin{array}{ccc}
\cos \theta & -\sin \theta & 0 \\
\sin \theta & \cos \theta & 0 \\
0 & 0 & 1
\end{array}\right)
$$

and there is a correspondence between the squeeze matrix $S(\lambda, \theta)$ of Eq. (20) and the boost matrix applicable to $(x, y, t)$ :

$$
S(\phi, \lambda)=\left(\begin{array}{ccc}
1+(\cosh \lambda-1) \cos ^{2} \phi & \frac{1}{2}(1-\cosh \lambda) \sin (2 \phi) & (\sinh \lambda) \cos \phi \\
\frac{1}{2}(1-\cosh \lambda) \sin (2 \phi) & 1+(\cosh \lambda-1) \sin ^{2} \phi & (\sinh \lambda) \sin \phi \\
(\sinh \lambda) \sin \phi & (\sinh \lambda) \cos \phi & \cosh \lambda
\end{array}\right)
$$

If $\phi=0$, the above matrix becomes a boost matrix along the $x$ direction. If $\phi=\pi / 2$, this matrix represents a boost along the $y$ axis. It is indeed possible to establish the relation given in $\mathrm{Eq}$. (67) using this matrix representation. This correspondence allows us to study Lorentz transformations using squeezed light.

As an illustrative example, let us consider the following Lorentz transformations on a particle at rest with the fourmomentum $(0,0, m)$. We are interested in transforming this particle to a state with the momentum along the direction that makes a $45^{\circ}$ angle with the $x$ axis. First, we boost along the $x$ direction with $S_{x}(\eta)=S(0, \eta)$. The resulting four-momentum will be $m(\sinh \eta, 0, \cosh \eta)$. We then boost this four-momentum along the $y$ direction with $S_{y}(\lambda)=S(\pi / 2, \lambda)$. Then, the four-momentum becomes $m[\sinh \eta,(\sinh \lambda) \cosh \eta,(\cosh \lambda) \sinh \eta]$. In order that this momentum have the same $x$ and $y$ components, $\lambda$ and $\eta$ should satisfy the relation:

$$
\sinh \lambda=\tanh \eta
$$

The resulting transformation matrix is

$$
S_{y}(\lambda) S_{x}(\eta)=\left(\begin{array}{ccc}
\cosh \eta & 0 & \sinh \eta \\
(\tanh \eta) \sinh \eta & \sqrt{\cosh 2 \eta} / \cosh \eta & \sinh \eta \\
(\tanh \eta) \sqrt{\cosh 2 \eta} & \tanh \eta & \sqrt{\cosh 2 \eta}
\end{array}\right)
$$

We can reverse the order to get the same result on the momentum by performing the transformation $S_{x}(\lambda) S_{y}(\eta)$ on the particle at rest. However, are the transformation matrices identical to each other? The answer to this question is no:

$$
\left[S_{x}(\lambda) S_{y}(\eta)\right]^{-1} S_{y}(\lambda) S_{x}(\eta)=R(\Omega)
$$

with

$$
\sin \Omega=(\tanh \eta)^{2} \text {. }
$$


It would be very difficult, if not impossible, to carry out this experiment in special relativity. On the other hand, this experiment is possible in optics laboratories. For squeezed states, we can use the following $2 \times 2$ matrices for $S_{x}(\eta)$ and $S_{y}(\lambda)$ :

$$
\begin{aligned}
& S_{x}(\eta)=\left(\begin{array}{cc}
e^{\eta / 2} & 0 \\
0 & e^{-\eta / 2}
\end{array}\right) \\
& S_{y}(\lambda)=\left(\begin{array}{ll}
\cosh (\lambda / 2) & \sinh (\lambda / 2) \\
\sinh (\lambda / 2) & \cosh (\lambda / 2)
\end{array}\right) .
\end{aligned}
$$

Thus $S_{y}(\lambda) S_{x}(\eta)$ should be

$$
\begin{aligned}
& S_{y}(\lambda) S_{x}(\eta) \\
& \quad=\left(\begin{array}{ll}
e^{\eta / 2} \cosh (\lambda / 2) & e^{-\eta / 2} \sinh (\lambda / 2) \\
e^{\eta / 2} \sinh (\lambda / 2) & e^{-\eta / 2} \cosh (\lambda / 2)
\end{array}\right) .
\end{aligned}
$$

Then these matrices satisfy Eq. (73) with

$$
R(\Omega)=\left(\begin{array}{cc}
\cos (\Omega / 2) & -\sin (\Omega / 2) \\
\sin (\Omega / 2) & \cos (\Omega / 2)
\end{array}\right) .
$$

Each of these $2 \times 2$ matrices represents a concrete measurable operation in modern optics laboratories. To a coherent state with $\alpha=(a+i b) / \sqrt{2}$, we can apply two repeated squeezes, namely, $S_{y}(\lambda) S_{x}(\eta)$ and $S_{x}(\lambda) S_{y}(\eta)$. The difference between these two operations is the rotation $R(\Omega)$, which represents a phase change in $\alpha$ according to Eq. (56). In principle, this angle can be measured in optics laboratories. If the present pace of development continues in optical technology, ${ }^{30,36}$ it may be possible in the near future to include this or a similar experiment ${ }^{37}$ in an advanced laboratory course in the physics curriculum.

'Leonard I. Schiff, Quantum Mechanics (McGraw-Hill, New York, 1949).

${ }^{2}$ We would like to thank Professor Bertrand I. Halperin for informing us that he discussed the phase-space distribution function in his quantum mechanics class at Harvard University in 1988.

${ }^{3}$ There are textbooks on statistical mechanics containing discussions of the phase-space distribution function. See, for example, R. P. Feynman, Statistical Mechanics (Benjamin/Cummings, Reading, MA, 1972).

${ }^{4} \mathrm{E}$. Wigner, "On the quantum correction for thermodynamic equilibrium," Phys. Rev. 40, 749-759 (1932).

${ }^{5}$ M. Hillery, R. F. O'Connell, M. O. Scully, and E. P. Wigner, "Distribution functions in physics: Fundamentals," Phys. Rep. 106, 121-167 (1984); G. S. Agarwal, "Wigner-function description of quantum noise in interferometers," J. Mod. Opt. 34, 909-921 (1987); D. Han, Y. S. Kim, and Marilyn E. Noz, "Linear canonical transformations in the Wigner phase space II. Quantitative analysis," Phys. Rev. A 40, 902912 (1989).

"Eugene P. Wigner, "Quantum mechanical distribution functions revisited," in Perspective in Quantum Theory, edited by W. Yourgrau and A. van der Merwe (MIT, Cambridge, MA, 1971), pp. 25-36; R. F. O'Connell, "The Wigner distribution function-50th birthday," Found. Phys. 13, 83-93 (1983); P. Carruthers and F. Zachariassen, "Quantum collision theory with phase-space distributions," Rev. Mod. Phys. 55, 245285 (1983); N. L. Balazs and B. K. Jennings, "Wigner function and other distribution functions in mock phase space," Phys. Rep. 104, 347391 (1984).
${ }^{7}$ Y. S. Kim and E. P. Wigner, "Covariant phase space representation for localized light waves," Phys. Rev. A 36, 1293-1297 (1987). This paper contains an extensive list of the papers on applications of the phase-space picture of quantum mechanics to statistical mechanics, nuclear physics, elementary particle physics, condensed matter physics, atomic and molecular physics, chemical physics, and quantum optics.

"Herbert Goldstein, Classical Mechanics (Addison-Wesley, Reading, MA, 1980), 2nd ed.

${ }^{9}$ N. L. Balazs, "Weyl's association, Wigner's function and affine geometry," Physica A 102, 236-254 (1980) and "On the Weyl association of infinitesimal unitary and canonical transformations," Physica A 109, 317-327 (1981). See also M. Moshinsky, "The structure of phase space and quantum mechanics," in The Proceedings of the First International Conference on the Physics of Space, College Park, Maryland, 1986, edited by Y.S. Kim and W. W. Zachary (Springer-Verlag, Berlin, 1987), pp. 314-318.

${ }^{10} \mathrm{Jerzy}$ Kijowski, "On the time operator in quantum mechanics and the Heisenberg uncertainty relation for energy and time," Rep. Math. Phys. 6, 361-386 ( 1974); Hai-Woong Lee, "Spreading of a free wave packet," Am. J. Phys. 50, 438-440 (1982); Antoine Royer, "Squeezed states and their Wigner functions," in The Proceedings of the First International Conference on the Physics of Phase Space, College Park, Maryland, 1986, edited by Y. S. Kim and W. W. Zachary (Springer-Verlag, Berlin, 1987), pp. 253-257.

"Y. S. Kim and E. P. Wigner, "Covariant phase space representation for harmonic oscillators," Phys. Rev. A 38, 1159-1167 (1988).

12Edwin Goldin, Waves and Photons (Wiley, New York, 1982).

1.'John R. Klauder and Bo-Sture S. Skagerstam, Coherent States (World Scientific, Singapore, 1985).

${ }^{14}$ David Stoler, "Equivalence classes of minimum uncertainty product," Phys. Rev. D 1, 3217-3219 (1970); Horace P. Yuen, "Two-photon coherent states of the radiation field," Phys. Rev. A 13, 2226-2243 (1976); D. F. Walls, "Squeezed states of light," Nature 306, 141-146 (1983).

${ }^{15}$ For a pedagogical paper on squeezed states, see Richard W. Henry and Sharon C. Glotzer, "A squeezed states primer," Am. J. Phys. 56, 318328 (1988).

't D. Han, Y. S. Kim, and Marilyn E. Noz, "Linear canonical transformations of coherent and squeezed states in the Wigner phase space," Phys. Rev. A 37, 807-814 (1988).

${ }^{17}$ Vladmir I. Arnold, Mathematical Methods of Classical Mechanics (Springer, New York, 1978). This book is an English translation by $\mathbf{K}$. Vogtman and A. Weinstein of Arnold's original book in Russian, Matematischeskie Metody Klassicheskoi Mekheniki (Nauka, Moscow, 1974).

${ }^{1 \times}$ Ralph Abraham and Jerrold E. Marsden, Foundations of Mechanics (Benjamin/Cummings, Reading, MA, 1978), 2nd ed.

${ }^{19} \mathrm{Y}$. S. Kim and Marilyn E. Noz, "Illustrative examples of the symplectic group," Am. J. Phys. 51, 368-375 (1983).

${ }^{20}$ Victor Guillemin and Shlomo Sternberg, Symplectic Techniques in Physics (Cambridge U.P., London, 1984).

${ }^{21}$ Robert G. Littlejohn, "The semiclassical evolution of wave packets," Phys. Rep. 138, 193-291 (1986).

${ }^{27} F o r$ the uniqueness condition for $W(x, p, t)$ giving $\rho(x, t)$ or $\sigma(p, t)$ after integration, see R. F. O'Connell and E. P. Wigner, "Quantum mechanical distribution functions: Conditions for uniqueness," Phys. Lett. 83A, $145-148$ (1981).

${ }^{23}$ For physical applications of this formula, see W. Schleich, D. F. Walls, and J. A. Wheeler, "Area of overlap and interference in phase space versus Wigner pseudoprobabilities," Phys. Rev. A 38, 1177-1186 (1988); Y. S. Kim and E. P. Wigner, "Covariant phase space representation and overlapping distribution functions," Phys. Rev. A 39, 2829 (1989).

${ }^{24} \mathrm{E}$. Wigner, "'On unitary representations of the inhomogeneous Lorentz group," Ann. Math. 40, 149-204 (1939); Eugene P. Wigner, "Relativistic invariance and quantum phenomena," Rev. Mod. Phys. 29, 255-268 (1957).

${ }^{25}$ Y. S. Kim and Marilyn E. Noz, Theory and Applications of the Poincare Group (Reidel, Dordrecht, The Netherlands, 1986).

${ }^{26} \mathrm{~A}$. M. Perelomov, Generalized Coherent States and Their Applications (Springer, Heidelberg, 1986). 
${ }^{27}$ Carlton M. Caves, Kip S. Thorne, Ronald W. P. Drever, Vernon D. Sandberg, and Mark Zimmerman, "On the requirement of a weak classical force coupled to a quantum-mechanical oscillator," Rev. Mod. Phys. 52, 341-392 (1980).

${ }^{2 k}$ R. Dirl, P. Kasperkovitz, and M. Moshinsky, "Wigner distribution functions and the representation of a non-bijective canonical transformation in quantum mechanics," J. Phys. A 21, 1835-1846 (1988). Whilt 'his nonlinear transformation is possible in the phase-space picture of quantum mechanics in which the variables $q, p, n$, and $\phi$ are $c$ numbers, it is not possible to construct Hermitian operators for $n$ and $\phi$. See W. F. Louisell, "Amplitude and phase uncertainty relations," Phys. Lett. 7, 60-61 (1963); Leonard Susskind and Jonathan Glogower, "Quantum mechanical phase and time operator," Physics 1, 49-61 (1964)

${ }^{29}$ It was shown in Ref. 24 that the internal space-time symmetry group for massless particles is locally isomorphic to the two-dimensional Euclidean group. See D. Han and Y.S. Kim, "The little group for photons and gauge transformations," Am. J. Phys. 49, 348-351 (1981); D. Han, Y. S. Kim, and Marilyn E. Noz, "Internal space-time symmetries of massive and massless particles," Am. J. Phys. 52, 1037-1043 (1984); Y. S. Kim and E. P. Wigner, "Cylindrical group and massless particles," J. Math. Phys. 28, 1175-1179 (1987).

${ }^{30}$ For papers on the generation of squeezed states, see Horace $P$. Yuen and Jeffrey H. Shapiro, "Generation and detection of two-photon coherent states in degenerate four-wave mixing," Opt. Lett. 4, 334 (1979); R. E Slusher, L. W. Hollenberg, B. Yurke, J. C. Metz, and J. F. Valley, "Observation of squeezed states generated by four-wave mixing in an optical cavity," Phys. Rev. Lett. 55, 2409 (1995); R. M. Shelby, M. D. Levenson, S. H. Perlmutter, R. G. DeVoe, and D. F. Walls, "Broadband parametric deamplification of quant um noise in an optical fiber," Phys. Rev. Lett. 57, 691 (1986); Ling-An Wu, H. J. Kimble, J. L. Hall, and Huifa $\mathrm{Wu}_{\mathrm{u}}$ "Generation of squeezed states by parametric down conversion," Phys. Rev. Lett. 57, 2520 (1986); Mari W. Maeda, Prem Kumar, and Jeffrey $\mathbf{H}$. Shapiro, "Squeezing experiments in sodium vapor," $\mathbf{J}$.
Opt. Soc. Am. B 4, 1501-1513 (1987); Sasumu Machida and Yoshihisa Yamamoto, "Ultrabroad amplitude squeezing in a semiconductor laser," Phys. Rev. Lett. 60, 792 (1988).

${ }^{31}$ D. Han, E. E. Hardekopf, and Y. S. Kim, "Thomas precession and squeezed states of light," Phys. Rev. A 39, 1269-1276 (1989).

${ }^{32}$ This rotation is sometimes called the Wigner rotation in the literature. See Refs. 17 and 31. For earlier papers dealing with this rotation in the $(3+1)$-dimensional Lorentz group, see V. I. Ritus, "Transformations of the inhomogeneous Lorentz group and the relativistic kinematics of polarized states," Sov. Phys. JETP 13, 240-248 (1961); A. Chakrabarti, "Applications of the Lorentz transformation properties of canonical spin tensors," J. Math. Phys. 5, 1747-1755 (1964); D. Han, Y. S. Kim, and D. Son, "Eulerian parametrization of Wigner's little groups and gauge transformations in terms of rotations in two-component spinors," J. Math. Phys. 27, 2228-2235 (1986)

${ }^{33}$ D. Han, Y. S. Kim, and D. Son, "Thomas precession, Wigner rotations, and gauge transformations," Class. Quantum Grav. 4, 1777-1783 (1987)

${ }^{34}$ This situation is quite analogous to the case where the calculations of the three-dimensional rotation matrices can be carried out in the regime of the $2 \times 2$ Pauli matrices.

${ }^{35}$ Raymond $Y$. Chiao and Thomas F. Jordan, "Lorentz-group Berry phase in squeezed light," Phys. Lett. A 132, 77-80 (1988). See also Raymond Chiao, "Lorentz-group Berry phases in squeezed light," in The Proceedings of the International Symposium on Spacetime Symmetries in Commemoration of the 50th Anniversary of Eugene Paul Wigner's Fundamental Paper on the Inhomogeneous Lorentz Group, College Park, Maryland, 1988, edited by Y. S. Kim and W. W. Zachary (North-Holland, Amsterdam, 1989), pp. 327-223.

${ }^{36}$ Richard E. Slusher and Bernard Yurke, "Squeezed light," Sci. Am. 285(5), 50-56 (1988).

${ }^{37} \mathrm{M}$. Kitano and T. Yabuzaki, "On the observation of Lorentz-group Berry phases in polarization optics," Phys. Lett. A 142, 321-324 (1989).

\section{FEYNMAN ON THE MYSTERY OF QUANTUM MECHANICS}

The question is, how does [ the two-slit experiment] really work? What machinery is actually producing this thing? Nobody knows any machinery. Nobody can give you a deeper explanation than I have given... They can give you a wider explanation, in the sense that they can do more examples to show how it is impossible to tell which hole the electron goes through and not at the same time destroy the interference pattern... But that is just repeating the same thing to drive it in . It is not any deeper; it is only wider. The mathematics can be made more precise; you can mention that they are complex numbers instead of real numbers, and a couple of other minor points which have nothing to do with the main idea. But the deep mystery is what I have described, and no one can go any deeper today.

Richard P. Feynman, The Character of Physical Law (MIT, Cambridge, 1967) 


\section{Negative probability}

Richard P. Feynman California Institute of Technology

Some twenty years ago one problem we theoretical physicists had was that if we combined the principles of quantum mechanics and those of relativity plus certain tacit assumptions, we seemed only able to produce theories (the quantum field theories) which gave infinity for the answer to certain questions. These infinities are kept in abeyance (and now possibly eliminated altogether) by the awkward process of renormalization. In an attempt to understand all this better, and perhaps to make a theory which would give only finite answers from the start, I looked into the 'tacit assumptions' to see if they could be altered.

One of the assumptions was that the probability for an event must always be a positive number. Trying to think of negative probabilities gave me a cultural shock at first, but when I finally got easy with the concept I wrote myself a note so I wouldn't forget my thoughts. I think that Prof. Bohm has just the combination of imagination and boldness to find them interesting and amusing. I am delighted to have this opportunity to publish them in such an appropriate place. I have taken the opportunity to add some further, more recent, thoughts about applications to two-state systems.

Unfortunately I never did find out how to use the freedom of allowing probabilities to be negative to solve the original problem of infinities in quantum field theory!

It is usual to suppose that, since the probabilities of events must be positive, a theory which gives negative numbers for such quantities must be absurd. I should show here how negative probabilities might be interpreted. A negative number, say of apples, seems like an absurdity. A man starting a day with five apples who gives away ten and is given eight during the day has three left. I can calculate this in two 
steps: $5-10=-5$; and $-5+8=3$. The final answer is satisfactorily positive and correct, although in the intermediate steps of calculation negative numbers appear. In the real situation there must be special limitations of the time in which the various apples are received and given since he never really has a negative number, yet the use of negative numbers as an abstract calculation permits us freedom to do our mathematical calculations in any order, simplifying the analysis enormously and permitting us to disregard inessential details. The idea of negative numbers is an exceedingly fruitful mathematical invention. Today a person who balks at making a calculation in this way is considered backward or ignorant, or to have some kind of mental block. It is the purpose of this paper to point out that we have a similar strong block against negative probabilities. By discussing a number of examples, I hope to show that they are entirely rational of course, and that their use simplifies calculations and thought in a number of applications in physics.

First let us consider a simple probability problem, and how we usually calculate things, and then see what would happen if we allowed some of our normal probabilities in the calculations to be negative. Let us imagine a roulette wheel with, for simplicity, just three numbers: 1, 2, 3. Suppose, however, the operator, by control of a switch under the table, can put the wheel into one of two conditions, $A, B$, in each of which the probability of $1,2,3$ are different. If the wheel is in condition $A$, the probabilities of $1, p_{1 A}=0.3$ say, of 2 is $p_{2 A}=0.6$, of 3 is $p_{3 A}=0.1$. But if the wheel is in condition $\mathrm{B}$, these probabilities are $p_{1 \mathrm{~B}}=0.1, p_{2 \mathrm{~B}}=0.4, p_{3 \mathrm{~B}}=0.5$, say, as in Table 13.1.

Table 13.1 Probability table for roulette wheel with two conditions

\begin{tabular}{lll} 
& Condition $A$ & Condition $B$ \\
\hline 1 & 0.3 & 0.1 \\
2 & 0.6 & 0.4 \\
3 & 0.1 & 0.5 \\
\hline
\end{tabular}

We use the table in this way: suppose the operator puts the wheel into condition $A 7 / 10$ of the time and into $B$ the other $3 / 10$ of the time at random (that is, the probability of condition $\mathrm{A}, P_{\mathrm{A}}=0.7$, and of $\mathrm{B}$, $P_{\mathrm{B}}=0.3$.), then the probability of getting 1 is Prob. $1=0.7(0.3)+0.3$ $(0.1)=0.24$, etc. In general, of course, if $\alpha$ are conditions and $p_{i \alpha}$ is a conditional probability (the probability of getting the result $i$ if the condition $\alpha$ holds), we have ( $p_{i \alpha}=$ Prob (if $\alpha$ then $\left.\mathrm{i}\right)$ ):

$P_{i}=\sum_{\alpha} p_{i \alpha} \cdot P_{\alpha}$ 
where $P_{\alpha}$ are the probabilities that the conditions $\alpha$ obtain, and $P_{i}$ is the consequent probability of the result $i$. Since some result must occur in any condition, we have:

$\sum_{i} p_{i \alpha}=1$

where the sum is that over all possible independent results $i$. If the system is surely in some one of the conditions, so if:

$\sum_{\alpha} P_{\alpha}=1$

then:

$\sum_{i} P_{i}=1$

meaning we surely have some result, in virtue of [2].

Now, however, suppose that some of the conditional probabilities are negative; suppose the table reads so that, as we shall say, if the system is in condition B the probability of getting 1 is -0.4 (see Table 13.2). This sounds absurd, but we must say it this way if we wish that our way of thought and language be precisely the same whether the actual quantities $p_{i \alpha}$ in our calculations are positive or negative. That is the essence of the mathematical use of negative numbers - to permit an efficiency in reasoning so that various cases can be considered together by the same line of reasoning, being assured that intermediary steps which are not readily interpreted (like -5 apples) will not lead to absurd results. Let us see what $p_{1 \mathrm{~B}}=-0.4$ 'means' by seeing how we calculate with it.

Table 13.2 Probability table with negative probability

\begin{tabular}{lll}
\hline & Condition $A$ & Condition $B$ \\
\hline 1 & 0.3 & -0.4 \\
2 & 0.6 & 1.2 \\
3 & 0.1 & 0.2 \\
\hline
\end{tabular}

We have arranged the numbers in the table so that $p_{1 \mathrm{~B}}+p_{2 \mathrm{~B}}+p_{3 \mathrm{~B}}=1$, in accordance with equation [2]. For example, if the condition $\mathrm{A}$ has probability 0.7 and $\mathrm{B}$ has probability 0.3 , we have for the probability of result 1 :

$p_{1}=0.7(0.3)+0.3(-0.4)=0.09$

which would be all right. We have also allowed $p_{2 B}$ to exceed unity. A 
probability greater than unity presents no problem different from that of negative probabilities, for it represents a negative probability that the event will not occur.

Thus the probability of result 2 is, in the same way:

$p_{2}=0.7(0.6)+0.3(1.2)=0.78$

Finally, the probability of result 3 presents no problem for:

$p_{3}=0.7(0.1)+0.3(0.2)=0.13$

The sum of these is 1.00 as required, and they are all positive and can have their usual interpretation.

The obvious question is what happens if the probability of being in condition B is larger; for example, if condition B has probability 0.6 , the probability of result 1 is negative $0.4(0.3)+0.6(-0.4)=-0.12$. But suppose nature is so constructed that you can never be sure the system is in condition B. Suppose there must always be a limit of a kind to the knowledge of the situation that you can attain. And such is the limitation that you can never know for sure that condition $\mathbf{B}$ occurs. You can only know that it may occur with a limited probability (in this case less than $3 / 7$, say). Then no contradiction will occur, in the sense that a result 1 or 2 or 3 will have a negative probability of occurrence.

Another possibility of interpretation is that results 1,2,3 are not directly observable but one can only verify by a final observation that the result had been 1, 2 or 3 with certain probabilities. For example, suppose the truly physically verifiable observations can only distinguish two classes of final events. Either the result was 3 or else it was in the class of being either 1 or 2 . This class has the probability $p_{1}+p_{2}$, which is always positive for any positive $P_{\mathrm{A}}, P_{\mathrm{B}}$. This case corresponds to the situation that $1,2,3$ are not the finally observed results, but only intermediaries in a calculation.

Notice that the probabilities of conditions $\mathrm{A}$ and $\mathrm{B}$ might themselves be negative (for example, $P_{\mathrm{A}}=1.3, P_{\mathrm{B}}=-0.3$ ) while the probabilities of the results $1,2,3$ still remain positive.

It is not my intention here to contend that the final probability of a verifiable physical event can be negative. On the other hand, conditional probabilities and probabilities of imagined intermediary states may be negative in a calculation of probabilities of physical events or states.

If a physical theory for calculating probabilities yields a negative probability for a given situation under certain assumed conditions, we need not conclude the theory is incorrect. Two other possibilities of interpretation exist. One is that the conditions (for example, initial conditions) may not be capable of being realized in the physical world. The other possibility is that the situation for which the probability appears to be negative is not one that can be verified directly. A 
combination of these two, limitation of verifiability and freedom in initial conditions, may also be a solution to the apparent difficulty.

The rest of this paper illustrates these points with a number of examples drawn from physics which are less artificial than our roulette wheel.

Since the result must ultimately have a positive probability, the question may be asked: Why not rearrange the calculation so that the probabilities are positive in all the intermediate states? The same question might be asked of an accountant who subtracts the total disbursements before adding the total receipts. He stands a chance of going through an intermediary negative sum. Why not rearrange the calculation? Why bother? There is nothing mathematically wrong with this method of calculating and it frees the mind to think clearly and simply in a situation otherwise quite complicated. An analysis in terms of various states or conditions may simplify a calculation at the expense of requiring negative probabilities for these states. It is not really much expense.

Our first physical example is one in which one usually uses negative probabilities without noticing it. It is not a very profound example and is practically the same in content as our previous example. A particle diffusing in one dimension in a rod has a probability of being at $x$ at time $t$ of $P(x, t)$ satisfying $\partial P(x, t) / \partial t=-\partial^{2} P(x, t) / \partial x^{2}$. Suppose at $x=0$ and $x=\pi$ the rod has absorbers at both ends so that $P(x, t)=0$ there. Let the probability of being at $x$ at $t=0$ be given as $P(x, 0)=f(x)$. What is $P(x, t)$ thereafter? It is:

$P(x, t)=\sum_{n=1}^{\infty} p_{n} \sin n x \exp \left(-n^{2} t\right)$

where $p_{n}$ is given by:

$f(x)=\sum_{n=1}^{\infty} p_{n} \sin n x$

or:

$p_{n}=\frac{2}{\pi} \int f(x) \sin n x \mathrm{~d} x$

The easiest way of analyzing this (and the way used if $P(x, t)$ is a temperature, for example) is to say that there are certain distributions that behave in an especially simple way. If $f(x)$ starts as $\sin n x$ it will remain that shape, simply decreasing with time as $e^{-n^{2} t}$. Any distribution $f(x)$ can be thought of as a superposition of such sine waves. But $f(x)$ cannot be $\sin n x$ if $f(x)$ is a probability and probabilities must always be positive. Yet the analysis is so simple this way that no one has really objected for long.

To make the relation to our previous analysis more clcar, the 
various conditions $\alpha$ are the conditions $n$ (that is, the index $\alpha$ is replaced by $n$ ). The a priori probabilities are the numbers $p_{n}$. The conditions $i$ are the positions $x$ (the index $i$ is replaced by $x$ ) and the conditional probabilities (these do not satisfy equation [2], for we have particles 'lost' off the end of the rod, and the state of being off the rod is not included among the possibilities $i$ ) (if $n$ then $x$ at time $t$ ) are:

$p_{i \alpha} \rightarrow p_{x, n}=e^{-n^{2} t} \sin n x$

Equation [4] is then precisely equation [1], for the probabilities $p_{i}$ of having result $n$ is now what we call $P(x, t)$. Thus equation [4] is easily. interpreted as saying that if the system is in condition $n$, the chance of finding it at $x$ is $\exp \left(-n^{2} t\right) \sin n x$, and the chance of finding it in condition $n$ is $p_{n}$.

No objection should be made to the negative values of these probabilities. However, a natural question is: What are the restrictions which ensure that the final probability for the event (finding a particle at $x$ at time $t$ ) are always positive? In this case they are simple. It is that the a priori.probabilities, although possibly negative, are restricted by certain conditions. The condition is that they must be such that they could come from the Fourier analysis of an everywhere positive function. This condition is independent of what value of $x$ one wishes to observe at time $t$.

In this example, the restrictions to ensure positive probabilities can be stated once and for all in a form that does not depend on which state we measure. They are all positive simultaneously.

Another possibility presents itself. It can best be understood by returning to our roulette example. It may be that the restrictions on the conditions $\mathrm{A}, \mathrm{B}$ which yield a positive probability may depend on what question you ask. In an extreme example, there may be no choice for the $p_{\alpha}$ that simultaneously make all $p_{i}$ positive at once. Thus, although certain restrictions may make probability of result 1 positive, result 3 under these circumstances would have a negative probability. Likewise, conditions ensuring that $p_{3}$ is positive might leave $p_{1}$ or $p_{2}$ negative. In such a physical world, you would have such statements as: 'If you measure 1 you cannot be sure to more than a certain degree that the condition is $A$; on the other hand it will be all right to think that it is certainly in condition $\mathrm{A}$, provided you are only going to ask for the chance that the result is 3.' For such a circumstance to be a viable theory, there would have to be certain limitations on verification experiments. Any method to determine that the result was 3 would automatically exclude that at the same time you could determine whether the result was 1 . This is reminiscent of the situation in quantum mechanics in relation to the uncertainty principle. A particle can have definite momentum, or a definite position in the sense that an experiment may be devised to measure either one. But no experiment can be devised to decide what the momentum is, to error of 
order $\Delta p$, which at the same time can determine that the position $x$ is within $\Delta x$ unless $\Delta x>\hbar / \Delta p$.

It is possible, therefore, that a closer study of the relation of classical and quantum theory might involve us in negative probabilities, and so it does. In classical theory, we may have a distribution function $F(x, p)$ which gives the probability that a particle has a position $x$ and a momentum $p$ in $\mathrm{d} x$ and $\mathrm{d} p$ (we take a simple particle moving in one dimension for simplicity to illustrate the ideas). As Wigner has shown, the nearest thing to this in quantum mechanics is a function (the density matrix in a certain representation) which for a particle in a state with wave function $\psi(x)$ is:

$F(x, p)=\int \psi^{*}(x-y / 2) \exp (-i p y) \psi(x+y / 2) \mathrm{d} y$

(If the state is statistically uncertain we simply average $F$ for the various possible wave functions with their probabilities.)

In common with the classical expression, we have these properties.

$1 F(x, p)$ is real.

2 Its integral with respect to $p$ gives the probability that the particle is at $x$ :

$$
\int F(x, p) \mathrm{d} p /(2 \pi)=\psi^{*}(x) \psi(x)
$$

3 Its integral with respect to $x$ gives the probability that the momentum is $p$ :

$$
\int F(x, p) \mathrm{d} x=\varphi^{*}(p) \varphi(p)
$$

where $\varphi(p)$ is the usual Fourier transform of $\psi(x)$. $\varphi(p)=\int e^{-i p x} \psi(x) \mathrm{d} x$.

The average value of a physical quantity $M$ is given by:

$$
<M>=\int w_{M}(x, p) F(x, p) \mathrm{d} x \mathrm{~d} p
$$

where $w_{M}$ is a weight function depending upon the character of the physical quantity.

The only property it does not share is that in the classical theory $F(x, p)$ is positive everywhere, for in quantum theory it may have negative values for some regions of $x, p$. That we still have a viable physical theory is ensured by the uncertainty principle that no measurement can be made of momentum and position simultaneously beyond a certain accuracy.

The restriction this time which ensures positive probabilities is that the weight functions $w_{M}(x, p)$ are restricted to a certain class - namely, those that belong to hermitian operators. Mathematically, a positive probability will result if $w$ is of the form:

$w(x, p)=\int X(x-Y / 2) e^{+i p y} X^{*}(x+Y / 2) \mathrm{d} Y$

where $X$ is any function and $X^{*}$ is its complex conjugate. Generally, if $w(x, p)$ is the weight for the question 'What is the probability that the 
physical quantity $M$ has numerical value $\mathrm{m}$ ?', $w$ must be of the form equation [11] or the sum of such forms with positive weights. With this limitation, final probabilities are positive.

To make the analogy closer to those previously used, we can take two systems $a, b$, in interaction, such that measurements on $b$ can provide predictions of probabilities for $a$. Thus, using the onedimensional case again, we have a two-point correlation function $F\left(x_{a}, p_{a} ; x_{b}, p_{b}\right)$ defined via an obvious generalization of equation [7] to two variables. This corresponds to the conditional probability $p_{i \alpha}$. Then if a quantity $M$ is measured in $b$, the $a$ priori probabilities for various $x_{b}, p_{b}$ are given by an appropriate $w_{M}\left(x_{b}, p_{b}\right)$ (the analogue of $P_{\alpha}$ in equation [1]). The probability that system ' $a$ ' has position and momentum $x_{a}, p_{a}$ is (the analogue of $P_{i}$ ), then:

$P\left(x_{a}, p_{a}\right)=\int F\left(x_{a}, p_{a} ; x_{b}, p_{b}\right) w_{M}\left(x_{b}, p_{b}\right) \mathrm{d} x_{b} \mathrm{~d} p_{b}$

the analogue of equation [1]. As an example, we may take the strong correlation possible arising from the two-particle wave function $\delta\left(x_{a}-x_{b}\right)$ which is:

$F\left(x_{a}, p_{a} ; x_{b}, p_{b}\right)=\delta\left(p_{a}+p_{b}\right) \delta\left(x_{a}-x_{b}\right)$

which means that the particles $a, b$, have the same position and opposite momenta so that a measurement of $b$ 's position would permit a determination of $a$ 's and a measurement of $b$ 's momentum would determine $a$ 's (to be the opposite). This particular $F$ is entirely positive and classical in its behaviour, so that letting $w_{M}\left(x_{b}, p_{b}\right)$ be $\delta\left(x_{a}-b\right) \times$ $\delta\left(p_{a}-Q\right)$ would not lead to negative probabilities directly, for equation [1] gives $P\left(x_{a}, p_{a}\right)=\delta\left(x_{a}-b\right) \delta\left(P_{a}+Q\right)$ in this case, but further use of such a $P$ in subsequent interactions has the danger of producing negative probabilities. We have become quite used to the rules of thought and limitations of an experiment, which ensures that they never arise in quantum mechanics.

It is not our intention to claim that quantum mechanics is best understood by going back to classical mechanical concepts and allowing negative probabilities (for the equations for the development of $F$ in time are more complicated and inconvenient than those of $\psi$ ). (The classical equations for $F$ for a particle moving in a potential are:

$\partial F(x, p, t) / \partial t=-p / m . \partial F / \partial x+V^{\prime}(x) \partial F / \partial p$

while the quantum equations are:

$\partial F(x, t) / \partial t=-p / m . \partial F / \hat{o x}+\int G(x, Q) F(x, p+Q) \mathrm{d} Q$

so instead of the momentum changing infinitesimally during an infinitesimal time, $\Delta t$, it may jump by an amount $Q$ with probability when it is at $x$ :

$\Delta t G(x, Q)=\Delta t .2 \operatorname{Im} \int e^{i Q . Y} V(x+Y / 2) \mathrm{d} Y$ 
which is a real, but possibly negative probability.) Rather we should like to emphasize the idea that negative probabilities in a physical theory does not exclude that theory, providing special conditions are put on what is known or verified. But how are we to find and state these special conditions if we have a new theory of this kind? It is that a situation for which a negative probability is calculated is impossible, not in the sense that the chance for it happening is zero, but rather in the sense that the assumed conditions of preparation or verification are experimentally unattainable.

We may give one more example. In the quantum theory of electrodynamics, the free photon moving in the $z$ direction is supposed to have only two directions of polarization transverse to its motion $x, y$. When this field is quantized, an additional interaction, the instantaneous Coulomb interaction, must be added to the virtual transverse photon exchange to produce the usual simple:

$\left(j_{x} j_{x}{ }^{\prime}+j_{y} j_{y}{ }^{\prime}+j_{z} j_{z}^{\prime}-j_{t} j_{t}\right) e^{2} / q^{2}$

virtual interaction between two currents, $j$ and $j^{\prime}$. It is obviously relativistically invariant with the usual symmetry of the space $j_{x}, j_{y}, j_{z}$ and time $j_{t}$ components of the current (in units where the velocity of light is $c=1)$. The original starting Hamiltonian with only transverse components does not look invariant. Innumerable papers have discussed this point from various points of view but perhaps the simplest is this. Let the photon have four directions of polarization of a vector $x, y, z, t$, no matter which way it is going. Couple the time component with ie instead of $e$ so that the virtual contribution for it will be negative, as required by relativity in equation [12]. For real photons, then, the probability of a $t$-photon emission is negativc, proportional to $-\left|\left\langle f\left|j_{t}\right| i\right\rangle\right|^{2}$ the square of the matrix element of $j_{t}$ between initial and final states, just as the probability to emit an $x$ photon is $+\left|\left\langle f\left|j_{x}\right| i\right\rangle\right|^{2}$. The total probability of emitting any sort of photon is the algebraic sum of the probabilities for the four possibilities:

$\left|\left\langle f\left|j_{x}\right| i\right\rangle\right|^{2}+\left|\left\langle f\left|j_{y}\right| i\right\rangle\right|^{2}+\left|\left\langle f\left|j_{z}\right| i\right\rangle\right|^{2}-\left|\left\langle f\left|j_{t}\right| i\right\rangle\right|^{2}$

It is always positive, for by the conservation of current there is a relation of $j_{t}$ and the space components of $\mathbf{j}, k_{\mu} j_{\mu}=0$ if $k_{\mu}$ is the fourvector of the photon. For example, if $k$ is in the $z$ direction, $k_{z}=\omega$, and $k_{x}=k_{y}=0$ so $j_{t}=j_{z}$ and we see equation [13] is equal to the usual result where we add only the transverse emissions. The probability to emit a photon of definite polarization $e_{\mu}$ is (assume $e_{\mu}$ is not a null vector):

$-\left|\left\langle f\left|j_{\mu} e_{\mu}\right| i\right\rangle\right|^{2} /\left(e_{\mu} e_{\mu}\right)$

This has the danger of producing negative probabilities. The rule to avoid them is that only photons whose polarization vector satisfies 
$k_{\mu} e_{\mu}=0$ and $e_{\mu} e_{\mu}=-1$ can be observed asymptotically in the final or initial states. But this restriction is not to be applied to virtual photons, intermediary negative probabilities are not to be avoided. Only in this way is the Coulomb interaction truly understandable as the interchange of virtual photons, photons with time-like polarization which are radiated as real photons with a negative probability.

This example illustrates a small point. If one $t$ photon is emitted with a negative probability $-\alpha(\alpha>0)$, and another $t$ photon is emitted say independently with probability $-\beta(\beta>0)$, the chance of emitting both is positive $(-\alpha)(-\beta)=\alpha \beta>0$. Should we not expect then to see physical emission of two such photons? Yes, but (if these photons are moving in the $z$ direction) there is a probability to emit $z$ photons $\alpha$ and $\beta$ also, and there are four emission states: two $t$ photons with probability $+\alpha \beta$; two $z$ photons with probability $+\alpha \beta$; the first $z$ and second $t$ probability $(+\alpha)(-\beta)=-\alpha \beta$ and the first $t$ second $z$ with probabilities $-\alpha \beta$ so again, for total emission rate only the transverse photons contribute.

Although it is true that a negative probability for some situations in a theory means that that situation is unattainable or unverifiable, the contrary is not true; namely, a positive probability for a situation does not mean that that situation is directly verifiable. We have no technique for detecting $t$ photons which is not similarly sensitive to $z$ photons, so that we can only always respond to a combination of them. Likewise, no direct test can be made that the two $t$ photons are indeed present without including the additional probabilities of having $z$ photons. The fact for example, that $F(x, p)$ is everywhere positive:

$\left(\exp \left(-\frac{p^{2} / m+m \omega^{2} x}{2 \hbar \omega}\right)\right)$

for the ground state of an oscillator does not mean that for that state we can indeed measure both $x$ and $p$ simultaneously.

As another example we will give an analogue of the Wigner function for a spin half system, or other two-state system. Just as the Wigner function is a function of $x$ and $p$, twice as many variables as in the wave function, here we will give a 'probability' for two conditions at once. We choose spin along the $z$-axis and spin along the $x$-axis. Thus let $f_{++}$represent the 'probability' that our system has spin up along the $z$-axis and up along the $x$-axis simultaneously. We shall define the quantity $f_{++}$for a pure state to be the expectation of $\frac{1}{4}\left(1+\sigma_{z}+\sigma_{x}+\sigma_{y}\right)$, where $\sigma_{x}, \sigma_{y}$, and $\sigma_{z}$ are the Pauli matrices. For a mixed state we take an average over the pure state values. Likewise $f_{+-}$is the expectation of $\frac{1}{4}\left(1+\sigma_{z}-\sigma_{x}-\sigma_{y}\right), f_{-+}$is the expectation of $\frac{1}{4}\left(1-\sigma_{z}+\sigma_{x}-\sigma_{y}\right)$ and $f \ldots$ is the expectation of $\frac{1}{4}\left(1-\sigma_{z}-\sigma_{x}+\sigma_{y}\right)$.

Understanding that this 'probability' can be negative, we shall train 
ourselves to deal with it otherwise as a real probability and thus dispense with the warning quotes hereafter. Analogously $f_{+-}$is the probability that the spin is up along the $z$-axis and down along the $x$ axis (that is pointing in the negative $x$ direction). Likewise $f_{-+}$and

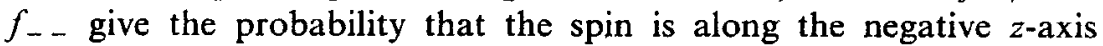
and along the $x$-axis in the positive or negative sense, respectively. These are all the possible conditions so we have $f_{++}+f_{+-}+f_{-+}+f_{--}=1$. As an example, we might have $f_{++}=0.6, f_{+-}=-0.1, f_{-+}=0.3$ and $f_{--}=0.2$.

Now the probability that the spin is up along $z$ is simply the sum of the probability that it is up along $z$ and up along $x$, and the other possibility, that it is up along $z$ but down along $x$; that is simply $f_{++}+f_{+-}$or $0.6+(-0.1)=0.5$ in our example. The probability the spin is down along $z$ is $f_{-+}+f_{-}$, also 0.5 . In the same way the probability that the spin is along the positive $x$-axis, independent of its value along $z$ is $f_{++}+f_{-+}$or 0.9 . We, of course, cannot measure simultaneously the spin in the $z$ and in the $x$ direction, so we cannot directly determine $f_{+}$- and there is no difficulty with its negative value.

These four numbers give a complete expression of the state of the system, and the probability for any other question you can ask experimentally is some linear combination of them. For example, the probability that a measurement of spin along the $y$-axis gives 'up' is $f_{+}+f_{-}$or 0.8 , and that it gives 'down' is $f_{+-}+f_{-+}$or 0.2 . In fact, for a two-state system any question is equivalent to the question 'Is the spin up along an axis in some direction?' If that direction is defined by the unit vector $V$ with components $V_{x}, V_{y}, V_{z}$ then we can say the probability that the spin is up along this direction if the condition of the electron is ++ is $p_{++}(V)=\frac{1}{2}\left(1+V_{z}+V_{x}+V_{y}\right)$. For the other conditions we have $p_{+-}(V)=\frac{1}{2}\left(1+V_{z}-V_{x}-V_{y}\right)$, $p_{-+}(V)=\frac{1}{2}\left(1-V_{z}+V_{x}-V_{y}\right)$, and

$p_{--}(V)=\frac{1}{2}\left(1-V_{z}-V_{x}+V_{y}\right)$. In the general case then where the $f \mathrm{~s}$ give the a priori probabilities of each condition the probability of finding the spin up along $V$ is the sum on $a$ of $p_{a}(V) f_{a}$ or $\frac{1}{2}\left(\left(1+V_{z}+V_{x}+V_{y}\right) f_{++}+\left(1+V_{z}-V_{x}-V_{y}\right) f_{+-}\right.$

$\left.+\left(1-V_{z}+V_{x}-V_{y}\right) f_{-+}+\left(1-V_{z}-V_{x}+V_{y}\right) f_{--}\right)$. In order that this always gives positive results, in addition to the condition that the sum of the $f s$ is unity, there is the restriction that the sum of the squares of the four $f s$ be less than $\frac{1}{2}$. It equals $\frac{1}{2}$ for a pure state.

If there are two electrons in a problem we can use classical logic, considering each of them as being in one of the four states, ++ , ,,+--+-- . Thus suppose we have two electrons, correlated so their total spin is zero, moving into two detectors, one set to determine if the spin of the first electron is in the direction $V$ and the other set to measure whether the second electron has its spin in the direction $U$. The probability that both detectors respond is $\frac{1}{4}(1-U . V)$. Thus if one is found up along any axis, the other is surely down along the 
same axis. This situation usually causes difficulty to a hidden variable view of nature. Suppose the electron can be in one of a number of conditions $a$, for each of which the chance of being found to be spinning up along the $V$-axis is $p_{a}(V)$. If the second electron is in condition $b$, its probability of being found along $U$ is $p_{b}(U)$. Suppose now that the chance of finding the two electrons in conditions $a, b$, respectively, is $P_{a b}$. This depends on how the electrons were prepared by the source. Then the chance of finding them along the $V$ and $U$ axes is $\sum_{a, b} P_{a b} p_{a}(V) p_{b}(U)$ which is equal to $\frac{1}{4}(1-U . V)$. This is well known to be impossible if all the 'probabilities' $P_{a b}$ and $p$ are positive. But everything works fine if we permit negative probabilities and use for $a$ our four states with the $p_{a}(V)$ as defined previously. The probabilities for the correlated states in the case that the total spin is zero are $P_{a b}$ equal $\frac{1}{8}$ if $a$ and $b$ are different states, and $-\frac{1}{8}$ if they are the same.

For another example of a two-state system, consider an electron going through a screen with two small holes to arrive at a second screen (see Figure 13.1). We can say there are four ways or conditions by which the electron can go through the holes, corresponding to the ,,+++--+ , and -- conditions. If we take up spin to correspond to going through hole number 1 and down spin to represent going through hole 2 , then the other variable corresponding to spin in the $x$ direction means going through the two holes equally in phase. Ordinarily we cannot say which hole it goes through and what the phase relation is (just as ordinarily we do not say which way the $z$ spin is and which way the $x$-spin is) but now we can and do. For example, $f_{-}$- gives the probability of going through hole 2 but 180 degrees out of phase (whatever that could mean). For each of these conditions we can calculate what the chance is that the electron arrives at a point $x$ along the screen. For example, $P_{++}(x)$, the probability for arrival at $x$ for the condition ++ (through 1 in phase) and $P_{+-}(x)$, the probability for +- (through 1 but out of phase) are sketched roughly in Figure 13.1 as the curves $(b)$ and $(c)$ respectively. The independent probabilities are negative for some values of $x$. The functions through hole 2 are these reflected in $x ; P_{-+}(x)=P_{++}(-x)$ and $P_{--}(x)=P_{+-}(-x)$. The total chance to go through hole 1 , $P_{++}+P_{+-}$, the sum of the two irregular curves shown in the figure, is just the smooth bump, the solid line at $(a)$, with its maximum under hole 1 , not showing interference effects. But the total probability to arrive with holes out of phase, $P_{+_{-}}+P_{--}$, shows the typical interference pattern at the bottom of the figure at $(d)$.

Obviously the particular choice we used for the two-state system is arbitrary, and other choices may have some advantages. One way that generalizes to any number of holes or of states, finite or otherwise, is this. Suppose an event can happen in more than one way, say ways $A$, $B, C$, etc., with amplitudes $a, b, c$, respectively, so that the probability 

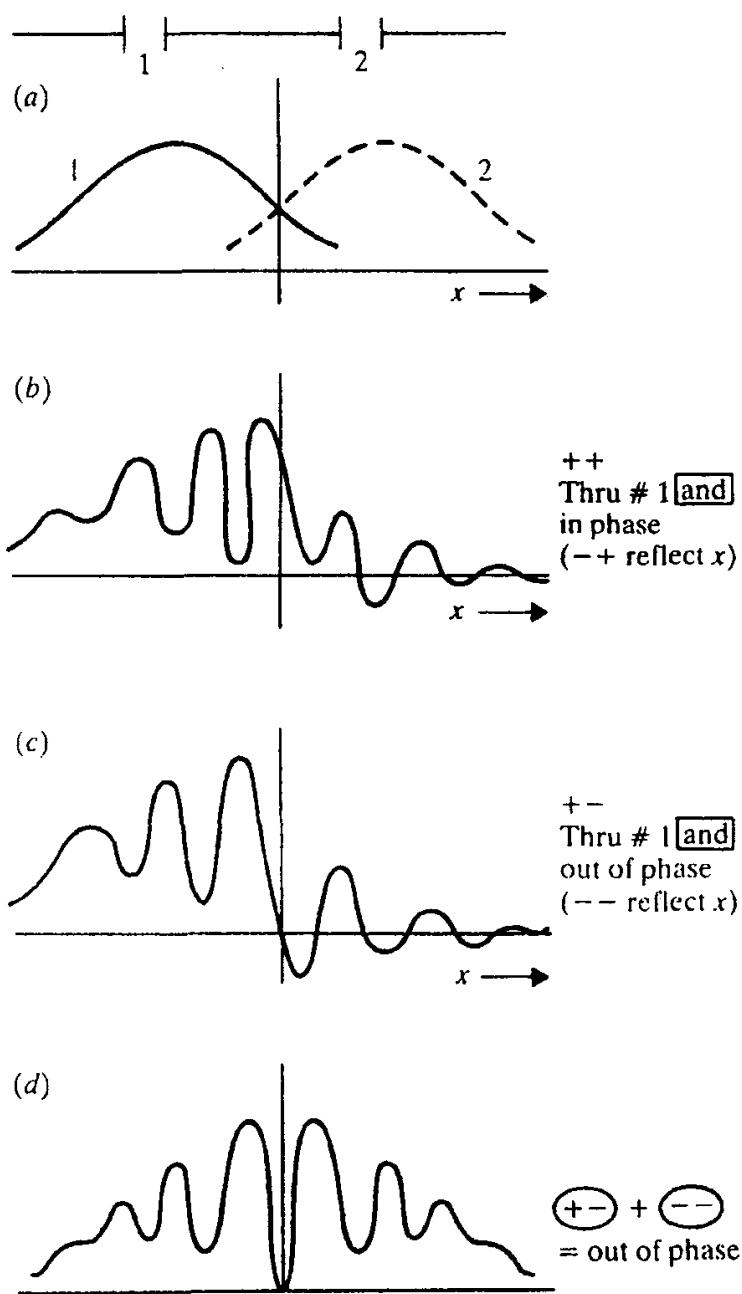

Figure 13.1 A two-state system in which an electron goes through a screen with two small holes to arrive at a second screen. (a) The total chance to go through hole 1. (b) The probability of going through hole 1 in phase. (c) The probability of going through hole 1 but out of phase. (d) The total probability to arrive with holes out of phase.

of occurring is the absolute square of $a+b+c+\ldots$ This can be described by saying the event can happen in two ways at once. For example we can say that the event happens by 'coming' in way $A$ and 'going' in way $B$ (or, if you prefer, by 'looping' via $A$ and $B$ ) with a 'probability' $P(A, B)=\frac{1}{2}(1+i) a^{*} b+\frac{1}{2}(1-i) b^{*} a$, where $a^{*}$ stands for the complex conjugate of $a$. The probability of 'coming' and 'going' by the same way $A$ is $P(A, A)=a^{*} a$ and is the conventional positive probability that the event would occur if way $A$ only 
were available to it. The total probability is the sum of these $P$ for every pair of ways. If the two ways in $P$, 'coming' and 'going' are not the same, $P$ is as likely to be negative as positive.

The density matrix, $\rho_{i j}$, if the states are $i$ is then represented instead by saying a system has a probability to be found in each of a set of conditions. These conditions are defined by an ordered pair of states 'coming' in $i$ and 'going' in $j$, with 'probability' $p(i, j)$ equal to the real part of $(1+i) \rho_{i j}$. The condition that all physical probabilities remain positive is that the square of $p(i, j)$ not exceed the product $p(i, i) p(j, j)$ (equality is reached for pure states).

Finally, suppose that, because of the passage of time, or other interaction, or simply a change in basis, the state $i$ has an amplitude $S_{m i}$ of appearing as state $m$, where $S$ is a unitary matrix (so the new density matrix $\rho^{\prime}$ is given by $S^{-1} \rho S$ ). We then discover we can find the new probabilities $p^{\prime}(m, n)$ by summing all alternatives $i, j$ of $p(i, j)$ times a factor that can be interpreted as the probability that the state 'coming' in $i$, 'going' in $j$ turns into the state 'coming' in $m$, 'going' in n. This 'probability' is:

$\frac{1}{2}\left(S_{i m}^{*} S_{j n}+S_{j n}^{*} S_{i m}\right)+\frac{i}{2}\left(S_{j m}^{*} S_{i n}-S_{i n}^{*} S_{j m}\right)$

With such formulas all the results of quantum statistics can be described in classical probability language, with states replaced by 'conditions' defined by a pair of states (or other variables), provided we accept negative values for these probabilities. This is interesting, but whether it is useful is problematical, for the equations with amplitudes are simpler and one can get used to thinking with them just as well.

My interest in this subject arose from many attempts to quantize electrodynamics or other field theories with cut-offs or using advanced potentials, in which work apparently negative probabilities often arose. It may have applications to help in the study of the consequences of a theory of this kind by Lee and Wick. 


\title{
EXISTENCE OF STAR-PRODUCTS AND OF FORMAL DEFORMATIONS OF THE POISSON LIE ALGEBRA OF ARBITRARY SYMPLECTIC MANIFOLDS
}

\author{
MARC DE WILDE and PIER RE B.A. LECOMTE \\ Université de Liège, Institut de Mathématique, 15 Avenue des Tilleuls, B-4000, \\ Liège, Belgium
}

\begin{abstract}
We prove the existence of star-products and of formal deformations of the Poisson Lie algebra of an arbitrary symplectic manifold. Moreover, all the obstructions encountered in the step-wise construction of formal deformations are vanishing.
\end{abstract}

\section{INTRODUCTION}

In the Hamiltonian formulation of classical mechanics, a phase space is nothing else but a symplectic manifold. Passing to quantum theory in the classical way implies a fundamental change in the nature of observables and makes the interpretation of the classical theory as a limit of the new one uneasy in many respects. An important aspect of quantization is its relation to deformations of classical theories. In that spirit, Flato, Lichnerowicz and Sternheimer have proposed building up quantum mechanics on an ordinary phase space in such a way that quantization manifests itself in a deformation of the algebra of observables. The value of the parameter of deformation is closely related to the Planck constant and letting it tend to zero gives back classical mechanics as a limit case. An account of the deformation approach to quantization can be found in $[1,6]$.

The algebra of observables is the space of smooth functions over a symplectic manifold with its natural structure of associative algebra and the appropriate deformations of this structure are called the star-products. The first star-product appeared as the inverse Weyl transform of the product of operators (Moyal [9]). It was rediscovered by Vey [10] who also proved the existence of nontrivial deformations of the Poisson Lie algebra structure for a symplectic manifold with a vanishing third De Rham cohomology group. The result was extended to associative deformations by Neroslavsky and Vlassov [8] under the same assumption. In the mean time, various classes of manifolds where this assumption is not necessary have been exhibited [4].

The cohomological obstructions appear as follows: a star-product or a deformation of the Poisson bracket are usually constructed step by step.

In passing from step $k$ to step $k+1$, one encounters a Chevalley or a Hochschild cocycle which should be a coboundary to allow the construction to continue. The work of Vey and Neroslavsky and Vlassov consists of confining this cocycle in the De Rham cohomology.

We show in this paper that there exists no obstruction at all: each formal deformation of order

Letters in Mathematical Physics 7 (1983) 487-496. 0377-9017/83/0076-0487\$01.50. ( 1983 by D. Reidel Publishing Company. 
$k$ of the Poisson bracket extends to a formal deformation and a similar result holds true for starproducts.

The basic tools are, first, cohomological properties of the Nijenhuis-Richardson bracket, showing in particular that the bracket of a one-differentiable cocycle with an arbitrary cocycle is always exact. Secondly, if $\xi$ is a conformal nonsymplectic vector field for the symplectic form $F$ of $M$, homogeneity with respect to $\xi$ allows us to avoid the obstructions. This was first observed in an analytic setting in [2]. An algebraic interpretation led to the proof of the existence of starproducts for exact symplectic manifolds $[4,5]$. A further refinement combined with gluing allows us to use this type of argument for nonexact $F$.

\section{NOTATIONS AND DEFINITIONS}

We will mainly use the notations and definitions of [5]. Some of them have just to be précised.

Let $M$ be a smooth connnected Hausdorff second countable manifold equipped with a symplectic form $F$. We suppose $\operatorname{dim} M>2$. We denote by $\Lambda(M)$ the space of smooth forms on $M$ and by $\nVdash(M)$ the space of smooth vector fields on $M$. As usual, we set $N=\Lambda^{\circ}(M)$ and $L_{X}$ denotes the Lie derivative in the direction of $X \in \mathcal{H}(M)$ acting on $\Lambda(M)$.

If $V$ and $V^{\prime}$ are vector spaces, $A^{p}\left(V, V^{\prime}\right)$ is the space of $(p+1)$-linear alternating maps from $V^{p+1}$ into $V^{\prime}$ and $A\left(V, V^{\prime}\right)$ is the direct sum of the $A^{p}\left(V, V^{\prime}\right)^{\prime}$ s $(p \geqslant-1)$. For simplicity, we set $A^{p}(V)=A^{p}(V, V)$ and $A(V)=A(V, V)$. It is known that $(A(V),[]$,$) , where [$,$] is the Nijenhuis-$ Richardson bracket, is a graded Lie algebra, the degree of $C \in A^{p}(V)$ being $p$. If $\mathscr{P}$ is a Lie algebra structure on $V$, the Chevalley coboundary operator of the adjoint representation of $(V, \mathscr{P})$ is up to \pm 1 the adjoint action of $\mathscr{P}$ on $A(V)$.

We denote by $A_{\text {loc }}\left(\mathcal{H C}(M), \Lambda^{q}(M)\right)$ [resp. $A_{\text {loc, nc }}(N)$ ] the space of all $C \in A\left(\mathcal{H C}(M), \Lambda^{q}(M)\right)$ [resp. $A(N)$ ] which are local [resp. local and vanishing on the constants]. We set also $A_{\nu}(N)=E(A(N), \nu]$ and $A_{\nu, \text { loc, nc }}(N)=E\left(A_{\text {loc, nc }}(N), \nu\right)$, where $E(V, \nu)$ denotes the space of formal power series in $\nu$ with coefficients in $V$.

The mapping $\mu: \mathcal{H}(M) \rightarrow \Lambda^{1}(M): X \rightarrow-i(X) F$ induces an isomorphism between the spaces of contravariant and covariant tensor fields on $M$. One sets $\Lambda=\mu^{-1} F$ and, for $u \in N, X_{u}=\mu^{-1} \mathrm{~d} u$.

For $C \in A^{p}\left(\mathcal{H}(M), \Lambda^{q}(N)\right)$, set $\mu^{*} C\left(u_{0}, \ldots, u_{p}\right)=C\left(X_{u_{0}}, \ldots, X_{u_{p}}\right)$ and, if $q=2, \mu^{\prime} C=\left\langle\Lambda, \mu^{*} C\right\rangle$.

In particular, $P=\mu^{*} F$ is the Poisson bracket of $M(\Lambda(M)$ being identified once and for all with a subspace of $A(\mathcal{K}(M), N)$ in the natural way). Denote by $Z_{\text {loc, nc }}^{2}(N)$ the space of Chevalley twococycles of $(N, P)$. Then $\partial$ being the coboundary operator and $\Gamma$ a symplectic connection of $(M, F)$, each $C \in Z_{\text {loc, nc }}^{2}$ is of the form $C=r S_{\Gamma}^{3}+\mu^{*} \Omega+\partial E\left(r \in \mathbb{R}, \Omega \in \Lambda^{2}(M)\right.$ closed and $\left.E \in A_{\mathrm{loc}, \mathrm{nc}}^{0}(N)\right) ; S_{\Gamma}^{3}$ is a cocycle of the form $\mu^{\prime} \Phi_{\Gamma}$, where $\Phi_{\Gamma}$ is a cocycle of the Chevalley cohomology of the representation $\left(\Lambda(M), X \rightarrow L_{X}\right)$ of $\mathcal{H}(M)$. Further details may be found in $[3,5,7]$.

PROPOSITION: 1.1. There exists a linear map $\tau: A_{\mathrm{loc}, \mathrm{nc}}^{\mathrm{n}}(N) \rightarrow A_{\mathrm{loc}}^{1}(\mathcal{H}(M), N)$ such that $\mu^{*} \circ \tau=\mathbb{1}$, $\tau \circ \mu^{*}=\mathbb{1}$ on $\Lambda^{2}(M), \tau\left(S_{\Gamma}^{3}\right)=\left\langle\Lambda, \phi_{\Gamma}\right\rangle$ and $\tau \circ \partial A_{\mathrm{loc}, \mathrm{nc}}^{0}(N) \subset \mathrm{im} \partial^{\prime}(\mathbb{1}$ denotes the appropriate identical map; $\partial^{\prime}$ is the coboundary operator of the cohomology of the representation $(\Lambda(M)$, $\left.X \rightarrow L_{X}\right)$ of $\mathcal{J}(M)$.)

Proof. It is easily seen that $\mu^{*}: A_{\text {loc }}^{1}(\mathcal{H}(M), N) \rightarrow A_{\text {loc, nc }}^{1}(N)$ is surjective. Take then a decomposition 


$$
A_{\mathrm{loc}, \mathrm{nc}}^{1}(N)=\mathbb{R R}_{\Gamma}^{3} \oplus \mu^{*} \Lambda^{2}(M) \oplus \partial E_{1} \oplus E_{2},
$$

where

$$
\partial A_{\text {loc, nc }}^{0}(N)=\mu^{*} \Lambda^{2}(M) \cap \partial A_{\text {loc, nc }}^{0}(N) \oplus \partial E_{1} .
$$

Observe that $\mu^{*}: \Lambda^{2}(M) \rightarrow A_{\text {loc, nc }}^{1}(N)$ is injective. Choose then any right inverse of $\mu^{*}, \tau_{1}$ on $E_{1}$ and $\tau_{2}$ and $E_{2}$ and set $\tau S_{\Gamma}^{3}=\left\langle\Lambda, \Phi_{\Gamma}\right\rangle,\left.\tau \circ \mu^{*}\right|_{\Lambda^{2}(M)}=\mathbb{1}, \tau \circ \partial=\partial^{\prime} \circ \tau_{1}$ on $E_{1}$ and $\tau=\tau_{2}$ on $E_{2}$. This defines a linear map $\tau: A_{\text {loc, nc }}^{1}(N) \rightarrow A_{\text {boc }}^{1}(\mathcal{H}(M), N)$, which obviously verifies the first three required properties.

For the last property, one notes that by [5, prop. 2.2], $\mu^{*} \Lambda(M) \cap \partial A_{\text {loc, } \mathrm{nc}}^{0}(N)=\partial \mu^{*} \Lambda^{1}(M)$ and that on $\Lambda^{1}(M), \tau \circ \partial \circ \mu=\tau \circ \mu^{*} \circ \partial^{\prime}=\partial^{\prime}$.

In this paper, we fix once and for all a $\tau$ such as in Proposition 1.1.

LEMMA 1.2. Let $R_{i} \in A_{\text {loc, nc }}(N), S_{i} \in A_{\text {loc }}^{s_{i}}(N)$ and a closed $\Omega \in \Lambda^{2}(M)$ be given. Let also $R_{i}^{\prime}, S_{i}^{\prime}, T^{\prime} \in A_{\mathrm{loc}}(\mathcal{H}(M) ; N)$ be such that $R_{i}=\mu^{*} R_{i}^{\prime}, S_{i}=\mu^{*} S_{i}^{\prime}$ and $\Sigma_{i}\left[R_{i}, S_{i}\right]=\mu^{*} T^{\prime}$. There exists $T \in A_{\text {loc , nc }}(N)$ such that

$$
\left.T\right|_{U}=\mu^{*} i(X) T^{\prime}-\sum_{i}(-1)^{s_{i}}\left[\mu^{*} i(X) R_{i}^{\prime}, S_{i}\right]-\sum_{i}\left[R_{i}, \mu^{*} i(X) S_{i}^{\prime}\right]
$$

whenever $\Omega=\mathrm{d} i(X) F$ on an open subset $U \subset M$.

Proof. If $\left.\Omega\right|_{U^{\prime}}=\mathrm{d} i\left(X^{\prime}\right) F$ and $U \cap U^{\prime} \neq \phi$, then $X^{\prime}-X$ is a symplectic vector field on $U \cap U^{\prime}$. It is, thus, locally of the form $X_{u}$. Since $\mu^{*} i\left(X_{u}\right)=i(u) \mu^{*}$, the right-hand side of (1) vanishes for $X=X_{u}$ by the graded Jacobi identity.

\section{ONE-DIFFERENTIABLE DEFORMATIONS OF $P$}

Recall that a formal deformation of order $k$ of $P$ is an element $\Sigma_{k=0}^{\infty} \nu^{k} C_{k}$ of $A_{\nu, \text { loc , nc }}^{1}(N)$ such that $C_{\mathrm{c}}=P$ and such that $\left|\mathcal{L}_{\nu}, \mathcal{L}_{\nu}\right|$ vanishes at order $k$ (i.e., the components $\left[\mathcal{L}_{\nu}, \mathcal{L}_{\nu}\right]_{l}$ of $\left[\mathcal{L}_{\nu}, \mathcal{L}_{\nu}\right]$ are vanishing for $\left.l \leqslant k\right)$. A formal deformation of $P$ is an element $\mathcal{L}_{\nu} \in A_{\nu}^{1}$, loc, nc $(N)$ such that $C_{0}=P$ and that $\left|\mathcal{L}_{\nu}, \mathcal{L}_{\nu}\right|=0$.

THEOREM 2.1. Let $\mathcal{L}_{\nu}$ be a formal deformation of $P$ and let $\Omega \in \Lambda^{2}(M)$ be closed.

(i) There exists a sequence $\mathbb{L}_{\nu}^{k}(k \in \mathbb{N})$ of elements of $A_{\nu, \text { loc, nc }}(N)$ such that $\mathbb{L}_{\nu}^{0}=\mathcal{L}_{\nu}$ and that

$$
I \mathbb{L}_{\nu}^{l} i_{U}=\sum_{p+q=l-1}\left[\mathbb{L}_{\nu}^{p}, \mu^{*} i(X) \tau\left(\mathbb{L}_{\nu}^{q}\right)\right]
$$

whenever $\Omega=\mathrm{d} i(X) F$ on the open subset $U \subset M$.

(ii) $\mathbb{L}_{\nu}^{1}$ is a cocycle for $\mathcal{L}_{\nu}$ and its first term is $\mu^{*} \Omega$. More generally, 


$$
\mathbb{L}_{\mu}\left(\mathcal{L}_{\nu} ; \Omega\right)=\sum_{k=0}^{\infty} \mu^{k} \mathbb{L}_{\nu}^{k}
$$

is a formal deformation in $\mu$ of $\mathcal{L}_{\nu}$.

(iii) In particular, for each $t \geqslant 1$,

$$
\mathcal{L}_{\nu}^{\prime}=\sum_{k=0}^{\infty} \nu^{k t} \mathbb{L}_{\nu}^{k}
$$

is a formal deformation of $P$ such that $\mathcal{L}_{\nu}^{\prime}=\mathcal{L}_{\nu}+\nu^{t} \mu^{*} \Omega$ at order $t$.

(iv) If $\mathcal{L}_{\nu}$ is one-differentiable at order $s$ (i.e., $C_{l}$ is one-differentiable for $\left.l \leqslant s\right)$, then $\mathbb{L}_{\nu}^{k}(k \in \mathbb{N})$ and $\mathcal{L}_{\nu}^{\prime}$ are one-differentiable at order $s$.

(If it is needed to recall $\mathcal{L}_{\nu}$ and $\Omega$, we sometimes will write $\mathbb{L}_{\nu}^{k}=\mathbb{L}_{\nu}^{k} \downarrow\left(\mathcal{L}_{\nu} ; \Omega\right)$ ).

Proof. Assume the existence of solutions $\mathbb{L}_{\nu}^{l}(l<k)$ of $(2)$ such that

$$
\sum_{p+q=l}\left[\mathbb{L}_{\nu}^{p}, \mathbb{L}_{p}^{q}\right]=0, \quad \forall l<k
$$

From Lemma 1.2, we obtain the existence of a globally defined $\mathbb{I}_{\nu}^{k}$ verifying (2) for $l=k$. Then applying (2) and the graded Jacobi identity:

$$
\begin{aligned}
k & \sum_{p+q=k}\left[\mathbb{L}_{\nu}^{p}, \mathbb{L}_{\nu}^{q}\right] \\
= & \left.\sum_{p+q+r=k-1}\left\{\left[\mathbb{L}_{\nu}^{p}, \mu^{*} i(X) \tau\left(\mathbb{L}_{v}^{r}\right)\right], \mathbb{L}_{\nu}^{q}\right]+\left[\mathbb{L}_{\nu}^{p},\left[\mathbb{L}_{\nu}^{q}, \mu^{*} i(X) \tau\left(\mathbb{L}_{\nu}^{r}\right)\right]\right]\right\} \\
& =\sum_{p+q+r=k-1}\left[\left[\mathbb{L}_{\nu}^{p}, \mathbb{L}_{\nu}^{q}\right], \mu^{*} i(X) \tau\left(\mathbb{L}_{v}^{r}\right)\right]=0
\end{aligned}
$$

in view of (3). Hence, (i), (ii) and (iii). For (iv), one has simply to note that the NijenhuisRichardson bracket of one-differentiable cochains is one-differentiable.

Let us say that a formal deformation $\mathcal{L}_{\nu}$ of order $k$ is a driver of a formal deformation $\mathcal{L}_{\nu}^{\prime}$ if $\mathcal{L}_{\nu}^{\prime}=\mathcal{L}_{\nu}$ at order $k$.

THEOREM 2.2. Every one-differentiable formal deformation of order $k$ of $P$ is a driver of a onedifferentiable formal deformation of $P$. In particular, there exist one-differentiable formal deformations of $P$ with driver $P+\nu \mu^{*} \Omega$; where $\Omega$ is an arbitrary closed two-form of $M$.

Proof. Let $\mathcal{L}_{\nu}$ be a one-dimensional formal deformation of order $k$ of $P$. Let $0 \leqslant l<k$ be given. Suppose that there exists a one-differentiable formal deformation $\mathcal{L}_{\nu}^{l}$ of $P$ such that $C_{i}^{l}=C_{i}$ for $i \leqslant l$. Then $C_{l+1}^{l}-C_{l+1}$ is a one-differentiable cocycle. It is thus of the form $\mu^{*} \Omega$ for some closed two-form $\Omega$. By theorem 2.1

$$
\mathcal{L}_{\nu}^{l+1}=\mathbb{I}_{\nu^{l+1}}\left(\mathcal{L}_{\nu}^{l} ; \Omega\right)
$$


is a one-differentiable formal deformation of $P$ such that $C_{i}^{+1}=C_{i}$ for $i \leqslant l+1$. Taking $\mathscr{L}_{\nu}^{0}=P$, the result follows by induction on $l$.

\section{FORMAL DEFORMATIONS OF $P$ WITH DRIVER $P+\nu r S_{\Gamma}^{3}$}

Let $U$ be open and suppose that $\left.F\right|_{U}=\operatorname{di}(\xi) F$ for some $\xi \in \mathcal{H}(U)$. It has been seen in [6] that

LEMMA 3.1.

(i)

$$
L_{\xi} \cdot P=P
$$

(ii) $\quad L_{\xi} \circ \partial=\partial \circ L_{\xi}-\partial$,

(iii) $\quad L_{\xi} \circ \partial^{\prime}=\partial^{\prime} \circ L_{\xi}$,

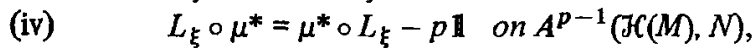

(v) $\quad L_{\xi} \circ \mu^{\prime}=\mu^{\prime} \circ L_{\xi}-p \mathbb{1}$ on $A^{p}\left(\mathcal{F C}(M), \Lambda^{2}(M)\right.$ ).

In addition, one may state

LEMMA 3.2. For $p \neq 2,3, L_{\xi}+p \mathbb{1}-\partial \circ \mu^{*} \circ i(\xi) \circ \tau$ is a linear proof bijection from $Z_{\mathrm{loc}, \mathrm{nc}}^{2}(N)$ into itself.

Proof. Recall that $C \in Z_{\text {loc, nc }}^{2}(N)$ admits a decomposition $C=r S_{\Gamma}^{3}+\mu^{*} \Omega+\partial E$ where $\Omega \in \Lambda^{2}(M)$ is closed, $r \in \mathbb{R}$. Moreover, $C$ is exact if and only if $r=0$ and $\Omega$ is exact.

By Proposition 1.1, $C^{\prime}=\mu^{*} \Omega+\partial E=\mu^{*} \tau\left(C^{\prime}\right)$ where $\tau\left(C^{\prime}\right)$ is a cocycle for $\partial^{\prime}$. Using Lemma 3.1,

$$
\left(L_{\xi}+p \mathbf{1}-\partial \circ \mu \circ i(\xi) \circ \tau\right)\left(r S_{\Gamma}^{3}+C^{\prime}\right)=r(p-3) S_{\Gamma}^{3}+(p-2) C^{\prime}
$$

Thus $L_{\xi}+p \mathbb{1}-\partial \circ \mu^{*} \circ i(\xi) \circ \tau$ is surjective. Moreover, if the right-hand side of (4) is vanishing, $r=0$ and $C^{\prime}=0$. Hence, the injectivity.

Let $\Pi \in A^{0}(E(N, \nu))$ be defined by

$$
\prod\left(\sum_{k=0}^{\infty} v^{k} u_{k}\right)=\sum_{k=0}^{\infty} k \nu^{k} u_{k}
$$

and set $\Theta=2 \Pi-\mathbb{1}$. As can easily be seen, for every $T_{\nu} \in A_{\nu}(N)$,

$$
T_{\nu}=\sum_{k=0}^{\infty} \nu^{k} T_{k} \Rightarrow\left[\Pi, T_{\nu}\right]=\sum_{k=0}^{\infty} k \nu^{k} T_{k}
$$

THEOREM 3.3. Let $r \in \mathbb{R}_{0}$ be given. There exists a unique formal deformation $\mathcal{L}_{\nu}$ of $P$ of driver $P+\nu r S_{\Gamma}^{3}$ such that

$$
\mathbb{I}_{\nu}^{1}\left(\mathcal{L}_{\nu} ; F\right)+\partial_{\nu} \Theta=0
$$


$\left(\partial_{\nu}\right.$ is the coboundary operator associated to the adjoint representation of $\left.\left(E(N, v), \mathcal{L}_{v}\right)\right)$.

Proof. (i) If $U$ is open and $\left.F\right|_{U}=\mathrm{d} i(\xi) F$ for some $\xi \in \mathcal{H}(U)$, after its definition in Theorem 2.1, $\mathbb{I}_{\boldsymbol{v}}(\mathcal{L} ; F)$ reads

$$
\sum_{k=0}^{\infty} \nu^{k} \sum_{p+q=k}\left[C_{p}, \mu^{*} i(\xi) \tau\left(C_{q}\right)\right]
$$

Thus, the $k$ th component of the left-hand side of (5) is

$$
\sum_{p+q=k}\left[C_{q}, \mu^{*} i(\xi) \tau\left(C_{q}\right)\right]-(2 k+1) C_{k}
$$

Observe, moreover, that $L_{\xi}=\mu^{*} i(\xi) F=\mu^{*} i(\xi) \tau\left(C_{0}\right)$. Hence, the above expression can be written, for $k>0$,

$$
-L_{\xi} C_{k}-(2 k+1) C_{k}+\partial \mu^{*} i(\xi) \tau\left(C_{k}\right)+\sum_{\substack{p+q=k \\ p, q>0}}\left[C_{p}, \mu^{*} i(\xi) \tau\left(C_{q}\right)\right]
$$

(ii) Let $\mathcal{L}_{\nu}$ and $\mathcal{L}_{\nu}^{\prime}$ have driver $P+\nu r S_{\Gamma}^{3}$ and satisfy (5). Assume that $k>1$ and that $C_{i}^{\prime}=C_{i}$ for $i<k$. Then

$$
\left(L_{\xi}+(2 k+1) \mathbb{1}-\partial \mu^{*} i(\xi) \tau\right)\left(C_{k}^{\prime}-C_{k}\right)=0
$$

It follows from Lemma 3.2 that $C_{k}^{\prime}=C_{k}$ on $U$. Thus $C_{k}^{\prime}=C_{k}$, hence, the uniqueness by induction on $k$.

(iii) Observe that (5) means that for every open subset $U$ on which $F=\mathrm{d} i(\xi) F, \mathscr{D}_{U}=\mu^{*} i(\xi) \tau\left(\mathcal{L}_{\nu}\right)+\Theta$ is a derivation of $\mathcal{L}_{\nu ! U}$. Set $C_{0}=P, C_{1}=r S_{\Gamma}^{3}, \mathcal{L}_{\nu}^{1}=C_{0}+\nu C_{1}$ and $\mathscr{D}_{U}^{1}=L_{\xi}+\mu^{*} i(\xi) \tau\left(S_{\Gamma}^{3}\right)+\Theta$. One has

$$
\left[\mathscr{D}_{U}^{1}, \mathcal{L}_{\nu}^{1}\right]_{0}=L_{\xi} P+P=0
$$

and

$$
\left[\mathscr{D}_{U}^{1}, \mathcal{L}_{\nu}^{1}\right]_{1}=r\left(L_{\xi} S_{\Gamma}^{3}+3 S_{\Gamma}^{3}-\partial \mu^{*} i(\xi) \tau\left(S_{\Gamma}^{3}\right)\right)=0
$$

by Lemma 3.1 .

Let now $k>1$ and suppose that the $C_{i}$ 's $\in A_{\text {loc, nc }}^{1}(N)(i<k)$ have been constructed such that $\mathcal{L}_{\nu}^{k-1}=\Sigma_{i<k} \nu^{i} C_{i}$ is a formal deformation of $P$ of order $k-1$ and that $\mathscr{D}_{U}^{k-1}=$ $\Sigma_{i<k} \nu^{i} \mu^{*} i(\xi) \tau\left(C_{i}\right)+\Theta$ is a derivation of $\mathcal{L}_{\nu}^{k-1}$ at order $k-1$. Set

$$
J_{k}=\sum_{\substack{p+q=k \\ p, q>0}}\left[C_{p}, C_{q}\right] \text { and } A_{U}^{k}=\sum_{\substack{p+q=k \\ p, q>0}}\left[C_{p}, \mu^{*} i(\xi) \tau\left(C_{q}\right)\right]
$$


Then $J_{k}$ is known to be a cocycle. As seen in [5], it has a decomposition. $J_{k}=\mu^{\prime} \Phi+\mu^{*} \Psi$ when $\Phi$ and $\Psi$ are three-cocycles of the cohomology of the representation $\left(\Lambda(M), X \rightarrow L_{X}\right)$ of $\mathcal{J}(M)$. Set $J_{k}^{\prime}=\langle\Lambda, \Phi\rangle+\Psi$. By Lemma 1.2 , there exists $A \in A_{\text {loc, nc }}^{2}(N)$ such that

$$
\left.A\right|_{U}=2 A_{U}^{k}-\mu^{*} i(\xi) V_{k}^{\prime}
$$

On the other hand, the coefficient of $\nu^{k}$ of the identity

$$
\left[\mathscr{D}_{U}^{k-1},\left[\mathcal{L}_{\nu}^{k-1}, \mathcal{L}_{\nu}^{k-1}\right]\right]=-2\left[\mathcal{L}_{\nu}^{k-1},\left[\mathcal{L}_{\nu}^{k-1}, \mathscr{D}_{U}^{k-1}\right]\right]
$$

reads

$$
\left(L_{\xi}+2 k+2\right) J_{k}=2 \partial A_{U}^{k}
$$

so that, applying Lemma 3.1 ,

$$
(2 k-2) \mu^{\prime} \Phi+(2 k-1) \mu^{*} \Psi=\partial\left(2 A_{U}^{k}-\mu^{*} i(\xi) J_{k}^{\prime}\right)=\partial A
$$

It follows that $\mu^{\prime} \Phi$ and $\mu^{*} \Psi$ are coboundaries [5], prop. 2.3, and thus $J_{k}=2 \partial C$ for some $C \in A_{\mathrm{loc}, \mathrm{nc}}^{1}(N)$.

Substituting $2 \partial C$ to $J_{k}$ in (6) and observing that $\partial L_{\xi}=L_{\xi} \partial+\partial$, we see that $L_{\xi} C+(2 k+1) C-A_{U}^{k}$ is a cocycle. It also reads, using Lemma 3.1 (iv),

$$
\partial \mu^{*} i(\xi) \tau(C)+\mu^{*} i(\xi) \partial^{\prime} \tau(C)-A_{U}^{k}+(2 k-1) C
$$

Therefore, $B \in A_{\mathrm{loc}, \mathrm{nc}}^{1}(N)$ defined by

$$
\left.B\right|_{U}=\mu^{*} i(\xi) \partial^{\prime} \tau(C)-A_{U}^{k}+(2 k-1) C .
$$

is a cocycle (cf. Lemma 1.2) and

$$
L_{\xi} C+(2 k+1) C-\partial \mu^{*} i(\xi) \tau(C)-A_{U}^{k}-B=0 .
$$

In view of the properties of $\tau$, the cocycle $B$ has a decomposition $B=r^{\prime} S_{\Gamma}^{3}+\mu^{*} B^{\prime}$ where $B^{\prime}=\tau\left(B-r^{\prime} S_{\Gamma}^{3}\right)$ is a cocycle. Taking

$$
C_{k}=C+(2 k-1)^{-1} \mu^{*} B^{\prime}+(2 k-2)^{-1} r^{\prime} S_{\Gamma}^{3},
$$

we still have $J_{k}=2 \partial C_{k}$ and, moreover, (7) transforms into

$$
L_{\xi} C_{k}+(2 k+1) C_{k}-\partial \mu^{*} i(\xi) \tau\left(C_{k}\right)-A_{U}^{k}=0 .
$$

This means that $\mathcal{L}_{v}^{k}=\mathcal{L}_{\nu}^{k-1}+\nu^{k} C_{k}$ is a formal deformation of $P$ of order $k$ and that $\mathscr{D}_{U}^{k}=\mathscr{D}_{U}^{k-1}+$ 
$\nu^{k} \mu^{*} i(\xi) \tau\left(C_{k}\right)$ is a derivation of order $k$ of $\mathcal{L}_{\nu}^{k} l_{U}$. Hence, the existence of $\mathcal{L}_{\nu}$, by induction on $k$.

Let $T \in A_{\text {loc, nc }}^{0}(N)$ or $T=r \Pi(r \in \mathbb{R})$. Denote by ad $T$ its adjoint action on $A(E(N, \nu))$. It is easily seen that, for $t \geqslant 1$, if $\mathcal{L}_{\nu}$ is a formal deformation of $P$, then so is

$$
\operatorname{Ad}\left(\exp \nu^{t} T\right) \mathcal{L}_{\nu}=\sum_{k=0}^{\infty} \frac{\nu^{t k}}{k !}(\operatorname{ad} T)^{k} \mathcal{L}_{\nu} .
$$

THEOREM 3.4. Every formal deformation of order $k$ of $P$ is a driver of a formal deformation of $P$.

Proof. (i) Let $\mathcal{L}_{\nu}$ be a formal deformation of order $k$ of $P$. Let us assume that $\mathcal{L}_{\nu}$ is one-differentiable at order $t-1$, where $t<k$. As

$$
2 \partial C_{t}=\sum_{\substack{p+q=t \\ p, q>0}}\left[C_{p}, C_{q}\right]
$$

is one-differentiable, we see that $C_{t}$ is of the form $\theta S_{\Gamma}^{3}+\mu^{*} \eta+\partial T$ for some $\theta \in \mathbb{R}$, some $\eta \in \Lambda^{2}(M)$ and some $T \in A_{\mathrm{loc}}^{0}$, nc $(N)$. If $\theta=0$, then $\operatorname{Ad}\left(\exp \nu^{t} T\right) \mathcal{L}_{\nu}$ is a formal deformation of order $k$ of $P$ and is one-differentiable at order $t$. Moreover, $\mathscr{L}_{\nu}$ is a driver for $\mathcal{L}_{\nu}^{\prime}$ if and only if $\operatorname{Ad}\left(\exp \nu^{t} T\right) \mathcal{L}_{\nu}$, truncated at order $k$, is a driver for $\left.\operatorname{Ad}\left(\exp \nu^{t} T\right) \mathcal{L}_{\nu}^{\prime}\right)$. Thus, replacing $\mathscr{L}_{\nu}$ by

$$
\operatorname{Ad}\left(\exp \nu^{k-1} T_{k-1}\right) \circ \cdots \circ \operatorname{Ad}\left(\exp \nu T_{1}\right) \mathcal{L}_{\nu}
$$

for suitable $T_{i}$ 's $\in A_{\text {loc, nc }}^{0}(N)$ if necessary, we may assume that either $\mathcal{L}_{\nu}$ is one-differentiable or that there exists $s \leqslant k$ such that $C_{i}$ is one-differentiable for $i<s$ and that $C_{s}-r S_{\Gamma}^{3}$ is onedifferentiable for some $r \in \mathbb{R}_{0}$.

(ii) In the first case, we may conclude by Theorem 2.2. Let us now deal with the second case. Let $\mathcal{L}_{\nu}^{*}$ be a formal deformation of $P$ with driver $P+\nu r S_{\Gamma}^{3}$ and define formal deformations $\mathfrak{L}_{\nu}^{0}, \ldots, \mathscr{L}_{\nu}^{S}$ of $P$ inductively by $\mathfrak{L}_{\nu}^{0}=\mathfrak{L}_{\nu}^{*}$ and, for $i>0$,

$$
\mathcal{L}_{\nu}^{i}=\mathbb{L}_{\nu}\left(\mathcal{L}_{\nu}^{i-1} ; \tau\left(C_{i}-C_{i}^{i-1}\right)\right)
$$

It is easily seen that $\mathcal{L}_{v}^{s}=\mathcal{L}_{\nu}$ at order $s$. If $s=k$, the proof is achieved. Suppose then that $s<k$ and that we have found a formal deformation $\mathfrak{L}_{\nu}^{\prime}$ of $P$ such that $\mathfrak{L}_{\nu}^{\prime}=\mathfrak{L}_{\nu}$ at order $l$, with $s<l<k$. Then the cocycle $C_{l+1}^{\prime}-C_{l+1}$ is of the form $r^{\prime} S_{\Gamma}^{3}+\mu^{*} \Omega+\partial T$ for some $r^{\prime} \in \mathbb{R}$, some closed $\Omega \in \Lambda^{2}(M)$ and some $E \in A_{\text {loc, nc }}^{0}(N)$. Replacing $\mathcal{L}_{\nu}^{\prime}$ by $\operatorname{Ad}\left(\exp \nu^{l+1} T\right) \mathcal{L}_{\nu}^{\prime}$, we may assume that $T=0$. On the other hand, set

$$
\mathcal{L}_{\nu}^{\prime \prime}=\operatorname{Ad}\left(\exp \nu^{l-s+1}\left(\frac{r^{\prime}}{s r}\right) \Pi \mathcal{L}_{\nu}\right.
$$

Then, $C_{i}^{\prime \prime}-C_{i}$ is one-differentiable for $i \leqslant l+1$ and vanishes for $i \leqslant l-s$. Define formal deformations $\hat{\mathcal{L}}_{\nu}^{l-s+1}, \ldots, \hat{\mathcal{L}}_{\nu}^{l+1}$ of $P$ inductively by $\hat{\mathcal{L}}_{\nu}^{l-s+1}=\mathcal{L}_{\nu}^{\prime \prime}$ and for $j \geqslant l-s$,

$$
\hat{\mathcal{L}}_{\nu}^{i}=\mathbb{L}_{\nu j}\left(\hat{\mathcal{L}}_{\nu}^{j-1} ; \tau\left(\hat{C}_{j}-C_{j}^{j-1}\right)\right)
$$


Then $\hat{\mathscr{L}}_{\nu}^{l+1}$ is a formal deformation of $P$ which coincides with $\mathcal{L}_{\nu}$ at order $l+1$. Hence, the result by induction on $l<k$.

It follows from Theorem 3.4 that $[C, C]$ is exact for each two-cocycle $C$. Moreover, $H_{1-\text { diff, nc }}(N)$ denoting the cohomology of one-differentiable nc cochains, it can be shown that

THEOREM 3.5 .

(ii) $\quad\left[\oplus_{i \leqslant 2} H_{\mathrm{loc}, \mathrm{nc}}^{i}(N), \oplus_{i \leqslant 2} H_{\mathrm{loc}, \mathrm{nc}}^{i}(N)\right]=0$.

\section{STAR-PRODUCTS}

Recall that a star-product of $(M, F)$ is a formal deformation $\mathscr{M}_{\lambda}=\Sigma_{k=0}^{\infty} \lambda^{k} C_{k}$ of the associative algebra $(N, \mathscr{M})$, with driver $\mathscr{M}+\lambda P$, where for $k>0$, the $C_{k}$ 's are local, vanishing on the constants and such that $C_{k}(v, u)=(-1)^{k} C_{k}(u, v)$ for all $u, v \in N$.

THEOREM 4.1. Every star-product of order $2 k$ is a driver of a star-product. In particular, every symplectic manifold admits a star-product.

Proof. Let $\mathscr{M}_{\lambda}=\Sigma_{i \leqslant 2 k} \lambda^{i} C_{i}$ be a star-product of order $2 k(k>0)$. Then

$$
\mathcal{L}_{\nu}=\sum_{i<k} \nu^{i} C_{2 i+1}
$$

is a formal deformation of order $k-1$ of $P$.

In the proof of the Neroslavsky-Vlassov theorem [8], which asserts the existence of a statproduct when the third De Rham cohomology space of $M$ vanishes, the key steps are the following.

(i) There exists $C_{2 k+1} \in A_{\text {loc, nc }}^{1}(N)$ such that $\mathscr{M}_{\lambda}^{\prime}=\mathscr{M}_{\lambda}+\nu^{2 k+1} C_{2 k+1}$ is a star-product of order $2 k+1 ; C_{2 k+1}$ is determined up to an arbitrary one-differentiable element of $A_{\text {loc, nc }}^{1}(N)$.

(ii) $\mathscr{M}_{\lambda}^{\prime}$ extends to a star-product of order $2 k+2$ if and only if $\mathcal{L}_{\nu}+\nu^{k} C_{2 k+1}$ is a formal deformation of order $k$ of $P$.

(iii)

$$
\sum_{p+q=k}\left[C_{2 p+1}, C_{2 q+1}\right]
$$

is a one-differentiable Chevalley cocycle.

By Theorem 3.5, (8) is a driver for a formal deformation of $P$. If $\nu^{k} C$ is its $k$ th component, then $\partial\left(C_{2 k+1}-C\right)$ is one-differentiable. Thus $C_{2 k+1}-C-\mu^{*} \Omega$ is a Chevalley cocycle for a suitable $\Omega \in \Lambda^{2}(M)$. Then replacing $C_{2 k+1}$ by $C_{2 k+1}-\mu^{*} \Omega$, (9) vanishes and $\mathscr{M}_{\lambda}$ extends to a star-product of order $2 k+2$. Hence, the existence of a star-product with driver $\mathscr{M}_{\lambda}$ by induction. on $k$.

To conclude, observe now that each symplectic manifold admits a star-product of order 2 [8] . 
REFERENCES

1. Arnal, D., Cortet, J.C., Flato, M., and Sternheimer, D., 'Star-Products: Quantization and Representation Without Operators', in E. Tirapegui (ed.), Field Theory Quantization and Statistical Physics, Reidel, Dordrecht, 1981, pp. 85-111.

2. Cahen, M. and Gutt, S., Lett. Math. Phys. 6, 395-404 (1982).

3. De Wilde, M., Gutt, S., and Lecomte, P., 'A propos des deuxième et troisième espaces de cohomologie de l'algèbre de Lie de Poisson d'une variété symplectique', Ann. Inst. Poincaré, to appear.

4. De Wilde, M. and Lecomte, P., Lett. Math. Phys. 7, 235-241 (1983).

5. De Wilde, M. and Lecomte, P., 'Existence of Star-Products on Exact Symplectic Manifolds', to appear.

6. Flato, M., and Sternheimer, D., 'Deformation of Poisson Brackets', in J. Wolf et al. (eds.), Harmonic Analysis and Representation of Semi Simple Lie Group, Reidel, Dordrecht, 1980, pp. 385-448.

7. Gutt, S., Ann. Inst. Poincaré 33, 1-31 (1981).

8. Lichnerowicz, A., Ann. Inst. Fourier 32, 157-209 (1982).

9. Moyal, J.E., Proc. Cambridge Phil. Soc. 45, 99-124 (1949).

10. Vey, J., Comm. Math. Helv. 50, 421-454 (1975).

(Received July 28,.1983) 


\title{
A SIMPLE GEOMETRICAL CONSTRUCTION OF DEFORMATION QUANTIZATION
}

\author{
BORIS V. FEDOSOV
}

\begin{abstract}
A construction, providing a canonical star-product associated with any symplectic connection on symplectic manifold, is considered. An action of symplectomorphisms by automorphisms of star-algebra is introduced, as well as a trace construction. Generalizations for regular Poisson manifolds and for coefficients in the bundle $\operatorname{Hom}(E, E)$ are given.
\end{abstract}

\section{Introduction}

A manifold $M$ is called a Poisson manifold, if for any two functions $u, v \in C^{\infty}(M)$, a Poisson bracket is defined by

$$
\{u, v\}=t^{i j} \frac{\partial u}{\partial x^{i}} \frac{\partial v}{\partial x^{j}} .
$$

The bracket is a bilinear skew-symmetric operation, satisfying the Jacobi identity

$$
\{u,\{v, w\}\}+\{v,\{w, u\}\}+\{w,\{u, v\}\}=0 .
$$

An important particular case is a symplectic manifold. In this case the matrix $t^{i j}$ has maximal rank $2 n$ equal to the manifold dimension. The inverse matrix $\omega_{i j}$ defines the exterior 2-form $\omega=\frac{1}{2} \omega_{i j} d x^{i} \wedge d x^{j}$ which is closed in virtue of Jacobi identity.

In [1] it has been proved that, if the tensor $t^{i j}$ has constant rank $2 n>$ $\operatorname{dim} M$, there exists a symplectic foliation of the manifold $M$, a Poisson manifold with this property being said to be regular. The leaves $F$ of this foliation locally are symplectic manifolds, and a Poisson bracket is defined by the symplectic form $\omega$ (closed 2-form of the rank $2 n=\operatorname{dim} F$ ) defined on the leaves.

In the same paper [1] the question of deformation quantization of Poisson and in particular symplectic manifolds is considered. The problem is to define an associative multiplication operation $*$, depending on parameter $h$ (Planck constant), of two functions so that the space $C^{\infty}(M)$ with

Received November 11, 1992 and, in revised form, April 27, 1993. 
usual linear operators and *-product would be a formal deformation of commutative algebra of functions with a Poisson bracket. More exactly it means the following. Let $Z$ be the linear space, the elements of which are formal series

$$
a=a(x, h)=\sum_{k=0}^{\infty} h^{k} a_{k}(x),
$$

where $a_{k}(x) \in C^{\infty}(M)$. Further for any $a, b \in Z$ let an associative product operation

$$
a * b=c=\sum_{k=0}^{\infty} h^{k} c_{k}(x)
$$

be defined with the following properties:

(i) $c_{k}$ are polynomials in $a_{k}, b_{k}$ and their derivatives;

(ii) $c_{0}(x)=a_{0}(x) b_{0}(x)$;

(iii) $[a, b] \equiv a * b-b * a=-i h\left\{a_{0}, b_{0}\right\}+\cdots$, where dots mean the terms of higher orders.

The algebra $Z$ is called the algebra of quantum observables. Property (i) means the locality of *-product, property (ii) means that algebra $Z$ is a deformation of the commutative algebra of $C^{\infty}$ functions, property (iii) is the so-called correspondence principle.

The question of the existence of such a product for symplectic manifolds has been completely solved in [2]. Subsequently, an equivariant generalization of this construction [7] for symplectic manifolds was obtained, as well as a generalization for regular Poisson manifolds [6]. The constructions considered in these works are based on the analysis of Hochschild cohomologies.

In [3] the author, being unaware of the results of [2], proposed another construction of *-product for a symplectic manifold. This construction admits straightforward generalizations for both the equivariant case and the case of a regular Poisson manifold. In subsequent papers [4], [5] the author studied the action of symplectic diffeomorphisms, proposed a trace construction in algebra $Z$, introduced the concept of index, generalizing the index of elliptic operators and obtained an index formula.

Unfortunately, work [3] was published in a local issue of Moscow Institute of Physics and Technology in very few copies, so it remained unknown to most mathematicians. The purpose of the present article, containing the extended exposition of some results of [3], [4], is to introduce the results to broader mathematical circles.

Let us briefly describe the contents of subsequent sections. In $\S 2$ we consider the Weyl algebras bundle $W, W$-valued differential forms, and a 
connection in the bundle $W$. These notions give us a basic machinery. In $\S 3$ we introduce the notion of Abelian connection and prove the existence of such connections. The sections of the Weyl algebras bundle, which are flat with respect to a fixed Abelian connection, form an associative algebra. We prove that these sections are in one to one correspondence with the functions from $Z$. This allows us to transfer the associative algebra structure to the set $Z$ and thus to define a *-product.

The next sections are concerned with the notion of trace in the algebra of flat sections. First of all we construct isomorphisms of this algebra, corresponding to any symplectic diffeomorphism of symplectic manifolds. This construction, introduced in $\S 4$, is used in $\S \S 5$ and 6 to define a trace by means of localization and reduction to the case of standard symplectic space $\mathbb{R}^{2 n}$. In $\S 7$ two generalizations are exposed. The first one gives the construction of deformation quantization and the trace for the case where the coefficients are homomorphisms of a vector bundle over $M$. The second one deals with a generalization of the results obtained in $\S \S 2$ and 3 for the case of regular Poisson manifolds.

A few years ago there appeared a paper [8], in which quantization is based on the idea of identifying functions on a symplectic manifold with the sections of the Weyl bundle. We use a similar approach. But their means of such an identification is much more complicated than ours.

This article has been written during a visit to MIT. Taking this opportunity, I would like to express my profound gratitude to the Department of Mathematics at MIT and to Professor Guillemin for the kind invitation. I would also like to thank Professor A. Weinstein for his useful corrections and remarks.

\section{Weyl algebras bundle}

Let $(M, \omega)$ be a symplectic manifold of dimension $2 n$. The form $\omega$ determines a symplectic structure in each tangent space $T_{x} M$.

Definition 2.1. The formal Weyl algebra $W_{x}$, corresponding to the symplectic space $T_{x} M$, is the associative algebra over $\mathbb{C}$ with a unit, its elements being formal series

$$
a(y)=\sum_{2 k+l \geq 0} h^{k} a_{k, i_{1} \cdots i_{l}} y^{i_{l}} \cdots y^{i_{l}},
$$

where $h$ is a formal parameter, $y=\left(y^{1}, \cdots, y^{2 n}\right) \in T_{x} M$ is a tangent vector, and $a_{k, i_{1} \cdots i_{l}}$ are covariant tensors. The degrees 1 and 2 are prescribed for the variables $y^{i}$ and $h$ respectively. The product of elements 
$a, b \in W_{x}$ is determined by the Weyl rule

$$
\begin{aligned}
a \circ b & =\left.\exp \left(-\frac{i h}{2} \omega^{i j} \frac{\partial}{\partial y^{i}} \frac{\partial}{\partial z^{j}}\right) a(y, h) b(z, h)\right|_{z=y} \\
& =\sum_{k=0}^{\infty}\left(-\frac{i h}{2}\right)^{k} \frac{1}{k !} \omega^{i_{1} j_{1}} \cdots \omega^{i_{k} j_{k}} \frac{\partial^{k} a}{\partial y^{i_{1}} \cdots \partial y^{i_{k}}} \frac{\partial^{k} b}{\partial y^{j_{1}} \cdots \partial y^{j_{k}}} .
\end{aligned}
$$

It is easily seen that the multiplication (2.2) does not depend on the choice of a basis in $T_{x} M$ and is associative.

Taking the union of the algebras $W_{x}, x \in M$, we obtain the bundle of formal Weyl algebras whose sections are "functions"

$$
a(x, y, h)=\sum_{2 k+l \geq 0} h^{k} a_{k, i_{1} \cdots i_{l}}(x) y^{i_{1}} \cdots y^{i_{l}},
$$

where $a_{k, i_{1} \cdots i_{l}}$ are symmetric covariant tensor fields on $M$. The set of sections also forms an associative algebra with respect to the fiberwise multiplication (2.2). The unit in this algebra is the "function" identically equal to 1 . To simplify notation we shall also denote the algebra of the sections by $W$ (instead of the pedantic $C^{\infty}(M, W)$ ), which, to our mind, should not cause any confusion.

It is easy to see that the center of $W$ consists of the sections not containing $y$ 's. Thus the central sections are defined by the series of form (1.2), and consequently the center of $W$ may be identified as a linear space with the space $Z$ mentioned in the introduction. There is a filtration in the algebra $W: W \supset W_{1} \supset W_{2} \supset \cdots$ with respect to the total degree $2 k+l$ of the terms of the series (2.3).

We shall also need differential forms on $M$ with values in $W$. A differential $q$-form is defined by the series

$$
a=\sum h^{k} a_{k, i_{1} \cdots i_{p}, j_{1} \cdots j_{q}}(x) y^{i_{1}} \cdots y^{i_{p}} d x^{j_{1}} \wedge \cdots \wedge d x^{j_{q}},
$$

whose coefficients are covariant tensor fields symmetric with respect to indices $i_{1}, \cdots, i_{p}$ and antisymmetric with respect to $j_{1}, \cdots j_{q}$. The differential forms constitute an algebra $W \otimes \Lambda=\bigoplus_{q=0}^{2 n}(W \otimes \Lambda)$, in which the multiplication is defined by means of the exterior product of differentials $d x^{i}$ and Weyl product (2.2) of polynomials in $y^{i}\left(d x^{i}\right.$ commute with $\left.y^{i}\right)$. The product of two forms will be denoted by the same symbol $a \circ b$, such as the product sections of $W$. A filtration $W \otimes \Lambda \supset W_{1} \otimes \Lambda \supset W_{2} \otimes \Lambda \supset \cdots$ is introduced with respect to the total degree $2 k+p$ corresponding to the variables $h, y^{i}$. 
Let us introduce the commutator of two forms $a \in W \otimes \Lambda^{q_{1}}, b \in$ $W \otimes \Lambda^{q_{2}}$ defined by $[a, b]=a \circ b-(-1)^{1^{q_{2}}} b \circ a$. A form $a$ is said to be central, if for any $b \in W \otimes \Lambda$ the commutator of $a$ and $b$ vanishes. It is clear that the central forms are just the ones not containing $y$ 's, i.e., $Z \otimes \Lambda$ is the center.

Define two projections of the form $a=a(x, y, d x, h)$ onto the center: $a_{0}=a(x, 0, d x, h)$ and $a_{00}=a(x, 0,0, h)$. In the particular case where $a=a(x, y, h) \in W$, we shall use the notation $\sigma(a)$ for $a_{0}=$ $a(x, 0, h)$ and call $\sigma(a)$ the symbol of the section $a$.

Consider two important operators on forms:

$$
\delta a=d x^{k} \wedge \frac{\partial a}{\partial y^{k}}, \quad \delta^{*} a=y^{k} i\left(\frac{\partial}{\partial x^{k}}\right) a,
$$

where $i\left(\partial / \partial x^{k}\right)$ means the contraction of the vector field $\partial / \partial x^{k}$ and the form, multiplication by $y^{k}$ being the usual commutative product of functions. The operator $\delta: W_{p} \otimes \Lambda^{q} \rightarrow W_{p-1} \otimes \Lambda^{q+1}$ which reduces the filtration by 1 is similar to the exterior derivation. The operator $\delta^{*}: W_{p} \otimes$ $\Lambda^{q} \rightarrow W_{p+1} \otimes \Lambda^{q-1}$ raises the filtration by 1 . In other words the operator $\delta$ acts on the monomial

$$
y^{i_{1}} y^{i_{2}} \cdots y^{i_{p}} d x^{j_{1}} \wedge d x^{j_{2}} \wedge \cdots \wedge d x^{j_{q}}
$$

by replacing one by one the variables $y^{i_{1}}, y^{i_{2}}, \cdots, y^{i p}$ by $d x^{i_{1}}, d x^{i_{2}}, \cdots$, $d x^{i_{p}}$ respectively; the operator $\delta^{*}$ acts on (2.6) by replacing $d x^{j_{1}}, d x^{j_{2}}$, $\cdots, d x^{j_{q}}$ by $y^{j_{1}},-y^{j_{2}}, \cdots,(-1)^{q} y^{j_{q}}$ respectively.

Lemma 2.2. The operators $\delta$ and $\delta^{*}$ do not depend on the choice of local coordinates and have the following properties:

(i) $\delta^{2}=\left(\delta^{*}\right)^{2}=0$,

(ii) for monomial (2.6) we have $\delta \delta^{*}+\delta^{*} \delta=(p+q)$ id.

The lemma is easily proved by a direct check. q.e.d.

Note that $\delta$ is an antiderivation, i.e., for $a \in W \otimes \Lambda^{q_{1}}$ and $b \in W \otimes \Lambda^{q_{2}}$ we have

$$
\delta(a \circ b)=(\delta a) \circ b+(-1)^{q_{1}} a \circ b,
$$

( $\delta^{*}$ does not possess this property).

Define the operator $\delta^{-1}$ acting on the monomial (2.6) by $\delta^{-1}=$ $\delta^{*} /(p+q)$ for $p+q>0$, and $\delta^{-1}=0$ for $p+q=0$. By Lemma 2.2 it can be derived that any form $a \in W \otimes \Lambda$ has the representation

$$
a=\delta \delta^{-1} a+\delta^{-1} \delta a+a_{00},
$$

which is similar to the Hodge-De Rham decomposition. 
Definition 2.3. A symplectic connection is a torsion-free connection preserving tensor $\omega_{i j}$, i.e., $\partial_{i} \omega_{j k}=0, \partial_{i}$ being a covariant derivative with respect to $\partial / \partial x^{i}$.

In Darboux local coordinates the coefficients $\Gamma_{i j k}=\omega_{i m} \Gamma_{j k}^{m}$ of the symplectic connection are completely symmetric with respect to indices $i j k$. The symplectic connection always exists but is not unique, unlike the Riemannian connection [1]. Two symplectic connections differ by a completely symmetric tensor $\Delta \Gamma_{i j k}$.

Let $\partial$ be a symplectic connection on the manifold $M$. Using the covariant derivation of tensor fields, which are coefficients in (2.4), define a connection in the bundle $W$ as an operator $\partial: W \otimes \Lambda^{q} \rightarrow W \otimes \Lambda^{q+1}$ by

$$
\partial a=d x^{i} \wedge \partial_{i} a
$$

Definition 2.3 implies the following properties of the connection $\partial$ in the bundle $W \otimes \Lambda$ :

(i) $\partial(a \circ b)=\partial a \circ b+(-1)^{q_{1}} a \circ \partial b$ for $a \in W \otimes \Lambda^{q_{1}}$.

(ii) For any scalar form $\varphi \in \Lambda^{q}, \partial(\varphi \wedge a)=d \varphi \wedge a+(-1)^{q} \varphi \wedge \partial a$.

In Darboux local coordinates the connection $\partial$ can be written in the form

$$
\partial a=d a+[(i / h) \Gamma, a],
$$

where $\Gamma=\frac{1}{2} \Gamma_{i j k} y^{i} y^{j} d x^{k}$ is a local 1 -form with values in $W, d=d x^{i} \wedge$ $\partial / \partial x^{i}$ being the exterior differential with respect to $x$.

We shall consider more general connections $D$ in the bundle $W$, namely, connections of the form

$$
D a=\partial a+[(i / h) \gamma, a]=d a+[(i / h)(\Gamma+\gamma), a],
$$

where $\gamma$ is a globally determined 1 -form on $M$ with values in $W$ (i.e., section of $W \otimes \Lambda^{1}$ ). Note that the operator $\delta$, introduced above, may be written in the form

$$
\delta a=-\left[(i / h) \omega_{i j} y^{i} d x^{j}, a\right] .
$$

Lemma 2.4. Let $\partial$ be a symplectic connection. Then

$$
\begin{gathered}
\partial \delta a+\delta \partial a=0, \\
\partial^{2} a=\partial(\partial a)=[(i / h) R, a],
\end{gathered}
$$

where

$$
R=\frac{1}{4} R_{i j k l} y^{i} y^{j} d x^{k} \wedge d x^{l},
$$

$R_{i j k l}=\omega_{i m} R_{j k l}^{m}$ being the curvature tensor of the symplectic connection. 
Proof. Identities (2.13), (2.14) are obvious consequences of equations $(2.10),(2.12)$. Note that (2.14) is a compact form of the Ricci identity.

Definition 2.5. Let $D$ be a connection in the bundle $W$ of the form (2.11) with

$$
\gamma_{0}=0
$$

We shall call the 2-form

$$
\frac{i}{h} \Omega=\frac{i}{h}\left(R+\partial \gamma+\frac{i}{h} \gamma^{2}\right)
$$

the curvature of the connection $D$.

Lemma 2.6. For any section $a \in W \otimes \Lambda$ we have

$$
D^{2} a=[(i / h) \Omega, a] .
$$

The proof is straightforward.

Remark. Note that the form $\gamma$ in (2.11) is determined by the connection $D$ not uniquely but up to a central 1 -form, because it appears in commutators. For the uniqueness of $\gamma$ and therefore of the curvature (2.16) some normalizing condition is required. We assume that this condition has the form (2.15) and call it Weyl normalizing condition. The corresponding curvature $(2.16)$ is called Weyl curvature.

\section{Abelian connections and quantization}

Definition 3.1. A connection $D$ in the bundle $W$ is said to be $A$ belian if for any section $a \in W \otimes \Lambda$,

$$
D^{2} a=[(i / h) \Omega, a]=0 .
$$

By (3.1) we can show that the curvature of Abelian connection is a central form and conversely.

In this section we prove the existence of an Abelian connection of the form

$$
D=-\delta+\partial+\left[\frac{i}{h} r, \cdot\right]=\partial+\left[\frac{i}{h}\left(\omega_{i j} y^{i} d x^{j}+r\right), \cdot\right],
$$

$\partial$ being a fixed symplectic connection, and $r \in W_{3} \otimes \Lambda^{1}$ being a globally defined 1-form, satisfying Weyl normalizing condition $r_{0}=0$. Calculating the curvature of this connection and using Lemma 2.4, we get

$$
\Omega=-\frac{1}{2} \omega_{i j} d x^{i} \wedge d x^{j}+R-\delta r+\partial r+(i / h) r^{2} .
$$

The Abelian property will be fulfilled, provided

$$
\delta r=R+\partial r+(i / h) r^{2} \text {. }
$$


Then for the curvature we shall have $\Omega=-\omega$, so that $\Omega$ will really be a scalar form.

Theorem 3.2. Equation (3.3) has a unique solution, satisfying the condition

$$
\delta^{-1} r=0
$$

(Note that (3.4) implies $r_{0}=0$ ).

Proof. Let $r \in W_{3} \otimes \Lambda^{1}$ satisfy (3.3), (3.4). The decomposition (2.8) for the form $r$ becomes $r=\delta^{-1} \delta r$ as $\delta \delta^{-1} r=0$ by (3.4) and $r_{00}=0$, since $r$ is a 1 -form. Applying the operator $\delta^{-1}$ to (3.3) we get

$$
r=\delta^{-1} R+\delta^{-1}\left(\partial r+(i / h) r^{2}\right) \text {. }
$$

The operator $\partial$ preserves the filtration and $\delta^{-1}$ raises it by 1 , so iteration of equation(3.5) shows that it has a unique solution.

Conversely, we will show that the solution of equation (3.5) satisfies (3.3), (3.4). The condition (3.4) is evidently fulfilled because of $\left(\delta^{-1}\right)^{2}=$ 0 . Let

$$
A=\delta r-R-\partial r-(i / h) r^{2}
$$

be the difference between the left-hand and the right-hand sides of (3.3), $r$ being the solution of (3.5). Show that $A$ satisfies the equation

$$
\delta A=\partial A+(i / h)[r, A]
$$

and the "initial" condition

$$
\delta^{-1} A=0 .
$$

From (3.6) and (3.7) it follows that $A$ vanishes. Indeed, applying $\delta^{-1}$ to both sides of equation (3.6) and using (3.7) we shall get similar to (3.5)

$$
A=\delta^{-1}(\partial A+(i / h)[r, A]),
$$

from which by iterations it follows that $A=0$.

For checking (3.7) we have

$$
\delta^{-1} A=\delta^{-1} \delta r-\delta^{-1}\left(R+\partial r+(i / h) r^{2}\right)=\delta^{-1} \delta r-r=0 .
$$

Here we have used (3.5), condition (3.4), and the Hodge-De Rham decomposition.

For checking (3.6) by taking into account that $\delta \delta r=0$, we obtain

$$
\delta A=-\delta R-\delta(\partial r)+[(i / h) r, \delta r],
$$

since

$$
\delta R=\frac{1}{2} R_{i j k l} y^{i} d x^{j} \wedge d x^{k} \wedge d x^{l}
$$


which is equal to 0 because of the relation

$$
R_{i j k l}+R_{i k l j}+R_{i l j k}=0
$$

for the curvature tensor. Further, $\delta(\partial r)=-\partial(\delta r)$ according to Lemma 2.4. Thus,

$$
\delta A=\partial(\delta r)+\left[(i / h) r, R+\partial r+(i / h) r^{2}\right] .
$$

We have $\partial R=0$ according to the Bianchi identity for the curvature tensor, $\partial \partial r=[(i / h) R, r]$ in virtue of Lemma 2.4 (Ricci identity), $\partial(i / h) r^{2}=$ $[\partial r,(i / h) r]$. Taking into account that $\left[(i / h) r,(i / h) r^{2}\right]=0$, we get that the last two terms in (3.8) would equal to 0 , and this proves equality (3.6). q.e.d.

Note that iterating equation (3.5) we can effectively construct the form $r$ and, consequently Abelian connection $D$. The first two terms are

$$
r=\frac{1}{8} R_{i j k l} y^{i} y^{j} y^{k} d x^{l}+\frac{1}{20} \partial_{m} R_{i j k l} y^{i} y^{j} y^{k} y^{m} d x^{l}+\cdots,
$$

$\partial_{m}$ being a covariant derivative with respect to the vector field $\partial / \partial x^{m}$. Further terms would contain not only $y$ 's but also powers of $h$ because of the term $(i / h) r^{2}$ in (3.5).

Introduce now the main object: the subalgebra $W_{D} \subset W$, consisting of flat sections, i.e., such that $D a=0$.

Theorem 3.3. For any $a_{0} \in Z$ there exists a unique section $a \in W_{D}$ such that $\sigma(a)=a_{0}$.

Recall that, for the section $a(x, y, h) \in W, \sigma(a)$ means the projection onto the center, i.e., $\sigma(a)=a(x, 0, h)$.

Proof. The equation $D a=0$ can be written in the form

$$
\delta a=\partial a+[(i / h) r, a] .
$$

Applying the operator $\delta^{-1}$ and using Hodge-De Rham decomposition yield

$$
a=a_{0}+\delta^{-1}(\partial a+[(i / h) r, a]),
$$

wherefrom by iterations we should get that equation (3.10) has a unique solution because $\delta^{-1}$ increases the filtration.

Conversely, let $a$ be the solution of (3.10). Then evidently we have $\sigma(a)=a_{0}$ since the result of applying $\delta^{-1}$ contains only positive powers of $y$ 's. Further, using reasoning similar to the proof of Theorem 3.2, we can show that the difference

$$
A=\delta a-\partial a-[(i / h) r, a] \equiv D a
$$


between the left-hand and the right-hand sides of (3.9) satisfy the equation

$$
\delta A=\partial A+[(i / h) r, A]
$$

and the trivial "initial" condition

$$
\delta^{-1} A=0 .
$$

Equation (3.11) is fulfilled, since it means that $D A=0$, so taking into account that $A=D a$ we shall have $D A=D(D a)=0$ because $D$ is an Abelian connection. Further,

$$
\delta^{-1} A=\delta^{-1} \delta a-\delta^{-1}(\partial a+[(i / h) r, a])=\delta^{-1} \delta a-a+a_{0}
$$

according to equation (3.10). The last expression is equal to 0 by HodgeDe Rham decomposition, since $\delta^{-1} a=0$. q.e.d.

It is easily seen that for any $a(y, h) \in W_{x_{0}}$ with fixed $x_{0} \in M$ there exists a flat section $a(x, y, h) \in W_{D}$ (not unique, of course) such that $a\left(x_{0}, y, h\right)=a(y, h)$. This fact implies that the centralizer of $W_{D}$ in $W$ coincides with the center $Z$ of $W$. In other words, if a section $b \in W$ commutes with any flat section $a \in W_{D}$, then $b \in Z$. Similarly, the centralizer of $W_{D}$ in $W \otimes \Lambda$ is $Z \otimes \Lambda$.

Iterating equation (3.10) we can effectively construct the section $a \in W_{D}$ by its symbol $a_{0}=\sigma(a)$ :

$$
\begin{aligned}
a= & a_{0}+\partial_{i} a_{0} y^{i}+\frac{1}{2} \partial_{i} \partial_{j} a_{0} y^{i} y^{j}+\frac{1}{6} \partial_{i} \partial_{j} \partial_{k} a_{0} y^{i} y^{j} y^{k} \\
& -\frac{1}{24} R_{i j k l} \omega^{l m} \partial_{m} a_{0} y^{i} y^{j} y^{k}+\cdots .
\end{aligned}
$$

If the curvature tensor is equal to 0 , iterations would give the explicit expansion

$$
a=\sum_{k=0}^{\infty} \frac{1}{k !}\left(\partial_{i_{1}} \partial_{i_{2}} \cdots \partial_{i_{k}} a_{0}\right) y^{i_{1}} y^{i_{2}} \cdots y^{i_{k}}
$$

It is clear that, provided Abelian connection $D$ is fixed, flat sections form a subalgebra $W_{D}$ with respect to fiberwise Weyl multiplication $\circ$ in the algebra $W$. Theorem 3.3 states that the map $\sigma: W_{D} \rightarrow Z$ is bijective. Thus, the inverse map $\sigma^{-1}: Z \rightarrow W_{D}$ has been defined.

Now we can explain the construction of *-product in the space $Z$. Namely, by using the bijections $\sigma$ and $\sigma^{-1}$ associative product $\circ$ in the algebra $W$ is transferred to the set $Z$, i.e., we assume for $a, b \in Z$

$$
a * b=\sigma\left(\sigma^{-1}(a) \circ \sigma^{-1}(b)\right) \text {. }
$$

Using (3.13) it is easily checked that such defined $*$-product satisfies all the 
conditions (i)-(iii), formulated in the introduction. However, as will be seen later, it is more convenient to use the subalgebra $W_{D}$ with o-product than the *-product. Therefore later on we shall not mention *-product at all. The subalgebra $W_{D}$ will be called an algebra of quantum observables.

\section{An action of symplectomorphisms}

Let $M, \omega, W, \partial, D, W_{D}$ denote, similar to those in the previous sections, a symplectic manifold, a symplectic form, the Weyl algebras bundle (and the algebra of its sections), a symplectic connection on $M$, the Abelian connection in the bundle $W$ and the subalgebra of flat sections. For a symplectic diffeomorphism $f: M \rightarrow M$ the pullbacks $f^{*}$ of these objects are evidently defined $\left(f^{*} \omega=\omega\right.$ since $f$ is a symplectic map). For example, for a section $a(x, y, h) \in W$ we assume

$$
\left(f^{*} a\right)(x, y, h)=a\left(f(x), f^{\prime} y, h\right),
$$

$f^{\prime}$ being a differential of the map $f$. Since $f$ is a diffeomorphism, both pullbacks $f^{*}$ and pushforwards $f_{*}=\left(f^{-1}\right)^{*}$ are defined for all geometric objects.

Consider in more detail the action of symplectomorphisms $f: M \rightarrow$ $M$ on connections. Let $\partial$ be a symplectic connection considered as the connection in the bundle $W$ according to (2.7), and $D$ be the Abelian connection corresponding to $D$ by Theorem 3.2. Since $f^{*}$ and $f_{*}$ are evidently automorphisms of the algebra $W$, we can define the connections $\tilde{\partial}=f_{*} \partial, \widetilde{D}=f_{*} D$ by the formulas

$$
\tilde{\partial} a=f_{*}\left(\partial\left(f^{*} a\right)\right), \quad \widetilde{D} a=f_{*}\left(D\left(f^{*} a\right)\right) .
$$

It is clear that $\widetilde{D}$ is also an Abelian connection. The operators $\delta, \delta^{-1}$ and Weyl normalizing condition are invariant under diffeomorphisms. (Because of the uniqueness of the solution of (3.3), (3.4), $\widetilde{D}$ corresponds to $\tilde{\partial}$, i.e., $\widetilde{D}$ is obtained from $\tilde{\partial}$ by Theorem 3.2 .

Theorem 4.1. The automorphism $f_{*}: W \rightarrow W$ isomorphically maps the subalgebra $W_{D}$ onto the subalgebra $W_{\widetilde{D}}$. Besides, if the symplectic connection $\partial$ is invariant under $f$, i.e., if $\tilde{\partial} \equiv f_{*} \partial=\partial$, then $f_{*}$ defines the automorphism of the algebra $W_{D}$.

Proof. The proof directly follows from the definitions. If $a \in W_{D}$, then $f_{*} a \in W_{\widetilde{D}}$, since $\widetilde{D} f_{*} a=f_{*}(D a)=0$. Further on, if $\tilde{\partial}=\partial$, the property of the uniqueness of Theorem 3.2 implies that $\widetilde{D}=D, W_{\widetilde{D}}=W_{D}$, i.e., $f_{*}$ is an automorphism of the algebra of quantum observables $W_{D}$. q.e.d. 
In particular, if $G$ is a group of symplectomorphisms of $M$, and $\partial$ is a $G$-invariant symplectic connection, then the corresponding Abelian connection is also $G$-invariant and the group $G$ acts by automorphisms on the algebra of quantum observables $W_{D}$.

In a general case, when $\partial$ is not invariant with respect to $f$, it is nevertheless possible to define automorphism $A_{f}$, corresponding to $f$, by using the fiberwise conjugation automorphisms. To do so introduce an extension $W^{+}$of the algebra $W$ as follows:

(i) Elements $U \in W^{+}$are given by the series (2.1), but the powers of $h$ can be both positive and negative.

(ii) The total degree $2 k+l$ of any term of the series is nonnegative.

(iii) There exists a finite number of terms with a given nonnegative total degree.

It is clear that $W^{+}$is also an algebra with respect to Weyl fiberwise multiplication, and the connections $\partial$ and $D$ act on sections $a \in W^{+}$.

Lemma 4.2. Let $a \in W^{+}$and $D a=0$. Then $a$ does not contain negative powers of $h$, i.e., $a \in W_{D} \subset W \subset W^{+}$.

Proof. Let $\sigma(a)=a(x, 0, h)$. Nonnegativeness of the total degree of series terms implies $\sigma(a) \in Z$, i.e., it does not contain negative powers of $h$. According to Theorem 3.3 a flat section is uniquely defined by its symbol $\sigma(a) \in Z$ and thus belongs to $W_{D}$. q.e.d.

Like $W$ the algebra $W^{+}$has the filtration with respect to the total degree $2 k+l$ of series terms (2.3).

Introduce a group, consisting of invertible elements of the algebra $W^{+}$ with the leading term 1 having the form

$$
U=\exp \left(\frac{i}{h} H\right)=\sum_{k=0}^{\infty}\left(\frac{i}{h}\right)^{k} \frac{1}{k !} \underbrace{H \circ H \circ \cdots \circ H}_{k},
$$

where $H \in W_{3}$. It follows from the Campbell-Hausdorff formula that such elements form a group. It is clear that the map

$$
a \mapsto U \circ a \circ U^{-1}=\sum_{k=0}^{\infty}\left(\frac{i}{h}\right)^{k} \frac{1}{k !}[H,[H, \cdots,[H, a], \cdots]]
$$

(the commutator is taken $k$ times) is an automorphism of $W^{+}$, which maps the algebra $W$ onto itself. It is also clear that this map preserves the filtration but not the degrees of the series terms.

Let $D$ be the Abelian connection in the bundle $W$ of the form (2.11), $\gamma$ satisfying Weyl normalizing condition $\gamma_{0}=0$. Automorphism (4.2) defines a new Abelian connection $\widetilde{D}$ by the rule 


$$
\widetilde{D} a=U \circ D\left(U^{-1} \circ a \circ U\right) \circ U^{-1}=D a-\left[D U \circ U^{-1}, a\right] .
$$

From (4.3) it follows that the form $\tilde{\gamma}$, corresponding to the connection $\widetilde{D}$ and satisfying normalizing condition, has the form

$$
\tilde{\gamma}=\gamma+\Delta \gamma=\gamma-D U \circ U^{-1}+\left(D U \circ U^{-1}\right)_{0} .
$$

Hence for the curvature we shall have

$$
\frac{i}{h} \widetilde{\Omega}=\frac{i}{h} \Omega+D\left(\frac{i}{h} \Delta \gamma\right)+\left(\frac{i}{\Delta} \gamma\right)^{2}=-\frac{i}{h} \omega+d\left(D U \circ U^{-1}\right)_{0} .
$$

The last equality is obtained by using the relation

$$
-D\left(D U \circ U^{-1}\right)+\left(D U \circ U^{-1}\right)^{2}=0 .
$$

The scalar form $\left(D U \circ U^{-1}\right)_{0}$ belongs to $W_{2} \otimes \Lambda^{1} \cap Z$, i.e., begins with the first power of $h$. Thus we obtain that the curvatures of these two connections $D$ and $\tilde{D}$ differ by an exact 2 -form belonging to $\left(W_{2} \otimes \Lambda^{2}\right) \cap$ $Z$.

Theorem 4.3. Let $\partial$, $\tilde{\partial}$ be two symplectic connections, and $D, \widetilde{D}$ be the Abelian connections corresponding to $\partial, \hat{\partial}$ by Theorem 3.2. Then there exists a section $U \in W^{+}$of the form (4.1) such that

$$
\widetilde{D}=D-\left[D U \circ U^{-1}, \cdot\right] \text {. }
$$

Proof. The connection $\widetilde{D}$ can be written in the form

$$
\widetilde{D}=D+[(i / h) \Delta \gamma, \cdot],
$$

where

$$
\Delta \gamma=\widetilde{\Gamma}-\Gamma+\tilde{r}-r \in W_{2} \otimes \Lambda^{1}
$$

satisfies Weyl normalizing condition $(\Delta \gamma)_{0}=0$. Hence for the curvature $(i / h) \widetilde{\Omega}$ of the connection $\widetilde{D}$,

$$
\frac{i}{h} \widetilde{\Omega}=\frac{i}{h} \Omega+\frac{i}{h} D(\Delta y)+\left(\frac{i}{h} \Delta y\right)^{2} .
$$

Since this expression is to be equal to $(i / h) \Omega$, we have

$$
D(\Delta \gamma)+(i / h)(\Delta \gamma)^{2}=0
$$

Find the section $U \in W^{+}$as a solution of the equation

$$
D U \circ U^{-1}=-(i / h) \Delta \gamma,
$$

which is equivalent to 


$$
D U=-(i / h) \Delta \gamma \circ U .
$$

Condition (4.5) is necessary for the solvability of equation (4.6) in $W^{+}$. Indeed, applying operator $D$, we get 0 on the left-hand side, since $D^{2} U=$ 0 . Thus

$$
0=-(i / h) D(\Delta \gamma) \circ U+(i / h) \Delta \gamma \circ D U .
$$

Substituting (4.6) for $D U$ in the above equation, we obtain

$$
0=-\left\{(i / h) D(\Delta \gamma)+((i / h) \Delta \gamma)^{2}\right\} \circ U,
$$

which is fulfilled according to (4.5).

Let us show that condition (4.5) is also sufficient for the solvability of equation (4.6). Rewrite (4.6) in the form

$$
\delta U=(D+\delta) U+(i / h) \Delta \gamma \circ U
$$

and apply the operator $\delta^{-1}$ to both sides of the equation. Taking $U_{0}=1$ and using the Hodge-De Rham decomposition, we get

$$
U=1+\delta^{-1}\{(D+\delta) U+(i / h) \Delta y \circ U\} .
$$

Since the operator $D+\delta=\partial+[(i / h) r, \cdot]$ does not change the filtration, multiplication by $(i / h) \Delta \gamma$ in $W_{0}^{+} \otimes \Lambda^{1}$ does not change the filtration either, and $\delta^{-1}$ raises the filtration by 1 , the iterations of equation (4.7) give a unique solution. The resulting solution is an invertible element of the algebra $W^{+}$, since its leading term is equal to 1 .

Conversely, let us show that the solution of equation (4.7) satisfies (4.6). Let

$$
A=D U+(i / h) \Delta \gamma_{\circ} U
$$

Then

$$
\delta^{-1} A=0
$$

according to (4.7). Further we have

$$
\begin{aligned}
D A & =\frac{i}{h}(D \Delta \gamma) \circ U-\frac{i}{h} \Delta \gamma \circ D U \\
& =\frac{i}{h}\left\{(D \Delta \gamma)+\frac{i}{h}(\Delta \gamma)^{2}\right\} \circ U-\frac{i}{h} \Delta \gamma \circ\left\{D U+\frac{i}{h} \Delta \gamma \circ U\right\},
\end{aligned}
$$

Hence, in consequence of (4.5), $A$ satisfies the equation

$$
D A+(i / h) \Delta y \circ A=0 \text {. }
$$

So, using reasoning similar to Theorem 3.2 , we get $A=0$. Indeed, equation (4.9) together with condition (4.8) gives 


$$
A=\delta^{-1}((D+\delta) A+(i / h) \Delta \gamma \circ A) .
$$

Thus the iterations yield a trivial solution.

The solution of equation (4.6) is not unique. Let $V$ be another solution. Then for $U^{-1} \circ V$ we get

$$
\begin{aligned}
D\left(U^{-1} \circ V\right) & =-U^{-1} \circ D U \circ U^{-1} \circ V+U^{-1} \circ D V \\
& =U^{-1} \circ(i / h) \Delta \gamma \circ V-U^{-1} \circ(i / h) \Delta \gamma \circ V=0 .
\end{aligned}
$$

Consequently, $U^{-1} \circ V=C \in W_{D}$, and the two solutions of equation (4.6) differ by the factor $C$, which is an invertible flat section.

Let us finally show that the solution can always be chosen in the form (4.1) with $H \in W_{3}$. Introduce the section

$$
H=-i h \ln U=-i h \ln (1+(U-1))=-i h \sum_{k=1}^{\infty} \frac{(-1)^{k+1}}{k}(U-1)^{k},
$$

where powers are understood with respect to the multiplication $\circ$. Since $U-1 \in W_{1}$, the series converges with respect to filtration in $W^{+}$and defines the section $H \in W_{3}^{+}$. Multiplying $U$ by the proper factor $C=e^{a}$ to the right $\left(a \in W_{D}\right.$ and the exponent is calculated in the algebra $W_{D}$ ) we can always achieve $H_{0}=0$. Indeed, if $H_{0} \in W_{4} \cap Z$ is not equal to 0 , then by Theorem 3.3, we can construct $a \in W_{D} \cap W_{4}$, such that $\sigma(a)=H_{0}$. Taking in (4.10) $U \circ e^{-a}$ instead of $U$, we get a new section $H$, for which $H_{0} \in W_{6} \cap Z$. Repeating this procedure, we shall get sections $H$ with $H_{0}$ having higher and higher degree so that in the limit we obtain $H$ with $H_{0}=0$. Let us show that this section belongs not only to $W_{3}^{+}$ but also to $W_{3}$ as well. Indeed, derivating the exponent $U=\exp ((i / h) H)$ and substituting into equation (4.6) we obtain

$$
D U \circ U^{-1}=\frac{\exp (\operatorname{ad}((i / h) H))-1}{\operatorname{ad}((i / h) H)} \frac{i}{h} D H=-\frac{i}{h} \Delta \gamma,
$$

where $\operatorname{ad}((i / h) H)=[(i / h) H, \cdot]$. This gives an equation for $H$, which can be written in the form

$$
\delta H=\frac{\operatorname{ad}((i / h) H)}{\exp (\operatorname{ad}((i / h) H))-1} \Delta \gamma+(D+\delta) H .
$$

Applying $\delta^{-1}$ and using $H_{0}=0$, we shall get, according to HodgeDeRham decomposition,

$$
H=\delta^{-1}\left(\frac{\operatorname{ad}((i / h) H)}{\exp (\operatorname{ad}((i / h) H))-1} \Delta \gamma+(D+\delta) H\right) .
$$

Since $\Delta \gamma \in W_{2} \otimes \Lambda^{1}$, all the iterations will give elements of $W_{3}$, so that the section $H$ belongs to $W_{3}$. Hence the theorem has been proved. q.e.d. 
Now if we are given a symplectic diffeomorphism $f: M \rightarrow M$, then an automorphism $A_{f}: W \rightarrow W$, mapping the subalgebra $W_{D}$ onto itself, can be associated with $f$ in the following way.

Let $\partial$ be a symplectic connection on $M$, and $D$ be the Abelian connection in the bundle $W$, corresponding to $\partial$ by Theorem 3.2. Let, further, $\tilde{\partial}=f_{*} \partial$ and $\widetilde{D}=f_{*} D$ be pushforwards of $\partial$ and $D$ under diffeomorphism $f$. Since Weyl curvatures of $D$ and $\widetilde{D}$ both are equal to $-(i / h) \omega$ according to Theorem 3.2 , by Theorem 4.3 there exists the section $U \in W^{+}$of the form (4.1) such that the connection $D$ goes to the connection $D$ under conjugation automorphism (4.2). So automorphism $A_{f}$ defined by the relation

$$
A_{f}: a \mapsto U \circ\left(f_{*} a\right) \circ U^{-1}
$$

maps the sections of $W_{D}$ to the sections belonging to $W_{D}$.

Generally speaking, these automorphisms do not satisfy natural cocycle condition

$$
A_{f_{1}} A_{f_{2}} A_{f_{3}}=\mathrm{id},
$$

if $f_{1} f_{2} f_{3}=\mathrm{id}$. However, we can state that the left-hand side of (4.12) is the conjugation automorphism by the section $U=U_{1} \circ f_{1 *}\left(U_{2} \circ f_{2 *} U_{3}\right) \in$ $W^{+}$of the form (4.1).

Lemma 4.4. Let conjugation automorphism (4.2) map the subalgebra $W_{D}$ onto itself. Then locally there exists a function $\varphi$ such that $U e^{\varphi} \in W_{D}$.

Proof. For any $U \in W_{D}$ we have $A a=U \circ a \circ U^{-1} \in W_{D}$. Then

$$
0=D\left(U \circ a \circ U^{-1}\right)=\left[D U \circ U^{-1}, U \circ a \circ U^{-1}\right]+U \circ D a \circ U^{-1} \text {, }
$$

wherefrom it follows that

$$
\left[D U \circ U^{-1}, U \circ a \circ U^{-1}\right]=0 .
$$

Thus, the form $\psi=D U \circ U^{-1}$ commutes with any section $U \circ a \circ U^{-1} \epsilon$ $W_{D}$, i.e., it is the central form. This form is closed since

$$
d \psi=D\left(D U \circ U^{-1}\right)=\left(D U \circ U^{-1}\right)^{2}=\psi \wedge \psi=0 .
$$

So, locally $\psi=d \varphi$, and

$$
D\left(U e^{-\varphi}\right) e^{\varphi} \circ U^{-1}=D U \circ U^{-1}-d \varphi=0,
$$

which means that the section $U e^{-\varphi}$ is flat in $W^{+}$and then, according to Lemma 4.2, it automatically belongs to $W$. 
Corollary 4.5. Automorphism $A_{f_{1}} A_{f_{2}} A_{f_{3}}$, where $f_{1} f_{2} f_{3}=\mathrm{id}$, locally is an inner automorphism of the algebra $W$.

\section{A trace in the algebra of quantum observables on $\mathbf{R}^{2 n}$}

In this section we shall consider the case $M=\mathbf{R}^{2 n}$ with the standard symplectic structure. The standard symplectic form has constant coefficients, therefore we can take the operator of exterior derivation as a symplectic connection. The Abelian connection $D$ in the bundle $W=$ $W\left(\mathbf{R}^{2 n}\right)$, corresponding to $d$ by Theorem 3.2, has the form $D=-\delta+D$. In this case the isomorphism $\sigma^{-1}$ and the multiplication $*$ have a very simple explicit form

$$
\begin{aligned}
& \sigma^{-1}: a(x, h) \mapsto a(x+y, h)=\sum_{|\alpha|=0}^{\infty} \frac{1}{\alpha !} \partial^{(\alpha)} a(x, h) y^{\alpha}, \\
& a * b=\left.\exp \left(-\frac{i h}{2} \omega^{i j} \frac{\partial}{\partial x^{i}} \frac{\partial}{\partial y^{j}}\right) a(x, h) b(y, h)\right|_{y=x} \\
& =\sum_{k=0}^{\infty}\left(-\frac{i h}{2}\right)^{k} \frac{1}{k !} \omega^{i_{1} j_{1}} \cdots \omega^{i_{k} j_{k}} \frac{\partial^{k} a}{\partial x^{i_{1}} \cdots \partial x^{j_{1}}} \frac{\partial^{k} b}{\partial x^{j_{1}} \cdots \partial x^{j_{k}}} .
\end{aligned}
$$

Definition 5.1. The trace in the algebra $W_{D}\left(\mathbf{R}^{2 n}\right)$ is the linear functional defined on the ideal $W_{D}^{\text {comp }}\left(\mathbf{R}^{2 n}\right)$, consisting of the flat sections with compact support by formula

$$
\operatorname{tr} a=\frac{1}{(2 \pi h)^{n}} \int_{\mathbf{R}^{2 n}} \sigma(a) \frac{\omega^{n}}{n !} .
$$

Thus the trace has values in Laurent formal series in $h$ with negative powers of $h$ not greater than $n$, i.e.,

$$
\operatorname{tr} a=\sum_{k=0}^{\infty} h^{k-n} c_{k} .
$$

Lemma 5.2. The trace has the property

$$
\operatorname{tr} a \circ b=\operatorname{tr} b \circ a,
$$

where $a \in W_{D}^{\text {comp }}\left(\mathbf{R}^{2 n}\right), b \in W\left(\mathbf{R}^{2 n}\right)$.

Proof. Since $\sigma(a \circ b)=\sigma(a) * \sigma(b)$, according to (5.1) it is sufficient to check the equality

$$
\int_{\mathbf{R}^{2 n}} \frac{\partial^{k} a}{\partial x^{i_{1}} \cdots \partial x^{i_{k}}} \frac{\partial^{k} b}{\partial x^{j_{1}} \ldots \partial^{j_{k}}} \omega^{n}=\int_{\mathbf{R}^{2 n}} \frac{\partial^{k} a}{\partial x^{j_{1}} \cdots \partial x^{j_{k}}} \frac{\partial^{k} b}{\partial x^{i_{1}} \ldots \partial x^{i_{k}}} \omega^{n},
$$

which is easily verified by integrating by parts. q.e.d. 
We shall prove that property (5.3) implies the invariance of the trace under isomorphisms $A_{f}$, considered in $\S 4$. For an open contractible set $O \subset \mathbf{R}^{2 n}$ we shall denote the algebra of flat sections with support in $O$ by $W_{D}^{\text {comp }}(O)$. Let $f$ be a symplectic diffeomorphism, defined on $O$ and mapping it onto the open set $f(O)$, and let $A_{f}: W_{D}^{\text {comp }}(O) \rightarrow W_{D}^{\text {comp }}(f(O))$ be an isomorphism corresponding to $f$ by formula (4.11).

Theorem 5.3. For any $a \in W_{D}^{\text {comp }}(O)$,

$$
\operatorname{tr} a=\operatorname{tr}\left(A_{f} a\right) .
$$

Proof. For the proof we construct a family $a(t), t \in[0,1]$, of flat sections with compact support such that $a(0)=a, a(1)=A_{f} a$, satisfying the Heisenberg equation

$$
\dot{a}(t)=(i / h)[H(t), a(t)],
$$

with the Hamiltonian $H(t) \in W_{D}\left(\mathbf{R}^{2 n}\right)$. Then according to (5.3) we have

$$
\frac{d}{d t} \operatorname{tr} a(t)=\frac{i}{h} \operatorname{tr}[H(t), a(t)]=0,
$$

wherefrom it follows that tr $a(t)=$ const .

Lemma 5.4. Let $f_{t}$ be a family of symplectic diffeomorphisms of the open set $O$ and let

$$
A_{t}: W_{D}^{\text {comp }}(O) \rightarrow W_{D}^{\text {comp }}\left(f_{t}(O)\right) \subset W_{D}^{\text {comp }}\left(\mathbf{R}^{2 n}\right)
$$

be the corresponding family of isomorphisms

$$
A_{t} a=U_{t} \circ\left(f_{t *} a\right) \circ U^{-1} \text {. }
$$

Then $a(t)=A_{t} a$ satisfies equation (5.5) with the Hamiltonian $H(t) \in$ $W_{D}\left(\mathbf{R}^{2 n}\right)$.

Proof of the Lemma. We have

$$
\dot{a}(t)=\dot{U}_{t} \circ U_{t}^{-1} \circ a(t)-a(t) \circ \dot{U}_{t} \circ U_{l}^{-1}+U_{t} \circ\left(f_{t *} a\right) \circ U_{t}^{-1} .
$$

Denoting the map, inverse to $f_{t}$ by $g_{t}$, we shall have

$$
\left(f_{t *} a\right)=\frac{d}{d t} a\left(g_{t}(x), \frac{\partial g_{t}(x)}{\partial x^{i}} y^{i}, h\right)=\left(f_{t *} \frac{\partial a}{\partial x^{j}}\right) \dot{g}_{t}^{j}\left(f_{t *} \frac{\partial a}{\partial y^{j}}\right) \frac{\partial \dot{g}_{t}^{j}}{\partial x^{i}} y^{i}
$$

Since the section $a$ is flat, $\partial a / \partial x^{j}=\partial a / \partial y^{j}$, so that the last expression can be written in the form 


$$
\begin{aligned}
f_{t *}\left(\frac{\partial a}{\partial y^{j}}\right)\left(\dot{g}_{t}^{j}+\frac{\partial \dot{g}_{t}^{j}}{\partial x^{i}} y^{i}\right) & =\frac{\partial}{\partial y^{k}}\left(f_{t *} a\right) \frac{\partial f^{k}}{\partial x^{j}}\left(\dot{g}^{j}+\frac{\partial \dot{g}_{t}^{j}}{\partial x^{i}} y^{l}\right) \\
& =\frac{i}{h}\left[f_{t *} a, \omega_{i k} y^{i} \frac{\partial f^{k}}{\partial x^{j}}\left(\dot{g}^{j}+\frac{1}{2} \frac{\partial \dot{g}_{t}^{j}}{\partial x^{l}} y^{l}\right)\right] .
\end{aligned}
$$

Here we have used the fact that for a symplectic map $f$ the expression $\omega_{i j} u^{i}\left(\partial f^{k} / \partial x^{j}\right)\left(\partial \dot{g}_{t}^{j} / \partial x^{l}\right) v^{l}$ is symmetric with respect to $u, v \in \mathbf{R}^{2 n}$. Substituting into (5.7), we get equation (5.5), where $H(t)$ belongs to $W_{1}^{+}$ but is, generally speaking, not a flat section. We will show that it is possible to pick $H(t) \in W_{D}\left(\mathbf{R}^{2 n}\right)$. Applying the operator $D$ to the both sides of (5.5) and taking into account that $D a(t)=0$ we get $(i / h)\left[D H(t), A_{t} a\right]=$ 0 . Being fulfilled for any $a \in W_{D}^{\text {comp }}(O)$, this equation means that $D H(t)$ is a central (i.e., scalar) 1-form $\psi$, which is closed because

$$
d \psi=D \psi=D(D H)=0 .
$$

Hence, $\psi=d \varphi$, where $\varphi_{t}=\varphi_{t}(x, h)$ is a scalar function, which is uniquely defined if subjected to the normalizing condition $\varphi_{t}\left(f_{t}\left(x_{0}\right)\right)=0$, where $x_{0} \in O$ is any fixed point. Replacing $H(t)$ by $H(t)-\varphi_{t}$ we do not change equation (5.5), as $\varphi_{t}$ belongs to the center, and, on the other hand, $D\left(H(t)-\varphi_{t}\right)=0$, i.e., $H(t)=\varphi_{t}$ is a flat section. q.e.d.

Let us proceed to prove the theorem. According to the lemma, it is sufficient to construct a family of symplectic diffeomorphisms $f_{t}$, so that $f_{0}=\mathrm{id}$, and $f_{1}=f$. Besides, we may confine ourselves to a sufficiently small neighborhood $O_{x_{0}}$ of an arbitrary fixed point $x_{0} \in O$. A general case would be obtained by using a partition of unit subordinated to a sufficiently fine covering of a compact set $\operatorname{supp} a$.

The desired deformation $f_{t}$ is constructed in two steps. At the first step, consider the linear part $L_{f}$ of the map $f$ at the point $x_{0}$ given by

$$
L_{f} x=f\left(x_{0}\right)+\frac{\partial f\left(x_{0}\right)}{\partial x^{i}}\left(x^{i}-x_{0}^{i}\right) .
$$

Since the group of linear symplectic transformations is connected, there exists a deformation, connecting the identity map with $L_{f}$. At the second step, consider a nonlinear map $L_{f}^{-1} f(x)$. In a sufficiently small neighborhood of $x_{0}$ it is close to the identity map, so it may be given by a generating function $S(z)$ according to the formulas

$$
x^{i}=z^{i}+\omega^{i j} \frac{\partial S(z)}{\partial z^{j}}, \quad f^{i}(x)=z^{i}-\omega^{i j} \frac{\partial S(z)}{\partial z^{j}} .
$$


From (5.8) we get

$$
z=\frac{x+f(x)}{2}, \quad d S(z)=\frac{1}{2} \omega_{i j}\left(f^{j}(x)-x^{j}\right) d z^{j} .
$$

It is easy to see that the 1 -form on the right-hand side of the second equation of (5.9) is exact. Indeed, its exterior differential is equal to

$$
\begin{aligned}
\omega_{i j}\left(d f^{i}-d x^{i}\right) \wedge\left(d f^{j}+d x^{j}\right)= & \omega_{i j} d f^{i} \wedge d f^{j}-\omega_{i j} d x^{i} \wedge d x^{j} \\
& +\omega_{i j} d f^{i} \wedge d x^{j}-\omega_{i j} d x^{i} \wedge d f^{j} .
\end{aligned}
$$

The first two summands give 0 , since $f$ is a symplectic diffeomorphism. The second two summands also give 0 , because

$$
\omega_{i j} d x^{i} \wedge d f^{j}=-\omega_{i j} d f^{j} \wedge d x^{i}=\omega_{j i} d f^{j} \wedge d x^{i} .
$$

Thus, (5.9) determine the generating function $S(z)$, provided the first equation of (5.9) determines a diffeomorphism $x \mapsto z$, which is just so in a sufficiently small neighborhood $O_{x_{0}}$. Besides, we have $S(z)=0\left(|z|^{3}\right)$. Replacing the function $S(z)$ in $(5.8)$ by the functions $t S(z), t \in[0,1]$, we shall have the desired deformation $f_{t}(x)$ in the sufficiently small neighborhood $O_{x_{0}}$ by formulas (5.8).

Remark. If $f$ is a linear transformation $f^{j}(x)=A_{j}^{i} x^{j}$ with a symplectic matrix $A_{j}^{i}$, formulas (5.8), (5.9) give the Cayley transformation.

\section{A localization and a trace}

In this section we construct a trace in the algebra $W_{D}(M)$ on an arbitrary symplectic manifold $M$. The basic tool is a localization, i.e., a representation of the algebra $W_{D}(M)$ by a compatible family of the algebras of quantum observables in $\mathbf{R}^{2 n}$. We shall denote the standard symplectic form on $\mathbf{R}^{2 n}$ by $\omega_{0}$ and the Abelian connection $-\delta+d$ in $W\left(\mathbf{R}^{2 n}\right)$ by $D_{0}$.

Let $\left\{O_{i}\right\}$ be a locally finite covering of the manifold $M$ by local Darboux charts, $\left\{\rho_{i}(x)\right\}$ be a partition of unity subordinated to this covering, and $\chi_{i}: O_{i} \rightarrow \mathbf{R}^{2 n}$ be coordinate maps. For a given symplectic connection $\partial$ and the corresponding Abelian connection $D$ in the bundle $W=W(M)$ consider the algebra $W_{D}(M)$ of flat sections determined on $M$ and its subalgebra $W_{D}^{\text {comp }}\left(O_{i}\right)$, consisting of flat sections with supports in $O_{i}$. Using the constructions of $\S 4$ we may define isomorphisms

$$
A_{i}: W_{D}^{\text {comp }}\left(O_{i}\right) \rightarrow W_{D_{0}}^{\text {comp }}\left(\chi_{i}\left(O_{i}\right)\right)
$$


of the form (4.11). More precisely, for $a \in W_{D}^{\text {comp }}\left(O_{i}\right)$ we take its pushforward $\chi_{i *} a$, which is a flat section in $W^{\text {comp }}\left(\mathbf{R}^{2 n}\right)$ with respect to the connection $\widetilde{D}_{i}=\chi_{i *} D$, i.e., $\chi_{i *} a \in W_{\widetilde{D}_{i}}^{\text {comp }}\left(\chi_{i}\left(O_{i}\right)\right)$. After that we pass from the connection $\widetilde{D}_{i}$ to the connection $D_{0}$ using the conjugation automorphism. Finally we get

$$
A_{i}: W_{D}^{\text {comp }}\left(O_{i}\right) \ni a \mapsto U_{i} \circ\left(\chi_{i *} a\right) \circ U_{i}^{-1} \in W_{D_{0}}^{\text {comp }}\left(\chi_{i}\left(O_{i}\right)\right) .
$$

We shall call $A_{i}$ coordinate isomorphisms.

For the algebra $W_{D}^{\text {comp }}\left(O_{i} \cap O_{j}\right)$ we have two coordinate isomorphisms $A_{i}$ and $A_{j}$, and thus transition isomorphisms are defined as follows:

$$
A_{i j}=A_{i} A_{j}^{-1}: W_{D_{0}}^{\text {comp }}\left(\chi_{j}\left(O_{i} \cap O_{j}\right)\right) \rightarrow W_{D_{0}}^{\text {comp }}\left(\chi_{i}\left(O_{i} \cap O_{j}\right)\right) \text {. }
$$

From (6.2) it immediately follows that $A_{i j}$ satisfies a cocycle condition

$$
A_{i j} A_{j k} A_{k i}=\mathrm{id}
$$

in the algebra $W_{D_{0}}^{\text {comp }}\left(O_{i} \cap O_{j} \cap O_{k}\right)$.

Using Theorem 3.3 we can construct the flat sections $\hat{\rho}_{i}=\sigma^{-1}\left(\rho_{i}\right) \epsilon$ $W_{D}^{\text {comp }}\left(O_{i}\right)$, which form a partition of unity in the algebra $W_{D}(M)$. Indeed

$$
\sum_{i} \hat{\rho}_{i}=\sum_{i} \sigma^{-1}\left(\rho_{i}\right)=\sigma^{-1}\left(\sum_{i} \rho_{u}\right)=\sigma^{-1}(1)=1 .
$$

So, we obtain a set of flat sections

$$
a_{i}=A_{i}\left(\hat{\rho}_{i} \circ a\right) \in W_{D_{0}}^{\text {comp }}\left(\chi_{i}\left(O_{i}\right)\right) \subset W_{D_{0}}\left(\mathbf{R}^{2 n}\right)
$$

corresponding to the flat section $a \in W_{D}\left(O_{i}\right)$. We shall call this set a local representation of the section $a$, or shorter a localization. It is clear that $a=\sum_{i} A_{i}^{-1} a^{i}$.

Definition 6.1. A trace in the algebra $W_{D}(M)$ is a linear functional defined on an ideal $W_{D}^{\text {comp }}(M)$ with values in Laurent formal series, containing negative powers of $h$ not greater than $n=\frac{1}{2} \operatorname{dim} M$. For any $a \in W_{D}^{\text {comp }}(M)$ and $b \in W_{D}(M)$ the equality

$$
\operatorname{tr} a \circ b=\operatorname{tr} b \circ a
$$

must be fulfilled.

Theorem 6.2. A trace in the algebra $W_{D}(M)$ does exist.

Proof. For a given coordinate covering $\left\{O_{i}\right\}$ and a partition of unity $\left\{\rho_{i}(x)\right\}$ take

$$
\operatorname{tr} a=\sum_{i} \operatorname{tr} a_{i}=\sum_{i} \operatorname{tr} A_{i}\left(\hat{\rho}_{i} \circ a\right)
$$


where $a \in W_{D}(M)$ and the traces $\operatorname{tr} a_{i}$ are given by formula (5.2) in $W_{D_{0}}^{\text {comp }}\left(\mathbf{R}^{2 n}\right)$. We should check the correctness of the definition, i.e., independence of the choice of a covering, a partition of unity, and coordinate isomorphisms $A_{i}$, and then prove property (6.5).

Let us prove the independence of the choice of coordinate isomorphisms. Let $a \in W_{D}^{\text {comp }}(O)$ be a flat section with a support in the coordinate neighborhood $O \subset M, \chi$ and $\chi^{\prime}$ be two coordinate diffeomorphisms $O \rightarrow \mathbf{R}^{2 n}$, and $A$ and $A^{\prime}$ be the corresponding coordinate isomorphisms, mapping $W_{D}^{\text {comp }}(O)$ onto $W_{D_{O}}^{\text {comp }}(\chi(O)), W_{D_{0}}^{\text {comp }}\left(\chi^{\prime}(O)\right)$ respectively. Then the symplectic map $f=\chi^{\prime} \chi^{-1}: \chi(O) \rightarrow \chi^{\prime}(O)$ and the corresponding isomorphism $A_{f}: W_{D_{0}}^{\text {comp }}(\chi(O)) \rightarrow W_{D_{0}}^{\text {comp }}\left(\chi^{\prime}(O)\right)$ are defined. According to Theorem 5.3 we have

$$
\operatorname{tr} A_{f} A a=\operatorname{tr} A a .
$$

Generally speaking, the automorphisms $A_{f} A$ and $A^{\prime}: W_{D}^{\text {comp }}(O) \rightarrow$ $W_{D_{0}}^{\text {comp }}\left(\chi^{\prime}(O)\right)$ do not coincide. However they differ by an inner automorphism of the algebra $W_{D_{0}}^{\text {comp }}\left(\chi^{\prime}(O)\right.$ ) (see Corollary 4.5), i.e., there exists a section $S \in W_{D_{0}}^{\text {comp }}\left(\chi^{\prime}(O)\right)$, such that $A_{f} A a=S \circ\left(A^{\prime} a\right) \circ S^{-1}$. Hence, according to property (5.3) of the trace in the algebra $W_{D_{0}}\left(\mathbf{R}^{2 n}\right)$ we get

$$
\operatorname{tr} A_{f} A a=\operatorname{tr} S \circ\left(A^{\prime} a\right) \circ S^{-1}=\operatorname{tr} A^{\prime} a,
$$

as desired. The independence of a covering and a partition of unity is now proved in a standard way, i.e., by passing to a refined covering $\left\{O_{i} \cap O_{j}\right\}$ and the corresponding partition of unity $\left\{\rho_{i} \rho_{j}\right\}$.

Let us prove the equality (6.5). We have

$$
a \circ b=\sum_{i, j}\left(\hat{\rho}_{i} \circ a\right) \circ\left(\hat{\rho}_{j} \circ b\right) \text {, }
$$

so

$$
\begin{aligned}
\operatorname{tr} a \circ b & =\sum_{i, j} \operatorname{tr} A_{i}\left(\left(\hat{\rho}_{i} \circ a\right) \circ\left(\hat{\rho}_{j} \circ b\right)\right) \\
& =\sum_{i, j} \operatorname{tr} A_{j}\left(\left(\hat{\rho}_{i} \circ a\right) \circ\left(\hat{\rho}_{j} \circ b\right)\right)=\sum_{i, j} \operatorname{tr}\left(A_{j}\left(\hat{\rho}_{i} \circ a\right)\right) \circ\left(A_{j}\left(\hat{\rho}_{j} \circ b\right)\right) \\
& =\sum_{i, j} \operatorname{tr}\left(A_{j}\left(\hat{\rho}_{j} \circ b\right)\right) \circ\left(A_{j}\left(\hat{\rho}_{i} \circ a\right)\right)=\sum_{i, j} \operatorname{tr} A_{j}\left(\left(\hat{\rho}_{j} \circ b\right) \circ\left(\hat{\rho}_{i} \circ a\right)\right) \\
& =\operatorname{tr} b \circ a,
\end{aligned}
$$

which proves the theorem. 


\section{Generalizations}

The above constructions of the deformation quantization and the trace in the algebra of quantum observables allow different generalizations.

Quantization with coefficients in $\operatorname{Hom}(E, E)$. An evident generalization consists in considering matrix coefficients. No change is necessary, except that in the definition of the trace (5.2) a matrix trace under integral sign must be taken. A less evident generalization is obtained if we admit that the coefficients $a_{k, i_{1} \cdots i_{p}, j_{1} \cdots j_{q}}(x)$ of series (2.3), (3.4) take values in a bundle $\operatorname{Hom}(E, E)$, where $E$ is a vector bundle over $M$. Let us consider this case in more detail.

Let $\partial_{s}$ be a symplectic connection on $M$, and $\partial_{E}$ be a connection in the vector bundle $E$. Then $\partial=\partial_{s} \otimes 1+1 \otimes \partial_{E}$ defines the connection in Weyl algebras bundle $W \otimes \operatorname{Hom}(E, E)$; we will denote this bundle by $W$ as before for short. We shall look for Abelian connection $D$ in the bundle $W$ in the same form as in (3.1). The same equation (3.3) is obtained for $r, R$ being now equal to

$$
(h / 2) R_{i j}^{E} d x^{i} \wedge d x^{j}+\frac{1}{4} R_{i j k l}^{s} y^{i} y^{j} d x^{k} \wedge d x^{l},
$$

where the first term is the curvature of $\partial_{E}$, and the second one is the same as in (2.11); the superscript $s$ means "symplectic". Theorems 3.2 and 3.3 are completely valid in this case.

As to the action of symplectic diffeomorphisms, the results of $\S 4$ are also valid with some modifications. Let $f_{s}: M \rightarrow M$ be a symplectic diffeomorphism of $M$, and $f_{s *} E=\left(f_{s}^{-1}\right)^{*} E$ be a pushforward of the bundle $E$ under $f_{s}$, i.e., $\left(f_{s}^{-1}\right)^{*}$ is an induced bundle. Let a fiberwise homomorphism $\varphi:\left(f_{s *} E\right) \rightarrow E$ be given as well. Then the formula

$$
\left(f_{8} a\right)(x)=\varphi a\left(f^{-1}(x)\right) \varphi^{-1}
$$

defines a lifting of the map $f^{s}$ onto a bundle space $\operatorname{Hom}(E, E)$. We define the pushforward of a section $a(x, y, h) \in W \otimes \operatorname{Hom}(E, E)$, by assuming

$$
\left(f_{*} a\right)(x, y, h)=\varphi a\left(f_{s}^{-1}(x),\left(f_{s}^{\prime}\right)^{-1} y, h\right) \varphi^{-1} .
$$

So, if lifting (7.1) is given, the pushforwards and pullbacks of the sections and the connections $\partial$ and $D$ are defined as in $\S 4$.

In the case of coefficients in $\operatorname{Hom}(E, E)$ localization, considered in $\S 6$, is constructed as before with some modifications. More exactly, not only 
a coordinate mapping $\chi_{s}: O \rightarrow \mathbf{R}^{2 n}$ is to be given, but the trivialization of the bundle $E$ as well. The trivialization defines a lifting $\chi$ of $\chi_{s}$, so that sections of $\operatorname{Hom}(E, E)$ over $O$ go to matrix-valued functions on $\chi_{s}(O)$ and allow us to define coordinate isomorphisms

$$
A: W_{D}^{\text {comp }} \rightarrow W_{D_{0}}^{\text {comp }}\left(\chi_{s}(O)\right),
$$

and then a trace can be defined as before by formulas (6.6), (5.2) with the matrix trace under integral sign in (5.2).

Deformation quantization of regular Poisson manifolds. As mentioned in the introduction, a regular Poisson manifold has a symplectic foliation. It means that it is possible to introduce local coordinates (Darboux coordinates)

$$
x^{1}, x^{2}, \cdots, x^{2 n}, x^{2 n+1}, \cdots, x^{m} ; \quad 2 n=\operatorname{rank}\left(t^{i j}\right), m=\operatorname{dim} M,
$$

in which the components of Poisson tensor $t^{i j}$ have the form

$$
t^{i, i+n}=1, \quad t^{i+n, i}=-1 ; \quad i=1,2, \cdots, n,
$$

and the rest of its components are equal to 0 . The leaves $F$ of the foliation are locally defined by equations $x^{k}=$ const, $k=2 n+1, \cdots, m$, and the form $\omega=\sum_{i=1}^{n} d x^{i} \wedge d x^{n+i}$ defines a symplectic structure on the leaves. Thus the regular Poisson manifold can be locally considered as a family of symplectic manifolds depending on parameters $x^{2 n+1}, \cdots, x^{m}$. The quantization construction, given in $\S \S 2,3$, smoothly depends on parameters and is local, so it is evidently valid for the case of regular Poisson manifolds.

More precisely, the construction looks as follows. We consider a tangent bundle $T F$ along the leaves and the exterior algebra $\Lambda_{F}=\Lambda\left(T^{*} F\right)$. A homomorphism $i^{*}: T^{*} M \rightarrow T^{*} F$ is defined, induced by a local embedding of the leaf $i: F \rightarrow M$. In Darboux local coordinates we introduce the natural basis of vector fields $e_{k}=\partial / \partial x^{k} \quad(k=1, \cdots, 2 n)$ tangent to the leaves and the dual basis $\theta=\left(\theta^{1}, \cdots, \theta^{2 n}\right)$ in $T^{*} F$. Instead of series (2.4) we will now consider the series

$$
\begin{aligned}
a & =\sum_{2 k+p \geq 0} h^{k} a_{k, p, q} \\
& =\sum_{2 k+p \geq 0} h^{k} a_{k, i_{1} \cdots i_{p}, j_{1} \cdots j_{q}}(x) y^{i_{1}} \cdots y^{i_{p}} d x^{j_{1}} \wedge \cdots \wedge d x^{j_{q}},
\end{aligned}
$$

where the terms $a_{k, p, q}$ are the sections of $S^{p}(T F) \otimes \Lambda^{q}\left(T^{*} F\right), x \in M$, the range of the indices $i_{k}, j_{k}$ is from 1 to $2 n$. Such series form an 
algebra with respect to the fiberwise multiplication o (the exterior product of $\theta^{j}$ and Weyl product (2.2) for monomials in $y$ 's). The algebra of such series will be denoted by $W \otimes \Lambda_{F}$. The operators $\delta, \delta^{*}, \delta^{-1}$ are introduced similar to (2.5) as follows:

$$
\begin{gathered}
\delta a=\theta^{k} \wedge \frac{\partial a}{\partial y^{k}} ; \quad \delta^{*} a=y^{k} i\left(e_{k}\right) a, \\
\delta^{-1} a_{k, p, q}=\frac{1}{p+q} \delta^{*} a_{k, p, q}, \quad(p+q>0) ; \quad \delta^{-1} a_{k, 0,0}=0,
\end{gathered}
$$

and have the same properties, including Hodge-De Rham decomposition.

We shall also need a Poisson connection along the leaves $\partial: C^{\infty}(T F) \rightarrow$ $C^{\infty}\left(T F \otimes \Lambda_{F}^{1}\right)$. For such a connection, its local restriction on each leaf gives a symplectic connection on the leaf. For the sake of completeness let us give the construction of such a connection.

Let $\nabla$ be an arbitrary connection in the bundle $T F$ over $M$. Let us denote the indices ranging from 1 to $2 n$ by Roman letters and those ranging from 1 to $m$ by Greek letters. In Darboux local coordinates we have

$$
\nabla e^{i}=e^{j} \Gamma_{j \alpha}^{i} d x^{\alpha}
$$

Restricting it to the vectors tangent to the leaves, we get a connection $\nabla_{F}$ along the foliation

$$
\nabla_{F} e^{i}=e^{j} \Gamma_{j k}^{i} \theta^{k}
$$

the Jacobian matrix of the transition diffeomorphism between two Darboux local charts

$$
f_{\beta}^{\alpha}=\partial x^{\alpha} / \partial x^{\beta}
$$

has a triangular form, because

$$
\partial x^{\prime \alpha} / \partial x^{i}=0, \quad \alpha=2 n+1, \cdots, m,
$$

and its upper left block $\left(f_{j}^{i}\right)$ gives a transition function of the bundle $T F$. Hence, a skew-symmetric part of the connection coefficients defines a tensor $\Gamma_{\{j k\}}^{i}$ in the bundle $T F$ (a torsion tensor), since $\partial f_{j}^{i} / \partial x^{k}=$ $\partial^{2} f^{i} / \partial x^{j} \partial x^{k}$ are symmetric with respect to $j, k$. Thus, symmetrizing the coefficients $\Gamma_{j k}^{i}$ in (7.5), we get a new torsion-free connection $\widetilde{\nabla}_{F}$ along the foliation.

Finally we find a tensor $\Delta \Gamma_{j k}^{i}$, which is symmetric in lower indices and such that the connection $\partial=\widetilde{\nabla}_{F}+\Gamma_{j k}^{i} \theta^{k}$ preserves the tensor $\omega_{i j}$ inverse to $t^{i j}$. We have

$$
\partial_{k} \omega_{i j}=\left(\widetilde{\nabla}_{F}\right)_{k} \omega_{i j}-\Delta \Gamma_{i k}^{p} \omega_{p j}-\Delta \Gamma_{j k}^{p} \omega_{i p}=0
$$


wherefrom we obtain the equations

$$
\Delta \Gamma_{i j k}-\Delta \Gamma_{j i k}=\left(\tilde{\nabla}_{F}\right)_{k} \omega_{i j}
$$

for $\Delta \Gamma_{i j k}=\omega_{i p} \Delta \Gamma_{j k}^{p}$. In Darboux local coordinates

$$
\left(\tilde{\nabla}_{F}\right)_{k} \omega_{i j}=\tilde{\Gamma}_{i k}^{p} \omega_{p j}+\widetilde{\Gamma}_{j k}^{p} \omega_{i p}=\widetilde{\Gamma}_{i j k}-\widetilde{\Gamma}_{j i k},
$$

$\tilde{\Gamma}_{j k}^{i}$ being the coefficients of $\tilde{\nabla}_{F}$. A partial solution of system (7.6) is given by

$$
\Delta \Gamma_{i j k}=\frac{1}{3}\left(2 \widetilde{\Gamma}_{i j k}-\widetilde{\Gamma}_{j k i}-\widetilde{\Gamma}_{k i j}\right),
$$

(the general solution is obtained by adding to (7.7) any completely symmetric 3-tensor).

Thus, we obtain the connection $\partial$ along the leaves in the bundle $T F$ such that its restriction to any leaf gives a symplectic connection on the leaf. According to (7.7) it smoothly depends on the coordinates $x^{2 n+1}, \ldots$, $x^{m}$, which are parameters, defining the leaf. Theorems 3.2 and 3.3 give a smooth dependence on these parameters and thus define quantization for regular Poisson manifolds.

As for the results of $\S \S 4,5,6$ it is not quite clear whether a reasonable generalization of these results for regular Poisson manifolds could be made.

\section{References}

[1] F. Bayen, M. Flato, C. Fronsdal, A. Lichnerovicz \& D. Sternheimer, Deformation theory and quantization, Ann. Phys. 111 (1978) 61-151.

[2] M. De Wilde \& P. B. A. Lecomte, Existence of star-product and of formal deformations in Poisson Lie algebra of arbitrary symplectic manifold, Lett. Math. Phys. 7 (1983) 487-496.

[3] B. Fedosov, Formal quantization, Some Topics of Modern Math. and Their Appl. to Problems of Math. Phys., Moscow, 1985, pp. 129-136.

[4] __, Quantization and index, Dokl. Akad. Nauk. SSSR 291 (1986) 82-86, English transl. in Soviet Phys. Dokl. 31 (1986) 877-878.

[5] __ An index theorem in the algebra of quantum observables, Dokl. Akad. Nauk SSSR 305 (1989) 835-839, English transl. in Soviet Phys. Dokl. 34 (1989) 318-321.

[6] A. Masmoudi, Ph.D. Thesis, Univ. de Metz (1992).

[7] D. Mélotte, Invariant deformations of the Poisson Lie algebra of a symplectic manifold and star-products, Deformation Theory of Algebras and Structures and Applications, Ser. C: Math. and Phys. Sci., Vol. 247, Kluwer Acad. Publ., Dordrecht, 1988, 961-972.

[8] H. Omori, Y. Macda \& A. Yoshioka, Weyl manifolds and deformation quantization, Advances in Math. (China) 85 (1991) 224-255. 
PHYSICAL REVIEW D, VOLUME 58, 025002

\title{
Features of time-independent Wigner functions
}

\author{
Thomas Curtright* \\ Department of Physics, University of Miami, Box 248046, Coral Gables, Florida 33124
}

David Fairlie ${ }^{\dagger}$

Department of Mathematical Sciences, University of Durham, Durham, DHI 3LE, United Kingdom

Cosmas Zachos ${ }^{\ddagger}$

High Energy Physics Division, Argonne National Laboratory, Argonne, Illinois 60439-4815

(Received 26 November 1997; published 8 June 1998)

\begin{abstract}
The Wigner phase-space distribution function provides the basis for Moyal's deformation quantization alternative to the more conventional Hilbert space and path integral quantizations. The general features of time-independent Wigner functions are explored here, including the functional ("star") eigenvalue equations they satisfy; their projective orthogonality spectral properties; their Darboux ("supersymmetric") isospectral potential recursions; and their canonical transformations. These features are illustrated explicitly through simple solvable potentials: the harmonic oscillator, the linear potential, the Pöschl-Teller potential, and the Liouville potential. [S0556-2821(98)00714-0]
\end{abstract}

PACS number(s): 11.15.Tk, 03.65.Db, 04.20.Fy, 05.30.-d

\section{INTRODUCTION}

Wigner functions have been receiving increasing attention in quantum optics, dynamical systems, and the algebraic structures of $M$ theory [1]. They were invented by Wigner and Szilard [2], and serve as a phase-space distribution alternative to the density matrix, to whose matrix elements they are related by Fourier transformation. The diagonal, hence, real, time-independent pure-state Wigner function $f(x, p)$ corresponding to the eigenfunction $\psi$ of $\mathbf{H} \psi=E \psi$, is

$$
f(x, p)=\frac{1}{2 \pi} \int d y \psi^{*}\left(x-\frac{\hbar}{2} y\right) e^{-i y p} \psi\left(x+\frac{\hbar}{2} y\right)
$$

These functions are not quite probability distribution functions, as they are not necessarily positive-this is illustrated below. However, upon integration over $p$ or $x$, they yield bona fide positive probability distributions, in $x$ or $p$, respectively.

Wigner functions underlie Moyal's formulation of quantum mechanics [3], through the unique $[4,5]$ one-parameter $(\hbar)$ associative deformation of the Poisson-brackets structure of classical mechanics. Expectation values can be computed on the basis of phase-space $c$-number functions: given an operator $\mathbf{A}(\mathbf{x}, \mathbf{p})$, the corresponding phase-space function $A(x, p)$ obtained by $\mathbf{p} \mapsto p, \mathbf{x} \mapsto x$ yields that operator's expectation value through

$$
\langle\mathbf{A}\rangle=\int d x d p f(x, p) A(x, p)
$$

*Electronic address: curtright@phyvax.ir.Miami.edu ${ }^{\dagger}$ Electronic address: David.Fairlie@durham.ac.uk ‡Electronic address: zachos@hep.anl.gov assuming the usual normalization $\int d x d p f(x, p)=1$ and further assuming Weyl ordering, as addressed by Moyal, who took matrix elements of all such operators:

$$
\begin{aligned}
\mathbf{A}(\mathbf{x}, \mathbf{p})= & \frac{1}{(2 \pi)^{2}} \int d \tau d \sigma d x d p A(x, p) \\
& \times \exp [i \tau(\mathbf{p}-p)+i \sigma(\mathbf{x}-x)]
\end{aligned}
$$

Wigner functions are $c$ numbers, but they compose with each other nonlocally. The properties of these compositions were explored in, e.g., $[6,7]$, and were codified in an elegant system in [5]: to parallel operator multiplication, the Wigner functions compose with each other through the associative star product

$$
\star \equiv e^{(i \hbar / 2)\left(\dot{\partial}_{x} \vec{\partial}_{p}-\dot{\partial}_{p} \vec{\partial}_{x}\right)}
$$

Recalling the action of a translation operator $\exp \left(a \partial_{x}\right) h(x)$ $=h(x+a)$, it is evident that the $\star$ product induces simple "Bopp"' shifts:

$$
\begin{aligned}
f(x, p) \star g(x, p) & =f\left(x, p-\frac{i \hbar}{2} \vec{\partial}_{x}\right) g\left(x, p+\frac{i \hbar}{2} \dot{\partial}_{x}\right) \\
& =f\left(x+\frac{i \hbar}{2} \vec{\partial}_{p}, p-\frac{i \hbar}{2} \vec{\partial}_{x}\right) g(x, p),
\end{aligned}
$$

etc., where $\bar{\partial}$ and $\vec{\partial}$ here act on the arguments of $f$ and $g$, respectively. This intricate convolution samples the Wigner function over the entire phase space, and thus provides an alternative to operator multiplication in Hilbert space.

Antisymmetrizing and symmetrizing the star product, yields the Moyal (sine) brackets [3]

$$
\{\{f, g\}\} \equiv \frac{f \star g-g \star f}{2 i}
$$


and Baker's [6] cosine brackets

$$
((f, g)) \equiv \frac{f \star g+g \star f}{2},
$$

respectively. Note $[7,8]$ that

$$
\int d p d x f \star g=\int d p d x f g .
$$

Further note the Wigner distribution has a $\star$-factorizable integrand:

$$
f(x,-2 p)=\frac{1}{2 \pi} \int d y\left[\psi^{*}(x) e^{i y p}\right] \star\left[\psi(x) e^{i y p}\right] .
$$

In general, a systematic specification of time-dependent Wigner functions is predicated on the eigenvalue spectrum of the time-independent problem. For pure-state static distributions, Wigner and, more explicitly, Moyal showed that

$$
\{\{H(x, p), f(x, p)\}\}=0 ;
$$

i.e., $H$ and $f \star$ commute. However, there is a more powerful functional equation, the "star-genvalue" equation, which holds for the time-independent pure-state Wigner functions (lemma 1), and amounts to a complete characterization of them (lemma 2).

We will explore the features of this $\star$-genvalue equation, and illustrate its utility on a number of solvable potentials, including both the harmonic oscillator and the linear one. The $\star$ multiplications of Wigner functions will be seen to parallel Hilbert-space operations in marked detail. The Pöschl-Teller potential will reveal how the hierarchy of factorizable Hamiltonians familiar from supersymmetric quantum mechanics finds its full analogue in $\star$ space. We determine the Wigner function's transformation properties under (phase-space volume-preserving) canonical transformations, which we finally elaborate in the context of the Liouville potential.

\section{II. *-GENVALUE EQUATION}

Lemma 1. Static, pure-state Wigner functions obey the $\star$-genvalue equation

$$
H(x, p) \star f(x, p)=E f(x, p) .
$$

Without essential loss of generality, consider $H(x, p)$ $=p^{2} / 2 m+V(x)$,

$$
\begin{aligned}
H(x, p) \star f(x, p) & =\frac{1}{2 \pi}\left[\left(p-i \frac{\hbar}{2} \vec{\partial}_{x}\right)^{2} / 2 m+V(x)\right] \int d y e^{-i y\left[p+i(\hbar / 2) \dot{\partial}_{x}\right]} \psi^{*}\left(x-\frac{\hbar}{2} y\right) \psi\left(x+\frac{\hbar}{2} y\right) \\
& =\frac{1}{2 \pi} \int d y\left[\left(p-i \frac{\hbar}{2} \vec{\partial}_{x}\right)^{2} / 2 m+V\left(x+\frac{\hbar}{2} y\right)\right] e^{-i y p} \psi^{*}\left(x-\frac{\hbar}{2} y\right) \psi\left(x+\frac{\hbar}{2} y\right) \\
& =\frac{1}{2 \pi} \int d y e^{-i y p}\left[\left(i \vec{\partial}_{y}+i \frac{\hbar}{2} \vec{\partial}_{x}\right)^{2} / 2 m+V\left(x+\frac{\hbar}{2} y\right)\right] \psi^{*}\left(x-\frac{\hbar}{2} y\right) \psi\left(x+\frac{\hbar}{2} y\right) \\
& =\frac{1}{2 \pi} \int d y e^{-i y p} \psi^{*}\left(x-\frac{\hbar}{2} y\right) E \psi\left(x+\frac{\hbar}{2} y\right)=E f(x, p),
\end{aligned}
$$

since the action of the effective differential operators on $\psi^{*}$ turns out to be null, and, likewise,

$$
\begin{aligned}
f \star H & =\frac{1}{2 \pi} \int d y e^{-i y p}\left[-\left(\vec{\partial}_{y}-\frac{\hbar}{2} \vec{\partial}_{x}\right)^{2} / 2 m+V\left(x-\frac{\hbar}{2} y\right)\right] \psi^{*}\left(x-\frac{\hbar}{2} y\right) \psi\left(x+\frac{\hbar}{2} y\right) \\
& =E f(x, p) .
\end{aligned}
$$

Thus, both of the above relations (10) and lemma 1 obtain.

This time-independent equation was introduced in Ref. [7], such that the expectation of the energy $H(x, p)$ in a pure state time-independent Wigner function $f(x, p)$ is given by

$$
\int H(x, p) f(x, p) d x d p=E \int f(x, p) d x d p
$$

On account of the integration property of the star product, Eq. (8), the left-hand side of this amounts to $\int d x d p H(x, p) \star f(x, p)$. Implicitly, this equation could have been inferred from the Bloch equation of the temperatureand time-dependent Wigner function, in the early work of [9]. $\star$-genvalue equations are discussed in some depth in the second reference of Ref. [5] and in [10].

By virtue of this equation, Fairlie also derived the general $\star$-orthogonality and spectral projection properties of static Wigner functions [7]. His results were later formalized in the spectral theory of the second of Ref. [5] [e.g., Eq. (4.4)]. Consider $g$ corresponding to the (normalized) eigenfunction $\psi_{g}$ corresponding to energy $E_{g}$. By lemma 1 and the associativity of the $\star$ product, 


$$
f \star H \star g=E_{f} f \star g=E_{g} f \star g .
$$

Then, if $E_{g} \neq E_{f}$, this is only satisfied by

$$
f \star g=0 .
$$

N.B. The integrated version is familiar from Wigner's paper,

$$
\int d x d p f \star g=\int d x d p f g=0
$$

and demonstrates that all overlapping Wigner functions cannot be everywhere positive. The unintegrated relation intro- duced by Fairlie appears local, but is, of course, highly nonlocal, by virtue of the convolving action of the $\star$ product.

Precluding degeneracy, for $f=g$,

$$
f \star H \star f=E_{f} f \star f=H \star f \star f,
$$

which leads, by virtue of associativity, to the normalization relation $[6]$

$$
f \star f \propto f .
$$

Both relations (16) and (19) can be checked directly:

$$
\begin{aligned}
f(x, p) \star g(x, p)= & f\left(x, p-\frac{i \hbar}{2} \vec{\partial}_{x}\right) g\left(x, p+\frac{i \hbar}{2} \dot{\partial}_{x}\right) \\
= & \left.\frac{1}{(2 \pi)^{2}} \int d y \psi_{f}^{*}\left(x-\frac{\hbar}{2} y\right) \psi_{f}\left(x+\frac{\hbar}{2} y\right) e^{-i y\left[p-(i \hbar / 2) \dot{\partial}_{x}\right]}\right) d Y e^{-i Y\left[p+(i \hbar / 2) \dot{\partial}_{x}\right]} \psi_{g}^{*}\left(x-\frac{\hbar}{2} Y\right) \psi_{g}\left(x+\frac{\hbar}{2} Y\right) \\
= & \frac{1}{(2 \pi)^{2}} \int d y d Y e^{-i(y+Y) p} \psi_{f}^{*}\left(x-\frac{\hbar}{2} y+\frac{\hbar}{2} Y\right) \psi_{f}\left(x+\frac{\hbar}{2} y+\frac{\hbar}{2} Y\right) \psi_{g}^{*}\left(x-\frac{\hbar}{2} Y-\frac{\hbar}{2} y\right) \psi_{g}\left(x+\frac{\hbar}{2} Y-\frac{\hbar}{2} y\right) \\
= & {\left[\frac{1}{2 \pi} \int d(Y+y) e^{-i(y+Y) p} \psi_{g}^{*}\left(x-\frac{\hbar}{2}(Y+y)\right) \psi_{f}\left(x+\frac{\hbar}{2}(y+Y)\right)\right] } \\
& \times\left[\frac{1}{h} \int d\left(\frac{\hbar(Y-y)}{2}\right) \psi_{f}^{*}\left(\frac{\hbar}{2}(Y-y)\right) \psi_{g}\left(\frac{\hbar}{2}(Y-y)\right)\right]
\end{aligned}
$$

The second integral factor is 0 or $1 / h$, depending on $f \neq g$ or $f=g$, respectively, specifying the normalization $f * f=f / h$ in Eq. (19). In conclusion,

Corollary 1. $f_{a} \star f_{b}=1 / h \delta_{a, b} f_{a}$.

These spectral properties are summoned up by their own necessity; much of their meaning, nevertheless, resides in their margins: For nonnormalizable wave functions, the above second integral factor may diverge, as illustrated below for the linear potential, but the orthogonality properties still hold.

Thus, e.g., for an arbitrary function(al) $F(z)$,

$$
F[f \star] f=F(1 / h) f,
$$

and, for $\star$ genfunctions of lemma 1 ,

$$
F[H \star] f=F(E) f .
$$

Baker's converse construction extends to a full converse of lemma 1, namely, the following lemma.

Lemma 2. Real solutions of $H(x, p) \star f(x, p)=E f(x, p)$ $[=f(x, p) \star H(x, p)]$ must be of the Wigner form, $f=\int d y e^{-i y p} \psi^{*}[x-(\hbar / 2) y] \psi[x+(\hbar / 2) y] / 2 \pi$, such that $\mathbf{H} \psi=E \psi$.

As seen above, the pair of $\star$-eigenvalue equations dictate, for $f(x, p)=\int d y e^{-i y p} \widetilde{f}(x, y)$,

$$
\begin{array}{r}
\int d y e^{-i y p}\left[-\frac{1}{2 m}\left(\vec{\partial}_{y} \pm \frac{\hbar}{2} \vec{\partial}_{x}\right)^{2}\right. \\
\left.+V\left(x \pm \frac{\hbar}{2} y\right)-E\right] \tilde{f}(x, y)=0 .
\end{array}
$$

This constrains $\tilde{f}(x, y)$ to consist of bilinears $\psi^{*}[x$ $-(\hbar / 2) y] \psi[x+(\hbar / 2) y]$ of unnormalized eigenfunctions $\psi(x)$ corresponding to the same eigenvalue $E$ in the Schrödinger equation with potential $V$.

These two lemmata then amount to the statement that, for real functions $f(x, p)$, the Wigner form is equivalent to compliance with the $\star$-genvalue equation (real and imaginary part).

\section{EXAMPLE: THE SIMPLE HARMONIC OSCILLATOR}

The eigenvalue equation of lemma 1 may be solved directly to produce the Wigner functions for specific potentials, without first solving the corresponding Schrödinger problem (as in, e.g., [11]). Following [7], for the harmonic oscillator, $H=\left(p^{2}+x^{2}\right) / 2$ (with $\hbar=1, m=1$ ), the resulting equation is

$$
\left[\left(x+\frac{i}{2} \partial_{p}\right)^{2}+\left(p-\frac{i}{2} \partial_{x}\right)^{2}-2 E\right] f(x, p)=0
$$


By virtue of its imaginary part $\left(x \partial_{p}-p \partial_{x}\right) f=0, f$ is seen to depend on only one variable, $z=4 H=2\left(x^{2}+p^{2}\right)$, and so the equation reduces to a simple ordinary differential equation;

$$
\left(\frac{z}{4}-z \partial_{z}^{2}-\partial_{z}-E\right) f(z)=0
$$

Moreover, setting $f(z)=\exp (-z / 2) L(z)$, this yields

$$
\left(z \partial_{z}^{2}+(1-z) \partial_{z}+E-\frac{1}{2}\right) L(z)=0
$$

which is the equation satisfied by Laguerre polynomials $L_{n}$ $=e^{z} \partial^{n}\left(e^{-z} z^{n}\right)$, for $n=E-1 / 2=0,1,2, \ldots$, so that the unnormalized Wigner eigenfunctions are

$$
\begin{aligned}
f_{n}= & e^{-2 H} L_{n}(4 H), \\
& L_{0}=1, \quad L_{1}=1-4 H, \quad L_{2}=16 H^{2}-16 H+2, \ldots .
\end{aligned}
$$

Note that the eigenfunctions are not positive definite, and are the only ones satisfying the boundary conditions, $f(0)$ finite and $f(z) \rightarrow 0$, as $z \rightarrow \infty$.

In fact, Dirac's Hamiltonian factorization method for algebraic solution carries through (cf. [5]) intact in $\star$ space. Indeed,

$$
H=\frac{1}{2}(x-i p) \star(x+i p)+\frac{1}{2},
$$

motivating the definition of

$$
a \equiv \frac{1}{\sqrt{2}}(x+i p), \quad a^{\dagger} \equiv \frac{1}{\sqrt{2}}(x-i p) .
$$

Thus, noting that

$$
a \star a^{\dagger}-a^{\dagger} \star a=1
$$

and also that, by the above,

$$
a \star f_{0}=\frac{1}{\sqrt{2}}(x+i p) \star e^{-\left(x^{2}+p^{2}\right)}=0
$$

provides a $\star$-Fock vacuum, it is evident that associativity of the $\star$ product permits the entire ladder spectrum generation to go through as usual. The $\star$ genstates of the Hamiltonian, such that $H \star f=f \star H$, are thus

$$
f_{n} \propto\left(a^{\dagger} \star\right)^{n} f_{0}(\star a)^{n} .
$$

These states are real, like the Gaussian ground state, and are thus left-right symmetric $\star$ genstates. They are also transparently $\star$ orthogonal for different eigenvalues, and they project to themselves, as they should, since the Gaussian ground state does, $f_{0} \star f_{0} \propto f_{0}$. It will be seen below that even the generalization of this factorization method for isospectral potential pairs goes through without difficulty.

\section{FURTHER EXAMPLE: THE LINEAR POTENTIAL}

For simplicity, take $m=1 / 2, \hbar=1$. Recall [12] that the problem readily reduces to a free particle: $H(x, p)=p^{2}$ $+x \mapsto H_{\text {free }}=P$ is accomplished by canonically transforming through the generating function $F(x, X)=-\frac{1}{3} X^{3}-x X$. The energy eigenfunctions are Airy functions,

$$
\psi_{E}(x)=\frac{1}{2 \pi} \int_{-\infty}^{+\infty} d X e^{i F(x, X)} e^{i E X}=\operatorname{Ai}(x-E) .
$$

The $\star$-genvalue equation in this case is

$$
\left[\left(x+\frac{i}{2} \partial_{p}\right)+\left(p-\frac{i}{2} \partial_{x}\right)^{2}-E\right] f(x, p)=0
$$

whose imaginary part $\left(\frac{1}{2} \partial_{p}-p \partial_{x}\right) f(x, p)=0$ gives $f(x, p)$ $=f\left(x+p^{2}\right)=f(H)$. The real part of the equation is then an ordinary second-order equation, just as in the above harmonic oscillator case. Moreover, here the real part of the *-genvalue equation is essentially the same as the usual energy eigenvalue equation:

$$
\left(z-\frac{1}{4} \partial_{z}^{2}-E\right) f(z)=0
$$

where $z=x+p^{2}$. Hence, the Wigner function is again an Airy function, like the above wave functions, except that the argument has a different scale and shift: ${ }^{1}$

$$
\begin{aligned}
f(x, p) & =\frac{2^{2 / 3}}{2 \pi} \operatorname{Ai}\left(2^{2 / 3}(z-E)\right)=\frac{2^{2 / 3}}{2 \pi} \operatorname{Ai}\left(2^{2 / 3}\left(x+p^{2}-E\right)\right) \\
& =\frac{1}{(2 \pi)^{2}} \int d y e^{i y\left(E-x-p^{2}-y^{2} / 12\right)}
\end{aligned}
$$

The Airy functions are not square integrable, so that the conventional normalization $f \star f=(1 / 2 \pi) f$ does not strictly apply. On the other hand, the energy eigenfunctions are nondegenerate, and the general corollary 1 projection relations $f_{a} \star f_{b} \propto \delta_{a, b} f_{a}$ still hold for the continuous spectrum:

\footnotetext{
'This case is similar to the Gaussian wave function, i.e., the harmonic oscillator ground state encountered above, whose Wigner function is also a Gaussian, but of different width. S. Habib kindly informed us that this solution is also given in Ref. [13], Eq. (29).
} 


$$
\begin{aligned}
f_{E 1} \star f_{E 2} & =f_{E 1}\left[\left(x+\frac{i}{2} \vec{\partial}_{p}\right)+p^{2}\right] f_{E 2}\left[\left(x-\frac{i}{2} \dot{\partial}_{p}\right)+p^{2}\right]=\frac{1}{(2 \pi)^{4}} \int d y d Y e^{i y\left[E 1-x-(p-Y / 2)^{2}-y^{2} / 12\right]} e^{i Y\left[E 2-x-(p+y / 2)^{2}-Y^{2} / 12\right]} \\
& =\frac{1}{(2 \pi)^{4}} \int d(y+Y) e^{i(y+Y)\left[(E 1+E 2) / 2-x-p^{2}-(y+Y)^{2} / 12\right]} \int d \frac{(y-Y)}{2} e^{i[(y-Y) / 2](E 1-E 2)} \\
& =\frac{1}{(2 \pi)} \delta(E 1-E 2) f_{(E 1+E 2) / 2}\left(x+p^{2}\right)
\end{aligned}
$$

by virtue of the direct definition (36).

\section{DARBOUX CONSTRUCTION OF WIGNER FUNCTION RECURSIONS}

Analogous ladder operators for eigenstates corresponding to "essentially isospectral" pairs of partner potentials [14] [familiar from supersymmetric quantum mechanics (SSQM)] can also be defined mutatis mutandis for Wigner functions and $\star$ products. They faithfully parallel the differential equation structures.

Consider a positive semidefinite Hamiltonian

$$
H=p^{2} / 2 m+V(x) \text {. }
$$

This can be written as a $\star$ product of two operators,

$$
H=Q^{*} \star Q=\left(\frac{p}{\sqrt{2 m}}+i W(x)\right) \star\left(\frac{p}{\sqrt{2 m}}-i W(x)\right)
$$

provided

$$
W^{2}-\frac{\hbar}{\sqrt{2 m}} \partial_{x} W=V(x)
$$

This Riccati equation, familiar from SSQM, can be Darboux transformed by changing variable for the "superpotential" $W(x)$,

$$
W=-\frac{\hbar \partial_{x} \psi_{0}}{\sqrt{2 m} \psi_{0}}
$$

which reduces the condition to the Schrödinger equation for a zero eigenvalue:

$$
-\frac{\hbar^{2}}{2 m} \partial_{x}^{2} \psi_{0}+V(x) \psi_{0}=0
$$

Also note $Q \star f_{0}=0$ for the corresponding Wigner function. It is easy to generalize this by adding a constant to $H$ to shift the ground state eigenvalue from zero.

By virtue of associativity, it is evident that the partner Hamiltonian

$$
H^{\prime}=Q \star Q^{*}=H+\frac{2 \hbar}{\sqrt{2 m}} \partial_{x} W
$$

i.e., the one with a partner potential

$$
V^{\prime}=W^{2}+\frac{\hbar}{\sqrt{2 m}} \partial_{x} W
$$

has Wigner function $\star$ genstates of the same energy as those of $H$. Specifically,

$$
H \star f=Q^{*} \star Q \star f=f \star Q^{*} \star Q=E f
$$

implies that the real functions $Q \star f \star Q^{*}$ are $\star$ genfunctions of $H^{\prime}$ with the same eigenvalue $E$,

$$
H^{\prime} \star\left(Q \star f \star Q^{*}\right)=Q \star Q^{*} \star Q \star f \star Q^{*}=E\left(Q \star f \star Q^{*}\right),
$$

unless $f$ is the Wigner function corresponding to $\psi_{0}$, since $Q \star f_{0}=0$.

In consequence, $E_{n}^{\prime}=E_{n+1}$ for $n \geqslant 0$. Conversely, for $g \star$ genfunctions of $H^{\prime}, Q^{*} \star g \star Q$ are $\star$ genfunctions of $H$ with the same eigenvalues.

Moreover, $\psi_{0}^{\prime} \equiv 1 / \psi_{0}$ will be an invalid zero mode eigenfunction of $\mathbf{H}^{\prime}$, as seen from the sign flip in Eqs. (41) and (44). Consequently, an unnormalized, runaway zero-energy solution of the Schrödinger equation with $V^{\prime}(x)$ will invert to the legitimate ground state of $\mathbf{H}$ and will permit construction of $V$ given $V^{\prime}$

For example, starting from the trivial potential with a continuous (unnormalizable) spectrum,

$$
V^{\prime}=1
$$

and the solution

$$
\psi_{0}^{\prime}=\cosh \left(\frac{\sqrt{2 m} x}{\hbar}\right), \quad \Rightarrow W=\tanh \left(\frac{\sqrt{2 m} x}{\hbar}\right),
$$

results via Eq. (40) in the symmetric, reflectionless PöschlTeller potential $[15], \quad V=1-2 / \cosh ^{2}[(\sqrt{2 m} x / \hbar)]$. Conversely, starting from this potential,

$$
V(x)=1-\frac{2}{\cosh ^{2}\left(\frac{\sqrt{2 m x}}{\hbar}\right)},
$$

there is a single bound state (normalizable to $\int \psi_{0}^{2}=2$ ), 


$$
\psi_{0}=\operatorname{sech}\left(\frac{\sqrt{2 m} x}{\hbar}\right), \quad \Rightarrow W=\tanh \left(\frac{\sqrt{2 m} x}{\hbar}\right)
$$

so that

$$
V^{\prime}=1
$$

Thus, the Wigner function ground state (for $m=1 / 2$ ) is

$$
\begin{aligned}
f_{0}(x, p) & =\frac{1}{2 \pi} \int d y \frac{e^{-i y p}}{2 \cosh (x / \hbar-y / 2) \cosh (x / \hbar+y / 2)} \\
& =\frac{1}{\pi} \int_{0}^{\infty} d y \frac{\cos (y p)}{\cosh (2 x / \hbar)+\cosh (y)} \\
& =\frac{\sin (2 x p / \hbar)}{\sinh (2 x / \hbar) \sinh (\pi p)}
\end{aligned}
$$

[N.B. It is not positive definite or a function of just $H(x, p)$.] It may be verified directly that

$$
Q \star f_{0}=\left[p-\frac{i \hbar}{2} \partial_{x}-i \tanh \left(\frac{x}{\hbar}+\frac{i}{2} \partial_{p}\right)\right] f_{0}(x, p)=0 .
$$

This appendage of bound states to a potential generalizes [16] to the hierarchy associated with the Korteweg-de Vries $(\mathrm{KdV})$ equation. Specifically,

$$
W(n)=n \tanh \left(\frac{\sqrt{2 m x}}{\hbar}\right)
$$

connects the reflectionless Pöschl-Teller potential

$$
V^{\prime}(x)=n^{2}-n(n-1) / \cosh ^{2}\left(\frac{\sqrt{2 m x}}{\hbar}\right)
$$

to its contiguous

$$
V(x)=n^{2}-n(n+1) / \cosh ^{2}\left(\frac{\sqrt{2 m x}}{\hbar}\right),
$$

which has one more bound state (shape invariance). Recursively, then, one may go in $N$ steps, with the suitable shifts of the potential by $2 n-1$ in each step, from the constant potential to

$$
V(N ; x)=N^{2}-N(N+1) / \cosh ^{2}\left(\frac{\sqrt{2 m} x}{\hbar}\right) .
$$

Shifting this potential down by $N^{2}$ assigns the energy $E$ $=-N^{2}$ to the corresponding ground state $\psi_{0}(N)=\operatorname{sech}^{N}(x)$ (unnormalized), which is the null state of $(\hbar / \sqrt{2 m}) \partial_{x}$ $+W(N)$. The corresponding (unnormalized) Wigner function is the $\star$-null state of $Q(N)$,

$$
\begin{aligned}
f_{0}(N ; x, p) & =\frac{1}{\pi} \int_{0}^{\infty} d y \frac{\cos (y p)}{[\cosh (2 x / \hbar)+\cosh (y)]^{N}} \\
& =\frac{1}{(N-1) !}\left(\frac{-\hbar}{2 \sinh (2 x / \hbar)} \partial_{x}\right)^{N-1} f_{0}(1 ; x, p),
\end{aligned}
$$

where the integral only need be evaluated from the above $f_{0}(1 ; x, p)$. Alternatively,

$f_{0}(N ; x, p)=[\operatorname{sech}(x / \hbar) \star]^{N-1} f_{0}(1 ; x, p)[\star \operatorname{sech}(x / \hbar)]^{N-1}$

The (unnormalized) state above the ground state at $E$ $=-(N-1)^{2}$ is $\left[(\hbar / \sqrt{2 m}) \partial_{x}-W(N)\right] \psi_{0}(N-1)$, and its corresponding Wigner function (setting $m=1 / 2$ ) is found recursively from the ground state of $H(N-1)$, through $Q^{*}(N) \star f_{0}(N-1) \star Q(N)$,

$$
\begin{aligned}
{[p} & \left.\star f_{0}(N-1)+i N \tanh \left(\frac{x}{\hbar}\right) \star f_{0}(N-1)\right] \star Q(N) \\
& =\left(p \star f_{0}(N-1)+\frac{N}{N-1} p \star f_{0}(N-1)\right) \star Q(N) \\
& =\left(\frac{2 N-1}{N-1}\right)^{2} p \star f_{0}(N-1) \star p,
\end{aligned}
$$

by virtue of

$$
Q(N-1) \star f_{0}(N-1)=0=f_{0}(N-1) \star Q^{*}(N-1) .
$$

The state above that, at $E=-(N-2)^{2}$, is found recursively through

$$
Q^{*}(N) \star Q^{*}(N-1) \star f_{0}(N-2) \star Q(N-1) \star Q(N),
$$

and so forth. Thus, the entire Wigner $\star$-genfunction spectrum of $H(N)$ is obtained with hardly any reliance on Schrödinger eigenfunctions.

\section{CANONICAL TRANSFORMATION OF THE WIGNER FUNCTION}

For notational simplicity, take $\hbar=1$ in this section. The area element in phase space is preserved by canonical transformations

$$
(x, p) \mapsto(X(x, p), P(x, p))
$$

which yield trivial Jacobians ( $d X d P=d x d p\{X, P\}$ ) by preserving the Poisson brackets

$$
\{u, v\}_{x p} \equiv \frac{\partial u}{\partial x} \frac{\partial v}{\partial p}-\frac{\partial u}{\partial p} \frac{\partial v}{\partial x} .
$$

They thus preserve the "canonical invariants" of their functions:

$$
\{X, P\}_{x p}=1 \text { and hence }\{x, p\}_{X P}=1
$$


Equivalently,

$$
\{x, p\}=\{X, P\},
$$

in any basis. Motion being a canonical transformation, Hamilton's classical equations of motion are preserved, for $\mathcal{H}(X, P) \equiv H(x, p)$, as well [17]. What happens upon quantization?

Since, in deformation quantization, the Hamiltonian is a $c$-number function, and so transforms "classically," $\mathcal{H}(X, P) \equiv H(x, p)$, the effects of a canonical transformation on the quantum $\star$-genvalue equation of lemma 1 will be carried by a suitably transformed Wigner function. Predictably, the answer can be deduced from Dirac's quantum transformation theory. Consider the canonical transformations generated by $F(x, X)$ :

$$
p=\frac{\partial F(x, X)}{\partial x}, \quad P=-\frac{\partial F(x, X)}{\partial X} .
$$

Following Dirac's celebrated exponentiation [18] of such a generator, in the implementation of $[12,19]$, the energy eigenfunctions transform canonically through a generalization of the "representation-changing" Fourier transform:

$$
\psi_{E}(x)=N_{E} \int d X e^{i F(x, X)} \Psi_{E}(X)
$$

Thus,

$$
f(x, p)=\frac{\left|N_{E}\right|^{2}}{2 \pi} \int d y \int d X_{1} e^{-i F^{*}\left(x-y / 2, X_{1}\right)} \Psi_{E}^{*}\left(X_{1}\right) e^{-i y p} \int d X_{2} e^{i F\left(x+y / 2, X_{2}\right)} \Psi_{E}\left(X_{2}\right)
$$

The pair of Wigner functions in the respective canonical variables, $f(x, p)$ and

$$
\mathcal{F}(X, P)=\frac{1}{2 \pi} \int d Y \Psi^{*}\left(X-\frac{\hbar}{2} Y\right) e^{-i Y P} \Psi\left(X+\frac{\hbar}{2} Y\right)
$$

are connected by a transformation functional $\mathfrak{T}(x, p ; X, P)$,

$$
f(x, p)=\int d X \int d P \mathfrak{T}(x, p ; X, P) \circledast \mathcal{F}(X, P)=\int d X \int d P \mathfrak{T}(x, p ; X, P) \mathcal{F}(X, P)
$$

where $\circledast$ is with respect to the variables $X$ and $P$.

To find this functional, let $X=\frac{1}{2}\left(X_{1}+X_{2}\right)$ and $Y=X_{2}-X_{1}$, so that $\int d X_{1} \int d X_{2}=\int d X \int d Y$. Noting that

$$
\Psi *\left(X-\frac{\hbar}{2} Y\right) \Psi\left(X+\frac{\hbar}{2} Y\right)=\int d P e^{i Y P} \mathcal{F}(X, P)
$$

it follows that Eq. (68) reduces to

$$
\begin{aligned}
f(x, p) & =\frac{|N|^{2}}{2 \pi} \int d y \int d X_{1} e^{-i F^{*}\left(x-y / 2, X_{1}\right)} \Psi^{*}\left(X_{1}\right) e^{-i y p} \int d X_{2} e^{i F\left(x+y / 2, X_{2}\right)} \Psi\left(X_{2}\right) \\
& =\frac{|N|^{2}}{2 \pi} \int d X d Y d y e^{-i y p} e^{-i F^{*}(x-y / 2, X-Y / 2)} \Psi^{*}(X-Y / 2) \Psi(X+Y / 2) e^{i F(x+y / 2, X+Y / 2)} \\
& =\frac{|N|^{2}}{2 \pi} \int d X d P d Y d y e^{-i y p+i P Y-i F^{*}(x-y / 2, X-Y / 2)+i F(x+y / 2, X+Y / 2)} \mathcal{F}(X, P),
\end{aligned}
$$


which leads to the following lemma.

Lemma 3. $\mathfrak{T}(x, p ; X, P)=\left(|N|^{2} / 2 \pi\right) \int d Y d y \exp [-i y p$ $\left.+i P Y-i F^{*}(x-y / 2, X-Y / 2)+i F(x+y / 2, X+Y / 2)\right]$.

Corollary 2. This phase-space transformation functional obeys the "two-star" equation

$$
H(x, p) \star \mathfrak{T}(x, p ; X, P)=\mathfrak{T}(x, p ; X, P) \circledast \mathcal{H}(X, P),
$$

as follows from $H\left(x,-i \partial_{x}\right) \exp [i F(x, X)]$ $=\mathcal{H}\left(X, i \partial_{X}\right) \exp [i F(x, X)]$. If $\mathcal{F}$ satisfies a $\circledast$-genvalue equation, then $f$ satisfies a $\star$-genvalue equation with the same eigenvalue, and vice versa.

Note that, by virtue of the spectral projection feature (16), (19), this equation is also solved by any representationchanging equal-energy bilinear in real Wigner $\star$ genfunctions of $H$ and $\mathcal{H}$,

$$
\mathfrak{T}(x, p ; X, P)=\sum_{E} g(E) f_{E}(x, p) \mathcal{F}_{E}(X, P)
$$

for arbitrary real $g(E)$. Such a bilinear transformation functional is nonsingular (invertible) if and only if $g(E)$ has no zeros on the spectrum of either Hamiltonian. ${ }^{2}$

As an example, consider the linear potential again, which transforms into a free particle $(\mathcal{H}=P)$ through

$$
F=-\frac{1}{3} X^{3}-x X \Rightarrow p=-X, \quad x=P-X^{2}
$$

By direct computation,

$$
\mathcal{T}(x, p ; X, P)=2^{2 / 3} \mathrm{Ai}\left(2^{2 / 3}\left(x+X^{2}-P\right)\right) \delta(p+X)
$$

\footnotetext{
${ }^{2}$ In general, if the transformation functional effects a map to a free particle, the $P$ integration is trivial in Eq. (70), and the result for the Wigner function of the $x, p$ theory is just an average over $X$ of the transformation functional. That is, if $\mathcal{F}(X, P)=\delta(P-k(E))$, where $k(E)$ is the momentum-energy relation for the free particle theory in question:

$$
f(x, p)=\int d X \int d P \mathfrak{T}(x, p ; X, P) \mathcal{F}(X, P)=\int d X \mathfrak{T}(x, p ; X, k(E)) .
$$

One might then be tempted to wonder if just $\mathfrak{T}(x, p ; X, P)=\psi_{P}^{*}(x$ $-\hbar X / 2) e^{-i X_{p}} \psi_{P}(x+\hbar X / 2) / 2 \pi \cong \mathfrak{B}(x, p ; X, P)$. However, what determines the allowed range for $P$ ? It is always possible to embed any real energy spectrum into the real line, but knowing this does not help at all to determine what points are to be embedded. From the point of view of this paper, even when the spectrum is obvious, such a choice for the transformation functional in general does not satisfy the two- $\star$ equation (73). Rather, the equation fails by total derivatives that vary contingent on particularities of the case. E.g., for free-particle plane waves, $\psi_{E}(x)=\exp (i E x)$, so that $p \star \mathbb{B}$ $-\mathfrak{B} \circledast P=\partial_{\chi} \mathfrak{G}$. This choice for $\mathfrak{T}$, then, does not yield useful information on the Wigner functions.
}

$$
=(2 \pi)^{2} \int d E f_{E}(x, p) \mathcal{F}_{E}(X, P) \delta(p+X) .
$$

Note $N_{E}=1 / \sqrt{2 \pi}$ for the free-particle energy eigenfunction normalization choice $\Psi_{E}(X)=(2 \pi)^{-1 / 2} \exp (i E X)$. Thus, indeed, the free-particle Wigner function $\mathcal{F}_{E}(X, P)=\delta(E$ $-P) /(2 \pi)$ transforms into

$$
\begin{aligned}
f(x, p) & =\frac{1}{2 \pi} \int d P d X \mathfrak{T} \delta(E-P) \\
& =\frac{2^{2 / 3}}{2 \pi} \operatorname{Ai}\left(2^{2 / 3}\left(x+p^{2}-E\right)\right),
\end{aligned}
$$

as it should, and Eq. (73) is seen to be satisfied directly, by virtue of the linearity of the respective Hamiltonians in the variables $P, x$, conjugate to those of the arguments of $\delta(p$ $+X)$.

The structure of the result in Eq. (76) underscores that the linear potential is as "close to classical" as one can get, in simple quantum mechanics. It has been noted before [12] that the transformation functional for linear potential wave functions is exactly the exponential of the classical generating function for the canonical transformation to a free particle, and that this is not the case for any other potential. The present result for the transformation functional for Wigner functions is further evidence for this "close to classical" behavior. The delta function $\delta(p+X)$ in Eq. (76) is half of the classical story. Were the Airy function also a delta function of its argument, we would have an exact implementation of the $X, P \mapsto x, p$ classical correspondence. As it is, there is some typically quantum mechanical spread around the classical constraint $x+X^{2}-P=0$, in the form of oscillations of the Airy function, and, in consequence, the Wigner functions of the free particle do not retain their delta-function form under the canonical transformation to the linear potential Wigner functions. Reinstating $\hbar$ into Eq. (36), ${ }^{3}$ and taking the limit $\hbar \rightarrow 0$ converts the Airy function to a delta function, $\delta\left(x+X^{2}-P\right)$, thereupon producing the complete classical correspondence between the two sets of phase space variables, in that limit.

As already seen, there is substantial nonuniqueness in the choice of transformation functional. For example, for the Iinear potential again, Eq. (73),

$$
\left(x+p^{2}\right) \star \mathfrak{S}(x, p ; X, P)=\mathfrak{S}(x, p ; X, P) \circledast P
$$

is also satisfied by a different (and somewhat simpler) choice:

$$
\mathfrak{S}(x, p ; X, P)=\exp \left\{-i\left[\frac{2}{3} X^{3}+2\left(x+p^{2}-P\right) X\right]\right\} .
$$

\footnotetext{
${ }^{3}$ The exponent of the integrand turns into $i y\left(E-x-p^{2}\right.$ $\left.-\hbar^{2} y^{2} / 12\right)$.
} 
This transformation functional also converts the free-particle Wigner function $\mathcal{F}_{E}(X, P)=\delta(E-P) / 2 \pi$ into an Airy function (as above) after integrating over the free-particle phase space, $\int d X d P$.
Actually, it is not necessary to integrate over the phase space. In general, $\star$ multiplying a delta function spreads it out, and yields a Fourier transform with respect to the conjugate variable. Thus, for the example considered,

$$
\begin{aligned}
e^{i\left[(-2 / 3) X^{3}-2\left(x+p^{2}-P\right) X\right]} \star \delta(P-E) & =e^{2 i X(P-E)} \frac{1}{\pi} \int d Z e^{-2 i Z(P-E)} e^{i\left[(-2 / 3) Z^{3}-2\left(x+p^{2}-P\right) Z\right]} \\
& =e^{2 i X(P-E)} \frac{1}{\pi} \int d Z e^{i\left[(-2 / 3) Z^{3}-2\left(x+p^{2}-E\right) Z\right]}=e^{2 i X(P-E)} 2^{2 / 3} A i\left(2^{2 / 3}\left(x+p^{2}-E\right)\right)
\end{aligned}
$$

Hence,

$$
\int d X \int d P e^{i\left[(-2 / 3) X^{3}-2\left(x+p^{2}-P\right) X\right]} \star \delta(P-E)=2^{2 / 3} \pi \operatorname{Ai}\left(2^{2 / 3}\left(x+p^{2}-E\right)\right) .
$$

Compare this to the action of the above $\mathfrak{T}(x, p ; X, P)$,

$$
\begin{aligned}
{\left[\operatorname{Ai}\left(2^{2 / 3}\left(x+X^{2}-P\right)\right) \delta(p+X)\right] \star \delta(P-E) } & =e^{2 i X(P-E)} \frac{1}{\pi} \int d Z e^{-2 i Z(P-E)} \operatorname{Ai}\left(2^{2 / 3}\left(x+Z^{2}-P\right)\right) \delta(p+Z) \\
& =e^{2 i(p+X)(P-E)} \frac{1}{\pi} \operatorname{Ai}\left(2^{2 / 3}\left(x+p^{2}-P\right)\right)
\end{aligned}
$$

Aside from innocuous normalizations, the difference in the two transformation functionals acting on the free-particle Wigner function is just the phase factor $e^{2 i p(P-E)}$ and the argument of the Airy function, where $E$ has been replaced by $P$. Indeed, the phase factor precisely compensates for the different energy eigenvalue occurring in the argument of $\mathrm{Ai}$, when acted upon by $\left(x+p^{2}\right) \star$. Such simple phase factors may be used to shift $a \star$ genvalue whenever the Hamiltonian is linear in any variable.

\section{ILLUSTRATIONS USING LIOUVILLE QUANTUM MECHANICS}

A summary illustration of all the above, in particular the canonical transformation effects on Wigner functions, is provided by the Liouville model [20]. Our conventions for the model [which are essentially those of [21], with their $m$ $\equiv 1 /(4 \pi)$ and their $g=1$ ] are given by

$$
H_{\text {Liouville }}=p^{2}+e^{2 x} \text {. }
$$

The energy eigenfunctions are then solutions of

$$
\left(-\frac{d^{2}}{d x^{2}}+e^{2 x}\right) \psi_{E}(x)=E \psi_{E}(x)
$$

The solutions are Kelvin (modified Bessel) $K$ functions, for $0<E<\infty$,

$$
\psi_{E}(x)=\frac{1}{\pi} \sqrt{\sinh (\pi \sqrt{E})} K_{i \sqrt{E}}\left(e^{x}\right)
$$

which are normalized such that $\int_{-\infty}^{+\infty} d x \psi_{E_{1}}^{*}(x) \psi_{E_{2}}(x)$ $=\delta\left(E_{1}-E_{2}\right)$. There is no solution [20] for $E=0$.

For completeness, consider the Fourier transform (including a convergence factor, necessary for $x \rightarrow-\infty$ to control plane wave behavior, but not for $x \rightarrow \infty$ )

$$
\begin{aligned}
\Phi_{E}(p+i \epsilon)= & \int_{-\infty}^{+\infty} d x e^{-i x(p+i \epsilon)} \psi_{E}(x) \\
= & \frac{1}{4 \pi} \sqrt{\sinh (\pi \sqrt{E}) 2^{-i(p+i \epsilon)}} \\
& \times \Gamma\left(\frac{-i(p+i \epsilon)+i \sqrt{E}}{2}\right) \Gamma\left(\frac{-i(p+i \epsilon)-i \sqrt{E}}{2}\right) .
\end{aligned}
$$

This follows, e.g., from a result in [22], Vol. II, p 51, Eq (27):

$$
\int_{0}^{+\infty} d z z^{\mu} K_{\nu}(z)=2^{\mu-1} \Gamma\left(\frac{1+\mu+\nu}{2}\right) \Gamma\left(\frac{1+\mu-\nu}{2}\right),
$$

valid for $\mathfrak{R}(1+\mu \pm \nu)>0$ (i.e., the previous transform is valid for $\epsilon>0$ ). The right-hand side of this last relation clearly displays the symmetry $\nu \rightarrow-\nu$, which just amounts 
to the physical statement that the energy eigenfunctions are nondegenerate for the transmissionless exponential potential of the Liouville model.

Further note the effect on $\Phi_{E}(p+i \epsilon)$ of shifting $p \rightarrow p$ $+2 i$, using $\Gamma(1+z)=z \Gamma(z)$

$$
\begin{aligned}
\Phi_{E}(p+2 i+i \epsilon)= & 4\left(\frac{-i(p+i \epsilon)+i \sqrt{E}}{2}\right) \\
& \times\left(\frac{-i(p+i \epsilon)-i \sqrt{E}}{2}\right) \Phi_{E}(p+i \epsilon) \\
= & {\left[E-(p+i \epsilon)^{2}\right] \Phi_{E}(p+i \epsilon) . }
\end{aligned}
$$

So, as $\epsilon \rightarrow 0, \Phi_{E}(p+2 i)=\left(E-p^{2}\right) \Phi_{E}(p)$. But this simple difference equation is just the Liouville energy eigenvalue equation in the momentum basis,

$$
\left(p^{2}-E\right) \Phi_{E}(p)+e^{2 i \partial_{p}} \Phi_{E}(p)=0 .
$$

Such first-order difference equations invariably lead to gamma functions [23]. Below, it turns out that the Wigner functions also satisfy momentum difference equations, but of second order.
Many, if not all, properties of the Liouville wave functions may be understood from the following integral representation [[24], Chap. VI, Sec. 6.22, Eq. (10)]. Explicitly emphasizing the abovementioned nondegeneracy,

$$
K_{i k}\left(e^{x}\right)=K_{-i k}\left(e^{x}\right)=\frac{1}{2} e^{\pi k / 2} \int_{-\infty}^{+\infty} d X e^{i e^{x} \sinh X} e^{i k X}
$$

(Also see [25], Eq. 9.6.22.) This integral representation may be effectively regarded as the canonical transformation of a free-particle energy eigenfunction $e^{i k X}$ through use of the generating function $F(x, X)=e^{x} \sinh X$. Classically, $p$ $=\partial F / \partial x=e^{x} \sinh X$ and $P=-\partial F / \partial X=-e^{x} \cosh X$, and so $P^{2}-p^{2}=e^{2 x}$. That is, $H_{\text {Liouville }}=\mathcal{H}_{\text {free }} \equiv P^{2}$ under the classical effects of the canonical transformation. The quantum effects are detailed below, by $\star$ acting with the Liouville and free Hamiltonians on the suitable transformation functional.

The Liouville Wigner function may be obtained from the definition (1) in terms of known higher transcendental functions:

$$
\begin{aligned}
f(x, p) & =\frac{1}{2 \pi} \int_{-\infty}^{+\infty} d y \frac{1}{\pi^{2}} \sinh (\pi \sqrt{E}) K_{i \sqrt{E}}\left(e^{x-y / 2}\right) e^{-i y p} K_{i \sqrt{E}}\left(e^{x+y / 2}\right) \\
& =\frac{1}{4 \pi^{3}} \sinh (\pi \sqrt{E}) 2^{2 i p} e^{(-1-2 i p) x} G_{04}^{40}\left(\frac{e^{4 x}}{16} \mid \frac{1+2 i \sqrt{E}}{4}, \frac{1-2 i \sqrt{E}}{4}, \frac{1+2 i \sqrt{E}+4 i p}{4}, \frac{1-2 i \sqrt{E}+4 i p}{4}\right) .
\end{aligned}
$$

The following $K$ transform was utilized to express this result in closed form:

$$
\int_{0}^{\infty} d w(w z)^{1 / 2} w^{\sigma-1} K_{\mu}(a / w) K_{\nu}(w z)=2^{-\sigma-5 / 2} a^{\sigma} G_{04}^{40}\left(\frac{a^{2} z^{2}}{16} \mid \frac{\mu-\sigma}{2}, \frac{-\mu-\sigma}{2}, \frac{1}{4}+\frac{\nu}{2}, \frac{1}{4}-\frac{\nu}{2}\right) .
$$

The right-hand side involves a special case of Meijer's $G$ function,

$$
G_{p q}^{m n}\left(z \begin{array}{ll}
a_{i}, & i=1, \ldots, p \\
b_{j}, & j=1, \ldots, q
\end{array}\right)
$$

(cf. [22], Sec. 5.3), which is fully symmetric in the parameter subsets $\left\{a_{1}, \ldots, a_{n}\right\},\left\{a_{n+1}, \ldots, a_{p}\right\},\left\{b_{1}, \ldots, b_{m}\right\}$, and $\left\{b_{m+1}, \ldots, b_{q}\right\}$. It is possible to reexpress the result as a linear combination of generalized hypergeometric functions of type ${ }_{0} F_{3}$, but there is little reason to do so here. This transform is valid for $\Re a>0$, and is taken from [26], p. 711, Eq. (55). ${ }^{4}$ The transform is complementary to [27], Sec. 10.3, Eq. (49), in an obvious way, a $K$ transform which appears in perturbative computations of certain Liouville correlation functions [21].

The result (91) may be written in slightly different alternate forms

$$
\begin{aligned}
f(x, p) & =\frac{\sinh (\pi \sqrt{E}) e^{-x}}{4 \pi^{3}} G_{04}^{40}\left(\frac{e^{4 x}}{16} \mid \frac{1+2 i \sqrt{E}-2 i p}{4}, \frac{1-2 i \sqrt{E}-2 i p}{4}, \frac{1+2 i \sqrt{E}+2 i p}{4}, \frac{1-2 i \sqrt{E}+2 i p}{4}\right) \\
& =\frac{\sinh (\pi \sqrt{E})}{8 \pi^{3}} G_{04}^{40}\left(\frac{e^{4 x}}{16} \mid \frac{i \sqrt{E}-i p}{2}, \frac{-i \sqrt{E}-i p}{2}, \frac{i \sqrt{E}+i p}{2}, \frac{-i \sqrt{E}+i p}{2}\right),
\end{aligned}
$$

\footnotetext{
${ }^{4}$ There is an error in this result as it appears in [27], Vol. II, Sec. 10.3, Eq. (58), where the formula has $a^{2} z^{2} / 4$ instead of $a^{2} z^{2} / 16$ as the argument of the $G$ function. The latter argument is correct, and appears in Meijer's original paper cited here.
} 
by making use of the parameter translation identity for the $G$ function [[22], Sec. 5.3.1, Eq. (9)]:

$$
z^{\lambda} G_{p q}^{m n}\left(z \mid \begin{array}{l}
a_{r} \\
b_{s}
\end{array}\right)=G_{p q}^{m n}\left(\begin{array}{l}
a_{r}+\lambda \\
b_{s}+\lambda
\end{array}\right)
$$

Yet another way to express the result utilizes the Fourier transform of the wave function, Eq. (86), in terms of which the Wigner function reads, in general,

$$
f(x, p)=\left(\frac{1}{2 \pi}\right)^{2} \int_{-\infty}^{+\infty} d k \Phi_{E}^{*}\left(p-\frac{1}{2} k\right) e^{i x k} \Phi_{E}\left(p+\frac{1}{2} k\right)
$$

The specific result (86) then gives, as $\epsilon \rightarrow 0$,

$$
\begin{aligned}
f(x, p)= & \left(\frac{1}{8 \pi^{2}}\right)^{2} \sinh (\pi \sqrt{E}) \int_{-\infty}^{+\infty} d k e^{i x k} 4^{-i(k / 2+i \epsilon)} \Gamma\left(\frac{i(p-k / 2-i \epsilon)-i \sqrt{E}}{2}\right) \\
& \times \Gamma\left(\frac{i(p-k / 2-i \epsilon)+i \sqrt{E}}{2}\right) \Gamma\left(\frac{-i(p+k / 2+i \epsilon)+i \sqrt{E}}{2}\right) \Gamma\left(\frac{-i(p+k / 2+i \epsilon)-i \sqrt{E}}{2}\right) .
\end{aligned}
$$

However, this is a contour integral representation of the particular $G$ function given above. Because of the $\epsilon$ prescription, the contour in the variable $z=k / 2+i \epsilon$ runs parallel to the real axis, but slightly above the poles of the $\Gamma$ functions located on the real axis at $z=p-\sqrt{E}, z=p+\sqrt{E}, z=-p+\sqrt{E}$, and $z=-p-\sqrt{E}$. Changing variables to $s=\frac{1}{2} i z$ yields

$$
f(x, p)=\frac{1}{8 \pi^{3}} \sinh (\pi \sqrt{E}) \frac{1}{2 \pi i} \int_{C} d s\left(\frac{e^{4 x}}{16}\right)^{s} \Gamma\left(\frac{i p-i \sqrt{E}}{2}-s\right) \Gamma\left(\frac{i p+i \sqrt{E}}{2}-s\right) \Gamma\left(\frac{-i p+i \sqrt{E}}{2}-s\right) \Gamma\left(\frac{-i p-i \sqrt{E}}{2}-s\right)
$$

where the contour $C$ in the $s$ plane runs from $-i \infty$ to $+i \infty$, just to the left of the four poles on the imaginary $s$ axis at $i(p+\sqrt{E}) / 2, \quad i(p-\sqrt{E}) / 2, \quad i(-p+\sqrt{E}) / 2, \quad$ and $i(-p$ $-\sqrt{E}) / 2$. This is recognized as the Mellin-Barnes-type integral definition of the $G_{04}^{40}$ function [cf. [22], Sec. 5.3, Eq. (1)] in agreement with the second result above, Eq. (94).

The translation identity (95) is seen to hold by virtue of Eq. (98), through simply shifting the variable of integration, $s$. Moreover, deforming the contour in Eq. (98) to enclose the four sequences of poles $s_{n}=n+i( \pm p \pm \sqrt{E}) / 2$ reveals the equivalence of this particular $G$ function to a linear combination of four ${ }_{0} F_{3}$ functions, one for each of the sequences of poles. Evaluating the integral by the method of residues for all these poles produces the standard ${ }_{0} F_{3}$ hypergeometric series.

It should now be straightforward to directly check that the explicit result for $f(x, p)$ is indeed a solution to the Liouville $\star$-genvalue equation,

$$
\begin{aligned}
& H_{\text {Lionville }}^{\star} f(x, p) \\
& \quad=\left[\left(p-\frac{i}{2} \partial_{x}\right)^{2}+e^{2\left[x+(i / 2) \partial_{p}\right]}\right] f(x, p)=E f(x, p) .
\end{aligned}
$$

For real $E$ and real $f(x, p)$, the imaginary part of this * genvalue equation is

$$
\left(-p \partial_{x}+e^{2 x} \sin \partial_{p}\right) f(x, p)=0,
$$

while the real part is

$$
\left(p^{2}-E-\frac{1}{4} \partial_{x}^{2}+e^{2 x} \cos \partial_{p}\right) f(x, p)=0
$$

The first of these is a first-order differential-difference equation relating the $x$ and $p$ dependence:

$$
e^{-2 x} \partial_{x} f(x, p)=\frac{1}{2 i p}[f(x, p+i)-f(x, p-i)] .
$$

Similarly, the real part of the $\star$-genvalue equation is a second-order differential-difference equation:

$$
e^{-2 x}\left(p^{2}-E-\frac{1}{4} \partial_{x}^{2}\right) f(x, p)+\frac{1}{2}[f(x, p+i)+f(x, p-i)]=0 .
$$

The previous first-order equation may now be substituted (twice) into this last second-order equation, to convert it from a differential-difference equation into a second-order difference-only equation in the momentum variable, with nonconstant coefficients:

$$
\begin{aligned}
0= & \left(p^{2}-E\right) f(x, p)+\left(\frac{e^{2 x}}{4 p}\right)^{2}[f(x, p+2 i)-2 f(x, p) \\
& +f(x, p-2 i)]+i \frac{e^{2 x}}{4 p}[f(x, p+i)-f(x, p-i)] \\
& +\frac{e^{2 x}}{2}[f(x, p+i)+f(x, p-i)]
\end{aligned}
$$


We leave it as an exercise for the reader to exploit the recursive properties of the Meijer $G$ function and show that this difference equation is indeed obeyed by the result (91). Rather than pursue this in detail, we turn our attention to the transformation functional which connects the above result for $f$ to a free-particle Wigner function.

Given Eq. (90), it follows that

$$
\psi_{E}(x)=\frac{1}{\pi} \sqrt{\sinh (\pi \sqrt{E})} K_{i \sqrt{E}}\left(e^{x}\right)=\frac{1}{2 \pi} \sqrt{\sinh (\pi \sqrt{E})} e^{\pi \sqrt{E} / 2} \int_{-\infty}^{+\infty} d X e^{i e^{x} \sinh X} e^{i \sqrt{E} X},
$$

and hence $N_{E}=\left[4 \pi \sqrt{E} e^{\pi \sqrt{E}} \sinh (\pi \sqrt{E})\right]^{1 / 2} / 2 \pi$, if we choose a $\delta\left(E_{1}-E_{2}\right)$ normalization for the free-particle plane waves as well as for the Liouville eigenfunctions. Therefore, lemma 3 yields

$$
\begin{aligned}
\mathfrak{T}(x, p ; X, P)= & \frac{|N|^{2}}{2 \pi} \int d Y d y \exp \left[-i y p+i P Y-i F^{*}(x-y / 2, X-Y / 2)+i F(x+y / 2, X+Y / 2)\right] \\
= & \frac{1}{(2 \pi)^{3}}\left[4 \pi \sqrt{E} e^{\pi \sqrt{E}} \sinh (\pi \sqrt{E})\right] \int d Y d y \exp \left[-i y p+i P Y-i e^{x-y / 2} \sinh \left(X-\frac{Y}{2}\right)+i e^{x+y / 2} \sinh \left(X+\frac{Y}{2}\right)\right] \\
= & \frac{1}{4 \pi^{3}}\left[4 \pi \sqrt{E} e^{\pi \sqrt{E}} \sinh (\pi \sqrt{E})\right] \int d\left(\frac{y+Y}{2}\right) \exp \left[i(P-p) \frac{y+Y}{2}+i e^{x+X} \sinh \left(\frac{y+Y}{2}\right)\right] \\
& \times \int d\left(\frac{Y-y}{2}\right) \exp \left[i(P+p) \frac{Y-y}{2}+i e^{x-X} \sinh \left(\frac{Y-y}{2}\right)\right]
\end{aligned}
$$

We thus conclude that

$$
\mathfrak{I}(x, p ; X, P)=\frac{4}{\pi^{2}} \sqrt{E} e^{\pi \sqrt{E}} \sinh (\pi \sqrt{E}) e^{-\pi P} K_{i(P-p)}\left(e^{x+X}\right) K_{i(P+p)}\left(e^{x-X}\right) .
$$

We now check that this result obeys Eq. (73) and, in so doing, carry out the nontrivial steps needed to show the Liouville Wigner functions satisfy the Liouville $\star$-genvalue equation (99). That is to say, we shall show

$$
\left(\left(p-\frac{i}{2} \vec{\partial}_{x}\right)^{2}+e^{2\left[x+(i / 2) \vec{\partial}_{p}\right]}\right) \mathfrak{T}(x, p ; X, P)=\mathfrak{T}(x, p ; X, P)\left[\left(P+\frac{i}{2} \tilde{\partial}_{X}\right)^{2}\right]
$$

or, equivalently,

$$
\left[\left(p-\frac{i}{2} \vec{\partial}_{x}\right)^{2}+e^{2\left[x+(i / 2) \dot{\partial}_{p}\right]}-\left(P+\frac{i}{2} \vec{\partial}_{X}\right)^{2}\right] K_{i(P-p)}\left(e^{x+x}\right) K_{i(P+p)}\left(e^{x-X}\right)=0
$$

Specifically,

$$
\begin{gathered}
\frac{-1}{4}\left(\vec{\partial}_{x}^{2}-\vec{\partial}_{X}^{2}\right) K_{i(P-p)}\left(e^{x+X}\right) K_{i(P+p)}\left(e^{x-X}\right)=-e^{2 x} K_{i(P-p)}^{\prime}\left(e^{x+X}\right) K_{i(P+p)}^{\prime}\left(e^{x-X}\right) \\
\left(-i p \vec{\partial}_{x}-i P \vec{\partial}_{X}\right) K_{i(P-p)}\left(e^{x+X}\right) K_{i(P+p)}\left(e^{x-X}\right)= \\
-i(p+P) e^{x+X} K_{i(P-p)}^{\prime}\left(e^{x+X}\right) K_{i(P+p)}\left(e^{x-X}\right)-i(p-P) e^{x-X} K_{i(P-p)} \\
\times\left(e^{x+X}\right) K_{i(P+p)}^{\prime}\left(e^{x-X}\right)
\end{gathered}
$$

and

$$
e^{2\left[x+(i / 2) \vec{\partial}_{p}\right]} K_{i(P-p)}\left(e^{x+X}\right) K_{i(P+p)}\left(e^{x-X}\right)=e^{2 x} K_{1+i(P-p)}\left(e^{x+X}\right) K_{-1+i(P+p)}\left(e^{x-X}\right) .
$$

Now, recall the recurrence relations ([25], Eq. 9.6.26)

$$
\begin{aligned}
K_{1+i(P-p)}\left(e^{x+X}\right) & =-K_{i(P-p)}^{\prime}\left(e^{x+X}\right)+i(P-p) e^{-x-X} K_{i(P-p)}\left(e^{x+X}\right), \\
K_{-1+i(P+p)}\left(e^{x-X}\right) & =-K_{i(P+p)}^{\prime}\left(e^{x-X}\right)-i(P+p) e^{-x+X} K_{i(P+p)}\left(e^{x-X}\right) .
\end{aligned}
$$

So the previous relation (112) becomes 


$$
\begin{aligned}
e^{2\left(x+i / 2 \dot{\partial}_{p}\right)} K_{i(P-p)}\left(e^{x+X}\right) K_{i(P+p)}\left(e^{x-X}\right)= & e^{2 x} K_{i(P-p)}^{\prime}\left(e^{x+X}\right) K_{i(P+p)}^{\prime}\left(e^{x-X}\right)+i(P+p) e^{x+X} K_{i(P-p)}^{\prime}\left(e^{x+X}\right) K_{i(P+p)}\left(e^{x-X}\right) \\
& -i(P-p) e^{x-X} K_{i(P-p)}\left(e^{x+X}\right) K_{i(P+p)}^{\prime}\left(e^{x-X}\right)+\left(P^{2}-p^{2}\right) K_{i(P-p)}\left(e^{x+X}\right) \\
& \times K_{i(P+p)}\left(e^{x-X}\right)
\end{aligned}
$$

The sum of Eqs. (110), (111), and (115) shows that Eq. (109) is, indeed, satisfied.

Integrating over $X$ and $P$ the product of $\mathfrak{T}(x, p ; X, P)$ and the free-particle Wigner function, as given here by $(4 \pi \sqrt{E})^{-1} \delta(P-\sqrt{E})$, yields another expression for the Liouville Wigner function which checks against the previous result, Eq. (91). Using Eq. (92) and the parameter translation identity for the $G$ function, this other expression is just Eq. (94).

Supersymmetric Liouville quantum mechanics is obtained by carrying through the Darboux construction detailed above (with $\hbar=1=2 m$ ), for the choice

$$
W(x)=e^{x} .
$$

The conventions used essentially follow [28].

The first Hamiltonian of the essentially isospectral pair is then

$$
H=p^{2}+e^{2 x}-e^{x}
$$

and the allowed spectrum is $0 \leqslant E<\infty$, including zero energy, for which there is a bounded wave function normalized as part of the continuum,

$$
\psi_{0}(x)=\frac{1}{\sqrt{\pi}} e^{-e^{x}}
$$

The other, $E>0$, eigenfunctions are

$$
\begin{aligned}
\psi_{E}(x)= & {\left[\frac{1}{4 \pi^{2} \sqrt{E}} e^{x} \cosh (\pi \sqrt{E})\right]^{1 / 2} } \\
& \times\left[K_{1 / 2-i \sqrt{E}}\left(e^{x}\right)+K_{1 / 2+i \sqrt{E}}\left(e^{x}\right)\right],
\end{aligned}
$$

again normalized so that $\int_{-\infty}^{+\infty} d x \psi_{E_{1}}^{*}(x) \psi_{E_{2}}(x)=\delta\left(E_{1}\right.$ $\left.-E_{2}\right)$.
The second Hamiltonian of the pair is

$$
H^{\prime}=p^{2}+e^{2 x}+e^{x},
$$

and the allowed spectrum is $0<E<\infty$, excluding zero energy. ${ }^{5}$ The $E>0$ eigenfunctions are then

$$
\begin{aligned}
\psi_{E}^{\prime}(x)= & {\left[\frac{1}{4 \pi^{2} \sqrt{E}} e^{x} \cosh (\pi \sqrt{E})\right]^{1 / 2} } \\
& \times\left[i K_{1 / 2-i \sqrt{E}}\left(e^{x}\right)-i K_{1 / 2+i \sqrt{E}}\left(e^{x}\right)\right],
\end{aligned}
$$

and may be obtained from the previous $E>0$ eigenfunctions, as $\psi_{E}^{\prime}(x)=(1 / \sqrt{E})\left(\partial_{x}+W\right) \psi_{E}(x)$.

For both Hamiltonians, the Wigner functions are straightforward to construct directly, once again leading to the $K$ transform (92) and particular Meijer $G$ functions. We find it sufficient here to consider only the ground state for $H$,

$$
f_{0}(x, p)=\frac{1}{2 \pi^{2}} \int_{-\infty}^{+\infty} d y e^{-2 e^{x} \cosh (y / 2)-i y p}=\frac{2}{\pi^{2}} K_{2 i p}\left(2 e^{x}\right),
$$

a single modified Bessel function. It smoothly [29] satisfies $[p-i W(x)] \star f_{0}=0$ and, hence, the $\star$-genvalue equation $H \star f_{0}=0$.

\section{ACKNOWLEDGMENTS}

We thank Y. Hosotani for helpful discussions. This work was supported in part by NSF Grant No. PHY 9507829 and by the U.S. Department of Energy, Division of High Energy Physics, Contract No. W-31-109-ENG-38.

${ }^{5}$ The candidate $\psi_{0}^{\prime}(x)=1 / \psi_{0}(x)=\sqrt{\pi} \exp \left(e^{x}\right)$ solves the Schrödinger equation, but is obviously unbounded, as expected.
[1] M. Hillery, R. O'Conell, M. Scully, and E. Wigner, Phys. Rep. 106, 121 (1984); H.-W. Lee, ibid. 259, 147 (1995); N. Balasz and B. Jennings, ibid. 104, 347 (1984); R. Littlejohn, ibid. 138, 193 (1986); T. Curtright, D. Fairlie, and C. Zachos, Phys. Lett. B 405, 37 (1997); D. Fairlie, Mod. Phys. Lett. A 13, 263 (1998).

[2] E. Wigner, Phys. Rev. 40, 749 (1932).

[3] J. Moyal, Proc. Cambridge Philos. Soc. 45, 99 (1949).

[4] J. Vey, Comments Math. Helvet. 50, 412 (1975); M. Flato, A. Lichnerowicz, and D. Sternheimer, J. Math. Phys. 17, 1754
(1976); M. de Wilde and P. Lecomte, Lett. Math. Phys. 7, 487 (1983); P. Fletcher, Phys. Lett. B 248, 323 (1990).

[5] F. Bayen, M. Flato, C. Fronsdal, A. Lichnerowicz, and D. Sternheimer, Ann. Phys. (N.Y.) 111, 61 (1978); 111, 111 (1978).

[6] G. Baker, Phys. Rev. 109, 2198 (1958).

[7] D. Fairlie, Proc. Cambridge Philos. Soc. 60, 581 (1964); D. Fairlie and C. Manogue, J. Phys. A 24, 3807 (1991).

[8] F. Hansen, Publ. RIMS Kyoto Univ. 26, 885 (1990).

[9] I. Oppenheim and J. Ross, Phys. Rev. 107, 28 (1957); aiso see 
K. Imre et al., J. Math. Phys. 8, 1097 (1967)

[10] K. Takahashi, Prog. Theor. Phys. Suppl. 98, 109 (1989); J. Dahl, in Energy Storage and Redistribution, edited by J. Hinze (Plenum, New York, 1983), pp. 557-571; L. Cohen, J. Math. Phys. 17, 1863 (1976); W. Kundt, Z. Naturforsch. 22A, 1333 (1967).

[11] H. Groenewold, Physica (Amsterdam) 12, 405 (1946); this work may well be the first to define the * product, under a different name. M. Bartlett and J. Moyal, Proc. Cambridge Philos. Soc. 45, 545 (1949).

[12] T. Curtright and G. Ghandour, in Quantum Field Theory, Statistical Mechanics, Quantum Groups, and Topology, edited by T. Curtright, L. Mezincescu, and R. Nepomechie (World Scientific, Singapore, 1992), pp. 333-335 [hep-th/9503080].

[13] S. Habib, Phys. Rev. D 42, 2566 (1990); also see N. Balazs and G. Zipfel, Ann. Phys. (N.Y.) 77, 139 (1973).

[14] G. Darboux, C. R. Hebd. Seances Acad. Sci. 94, 1456 (1882), cited E. L. Ince, Ordinary Differential Equations (Dover, New York, 1926), p. 132; M. M. Crum, Q. J. Math. 6, 121 (1955); P. Deift, Duke Math. J. 45, 267 (1978); E. Witten, Nucl. Phys. B188, 513 (1981); reviewed in F. Cooper, A. Khare, and U. Sukhatme, Phys. Rep. 251, 267 (1995).

[15] G. Pöschl and E. Teller, Z. Phys. 83, 143 (1933).

[16] W. Kwong and J. Rosner, Prog. Theor. Phys. Suppl. 86, 366 (1986).

[17] For a review of the relevant features, consider Appendix $A$ in
T. Curtright, T. Uematsu, and C. Zachos, Nucl. Phys. B469, 488 (1996)

[18] P. Dirac, Phys. Z. Sowjetunion 3, 64 (1933).

[19] T. Curtright and C. Zachos, Phys. Rev. D 49, 5408 (1994).

[20] E. D'Hoker and R. Jackiw, Phys. Rev. D 26, 3517 (1982).

[21] E. Braaten, T. Curtright, G. Ghandour, and C. Thorn, Ann. Phys. (N.Y.) 153, 147 (1984).

[22] A. Erdélyi et al., Higher Transcendental Functions, Bateman Manuscript Project (McGraw-Hill, New York, 1953).

[23] C. Bender and S. Orszag, Advanced Mathematical Methods for Scientists and Engineers (McGraw-Hill, New York, 1978), Chap. 5.

[24] G. Watson, A Treatise on the Theory of Bessel Functions (Cambridge University Press, Cambridge, England, 1966).

[25] Handbook of Mathematical Functions, edited by M. Abramowitz and I. Stegun, Natl. Bur. Stand. Appl. Math. Ser. No. 55 (U.S. GPO, Washington, D.C., 1965).

[26] C. Meijer, Proc. K. Ned. Akad. Wet. 43, 702 (1940).

[27] A. Erdélyi et al., Tables of Integral Transforms, Bateman Manuscript Project (McGraw-Hill, New York, 1954).

[28] T. Curtright and G. Ghandour, Phys. Lett. 136B, 50 (1984); also see E. D'Hoker, Phys. Rev. D 28, 1346 (1983).

[29] "To think intellectually is a wonderfully human trait. My dog has no interest in the Associative Law of Multiplication." The Recollections of Eugene P. Wigner, as told to Andrew Szanton (Plenum, New York, 1992), p. 307. 
Modern Physics Letters A, Vol. 16, No. 37 (2001) 2381-2385

(C) World Scientific Publishing Company

\title{
NEGATIVE PROBABILITY AND UNCERTAINTY RELATIONS
}

\author{
THOMAS CURTRIGHT \\ Department of Physics, University of Miami, Box 248046, Coral Gables, FL 33124, USA \\ curtright@physics.miami.edu \\ COSMAS ZACHOS
}

High Energy Physics Division, Argonne National Laboratory, Argonne, IL 60439-4815, USA

zachos@hep.anl.gov

Received 31 October 2001

\begin{abstract}
A concise derivation of all uncertainty relations is given entirely within the context of phase-space quantization, without recourse to operator methods, to the direct use of Weyl's correspondence, or to marginal distributions of $x$ and $p$.
\end{abstract}

Keywords: Uncertainty relations; star product; Wigner functions; phase-space quantization; negative probability.

PACS Nos.: 03.65.Ta, 03.65.Db, 03.65.Fd, 11.15.Kc

Phase-space quantization is the third autonomous and logically complete formulation of quantum mechanics beyond the conventional ones based on operators in Hilbert space or path integrals. ${ }^{1-3}$ It is free of operators and wave functions: observables and matrix elements are computed through phase-space integrals of c-number functions ("classical kernels") weighted by a Wigner function (WF) ${ }^{3,4}$ This is a phase-space distribution function which is not positive semi-definite, and constitutes the Weyl correspondent ${ }^{5}$ of the density matrix in the conventional formulation,

$$
f_{m n}(x, p)=\frac{1}{2 \pi} \int d y e^{-i y p} \psi_{m}^{*}\left(x-\frac{\hbar}{2} y\right) \psi_{n}\left(x+\frac{\hbar}{2} y\right)=f_{n m}^{*}(x, p) .
$$

Operators of the conventional formulation, when properly ordered (e.g. Weylordered), correspond uniquely to phase-space classical kernel functions, while operator products correspond to $\star$-products ${ }^{6}$ of these classical kernels, the $\star$-product being a noncommutative and associative operation encoding quantum mechanical action. The above wave functions, however, may be forfeited, since the WFs are determined, in principle, as the solutions of the celebrated $\star$-genvalue functional equations. ${ }^{7-10}$ Connections to the original, operator, formulation of quantum mechanics may thus be ignored. 
Recent M-theory advances linked to noncommutative geometry and matrix models ${ }^{11}$ apply space-time uncertainty principles ${ }^{12}$ reliant on phase-space quantization and the $\star$-product. Transverse spatial dimensions act formally as momenta, and, analogously to quantum mechanics, their uncertainty is increased or decreased inversely to the uncertainty of a given direction.

For classical (non-negative) probability distributions, expectation values of nonnegative functions are likewise non-negative, and thus result in standard constraint inequalities for the constituent pieces of such functions. On the other hand, in phase-space quantization, the distribution functions are non-positive-definite, such as, in general, the quasi-probability WF: it was interpreted early on by Bartlett, ${ }^{13}$ and later by Feynman, ${ }^{14}$ as a "negative probability function", with the proper nonnegative marginal probabilities upon projection to either $x$ or $p$ space. Hence, a frequent first question in phase-space quantization is how Heisenberg's standard quantum mechanical uncertainty relation arises for moments of such distributions.

To be sure, Moyal derived these uncertainty relations, in his original formulation of quantum mechanics in phase space, by careful analysis of conditioned and marginal probabilities. Nevertheless, plain evaluations of expectation values of the c-number variables $\left\langle x^{2}\right\rangle,\left\langle p^{2}\right\rangle$, etc., do not evince constraints; and the student of deformation quantization is left wondering how $\hbar$ enters the constraint of such expectation values of (c-number) observables when the variables $x, p$ do not contain $\hbar$. How do their moments manage to constrain each other by extracting $\hbar$ out of the Wigner function?

The answer lies in Groenewold's associative $\star$-product, ${ }^{6}$

$$
\star \equiv e^{i \hbar\left(\overleftarrow{\partial}_{x} \vec{\partial}_{p}-\overleftarrow{\partial}_{p} \vec{\partial}_{x}\right) / 2}
$$

which is the cornerstone of phase-space quantization. Its mechanics is reviewed in Refs. 7, 10 and 15. An alternate, integral, representation of this product is ${ }^{16}$

$$
\begin{aligned}
f \star g= & (\hbar \pi)^{-2} \int d u d v d w d z f(x+u, p+v) g(x+w, p+z) \\
& \times \exp \left(\frac{2 i}{\hbar}(u z-v w)\right)
\end{aligned}
$$

which readily displays associativity. The phase-space trace is directly seen in this representation to obey

$$
\int d p d x f \star g=\int d p d x f g=\int d p d x g \star f .
$$

The WF spectral properties ${ }^{1}$ are reviewed and illustrated in Refs. 8 and 10. For example the trace-normalization condition,

$$
\int d x d p f_{m n}(x, p)=\delta_{m n}
$$


and the spectral orthogonality conditions, ${ }^{7} f_{m n} \star f_{k l}=\delta_{m l} f_{k n} / 2 \pi \hbar$. Given (4), it follows that $\int d x d p f_{m n}(x, p) f_{l k}^{*}(x, p)=\delta_{m l} \delta_{n k} / 2 \pi \hbar$. For complete sets of input wave functions, it also follows that

$$
\sum_{m, n} f_{m n}(x, p) f_{m n}^{*}\left(x^{\prime}, p^{\prime}\right)=\frac{1}{2 \pi \hbar} \delta\left(x-x^{\prime}\right) \delta\left(p-p^{\prime}\right) .
$$

An arbitrary phase-space function $\varphi(x, p)$ can thus be expanded as $\varphi(x, p)=$ $\sum_{m, n} c_{m n} f_{m n}(x, p)$.

Here, a concise proof of all uncertainty relations is provided completely within the autonomous framework of phase-space quantization, unlike extant discussions of such correlation inequalities, which rely on the operator formulation of quantum mechanics. It is stressed that, in the following, no operators occur, only the $\star$-product operation, and $x$ and $p$ are c-numbers. The controlling fact is that expectation values of arbitrary real $\star$-squares are positive semi-definite, even though the Wigner distribution $f(x, p)$ itself is not. Specifically, for any complex phase-space function $g(x, p)$, and any (real) Wigner function $f(x, p)$ representing a pure state, the following inequality holds:

$$
\left\langle g^{*} \star g\right\rangle=\int d p d x\left(g^{*} \star g\right) f \geq 0 .
$$

The $\star$ is absolutely crucial here, and its removal leads to violation of the inequality, as can easily be arranged by choosing the support of $g$ to lie mostly in those regions of phase-space where the Wigner function is negative. (The only pure state WF which is non-negative is the Gaussian. ${ }^{3,8,17}$ ) In Hilbert space operator formalism, this relation (7) would correspond to the positivity of the norm. By (4), $\int d p d x\left(g^{*} \star g\right) f=\int d p d x\left(g^{*} \star g\right) \star f$, i.e. inside a phase-space integral an ordinary product can be extended to a $\star$-product, provided it not be part of a longer string. For example the one $\star$-product of the left-hand side cannot be eliminated, because of the extra ordinary product with $f$.

To prove the inequality ( 7 ), it suffices to recognize that, for a pure state, its (real) Wigner function can be expanded in a complete basis of Wigner $\star$-genfunctions of a convenient Hamiltonian, ${ }^{10} f=\sum_{n, m} c_{m}^{*} c_{n} f_{m n}$, for complex coefficients $c_{n}$, s.t. $\sum_{n}\left|c_{n}\right|^{2}=1$, to satisfy (5). Then, it follows that ${ }^{18,19}$

$$
f \star f=f / h \text {. }
$$

Consequently, given the relations $(4),(g \star f)^{*}=f \star g^{*}$, and the associativity of the «-product,

$$
\begin{aligned}
\int d p d x\left(g^{*} \star g\right) f & =h \int d x d p\left(g^{*} \star g\right)(f \star f) \\
& =h \int d x d p\left(f \star g^{*}\right) \star(g \star f)=h \int d x d p|g \star f|^{2}
\end{aligned}
$$


This expression, then, involves a real non-negative integrand and is itself positive semi-definite. (Similarly, if $f_{1}$ and $f_{2}$ are pure state WFs, the transition probability between the respective states ${ }^{3}$ is also manifestly non-negative by the same argument: $\int d p d x f_{1} f_{2}=(2 \pi \hbar)^{2} \int d x d p\left|f_{1} \star f_{2}\right|^{2}$.)

Given $(7)$, correlations of observables follow conventionally from specific choices of $g(x, p)$. For example, to produce Heisenberg's uncertainty relation, one only need to choose

$$
g=a+b x+c p
$$

for arbitrary complex coefficients $a, b, c$. The resulting positive semi-definite quadratic form is then

$$
\begin{aligned}
& a^{*} a+b^{*} b\langle x \star x\rangle+c^{*} c\langle p \star p\rangle+\left(a^{*} b+b^{*} a\right)\langle x\rangle \\
& \quad+\left(a^{*} c+c^{*} a\right)\langle p\rangle+c^{*} b\langle p \star x\rangle+b^{*} c\langle x \star p\rangle \geq 0,
\end{aligned}
$$

for any $a, b, c$. The eigenvalues of the corresponding matrix are then non-negative, and thus so must be its determinant. Given

$$
x \star x=x^{2}, \quad p \star p=p^{2}, \quad p \star x=p x-i \hbar / 2, \quad x \star p=p x+i \hbar / 2,
$$

and the usual

$$
(\Delta x)^{2} \equiv\left\langle(x-\langle x\rangle)^{2}\right\rangle, \quad(\Delta p)^{2} \equiv\left\langle(p-\langle p\rangle)^{2}\right\rangle,
$$

this condition on the $3 \times 3$ matrix determinant amounts to

$$
(\Delta x)^{2}(\Delta p)^{2} \geq \hbar^{2} / 4+(\langle(x-\langle x\rangle)(p-\langle p\rangle)\rangle)^{2}
$$

and hence

$$
\Delta x \Delta p \geq \hbar / 2 .
$$

The inequality is saturated for a vanishing original integrand $g \star f=0$, for suitable $a, b, c$, and when the last term of (14) vanishes: $x, p$ statistical independence, such as in a Gaussian ground state WF, $f_{00}=2 h \exp \left(-\left(x^{2}+p^{2}\right) / \hbar\right)$.

More general choices of $g$ will likewise constrain as many observables as this function has terms $(-1$, if there is a constant term). For instance, for more general (real) observables $u(x, p), v(x, p)$, the resulting inequality is

$$
\Delta u \Delta v \geq \frac{1}{2} \sqrt{|\langle u \star v-v \star u\rangle|^{2}+\langle(u-\langle u\rangle) \star(v-\langle v\rangle)+(v-\langle v\rangle) \star(u-\langle u\rangle)\rangle^{2}} .
$$

The minimum uncertainty is realized at $\langle u \star v+v \star u\rangle=2\langle u\rangle\langle v\rangle$, with $g \star f=0$ for specific coefficients, i.e.

$$
(\Delta u(v-\langle v\rangle)-k i \Delta v(u-\langle u\rangle)) \star f=0,
$$

where $k$ is the sign of $i\langle u \star v-v \star u\rangle$. Solving such $\star$-equations is elaborated in Refs. 8-10 and 15 . 


\section{Acknowledgment}

This work was supported in part by the U.S. Department of Energy, Division of High Energy Physics, Contract W-31-109-ENG-38, and the NSF Award 0073390.

\section{References}

1. J. Moyal, Proc. Camb. Phil. Soc. 45, 99 (1949).

2. F. Bayen, M. Flato, C. Fronsdal, A. Lichnerowicz and D. Sternheimer, Ann. Phys. 111, 61; 111 (1978).

3. For reviews, see M. Hillery, R. O'Connell, M. Scully and E. Wigner, Phys. Rep. 106, 121 (1984); H.-W. Lee, ibid. 259, 147 (1995); N. Balasz and B. Jennings, ibid. 104, 347 (1984); R. Littlejohn, ibid. 138, 193 (1986); M. Berry, Philos. Trans. R. Soc. London A287, 237 (1977); M. Gadella, Fortschr. Phys. 43, 229 (1995); L. Cohen, Time-Frequency Analysis (Prentice-Hall, 1995); F. Berezin, Sov. Phys. Usp. 23, 763 (1980); P. Carruthers and F. Zachariasen, Rev. Mod. Phys. 55, 245 (1983); A. M. Ozorio de Almeida, Phys. Rep. 295, 265 (1998).

4. E. Wigner, Phys. Rev. 40, 749 (1932).

5. H. Weyl, Z. Phys. 46, 1 (1927); also reviewed in H. Weyl, The Theory of Groups and Quantum Mechanics (Dover, 1931).

6. H. Groenewold, Physica 12, 405 (1946).

7. D. Fairlie, Proc. Camb. Phil. Soc. 60, 581 (1964).

8. T. Curtright, D. Fairlie and C. Zachos, Phys. Rev. D58, 025002 (1998).

9. M. Hug, C. Menke and W. Schleich, Phys. Rev. A57, 3188 (1998).

10. T. Curtright, T. Uematsu and C. Zachos, J. Math. Phys. 42, 2396 (2001), hepth/0011137.

11. N. Seiberg and E. Witten, JHEP 9909, 032 (1999); for a review, see L. Castellani, Class. Quantum Grav. 17, 3377 (2000), hep-th/0005210.

12. T. Yoneya, Mod. Phys. Lett. A4, 1587 (1989); A. Jevicki and T. Yoneya, Nucl. Phys. B535, 335 (1998), hep-th/9805069; N. Seiberg, L. Susskind and N. Toumbas, JHEP 0006, 044 (2000), hep-th/0005015.

13. M. Bartlett, Proc. Camb. Phil. Soc. 41, 71 (1945).

14. R. Feynman, "Negative probability", in Essays in Honor of David Bohm, eds. B. Hiley and F. Peat (Routledge and Kegan Paul, 1987); for a popular review, see D. Leibfried, T. Pfau and C. Monroe, Physics Today, 22 (April 1998).

15. F. Hansen, Rep. Math. Phys. 19, 361 (1984); C. Roger and V. Ovsienko, Russ. Math. Surv. 47, 135 (1992); C. Zachos, J. Math. Phys. 41, 5129 (2000), hep-th/9912238.

16. J. von Neumann, Math. Ann. 104, 570 (1931).

17. R. Hudson, Rep. Math. Phys. 6, 249 (1974).

18. T. Takabayasi, Prog. Theor. Phys. 11, 341 (1954).

19. G. Baker, Phys. Rev. 109, 2198 (1958). 


\section{Generating all Wigner functions}

Thomas Curtright ${ }^{\text {a) }}$

Department of Physics, University of Miami, P.O. Box 248046,

Coral Gables, Florida 33124

Tsuneo Uematsu ${ }^{\text {b) }}$

Department of Fundamental Sciences, FIHS, Kyoto University, Kyoto 606-8501, Japan

Cosmas Zachos ${ }^{\mathrm{c})}$

High Energy Physics Division, Argonne National Laboratory,

Argonne, Illinois 60439-4815

(Received 15 January 2001; accepted for publication 26 February 2001)

In the context of phase-space quantization, matrix elements and observables result from integration of $c$-number functions over phase space, with Wigner functions serving as the quasiprobability measure. The complete sets of Wigner functions necessary to expand all phase-space functions include off-diagonal Wigner functions, which may appear technically involved. Nevertheless, it is shown here that suitable generating functions of these complete sets can often be constructed, which are relatively simple, and lead to compact evaluations of matrix elements. New features of such generating functions are detailed and explored for integer-indexed sets, such as for the harmonic oscillator, as well as continuously indexed ones, such as for the linear potential and the Liouville potential. The utility of such generating functions is illustrated in the computation of star functions, spectra, and perturbation theory in phase space. (C) 2001 American Institute of Physics.

[DOI: $10.1063 / 1.1366327]$

\section{INTRODUCTION}

General phase-space functions $f(x, p)$ and $g(x, p)$ compose noncommutatively through Groenewold's $\star$-product, ${ }^{1}$ which is the unique associative pseudodifferential deformation ${ }^{2}$ of ordinary products:

$$
\star \equiv e^{i \hbar\left(\dot{\partial}_{x} \dot{\partial}_{p}-\dot{\partial}_{p} \dot{\partial}_{x}\right) / 2}
$$

This product is the cornerstone of deformation (phase-space) quantization, ${ }^{2-5}$ as well as applications of matrix models and noncommutative geometry ideas in M-physics. ${ }^{6}$ Its mechanics, however, is not always straightforward.

The practical Fourier representation of this product as an integral kernel has been utilized widely since Baker's ${ }^{7}$ early work,

$$
\begin{aligned}
f \star g= & \frac{1}{\hbar^{2} \pi^{2}} \int \mathrm{d} p^{\prime} \mathrm{d} p^{\prime \prime} \mathrm{d} x^{\prime} \mathrm{d} x^{\prime \prime} f\left(x^{\prime}, p^{\prime}\right) g\left(x^{\prime \prime}, p^{\prime \prime}\right) \\
& \times \exp \left(\frac{-2 i}{\hbar}\left(p\left(x^{\prime}-x^{\prime \prime}\right)+p^{\prime}\left(x^{\prime \prime}-x\right)+p^{\prime \prime}\left(x-x^{\prime}\right)\right)\right) .
\end{aligned}
$$

The determinantal nature of the star product controls the properties of the phase-space trace, ${ }^{8,9}$

\footnotetext{
a)Electronic mail: curtright@physics.miami.edu

b)Electronic mail: uematsu@phys.h.kyoto-u.ac.jp

c)Electronic mail: zachos@hep.anl.gov
}

$0022-2488 / 2001 / 42(6) / 2396 / 20 / \$ 18.00$ 


$$
\int \mathrm{d} p \mathrm{~d} x f \star g=\int \mathrm{d} p \mathrm{~d} x f g=\int \mathrm{d} p \mathrm{~d} x g \star f .
$$

The above-mentioned $\star$-product and phase-space integrals provide the multiplication law and, respectively, the trace in phase-space quantization, ${ }^{3}$ the third autonomous and logically complete formulation of quantum mechanics beyond the conventional formulations based on operators in Hilbert space or path integrals. (This formulation is reviewed in Refs. 2 and 5.) Properly ordered operators (e.g., Weyl-ordered) correspond uniquely to phase-space $c$-number functions (referred to as "classical kernels" of the operators in question); operator products correspond to $\star$-products of their classical kernels; and operator matrix elements, conventionally consisting of traces thereof with the density matrix, correspond to phase-space integrals of the classical kernels with the Wigner function (WF), the Weyl correspondent of the density matrix. ${ }^{5,10}$ The celebrated *-genvalue functional equations determining the Wigner functions ${ }^{8,11}$ and their spectral properties (e.g., projective orthogonality ${ }^{12}$ ) are reviewed and illustrated in Ref. 4.

The functions introduced by Wigner ${ }^{10}$ and Szilard correspond to diagonal elements of the density matrix, but quantum mechanical applications (such as perturbation theory), as well as applications in noncommutative soliton problems ${ }^{13}$ often require the evaluation of off-diagonal matrix elements; they therefore utilize the complete set of diagonal and off-diagonal generalized Wigner functions introduced by Moyal. ${ }^{3}$ For instance, in noncommutative soliton theory, the diagonal WFs are only complete for radial phase-space functions (functions $\star$-commuting with the harmonic oscillator Hamiltonian-the radius squared), whereas deviations from radial symmetry necessitate the complete off diagonal set.

As for any representation problem, the particular features of the $\star$-equations under consideration frequently favor an optimal basis of WFs; but, even in the case of the oscillator, the equations are technically demanding. It is pointed out here, however, that suitable generating functions for them, acting as a transform of these basis sets, often result in substantially simpler and more compact objects, which are much easier to use, manipulate, and intuit. In the following, after some elementary overview of the Weyl correspondence formalism (Sec. II), we illustrate such functions for the harmonic oscillator (Sec. III), which serves as the archetype of WF bases indexed discretely; it turns out that these generating functions amount to the phase-space coherent states for WFs, and also the WFs of coherent state wave functions (Appendix A). Direct applications to first-order perturbation theory are illustrated in Appendix B.

For sets indexed continuously, the generating function may range from a mere Fourier transform, illustrated by the linear potential (Sec. IV), to a less trivial continuous transform we provide for the Liouville potential problem (Sec. V), where the advantage of the transform method comes to cogent evidence.

Throughout our discussion, we provide the typical $\star$-composition laws of such generating functions, as well as applications such as the evaluation of $\star$-exponentials of phase-space functions (Appendix C), or $\star$-versions of modified Bessel functions (technical aspects of integral transforms of which are detailed in Appendix D). Appendix E provides the operator (Weyl-) correspondent to the generating function for the Liouville diagonal WF introduced in Sec V.

\section{OVERVIEW OF GENERAL RELATIONS IN THE WEYL REPRESENTATION}

Without loss of generality, we review basic concepts in two-dimensional phase space, $(x, p)$, as the extension to higher dimensions is straightforward. In addition, we first address discrete spectra, $E_{n}, n=0,1,2,3, \ldots$, and will only later generalize to continuous spectra.

In the Weyl correspondence, ${ }^{14}$ c-number phase-space kernels $a(x, p)$ of suitably ordered operators $\mathcal{A}(\mathcal{X}, \mathcal{P})$ are defined by

$$
a(x, p) \equiv \frac{1}{2 \pi} \int \mathrm{d} y e^{-i y p}\left\langle x-\frac{\hbar}{2} y|\mathcal{A}(\mathcal{X}, \mathcal{P})| x+\frac{\hbar}{2} y\right\rangle .
$$

Conversely, the ordering of these operators is specified through 


$$
\mathcal{A}(\mathcal{X}, \mathcal{P})=\frac{1}{(2 \pi)^{2}} \int \mathrm{d} \tau \mathrm{d} \sigma \mathrm{d} x \mathrm{~d} p a(x, p) \exp (i \tau(\mathcal{P}-p)+i \sigma(\mathcal{X}-x))
$$

An operator product then corresponds to a star-composition of these kernels,

$$
a(x, p) \star b(x, p)=\frac{1}{2 \pi} \int \mathrm{d} y e^{-i y p}\left(x-\frac{\hbar}{2} y|\mathcal{A}(\mathcal{X}, \mathcal{P}) \mathcal{B}(\mathcal{X}, \mathcal{P})| x+\frac{\hbar}{2} y\right)
$$

Moyal $^{3}$ appreciated that the density matrix in this phase-space representation is a Hermitean generalization of the Wigner function:

$$
\begin{aligned}
f_{m n}(x, p) & \equiv \frac{1}{2 \pi} \int \mathrm{d} y e^{-i y p}\left\langle x-\frac{\hbar}{2} y \mid \psi_{n}\right\rangle\left\langle\psi_{m} \mid x+\frac{\hbar}{2} y\right\rangle \\
& =\frac{1}{2 \pi} \int \mathrm{d} y e^{-i y p} \psi_{m}^{*}\left(x-\frac{\hbar}{2} y\right) \psi_{n}\left(x+\frac{\hbar}{2} y\right)=f_{n m}^{*}(x, p),
\end{aligned}
$$

where the $\psi_{m}(x)$ 's are (ortho-) normalized solutions of a Schrödinger problem. (Wigner ${ }^{10}$ mainly considered the diagonal elements of the density matrix (pure states), usually denoted as $f_{m}$ $\equiv f_{m m}$.) As a consequence, matrix elements of operators are produced by mere phase-space integrals, ${ }^{3}$

$$
\left\langle\psi_{m}|\mathcal{A}| \psi_{n}\right\rangle=\int \mathrm{d} x \mathrm{~d} p a(x, p) f_{m n}(x, p) .
$$

The standard machinery of density matrices then is readily transcribed in this language, e.g., the trace relation, ${ }^{3}$

$$
\int \mathrm{d} x \mathrm{~d} p f_{m n}(x, p)=\int \mathrm{d} x \psi_{n}^{*}(x) \psi_{m}(x)=\delta_{m n}
$$

and $^{8}$

$$
f_{m n} \star f_{k l}=\frac{1}{2 \pi \hbar} \delta_{m l} f_{k n}=\frac{1}{h} \delta_{m l} f_{k n}
$$

Given (3), it follows from Eqs. (9) and (10) that ${ }^{3}$

$$
\int \mathrm{d} x \mathrm{~d} p f_{m n}(x, p) f_{l k}^{*}(x, p)=\frac{1}{2 \pi \hbar} \delta_{m l} \delta_{n k}
$$

For complete sets of input wave functions, it also follows that ${ }^{3}$

$$
\sum_{m, n} f_{m n}(x, p) f_{m n}^{*}\left(x^{\prime}, p^{\prime}\right)=\frac{1}{2 \pi \hbar} \delta\left(x-x^{\prime}\right) \delta\left(p-p^{\prime}\right) .
$$

An arbitrary phase-space function $\varphi(x, p)$ can thus be expanded as

$$
\varphi(x, p)=\sum_{m, n} c_{m n} f_{m n}(x, p)
$$

the coefficients being specified through (11),

$$
c_{m n}=2 \pi \hbar \int \mathrm{d} x \mathrm{~d} p f_{m n}^{*}(x, p) \varphi(x, p)
$$


Further note the resolution of the identity, ${ }^{3}$

$$
\sum_{n} f_{n n}(x, p)=\frac{1}{2 \pi \hbar}=\frac{1}{h} .
$$

For instance, for eigenfunctions of the Hamiltonian $\mathcal{H}(\mathcal{X}, \mathcal{P})$ with eigenvalues $E_{n}$, the corresponding WFs satisfy the following star-genvalue equations ${ }^{8}$ (also see Refs. 11 and 4), with $H(x, p)$, the phase-space kernel of $\mathcal{H}(\mathcal{X}, \mathcal{P})$ :

$$
H \star f_{m n}=E_{n} f_{m n}, \quad f_{m n} \star H=E_{m} f_{m n} .
$$

The time dependence of a pure state WF is given by Moyal's dynamical equation: ${ }^{3}$

$$
i \hbar \frac{\partial}{\partial t} f(x, p ; t)=H \star f(x, p ; t)-f(x, p ; t) \star H .
$$

By virtue of the $\star$-unitary evolution operator (a “ $\star$-exponential" ${ }^{2}$ ),

$$
U_{\star}(x, p ; t)=e_{\star}^{i t / \hbar} \equiv 1+(i t / \hbar) H(x, p)+\frac{(i t / \hbar)^{2}}{2 !} H \star H+\frac{(i t / \hbar)^{3}}{3 !} H \star H \star H+\cdots,
$$

the time-evolved WF is obtained formally in terms of the WF at $t=0$,

$$
f(x, p ; t)=U_{\star}^{-1}(x, p ; t) \star f(x, p ; 0) \star U_{\star}(x, p ; t) .
$$

(These associative combinatoric operations completely parallel those of operators in the conventional formulation of quantum mechanics in Hilbert space. ${ }^{15}$ ) Just like any star-function of $H$, this $\star$-exponential can be computed, ${ }^{16}$

$$
\exp _{\star}(i t H / \hbar)=\exp _{\star}(i t H / \hbar) \star 1=\exp _{\star}(i t H / \hbar) \star 2 \pi \hbar \sum_{n} f_{n n}=2 \pi \hbar \sum_{n} e^{i t E_{n} / \hbar} f_{n n} .
$$

(Of course, for $t=0$, the obvious identity resolution is recovered.)

For continuous spectra, the sums in the above-mentioned relations extend to integrals over a continuous parameter (the energy), and the Kronecker $\delta_{m n}$ 's into $\delta$-functions (these last ones reflecting the infinite normalizations of unnormalizable states). For example, Eqs. (9) and (11) extend to

$$
\begin{gathered}
\int \mathrm{d} x \mathrm{~d} p f_{E_{1} E_{2}}(x, p)=\delta\left(E_{1}-E_{2}\right), \\
\int \mathrm{d} x \mathrm{~d} p f_{E_{1} E_{2}}(x, p) f_{E_{1}^{\prime} E_{2}^{\prime}}^{*}(x, p)=\frac{1}{2 \pi \hbar} \delta\left(E_{1}-E_{1}^{\prime}\right) \delta\left(E_{2}-E_{2}^{\prime}\right) .
\end{gathered}
$$

Completeness (12) extends to

$$
\int \mathrm{d} E_{1} \mathrm{~d} E_{2} f_{E_{1} E_{2}}(x, p) f_{E_{1} E_{2}}^{*}\left(x^{\prime}, p^{\prime}\right)=\frac{1}{2 \pi \hbar} \delta\left(x-x^{\prime}\right) \delta\left(p-p^{\prime}\right) .
$$

More generally, (10) extends to

$$
f_{E_{1} E_{2}} \star f_{E_{1}^{\prime} E_{2}^{\prime}}=\frac{1}{2 \pi \hbar} \delta\left(E_{1}-E_{2}^{\prime}\right) f_{E_{1}^{\prime} E_{2}} .
$$

Finally, Eq. (15) extends to 


$$
\frac{1}{2 \pi \hbar}=\frac{1}{2 \pi} \int \mathrm{d} y e^{-i p y} \int \mathrm{d} E\left\langle x-\frac{\hbar y}{2} \mid E\right\rangle\left\langle E \mid x+\frac{\hbar y}{2}\right\rangle=\int \mathrm{d} E f_{E E}(x, p),
$$

and hence (20) extends to

$$
\exp _{\star}(i t H / \hbar)=2 \pi \hbar \int \mathrm{d} E e^{i t E / \hbar} f_{E E}(x, p) .
$$

\section{GENERATING FUNCTIONS FOR THE HARMONIC OSCILLATOR}

Consider the harmonic oscillator,

$$
H(x, p)=\frac{1}{2}\left(p^{2}+x^{2}\right),
$$

where, without loss of generality, parameters have been absorbed in the phase space variables: $m=1, \omega=1$. Further recall that the normalized eigenfunctions of the corresponding operator Hamiltonian $\mathcal{H}$ are $\psi_{n}(x)=\left(\sqrt{\pi} 2^{n} n !\right)^{-1 / 2} e^{-(1 / 2) x^{2}} H_{n}(x)$, for the eigenvalues $E_{n}=\hbar(n+1 / 2)$. Define a radial and an angular variable,

$$
z=4 H=2\left(x^{2}+p^{2}\right), \quad \tan \theta=\frac{p}{x},
$$

so that

$$
a \sqrt{2} \equiv(x+i p)=|x+i p| e^{i \theta}=\left(\frac{z}{2}\right)^{1 / 2} e^{i \theta} .
$$

Groenewold, ${ }^{1}$ as well as Bartlett and Moyal, ${ }^{17}$ have worked out the complete sets of solutions to Moyal's time-evolution equation (17), which are all linear combinations of terms $\exp (i t(m$ $-n)) f_{m n}$. They solved that equation indirectly, by evaluating the integrals (7) for time-dependent Hermite wave functions, which yield generalized Laguerre polynomial-based functions. More directly, Fairlie ${ }^{8}$ dramatically simplified the derivation of the solution by relying on his fundamental equation (16). He thus confirmed Groenewold's WFs, ${ }^{1,17}$

$$
f_{m n}(x, p)=\frac{(-1)^{m}}{\pi} \sqrt{\frac{m !}{n !}} z^{(n-m) / 2} e^{-z / 2} e^{i(n-m) \theta} L_{m}^{n-m}(z) .
$$

The special case of diagonal elements,

$$
f_{n} \equiv f_{n n}=\frac{(-1)^{n}}{\pi} e^{-z / 2} L_{n}(z),
$$

constitutes the time-independent " $\star$-genfunctions" of the oscillator hamiltonian kernel ${ }^{4}$ [i.e., the complete set of solutions of the time-independent Moyal equation $H \star f-f \star H=0$, where $H \star f_{n}$ $=E_{n} f_{n}$. Incidentally, (10) restricted to diagonal WFs closes them under $\star$-multiplication, ${ }^{12}$ $f_{m} \star f_{n}=\delta_{m n} f_{m} /(2 \pi \hbar)$.] That is to say, "radially symmetric" phase-space functions, i.e., functions that only depend on $z$ but not $\theta$, can be expanded in terms of merely these diagonal elements-unlike the most general functions in phase space which require the entire set of offdiagonal $f_{m n}$ above for a complete basis. Note, however, that all $\star$-products of such radially symmetric functions are commutative, since, manifestly,

$$
\sum_{n} c_{n} f_{n} \star \sum_{m} d_{m} f_{m}=\sum_{m} d_{m} f_{m} \star \sum_{n} c_{n} f_{n}
$$


Moreover, the $\star$-exponential (20) for this set of $\star$-genfunctions is directly seen to amount to

$$
\exp _{\star}(i t H / \hbar)=\left(\cos \left(\frac{t}{2}\right)\right)^{-1} \exp \left(\frac{2 i}{\hbar} H \tan \left(\frac{t}{2}\right)\right)
$$

which is, to say, a Gaussian in phase space. ${ }^{2}$ As an application, note that the hyperbolic tangent $\star$-composition law of Gaussians follows trivially, since these amount to $\star$-exponentials with additive time intervals, $\exp _{\star}(t f) \star \exp _{\star}(T f)=\exp _{\star}((t+T) f),{ }^{2}$

$$
\exp \left(-\frac{a}{\hbar}\left(x^{2}+p^{2}\right)\right) \star \exp \left(-\frac{b}{\hbar}\left(x^{2}+p^{2}\right)\right)=\frac{1}{1+a b} \exp \left(-\frac{a+b}{\hbar(1+a b)}\left(x^{2}+p^{2}\right)\right) .
$$

We now introduce the following generating function for the entire set of generalized Wigner functions:

$$
G(\alpha, \beta ; x, p) \equiv \sum_{m, n} \frac{\alpha^{m}}{\sqrt{m !}} \frac{\beta^{n}}{\sqrt{n !}} f_{m n}=\frac{1}{\pi} \sum_{n} \beta^{n} \frac{1}{n !} z^{n / 2} e^{-z / 2} e^{i n \theta} \sum_{m}\left(-z^{-i / 2} e^{-i \theta} \alpha\right)^{m} L_{m}^{n-m}(z)
$$

Utilizing the identity ${ }^{18} 8.975 .2$,

$$
\sum_{m=0}^{\infty} L_{m}^{n-m}(z) k^{m}=e^{-z k}(1+k)^{n}
$$

we obtain

$$
\begin{aligned}
G(\alpha, \beta ; x, p) & =\frac{1}{\pi} e^{-z / 2} \sum_{n} \frac{1}{n !}\left(\beta \sqrt{z} e^{i \theta}\right)^{n} e^{-z\left(-z^{-1 / 2} e^{-i \theta} \alpha\right)}\left(1-z^{-1 / 2} e^{-i \theta} \alpha\right)^{n} \\
& =\frac{1}{\pi} e^{-z / 2} \sum_{n} \frac{1}{n !}\left(\beta \sqrt{z} e^{i \theta}-\alpha \beta\right)^{n} e^{\sqrt{z} e^{-i \theta} \alpha}=\frac{1}{\pi} e^{-z / 2} e^{\beta \sqrt{z} e^{i \theta}-\alpha \beta} e^{\sqrt{z} e^{-i \theta} \alpha} .
\end{aligned}
$$

Thus,

$$
G(\alpha, \beta ; x, p)=\frac{1}{\pi} \exp \left(\sqrt{z}\left(\alpha e^{-i \theta}+\beta e^{i \theta}\right)-\alpha \beta-\frac{z}{2}\right)
$$

Since

$$
\sqrt{z}\left(\alpha e^{-i \theta}+\beta e^{i \theta}\right)=\sqrt{2}(\alpha+\beta) x-\sqrt{2} i p(\alpha-\beta),
$$

one can re-express:

$$
G(\alpha, \beta ; x, p)=G^{*}(\beta, \alpha ; x, p)=\frac{1}{\pi} \exp \left(\alpha \beta-\left(x-\frac{\alpha+\beta}{\sqrt{2}}\right)^{2}-\left(p+i \frac{\alpha-\beta}{\sqrt{2}}\right)^{2}\right) .
$$

As the name implies, from $G(\alpha, \beta ; x, p)$, the $f_{m n}$ 's are generated by

$$
f_{m n}(x, p)=\left.\frac{1}{\sqrt{m ! n !}} \frac{\partial^{m}}{\partial \alpha^{m}} \frac{\partial^{n}}{\partial \beta^{n}} G(\alpha, \beta ; x, p)\right|_{\alpha=\beta=0}
$$

These functions $\star$-compose as 


$$
G(\alpha, \beta) \star G(\epsilon, \zeta)=\frac{e^{\alpha \zeta}}{2 \pi \hbar} G(\epsilon, \beta)
$$

The phase-space trace is

$$
\int \mathrm{d} x \mathrm{~d} p G(\alpha, \beta)=e^{\alpha \beta} .
$$

By (16), the action of the Hamiltonian kernel on this function is

$$
H \star G=\hbar\left(\frac{1}{2}+\beta \frac{\partial}{\partial \beta}\right) G=\hbar\left(\frac{1}{2}-\alpha \beta+\beta \sqrt{z} e^{i \theta}\right) G,
$$

and

$$
G \star H=\hbar\left(\frac{1}{2}+\alpha \frac{\partial}{\partial \alpha}\right) G=\hbar\left(\frac{1}{2}-\alpha \beta+\alpha \sqrt{z} e^{-i \theta}\right) G
$$

Consequently,

$$
\int \mathrm{d} x \mathrm{~d} p H \star G(\alpha, \beta)=\hbar\left(\frac{1}{2}+\beta \frac{\partial}{\partial \beta}\right) e^{\alpha \beta}=\hbar\left(\frac{1}{2}+\alpha \beta\right) e^{\alpha \beta} .
$$

The spectrum then follows by operating on both sides of this equation,

$$
E_{n}=\left.\frac{1}{n !} \frac{\partial^{n}}{\partial \alpha^{n}} \frac{\partial^{n}}{\partial \beta^{n}} \int \mathrm{d} x \mathrm{~d} p H \star G(\alpha, \beta)\right|_{\alpha=\beta=0}=\left.\frac{\hbar}{n !} \frac{\partial^{n}}{\partial \alpha^{n}} \frac{\partial^{n}}{\partial \beta^{n}}\left(\frac{1}{2}+\alpha \beta\right) e^{\alpha \beta}\right|_{\alpha=\beta=0}=\hbar\left(\frac{1}{2}+n\right) .
$$

In general, matrix elements of operators may be summarized compactly through this generating function in phase space.

This generating function could be interpreted as a phase-space coherent state, or the offdiagonal WF of coherent states, as discussed in Appendix $\mathrm{A},{ }^{19}$

$$
\begin{gathered}
G(\alpha, \beta ; x, p)=\exp _{\star}\left(\beta a^{\dagger}\right) f_{0} \exp _{\star}(\alpha a), \\
a \star G(\alpha, \beta)=\hbar \beta G(\alpha, \beta), \quad a^{\dagger} \star G(\alpha, \beta)=\frac{\partial}{\partial \beta} G(\alpha, \beta), \\
G(\alpha, \beta) \star a=\frac{\partial}{\partial \alpha} G(\alpha, \beta), \quad G(\alpha, \beta) \star a^{\dagger}=\hbar \alpha G(\alpha, \beta),
\end{gathered}
$$

and hence Eqs. (44) and (45) amount to

$$
\begin{aligned}
& H \star G(\alpha, \beta)=\left(a^{\dagger} \star a+\frac{\hbar}{2}\right) \star G(\alpha, \beta)=\hbar\left(\beta \frac{\partial}{\partial \beta}+\frac{1}{2}\right) G(\alpha, \beta), \\
& G(\alpha, \beta) \star H=G(\alpha, \beta) \star\left(a^{\dagger} \star a+\frac{\hbar}{2}\right)=\hbar\left(\alpha \frac{\partial}{\partial \alpha}+\frac{1}{2}\right) G(\alpha, \beta) .
\end{aligned}
$$

This formalism finds application in, e.g., perturbation theory in phase space, cf. Appendix B. 


\section{GENERATING FUNCTIONS FOR THE LINEAR POTENTIAL}

The linear potential in phase space has been addressed ${ }^{11}$ (also see Refs. 19 and 4). We shall adopt the simplified conventions of Ref. 4 , i.e., $m=1 / 2, \hbar=1$. The Hamiltonian kernel is then

$$
H(x, p)=p^{2}+x,
$$

and the eigenfunctions of $\mathcal{H}$ are Airy functions,

$$
\psi_{E}(x)=\frac{1}{2 \pi} \int_{-\infty}^{+\infty} \mathrm{d} X e^{i X\left(E-x-X^{2} / 3\right)}=\mathrm{Ai}(x-E),
$$

indexed by the continuous energy $E$. The spectrum being continuous, the Airy functions are not square integrable, but have continuum normalization, $\int \mathrm{d} x \psi_{E_{1}}^{*}(x) \psi_{E_{2}}(x)=\delta\left(E_{1}-E_{2}\right)$, instead. Thus, (21) et seq. are now operative. The generalized WFs are ${ }^{i l}$

$$
\begin{aligned}
f_{E_{1} E_{2}}(x, p) & =\frac{1}{4 \pi^{2}} \int \mathrm{d} z \exp \left(i z\left(\frac{E_{1}+E_{2}}{2}-x-p^{2}-z^{2} / 12\right)\right) \exp \left(i p\left(E_{1}-E_{2}\right)\right) \\
& =\exp \left(i p\left(E_{1}-E_{2}\right)\right) \frac{2^{2 / 3}}{2 \pi} \mathrm{Ai}\left(2^{2 / 3}\left(x+p^{2}-\frac{E_{1}+E_{2}}{2}\right)\right)
\end{aligned}
$$

The $\star$-exponential (26) then is again a plain exponential of the shifted Hamiltonian kernel,

$$
\exp _{\star}\left(i t\left(x+p^{2}\right)\right)=2 \pi \int_{-\infty}^{\infty} \mathrm{d} E e^{i E t} \frac{2^{2 / 3}}{2 \pi} \mathrm{Ai}\left(2^{2 / 3}\left(x+p^{2}-\frac{E_{1}+E_{2}}{2}\right)\right)=\exp \left(i t\left(x+p^{2}+t^{2} / 12\right)\right) .
$$

(Thts could also be derived directly, as the CBH expansion simplifies dramatically in this case, cf. Appendix C.) As before, the $\star$-composition law for plain exponentials of the hamiltonian kernel function follows,

$$
\exp \left(a\left(x+p^{2}\right)\right) \star \exp \left(b\left(x+p^{2}\right)\right)=\exp \left((a+b)\left(x+p^{2}-\frac{1}{4} a b\right)\right)
$$

Since the complete basis Wigner functions are now indexed continuously, a generating function for them must rely on an integral instead of an infinite sum. The simplest transform is possibly a double Fourier transform with respect to the energy indices [but note the transform factors $\exp \left(i E_{1} X\right), \exp \left(-i E_{2} Y\right)$ may also be regarded as plane waves]. Suitably normalized,

$$
\begin{aligned}
G(X, Y ; x, p) & \equiv 2 \pi \int_{-\infty}^{+\infty} \mathrm{d} E_{1} \int_{-\infty}^{+\infty} \mathrm{d} E_{2}\left(\frac{1}{\sqrt{2 \pi}} e^{i E_{1} X}\right) f_{E_{1} E_{2}}(x, p)\left(\frac{1}{\sqrt{2 \pi}} e^{-i E_{2} Y}\right) \\
& =\frac{1}{2 \pi} \int_{-\infty}^{+\infty} \mathrm{d} E_{1} \int_{-\infty}^{+\infty} \mathrm{d} E_{2} e^{i\left(E_{1}-E_{2}\right) p+i E_{1} X-i E_{2} Y 2^{2 / 3}} \mathrm{Ai}\left(2^{2 / 3}\left(x+p^{2}-\frac{E_{1}+E_{2}}{2}\right)\right) \\
& =\frac{1}{2 \pi} \int_{-\infty}^{+\infty} \mathrm{d} E \int_{-\infty}^{+\infty} \mathrm{d} \omega e^{i \omega p+i(E+\omega / 2) X-i(E-\omega / 2) Y} 2^{2 / 3} \mathrm{Ai}\left(2^{2 / 3}\left(x+p^{2}-E\right)\right) \\
& =\delta\left(p+\frac{X+Y}{2}\right) \int_{-\infty}^{+\infty} \mathrm{d} E e^{i E(X-Y)} 2^{2 / 3} \mathrm{Ai}\left(2^{2 / 3}\left(x+p^{2}-E\right)\right) \\
& =\delta\left(p+\frac{X+Y}{2}\right) \int_{-\infty}^{+\infty} \mathrm{d} E e^{i E(X-Y)} \frac{1}{2 \pi} \int \mathrm{d} z e^{i z\left(E-x-p^{2}-z^{2 / 12)}\right.}
\end{aligned}
$$




$$
=\delta\left(p+\frac{X+Y}{2}\right) e^{i(X-Y)\left(x+p^{2}+(X-Y)^{2} / 12\right)} .
$$

The phase-space trace is

$$
\int \mathrm{d} x \mathrm{~d} p G(X, Y ; x, p)=2 \pi \delta(X-Y),
$$

and, given (24) for these functions, $f_{E_{1} E_{2}} \star f_{E_{1}^{\prime} E_{2}^{\prime}}=(1 / 2 \pi) \delta\left(E_{1}-E_{2}^{\prime}\right) f_{E_{1}^{\prime} E_{2}}$, the $\star$-composition law for these $G$ 's is

$$
G(X, Y ; x, p) \star G(W, Z ; x, p)=\delta(X-Z) G(W, Y ; x, p) .
$$

\section{GENERATING FUNCTIONS FOR THE LIOUVILLE POTENTIAL}

A less trivial system with a continuous spectrum is the Hamiltonian with the Liouville potential. ${ }^{20,21}$ In the conventions of Ref. $4(\hbar=1, m=1 / 2)$, the Hamiltonian kernel is

$$
H=p^{2}+e^{2 x},
$$

and the eigenfunctions of the corresponding $\mathcal{H}$ are

$$
\psi_{E}(x)=\psi_{E}^{*}(x)=\frac{1}{\pi} \sqrt{\sinh (\pi \sqrt{E})} K_{i \sqrt{E}}\left(e^{x}\right),
$$

with continuum normalizations $\int \mathrm{d} x \psi_{E_{1}}^{*}(x) \psi_{E_{2}}(x)=\delta\left(E_{1}-E_{2}\right)$. The modified Bessel function (Ref. 22, Chap. VI, Sec. 6.22) can be written in the Heine-Schläfli form,

$$
K_{i p}\left(e^{x}\right)=\frac{1}{2} \int_{-\infty}^{\infty} \mathrm{d} X \exp \left(-e^{x} \cosh X+i X p\right)=K_{-i p}\left(e^{x}\right) .
$$

The nondiagonal WF is then

$$
f_{E_{1} E_{2}}(x, p)=\frac{1}{\pi^{3}} \int \mathrm{d} y e^{-2 i p y} \sqrt{\sinh \left(\pi \sqrt{E_{1}}\right)} K_{i \sqrt{E_{1}}}^{*}\left(e^{x-y}\right) \sqrt{\sinh \left(\pi \sqrt{E_{2}}\right)} K_{i \sqrt{E_{2}}}\left(e^{x+y}\right) .
$$

This Wigner function amounts to Meijer's $G$ function,

$$
\begin{aligned}
f_{E_{1} E_{2}}(x, p)= & \frac{1}{8 \pi^{3}} \sqrt{\sinh \left(\pi \sqrt{E_{1}}\right) \sinh \left(\pi \sqrt{E_{2}}\right)} \\
& \times G_{04}^{40}\left(\frac{e^{4 x}}{16} \mid \frac{i p+i \sqrt{E_{1}}}{2}, \frac{i p-i \sqrt{E_{1}}}{2}, \frac{-i p+i \sqrt{E_{2}}}{2}, \frac{-i p-i \sqrt{E_{2}}}{2}\right) .
\end{aligned}
$$

Alternatively, the WF may be written as a double integral representation,

$$
\begin{aligned}
f_{E(k) E(q)}(x, p)= & \frac{1}{2 \pi^{3}} \sqrt{\sinh (\pi \sqrt{E(k)}) \sinh (\pi \sqrt{E(q)})} \\
& \times \int \mathrm{d} X \mathrm{~d} Y e^{i k X} e^{i q Y}\left(\frac{\cosh Y}{\cosh X}\right)^{i p} K_{2 i p}\left(e^{x} \sqrt{4 \cosh X \cosh Y}\right),
\end{aligned}
$$

where $E(k) \equiv k^{2}, E(q) \equiv q^{2}$. This is an inverse integral transform, as in Sec. IV, of a generating function 


$$
\begin{aligned}
G(X, Y ; x, p) & \equiv \int_{-\infty}^{\infty} \frac{\mathrm{d} k}{\sqrt{\sinh (\pi \sqrt{E(k)})}} \int_{-\infty}^{\infty} \frac{\mathrm{d} q}{\sqrt{\sinh (\pi \sqrt{E(q)})}} e^{-i k X} e^{-i q Y} f_{E(k) E(q)}(x, p) \\
& =\frac{2}{\pi}\left(\frac{\cosh Y}{\cosh X}\right)^{i p} K_{2 i p}\left(e^{x} \sqrt{4 \cosh X \cosh Y}\right)=G^{*}(Y, X ; x, p) .
\end{aligned}
$$

The form and construction of this $G$ are consequences of (61), as detailed in Appendix D.

However, the $\star$-composition law of this particular generating function is not so straightforward. It is singular, as a consequence of the general relation (24) and the behavior of the integrand in (65) as $k, q \rightarrow 0$.

The singularity may be controlled by regulating the $\star$-product through imaginary shifts in the momenta,

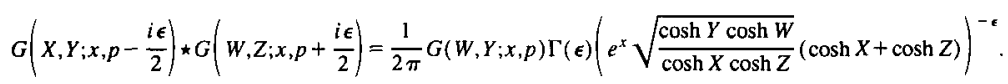

It follows that one derivative with respect to either of $X$ or $Z$ suffices to eliminate the divergence at $\epsilon=0$,

$$
\begin{gathered}
\lim _{\epsilon \rightarrow 0} \partial_{X} G\left(X, Y ; x, p-\frac{i \epsilon}{2}\right) \star G\left(W, Z ; x, p+\frac{i \epsilon}{2}\right) \\
=\frac{1}{2 \pi} G(W, Y ; x, p)\left(-\partial_{X}\right) \ln \left(e^{x} \sqrt{\frac{\cosh Y \cosh W}{\cosh X \cosh Z}}(\cosh X+\cosh Z)\right) \\
=\frac{1}{2 \pi} G(W, Y ; x, p)\left(\frac{1}{2} \tanh X-\frac{\sinh X}{\cosh X+\cosh Z}\right)
\end{gathered}
$$

Unlike the situation in (58), here the right-hand side vanishes at $X=Z$. More symmetrically,

$$
\lim _{\varepsilon \rightarrow 0} \partial_{X} G\left(X, Y ; x, p-\frac{i \epsilon}{2}\right) \star \partial_{W} G\left(W, Z ; x, p+\frac{i \epsilon}{2}\right)=\frac{1}{2 \pi} \partial_{W} G(W, Y ; X, p)\left\{\frac{1}{2} \tanh X-\frac{\sinh X}{\cosh X+\cosh Z}\right\}
$$

By some contrast to the above, Eq. (65), an alternate generating function for just the diagonal WFs, $f_{E E} \equiv f_{E}$, could be defined through the spectral resolution of the $\star-K$ function,

$$
\mathcal{G}(z ; x, p) \equiv K_{\star i \sqrt{H(x, p)}}\left(e^{z}\right)=2 \pi \int_{0}^{\infty} \mathrm{d} E K_{i \sqrt{E}}\left(e^{z}\right) f_{E}(x, p)
$$

This can be evaluated by reliance on Macdonald's trilinear identity, ${ }^{22,23}$

$$
\int_{0}^{\infty} \mathrm{d} E K_{i \sqrt{E}}\left(e^{z}\right) \psi_{E}(x) \psi_{E}^{*}(y)=\frac{1}{2} \exp \left(-\frac{1}{2}\left(e^{x+y-z}+e^{x-y+z}+e^{-x+y+z}\right)\right)
$$

$\mathcal{G}$ then is obtained by replacing $x \rightarrow x+Y$ and $y \rightarrow x-Y$, and Fourier transforming by $(1 / \pi) \int \mathrm{d} Y e^{-2 i p Y}$, 


$$
\int_{0}^{\infty} \mathrm{d} E K_{i \sqrt{E}}\left(e^{z}\right) f_{E}(x, p)=\frac{1}{2 \pi} \int \mathrm{d} Y e^{-2 i p Y} \exp \left(-\frac{1}{2}\left(e^{2 x-z}+e^{z+2 Y}+e^{z-2 Y}\right)\right) .
$$

Finally, simplifying the right-hand side gives

$$
\begin{aligned}
2 \pi \int_{0}^{\infty} \mathrm{d} E K_{i \sqrt{E}}\left(e^{z}\right) f_{E}(x, p) & =\exp \left(-\frac{1}{2} e^{2 x-z}\right) \int \mathrm{d} Y e^{-2 i p Y} \exp \left(-\frac{1}{2} e^{z}\left(e^{2 Y}+e^{-2 Y}\right)\right) \\
& =\exp \left(-\frac{1}{2} e^{2 x-z}\right) K_{i p}\left(e^{z}\right)=\mathcal{G}(z ; x, p) .
\end{aligned}
$$

As a side check of this expression, (69), note that it must satisfy

$$
H \star \mathcal{G}(z ; x, p)=\mathcal{G}(z ; x, p) \star H=\left(-\partial_{z}^{2}+e^{2 z}\right) \mathcal{G}(z ; x, p),
$$

which follows from the spectral resolution evident in (66). Indeed, since $e^{-z} \partial_{z} K_{i p}\left(e^{z}\right)$ $=i p e^{-z} K_{i p}\left(e^{z}\right)-K_{i p+1}\left(e^{z}\right)$, and $\left(-\partial_{z}^{2}+e^{2 z}\right) K_{i p}\left(e^{z}\right)=p^{2} K_{i p}\left(e^{z}\right)$, these relations are satisfied,

$$
\begin{aligned}
\left(p^{2}+e^{2 x}\right) \star\left(\exp \left(-\frac{1}{2} e^{2 x-z}\right) K_{i p}\left(e^{z}\right)\right)= & \left(\exp \left(-\frac{1}{2} e^{2 x-z}\right) K_{i p}\left(e^{z}\right)\right) \star\left(p^{2}+e^{2 x}\right) \\
= & \exp \left(-\frac{1}{2} e^{2 x-z}\right)\left(-e^{2 x-z} \partial_{z} K_{i p}\left(e^{z}\right)\right) \\
& +\left(p^{2}+\frac{1}{2} e^{2 x-z}-\frac{1}{4} e^{4 x-2 z}\right) \exp \left(-\frac{1}{2} e^{2 x-z}\right) K_{i p}\left(e^{z}\right) \\
= & \left(-\partial_{z}^{2}+e^{2 z}\right)\left(\exp \left(-\frac{1}{2} e^{2 x-z}\right) K_{i p}\left(e^{z}\right)\right) .
\end{aligned}
$$

Parenthetically, as an alternative to the ordinary product form in (69), the phase-space kernel $\mathcal{G}$ may also be represented as an integral either of a $\star$-exponential or of a single $\star$-product (Note: Do not shift the integration parameter $y$ by the phase-space variable $x$ before the star products are evaluated.),

$$
\begin{aligned}
\mathcal{G}(z ; x, p) & =\frac{1}{2} \int \mathrm{d} y \exp *\left(-\frac{y}{2 \sinh y} e^{2 x-z}+i y p-e^{z} \cosh y\right) \\
& =\frac{1}{2} \int \mathrm{d} y \exp \left(-\frac{1}{2} e^{y-z} e^{2 x}\right) \star \exp \left(i y p-e^{z} \cosh y\right) .
\end{aligned}
$$

This follows from the identities (cf. Appendix C)

$$
\exp \left(-\frac{y}{2 \sinh y} e^{2 x-z}+i y p\right)=\exp \left(-\frac{1}{2} e^{y-z} e^{2 x}\right) \star \exp (i y p)=\exp \left(-\frac{1}{2} e^{2 x-z}+i y p\right)
$$

The ordinary product form in (69) and the $\star$-exponential form in (72) reveal that $\mathcal{G}(z ; x, p)$ $=\mathcal{G}(z ; x,-p)$, so one may replace exp $(i y p)$ by $\cos (y p)$ in the second line of $(72)$. Given these, there are several ways to verify (70). These relations and the star-product expressions for the kernel in (72) are isomorphic to those of the corresponding operators, as discussed in Appendix E.

The $\star$-composition law of these generating functions follows from (24) and Macdonald's identity,

$$
\mathcal{G}(u ; x, p) \star \mathcal{G}(v ; x, p)=\frac{1}{2} \int \mathrm{d} w \exp \left(-\frac{1}{2}\left(e^{u+v-w}+e^{u-v+w}+e^{-u+v+w}\right)\right) \mathcal{G}(w ; x, p)
$$

This also follows directly from the explicit form (69). Again, this is isomorphic to the corresponding operator composition law given in Appendix E.

From the orthogonality of the $\psi_{E}$ 's, the diagonal WFs may be recovered by inverse transformation, 


$$
f_{E}(x, p)=\int \mathrm{d} z \frac{\sinh (\pi \sqrt{E})}{2 \pi^{3}} K_{i \sqrt{E}}\left(e^{z}\right) \mathcal{G}(z ; x, p) .
$$

This representation and the specific factorized $x, p$-dependence of $\mathcal{G}$ can be of considerable use, e.g., in systematically computing diagonal matrix elements in phase space.

In illustration of the general pattern, consider the first-order energy shift effected by a perturbation Hamiltonian kernel $H_{1}$. It is, cf. Appendix B; Eq. (B11),

$$
\Delta E=\int \mathrm{d} z \mathrm{~d} x \mathrm{~d} p H_{1} \frac{\sinh (\pi \sqrt{E})}{2 \pi^{3}} K_{i \sqrt{E}}\left(e^{z}\right) \mathcal{G}(z ; x, p) .
$$

Choosing

$$
H_{1}=e^{2 n x} e^{i s p / 2},
$$

yields

$$
\Delta E=\frac{\sinh (\pi \sqrt{E})}{2 \pi^{3}} \int \mathrm{d} z K_{i \sqrt{E}}\left(e^{z}\right)\left(\int \mathrm{d} x e^{2 n x} \exp \left(-\frac{1}{2} e^{2 x-z}\right)\right)\left(\int \mathrm{d} p K_{i p}\left(e^{z}\right) e^{i s p / 2}\right) .
$$

Now,

$$
\int \mathrm{d} x e^{2 n x} \exp \left(-\frac{1}{2} e^{2 x-z}\right)=2^{n-1} \Gamma(n) e^{n z},
$$

and hence (Ref. 18, 6.576.4, $a=b$ ),

$$
\begin{aligned}
\int \mathrm{d} z K_{i \sqrt{E}}\left(e^{z}\right) K_{i p}\left(e^{z}\right) e^{n z}= & \frac{2^{n-3}}{\Gamma(n)} \Gamma\left(\frac{n+i \sqrt{E}+i p}{2}\right) \Gamma\left(\frac{n+i \sqrt{E}-i p}{2}\right) \\
& \times \Gamma\left(\frac{n-i \sqrt{E}+i p}{2}\right) \Gamma\left(\frac{n-i \sqrt{E}-i p}{2}\right) .
\end{aligned}
$$

Thus,

$$
\begin{aligned}
\Delta E= & \frac{\sinh (\pi \sqrt{E})}{2 \pi^{3}} 4^{n-2} \int \mathrm{d} p e^{i s p / 2} \Gamma\left(\frac{n+i \sqrt{E}+i p}{2}\right) \\
& \times \Gamma\left(\frac{n+i \sqrt{E}-i p}{2}\right) \Gamma\left(\frac{n-i \sqrt{E}+i p}{2}\right) \Gamma\left(\frac{n-i \sqrt{E}-i p}{2}\right) .
\end{aligned}
$$

Finally (Ref. 18, 6.422.19),

$$
\begin{aligned}
& \int \mathrm{d} p e^{i s p / 2} \Gamma\left(\frac{n+i \sqrt{E}+i p}{2}\right) \Gamma\left(\frac{n+i \sqrt{E}-i p}{2}\right) \Gamma\left(\frac{n-i \sqrt{E}+i p}{2}\right) \Gamma\left(\frac{n-i \sqrt{E}-i p}{2}\right) \\
& =4 \pi G_{22}^{22}\left(e^{s}\left(\begin{array}{c}
\frac{2-n+i \sqrt{E}}{2}, \frac{2-n-i \sqrt{E}}{2} \\
\frac{n+i \sqrt{E}}{2}, \frac{n-i \sqrt{E}}{2}
\end{array}\right) .\right.
\end{aligned}
$$

To sum up, the perturbed energy shift is a Meijer function, 


$$
\Delta E=\frac{4^{n} \sinh (\pi \sqrt{E})}{8 \pi^{2}} G_{22}^{22}\left(e^{s}\left(\begin{array}{c}
\frac{2-n+i \sqrt{E}}{2}, \frac{2-n-i \sqrt{E}}{2} \\
\frac{n+i \sqrt{E}}{2}, \frac{n-i \sqrt{E}}{2}
\end{array}\right) .\right.
$$

In principle, any polynomial perturbation in either $x$ or $p$ can be obtained from this, by differentiation with respect to $n$ and $s$. (Retaining a bit of exponential in $x$ would be helpful to suppress the region of large negative $x$ ).

\section{ACKNOWLEDGMENTS}

We wish to thank D. Fairlie and T. Hakioglu for helpful conversations. This work was supported in part by the US Department of Energy, Division of High Energy Physics, Contract No. W-31-109-ENG-38; NSF Award No. 0073390; and by the Grant-in-Aid for Priority Area No. 707 of the Japanese Ministry of Education. T. U. and T. C. thank Argonne National Laboratory for its hospitality in the summer of 2000 .

\section{APPENDIX A: $\star-F O C K$ SPACE AND COHERENT STATES}

Dirac's Hamiltonian factorization method for algebraic solution of the harmonic oscillator carries through (cf. Ref. 2) intact in $\star$-space. Indeed,

$$
H=\frac{1}{2}(x-i p) \star(x+i p)+\frac{\hbar}{2},
$$

motivating definition of

$$
a \equiv \frac{1}{\sqrt{2}}(x+i p), \quad a^{\dagger} \equiv \frac{1}{\sqrt{2}}(x-i p) .
$$

Thus, noting

$$
a \star a^{\dagger}-a^{\dagger} \star a=\hbar,
$$

and also that, by above,

$$
a \star f_{0}=\frac{1}{\sqrt{2}}(x+i p) \star e^{-\left(x^{2}+p^{2}\right)}=0,
$$

provides a $\star$-Fock vacuum, it is evident that associativity of the $\star$-product permits the entire ladder spectrum generation to go through as usual. The $\star$-genstates of the Hamiltonian, such that $H \star f=f \star H$, are thus

$$
f_{n n}=f_{n}=\frac{1}{n !}\left(a^{\dagger} \star\right)^{n} f_{0}(\star a)^{n} .
$$

These states are real, like the Gaussian ground state, and are thus left-right symmetric $\star$-genstates. They are also transparently $\star$-orthogonal for different eigenvalues; and they project to themselves, as they should, since the Gaussian ground state does, $f_{0} \star f_{0}=f_{0} / 2 \pi \hbar$.

The complete set of generalized WFs can thus be written as

$$
f_{m n}=\frac{1}{\sqrt{n ! m !}}\left(a^{\dagger} \star\right)^{n} f_{0}(\star a)^{m}, \quad m, n=0,1,2,3, \cdots
$$


The standard combinatoric features of conventional Fock space apply separately to left and right (its adjoint) $\star$-multiplication:

$$
\begin{gathered}
a \star f_{n} \equiv a \star f_{n n}=\hbar \sqrt{n} f_{n, n-1}, a^{\dagger} \star a \star f_{n}=\hbar \sqrt{n} a^{\dagger} \star f_{n, n-1}=\hbar n f_{n}, \\
a^{\dagger} \star f_{n} \equiv a^{\dagger} \star f_{n n}=\sqrt{n+1} f_{n, n+1}, \\
a \star a^{\dagger} \star f_{n}=\sqrt{n+1} a \star f_{n, n+1}=\hbar(n+1) f_{n}, \\
f_{n} \star a=\sqrt{n+1} f_{n+1, n}, \\
f_{n} \star a \star a^{\dagger}=\hbar(n+1) f_{n}, \\
f_{n} \star a^{\dagger}=\hbar \sqrt{n} f_{n-1, n}, \quad f_{n} \star a^{\dagger} \star a=\hbar n f_{n} .
\end{gathered}
$$

Furthermore, a left/right (non-self-adjoint) coherent state is naturally defined ${ }^{19,24}$

$$
\Phi(\alpha, \beta)=\exp _{\star}\left(\alpha a^{\dagger}\right) f_{0} \exp _{\star}(\beta a), \quad a \star \Phi(\alpha, \beta)=\alpha \Phi(\alpha, \beta), \quad \Phi(\alpha, \beta) \star a^{\dagger}=\beta \Phi(\alpha, \beta) .
$$

Up to a factor of $\exp \left(\left(|\alpha|^{2}+|\beta|^{2}\right) / 2\right)$, this is also the WF of coherent states $|\alpha\rangle$ and $\langle\beta|{ }^{24}$ As indicated in the text, this coherent state is identifiable with the generating function $G$ for the harmonic oscillator.

\section{APPENDIX B: STATIONARY PERTURBATION THEORY}

Perturbation theory could be carried out in Hilbert space and its resulting wave functions utilized to evaluate the corresponding WF integrals. However, in the spirit of logical autonomy of Moyal's formulation of quantum mechanics in phase space, the perturbed Wigner functions may also be computed $a b$ initio in phase space, ${ }^{17,25}$ without reference to the conventional Hilbert space formulation. The basics are summarized in the following.

As usual, the Hamiltonian kernel decomposes into free and perturbed parts,

$$
H=H_{0}+\lambda H_{1} \text {. }
$$

Fairlie's stationary, real, $\star$-genvalue equations $s^{8,4}$ for the full Hamiltonian,

$$
H(x, p) \star f_{n}(x, p)=f_{n}(x, p) \star H(x, p)=E_{n}(\lambda) f_{n}(x, p),
$$

are solved upon expansion of their components $E$ and $f$ in powers of $\lambda$, the perturbation strength,

$$
\begin{gathered}
E_{n}=E_{n}^{0}+\lambda E_{n}^{1}+\lambda^{2} E_{n}^{2}+\cdots, \\
f_{n}=f_{n}^{0}+\lambda f_{n}^{1}+\lambda^{2} f_{n}^{2}+\cdots .
\end{gathered}
$$

Note the superscripts on $E$ and $f$ are order indices and not exponents. Resolution into individual powers of $\lambda$ yields the real equations:

$$
\begin{gathered}
H_{0} \star f_{n}^{0}=f_{n}^{0} \star H_{0}=E_{n}^{0} f_{n}^{0}, \\
H_{0} \star f_{n}^{1}+H_{1} \star f_{n}^{0}=f_{n}^{1} \star H_{0}+f_{n}^{0} \star H_{1}=E_{n}^{0} f_{n}^{1}+E_{n}^{1} f_{n}^{0}, \\
H_{0} \star f_{n}^{2}+H_{1} \star f_{n}^{1}=f_{n}^{2} \star H_{0}+f_{n}^{1} \star H_{1}=E_{n}^{0} f_{n}^{2}+E_{n}^{1} f_{n}^{1}+E_{n}^{2} f_{n}^{0} .
\end{gathered}
$$

Left multiplication of (B6) by $f_{n}^{0}$ yields

$$
f_{n}^{0} \star H_{0} \star f_{n}^{1}+f_{n}^{0} \star H_{1} \star f_{n}^{0}=E_{n}^{0} f_{n}^{0} \star f_{n}^{1}+E_{n}^{1} f_{n}^{0} \star f_{n}^{0},
$$


and, by (B5),

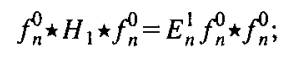

by (11), (10), and the cyclicity of the trace (3),

$$
\int \mathrm{d} x \mathrm{~d} p E_{n}^{1} f_{n}^{0} \star f_{n}^{0}=\int \mathrm{d} x \mathrm{~d} p\left(f_{n}^{0} \star H_{1} \star f_{n}^{0}\right)=\int \mathrm{d} x \mathrm{~d} p\left(H_{1} \star f_{n}^{0} \star f_{n}^{0}\right)=\frac{1}{2 \pi \hbar} \int \mathrm{d} x \mathrm{~d} p H_{1} \star f_{n}^{0} .
$$

Hence,

$$
E_{n}^{1}=\int \mathrm{d} x \mathrm{~d} p H_{1} f_{n}^{0}
$$

the diagonal element of the perturbation. For the off-diagonal elements, similarly left- $\star$-multiply (B6) by $f_{m}^{0}$,

$$
f_{m}^{0} \star H_{0} \star f_{n}^{1}+f_{m}^{0} \star H_{1} \star f_{n}^{0}=E_{n}^{0} f_{m}^{0} \star f_{n}^{1}+E_{n}^{1} f_{m}^{0} \star f_{n}^{0} .
$$

By completeness, $f_{n}^{i}, i \neq 0$, resolves to

$$
f_{n}^{i}=\sum_{k, l} a_{n, k l}^{i} f_{k l}^{0}
$$

the reality condition dictating

$$
a_{n, k l}^{i}=a_{n, l k}^{* i} .
$$

Consequently, by (10),

$$
E_{m}^{0} \sum_{k, l} a_{n, k l}^{1} f_{m}^{0} \star f_{k l}^{0}+f_{m}^{0} \star H_{1} \star f_{n}^{0}=E_{n}^{0} \sum_{k, l} a_{n, k}^{1} f_{m}^{0} \star f_{k l}^{0}+E_{n}^{1} \frac{1}{2 \pi \hbar} f_{n}^{0} \delta_{m n},
$$

and hence

$$
E_{m}^{0} \sum_{k} a_{n, k m}^{1} f_{k m}^{0}+2 \pi \hbar f_{m}^{0} \star H_{1} \star f_{n}^{0}=E_{n}^{0} \sum_{k} a_{n, k m}^{1} f_{k m}^{0}+E_{n}^{1} f_{n}^{0} \delta_{m n}
$$

For $m \neq n$,

$$
\left(E_{n}^{0}-E_{m}^{0}\right) \sum_{l} a_{n, l m}^{1} f_{l m}^{0}=2 \pi \hbar\left(f_{m}^{0} \star H_{1} \star f_{n}^{0}\right)
$$

so that

$$
\sum_{l} a_{n, l m}^{1} f_{l m}^{0}=\frac{2 \pi \hbar\left(f_{m}^{0} \star H_{1} \star f_{n}^{0}\right)}{E_{n}^{0}-E_{m}^{0}}
$$

Finally, use of (11), yields 


$$
\begin{aligned}
a_{n, l m}^{1} & =(2 \pi \hbar)^{2} \int \mathrm{d} x \mathrm{~d} p \frac{f_{m l}^{0} \star f_{m}^{0} \star H_{1} \star f_{n}^{0}}{E_{n}^{0}-E_{m}^{0}} \\
& =(2 \pi \hbar)^{2} \int \mathrm{d} x \mathrm{~d} p \frac{1}{2 \pi \hbar} \frac{f_{m l}^{0} \star H_{1} \star f_{n}^{0}}{E_{n}^{0}-E_{m}^{0}} \\
& =(2 \pi \hbar) \int \mathrm{d} x \mathrm{~d} p \frac{H_{1} \star f_{n}^{0} \star f_{m l}^{0}}{E_{n}^{0}-E_{m}^{0}} \\
& =\frac{\delta_{n l}}{E_{n}^{0}-E_{m}^{0}} \int \mathrm{d} x \mathrm{~d} p H_{1} f_{m n}^{0}, \quad(m \neq n) .
\end{aligned}
$$

We also have the similar equation for $l \neq n$. Consequently, $a_{n, l m}^{1}$ is proportional to the matrix element of the perturbation, and it vanishes unless $l$ or $m$ is equal to $n$. [Note: This differs from Ref. 25, Eq. (45).] To sum up,

$$
\begin{aligned}
f_{n}^{\mathrm{l}}= & \sum_{m \neq n} \frac{1}{E_{n}^{0}-E_{m}^{0}}\left(f_{n m}^{0}\left(\int \mathrm{d} x^{\prime} \mathrm{d} p^{\prime} H_{1}\left(x^{\prime}, p^{\prime}\right) f_{m n}^{0}\left(x^{\prime}, p^{\prime}\right)\right)\right. \\
& \left.+f_{m n}^{0}\left(\int \mathrm{d} x^{\prime} \mathrm{d} p^{\prime} H_{1}\left(x^{\prime}, p^{\prime}\right) f_{n m}^{0}\left(x^{\prime}, p^{\prime}\right)\right)\right) .
\end{aligned}
$$

By (8), it can be seen that the same result may also follow from evaluation of the WF integrals of perturbed wave functions obtained in standard perturbation theory in Hilbert space.

For example, consider $H_{1}=\sqrt{2} x=a+a^{\dagger}$. It follows that $E_{0}^{1}=0$, and

$$
\begin{aligned}
a_{n, l m}^{1} & =\frac{\delta_{n, l}}{\left(E_{n}^{0}-E_{m}^{0}\right)} \iint \mathrm{d} x \mathrm{~d} p f_{m n}^{0} \star\left(a+a^{\dagger}\right) \\
& =\frac{\delta_{n,}}{\left(E_{n}^{0}-E_{m}^{0}\right)} \iint \mathrm{d} x \mathrm{~d} p\left(\sqrt{m+1} f_{m+1, n}^{0}+\sqrt{n+1} f_{m, n+1}^{0}\right) \\
& =\delta_{n, l}\left(\sqrt{m+1} \delta_{m+1, n}-\sqrt{n+1} \delta_{m, n+1}\right),
\end{aligned}
$$

for $m \neq n$, and the $(m \leftrightarrow l)$ expression for $l \neq n$. Hence,

$$
f_{n}^{1}=\sqrt{n}\left(f_{n-1, n}^{0}+f_{n, n-1}^{0}\right)-\sqrt{n+1}\left(f_{n, n+1}^{0}+f_{n+1, n}^{0}\right) .
$$

\section{APPENDIX C: COMBINATORIC DERIVATION OF IDENTITIES (54) AND (73)}

The $\star$-exponential (54) of the Hamiltonian kernel for the linear potential is also easy to work out directly, since the combinatorics in $\star$-space are identical to the combinatorics of any associative algebra. In particular, the Campbell-Baker-Hausdorff expansion also holds for $\star$-exponentials,

$$
\exp _{\star}(A) \star \exp _{\star}(B)=\exp _{\star}\left(A+B+\frac{1}{2}[A, B]_{\star}+\frac{1}{12}\left[A,[A, B]_{\star}\right]_{\star}+\frac{1}{12}\left[[A, B]_{\star}, B\right]_{\star}+C\right),
$$

where $C$ represents a sum of triple or more nested $\star$-commutators (Moyal Brackets, $[A, B]$ * $\equiv A \star B-B \star A)$. Now, choosing $A=i t x$ and $B=i t p^{2}+i t^{2} p+\frac{1}{3} i t^{3}$, yields $[A, B]_{\star}=-2 i t^{2} p$ $-i t^{3},\left[A,[A, B]_{\star}\right]_{\star}=2 i t^{3},\left[[A, B]_{\star}, B\right]_{\star}=0$, and hence $C=0$.

Consequently,

$$
\exp _{\star}(i t x) \star \exp _{\star}\left(i t p^{2}+i t^{2} p+\frac{1}{3} i t^{3}\right)=\exp _{\star}\left(i t x+i t p^{2}\right)
$$

But further note $\exp _{\star}(a x)=\exp (a x)$, and also $\exp _{\star}\left(b p^{2}+c p+d\right)=\exp \left(b p^{2}+c p+d\right)$. This reduces the $\star$-product to a mere translation, 


$$
\begin{aligned}
\exp _{\star}(a x) \star \exp _{\star}\left(b p^{2}+c p+d\right) & =\exp (a x) \star \exp \left(b p^{2}+c p+d\right) \\
& =\exp \left(a x+\frac{1}{2} i a \partial_{p}\right) \exp \left(b p^{2}+c p+d\right) \\
& =\exp \left(a x+b\left(p+\frac{1}{2} i a\right)^{2}+c\left(p+\frac{1}{2} i a\right)+d\right) \\
& =\exp \left(a x+b p^{2}+(c+i a b) p+d-\frac{1}{4} a^{2} b+\frac{1}{2} i a c\right)
\end{aligned}
$$

Consequently,

$$
\exp _{\star}(i t x) \star \exp _{\star}\left(i t p^{2}+i t^{2} p+\frac{1}{3} i t^{3}\right)=\exp \left(i t\left(x+p^{2}+t^{2} / 12\right)\right)
$$

and the identity

$$
\exp _{\star}\left(i t\left(x+p^{2}\right)\right)=\exp \left(i t\left(x+p^{2}+t^{2} / 12\right)\right)
$$

follows.

The proof of

$$
\exp _{\star}\left(-\frac{y}{2 \sinh y} e^{2 x-z}+i y p\right)=\exp \left(-\frac{1}{2} e^{y-z} e^{2 x}\right) \star \exp (i y p)=\exp \left(-\frac{1}{2} e^{2 x-z}+i y p\right)
$$

is similar. Choosing now $A=-\frac{1}{2} e^{y-z} e^{2 x}$ and $B=i y p$, it follows that $[A, B]_{\star}=-2 y A$, so that only those multiple Moyal commutators survive which are linear in $A$. This means, then, that in the Hausdorff expansion ${ }^{26}$ for $Z(A, B) \equiv \ln _{\star}\left(\exp _{\star}(A) \star \exp _{\star}(B)\right)$, only $B$ and terms linear in $A$ survive. Hence, $Z$ reduces to merely

$$
Z=B+A\left(\frac{B]_{\star}}{1-e^{-B I_{*}}}\right)
$$

The Hadamard expansion in $B]_{\star}$ means successive right $\star$-commutation with respect to $B$ as many times as the regular power expansion of the function in the parenthesis dictates. Consequently,

$$
\exp \left(-\frac{1}{2} e^{y-z} e^{2 x}\right) \star \exp (i y p)=\exp _{\star}\left(-\frac{1}{2} e^{y-z} e^{2 x}\right) \star \exp p_{\star}(i y p)=\exp _{\star}\left(-\frac{y}{2 \sinh y} e^{2 x-z}+i y p\right) .
$$

On the other hand,

$$
\exp \left(-\frac{1}{2} e^{y-z} e^{2 x}\right) \star \exp (i y p)=\exp \left(-\frac{1}{2} e^{y-z+2 x}\right) \exp \left(i y\left(p+i \check{\partial}_{x} / 2\right)\right)=\exp \left(-\frac{1}{2} e^{2 x-z}+i y p\right)
$$

and the identity is proven.

\section{APPENDIX D: CONSTRUCTION OF THE GENERATING FUNCTION FOR THE LIOUVILLE WFS}

From (60) and (61), it is evident that the Liouville wave functions can be generated by

$$
\exp \left(-e^{x} \cosh X\right)=\int_{-\infty}^{\infty} \frac{d k}{\sqrt{\sinh (\pi \sqrt{E(k)})}} e^{-i k X} \psi_{E(k)}(x)
$$

where $E(k) \equiv k^{2}$. Therefore, the usual wave function bilinears appearing in the WFs are generated by (recalling that the $\psi$ 's are real) 


$$
\begin{aligned}
\exp \left(-e^{x-y} \cosh X\right) \exp \left(-e^{x+y} \cosh Y\right)= & \int_{-\infty}^{\infty} \frac{d k}{\sqrt{\sinh (\pi \sqrt{E(k)})}} \int_{-\infty}^{\infty} \frac{d q}{\sqrt{\sinh (\pi \sqrt{E(q)})}} \\
& \times e^{-i k X-i q Y} \psi_{E(k)}(x-y) \psi_{E(q)}(x+y) .
\end{aligned}
$$

Consequently, Fourier transforming this produces a generating function for WFs,

$$
\begin{aligned}
& \frac{1}{\pi} \int_{-\infty}^{\infty} \mathrm{d} y e^{-2 i p y} \exp \left(-e^{x-y} \cosh X\right) \exp \left(-e^{x+y} \cosh Y\right) \\
& =\int_{-\infty}^{\infty} \frac{\mathrm{d} k}{\sqrt{\sinh (\pi \sqrt{E(k)})}} \int_{-\infty}^{\infty} \frac{\mathrm{d} q}{\sqrt{\sinh (\pi \sqrt{E(q)})}} e^{-i k X-i q Y} f_{E(k) E(q)}(x, p) .
\end{aligned}
$$

Evaluation of this expression yields just a factor multiplying a modified Bessel function,

$$
\begin{aligned}
& \int_{-\infty}^{\infty} \mathrm{d} y e^{-2 i p y} \exp \left(-e^{x-y} \cosh X-e^{x+y} \cosh Y\right) \\
& =\int_{-\infty}^{\infty} \mathrm{d} y \exp \left(-2 i p\left(y+\frac{1}{2} \ln (\cosh X / \cosh Y)\right)\right) \exp \left(-\left(e^{x} \sqrt{4 \cosh X \cosh Y}\right) \cosh y\right) \\
& =2\left(\frac{\cosh Y}{\cosh X}\right)^{i p} K_{2 i p}\left(e^{x} \sqrt{4 \cosh X \cosh Y}\right)
\end{aligned}
$$

Thus, a generating function for the complete set of Liouville Wigner functions is

$$
\begin{aligned}
\frac{2}{\pi}\left(\frac{\cosh Y}{\cosh X}\right)^{i p} K_{2 i p}\left(e^{x} \sqrt{4 \cosh X \cosh Y}\right)= & \int_{-\infty}^{\infty} \frac{\mathrm{d} k}{\sqrt{\sinh (\pi \sqrt{E(k)})}} \int_{-\infty}^{\infty} \frac{\mathrm{d} q}{\sqrt{\sinh (\pi \sqrt{E(q)})}} \\
& \times e^{-i k X-i q Y} f_{E(k) E(q)}(x, p),
\end{aligned}
$$

as in the text.

\section{APPENDIX E: OPERATOR ORDERING AND EQ. (69)}

Given the factorized phase-space generating function

$$
\mathcal{G}(z ; x, p)=\exp \left(-\frac{1}{2} e^{2 x-z}\right) K_{i p}\left(e^{z}\right),
$$

what is the operator corresponding to it? According to Weyl's prescription, Eq. (5), the associated operator is

$$
\begin{aligned}
\mathfrak{G}(z ; \mathcal{X}, \mathcal{P}) & =\frac{1}{(2 \pi)^{2}} \int \mathrm{d} \tau \mathrm{d} \sigma \mathrm{d} x \mathrm{~d} p \mathcal{G}(z ; x, p) \exp (i \tau(\mathcal{P}-p)+i \sigma(\mathcal{X}-x)) \\
& =\frac{1}{(2 \pi)^{2}} \int \mathrm{d} \tau \mathrm{d} \sigma \mathrm{d} x \mathrm{~d} p \exp (i \tau \mathcal{P}+i \sigma \mathcal{X}) \exp \left(-\frac{1}{2} e^{2 x-z}-i \sigma x\right) K_{i p}\left(e^{z}\right) \exp (-i \tau p) .
\end{aligned}
$$

The integrals over $x$ and $p$ may be evaluated separately, if the $\sigma$ contour is first shifted slightly above the real axis, $\sigma \rightarrow \sigma+i \epsilon$, thereby suppressing contributions to the $x$-integral as $x \rightarrow-\infty$. Now $s \equiv \frac{1}{2} e^{2 x-z}$ gives 


$$
\begin{aligned}
\int_{-\infty}^{+\infty} \mathrm{d} x \exp \left(-\frac{1}{2} e^{2 x-z}-i(\sigma+i \epsilon) x\right) & =\int_{0}^{\infty} \frac{\mathrm{d} s}{2 s}\left(2 s e^{z}\right)^{-i(\sigma+i \epsilon) / 2} \exp (-s) \\
& =\frac{1}{2} e^{-i(z+\ln 2) \sigma / 2} \Gamma(-i(\sigma+i \epsilon) / 2)
\end{aligned}
$$

By (61),

$$
\int \mathrm{d} p K_{i p}\left(e^{z}\right) \exp (-i \tau p)=\frac{1}{2} \int_{-\infty}^{\infty} \mathrm{d} X e^{-e^{2} \cosh X} 2 \pi \delta(X-\tau)=\pi e^{-e^{z} \cosh \tau}
$$

So

$$
\mathfrak{G}(z ; \mathcal{X}, \mathcal{P})=\frac{1}{8 \pi} \int \mathrm{d} \tau \mathrm{d} \sigma e^{-i(z+\ln 2) \sigma / 2} \Gamma(-i(\sigma+i \epsilon) / 2) e^{-e^{z} \cosh \tau} \exp (i \tau \mathcal{P}+i \sigma \mathcal{X})
$$

The shifted $\sigma$ contour avoids the pole in $\Gamma$ at the origin.

Ordering with all $\mathcal{P}$ 's to the right, thereby departing from Weyl ordering, yields $\exp (i \tau \mathcal{P}$ $+i \sigma \mathcal{X})=\exp (i \sigma \mathcal{X}) \exp (i \sigma \tau / 2) \exp (i \tau \mathcal{P})$. Performing the $\sigma$ integration before the $\tau$ integration, permits taking the limit $\epsilon \rightarrow 0$ to obtain

$$
\begin{aligned}
\mathfrak{G}(z ; \mathcal{X}, \mathcal{P})= & \frac{1}{8 \pi} \int \mathrm{d} \tau\left(\int d \sigma \Gamma(-i(\sigma+i \epsilon) / 2) \exp (i \sigma \mathcal{X}+i \sigma \tau / 2-i \sigma(z+\ln 2) / 2)\right) \\
& \times e^{-e^{z} \cosh \tau} \exp (i \tau \mathcal{P}) \\
= & \frac{1}{8 \pi} \int \mathrm{d} \tau\left(4 \pi \exp \left(-e^{2 \mathcal{X}+\tau-(z+\ln 2)}\right)\right) e^{-e^{z} \cosh \tau} \exp (i \tau \mathcal{P}) \\
= & \frac{1}{2} \int \mathrm{d} \tau \exp \left(-\frac{1}{2} e^{2 \mathcal{X}+\tau-z}-\frac{1}{2} e^{z+\tau}-\frac{1}{2} e^{z-\tau}\right) \exp (i \tau \mathcal{P}) .
\end{aligned}
$$

This is the operator correspondent to (72); it reflects the Weyl correspondence through which it was originally defined (although, technically, it was taken out of Weyl ordering above, merely as a matter of convenience, not a bona-fide change of representation).

This form leads to a more intuitive Hilbert space representation. Acting to the right of a position eigen-bra, $\langle x| \mathcal{X}=\langle x| x$, while the subsequent exponential of the momentum operator just translates, $\langle x| \exp (i \tau \mathcal{P})=\langle x+\tau|$. So the full right-operation of $\mathfrak{G}$ is

$$
\begin{aligned}
\langle x| \mathfrak{G}(z ; \mathcal{X}, \mathcal{P}) & =\frac{1}{2} \int \mathrm{d} \tau\langle x+\tau| \exp \left(-\frac{1}{2} e^{2 x+\tau-z}-\frac{1}{2} e^{z+\tau}-\frac{1}{2} e^{z-\tau}\right) \\
& =\frac{1}{2} \int \mathrm{d} y\langle y| \exp \left(-\frac{1}{2} e^{x+y-z}-\frac{1}{2} e^{z+y-x}-\frac{1}{2} e^{z-y+x}\right)
\end{aligned}
$$

Inserting $1=\int \mathrm{d} x|x\rangle\langle x|$ gives $\mathfrak{G}(z ; \mathcal{X}, \mathcal{P})=\int \mathrm{d} x|x\rangle\langle x| \mathfrak{G}(z ; \mathcal{X}, \mathcal{P})$, and leads to a coordinate space realization of the operator involving an $x, y$-symmetric kernel,

$$
\mathfrak{G}(z ; \mathcal{X}, \mathcal{P})=\frac{1}{2} \int \mathrm{d} x \mathrm{~d} y|x\rangle\langle y| \exp \left(-\frac{1}{2} e^{x+y-z}-\frac{1}{2} e^{x-y+z}-\frac{1}{2} e^{-x+y+z}\right) .
$$

This operator is diagonal on energy states: by Macdonald's identity (67), and the reality and orthogonality of the wave functions, 


$$
\begin{aligned}
\left\langle E_{1}|\mathfrak{G}(z ; \mathcal{X}, \mathcal{P})| E_{2}\right\rangle & =\frac{1}{2} \int \mathrm{d} x \mathrm{~d} y \psi_{E_{1}}^{*}(x) \psi_{E_{2}}(y) \exp \left(-\frac{1}{2} e^{x+y-z}-\frac{1}{2} e^{z+y-x}-\frac{1}{2} e^{z-y+x}\right) \\
& =\delta\left(E_{1}-E_{2}\right) K_{i \sqrt{E_{1}}}\left(e^{z}\right) .
\end{aligned}
$$

This is in agreement with the corresponding phase-space expression, (66).

The composition law of this operator also parallels its phase-space isomorph, (74),

$$
\mathfrak{G}(u) \mathfrak{G}(v)=\frac{1}{2} \int \mathrm{d} w \exp \left(-\frac{1}{2}\left(e^{u+v-w}+e^{u-u+w}+e^{-u+v+w}\right)\right) \mathfrak{G}(w) .
$$

${ }^{1}$ H. Groenewold, Physica (Amsterdam) 12, 405 (1946).

${ }^{2}$ F. Bayen, M. Flato, C. Fronsdal, A. Lichnerowicz, and D. Sternheirner, Ann. Phys. (N.Y.) 111, 61 (1978); 111, 111 (1978); Lett. Math. Phys. 1, 521 (1977).

${ }^{3}$ J. Moyal, Proc. Cambridge Philos. Soc. 45, 99 (1949).

${ }^{4} T$. Curtright, D. Fairlie, and C. Zachos, Phys. Rev. D 58, 025002 (1998).

${ }^{5}$ For reviews, see M. Hillery, R. O'Conell, M. Scully, and E. Wigner, Phys. Rep. 106, 121 (1984); H.-W. Lee, ibid. 259, 147 (1995); N. Balasz and B. Jennings, ibid. 104, 347 (1984); R. Littlejohn, ibid. 138, 193 (1986); M. Berry, Philos. Trans. R. Soc. London, Ser. A 287, 237 (1977); M. Gadella, Fortschr. Phys. 43, 229 (1995); P. Camuthers and F. Zachariasen, Rev. Mod. Phys. 55, 245 (1983); L. Cohen, Time-Frequency Analysis (Prentice-Hall, Englewood Cliffs, NJ, 1995); F. Berezin, Sov. Phys. Usp. 23, 763 (1980); A. M. Ozorio de Almeida, Phys. Rep. 295, 265 (1998).

${ }^{6}$ N. Seiberg and E. Witten, J. High Energy Phys. 9909, 032 (1999); for a review, see L. Castellani, Class. Quantum Grav. 17,3377 (2000) [hep-th/0005210]

${ }^{7}$ G. Baker, Phys. Rev. 109, 2198 (1958); formally underlain by J. v. Neumann. Math. Ann. 104, 570 (1931).

${ }^{8}$ D. Fairlie, Proc. Cambridge Philos. Soc. 60, 581 (1964).

${ }^{9}$ F. Hansen, Rev. Mod. Phys. 19, 361 (1984); C. Roger and V. Ovsienko, Russ Math. Surv. 47, 135 (1992); C. Zachos, J. Math. Phys. 41, 5129 (2000) [hep-th/9912238].

${ }^{10}$ E. Wigner, Phys. Rev. 40, 749 (1932).

"J. Dahl, in Energy Storage and Redistribution, edited by J. Hinze (Plenum, New York, 1983), pp. 557-571, see also L. Cohen, J. Math. Phys. 17, 1863 (1976); W. Kundt, Z. Naturforsch. A 22, 1333 (1967)

${ }^{12}$ T. Takabayasi, Prog. Theor. Phys. 11, 341 (1954).

${ }^{13}$ R. Gopakumar, S. Minwalla, and A. Strominger, J. High Energy Phys. 0005, 020 (2000) [hep-th/0003160]; J. Harvey, P. Kraus, F. Larsen, and E. Martinec, ibid. 0007, 042 (2000) [hep-th/0005031]; K. Dasgupta, S. Mukhi, and G. Rajesh, ibid. 0006, 022 (2000) [hep-th/0005006]; A. Polychronakos, Phys. Lett. B 495, 407 (2000) [hep-th/0007043]; J. Harvey, hep-th/0102076.

${ }^{14} \mathrm{H}$. Weyl, Z. Phys. 46, 1 (1927); also reviewed in H. Weyl, The Theory of Groups and Quantum Mechanics (Dover, New York, 1931).

${ }^{15}$ T. Curtright and C. Zachos, J. Phys. A 32, 771 (1999)

${ }^{16}$ J. Gracia-Bondia, Phys. Rev. A 30, 691 (1984).

${ }^{17} \mathrm{M}$. Bartlett and J. Moyal, Proc. Cambridge Philos. Soc. 45, 545 (1949).

${ }^{18}$ I. Gradshteyn and I. Ryzhik, Table of Integrals, Series, and Products, 5th ed. (Academic, New York, 1994).

${ }^{19} \mathrm{~V}$. Dodonov and V. Man'ko, Physica A 137, 306 (1986).

${ }^{20}$ E. D'Hoker and R, Jackiw, Phys. Rev. D 26, 3517 (1982); E. Braaten, T. Curtright, G. Ghandour, and C. Thorn, Ann. Phys. (N.Y.) 153, 147 (1984); T. Curtright and G. Ghandour, Phys. Lett. B 136, 50 (1984); E. D'Hoker, Phys. Rev. D 28, 1346 (1983).

${ }^{21}$ C. Grosche and F. Steiner, Phys. Lett. A 123, 319 (1987).

${ }^{22} \mathrm{G}$. Watson, A Treatise on the Theory of Bessel Functions, 2nd ed. (Cambridge University Press, Cambridge, 1995).

${ }^{23} \mathrm{~T}$. Curtright, quant-ph/0011101.

${ }^{24}$ D. Han, Y. Kim, and M. Noz, Phys. Rev. A 40, 902 (1989); M. Hennings, T. Smith, and D. Dubin, J. Phys. A 28, 6779 (1995); 28, 6809 (1995); J. Klauder and B. Skagerstam, Coherent States (World Scientific, Singapore, 1985).

${ }^{25} \mathrm{~L}$. Wang and R. O'Connell, Found. Phys. 18, 1023 (1988).

${ }^{26}$ W. Magnus, Commun. Pure Appl. Math. VII, 649 (1954). 


\title{
Modified spectral method in phase space: Calculation of the Wigner function. I. Fundamentals
}

\author{
M. Hug, ${ }^{1}$ C. Menke, ${ }^{2}$ and W. P. Schleich ${ }^{1}$ \\ ${ }^{1}$ Abteilung für Quantenphysik, Universität Ulm, D-89069 Ulm, Germany \\ ${ }^{2}$ Abteilung Numerik, Universität Ulm, D-89069 Ulm, Germany
}

(Received 30 October 1997)

\begin{abstract}
We present a method for the direct computation of the Wigner function by solving a coupled system of linear partial differential equations. Our procedure is applicable to arbitrary binding potentials. We introduce a modified spectral tau method that uses Chebyshev polynomials as shape functions to approximate the solution. Since two differential equations are solved simultaneously, the resulting linear equation system is overdetermined. We approximate its solution by a least-squares method. We prove the stability and convergence of our scheme. As an application, we compute numerically the Wigner function for the harmonic oscillator. Our calculations show excellent agreement with known analytic results. [S1050-2947(98)04704-0]
\end{abstract}

PACS number(s): 03.65.Bz, 02.70.Hm

\section{INTRODUCTION}

An alternative formulation of standard quantum mechanics $\grave{a}$ la Schrödinger or Heisenberg is the phase-space approach pioneered by Wigner. Here the standard definition of a Wigner function [1] is based on the density matrix. Hence once we know the density matrix we find the Wigner function by performing a Fourier integral. However, one might ask if phase space alone defines the Wigner function $\Psi$. Does there exist a set of real partial differential equations in the phase-space variables $q$ and $p$ which determine $\Psi$ ? This would avoid the detour through the density operator and the Fourier integral. Indeed, a set of two real linear partial differential equations $[2,3]$ defines the Wigner function. This set is rarely investigated in the literature [4], although it offers new insights into the Wigner function. To derive solutions for these phase-space equations is the topic of these two papers.

According to Heisenberg's uncertainty principle, position and momentum cannot be measured simultaneously and precisely. So, strictly speaking, one cannot define a phase-space probability distribution in quantum mechanics. However, several quasiprobability distributions $[1,5,6]$ have been proposed and widely used that carry some of the key features of classical phase-space densities. The most famous quasiprobability distribution is the Wigner function [7]. This function has found a wide range of applications (in the fundamentals of quantum mechanics, quantum optics, nuclear physics, and plasma physics, to name just a few areas). The Wigner function shows many features of a classical phase-space density. In particular, this quasiprobability has quantummechanically correct marginal distributions [8]. However, because of the uncertainty principle the Wigner function differs in two important points from a classical phase-space distribution [9]. One is a required symmetrical ordering of observables [1]. Second, the Wigner function may contain areas of negative "probabilities." These negativities have been considered prominent features of nonclassical behavior [10]. Quite typically, the negative areas occur as oscillations arising from interference effects $[11,12]$.

In this paper we introduce a spectral tau method [13] to compute the Wigner function directly for energy eigenstates. We apply proposals of Fairlie [2(a)] and Kundt [2(b)]. They derived two real linear partial differential equations for the Wigner function of a bound energy eigenstate. To our knowledge, the present work is the first one that describes how to solve these equations numerically for an arbitrary one-dimensional binding potential. We approximate their solution as a finite sum of Chebyshev polynomials in the two phase-space variables position and momentum. Since we simultaneously solve two differential equations, the resulting linear system of equations is overdetermined. We approximate its solution by a least-squares method. We prove the stability and convergence of our method. Traditionally the Wigner function is calculated by first finding the stationary wave function (solving the Schrödinger equation) and then performing a Fourier transformation. Our method avoids the detour of calculating the wave function.

We believe that this procedure may provide new insight into the fascinating properties of quasiprobability distributions, and that our method will become a valuable tool for numerical computations of the Wigner function. We note that our approach can be generalized to any similar system of partial differential equations.

In Sec. II we present the differential equations for the Wigner function. Section III introduces the fundamentals of spectral methods. The truncated system of differential equations that we use in this paper to outline our method is given in Sec. IV. In Sec. V we perform the required calculations to implement our modified spectral method. Aspects of stability, convergence, and error estimates are discussed in Sec. VI. A numerical example of the harmonic oscillator is given in Sec. VII.

\section{FORMULATION OF THE PROBLEM}

In the present section we briefly summarize the two phase-space equations defining the Wigner function of an energy eigenstate of a one-dimensional binding potential. We introduce dimensionless variables on a quadratic domain of phase space which will make it convenient to apply our method of solving these equations.

In Appendix A we show that the Wigner function

$$
\Psi(q, p) \equiv \frac{1}{2 \pi \hbar} \int_{-\infty}^{\infty} d y e^{\mathrm{i} p y / \hbar} \psi_{\bar{E}}^{*}\left(q-\frac{y}{2}\right) \psi_{\widetilde{E}}\left(q+\frac{y}{2}\right)
$$


of an eigenstate $\left|\psi_{\widetilde{E}}(q)\right\rangle$ in position representation of energy $\widetilde{E}$ in a one-dimensional potential $U \equiv U(q)$ follows from the equations

$$
\left[-\frac{p}{M} \frac{\partial}{\partial q}+\sum_{r=1,3,5, \ldots}^{\infty} \frac{1}{r !}\left(\frac{\mathrm{i} \hbar}{2}\right)^{r-1} \frac{d^{r} U}{d q^{r}} \frac{\partial^{r}}{\partial p^{r}}\right] \Psi(q, p)=0
$$

and

$$
\begin{aligned}
{\left[\frac{p^{2}}{2 M}\right.} & +U(q)-\frac{\hbar^{2}}{8 M} \frac{\partial^{2}}{\partial q^{2}} \\
& \left.+\sum_{r=2,4,6, \ldots}^{\infty} \frac{1}{r !}\left(\frac{\mathfrak{i} \hbar}{2}\right)^{r} \frac{d^{r} U}{d q^{r}} \frac{\partial^{r}}{\partial p^{r}}\right] \Psi(q, p)=\widetilde{E} \Psi(q, p)
\end{aligned}
$$

in the phase-space variables' positions $q$ and momentum $p$, respectively. Here $M$ and $\hbar$ denote the mass of the particle in the potential and Planck's constant, respectively.

In general, these equations are of infinite order in $p$. How ever, in the case of a polynomial potential $U$ only a finite number of derivatives contributes. In any case the solution $\Psi(q, p)$ is symmetric in the momentum variable $p$, that is

$$
\Psi(q,-p)=\Psi(q, p) .
$$

When we introduce the dimensionless variables $Q \equiv q / a_{0}$ and $P \equiv\left(a_{0} / \hbar\right) p$ with the appropriate characteristic length $a_{0}$, we find

$$
\left[-P \frac{\partial}{\partial Q}+\sum_{r=1,3,5 \ldots}^{\infty} \frac{1}{r !}\left(\frac{\mathrm{i}}{2}\right)^{r-1} \frac{d^{r} V}{d Q^{r}} \frac{\partial^{r}}{\partial P^{r}}\right] \Psi(Q, P)=0
$$

and

$$
\begin{aligned}
{\left[\frac{P^{2}}{2}+V(Q)-E-\frac{1}{8} \frac{\partial^{2}}{\partial Q^{2}}\right.} \\
\left.\quad+\sum_{r=2,4,6, \ldots}^{\infty} \frac{1}{r !}\left(\frac{\mathrm{i}}{2}\right)^{r} \frac{d^{r} V}{d Q^{r}} \frac{\partial^{r}}{\partial P^{r}}\right] \Psi(Q, P)=0
\end{aligned}
$$

where $V(Q) \equiv\left(M a_{0}^{2} / \hbar^{2}\right) U(q)$ and $E=M\left(a_{0}^{2} / \hbar^{2}\right) \tilde{E}$ denote the corresponding dimensionless potential and the energy eigenvalue, respectively.

To apply our tau ansatz, it is convenient to transform the phase-space domain $\left[-P_{0}, P_{0}\right] \times\left[Q_{1}, Q_{2}\right]$ with $P_{0}>0$ and $Q_{1}<Q_{2}$, onto the square $[-1,1] \times[-1,1]$. This is the range for which the Chebyshev polynomials used in our method are defined. We can easily invert this linear mapping once we have found the solution.

We accomplish this transformation by introducing the new momentum variable

$$
y \equiv \frac{P}{P_{0}}
$$

and the new position variable

$$
x \equiv \frac{1}{Q_{0}}\left[Q-\frac{1}{2}\left(Q_{1}+Q_{2}\right)\right]
$$

where

$$
Q_{0} \equiv \frac{1}{2}\left(Q_{2}-Q_{1}\right)
$$

With the potential

$$
V(x) \equiv V\left(Q_{0} x+\frac{1}{2}\left(Q_{1}+Q_{2}\right)\right)
$$

we arrive at the two coupled equations

$$
\begin{aligned}
L_{\text {odd }} \Psi \equiv & {\left[-\frac{P_{0}}{Q_{0}} y \frac{\partial}{\partial x}\right.} \\
& \left.+\sum_{r=1,3,5, \ldots}^{\infty} \frac{1}{r !}\left(\frac{\mathrm{i}}{2}\right)^{r-1} \frac{1}{P_{0}^{r} Q_{0}^{r}} \frac{d^{r} V}{d x^{r}} \frac{\partial^{r}}{\partial y^{r}}\right] \Psi(x, y)=0
\end{aligned}
$$

and

$$
\begin{aligned}
L_{\text {even }} \Psi \equiv & {\left[\frac{P_{0}^{2} y^{2}}{2}+V(x)-E-\frac{1}{8 Q_{0}^{2}} \frac{\partial^{2}}{\partial x^{2}}\right.} \\
& \left.+\sum_{r=2,4,6, \ldots}^{\infty} \frac{1}{r !}\left(\frac{\mathrm{i}}{2}\right)^{r} \frac{1}{P_{0}^{r} Q_{0}^{r}} \frac{d^{r} V}{d x^{r}} \frac{\partial^{r}}{\partial y^{r}}\right] \Psi(x, y)=0 .
\end{aligned}
$$

This is the set of equations we solve using our modified tau method. In the present paper we truncate this set after the second derivative of the potential in order to outline our modified spectral method. In paper II [14] we extend this technique to treat arbitrary high orders. We conclude this section by noting that indeed these definitions limit the range of the variables $x$ and $y$ to the phase-space square $[-1,1] \times[-1,1]$.

\section{SPECTRAL AND TAU METHODS: A BRIEF REVIEW}

In the present section we first briefly review the spectral and tau methods for finding solutions of partial differential equations. Detailed descriptions of these methods can be found in the mathematical literature, e.g., Refs. $[13,15]$, and the references therein. We then adopt these techniques to the specific problem of the two coupled equations (4) and (5).

Spectral methods belong to the class of weighted residual methods and address differential equations of the form

$$
L \psi=f
$$

where $L$ is an arbitrary differential operator, $f$ an inhomogeneity, and $\psi$ the solution of that problem in a domain $D$. The spectral method starts from the approximate solution

$$
\psi_{N}=\sum_{i=1}^{N} a_{i} \phi_{i}
$$

of Eq. (6), that is a linear superposition of $N$ known trial or shape functions $\phi_{i}$. Here the coefficients $a_{i}$ are the constant 
coefficients to be determined. When we substitute the approximate solution $\psi_{N}$ into $\mathrm{Eq}$. (6), the residual

$$
R \equiv L \psi_{N}-f=L\left(\sum_{i=1}^{N} a_{i} \phi_{i}\right)-f
$$

of the equation is in general not equal to zero. The aim of the method is to find $\psi_{N}$, i.e., the unknown coefficients $a_{i}$, such that $R$ is small. We achieve this goal by requiring that the integral

$$
\int_{D} R \varphi_{\nu}=0
$$

of the weighted residuals over $D$ vanishes. Here the quantities $\varphi_{\nu}$ with $\nu=1, \ldots, N$ are called weight or test functions. From Eq. (9) we find, with Eq. (8), the $N$ equations for linear operators $L$,

$$
\sum_{i=1}^{N} a_{i} \int_{D}\left(L \phi_{i}\right) \varphi_{\nu}=\int_{D} f \varphi_{\nu},
$$

for the $N$ unknown coefficients $a_{i}$. When we define the components

$$
(\Gamma)_{\nu i} \equiv \Gamma_{\nu i} \equiv \int_{D}\left(L \phi_{i}\right) \varphi_{\nu}
$$

of the $N \times N$ matrix $\boldsymbol{\Gamma}$, and the components

$$
(\mathbf{b})_{\nu} \equiv b_{\nu} \equiv \int_{D} f \varphi_{\nu}
$$

of the $N$ vector $\mathbf{b}$, this problem can be written as the linear system of equations

$$
\Gamma \mathbf{a}=\mathbf{b}
$$

for the vector (a) ${ }_{i} \equiv a_{i}$ containing the $N$ unknown coefficients $a_{i}$ of the spectral ansatz (7).

The spectral method uses the same orthogonal functions $\phi_{i}=\varphi_{i}$ as trial and weight functions leading to the relation

$$
\int_{D} \phi_{i} \varphi_{\nu} \chi=\delta_{i \nu} \text { const }
$$

whereby $\delta_{i,}$ and $\chi$ denote the Kronecker symbol Eq. (C1) and a positive weight function depending on the particular choice of the $\phi_{i}$, respectively. Making use of these orthogonality relations only pairs $\phi_{i} \varphi_{\nu}$ with $i=\nu$ give a nonvanishing contribution to the system of equations (10).

Usually the trial functions satisfy the same boundary conditions as required for the solution $\psi$. When this is not the case the method is called the tau method. Then certain equations of system (10) are discarded and replaced by the boundary constraints. It is worth mentioning that for sufficiently smooth solutions the spectral tau method yields results that are much more accurate than any finite-difference scheme with the same number of unknowns, see Ref. [16].

Since in our specific problem there are no boundary conditions, the tau method is the basis of our approach. In contrast to usual applications of tau methods we have to solve two real partial differential equations simultaneously corresponding to the two operators $L_{\text {even }}$ and $L_{\text {odd }}$. This leads to an overdetermined linear system consisting of $2 \mathrm{~N}$ equations for $N$ unknowns. Here we have two choices: Either we find a way to reduce the system to a $N \times N$ system of full rank, or we keep all the equations with more than one nonvanishing coefficient, and apply a least-squares method to the full system. The second approach is valid, provided that the error introduced by the least-squares approximation is not larger than the spectral error. That means that in practice we do not require that the weighted residuals Eq. (9) vanish, but we minimize them in a least-squares sense. Our numerical experiments show that this approach does indeed yield solutions of very high accuracy for our model problem, where the exact solution is known and can be used to check the numerical solution.

\section{TRUNCATION OF THE SYSTEM}

In the preceding sections we have laid the foundations for both papers. To bring out most clearly the essential ingredients of our modified tau method we now illustrate this technique for the truncated system of equations. This is the set of equations which we actually solve in this paper. The generalization to infinite order-that is the full Eqs. (4) and (5) - is the topic of paper II [14].

In general, Eqs. (1) and (2) are of infinite order in the momentum $p$. However, in the case of a polynomial potential only a finite number of derivatives contributes. For example, the equations for the harmonic oscillator with $U(q)=\frac{1}{2} m \omega^{2} q^{2}$ are of second order. In this case analytic solutions of the two coupled equations exist [4]. The ultimate goal of the present work is to solve this set of equations including all derivatives. However, to demonstrate our modified spectral tau method and to illustrate the structure of the resulting linear equation system, we neglect in a first approach terms of higher than second order in $p$. Hence we here consider the simplified equations

$$
L_{1} \Psi \equiv\left[-\frac{P_{0}}{Q_{0}} y \frac{\partial}{\partial x}+\frac{1}{P_{0} Q_{0}} \frac{d V}{d x} \frac{\partial}{\partial y}\right] \Psi(x, y)=0
$$

and

$$
\begin{aligned}
L_{2} \Psi \equiv & {\left[\frac{P_{0}^{2} y^{2}}{2}+V(x)-E-\frac{1}{8 Q_{0}^{2}} \frac{\partial^{2}}{\partial x^{2}}\right.} \\
& \left.-\frac{1}{8 Q_{0}^{2} P_{0}^{2}} \frac{d^{2} V}{d x^{2}} \frac{\partial^{2}}{\partial y^{2}}\right] \Psi(x, y)=0 .
\end{aligned}
$$

This is the set of equations we use throughout this paper. We note that Eq. (11) is closely related [7] with the Liouville equation of classical statistical mechanics.

\section{IMPLEMENTATION OF OUR METHOD}

In this section we present an implementation of our modified spectral tau method and proceed in three steps: First we formulate our spectral ansatz Eq. (7) for the two coupled differential equations (11) and (12). Since our problem involves two differential equations we have to evaluate two 
residuals Eq. (8) in the second step. The last step is to build up the linear system of equations Eq. (10).

We emphasize that the set of equations (11) and (12) can be solved analytically [4] for the harmonic oscillator $V(Q)=Q^{2} / 2$, and thus provides a good test of our numerical results. When we include higher-order terms of the differential equations (1) and (2), the procedure remains the same. Each additional order leads to one additional term in the matrix coefficients of system (10). Since this does not increase the number of equations or the number of unknowns, it is computationally not more expensive to include higherorder terms (see Ref. [14]).

\section{A. Establishing the spectral ansatz}

We now present our modified tau method for the secondorder differential equations (11) and (12) for the Wigner function. We follow Ref. [17], and use Chebyshev polynomials in our approach. They are recommended as the best choice whenever a nonperiodic problem occurs or whenever one works with general functions that do not allow us to use special geometries. Since we seek a universal method valid for an arbitrary potential, we face just such a situation. Chebyshev polynomials give good results, and converge fast enough under almost all circumstances. Furthermore, they are easy to handle, because all terms, products, and derivatives can be reexpressed in terms of Chebyshev polynomials.

We assume a solution of the form

$$
\Psi_{N}(x, y)=\sum_{j=0}^{N_{x}}, \sum_{k=0}^{N_{y}} a_{j, k} T_{j}(x) T_{k}(y),
$$

which is a special case of the ansatz Eq. (7). Here we denote the Chebyshev polynomial of order $j$ by $T_{j}$, and refer for their properties to Ref. [18] and Appendix B. As usual in Chebyshev series, the primes indicate that the first term in each sum is multiplied by the factor $\frac{1}{2}$.

To reduce the number of unknowns we take advantage of the symmetry of Eqs. (11) and (12) in $y$, following from Eq. (3). For any approximation $\Psi_{N}$ of the Wigner function that has a continuous derivative this symmetry is equivalent to von Neumann boundary conditions

$$
\left.\frac{\partial}{\partial y} \Psi_{N}(x, y)\right|_{y=0}=0
$$

on the $x$ axis. When we substitute ansatz (13) into condition (14) we find-expressing with the help of Eq. (B2) the derivative of a Chebyshev series in another Chebyshev seriesthe constraint

$$
\begin{aligned}
&\left.\sum_{\substack{j \leqslant N_{x} \\
k \leqslant N_{y}}} a_{j, k} T_{j}(x) \frac{d T_{k}(y)}{d y}\right|_{y=0} \\
&=\left.\sum_{j \leqslant N_{x}}^{\prime} T_{j}(x) \sum_{k \leqslant N_{y}-1}^{\prime} a_{j, k}^{y} T_{k}(y)\right|_{y=0}=0,
\end{aligned}
$$

where the coefficients for $k=0,1, \ldots$ read

$$
\begin{gathered}
a_{j, 2 k}^{y}=\sum_{s=k}^{N_{y}} 2(2 s+1) a_{j, 2 s+1}, \\
a_{j, 2 k+1}^{y}=\sum_{s=k}^{N_{y}} 2(2 s+2) a_{j, 2 s+2} .
\end{gathered}
$$

To satisfy Eq. (15) for all $x$ the products $a_{j, k}^{y} T_{k}(0)$ have to vanish for all $k$. Since Chebyshev polynomials $T_{2 k+1}(y)$ of odd order vanish at the origin the condition $a_{j, 2 k}^{y}=0$ has to be satisfied. According to Eq. (16) this translates itself into the requirement

$$
a_{j, 2 k+1}=0
$$

for all $k$. Hence in our specific problem of Eqs. (11) and (12) the number of unknowns is reduced by a factor of 2 . Since in contrast to the usual spectral method no boundary conditions are present, Eq. (18) is the only information we can extract from the boundaries.

\section{B. Evaluating the residuals}

We now insert our spectral ansatz Eq. (13) for $\Psi$ into the two coupled differential equations (11) and (12) for the Wigner function and evaluate the two residuals of these equations. For the sake of simplicity we here only present the main ideas and results and refer to Appendix B for the calculation.

Since we have represented the Wigner function $\Psi$ by a Chebyshev series, it is convenient also to express the potential

$$
V(x)=\sum_{l \leqslant N_{v}}^{\prime} V_{l} T_{l}(x)
$$

as a Chebyshev series. For polynomial potentials this representation is exact, while for other smooth potentials the approximation can be made as accurate as desired. This we achieve by an appropriate choice of the upper limit $N_{v}$. When, according to Appendix $B$, we express all the terms in Eqs. (11) and (12) by Chebyshev polynomials, for the residual of Eq. (11) we obtain the expression

$$
\begin{aligned}
R_{1} \equiv & -\frac{P_{0}}{Q_{0}}\left(\sum_{\substack{j \leqslant N_{x}-1 \\
2 k \leqslant N_{y}}} \frac{1}{2} a_{j, 2 k}^{x} T_{j}(x)\left[T_{|2 k-1|}(y)+T_{2 k+1}(y)\right]\right) \\
& +\frac{1}{P_{0} Q_{0}}\left(\sum_{\substack{j \leqslant N_{x} \\
2 k+1 \leqslant N_{y}-1 \\
l \leqslant N_{v}-1}} \frac{1}{2} V_{l}^{x} a_{j, 2 k+1}^{y}\left[T_{j+l}(x)+T_{|j-l|}(x)\right] T_{2 k+1}(y)\right),
\end{aligned}
$$

whereas the residual of Eq. (12) reads 


$$
\begin{aligned}
R_{2} \equiv & \frac{P_{0}^{2}}{2} \sum_{\substack{j \leqslant N_{x} \\
2 k \leqslant N_{y}}} \frac{1}{4} a_{j, 2 k} T_{j}(x)\left[T_{|2 k-2|}(y)+2 T_{2 k}(y)+T_{2 k+2}(y)\right] \\
& +\sum_{\substack{j \leqslant N_{x} \\
2 k \leqslant N_{k} \\
l \leqslant N_{u}}} \frac{1}{2} V_{l} a_{j, 2 k}\left[T_{j+l}(x)+T_{|j-l|}(x)\right] T_{2 k}(y)-E \sum_{\substack{j \leqslant N_{x} \\
2 k \leqslant N_{y}}}^{\prime} a_{j, 2 k} T_{j}(x) T_{2 k}(y) \\
& -\frac{1}{8 Q_{0}^{2}}\left(\sum_{\substack{j \leqslant N_{x}-2 \\
2 k \leqslant N_{y}}} a_{j, 2 k}^{x x} T_{j}(x) T_{2 k}(y)\right)-\frac{1}{8 P_{0}^{2} Q_{0}^{2}}\left(\sum_{\substack{j \leqslant N_{x} \\
2 k \leqslant N_{y}-2 \\
l \leqslant N_{v}-2}} \frac{1}{2} V_{l}^{x x} a_{j, 2 k}^{y y}\left[T_{j+l}(x)+T_{i j-l \mid}(x)\right] T_{2 k}(y)\right)
\end{aligned}
$$

The coefficients of the series follow from Eq. (B3), and are given by

$$
\begin{gathered}
a_{j, 2 k}^{x}=\sum_{s=0}^{N_{x}} 2(j+1+2 s) a_{j+1+2 s, 2 k}, \\
a_{j, 2 k+1}^{y}=\sum_{s=k}^{N_{y}} 2(2 s+2) a_{j, 2 s+2}
\end{gathered}
$$

and

$$
\begin{gathered}
a_{j, 2 k}^{x x}=\sum_{t=0}^{N_{x}} \sum_{s=t}^{N_{x}} 4(j+1+2 t)(j+2+2 s) a_{j+2+2 s, 2 k}, \\
a_{j, 2 k}^{y y}=\sum_{t=k}^{N_{y}} \sum_{s=t}^{N_{y}} 4(2 t+1)(2 s+2) a_{j, 2 s+2 .}
\end{gathered}
$$

We obtain the latter relations by applying Eq. (B2) twice. Note that, due to Eq. (18), $a_{j, 2 k+1}^{x x}=a_{j, 2 k+1}^{y y}=0$. To bring out clearly the variable $x$ or $y$ of the partial derivatives, we have introduced a superscript in the coefficients of the differentiated series. Also, the coefficients of second derivatives carry a double superscript and are double sums given by Eq. (B6). For a detailed discussion of these points we refer to Appen$\operatorname{dix} B$.

These residuals seem to be very complicated, but their structure can easily be understood. Indeed every term in $R_{1}$ and $R_{2}$ corresponds to a term in Eqs. (11) and (12). Any derivative of a Chebyshev series is again a Chebyshev series. However each derivative decreases the order of the sum by 1 , since a Chebyshev series is a polynomial. The upper limits $N_{x}-1, N_{y}-1$, and $N_{v}-1$ in the multiple sums of $R_{1}$ arise from the differentiation of the corresponding Chebyshev series. Equivalently the upper limits $N_{x}-2, N_{y}-2$, and $N_{v}-2$ in the multiple sums of $R_{2}$ occur, where the corresponding quantities have been differentiated twice. Furthermore one has to perform products of Chebyshev polynomials. As shown in Appendix B this leads to symmetrical shifts in the indices of the Chebyshev polynomials, which can also be easily identified in the expressions Eqs. (20) and (21). At last one has to multiply an ordinary polynomial, $y^{2}$, with Chebyshev polynomials, which gives a symmetrical structure of three Chebyshev polynomials $T_{2 k-2}, T_{2 k}$, and $T_{2 k+2}$.
These simple properties of Chebyshev polynomials bring out most clearly the structure of the residuals.

\section{Setting up the linear system of equations}

Now we are ready to set up the system of equations (10) for the coefficients $a_{j, k}$. We require that the integral of the weighted residuals ( 9 ) over the computational domain $\Omega \equiv[-1,1] \times[-1,1]$ vanishes. With the Chebyshev weight

$$
\chi(x, y)=\frac{1}{\sqrt{1-x^{2}}} \frac{1}{\sqrt{1-y^{2}}},
$$

this yields the conditions

$$
\int_{-1}^{1} \int_{-1}^{1} R_{\alpha} T_{\nu}(x) T_{\mu}(y) \chi(x, y) d x d y=0
$$

for both residuals, that is for $\alpha=1$ and $\alpha=2$ and all pairs $\nu, \mu$ with $\nu=0,1,2, \ldots, N_{x}$ and $\mu=0,1,2, \ldots, N_{y}$.

We substitute Eqs. (20) and (21) for the residuals $R_{1}$ and $R_{2}$ into Eq. (23), and note that due to the orthogonality

$$
\int_{-1}^{1} T_{j}(x) T_{k}(x) \frac{d x}{\sqrt{1-x^{2}}}=\left\{\begin{array}{l}
0, j \neq k \\
\pi, j=k=0 \\
\frac{\pi}{2}, j=k=1,2, \ldots
\end{array}\right.
$$

of the Chebyshev polynomials only the integrals

$$
\int_{-1}^{1} \int_{-1}^{1} T_{\nu}^{2}(x) T_{\mu}^{2}(y) \chi(x, y) d x d y
$$

contribute. To satisfy Eq. (23) the prefactors of these integrals, that is, the prefactors belonging to the product $T_{\nu}(x) T_{\mu}(y)$, must vanish. This condition leads to the homogeneous system of equations

$$
\sum_{\substack{j \leqslant N_{x} \\ k \leqslant N_{y}}} \Gamma_{j, k}^{\nu, \mu} a_{j, k}=0 .
$$

We note that this system corresponds to the system Eq. (10) with $\mathbf{b}=\mathbf{0}$.

We identify the coefficients $\Gamma_{j, k}^{\nu, \mu}$ according to Appendix $\mathrm{C}$, and find 


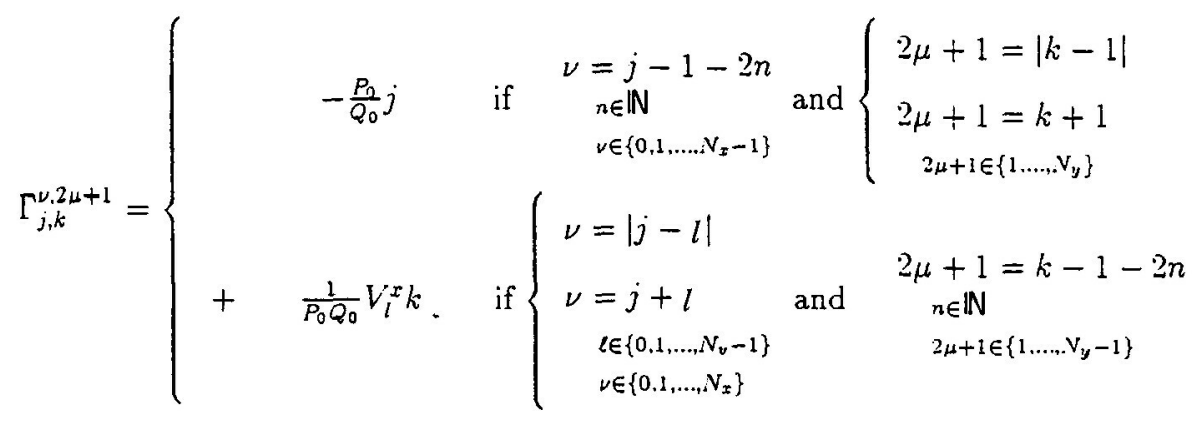

and

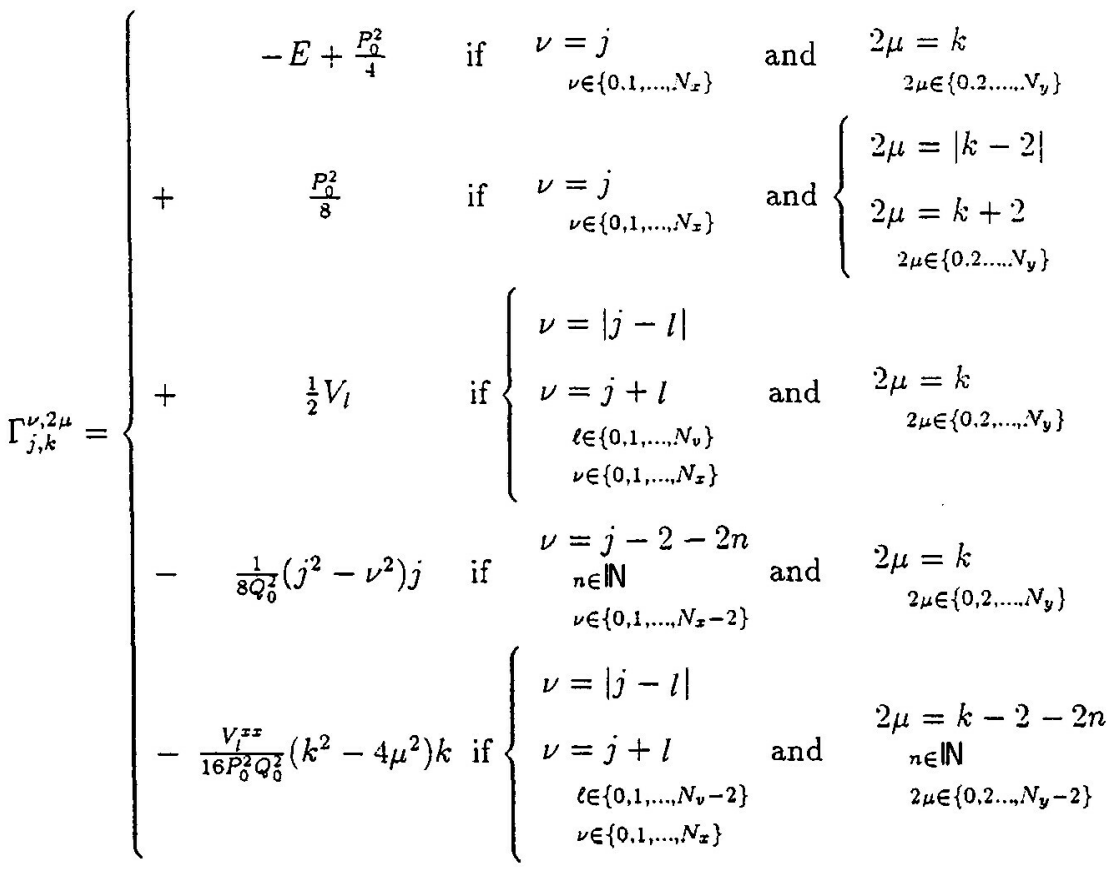

Here the terms $V_{l}^{x}$ and $V_{l}^{x x}$ follow from Eq. (B4). We note that the coefficients $\Gamma_{j, k}^{\nu, 2 \mu+1}$ (odd in $\mu$ ) result from the residual $R_{1}$ whereas the coefficients $\Gamma_{j, k}^{\nu, 2 \mu}$ (even in $\mu$ ) originate from $R_{2}$.

The linear system (24) obviously has the trivial solution. To find nontrivial solutions, we need at least one additional equation. We do this by setting the value of the solution at an arbitrary point in the computational domain, such as the origin, to a nonzero value, for example unity. We then obtain from Eq. (13), recalling the properties $T_{2 j+1}(0)=0$ and $T_{2 j}(0)=(-1)^{j}$, the additional equation

$$
\Psi(0,0)=1=\sum_{\substack{j \leqslant N_{x} \\ k \leqslant N_{y}}}(-1)^{j+k} a_{2 j, 2 k}
$$

Since the original equations (11) and (12) are linear, we can arbitrarily choose the value of the Wigner function and the solution can be normalized after the computation of the unknown coefficients.

We approximate the solution of the overdetermined linear system (24) by a standard least-squares algorithm [19]. This introduces an additional error to our solution since then the 
residuals are not exactly zero, but are minimized in a leastsquares sense using the $L_{2}$ norm. In general, the norm of the residuals decreases with increasing $N_{x}$ and $N_{y}$, and therefore can be used as a measure to check the accuracy of the approximation. In Sec. VII we present numerical calculations for our model problem. As the results are of high accuracy for appropriate $N_{x}$ and $N_{y}$, the least-squares approach can be justified.

\section{CONVERGENCE OF OUR METHOD}

In this section we analyze the convergence of our integration scheme for the set of differential equations (11) and (12). Throughout the section we make heavy use of results of Canuto et al. [16]. We discuss error estimates, stability, and consistency. For an introduction into the elements of functional analysis and definitions such as stability, consistency, and well-posed problems, we refer to Appendix D. In the present section we just discuss the results qualitatively.

The convergence properties and the errors of a Chebyshev series approximating a given function have been studied extensively [16]. We make use of these results in our approach to control the error of the approximation to the potential $V(x)$ by a Chebyshev series. However, these properties are not applicable to the approximation of the solution of Eqs. (11) and (12), since here the approximated function is not given explicitly but implicitly as a solution of differential equations. In order to apply the convergence theorems of Chebyshev series we have to ensure that the approximation converges toward the solution of the differential equation. Hence we have to show that the differential equation has a unique solution. Furthermore we have to investigate whether our approximation converges and represents this solution in the limit $N \rightarrow \infty$. Therefore the question of convergence of a numerical approximation to the exact solution is central to our scheme.

According to the Lax-Richtmyer theorem [20], stability and consistency imply the convergence of a well-posed problem. The most straightforward technique for establishing the stability as well as the consistency of the spectral schemes is the so-called energy method [16]. To apply this technique in our specific problem, we have to prove the inequalities

$$
C_{1}\|\psi\|_{H_{x}^{1}}^{2} \leqslant(L \psi, \psi)_{\chi}
$$

and

$$
\left|(L \psi, \widetilde{\psi})_{X}\right| \leqslant C_{2}\|\psi\|_{H_{X}^{1}}\|\widetilde{\psi}\|_{H_{x}^{1}}
$$

where $C_{1}$ and $C_{2}$ denote positive constants. These inequalities have to be valid for all functions $\psi \in D(L)$ and $\widetilde{\psi}$ $\in H_{X}^{1}$, where $D(L)$ is the domain of the differential operator $L$. For a definition of the Sobolev spaces $H_{\chi}^{0}$ and $H_{\chi}^{1}$, we refer to Appendix D. Here it will be sufficient to note that the norm $\|\psi\|_{H_{x}^{0}}^{2}$ is simply the scalar product

$$
\|\psi\|_{H_{X}^{0}}^{2} \equiv(\psi, \psi)_{X} \equiv \iint_{\Omega} \psi \psi \chi d x d y
$$

and the $H_{X}^{1}$ norm additionally contains all the first derivatives, that is,

$$
\|\psi\|_{H_{X}^{1}}^{2}=(\psi, \psi)_{X}+\left(\frac{\partial \psi}{\partial x}, \frac{\partial \psi}{\partial x}\right)_{\chi}+\left(\frac{\partial \psi}{\partial y}, \frac{\partial \psi}{\partial y}\right)_{\chi} .
$$

Inequality (28) states that $L$ is a positive operator, which is called coercive over $H_{\chi}^{1}$, while Eq. (29) is a continuity condition for $L$ in the sense that $(L \psi, \widetilde{\psi})_{X}$ depends continuously on $\psi$ and $\widetilde{\psi}$. If these inequalities hold there exists a unique solution of the problem $L \psi=f$ according to a theorem in Ref. [16].

The application of this result to the Chebyshev polynomials of degree $N$ yields, furthermore, the stability and consistency of our spectral scheme in the sense of the energy method, if $N$ is sufficiently large. Under this hypothesis convergence is a consequence of the Lax-Richtmyer theorem.

If the inequalities required by the energy method are fulfilled, then the corresponding error estimate for the approximate solution $\Psi_{N}$ reads

$$
\left\|\psi-\psi_{N}\right\|_{H_{x}^{1}(\Omega)} \leqslant C N^{1-m}\|\psi\|_{H_{\chi}^{m_{(\Omega)}}}
$$

for each $\psi \in H_{\chi}^{m}(\Omega)$. For the second-order equations we have $m=2$, and hence the error is proportional to $1 / N$. The second term on the right-hand side contains all derivatives up to second order. This has the consequence that other parameters such as the size of the integration domain $D$ can also influence the error estimate. We will see this in Sec. VII when we investigate the harmonic oscillator.

To prove the stability of our scheme, we simply have to follow these instructions with one modification. Usually one has to solve only a single equation with boundary conditions. In the context of Wigner function, however, we have to actually solve two equations simultaneously. The first-order equation is hyperbolic and the second-order equation is elliptic provided $d^{2} V / d x^{2}>0$. It is easy to see that a hyperbolic differential operator does not fulfill inequality (28). Nevertheless we can apply the energy method to the system of equations (11) and (12). To see that, we add Eq. (11) to Eq. (12), and arrive at the equivalent system

$L_{2} \Psi=\left(\frac{P_{0}^{2} y^{2}}{2}+V(x)-E\right.$

$$
\left.-\frac{1}{8 Q_{0}^{2}} \frac{\partial^{2}}{\partial x^{2}}-\frac{1}{8 Q_{0}^{2} P_{0}^{2}} \frac{d^{2} V(x)}{d x^{2}} \frac{\partial^{2}}{\partial y^{2}}\right) \Psi(x, y)=0
$$

and

$$
\begin{aligned}
L_{+} \Psi= & \left(\frac{P_{0}^{2} y^{2}}{2}+V(x)-E-\frac{P_{0}}{Q_{0}} y \frac{\partial}{\partial x}+\frac{1}{P_{0} Q_{0}} \frac{d V(x)}{d x} \frac{\partial}{\partial y}\right. \\
& \left.-\frac{1}{8 Q_{0}^{2}} \frac{\partial^{2}}{\partial x^{2}}-\frac{1}{8 Q_{0}^{2} P_{0}^{2}} \frac{d^{2} V(x)}{d x^{2}} \frac{\partial^{2}}{\partial y^{2}}\right) \Psi(x, y)=0 .
\end{aligned}
$$

Indeed, both equations are now elliptic for $d^{2} V(x) / d x^{2}>0$. 
Now we can start to prove stability, because both equations lead to the same coercivity evaluation as we show in Appendix E. In addition we also prove that inequality (28) holds under certain conditions for an appropriate function $\Psi(x, y)$ which is even in $y$. According to Appendix E, for positive $d^{2} V / d x^{2}$ we obtain the estimate

$$
\begin{aligned}
\left(L_{2} \Psi, \Psi\right)_{X} \geqslant & \frac{C}{32 Q_{0}^{2}} \min \left(1, \frac{1}{P_{0}^{2}} \frac{d^{2} V}{d x^{2}}\right)\|\Psi\|^{2} \\
& +\int_{-1}^{1} \int_{-1}^{1}\left(\frac{P_{0}^{2} y^{2}}{2}+V(x)-E\right) \Psi^{2} \chi d x d y \\
& +\mathcal{B}
\end{aligned}
$$

where $\mathcal{B}$ represents the boundary terms, given explicitly in Appendix E. Here we used the weighted scalar product Eq. (E1). Hence to achieve stability according to Eq. (28), we have to require that the sum of the integral and the boundary terms on the right-hand side of Eq. (33) is greater than a constant times $\|\Psi\|^{2}$. For this purpose it is sufficient that the sum of these terms is not negative. We denote the phasespace domain, where $\left\{P_{0}^{2} y^{2} / 2-[E-V(x)]\right\} \geqslant 0$ by $\Omega_{1}$. This area corresponds to the "nonclassical" phase-space region outside the classical trajectory $E=P / 2+V(Q)$. Let $\Omega_{2}=\Omega-\Omega_{1}$, the complement of $\Omega_{1}$, then

$$
\begin{aligned}
\int_{-1}^{1} \int_{-1}^{1}\left(\frac{P_{0}^{2} y^{2}}{2}+V(x)-E\right) \Psi^{2} \chi d x d y \\
=\iint_{\Omega_{1}}\left(\frac{P_{0}^{2} y^{2}}{2}-[E-V(x)]\right) \Psi^{2} \chi d x d y \\
-\iint_{\Omega_{2}}\left([E-V(x)]-\frac{P_{0}^{2} y^{2}}{2}\right) \Psi^{2} \chi d x d y .
\end{aligned}
$$

Whenever the integral over $\Omega_{1}$ in Eq. (34) is greater than the integral over $\Omega_{2}$, the right-hand side is positive. Then it can be written as a positive constant times $\|\Psi\|^{2}$ by applying a mean value theorem for integrals. Note that the boundary terms of Eq. (33) are zero when the Wigner function at the borders of the computational domain is zero or at least neg-

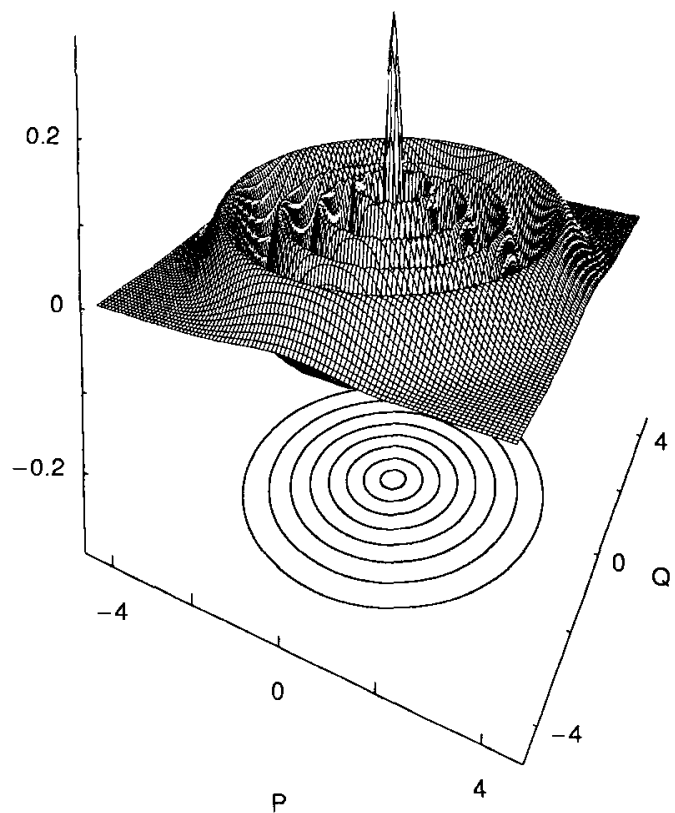

FIG. 1. Wigner function (top) and zero phase-space contour lines (bottom) of the eighth energy eigenstate of the harmonic oscillator.

ligibly small. In this case inequality (33) is valid. This argumentation holds if the domain $\Omega$ is chosen in such a way that most of it lies outside the classical region. Hence the choice of $\Omega$, i.e., $P_{0}, Q_{1}$, and $Q_{2}$, influences the stability. For other choices of the computational domain we have to require that the right-hand side of Eq. (33) does not become negative.

Our proof of stability might fail, if $d^{2} V / d x^{2}$ becomes negative. Since we have only binding potentials, there is always a phase-space region, where the curvature is convex and therefore $d^{2} V / d x^{2}$ is positive. In this case we can decompose all integrals containing $d^{2} V / d x^{2}$ into positive and negative parts in exactly the same way as in Eq. (34), and we

TABLE I. Mean and maximal absolute errors for the Wigner function approximation of the eighth energy eigenstate of the harmonic oscillator depending on the number $N_{\mathrm{eq}}=N_{x}=N_{y}$ of Chebyshev polynomials in our ansatz (13). We applied our modified spectral method on the computational phase space domains, $D_{1}=[-4.5,4.5] \times[-4.5,4.5], D_{2}=[-4.0,4.0] \times[-4.0,4.0]$, and $D_{3}=[-3.5,3.5] \times[-3.5,3.5]$. In the left part of the table we compare the mean absolute errors with increasing $N_{\mathrm{eq}}$ and on the right part the maximal absolute errors which are located in the edges as shown in Table II. Note that to find an error of the same order of magnitude we have to increase the number of Chebyshev polynomials $N_{\text {eq }}$ with increasing size of the computational domain.

\begin{tabular}{cccccccc}
\hline \hline & \multicolumn{3}{c}{ Mean absolute error } & & \multicolumn{3}{c}{ Maximal absolute error } \\
\cline { 2 - 3 } \cline { 6 - 7 }$N_{x}=N_{y}$ & $D_{1}$ & $D_{2}$ & $D_{3}$ & & $D_{1}$ & $D_{2}$ & $D_{3}$ \\
\hline 30 & $1.4 \times 10^{ \pm 0}$ & $4.3 \times 10^{-1}$ & $1.6 \times 10^{-2}$ & & $6.6 \times 10^{+2}$ & $9.8 \times 10^{+1}$ & $3.2 \times 10^{-1}$ \\
40 & $1.1 \times 10^{+1}$ & $3.3 \times 10^{-2}$ & $2.6 \times 10^{-5}$ & & $5.4 \times 10^{+3}$ & $6.4 \times 10^{-1}$ & $1.7 \times 10^{-4}$ \\
50 & $4.1 \times 10^{-3}$ & $6.7 \times 10^{-7}$ & $6.0 \times 10^{-9}$ & & $2.0 \times 10^{ \pm 0}$ & $9.2 \times 10^{-6}$ & $4.6 \times 10^{-8}$ \\
60 & $4.1 \times 10^{-8}$ & $1.7 \times 10^{-10}$ & $4.1 \times 10^{-13}$ & & $1.0 \times 10^{-5}$ & $1.4 \times 10^{-9}$ & $3.0 \times 10^{-12}$ \\
70 & $9.3 \times 10^{-12}$ & $3.7 \times 10^{-14}$ & $2.2 \times 10^{-15}$ & & $1.7 \times 10^{-9}$ & $6.6 \times 10^{-12}$ & $1.3 \times 10^{-14}$ \\
\hline
\end{tabular}


TABLE II. Dependence of the absolute errors (times $10^{-5}$ ) of the Wigner function approximation $\mathrm{Eq}$. (13) of the eighth energy eigenstate of the harmonic oscillator on the location $(Q, P)$ in the phase-space domain $D_{1}$ with $N_{\text {eq }}=50$. We note the dramatic error located in the corner $(Q, P)=(4.5,4.5)$.

\begin{tabular}{rr|rrrrrr}
\hline \hline & 4.5 & 1.9 & 1.7 & 3.7 & 30.4 & 1100.0 & 198000.0 \\
& 3.6 & 3.7 & 4.3 & 3.7 & 1.7 & 12.2 & 1100.0 \\
& 2.7 & 0.9 & 1.0 & 2.7 & 4.3 & 1.7 & 30.4 \\
& 1.8 & 2.2 & 3.2 & 3.8 & 2.7 & 3.7 & 3.7 \\
& 0.9 & 10.5 & 2.1 & 3.2 & 1.0 & 4.3 & 1.7 \\
& 0.0 & 0.0 & 10.5 & 2.2 & 0.9 & 3.7 & 1.9 \\
\hline & & 0.0 & 0.9 & 1.8 & 2.7 & 3.6 & 4.5 \\
& & & & $Q$ & & \\
\hline \hline
\end{tabular}

have to require that the negative parts do not dominate. Again this is influenced by the choice of $Q_{1}$ and $Q_{2}$. Thus one has to be very careful in choosing a proper domain. To obtain stability with the energy method, one has to choose a domain where the positive parts of $d^{2} V / d x^{2}$ outweigh the negative parts, and where the additional negative terms do not dominate.

To complete our proof of stability, we have to show the inequality (29). For each term of $\left(L_{2} \Psi, \widetilde{\Psi}\right)$, this can be done in a straightforward way by using the triangle inequality, partial integrations, the Cauchy-Schwartz inequality, and Hardy's inequality. With that estimation, stability and consistency, and hereby convergence of our method, are achieved, if the coordinate range is chosen carefully. The error estimate (30) holds.

We conclude this section by noting that higher-order terms lead to more complicated investigations because more cases occur. Nevertheless the convergence and stability results remain valid under conditions analogous to $\mathrm{Eq}$. (33).

\section{NUMERICAL RESULTS}

As a first application and a test of our method we choose the harmonic-oscillator potential $V(Q)=Q^{2} / 2$. This is motivated by the fact that an analytic expression for the Wigner function of an energy eigenstate is known in this case. Indeed, the Wigner function of the $n$th energy eigenstate with energy $E=n+\frac{1}{2}$ of the harmonic oscillator is [21]

$$
\Psi_{n}(Q, P)=\frac{(-1)^{n}}{\pi} e^{-R^{2}} L_{n}\left(2 R^{2}\right),
$$

where $L_{n}$ is a Laguerre polynomial and

$$
R^{2}=Q^{2}+P^{2}
$$

In Fig. I we show the Wigner function of the eighth eigenstate together with the contour lines of $\Psi(Q, P)$. According to Eq. (35) the latter are circles centered at the origin of phase space.

Multiplying our numerical solution based on the method of Sec. V with a normalization factor enables us to compare it with the exact solution and to calculate the absolute errors.
TABLE III. Dependence of the absolute errors (times $10^{-12}$ ) of the Wigner function approximation Eq. (13) of the eighth energy eigenstate of the harmonic oscillator on the location $(Q, P)$ in the phase-space domain $D_{1}$ with $N_{\mathrm{eq}}=70$. Note that in contrast to Table II, due to the larger number of polynomials the error decreases enormously and the error in the corner is much less dramatic. It will completely disappear for any higher $N_{\mathrm{eq}}$.

\begin{tabular}{rr|rrrrrr}
\hline & 4.5 & 2.6 & 1.5 & 0.3 & 0.2 & 9.1 & 1675.0 \\
& 3.6 & 10.3 & 10.8 & 8.3 & 1.7 & 0.1 & 9.1 \\
$P$ & 2.7 & 0.2 & 4.0 & 5.9 & 10.3 & 1.7 & 0.2 \\
& 1.8 & 19.7 & 3.7 & 9.8 & 5.9 & 8.3 & 0.3 \\
& 0.9 & 4.0 & 12.9 & 3.7 & 4.0 & 10.8 & 1.5 \\
& 0.0 & 0.0 & 4.0 & 19.7 & 0.2 & 10.3 & 2.6 \\
\hline & & 0.0 & 0.9 & 1.8 & 2.7 & 3.6 & 4.5 \\
& & & & & & & \\
& & &
\end{tabular}

Table I displays the mean errors ${ }^{1}$ of our approximation of the Wigner function for various numbers $N_{\mathrm{eq}}=N_{x}=N_{y}$ of Chebyshev polynomials in the variables $x$ and $y$. Here we chose $E=8.5$ and calculated the approximation in the three computational domains $D_{1} \equiv[-4.5 \leqslant Q \leqslant 4.5] \times[-4.5 \leqslant P$ $\leqslant 4.5], D_{2} \equiv[-4 \leqslant Q \leqslant 4] \times[-4 \leqslant P \leqslant 4]$, and $D_{3} \equiv[-3.5$ $\leqslant Q \leqslant 3.5] \times[-3.5 \leqslant P \leqslant 3.5]$ of phase space. The smallest domain $D_{3}$ is chosen in such a way that it contains all oscillations of the Wigner function and thus all relevant physical information. The largest domain $D_{1}$ contains the whole region in which the Wigner function is nonzero. For a constant number of Chebyshev polynomials in our ansatz Eq. (13), the errors increase with the size of the chosen domain. In each domain the errors decrease with increasing number of Chebyshev polynomials. The consequence is that for larger computational domains we have to incorporate more Chebyshev polynomials to keep the error constant. Therefore it is important to find the balance to properly choose a computational domain which is large enough to obtain properties of the Wigner function resolved, but not too large, since then the system of equation is very large when we want to arrive at a distinct error. The numerical results for $N_{\text {eq }}=N_{x}=N_{y}=50$ in Table II show that the maximum of the absolute error occurs in the edges of the chosen domain (here $D_{1}$ ). Far away from the edges the errors are much smaller. The data in Table III illustrate that this effect is compressed for a higher number of Chebyshev polynomials $N_{\text {eq }}=N_{x}=N_{y}=70$. In this case the absolute errors are nearly constant. Only in the corners they are three orders of magnitude larger but still of order $10^{-9}$. Therefore the Wigner function is now approximated very well in the whole computational domain. In the regions where the Wigner function is strongly oscillating the absolute errors are of order $10^{-9}$ for the domain $D_{3}=[-3.5,3.5] \times[-3.5,3.5]$ and of order $10^{-7}$ for the domain $D_{2}=[-4.0,4.0] \times[-4.0,4.0]$, with $N_{\text {eq }}=50$. In the larger domain $D_{1}=[-4.5,4.5]$ $x[-4.5,4.5]$ the errors are of order $10^{-3}$ but when we in-

${ }^{1}$ In order to compare our approximation to the exact solution we evaluate our spectral solution on an equidistant grid consisting of $100 \times 100$ points. At each grid point we calculate the absolute difference between the approximate and the exact solution. The mean value of these differences we call mean absolute error and their maximum we call maximal absolute error. 
crease $N_{\text {eq }}$ only by 10 we obtain errors of order $10^{-8}$. The errors for $N_{\mathrm{eq}}=50$ are all still small enough to obtain an accurate impression of the Wigner function, since the error can hardly be seen on the scale of the Wigner function. Our numerical results confirm that our method is a valuable tool for the computation of the solution of partial differential equations of forms (1) and (2).

\section{CONCLUSION}

We have presented an alternative approach for the calculation of the Wigner function. Our method ayoids the solution of the Schrödinger equation for the wave function. Instead, we apply a result from Fairlie and Kundt [2] and others [3] and solve two coupled real linear partial differential equations. Our numerical method is a modification of the spectral tau method, which uses Chebyshev polynomials as shape functions. In contrast to usual applications, no boundary conditions are available for the equations. Since two differential equations have to be solved simultaneously, the resulting linear equation system is overdetermined. Its solution is approximated by a least-squares method. We could prove stability and convergence of our scheme by making use of results of Ref. [16]. Generalizations of our approach to any similar system of partial differential equations are straightforward.

Our numerical results for the harmonic oscillator are in excellent agreement with the known analytic solution. The mean absolute error is of order $10^{-14}$ for an appropriate choice of the domain and the approximation order $N_{\text {eq }}=70$. Our modified spectral method is equally applicable to any potential $V$, and can be extended to the higher-order differential equations. This will be the subject of the following paper. Our results encourage further research on potentials for which no analytic solution can be calculated.

\section{ACKNOWLEDGMENTS}

We thank R. Baltin, M. V. Berry, J. P. Dahl, U. Leonhardt, H. Leschke, S. Schneider, and R. Seydel for many fruitful discussions. This work was partially supported by the Deutsche Forschungsgemeinschaft. M. H. is most grateful to the Studienstiftung des deutschen Volkes for its continuous support.

\section{APPENDIX A: A DERIVATION OF THE PHASE-SPACE EQUATIONS}

In this appendix we briefly summarize the central ideas of the derivation of the phase-space equations (1) and (2) for the Wigner function. Here we follow Ref. [3(c)] closely.

One of the most important properties of the Wigner function

$$
\Psi(q, p)=\frac{1}{2 \pi \hbar} \int_{-\infty}^{\infty} d y e^{i p y / \hbar}\left\langle q-\frac{y}{2}|\hat{\rho}| q+\frac{y}{2}\right\rangle
$$

of the density operator $\hat{\rho}$ is that it yields the correct quantummechanical marginal probability distributions of position and momentum. Moreover, it enables us to evaluate the expectation value

$$
\langle\hat{A}\rangle=\int_{-\infty}^{\infty} \int_{-\infty}^{\infty} d q d p \Psi(q, p) A(q, p)
$$

of any operator $\hat{A}$ through an integration in phase space. In this sense the Wigner function acts like a classical phasespace distribution. Here

$$
A(q, p)=\int_{-\infty}^{\infty} d y e^{i p y / \hbar}\left\langle q-\frac{y}{2}|\hat{A}| q+\frac{y}{2}\right)
$$

denotes the Weyl-Wigner correspondence of the operator $\hat{A}$. Therefore the Wigner function itself is the Weyl-Wigner correspondence of the operator $\hat{\rho}$.

We can interpret the two coupled partial differential equations (1) and (2) as the phase-space correspondence of the time-independent Schrödinger equation

$$
\hat{H} \hat{\rho}=\widetilde{E} \hat{\rho}
$$

for the density operator which in this case equals the projection operator $\hat{\rho} \equiv\left|\psi_{\vec{E}}\right\rangle\left\langle\psi_{\vec{E}}\right|$ corresponding to the energy eigenstate $\left|\psi_{\vec{E}}\right\rangle$ with energy eigenvalue $\widetilde{E}$ and the Hamiltonian $\hat{H}=\hat{p}^{2} / 2 M+U(\hat{q})$. When we perform the WeylWigner correspondence Eq. (A2) of both sides of this operator equation, with Eq. (A1) we find the relation

$$
(H \rho)(q, p)=\widetilde{E} \Psi(q, p) .
$$

We recall the Weyl-Wigner correspondence [22]

$$
(A B)(q, p)=A\left(q-\frac{\hbar}{2 \mathrm{i}} \frac{\partial}{\partial p}, p+\frac{\hbar}{2 \mathrm{i}} \frac{\partial}{\partial q}\right) B(q, p)
$$

for products of operators $\hat{A} \hat{B}$, and arrive at

$$
H\left(q-\frac{\hbar}{2 \mathrm{i}} \frac{\partial}{\partial p}, p+\frac{\hbar}{2 \mathrm{i}} \frac{\partial}{\partial q}\right) \Psi(q, p)=\widetilde{E} \Psi(q, p)
$$

or

$$
\begin{aligned}
& {\left[\frac{p^{2}}{2 M}+\frac{p \hbar}{2 M \mathrm{i}} \frac{\partial}{\partial q}-\frac{\hbar^{2}}{8 M} \frac{\partial^{2}}{\partial q^{2}}\right] \Psi(q, p)} \\
& +U\left(q-\frac{\hbar}{2 \mathrm{i}} \frac{\partial}{\partial p}\right) \Psi(q, p)=\widetilde{E} \Psi(q, p) .
\end{aligned}
$$

When we expand the potential $U$ into a Taylor series and take the real and imaginary parts, we arrive at the two real coupled partial differential equations (1) and (2) for the Wigner function in phase space.

\section{APPENDIX B: PROPERTIES OF CHEBYSHEV POLYNOMIALS AND EVALUATION OF RESIDUALS}

In this appendix we first briefly review some useful properties of Chebyshev polynomials, and then apply them to express all terms of the coupled differential equations (11) and (12) in terms of Chebyshev polynomials. Since the operators $L_{1}$ and $L_{2}$, are linear, this can be done term by term. Here we demonstrate this procedure for one term only, and then outline how to proceed to evaluate the residuals. The 
application of the same technique to all the other terms is straightforward, and therefore not shown here.

\section{Properties of Chebyshev polynomials}

Chebyshev polynomials were investigated in great detail in Ref. [18]. Here we only specify those properties that we use in the derivation of our modified spectral method. Products $T_{s}(x) T_{r}(x)$ of Chebyshev polynomials with positive integers $s$ and $r$ can be written as

$$
T_{s}(x) T_{r}(x)=\frac{1}{2}\left[T_{s+r}(x)+T_{s-r}(x)\right],
$$

where we defined $T_{-s}(x) \equiv T_{s}(x)$. Products of the form $x^{r} T_{s}(x)$ are given by

$$
x^{r} T_{s}(x)=\frac{1}{2^{r}} \sum_{i=0}^{r}\left(\begin{array}{l}
r \\
i
\end{array}\right) T_{s-r+2 i}(x) .
$$

The derivative of a finite Chebyshev series of degree $n$ can be expressed as

$$
\frac{d}{d x}\left(\sum_{i=0}^{n} a_{i} T_{i}(x)\right)=\sum_{i=0}^{n-1} a_{i}^{x} T_{i}(x),
$$

that is a Chebyshev series of degree $n-1$ with coefficients

$$
a_{i}^{x}=\sum_{s=0}^{n} 2(i+1+2 s) a_{i+1}+2 s
$$

for $i=0,1, \ldots$ and with $a_{i}=0$ for $i>n$. Hence the differentiated Chebyshev series is a sum containing the coefficients $a_{i}$ of the original Chebyshev series. Note that, for higher derivatives, Eq. (B3) is a recurrence relation that connects the coefficients of the $n$-times differentiated Chebyshev series with the coefficients of the $(n-1)$-times differentiated series. Finally these coefficients of the $n$-times differentiated series consist of $n$-fold sums containing the coefficients $a_{i}$ of the original series.

\section{Evaluation of residuals}

We now demonstrate our technique and express the term $\left[d^{2} V(x) / d x^{2}\right]\left(\partial^{2} \Psi / \partial y^{2}\right)$ appearing in Eq. (12), in terms of Chebysher polynomials. The second derivative $d^{2} V(x) / d x^{2}$ of the potential Eq. (19) reads

$$
\frac{d^{2}}{d x^{2}} V(x)=\sum_{l \leqslant N_{\nu}-2}^{\prime} V_{l}^{x x} T_{l}(x) .
$$

From Eq. (B2), we find

$$
V_{l}^{x x}=\sum_{t=0}^{N_{u}} 2(l+1+2 t) V_{l+1+2 t}^{x}
$$

where

$$
V_{l+1+2 t}^{x}=\sum_{s=t}^{N_{v}} 2(l+2+2 s) V_{l+2+2 s},
$$

and hence

$$
V_{l}^{x x}=4 \sum_{t=0}^{N_{v}} \sum_{s=t}^{N_{v}}(l+1+2 t)(l+2+2 s) V_{l+2+2 s}
$$

Here we have applied Eq. (B3) twice.

When we insert our spectral ansatz Eq. (13) into $\left(\partial^{2} / \partial y^{2}\right) \Psi$, we obtain, from Eq. (B2),

$$
\frac{\partial^{2}}{\partial y^{2}} \Psi=\sum_{\substack{j \leqslant N_{x} \\ k \leqslant N_{y}}} a_{j, k} T_{j}(x) \frac{d^{2}}{d y^{2}} T_{k}(y)=\sum_{\substack{j \leqslant N_{x} \\ k \leqslant N_{y}-2}} a_{j, k}^{y y} T_{j}(x) T_{k}(y),
$$

where it is now convenient to decompose the coefficients of the differentiated Chebyshev series (B3) into even and odd parts in order to use the symmetry relation (18). The coefficients for the even terms read

$$
a_{j, 2 k}^{y y}=\sum_{t=k}^{N_{y}} 2(2 t+1) a_{j, 2 t+1}^{y},
$$

with

$$
a_{j, 2 t+1}^{y}=\sum_{s=t}^{N_{y}} 2(2 s+2) a_{j, 2 s+2},
$$

and for the odd terms,

$$
a_{j, 2 k+1}^{y y}=\sum_{t=k}^{N_{y}} 2(2 t+2) a_{j, 2 t+2}^{y},
$$

with

$$
a_{j, 2 t+2}^{y}=\sum_{s=t+1}^{N_{y}} 2(2 s+1) a_{j, 2 s+1}=0
$$

that is,

$$
a_{j, 2 k+1}^{y y}=0
$$

Here we exploited the symmetry relation Eq. (18). Hence we arrive at

$$
\frac{\partial^{2}}{\partial y^{2}} \Psi=\sum_{\substack{j \leqslant N_{x} \\ 2 k \leqslant N_{y}-2}} a_{j, 2 k}^{y y} T_{j}(x) T_{2 k}(y)
$$

where

$$
a_{j, 2 k}^{y y}=4 \sum_{i=k}^{N_{y}} \sum_{s=t}^{N_{y}}(2 t+1)(2 s+2) a_{j, 2 s+2} .
$$

Now we can perform the product

$$
\begin{aligned}
& \frac{d^{2}}{d x^{2}} V(x) \frac{\partial^{2}}{\partial y^{2}} \Psi \\
& \quad=\sum_{\substack{j \leqslant N_{x} \\
2 k \leqslant N_{y}-2 \\
l \leqslant N_{v}-2}} \frac{1}{2} V_{l}^{x x} a_{j, 2 k}^{y y}\left[T_{j+l}(x)+T_{j-l}(x)\right] T_{2 k}(y)
\end{aligned}
$$

of these two terms, where we used Eq. (B1). Note that $T_{j-l}(x)=T_{|j-l|}(x)$. For all the other terms of the coupled 
differential equations (11) and (12) we can proceed in exactly the same way, and find the residuals $R_{1}$ and $R_{2}$ presented in Eqs. (20) and (21).

\section{APPENDIX C: DERIVATION OF THE LINEAR SYSTEM}

In this appendix we calculate the coefficients $\Gamma_{j, k}^{\nu, \mu}$ of the linear system Eq. (24). As mentioned in Sec. V, the system is defined by the vanishing prefactors of the integrals in Eq. (23). We have to compute explicitly the prefactors belonging to a given product $T_{\nu}(x) T_{\mu}(y)$ in their dependence on $\nu$ and $\mu$. Because of the symmetry Eq. (14) in $y$, the residual $R_{1}$ only yields odd coefficients $2 \mu+1$ in $y$, and the residual $R_{2}$ only yields even coefficients $2 \mu$ in $y$. The problem now is to find, for any fixed pair of numbers $\nu$ and $\mu$, those pairs $j$ and $k$ for which the corresponding product $T_{\nu}(x) T_{\mu}(y)$ of Chebyshev polynomials occurs. For that purpose we introduce the Kronecker delta

$$
\delta_{j, \nu}= \begin{cases}1 & j=\nu \\ 0 & \text { otherwise }\end{cases}
$$

which we use in two dimensions as a product of two Kronecker deltas. With this notation, for the residual $R_{1}$, Eq. (20), we find

$$
\begin{aligned}
c_{1} \int_{-1}^{1} \int_{-1}^{1} R_{1} T_{\nu}(x) T_{2 \mu+1}(y) \chi(x, y) d x d y= & -\frac{P_{0}}{Q_{0}} \frac{1}{2} a_{j, 2 k}^{x}\left[\delta_{j, \nu} \delta_{|2 k-1|, 2 \mu+1}+\delta_{j, \nu} \delta_{2 k+1,2 \mu+1}\right]_{\nu \leqslant N_{x}-1} \\
& +\frac{1}{P_{0} Q_{0}} \frac{1}{2} \sum_{l \leqslant N_{u}-1}^{\prime} V_{l}^{x} a_{j, 2 k+1}^{y}\left[\delta_{j+l, \nu} \delta_{2 k+1,2 \mu+1}+\delta_{|j-l|, \nu} \delta_{2 k+1,2 \mu+1}\right]_{2 \mu+1 \leqslant N_{y}-1} \\
= & 0
\end{aligned}
$$

where the constant $c_{1}=1 / \pi^{2}$ for $\nu>0$ and $c_{1}=2 / \pi^{2}$ for $\nu=0$. Similarly, for the residual $R_{2}$, Eq. (21), we find

$$
\begin{aligned}
c_{2} \int_{-1}^{1} \int_{-1}^{1} R_{2} T_{\nu}(x) T_{2 \mu}(y) \chi(x, y) d x d y \\
\quad=\frac{P_{0}^{2}}{2} \frac{1}{4} a_{j, 2 k}\left[\delta_{j, \nu} \delta_{|2 k-2|, 2 \mu}+2 \delta_{j, \nu} \delta_{2 k, 2 \mu}+\delta_{j, \nu} \delta_{2 k+2,2 \mu}\right]+\sum_{l \leqslant N_{v}}^{\prime} \frac{V_{l} a_{j, 2 k}}{2}\left[\delta_{j+l, \nu} \delta_{2 k, 2 \mu}+\delta_{|j-l|, \nu} \delta_{2 k, 2 \mu}\right]-E a_{j, 2 k} \delta_{j, \nu} \delta_{2 k, 2 \mu} \\
\quad-\frac{1}{8 Q_{0}^{2}} a_{j, 2 k}^{x x}\left[\delta_{j, \nu} \delta_{2 k, 2 \mu}\right]_{2 \mu \leqslant N_{y}-2}-\frac{1}{8 P_{0}^{2} Q_{0}^{2}} \sum_{l \leqslant N_{v}-2}^{\prime} \frac{1}{2} V_{l}^{x x} a_{j, 2 k}^{y y}\left[\delta_{j+l, \nu} \delta_{2 k, 2 \mu}+\delta_{|j-l|, \nu} \delta_{2 k, 2 \mu}\right]_{2 \mu \leqslant N_{y}-2} \\
=0
\end{aligned}
$$

Here the constant $c_{2}=1 / \pi^{2}$ when both coefficients $\nu$ and $\mu$ are positive, $c_{2}=2 / \pi^{2}$ when one of them is zero, and $c_{2}=4 / \pi^{2}$ when both are zero.

Equations (C2) and (C3) represent system (10) of equations, $\Gamma \mathbf{a}=0$. Note, however, that it contains the unknown coefficients $a_{j, k}$ only implicitly. To obtain the matrix coefficients $\Gamma_{j, k}^{\nu, \mu}$ explicitly, we have to express the coefficients of the differentiated Chebyshev series $a_{j, k}^{x}$, etc., in terms of the unknowns $a_{j, k}$. To do so we have to change the order of summation in the double sums in Eq. (B6), and the equivalent equation for $\partial^{2} \Psi / \partial x^{2}$. We start from

$$
a_{j, 2 k}^{x x}=4 \sum_{i=0}^{N_{x}} \sum_{s=1}^{N_{x}}(j+1+2 t)(j+2+2 s) a_{j+2+2 s, 2 k}
$$

and

$$
a_{\tilde{j}, 2 k}^{y y}=4 \sum_{t=k}^{N_{y}} \sum_{s=t}^{N_{y}}(2 t+1)(2 s+2) a_{\tilde{j}, 2 s+2}=4 \sum_{t=k}^{N_{y}+k} \sum_{s=t}^{N_{y}}(2 t+1)(2 s+2) a_{\tilde{j}, 2 s+2} .
$$

Here $\tilde{j}=|j-l|$ or $\tilde{j}=j+l$, and we have used Eq. (B3) twice. For convenience, we have shifted the upper limit of the sum for $a_{\tilde{\nu}, 2 \mu}^{y y}$ by $k$. This does not change the sum since $a_{j, k}=0$ for $k>N_{y}$. When we interchange the order of summation we obtain

$$
a_{j, 2 k}^{x x}=\sum_{s=0}^{N_{x}} \sum_{t=0}^{s} 4(j+1+2 t)(j+2+2 s) a_{j+2+2 s, 2 k}
$$




$$
a_{\tilde{j}, 2 k}^{y y}=\sum_{s=k}^{N_{y}+k} \sum_{i=k}^{s} 4(2 t+1)(2 s+2) a_{j, 2 s+2} .
$$

The inner sums over $t$ can be written as products

$$
\sum_{t=0}^{s}(j+1+2 t)=(s+1)(j+1)+s(s+1)=(s+1)(j+s+1)
$$

and

$$
\sum_{i=k}^{s}(2 t+1)=\sum_{t=0}^{s-k}(2 \tilde{t}+2 k+1)=(s-k+1)(k+s+1) .
$$

Thus the equations of the weighted residuals [Eqs. (C2) and (C3)] take on the forms

$$
\begin{aligned}
& -\frac{P_{0}}{Q_{0}} \frac{1}{2} \sum_{s=0}^{N_{x}} 2(j+1+2 s) a_{j+1+2 s, 2 k}\left[\delta_{j, \nu} \delta_{|2 k-1|, 2 \mu+1}+\delta_{j, \nu} \delta_{2 k+1,2 \mu+1}\right]_{v \leqslant N_{x}-1} \\
& \quad+\frac{1}{P_{0} Q_{0}} \sum_{l \leqslant N_{v}-1} \frac{1}{2} V_{l}^{x} \sum_{s=0}^{N_{y}} 2(2 k+2 s+2) a_{j, 2 k+2 s+2}\left[\delta_{j+l, \nu} \delta_{2 k+1,2 \mu+1}+\delta_{|j-l|, \nu} \delta_{2 k+1,2 \mu+1}\right]_{2 \mu+1 \leqslant N_{y}-1}=0
\end{aligned}
$$

and

$$
\begin{aligned}
-E & a_{j, 2 k} \delta_{j, \nu} \delta_{2 k, 2 \mu}+\frac{P_{0}^{2}}{2} \frac{a_{j, 2 k}}{4}\left[\delta_{j, \nu} \delta_{|2 k-2|, 2 \mu}+2 \delta_{j, \nu} \delta_{2 k, 2 \mu}+\delta_{j, \nu} \delta_{2 k+2,2 \mu}\right]+\sum_{l \leqslant N_{u}}^{\prime} \frac{1}{2} V_{l} \frac{a_{j, 2 k}}{2}\left[\delta_{j+l, \nu} \delta_{2 k, 2 \mu}+\delta_{|j-l|, \nu} \delta_{2 k, 2 \mu}\right] \\
& -\frac{1}{8 Q_{0}^{2}} \sum_{s=0}^{N_{x}} 4(s+1)(j+s+1)(j+2+2 s) a_{j+2+2 s, 2 k}\left[\delta_{j, \nu} \delta_{2 k, 2 \mu}\right]_{\nu \leqslant N_{x}-2} \\
& -\frac{1}{8 P_{0}^{2} Q_{0}^{2}} \sum_{l \leqslant N_{\nu}-2} \frac{1}{2} V_{l}^{x x} \sum_{s=0}^{N_{y}} 4(s+1)(2 k+s+1)(2 k+2 s+2) a_{j, 2 k+2 s+2}\left[\delta_{j+l, \nu} \delta_{2 k, 2 \mu}+\delta_{|j-l|, \nu} \delta_{2 k, 2 \mu}\right]_{2 \mu \leqslant N_{y}-2}=0
\end{aligned}
$$

When we shift some indices of the first equation by $\widetilde{j} \equiv j+1+2 s$ and $\widetilde{k} \equiv 2 k+2+2 s$, it finally has the form

$$
\begin{aligned}
& -\frac{P_{0}}{Q_{0}} \frac{1}{2} \sum_{s=0}^{N_{x}} 2 \tilde{j} a_{\tilde{j}, 2 k}\left[\delta_{\tilde{j}-1-2 s, \nu} \delta_{\{2 k-1 \mid, 2 \mu+1}+\delta_{\tilde{j}-1-2 s, \nu} \delta_{2 k+1,2 \mu+1}\right]_{\nu \leqslant N_{x}-1} \\
& \quad+\frac{1}{P_{0} Q_{0}} \sum_{l \leqslant N_{v}-1} \frac{1}{2} V_{l}^{x} \sum_{s=0}^{N_{y}} 2 \widetilde{k} a_{j, \tilde{k}}\left[\delta_{j+l, \nu} \delta_{\widetilde{k}-1-2 s, 2 \mu+1}+\delta_{|j-l|, \nu} \delta_{\widetilde{k}-1-2 s, 2 \mu+1}\right]_{2 \mu+1 \leqslant N_{y}-1}=0 .
\end{aligned}
$$

Similarly we shift some indices of the second equation by $\tilde{j} \equiv j+2+2 s$ and $\tilde{k} \equiv 2 k+2+2 s$. With $\nu=\tilde{j}-2-2 s$ and $2 \mu=\widetilde{k}-2-2 s$, we can furthermore collect the prefactors

$$
4(s+1)(j+s+1)=(\tilde{j}-\nu)(\tilde{j}+\nu)=\left(\tilde{j}^{2}-\nu^{2}\right)
$$

and

$$
4(s+1)(2 k+s+1)=(\widetilde{k}-2 \mu)(\widetilde{k}+2 \mu)=\left(\widetilde{k}^{2}-4 \mu^{2}\right) .
$$

This finally yields 


$$
\begin{aligned}
& -E a_{j, 2 k} \delta_{j, \nu} \delta_{2 k, 2 \mu}+\frac{P_{0}^{2}}{2} \frac{a_{j, 2 k}}{4}\left[\delta_{j, \nu} \delta_{|2 k-2|, 2 \mu}+2 \delta_{j, \nu} \delta_{2 k, 2 \mu}+\delta_{j, \nu} \delta_{2 k+2,2 \mu}\right]+\sum_{l \leqslant N_{\nu}} \frac{1}{2} V_{l} \frac{a_{j, 2 k}}{2}\left[\delta_{j+l, \nu} \delta_{2 k, 2 \mu}+\delta_{|j-l|, \nu} \delta_{2 k, 2 \mu}\right] \\
& -\frac{1}{8 Q_{0}^{2}} \sum_{s=0}^{N_{x}}\left(\tilde{j}^{2}-\nu^{2}\right) \tilde{j} a_{\tilde{j}, 2 k}\left[\delta_{\tilde{j}-2-2 s, \nu} \delta_{2 k, 2 \mu}\right]_{\nu \leqslant N_{x}-2} \\
& \quad-\frac{1}{8 P_{0}^{2} Q_{0}^{2}} \sum_{l \leqslant N_{v}-2}^{\prime} \frac{1}{2} V_{l}^{x x} \sum_{s=0}^{N_{y}}\left(\widetilde{k}^{2}-4 \mu^{2}\right) \tilde{k} a_{j, \widetilde{k}}\left[\delta_{j+l, \nu} \delta_{\widetilde{k}-2-2 s, 2 \mu}+\delta_{|j-l|, \nu} \delta_{\widetilde{k}-2-2 s, 2 \mu}\right]_{2 \mu \leqslant N_{y}-2}=0
\end{aligned}
$$

From Eqs. (C4) and (C5), we immediately can read off the matrix elements $\Gamma_{j, k}^{\nu, \mu}$ of the system of equations for $a_{j, k}$. We finally arrive at Eqs. (25) and (26).

\section{APPENDIX D: ELEMENTS OF FUNCTIONAL ANALYSIS}

In this appendix we briefly review fundamental definitions of the numerical functional analysis and the energy method. This summary provides the theoretical background for the convergence analysis of our spectral scheme (Sec. VI).

\section{Definitions}

According to the Lax-Richtmyer [20] theorem the convergence of a numerical solution to the exact solution of a wellposed problem is implied by stability and consistency. What do well posed, stability, and consistency mean? To motivate the expressions used here, we return to $\mathrm{Eq}$. (6),

$$
\llcorner\psi=f
$$

and Eq. (7),

$$
L \psi_{N}=f_{N}
$$

for the approximate solution $\psi_{N}$ with the variable approximation coefficient $N=1,2 \ldots$. Here the functions $\psi, f, \psi_{N}$, and $f_{N}$ are elements of the Hilbert spaces $X, Y, X_{N}$, and $Y_{N}$, respectively. We investigate the approximation scheme

$$
\begin{gathered}
\stackrel{L}{X \rightarrow Y} \\
\mathcal{P}_{N} \downarrow \quad \downarrow \mathcal{Q}_{N} \\
\stackrel{L}{X_{N} \rightarrow Y_{N}}
\end{gathered}
$$

where $\mathcal{P}_{N}$ and $\mathcal{Q}_{N}$ denote mappings of $\psi$ onto $\psi_{N}$ and $f$ onto $f_{N}$, respectively. When Eq. (D1) has a unique solution $\psi$ for a fixed $f \in Y$, and when the sequence $f_{N}$ is given in such a way that Eq. (D2) has a unique solution $\psi_{N}$ for a fixed $N$, we call the problem well posed.

Consistency implies that there are functions $\delta=\delta(N)$ and $\epsilon=\epsilon(N)$ which tend to zero when $N$ increases to infinity with

$$
\left\|\mathcal{Q}_{N} L \psi-L \mathcal{P}_{N} \psi\right\| \leqslant \delta(N)
$$

and

$$
\left\|\mathcal{Q}_{N} f-f_{N}\right\| \leqslant \epsilon(N)
$$

for every $N$. Here the norm \|\| is the usual Hilbert space norm. These two conditions are a mathematical formulation of the fact that the result must be independent of the path taken in approximation scheme (D3).

We can define stability by requiring that there exist two positive numbers $r$ and $s$ such that the inequality

$$
\|\psi-\widetilde{\psi}\|_{X_{N}}^{r} \leqslant s\|L \psi-L \bar{\psi}\|_{Y_{N}}
$$

holds for all $\psi \in X$ and $\widetilde{\psi} \in X_{N}$ and for all $N$. Note that the parameter $s$ must not depend on $N$. This means, roughly speaking, that the errors are bounded by the residuals.

In Sec. VI, we assume that $\Psi$ is an element of a Sobolev space. The Sobolev space

$$
H_{\chi}^{m}(\Omega) \equiv\left\{\psi \mid \iint_{\Omega} D^{\alpha} \psi D^{\alpha} \psi \chi d x d y<\infty\right\}
$$

contains those functions $\psi$ for which all derivatives up to an order $m$ are square integrable with respect to the Chebyshev weight $\chi$ on the domain $\Omega$. Thereby $\alpha$ is a multi-index $\alpha=\left(\alpha_{1}, \alpha_{2}\right)$ of non-negative integers, and $D^{\alpha} \psi$ denotes the partial derivative

$$
D^{\alpha} \psi=\frac{\partial^{\alpha_{1}+\alpha_{2}} \psi}{\partial x^{\alpha_{1}} \partial y^{\alpha_{2}}}
$$

The space $H_{\chi}^{m}(\Omega)$ is a Hilbert space with the norm \|\| defined by

$$
\|\psi\|_{H_{x}^{m(\Omega)}}^{2}=(\psi, \psi)_{H_{\chi}^{m_{(}(\Omega)}} \equiv \sum_{|\alpha| \leqslant m} \iint_{\Omega} D^{\alpha} \psi D^{\alpha} \psi \chi d x d y,
$$

where $|\alpha|=\alpha_{1}+\alpha_{2}$. We conclude this subsection by noting that the phrase "appropriate function" stands for a function $\psi \in H_{\chi}^{2}$ that is symmetric in $y$.

\section{Energy method}

In this subsection we summarize results that were presented in full detail in Ref. [16]. The most straightforward technique for establishing the stability of spectral schemesthe so-called energy method-is based on choosing the solution itself as the weight function discussed in Sec. V. This approach is successful if the spaces of the trial and test functions coincide, and if the spectral operator is positive with respect to a suitable inner product. 
The well posedness of a problem $L \psi=f$ is guaranteed when $L$ satisfies a coercivity condition: We assume that there exists a Hilbert space $X$ such that the linear differential operator $L$ is an unbounded operator in $X$. Let us further assume that there is a Hilbert space $E \subseteq X$ with a norm $\|\psi\|_{E}$, for which there exists a positive constant $C$ such that $\|\psi\| \leqslant C\|\psi\|_{E}$ for all $\psi \in E$. Here $E$ is the subspace of the functions $\psi \in X$ with "finite" energy, the energy being accurately given by $\|\psi\|_{E}^{2}$. Assume that constants $\alpha>0$ and $\beta>0$ exist such that

$$
\begin{gathered}
\alpha\|\psi\|_{E}^{2} \leqslant(L \psi, \psi), \\
|(L \psi, \widetilde{\psi})| \leqslant \beta\|\psi\|_{E}\|\widetilde{\psi}\|_{E}
\end{gathered}
$$

for all $\psi \in D(L)$ and $\widetilde{\psi} \in E$, where $D(L)$ is the domain of $L$.

Inequality (D4) states that $L$ is a positive operator, which is called coercive over $E$, while inequality (DS) is a continuity condition for $L$ in the sense that $(L \psi, \widetilde{\psi})_{\chi}$ depends continuously on $\psi$ and $\widetilde{\psi}$. If these inequalities hold there exists a unique weak solution of the problem $L \psi=f$, that is a solution of

$$
(L \psi, \widetilde{\psi})=(f, \widetilde{\psi})
$$

This theorem is a consequence of the Lax-Milgram theorem. Finally one can prove that the weak solution is indeed a strong solution, that is, it satisfies $L \psi=f$.
Applying this result to the Chebyshev polynomials of degree $N$ guarantees the stability and consistency of our spectral scheme in the sense of the energy method, if $N$ is sufficiently large. Under this hypothesis, convergence is a consequence of the Lax-Richtmyer [20] theorem. Then the corresponding error estimate reads

$$
\left\|\psi-\psi^{N}\right\|_{H_{x}^{1}(\Omega)} \leqslant C N^{1-m}\|\psi\|_{H_{x}^{m}(\Omega)}
$$

for each $\psi \in H_{\chi}^{1}(\Omega)$. Since Eqs. (11) and (12) are of second order, we have $m=2$, and hence the error reduces in proportion to $1 / N$.

\section{APPENDIX E: PROOF OF COERCIVITY}

In this appendix we first show that Eqs. (31) and (32) yield the same coercivity condition Eq. (28). We then estimate the relevant scalar product and prove the inequality Eq. (33).

To apply Canuto's theorem we first have to check if inequality (28) holds for any function $\Psi(x, y) \in H_{\chi}^{2}(\Omega)$ which is even in $y$. We define the weighted scalar product

$$
(\Psi, \tilde{\Psi})_{\chi}=\int_{1}^{1} \int_{1}^{1} \Psi \widetilde{\Psi} \chi d x d y
$$

and evaluate the expressions $\left(L_{+} \Psi, \Psi\right)_{\chi}$ and $\left(L_{2} \Psi, \Psi\right)_{\chi}$ for the operators $L_{+}$and $L_{2}$. From Eqs. (32) and (31), we note that they differ only by two terms. Moreover, the difference

$$
\left(L_{+} \Psi, \Psi\right)_{\chi}-\left(L_{2} \Psi, \Psi\right)_{\chi}=\frac{1}{Q_{0}} \int_{-1}^{1} \int_{-1}^{1}\left(-P_{0} y \frac{\partial \Psi}{\partial x} \Psi \chi+\frac{1}{P_{0}} \frac{d V}{d x} \frac{\partial \Psi}{\partial y} \Psi \chi\right) d x d y
$$

is zero because the integrand is an odd function in $y$. Therefore the relation $\left(L_{+} \Psi, \Psi\right)_{\chi}=\left(L_{2} \Psi, \Psi\right)_{\chi}$ holds for the operators $L_{+}$and $L_{2}$ in Eqs. (32) and (31). Consequently, it is sufficient to investigate $L_{2}$ only.

When we integrate the last integral of the scalar product

$$
\left(L_{2} \Psi, \Psi\right)_{X}=\int_{-1}^{1} \int_{-1}^{1}\left(\frac{P_{0}^{2} y^{2}}{2}+V(x)-E\right) \Psi^{2} \chi d x d y-\frac{1}{8 Q_{0}^{2}} \int_{-1}^{1} \int_{-1}^{1}\left(\frac{\partial^{2} \Psi}{\partial x^{2}} \Psi \chi+\frac{1}{P_{0}^{2}} \frac{d^{2} V}{d x^{2}} \frac{\partial^{2} \Psi}{\partial y^{2}} \Psi \chi\right) d x d y
$$

by parts, we obtain

$$
\begin{aligned}
\left(L_{2} \Psi, \Psi\right)_{\chi}= & \int_{-1}^{1} \int_{-1}^{1}\left(\frac{P_{0}^{2} y^{2}}{2}+V(x)-E\right) \Psi^{2} \chi d x d y \\
& +\frac{1}{8 Q_{0}^{2}} \int_{-1}^{1} \int_{-1}^{1}\left(\frac{\partial \Psi}{\partial x} \frac{\partial}{\partial x}(\Psi \chi)+\frac{1}{P_{0}^{2}} \frac{d^{2} V}{d x^{2}} \frac{\partial \Psi}{\partial y} \frac{\partial}{\partial y}(\Psi \chi)\right) d x d y \\
& -\frac{1}{8 Q_{0}^{2}} \int_{-1}^{1}\left[\frac{\partial \Psi}{\partial x} \Psi \chi\right]_{-1}^{1} d y-\frac{1}{8 Q_{0}^{2}} \int_{-1}^{1}\left[\frac{1}{P_{0}^{2}} \frac{d^{2} V}{d x^{2}} \frac{\partial \Psi}{\partial y} \Psi \chi\right]_{-1}^{1} d x
\end{aligned}
$$

After a second partial integration, Eq. (E3) becomes

$$
\begin{aligned}
\left(L_{2} \Psi, \Psi\right)_{\chi}= & \int_{-1}^{1} \int_{-1}^{1}\left(\frac{P_{0}^{2} y^{2}}{2}+V(x)-E\right) \Psi^{2} \chi d x d y \\
& +\frac{1}{8 Q_{0}^{2}} \int_{-1}^{1} \int_{-1}^{1}\left[\left(\frac{\partial \Psi}{\partial x}\right)^{2}+\frac{1}{P_{0}^{2}} \frac{d^{2} V}{d x^{2}}\left(\frac{\partial \Psi}{\partial y}\right)^{2}\right] \chi d x d y-\frac{1}{16 Q_{0}^{2}} \int_{-1}^{1} \int_{-1}^{1}\left(\Psi^{2} \frac{\partial^{2} \chi}{\partial x^{2}}+\frac{1}{P_{0}^{2}} \frac{d^{2} V}{d x^{2}} \Psi^{2} \frac{\partial^{2} \chi}{\partial y^{2}}\right) d x d y-\mathcal{B}_{1}
\end{aligned}
$$

with 


$$
\begin{aligned}
\mathcal{B}_{1}= & +\frac{1}{8 Q_{0}^{2}} \int_{-1}^{1}\left[\frac{\partial \Psi}{\partial x} \Psi \chi\right]_{-1}^{1} d y+\frac{1}{8 Q_{0}^{2} P_{0}^{2}} \int_{-1}^{1} \frac{d^{2} V}{d x^{2}}\left[\frac{\partial \Psi}{\partial y} \Psi \chi\right]_{-1}^{1} d x \\
& -\frac{1}{16 Q_{0}^{2}} \int_{-1}^{1}\left[\Psi^{2} \frac{\partial \chi}{\partial x}\right]_{-1}^{1} d y-\frac{1}{16 Q_{0}^{2} P_{0}^{2}} \int_{-1}^{1} \frac{d^{2} V}{d x^{2}}\left[\Psi^{2} \frac{\partial \chi}{\partial y}\right]_{-1}^{1} d x
\end{aligned}
$$

Since only first derivatives of $\Psi$ occur in Eq. (E3), $\Psi$ need only to be in $H_{x}^{l}(\Omega)$.

We now want to estimate Eq. (E4). With

$$
\frac{\partial^{2} \chi}{\partial x^{2}}=\left(1+2 x^{2}\right)\left(1-y^{2}\right)^{2} \chi^{5} \leqslant 3 \chi^{5}
$$

and

$$
\frac{\partial^{2} \chi}{\partial y^{2}}=\left(1+2 y^{2}\right)\left(1-x^{2}\right)^{2} \chi^{5} \leqslant 3 \chi^{5}
$$

following from the definition Eq. (22) of the Chebyshev weight, we obtain

$$
\frac{1}{16 Q_{0}^{2}} \int_{-1}^{1} \int_{-1}^{1}\left(\Psi^{2} \frac{\partial^{2} \chi}{\partial x^{2}}+\frac{1}{P_{0}^{2}} \frac{d^{2} V}{d x^{2}} \Psi^{2} \frac{\partial^{2} \chi}{\partial y^{2}}\right) d x d y \leqslant 3 \frac{1}{16 Q_{0}^{2}} \int_{-1}^{1} \int_{-1}^{1}\left(1+\frac{1}{P_{0}^{2}} \frac{d^{2} V}{d x^{2}}\right) \Psi^{2} \chi^{5} d x d y
$$

In Appendix $\mathbf{F}$ we prove the inequality

$$
\begin{aligned}
& \int_{-1}^{1} \int_{-1}^{1}\left(\frac{\partial \Psi}{\partial x} \frac{\partial}{\partial x}(\Psi \chi)+\frac{1}{P_{0}^{2}} \frac{d^{2} V}{d x^{2}} \frac{\partial \Psi}{\partial y} \frac{\partial}{\partial y}(\Psi \chi)\right) d x d y \\
& \quad \geqslant \frac{1}{2} \int_{-1}^{1} \int_{-1}^{1} \Psi^{2} \chi^{5}\left(1+\frac{1}{P_{0}^{2}} \frac{d^{2} V}{d x^{2}}\right) d x d y-\frac{1}{2} \int_{-1}^{1}\left[\Psi^{2} \frac{\partial \chi}{\partial x}\right]_{-1}^{1} d y-\frac{1}{2 P_{0}^{2}} \int_{-1}^{1} \frac{d^{2} V}{d x^{2}}\left[\Psi^{2} \frac{\partial \chi}{\partial y}\right]_{-1}^{1} d x,
\end{aligned}
$$

which holds true whenever $\Psi \in H_{\chi}^{1}(\Omega)$ is a symmetrical function in $y$ and $d^{2} V / d x^{2}$ is positive. This relation yields

$$
\begin{aligned}
& \frac{1}{16 Q_{0}^{2}} \int_{-1}^{1} \int_{-1}^{1}\left(\Psi^{2} \frac{\partial^{2} \chi}{\partial x^{2}}+\frac{1}{P_{0}^{2}} \frac{d^{2} V}{d x^{2}} \Psi^{2} \frac{\partial^{2} \chi}{\partial y^{2}}\right) d x d y \\
& \quad \leqslant \frac{3}{8 Q_{0}^{2}}\left\{\int_{-1}^{1} \int_{-1}^{1}\left(\frac{\partial \Psi}{\partial x} \frac{\partial}{\partial x}(\Psi \chi)+\frac{1}{P_{0}^{2}} \frac{d^{2} V}{d x^{2}} \frac{\partial \Psi}{\partial y} \frac{\partial}{\partial y}(\Psi \chi)\right) d x d y+\frac{1}{2} \int_{-1}^{1}\left[\Psi^{2} \frac{\partial \chi}{\partial x}\right]_{-1}^{1} d y+\frac{1}{2 P_{0}^{2}} \int_{-1}^{1} \frac{d^{2} V}{d x^{2}}\left[\Psi^{2} \frac{\partial \chi}{\partial y}\right]_{-1}^{1} d x\right\},
\end{aligned}
$$

and, with Eq. (E3), we finally arrive at

$$
\begin{aligned}
& \left(L_{2} \Psi, \Psi\right)_{\chi} \\
& \quad \geqslant \frac{1}{8 Q_{0}^{2}} \int_{-1}^{1} \int_{-1}^{1}\left[\left(\frac{\partial \Psi}{\partial x}\right)^{2}+\frac{1}{P_{0}^{2}} \frac{d^{2} V}{d x^{2}}\left(\frac{\partial \Psi}{\partial y}\right)^{2}\right] \chi d x d y+4 \int_{-1}^{1} \int_{-1}^{1}\left(\frac{P_{0}^{2} y^{2}}{2}+V(x)-E\right) \Psi^{2} \chi d x d y-3\left(L_{2} \Psi, \Psi\right)_{\chi}+\mathcal{B}_{2},
\end{aligned}
$$

with

$$
\begin{aligned}
\mathcal{B}_{2}= & -\frac{1}{2 Q_{0}^{2}} \int_{-1}^{1}\left[\frac{\partial \Psi}{\partial x} \Psi \chi\right]_{-1}^{1} d y-\frac{1}{2 Q_{0}^{2} P_{0}^{2}} \int_{-1}^{1} \frac{d^{2} V}{d x^{2}}\left[\frac{\partial \Psi}{\partial y} \Psi \chi\right]_{-1}^{1} d x-\frac{1}{8 Q_{0}^{2}} \int_{-1}^{1}\left[\Psi^{2} \frac{\partial \chi}{\partial x}\right]_{-1}^{1} d y \\
& -\frac{1}{8 Q_{0}^{2} P_{0}^{2}} \int_{-1}^{1} \frac{d^{2} V}{d x^{2}}\left[\Psi^{2} \frac{\partial \chi}{\partial y}\right]_{-1}^{1} d x
\end{aligned}
$$

The first term on the right-hand side we can easily estimate with the help of the Poincare inequality $[16]\|\Psi\|_{L_{X}^{2} \leqslant C \| \nabla \Psi} \|_{\left(L_{X}^{2}\right)^{2}}$ which holds true for all $\Psi \in H_{\chi}^{1}(\Omega)$, where $C$ denotes a positive constant. The Poincaré inequality is valid, whenever $\Psi$ 
vanishes on some one-dimensional curve on the domain $\Omega$. The Wigner function $\Psi$ satisfies this assumption since it vanishes for sufficiently large arguments $x$ and $y$. Hence for positive $d^{2} V / d x^{2}$ we find from Eq. (E5) the final estimate Eq. (33),

$$
\left(L_{2} \Psi, \Psi\right)_{\chi} \geqslant \frac{C}{32 Q_{0}^{2}} \min \left(1, \frac{1}{P_{0}^{2}} \frac{d^{2} V}{d x^{2}}\right)\|\Psi\|^{2}+\int_{-1}^{1} \int_{-1}^{1}\left(\frac{P_{0}^{2} y^{2}}{2}+V(x)-E\right) \Psi^{2} \chi d x d y+\frac{\mathcal{B}_{2}}{4},
$$

with $\mathcal{B}_{2}$ from Eq. (E5). In Sec. VI we use this result with $\mathcal{B} \equiv \mathcal{B}_{2} / 4$ to discuss the stability of our scheme with the energy method. Equation (28) and hence Eq. (E6) requires that the sum of the last three terms have to be greater than a constant times $\|\Psi\|$.

\section{APPENDIX F: A USEFUL, INEQUALITY}

In this appendix we prove the inequality (E4),

$$
\begin{aligned}
& \int_{-1}^{1} \int_{-1}^{1}\left(\frac{\partial \Psi}{\partial x} \frac{\partial}{\partial x}(\Psi \chi)+\frac{1}{P_{0}^{2}} \frac{d^{2} V}{d x^{2}} \frac{\partial \Psi}{\partial y} \frac{\partial}{\partial y}(\Psi \chi)\right) d x d y \\
& \quad \geqslant \frac{1}{2} \int_{-1}^{1} \int_{-1}^{1} \Psi^{2} \chi^{5}\left(1+\frac{1}{P_{0}^{2}} \frac{d^{2} V}{d x^{2}}\right) d x d y-\frac{1}{2} \int_{-1}^{1}\left[\Psi^{2} \frac{\partial \chi}{\partial x}\right]_{-1}^{1} d y-\frac{1}{2 P_{0}^{2}} \int_{-1}^{1} \frac{d^{2} V}{d x^{2}}\left[\Psi^{2} \frac{\partial \chi}{\partial y}\right]_{-1}^{1} d x,
\end{aligned}
$$

which is crucial for the estimate Eq. (E6). This inequality is valid for a function $\Psi \in H_{\chi}^{1}(\Omega)$ symmetric in $y$ and $d^{2} V / d x^{2}>0$. For a similar inequality, however, restricted to one dimension and without boundary terms, we refer to Ref. [16].

We start the derivation by performing the differentiation on the left-hand side of the inequality, and find

$$
\int_{-1}^{1} \int_{-1}^{1}\left[\left(\frac{\partial \Psi}{\partial x}\right)^{2} \chi^{2}+\Psi \frac{\partial \Psi}{\partial x} \chi \frac{\partial \chi}{\partial x}\right] \chi^{-1} d x d y+\frac{1}{P_{0}^{2}} \int_{-1}^{1} \int_{-1}^{1} \frac{d^{2} V}{d x^{2}}\left[\left(\frac{\partial \Psi}{\partial y}\right)^{2} \chi^{2}+\Psi \frac{\partial \Psi}{\partial y} \chi \frac{\partial \chi}{\partial y}\right] \chi^{-1} d x d y
$$

When we complete the square in the integrals, this equals

$$
\begin{aligned}
& \int_{-1}^{1} \int_{-1}^{1}\left[\left(\frac{\partial \Psi}{\partial x}\right)^{2} \chi^{2}+2 \Psi \frac{\partial \Psi}{\partial x} \chi \frac{\partial \chi}{\partial x}+\Psi^{2}\left(\frac{\partial \chi}{\partial x}\right)^{2}\right] \chi^{-1} d x d y \\
& +\frac{1}{P_{0}^{2}} \int_{-1}^{1} \int_{-1}^{1} \frac{d^{2} V}{d x^{2}}\left[\left(\frac{\partial \Psi}{\partial y}\right)^{2} \chi^{2}+2 \Psi \frac{\partial \Psi}{\partial y} \chi \frac{\partial \chi}{\partial y}+\Psi^{2}\left(\frac{\partial \chi}{\partial y}\right)^{2}\right] \chi^{-1} d x d y \\
& \quad-\int_{-1}^{1} \int_{-1}^{1}\left[\Psi \frac{\partial \Psi}{\partial x} \frac{\partial \chi}{\partial x}+\Psi^{2}\left(\frac{\partial \chi}{\partial x}\right)^{2} \chi^{-1}\right] d x d y-\frac{1}{P_{0}^{2}} \int_{-1}^{1} \int_{-1}^{1} \frac{d^{2} V}{d x^{2}}\left[\Psi \frac{\partial \Psi}{\partial y} \frac{\partial \chi}{\partial y}+\Psi^{2}\left(\frac{\partial \chi}{\partial y}\right)^{2} \chi^{-1}\right] d x d y
\end{aligned}
$$

When we then perform an integration by parts in the same way as done in Eq. (E4), we arrive at

$$
\begin{aligned}
& \int_{-1}^{1} \int_{-1}^{1}\left[\left(\frac{\partial}{\partial x}(\Psi \chi)\right)^{2}+\frac{1}{P_{0}^{2}} \frac{d^{2} V}{d x^{2}}\left(\frac{\partial}{\partial y}\left(\Psi_{\chi}\right)\right)^{2}\right] \chi^{-1} d x d y+\int_{-1}^{1} \int_{-1}^{1} \Psi^{2}\left[\frac{1}{2} \frac{\partial^{2} \chi}{\partial x^{2}}-\left(\frac{\partial \chi}{\partial x}\right)^{2} \chi^{-1}\right] d x d y \\
& +\frac{1}{P_{0}^{2}} \int_{-1}^{1} \int_{-1}^{1} \frac{d^{2} V}{d x^{2}} \Psi^{2}\left[\frac{1}{2} \frac{\partial^{2} \chi}{\partial y^{2}}-\left(\frac{\partial \chi}{\partial y}\right)^{2} \chi^{-1}\right] d x d y-\frac{1}{2} \int_{-1}^{1}\left[\Psi^{2} \frac{\partial \chi}{\partial x}\right]_{-1}^{1} d y-\frac{1}{2 P_{0}^{2}} \int_{-1}^{1} \frac{d^{2} V}{d x^{2}}\left[\Psi^{2} \frac{\partial \chi}{\partial y}\right]_{-1}^{1} d x
\end{aligned}
$$

With the help of the identities

$$
\frac{\partial^{2} \chi}{\partial x^{2}}-2\left(\frac{\partial \chi}{\partial x}\right)^{2} \chi^{-1}=\chi^{5}\left(1-y^{2}\right)^{2}
$$

and

$$
\frac{\partial^{2} \chi}{\partial y^{2}}-2\left(\frac{\partial \chi}{\partial y}\right)^{2} \chi^{-1}=\chi^{5}\left(1-x^{2}\right)^{2}
$$

following from the definition Eq. (22) of the Chebyshev weight, we obtain inequality (E4) when we omit the first integral of Eq. (F1) which is positive and use that $\left(1-x^{2}\right)^{2}$ and $\left(1-y^{2}\right)^{2}$ are bounded from above by 1 . 
[1] M. Hillery, R. F. O'Connell, M. O. Scully, and E. P. Wigner, Phys. Rep. 106, 121 (1984).

[2] (a) D. B. Fairlie, Proc. Camb. Philos. Soc. 60, 581 (1964); (b) W. Kundt, Z. Naturforsch. A 22, 1333 (1967).

[3] (a) U. Uhlhom, Ark. Fys. 11, 87 (1956); (b) J. P. Dahl, in Energy Storage and Redistribution in Molecules, edited by $\mathrm{J}$. Hinze (Plenum, New York, 1983), pp. 557-571; (c) L. Wang and R. F. O'Connell, Found. Phys. 18, 1023 (1988).

[4] (a) See Ref. [3(a)]; (b) see Ref. [2(a)]; (c) see Ref. [3(b)]; (d) P. Carruthers and F. Zachariasen, Rev. Mod. Phys. 55, 245 (1983).

[5] H.-W. Lee, Phys. Rep. 259, 147 (1995).

[6] J. E. Moyal, Proc. Cambridge Philos. Soc. 45, 99 (1947).

[7] E. Wigner, Phys. Rev. 40, 749 (1932).

[8] J. Bertrand and P. Bertrand, Found. Phys. 17, 397 (1987).

[9] U. Leonhardt, Measuring the Quantum State of Light, Cambridge Studies in Modern Optics (Cambridge University Press, Cambridge, 1997).

[10] N. Lütkenhaus and S. M. Bamett, Phys. Rev. A 51, 3340 (1995).

[11] W. P. Schleich, D. S. Krähmer, and E. Mayr, Quantum Optics in Phase Space (VCH, Weinheim, in press)

[12] M. V. Berry, Philos. Trans. R. Soc. London, Ser. A 287, 237 (1977).
[13] D. Gottlieb and S. A. Orszag, Numerical Analysis of Spectral Methods: Theory and Applications (SIAM, Philadelphia, 1977).

[14] M. Hug, C. Menke, and W. P. Schleich, following paper, Phys. Rev. A 57, 3206 (1998).

[15] C. A. Fletcher, Computational Galerkin Methods (Springer, New York, 1984)

[16] C. Canuto, M. Y. Hussaini, A. Quarteroni, and T. A. Zang, Spectral Methods in Fluid Dynamics. Springer Series in Computational Physics (Springer-Verlag, Berlin, 1988).

[17] J. P. Boyd, Chebyshev \& Fourier Spectral Methods, Lecture Notes in Engineering (Springer-Verlag, Berlin, 1989).

[18] L. Fox and I. B. Parker, Chebyshev Polynomials in Numerical Analysis, Oxford Mathematical Handbooks (Oxford University Press, London, 1968).

[19] E. Anderson, Z. Bai, C. Bischof, J. Dernmel, J. Dongarra, J. Du Croz, A. Greenbaum, S. Hammarling, A. McKenney, S. Ostrouchov, and D. Sorensen, LAPACK Users' Guide (SIAM, Philadelphia, 1992).

[20] R. D. Richtmyer and K. W. Morton, Difference Methods for Initial-Value Problems (Interscience, New York, 1967).

[21] J. P. Dahl and M. Springborg, J. Chem. Phys. 88, 4535 (1988).

[22] F. Bopp, in Werner Heisenberg und die Physik unserer Zeit (Vieweg, Braunschweig, 1961), p. 128. 


\title{
Modified spectral method in phase space: Calculation of the Wigner function. II. Generalizations
}

\author{
M. Hug, ${ }^{1}$ C. Menke, ${ }^{2}$ and W. P. Schleich ${ }^{1}$ \\ 'Abteilung für Quantenphysik, Universität Ulm, D-89069 Ulm, Germany \\ ${ }^{2}$ Abteilung Numerik, Universität Ulm, D-89069 Ulm, Germany
}

(Received 30 October 1997)

\begin{abstract}
We generalize our modified spectral method for the solution of the coupled real partial differential equations in phase space for the stationary Wigner function of an energy eigenstate. This generalization allows us to apply our algorithm to arbitrary high-order partial derivatives without increasing the numerical costs. This is possible since we can derive a sum factorization formula converting a multiple sum into a simple product. We apply our method to evaluate the Wigner function of the Morse oscillator and an asymmetric double-well potential, and compare our results with the exact solution when it is known. [S1050-2947(98)04804-5]
\end{abstract}

PACS number(s): 03.65. Bz, 02.70.Hm

\section{INTRODUCTION}

In paper I [1] we laid the foundations of a method calculating the Wigner function of an energy eigenstate directly from phase space. We introduced a modified spectral method for the solution of the two coupled partial differential equations defining the corresponding Wigner function in phase space. We approximated the solution as a finite sum of Chebyshev polynomials in the two phase-space variables position and momentum. To keep the analysis of our method simple, we restricted the discussion in paper I to secondorder derivatives. In the present paper we focus on the generalization of our modified spectral method to differential quotients of arbitrary high order in the two partial differential equations for the Wigner function.

By the extension of our method to the full system, we are able to calculate the Wigner function of any energy eigenstate in any smooth potential. High-order differential terms which occur in differential equations describing a physical system are often neglected because it seems to be too complicated to handle them. Our method turns out to be a very powerful tool to solve such equations, since high-order derivatives do not increase the number of unknown coefficients and therefore the numerical costs. We derive a sum factorization formula which shows that the $n$ th-order derivative only contributes by a simple product of $n$ terms to the system of equations for the unknown Chebyshev coefficients, and not by an $n$-fold sum as one might expect. This formula is universal since it remains valid whenever any spectral method which uses Chebyshev polynomials as shape functions is applied to any high-order differential equation. Generalizations of our method to any other high-order differential equations are therefore straightforward.

This paper is organized as follows: After a short summary of the fundamentals in Sec. II, in Sec. III we analyze the higher-order terms which we neglected in paper I. This analysis makes use of the sum factorization formula mentioned in the preceding paragraph. We give the proofs in the Appendixes. In Sec. IV we apply our method to evaluate the Wigner function of the Morse oscillator, which requires including higher order terms to obtain satisfying results for the Wigner function, and to an asymmetric double-well potential where neither an analytic expression for the Wigner function nor for the wave function is known. In this potential even semiclassical approaches fail for low excited states.

\section{SUMMARY OF THE FUNDAMENTALS}

In this section we briefly summarize the fundamentals introduced in paper I [1] that are actually necessary to understand the analysis of this paper. In particular we define the phase-space equations for the Wigner function, and sketch our spectral ansatz and the central ideas of our method.

Note that we still concentrate on energy eigenstates of one-dimensional potentials whose phase-space description leads to a two-dimensional phase space spanned by dimensionless position $Q$ and momentum $P$. We compute the Wigner function on a square domain in phase space $\left[Q_{1}, Q_{2}\right] \times\left[-P_{0}, P_{0}\right]$, with $Q_{1}<Q_{2}$ and $P_{0}>0$. For our method it is convenient to map this domain onto the square $\Omega \equiv[-1,1] \times[-1,1]$, and to formulate our theory in the mapped position variable $x \in[-1,1]$ and the momentum variable $y \in[-1,1]$. Once we have found the Wigner function in these variables it is straightforward to invert this linear mapping.

In phase-space language the Wigner function $\Psi(x, y)$ of an energy eigenstate with energy $E$ in a one-dimensional binding potential $V(x)$ is defined as the unique solution of the coupled partial differential equations

$$
L_{\text {odd }} \Psi \equiv\left[-\frac{P_{0}}{Q_{0}} y \frac{\partial}{\partial x}+\sum_{m=0}^{\infty} \Lambda_{2 m+1}\right] \Psi(x, y)=0,
$$

where

$$
\Lambda_{2 m+1} \equiv \frac{1}{(2 m+1) !}\left(\frac{\mathrm{i}}{2}\right)^{2 m} \frac{1}{P_{0}^{2 m+1} Q_{0}^{2 m+1}} \frac{d^{2 m+1} V}{d x^{2 m+1}} \frac{\partial^{2 m+1}}{\partial y^{2 m+1}}
$$

and

$$
\begin{aligned}
L_{\text {even }} \Psi & \equiv\left[\frac{P_{0}^{2} y^{2}}{2}+V(x)-E-\frac{1}{8 Q_{0}^{2}} \frac{\partial^{2}}{\partial x^{2}}+\sum_{m=1}^{\infty} \Lambda_{2 m}\right] \Psi(x, y) \\
& =0
\end{aligned}
$$

with 


$$
\Lambda_{2 m} \equiv \frac{1}{(2 m) !}\left(\frac{\mathrm{i}}{2}\right)^{2 m} \frac{1}{P_{0}^{2 m} Q_{0}^{2 m}} \frac{d^{2 m} V}{d x^{2 m}} \frac{\partial^{2 m}}{\partial y^{2 m}} .
$$

In order to accentuate the fundamental ideas of our modified spectral method, we restricted ourselves in the analysis of paper I to investigating the solution of these equations with $\Lambda_{1}$ and $\Lambda_{2}$, that is, we truncated Eqs. (1) and (2) after the second-order derivatives. The purpose of this paper is to include any arbitrary high-order $m$ into the analysis without increasing the size of the resulting linear system of equations. For that purpose we again choose the ansatz

$$
\Psi_{N}(x, y)=\sum_{j=0}^{N_{x}} \sum_{k=0}^{N_{y}}{ }^{\prime} a_{j, k} T_{j}(x) T_{k}(y)
$$

where $T_{j}$ denotes the Chebyshev polynomial of order $j$. The end of the method is to find the unknown coefficients $a_{j, k}$ in such a way that the approximated solution of our ansatz fits the exact solution of Eqs. (1) and (2) best. The logical train of thought of the modified spectral method is to insert this ansatz into Eqs. (1) and (2). We call the deviation of these expressions from the exact solution the residuals $R_{1}=L_{\text {odd }} \Psi_{N}$ and $R_{2}=L_{\text {even }} \Psi_{N}$. We obtain the equation system for the unknown coefficients $a_{j, k}$ by requiring that the integrals

$$
\int_{\Omega} R_{1} T_{\nu} T_{\mu} \chi \text { and } \int_{\Omega} R_{2} T_{\nu} T_{\mu} \chi
$$

of the weighted residuals over $\Omega$ vanish. Here $\chi$ denotes the Chebyshev weight, which allows us to use the orthogonality relations of the Chebyshev polynomials to derive a linear system of equations

$$
\Gamma \mathbf{a}=\mathbf{0}
$$

for the unknown coefficients ( $\mathbf{a})_{j, k} \equiv a_{j, k}$, which in our case is an overdetermined system. To find nontrivial solutions of Eq. (5), we have to require that the solution value at a specific point in the computational domain, for example the origin, is not zero. Since Eqs. (1) and (2) are linear, we can arbitrarily choose a nonzero value and normalize the solution after computation. The matrix elements $\Gamma_{\nu, \mu}^{j, k}$ do not contain integrals because we can make use of the orthogonality relations of the Chebyshev polynomials.

We finally approximate the solution of this system, and therefore the equations for the weighted residuals, by a standard least-squares algorithm. That means that in practice we do not require that the weighted residuals, Eq. (4) vanish, but we minimize them in a least-squares sense.

\section{ANALYSIS OF THE HIGHER-ORDER TERMS}

In this section we concentrate on the additional aspects we have to consider, when we do not truncate the system after the second derivative of the potential but take all terms into account. As there are no changes in the terms correlated to the truncated equations Eqs. (11) and (12) of paper I [1], the analysis presented there remains valid. For each higherorder differential quotient which we additionally take into account, we obtain one further summand in the equation for the coefficients of the linear system of equations (5). In this paper we prove a general formula which allows us to calculate these terms directly without multiple sums, which makes it straightforward to implement any arbitrary order on the computer. Note that these higher-order terms do not increase the number of unknowns or the size of the matrix, and therefore do not increase the computational cost. Only the number of terms for the residuals, and consequently the effort for setting up the system matrix $\Gamma$ of Eq. (5), are affected.

\section{A. Evaluating the residuals}

Since in paper I we showed explicitly how the terms up to the second-order derivatives set up the equation system (5) we now deal with the higher-order terms $\left(d^{m} V / d x^{m}\right)\left[\partial^{m} \Psi(x, y) / \partial y^{m}\right]$ for $m>2$ appearing in $\Lambda_{2 m-1}$ and $\Lambda_{2 m}$ [Eqs. (1) and (2)].

Taking the derivative $\partial^{m} \Psi_{N}(x, y) / \partial y^{m}$ for any $m>0$ of our spectral ansatz Eq. (3), we obtain

$$
\begin{aligned}
\frac{\partial^{m}}{\partial y^{m}} \Psi_{N} & =\sum_{\substack{j \leqslant N_{x} \\
k \leqslant N_{y}}} a_{j, k} T_{j}(x) \frac{d^{m}}{d y^{m}} T_{k}(y) \\
& =\sum_{\substack{j \leqslant N_{x} \\
k \leqslant N_{y}-m}} a_{j, k}^{m} T_{j}(x) T_{k}(y),
\end{aligned}
$$

where now the superscript $m$ of $a_{j, k}^{m}$ denotes the coefficient of the $m$ th derivative with respect to $y$ of the Chebyshev series (3) which is again a Chebyshev series [2]. Note that in contrast to paper I, we do not have to indicate the variable of the differentiation since for any term of higher order than the second all the derivatives of $\Psi$ are with respect to $y$. The coefficient $a_{j, k}^{m}$ is determined by a recurrence relation that connects the coefficients of the $m$-times differentiated Chebyshev series with the coefficients of the $(m-1)$-times differentiated series. As shown in Appendix A, we can use this recurrence relation to express these coefficients by the coefficients $a_{j, k}$ of the original Chebyshev series (3) via an $(m-1)$-fold sum. Surprisingly we can factorize this multiple sum and therefore finally this reads for odd indices $2 k+1$,

$$
\begin{aligned}
a_{j, 2 k+1}^{2 m-1}= & \sum_{\kappa=k+m}^{N_{y}} \frac{1}{(2 m-2) ! 2^{2 m-2}} \\
& \times \prod_{\sigma=-(m-2)}^{m-1}\left[(2 \kappa)^{2}-4(k+\sigma)^{2}\right] 4 \kappa a_{j, 2 \kappa},
\end{aligned}
$$

and for the even ones,

$$
\begin{aligned}
a_{j, 2 k}^{2 m}= & \sum_{\kappa=k+m}^{N_{y}} \frac{1}{(2 m-1) ! 2^{2 m-1}} \\
& \times \prod_{\sigma=-(m-1)}^{m-1}\left[(2 \kappa)^{2}-4(k+\sigma)^{2}\right] 4 \kappa a_{j, 2 \kappa} .
\end{aligned}
$$

Due to the symmetry relation $\Psi(x,-y)=\Psi(x, y)$ following from Eqs. (1) and (2), the coefficients $a_{j, 2 k+1}=0$, and consequently $a_{j, 2 k+1}^{2 m}$ and $a_{j, 2 k}^{2 m-1}$, are zero. 
The remarkable consequence of formulas (6) and (7) for the implementation of our method is that we do not have to calculate the multiple sums arising from the recurrence relation, since they can be factorized. Instead we only have to evaluate simple products. Therefore we are able to treat the derivative $\partial^{m} \Psi / \partial y^{m}$ for arbitrary $m$. We give an explicit expression for this sum factorization formula in Appendix A, and prove it in Appendix B.
In the same way we can calculate the expression

$$
\frac{d^{m} V}{d x^{m}}=\sum_{l \leqslant N_{v}-m}^{\prime} V_{l}^{m} T_{l}(x)
$$

Note that again we can use a recurrence relation and apply the sum factorization formula and arrive at

$$
V_{l}^{m}=\sum_{\kappa=(l+m) / 2}^{N_{y}} \frac{1}{(m-1) ! 2^{m-1}} \prod_{\sigma=-[(m / 2)-1]}^{m / 2-1}\left[(2 \kappa)^{2}-(l+2 \sigma)^{2}\right] 4 \kappa V_{2 \kappa} .
$$

For the evaluation of the higher-order terms of Eqs. (I) and (2), we have to calculate the product

$$
\frac{d^{m}}{d x^{m}} V(x) \frac{\partial^{m}}{\partial y^{m}} \Psi=\left[\sum_{l \leqslant N_{v}-m}^{\prime} V_{l}^{m} T_{l}(x)\right]\left[\sum_{\substack{j \leqslant N_{x} \\ k \leqslant N_{y}-m}} a_{j, k}^{m} T_{j}(x) T_{k}(y)\right]=\frac{1}{2} \sum_{\substack{j \leqslant N_{x} \\ k \leqslant N_{y}-m \\ l \leqslant N_{v}-m}}^{\prime} V_{l}^{m} a_{j, k}^{m}\left[T_{j+l}(x)+T_{j-l}(x)\right] T_{k}(y),
$$

where $V_{l}^{m}$ is determined by Eq. (8), and the coefficients $a_{j, k}^{m}$ by Eqs. (6) and (7). Here we used

$$
T_{s}(x) T_{r}(x)=\frac{1}{2}\left[T_{s+r}(x)+T_{s-r}(x)\right]=\frac{1}{2}\left[T_{s+r}(x)+T_{|s-r|}(x)\right],
$$

where $s$ and $r$ are integers. Therefore the terms $\left[d^{m} V(x) / d x^{m}\right]\left(\partial^{m} \Psi / \partial y^{m}\right)$ of Eqs. (1) or (2) contribute to the residual

$$
R_{1}=L_{\text {odd }} \Psi_{N}=-\frac{P_{0}}{Q_{0}}\left(\sum_{\substack{j \leqslant N_{x}-1 \\ 2 k \leqslant N_{y}}} \frac{1}{2} a_{j, 2 k}^{x} T_{j}(x)\left[T_{|2 k-1|}(y)+T_{2 k+1}(y)\right]\right)+\sum_{m=1}^{\infty} \mathcal{R}_{2 m-1}
$$

where Eq. (9) generates the summands

$$
\mathcal{R}_{2 m-1} \equiv \frac{1}{(2 m-1) !}\left(\frac{\mathrm{i}}{2}\right)^{2 m-2} \frac{1}{P_{0}^{2 m-1} Q_{0}^{2 m-1}} \sum_{\substack{j \leqslant N_{x} \\ 2 k+1 \leqslant N_{y}-(2 m-1) \\ l \leqslant N_{y}-(2 m-1)}} \frac{1}{2} V_{l}^{2 m-1} a_{j, 2 k+1}^{2 m-1}\left[T_{j+l}(x)+T_{|j-l|}(x)\right] T_{2 k+1}(y) .
$$

In an analogous way, we obtain the residual

$$
\begin{aligned}
& R_{2}=L_{\text {even }} \Psi_{N} \\
& =\frac{P_{0}^{2}}{2} \sum_{\substack{j \leqslant N_{x} \\
2 k \leqslant N_{y}}}^{\prime} \frac{1}{4} a_{j, 2 k} T_{j}(x)\left[T_{\mid 2 k-2\}}(y)+2 T_{2 k}(y)+T_{2 k+2}(y)\right]-E \sum_{\substack{j \leqslant N_{x} \\
2 k \leqslant N_{y}}}^{\prime} a_{j, 2 k} T_{j}(x) T_{2 k}(y) \\
& -\frac{1}{8 Q_{0}^{2}}\left(\sum_{\substack{j \leqslant N_{x}-2 \\
2 k \leqslant N_{y}}} a_{j, 2 k}^{x x} T_{j}(x) T_{2 k}(y)\right)+\sum_{\substack{j \leqslant N_{x} \\
2 k \leqslant N_{k} \\
l \leqslant N_{y}}} \frac{V_{l} a_{j, 2 k}}{2}\left[T_{j+l}(x)+T_{|j-l|}(x)\right] T_{2 k}(y)+\sum_{m=1}^{\infty} \mathcal{R}_{2 m},
\end{aligned}
$$

with the summands

$$
\mathcal{R}_{2 m} \equiv \frac{1}{(2 m) !}\left(\frac{\mathrm{i}}{2}\right)^{2 m} \frac{1}{P_{0}^{2 m} Q_{0}^{2 m}} \sum_{\substack { j \leqslant N_{x} \\
\begin{subarray}{c}{k \leqslant N_{y}-2 m \\
l \leqslant N_{v}-2 m{ j \leqslant N _ { x } \\
\begin{subarray} { c } { k \leqslant N _ { y } - 2 m \\
l \leqslant N _ { v } - 2 m } }\end{subarray}} \frac{1}{2} V_{l}^{2 m} a_{j, 2 k}^{2 m}\left[T_{j+l}(x)+T_{|j-l|}(x)\right] T_{2 k}(y)
$$


These expressions are for the summation index $m=1$ the very same as in paper 1 , and are regularly continued for higher orders $m>1$. Therefore, the residual structure does not become more complicated, when we add arbitrary high orders to the calculation.

\section{B. Setting up the linear system of equations}

We follow the next step of our scheme and set up the linear system of equations which determines the unknown coefficients $a_{j, k}$. We do this by requiring

$$
\int_{-1}^{1} \int_{-1}^{1} R_{\alpha} T_{\nu}(x) T_{\mu}(y) \chi(x, y) d x d y=0,
$$

which means that the weighted residuals over the domain $\Omega \equiv[-1,1] \times[-1,1]$ must vanish for $\alpha=1$ and 2 and all pairs $\nu, \mu$ with $\nu=0,1,2, \ldots, N_{x}$ and $\mu=0,1,2, \ldots, N_{y}$. The abbreviation $\chi(x, y)$ denotes the Chebyshev weight

$$
\chi(x, y)=\frac{1}{\sqrt{1-x^{2}}} \frac{1}{\sqrt{1-y^{2}}} .
$$

All terms of the residuals $R_{1}$ and $R_{2}$ [Eqs. (11) and (12)] are expressed in Eq. (9) by Chebyshev polynomials. Because the orthogonality relation for Chebyshev polynomials reads

$$
\int_{-1}^{1} T_{j}(x) T_{k}(x) \frac{d x}{\sqrt{1-x^{2}}}= \begin{cases}0, & j \neq k \\ \pi, & j=k=0 \\ \frac{\pi}{2}, & j=k=1,2, \ldots\end{cases}
$$

we conclude that only the integrals

$$
\int_{-1}^{1} \int_{-1}^{1} T_{\nu}^{2}(x) T_{\mu}^{2}(y) \chi(x, y) d x d y \neq 0
$$

contribute. Therefore we only have to identify the terms in Eq. (13) containing this specific combination of Chebyshev polynomials. For this combination the integral does not vanish. This means that the prefactors of these terms have to vanish in order to satisfy Eq. (13), yielding a system of linear equations for the unknown coefficients $a_{j, k}$.

Since the product $\left(d^{m} / d x^{m}\right) V(x)\left(\partial^{m} / \partial y^{m}\right) \Psi$ in Eq. (9) produces only shifts $j+l$ and $j-l$, which are exactly the same shifts that are present in the truncated equations, the technical procedure of finding out these coefficients is the very same as we have done in Appendix $\mathrm{C}$ of paper $\mathbf{I}$ [1]. When we use these results, the weighted residual equations (13) now read

$$
\begin{aligned}
c_{1} \int_{-1}^{1} \int_{-1}^{1} R_{1} T_{\nu}(x) T_{2 \mu+1}(y) \chi(x, y) d x d y \\
=-\frac{P_{0}}{Q_{0}} \frac{1}{2} a_{j, 2 k}^{x}\left[\delta_{j, \nu} \delta_{|2 k-1|, 2 \mu+1}+\delta_{j, \nu} \delta_{2 k+1,2 \mu+1}\right] \\
\quad+\sum_{r=1,3,5, \ldots}^{\infty} \frac{1}{r !}\left(\frac{\mathrm{i}}{2}\right)^{r-1} \frac{1}{P_{0}^{r} Q_{0}^{r}} \sum_{l \leqslant N_{v}} \frac{V_{l}^{r}}{2} a_{j, 2 k+1}^{r}\left[\delta_{j+l, \nu} \delta_{2 k+1,2 \mu+1}+\delta_{|j-l|, \nu} \delta_{2 k+1,2 \mu+1}\right]_{2 \mu+1 \leqslant N_{y}-r}=0
\end{aligned}
$$

and

$$
\begin{aligned}
& c_{2} \int_{-1}^{1} \int_{-1}^{1} R_{2} T_{\nu}(x) T_{2 \mu}(y) \chi(x, y) d x d y \\
& =+\frac{P_{0}^{2}}{8} a_{j, 2 k}\left[\delta_{j, \nu} \delta_{\mid 2 k-2 !, 2 \mu}+2 \delta_{j, \nu} \delta_{2 k, 2 \mu}+\delta_{j, \nu} \delta_{2 k+2,2 \mu}\right]-E a_{j, 2 k} \delta_{j, \nu} \delta_{2 k, 2 \mu}+\sum_{l \leqslant N_{v}} \frac{1}{2} V_{l}^{r} a_{j, 2 k}\left[\delta_{j+l, \nu} \delta_{2 k, 2 \mu}+\delta_{|j-l|, \nu} \delta_{2 k, 2 \mu}\right] \\
& \quad-\frac{1}{8 Q_{0}^{2}} a_{j, 2 k}^{x x} \delta_{j, \nu} \delta_{2 k, 2 \mu}+\sum_{r=2,4,6, \ldots}^{\infty} \frac{1}{r !}\left(\frac{i}{2}\right)^{r} \frac{1}{P_{0}^{r} Q_{0}^{r}} \sum_{l \leqslant N_{v}-r}{ }^{\prime} \frac{1}{2} V_{l}^{r} a_{j, 2 k}^{r}\left[\delta_{j+l, \nu} \delta_{2 k, 2 \mu}+\delta_{|j-l|, \nu} \delta_{2 k, 2 \mu}\right]_{2 \mu \leqslant N_{y}-r}=0 .
\end{aligned}
$$

Here the constant $c_{1}=1 / \pi^{2}$ when $\nu$ is positive, $c_{1}=2 / \pi^{2}$ when $\nu=0, c_{2}=1 / \pi^{2}$ when both coefficients $\nu$ and $\mu$ are positive, $c_{2}=2 / \pi^{2}$ when one of them is zero, and $c_{2}=4 / \pi^{2}$ when both are zero.

We obtain all Chebyshev coefficients with a superscript from Eqs. (6), (7), and (8). Then Eqs. (15) and (16) yield the overdetermined system (5) of linear equations

$$
\sum_{\substack{j \leqslant N_{x} \\ k \leqslant N_{y}}} \Gamma_{j, k}^{\nu, \mu} a_{j, k}=0
$$




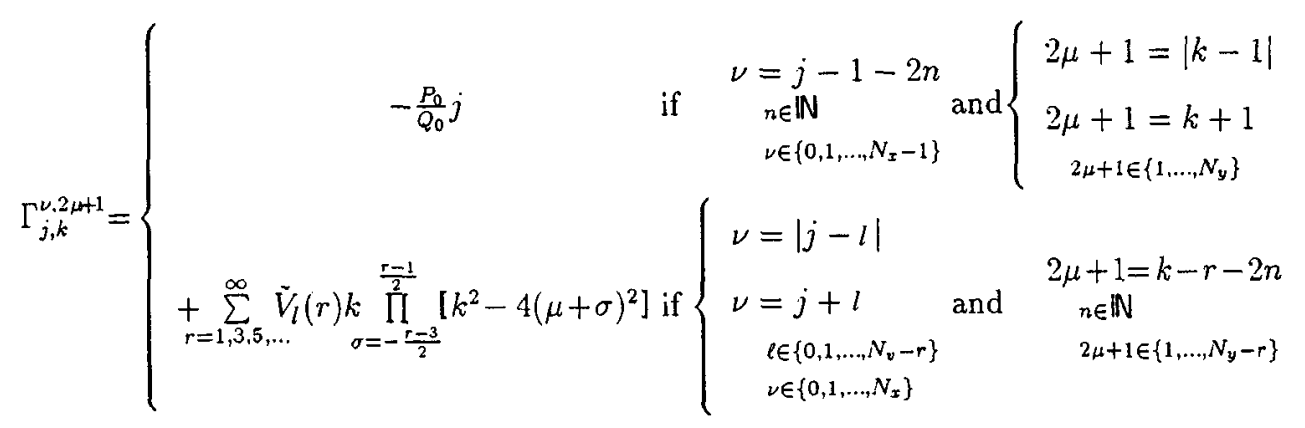

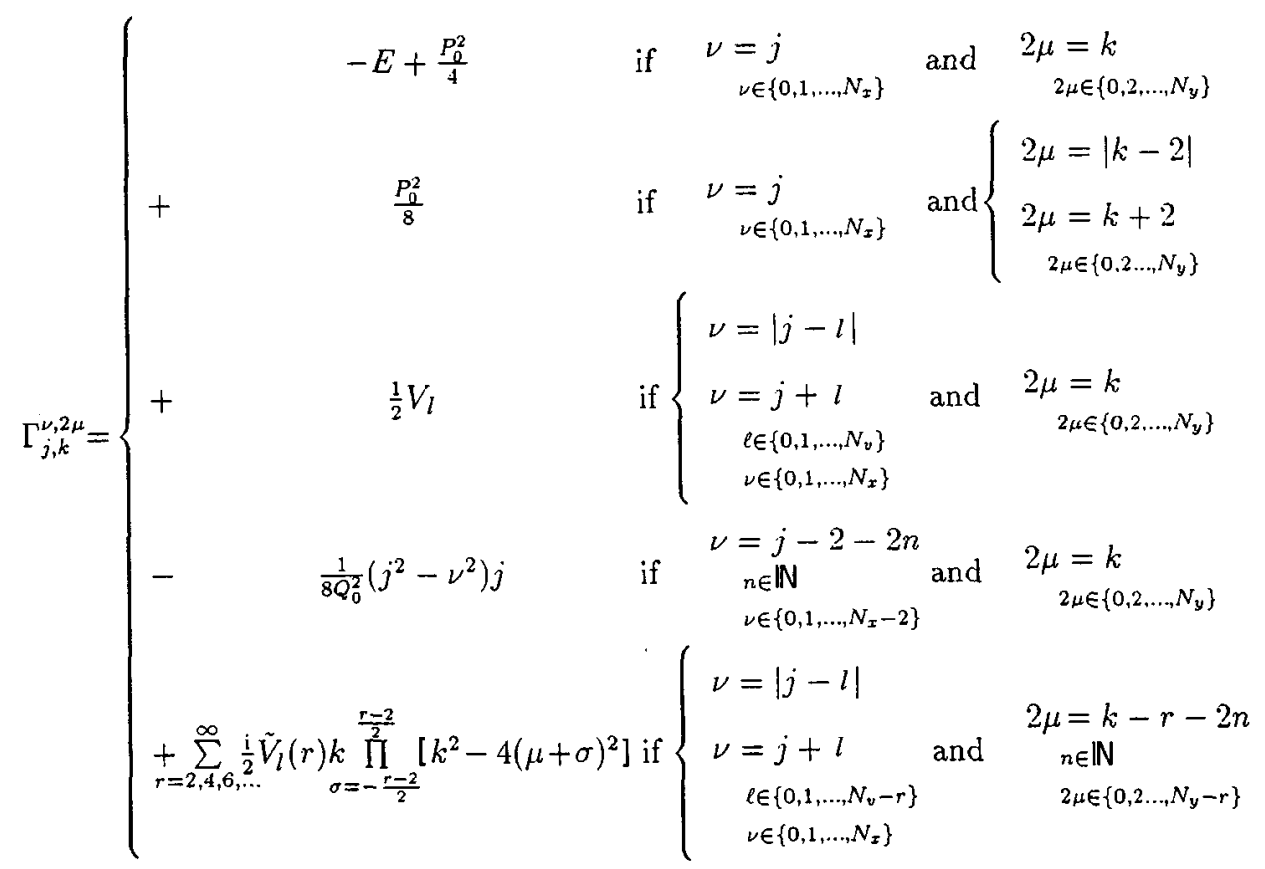

Here, for convenience, we have defined the modified prefactor

$$
\widetilde{V}_{l}(r) \equiv \frac{1}{r !}\left(\frac{\mathrm{i}}{2}\right)^{r-1} \frac{1}{P_{0}^{r} Q_{0}^{r}} \frac{V_{l}^{r}}{(r-1) ! 2^{r-1}}
$$

where the terms $V_{l}^{r}$ follow from Eq. (8).

This scheme gives the rule about how we have to set up the matrix of the system of equations. We approximate the solution of the overdetermined system Eq. (17) by a standard least-squares algorithm [3]. To avoid calculating only the trivial solution, we have to add at least one further equation. We do this by setting the value of the solution at an arbitrary point in the computational domain, such as the origin to a nonzero value, for example unity. Thus we obtain from Eq.
(3), recalling the properties $T_{2 j+1}(0)=0$ and $T_{2 j}(0)$ $=(-1)^{j}$, the additional equation

$$
\Psi(0,0)=1=\sum_{\substack{j \leqslant N_{x} \\ k \leqslant N_{y}}}^{\prime}(-1)^{j+k} a_{2 j, 2 k} .
$$

Since the original equations (1) and (2) are linear, we can arbitrarily choose the value of the Wigner function at the origin and the solution can be normalized after the computation of the unknown coefficients.

We note that the coefficients $\Gamma_{j, k}^{\nu .2 \mu+1}$ (odd in $\mu$ ) result from the residual $R_{1}$, whereas the coefficients $\Gamma_{j, k}^{\nu, 2 \mu}$ (even in $\mu$ ) originate from $R_{2}$. Thus the original two differential equations still occur separately in the resulting system of equations (17). We further note that this equation system contains all orders of the differential equations (1) and (2). 
Nevertheless it consists of $\left(N_{x}+1\right)\left(N_{y} / 2+1\right)$ unknowns; that is, the number of Chebyshev polynomials in our ansatz without odd ones in the $y$ direction. Therefore the higherorder terms of the derivatives of Eqs. (1) and (2) do not contribute to the numerical cost that is determined by the number of unknowns. The only effect is that the matrix $\boldsymbol{\Gamma}$ has more nonzero entries, because there are, due to Eqs. (18) and (19), more cases for which a term has to be written into the matrix.

Note that the stability analysis would follow the same path that we outlined in paper I. We would obtain more condition equations which have to be fulfilled to prove stability with the energy method. Instead of deriving these conditions, we prefer to show examples in Sec. IV to accentuate the practical benefit of our method.

To conclude this section, we note that solving the system of equations (17) by a least-squares algorithm introduces an additional error to our solution, since then the residuals are not exactly zero. This algorithm minimizes the residuals in a least-squares sense using the Euclidean norm. Here the weighted residuals are no longer exactly zero but minimized. In general, the norm of the residuals decreases with increasing $N_{x}$ and $N_{y}$, and therefore can be used as a measure to check the accuracy of the approximation.

\section{APPLICATIONS}

In this section we apply our algorithm to two potentials: a Morse oscillator and an asymmetric double-well potential that is given by a fourth order polynomial. We use these two potentials to investigate different aspects of our method. To obtain satisfactory results for the Morse potential we have to include higher-order terms of Eqs. (1) and (2). In order to obtain a reference solution, we use an analytical expression for the wave functions of the energy eigenstates, and numerically perform the Fourier transform defining the Wigner function using this expression. This allows us to obtain the Wigner function with high accuracy. Thus we can estimate the errors of our method together with those errors that are due to the truncation of higher-order terms in Eqs. (1) and (2). For the asymmetric double-well potential no analytic solutions are known, and even semiclassical approximations fail for low excited states. Nevertheless these states are most interesting since they are most affected by the barrier of the potential. By qualitative arguments we verify that our method leads to a very good approximation even in cases where other approximations are not valid.

\section{A. Morse oscillator}

For the Wigner function of the Morse oscillator we present a sequence of examples where we increase the maximum order of the derivatives included in Eqs. (1) and (2) while we keep the number of Chebyshev polynomials constant. This illustrates how many terms we need to calculate a satisfactory approximation for the Wigner function in this particular example. We present results for two different computational domains, since according to the stability considerations of paper I the appropriate choice of the domain is important to obtain good results. Furthermore we show for one specific set of parameters how the error decreases with increasing number $N_{\text {eq }}$ of Chebyshev polynomials. Note that in most examples we did not use more than 50 Chebyshev polynomials in each direction. Due to this relatively low number of polynomials, we obtain all numerical results with few computational cost $(\sim 4 \mathrm{~min}$ on a HP9000/K260 workstation).

The Morse oscillator potential [4] is given by

$$
V(Q)=\frac{1}{2} \lambda\left(1-e^{-Q / \sqrt{\lambda}}\right)^{2},
$$

and its energy eigenstates by
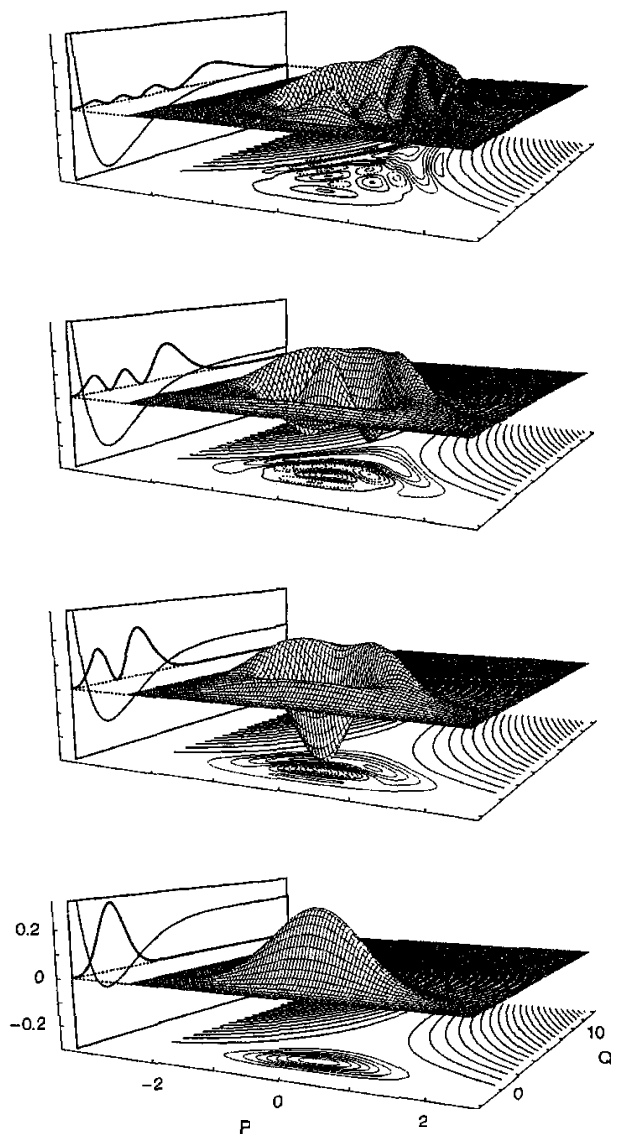

FIG. 1. Exact Wigner functions of all energy eigenstates of the Morse oscillator potential [Eq. (20)] with $\lambda=4$. The figure on the bottom shows the ground state, above the first, second and third, i.e., the highest possible energy eigenstate of the Morse oscillator with this specific choice of the parameter $\lambda$. The potential (thin line) with the energy levels (dashed line) of the energy eigenstates and the position probability distribution (thick line) of each particular state are shown projected on the left-hand wall for each energy eigenstate. To keep the scaling consistent we compressed the potential by a factor of 7 and the position probability distribution by 3.5. Below the three-dimensional representation of the Wigner function of each eigenstate, we show its contour lines. The thicker contour lines denote the zero level, the thin solid contours denote positive values in steps of 0.04 , and the dashed contours the negative values, respectively. Note that the position probability distribution is obtained by integrating the Wigner function over $y$. 
TABLE I. Mean absolute errors for a series of Wigner function approximations of the second excited energy eigenstate of the Morse oscillator with constant number of Chebyshev polynomials $N_{\mathrm{eq}}=N_{x}=N_{y}=50$ calculated on the computational domains $D_{1}$ and $D_{2}$. The series index $m$ denotes the truncation order of the Egs. (1) and (2).

\begin{tabular}{ccc}
\hline$N_{\text {eq }}=50$ & \multicolumn{2}{c}{ Mean absolute error } \\
\cline { 2 - 3 }$m$ & $D_{1}$ & $D_{2}$ \\
\hline 2 & $7.4 \times 10^{-2}$ & $8.9 \times 10^{-2}$ \\
3 & $7.0 \times 10^{-2}$ & $2.9 \times 10^{-2}$ \\
4 & $2.8 \times 10^{-2}$ & $2.7 \times 10^{-2}$ \\
5 & $3.1 \times 10^{-2}$ & $3.8 \times 10^{-2}$ \\
6 & $1.0 \times 10^{-2}$ & $8.9 \times 10^{-3}$ \\
7 & $3.4 \times 10^{-3}$ & $2.9 \times 10^{-3}$ \\
8 & $1.7 \times 10^{-3}$ & $6.8 \times 10^{-4}$ \\
9 & $1.3 \times 10^{-3}$ & $3.9 \times 10^{-4}$ \\
10 & $2.5 \times 10^{-4}$ & $1.1 \times 10^{-4}$ \\
\hline \hline
\end{tabular}

$$
\begin{aligned}
\psi_{\lambda, n}(Q)= & \mathcal{N}(\lambda, n) \xi(\lambda, Q)^{\lambda-n-(1 / 2)} \\
& \times e^{-\xi(\lambda, Q) / 2} L_{n}^{(2 \lambda-2 n-1)}(\xi(\lambda, Q)),
\end{aligned}
$$

with the abbreviation

$$
\xi(\lambda, Q)=2 \lambda e^{-Q / \sqrt{\lambda}}
$$

and the normalization

$$
\mathcal{N}(\lambda, n)=\sqrt{\frac{(2 \lambda-2 n-1) \Gamma(n+1)}{\sqrt{\lambda} \Gamma(2 \lambda-n)}} .
$$

$L_{n}^{(\alpha)}$ denotes a generalized Laguerre polynomial. The energy eigenvalues read

TABLE II. Mean absolute errors for a series of Wigner function approximations of the ground state and the first excited energy eigenstate of the Morse oscillator with constant number of Chebyshev polynomials $N_{\mathrm{eq}}=N_{x}=N_{y}=50$ calculated on the computa* tional domains $D_{3}$ and $D_{4}$. The series index $m$ on the left denotes

\begin{tabular}{|c|c|c|c|}
\hline \multirow{3}{*}{$\begin{array}{c}N_{\mathrm{eq}}=50 \\
m\end{array}$} & \multicolumn{3}{|c|}{ Mean absolute error } \\
\hline & \multirow{2}{*}{$\begin{array}{c}\text { Ground state } \\
D_{3}\end{array}$} & \multicolumn{2}{|c|}{ first excited state } \\
\hline & & $D_{3}$ & $D_{4}$ \\
\hline 2 & $5.5 \times 10^{-3}$ & $4.5 \times 10^{-2}$ & $4.5 \times 10^{-2}$ \\
\hline 3 & $3.3 \times 10^{-3}$ & $4.0 \times 10^{-2}$ & $3.5 \times 10^{-2}$ \\
\hline 4 & $1.0 \times 10^{-3}$ & $3.3 \times 10^{-2}$ & $9.7 \times 10^{-3}$ \\
\hline 5 & $2.6 \times 10^{-4}$ & $1.1 \times 10^{-1}$ & $2.8 \times 10^{-3}$ \\
\hline 6 & $1.7 \times 10^{-4}$ & $1.4 \times 10^{-3}$ & $9.4 \times 10^{-4}$ \\
\hline 7 & $2.1 \times 10^{-5}$ & $4.9 \times 10^{-4}$ & $2.5 \times 10^{-4}$ \\
\hline 8 & $2.6 \times 10^{-5}$ & $1.1 \times 10^{-3}$ & $7.9 \times 10^{-5}$ \\
\hline 9 & $2.6 \times 10^{-4}$ & $3.9 \times 10^{-4}$ & $2.3 \times 10^{-5}$ \\
\hline 10 & $2.1 \times 10^{-4}$ & $5.1 \times 10^{-4}$ & $5.0 \times 10^{-6}$ \\
\hline
\end{tabular}
the truncation order of the Eqs. (1) and (2). For the ground state and the first excited state we chose the same computational domain $D_{3}$ to compare the errors.
TABLE III, Mean absolute errors for the Wigner function approximation of the second excited energy eigenstate of the Morse oscillator with constant truncation order $m=10$ for various numbers of Chebyshev polynomials $N_{\mathrm{eq}}=N_{x}=N_{y}$.

\begin{tabular}{lcc}
\hline & \multicolumn{2}{c}{ Mean absolute error } \\
\cline { 2 - 3 }$N_{\text {eq }}$ & $D_{1}$ & $D_{2}$ \\
\hline 20 & $2.1 \times 10^{-2}$ & $9.4 \times 10^{-2}$ \\
30 & $3.1 \times 10^{-3}$ & $1.0 \times 10^{-2}$ \\
40 & $2.6 \times 10^{-4}$ & $5.6 \times 10^{-4}$ \\
50 & $2.5 \times 10^{-4}$ & $1.1 \times 10^{-4}$ \\
\hline
\end{tabular}

$$
E_{n}=\left(n+\frac{1}{2}\right)-\frac{1}{2 \lambda}\left(n+\frac{1}{2}\right)^{2},
$$

with $n=0,1, \ldots, \lambda-1$. In our specific case we choose the dimensionless parameter $\lambda=4$. This parameter designates the relation between the height and width of the potential, and therefore the number of bounded states. This potential and all its squared eigenfunctions are sketched on the left walls in Fig. 1, where we also show the corresponding exact Wigner function.

We approximated the solutions for the Wigner function of the second excited state shown in Fig. 1 with our modified spectral method on the two computational domains $D_{1}=[-2.0 \leqslant Q \leqslant 8.0] \times[-2.5 \leqslant P \leqslant 2.5]$ and $D_{2}=[-4.0$ $\leqslant Q \leqslant 8.0] \times[-3.0 \leqslant P \leqslant 3.0]$. In both cases we used $N_{\text {eq }}=N_{x}=N_{y}=50$. To compare the results with the exact Wigner function, we reproduce in Fig. 2 only the approximations on the domain $D_{1}$, and cut off the outer parts from the computations on the larger domain $D_{2}$. On the top we show the exact solution, denoted by $m=\infty$. Below we reproduce a sequence of calculations on both domains in decreasing (from top to bottom) order $m$ of the partial derivatives incorporated from Eqs. (1) and (2). We compare the results for the two domains $D_{1}$ on the left, and $D_{2}$ on the right. In the case $m=10$ we have taken into account all terms of the original system up to the tenth order. Nevertheless, on the left-hand side one can see some tiny errors near the boundary. On the right-hand side these errors are outside the region of interest. Because the larger errors are located in the corners of the computational domain, we obtain better results when we calculate the solution on a larger domain and cut off the outer parts. For $m=8$ the result on the larger domain is still excellent. The left-hand side also shows qualitatively good results. It seems to be sufficient and necessary to include the eighth-order derivatives to obtain a qualitatively correct impression of the Wigner function. The inclusion of the tenth-order terms does not yield a significant improvement. For the two discussed regions the visible errors mainly correspond to numerical errors. When we truncate more terms of Eqs. (1) and (2), the truncation error becomes dominant, as we see in the next example below where $m=5$. Here we also observe that the solution on the two domains become different. The calculation on the domain $D_{1}$ shows larger deviations from the exact Wigner function than the approximation on $D_{2}$. We also observe this effect for the last two pictures at the bottom for $m=2$, where we have truncated Eqs. (1) and (2) after the second order, which is the approxi- 

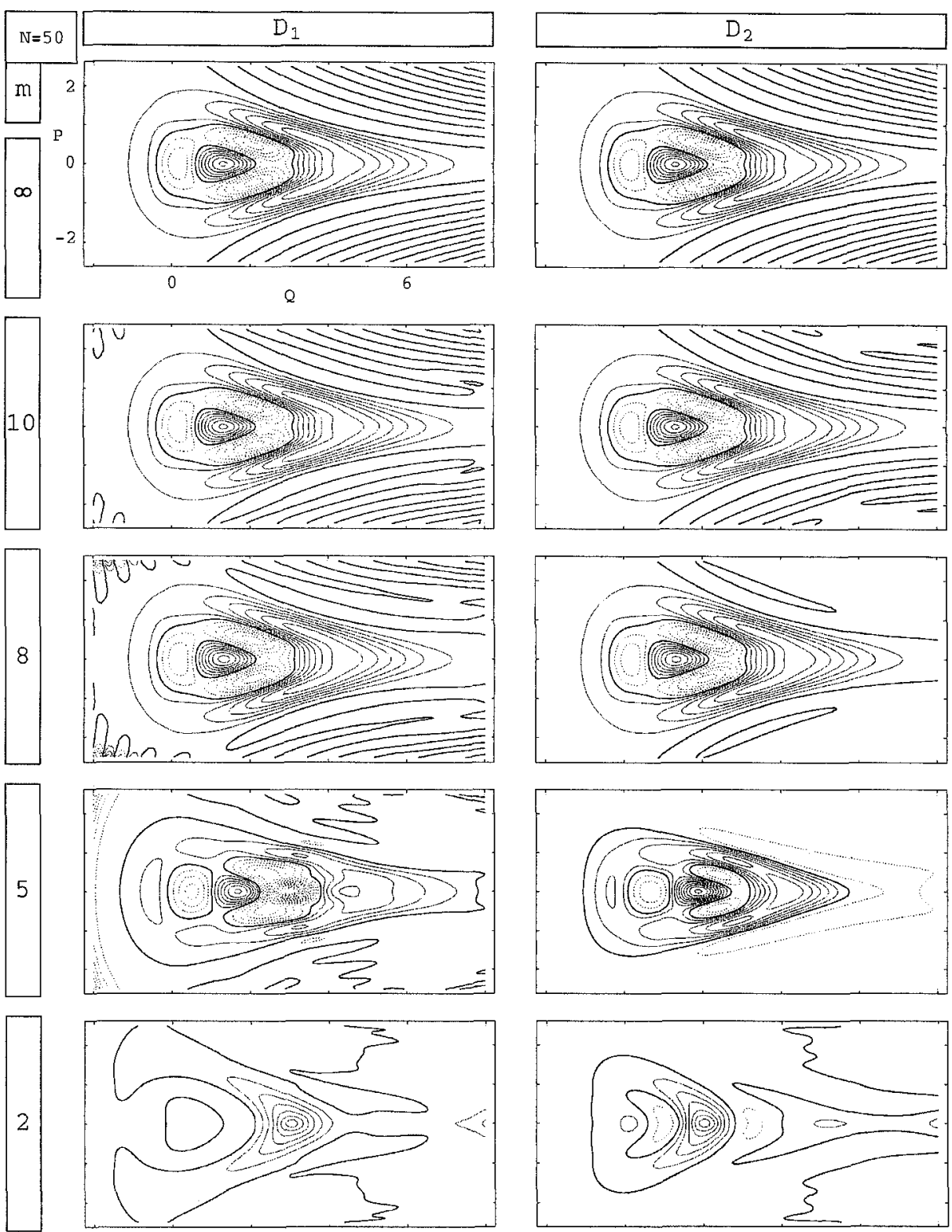

FIG. 2. Table of contour plots showing approximations for the Wigner function of the second excited energy eigenstate of the Morse oscillator shown in Fig. 1 with a constant number of Chebyshev polynomials $N_{\mathrm{eq}}=N_{x}=N_{y}=50$. The thicker contour lines denote the zero level, the thin solid contours denote positive values in steps of 0.03 , and the dashed contours the negative values, respectively. We calculated each approximation on two domains $D_{1}$ (left) and $D_{2}$ (right). On the top, the exact solution for the Wigner function $(m=\infty)$ is shown twice, where the left figure clarifies the scaling. Below, a sequence of calculations on both domains is shown, where from top to bottom the truncation order $m=10,8,5$, and 2 of the original equations (1) and (2) is decreased. Although the computations on the right-hand side were carried out in the larger domain $D_{2}$, here we show only the approximation on the smaller domain $D_{1}$ to compare the solutions. Note that the truncation after the second order-the approximation we used in paper I to introduce our method-is not suitable for the Morse oscillator. At least all terms up to the eighth order have to be included to obtain satisfactory results. 
mation we performed in paper I. This most clearly brings out the fact that in this example the truncation order 2 is not sufficient to obtain satisfactory approximations for the Wigner function. On both domains the numerical solution clearly tends toward the exact solution with increasing order. We can use the qualitative difference of these results on various domains as an indicator to find the optimal order to truncate Eqs. (1) and (2).

In Table I we compare the mean absolute errors ${ }^{1}$ for the second excited state on the two domains $D_{1}$ and $D_{2}$. This table contains results from a complete sequence of calculations where we increased the truncation order $m$ of the partial derivatives of Eqs. (1) and (2). Here we can see the influence of the choice of the computational domain on the magnitude of the errors. For the computations on the larger domain $D_{2}$, the errors in the subdomain $D_{1}$ are in general smaller by a factor of 2 than on $D_{1}$. This is due to the fact that the errors of great magnitude are located near the boundaries of the computational domain. These errors are not included in the table. From the data in Table I we also observe that the approximation tends toward the exact solution with increasing truncation order $m$.

Table II contains the mean absolute errors from calculations with various truncation order $m$ for the ground state and the first excited state on the domains $D_{3}$ $=[-1.5 \leqslant Q \leqslant 4.5] \times[-2.0 \leqslant P \leqslant 2.0]$ and $D_{4}=[-4.5$ $\leqslant Q \leqslant 4.5] \times[-3.0 \leqslant P \leqslant 3.0]$. The comparison of the errors of the ground state and the first excited state on the same domain $D_{3}$ illustrates the influence of the complexity of the solution on the approximation errors. The approximation to the smoother Wigner function of the ground state is more precise than that of the first excited state, which has a more complicated structure. The errors for the first excited state are smaller than for the second excited state (cf. Table I). Inspection of the data for the ground state reveals that the mean error has a minimum for truncation order $m=8$, and increases for $m>8$. This is due to the fact that the domain $D_{3}$ is much larger than the area where the Wigner function has its main contribution. Therefore the errors near the boundary are of greater magnitude than they would be with a proper choice of the computational domain. Since we can simply cut away the boundary region, these effects are not serious. Note that the errors are still smaller than for the first excited state on $D_{3}$.

The last two columns of Table II contain the results for the first excited state. The calculations were performed on $D_{3}$ and $D_{4}$, but the errors were taken only on $D_{3}$. So the errors near the boundary of $D_{4}$ are not included in the data of the last column. This again illustrates that the errors of our spectral approximation are smaller in the core region of the computational domain than near the boundaries. With rather small computational effort we obtain a mean error of order $10^{-6}$ for $N_{\mathrm{eq}}=N_{x}=N_{y}=50$.

\footnotetext{
In order to compare our approximation to the exact solution we evaluate our spectral solution on an equidistant grid consisting of $100 \times 100$ points. At each grid point we calculate the absolute difference between the approximate and the exact solution. The mean value of these differences we call mean absolute error and their maximum we call maximal absolute error.
}

So far we can qualitatively estimate the error of neglecting higher-order terms in the original equations (1) and (2). We do not need very many terms to obtain all the essential information about the Wigner function. A truncation order of $m=8$ is sufficient for excellent agreement with the exact solution. This leads to the conclusion that we can extract all relevant physical information from the low-order terms of Eqs. (1) and (2), at least in the case of the Morse oscillator.

When we keep $m=10$ fixed, we can analyze the convergence properties for increasing $N_{\mathrm{eq}}$. We illustrate this for the second excited state for the domains $D_{1}$ and $D_{2}$ in Table III. As expected, the absolute errors decrease with increasing $N_{\text {eq }}$, the number of Chebyshev polynomials in our ansatz.

Finally we show the solution for the third (the highest) excited state in the Morse potential with $\lambda=4$. Here the Wigner function spreads out over a large area of phase space, since the energy is close to the dissociation energy. However, we obtain qualitatively excellent agreement even with $N_{\text {eq }}=50$ as we can see in Fig. 3.

\section{B. Asymmetric double well} tial

Our second example is an asymmetric double-well poten-

$$
V(Q)=k_{4} Q^{4}+k_{3} Q^{3}-k_{2} Q^{2}+k_{0}
$$

It is reproduced in Fig. 4 for the parameter values $k_{0}=0$, $k_{2}=3.5, k_{3}=0.25$, and $k_{4}=0.5$. We have chosen this set of parameters to make our data comparable with former applications (Ref. [5] and references therein) where it was frequently used as a test problem for a numerical calculation of the position eigenfunctions $\psi_{E}(Q)$. We note that Ref. [5] also offers a valuable scheme to generate the energy spectrum of an arbitrary smooth potential.

Since we can easily apply our method to the onedimensional time-independent Schrödinger equation

$$
-\frac{1}{2} \frac{d^{2}}{d Q^{2}} \psi_{E}(Q)+V(Q) \psi_{E}(Q)=E \psi_{E}(Q)
$$

we are able to reproduce the numerical results of Ref. [5]. Figure 4 shows the potential with the parameter values from above, and the energy levels with the wave functions that we reconstructed with our method. Furthermore we calculated approximations for the Wigner function of these states with our method that we show in Fig. 5. Here we show the Wigner functions of the ground state and five excited energy eigenstates. Since we obtain the marginal distribution by integrating the Wigner function over $P$, we can at least show the consistency of our computations with numerical calculations of the eigenstates by comparing the marginal distributions of the Wigner functions to the position distribution functions. The position probability distribution is shown together with the potential and the energy level on the left walls in Fig. 5.

Figure 5 illustrates that the ground state and first excited state are similar to the ground state of the Morse potential 

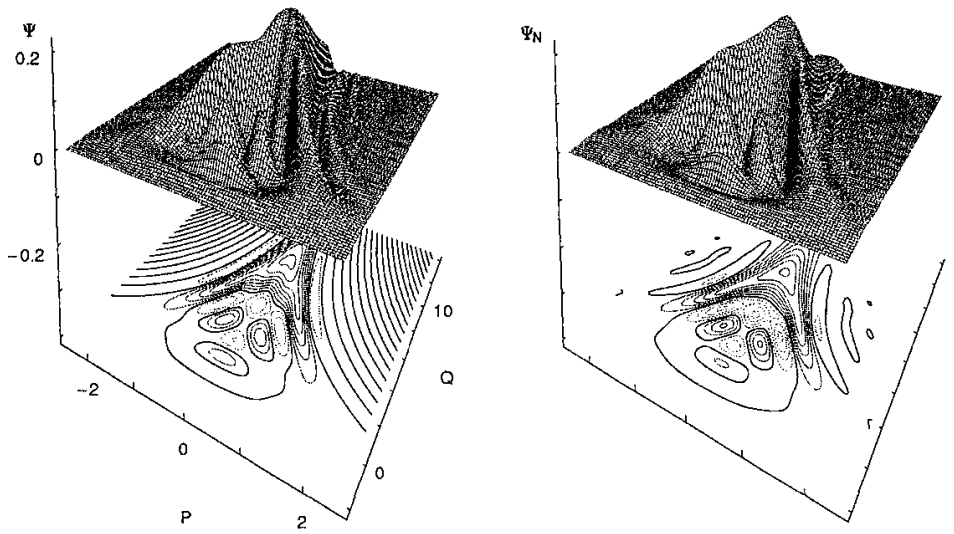

FIG. 3. Exact solution $\Psi$ and approximation $\Psi_{N}$ for the third (the highest) excited state in the Morse potential with $N_{\mathrm{eq}}=N_{x}$ $=N_{y}=50$. The approximation on the right was calculated on the computational domain $[-8.0$ $\leqslant Q \leqslant 16.0] \times[-3.0 \leqslant P \leqslant 3.0]$, but is shown here only in the subdomain $[-2.0 \leqslant Q \leqslant 14.0]$ $\times[-2.5 \leqslant P \leqslant 2.5]$. Note that although the computational domain is very large, we obtain a satisfactory approximation for the Wigner function. since they are confined to the left and right wells, respectively. Therefore the Wigner functions of these states are quite similar to the Wigner function of the Morse oscillator ground state. This is different for the second and third ex-

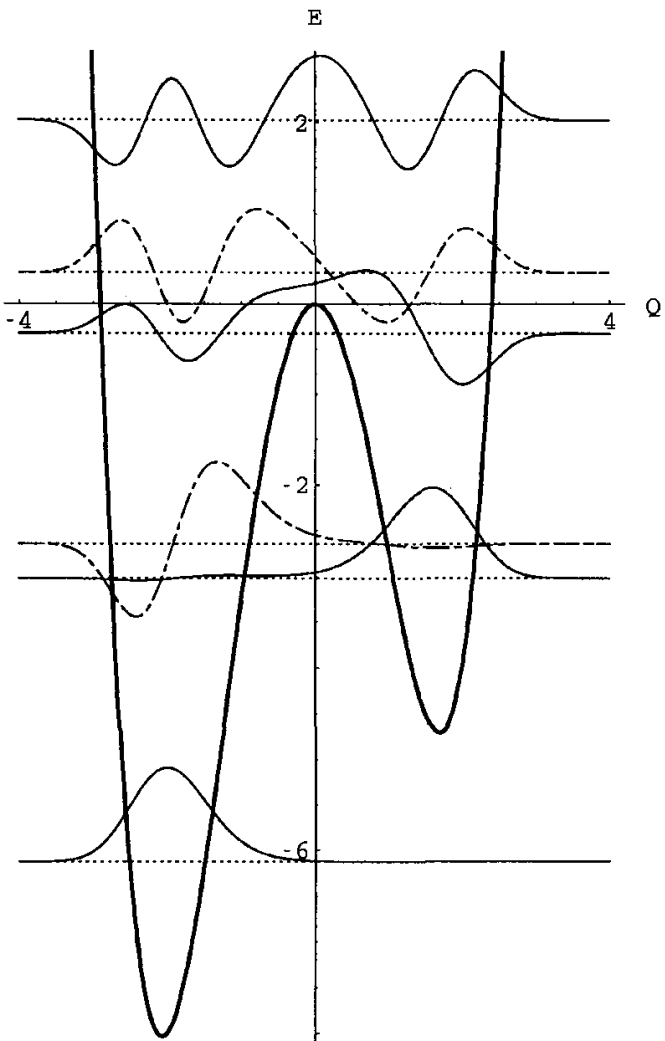

FIG. 4. Energy eigenfunctions (thin solid or dashed lines) of the double-well potential Eq. (21) (thick solid line) with their corresponding energy levels (dotted lines). The eigenfunctions are obtained by applying the modified spectral method to the Schrödinger equation with 200 Chebyshev polynomials in the one-dimensional Chebyshev series. cited states, where the energy level is still below the barrier but the wave function is spread out over both wells. This can also be seen in the Wigner function especially for the third excited state. Above the barrier (fourth and fifth excited states) the wave function becomes more and more similar to an oscillator wave function. The Wigner function also exhibits such a behavior. The oscillations for large values of the momentum variable $P$ give a hint of the existence of an inflexion [6] of the classical trajectory which is a consequence of the barrier.

In Fig. 6, for the third excited state, we directly compare the numerically integrated marginal distribution of our approximated Wigner function with the position probability distribution of Fig. 4 which we also calculated numerically. Since we obtained the wave functions from a onedimensional problem where the highest derivative is of order 2 it is obvious that the latter error is much smaller than the error arising from applying our method to the twodimensional fourth-order coupled differential equations and then integrating the approximated Wigner function numerically. Nevertheless when we compare the two resulting curves we obtain an excellent agreement in Fig. 6. This also holds true for all other eigenstates. This is not a proof but a strong indication that our method yields an excellent approximation of the Wigner function for the asymmetric double-well potential. This is a remarkable result since most former approximations of the Wigner function are semiclassical expressions and therefore only valid for higher excited states. Here we obtain very good approximations even for the lower excited states.

\section{CONCLUSION}

We have presented an alternative approach for the calculation of the Wigner function. For that purpose we solved two coupled linear partial phase-space equations which define the Wigner function directly. These equations are of infinite high order in the derivatives, and finite only for polynomial potentials. For the first time one can compute the Wigner function for arbitrary potentials as a solution of these equations. Our numerical method is a modification of the spectral tau method which uses Chebyshev polynomials as 

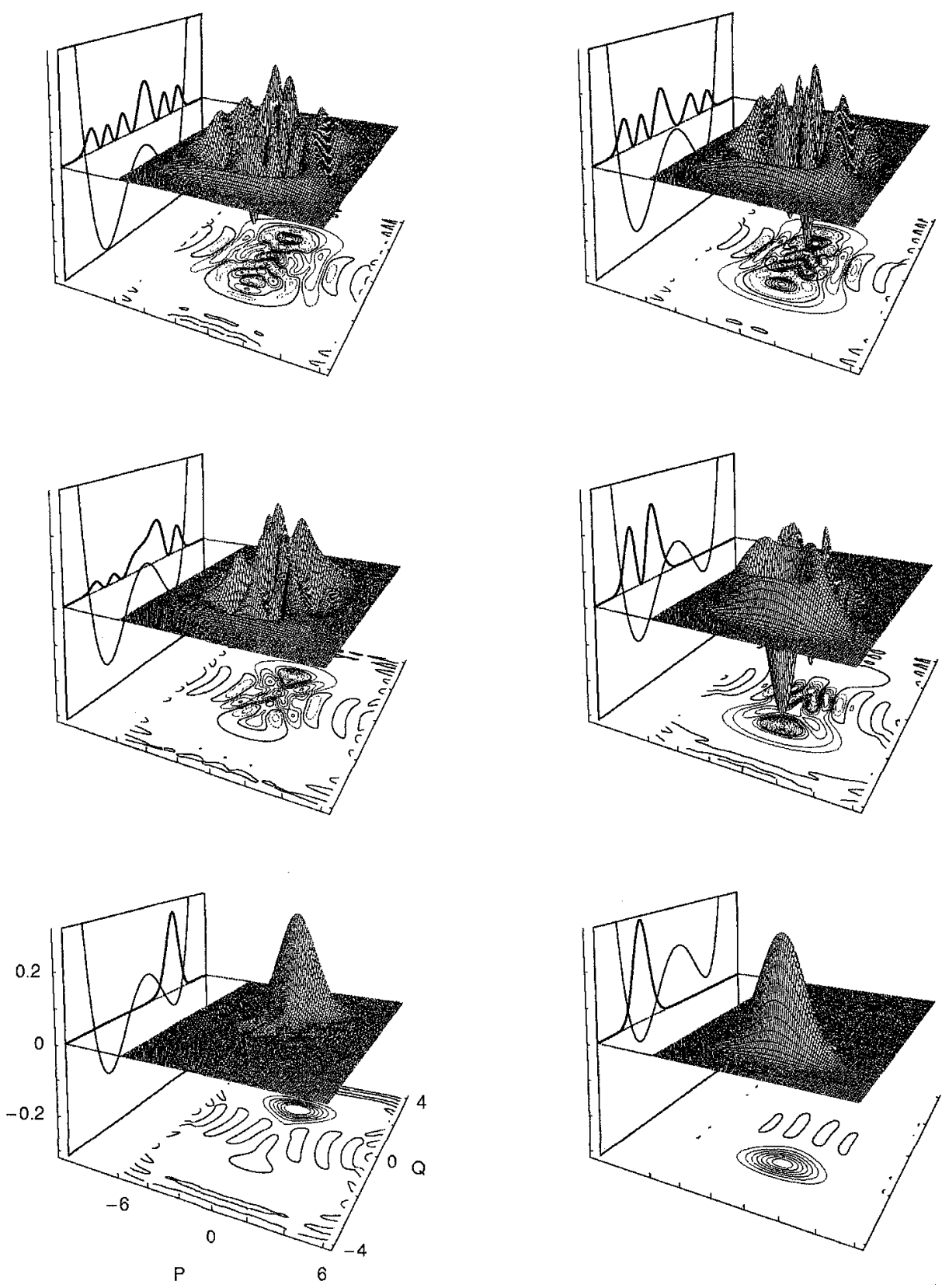

FIG. 5. Approximations for the Wigner functions of the lowest-energy eigenstates of the double-well potential proposed by Ref. [5]. The two figures on the top shows the fifth and fourth excited states the middle the third and second excited states, and the bottom the first excited state and the ground state, respectively. The potential (thin solid line) with the energy levels (dashed line) of the energy eigenstates and the approximated position probability distribution (thick solid line), that is, the square of the approximated position wave function of each particular state (see Fig. 4), are shown projected on the left-hand wall for each energy eigenstate. To keep the scaling consistent we compressed the potential by a factor of 32 and the position probability distribution by 3.5 . The meaning of the contour lines below the three-dimensional representation of the Wigner function is the same as in Fig. 1. 


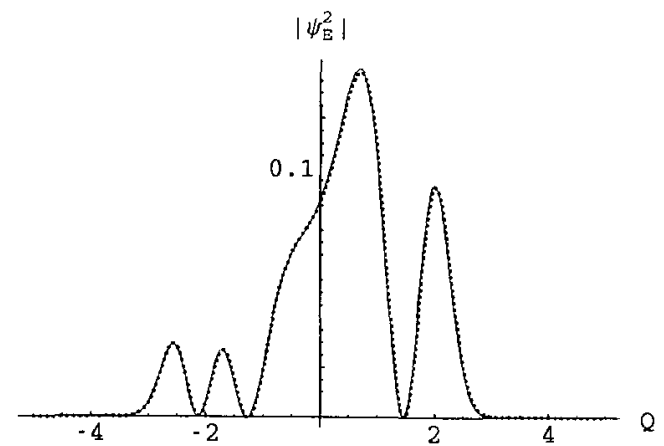

FIG. 6. Comparison of the marginal distribution of the Wigner function (dotted curve) of the third excited state of the double-well potential, obtained by numerical integration of the approximated Wigner function, with the probability distribution (solid curve) arising from numerical integration of the time-independent Schrödinger equation.

shape functions. This special choice allows us to derive and prove a sum factorization formula which replaces the multiple sums occurring in the high-order derivatives by a simple product. Since furthermore the size of the system is independent of the order of the derivative, our method is a valuable tool to solve differential equations of arbitrary high order. In contrast to usual problems there are no boundary conditions available for the equations for the Wigner function. Instead we have to solve two real equations simultaneously; therefore the resulting linear system of equations is overdetermined. We have approximated its solution by a least-squares algorithm. The application of our approach to any similar system of partial differential equations is straightforward.

Our numerical results for the Morse oscillator show that we have to include all the derivatives up to eighth order for a good approximation of the Wigner function of an energy eigenstate. Therefore a simple approximation by neglecting all terms of higher than the second order seems not to be reasonable. When we apply our method to the higher-order equations, this yields an excellent agreement with the known analytic solution. The mean absolute error is of order $10^{-5}$ for an appropriate choice of the domain and the approximation order, which is altogether sufficient for the Wigner function. The application of our method to an asymmetric double-well potential shows that it is a valuable tool to approximate the Wigner function of eigenstates that have no analytical solution, and for which even no approximate expressions are known.

\section{ACKNOWLEDGMENTS}

We thank R. Baltin, M. V. Berry, J. P. Dahl, U. Leonhardt, H. Leschke, S. Schneider, and R. Seydel for many fruitful discussions. This work was partially supported by the Deutsche Forschungsgemeinschaft. M. H. is most grateful to the Studienstiftung des deutschen Volkes for its continuous support.

\section{APPENDIX A: SUM FACTORIZATION FORMULA FOR THE COEFFICIENTS OF THE HIGHER-ORDER DERIVATIVES}

In this appendix we formulate the sum factorization formula which we apply to the $m$-fold sums arising from a recurrence relation to arrive at expressions (6) and (7). The coefficients of the $m$ th derivative of a Chebyshev series can be calculated from the coefficients of the original Chebyshev series by a recurrence relation which reads, for coefficients with even indices $2 k$,

$$
a_{j, 2 k}^{m}=\sum_{t=k}^{N_{y}} 2(2 t+1) a_{j, 2 t+1}^{m-1}
$$

and for odd indices,

$$
a_{j, 2 k+1}^{m}=\sum_{t=k}^{N_{y}} 2(2 t+2) a_{j, 2 t+2}^{m-1} .
$$

This recurrence relation expresses the coefficients of the $m$-times differentiated series by the coefficients of the $(m-1)$-times differentiated series. By induction follows that the coefficients of the $m$-times differentiated series are $m$-fold sums containing the coefficients $a_{j, k}$ of the original series. Note that in the recurrence relation the even subscript $2 k$ changes to odd subscripts $2 t+1$, and the odd subscript $2 k+1$, to even subscripts $2 t+2$, respectively. Remember also that due to the symmetry

$$
\Psi(x,-y)=\Psi(x, y)
$$

in $y$ following from Eqs. (1) and (2) for the Wigner function, the coefficients $a_{j, 2 k+1}$ in our spectral ansatz Eq. (3) vanish for all $k=0,1, \ldots$.

We observe that Eq. (1) contains only odd derivatives with respect to $y$. Due to the symmetry condition (A3), $\Psi_{N}$ only consists of Chebyshev polynomials of even order in $y$. We find from the recurrence relations (A1) and (A2) that odd derivatives of even-order Chebyshev polynomials can be written as the sum of Chebyshev polynomials of odd order. Therefore Eq. (1) yields only terms with Chebyshev polynomials of odd order. Similarly Eq. (2) produces only terms with even-order Chebyshev polynomials, because it contains only even derivatives with respect to $y$. Thus the two Eqs. (1) and (2) still occur separately in the final equation system (17) for the coefficients of $\Psi_{N}$.

Making use of the symmetry condition (A3) together with the recurrence relations (A1) and (A2), we can explicitly write down the multiple sums describing the relationship between the coefficients $a_{j, k}^{m}$ of the $m$ th derivative of the Chebyshev series of our ansatz and the original coefficients $a_{j, k}$. Starting from Eq. (A2), for derivatives of odd order $2 m-1$ with $m \geqslant 2$ we obtain 


$$
\begin{aligned}
a_{j, 2 k+1}^{2 m-1} & =\sum_{\tau_{2 m-1}=k}^{N_{y}} \cdots \sum_{\tau_{1}=\tau_{2}}^{N_{y}} 2^{2 m-1}\left(2 \tilde{t}_{2 m-1}+2\right)\left(2 \tilde{t}_{2 m-2}+3\right) \cdots\left(2 \tilde{t}_{1}+2 m\right) a_{j, 2 \tilde{t}_{1}+2 m} \\
& =\sum_{t_{2 m-1}=0}^{N_{y}} \cdots \sum_{t_{1}=t_{2}}^{N_{y}} 2^{2 m-1} \prod_{\varrho=2}^{2 m}\left(2 t_{2 m+1-\varrho}+2 k+\varrho\right) a_{j, 2 t_{1}+2 k+2 m},
\end{aligned}
$$

where we have written the product in a closed form and simultaneously shifted the indices of summation by $k$, that is, $t_{\nu}=\widetilde{t}_{\nu}-k$. Therefore, the upper limit of the first sum should be $N_{y}-k$, but we can also write $N_{y}$ due to the condition $a_{j, k}=0$ if $k>N_{y}$. Similarly, for derivatives of even order $2 m$ with $m \geqslant 2$, from Eqs. (A1) and (A2) we obtain

$$
\begin{aligned}
a_{j, 2 k}^{2 m} & =\sum_{\tau_{2 m}=k}^{N_{y}} \cdots \sum_{t_{1}=\tau_{2}}^{N_{y}} 2^{2 m}\left(2 \tilde{t}_{2 m}+1\right)\left(2 \tilde{t}_{2 m-1}+2\right) \cdots\left(2 \tilde{t}_{1}+2 m\right) a_{j, 2 \tau_{1}+2 m} \\
& =\sum_{t_{2 m}=0}^{N_{y}} \cdots \sum_{t_{1}=t_{2}}^{N_{y}} 2^{2 m} \prod_{\varrho=1}^{2 m}\left(2 t_{2 m+1-e}+2 k+\varrho\right) a_{j, 2 t_{1}+2 k+2 m} .
\end{aligned}
$$

We now can simply interchange the order of summation and write

$$
\sum_{t_{m}=0}^{N_{y}} \sum_{t_{m}=t_{m}}^{N_{y}} \ldots \sum_{t_{1}=t_{2}}^{N_{y}}=\sum_{t_{1}=0}^{N_{y}} \sum_{t_{2}=0}^{t_{1}} \ldots \sum_{t_{m}=0}^{t_{m-1}} .
$$

Since this expression contains multiple sums it seems to be impracticable to apply it to an arbitrary order $m$. But the inner sums with summation indices $t_{2}, t_{3}, \ldots$ can be factorized. This is shown in Appendix B. With the abbreviation

$$
\kappa_{m t_{1}}:=2 t_{1}+2 k+2 m
$$

we obtain, for the $2 m-2$ inner sums of the odd order $2 m-1$ [Eq. (A4)],

$$
\begin{aligned}
& \sum_{t_{2} \ldots t_{2 m-1}} 2^{2 m-2} \prod_{\varrho=2}^{2 m-1}\left(2 t_{2 m+1-}+2 k+\varrho\right) \\
& \quad=\frac{1}{(2 m-2) ! 2^{2 m-2}} \prod_{\sigma=-(m-2)}^{m-1}\left[\kappa_{m t_{1}}^{2}-4(k+\sigma)^{2}\right],
\end{aligned}
$$

and for the $2 m-1$ inner sums of the even order $2 m$ [Eq. (A5)],

$$
\begin{aligned}
& \sum_{i_{2} \ldots t_{2 m}} 2^{2 m-1} \prod_{\varrho=1}^{2 m-1}\left(2 t_{2 m+1-\varrho}+2 k+\varrho\right) \\
& =\frac{1}{(2 m-1) ! 2^{2 m-1}} \prod_{\sigma=-(m-1)}^{m-1}\left[\kappa_{m t_{1}}^{2}-4(k+\sigma)^{2}\right] .
\end{aligned}
$$

The important consequence of this sum factorization formula for the implementation of our algorithm is that we do not have to calculate multiple sums any more. Instead we only have to evaluate simple products. With Eq. (A6) we can now formulate Eq. (A4) as

$$
\begin{aligned}
a_{j, 2 k+1}^{2 m-1} & =\sum_{t_{1}=0}^{N_{y}} \frac{1}{(2 m-2) ! 2^{2 m-2}} \prod_{\sigma=-(m-2)}^{m-1}\left[\kappa_{m t_{1}}^{2}-4(k+\sigma)^{2}\right] 2 \kappa_{m t_{1}} a_{j, \kappa_{m r_{1}}} \\
& =\sum_{\kappa=k+m}^{N_{y}} \frac{1}{(2 m-2) ! 2^{2 m-2}} \prod_{\sigma=-(m-2)}^{m-1}\left[(2 \kappa)^{2}-4(k+\sigma)^{2}\right] 4 \kappa a_{j, 2 \kappa},
\end{aligned}
$$

where we have finally shifted the summation index by $\kappa=t_{1}+k+m=\kappa_{m t_{1}} / 2$. Since $a_{j, k}=0$ for $k>N_{y}$ we do not have to change the upper limit of the sum. Similarly with Eq. (A7), we find, for Eq. (A5),

$$
\begin{aligned}
a_{j, 2 k}^{2 m} & =\sum_{i_{1}=0}^{N_{y}} \frac{1}{(2 m-1) ! 2^{2 m-1}} \prod_{\sigma=-(m-1)}^{m-1}\left[\kappa_{m t_{1}}^{2}-4(k+\sigma)^{2}\right] 2 \kappa_{m t_{1}} a_{j, \kappa_{m t_{1}}} \\
& =\sum_{\kappa=k+m}^{N_{y}} \frac{1}{(2 m-1) ! 2^{2 m-1}} \prod_{\sigma=-(m-1)}^{m-1}\left[(2 \kappa)^{2}-4(k+\sigma)^{2}\right] 4 \kappa a_{j, 2 \kappa} .
\end{aligned}
$$


With that result we are now able to treat the derivative $\partial^{m} \Psi / \partial y^{m}$ for arbitrary $m$.

In the same way we can calculate the derivatives of the potential $V(x)$,

$$
\frac{d^{m} V}{d x^{m}}=\sum_{l \leqslant N_{v}-m}^{\prime} V_{l}^{m} T_{l}(x)
$$

We conclude this appendix by mentioning that with the above formulas we can also factorize the coefficients $V_{l}^{m}$ for the $m$ th derivative of the Chebyshev series for the potential $V(x)$ appearing in Eqs. (1) and (2). We need not apply these results, if the derivatives $d^{m} V / d x^{m}$ are explicitly given, because in this case we can calculate directly the Chebyshev series of $d^{m} V / d x^{m}$.

\section{APPENDIX B: PROOF OF THE SUM FACTORIZATION FORMULA}

In this appendix we prove the sum factorization formulas Eqs. (A6) and (A7). Once we have reorganized the formula in a form which is appropriate for the proof, we carry out the proof by mathematical induction. To accomplish this we need two further formulas which we prove in Appendixes C and $\mathrm{D}$.

\section{Reorganization of the sum factorization formulas}

To carry out the proof of the sum factorization formulas Eqs. (A6) and (A7) we rewrite the factors on the right-hand sides as sums. Then the right-hand sides consist of a product of sums, whereas the left-hand sides consist of a sum of products. In this reorganized form we are able to prove the sum factorization formulas.

To achieve this form we insert $\kappa_{m t_{1}}:=2 t_{1}+2 k+2 m$ into the right-hand side of Eq. (A6), and obtain

$$
\begin{aligned}
\frac{1}{(2 m-2) ! 2^{2 m-2}} \prod_{\sigma=-(m-2)}^{m-1}\left[\kappa_{m t_{1}}^{2}-4(k+\sigma)^{2}\right] & =\frac{1}{(2 m-2) ! 2^{2 m-2}} \prod_{\sigma=-(m-2)}^{m-1}\left[\kappa_{m t_{1}}-2(k+\sigma)\right]\left[\kappa_{m t_{1}}+2(k+\sigma)\right] \\
& =\frac{2^{2 m-2}}{(2 m-2) !} \prod_{\sigma=-(m-2)}^{m-1}\left(t_{1}+m-\sigma\right)\left(t_{1}+2 k+m+\sigma\right) \\
& =\frac{2^{2 m-2}}{(2 m-2) !} \prod_{\sigma=-(m-2)}^{m-1} \sum_{\lambda=0}^{t_{1}+m-\sigma-1}(2 \lambda+2 k+2 \sigma+1) .
\end{aligned}
$$

The last step is valid, since we can rewrite the product

$$
\left(t_{1}+m-\sigma\right)\left(t_{1}+2 k+m+\sigma\right)=\underbrace{\left(t_{1}+m-\sigma-1+1\right)}_{M+1}(\underbrace{t_{1}+m-\sigma-1}_{M}+\underbrace{2 k+2 \sigma+1}_{A}),
$$

which is of the form

$$
(M+1)(M+A)=(M+1) M+(M+1) A=\sum_{\lambda=0}^{M} 2 \lambda+\sum_{\lambda=0}^{M} A .
$$

An analogous result holds for the right-hand side of Eq. (A7). Thus Eqs. (A6) and (A7) are rewritten as

$$
\sum_{t_{2}, \ldots t_{2 m-1}} 2^{2 m-2} \prod_{\varrho=2}^{2 m-1}\left(2 t_{2 m+1-\varrho}+2 k+\varrho\right)=\frac{2^{2 m-2}}{(2 m-2) !} \prod_{\sigma=-(m-2)}^{m-1} \sum_{\lambda=0}^{t_{1}+m-\sigma-1}(2 \lambda+2 k+2 \sigma+1)
$$

and

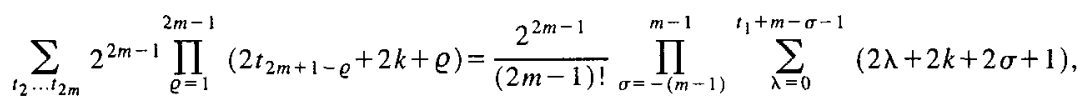

where now the multiple sums of a product are represented as a decomposition into a product of independent sums.

We now have two possibilities to carry out the proof by induction. We can strictly separate the even case Eq. (B1) and the odd case Eq. (B2), and prove each of these cases independently. This turns out to be very complicated. We find it easier to start with an even-order $N=2 m-2$, and increase $N$ by 1 . Then we have to insert different formulas for $N$ and $N+1=2 m-1$, namely, Eq. (B1) for $N$ and Eq. (B2) for $N+1$. The second step is to start with an odd $N=2 m-1$ using Eq. (B2), and investigate $N+1=2 m$ using Eq. (B1). 


\section{Proof of the sum factorization formulas}

In this subsection we prove the sum factorization formula by induction. As mentioned in Appendix B 1, we have to make a distinction between even and odd integers $N$. We start this proof as usual, and show that the formulas hold for $N=1$ and 2 . The induction step has to be performed twice. First we start with an even $N=2 m-2$ and deduce the formula Eq. (B2) for odd $N+1=2 m-1$. Second, we have to start at this $\widetilde{N}=2 m-1$ to prove the formula Eq. (B1) for even $\widetilde{N}+1=2 m$.

(a) First step of the induction. The starting point is a convenient formulation of Eqs. (B1) and (B2). When $N=2 m-1$ is odd, we can rewrite Eq. (B2),

$$
\sum_{t_{2} \ldots t_{N+1}} 2^{N} \prod_{\varrho=1}^{N}\left(2 t_{N+2-\varrho}+2 k+\varrho\right)=\frac{2^{N}}{N !} \prod_{\sigma=-(N-1) / 2}^{(N-1) / 2} \sum_{\lambda=0}^{t_{1}+[(N-1) / 2]-\sigma}(2 \lambda+2 k+2 \sigma+1),
$$

whereas for even $N=2 m-2$ we have

$$
\sum_{t_{2} \ldots t_{N+1}} 2^{N} \prod_{\varrho=2}^{N+1}\left(2 t_{N+3-\varrho}+2 k+\varrho\right)=\frac{2^{N}}{N !} \prod_{\sigma=-(N-2) / 2}^{N / 2} \sum_{\lambda=0}^{t_{1}+(N / 2)-\sigma}(2 \lambda+2 k+2 \sigma+1) .
$$

By simple inserting we check that Eq. (B3) holds for $N=1$ and Eq. (B4) holds for $N=2$. For $N=1$, Eq. (B3) reduces to

$$
\sum_{t_{2}=0}^{t_{1}} 2^{1} \prod_{\varrho=1}^{1}\left(2 t_{1+2-\varrho}+2 k+\varrho\right)=\frac{2^{1}}{1 !} \prod_{\sigma=-0}^{0} \sum_{\lambda=0}^{t_{1}+0-\sigma}(2 \lambda+2 k+2 \sigma+1)
$$

and we immediately see that the right-hand side equals the left-hand side. For the case $N=2$ we need some more transformations to see the coincidence of the left- and right-hand sides of Eq. (B4). We split up the left-hand side,

$$
\sum_{t_{2}=0}^{t_{1}} \sum_{t_{3}=0}^{t_{2}} 2^{2}\left(2 t_{3}+2 k+2\right)\left(2 t_{2}+2 k+3\right)=2 \sum_{t_{2}=0}^{t_{1}} \sum_{t_{3}=0}^{t_{2}}\left(2 t_{2}+2 k+3\right)\left(2 t_{3}+2 k+1\right)+2 \sum_{t_{2}=0}^{t_{1}} \sum_{t_{3}=0}^{t_{2}}\left(2 t_{2}+2 k+3\right)\left(2 t_{3}+2 k+3\right) \text {. }
$$

into two sums. In the first double sum we introduce the new indices $\tilde{t}_{2}=t_{2}$ and $\tilde{t}_{3}=t_{3}-1$. In the second double sum we interchange the order of summation

$$
\sum_{t_{2}=0}^{t_{1}} \sum_{t_{3}=0}^{t_{2}}=\sum_{t_{3}=0}^{t_{1}} \sum_{t_{2}=t_{3}}^{t_{1}}
$$

We rename $\widetilde{t}_{2}=t_{3}$ and $\widetilde{t}_{3}=t_{2}$ in this sum, and find

$$
\begin{aligned}
& 2 \sum_{t_{2}=0}^{t_{1}} \sum_{t_{3}=-1}^{\tilde{t}_{2}-1}\left(2 \tilde{t}_{2}+2 k+3\right)\left(2 \tilde{t}_{3}+2 k+3\right)+2 \sum_{t_{2}=0}^{t_{1}} \sum_{t_{3}=t_{2}}^{t_{1}}\left(2 \tilde{t}_{2}+2 k+3\right)\left(2 \tilde{t}_{3}+2 k+3\right) \\
& \quad=2 \sum_{\tau_{2}=0}^{t_{1}} \sum_{t_{3}=-1}^{t_{1}}\left(2 \tilde{t}_{2}+2 k+3\right)\left(2 \tilde{t}_{3}+2 k+3\right),
\end{aligned}
$$

which we can easily combine to one double sum. When we shift back the index $\tilde{t}_{3}=t_{3}-1$, the right-hand side of Eq. (B4) with $N=2$ results:

$$
\frac{2^{2}}{2 !}\left(\sum_{\lambda=0}^{t_{1}+1}(2 \lambda+2 k+1)\right)\left(\sum_{\lambda=0}^{t_{1}}(2 \lambda+2 k+3)\right) .
$$

(b) Starting from $N$ even. We carry out the main step of the proof by induction by starting from the left-hand side of Eq. (B3) for $N+1$, which is in this case supposed to be odd:

$$
\begin{aligned}
& \sum_{t_{2} \ldots t_{N+2}} 2^{N+1} \prod_{\varrho=1}^{N+1}\left(2 t_{N+3-}+2 k+\varrho\right) \\
& \quad=\frac{2}{(N+1)}\left(\sum_{t_{2} \ldots t_{N+1}} 2^{N} \prod_{\varrho=2}^{N+1}\left(2 t_{N+3-\varrho}+2 k+\varrho\right)\right)\left(\sum_{t_{N+2}=0}^{t_{1}+N}\left(2 t_{N+2}+2 k-N+1\right)\right) .
\end{aligned}
$$

The validity of this equation is proven in Appendix C. Now we can insert the induction hypothesis Eq. (B4) for even $N$, and find 


$$
\begin{aligned}
& \frac{2^{N+1}}{(N+1) !}\left(\prod_{\sigma=-(N-2) / 2}^{N / 2} \sum_{\lambda=0}^{t_{1}+(N / 2)-\sigma}(2 \lambda+2 k+2 \sigma+1)\right)\left(\sum_{t_{N+2}=0}^{t_{1}+N}\left(2 t_{N+2}+2 k-N+1\right)\right) \\
& =\frac{2^{N+1}}{(N+1) !} \prod_{\sigma=-N / 2}^{N / 2} \sum_{\lambda=0}^{t_{1}+(N / 2)-\sigma}(2 \lambda+2 k+2 \sigma+1),
\end{aligned}
$$

that can easily be verified to be the right-hand side of Eq. (B3) formulated with $N+1$, which we assumed to be odd. Hence we have shown that if Eq. (B4) holds, then Eq. (B3) also holds.

(c) Starting from $N$ odd. This case is more complicated and needs some transformations. When we start from $N$ odd, the hypothesis of the induction is Eq. (B3). The left-hand side of Eq. (B4) for $N+1$, which is now even, reads

$$
\sum_{t_{2} \ldots t_{N+2}} 2^{N+1} \prod_{\varrho=2}^{N+2}\left(2 t_{N+4-\varrho}+2 k+\varrho\right)=\frac{2}{(N+1)}\left(\sum_{t_{2} \ldots t_{N+1}} 2^{N} \prod_{\varrho=3}^{N+2}\left(2 t_{N+4-\varrho}+2 k+\varrho\right)\right)\left(\sum_{t_{N+2}=0}^{t_{1}+N}\left(2 t_{N+2}+2 k-N+2\right)\right)
$$

We prove this equality in Appendix $\mathrm{C}$. When we shift the index of the product $\widetilde{\varrho}=\varrho-2$ by 2 , and furthermore define $\widetilde{k}=k+1$, this reads

$$
\frac{2}{(N+1)}\left(\sum_{t_{2}, \ldots t_{N+1}} 2^{N} \prod_{\varrho=1}^{N}\left(2 t_{N+2-\tilde{\varrho}}+2 \tilde{k}+\widetilde{\varrho}\right)\right)\left(\sum_{t_{N+2}=0}^{t_{1}+N}\left(2 t_{N+2}+2 k-N+2\right)\right) .
$$

This formulation allows us to apply the hypothesis of the induction equation (B3), and we find

$$
\frac{2}{(N+1)} \frac{2^{N}}{N !}\left(\prod_{\sigma=-(N-1) / 2}^{(N-1) / 2} \sum_{\lambda=0}^{t_{1}+[(N-1) / 2]-\sigma}(2 \lambda+2 \widetilde{k}+2 \sigma+1)\right)\left(\sum_{t_{N+2}=0}^{t_{1}+[(N-1) / 2]+[(N+1) / 2]}\left[2 t_{N+2}+2 k-(N+1)+3\right]\right)
$$

We combine these factors making use of $\tilde{k}=k+1$, and with a further shift of the index $\tilde{\sigma}=\sigma+1$ we obtain

$$
\frac{2^{N+1}}{(N+1) !} \prod_{\sigma=-(N+1) / 2}^{(N-1) / 2} \sum_{\lambda=0}^{t_{1}+[(N+1) / 2]-\sigma-1}(2 \lambda+2 k+2 \sigma+3)=\frac{2^{N+1}}{(N+1) !} \prod_{\tilde{\sigma}=-[(N-1) / 2]}^{(N+1) / 2} \sum_{\lambda=0}^{t_{1}+[(N+1) / 2]-\tilde{\sigma}}(2 \lambda+2 k+2 \tilde{\sigma}+1),
$$

which is indeed the right-hand side of Eq. (B4) for $N+1$ (even). Thus we now have shown that if Eq. (B3) holds, then Eq. (B4) also holds. Together with the results of the former subsection where we showed that if Eq. (B4) holds, then Eq. (B3) also holds, and with the special cases $N=1$ and 2 , the proof is now complete.

\section{APPENDIX C: PROOF OF EQS. (B5) AND (B6)}

In this appendix we prove formulas (B5) and (B6). These are two different formulations but essentially identical. In Appendix B $2 \mathrm{c}$ we used the formulation

$$
(N+1) \sum_{t_{2} \ldots t_{N+2}} \prod_{\varrho=2}^{N+2}\left(2 t_{N+4-\varrho}+2 k+\varrho\right)=\left(\sum_{t_{2} \ldots t_{N+1}} \prod_{\varrho=3}^{N+2}\left(2 t_{N+4-\varrho}+2 k+\varrho\right)\right)\left(\sum_{t_{N+2}=0}^{t_{1}+N}\left(2 t_{N+2}+2 k-N+2\right)\right)
$$

for $N$ odd. When we shift the index $\widetilde{\varrho}=\varrho-1$ and define $\widetilde{k}=k+\frac{1}{2}$, we obtain

$$
2^{N+1} \sum_{t_{2} \ldots t_{N+2}} \prod_{\tilde{\varrho}=1}^{N+1}\left(2 t_{N+3}-\tilde{\varrho}+2 \widetilde{k}+\tilde{\varrho}\right)=\frac{2^{N+1}}{(N+1)}\left(\sum_{t_{2}} \sum_{t_{N+1}}^{N+1}\left(2 t_{N+3}-\tilde{\varrho}+2 \tilde{k}+\tilde{\varrho}\right)\right)\left(\sum_{t_{N+2}=0}^{t_{1}+N}\left(2 t_{N+2}+2 \tilde{k}-N+1\right)\right),
$$

which is the formula we used in Appendix B $2 b$ for $N$ even.

To prove this relationship, we concentrate on Eq. (C1). We use a further formula that we finally prove in Appendix D, which reads

$$
\begin{aligned}
& (N+1) \prod_{\varrho=2}^{N+2}\left(2 t_{N+4-\varrho}+2 k+\varrho\right) \\
& \quad=\sum_{\sigma=2}^{N+2}\left(\prod_{\varrho=2}^{\sigma-1}\left[2 t_{N+4-\varrho}+2 k+(\varrho+1)\right]\right)\left(2 t_{N+4-\sigma}+2 k-N-2+2 \sigma\right)\left(\prod_{\varrho=\sigma+1}^{N+2}\left(2 t_{N+4-\varrho}+2 k+\varrho\right)\right),
\end{aligned}
$$


and shows how the multiplication of $N+1$ with a product can be written as a discrete sum of $N$ diverse products. Note that $\Pi_{\varrho=\alpha}^{\beta}=1$ for $\alpha>\beta$. With Eq. (C3), we can rewrite the left-hand side of Eq. (C1),

$$
\begin{aligned}
(N+1) & \sum_{t_{2} \ldots t_{N+2}} \prod_{\varrho=2}^{N+2}\left(2 t_{N+4-\varrho}+2 k+\varrho\right) \\
= & \sum_{t_{2} \ldots t_{N+1}} \sum_{t_{N+2}=0}^{t_{N+1}}\left(2 t_{N+2}+2 k-N+2\right)\left(\prod_{\varrho=3}^{N+2}\left(2 t_{N+4-\varrho}+2 k+\varrho\right)\right) \\
& +\sum_{\sigma=3}^{N+2} \sum_{t_{2} \ldots t_{N+4-(\sigma+1)}} \sum_{t_{N+4-\sigma}=0}^{t_{N+4-\{\sigma+1)}} \sum_{t_{N+4-(\sigma-1)}=0}^{t_{N+4-\sigma}} \sum_{t_{N+4-(\sigma-2)} \ldots t_{N+2}}\left(\prod_{\varrho=2}^{\sigma-1}\left[2 t_{N+4-\varrho}+2 k+(\varrho+1)\right]\right) \\
& \times\left(2 t_{N+4-\sigma}+2 k-N-2+2 \sigma\right)\left(\prod_{\varrho=\sigma+1}^{N+2}\left(2 t_{N+4-\varrho}+2 k+\varrho\right)\right),
\end{aligned}
$$

where we have written the term $\sigma=2$ separately. We now rename the variables in each summand in such a way that the separately written factor $t_{N+4-\sigma}$ is labeled with the same index $t_{N+2}$ in each summand. To accomplish this we shift, all indices $t_{\nu}$ with $\nu \geqslant N+4-\sigma$ by 1 , that is, $t_{N+4-}$ is renamed by $t_{N+4-(\varrho+1)}$ if $\varrho \leqslant \sigma$, which is the case in the first product. Hence Eq. (C4) now reads

$$
\begin{aligned}
& \sum_{t_{2} \ldots t_{N+1}} \sum_{t_{N+2}=0}^{t_{N+1}}\left(2 t_{N+2}+2 k-N+2\right)\left(\prod_{\varrho=3}^{N+2}\left(2 t_{N+4-\varrho}+2 k+\varrho\right)\right) \\
& \quad+\sum_{\sigma=3}^{N+2} \sum_{t_{2} \ldots t_{N+4-(\sigma+1)}} \sum_{t_{N+2}=0}^{t_{N+4-(\sigma+1)}} \sum_{t_{N+4-\sigma}=0}^{t_{N+2}} \sum_{t_{N+4-(\sigma-1)} \ldots t_{N+1}}\left(\prod_{\varrho=2}^{\sigma-1}\left[2 t_{N+4-(\varrho+1)}+2 k+(\varrho+1)\right]\right) \\
& \quad \times\left(2 t_{N+2}+2 k-N-2+2 \sigma\right)\left(\prod_{\varrho=\sigma+1}^{N+2}\left(2 t_{N+4-\varrho}+2 k+\varrho\right)\right)
\end{aligned}
$$

Now we interchange the order of summation of the double sum

$$
\sum_{t_{N+2}=0}^{t_{N+4 \sim(\sigma+1)}} \sum_{t_{N+4-\sigma}=0}^{t_{N+2}}=\sum_{t_{N+4-\sigma}=0}^{t_{N+4-(\sigma+1)}} \sum_{t_{N+2}=t_{N+4-\sigma}}^{t_{N+4-(\sigma+1)}},
$$

and shift the index $\tilde{\varrho}=\varrho+1$ of the first product. Thus Eq. (C5) reads

$$
\begin{aligned}
& \sum_{t_{2} \ldots t_{N+1}} \sum_{t_{N+2}=0}^{t_{N+1}}\left(2 t_{N+2}+2 k-N+2\right)\left(\prod_{\varrho=3}^{N+2}\left(2 t_{N+4-\varrho}+2 k+\varrho\right)\right) \\
& +\sum_{\sigma=3}^{N+2} \sum_{t_{2} \ldots t_{N+4-(\sigma+1)}} \sum_{t_{N+4-\sigma}=0}^{t_{N+4-(\sigma+1)}} \sum_{t_{N+2}=t_{N+4-\sigma} t^{t_{N+4-(\sigma-1)}} \sum_{N+1}}\left(\prod_{\tilde{\varrho}=3}^{\sigma}\left(2 t_{\left.N+4-\tilde{\varrho}^{+}+2 k+\tilde{\varrho}\right)}\right)\right. \\
& \times\left(2 t_{N+2}+2 k-N-2+2 \sigma\right)\left(\prod_{\varrho=\sigma+1}^{N+2}\left(2 t_{N+4-\varrho}+2 k+\varrho\right)\right) \\
& =\sum_{t_{2} \ldots t_{N+1}} \sum_{t_{N+2}=0}^{t_{N+1}}\left(2 t_{N+2}+2 k-N+2\right)\left(\prod_{\varrho=3}^{N+2}\left(2 t_{N+4-\varrho}+2 k+\varrho\right)\right) \\
& +\sum_{\sigma=3}^{N+2} \sum_{t_{2} \ldots t_{N+1}} \sum_{t_{N+2}=t_{N+4-\sigma}}^{t_{N+4-(\sigma+1)}}\left(\prod_{e=3}^{N+2}\left(2 t_{N+4-e}+2 k+\varrho\right)\right)\left(2 t_{N+2}+2 k-N-2+2 \sigma\right),
\end{aligned}
$$

where we now are able to combine the first and second products. The factors containing the indices $t_{2}, \ldots, t_{N+1}$ are common to all summands $\varrho=2, \ldots, N+2$. We therefore can factor them out. Hence the right-hand side of the last equation reads

$$
\sum_{t_{2} \ldots t_{N+1}}\left(\prod_{\varrho=3}^{N+2}\left(2 t_{N+4-e}+2 k+e\right)\right)\left[\sum_{t_{N+2}=0}^{t_{N+1}^{N+1}}\left(2 t_{N+2}+2 k-N+2\right)+\sum_{\sigma=3}^{N+2} \sum_{t_{N+2}=t_{N+4-\sigma}}^{t_{N+4-(\sigma+1)}}\left(2 t_{N+2}+2 k-N-2+2 \sigma\right)\right] \text {. }
$$


When we shift $\tilde{t}_{N+2}=t_{N+2}+(\sigma-2)$ by $\sigma-2$, this reads

$$
\sum_{t_{2} \ldots t_{N+1}}\left(\prod_{\varrho=3}^{N+2}\left(2 t_{N+4-\varrho}+2 k+\varrho\right)\right)\left[\sum_{t_{N+2}=0}^{t_{N+1}}\left(2 t_{N+2}+2 k-N+2\right)+\sum_{\sigma=3}^{N+2} \sum_{t_{N+2}=t_{N+4-\sigma}+(\sigma-2)}^{t_{N+4-(\sigma+1)}^{+(\sigma-2)}}\left(2 \tilde{t}_{N+2}+2 k-N+2\right)\right]
$$

We can finally combine the sums

$$
\sum_{t_{N+2}=0}^{t_{N+1}}+\sum_{\sigma=3}^{N+2} \sum_{\tau_{N+2}=t_{N+4-\sigma}+(\sigma-2)}^{t_{N+4-(\sigma+1)}+(\sigma-2)}=\sum_{t_{N+2}=0}^{t_{1}+N}
$$

and end up with

$$
\sum_{t_{2} \ldots t_{N+1}}\left(\prod_{\varrho=3}^{N+2}\left(2 t_{N+4-\varrho}+2 k+\varrho\right)\right)_{\tau_{N+2}=0}^{t_{1}+N}\left(2 \tilde{t}_{N+2}+2 k-N+2\right)
$$

which is indeed the right-hand side of Eq. (CI).

\section{APPENDIX D: PROOF OF EQ. (C3)}

In this appendix we finally show the formula Eq. (C3) which we used in Appendix C. We carry out our proof by mathematical induction. Equation (C3) formulated for any integer $N$ reads

$$
\begin{aligned}
& (N+1) \prod_{\varrho=2}^{N+2}\left(2 t_{N+4-\varrho}+2 k+\varrho\right) \\
& \quad=\sum_{\sigma=2}^{N+2}\left(\prod_{\varrho=2}^{\sigma-1}\left[2 t_{N+4-\varrho}+2 k+(\varrho+1)\right]\right)\left(2 t_{N+4-\sigma}+2 k-N-2+2 \sigma\right)\left(\prod_{\varrho=\sigma+1}^{N+2}\left(2 t_{N+4-\varrho}+2 k+\varrho\right)\right),
\end{aligned}
$$

where we recall that $\Pi_{Q=\alpha^{*}}^{\beta}=1$ for $\alpha>\beta$. The starting point of the induction is to verify Eq. (D1) for $N=0$, that is,

$$
(0+1)\left(2 t_{2}+2 k+2\right)=\sum_{\sigma=2}^{2}\left(2 t_{2}+2 k-0-2+2 \sigma\right) .
$$

After this trivial step we start for the further proof from Eq. (D1), which is our induction hypothesis. We substitute $N+1$ for $N$ in Eq. (Dl) and obtain

$$
\begin{aligned}
& (N+2) \prod_{\varrho=2}^{N+3}\left(2 t_{N+5-\varrho}+2 k+\varrho\right) \\
& \quad=\sum_{\sigma=2}^{N+3}\left(\prod_{\varrho=2}^{\sigma-1}\left[2 t_{N+5-\varrho}+2 k+(\varrho+1)\right]\right)\left(2 t_{N+5-\sigma}+2 k-N-3+2 \sigma\right)\left(\prod_{\varrho=\sigma+1}^{N+3}\left(2 t_{N+5-\varrho}+2 k+\varrho\right)\right) .
\end{aligned}
$$

We now have to reduce the left-hand side of Eq. (D2) to the left-hand side of Eq. (D1). We do this by rewriting the product

$$
(N+2)\left(2 t_{N+3}+2 k+2\right)=(N+1)\left(2 t_{N+3}+2 k+3\right)+\left(2 t_{N+3}+2 k-N+1\right) .
$$

When we use this relation and shift the index of the product $\widetilde{\varrho}=\varrho-1$ by $1, \mathrm{Eq}$. (D2) changes to

$$
\begin{aligned}
(N+2) \prod_{\varrho=2}^{N+3}\left(2 t_{N+5-\varrho}+2 k+\varrho\right) & =\left(\prod_{\varrho=3}^{N+3}\left(2 t_{N+5-\varrho}+2 k+\varrho\right)\right)(N+2)\left(2 t_{N+3}+2 k+2\right) \\
& =\prod_{\tilde{\varrho}=2}^{N+2}\left(2 t_{N+4-\tilde{\varrho}}+2 k+\tilde{\varrho}+1\right)\left[(N+1)\left(2 t_{N+3}+2 k+3\right)+\left(2 t_{N+3}+2 k-N+1\right)\right] .
\end{aligned}
$$

When we define $\widetilde{k}=k+\frac{1}{2}$ we now can replace the left-hand side of the hypothesis Eq. (D1) by the right-hand side, and obtain 


$$
\begin{aligned}
& (N+1)\left(\prod_{\tilde{\varrho}=2}^{N+2}\left(2 t_{N+4-\tilde{\varrho}}+2 \widetilde{k}+\widetilde{\varrho}\right)\right)\left(2 t_{N+3}+2 \widetilde{k}+2\right)+\left(\prod_{\tilde{\varrho}=2}^{N+2}\left(2 t_{N+4-\tilde{\varrho}}+2 \widetilde{k}+\widetilde{\varrho}\right)\right)\left(2 t_{N+3}+2 \widetilde{k}-N\right) \\
& =\sum_{\sigma=2}^{N+2}\left(\prod_{\tilde{\varrho}=2}^{\sigma-1}\left[2 t_{N+4-\tilde{\varrho}}+2 \tilde{k}+(\tilde{\varrho}+1)\right]\right)\left(2 t_{N+4-\sigma}+2 \tilde{k}-N-2+2 \sigma\right)\left(\prod_{\tilde{\varrho}=\sigma+1}^{N+2}\left(2 t_{N+4} \tilde{\varrho}+2 \tilde{k}+\tilde{\varrho}\right)\right)\left(2 t_{N+3}+2 \tilde{k}+2\right) \\
& +\left(\prod_{\tilde{\varrho}=2}^{N+2}\left(2 t_{N+4}-\tilde{\varrho}^{+2} \tilde{k}+\widetilde{\varrho}\right)\right)\left(2 t_{N+3}+2 \widetilde{k}-N\right)
\end{aligned}
$$

Since we can include the term $\left(2 t_{N+3}+2 \tilde{k}+2\right)$ into the first product, and since the last summand is the term $\sigma=1$, we can combine this to

$$
\sum_{\sigma=1}^{N+2}\left(\prod_{\varrho=1}^{\sigma-1}\left[2 t_{N+4-\tilde{\varrho}}+2 \widetilde{k}+(\tilde{\varrho}+1)\right]\right)\left(2 t_{N+4-\sigma}+2 \widetilde{k}-N-2+2 \sigma\right)\left(\prod_{\tilde{\varrho}=\sigma+1}^{N+2}\left(2 t_{N+4-\tilde{\varrho}}+2 \widetilde{k}+\widetilde{\varrho}\right)\right)
$$

With $\widetilde{\sigma}=\sigma+1$, we arrive at

$$
\begin{aligned}
& \sum_{\tilde{\sigma}=2}^{N+3}\left(\prod_{\tilde{\varrho}=1}^{\tilde{\sigma}-2}\left[2 t_{N+4-\tilde{\varrho}}+2 \tilde{k}+(\tilde{\varrho}+1)\right]\right)\left(2 t_{N+5-\tilde{\sigma}}+2 \tilde{k}-N-4+2 \tilde{\sigma}\right)\left(\prod_{\tilde{\varrho}=\tilde{\sigma}}^{N+2}\left(2 t_{N+4-\tilde{\varrho}}+2 \tilde{k}+\tilde{\varrho}\right)\right)
\end{aligned}
$$

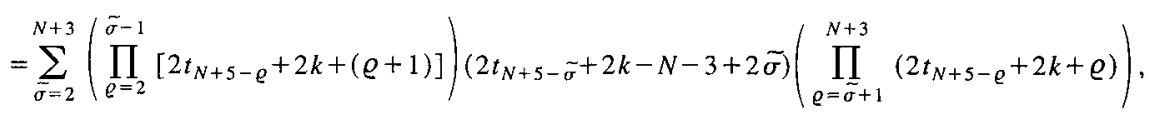

which is the right-hand side of our formula Eq. (D2) for $N+1$ after resubstitution of $\widetilde{\varrho}$ and $\widetilde{k}$ by $\varrho$ and $k$, respectively.

[1] M. Hug, C. Menke, and W. P. Schleich, preceding paper, Phys. Rev. A, 57, 3188 (1998).

[2] L. Fox and I. B. Parker, Chebyshev Polynomials in Numerical Analysis, Oxford Mathematical Handbooks (Oxford University Press, London, 1968).

[3] E. Anderson, Z. Bai, C. Bischof, J. Demmel, J. Dongarra, J. Du Croz, A. Greenbaum, S. Hammarling, A. McKenney, S.
Ostrouchov, and D. Sorensen, LAPACK Users' Guide (SIAM, Philadelphia, 1992).

[4] P. M. Morse, Phys. Rev. 34, 57 (1929).

[5] M. D. Feit, J. A. Fleck, Jr., and A. Steiger, J. Comput. Phys. 47, 412 (1982), and references therein.

[6] For a nice presentation and resolution of this problem, see $M$. V. Berry, Philos. Trans. R. Soc. London, Ser. A 287, 237 (1977). 